
48

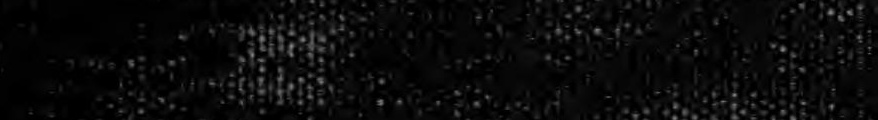



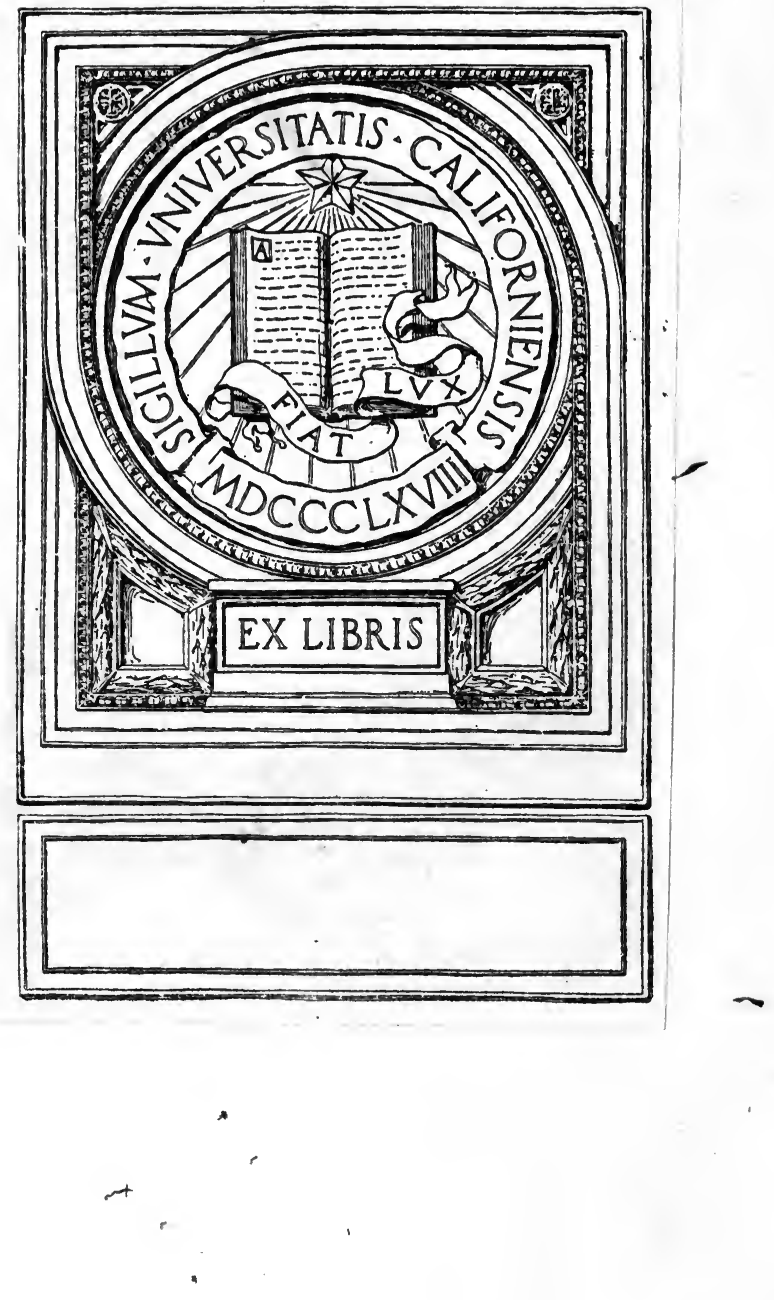

Digitized by the Internet Archive in 2007 with funding from Microsoft Corporation 




\section{A HISTORY OF BANKING \\ IN THE}

\section{UNITED STATES}



O 


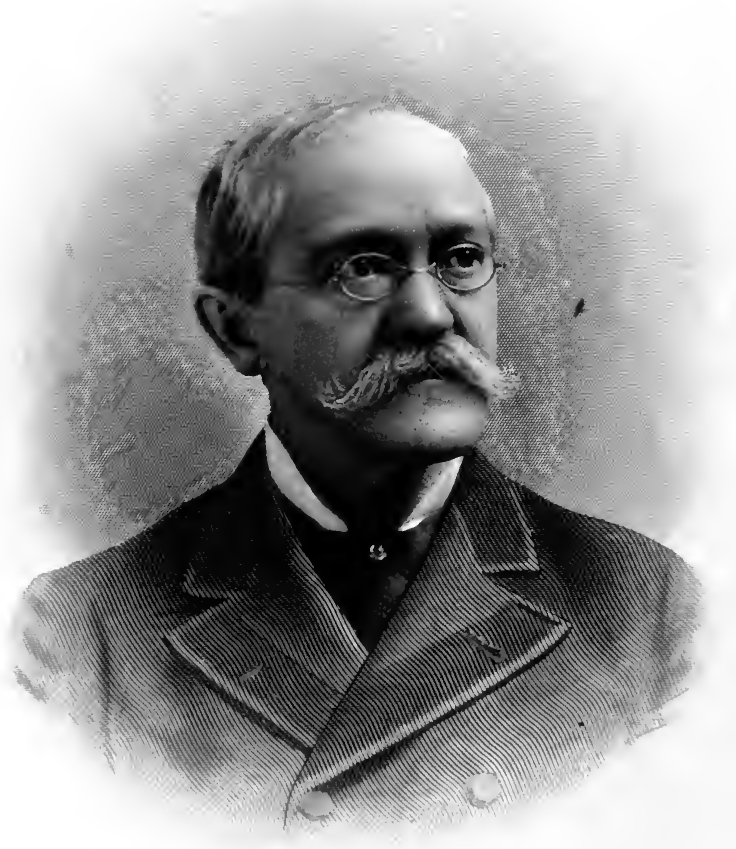

Onowenterat 


\section{A \\ HISTORY 0F BANKING}

IN THE

\section{UNITED STATES}

BY THE LATE

\section{JOHN JAY KNOX}

FOR SEVENTEEN YEARS DEPUTY COMPTROLLER AND CONITROLLER OF THE CURRENCY

ASSISTED BY

A CORPS OF FINANCIAL WRITERS IN THE VARIOUS STATES

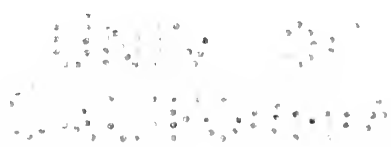

THE ENTIRE WORK CAREFULLY REVISED AND BROUGHT UP TO DATE BY

BRADFORD RHODES, Editor of The Bankers' Magazine AND

ELMIER H. YOUNGMIAN, Associate Editor

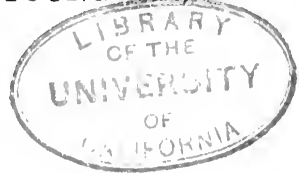

NEW YORK

BRADFORD RHODES \& COMPANY 


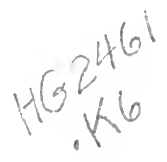

COPYRIGHT, 1900 , BY BRADFORD RHODES.

All rights reserved.

\section{GENERAL}

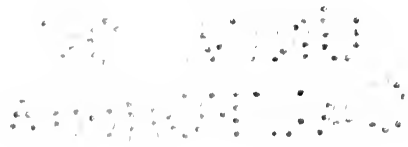




\section{EDITOR'S PREFACE.}

An orderly presentation of the salient facts in the banking history of the United States is a task beset with so many difficulties that heretofore no attempt has been made in this direction. It is believed that the important relation which the banks sustain to the business and political life of the country justifies the present endeavor to set forth in detail the experience with the various classes of banks operating under State and National laws, and with those whose transactions were carried on without legal sanction.

There is no lack of information available in regard to banks deriving their authority from the Federal Government, and particularly since the adoption of the National banking system there has been a complete record, statistical and otherwise, of the progress of these institutions. But with the State banks it is entirely different. While in some of the States, where banks have been placed under public supervision, considerable historical material is to be found, in others the collation of such data is exceedingly difficult, no statistics ever having been compiled and but few, if any, laws enacted regulating the business of banking.

The late John Jay Knox, who as Comptroller of the Currency for many years had charge of the execution of the laws relating to National banks, was in the best position to obtain the information and gather the material for a work of this kind. As Comptroller of the Currency he was required by law to furnish to Congress annually statisties not only as to National banking associations, but also as to State banks, private banks, Savings banks and trust companies. In Mr. Knox's report as Comptroller for 1876 will be found the germ of this work. In that year and since, but especially during the last five years of his life, he was collecting gradually from all sources all that could possibly throw light upon every phase of banking in every State of the Union. It was his hope, as expressed in the preface to his well-known work on "United States Notes," to publish a volume worthy of the title "History of Banking in the United States." With this purpose in view he substantially completed that portion of the work relating to National banks, and also accumulated a large part of the facts desired for treating of

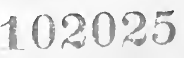


the State banks; but he did not live to finish what he regarded as one of the most important undertakings of his life. Through the editorial co-operation of Mr. Wm. B. Greene, for many years Chief of Division in the Comptroller's Bureau under the administration of Mr. Knox, and who was entirely familiar with the author's plans, it has been possible to carry out these plans in accordance with their original scope. A comprehensive history of banking in the various States was deemed an essential feature of the book, especially as there was nothing of the kind in existence, and as the public records were either incomplete or nonexistent in many cases, it was thought best in the preparation of this part of the work to secure the aid of those who were familiar with banking traditions and who understood the best means of bringing out the striking features of State bank history. As a result of their long and patient researches a record is here presented that may be found nowhere else and that constitutes an invaluable source of knowledge to students of American banking. A list of these contributing authors follows: Arkansas, Robert J. Brown; Connecticut, Charles E. Curtis; Florida, Charles A. Choate; Georgia, W. G. Cooper; Illinois, Frank W. Tracy; Indiana, W. H. Sinith; Iowa, George G. Hunter; Kentucky, John H. Leathers; Maine, E. A. Noyes; Maryland, Alfred Cookman Bryan, Ph. D.; Minnesota, E. M. Pope; Missouri, Chas. Parsons, assisted by D. M. Grissom; Nebraska, Henry W. Yates; New Hampshire (Savings banks), James O. Lyford; New Jersey, Thomas Holmes; North Carolina, W. A. Blair; North Dakota, R. E. Wallace; Ohio, Wm. A. Graham; Pennsylvania, Frank M. Eastman; South Carolina, George W. Williams; South Dakota, Maris Taylor; Tennessee, John W. Faxon; Utah, Geo. M. Cannon; Virginia, John D. Murrell; West Virginia, W. C. Beans; Wisconsin, N. B. Van Slyke.

The history of banking in the States not enumerated above has been compiled from memoranda left by Mr. Knox and from other sources.

- Acknowledgment is due to the many bankers and State bank supervising officers for their co-operation. The publications issued by the Reform Club, of New York, under the title of "Sound Currency" and the reports of the Comptroller of the Currency have been freely quoted.

Valuable assistance in the preparation of the volume has been rendered by Mr. E. H. Youngman, Associate Editor of the BANkers' Magazine, the entire work being under his inmediate editorial supervision.

The statistics of banking in many of the States are incomplete. In the Comptroller's report for $\mathbf{1 8 7 6}$ will be found tables showing the condition of these institutions from 1834 to 1863 . The items that seemed to be most important, viz., the number of banks, loans and discounts, 
specie, capital, circulation and deposits, have been reproduced. For the years subsequent to 1863 the figures are in most instances from the reports of the Bureau of Statistics of the United States Treasury Department or from the Comptroller's reports. As the law does not compel State banks to report to the Federal Government, these statements are believed in some cases to be incomplete, but are as nearly correct as it is now possible to obtain. Fortunately, however, it has been found possible, after much laborious research, to obtain accurate statistics from most of the State banks in more extended form. Official publications have been consulted for this information in those States having a State banking department. The statistics of the National banks are from the reports of the Comptroller of the Currency, and are full and accurate from the beginning of the system to the present time.

No country in the world can equal the United States in the number of its banks or in the variety of banking systems. At some time in our history nearly every theory in regard to eredit and banking has been tried, with results that may be studied with interest and profit. To chronicle these experiences without conscious bias has been the aim of the publishers of this volume.

BRADFORD RHODES.

New York, May, 1900. 



\section{HON. JOHN JAY KNOX.}

The author of this work was distinguished among recent American financiers by reason of his long official connection with the Bureau of the Comptroller of the Currency-five years as Deputy Comptroller and twelve years as Comptroller-by his relationship to the famous coinage act of 1873 , and by the reputation which he earned as a successful banker and as a writer and lecturer on banking and financial topies. While he was long regarded as an authority on these subjects, he was to the end of his life a student, ever learning by study and experience, and in the light of such information he did not hesitate to change his opinions, valuing truth always above consistency.

His public acts were marked by lofty intelligence and absolute devotion to the great interests intrusted to his keeping, and in business and private life he measured up to the highest requirements. He was straightforward and candid in what he did and said, and no man was less likely to resort to evasion and subterfuge to carry out his plans. His fights were made in the open field, and no one need question where he stood on any public issue. His advancement to a high position in the administrative affairs of the Government was due to his ability and character and not to political influence.

Mr. Knox was born at Knoxboro, Oneida County, N. Y., March 19, 1828, his father's ancestors being Scotch-Irish. His early education was received at the Augusta Academy, near Knoxboro, and at the Watertown Classical Institute. In 1849 he graduated from Hamilton College. Among his fellow students were Hon. Joseph R. Hawley and Charles Dudley Warner, of Hartford, Conn., and Rev. Dr. Thomas S. Hastings and Col. Emmons Clark, of New York.

He began his business career in a bank at Vernon, N. Y., of which his father was President, remaining there for two years, until 1852, when he entered the Burnett Bank, of Syracuse, N. Y., where he remained for four years. Subsequently he was for a brief period Cashier of the Susquehanna Valley Bank, at Binghamton, N. Y. In 1857 with his brother, Henry M. Knox, afterwards Public Examiner for the State of Minnesota, he started a private bank at St. Paul, the business being continued for six years.

Mr. Knox first attracted attention as a financier in the discussions preceding the establishment of the National banking system. In 1861 
and 1862 he published two carefully prepared papers in "Hunt's Merchants' Magazine," of New York.

Secretary Chase, in his report to Congress for 1861, suggested the issue of bank circulation on a basis of United States stock as one of two plans for assisting the Government in carrying on the war. Mr. Knox's second paper, published in January, 1862, advocated the establishment of a National banking system as suggested by Secretary Chase. His principal argument in favor of his plan was the absolute safety it would insure in the currency of the country. In his last address upon the subject of a permanent National bank circulation before the convention of the American Bankers' Association in New Orleans in 1891, in enumerating the attributes of a perfect system of paper currency, he named first safety, second elasticity, third convertibility and fourth uniformity. These points were considered in the same order in his article in "Hunt's Merchants' Magazine" in 1862, which attracted the attention of Secretary Chase. He was first appointed by the Secretary to a clerkship under Treasurer Spinner, but was soon transferred to the office of Mr. Chase as a disbursing clerk. He held this position three years, when he becane Cashier of the Exchange National Bank, Norfolk, Va. The climate did not agree with him and he returned to Washington and was placed in charge of the Mint and Coinage correspondence of the Treasury Department. In 1866 Secretary McCulloch, who recognized his ability, sent him to San Francisco to examine the branch mint in that city. His report was published in the Finance Report for that year with the commendation of the Secretary. Mr. Knox also made an examination of the mint at New Orleans in 1866 and discovered a defalcation of $\$ 1,100,000$ in the offlce of the Assistant Treasurer of the United States. For a time during his stay in New Orleans he was acting Assistant Treasurer. In 1867 a vacancy occurred in the office of Deputy Comptroller of the Currency, and Mr. Knox was appointed to the position by Secretary McCulloch. While engaged in these various offices he continued to have charge of the Mint and Coinage correspondence of the Treasury Department. It was in this connection that he came to be the author of the coinage act of 1873 , since famous as the law discontinuing the coinage of the silver dollar. He drew up a bill codifying the mint and coinage laws, and in his letter to the Secretary of the Treasury, under date of April 25, 1870, Mr. Knox wrote:

"The coinage of the silver dollar piece, the history of which is here given, is discontinued in the proposed bill. * * * The present gold dollar piece is made the dollar unit in the proposed bill, and the silver dollar piece is discontinued. If, however, such a coin is authorized, it should be issued as a commercial dollar, not as a standard unit of account, and of the exact value of the Mexican dollar, which is the favorite for circulation in China and Japan and other Oriental countries."

The preliminary draft of the bill provided for a silver dollar of 384 grains, and this coin was to be a legal tender for debts of not more than 
\$5. Mr. Knox submitted this preliminary draft to a number of experts in various parts of the country, for an expression of their opinions as to its merits. As a result of this interchange of views Mr. Knox prepared another draft of a bill omitting the silver dollar, as stated in the letter above quoted.

The bill was before Congress for three years, and passed the Senate January 10, 1871, with no provision for coining a silver dollar. The silver dollar was not in the bill reported to the House on March 9, 1871. In the following year the measure was brought up in the House, and a sentiment was developed in favor of restoring the silver dollar to be of the weight of two half-dollars, or 384 grains. The bill was reported to the House February 13, 1872, containing a provision to this effect, the legal-tender quality being limited to $\$ 5$. The bill passed the House in this form May 27, 1872.

In the Senate a trade dollar of 420 grains was substituted for the dollar of 384 grains, the legal-tender limit still being $\$ 5$, and in this form the bill passed the Senate January 17, 1873, the House February 7, and was signed by the President February 12, 1873.

During the three years that the measure was before Congress it was fully debated, the speeches on it in the Senate occupying sixty-six columns of the "Congressional Globe" and the House debates seventyeight columns of that publication.

When submitted to Congress the bill was accompanied by elaborate and extensive reports. These reports were printed and the reasons for discontinuing the silver dollar fully stated.

The standard silver dollar could not have been secretly omitted from this bill, for the reason that it never was in the bill at any time.

A complete documentary history of this act will be found in the Report of the Director of the Mint for 1896, p. 461, and the relation of Mr. Knox to the measure was fully set forth in his hearing before the House Committee on Coinage, Weights and Measures, February 20, 1891.

John Jay Knox was too much of an expert in finance to be deceived by the terms of the bill in question, and he was too honest to lend himself to trickery of any sort. He frankly stated at the outset that it was the purpose of his bill to discontinue the silver dollar and make the gold dollar the unit of value. As the author of the law firmly establishing the credit of the United States upon the gold standard, Mr. Knox performed a service to the country equal to that of any of its statesmen.

Mr. Knox was Deputy Comptroller until April, 1872, when he was appointed Comptroller by President Grant. At the expiration of his term, in 1877, he was reappointed by President Hayes and the appointment was at once confirmed, on motion of Senator Windom, without reference to the Finance Committee. In 1882 President Arthur appointed him for another five years' term, but on May 1, 1884, he resigned to become President of the National Bank of the Republic, New 
York city. He was President Garfield's first choice for Secretary of the Treasury, but political complications prevented the President from making the appointment.

As Comptroller of the Currency he made twelve reports to Congress, and they contain invaluable statistical and other information in relation to the banks of the country. During his incumbency the National banks were much more important as regards their currency-issuing functions than they are now, this feature of their business having been largely usurped by the Government paper and silver certificates. He was instrumental in carrying on the negotiations by which the SubTreasury at New York was made a member of the clearing-house, thus effecting great economy in the banking transactions with the Government.

Mr. Knox was successful as a banker, the deposits of the institution of which he became President increasing from $\$ 4,000,000$ to over $\$ 15$,000,000 in the eight years of his management. His death occurred at his home in New York, February 9, 1892.

The nucleus of the present work is contained in a series of papers published in "Rhodes' Journal of BANKING" in 1892. Besides these and other contributions to this publication, Mr. Knox lectured at frequent intervals before several chambers of commerce, the American Bankers' Association, the students of Yale, Harvard, Hamilton, Columbia and Johns Hopkins Universities. $\mathrm{He}$ is besides the author of a well-known work on "United States Notes," a history of the various forms of paper money issued by the Government.

Mr. Knox was admirably fitted by training and experience for the important stations which he filled, and his long executive experience and excellent business habits proved of great value when he became the head of a large metropolitan bank. The honesty of purpose which characterized him when acting for himself also marked all his dealings as a trustee for others. His acquaintance was extensive and his high mental and moral qualities won him many friends in private and business life.

The Chamber of Commerce of the State of New York, one of the oldest and greatest commercial organizations of the country, at a meeting held on March 3, 1892, paid a special tribute to the inemory of Mr. Knox, addresses being made by a number of distinguished citizens of New York and suitable resolutions were adopted, closing in these words: "Patriotic in his impulses, strong in his convictions, thoughtful but reserved, modest yet courageous, a deep thinker, an able financier, an agreeable companion, a kind friend, an upright citizen and a courteous Christian gentleman. Such is our judgment of his character, and so shall the record stand." 


\title{
CONTENTS.
}

\author{
PART I. \\ BANKS AND BANKERS UNDER FEDERAL LAWS.
}

\author{
CHAPTER I. \\ Origin and Development of Banking.
}

General plan - Origiz of banking - Bank of Venice-Bank of Genoa-Bank of Amsterdam - Early banking in England-Bank of England-Scotch and Irish banks - Bank of France - Banking methods and principles compared - Origin of word bank - Early banking in the United States - Political unpopularity of banks - Abuse of note-issuing function - Losses from bad banking - National banking system - Issue of paper money by the United States Treasury - Banking in the States.

\section{CHAPTER II.}

\section{Banking in the Colonies, Continental Money and State Banks.}

Issue of paper money in Colonies - Massachusetts land bank - Copy of English land bank - Land bank started - Colonial loan banks - Hutchinson's specie banks - Depreciation of colonial paper in 1748 - Parliament suppresses loan and other banks in Colonies - Forbids use of paper as legal tender - Power of Continental Congress - Issue of Continental money Jefferson's account of - Other authorities - Its depreciation and final disposition - Power of Congress and States to establish banks under Federal Constitution - Webster's opinion as to bank notes - Chase's opinion — Discussion of right of State bank to nspte notes. . . . . . . 15-24

\section{CHAPTER III.}

Banking Under the Laws of the Continental Congress and Federal Constitution, 1784-1817.

Introductory - Bank of North America chartered by Continental Congress Subscription in aid of Revolution-Thomas Paine - Sketch of Robert Morris - Hamilton's proposal - Design of Robert Morris - Bank of North America - Specie from France - Charter from Pennsylvania - Subsequent history - Becomes National bank - Considerations - First Bank of United States - Hamilton's report to Congress - Opposition - Constitutionality 
- Opinions of Hamilton, Jefferson and Randolph - Condition in 1809-1811 - Sketch of Alexander Hamilton - Application for renewal of charter Report of Mr. Gallatin - Sketch of Mr. Gallatin - Stock held by foreigners - Debates on renewal of charter - Clay's position - Refusal to recharter - Liquidation of bank and disposition of its assets - State banks, increase of-Secretary Dallas appointed - Sketch of Mr. Dallas' life - Sketch of Stephen Girard.

\section{CHAPTER IV}

\section{Banking Under Federal Constitution, Continued - Second} Bank of the United States, 1817-1829.

Petition from New York city for National bank - Secretary Dallas recommends National bank and furnishes plan-Action upon it unfavorable - Amended by Senate committee-Vote analyzed - Veto of President Madison-Recommendations of Madison-Report of Dallas' plan presented to House-Bill passes House and Senate-Synopsis of law for seeond Bank of the United States - Operations of bank in 1817-1818Speculation in its stock - Influence on State banks $\frac{1}{4}$ Causes of dissatisfaction - Investigation by Congress - Mismanagement shown - Change of officers - Great success of bank from 1820 to 1829 - Nicholas Biddle becomes President-Sketch of Biddle and other Presidents - Beginning of attack by Jackson - Message of 1829 - Jackson's position - Report of House committee - Amos Kendall - Kitchen cabinet.

\section{CHAPTER V.}

\section{Attack Upon the Bank of the United States.}

Message of Jackson in 1831 - Renewal of Charter applied for - Position of parties - Cry of fraud and corruption - Subsidies to newspapers - Charter extension passes both Houses - President's veto-Message of 1832 - Stock owned by United States - Removal of deposits - Sounding State banks - President's manifesto to cabinet-Duane superseded-Order for removal - Congress notified - Resolutions of censure-Benton and Webster-Expunging resolution - Exciting scene at its final passageMajority against recharter - Policy of bank-Financial distress - New charter granted by State of Pennsylvania-Bad management-Final liquidation.

\section{CHAPTER VI.}

\section{Removal of Public Deposits from the Bank of the Unted} States-Independent Treasury.

Public money deposited with the State banks - Pet banks - Increase of surplus public money - Party advancement by favor to banks - Stimulation of public land sales - Losses from bank failures - Specie circular - Bill to compel receipt of specie-paying bank notes vetoed-Law regulating deposits in State banks - State bank statistics - Effect of specie circular - Surplus distributed among States - Effect on banks - Suspen-

a sion of specie payments - Extra session of Congress - Independent Treasury - Government almost bankrupt - Treasury notes - National bank contest - Clay and Tyler - Political intrigues - Veto of first bank bill - Tyler's vacillation - Final veto of bank bill. 


\section{CHAPTER VII.}

\section{National Banking Law, 1863-1872.}

Underlying principles of National Bank Act - Attempt of Secretary Dallas in 1813 to unite State banks in a system - Article in "Analectic Magazine," 1815 - Alexander Hamilton's proposition - Letter of Prof. John McVickar - Banking law of Michigan - Free banking law of New York - Abijah Mann's claim - Difference between banking law of New York and National Bank Act - Mr. Potter's proposition - Draft of National Currency Act - Office of Comptroller of Currency - Appointment of Hugh MeCulloch - Enabling acts - Comptroller's reports of 1863 and 1864-Admission of State banks to the system - Tax on State bank notes - Meeting of New York Clearing-House - Objections to National system - Unfavorable report - Reply thereto - Report of Comptroller for 1865 - Hon. Freeman Clarke succeeds Mr. McCulloch - Difficulty in redeeming notes - Freeman Clarke succeeded by Mr. Hulburd - Progress of system from 1867-1870 - Reports of condition - Interest on deposits - Failures - Correction of defects in law - Resumption of specie payments - Unequal distribution of circulation - Attempted legislation of 1870 - Sherman's prophecy - Increase of circulation - Mr. Knox succeeds Mr. Hulburd - License and income taxes repealed - Report of 1872.

\section{CHAP'TER VIII.}

\section{Progress of National Banking System, 1872-1878.}

Criticism of fixed reserves-Great fire in Chicago-Locking up money in New York - Action of clearing-house - United States not preferred creditor of National banks - Evasion of ten per cent. tax law-Marking counterfeit and spurious notes - Panic of 1873-Issue of clearing-house loan certificates - Panic investigations - Reforms of clearing-houseForced redemption of notes proposed - Withdrawal act of 1870 , difficulty of execution - Proposed exchequer bank - Act of June 20, 1874-Opinion of Attorney-General-Fluctuations of circulation-Operation of Section 4, aćt of 1874-Large reserves held, 1874-75-Comptroller's report of 1875 - Gold notes in California-Operation of redemption agency - Designs and denominations of National bank notes - Discrimination in the taxation of bank shares - Two-cent stamp tax - Usury - Printing of notes - National bank law consolidated in revised statutes

- Recommendations of the Comptroller.

\section{CHAPTER IX.}

\section{Contest Betwefn the Legal-Tender Notes and National Bank Notes, 1862-1878.}

Two measures for furnishing currency for war - Legal-tender act temporary and the National bank currency a permanent measure-Senator Sherman's opinion - Opinion of Mr. Spaulding - Obstacles in the way of the banking system - Lack of organization among the banks in 1862 - Bank loans to the Government in 1862 - National system suggested-Could the war have been carried on with bank notes - Legal-tender funding repealed - Comparison of legal tenders and bonds in 1863-Secretary McCulloch's contraction policy - Errors in limiting bank issues - Act 
of July 12, 1870 - Effect of premiums on bonds - Unfavorable attitude of Congress toward banks - Popular opposition to banks - Fiat money and interchangeable bonds - Greenback convention of 1876 - Bills in House and Senate in 1878 - Other measures - Interview of Comptroller of Currency with Banking and Currency Committee-Pamphlets in 1878 - Attacks on Resumption Act on the stump - Opinions of financiers and others before Banking and Currency Committee - Operation of Act of July, 1870, for redistribution of bank circulation - Redemption of $\mathrm{Na}$ tional bank notes - Act of June 20, 1874, and its operation - Effect of Treasury influence on legal-tender notes - Uniformity of value prevents redemption of bank notes in legal-tender notes - Voluntary retirement of bank circulation - Act of January 14, 1875 - Operation of act of 1875 - Effect of bond premiums.

\section{CHAPTER $\mathrm{X}$.}

\section{Progress of the National Banking System, 1878 to 1880.}

Act of January 14, 1875 - Views of the Comptroller on Resumption - History of National bank circulation - Comptroller's report for 1879-Gold obtained for resumption-Refunding of the public debt-Contracts for sales of bonds - Public debt of England-Imports of gold - Proposals to substitute legal-tender notes for National bank notes - Value of circulation privilege in 1879 - Illegal certification of checks - Comptroller's report for 1880 - Gold certificates. . . . . .

\section{CHAPTER XI.}

\section{History of the National Banking System, 1881 to 1884.}

Legislation of 1881 - Forcing National banks to buy bonds - Proposed repeal of act of June 20,1874-Synopsis of bill of 1881 - Veto of billWithdrawal of bonds by banks - Attitude of the Treasurer of the United States - Extension of bonds in 1881 - Renewal of National bank charters - Extension act of 1882 - Organization of new banks - Bank failures in 1882 - Losses by National bank insolvency - Contraction of National bank currency - Comptroller's plan for reducing interest on bonds Over-certification of checks - Legislation of 1883-84.

\section{CHAPTER XII.}

\section{History of the National Banking System, 1884-1891.}

Henry W. Cannon appointed Comptroller - Panic of 1884 - Action of clearing-house-National bank failures in New York-Form of clearinghouse loan certificates - Over-certification of checks - New York law Legal-tender certificates - Interest on deposits - Demand loans as a resource in panics - Comptroller's report for 1885 - Liquidation of failed banks - W. L. Trenholm appointed Comptroller - Decrease in National bank circulation - Organization of National banks from 1882-1887 - Redemption of three per cent. bonds - Comptroller's report for 1887 Government deposits in National banks - Surplus revenues used in the purchase of bonds - National bank failures in 1888-E. S. Lacey appointed Comptroller -- Suburban banks - Indian Territory banks - Legislation recommended - Reduction of circulation -- Panic of 1890 - Fail- 
ures of Panama Canal Company and the French Copper Syndicate-

Baring failure - Action of banks in New York, Boston and Philadelphia

- Bond purchases.

\section{CHAPTER XIII.}

\section{Progress of the National Banking Sxstem, 1892-1899.}

Decline in National bank circulation - Silver-purchase acts of $18 \pi 8$ and 1890 - Panic of 1893 - Bank failures - Clearing-house loan certificates Decline in banking profits - Consolidation of banks - State and National banks in New York - Presidential campaign of 1896 - Condition of the National banks in 1892 and 1896 compared - Gold holdings of the banks - Increase of deposits and clearings - Per cent. of dividends paid by failed banks - Use of checks and credit instruments - Branch banks recommended - Issue of notes by the Government and the banks - Revenues received from the National banks - Comptroller's report for 1898. 200-219

\section{CHAPTER XIV.}

\section{Review of National Bank Legislation.}

Secretary Chase's report of 1861 - Drafting the National Currency ActLegal tender act - Debate on legal-tender bill-Tax bill - National Currency Act - Debate on Currency Act-Amendments - Criticism of sections - Opposition of State banks - Bill passes Senate-Secretary of the Treasury on bond negotiations - Repeal of provision of law for funding legal-tender notes into bonds - Currency bill in House - Debate in House - Bill passes House and becomes a law - Defects of act of 1863-Comptroller McCulloch's report of 1863-President Lincoln on Currency Act. 220-234

\section{CHAPTER XV.}

\section{Currency ACt of June 3, 1864.}

Proposed amendments of the National Currency Act-Secretary Chase's policy arraigned - Banks of $\$ 50,000$ capital- Interest to be charged by National banks - Provisions for redemption of notes - State taxation of National banks - Proposed conversion of State banks - Deposits of Government funds in the banks - Withdrawal of State bank circulation Denunciation of National banks - State taxation amendment-Prejudice against National banks - Mr. Hooper's speech - Bill amended and passed by the House - Senator Sherman's explanation of the measureBank of Commerce, of New York city, exempted from double liability of shareholders - Senator Sumner's views - Secretary Chase on State taxation-Market value of bonds as a basis of circulation-Bill amended and passed by both Houses - Signed by President. . . . . 235-269

\section{CHAPTER XVI.}

\section{National Bank Legislation, 1864-1900.}

Act of March 3, 1865 - Inequalities in the distribution of circulation - Withdrawal of bonds by banks in liquidation - Certificates of deposit for legaltender notes-Trying to account for the panic of $18 \% 3$ - Remedies proposed-Veto of the inflation act-Repeal of law requiring reserve on circulation - Proposed resumption of specie payments - The greenback

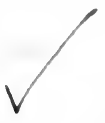


theory - Further retirement of legal tenders prohibited - Extension of PAGES corporate existence - Lack of commercial redemption of notes - Indisposition of Congress to enlarge the circulation privilege-Amendment of the law in 1900.

\section{CHAPTER XVII.}

\section{Portraits and Sketches of Noted Financiers of the Civil WAR Period.}

Salmon P. Chase, Lincoln's first Secretary of the Treasury -John Sherman, author of the Resumption Act - Hugh McCulloch, the first Comptroller of the Currency and twice Secretary of the Treasury - Elbridge G. Spaulding, the "Father of the Greenbacks."

\section{CHAPTER XVIII.}

National Bank Statistics, 1863 to 1899.

Complete statement of resources and liabilities of all the National banks in the United States, and number of banks in operation, for each year from 1863 to 1899.

\section{PART II.}

\section{BANKING UNDER STATE LAWS.}

\section{CHAPTER I.}

\section{State Banks in the United States.}

Establishment of the first State banks - Difficulity of procuring statistics Condition of banks from 1811 to 1829 - Banks of the United States and State banks, 1811 to 1840 - State banks from 1834 to 1898 - Financial heresies from 1811 to 1861 - Various laws under which banks were organ-

- ized-Losses through bank failures - States as bank stockholdersEarly proposal to tax State bank notes-Failures of State banks.

\section{CHAPTER II.}

\section{New England States.}

MaINE. - First banks chartered-Methods of redeeming bills- Losses in making collections - Maine admitted into the Union - State banking legislation-Operations of the Suffolk system - Suspension of specie payments in 1837 and 1857 - Conversion of State banks into National banks - Statistics of State and National banks-Savings banks.

NEw HAMPSHIRE. - The New Hampshire Bank - Rival banks operating under the same charter - State assumes supervision of the banks - Progress of the banks from 1831 to $1843-$ Bank failures - Banking law declared to be aristocratic-Private banking prohibited-Board of Bank Commis- 
sioners established - State banks absorbed hy National system - Statistics of State and National banks - Savings banks, complete history of the Savings bank system of the State, with statistics.

VERMONT. - Experience with counterfeit and depreciated paper - Opposition to a State bank - Banks declared to be productive of gambling, and fatal to any country where they exist-Bad bank bills from other StatesVermont State bank - Launching a bank with $\$ 500$ capital invested in plates from which to print notes - Stringent laws for collecting debts Banks required to redeem in specie - Outline of provisions of bank charters - Safety-fund system - Limitation of circulation - Free banking act of 1851 - Statistics of National and State banks - Savings banks and trust companies.

Massachusetrs. - Colonial bills issued and loaned to the people-Massachusetts Bank chartered - Issue of notes of small denominations-Successful resistance of the crisis of 1814 - Forty-one years of banking history - Banking law of 1829 - Financial convulsion of 1837 - Official examination instituted - A sound system of banks - Free banking law of 1851 - The Suffolk banking plan of redemption - Comparison of redemptions under Suffolk and National systems - Statistics of State and National banks - Savings banks - Trust companies.

RHode IsLAND. - Great banking power of a small State - Early banks Novel plan of issuing circulation-Penalties imposed on directors for violation of banking laws - Statistics of State and National banks-Savings banks and trust companies.

ConNecticut. - Colonial bills-Bank notes supplant State currencyStrength of the banks demonstrated in 1814-Public examination - Condition of the banks in 1836-Loans outside the State - Small bills prohibited - Maintaining specie payments in 1839 - Post notes - Suffolk system-General expansion - Banking law of 1852 - Panic of 1857 - Loans to the Government during the Civil War - Decline in bank earnings Statistics of National and State banks and trust companies - Savings banks.

\section{CHAPTER III.}

\section{EASTERN STATES.}

New YoRk. - The chartered banks - How Aaron Burr got a bank charter Bank of New York, The Manhattan Company, Bank of America and other early banks - Safety-fund system of chartered banks - Free banking law - Comparison of systems - Why the safety fund was not a complete success - Issue of notes on State securities - Imperfect methods of redemption - Revision and consolidation of the banking laws - Statistics of National and State banks - New York Clearing-House Association-Savings banks - Trust companies - Historic New York city banks. . . W JERSEY. - Oldest banks of the State-- A royal customer-Assistance to the Government - First banking law - Law of 1850-Organization of banks - Statistics of National and State banks - Revision of the banking laws in 1899 - Savings banks - Trust companies. . . . . .

Pennsyluania. - Bills of credit issued by the Province and made a legal tender - Bank of North America - Bank of Pennsylvania and other historic institutions - Act of March 21, 1814-Condition of the banks in 
1816 - Financial distress, 1816-1820 - Bank of the United States becomes

$\checkmark$ a State bank-Panic of 1837-Agitation against banks-Compulsory resumption of specie payments - United States Bank fails-Crisis of

- 1857 -Free banking system - Present condition of the banks - Statistics of State and National banks - Savings banks - Trust companies - Taxation - State Banking Department.

Delaware. - Bank of North America chartered - Farmers' Bank of Delaware - State as owner of bank stock - A sound banking system - Statistics of State and National banks.

MARYLAND. - Depreciation of Continental and State money - The first bank - Banks formed to aid agriculture - A typical bank charter - Characteristics of the early banks - Scotch system of cash credits - Industrial experiments by the banks - Lack of proper restraints on circulation - Capital paid in stock notes - Banks buying their circulation at a discountBanking expansion - Uniform laws - Increase of taxation - Crisis of 1834, 1837 and 1839 - General banking law of 1853 - Crisis of 1857 - Baltimore Clearing-House - Suspension of 1860 - Effects of the National

- Bank Act-Statistics of State and National banks. . . . . 4 469-518

District of Columbia. - How banks are organized and controlled - Bank of Columbia chartered in 1793 - Condition of the banks in 1836- Statistics.

\section{CHAPTER IV.}

\section{SOUTHERN States.}

Virginia. - Colonial banking - Issue of notes by individuals prohibited Bad state of the coins in circulation - Tobacco as money - Notes issued secured by tobacco - Depreciation of Continental and other notes - First chartered bank - Banks under State control, modelled on the Scotch system - Soundness of the old State banks - Provisions for banks of issue in the law of 1837 - Free banks of Virginia - Saving a bank's gold -

- Banks of discount and deposit-Banking subsequent to the Civil War - Simplicity of the banking laws - Statistics of National, State and private banks.

West Virginia. - The pioneer banks - Growth of the banking business Distribution of banks - Public examination-A record of successState and National bank statistics.

North Carolina. - Bills of credit issued - Depreciation and substitution of other bills - First chartered banks - State Bank of North Carolina-Private note issues - How banks were managed in 1828-Banking legislation - Condition of the banks in 1839 and 1849 - Increase of banks History of the Bank of North Carolina - Methods of issuing circulation - Gold and silver holdings - Banking during and subsequent to the Civil War - Statistics of National, State, Savings and private banks.

South Carolina. - Experience with depreciated State currency - Land and loan bank - Beginning of State banking system - The Bank of South Carolina-Notable banks and bankers of the State-The Bank of Charleston - Soundness of the State banks - Destruction wrought by the Civil War - Statistics of State and National banks.

Georgia. - Paper money at a tremendous discount-Heavy depreciation of State currency - Establishment of State banks - Specimen of a primi- 
tive form of paper money - Organization of a Central Bank by the State

PAGES - Branch Bank of the United States - Central Railroad and Banking Company - Profits of the older banks - The Civil War - Issue of notes redeemable in Confederate currency - Restoration of prosperity - Summary of the banking laws - Statistics of State and National banks.

FloRIDA. - Territorial banks - Land banking - Union Bank of FloridaLegislation relating to banks - Present banking law - Statistics of National and State banks.

Alabama. - Rise and fall of the Bank of the State of Alabama - Second bank of this name chartered-Its history - Some peculiarities of bank management in 1837 - How a countryman lived royally without expense to himself - Conviviality as a qualification for a bank directorship - Liquidation of the bank - Other historic banks - State and National bank statistics - Present banking law.

MississiPPI. - Bank of Mississippi-Other noted banks - Bank based on State credit-Attack on the validity of bonds issued in aid of banksMississippi Union Bank - Crude ideas in regard to banking - Strength - of the existing banks - Statistics of Nationa and State banks.

Louisiana. - Successful operations of the Bank of Louisiana - The Union Bank of Louisiana - Plan of organization - State partnership in banks prohibited-Bank eirculation from 1835 to 1852 - Bank act of $1842-$ Description of the leading features of a sound and notable banking system - Present law - State and National bank statistics.

Texas. - Various forms of go vernment - Finances of the Republic of Texas - Banking legislation of the Texas Congress - Government bank proposed - How a herd of swine prevented Texas from obtaining a loanAnnexation to the United States-Evolution of Texas currency-Banks prohibited by the constitution - Circulation of notes issued on the credit of individuals - Banking during the reconstruction era - State banks permitted, and again forbidden - Reports of State banks - National and

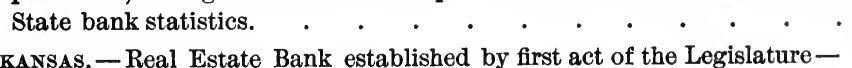

ARKansas. - Real Estate Bank established by first act of the Legislature-
Bank of the State of Arkansas - Disastrous experience due to imperfection of plan of organization - Pioneer banks and bankers - First National Bank, of Little Rock - Absence of banking laws-Little Rock bank clearings - Statistics of National and State banks. $\cdot \cdot \cdot \cdot$

KENTUCKY. - Devices for obviating the scarcity of currency - Clandestine
bank charters - Bad effect of stay laws - Banking monopoly broken upBank of the Commonwealth - Suspension of specie payments in 1837History of the Bank of Kentucky - Louisville Clearing-House Association - Crisis of 1890 - New bank tax law - Louisville banks - Crisis of 1893-Statistics of National and State banks.

Tensessee. - Barter currency - State as a banker - Reports of the first banks-Second bank of the State-Andrew Jackson's hard-money views-Union Bank of Tennessee-Bank of Tennessee-Mixture of politics with banking - Free banking law - Unsatisfactory experience with banks of issue-Banking during the Civil War-Liquidation of the Bank of Tennessee - Losses to depositors - Specimens of State bank currency-History of the various issues of notes - Principal banking cities - Laws relating to banks - Failures and liquidations-Statistics of National and State banks. 


\section{CHAPTER V.}

\section{MIDde States.}

Онго. - Bank incorporated by the first Legislature - Unauthorized circula tion prohibited - Suspension due to War of 1812-Salmon P. Chase on speculative banking - Legislation - Branch Bank of the United States prohibited - Banking law of 1839-Revision of the law in 1842-Opposition to the Bank of the United States - Taxation - Causes of suspension in 1837 - How the banks were organized and operated - Unsatisfactory experience with notes based on commercial assets-Act of 1845-Free banking law - Forged notes - "Crowbar law" to enforce payment of

- taxes - National banking - Noted names in the banking history of the

- State-Panic of 1873-Progress of the banking business - Savings banks - Statistics of National and State banks.

INDIANA. - Good and bad banking illustrated - Territorial banks - Provision of the constitution - State Bank of Indiana - A notably successful institution - General banking law - Bank of the State of Indiana - Resisting the panic of 1859-"Red dog" and "blue pup" bank notes - The "wildcats" - Free banks - Private banks and bankers - Savings banks and trust companies - Distinguished bankers-Statistics of State and National banks.

ILLinors. - Bank of Illinois - A phantom bank - History of the State Bank of Illinois - Political banking - Banking inflation and failure of the State bank - Prominent bankers - Prejudice against banks - State forbidden to engage in banking - Small notes of banks of other States prohibited - Crisis of 1861 - Early banking in Chicago - George Smith's successful

- bank - Banking of to-day - Statistics of National and State banks.

Mrchigan. - Bank of Michigan - Michigan State Bank - Disastrous loan negotiations - Free banking law of 1837 - Imperfect administration of the law - Manner of starting a bank - Disasters due to lack of enforcement of the law - Free banking act declared unconstitutional - Unsuccessful - attempt to start a State bank - Later banking law-Growth of State

- banks - Statistics of National and State banks. . . . . .

Wisconsin. - Territorial experiences - George Smith's bank - Specimen of deposit currency - General banking law of 1852-Provision for State examination-Wildcat banks described-First meeting of bankers Changes wrought by the Civil War - Panics and their effects on the banks - Some of the pioneers of Wisconsin banking - Reports of condition of State, private and Savings banks - National and State bank statistics. 738-752

Minnesota. - Constitutional restrictions on banking - First banking lawBanks of issue located at inaccessible points - Plan for securing notes Bank of the State of Minnesota - Legitimate banks of issue unprofitable - Discount on bank notes - Facts about the early banks - Public Examiner made ex-officio Superintendent of Banks - Law of 1881 and subsequent acts - Growth of the discount and deposit banks - Savings banks and trust companies - National bank statistics.

Iow A. - The Miners' Bank, of Dubuque - Congress restricts the powers of the bank - Territorial banking - Admission into the Union - Character of the circulation-Equipment of the primitive banks - Banking made a penal offence-Bad results of the law prohibiting banking - Depreciated currency from other States - New constitution adopted permitting 
banking - The State Bank of Iowa - Organization and management -

Security for circulation - Suspension during the Civil War - Closing of the State Bank - Report of condition at two different dates - Present system of banking - Table showing condition of State banks for a series of years - Savings banks, with statistics - Organization and growth of

- National banks - Private banks - Iowa Bankers' Association - Business and banking characteristics of the State-Good record of the banks National bank statistics.

Missouri. - Skins as currency - Introduction of coin - Establishment of a bank - Bank of Missouri - Bank of the State of Missouri-Conservative policy regarding circulation - Conversion into a National bankFailure - State banks of issue chartered - A safe convertible bank "currency - Pioneer banks of St. Louis - Banks organized under the National system - Establishment of Savings banks - Noted private bankers - St. Louis Clearing-House - Trust companies - Panic of 1873 - Improvement of banking conditions - State, private and National bank statistics.

\section{CHAPTER VI.}

\section{Western States.}

North Dakota. - Beginning of the banking business-First incorporated bank - Law of 1890 - Private banks prohibited - Speculative banks Increase in the number of banks - Comparative statistics of State and National banks.

South DakотA. - A successful private banker - Establishment of National banks - Multiplication of banking facilities - Rapid increase of population-Mortgage loan companies - High interest rates - Reaction from inflation period - Banking legislation - Provisions of the law - Statistics of National, State and private banks. . . . . . .

Nebraska. - Flood of bank notes - Banking declared a crime-How bank charters were obtained under cover of other titles - The Bank of Nebraska - A bank that always redeemed its notes - Era of deposit banking - Descendants of historic banks-Banking in the sixties-Banks doing business in 1873 - The railroad era-Statistical informationSavings banks - Nebraska Bankers' Association - Lessons derived from experience with banks of issue - National bank statistics.

ANsas. - Real estate speculation fostered by mortgage companies - Banking law of 1891 - Fraudulent loan companies - New banking law adopted - Review of its provisions - State and National bank statistics - Comparison of the different kinds of banks - Proposal to insure depositors. 819-824

Montana. - Regulations governing banking - Careful enforcement of the law - Average capital of the banks - A brief, but creditable banking record - State and National bank statistics.

Wroming. - Admission into the Union - Strength of the private banks Gain in resources of State institutions - Requirements of the banking law - Strict State supervision - Statistics of National, State and private banks.

CoLoraDo. - Gold-dust banking - Private bankers - How the product of the mines was handled - Private mints - Bank chartered by Territorial Legislature - Noted firm of bankers - Private and State banks reorganized 
under National system - Comparison of State and National banks - FailPAGES ure of attemps to secure State supervision - Hoarding of bankable funds - High rates of interest - Laws governing banks - Business prosperity - Statistics of National and State banks. $\quad . \quad . \quad . \quad . \quad . \quad .829-836$

New Mexico. - Primitive places of deposit - Laws relating to banks - Sta-

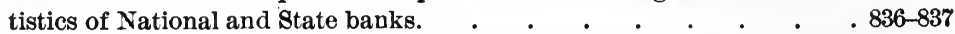

OKLAнома. - Private banking prohibited - A stringent banking law - Rapid growth of banking - Statistics of National and Territorial banks.

INDIAN TERRITORY. - How banks other than National may be established -The first bank - National bank statistics. . . . . . . 838-839

\section{CHAPTER VII.}

\section{Pacific States.}

WASHINGTON. - Circulating notes prohibited-General laws relating to banks - Seattle banks resist a panic-Statistics of National and State

OREGON. - Provisions of law for incorporating banks - Specially-chartered banks and banks of issue prohibited - First bank established in Portland - Other early banks - Preponderance of National over State institutions - Statistics of State and National banks.

California. - Gold discoveries of 1848 - Brokers in gold dust-Private coinage - Crisis of $\mathbf{1 8 5 5}$ - United States Mint established in San Francisco-Suspension of the Bank of California and suicide of W. C. Ralston - National gold banks - Bank of the bonanza kings, Flood, O'Brien, Mackay and Fair - San Francisco Clearing-House-Board of Bank Commissioners created-Private banks compelled to make reports - Panic of 1893-Condition of the banks in 1899 - Comparative statistics of Savings, commercial and private banks - Savings banks - Growth of deposits - National bank statistics. . $\cdot{ }^{\circ} \cdot{ }^{\circ} \cdot{ }^{\circ} \cdot{ }^{\circ} \cdot$

IDAHo. - Admission into the Union in 1890 - Meager banking history-
Banks organized under general corporation law - Statistics of National and State banks.

UтAн. - Plan of the pioneer settlements-Brigham Young establishes a private mint-Merchants as bankers - Development of banking - Comparative figures of National, State and private banks - Requirements in regard to reports - Statistics of National banks. . . . . .

NevadA. - Small population of the State - Licenses imposed upon banks Voluntary publication of statements - Early banking facilities - Statistics of National and State banks. $\quad . \quad . \quad . \quad . \quad . \quad . \quad . \quad .85$ Izona. - Organization and supervision of banks - Summary of the law Restrictions on Savings banks - Statistics of State and National banks. 856-857

ALASKA. - Characteristics of Alaskan banking - National bank statistics.

Growth of Savings Banks. - Statistics showing the number of banks, number of depositors, amount of deposits and average to each depositor of the Savings banks of the United States, 1820-1899.

Statistics OF BANKs OtHer than NATIONAL. - Statement of the resources and liabilities of State banks, loan and trust companies, Savings and private banks in the United States in 1899. 


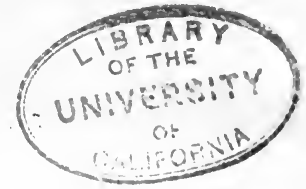

\title{
HISTORY OF BANKING
}

IN THE

\section{UNITED STATES.}

\author{
PART I
}

\section{BANKS AND BANKERS UNDER FEDERAL LAWS.}

\section{ORIGIN AND DEVELOPMENT OF BANKING.}

General plan-Origin of banking-Bank of Venice-Bank of Genoa-Bank of Amsterdam - Early banking in England - Bank of England - Scotch and Irish banks-Bank of France-Banking methods and principles compared-Origin of word bank-Early banking in the United States-Political unpopularity of banks-Abuse of note-issuing function-Losses from bad banking - National banking system - Issue of paper money by the United States Treasury - Banking in the States.

\section{Generax Plan of Work.}

A complete History of Banking in the United States should give an account of banks chartered by or doing business under the general banking laws of the Federal, State and Territorial Governments, both commercial and Savings banks, and such other financial institutions as do a banking business. It should also give an account of private banks.

Instead of adopting the chronological method of treating the subject it has been thought best to distinguish between the history of banks operating under powers derived from the Federal Government and those under the laws of the respective States. Division of the work has been made on these lines in so far as possible.

The history of banking under the Federal Government is introduced by a preliminary chapter relating to banking as it existed in the Colonies prior to the Revolutionary War, including an account of the Continental money. The following chapters narrate the events connected with the several banks that received charters from Congress and with the rise and progress of the National banking system. Subsequent chapters give the banking history of State, commercial, Savings and private banks and trust companies in the respective States. Other 
chapters in the course of the work are devoted to the correlation of important banking principles, and the results of banking experience under the diverse systems that have been tried in one or more of the States. Still other chapters are devoted to the history of bank taxation, of clearing-houses and kindred topies.

\section{Origin of the Banking Business.}

The business of banking is of great antiquity and in its simpler forms no doubt was understood and practiced by the Assyrians, Babylonians and Athenians. As the taking of interest for money lies at the root of all banking and furnishes the chief motive for it, wherever a people were sufficiently advanced to loan money for hire there would naturally spring up many of the practices and methods of modern banking. The transfer of credits was undoubtedly known among the ancients. They used checks and bills of exchange, but for all that they were very far from having the confidence in credit business that has been fostered by modern banking methods. They used gold and silver coin or other commodities then in use as standards of value and media of exchange and had not invented representative money. It is more fanciful than correct to ascribe to the Romans the invention of modern banking. The business carried on by their money loaners and dealers was similar to that of the Jews of the Middle Ages and the Lombards. When gold or silver was deposited it was more in the nature of a special deposit to be kept until called for. There have always been money lenders, but banks for lending money are of comparatively modern origin.

\section{BANK OF Venice, 1171.}

The Bank of Venice may be pronounced the forerunner of modern banks. It had its origin in 1171 in' the necessities of the Republic of Venice. A forced loan was levied upon the opulent citizens. Instead of issuing bonds as a sign of the indebtedness, the amount of specie loaned by each citizen was entered in a book. The republic paid punctually four per cent. annual interest to those who advanced the money, but did not repay the principal. The citizens in their transactions among thernselves transferred such portions of the credit thus due them from one to the other. This method of transacting business was seen to be so convenient and so superior to handling the coined money that people made haste to deposit their specie in the bank and obtain bank credits. There were no bills issued or checks used but the credits could be transferred in any amount required, the entries on the books of the bank being evidence of payment. This was banking on the security of a Government loan in the same manner as under the National banking system, except that the credits are in the latter system transferred by passing notes representing the credit in various denominations from hand to hand. If the Bank of Venice had been founded on a diminishing loan as is the currency of the National banks, 
the useful accounts would soon have been closed; but in Venice the loan was permanent and continually increased.

\section{BANK OF GENOA, 1320.}

The Bank of Genoa, founded about 1320, was similar in its origin to that of Venice although of slower growth, having for its basis a series of Government loans. This bank issued paper notes during the latter portion of its career, which became worthless when the bank failed in 1798 .

\section{BANK of Amsterdam, 1609.}

The Bank of Amsterdam was started in 1609 to obviate difficulties arising from the accumulation of light-weight coin received in the extensive foreign trade of Holland. The bank received all coin, light or otherwise, at its real value in standard coin, practically as bullion, and gave in return a credit on its books. These credits, because of their convenience in making payments and their safety, were generally at a premium over coin, so that although the bank was bound to restore the latter on demand when the bank credit was surrendered, practically the demand for coin was very small. Another part of its business was to receive deposits of bullion. For these it gave a bank credit, five per cent. less than the mint value of the bullion, and also a receipt reciting that the depositor was permitted to take the bullion at any time by depositing a corresponding amount of bank money, paying one-fourth per cent. for storage if the bullion were silver and one-half per cent. if it were gold. The receipt also provided that if the bullion were not withdrawn in six months it should belong to the bank at the price of the original credit; that is, the bank in that case gained the five per cent. margin. The depositor had his bank credit and his receipt; the former he could use and the latter he could transfer. The five per cent. margin was generally sufficient to induce some one to buy the receipt in time to prevent this margin from reverting to the bank. The city of Amsterdam guaranteed the bank. The credit of the institution was very great; no examinations of its real condition were ever made. The specie and bullion deposits were loaned to the East India Company, to Holland and the city of Amsterdam. For fifty years this was not discovered and the credit of the bank was as high as ever. In 1790 the secret was revealed and the bank failed.

\section{Notes not Originated By the Banks of Venice, GeNoA and} Amsterdam.

The banks of Venice, Genoa and Amsterdam represent the earliest efforts to establish machinery for the more effectual and economical use of money. No one of them issued bank notes when first started; the Bank of Venice never issued notes, and the banks of Genoa and Amsterdam only after bank notes had been invented and used in other countries by other banks. 


\section{Early Banking in England-Jews and Lombards.}

Banking in the United States has followed English precedents, and therefore a brief history of the commencements of English banks wil be proper in this place. The Jews were the first bankers in England. They came to the country with William the Conqueror; used, if they did not invent, bills of exchange, accumulated goodly stocks of coin, which they loaned at high rates of interest to the nobility and others on the security of their estates. Sir Walter Scott, in his famous tale of "Ivanhoe," has given us a vivid picture of Isaac of York and the barbarous cruelties to which the wealthy Jews were sometimes subjected, and in Ivanhoe's case at least an instance of their gratitude and generosity. Edward I. robbed 15,000 Jews of their wealth and then banished them all. The business was then taken up by the Lombards, from Italy, whose business combined the occupations of goldsmith, pawnbroker and banker. Lombard Street, London, takes its name from them.

\section{Goldsmiths' Company, 1566.}

There was a goldsmiths' company as early as 1566, and they were then one hundred and seven in number. About the year 1645 the goldsmiths first began to act as bankers. They collected rents for their customers and received moneys from them on which they paid interest. They also acted as pawnbrokers and issued notes. These notes were first simply receipts payable on demand. They were called goldsmiths' notes. Checks also soon originated by customers giving orders on their goldsmiths. The invention and use of bank notes seem certainly to have thus occurred in England. Nothing like bank notes was used by the banks of Genoa and Amsterdam as exrly as 16\%\%. Macaulay says that Sir Dudley North, returning to England in 1680 after many years residence abroad, found that the new practice of depositing cash with the goldsmiths and drawing checks on them and using their notes, had grown up in his absence. When one of his friends asked him where he kept his cash-"Where should I keep it," he asked, "but in my own house?"

\section{BANK of ENGLAND, 1694.}

Private banking having been instituted in England with great advantage to her trade, the next step taken was to establish the Bank of England. Like the banks of Venice and Genoa, this bank grew out of a loan of $£ 1,200,000$ advanced to the Government. The details of the institution were modelled on the plan advanced by Mr. William Paterson, a Scotchman. The bank was incorporated by royal charter on July 27, 1694. The Government at first allowed eight per cent. interest upon the loan and $£ 4,000$ per annum for management. The charter was granted for short periods and was renewed by Parliament from time to time until 1844, when the law under which the. bank now does 
business was formulated. As it is not the intention to do more than to indicate the banking and legal principles upon which this great institution now carries on its operations, the history of the bank will not be

followed during the period previous to 1844 .

\section{BANK ACT of 1844.}

The Act of 1844 regulated the issue of bank notes not only by the Bank of England but also of all other banks in the Kingdom. In addition to the great bank there were joint-stock and private banks, many of them the lineal descendants of the goldsmiths. The circulation to which each of these banks was entitled under the act was to be arrived at by taking the average amount of circulation, in each case, for twelve weeks prior to April 27, 1844. The amount for all these banks was by this method found to be eight and three-quarter millions of pounds sterling. The amount to be issued by the Bank of England was fixed at fourteen millions of pounds sterling through an issue department to which was to be transferred an equal amount of Government securities. The other banks might cede their circulation privilege to the Bank of England for a consideration of one per cent. per annum, up to August 1,1856 , and the privilege was forfeited by them in case of bankruptcy or of certain changes in the nature of their partnership. The Bank of England was authorized to issue its own notes for the full amount of the eirculation ceded, and by order of the Crown in Council to the extent of two-thirds of the lapsed circulation, upon the due deposit of Government securities, in addition to the fourteen millions granted to it by the act. The circulation of the bank based on securities has thus, since 1844, been increased by about two millions of pounds sterling, being now $£ 16,800,000$. In addition the bank may issue notes to any extent, provided an equal amount of coin or bullion is deposited in the issue department. One-fifth of this coin and bullion may be silver, but as a fact no silver is stored in the issue department, as it cannot be legally tendered for a five-pound note. The notes are a legal tender between all parties, except in favor of the bank itself, and only so long as they are paid by the bank in gold coin on demand. Bank of England notes are not a legal tender in Scotland or Ireland.

\section{Note Issues of the BaNk of ENgland.}

The theory upon which the note issues of the Bank of England is founded is that a certain amount of paper notes will at all times be kept in use by the public, and will on account of this use never be presented for redemption. What this amount is was determined, as has been seen, by the experience of the banks as to the average amount outstanding for a given period of time. To secure the ultimate redemption of these notes Government securities are deposited. The notes issued on gold simply constitute another way of using the gold. Practically, as there is no outward distinction in any of the notes in the 
hands of the public, the gold in the issue department of the bank is a reserve for the prompt redemption of such portion of the whole issue as may be presented at any time.

By the Bank Act of 1844 it was provided that all persons shall be entitled to demand from the issue department of the Bank of England notes in exchange for gold bullion at the rate of $£ 317 \mathrm{~s}$. 9d. per ounce of standard gold. The bank is required by law to give gold for notes or notes for gold on demand. Under such a plan of issue, which it has been suggested that the United States Treasury should adopt with reference to its notes, ${ }^{*}$ when gold goes in the notes go out, and when the notes come in, the gold goes out; thus making either operation one of no serious concern.

\section{SCOTCH AND IRISH BANKS.}

The Scotch and Irish banks, by the Act of Parliament of 1845, were privileged, as were the English banks, to issue permanently the average amount of their circulation then outstanding. Unlike the English banks they received the privilege, similar to that of the Bank of England, to issue additional circulation, upon the basis of gold coin and bullion of equal amount. $\dagger$ The permanent cireulation was not, however, like that of the Bank of England based on Government securities, but upon the security of the general assets of the bank including the unlimited liability of the individual shareholders, or partners. This unlimited liability means that as long as any of the shareholders or partners are solvent their property is liable for the indebtedness of the bank until the latter is fully paid.

\section{How the Bank of England Checks Gold Exports.}

The Bank of England controls the flow of specie and bullion in and out of the Kingdom by changes in the rate of discount. As it discounts the notes of merchants by giving its own notes in exchange, which are redeemable in gold, the raising of the discount rate at once reduces the amount of its notes that can be used to procure gold for export, and increases the expense at which they can be obtained. As a consequence of the advance in the discount rate, gold is attracted to London for the sake of the higher interest rate. If through the over-supply of money offered in the open market, the bank is unable to control the discount rate, it borrows the surplus funds itself and thus reduces the supply of loanable funds.

No notes are issued by any of the English banks of a denomination

* Report of Secretary Sherman, December 2, 1878; Report of Secretary Gage, December 7,1897 .

+ Although Scotch and Irish banks must hold coin equal to the amount issued in excess of their authorized limit, the coin is in no sense hypothecated, and in the event of a failure no note holder could claim a lien on the coin, which would doubtless be merged in the general assets of the bank.-English and Foreign Banks, J. B. Attfield ; p. 106. 
less than five pounds.* This renders necessary the use of gold sovereigns and silver in transactions less than that amount. The same law that keeps a certain sum in bank notes always in circulation to carry on transactions over five pounds, keeps in circulation in England gold coin to a large anount to carry on transactions under five and over one pound. This stock of gold plays an important part and acts as a buffer in protecting the stock in the bank.

First Bank of France, 1716.

The celebrated John Law was the originator of the first Bank of France. In 1716 he was authorized by the Regent, the Duke of Orleans, to establish a private bank of discount and deposit with the right to issue notes. It was to exist for twenty years, and its profits were to be free of taxes. The Regent was its protector, and it was subject to examination by Government inspectors. Its capital was divided into 1,200 shares of 5,000 livres each. By public ordinances its notes were made receivable for public dues, and they were made payable at the public offices for collection of the revenue, when any one required cash. They thus secured wide acceptance throughout France. The specie poured into the bank coffers and notes were issued to a large extent and still continued in good credit. In 1718, so great was its success, it was converted into a National bank, the Government purchasing all the shares, and guaranteeing its liabilities.

Conpany of the West and Fallure of First Bank of France, 1720.

The bank might very well have contir'sed solvent, had not two mercantile schemes been appended to it. These were the Company of the West and the Company of the Indies. The Company of the West was organized to develop the resources of Louisiana and Canada. Enormous speculation in the shares of this bubble company ruined the bank and it collapsed for an existence of four years. Like the Panama Canal Company, in recent times, the Company of the West spread financial ruin throughout France. This collapse also inspired a wholesome distrust of all banking operations, and for fifty years no bank could be successfully started.

\section{Second Bank of France, 1776.}

In 1776 a bank was started by Turgot, which issued bank notes to the amount of 12,000,000 francs, equal to its capital. This bank had great effect in encouraging trade during the period of the American Revolution. It became embarrassed by the revolutionary troubles in France and was closed by a decree of the Convention in 1793 .

* Notes of the denomination of $£ 1$ are issued by the Scotch and Irish banks. 


\section{Present Bank of France, 1800.}

The present Bank of France was established by the First Napoleon; subscriptions to the shares were invited in 1800, and it began business February 20 of that year, and its charter has been renewed from time to time. The shares are held by private individuals; the Governor is appointed for life; it is governed by a general council of regents. The bank is a private institution under the fostering care of the Goverument, and was created both as a fiscal agent and to meet the demands of commerce. It has a monopoly of note issues and can raise the rate of discount when circumstances require it, but as a matter of fact the discount rate is changed less frequently than that of any other great European bank. The Bank of France protects its gold reserve by charging a premium on gold, when the metal is demanded for export. The issue of notes is controlled by the council, who report to the Government. Sometimes the latter guarantees a temporary or excessive issue. The notes have no other security than the general assets of the bank, although the Government sustains the bank when necessary with its credit. There is no law fixing any limit on the circulation, as long as the bank redeems in specie, but when specie payments have been suspended and the Government has permitted the issue of inconvertible notes, a limit is always fixed to such issues, as was done during the Franco-Prussian War.

\section{Note Issues of Bank of France.}

The typical principle upon which the note issues of the Bank of France are founded in ordinary times, that is when trade is normal and there is no disturbance on account of war or civil contentions, is the interchange of materials and products among citizens engaged in trade. To facilitate this the bank takes the evidences of ownership, and opens accounts with the owners, who by the transfer of these accounts among themselves transfer the materials and products represented by the accounts. This may be done as in the Bank of Venice by entries on the books, the parties appearing in person and authorizing them; by checks drawn by the owners of the accounts, or by notes issued by the bank, which are simply checks drawn by the bank on itself in convenient denominations. So long as the bank notes do not exceed the evidences of ownership of property placed in the bank and made over to it by the owners in a fiduciary capacity, and the business is conducted with wisdom and honor, the notes are perfectly safe.

\section{The Main Banking Principle.}

This principle really underlies all banking, and the further precautions adopted by the laws creating the Bank of England are merely modifications of it to insure proper management of the evidences of 
ownership, upon which bank notes are based. In the Bank of France no part of the property deposited with it is set apart for special security of the circulating notes, but in the Bank of England securities of the Government, and gold, the one a first lien on all the property of the country and the other itself property, are set apart to be devoted to the sole purpose of paying the notes. The method of the Bank of England appears to be the safer, but the method of the Bank of France is, other things being equal, the much more economical. The method of the Bank of France can be used with safety when the business is conducted by trained and responsible men under the safeguard and paternal protection of the State. The English method and its modifications are better adapted to circumstances and governments which foster no monopolies, and permit all citizens alike to engage in any business whatever to an extent not injurious to the public good. These two systems of banking, one permitting the issue of bank notes without setting aside any special assets or securities to provide for their payment, and the other requiring such a segregation of a part of the bank's resources, will be found to be the bone of contention between advocates of different banking propositions. The principles that a certain amount of bank notes or of other paper currency once in good credit will circulate freely and never be presented for redemption, and that a certain average amount of deposits will lie unused without being called for, are common to all systems of banking.

\section{Proper Functions of Banks.}

The business of banking, in its widest sense, is to collect in banks or masses the capital of a community, that which either is money or can readily be turned into money, and upon the capital so collected to build up, by proper management and machinery, a credit which will extend and enlarge the usefulness to the community of its actual moneyed capital.* There is nothing in this which may not be accomplished by a private individual, and, as a matter of fact, English and American banking grew in great measure out of the business of the London goldsmiths. Private business men and firms received deposits, collected the moneyed capital of the community into masses, and on the credit they gradually obtained issued notes that passed as money, thus building up a machinery of credit that enlarged and extended the usefulness of the actual moneyed capital deposited with them. Joint-stock banks were a means of collecting larger masses of capital and using an enlarged credit.

During the latter part of the seventeenth and the beginning of the eighteenth century, men began to awake to the possibilities of eredit. At first its limitations were not at all understood. But financial disasters of various kinds soon inspired caution, and it was discovered that

* Banks are constituted to make capital circulate, not to lock it up.-Leroy-Beaulieu, "Traité d'Êconomie Politique," III, p. 479. 
banking, while a powerful instrument of production, manufactures and trade, when properly used, was liable to great abuses, and that, to insure safety to the public, it must be more securely bound down by law than ordinary occupations or professions. For this reason the State very early stepped in with restrictions and special penalties.

Of all the functions of a banker, that which enabled him to use credit by means of promissory notes was early found to be both the greatest source of profit to the banker and the most dangerous to the community. It was most dangerous for the very reason that it was also the most useful. If all who chose were allowed to use the machinery of credit in this way without restraint, it was generally admitted that disastrous results would follow. On the other hand, the State itself began to find an advantage in granting exclusive privileges of banking to companies or associations. Certain payments and duties to the State were exacted for these privileges. There grew up a kind of trade between the State and certain of its citizens, and to render these privileges really exclusive it became necessary to restrict the rights of the individual citizen to carry on the banking business, on the eminently conclusive moral ground that unless such rights were restricted the welfare of the public would be endangered.

\section{ORIGIN OF THE WORD BANK.}

At this point it may not be inappropriate to introduce some considerations as to the meaning and derivation of the word bank. In many dictionaries the word is said to come from the Italian banco, a bench, and that the Lombard money changers using a bench upon which to transact business as money changers, this article of furniture became the insignia of their trade. When the money changer failed his bench was broken, and hence was derived the English word bankrupt. If there is no truth as to this derivation, then a great many dictionaries and financial authorities have fallen into error.

H. D. MacLeod, however, in his "Theory and Practice of Banking," says that the popular idea that the word comes from the custom of the Lombards as above stated is a pure delusion. The Italian word banco is, he says, according to Italian authority, derived from the Gothic word banck, a heap or mound, and the word banco was metaphorically ascribed to a common fund, or joint-stock, formed by the contributions of a multitude of persons.

It is curious to note that the very plausible story of breaking the benches of insolvent Lombards and the word bankrupt supposed to be derived therefrom have, perhaps, had much to do with the popular delusion. The story of the bench-breaking of the Lombards may as easily have been invented on account of the word bankrupt as the word derived from the alleged practice. From the earliest history of banks the word bank has certainly been understood as meaning an aggregation of capital. 


\section{Banking in the United States Molded by Popular Sentiment.}

Banking in the United States has been conducted on all the different lines described in the foregoing sketch of foreign banking, and on some other lines, which have grown out of the foregoing through the ingenuity of legislators and through the real and supposed necessities of business. There-have been private banks and chartered banks, and banks under general banking laws. The latter were the result of the general antipathy of the American people to anything like monopoly, or the granting of privileges of any kind to one class of citizens that could not be enjoyed by citizens of all other classes. Notwithstanding these general laws, however, enacted both by the State and the general Government, permitting all citizens with the necessary capital to start a bank to enter the banking business, and also notwithstanding the fact that any citizen can in most of the States enter upon the business of private banking, the banking business has been viewed with more or less suspicion by the masses of the people, and it has been found diffcult to secure banking legislation the most necessary and liberal and beneficial to all, because of the supposition that all such legislation must confer undue favors on the possessors of banking capital. Owing to this fact, and as the successful result of the issue of paper money by the Treasury of the United States during the war, the whole tendency of political action for the last twenty years has been to deprive banks in the United States of that portion of their natural functions by which they use their credit in the issue of circulating notes, and to give this function entirely to the Treasury of the United States. This tendency may be safely ascribed to the abuse of the note-issuing function by the banks themselves, to the establishment of the National banking system, to the great credit of the Treasury, to the agitation of the silver question, and to the growth of socialistic ideas.

\section{Abuse of Note-Issuing Privilege.}

The history of banking in the various States before the war will make plain to any one that the note-issuing privilege was much abused, to the great detriment of individuals and of the public. Banks were started for the sole purpose of foisting worthless notes upon a confiding public. A writer in 1841 says:

"The currency of the United States consists of a small amount of gold and silver coins and bullion; a larger amount of State-chartered bank notes, exchangeable for specie; a far larger amount of bank notes not convertible into specie, composed of the notes of non-specie paying banks, the notes of banks of States other than those in which the notes circulated, unauthorized paper of individuals, of companies and of associations, in the similitude of bank notes, issued and circulated as money, and post notes, deposit notes, checks, State scrip and bills of exchange. * * Bank notes compose so large a proportion of the circulating medium that those who will not take them in payment of their debts cannot collect their dues, nor carry on their 
business requiring the use of money. The efforts of State legislators to correct the defects of the currency must eyer be as unavailing as their attempts to suppress small bills have hitherto proved. Their actions are desultory, unconnected and temporary ; liable to the influence of private interest, or political party feeling, that may vary in the several States and prevent their uniform action. All the States cannot be expected to pass similar laws upon this subject, simultaneously; consequently the currency might be changed by State legislation, but it could never be radically reformed. Some of the States have passed laws to suppress the circulation of small bills within their own territories; but their immediate inundation with those of other States, often much more uncurrent than their own, aided in obtaining a repeal of the laws for their suppression, just at the moment when the neighboring States, from seeing the advantage of the measure, were about to pass similar laws."

\section{Hugh McCulloch on State Bank Currency.}

Hon. Hugh McCulloch, in an address delivered in 1876 before the American Bankers' Association in Philadelphia, said:

"From the time of the expiration of the charter of the United States Bank (second) up to 1861, the State banks furnished the country with its paper circulation and to a great extent controlled its business. It is not necessary to dwell upon the defects of the State bank systems, or the character of a considerable part of the notes which the people were compelled to receive and treat as money. There were scarcely two States in the Union whose systems were alike. In some States banks were chartered with proper restrictions on their discounts and their circulation; in others without any such restrictions. In some there was individual liability, in others no liability whatever, not even in cases of gross mismanagement. In some States the circulation of the banks was secured, partially at least, by mortgages and bonds; in others there was no security except capital, which was frequently a myth. In some States banking was a monopoly, in others it enjoyed the largest liberty. The consequence was that we had a bank-note eirculation frequently worthless; and when solvent, lacking that uniform value which was needed in business transactions between the citizens of different States. It is enough to say that the circulation of the State banks was entirely unfitted to a country like ours; that by it the people were subjected to enormous losses, not only in the way of exchanges, but in the inability of a great many banks to redeem their notes."

\section{Statistics of State Banks.}

It is very difficult to obtain statistics of the operations of the State banks prior to 1832. In July of that year a resolution of the House of Representatives directed the Secretary of the Treasury to lay before the House yearly thereafter such statements relating to banks organized under State laws as could be obtained from the several State officials. Previous to 1832, Mr. Gouge says, in his "Short History of Paper Money and Banking in the United States:"

"Efforts extending over seven years to collect the accounts of the banks of the country had proved so unsatisfactory in results, and so little success had crowned the labors of Mr. Crawford, Mr. Gallatin and Mr. Niles in the same directions, that it was not thought worth while to arrange for publication the materials so provided. To collect and arrange the accounts of five or six hundred banks which are or which have been scattered through twenty-four States and two or three Territories, would be no easy task." 


\section{LOSSES FROM BAD BANKING.}

The losses from the failures of the banks under these ill-advised systems of banking have never and will probably never be calculated. On November 1, 1836, eighty-nine State banks held over forty-nine millions of public deposits and twenty-six millions of individual deposits. They had outstanding about forty-two millions of dollars in eirculation. In less than a year all but six of these had suspended. Of these failures, speaking of the losses to the Government alone, Secretary Woodbury says in his report of September, 1837:

"The direct losses under it appear to be large. But in the end they are not considered likely to amount to anything, though the disappointments, delays and injuries must, it is manifest, in several cases, be great. The indirect losses to the public creditors and contractors have been considerable and difficult to be computed."

Notwithstanding the Secretary's hope that there would be very little loss to the Government, the Treasury carries a large portion of the public deposits in these banks as unavailable funds to this day. Considering all the circumstances it is not surprising that a deep and lasting spirit of hostility to State banks and their cireulation grew up in the minds of the people of the United States.

\section{National Banking System, 1863.}

The National banking system, in the wisdom and uniformity of its laws and the security and homogenity of its eirculating notes, was the very reverse of the old State banking systems. The people quickly recognized, however, that it was the Government guarantee and the Government securities that gave the value to the circulation. As the system was at first limited in the amount of circulation it could issue, and afterwards, when the limit was removed, was restricted by the high price of bonds, it fell into great disfavor with the class of demagogues and others who are constantly reiterating the demand for more money. First the greenback enthusiasts, and after them the advocates of the free coinage of silver, have made National bank circulation their target. It was easy to make it appear that by issuing circulating notes directly instead of through the banks, that the Government might pay its bonds and stop interest, without mentioning disastrous results in other directions. At any rate it seemed easier to obtain the issue of the money they wanted directly through a paternal government than through the banks, and the result has been that silver certiflcates and Treasury notes have since 1878 been slowly but surely driving out the National bank note. The National system has accustomed the people to a kind of banking so superior to any they had ever experienced before, in the discount and deposit line, that it is not likely, if the paper circulation of the country is again to be issued by banks, that it will ever be delegated to the State banks. 


\section{Issue of Paper Monex by Government.}

The idea that the Government should issue the paper money as well as coin the gold and silver has taken a firm hold of the public mind, and as long as the Treasury retains its present credit is not likely to be overturned, although its disadvantages are known to financiers, especially that lack of elasticity which is the cause of a real scarcity of money in some places when there is a plethora in others. 
BANKING IN THE COLONIES, CONTINENTAL MONEY AND STATE BANKS.

Issue of paper money in Colonies - Massachusetts land bank - Copy of English land bank - Land bank started - Colonial loan banks - Hutchinson's specie banksDepreciation of colonial paper in 1748 - Parliament suppresses loan and other banks in Colonies - Forbids use of paper as legal tender - Powers of Continental Congress - Issue of Continental money - Jefferson's account of - Other authorities - Its depreciation and final disposition-Power of Congress and States to establish banks under Federal Constitution - Webster's opinion as to State bank notes - Chase's opinion - Discussion of right of State bank to issue notes.

\section{Issues of Colonial Paper Monex.}

The first issue of paper money in the Colonies was by Massachusetts in 1690, in aid of the expedition against Canada. Sir William Phips, of the Province of Maine, who was knighted because he had raised a treasure * from a Spanish wreck in the West Indies, was the leader of this expedition, and it failed ignominiously before Quebec. Previous to 1711 paper money had been issued by New Hampshire, Rhode Island, Connecticut, New York and New Jersey. South Carolina followed in 1712 , Pennsylvania in 1723, Maryland in 1734, Delaware in 1739, Virginia in $\mathbf{1 7 5 5}$, and Georgia in 1760. These issues were at first for the benefit of the Colonial Treasuries.

\section{Land Bank Proposed.}

A land bank was proposed in Massachusetts as early as $1701+$ and again in 1714, as a remedy for the embarrassment of trade, having the right to issue notes secured by land. John Colman, a merchant of Boston, was the author of the latter scheme, and advocated it with much force and energy. This was a copy of a celebrated proposition made in England some twenty years before, about the time of the establishment of the Bank of England. Hugh Chamberlayne and John Briscoe in 1693 affirmed to the English nation that a land bank would work miracles for England. These were to be effected by simply issuing notes on the security of land. The projectors claimed that every person who had real property ought to have besides that property paper

* He recovered $£ 300,000$ of which he received $£ 16,000$ as his share.

$+\mathbf{A}$ private bank is said to have been authorized in Massachusetts in $\mathbf{1 6 8 6}$. 
money to the full value of that property. If the estate were worth two thousand pounds he ought to have two thousand pounds in paper money. There cuuld be no overissue as long as there was in the country, for every ten-pound note, a piece of land worth ten pounds. Owing to the natural difficulties of immediate redemption, the notes were to be inconvertible and a legal tender. As in this scheme we find the germ of the idea that has so often revived and flourished in the various forms of irredeemable and fiat money, and has, in the United States, suggested so many financial propositions based on real estate, and that vague term the wealth of the country, we will give our readers a portion of the language of the petition for the Land Bank as it was first proposed, which went so far as to be referred to a Parliamentary committee and to obtain the favorable report that the "plan was practicable and would tend to the benefit of the nation." The plan was as given below :

\section{Petition for First English Land Bank, 1693.}

"In consideration of the freebolders bringing their lands into this bank, for a fund of current credit, to be established by act of Parliament, it is now proposed for every $£ 150$ per annum, secured for 150 years, for but one hundred yearly payments of $£ 100$ per annum, free from all manner of taxes and deductions whatsoever, every such freeholder shall receive $£ 4,000$ in said current credit, and shall have $£ 2,000$ more put into the fishery stock for his proper benefit; and there may be further $£ 2,000$ reserved at the Parliament's disposal towards the carrying on this present war. * * * The freeholder is never to quit the possession of his said estate unless the yearly rent happen to be in arrears."

Parliament, however, was not so foolish as to act on the report of the committee, and the plan fell through. In 1696, however, the plan was revived in a less objectionable form. In spite of Chamberlayne's protestations nobody was able to believe that by simply printing inconvertible notes any addition could be made to the wealth of the nation. Many, however, were of the opinion that a bank which should make a special business of advancing money on land would be a benefit. An act of Parliament accordingly authorized a loan of $£ 2,564,000$ to be subscribed, upon which the Government would pay eight per cent. The bank was to issue notes based on this Government indebtedness, and confine its operations to loans on landed securities. The prospect: of having this bank as a rival caused the notes of the Bank of England, then in the third year of its existence, to fall to a heavy discount. The subscription did not fill as there were doubts that the country could sustain two banks. This secured land bank was similar in the business to which it was confined to a modern real estate loan company, having, in addition, the power to issue notes to circulate as money.

Massachusetts Land Bank Started, 1739.

The Massachusetts Land Bank proposed by John Colman was an elaboration of the English land bank ideas. In 1715 it was forbidden 
by the Province Council, unless authorized by the General Assembly, but Colman revived the plan in 1739. The stock of this bank was fixed at $£ 150,000$; no one was permitted to subscribe more than $£ 2,000$, nor less than $£ 100$. The subscribers were for each $£ 1,000$ subseribed to pay forty shillings in money, and for the remainder to pledge security in lands to the satisfaction of the directors. Circulating notes were to be issued payable in twenty years, in produce or manufactures, and five per cent. of the subscribed capital was to be annually paid in, in notes of the bank, produce or articles manufactured. The produce and manufactures comprised the subjoined list: Hemp, flax, cordage, bar iron, cast iron, linens, sheep's wool, copper, tanned leather, flaxseed, beeswax, bayberry wax, sail cloth or canvas, nails, tallow, lumber or cordwood, or logwood from Spain. Although strenuously opposed by the Royal Governor, Belcher, $£ 49,250$ of its notes were struck off, and $£ 35$,582 issued in due course, while the directors employed $£ 4,067$ in trade.

\section{Colonial Loan Banks.}

In 1715 the Treasury of Massachusetts was authorized to issue paper money to the extent of $£ 50,000$. This round sum or aggregate of $£ 50$,000 was styled "a bank." It was to be loaned out to citizens in sums not exceeding $£ 500$, nor less than $£ 50$, to one person, on mortgage security, as a measure of relief from the distress then existing caused by a scarcity of money. For these loans five per cent. annual interest was to be paid, and one-fifth of the principal was to be returned annually. This is a specimen of the so-called "loan banks" resorted to as a means of relief in almost all of the Colonies. Paper money was thus issued by them for two purposes-to pay their own expenses, this kind being redeemed from taxes; and to relieve the people, this variety to be repaid by the latter to the Treasury.

\section{SPECIE BaNks, 1733, 1739.}

Specie banks were also formed in 1733 and 1739, the last by Edward Hutchinson and others, in Boston, issuing bills redeemable in fifteen years in silver, to the amount of $£ 120,000$. These notes did not do much good as they were generally hoarded the same as specie.

\section{Depreciation of Colonial Papeir Monex, 1748.}

As in most all governmental experiments with paper money, especially in new States where credit is not well established, the Colonies did not know where to stop and the bills and notes issued, whether as loans to the people or for the payment of public expenses, soon depreciated. A part of this depreciation was no doubt due to the determined opposition of the Royal Governors, sustained by the "men of the most considerable estates and business" in the Colonies. In 1748 the value of one hundred pounds in coin was as follows in eight of the Colonies: New England, £1,100; New York, £190; New Jersey, £180 to $₫ 190$; 
Pennsylvania, £180; Maryland, £200; North Carolina, $£ 1,000$; South Carolina, $£ 750$; Virginia, $£ 120$ to $£ 125$.

\section{Parliament Forbids Banks, 1740.}

In 1740 Parliament extended to the American Colonies the provisions of the previous Act of 1720, which prevented the formation, in England, of all companies for the purpose of issuing paper money. The Massachusetts land and specie banks were compelled to wind up under this act. In 1751 Parliament went a step further and forbade the use of legal-tender paper money issued by the Colonial Treasuries, although later it permitted the currency of its own issue to be received by each of the Treasuries. This interference by Parliament with the right of the colonists to avail themselves of the supposed blessings of paper money either directly by their Treasuries or by means of banks, excited the most intense indignation, and was one of the causes that led to the final outbreak.

\section{First Continental Congress in 1774.}

When the Revolutionary War broke out no one appears to have thought of a bank to conserve the resources of the country and give credit to its paper. The great results accomplished by the men of that period have obscured what might have been done. The first Continental Congress met on September 5, 1774. From that date until 1781, when the Articles of Confederation were ratified by the several Colonies or States, and went into effect, the Congress acted upon authority, derived not from the Colonies as such, but from the people. Its power was supported by the signing of Articles of Association by the people throughout the country stopping the importation of goods from Great Britain and the exportation of goods to that country, the use of such goods, and the slave trade, and by passing an act calling upon the people to sustain by force what they had agreed to by signing the articles. Its power was consolidated by the action of the people and the provincial congresses compelling it to assume the conduct of the war. Until the Articles of Confederation went into effect the Continental Congress, although acting with great moderation, really possessed as much power as the revolutionary assembly of France. Although this was so, the Congress never attempted to lay taxes, contenting itself with recommending to the States to lay such taxes as were necessary to supply financial strength to the united Government. From this lack of assumption, however, of powers it might have exercised with the consent of the people, there came a gradual weakening of the credit and authority of the general Government, culminating in the Articles of Confederation asserting the authority and sovereignty of the States which, in the meantime, had formed themselves from the colonial governments. 


\section{Continental Money, 1775.}

The Continental money was issued in anticipation of funds to be received from the taxation that Congress from time to time recommended the several Colonies or States to lay for the benefit of the common Treasury. A connection may be traced between its depreciation and the gradually weakening power of the Continental Congress. In regard to this money Jefferson says:

"At the commencement of the late Revolution Congress had no money. The external commerce of the States being suppressed, the farmer could not sell his produce, and, of course, could not pay a tax. Congress had no resource then but in paper money. Not being able to pay a tax for its redemption, they could only promise that taxes should be laid for that purpose, so as to redeem the bills by a certain day. They did not foresee the long continuance of the war, the almost total suppression of their exports, and other events which rendered the performance of their engagements impossible. The paper money continued for a twelvemonth equal to gold and silver; but the quantities which they were obliged to limit for the purpose of the war exceeded what had been the usual quantity of the circulating medium. It began, therefore, to become cheaper or, as we expressed it, it depreciated, as gold and silver would have done had they been thrown into circulation in equal quantities. But not having, like them, an intrinsic value, its depreciation was more rapid and greater than could ever have happened with them. In two years it had fallen to two dollars of paper money to one of silver; in three years to four for one; in nine months more it fell to ten for one; and, in the six months following, that is to say, by September, 1779, it had fallen to twenty for one."

\section{Attempts to Stop Depreciation.}

Congress, alarmed at the consequences which were to be apprehended should they lose this resource altogether, thought it necessary to take a vigorous effort to stop its further depreciation. It was therefore determined, in the first place, that the emissions should not exceed two hundred millions of dollars, which sum had then been almost reached, and though Congress knew that twenty dollars of the money then being issued would buy no more for the army than one silver dollar would buy, yet it was thought it would be worth while to submit to the sacrifice of nineteen out of twenty dollars if thereby further depreciation could be prevented. The members of Congress therefore published an address to their constituents, in which they renewed their original declaration, that this paper money should be redeemed at dollar for dollar. They proved the ability of the States to do this, and that their liberty would be cheaply bought at this price. The declaration was ineffectual. No man received the money at a better rate. On the contrary, the events that followed are thus described:

"In six months more, that is, by March, 1780, it had fallen to forty to one. Congress then tried an experiment of a different kind. Considering their former offers to redeem this money at par as relinquished, by the general refusal to take it, but in progressive depreciation, they required the whole to be brought in, declared it should be redeemed at its present value of forty for one, and that they would give 
to the holder new bills, reduced in their denomination to the sum of gold or silver which was actually to be paid for them. This would reduce the nominal sum of the mass in circulation to the present worth of that mass, which was five millions, a sum not too great for the circulation of the States, and which they therefore hopcd would not depreciate further, as they continued firm in their purpose of emitting no more. This effort was as unavailing as the former. Very little of the money was brought in.

\section{Continental Money Ceases to Circulate, 1780-81.}

It continued to circulate and depreciate till the end of 1780 , when it had fallen to seventy-five for one; and the money circulated from the French army being, by that time, sensible in all of the States north of the Potomac, the paper ceased its circulation altogether in those States. In Virginia and North Carolina it continued a year longer, within which time it fell to 1,000 to 1, and then expired, as it had done in the other States, without a groan. Not a murmur was heard on this oceasion among the people. On the contrary universal congratulations took place on their seeing this gigantic mass, whose dissolution had threatened convulsions which should shake their infant Confederacy to its center, quietly interred in its grave."

In addition to the two hundred millions of paper money issued by the Continental Congress, two hundred millions more are estimated by Jefferson to have been issued by the Colonies. Naturally this additional flood of inconvertible paper did not retard the depreciation.

Funding of Revolutionary Debt, 1790.

Although Jefferson says that the Continental paper was never redeemed, yer the scheme for the funding of the Revolutionary debt, drawn up by Hamilton and approved by the Federal Congress in 1790 provided for the funding of such portion of the Continental currency as was then in existence, accepting one hundred dollars for one. How much, if any, was funded in this way does not appear.

\section{Amount and Value of the Issues of Continental Currency.}

Other authorities than Jefferson place the amount of the issues of Continental money much higher. Joseph Nourse, Register of the Treasury in 1828 , places it at $\$ 241,552,780$. The amount as given in the Treasury statement of 1843 was $\$ 242,100,176$. The aggregate loss from this currency was estimated by Secretary Woodbury at $\$ 196,000$, 000. This last estimate does not agree very well with Jefferson's estimate that the real value of the $\$ 200,000,000$ of Continental money at the time of its emission, the value at which it was taken by the people for supplies, was $\$ 36,316,719$ in specie. The depreciation as it passed from hand to hand among the people was gradual, each holder losing a part, until the holders in whose hands it expired, as Jefferson says, "without a groan," had not much left to complain of.

If Congress in 1775-76, with the ample power it then possessed, had started such a bank as Hamilton designed afterwards, holding the specie in the country and that obtained by the French subsidies and loans as a reserve, ample financial resources for the war might have no doubt been found in notes issued by such an institution aided also by 
the taxes received from the Colonies. It is probable, however, if this course had been followed, Congress would have gained power continually, and the importance of the separate Colonies would have diminished, so that at the close of the Revolutionary War the States would have lost the power to resist the tendency to one strong centralized government. As it was the States grew in importance, and after 1781 showed a predominance that rendered the central Government almost powerless for good. This led to the adoption of the Constitution of $\mathbf{1 7 8 9}$, in which the powers of the central Government and the States were justly balanced, the one against the other.

\section{Federal Constitution, 1789.}

The Federal Constitution, which went into operation in 1789, nowhere forbids the States to grant power to establish banks within their borders, nor does it anywhere in specific terms grant the power to the Federal Government to charter a bank or banks to do business within the States. Congress, however, within two years after the inauguration of the new Government decided that under the Constitution it had power to charter a bank, and did in January, 1791, charter the first Bank of the United States. The Supreme Court has affirmed the constitutionality of this decision. The Constitution, however, grants to the Federal Government the exclusive right to coin money. It deprives the States of this right and forbids them to emit bills of credit. It does not forbid the United States to emit bills of credit, but a permission to this effect was struck out of the original draft as unnecessary, and as being liable to misconstruction and abuse.

\section{Webster's Opinion Ás to State Bank Notes.}

It has been held that the lack of power of a State to coin money, taken in connection. with the prohibition of the emission of bills of credit, prevents the issue of paper money by banks chartered by the State as well as the issue of paper money by the State itself. This view was held by Daniel Webster in his speech on the Bank of the United States, on the 25th and 28th of May, 1832, and his arguments are quoted with commendation by Mr. Justice Story in his Commentaries on the Constitution as follows:

"It will be hereafter seen that this (the power to coin money) is an exclusive power in Congress, the States being expressly prohibited from coining money. And it has been said by an eminent statesman that it is difficult to maintain on the face of the Constitution itself, and independent of long-continued practice, the doctrine that the States, not being at liberty to coin money, can authorize the circulation of bank paper as currency at all. His reasoning deserves grave consideration and to the following effect: The States cannot coin money. Can they then coin that which becomes the actual and almost universal substitute for money? Is not the right of issuing paper, intended for circulation in the place and as the representative of metallic currency, derived merely from the powes of coining and regulating the metal lic currency? Could Congress, if it did not possess the power of 
regulating the value of foreign coins, create a bank with the power to circulate bills? It would be difficult to make it out. Where then do the States, to whom all control over the metallic currency is altogether prohibited, obtain this power? It is true that in other countries private bankers, having no legal authority over the coin, issue notes for circulation. But this they do always with the consent of the Government, express or implied; and Government restrains and regulates all their operations at its pleasure. It would be a startling proposition in any other part of the world, that the prerogative of coining money held by the Government was liable to be defeated, counteracted, or impeded by another prerogative held in other hands authorizing a paper circulation. It is further to be observed that the States cannot issue bills of credit, not that they cannot make them a legal tender, but that they cannot issue them at all. This is a clear indication of the intent of the Constitution to restrain the States from establishing a paper circulation, or from interfering with the metallic circulation. Banks have been created by States with no capital whatever, their notes being put in circulation simply on the credit of the State. What are the issues of such banks but bills of credit issued by the State."

\section{Chase's Opinion as to State Bank Notes.}

Hon. Salmon P. Chase, when Secretary of the Treasury, in his report to Congress of December 9, 1861, expressed similar views. Both of these eminent statesmen, however, may be said to have approached this important subject with the bias of advocates. Webster desired to have the State banks give way to the Bank of the United States, and Chase desired to clear the field for the National banking system.

\section{Constitutionality of State Bank Notes Considered.}

If the issue of notes by banks is permitted to economize the use of real money, and such is the true function of the bank note, the issues in no way interfere with the function of the Government to coin and regulate real money. No doubt if the Federal Government charters a bank it has the right to regulate how it shall perform its functions, even that of issuing notes. The Government creating it can say just what functions the bank may perform, whether it shall issue notes at its own discretion, under certain restrictions, or not at all. But if it grants a charter to a bank simply to perform all the natural functions of a bank without restriction, then the bank so chartered would have the right to issue notes. If a State has the right to charter a bank at all, such bank has the right, from the mere fact of its being a bank, to issue circulating notes, because such notes are a use of its credit. Webster admits that private banks do issue paper money, and he might have added that they issued money long before the Government chartered any bank. The difficulty springs from the misconception that bank notes or any kind of notes are money. They are substitutes for real money invented to economize the use of the latter. While, of course, the Government has a right to regulate them, to tax them, and even to stop their issue, it is not because the Government has the sole right to coin money, but because it has the right to regulate business generally for the welfare of all. Under the Constitution the States have no right 
to coin money. They could not charter banks to coin money. But banks do not coin money, they simply issue promises to pay money. The Constitution forbids States to emit bills of credit; that is to issue the promise to pay of the State, but it nowhere forbids them to charter banks to issue bills on the credit of a capital of their own. These banks once chartered, unless strictly forbidden to issue notes, would have a right to do so, because issuing notes is a part of the banking business. Of course, a bank put forward without other capital than the credit of the State, issuing notes involving the faith of the State, and designed to circulate as inoney on the credit of the State in the ordinary course of business, would be an unconstitutional bank. But if the State chartered a bank and furnished the capital either as a gift to the bank or retaining ownership of the stock, and this capital was actually paid in, and there was no further liability of the State, then it would appear that the notes of such a bank, not being based on the faith or eredit of the State, but upon capital actually paid in, might not be unconstitutional. In other words it would not, under decisions of the Supreme Court, be unconstitutional for a State to charter a bank and subscribe to the whole or a portion of its stock, nor would the notes issued by such a bank be unconstitutional.

\section{Power of the Federal Government to Tax State Bank Notes.}

Admitting, therefore, that the States have the power to charter banks, and that the issue of eirculation by such banks, when not forbidden by the terms of the charter, is not unconstitutional, the Federal Government, as has been decided by the Supreme Court, has the power to tax these notes. It appears from the foregoing considerations that this power to tax, while it may easily be deduced from the power to regulate commerce, cannot justly be deduced from any power given to Congress by the Constitution to regulate the currency other than gold or silver coin. Any argument that Congress has power to regulate the currency as such, because it has exclusive right to coin gold and silver, appears to be based on the confusion of promises to pay money with real money. The right of Congress to authorize legaltender notes is based on altogether different provisions of the Constitution. There seems to be little doubt that the practice of the States, followed and acquiesced in since the beginning of the Government, to charter banks with the right to issue notes, is constitutional; and also that Congress has the right, under the power to regulate commerce, to tax these notes or otherwise regulate their issue. The degree of taxation is, of course, a question of policy about which opinions differ. Taxation imposed by Congress to the extent practiced with regard to State bank circulation, if sustained by the Supreme Court, might very well overturn almost any of the commercial relations of a State government, where they seemed to involve commerce with other States. 


\section{Decisions of United States Supreme Court.}

The Supreme Court of the United States, in Briscoe vs. Bank of Kentucky (11 Peters, 257), held that a note "issued by a State, involving the faith of the State, and designed to circulate as money on the credit of the State in the ordinary course of business, is a bill of credit." Other decisions of the Supreme Court (Craig vs. Missouri, 4 Peters, 410; Byrne vs. Missouri, 8 Peters, 40) hold "that certificates issued by a State in sums not exceeding ten dollars nor less than fifty cents, receivable in payment of taxes, the faith and credit of the State being pledged for their redemption, are bills of credit within the prohibition of the Constitution." 


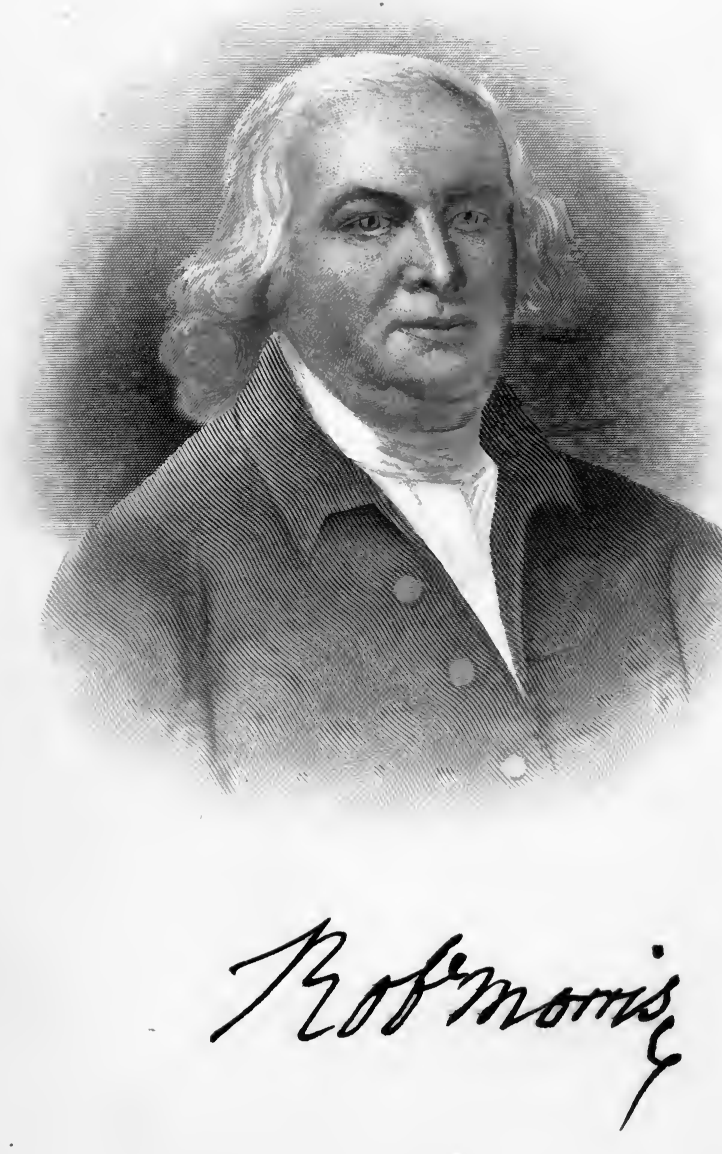


9 


\section{BANKING UNDER THE LAWS OF THE CONTINENTAL CON- GRESS AND FEDERAL CONSTITUTION, 1784-1817.}

Introductory - Bank of North America chartered by Continental Congress - Subscription in aid of Revolution - Thomas Paine - Sketch of Robert Morris Hamilton's proposal - Design of Robert Morris - Bank of North America Specie from France-Charter from Pennsylvania - Subsequent history - Becomes National bank - Considerations - First Bank of United States - Hamilton's report to Congress - Opposition - Constitutionality - Opinions of Hamilton, Jefferson and Randolph - Condition in 1809-1811 - Sketch of Alexander Hamilton - Application for renewal of charter - Report of Mr. Gallatin - Sketch of Mr. Gallatin - Stock held by foreigners - Debates on renewal of charter Clay's position - Refusal to recharter - Liquidation of bank and disposition of its assets - State banks, increase of - Secretary Dallas appointed-Sketch of Mr. Dallas' life.

\section{First Permanentuy-Organized Bank.}

The Continental Congress of the thirteen original States granted but one bank charter, a perpetual one to the Bank of North America, of Philadelphia; and this charter, it is claimed by the bank, is still in existence and in force at the present day. After the adoption of the Federal Constitution, and the inauguration of the Government under it in 1789, the first Bank of the United States was chartered for twenty years. The franchises of this institution terminated by limitation in the year 1811, and were not renewed. A second Bank of the United States was, however, chartered in 1816 for a like period of twenty years. At the end of this term a renewal of its franchises was refused to the bank, which then went into liquidation, and terminated its existence as a National banking institution. Its stockholders and directors, however, accepted a charter from the State of Pennsylvania, under which it continued to do business for some years longer until its final failure in 1841. From this last-mentioned date until February 25, 1863, there were no banks in the United States doing business under Federal laws except one or two small institutions in the District of Columbia. During this period attempts were made to enact a law authorizing a Bank of the United States. The question of bank or no bank was a party shibboleth. The proposed measures failed to secure the approval of the President. Some of the time the Government managed its finances through the State banks, and subsequently by means of the Inde- 
endent Treasury. In 1863 the National banking system went into opution, and has continued until the present time.

\section{North America and Action of Thomas Paine.}

The Bar North America, at Philadelphia, the first permanentlyorganized bann 1 the United States, and also the first that had any direct relation to linernment, commenced operations on January 7, 1782; but before th. date there were attempts to establish similar institutions, one of which was successful for a time. In 1780, occurred the darkest days of the Revolutionary War. The army was in great distress. Washington reported it as lacking the common necessaries of life and on the verge of mutiny. Thomas Paine, ${ }^{*}$ then Clerk in the Pennsylvania Assembly, in a letter to Blair McClenachan, suggested a subscription for the relief of the army, and enclosed a contribution of $\$ 500$. A meeting of patriotic citizens was held on June 7, 1780, at the Coffee House, among whom Robert Morris and Mr. McClenachan were prominent, and it was resolved that a subscription should be started, "to be given in bounties to promote the recruiting service of the United States." Four hundred pounds in hard money and $£ 103,360$ in Continental money were raised in nine days. The distress and danger were soon increased by the news of the capture of Charleston by the enemy, and the necessity of extending the plan of assistance was at once seen. Another meeting $\dagger$ was called of the subscribers and other citizens, which was held on June 17, and the original plan was abandoned. In its place it was resolved to open a security "subscription to the amount of three hundred thousand pounds Pennsylvania currency, in real money." Bonds were to be executed by the subscribers to the amount of their subscription to form the capital of the socalled bank. The full amount was soon subscribed by ninety-two persons in amounts varying from one to ten thousand pounds, Robert Morris and Blair McClenachan each subscribing the latter sum. It was called the Pennsylvania Bank. Ten per cent. of the subscriptions were to be paid at once and the balance from time to time as required. Notes were to be issued bearing interest at six per cent., and the credit of the bank or association of subscribers was to be used to borrow money. All sums borrowed or received from Congress were to be applied to meeting notes and expenses of the bank and purchasing and transporting supplies of provisions and rum for the use of the Continental army. Congress was notified that the institution had been organized, and awaited recognition and co-operation.

\section{Revolutionary Subscription BANK.}

In response to this intimation Congress appointed a committee of three to confer with the directors of the organization; and this com-

* Paine's "Dissertations on Government," Philadelphia, 1786, pp. 17, 18.

$+"$ History of the Bank of North America," p. 18. 
mittee reported a series of resolutions, which were unanimously ador accepting the offerings of the associators as a distingum oof of their patriotism, and pledging the faith of the Govern for the effectual reimbursement of the amount advanced. Fif thousand pounds in bills of exchange were to be deposited wit me bank, and such of the current funds of Congress as could pared were to be advanced if the bank should need assistance. The resolution was accompanied by the following preamble:

"Whereas, A number of patriotic citizens of Pennsylvania have communicated to Congress a liberal offer, on their own credit, and by their own exertions, to supply and transport 3,000,000 rations and 300 hogsheads of rum for the use of the army, and have established a bank for the sole purpose of obtaining and transporting the said supplies with the greater facility and despatch; and,

Whereas, On the one hand, the associators, animated to this laudable exertion by a desire to relieve the public necessities, mean not to derive from it the least pecuniary advantage, so, on the other, it is just and reasonable that they should be fully reimbursed and indemnified."

The bank began business on July 17 , and remained open for a year and a half, being wound up towards the end of 1784 . Those who lent their money received bank notes bearing interest for it.* The money as invested in provisions, which were forwarded to the army, amounting to 3,000,000 rations and three hundred hogsheads of rum. It was believed that these supplies could not have been obtained without the assistance of the bank. This bank or association, while it may have suggested the possible assistance and benefit the Government might receive from a National bank, appears to have had little or no connection with the subsequent institution of the Bank of North America.

\section{SKetch OF RoBert MoRris.}

The financial operations incident to the achievement of American independence were largely carried on by Robert Morris, and the integrity, zeal and ability which he displayed greatly aided the military campaigns of Washington and hastened the success of the American arms. The military genius of Washington, the diplomatic skill of Franklin and the financial sagacity of Morris were, perhaps, the three most important factors in bringing victory to the Patriot cause.

Robert Morris was born in 17this He was a successful Philadelphia merchant, and as a business man he early recognized the value of a properly organized bank in promoting trade. He started a movement in 1763 for establishing a bank, but owing to the failure to secure expected foreign aid the attempt was unsuccessful. In 1780 he subscribed $£ 10,000$ to the Pennsylvania Bank, which was not a bank in the ordinary sense, but an organization formed for the purpose of furnishing supplies to the army.

On February 20, 1781, Morris was elected by Congress to be Super-

*Pennsylvania "Gazette," December 29, 1784. 
intendent of Finance. His qualifications for the position are thus described:*

"Ful'. of energy and self-reliance, he was, perhaps, by bis business talent and mercantile experience, better qualified than any man in America to control and direct its financial affairs. He thought no sacrifice too great to be made for the service of his country. Possessed of a splendid personal credit, he often racked it to the uttermost to carry on some national project. He spared neither time, labor, nor thought," etc.

In his acceptance of the office of Superintendent of Finance, May 14, 1781, Morris wrote: $\dagger$

"In accepting the office bestowed upon me I sacrifice much of my interest, my ease, my domestic enjoyments and internal tranquillity. If I know my own heart, I make these sacrifices with a disinterested view to the service of my country. I am ready to go further; and the Cnited States may command ererything I have except my integrity, and the loss of that would effectually disable me from serving them more."

Of his herculean and wonderfully efficient labors in this position, in which he is said to have raised a million and a half of dollars upon his own notes, that enabled Washington to defeat Cornwallis at Yorktown, a disinterested writer of note says :

"Certainly the Americans owed and still owe as much acknowledgments to the financial operations of Robert Morris as to the negotiations of Benjamin Franklin or even to the arms of George Washington."

He was a delegate to the convention that met in Philadelphia in 1787 and framed the Constitution of the United States, during the sessions of which convention Washington was his guest. In October, 1788, he was chosen the first Senator from Pennsylvania to the first Congress of the United States under the Constitution, which met in New York on March 4, 1789, and served a full term until 1795. When chosen President, Washington desired to appoint Morris Secretary of the Treasury, but he declined the position and named Alexander Hamilton, who thus became the first to fill that high office.

It should not be without its lesson to the thoughtful banker that the declining years of this sterling patriot and eminent financier, who had repeatedly saved the nation from bankruptcy and its armies from defeat, were clouded by sad misfortunes resulting from the disastrous failure of vast business operations and speculations in land, unwisely conducted too largely upon credit, thus showing that the ablest and best of men have their limitations beyond which they may not safely pass. $\|$

Morris died in 1806 at the age of seventy-two years.

* "History of Bank of North America," p. 26.

+ Robert Morris, by Mrs. Armine Nixon Hart, in "Watson's Annals of Philadelphia," Vol. Il I, p. 255.

* Carlo Botta, in bis "History of the American Revolution."

\| Sketch of Robert Morris by Wm. H. Rhawn; Proceedings of Convention of Pennsylvania Bankers' Association, 1895. 


\section{Suggestions of Robert Morris and Alexander Hamilton.}

Alex. Hamiiton* had, as early as $17 \% 9$, conceived that the finances of the country might be much benefited by the establishment of a banking institution, and he proposed "The Company of the Bank of the United States," with a capital of two hundred millions of dollars, to be incorporated by Congress for ten years. Previous to this, in 1763, $\dagger$ Robert Morris, together with some of the principal merchants of Philadelphia, had entertained the design of a commercial bank to facilitate American trade. Morris was Superintendent of Finances in 1781; and, on April 30 of that year, Hamilton $\ddagger$ wrote to him urging the establishment of a National bank with a capital of $\$ 3,000,000$.

Morris drew up a scheme, not on so extensive a scale as that recommended by Hamilton, but, as he believed, adequate for the necessities of the Government; and his plan for the establishment of the Bank of North America was presented to Congress May 26, 1781; it was to open a subscription for $\$ 400,000$ in shares of $\$ 400$ each, payable in gold and silver. Subscribers of five shares were to pay one-half at once and the remainder in three months. After the capital was paid in the organization was to be completed. There were to be twelve directors chosen annually, who were to elect one of their number as President and two as inspectors to control the affairs of the bank. It was to be a National bank, and its notes were to be receivable for duties and taxes in each State; and, in settlement of accounts between States and Congress, were to be taken as specie. The plan was referred to a committee, who reported favorably upon it. There was, however, a strong opposition in Congress, Madison especially being bitterly adverse to it, claiming that, in establishing a banking institution, the Congress of the Confederation would transcend its powers. Resolutions approving Mr. Morris' plan were finally passed. 'The subscription was opened. At first the outlook was very inauspicious. The result of the war was doubtful. Morris failed to obtain specie he expected from Havana, upon which he relied to establish the bank. At length those interested in the Pennsylvania Bank, seeing that the new institution would probably supersede the former, resolved to wind up their institution and transfer its capital to the new bank. By November, $\$ 70,000$ had been paid in in cash. About $\$ 470,000$ in specie had been received from France by the Government and had been placed in the bank vault. On November 1 , directors were chosen and Thomas Willing was elected President. $\S$

* Hamilton's Works, Vol. I, p. 116.

+ Gouge, "History of Paper Money and Banking," p. 34.

\$ Hamilton's Works, Vol. I, p. 223.

8 Mr. Willing was, from his social position, business talents and political experience, well qualified to fill the responsible position to which he was now called. He was to be reckoned, undoubtedly, as a leading man in the State if not in the country 


\section{Perpetual Charter Granted by Congress.}

The private subscriptions in cash increased by December 1 to the sum of $\$ 85,000$. Application was then made to Congress for an act of incorporation, and on December 31 such an act was passed granting a perpetual charter and the right to hold property to the amount of 10,000,000 Spanish milled dollars. To pacify Mr. Madison and others of the same school the bank was forbidden to exercise any powers in any State repugnant to the laws thereof; and it was suggested to the States that they should each ratify the charter and by proper laws provide that no other bank or banks should be established or permitted within the said States. The bank began business on January 7, 1782; and for nearly two years its operations and those of the so-called Pennsylvania Bank appear to have been contemporary. The existence of the new institution was recognized by Connecticut, Rhode Island, New York and Massachusetts.

Of $\$ 470,000$ in specie received from France, Morris, the Superintendent of Finance, with the utmost care retained $\$ 254,000$ with which he subscribed for 633 shares of the stock. But the exigencies of the Government were so great that by July he had borrowed $\$ 400,000$ from the bank. The amount of specie in the bank dwindled to an alarming extent and its bills did not readily circulate.

Various contrivances were adopted, so it was reported, to make the public believe that the institution had a large stock of specie. Those who went into the offices were greeted with a display of silver on the counter, and boxes containing or supposed to contain silver were seen being raised or lowered from cellar to banking room or from banking room to cellar. The amount of specie in its vault was about $\$ 40,000$, but those demanding specie were followed by the friends of the bank, and urged to return it, so as not to diminish its coin reserve at the beginning of its operations. Three years after its organization it

at large. Born on the 19th of December, 1731, he was now, at the age of fifty, in the very prime of his powers. He was a partner of Robert Morris in a large and prosperous business, and had served successively as Secretary to the Congress of Delegates at Albany, Judge of the Supreme Court of Pennsylvania, Mayor of Philadelphia, Member of the Colonial Assembly, and President of the Provincial Congress. He was afterwards chosen as a delegate to Congress ("Lives of Eminent Philadelphians Now Deceased :" title "Thomas Willing") under the Confederation, and as first President of the Bank of the United States.

"His character," says Mr. Binney, "was not unlike that of Washington; and in the discretion of his conduct, the fidelity of his professions, and the great influence, both public and private, which belonged to him, the destined leader (Washington) was certain to find the elements of an affinity by which they would be united in the ciosest manner."

"This excellent man," he says again ("The Rcpublican Court,' page 161), "in all the relations of private life, and in various stations of high public trust, deserved and acquired (inscription upon his tombstone written by Horace Binney, Esq.) the devoted affection of his family and friends and the universal respect of his fellow citizens." -("History of the Bank of North America," p. 34.) 
became strong, and notwithstanding the fact that the Government, at that time, was refusing Continental money, even in payment of postage, its notes were current throughout the country at par, and the directors of the bank were obliged to increase its stock froin $\$ 100,000$ to $\$ 2,000,000$ and distribute the increase largely among the projectors of a new banking enterprise in order to prevent the organization of a rival institution.

\section{Charter from the State of Pennsyluania.}

From the very first the President and directors were not satisfied with having a perpetual charter from the Congress of the Confederation, but petitioned the Assembly of Pennsylvania for the grant of a similar one by the State. Objections were made both to the perpetual term asked for and also to the patriotism of the President, Thomas Willing. This latter charge had its foundation in the declaration of one of the messengers sent by Sir William Howe, in command of the British, with secret messages to inembers of Congress to induce them to make peace, when arrested and sent before the Committee of Public Safety, that he had been induced to act as such messenger through the influence of Mr. Willing. It is probable that doubts as to the power of Congress to create such a corporation cast somewhat of a cloud upon the bank's title. Nevertheless the bank got the charter it desired from the State on March 26,1782, three months after it commenced business under the charter granted by Congress. As before stated, the Government, by July, 1782, had borrowed $\$ 400,000$ of the bank; and, in December, the directors and President became uneasy and asked for payment. The Superintendent of Finance sold out stock in his hands to the amount of $\$ 200,000$ and paid the bank $\$ 300,000$ of the amount borrowed. The next July the rest of the Government stock was sold, principally in Holland, but by October the Government owed the bank $\$ 165,000$. This last sum was not finally paid until 1784 . The bank also advanced large amounts of cash in the discount of bills drawn on the Superintendent of Finance for the sustenance of the army.

\section{Repeal of State Charter.}

The State of Pennsylvania in 1785 repealed the perpetual charter previously granted, and the bank continued its business under the Act of Congress. The repeal was accomplished through the influence of parties who desired the issue of additional paper money and considered the bank a hindrance to such issues. Early, therefore, in 1786 the directors of the bank resolved to take steps to reëstablish, if possible, their corporate existence under State sanction. Their counsel advised them that " the modification of the bank's charter, as to limitation of time or capital, would not at all affect the charter granted by Congress and that it would not be improper for them to receive such a charter. Overtures were, therefore, at once made to the State of Delaware for a grant of corporate rights, which were so successful that on February 
2, 1786, the Assembly of the Commonwealth passed a bill conferring upon the bank the usual franchises of a corporation. On February 7 the directors received a notice of this fact, and readily accepted the charter; and, if necessary to the transaction of their business, they actually contemplated the removal of the bank to Wilmington, New Castle, or some other proper point within the State of Delaware.* A change of parties in 1787 brought with it a renewal of the charter by the State of Pennsylvania for fourteen years with a capital of $\$ 2,000,000$.

Hamilton, in a letter dated September 22, 1789, directs the Collector of Customs, Otho H. Williams, of Baltimore, to receive the notes of the Bank of North America and of the Bank of New York, payable either on demand or at no longer period than thirty days after their respective dates, in payment of duties, as equivalent to gold and silver. He says that arrangements had been made with these institutions for the accommodation of the Government. It was the moneys received from these banks that paid the first installment of the salary due President Washington and the Senators and Representatives and officers of Congress during the first session under the Constitution, which began at the city of New York, March 4, 1789.

In 1790 Hamilton, in his report, refers to the "ambiguous situation in which the Bank of North America has placed itself by the acceptance of its last State charter," and concludes that, as this has rendered it a bank of an individual State, with a capital of but two millions, liable to dissolution at the expiration of its charter in fourteen years, it would not be expedient to accept it as an equivalent for a Bank of the United States.

\section{Conversion to a National Bank.}

The State charter of the bank was renewed from time to time until December 3, 1864, when it became a National bank, retaining its original name, with a capital of $\$ 1,000,000$, and a surplus nearly the same.

All other State institutions which were converted to National banks were required to change their names at least to the extent of inserting the word National. Under this rule the Bank of North America might have been required to eall itself the National Bank of North America; but the Hon. Hugh McCulloch, then Comptroller of the Currency, in consideration of the ancient and honorable history of the institution and its services to the Government of the United States in the dark days of the Revolution, permitted it, although having become a National bank, to continue to be called simply the Bank of North America. $†$

* "History of Bank of North America," p. 67.

+ Correspondence with the Comptroller of the Currency as to the retention by the bank of the name of the "Bank of North America" on becoming a National bank.

Thomas Smith, Esq., President, to Hon. Hugh McCulloch, Comptroller :

Philadelphia, October 28, 1864.

Proposing that the Bank of North America should become a National bank, and suggesting that it should retain the title of the "Bank of North America" without the usual prefix of "National." 
In the correspondence with the Comptroller of the Currency, Thos. Smith, President of the Bank of North America, claims that the bank had always continued under its national charter. He said: "We hold

Hon. Hugh McCulloeh, Comptroller, to Thomas Smith, Esq., President :

WASHrNGTon, October $29,1864$.
DEAR SIR :-Your tavor of the 28th inst. is received. Such has been the history and such the relations of the Bank of North America to the general Government that it seems to be eminently proper that in its reorganization and rejuvenation under the National Curreney Aet it should assume as its title "The National Bank of North America." Every State bank hitherto ehanged into a National association has taken, in eonnection with its former name, the word "National;" and I should regret it if the oldest and most loyal of all of them should be unwilling to indicate by its title its relation to the National banking system of the national Government.

In order to make the change you must obtain the consent of the owners of twothirds of the capital stock of your bank; and, if you advise it, I do not believe that a single one of them will hesitate to assent to the introduction of the word "National" into the title. Please let me hear from you on this point.

I do not now say that I shall deeline sanctioning the reorganization of your bank under its present title alone. If $I$ do it, it will be against my own judgment and with extreme reluctanee.

There was, I think, well-founded objection to the "numeral system " of Mr. Chase: but, of the 561 banks organized under the National system, not one has objected to the word "National" as a part of its title; and I do not believe that, upon reflection, you will.

Some parts of your letter please me so much that I would publish them if I felt at liberty to do so. I forward you a half dozen sets of forms, etc. Very truly yours,

H. McCulloch, Comptroller.

Thomas Smith, Esq., President of the Bank of North America, Philadelphia.

Thomas Smith, Esq., President, to Hugh McCulloch, Esq., Comptroller:

Philadelphia, November 1, 1864.

Hon. Hugh McCulloch, Comptroller of the Currency:

DEAR SIR:-Your valued favor of the 29 th is at hand. Wishing to avoid the use of your valuable time in a matter of so little moment as the addition of the word "National" in the name of this bank, I am compelled to do so because there is so much feeling about any change of name with the stockholders and directors, arising principally from the fact that its present is its old National name given to it by Congress in 1781, retained by it, after much violent opposition, in eonfirmatory charters had from Delaware, Massaehusetts and Pennsylvania, the same political heresy of state rights being then, as now, rampant.

There is no similarity between this and any other bank, either State or National.

First. We hold the national eharter, December 31, 1781, which has never been abandoned or relinquished; but, in consequence of the partisan opposition to the bank, this charter was confirmed by the three States in which its business was chietly done. No new eharter was given or made. It was simply confirmatory of the charter made by the United States, which eonfirmatory charters by this State have been renewed (being limited in duration) as they expired. The original charter is perpetual.

The great merit of the eorporation and pride has always been its national character. We have it in brass in the building and printed on the notes. In July, 186?, we passed, and published in the papers, a resolution, a copy of which I enclose. We loaned all we had to the Government when they wanted it, and the timid sajd it was imprudent to do so; and we have and hold two and one-half times the amount of the capital in United States securities now, and intend to do so. The National banks are grenerally organized to benefit the stockholders and for that purpose only. This bank was created avowedly to sid the United States. It fulfilled its mission, and then went on prosperously, filed with the pride of that mission.

These are some of the reasons for asking permission to retain our national name of "The Bank of North Amerjca." The matter has been thoroughly canvassed by the directors; and 1 will frarkly state that $I$ heartily agree with them in pressing the request. With a personal interview, and the documents in our possession. I feel you would say we were right. At the same time, we shall do nothing, however sinall, to detract from the strength of the nation in this, her struggle, for existence. And we detrict from the strength of the nation in this, her strugge, for suecessand strength. should you determine that we cannot change without an alteration of name, please 
a national charter dated December 31, 1731, which has never been abandoned or relinquished; but, in consequence of the partisan opposition to the bank. this charter was confirmed by the three States in which its business was chiefly done. No new charter was given or unade. It was simply contirmatory of the charter made by the Cnited States, which contimatory charters by this State (Pennsylvania) have be'n renewed (being limited in duration) as they expired. The original charter is perpetual."

This is one view of the matter. The other is that the Bank of North America never had any charter from the existing Government of the Enited states The charter of 1721 was granted br the Government of the confeleration, and was never confirmed br the Grorernment of the Inited states, which went into operation in $17 \mathrm{is}$. So it seems that, as much amxiery was exhibited to secure confirmatory State charters, some pains would have been taken to obtain a confirmation of the national charter by the new national Government if it had been deemed of importance. It appears on the whole that the State charters were preferred, and that, practically, the Bank of North America was a State kwnk. and that it never worked long under its national charter, which

infurm une in relation to it, our arransements all teins made for the cld name. In the metutime I enclese you spevimens of the issue of the notes of the tank, if you sre at all curious in such natters-the issues of the Revdution, the war with Great Britain. ami the Ketelliven. They are senuine, and sind for redemption at any time.

I wairing your kisure to bear from nou, I am. respetrfuly, your obedient serrant. Tauxas serri. President.

The sume to the sume:

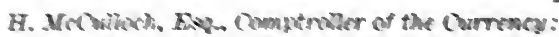

Pailadupita, Norember I1, 1864.

Dxak SIR:- Iour faror of the th was aulr reveired. I should have felt much relieved by suemethins to warrant the telief that rou would sanction the old naroe. The meering of stockholiers is on Nondar next, and it is by no means certain tbat the ryuisite numter of twhihinds can te obtained sit all. The election has demonstrated that Inck sum can take care of himself now, and there is, therefore, no pecesity for any littk moval support: tesides there sure several Bunks of Norch America, aud After a time, there mav be the sabe number of Nationsl Bunks of North America.

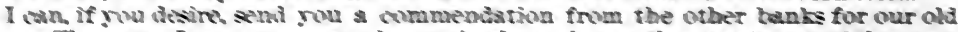

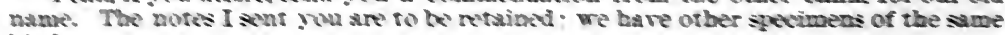
simi.

$$
\text { kesperfullr, nour otevient serrant. }
$$

Tguaras Sx:TR, Prreident.

The sume to the sine:

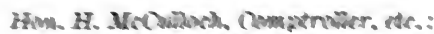

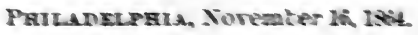

Deak Sik:-The stowbowiers of this hask hare noted satbority to its directors to

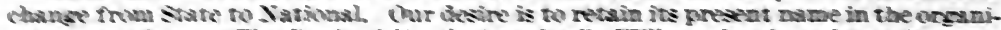

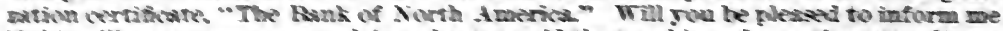

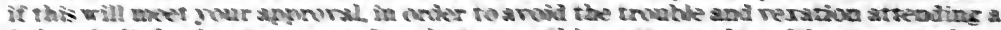

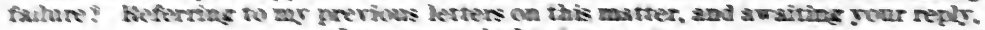
I sma pour coblieat servint.

Trovas Surre. Provibont.

We sure profrswing shwir with obraibing tbe clasent of twa-thinks of the steckDowhers

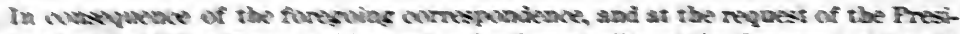

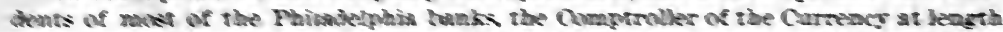

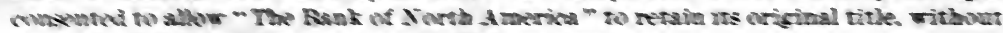

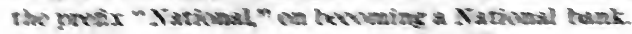


last had lapsed from non-user before 1789 , and was never revived after that date.

The national charter of the Bank of North America was dated December 30,1781 . It did not commence business until January 7 , 1782. On March 26, 1782, it obtained the grant of a perpetual charter from the State of Pennsylvania. Under this it continued until 1785, when the State repealed the perpetual charter. In 1787 the State again granted a charter, which was for fourteen years only, but was renewed from time to time apparently without break until 1864, when the bank entered the National banking system. Three months in 1782, and about two years between 1785 and 1787 , make up the whole period this bank worked under its national charter.

\section{Haniltox and the First Bank of the United States.}

When the change in the Government was effected by the adoption of the present Constitution, Hamilton became the first Secretary of the Treasury. He regarded the establishment of a National bank as a most important step in settling the financial affairs of the United States. In his report of 1790 he proposed a plan for such an institution. In this report he considered the position of the Bank of North America, and, after giving that institution due credit for the services rendered the Government, he thought that an institution upon different principles was required. He said: "The directors of this bank, on behalf of their constituents, hare since acted under a new charter from the State of Pennsrlvania materially variant from their original one, which so narrows the foundation of the institution as to render it an incompetent basis for the extensive purposes of a National bank." He thought it the general opinion of the citizens of the United States that the Bank of North America had taken the station of a bank of Pennsylvania only. He suggested, however, that if the bank would come forward with a proposition to accept such legislative amendments as might be deemed necessary to the due extent and safety of a National bank, there were weighty inducements to give every reasonable facility to such a measure. "As far as can be ascertained,* however, the management of the bank took no steps in accordance with these suggestions. The quiet and prosperous business in which they were engaged, under State auspices, was to them preferable to the anxieties and hazards which would probably attend the new national undertaking."

\section{Plax of the First Bask of the United States.}

In Hamilton's report, already referred to, he gires his reasons for the necessity of the organization of the proposed bank, and with great elaboration and exhaustireness he considers the objections that might be urged against such an institution, and also shows the inferiority of

\footnotetext{
* "History of the Bank of North America," p. 79.
} 
the various substitutes that might be proposed. Among the latter he considers the proposition to issue United States notes, and on this subject he says :

"The emitting of paper money by the authority of Government is wisely prohibited to the individual States by the national Constitution; and the spirit of that prohibition ought not to be disregarded by the Government of the United States. Though paper emissions, under a general authority, might have some advantages not applieable, and be free from some disadvantages which are applicable to the like emissions by the States separately, yet they are of a nature so liable to abuse, and, it may even be affirmed, so certain of being abused, that the wisdom of the Government will be shown in never trusting itself with the use of so sedueing and dangerous an expedient."

The proposed plan was arranged under twenty-four heads. The capital of the proposed bank was fixed at $\$ 10,000,000$; one-fourth of all the private and corporate subscriptions was to be paid in gold and silver and three-fourths in United States stock bearing six per cent. interest. Two million dollars were to be subscribed by the United States, a loan of equal amount being made in return by the bank, which was to be reimbursed in ten equal annual installments in money or in the bonds of the Government in a manner similar to that pursued by the British Government upon the organization of the Bank of England; or, as Mr. Hamilton described the operation, by "borrowing with one hand what is lent with the other." The board of directors of the bank was to consist of twenty-five persons, not more than three-fourths of them to be eligible for reëlection in the next succeeding year. The bank had authority to loan on real estate security, but could only hold such real estate as was requisite for the erection of suitable banking houses or should be conveyed to it in satisfaction of mortgages or judgments. No stockholder, unless a citizen of the United States, could be a director, and the directors were to give their services without compensation. The bills and notes of the bank were made receivable in payment of all debts to the United States. The total amount of debts which the corporation might at any time owe in any way, except for moneys actually deposited in the bank for safe keeping, was never to exceed $\$ 10,000,000$, and if this limit was exceeded, the directors under whose administration the excess might occur were to be personally liable for the amount. The corporation was allowed to sell the evidences of the public debt subscribed to its stock, but was not to purchase any public debt whatever. Notes were allowed to be issued, payable to any person or persons, assignable and negotiable, or to bearer assignable by delivery. The directors were permitted to establish offices for discount and deposit only, wherever they should think fit in the United States. A report of the condition of the bank was to be furnished whenever the Secretary of the Treasury required it, but not oftener than once a week. The charter was to expire March $4,1811$. 


\section{Arguments for and against the Proposed Bank.}

The act of incorporation was opposed in the House of Representatives by James Madison and eighteen others, all of whom, with one exception, were members from the States of Virginia, Maryland, North Carolina and South Carolina. It was also opposed by Thomas Jefferson, Secretary of State, and Edmund Randolph, Attorney-General, in opinions requested by the President. The grounds taken by the opponents of the charter were a denial of the general utility of banking systems and opposition to the special provisions of the bill; but the main force of their objections was directed against the constitutional authority of Congress to pass an act for the incorporation of a National bank. The supporters of the bill in the House of Representatives numbered thirty-nine, a majority of twenty; all of them except four being representatives of Northern States, among whom were Fisher Ames, Elbridge Gerry and Theodore Sedgwick, of Massachusetts ; Roger Sherman and Jonathan Trumbull, of Connecticnt, Elias Boudinot of New Jersey, and Peter Muhlenburg, of Pennsylvania.

Hamilton, Secretary of the Treasury, and Knox, Secretary of War, in official communications to the President, maintained the constitutionality and the policy of the act. Hamilton's plan, substantially unchanged, was adopted by Congress. Washington, before signing the bill, called for the opinions of Attorney-General Randolph and Secretary of State Thomas Jefferson. Both of these gentlemen returned arguments adverse to the power of Congress to create a National bank. Both, but especially Jefferson, insisted with great stress of argument that the word necessary in the clause of the Constitution giving power "to make all laws necessary and proper for carrying into execution the enumerated powers," did not give power to create a bank. 'They both took the narrow view that nothing could be looked upon as necessary that could be done without. On receiving these papers Washington asked for Hamilton's opinion in order that he might "be fully possessed of the arguments for and against the measure " before expressing any opinion of his own.

\section{Hamilton's Argument.}

The essential point in Hamilton's argument was that the Government of the United States, in the exercise of its sovereign powers and from the very nature of sovereignty, had the right to employ all the means requisite and fairly applicable to the attainment of the ends of such powers. In proof of this inherent sovereignty he cited the clause of the Constitution which declares that the Constitution and the laws of the United States made in pursuance thereof, and all treaties made or which shall be made under their authority, shall be the supreme law of the land. 
Hamilton claimed that, to carry into effect any of the express powers, Congress had the right to erect a corporation. "The only question," he says, "in this case or any other case must be whether the ineans to be employed-in this instance the corporation-has a national relation to any of the acknowledged objects or lawful ends of the Government. Thus a corporation may not be erected by Congress for superintending the police of the city of Philadelphia, because they are not authorized to regulate the police of that city; but one may be erected in relation to the collection of taxes, or to the trade with the foreign countries, or to the trade within the States, or with the Indian tribes."

He further remarks that, to insist on the narrow construction of the necessity clause adhered to by Randolph and Jefferson, "would be to make the criterion of the exercise of any implied power a case of extreme necessity, which is rather a rule to justify the overleaping of the bounds of constitutional authority than to govern the ordinary exercise of it."

Washington was convinced that the bill was constitutional, and on February 25, 1791, it became a law.

\section{OPERATION OF THE BANK.}

The bank went into operation very soon after the act authorizing it became a law, and before the Government subscription of $\$ 2,000,000$ was paid, and a dividend of four per cent. was declared in July, 1792. The manner of paying the Government subscription was as follows: The President drew bills of exchange on Holland, where money borrowed in that country under the laws of August 4 and 12, 1790, was lying available. These were handed to the bank and the latter issued two millions in its stock. Immediately the bank loaned two millions in its own bills to the Treasury and received two millions of United States stocks bearing six per cent. interest, and payable in ten equal annual installments beginning in 1793. The bank was very well managed and was of great benefit to the Government and the people at large. It assisted the Treasury with loans whenever called on, and it forced the State banks to keep their issues within reasonable bounds. It received and disbursed more than $\$ 100,000,000$ of public moneys without the loss of a dollar.

Under the requirement that a report of the condition of the bank should be furnished to the Secretary whenever required by him, but not oftener than once a week, the Treasury records do not show that any formal reports were ever made to the Department. The only balanced statements to be found showing the condition of the bank are two, which are contained in letters* of Albert Gallatin, Secretary of the Treasury, communicated to Congress on March 2, 1809, and January 24, 1811, respectively. The reports are as follows:

*American State Papers, Finance, Vol. II, pp. 352, 470. 
First Bank of United States-Statement of Condition.

\begin{tabular}{|c|c|c|}
\hline RESOURCES. & January, 1809. & January, 181 \\
\hline Loans and discounts.. $\ldots \ldots \ldots \ldots \ldots \ldots \ldots$ & $\$ 15,000,000$ & $\$ 14,578,294$ \\
\hline United States six per cent. stock............ & $\quad 2,230,000$ & $2,750,000$ \\
\hline Other United States indebtedness............ & $\ldots \ldots \ldots$ & 57,046 \\
\hline 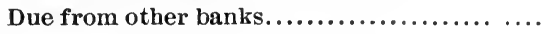 & 800,000 & 894,145 \\
\hline 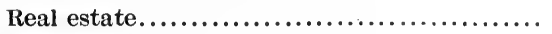 & 480,000 & 500,653 \\
\hline 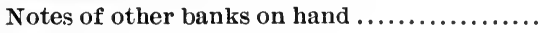 & $\ldots \ldots \ldots$ & 393,341 \\
\hline 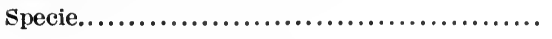 & $5,000,000$ & $5,009,567$ \\
\hline Totals............................. & - $\$ 23,510,000$ & $\$ 24,183,046$ \\
\hline \multicolumn{3}{|l|}{ LIABILITIES. } \\
\hline Capital stock $\ldots \ldots \ldots \ldots \ldots \ldots \ldots \ldots \ldots \ldots \ldots$ & . $\$ 10,000,000$ & $\$ 10,000,000$ \\
\hline 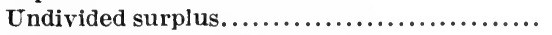 & . $\quad 510,000$ & 509,678 \\
\hline 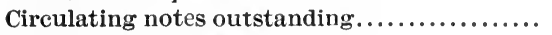 & $4,500,000$ & $5,037,125$ \\
\hline 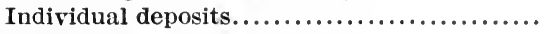 & $8,500,000$ & $5,900,423$ \\
\hline 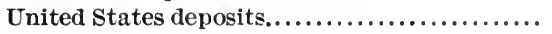 & ........ & $1,929,999$ \\
\hline Due to other banks......................... & ........ & 634,348 \\
\hline Unpaid drafts outstanding $\ldots \ldots \ldots \ldots \ldots \ldots$ & $\ldots \ldots \ldots$ & 171,473 \\
\hline$\cdots \cdots \cdots \cdots \cdots \cdots \cdots \cdots \cdots \cdots \cdots \cdots \cdots \cdots \cdots \cdots \cdots \cdots$ & . $\$ 23,510,000$ & $\$ 24,183,046$ \\
\hline
\end{tabular}

The average dividends of the bank from its organization to March, 1809 , were at the rate of eight and a half per centum per annum. The - 5,000 shares of $\$ 400$ each owned by the United States were disposed of in the years 1796 to 1802 at a considerabie profit, 2,220 shares having been sold in the last-mentioned year at a premium of forty-five per cent. According to the Treasury records the Government subscription, with the addition of the interest which was paid by the United States on stock issued for it, amounted to $\$ 3,200,000$, while there was received by the Treasury in dividends and from the sale of the bank stock at various times $\$ 3,773,580$, the profit realized by the Government being $\$ 573,580$, or nearly 28.7 per cent. upon the original investment.

In addition to the act of December, 1791, chartering the bank, four supplementary acts were passed by Congress in reference to it: one on March 2, 1781, which varied the manner in which the capital stock was to be subscribed for and paid in; two passed in 1798 and 1807, respectively, having reference to counterfeiting its notes and papers or otherwise defrauding it; and one in 1804 permitting the establishment of offices of deposit and discount in the Territories and dependencies.

\section{Sketch of Alexander Hamilton.}

Alexander Hamilton was born in the Island of Nevis, one of the British West Indies, on January 11, 1757. When under twelve years of age he was placed in a counting-room as a clerk, and before he was thirteen had been put in entire charge of his employer's affairs. In his fifteenth year he left his birthplace and sailed for Boston, where he arrived in October, 17\%2, proceeding thence to New York. He perfected his education by entering a grammar school and later King's College. He first attracted public attention by a patriotic address delivered at a 
meeting in New York, July 6, 1774. Though he was a strong champion of the colonists' cause, his love of order and justice was shown by his efforts to restrain mob attacks on inoffensive Tories. He entered the American army, served with distinction until the close of the war, leading a brilliant and successful assault on one of the redoubts of the enemy at Yorktown.

Hamilton early perceived the need of a sound financial system, and in 1779 he wrote to Robert Morris favoring a bank of issue based upon landed security. Later, he realized that the proper security for bank notes was quick assets and not real estate. In 1780 he wrote to Morris regarding the finances of the Confederation, pointing out the causes of the depreciation of the paper currency. As a remedy he proposed gradual contraction and a foreign loan, the latter to be used as the basis of a National bank. The great purpose of the bank was to unite the interests of the moneyed classes in the support of the Government credit. The bank was to be a great trading and banking corporation in private hands, but backed and partly controlled by the Government, to which it was to be under certain obligations.* His suggestions for a National bank were renewed more in detail in a letter addressed to Morris on April 30, 1781. This proposal was adopted substantially by Morris, who had been elected Superintendent of Finance, and made the basis of his report to Congress recommending the establishment of the Bank of North America.

In 1782, after a few months of study, Hamilton was admittedoto the bar, and in June of the same year was appointed Continental Receiver of Taxes in New York. The following November he was elected to Congress. He was subsequently chosen as a member of the New York Legislature, where he was instrumental in securing the appointment of delegates to represent the State in the Constitutional Convention, which met in Philadelphia in May, 1787, Hamilton himself being one of the delegates. His papers in favor of the new Constitution, published in "The Federalist," constitute one of the best expositions of the principies of that document. He was elected to Congress, was subsequently defeated for reëlection for the unexpired term of the old Congress, and on the creation of the Treasury Department under the new Constitution, he was appointed Secretary of the Treasury. The report sent to Congress in January, 1790, regarding the best means for establishing the public credit, was a strong presentation of the principles of a sound financial policy. Hamilton's relations to the Bank of North America, the Bank of New York and the Bank of the United States are referred to at length elsewhere in this work. He was a believer in a strong central government, and has left upon our institutions the impress of his great abilities. His talents were conspicuous in an age noted for men of remarkable powers, while his financial policy and his views in regard to banking attest the soundness of his judgment and the breadth

* "Alexander Hamilton," by Henry Cabot Lodge. 
of his knowledge of those subjects. Hamilton became involved in a quarrel with Aaron Burr, whose treasonable schemes and political ambitions he had defeated. A duel was fought between them in 1804, resulting in the death of Hamilton.

\section{Change of Political Feeling.}

When the charter of the first Bank of the United States was granted the Federalists were in power; but in 1801 Jefferson became President -one of its earliest opposers and the representative of the Republicans who were rapidly gaining control of national affairs. He was succeeded in 1809 by Madison, his friend and disciple; and thus, at the time when the charter of the bank expired by limitation, in its efforts for a renewal it was to be encountered by a state of political feeling very different from that existing when the charter was granted. It does not appear, however, that the executive branch of the Government interfered to prevent the recharter.

\section{Application for Recharter, Gallatin's Report.}

In 1808 the directors thought it advisable to apply to Congress for a renewal of the powers of the bank; and, on March 26 of that year, a memorial for that purpose was presented in the House, and upon April 20 in the Senate. By order of the Senate the memorial was referred to the Secretary of the Treasury, to be reported on at the next session of Congress; and, on March 2, 1809, Albert Gallatin, the Secretary, made his report.

It appears from the report that of the $\$ 10,000,000$ of stock $\$ 2,000,000$ was subscribed by the Government and paid in ten equal annual installments. The United States thus obtained 5,000 shares of $\$ 400$ each, which it disposed of by 1802 , receiving a premium on the same of $\$ 6 \% 1$, 800 in addition to the regular dividends. The $\$ 8,000,000$ of stock taken by individuals was subscribed, $\$ 2,000,000$ in specie and the remainder in United States six per cent. stock. Of the total 25,000 shares of stock 18,000 were held abroad; and, as foreign stockholders could not vote, the bank was controlled by the stockholders in the United States owning the remaining 7,000 shares. They elected twenty-five directors, who managed the affairs of the parent institution in Philadelphia and had the general superintendence and appointment of the directors and Cashiers of the offices of discount and deposit in other places. There were eight of these offices or branches, at Boston, New York, Baltimore, Norfolk, Charleston, Savannah, Washington and New Orleans. The dividends averaged 8 13-14 per cent. per annum. Mr. Gallatin concluded "that the affairs of the bank as a moneyed institution had been wisely and skillfully managed." He enumerated the advantages the Government had received as consisting of the safe keeping of public deposits, the transmission of public moneys, aid in collection of revenues by means of the punctuality of payments introduced by its sys- 
tem, the facilities granted to importers, and loans that as long as the necessities of the Treasury required were made to it by the bank. The loans thus made amounted to $\$ 6,200,000$.

The large amount of 'capital held by foreigners who had no share in the control of the institution was an objection in the minds of some. But, as Mr. Gallatin very adroitly put it, "if the charter is not renewed the principal of that portion, amounting to about $\$ 7,200,000$, must at once be remitted abroad; but, if the charter is renewed, dividends equal to an interest of about eight and one-half per cent. a year must be remitted in the same manner." He suggests that the charter might be inodified so that all the stock might be held at home; but the objection did not, in his opinion, outweigh the manifest public advantages to be derived from a renewal of the charter. He thought that, if a renewal was granted, the bank could, perhaps, afford to pay a bonus for the same of $\$ 1,250,000$; but believed that the renewal should, if granted, be based on weightier considerations than the mere payment of such a sum into the Treasury.

He suggested, as modifications of the charter to be adopted in case of renewal, that the bank should pay interest on Government deposits in excess of $\$ 3,000,000$, that it should be bound to lend the United States at any time not to exceed three-fifths of its capital at six per cent. interest, payable in monthly installments at the Government's pleasure; that the capital be increased to $\$ 30,000,000-\$ 5,000,000$ of the increase to be taken by individual citizens to be equitably apportioned among the several States and Territories, and $\$ 15,000,000$ by the several States, each State to have a branch established within its limits if it desired; the payments both by individuals or States to be in specie or public stocks. By this plan Mr. Gallatin believed that by means of the interest the bank would pay on public deposits, the United States could accumulate a treasure in time of peace ready for any emergency. They could rely on a loan of $\$ 18,000,000$. The bank would form a bond of interest among the States.

\section{Biographical Sketch of Albert Gallatin.}

Albert Gallatin was born in Geneva, Switzerland, January 29, 1761, where he received a good education. When nineteen years old he emigrated to America, being imbued with an enthusiasm for the new order of things suggested by the Revolutionary War. He arrived in 1780. His dislike of a strong government made him an anti-Federalist, but after the adoption of the Constitution, which he opposed, on account of his education and intellectual force and gifts, he became a leader in Western Pennsylvania where he had settled, and was elected to the Senate of the United States in 1793. Owing to some defect in his naturalization papers, the Senate refused him his seat. When he returned to Pennsylvania the Whiskey Rebellion had broken out. He sympathized with those who resisted the excise, and took a leading part. 
When the insurgents begun to resort to acts of violence, however, he used his great influence to prevent bloodshed. Elected to the House of Representatives, he kept up a warfare on the Federalists, and when in 1801 Jefferson became President, Gallatin was made Secretary of the Treasury. His administration was most successful; his natural conservatism checked his democratic ideas and he made little change in the arrangements of Hamilton. Until the breaking out of the troubles with England the condition of the Treasury improved under his management, the debt was paid off as it became due and there was a surplus balance available. After leaving the Treasury he became one of the American commissioners engaged in negotiating the Treaty of Ghent. He was subsequently appointed Minister to France, and in 1826 Minister to England. He settled finally in New York, where he died August 12, 1849. The Gallatin Bank, now the Gallatin National Bank, was named after him.

\section{Bill Introduchi in CoNgress For Recharter.}

When Congress met in 1809 several measures were introduced having reference to the continuance of a National bank, all more or less modelled upon Mr. Gallatin's recommendations. One was a bill to establish a new National bank in Washington with a capital of $\$ 15$,000,000 to be subscribed by the United States, the States and individual citizens and corporations. The others were for the extension of the existing bank, with provision for a bonus to be paid to the Grovernment either in money or bank stock, and for the increase of capital. No action was taken at this session of Congress. The bill to continue the charter came up again in December, 1810. The question of the constitutionality of the bank was immediately raised by Mr. Burwell, of Virginia, but it was contended by Mr. Fisk, of New York, that since Mr. Jefferson's election the party he represented had twice virtually admitted the constitutionality of the measure, once in selling a large part of the shares of the bank, which sale, although made to a foreigner, Mr. Baring, was sanctioned by the vote of the House of Representatives in 1802, and again by the passage of an act in 1804 authorizing the bank to establish branches in the Territories. Mr. Fisk went on to show the danger and difficulty that would ensue in the financial operations of the country and Government if dependence was had on State banks alone. "The destruction of the bank would result in doubling the quantity of State bank paper. He spoke of numerous applications made for new bank charters, and regarded thein as the evidence of the destroying spirit of speculation which threatens to stand upon the ruins of the United States Bank until the country shall be overwhelmed with emissions of paper from these new manufactories.

Mr. Seybert thought the charter was constitutional when it was granted, because the bank was then a necessity; it was no longer such. 


\section{Denunciation of THE Bank.}

P. B. Potter, of New York, said the bank was unconstitutional; that Hamilton was wrong in assuming that the United States Government was sovereign; it was only sovereign within the Constitution.

Mr. Desha, of Kentucky, agreed with Mr. Potter. The question was whether we will foster a viper in the bosom of our country that will spread its deadly venom on the land and finally affect the vitals of our republican institutions, or whether we will, as is our duty, apply the proper antidote by a refusal to renew the charter, thereby checking the cankering poison. He thought the bonus offered by the bank was a bribe offered to the nation. He had no doubt that George III was a principal stockholder in the bank, and that the English monarch regarded it as an instrument in effecting his nefarious purposes against the United States, and would bid up several millions of dollars rather than not have the charter renewed. This was a safer method than encountering Americans in arms. Of that we made him extremely tired when we were in a state of infancy.

Mr. Pickman was anxious to have the charter renewed. He spoke of the pressure its liquidation and the payments of the amounts due it in specie would bring upon the creditors of the institution, including among the latter the State banks.

Mr. Alston (N. C.) had no doubt of the constitutional power to create a National bank ; he, however, desired an institution the stock of which should be held by the States.

Mr. Key thought it was both constitutional and expedient that the charter be renewed.

Mr. Love and Mr. Newton wanted an immediate decision. The former believed that, considering the near approach of the date of expiration, Congress should take action so that the Government or bank should not be embarrassed.

Mr. Troup said the bank should have got ready to wind up three years since.

Mr. Fisk asked whether the Government deposits were to be transferred to the State banks without sanction of law.

Mr. Wright (Md.) regarded the measure as unconstitutional. He referred to the fears expressed that agriculture, commerce and manufactories will receive a vital stab by suffering the charter of this bank to expire. This is a groundless phantom, produced by the feverish fancy of those laboring under the bank mania. But if it should be felt to the extent apprehended he trusted that it would be borne with fortitude by our fellow citizens when they reflect that it could not be renewed but by a violation of the Constitution, and perhaps of our independence. This charter is a cancer upon our body politic which he hoped the hand of time would be suffered to eradicate.

Mr. Boyd considered the bank a great swindle founded on paper 
of the State issued to speculators for Revolutionary claims at their par value, which the speculators, as soon as they knew of Hamilton's funding scheme, had sent out runners to purchase at $2 \mathrm{~s}$. 6d. up to $8 \mathrm{~s}$. in the pound. He was an anti-bank man, and thought that what little good they might do was counterbalanced by greater disadvantages.

Mr. McKee had believed the constitutional question settled by the original grant of the charter and by the confirmation of Mr. Jefferson and the votes of a Republican Congress. He stated that if the question had been brought before Congress in 1808 the charter would have passed by a large majority.

According to Mr. Barry, the measure was unconstitutional.

Mr. Findley regarded it as a dangerous experiment to refuse to recharter the bank.

Mr. McKim did not think the consequence of winding up the institution would be as serious as imagined. Its debts exceeded the amount due to it. What it called in with one hand it would pay out with the other.

Mr. Gold's opinion was that the answer made by those who opposed the recharter, viz., that the State banks could be relied upon to administer the finances of the Government, was an admission that a bank was necessary. Gentlemen look with fear and trembling lest there should be the intermission of a day between the separation of the charter of the United States Bank and the gladdening reign of State banks. Preparations are in forwardness for celebrating the nuptials of these State damsels who with little modesty attend the ante-chamber eager to rush into the arms of the patronage of the Treasury.

Mr. Johnson opposed the recharter from a sense of duty, believing it to be unconstitutional and inexpedient. He regarded its stockholders as a moneyed aristocracy, a privileged class.

Mr. Sheffy, far from believing the country in danger from the bank, which had been characterized as a viper, feared a much more deadly viper in the encroachments made on the Federal Government by the States. If it is seriously wished that this Government and this Union should be preserved, it is time that the spirit of encroachment and control assumed by some of the States should be discouraged.

Mr. Garland, Mr. Tallmadge, Mr. Nicholson and Mr. Stanley argued for the constitutionality of the bank, and Mr. Crawford, Mr. Rhea and Mr. Eppes replied to them.

The House postponed the bill by a vote of sixty-five to sixty-four.

A resolution of the State of Virginia requested its Senators and Representatives to use their best efforts to defeat the recharter.

Views of SECRETARy GaLlatin.

When the petition of the bank for renewal was presented in the United States Senate, in December, 1810, the committee to whom it 
was referred requested the opinion of Albert Gallatin. In a letter of January 20, 1811, Mr. Gallatin was manifestly in favor of the renewal. Upon the question of constitutionality he wrote: "Permit me simply to state that the bank charter, having for a number of years been acted upon, or acquiesced in, as if constitutional by all the constituted authorities of the nation, and thinking myself the use of banks to be at present necessary for the exercise of the legitimate powers of the general Government, the continuation of a Bank of the United States has not, in the view I have been able to take of the subject, appeared to me to be unconstitutional."

The debate on the measure commenced on February 11 on a motion to strike out the first section.

Mr. Crawford argued in favor of the constitutionality and expediency of the measure. He alluded to the abuse of the recharter, current in the Democratic * papers of the day, saying that he had always thought that a corporation was an artificial body existing only in contemplation of law : but, if we can believe the rantings of the Demoeratic editors in these great States, and the denunciations of our public declaimers, it exists under the form of every foul and hateful beast and bird and ereeping thing. It is an hydra ; it is a cerberus ; it is a gorgon; it is a vulture; it is a viper. This is what is called the liberty of the press. It is tyranny. To him it was perfectly indifferent whether the tyrant is an irresponsible editor or a despotic monareh.

Mr. Leib presented resolutions by the Legislature of Pennsylvania, requesting their Senators and Representatives to oppose the recharter. $\checkmark$ Mr. Lloyd was in favor of the recharter, and spoke of the various classes of people who were in favor of it.

Mr. Giles followed at great length against the bill.

Henry Clay followed Mr. Giles, and remarked that his argument was both instructive and amusing. He had discussed both sides of the question with great ability and eloquence, and certainly demonstrated to the satisfaction of all who heard him both that it was constitutional and unconstitutional, highly proper and highly improper to prolong the charter of the bank. He was against the recharter-and alnost entirely upon the ground that the power to create such institution was not granted by the Constitution.

Mr. Pope said this question had become a contest between a few importing States and the people of the United States. The Legislatures of two large States had instructed Congress to give up the collection of the revenues to the State banks. He did not believe in making an unnecessary and wanton attack upon the commercial interests of the country. He thought the bill was opposed by some who were in favor

* The party opposed to the Federalists was first known as the Republican and aftervards as the Democratic Republican party. The latter name was gradually omitted and the party has from that time until the present day been designated as the Democratic party. 
of a new National bank. It was questionable if, on the downfall of this institution, any one, either foreigners or citizens, would invest in a new national organization. The fall of this will throw most of the banking capital into the banks of the great commercial States whose hostility will be increased against any new national institution.

Mr. Smith, of Maryland, was against the recharter.

Mr. Brent was in favor of the bill. He began with some diffidence, but made one of the longest speeches in the debate.

Mr. Taylor believed in the constitutionality and expediency of the recharter.

Mr. Pickering stated he had received an instruction in the form of a request from the House of Representatives of the State of Massachusetts to vote against the bill. He went on to show that such instructions were not obligatory, as they interfered with the independence of representatives and violated the Constitution of the United States.

When the vote on the question to strike out the first section was taken, it stood seventeen to seventeen, and George Clinton, of New York, the presiding officer, cast the deciding vote in favor of rejecting the bill. In casting the deciding vote he said that the power to create corporations is not expressly granted; "it is a high attribute of sovereignty, and in its nature not accessorial or derivative by implication, but primary and independent. He thought this interpretation of the Constitution safer than the other, which had an inevitable tendency to consolidation."

\section{Liquidation OF THE Bank.}

After the final rejection of the bill for the recharter the bank presented a further memorial to both the House and Senate asking for a temporary extension of its powers for two years to enable it to close up its affairs. In each case the memorial was referred to a committee, and both committees reported adversely to granting the prayer of the memorialists.

The trustees of the Bank of the United States applied for charters for new banks to succeed to the business, to the Legislatures of New York and Pennsylvania. The charter of the Bank of America was finally granted by the State of New York after some exciting episodes in the Legislature of that State, continuing for a year or two, the history of which is included in that of the Bank of America, of New York. The Bank of Commerce was the name desired in the application of the trustees to the State of Pennsylvania. It was reported upon favorably by a grand committee of thirty-one members. The bill provided for a bank with a capital of $\$ 7,500,000$, to continue till 1832 .

The banking house and most of the assets of the Bank of the United States, including over five inillions of dollars in specie, were purchased by Stephen Girard, of Philadelphia, who at once started the Girard Bank, which, converted to a National bank in 1865 , continues to this 
day. The purchase and transfer came about in this way. In 1810 Girard had large balances with the Barings, amounting to $£ 116, ; 01$. In 1811 the indebtedness of that firm to him was nearly $£ 200,000$. The difficulties in trade with the Continent were great and the Barings were in danger. Mr. Girard sent two agents to London to do what they could to withdraw the amount due and transmit it to America. Part of the funds were invested in goods and part in American six per cent. stocks and United States Bank shares, then at about $\$ 4301 / 3$ (£98 10s.) per share. The Barings, it will be remembered, had purchased a large amount of the bank stock from the United States Government in 1804. The stock Girard had purchased gave him a large interest in the bank; and, in the spring of 1812 , he found by consultation with George Simpson, the Cashier of the old institution, that the bank building and Cashier's house could be purchased for $\$ 120,000$, less than one-third of its cost. The purchase was made, the property was transferred to Girard, and his new bank commenced operations on May 12 , 1812, with $\$ 1,200,000$ capital, which was afterward increased to $\$ 1,300,000$.

Much of the business of the Bank of the United States was transferred to Girard's bank, together with $\$ 5,000,000$ in specie. The officers and employees of the old bank were retained at the same salaries. Girard bought the stock expecting the charter of the Bank of the United States to be renewed. If this had occurred he would have made a fortune by the rise in stock. But, as it was, he saved himself by the purchase of the old bank. He did not use the old circulating notes, but paid out notes of State banks till his own were printed, which bore the device of a ship under full sail and an American eagle.

The stockholders of the Bank of the United States received, on the final winding up of the institution, $\$ 434$ per share, which, with dividends averaging about eight per cent. per annum, made it no bad investment.* Many, however, had bought and sold at much higher rates some years previous to the expiration of its charter. The United States Government sold to the Barings for a premium of forty-five per cent. in 1802 , or $\$ 580$ per share.

\section{Condition of State Banks.}

The State banks, which the opponents of the recharter believed adequate to the fiscal requirements of the Government and to the monetary necessities of trade and industry, failed in the trial to which the exigencies of the War of 1812 subjected them. In September, 1814, all of them which were south of New England suspended specie payments. Nearly one hundred of them in different sections of the country had been of necessity, in the absence of a National bank, selected as depositories of Government funds. The check on the redemption of their notes being removed, an expansion of their issues followed; its amount,

\footnotetext{
* Parton, "Life Eminent Americans," p. 22\%.
} 
which was estimated in 1811 at $\$ 28,100,000$, being in succeeding years according to Mr. Crawford, as follows:* In 1813, from $\$ 62,000,000$ to $\$ 70,000,000$; in 1815 , from $\$ 99,000,000$ to $\$ 110,000,000$, and in 1819 , from $\$ 45,000,000$ to $\$ 53,000,000$.

During the year 1816 the banks continued to issue largely, and, in addition to this, floods of unchartered currency were poured out in notes of all denominations from six cents upward. Great distress resulted to the country from the depreciation of the currency and from the failures of banks in 1818, 1819 and 1820. The root of the evil lay in the attempt of the Government to carry on an expensive war by means of bank loans and the notes of State corporations over which it had no control, thereby converting an irredeemable paper issued by irresponsible institutions into a national currency by assisting in its circulation and encouraging its expansion. In 1814 Treasury funds to the amount of nearly nine millions of dollars were in the suspended banks; and the correspondence of Secretary Crawford with the deposit banks from January 1,1817 , to May 8,1822 , fills two volumes, comprising 1,237 pages. $\dagger$ The loans of the Government in 1815 amounted to $\$ 35,220,671$. Treasury notes were not redeemed, and general distrust prevailed.

On October 6, 1814, Mr. Dallas was appointed Secretary of the Treasury; and on the 14th of the same month, in response to a communication from the Committee on Ways and Means, he transmitted a report strongly recommending the organization of a National bank. In that report he says: "The multiplication of State banks in the several States has so increased the quantity of paper currency that it would be dificult to calculate its amount and still more difficult to ascertain its value. * * * There exists, at this time, no adequate circulating medium common to the citizens of the United States. The moneyed transactions of private life are at a stand, and the fiscal operations of the Government labor with extreme inconvenience. $* * *$ Under favorable circumstances, and to a limited extent, an emission of Treasury notes would probably afford relief; but Treasury notes are an expensive and precarious substitute either for coin or bank notes, charged as they are with a growing interest, productive of no countervailing profit or emolument, and exposed to every breath of popular prejudice or alarm. The establishment of a National institution, operating upon credit, combined with capital, and regulated by prudence and good faith, is, after all, the only efficient remedy for the disordered condition of our circulating medium. The establishment of a National bank will not only be useful in promoting the general welfare, but it is necessary and proper for carrying into execution some of the most important powers constitutionally vested in the Government."

Alexander J. Dallas, like Mr. Gallatin, his predecessor in office, was

* Finance Report, Vol. XII, p. 59.

+ Eighteenth Congress, first session, No. 140. 
not a native of the United States. He came to this country from Jamaica when twenty-four years of age. He was a Jeffersonian Democrat, and one of Mr. Gallatin's most intimate friends. When the latter retired from the Treasury Mr. Dallas was called by President Madison to the position. He afterwards became Secretary of War, and died suddenly in 1817 .

After 1811, in place of one United States bank acting as its fiscal agent, the Government accounts were distributed among a large number of State banks scattered all over the Union. Such was the state of the public credit in 1813 and 1814 that in those two years $\$ 42.269$,776 of six per cent. stccks issued by the Government and running for twelve years were sold at a discount of nearly fifteen per cent., the Government realizing from their sale but $\$ 35,987,762$. On February 24,1815 , a loan of $\$ \$, \$ 56.960$, running for nine years, but with interest increased to seren per cent., was negotiated at par; and, on March 3 following, another loan of $\$ 9,745,745$ for nine months at six per cent. interest brought into the Treasury but $\$ 9,284,044$, the discount in this instance being nearly fire per cent. In addition to these losses the money received for the loans was at a heary discount for specie-the depreciation in the local currency at the close of the war ranging to twenty and even twenty-five per cent., and the Government supplies being obtained only at a proportionate rise in price. Such were some of the results of a State bank system during the period that followed the expiration of the charter of the bank on March 4, 1811, and until its re-establishment on January $7,1817$.

\section{Sketch of Stephen Girard.}

Stephen Girard was born May 20, 1750, near Bordeaux, France. His father was the owner of several vessels and an ex-officer in the Royal Navy of France, and was knighted by Louis XV for saving a burning ressel at sea. The son also became a mariner, and soon after his arrival at New York, in 1774, he engaged in trade with New Orleans and the West Indies. In 1776 he went into mercantile business at Philadelphia. His enterprises were highly prosperous. During the yellow fever epidemic in 1793, and subsequently, he was active in relieving the poor and afflicted. He purchased the assets of the United States Bank and founded the Stephen Girard Bank, which sustained the Government in the War of 1812 , taking an entire loan of $\$ 5,000,000$. The bank continues in business as the Girard National Bank, occupying what is believed to be the oldest bank building in the United States, its construction haring been commenced in 1795. Mr. Girard died December 26, 1831, bequeathing his large fortune principally to Girard College. The value of the residuary fund is now over $\$ 15,000,000$, and is constantly growing, only the income being used. Stephen Girard was one of the most successful bankers this country has known, while his benevolences insure him a permanent place among the world's great philanthropists. 


\section{BANKING UNDER FEDERAL CONSTITUTION CONTINUED- SECOND BANK OF THE UNITED STATES, 1817-1829.}

Petition from New York city for National bank - Secretary Dallas recommends National bank and furnishes plan-Action upon it unfarorable-Amended by Senate Committee - Vote analyzed - Veto of President Madison-Recommendations of Madison-Report of Dallas' plan presented to House-Bill passes House and Senate-Synopsis of law for second Bank of the United StatesOperations of Bank in 1817-1818 - Speculation in its stocks - Influence on State banks - Causes of dissatisfaction - Investigation by Congress - Mismanagement shown-Change of officers - Great success of bank from 1820 to 1829 - Nicholas Biddle becomes President - Sketch of Biddle and other Presidents - Beginning of attack by Jackson - Message of 1829 - Jackson's position - Report of House Committee-Amos Kendall - Kitchen cabinet.

\section{Petition for Bank from New York.}

On January 4, 1814, a petition was presented in the House of Representatives by Mr. Lefferts, signed by 150 inhabitants of New York city, praying that an act be passed incorporating a National bank with a capital of $\$ 30,000,000$, and was referred to the Committee of Ways and Means. This committee reported that the power to create corporations within the territorial limits of States was not delegated by the Constitution, nor was it essentially necessary to carry into effect any of the delegated powers.

Mr. Calhoun asked that the committee be instructed to inquire into the expediency of establishing a National bank in the District of Columbia, which was agreed to. On February 19, 1814, a bill was introduced for the purpose of creating a National bank in the District with a capital of $\$ 30,000,000$. The bill was opposed chiefly upon the ground that it would antagonize a Government loan of $\$ 25,000,000$ then authorized; and opposition was also manifested to its location. It was not again taken up. On April 2, 1814, Mr. Grening moved that a committee be appointed to inquire into the expediency of establishing a National bank. After some debate a motion to indefinitely postpone was lost by a vote of eighty to seventy-one. A committee was appointed, but, on April 8, discharged and the subject was not again taken up at this session. 


\section{Proposals of the Secretary of the Treasury.}

On October 14, 1814, John W. Eppes, chairman of the Committee on Ways and Means, wrote to the Secretary of the Treasury as to the best means of sustaining the public credit. On October 17 Secretary Dallas replied, recommending the incorporation of a National bank, to be established at Philadelphia, with a capital of $\$ 50,000,000$, divided into 100,000 shares of $\$ 500$ each. Two-fifths of the stock was to be taken by the Government. The subscriptions, with the exception of $\$ 600,000$ in specie, were to be in six per cent. stock or Treasury notes. The capital and circulation and all property of the bank except real estate, was to be exempt from National and State taxation; no other bank was to be incorporated by Congress during its life of twenty years; it was to have branch offices of discount and deposit, and its accounts were to be subject to the inspection of the Secretary of the Treasury. On December 21, 1814, the House took into consideration the Secretary's suggestions, and passed a resolution that it was expedient to establish a National bank, by a vote of ninety-three to fiftyfour. On November 13, 1814, a bill was introduced by Mr. Fisk, of the Committee on Ways and Means, which seems to have followed closely the plan of Secretary Dallas. This bill was taken up in Committee of the Whole, and, after some debate, Mr. Calhoun proposed a substitute by which all the stock was thrown open to individual subscriptionsnone to be taken by the United States. The subscriptions were to be paid for one-tenth in specie and the remainder in Treasury notes. Mr. Calhoun believed this would sustain at par a new issue of Treasury notes, which would give immediate relief to the Government. After a debate lasting four days Mr. Calhoun's amendment was agreed to by a majority of about sixty votes.

The Secretary of the Treasury was requested by the Chairman of the Committee on Ways and Means to communicate his views in regard to payment of the subscription on Treasury notes. He answered that an issue of Treasury notes would have an injurious effect upon the credit of the Government, and especially upon the loan of 1815; that he did not believe forty-four millions of Treasury notes could be got into circulation without depreciation. At the date of his letter the House had rejected the provision requiring a loan of $\$ 30,000,000$ to the Government, and had also struck out the permission given to the bank to suspend specie payments under certain conditions, and had given it permission to sell any of the public stocks it might receive for subscriptions. Another important change in the plan of the Secretary was the reduction in the capital from fifty to thirty millions. After the Secretary's letter was received the House refused to permit the bill to be read a third time, by a vote of one hundred and four to forty-nine, the vote being taken on November 28, 1814. 
A bill similar to that first introduced in the House was taken up in the Senate on December 2, and passed on December 9. By it the capital of the proposed bank was to be fifty millions; and it was bound to lend thirty millions to the Government. While the war lasted it had the right to suspend specie payments in certain contingencies, and was also during that period prohibited from selling any United States stocks received in subscriptions to its capital. This bill was rejected by the House on January 2, 1815, the vote standing eighty-one in its favor to eighty against-Mr. Cheves, the Speaker, making it a tie vote. The Speaker declared the decision of the House to be that the bill should not pass. Mr. Hall, of Georgia, moved to reconsider the bill, and the bill was recommitted to a select committee of seven. Mr. Webster had previously indicated that, if certain amendments were adopted, he and his friends would be willing to vote for the measure. Among these the most important were to reduce the capital, to strike out the right to suspend specie payments, the requirement of loan to Government, and the provision restraining the bank from selling stock during the war. When the committee again reported these amendments had been adopted, and the bill passed by a vote of one hundred and twenty to eighty-seven. After some conference, on January 20, the Senate agreed to it in its amended form. The vote in the House indicates that $\mathrm{Mr}$. Webster and his friends controlled about forty votes, and seem to have been more or less State bank men.

\section{Bill Vetoed by President Madison.}

The bill was now in precisely the same form that had been pronounced inadequate to the necessities of the Government by Secretary Dallas in his letter of November $2 \%, 1814$. On January 30, 1815, it was vetoed by President Madison on the same grounds of objection taken by the Secretary of the Treasury. Its capital was not large enougli; and part of that capital was to be made up of Treasury notes. It was not under obligation to make any loans to the Government. The bank being compelled to redeem its notes in specie, in time of war, its notes could not be kept in circulation to the extent required by the Government. The capital being so small the amount of public stocks subscribed for would have but little effect in enhancing the market value of the stocks; and even this effect the bank was permitted to counteract by the sale of the securities it received, being tempted to dispose of them to obtain the specie it might require to circulate its notes. On the whole, the law would make the bank very profitable to itself in time of peace, but of little use to the Government in time of war. He waived the question of constitutional authority of the Legislature to establish an incorporated bank as being precluded, in his judgment, by repeated recognitions, under varied circumstances, of the validity of such an institution in acts of the Legislative, Executive and Judicial branches of the Government, accompanied by indications, in different 
modes, of a concurrence of the general will of the nation. On February 2,1815 , the Senate refused to pass the bill over the President's veto, and, on the sixth, Mr. Barbour again introduced the bill in its original form, and it again passed the Senate on February 10, 1815; but the House postponed it indefinitely on February 13 by a vote of seventy-four to seventy-three.

\section{President's Message, 1815.}

President Madison, in his message on December 5, 1815, said:

"The absence of the precious metals will, it is believed, be a temporary evil; but, until they can again be rendered the general medium of exchange, it devolves on the wisdom of Congress to provide a substitute which shall equally engage the confidence and accommodate the wants of the citizens throughout the Union. If the operation of the State banks cannot produce this result the probable operation of a National bank will merit consideration; and, if neither of these expedients be deemed effectual, it may become necessary to ascertain the terms upon which the notes of the Government (no longer required as an instrument of credit) shall be issued upon motives of general policy, as a common medium of circulation."

It will be observed that now the President asks legislation, not for time of war, but to provide for the necessities of a time of peace. The war plan of Secretary Dallas for a National bank had been rejected by Congress, and the measure adopted by Congress in 1815 had been rejected by the President as insufficient for the necessities of war time.

\section{Plan of Mr. Dallas for a National Bank.}

Mr. Dallas, on December 6, 1815, sent to the Speaker of the House a proposition relating to the National circulating medium. He considered four questions: Whether it was practicable to renew the circulation of gold and silver coins; whether the State banks could be successfully employed to furnish a uniform currency; whether a National bank would be more advantageously employed for the purpose; and, last, whether the Government itself could supply and maintain a paper medium of exchange. In regard to the State banks, while acknowledging the valuable services and liberality of some of them, he said: "The truth is, that the charter restrictions of some of the banks, the mutual relation and dependence of the banks of the same State, and even of the banks of the different States, and the duty which the directors of each bank conceive they owe to their immediate constituents upon points of security or emolument, interpose an insuperable obstacle to any voluntary arrangement upon national considerations alone for the establishment of a national medium through the agency of the State banks." He concluded against the possibility of specie alone, against Government issues, and finally that a National bank was the best and perhaps the only resource. At the request of the National Currency Committee of the House, Mr. Dallas, on December 24, 1815, enclosed an outline of a plan for a National bank. He proposed now a 
bank for twenty years with a capital of $\$ 35,000,000$, seven million dollars of which was to be subseribed by the Government. This might be augmented to $\$ 50,000,000$ by Congress, the increase to be divided among the States. It was to be located at Philadelphia, and could establish branches or employ State banks as branches. It was to pay specie at all times, and not to suspend without authority of Congress. In lieu of the loan, it was to pay the Government a bonus of $\$ 1,500,000$. In time of peace the Administration had come to the terms which Congress had shown itself willing to accede to in time of war.

\section{The Bill Débated and Passed.}

A bill was introduced embodying Mr. Dallas' suggestions upon February 26,1816 . The debate was chiefly upon a motion to reduce the capital to $\$ 20,000,000$. In this debate Mr. Clay spoke in favor of the bank. Two reasons he gave for changing his position were that, in 1811, when he voted against the recharter of the old bank, he was instructed by the Legislature of his State to do so, and at that time he did not deem a National bank as necessary in a constitutional sense. He then relied upon the State banks as being able to meet all the wants of the Government financially; but it now appeared that the general Government could no longer depend upon them. A National bank seemed to him now not only necessary, but indispensable. At one time Philadelphia was struck out and New York selected as the principal seat of the bank by a vote of seventy to sixty-four, but this was reconsidered and Philadelphia replaced. The bill finally passed the House without important amendment, on March 14, 1816, by a vote of eighty to seventy-one. It was introduced in the Senate on March 22, and passed on April 3 with one or two amendments that, when the bill came to the House next day, Mr. Calhoun pronounced to be slight. Upon the fifth they were concurred in and on the tenth received President Madison's signature.

\section{Provisions of the Charter.}

The charter was limited to twenty years, expiring on March $3,1836$. The capital was fixed at $\$ 35,000,000$, seven millions of which was to be subscribed by the Government, payable in coin or in stock of the United States bearing interest at five per cent. and redeemable at the pleasure of the Government. The remaining stock was to be subscribed for by individuals and corporations, one-fourth being payable in coin and three-fourths in coin or in the funded debt of the United States. Five of the directors were to be appointed by the President, and all of them were required to be resident citizens of the United States, and to serve without compensation. The amount of the indebtedness, exclusive of deposits, was not to exceed the capital of the bank. The directors were empowered to establish branches, and the notes of the bank, payable on demand, were receivable in all payments to the United States. The 
penalty for refusing to pay its notes or deposits in coin, on demand, was twelve per cent. per annum until fully paid. The bank was required to give the necessary facilities, without charge, for transferring the funds of the Government to different portions of the Union and for negotiating public loans. The moneys of the Government were to be deposited in the bank and its branches, unless the Secretary of the Treasury should otherwise direct. No notes were to be issued of a less denomination than five dollars, and all notes smaller than one hundred dollars were to be made payable on demand. The bank was not, directly nor indirectly, to deal in anything except bills of exchange, gold or silver bullion, goods pledged for money lent, or in the sale of goods really and truly pledged for loans, or of the proceeds of its lands. No other bank was to be established by authority of Congress during the continuance of the corporation, except such as might be organized in the District of Columbia with an aggregate capital not exceeding six millions of dollars; and, in consideration of all the grants of the charter, the bank was to pay to the United States a bonus of $\$ 1,500,000$ in three annual installments.

Mr. Dallas, whose first plan for a National bank was so unceremoniously rejected, was appointed Secretary of the Treasury by Mr. Madison in February, 1814. His predecessor, Mr. Gallatin, who had been appointed Commissioner to Russia to negotiate a treaty of peace and commerce with Great Britain and treaty of commerce with Russia, left the country in May, 1813, and the Treasury without a head. In June the Senate refused to confirm Mr. Gallatin as commissioner, and Madison still regarded him, though absent, as head of the Treasury. Under these circumstances Mr. Mason moved a resolution in the Senate on January 24, 1814, declaring the Secretaryship of the Treasury vacant,* but the subject was postponed inasmuch as it was authoritatively announced that the President would appoint a Secretary in a few days, which promise was fulfilled. $\dagger$ Mr. Mason, in a letter to his wife, said: "The new Secretary is good for nothing; but that is not our fault." Mr. Dallas was thought extremely culpable in the encouragement he gave to State bank paper by receiving it for public dues when not payable in specie. His scheme of 1814-15 was looked upon as one for a paper National bank, which would only make matters worse. Mr. Gore, Senator from Massachusetts, in a letter to Mr. Jere. Mason, expresses the feeling against him. He could not conjecture, he wrote, what Dallas' plan at the next session would be, but he expected a sentiment in Congress which would enable them " to put down the schemes of this mountebank." There was, however, a general agreement that a National bank was necessary, the differences arising being those in regard to the plan. That then proposed by the Administration seemed to excite the opposition of all except its own immediate supporters.

* Letter Jeremiah Mason to Appleton, December 21, 1813, p. 70.

+ J. M. to Mrs. M., February $23,1814$. 


\section{The Bayk Commences Business.}

Section twenty-two of its charter required the bank to commence operations by the first Monday in April, 1817: The bank went into operation on January 7, 1817. This was at the worst stage of the monetary troubles, beginning with the suspension of specie payments in 1814, and continuing until the general erash of 1819 and 1820. At this time lands and agricultural products had fallen to one-half the prices which were readily obtainable in 1808 and 1810 , and to one-third of the value they possessed when the excessive indebtedness of the people was incurred -namely, during the inflation years of the State banks. The contraction of the circulation and the general failures of the State banks began in 1818. The second United States Bank, therefore, came into existence on the very verge of a great monetary crisis. When it commenced business the first installment of capital, amounting to $\$ 1,400,000$ in specie and $\$ 7,000,000$ in United States stocks, had been paid. The subscription had been opened July 7, 1816. The payment of the second installment of capital became due on January 7, 181\%. The law required this to be paid ten dollars in specie and twenty-five dollars in United States stock or specie. It appears, however, that instead of requiring the stockholders to pay in this installment from outside sources, the bank on January 7 began to discount the notes of stockholders upon the pledge of their stock to the amount required to pay the specie part, and in some cases to the full amount of both specie and United States stock required to make up the whole installment.* After a time discounts were made to the full value of the stock, which enabled the stockholders not only to pay up in full, but even to draw out what they had first advanced. The discounts were made in the bank's bills, which were considered equal to specie. Of the $\$ 28,000,000$ eapital subscribed by individuals $\$ 7,000,000$ was to have been paid in specie and $\$ 21,000,000$ in United States stock. The bank appears to have actually received nearly $\$ 2,000,000$ in specie and $\$ 13,872,610$ in public stocks. The difference represents about the amount made up by stocks. The bank, therefore, was forced to import the coin it needed, and up to November, 1818, had thus acquired $\$ 7,311,750$ in specie at an expense of $\$ 525,297$.

\section{Speculation in Bank's Stock.}

The directors of the new institution appear to have made every effort to boom the stock in the market. Not only did they "facilitate" the payments of the installments by discounting to the full amount of the stock, but they also encouraged trading in stock by authorizing the renewal of stock notes as they fell due and by permitting the purchaser to substitute his note, secured by the purchased stock, for that of the

* Report of Investigating Committee, 1818. 
previous holder.* Further than this, they soon began to authorize discounts on pledge of stock to its full market value. One could purchase bank shares without the advance of a cent. It was only necessary to apply for a loan upon the security of the shares to be bought, and pay for the stock with the proceeds. When the price of shares rose sufficiently a sale could be made and the difference pocketed. It appears that the President, William Jones, and a number of directors and officers, especially those connected with Baltimore branches, had direct personal interest in these transactions, which they did not pretend to conceal, but considered as lawful private concerns. The stock rose as high as $\$ 156$ per share in August, 1818, but soon after fell to about $\$ 110$. While there were no doubt gross irregularities in its management, for which the bank was very soon to suffer, it did much good even under these disadvantages. $\dagger$ It received upon deposit from the United States Treasury the notes of State banks, and in return furnished a uniform eurrency. It transferred funds whenever needed, and the amount paid in in United States stocks had its effect in enhancing the credit of the Government loans. It exerted sufficient influence upon the currency to make itself very unpopular with the State banks during the financial erisis of 1818, although even those who were hostile to it admitted its policy toward the State institutions had been marked by great consideration and lenity. In fact, on this point its enemies were obliged to fall back on the charge that by this very lenity and consideration it had led the State banks to unduly extend their business, had drawn them into temptation and made them unfit to meet the financial storm. It did not accustom the local banks to pay specie soon enough, and by putting off the evil day found them unprepared at last. Up to August, 1818, the bank redeemed its notes both of the parent bank or its branches at any of its offices where they might be presented, but after that date redeemed its bills only at the office which put them in circulation. This change was made because the bills were largely used for purposes of remittance, and in the localities where a sound local currency was most needed the bills were gathered up and sent off, leaving the field to the inferior State bank circulation. $\ddagger$ A more important reason was that the change enabled the bank to realize a profit by the sale of its drafts. This change was persevered in and afterwards afforded the basis of President Jackson's assertion that the bank did not furnish a uniform currency.

\section{Transactions of the Baltimore Branch.}

The transactions which placed the institution in a most dangerous position in 1818, and which resulted in serious losses, were connected with its Baltimore branch. The managers of this branch appear to have been in fact independent of the parent bank, and to have indulged 
their favorites with large discounts for speculative purposes, thus disposing of means far greater than properly belonged to that part of the concern. To make the discounts the Baltimore branch drew largely upon the parent bank and the northern branches at New York and Boston. Its debt to Philadelphia was at times as high as $\$ 9,000,000$ and to New York $\$ 1,500,000$. These heavy drafts were continued without regard to the expostulations of the directors of the central bank, and drained the northern branches of their specie.

In November, 1818, Mr. Spencer, of New York, moved in the House of Representatives that a committee be appointed to examine the affairs of the institution. A committee was accordingly appointed with Mr. Spencer, chairman, and the report of their examination was presented to the House on January 16, 1819. The committee criticized the discount of stock notes, the speculation in stock by the President and other officers of the bank, the dealings of the bank with the State banks, the manner of drawing drafts among the branches and of voting on stock, the sale of United States securities, and some other points of management, from which they concluded that some action regulating the business of the bank was necessary. Resolutions were introduced contemplating the forfeiture of the charter unless the stockholders submitted to some important modification of that instrument. Rufus King, in a letter to Jere. Mason, dated February 7, 1819, mentions the dissatisfaction growing out of the bad administration of the bank officers, and states that it was the fashion to ascribe all the troubles in banking matters to the Bank of the United States. He described its opponents in the House of Representatives as angry and intemperate, those from the interior and western world being ready, on account of the difficulties of the State banks in their sections, for any measures which would put down the Bank of the United States.* In a previous letter to Mr. King, Mr. Mason had dryly remarked, "I know but little of the doings of the bank. In its origin we supposed it was intended to be made in a special manner subservient to the views and interests of its patrons. I presume, from the stories of bank speculations which are told, that object had been attained. There is no doubt that much unexpected pressure was brought upon the bank by the fact that within the first four months of its existence $\$ 12,000,000$ of the $\$ 20,000,000$ United States stock which had been subscribed and paid in as a part of its capital was called and paid by the Government." $\dagger$

This seems to have worked badly for the bank in a threefold manner. The Government paid for the stock in bills of State banks, which formed the bulk of the Government receipts at this period, and the Bank of the United States had to exercise much discretion and care in realizing upon them, and no doubt sustained some losses, which by Mr. Biddle were afterwards estimated at over $\$ 200,000$. It lost the interest

* 1818.

+ Amer, State Papers, Fin., Vol. IV, p. 793 ; letter from Wm. Jones, Pres., May 16, 1817. 
on the Government stock and had to invest the proceeds in discounts in order to secure an income for its stockholders.* There was thus a great temptation to extend its credits at all hazards. The managers of the Baltimore branch discounted for themselves and friends with great recklessness, and large sums were lost to the institution. The suspended debt of these managers in 1820 amounted to $\$ 1,540,000$.

\section{Change in the Bank's Management.}

The agitation against the bank did not result in forfeiture or modification of its charter, but it did result in a change of management. William Jones, Esq., resigned the Presidency, and, awaiting the appointment of new Government directors, James C. Fisher was elected to succeed him temporarily. $\dagger$ On March 6, 1819, the full board elected Langdon Cheves to succeed Mr. Fisher. Mr. Cheves found the institution in a precarious condition. He at once instituted a searching examination into all its affairs, especially into those of the Baltimore branch. In his letter of January 12, 1821, he speaks of the frauds perpetrated upon the bank and the consequent losses, the lack of any legal penalty for such offences, and that unfaithful officers can even while an investigation is going on take the bank's property from its vaults and hold it for their own purposes. $f$ The losses at the branch were reported to be three millions of dollars. Under Mr. Cheves' management and the general improvement of business the bank soon recovered. "The prime object, and the one toward which he immediately bent his every energy, was the maintenance of specie payments." In $1823 \mathrm{Mr}$. Cheves was succeeded in the Presidency by Nicholas Biddle.

\section{Langdon Cheves, President Bank of the United States.}

Langdon Cheves was born in South Carolina in 17\%6. He first entered public life as a member of the Legislature of that State, and afterwards served as Attorney-General until he was elected to Congress in 1811, where he was first chairman of the Committee on Naval Affuirs and afterwards of the Committee on Ways and Means. He was Speaker of the House during the absence of Henry Clay in Europe in 1814, and the first bill for the creation of the second bank of the United States was lost by his casting vote. In 1819, however, as has been seen, he was elected President of the bank to succeed Mr. Jones.

He had to reform the abuses, arising from the too liberal policy of his predecessors, and bear the burden of forcing the banks of the country to contract their eirculation and resume specie payments. Naturally there was a short period of much financial distress that called out many complaints of his policy. He was a commissioner to carry out

* Amer. State Papers, Vol. III, p. 568.

+ Amer. State Papers, Fin., Vol. IV, p. 868.

" "Langdon Cheves and the United States Bank; " "Report Amer. Histor. Assn.," 1896, p. 367 . 
the provisions of the Treaty of Ghent. He never again held public office, but was a strong advocate of a separate Southern Confederacy when the relations between the North and the South became strained. The nullification movement in 1832 was opposed by him on the ground of inexpediency, and in $\mathbf{1 8 5 2}$ he opposed the secession of South Carolina, unless other Southern States joined the movement. He died in $\mathbf{1 8 5 7}$ at the age of eighty-one.

\section{Nicholas BIDdLe.}

Nicholas Biddle was born in Philadelphia in 1786. After graduating at Princeton College he went as Secretary of legation to Paris, and was. afterwards transferred in the same capacity to London. In 1807 he returned to Philadelphia and engaged in literary work of a commercial and financial character. He was a member of the State Legislature and endeavored to establish a general system of education. In 1814 he was a member of the State Senate. President Monroe, in 1819, appointed him a director of the Bank of the United States, and he became President of the institution in 1823.

He was a man of courtly manners, rather formal and ceremonious, and of considerable literary ability which he used with much influence upon public questions. He overrated his own power and that of the bank in the contest with Jackson, and perhaps to some extent permitted his judgment to be influenced by exaggerated views of his own importance caused by the adulation showered upon him as the controller of the financial destiny of the country. After the failure of the United States Bank of Pennsylvania, formed on the assets of the second Bank of the United States upon the expiration of its charter in 1836, he was attacked, tried for mismanagement and acquitted. Conscious of his good intentions and of undeserved obloquy, he died, it is said, heart broken in 1844.

The industries of the people and the finances of the Government prospered from 1820 to 1835 . In this interval the national debt was paid, and the stock of the bank rose in the market until it commanded a premium of twenty per cent. "Long before the election of General Jackson," says Mr. Parton, "the bank appeared to have lived down all opposition."

\section{Presidential Campaign and Election of 1824.}

In the Presidential campaign in 1824 it was not as much as mentioned, nor was it mentioned in that of 1828. In all the political pamphlets, volumes, newspapers, campaign papers, burlesques and caricatures of those years there is not the most distant allusion to the bank as a political issue.

The Presidential election of 1824 was, however the starting point of personal animosities that in time developed serious consequences for the Bank of the United States. There were four candidates for the 
high office, all of them belonging to the dominant Republican party. They were John Quiney Adams, Andrew Jackson, William H. Crawford, and Henry Clay. Jackson was the first Presidential candidate since Washington who was chosen for his military record. As might have been expected, with four leaders so equally matched, no one received a majority of the electoral votes, and the election was thrown into the House. The choice of the latter being limited to the three candidates having the highest number of votes, Clay was thrown out entirely. It was generally conceded that his popularity in the House gave him control of a sufficient number of votes to decide the contest. Instead of President he became the maker of the President. Overtures were made to him by the friends of Jackson, but Clay had strong objections to the election of a military chieftain. In a letter to a friend he wrote:

"Mr. Adams, you know well, I should never have selected if at liberty to draw from the whole mass of our citizens for a President. But there is no danger in his elevation now or in time to come. Not so of his competitor, of whom I cannot believe that the killing two thousand five hundred Englishmen at New Orleans qualifies for the various difficult and complicated duties of the chief magistracy."

The contest had narrowed down to Adams or Jackson, as Crawford had, since the election, been crippled by a stroke of paralysis. The friends of Jackson, discovering Clay's predilection for Adams, became furious, and the accusation was made that Clay had made a corrupt bargain with Adams, agreeing to make the latter President on condition that Clay should be appointed Secretary of State. This was a most effective and ingenious lie, inasmuch as Clay, as a party leader and from eminent fitness, was almost certain to have had a cabinet position offered to him, whoever was chosen President. When Adams became President, Clay, conscious of having acted from pure motives, did become, most unwisely as it turned out, the head of the Department of State; and ever after the calumny of the corrupt bargain with Adams was the stock cry against him whenever he again offered himself for the Presidency. From this time there was a bitter enmity between Jackson and Clay, and the bank suffered much as the central point of their contention.

JaCkson's Message, 1829.

President Jackson, in his first message in December, 1829, recommended that Congress should take into consideration the constitutional difficulties which might interfere to prevent a recharter of the bank. He said :

"In order to avoid the evils resulting from precipitancy in a measure involving such important principles and such deep and peculiar interests, I feel that I cannot, in justice to the parties interested, too soon present it to the deliberate consideration of the Legislature and people. Both the constitutionality and the expediency of the law creating this bank are well questioned by a large portion of our fellow citizens, 
and it must be admitted by all that it has failed in the great end of establishing a uniform and sound currency."

He suggested that if a National bank was deemed necessary that one might be devised founded upon the credit of the Government and its revenues, which would avoid the constitutional question.

\section{Condition of BANK IN 1829.}

At the beginning of the administration of General Jackson, says Mr. Parton, the Bank of the United States was a truly imposing institution. Its capital was thirty-five millions. The public money deposited in its vaults averaged six or seven millions; its private deposits six millions more; its circulation twelve millions; its discounts more than forty millions a year; its annual profits more than three millions. Its capital was, therefore, about one-quarter, and its loans, circulation, and deposits about one-fifth of the whole amount held and issued by all the banks of the country. Besides the parent bank at Philadelphia, with its marble palace and hundred clerks, there were twenty-five branches in the towns and cities of the Union, each of which had its President, Cashier, and board of directors. The employees of the bank were more than five hundred in number, all men of standing and influence, all liberally salaried. In every State in the Union and in many foreign nations of the globe were stockholders of the Bank of the United States. One-fifth of the stock was owned by foreigners. Onetenth of its stock was held by women, orphans, and the trustees of charity funds. Its bank notes were as good as gold in every part of the country. From Maine to Georgia, from Georgia to Astoria, a man could travel and pass these notes at every point without discount, and it is said that in London, Paris, Rome, Cairo, Calcutta, St. Petersburg and other prominent cities the notes of the Bank of the United States were within a fraction more or a fraction less than their value at home, according to the current rate of exchange. They could actually be sold at a premium at the remotest commercial centres. It was not uncommon for the stock of the bank to be sold at a premium of forty per cent. The directors of this bank were twenty-five in number, of whom five were appointed by the President of the United States. The bank and its branches received and disbursed the entire revenue of the nation.

\section{Report of Commitee on Ways and Means on President's Message.}

The portion of President Jackson's message having reference to the bank was on December 10, 1829, referred to the Committee on Ways and Means. On April 13, 1830, Mr. MeDuffie presented an elaborate report from the committee. This reviewed the distressing condition of the finances which had grown out of the dependence of the Government on State banks, and contended that a National bank would always be necessary to enable the Government to manage its finances 
to the best advantage. The report also showed that the currency furnished by the bank had been as uniform and safe as a currency of gold and silver; that the charges for internal exchanges made by the bank had always been less than it would have cost to transport a currency of the precious metals. The committee concluded that a National bank such as that suggested by the President would perform the duties re. quired of it no better than the present one, and would unduly extend the patronage of the Executive and give opportunities for peculation and favoritism. A committee of the Senate reported in 1829 that there seems nothing wanting to complete the evidence of the soundness and uniformity of the currency. The scheme for a National bank to be run by the Government was regarded as impracticable.

\section{Motive of the Attack on the Bank.}

The motive for bringing up in the President's message the question of the recharter of the Bank of the United States appears to have been largely if not altogether a political one. Mr. Calhoun, in a speech made in January, 1834, upon Secretary Taney's reasons for removing the deposits, asks : "Can the Secretary be ignorant that the avowed and open policy of the Government is to reward political friends and punish political enemies? $* * *$ Can he be ignorant that the real offence of the bank is not that it has intermeddled in politics, but because it would not intermeddle on the sido of power?" * A report made in 1833 by a committee of the directors of the Bank of the United States states that: "It is understood that soon after that event (the inauguration of Jackson in March, 1829), a meeting was held in Washington to consider the means of perpetuating their new authority, and the possession of the bank was among the most prominent objects of the party assembled."

The first overt act against the bank was the attempt to secure the removal of Jeremiah Mason, the President of the branch of Portsmouth, N. H. In 1828 Daniel Webster had written to Mr. Mason urging him to accept the Presidency of that branch, a previous offer having been regarded by him with some indifference. Webster's letter appears to have caused him to accept, and he was elected President in the summer of 1828. The branch had been laxly managed as to discounts, much of the resources being loaned on accommodation paper on long time. The customers had not been required to pay promptly, and when the new President instituted a reform many were offended and some ill will toward Mr. Mason was developed.

On June 27, 1829, Levi Woodbury, then an ardent supporter of Jackson, wrote a letter to Secretary of the Treasury Ingham, marked confidential, calling upon him to use the influence of the Government with the parent bank to have Mason removed. Woodbury said Mason was a friend of Daniel Webster and that his political character was

*Abridgement Debates, Vol. XII, p. 229. 
well known to the Secretary. Mr. Woodbury had for some time looked upon Mr. Mason as a rival. National politics were in a transition state; the candidates for the Presidency in 1824 were Mr. Adams, General Jackson, Mr. Crawford and Mr. Clay, all members of the old Republican party, and votes were mainly dictated by personal preferences. It was well known early in 1824 that the election would have to be decided by the House of Representatives. Mr. Mason was popular in New Hampshire. He had been a member of the Legislature for a number of years and had invariably thrown his great influence in favor of the power of the Federal Government as opposed to the doctrine of State rights. He was always conservative. In 1821 some resolutions introduced by him sustaining the power of the Government to establish a National bank were afterwards adopted in the House and postponed in the Senate by a vote of seven to five by the exertions either of Woodbury or his friend Hill. In 1824 public sentiment in the State was in favor of Mr. Mason's election to the Senate. There were two sessions of the New Hampshire Legislature, in June and November, and the election of Senator was postponed to the latter date to await the result of the Presidential election. There was, as expected, no choice in the electoral college, and the final decision was thrown into the House of Representatives. In the meantime Mr. Mason was chosen a Senator by the New Hampshire House of Representatives, but the Senate three times amended the House resolution by inserting a different name and each time the House adhered to its first purpose. When at length a motion was made in the Senate in favor of Mr. Mason, although it was understood that out of twelve members seven were pledged to vote for him, by some intrigue the vote stood six to six, the result being that the session closed without an election. It was claimed that Mr. Eastman, a brother-in-law of Woodbury, who was pledged to sustain Mr. Mason, had broken his word and brought about the tie vote. This view was sustained, inasmuch as at the June session of 1825 , Levi Woodbury was elected Senator by both branches of the Legislature. He was then a supporter of Mr. Adams, but afterwards became a zealous adherent of Jackson. It is thus easy to account for the hostile feeling of Woodbury toward the man against whom he had secretly and successfully intrigued, and his eagerness to avail himself of the opportunity of aiding the Jackson A.dministration in its attempt to control the bank, and at the same time gratifying his personal antagonism to Mr. Mason.

\section{An attack Planned on the Bank.}

On July 11 Secretary Ingham wrote to Biddle, the President of the Bank of the United States, enclosing Woodbury's letter, saying that similar complaints had been received in regard to the management of the branches in Kentucky and Louisiana, and intimating that the Administration would learn with extreme regret that political relation- 
ships had any influence upon the management of the bank in granting or withholding facilities. On July $18 \mathrm{Mr}$. Biddle answered that the bank had never been influenced by politics in granting loans or favors, and never should be. Mr. Ingham, in reply, regarded with astonishment Mr. Biddle's assurance that, with as many loans as must have been granted in the history of the bank, the managers had never, in any instance, been influenced by political motives.

In the meantime, on July 19, Isaac Hill caused two memorials complaining of Mason to be sent to Mr. Biddle; one of these was signed by members of the New Hampshire Legislature and the other by citizens of Portsmouth. Hill also endeavored to effect the removal of the pension agency from the bank at Portsmouth to Concord; and a letter was written on August 3 by Secretary of War Eaton to Mason notifying him of the appointment of a pension agent and directing that the books, papers and funds relating to the agency be delivered up to him. This Mr. Mason, on legal ground, refused to do. He informed the bank at Philadelphia of his action, and was sustained in it. In August, Biddle went to Portsmouth to examine into the truth of the charges made in Woodbury's letter and the memorials inspired by Hill, and after a thorough investigation found them to be groundless; and thereupon, upon September 15, 1829, wrote a further letter to Secretary Ingham, announcing the result of his Portsmouth investigations, and the vindication and re-election of Mr. Mason. He concluded by saying that the board of directors of the Bank of the United States and the boards of directors of the branches, "acknowledged not the slightest responsibility of any description whatever to the Secretary of the Treasury touching the political opinions and conduct of their officers, that being a subject on which they never consult, and never desire to know the views of any Administration." Mr. Ingham replied in a very long letter on October 8. He suggested that there were several ways in which the law brought the Government into contact with the bank, and refers to the possibility of the removal of the deposits. In November it was intimated by James Gordon Bennett that the President's message would take ground against the bank. His information was derived from Amos Kendall. The bank having been sounded and found adverse to the Administration, it had evidently been determined to attack it.

Amos Kendall was born in 1789, and after his graduation at Dartmouth College, settled in Lexington, Kentucky. He practiced law and edited a newspaper, and was at one time a tutor in the family of Henry Clay. He was made Fourth Auditor of the Treasury by Jackson, and was one of the so-called kitchen cabinet of that President. In 1835 he was made Postmaster-General. He was the author of a bill reorganizing the Treasury Department, substantially on its present basis. He died in 1866. 
InfLUence OF the Kitchen Cabinet.

Secretary of the Treasury Ingham, who aided Woodbury's intrigue, apart from his attack on the Bank of the United States, is chiefly noted for an exhaustive report on the Coinage of the United States, made to Congress in 1833. After he left the Treasury he confessed that the members of the "kitchen cabinet" used to abuse the trusting ear of Jackson with terrible tales of the corrupt influence the bank was exerting in controlling elections in opposition to him. Jackson came to believe that the bank was a dangerous monster, liable to subvert the Constitution and the liberties of the people. 


\section{ATTACK UPON BANK OF THE UNITED STATES.}

Message of Jackson in 1831 - Renewal of Charter applied for - Position of parties - Cry of fraud and corruption - Subsidies to newspapers - Charter extension passes both Houses - President's veto-Message of 1832-Stock owned by United States - Removal of deposits - Sounding State Banks - President's manifesto to cabinet-Duane superseded-Order for removal - Congress notified - Resolutions of censure-Bcnton and Webster - Expunging resolution - Exciting scene at its final passage - Majority against recharter - Policy of bankFinancial distress - New charter granted by State of Pennsylvania - Bad management-Final liquidation.

\section{Bill to Recharter the Second Bank of the United States.}

In his message of 1831, Jackson again called the attention of Congress to the question of recharter. The hostility of the President to the bank became by degrees more marked; and the agitation of the United States Bank question, involving the general subject of the currency, had become earnest in Congress at the session of 1829-30; and it grew more and more earnest as time went on.

At the triennial meeting of the stockholders of the Bank of the United States, held at Philadelphia under the eleventh section of the charter, on September 1, 1831, a committee of seven was appointed and authorized to make application for a renewal of charter if they should deem it best to do so at any time previous to the next triennial meeting. The near approach of the presidential election in 1832 caused some hesitation anong the friends of the bank whether or not at that time to petition Congress for a recharter. On the one hand it was held that to press the matter would most certainly make the bank question a political issue in the presidential campaign, and it was deemed inadvisable to trust the interests of the institution to the uncertainties of a popular vote. On the other it was urged that the bank now had a majority in both branches of Congress, and that the President would put himself in a serious dilemma by vetoing a bill, if it passed. Henry Clay, Jackson's opponent in the presidential election, held the latter opinion, and it is said that his view influenced the final decision in favor of making the petition. The memorial of the bank was accordingly presented by George Dallas, of Pennsylvania. The bill was opposed in the Senate by Thomas H. Benton, and through his efforts an investigation of the bank was ordered by the House, which resulted in 
three reports from the committee, a majority report, a minority report, and one by Mr. Adams. No real ground of complaint was found, although the majority report charged that profuse loans had been made to influential newspapers. The bill passed the Senate June 11, by a vote of twenty-eight to twenty, and the House on July 3 , by a vote of one hundred and nine to seventy-six. The main object of the opposition, hopeless of defeating the bill, had been to prepare the minds of the public for the veto and to furnish ammunition to be used on the stump in the coming campaign.

\section{President Jackson's Veto.}

On July 10 the President sent in his veto of the measure. This document was carefully prepared, and opposed the institution chiefly upon the ground of its being a monopoly. It raised the old charge about the stock being held largely by foreigners, and adds that, had the Executive been called on to furnish a project for a National bank, that duty would have been cheerfully performed.

Jackson's inconsistency in his messages and in his veto are thus summed up. In 1829, when the charter had yet seven years to run, he calls attention to the necessity of prompt action as to the recharter in order to avoid precipitancy. In 1830, when the charter had yet six years to run, he adrocates timely action. In 1831, there being five years more, he reiterates his previous advice; but, in his veto in 1832, when four years only remain to the bank, he says there is no need of haste.

But, although the veto was exceedingly vulnerable from almost every standpoint, it served its purpose in arousing the popular feeling against the bank and in favor of Jackson. Benton, who in the Senate defended the veto against the attacks of Webster, Clay, Calhoun and Ewing, voiced the whole spirit of the party he represented when he said:

"You may continue to be for a bank and for Jackson, but you cannot be for this bank and for Jackson. The bank is now the open, as it has long been the secret, enemy of Jackson. The war is now upon Jackson, and if he is defeated all the rest will fall an easy prey. What individual could stand in the States against the power of that bank, and that bank flushed with a victory over the conqueror of the conquerors of Bonaparte. The whole Government would fall into the hands of the moneyed power. An oligarchy would be immediately established, and that oligarchy in a few generations would ripen into a monarchy."

The bill for the recharter could not secure the necessary two-thirds vote for the passage over the veto. Nor did the supporters of the bank fully realize, even then, the effect of the President's opposition. They thought the people would be disgusted at Jackson's unreasonable attitude. Nicholas Biddle wrote to Clay that he was delighted with the veto. The campaign of 1832 was fought on the bank issue. It was the 
hero of New Orleans against a "monster monopoly." It was Jackson like a hero of romance fighting against "Old Nick's Money" and "Clay's Rags." The bank having foolishly gone into politics, was defeated and Jackson again elected. The support of the people was at once claimed for all past and future warfare on the bank, and the result of the election sealed its doom. The attack promised on the stump began at once.

In his message in 1832, after his re-election in November of that year, the President again fulminates against a recharter of the institution, recommending that the seven millions of stock of the bank held by the United States should be sold, and, going further, intimates that the United States deposits in the bank were not safe.* He either was or affected to be impressed with the idea that so long as the bank was the holder of the public funds it might use them to corrupt Congress to secure an extension of its existence. In consequence of the message bank stock fell from one hundred and twelve to one hundred and four. A Treasury agent who made an examination of the institution reported it solvent, and the stock went back to one hundred and twelve. Congress did not coincide with the views expressed by the President, and, refusing to sell the bank stock, passed a resolution, by a vote of one hundred and ten to forty-six, of confidence in the safety of the deposits.

\section{Public Removal of Deposits from the Bank.}

During the spring and summer of 1833 there was much consultation between Jackson and his cabinet as to the removal of the deposits. Louis McLane was Secretary of the Treasury. He was sounded by Amos Kendall, the Fourth Auditor, who was a strong advocate, if not the first suggestor, of the step, and found to be unfavorable to it. As an editor in Kentucky, Mr. Kendall had been an ardent supporter of the :ight of the States to tax the branch banks of the United States within their borders during the controversy between the States of Kentucky and Ohio and the bank. t The decision of the Supreme Court in McCulloch vs. State of Maryland judicially settled the question; but Mr. Kendall continued the controversy in his paper, and always afterward retained his hostility to the bank. Mr. McLane was promoted to the State Department, and Mr. Duane, of Pennsylvania, appointed Secretary of the Treasury. Soon after the President called for the written opinion of his cabinet. McLane was against the removal; so was Duane. General Cass pleaded ignorance of the question; but Woodbury, Secretary of the Treasury, Barry, Postmaster-General, and Attorney-General Taney were all in favor of it. At this meeting some doubt was expressed as to the reception of the deposits by the State banks. Kendall assured the President that he would settle this doubt. He went accordingly to Baltimore, Philadelphia, New York and Bos-

* McLane, who later on declined to remove deposits.

+ Amos Kendall, biography, 378 . 
ton, and in all but the latter place secured the acquiescence of the banks required for the purpose.

On September 18, everything being ready, the President read a manifesto on the subject to his cabinet, and in consequence of Duane's persistent refusal to carry out the wishes of the President he was displaced and supersede? by Attorney-General Taney, who, on September 26,1833 , issued the order for the removal. "The Globe," of September 20,1833 , announced that the public deposits would, "after the 1st of October, be made in the State banks, but that it is contemplated not to remove at once the whole of the public money now on deposit in the Bank of the United States, but to suffer it to remain there until it shall be gradually withdrawn by the usual operations of the Government." The bank thenceforward knew that, if its own policy should be pacific, it had nothing to fear from any unusual call from the Government; yet, with specie enough in its vaults to pay the entire public deposits at once, it maintained its stringency, under the pretext that it must be prepared for vindictive attacks from the Treasury Department.* The funds of the pension agencies were removed from the bank in February, 1834.

\section{President Jackson Chnsured.}

When Congress assembled in December, 1833, the President notified them of the removal of the deposits, and that the Secretary would furnish them with the reasons, which the Secretary did. From the first week in December, 1833, to the last day in June, 1834, says Parton, almost the only topic of debate in Congress, in the newspapers and among the people, was the removal of the deposits. It was discussed with great ability, bitterness and pertinacity. On March 28, 1834, Mr. Clay introduced two resolutions in the Senate, one "that the President, in the late executive proceedings in relation to the public revenue, has assumed upon himself authority and power not conferred by the Constitution and laws, but in derogation thereof." $\dagger$ This was passed by a vote of twenty-six to twenty, and was known as the censure resolution. The second was, that the reasons of the Secretary of the Treasury for removing the deposits are insufficient; this passed by vote of twentyeight to eighteen.

On April 17, the President replied by a protest, which he desired to have spread upon the Journal of the Senate as an offset to the resolution of censure. The view taken in the protest was the same as that taken in his veto, and was, that the President should, under his oath of office, sustain the Constitution as he understands it, not as the judiciary may expound or Congress declare it. Lodge, in his life of Webster, says of Jackson:

* "Autobiography of Amos Kendall," Boston, 1872, p. 398.

+ See "Memoirs of John Q. Adams," Vol. IX, p. 116. 
"He had the audacity to rest his veto upon the ground that the bill was unconstitutional, and that it was the duty of the President to decide upon the constitutionality of any measure without feeling in the least bound by the opinion of Congress or the Supreme Court. His ignorance was so crass that he failed to perceive the difference between a new bill and one for continuing an existing law, while his vanity and self-assumption were so colossal that he did not hesitate to assert that he had the right and the power to declare an existing law, passed by Congress, approved by Madison, and held to be constitutional by an express decision of the Supreme Court, to be invalid because he thought to say so."

A motion to have the protest engrossed on the Journal of the Senate was strenuously supported by Mr. Benton; but the President's request was denied by a vote of twenty-seven to sixteen; and Senator Benton immediately gave notice of a resolution to expunge the resolution of censure from the records of the Senate, and declared that from that hour one of the leading purposes of his career would be to obtain its passage. The indomitable persistency with which he devoted himself to this object, and the debates thereon in the Senate, exhibit the bitter feeling and animosity of spirit which prevailed at that time upon the bank question.

\section{Expunging the Resolution of Censure from the Records.}

During the session of the following year (1834) Benton introduced a resolution to expunge the resolution of censure from the Senate records, and during the same session a preamble and joint resolution of the General Assembly of the State of Alabama was presented by Senator King of that State, entreating the Senators to use their untiring efforts to cause this resolution to be expunged from the Journal of the Senate. These resolutions were not allowed to be printed and were finally laid upon the table by a vote of twenty-seven to twenty, Messrs. Clay Calhoun, Clayton, Ewing, Webster and Tyler voting in the affirmative. Before the vote was taken upon the resolution, the word "expunge" was stricken out, and the words "rescind, reverse and make null and void," were allowed to be inserted with great reluctance, but finally with the consent of Mr. Benton. Mr. Webster considered this assent of Mr. Benton to the substitution of other words for the word "expunge", as a great triumph, and declared "that nothing now can induce the Senate to falsify its own records, to disgrace its own proceedings, or violate the rights of members. The attempt to induce the Senate to expunge its Journal has failed-signally and effectually failed. The record remains neither blurred, blotted nor disgraced." Benton says in his "Thirty Years' View" (Vol. I, p. 550):

"The exulting speech of Mr. Webster restored me to my courage-made a man of me again, and the moment the vote was over I arose and submitted the original resolution over again, with the detested word in it, to stand for the second week of the next session, with the peremptory declaration that I would never yield it again to the solicitation of friend or foe." 
During the last session of the last term of President Jackson, Senator Benton again brought up his original resolution, but the Senate refused to act upon it until the meeting of the new Congress under the Van Buren Administration, at which time speeches were made by the leaders of the Senate, including Bayard and Clayton of Delaware, as well as Webster, Clay and Calhoun. The latter in his peroration said:

"But why should I detain the Senate and needlessly waste my breath in fruitless exertions. The decree has gone forth. It is one of urgency too. The deed is to be done-that foul deed which, like the blood-stained hands of the guilty Macbeth, all ocean's water will not wash out. Proceed then with the noble work that lies before you, and, like other skillful executioners, do it quickly, and when you have perpetrated it go home to the people and tell them what glorious honors you have achieved for your common country. Tell them that henceforward, no matter what daring or outrageous act any President may perform, you have hermetically sealed the mouth of the Senate. Tell them that he may fearlessly assume what powers he pleases, snatch from its lawful custody the public purse, command the military detachment to enter the halls of the Capitol over all Congress, trample the Constitution and raze every bulwark of freedom, but that the Senate must stand mute in silent submission, and not dare to raise its opposing roice."

Senator Benton gives a graphic description of the proceedings. “ Midnight was now approaching. The dense mass, which filled every inch of room in the lobbies and galleries, remained immovable. No one went out; no one could get in. The floor of the Senate was crammed with privileged persons, and it seemed as though all Congress was there. Expectation and determination to see the conclusion was depicted upon every countenance."

The vote upon the adoption of the resolution, was twenty-four to nneteen; and, in accordance with the resolution, and upon motion of Senator Benton, the Secretary of the Senate produced the original manuscript journal, and opening at the page which contained the condemnatory sentence of March 28, 1834, proceeded in open Senate to draw a square of broad black lines around the sentence, and to write across its face, in strong letters these words: "Expunged by order of the Senate this 16th day of March, 1837." Mr. Benton states that some of the Senators and others, in anticipation of disturbance, were armed for resistance During the process of expunging the resolution a great disturbance arose in the galleries, accompanied by hisses, groans and vociferations. The Senator from Missouri considered himself the object of the outrage; and when Mr. King, of Alabama, who was in the chair, ordered the galleries cleared, Mr. Benton objected, and said: "Let she ruffians be apprehended by the sergeant-at-arms, and brought to the bar of the Senate. Let him seize the ruffians-the bank ruffians!" This officer soon returned, having in his custody "a tall, well dressed man wrapped in a black overcoat," and presented him at the bar. Mr. Benton, allowing that the public exposure was sufficient punishment, moved that he be discharged, but Mr. Morris demanded the yeas and nays. and he was discharged by a vote of twenty-seven to one. After 
this he tried to speak in his own defence, but the chairman turned to the sergeant-at-arms and said in a loud tone, "take him out." *

The Senate, in 1833, was still anti-Jackson; but four resolutions were introduced in the House of Representatives; "the first (that the Bank of the United States ought not to be rechartered) was carried, one hundred and thirty-four to eighty-two. The second resolution, that the public deposits ought not to be restored to the Bank of the United States, passed by a vote of one hundred and eighteen to one hundred and three. The third resolution, that the State banks should be continued as depositories, and that Congress should further regulate the subject by law, passed by one hundred and seventeen to one hundred and five. The fourth resolution, directing the appointment of a select committee for a bank investigation, with power to visit the bank and any of its branches, was adopted by a vote of one hundred and seventy-five to forty-two. $\dagger$

\section{Policy of The BANK AFter JACKson's Veto.}

After the veto, and the large majority against the bank in the House of Representatives at the session of 1833-34, there was little hope of securing a recharter. It is said that a policy of expansion was first resolved upon by the management of the bank, and that circular letters to the branches were prepared to this effect. They were not, however, sent, as on second thought it was determined to curtail the business of the institution to the extent of the average United States deposits heretofore held by the bank. Whether the result of this or not, the year

*Colton's "Henry Clay."

+"Memoirs of John Quincy Adams," Vol. IX, p. 1:2.

Note.-Von Holst in his "Constitutional History of the United States," thus refers to this resolution, which occupied so much of the time of the Senate for three years.

"In my opinion, no definite legally unassailable answer can be given to the two questions which were directly in dispute: Whether the Senate had the right to give expression in a resolution to a formal censure of the President, and whether the President had the right to enter a protest against such a resolution or against any resolution whatever of the Senate; and for the reason that the Constitution furnished no sure basis for their solution. Legal arguments are here entirely cast into the shade of political arguments, and hence the answer to the question of law is strongly influenced by the political views of the person judging. One thing seems to me to be free from all doubt, that the Senate grossly violated the letter and spirit of the Constitution when it resolved, in 1837, to expunge the resolutions of 1834, from the journal. The Constitution provides: 'Each House shall keep a journal of its proceedings.' What has taken place in one of the Houses of Congress, and is entered upon its records, is part of the history of the country, and no one is authorized to alter one jot or tittle of it. The Senate, in 1837, had the same right to express its views that it had in 1834. No one could restrain it from making the declaration that the majority, in the resolution of March 28, had exceeded the Constitutional authority of the Senate. Between such a declaration and the expunging of the resolution, there was evidently more than a formal difference. The former would have been the giving and recording of a dissenting judgment; the latter was an entirely unworthy proceeding, a smiting of itself in the face by the Senate, inasmuch as it thereby dragged its own action into the arena of common party scuffling." (Von Holst, "History of the United States," Vol. XXII, p. 689.) 
1834 was one of great financial distress, and the policy of the Administration toward the bank was held to be the cause by large numbers of people. Petitions for return of the deposits and recharter poured in; delegations from New York and Philadelphia and other cities waited upon the President with the same object in view. The President refused to be moved, and even intimated, in no uncertain manner, that such demonstrations were useless and distasteful to him.

In his message of December, 1834, he again attacked the bank. This time his principal grievance was that from the dividends due upon the stock of the bank held by the Government, the bank had retained some $\$ 135,000$ as damages for the protest of a draft of $\$ 900,000$ drawn by the United States Treasury upon the French Government for the payment of the first installment of the French indemnity. The bank had purchased the draft and had sent it on for collection through England; and, upon the protest, its agent in Paris took up the draft with the bank's funds, to save the credit of the Bank of the United States. The President regarded the claim for damages as an insult to the Government, inasmuch as the bank had then a larger amount of Government funds on deposit. His other specific charges against the bank were that it had extended its loans in 1831 and 1832 to secure popularity, and that in 1834 it had contracted its business to cause distress.

In 1835, the board of directors of the bank authorized an exchange committee appointed by its President to make loans upon stocks, and a new policy was inaugurated for the last year of its operation under its old charter.

\section{Bank Applies for Charter to the State of Pennsylyania.}

The Bank of the United States did not wind up its affairs, nor even prepare to do so; on the contrary, it applied for and obtained a charter from the Legislature of Pennsylvania, which was granted and approved by the Governor of the State on February 18, 1836, just thirteen days before the expiration of its charter from the general Government. This charter differed in nothing essential from that just expiring, except in the term of the charter, which was extended to thirty years, and in the amount of the bonus paid, and to be paid for it. It was in effect a renewal and extension of the charter, without change of conditions or purposes, and under the old corporate name. The title of the act of incorporation, however, is worthy of note. It is styled "An Act to repeal the State tax on real and personal property, and to continue and extend the improvements of the State by railroads and canals, and to charter a State bank, to be called the United States Bank." The bonus or cost of the charter to the bank, if it had maintained its existence and solvency long enough to meet* the charges imposed, would not have fallen short of five millions of dollars, assuming, which it is safe to do, that the long list of subscriptions required to be made to rail- 
roads, canals, navigation companies and turnpike roads, scattered all over the State, should eventually prove to be unproductive.

Colonel Benton describes the Pennsylvania charter as a "transmigration of the Bank of the United States, *** changing itself from an imperial to a provincial institution, retaining all the while its body and essence, its nature and attributes, its name and location;" and he does not hesitate to ascribe " every circumstance of its enactment to corruption, bribery in the members who passed the act, and an attempt to bribe the people by distributing the bonus among them."

\section{The Bank Suspensions of 1837.}

But other results followed the removal of deposits and failure to recharter the Bank of the United States, which were of much more consequence than the question of the fitness or unfitness of a particular fiscal agency of the Government. The State banks which were selected as depositories of the large revenues of the Treasury expanded their issues, and a multitude of other banks, old and new, went wild in a general inflation of the circulation. The aggregate of their circulating notes (exclusive of those of the Bank of the United States) rose from $\$ 61,000,000$ in 1830 to $\$ 149,000,000$ in 1837. In March, 1830, the Finance Committee of the Senate had said: "They are satisfied that the country is in the enjoyment of a uniform national ourrency, not only sound and uniform in itself, but perfectly adapted to all the purposes of the Government and the community, and more sound and uniform than that possessed by any other country." And yet, but seven years after this, on May 10, 1837, all the banks then in operation, with the mammoth United States Bank of Pennsylvania among them, went into suspension, as if by common consent, or, as Colonel Benton has it, "with a concert and punctuality of action which announced arrangement and determination such as attend revolts and insurrections in other countries;" and he declares that "the prime mover and master manager of the suspension was the Bank of the United States, then rotten to the core and tottering to its fall, but strong enough to carry others with it, and seeking to hide its own downfall in the crash of a general catastrophe." This allegation derives some support from the report of the committee of the stockholders, made in January, 1841, after the failure of the bank. They say: "The origin of the course of policy which had conduced to the present situation of the affairs of the institution dates beyond the period of the recharter by the State."

Favored by an excess of importations of specie, amounting to nearly twenty millions in the two years ending September 20,1838, the banks of New York and New England resumed on May 10 of that year. The banks of Philadelphia made three resumptions and as many failures before February, 1841, and did not effectively resume until March of the following year; so that from 1834, a period of eight years of vicious fluctuation and depreciation of the currency elapsed before the banks 
again settled into what was then called "a state of regularity." During this period they reduced their circulation from one hundred and forty-nine millions in 1837 to fifty-eight millions in 1843, which is three millions below the amount at which it stood thirteen years before.

\section{Operations of United States Bank of Pennsyluania.}

The United States Bank of Pennsylvania suspended specie payments as often as other State institutions, and finally succumbed to trials which other banks, more prudently managed, survived. It made an assignment of eertain securities on May 1, 1841, to secure five millions of post notes which other banks had taken in exchange for its demand notes. The second assignment was made June 7, 1841, to secure its notes and deposits, "among which were notes and deposits of the late Bank of the United States, incorporated by Congress," so that it appears to have been, up to 1841, using its old issues. The third and final assignment, made on September 4, 1841, covered all its remaining property, "to provide for the payment of sundry persons and bodies corporate which the bank is at present unable to pay."

\section{Causes of the Bank's FaIlure.}

The final failure of the Bank of the United States under its Pennsylvania charter was no doubt due to the immense luans made upon bonds_and_stocks, and as stated by the stockholders' committee, the policy which led to this result was inaugurated in 1835 , one year before the expiration of the national charter, but not until all hope of securing a renewal of its powers from Congress had been given up. From 1835 to March 3, 1836, the latter the date of the expiration of the United States charter, loans on stocks increased from $\$ 1,800,000$ to over twenty millions of dollars. This locked up most of the active means of the institution, and to carry out its engagements, it was obliged to borrow abroad, and its credit was such that in 1836 it so obtained $\$ 7,500,000$ upon good terms. The inference which Benton wishes to have made, that the bank, during the time of Jackson's warfare upon it, was insolvent or "rotten to the core," is not a correct one, as its management was from all accounts comparatively conservative until 1835, when any restraint which its managers felt under its national charter appears to have been withdrawn. Instead of retrenching after 1836, the management grew more and more reckless, and by July, 1840, it had borrowed upon post notes and bonds more than twenty-three millions of dollars. During this time the loans on stocks continually increased. It seemed impossible for the managers to say no to any one. All projects were favorably received, and thus projectors found in Mr. Biddle a sympathetic listener. Commissioners and agents having bonds issued or guaranteed by the States they represented, to place upon the market to speculators in turnpike and land company stocks, all came to Mr. Bid- 
dle, and everything in the shape of an incorporation looked to him as the one who could place their credit upon a firm basis. Bonds of Mis sissippi, Michigan and Illinois, of the Territory of Florida, and even of the struggling Republic of Texas, received from him the impress that was to make them pass in the markets of the world. Few appear to have been sent away disappointed. He was the President of the bank from January, 1823, to March, 1839, when he resigned, leaving the bank, as he said, prosperous. In 1840 it was found that the assets of the institution consisted chiefly of all kinds of internal improvement, and bank and State stocks and bonds. There was hardly an enterprise, good, bad or indifferent in the United States that was not represented in the list.

For years Mr. Biddle had been courted and flattered as the financial autocrat of the country. He had, as a rule, been successful in the financial operations he had undertaken, representing as he did an institution of immense capital and in high credit both at home and abroad. As has been said, up to 1835 the operations of the bank were apparently conservative. The craze for internal improvements in most of the States had thrown on the market a new class of securities. Many others besides Mr. Biddle were deceived as to their value. The loans on stocks from 1835 to 1836 , inade contrary to the previous general policy of the bank, may have been made in anticipation of a rise in the stocks of all internal improvements from the distribution of the surplus among the States, authorized by the act of June 23,1836 , which had been under consideration for some time previous. This view is sustained by the fact that in the spring of $\mathbf{1 8 3 6}$ the following paragraph appeared in the Philadelphia "National Gazette," which was ascribed to Biddle:

"The great loss of the bank has been in the depreciation of the securities, and the only way to regain a capital is to restore their value. A large portion of them consists of State stocks, which are so far below their intrinsic worth that the present prices could not have been anticipated by any reasonable man. No doubt can be entertained of their ultimate payment. The States themselves, unaided, can satisfy every claim against them; they will do it speedily if Congress adopt the measures contemplated for their relief. A division of the public lands among the States, or a pledge of the proceeds of sales for that purpose, would be abundant security. Either of these acts would inspire confidence and enhance the value of all kinds of property."

The policy of earrying a load of these doubtful securities having once been accepted, there was much temptation to continue it to sustain the value of the stocks already held.

The $\$ 7,000,000$ of stock held by the United States, previous to the change to a State charter, was paid back in full, and the Government realized a very handsome profit upon its investment, as will appear by the following statement derived from the records of the Treasury Department. 


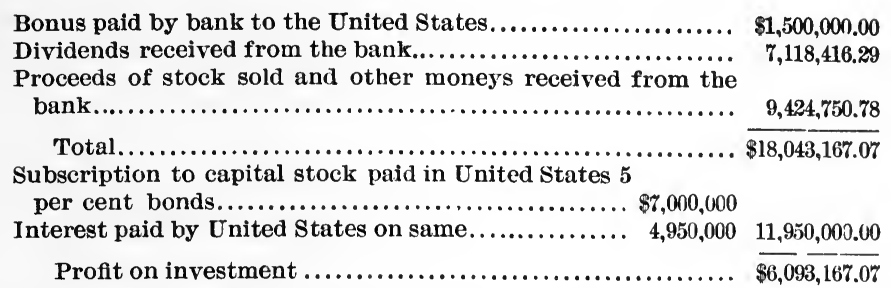

The history of the United States Bank under its Pennsylvania charter, subsequent to the crisis of 1837 , was a most disastrous one. It suspended specie payments during the ticklish period from 1837 to 1841 as often as other State banks, and finally went down under circumstances that might with prudent management, have been turned to a successful result. It made three several assignments in 1841 to secure various liabilities, the last and final assignment being on September 4 of that year.

The final result of the liquidation of the bank was briefly stated in a letter to the author from Thomas Robins, Esq., then President of the Philadelphia National Bank, who was the last survivor of its numerous assignees.

"All the circulating notes of the Bank of the United States together with the deposits, were paid in full, principal and interest, and the accounts of the assignees were finally settled in 1856. There were no funds, and no dividend was paid to the stockholders of the bank; the whole twenty-eight millions of dollars were a total loss to them."

Nicholas Biddle was President of the bank from January, 1823, to March, 1839, being President of the Bank of the United States until its charter expired in 1836, and for the next three years President of the United States Bank of Pennsylvania. At the time of his resignation the shares were selling at 111, having in 1837 sold at 137; but, in 1843, after the failure, its shares were quoted at $1 \frac{7}{8}$ per cent.

Both the first and second Banks of the United States were killed by the prejudice against banks, which exists to an even greater extent today. The fall of the latter institution was hastened by bad management. 
FEDERAL BANKING FROM THE REMOVAL OF DEPOSITS
FROM THE BANK OF THE UNITED STATES, TO THE
AUTHORIZATION OF THE NATIONAL BANKING SYSTEM.

Public money deposited with the State banks - Pet banks - Increase of surplus public money - Party advancement by favor to banks - Stimulation of public land sales - Losses from bank failures - Specie circular - Bill to compel receipt of specie-paying bank notes vetoed - Law regulating deposits in State banks Stace bank statistics - Effect of specie circular - Surplus distributed among States - Effect on banks - Suspension of specie payments - Extra session of Congress - Independent Treasury - Government almost bankrupt - Treasury notes - National bank contest - Clay and Tyler - Political intrigues - Veto of first bank bill - Tyler's vacillation - Final veto of bank bill.

\section{Removal of Public Deposits from the Bank of the United STATES.}

The order for the removal of the public deposits from the Bank of the United States was dated September 26, 1833. After this date the money collected from customs and other sources of revenue was no longer paid into the Federal bank, but was deposited with selected State banks called "pet banks" by the opponents of the Administration. The payment of the public debt and the great increase in the sales of public lands caused the surplus of revenue over expenditures to increase in an unprecedented manner. The Bank of the United States in its most prosperous days had never had in its vaults much over eight millions of dollars of the public moneys at any one time; but by November 1,1836 , eighty-eight State banks in twenty-four States with a capital of $\$ 77,576,449$, held public deposits amounting to $\$ 49,377,986$. Their ordinary individual deposits at the same time were only a little over twentyfive millions of dollars. That there was any very clear apprehension of the extent to which this accumulation of wealth would take place may be doubted, but it is certain that as early as 1829 there were calculations made upon an anticipated surplus of revenue as an aid to party advancement, either by means of the bank or in spite of it. The financial stringeney of 1834 indicated that the removal of the public funds to the State banks had seriously disturbed the usual course of loans, and the consequent suffering started a demand for the distribution of the accumulating surplus among the several States. The State banks had 
thrown their influence against the Federal bank in aid of the Administration, and they were allowed to reap their reward by the use of the public moneys entrusted to them as a basis for extending their loans and for enormous issues of their own notes. Banks were started for the sole purpose of issuing notes that might be turned in at the land offices for public land. Good land office money was the test of the credit of a bank bill. Speculators thus obtained vast tracts of valuable land. The notes appeared to go through the hands of innocent third parties. When the bank failed, as it usually did, the Treasury bore the loss. Even in less flagrant cases the bank credit enabled immense territory to be held for speculation, keeping out actual settlers. Under this stimulation the receipts from the sales of public lands rose from about $\$ 5.000,000$ in 1834 to $\$ 24,800,000$ in 1836 . These latter receipts were almost altogether in bills of State banks; and the consequent difficulty in securing specie, and the losses incurred from bank failures, impelled the President (Jackson) to cause the Secretary of the Treasury to issue on July 11, 1836, the celebrated specie circular forbidding the receipt of anything but specie in payment of the public lands. He also pocketed a bill passed by Congress to compel the receipt of the notes of specie-paying banks.

\section{The Specie Circular.}

"In consequence of complaints which have been made of frauds, speculations and monopolies, in the purchase of the public lands, and the aid which is said to be given to effect these objects by excessive bank credits, and dangerous if not partial facilities through bank drafts and bank deposits, and the general evil influence likely to result to the public interests, and especially the safety of the great amount of money in the Treasury, and the sound condition of the currency of the country, from the further exchange of the national domain in this manner, and chiefly for bank credits and paper money, the President of the United States has given directions, and you are hereby instructed, after the 15th of August next (1836), to receive in payment of public lands nothing except what is directed by the existing laws, viz., gold and silver, and in the proper cases, Virginia land scrip, provided that till the 15th of December next, the same indulgences heretofore extended as to the kind of money received, may be continued for any quantity of land not exceeding 320 acres to each purchaser who is an actual settler or bona fide resident in the State where the sales are made. In order to secure the faithful execution of these instructions, all receivers are strictly prohibited from accepting for lands sold any draft, certificate, or other evidence of money, or deposit, though for specie, unless signed by the Treasurer of the United States, in conformity to the act of April 24, 18:20. And each of these officers is required to annex to his monthly returns to this department, the amount of gold and of silver, respectively, as well as of the bills received under the foregoing exception, and each deposit bank is required to annex to every certificate given upon a deposit of money, the proportions of it actually paid in gold, in silver, and in bank notes. All former instructions on these subjects, except as now modified, will be considered as remaining in full force. The principal objects of the President in adopting this measure being to repress alleged frauds, and to withhold any countenance or facilities in the power of the Government from the monopoly of public lands in the hands of speculators and capitalists, to the injury of the actual settlers in the new States, and of emigrants in search of new homes, as well as to 
discourage the ruinous extension of bank issues and bank credits, by which those results are generally supposed to be promoted, your utmost vigilance is required and relied on to carry this order into effect."

This circular was directed to receivers of public money and to the deposit banks.

The act of June 23, 1836, regulated the deposit of public money with the State banks, the deposits previous to that date having been made on the authority of a clause in Section sixteen of the act of April 10, 1816, creating the second Bank of the United States, specifying that the funds of the Federal Government were to be deposited in the Bank of the United States or its branches, "unless the Secretary of the Treasury shall otherwise order and direct, in which case the Secretary of the Treasury shall immediately lay before Congress, if in session, and if not, immediately after the commencement of the next session, the reason of such order or direction." Besides regulating deposits with the State banks the act of June, 1836, further provided that, as soon as a State bank selected as a Government depository failed or ceased to pay specie, it could no longer act as such depnsitory. The removal of the deposits to the State banks and the issue of the specie circular were both acts of financial recklessness on the part of the President, and the circular had the effect of unduly precipitating the collapse of the wild speculation in which the handling of the public deposits by the State banks had resulted.

\section{INCREASE IN THE Number OF BANKS.}

From 1834 to 1837 one hundred and ninety-four new banks were organized in the United States, as far as is shown by the very imperfect records of that period. Of these, sixty-two were in New England, fortytwo in five Middle States, seventy-two in nime Southern States, and eighteen in four Western States. There was during the same period an increase of $\$ 6,000,000$ in the issues of the banks in the New England States, about fifty per cent.; of $\$ 14,000,000$ in the issues of the banks in the Middle States, a similar percentage; of $\$ 34,000,000$ in the issues of the banks in the Southern States, being over one hundred and thirty per cent.; and $\$ 6,800,000$ in the issues of the banks of the Western States, being over one hundred per cent. The records from which these figures are taken give only such banks as reported to the Secretary of the Treasury, and do not include a large number of institutions of the description commonly known as "wild cat," that did not conceive they owed allegiance or deference to any authority whatever. The larger number of banks that paid specie and redeemed their notes on demand were in the Eastern and Middle States, and the larger number of non-specie paying banks, together with most of the wild-catters, were in the more primitive parts of the South and West-the West and South then, all of it, being east of the Missouri river. The effect of the specie circular on the eirculating notes of all of these banks was 
terrible, inasmuch as it at once caused a run for specie upon them. The wonder is that so large a number endured so long.

\section{The Distribution of the Surplus Revenues.}

The law of June 23, 1836, also provided for the distribution of the surplus revenues of the Treasury on deposit January 1, 1837, in the State banks selected as depositories, among the several States, in four quarterly installments, viz., on January 1, April 1, July 1 and October $1,1837$.

This proposition had taken form gradually. The report of the Secretary of the Treasury, William $\mathrm{H}$. Crawford, for 1816 , and his reports and those of his successor, Richard Rush, for succeeding years up to 1827, had in the estimates made shown an available surplus of revenue over all expenditures of from two to six millions of dollars. This led to some discussion as to the best method of employing this surplus. Secretary Crawford, in 1816, suggested that it be used in internal improvements.

In 1827 the proposition to distribute the surplus was first made in Congress. A bill for the annual distribution of $\$ 5,000,000$ for four years was introduced and laid on the table. On motion of Mr. Dickerson, of New Jersey, the author of the measure, it was taken up for discussion. He stated its principal object to be to provide the States with money for educational purposes and internal improvements. Congress adjourning soon after, it received but little attention.

Secretary of the Treasury Ingham, in his report to Congress in December, 1829, estimated that the revenues of the Government for that year would amount, including the balance on hand January 1, to $\$ 30$,$\mathbf{5 7 4}, 666$, and the expenditures to $\$ 26,164,595$, of which $\$ 9,841,011$ was on account of principal, and $\$ 2,563,994$ on account of interest on the public debt. He also estimated that the public revenues for the next five years would be such as to leave free for application to the payment of the public debt about twelve millions yearly. The amount of the public debt due or becoming due during the next five years was $\$ 48,522$, 869. The surplus after paying this indebtedness would be twelve millions. The Secretary did not favor a sudden change in the tariff, but recommended such gradual changes as would reduce the revenues to correspond with the existing expenditure. President Jackson, in his message of 1829 , recommended the distribution of this anticipated surplus among the States, in the ratio of their representation, and if such a course was not constitutional, that the Constitution should be amended to permit it. The revenues, especially those from the sale of public lands, were greater rather than less than anticipated, and in his report for 1832 the Secretary of the Treasury was able to announce:

"After January 1, 1833, no part of the public debt, except the remaining fragments of the unfunded debt, of which only small portions are occasionally presented, will be redeemable before the following year, and though there will be in the Treas- 
ury during the year ample means to discharge the whole debt, they can be applied only to the purchase of stock at the market prices."

\section{Payment of the Public Debt.}

The whole public debt was virtually extinguished by January 1 , 1835 , on which date the balance of available funds in the Treasury was $\$ 5,586,232$. It was estimated that for the year 1835 the receipts from all sources would be twenty millions; the actual receipts were $\$ 35,430$,087 , the receipts from the sale of the public lands during that year having greatly increased. In 1834 these receipts were only $\$ 4,85 \%, 600$, but in 1835 they were $\$ 14,757,600$. The receipts from the sales of public lands in 1834-35-36 were $\$ 44,492,281$, the total receipts from this source from 1796 to 1834 being $\$ 44,595,000$ only. The balance left in the Treasury at the beginning of the year 1833 was $\$ 2,011,777$; in $1834, \$ 11$,702,905 ; in $1835, \$ 8,892,868$, and on January $1,1836, \$ 26,749,803$. In view of this large balance and its probable increase by January 1, 1837, the provision for distribution of the surplus among the States was embodied in the act of June 23, 1836.

\section{Suspension of Specie Payments by the Banks.}

The amount of the surplus the law required to be so distributed turned out to be $\$ 37,468,859$, and each quarterly installment was therefore $\$ 9,367,214.98$. The banks holding the Governinent funds numbered eighty-eight of the 788 State banks then in the country. The total net deposits of all the State banks was about $\$ 128,000,000$; of these more than seventy millions were held by the eighty-eight pet banks; and of this last sum thirty-seven millions had, by order of Congress, to be repaid in nine months. The pet banks included most of the strong banks in the country, and their failure or suspension meant failure or suspension to the others. The chief part of the cash in their hands consisted of the notes of other banks, of different exchange value, according as they were issued by banks in different sections of the United States. All of these notes were discredited more or less by the specie circular; nevertheless the depositories were required to pay the public moneys in specie or its equivalent. The first installment was paid by the banks in specie or its equivalent; the second, also, in bills of specie-paying banks. This was on April 1; but in May the pressure on the banks for the redemption of their notes in specie became so great that, with the exception of five or six institutions, they all suspended payment. The depository banks struggled on, however, and were permitted to pay the third installment in the bank notes they had that the States were willing to receive. The specie circular, by creating a fictitious demand for coin at a time when the banks were using a very large amount of currency in order to pay their obligations to the Government so suddenly called for, was no doubt very largely the cause of this suspension and the subsequent panic. The banks in the West and 
Southwest became discredited by this suspension to a greater extent than the Eastern banks; and, inasmuch as in making its payments the Treasury drew on the latter first, there were soon no funds in the possession of the Treasury, except those in the banks of the West and Southwest. Inasmuch as the public creditors would not receive drafts on these discredited banks in payment of the debt of the Government to them, and as the revenues from the public lands had fallen off on account of the specie circular, the Treasury was, in the autumn of 1837 , very close upon bankruptcy. In order to avoid this an extra session of Congress was called by President Van Buren, to meet in September, 1837, when an issue of ten millions of dollars in Treasury notes was authorized for the exigency. Mr. Benton, one of the strongest advocates of the specie circular, and the bitter opponent of all paper money devices, said that nothing but the fact that the Government must otherwise stop for want of funds would induce him to vote for paper money in time of peace.

\section{Independent Treasury System Proposed.}

President Van Buren, in his message at the opening of the session, declared that both National and State banks had now been tried as the custodians of the public moneys, and had been found wanting, and recommended legislation by which the Government might take the charge of its own funds; in other words, he suggested what is known as the Independent Treasury System, by which the moneys, as collected, are left in the hands of the Treasurer and Assistant Treasurers and the mint, until needed, the fidelity of the several officers being secured by bonds. A bill was introduced by Silas Wright, of New York, and passed by the Senate, but was tabled in the House.

The issue of the $\$ 10,000,000$ of Treasury notes did not much relieve the situation, and the Government, with $\$ 28,000,000$ deposited with the States and at least $\$ 4,600,000$ more owed to it by the banks, was still on the verge of bankruptey. The money with the States represented the first three installments of surplus which were paid over on January 1, April 1 and July 1, 1837. The failure to obtain any part of the amounts due from many of the banks had plainly made it impossible to pay the fourth installment, and Congress had, at the extra session in September, passed an act postponing the payment thereof; and not only this, but had further provided that the three payments already made to the States, ostensibly in the form of a deposit to be returned by the States when wanted by the Federal Treasury, should remain with the States until called for by act of Congress. This, in effect, put it out of the power of the Secretary of the Treasury to recall them. The $\$ 4,600,000$ in the banks was equally unavailable.

In May, 1838, therefore, to avoid the complete suspension of payments at the Treasury Department, the President, advising Congress that there were only $\$ 216,000$ of available funds on hand, again recom- 
mended the issue of Treasury notes to the extent found necessary. The limit, however, was to be the amount of the Treasury notes of the previous law (October, 1837) already redeemed and cancelled. Congress acceded, and it required an issue of $\$ 5,000,000$ Treasury notes within one month, to relieve the necessities of the Government. The President had, in the meantime, been very firm in not permitting any but the notes of specie-paying banks to be received for dues to the Government, and the result was that many of the suspended banks found it for their interest to resume specie payments. The Treasury notes of this period were looked upon as a temporary loan, to take the place of the amount of suspended bank debt to the Government, and it was claimed by the Secretary of the Treasury, Levi Woodbury, that the amount outstanding never exceeded this suspended debt.

\section{Independent Treasury Act Passed.}

Notwithstanding the failure of Congress to pass the Independent Treasury bill in 1837, Mr. Van Buren was persevering; the bill was again introduced in December, 1839, and finally became a law on July 4, 1840. Under it, vaults and safes were provided in the Treasury at Washington, and sub-Treasuries were instituted with proper accommodations at New York, Boston, Charleston and St. Louis. The mints and branch mints were also made places of deposit. Proper bonds were required of the officials connected with the various Treasuries and places of deposit. An important part of the law was the provision that after June 30, 1843, all payments to or by the United States should be in gold and silver exclusively. It has been said this change was not calculated to inflict injury on the State banks then existing, nor was it until the specie-receiving and paying clause went into effect. To understand the attack made on this act, resulting in its repeal, August 13, 1841 , about thirteen months after its first passage, the fact must be given full weight that the banks perceived that when the exclusive specie-paying and receiving clause went into effect it would cause continually an abnormally large redemption of their notes, and thereby lessen their profits on circulation, on account of the larger reserves of specie they would have to keep in their vaults. When customs or taxes or the price for public lands had to be paid, it was plain that the holders of bank notes would demand specie for them. Most of the State banks were used to the old ways, and did not take any more kindly to being forced to pay specie by the United States Treasury than they had to being made to redeem their notes by the Bank of the United States. In fact, the rule of the latter was found to be inore bearable, in that the Bank of the United States was managed and its policy directed by men who understood banking finance, who were themselves responsible to a power above them, and feared for their own sakes to be too merciless in requiring redemptions. The Treasury was managed with arbitrary force for political purposes, and was only 
to be moved by influences with which the banks had not yet become acquainted. Earnestly as the State banks had aided Jackson in pulling down the power of the Bank of the United States, they now, with equal earnestness, fought against the Independent Treasury. The election of Harrison in 1840, to succeed Van Buren, was accomplished by the union of all the dissatisfied elements in the country, and they were so many that the campaign of that year will long be remembered as a popular upheaval.

\section{Repeal of Independent Treasury ACT.}

The Independent Treasury Act was repealed about five months after Harrison's inauguration, and then was made the last attempt to revive a bank after the general pattern of the first two Banks of the United States. The Whig party had a large majority in Congress, and under the leadership of Clay they were determined to establish a National bank. The death of Harrison on April 13, 1841, and the succession of Tyler to the presidency, defeated their expectation. The election of the ticket had been due to a coalition of Whigs with a small remnant of the Nullifiers, who were really a dissatisfied wing of the Democratic party, and a quarrel springing up between Clay, the Whig leader, and Tyler, the latter, sustained at first by a small number of this fag end of a party, was gradually drawn over to the Democrats. The followers of Clay were a majority in both Houses, but not a two-thirds majority, and the President could therefore smother all their pet measures by his veto. The extra session of Congress, although called by Harrison, took place after his death. In his message, Tyler, the new President, professed to believe that Congress had power to create a National bank, but referred to his right to veto any such measure conflicting with his ideas of constitutionality, or which might, in his judgment be unwise.

A plan for a National bank was furnished to Congress by Mr. Ewing, Secretary of the Treasury, and a bill was drawn up according to the Secretary's recommendations. This bill was entitled an "Act to incorporate the subscribers to the Fiscal Bank of the United States." There was but little difference between the bill and the act of incorporation of the second Bank of the United States, but the expression "Fiscal" was in some way supposed to make a distinction. The President had even suggested that it be called the "Fiscal Institution," or the "Fiscal Incorporation." The bill was passed by both Houses, and went to the President for signature on August 6. While it was in his hands for consideration, the bill for the repeal of the Independent Treasury was rushed through both Houses and was sent for signature on August 9. This last bill he signed on August 13.

It is difficult to understand the serious estrangement that now took place between Mr. Tyler and the majority in Congress, without taking into consideration the fact of the very narrow and mediocre character 
of the President. He had been put on the ticket with Harrison for the purpose of conciliating the small remnant of the Nullifier party, and to the utter consternation of the Whigs the death of Harrison now made this man, who had attained the Vice-Presidency only by their help, their master. Clay and the others at first thought that he would of necessity follow their lead, and undoubtedly offended his sense of dignity, always peculiarly acute in weak men who attain position. There was a lack of deference toward Tyler, and an avoidance of consultation on the part of the Whig leaders that was particularly offensive. They did not even think it necessary to exercise the ordinary cunning, by which men of Tyler's character may be conciliated. A little flattery, a little affected recognition of him as a leader, would no doubt have prevented any separation. But Clay looked upon himself as the real leader, and upon Tyler as a man who had attained his position by the sheerest accident, and with no desert whatever. It was the first practical illustration of the possibilities of the Vice-Presidential office, that up to the death of Harrison had been one of very insignificant importance. Instead of conciliating this accidental President, whom they regarded as a shifty and mediocre politician, the Whig leaders undertook to whip him into line. They seem to have taken no pains to conceal their views or intentions, and these were straightway borne to the President's ears by interested politicians of the Democratic party, who by degrees began to feed his mind with hopes that he would be the Democratic nominee for President in 1844.

\section{Veto OF The BANK BILL.}

The passage of the bill, with this indifference and contempt on one side, and the Democratic intrigues gaining corresponding force on the other, was followed for the next few days by rumors of a veto, and on the other hand by ill-advised threats of forcing the President to sign the bill. These last took form in the hasty passage on August 9, of the law to repeal the Independent Treasury Act, with the purpose avowed in the debates, of leaving Tyler without any sub-Treasury. This must have been done most hastily, as nothing but haste and the overweening contempt felt for Tyler by Clay and his followers could have blinded them to the patent fact that they were playing directly into the hands not only of Tyler, but of opponents much more able and crafty than the President. In fact, by their whole course, they virtually drove a man, who with astute treatment would have been their own willing tool, into the hands of the Democrats, who gave him the adulation he craved, and used him most effectively to secure their triumph over the Whigs in 1844. It did not take long for these new adviser's of Tyler to prove to him that the Treasury would be even more at his disposal after the repeal of the Sub-Treasury Act than before. The repeal practically left the Treasury to be managed by the

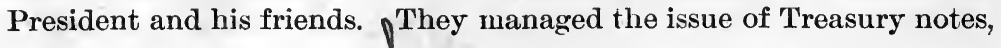


authorized by various acts between 1837 and 1843, so that they were practically demand notes. The acts all required the notes to bear interest not exceeding six per cent. Secretary of the Treasury Spenoer reduced this provision to a nullity, by making the interest one mill per annum on one hundred dollars. The repeal of the Independent Treasury Act was therefore signed by the President without hesitation, and it utterly failed in forcing him to sign the National Bank Bill. On August $16 \mathrm{Mr}$. Tyler sent in his veto of that measure on the ground that the provision allowing the establishment of branch banks in the various money centres was dangerous and unjust to the States. $\mathrm{He}$ signified, however, that he would sign a bill that was not open to constitutional objections. The followers of Clay were exasperated at this exhibition of recalcitrancy on the part of this man whom they looked upon as their creature. There was great difficulty in restraining them from open abuse. Finally a new bill was prepared in conformity with the views of the President as expressed in his veto, and hurried through the House August 23, and the Senate September 3.

In the meantime the President was listening more and more to the sweet voices of those who promised him a second term of office, who affected to admire his political wisdom and the clarity and power of his State papers. Although restrained with difficulty from breaking out into public vituperation, the smothered ragings of Clay and his_followers found some vent in private expressions, not complimentary to the President or his new advisers. These, of course, he was made aware of. There was also an angry letter from John Minor Botts of Virginia, who had been a personal friend of Tyler, but who now abused him as an ingrate. No doubt this spirit of abuse, properly driven home in Tyler's mind, had much effect; but still greater, no doubt, was the effect of the discovery that with the returning prosperity of the country the Treasury could, with the Treasury notes and the incoming revenues, run as well without the Independent Treasury Law as with it. In fact, the Administration had a more perfect control of the funds of the Government than ever before. This would give much more power in electing the next President, if Tyler could secure the nomination, and this bait was kept steadily before him. Therefore, after six days had elapsed, Tyler sent in a veto of a bill drawn in the strictest conformity with his own views, as expressed in his first veto. Thus ended the attempt to create a great National bank with which all the revenues of the Government should be deposited, and through which all the payments should be paid.

Fron August 13, 1841, when the first Independent Treasury Act was repealed, until August 6, 1846, when the same act was reënacted, the Treasury funds were paid in and paid out very much as they had been under the Independent Treasury Law, and after 1846 the Independent Treasury _ system was exclusively in operation until the passage of the National Currency Act in February, 1863. 


\section{Comparison of Present and Former Systems.}

The main difference between the National banking system of 1863 and the great National banks of 1793 and 1816, was that the latter had full control of the Government moneys which were deposited with them. All financial business pertaining to the Government was transacted through them. In return, they were expected to furnish a uniform and safe currency of bank notes, on which they also obtained a profit. The National banking system of 1863 provides for a number of banks limited only by the necessities of business, each acting independently of the other, but all bound by a uniform law. They may become depositories of Government money, but only as selected by the Secretary of the Treasury, and for these deposits they are obliged to give ample security. The proportion of public funds held by them to the whole balance in the Treasury has never been large. The requirement as to security prevents any favoritism. The old National bank was a great and powerful private monopoly, useful no doubt, and safe except when it mixed with politics. It was a foreign importation, and as a monopoly opposed to the genius of American institutions. The Treasury itself has taken its place to a very great extent, in the province of receiving, keeping and disbursing the revenues. It is fast assuming the function of a bank as an exclusive issuer of currency, and if a law should be passed authorizing loans on the products of the country, the Treasury would be in itself an almost exact copy of the old Bank of the United States, managed by the political party in power instead of by a private corporation. 


\section{VII}

NATIONAL BANKING LAW, 1863-1872.

Underlying principles of National Bank Act - Attempt of Secretary Dallas in 1813 to unite State banks in a system - Article in "Analectic Magazine," 1815 - Alexander Hamilton's proposition - Letter of Prof. John MeVickar - Banking law of Michigan - Free banking law of New York - Abijah Mann's claim - Difference between banking law of New York and National Bank Act - Mr. Potter's proposition - Draft of National Currency Act - Office of Comptroller of Currency-Appointment of Hugh McCulloch-Enabling acts-Comptroller's reports of 1863 and 1864 - Admission of State Banks to the system - Tax on State bank notes - Meeting of New York Clearing-House-Objections to National system - Unfavorable report - Reply thereto - Report of Comptroller for 1865 - Hon. Freeman Clarke succeeds Mr. McCulloch - Difficulty in redeeming notes - Freeman Clarke succeeded by Mr. Hulburd - Progress of system from 1867-1870 - Reports of condition - Interest on deposits - Failures - Correction of defects in law - Resumption of specie payments - Unequal distribution of circulation - Attempted legislation of 1870 - Sherman's prophecy - Increase of circulation-Mr. Knox succeeds Mr. Hulburd-License and income taxes repealed - Report of $18 \% 2$.

\section{Origin of the National Banking Srstem.}

The distinctive principles which underlie the National banking system, viz., Government supervision of the operations of the banks, and a circulation based directly upon the securities and the guarantee of the Government, do not appear to have been spontaneously discovered or suggested, but to have been adopted as the result of a long and

varied experience in banking in the United States and the several States.

The idea that the privilege of banking should be a monopoly to be exercised only by capitalists who were granted exclusive rights by the Government, was the one that at first prevailed. This plan would doubtless have secured safety to the public if it could have been strictly carried out. It was, however, repugnant to the ideas of liberty which control under the institutions of the United States. The Federal Government and the governments of the several States all claimed and exercised the right of granting charters to banking corporations; and while the Federal Government granted but one, to be exercised at any one time, most of the States were forced by the political parties which from time to time controlled them to extend the privilege, until, from competition, a State banking charter became of very little value. As 
the system of chartered banks lost the feature of monopoly, it became less safe to the public, inasmuch as a legitimate banking business could not afford profit to all, and many of the banks were forced to adopt doubtful and dangerous, if not dishonest, methods in order to secure dividends for their stockholders. In this way the public became the prey of dishonest institutions, and lost both upon deposits and circulation. These evils were felt at an early day in the history of the country, and the War of 1812 brought them into especial prominence.

The Bank of the United States, chartered in 1791 by the Federal Government, had exercised a genuine monopoly, and furnished a safe and uniform currency which at all times, during the existence of the bank, had been redeemable in specie. Its exclusive privileges were looked upon with popular disfavor, which culminated in 1811 in the refusal by Congress to grant an extension of its charter. While in existence this bank had occupied the field with few rivals, and during the twenty years of its existence we hear of little loss through the failures of banking institutions. The withdrawal of the first Bank of the United States gave the sjgnal for an enormous growth in the number of banks chartered by the States. The idea that the powers of the Federal Government must be curbed by self-assertion on the part of the States was in the ascendant, and this feeling found its outlet in the exercise of the somewhat doubtful power of the States to charter banks to issue circulating notes. As in the face of the liberal views then prevailing the State Legislatures did not dare to definitely restrict the number of charters granted, these privileges became the prize of all who chose to bring to bear the influences, political and otherwise, which were then necessary to secure legislative action. In 1812 the only paper currency of the country was that furnished by banks located in the several States, varying in value with the character of the banks.

\section{Plan of Secretary Dallas.}

It was plain that, in order to protect the Government and the public from loss, if the currency of the State banks was to be the currency of the country; it was necessary to bring them under some uniform control. The first attempt to associate these banks with reference to obtaining a uniformity of their currency was unsuccessfully undertaken in 1813 by Secretary Dallas; and, in his report of 1815, Mr. Dallas intimates that another "plan recently proposed, with the desire to curtail the issues of bank notes, to fix public confidence in the administration of the affairs of the banks, and to give to each bank a legitimate share in the circulation, is not likely to receive the general sanction of the banks." It is unfortunate for the endeavor to trace the germs from which the National system has developed, that the details of this second plan mentioned by Secretary Dallas do not appear to have been preserved. The features mentioned correspond with those of the National banking laws of 1863 and 1864. The curtailment or limit of the 
aggregate issues corresponds to the limit of eirculation fixed in 1863 and 1864. That public confidence in the administration of the banks was to be fixed, indicates a proposed system of governmental control analogous to the restrictions of the Currency Act, and, perhaps, including security for circulation. Each bank also was to receive a proportionate amount of the circulation. Whether it was to be in proportion to capital as in the Currency Act, or in what way security for circulation was to be given, does not appear.

\section{article in the "Analectic Magazine."}

About this time there was published in the "Analectic Magazine," of Philadelphia, for December, 1815, an article signed W., "On Banks and Paper Currency," which was a sprightly review of an essay published in Philadelphia entitled, "The History of a Little Frenchman and His Bank Notes-Rags, Rags, Rags!"-in which was proposed a plan that the public funds should serve, in the absence of specie, as a basis and support and limit of the paper currency. It is possible that the writer was either the author of the plan referred to by Secretary Dallas, or that he had seen and reproduced an important feature of that plan for the security of circulation. The proposition of the writer was that the banks should be required to redeem their notes in sums of not less than $\$ 100$ in United States six per cent. stock at par or specie. The effect would apparently have been to have brought about specie payments as soon as United States six per cent. stock rose in the market above par in specie. It would also have secured uniformity in the value of the currency if the Government had had power to enforce the compliance of the State banks.

\section{Suggestions of Alexander Hamilton and Albert Gallatin.}

Alexander Hamilton is said to have proposed a similar policy previous to his appointment as Secretary of the Treasury, when, on being asked by Washington, "What is to be done with our terrible debt?" he answered, "Bank on it as our only available capital, and the best in the world."

In an essay published in 1831, Albert Gallatin refers to the loans of the Bank of England to the Government, and says these funds are held " as the best security to the holders of its notes and to depositors." He says further, however, that such a plan would at that date be impracticable in the United States, as the capital of the banks was so much greater than the entire amount of the public stocks. The debt of the Government was then in process of rapid reduction and was paid by 1835. He suggested a resort to mortgages on real estate, which plan, however, he found liable to the objection that the accommodations, which the banks could in that case afford to individuals, might be too much curtailed.

All of these plans, while containing the principles of the National 
Currency Act, are defective in that they do not seem to contain any efficient method of enforcing them. There is no suggestion that the Government shall assume the responsibility of the notes by holding the securities. The latter are apparently to be left with the banks themselves, subject to the vicissitudes of dishonesty or bad management. Mr. Gallatin, it is true, speaks of the Bank of England; and it is also true that this institution cannot collect its debt from the Government until all its debts for circulation and deposits are paid to its creditors; but Mr. Gallatin does not seem to have this feature in mind.

\section{Prof. McVickar's Plan.}

In 1827 a plan, similar to that afterwards followed in the Free Banking System of New York State, appeared in a published letter, entitled "Hints on Banking," to a gentleman in Albany, by Prof. John McVickar. The problem seems to have been to permit free banking and yet to throw such guards around it as to secure the safety of the public. The "Hints" consisted of about thirty-eight pages of general reflections upon banking and credit and the defects of systems of banking. To correct the latter, Prof. MeVickar lays down five propositions:

"1. Banking is a free trade in so far that it may be freely entered into by individuals or associations under the provisions of a general statute.

2. The amount of thè banking capital of such individual or association to be freely fixed, but to be invested one-tenth at the discretion of the bank, the remaining nine-tenths in Government stock, whereon the bank is to receive the dividends, but the remainder to remain in pledge for the redemption of its promissory notes under such securities as to place the safety of the public beyond doubt or risk. The stock to be made untransferable, except by the order of such court as shall be cognizant of these subjects with a view to wind up the affairs of the bank.

3. The promissory notes of such individual or association to bear upon their face the nature and amount of stock thus pledged, together with the usual signatures; and in their amount never to exceed the amount of the pledged stock, under the penalty of the individual or the firm being declared bankrupt, and their affairs to be wound up under a commission, appointed by such court as shall have cognizance thereof, the refusal to redeem their notes being made in itself an act of bankruptcy and followed by the same result.

4. No notes of a denomination under five dollars to be issued by such bank under the penalty of tenfold damages.

5. The deposit of stock thus placed in pledge by such individual or association to be capable of indefinite increase at the will of the banker, but not of diminution -in order that the security and confidence of the public may never be shaken, though the whole may at anv time be withdrawn by an application to the court for the winding up of the affairs or the bank."

\section{Principles Similar to Those of The Banking Laws of New YoRK AND MICHIGAN.}

This plan seems a very near approach to the principles of the Free Banking Law of New York State. The last provision of the fifth proposition, permitting a bank to withdraw its bonds and wind up its own affairs, might, if it had been adopted into the law, have defeated all 
the wisdom of the other propositions by throwing open a door to fraud and dishonesty. In fact, the essence of the comparative safety of the New York free bank circulation and the entire safety of National bank circulation consisted in the retention of the securities by the Comptroller of the State in one case and the Treasury of the United States and the Comptroller of the Currency in the other until the redemption of all outstanding circulation was fully provided for.

The first State to embody this principle of requiring banks of circulation to deposit securities with the governing power was Michigan. That State in 1837 adopted a general banking law by which the banks were required to deposit bonds and mortgages and personal bonds. This was in accordance with the views of Albert Gallatin before referred to. The law was decided to be contrary to the Constitution of the State, the courts holding that fundamental law restricted the Legislature to granting single charters. Apart from this the great defect was that there was no efficient provision for supervising the character of the bonds and mortgages deposited. If no bond and mortgage had been accepted except upon good improved property actually worth double the value of the mortgage, there would have been very little loss upon the notes. But Michigan real estate had little intrinsic value at that time, and the mortgages deposited were based upon fancy valuations made for the purpose of creating currency. On the other hand it may be said a rigid inspection of mortgages would have resulted in few or no banks, as there was in reality but little requirement for genuine banking capital in the State.

\section{abijah Mann and the New York Free Banks.}

In 1838 the New York Free Banking Law was enacted. Abijah Mann, Jr., in a letter to the Hon. A. C. Flagg, claims that the State was indebted to him for the suggestion of the plan adopted, and that it occurred to him in a conversation with the Hon. Thomas H. Benton relative to the practice of the English joint-stock banks, in keeping a large portion of their capital in Government stocks. After the adoption of the Free Banking System by New York, the example set was followed by a number of States, among others by Ohio, Indiana, Illinois and Wisconsin.

The radical difference between the New York system and the National system was that the State did not guarantee the full payment of the notes of any of its banks. It became the trustee of the securities of a bank, and when it became necessary sold them, and with the proceeds redeemed the bank's notes as far as the proceeds permitted. If the securities were not equal in value to the circulation outstanding, the latter was redeemed at a pro rata discount. The United States Government, however, guarantees the payment of National bank notes and undertakes to reimburse itself from the proceeds of the bonds deposited and the other assets of the bank. The United States Govern- 
ment can well afford to do this, as it accepts none but its own stock as security, and to an extent ten per cent. in excess of the notes issued upon it. No matter what the depreciation of the stock in the market, the Government by redeeming the notes would simply be redeeming its own debt at par value.

\section{Authorship of the National Banking Law.}

The authorship of the immediate suggestion of the plan of the National Banking Law itself has been claimed by or for many. O. B. Potter, of New York, wrote a letter to Secretary Chase advocating the issue to State banks of circulating notes upon their deposit of United States securities with the Treasury. This was embodied in Sections 62 and 63 of the original banking laws of 1863 ; but, being pronounced impracticable by Comptroller McCulloch in his first report to Congress, was omitted from the act of June 3,1864. The general plan of the act was suggested in the report of Secretary Chase for December, 1861.*

A sub-conmittee of the House Committee on Ways and Means was appointed, to which the report of Secretary Chase was referred, consisting of Hon. E. G. Spaulding, of Buffalo, N. Y., Chairman; Mr. Hooper, of Massachusetts, and Mr. Corning, of New York. Mr. Chase was called on for a draft of a bill. He had not prepared any, and asked Mr. Spaulding to prepare one, and the original draft of the National bank bill was accordingly prepared by Mr. Spaulding during the December holidays. Considerable opposition was manifested to the bill on its presentation to the Ways and Means Committee, and it became certain that the bill could not be passed without prolonged discussion, $\dagger$ and that it could not be made available in time to aid in meeting the expenses of the war. The bill was therefore reported adversely by the Ways and Means Committee of the House on January 8, 1863. As the necessities of the Government were very pressing, the legal tender act was introduced by Mr. Spaulding as a temporary measure for meeting the exigencies of the war.

On February 2, 1863, the National Currency Act, which provided for the organization of National banks, was reported from the Finance Committee of the Senate by Senator Sherman, of Ohio. After being fully debated, it passed the Senate on February 12 by a vote of twentythree yeas to twenty-one nays. But for personal appeals made by Secretary Chase and Mr. Sherman, the bill would have failed in the Senate by a tie, as Senator Anthony was known to be opposed to it.

* " He urged its adoption both as a measure of currency reform and as a means of replenishing the public Treasury. As a matter of fact, the act brought little aid to the Treasury until the need of $\mathrm{st}$ had passed by. The war ended practically in April, 1865. The whole amount of National bank notes issued up to the third of that inonth, was only $\$ 98,896,488$. The sum total of fiscal aid gained by the operation of the act up to that time therefore did not exceed $\$ 109,000,000$, and this was only 3.6 per cent. of the borrowings of the Government."-"National and State Banks," by Horace White: "Sound Currency," Vol. IV.

+Address of Hon. E. G. Spaulding, delivered at Philadelphia, 1876. 
He voted for the bill because Mr. Chase convinced him that it was necessary to carry on the war.*

From the Senate the bill went to the House, where it remained on the Speaker's table from the 12th to the 19th of February. A motion to refer it to the Committee of the Whole having been defeated, Mr. Spaulding opened the debate in a long speech in favor of the bill, the debate continuing until the $20 \mathrm{th}$, when the bill was passed without amendment by a vote of seventy-eight yeas and sixty-four nays. $\dagger$

An analysis of the act shows that its general provisions were taken largely from the free banking laws of New York, Ohio and other States. The provisions in regard to circulation were carefully drawn and were novel in many important details. The evident intention was to avoid the imperfections which the practical workings of the State systems had disclosed in their laws. This draft was, during the debate upon it in the House, amended in many particulars, but its essential features were all retained.

Thus it will be seen that the National system of banking did not spring complete from the brain of any one individual, but was a growth. As in the case of the invention of printing, the steam-engine, or electric telegraph, there are many entitled to the claim of having entertained and proposed the abstract ideas upon which the practical realization is based. Similar ideas may have occurred independently to many students of the science of banking. The realization was owed to the pressure of a necessity which revealed the inadequacy, for the period, of the systems of State banking, and compelled legislators to agree upon a system more adapted to the needs of the times.

Appointment of Comptroller of Currency ANd first Report. 1863.

On or near January 1, 1863, there were, according to the information obtained by the Secretary of the Treasury, 1,466 banks in operation in the United States, with a capital of $\$ 405,045,829$, and a circulation of $\$ 238,677,218$.

The office of the Comptroller of the Currency was organized and Hon. Hugh McCulloch was appointed Comptroller. He gave up the Presidency of the State Bank of Indiana to accept the new appointment. The first report of the Comptroller to Congress was made November 28, 1863. Up to that date one hundred and thirty-four banks had been organized, thirty-eight in Ohio, twenty in Pennsylvania, twenty in Indiana and sixteen in New York. Illinois had seven, Iowa six, Wisconsin, Michigan and Connecticut four each. No other State had over three. The first bank authorized to commence business was the First National Bank of Philadelphia, Pennsylvania. Up to the date of the

* "John Sherman's Recollections," p. 299.

+ A more extended history of National bank legislation from the beginning of the system up to the present will be found in later chapters. 
report no circulation had been issued to any association. The work of preparing it had been attended by unlooked-for delays. The contracts for printing the notes were made with the Continental and American Bank Note Companies. Mr. McCulloch was in favor of a course of action in establishing the system which should not so much increase the aggregate banking capital of the country as induce the capital already invested in State banks to enlist itself under the National system. From this view he looked with some distrust upon the organization of new National banks in States where he deemed the banking capital already in existence sufficient, and encouraged as far as possible the conversion of State banks into National. In his report for 1864, he said: "It is perhaps to be regretted that so many new banks have been organized in States where, before the passage of the Act, there was no deficiency of banking capital." He was also in doubt whether State banks could become National associations without action upon the part of the Legislatures of the State permitting them to avail themselves of the National law. In 1864 he was happy to be enabled to say that his apprehensions of too rapid an increase of National banks had been lessened by the action of many of the State banks, which were becoming National banks. Massachusetts, Connecticut and Pennsylvania had passed enabling Acts.

During the year ending November 25, 1864, 282 new banks were organized, and 168 State banks had entered the system, making a total of 584 National banks in existence. The States of Pennsylvania and New York headed the list, the former with 109, and the latter with 100 banks. The total capital was $\$ 108,964,597$, the bonds deposited $\$ 81$,961,450 , and the circulation $\$ 65,864,560$. The question had already arisen why it was not better for the Government to issue its own notes rather than to grant this privilege to the National banks. 'Mr. McCulloch's argument in reply was that the banking interest of the United States was an important one, that the State banks had, notwithstanding failures and bad management, on the whole been of great advantage to the people and the Government; and, as it was indispensable that the Government should control the issue of paper money, it would be accomplished with less injustice to the State banks by creating the National system, and permitting the State banks to become a part of it-in other words, in exchange for the privilege of issuing circulation under the State systems, to receive that of issuing notes under the National system. The conservative policy which led Mr. McCulloch to favor State banks at the expense of new organizations may be seen in the following statement from his report of 1864 :

"For the double purpose, therefore, of keeping down the National circulation as far as it has seemed possible to do it, consistently with the establishment of the system throughout the country, and preventing an issue of banking capital that might. hereafter be instrumental in keeping up the inflation, and retarding the resumption of specie payments, or prove unprofitable to its owners, I have felt it to be my duty 
to discourage in many instances the organization of new banks, and in more instances to refuse my sanction to the increase of capital of those already organized."

\section{Ten Per Cent. Tax on State Bank Circulation.}

At this time the chief source of profit to the banks was the opportunity of dealing in the obligations of the Government, and the Comptroller feared that when, after the war, this opportunity had passed away, the banks would be tempted to use their means ${ }^{\bullet}$ in unprofitable and dangerous speculations. He thought the time had come to repress the issues of the State banks by taxation. The preference was everywhere given to the National bank notes, and Congress could, by imposing a sufficient tax, relieve the Treasury from embarrassment and the people from an unsatisfactory circulation. The recommendation of Secretary Fessenden in regard to circulation of State bank issues coincided with that of Mr. McCulloch. (The amount of State bank notes in circulation in 1864 was about $\$ 170,000,000$, and there seems to have been no tendency to their diminution. An Act was passed on March 3, 1865, imposing a tax of ten per cent. on the circulation of State banks. The legislative history of the tax is thus described :*,

"It was proposed by Mr. Hooper, of Massachusetts, in the House on February 17,1865 , and in the form in which he offered it, it was defeated. It was again offered in substantially the shape in which it now stands, on the same day, by Mr. Wilson, of Iowa, and it was adopted by an accident. The vote was sixty-eight yeas to sixtyseven nays, but Mr. Brooks, of New York, who had bitterly opposed it in debate, voted in the affirmative in order to move a reconsideration. When he moved the reconsideration, Mr. Washburn, of Illinois, moved to lay that motion on the table, and on the latter motion the vote was a tie, seventy-one to seventy-one. The Speaker then voted in the affirmative, and his vote saved the Wilson amendment. If Mr. Brooks had voted in the first instance as he had fought, there would have been a majority of one against it. In the Senate the Committee on Finance reported adversely to the tax, but was overruled by a majority of two. *** Although enacted on March 3, 1865, the tax did not go into effect until August 1, 1866, or fifteen months after the close of the war."

This measure has had the effect intended, viz., to prohibit the issue of circulating notes by State banks. Attempts have been made to secure the repeal of the tax, but the opposition to State bank notes is now much stronger than it was in 1863, and all these attempts have failed. Owing to the growth of national sentiment and the closer relations of the people of the different States as a result of improved means of communication, and because of the safety and uniformity of the notes issced by National banks, there appears to be no disposition on the part of the people to restore the privilege of issuing circulation to the State banks.

The act of March 3, 1865, imposing a tax on the circulating notes of State banks also empowered the Comptroller, in authorizing the creation of National banks, to give the preference to State institutions

* "National and State Banks," Horace White; "Sound Currency," Vol. IV. 
which desired to enter the system. The effect of these provisions was immediately seen. The number of National banks increased from 638 in January, 1865, to 1,513 in October of that year; the capital between the same dates went from $\$ 135,618,874$ to $\$ 393,157,206$, and the circulation from $\$ 66,769,375$ to $\$ 171,321,903$.

\section{action of New York Clearing-House Association.}

On December 5, 1863, a meeting of bank officers was held at the New York Clearing-House, and a committee appointed at a previous meeting "to take into consideration the National Bank Currency Act as to its prospective effects upon the currency of the nation and the national credit, and what action, if any, devolves on the banks in the premises," made its report. The committee's report was in the form of answers to three questions: 1 . What is this scheme to provide a national currency ? 2. What will be the effect of the proposed currency on the interests of the people? 3. What will be the final consequences to the national Government ?

The answers were: 1 . That from the fact that the applications were chiefly for banks with small capital and, judging by the localities where they were located, it was evident that the national law encouraged the organization of banks for circulation only, not regular business banks for deposits and discounts, but what are known in our Western States by the expressive term "wild-cat" banks. 2. As the national currency was "not a legal-tender between man and man, nor has any banking association or banking institution a legal right to pay them out in discharge of its debts to an individual or corporation, it would be a depreciated currency, and when used by the laboring man and poor woman, they would find five or ten per cent. added to the price they would be required to pay, provided they could offer legaltender notes;" and third, it would by its issue supplant a like amount of legal-tender notes which the Government could issue free of all interest, and which amount the Government would have to borrow and pay interest on at six per cent. This loss on $\$ 300,000,000$ would amount annually to $\$ 18,000,000$. The report was accepted by the clearinghouse.

\section{Reply to Clearing-House Report.}

This report called forth a reply from a member of Congress, who considered that its authors had not fairly investigated the subject, but criticized the Bank Act from the narrow and prejudiced standpoint of State bankers. Their answer to the first question he characterized as a mere assumption, not borne out by facts. That large National banks as well as small have been organized. That the National banks of small capital should be compared with small State banks, and the large State banks with National banks of similar capital. To the answer to the second question he replied that State bank notes were no more a 
legal tender than the National bank notes, and that the latter possessed the advantage of being receivable for public dues. Their answer to the third question was admitted to have some weight; but the same objections applied with equal force to the notes of State banks. The State bank notes were profitable only to stockholders of the banks. They did not benefit the Government or the people to the extent that National bank and legal-tender notes did. As between National bank currency and legal-tender notes, the loss the Government might experience in the withdrawal of a part of the latter would be made up to it by the greater stability of the currency.

\section{Progress of the National Banking System in 1865.}

During the year $1865,1,014$ banks were organized, of which 283 were new and 731 were converted from State banks. The total number in operation was 1,601 , of which 922 came under the national law from the State bank systems. Mr. McCulloch had been appointed Secretary of the Treasury in 1865, and Hon. Freeman Clarke had succeeded him in the office of Comptroller. Mr. Clarke, in his report, stated that nearly all the State banks had become National banking associations. Inasmuch as both he and his predecessor believed it to be the intention of the law that National bank notes should be substituted for State bank circulation, no new circulation was issued to converted State banks except as the notes issued under their State charters were reduced to an amount less than they could issue as National banks. The result was a contraction at this time of the aggregate bank circulation of the country. Some of the States had passed enabling acts, which permitted State institutions converted to National banks to continue to issue State bank circulation for some time after their conversion. This was not regarded as legal by the Comptroller. The National bank circulation outstanding on October 1,1865 , was $\$ 171,231,903$. The banks also had State bank notes outstanding amounting to $\$ 78$,867,575. At this date the banks in the National system held $\$ 427,731$,300 of United States bonds and securities and $\$ 189,988,496$ of legaltender notes, or over one-seventh of the total public debt at that time.

The removal of the office of the Comptroller of the Currency to New York city was agitated considerably at this period. The question of redemption of the notes was becoming an important one. As they were redeemable only in paper legal-tender notes, there was little object in presenting them for that purpose, especially as they were as freely taken by all and answered every purpose of the legal-tender note.

\section{Amasa J. Walker on Redemption of National Bank Notes.}

Amasa J. Walker, a member of the House of Representatives, in a speech prepared by him upon the original Bank Act of February, 1863, which was not, however, delivered on account of the calling of the previous question, but was published in the "Bankers' Magazine" for May, 
1863 , prophesied that, as there would be no redemption of National bank notes except in paper essentially the same, they would continue to circulate as long as the material of which they were made would permit them, and in their movements approach as near perpetual motion as anything yet discovered. It was thought that if some sure method of redemption in New York city could be devised, it would secure a larger return of the notes to the banks that issued them and bring about a more satisfactory local circulation. The Hon. Freeman Clarke, in his' recommendation for placing the Comptroller's office in New York, was principally actuated by the desire to save the expense of express between New York and the office. Most of the notes redeemed were redeemed in New York, and when in poor condition, had to be sent to the Comptroller's office for destruction. The notes were printed by bank note companies in New York city, and had to be sent to Washington before they could be issued to the banks. The location of the headquarters of the system at the financial centre would doubtless have proved a remedy for this difficulty.

This impossibility of prompt redemptions of National bank notes was constantly a source of annoyance until the establishment of the National Redemption Agency at Washington. It became a greater difficulty to contend with as the limit upon the aggregate amount of circulation began to be reached, and new organizations had to depend for obtaining the notes they were entitled to receive upon the circulation surrendered by insolvent National banks, or those which had gone into liquidation. In fact, this lack of practical redemption formed at this time, and until 1874, one of the most serious defects in the National system.

\section{Mr. Hulburd Succeeds Mr. Clarke as Comptroller.}

H. R. Hulburd succeeded Freeman Clarke as Comptroller in $\mathbf{1 8 6 7}$. For the next three years the number of the banks did not substantially increase; in October, 1866 , there were 1,644 with a capital of $\$ 415,000$,000 , circulation, $\$ 280,000,000$, and in October, 1870 , there were 1,648 banks, with a capital of $\$ 435,000,000$ and circulation amounting to $\$ 296,205,446$. During 1867 nine were organized, of which three were State bank conversions. During this year some of the blank notes were stolen from the vaults of the Comptroller's office, where they were kept ready for issue to the banks, by one of the colored messengers. They were put in circulation after signatures had been clumsily written on the notes where the President and Cashier would have signed, had the notes been legitimately put in circulation. The signatures were not the same as those of the bank officers, nor did they resemble them in any way. This experience indicated how freely and confidently the public received these notes, making it evident that the bank by which they were issued or purported to be issued, was not looked to as the source of security. After some difficulty, the person 
by whom the notes were stolen was arrested, but escaped punishment through a flaw in the indictment, which recited that money had been stolen, whereas, the notes were not strictly complete money until signed regularly by the bank officers.

Other real or fancied imperfections of the system were subjects of discussion in 1867. It was alleged that the law requiring the banks to make quarterly reports upon certain fixed days, viz., the first Mondays in January, April, July and October, was taken advantage of by many associations, which placed themselves in good condition just previous to the dates upon which the reports were required, and grew careless in the intervals.

\section{IMPERFECTIONS OF THE SYSTEM.}

The necessity of more effective redemptions of notes was becoming more and more apparent, and this difficulty and the practice of the banks in the financial centres of offering interest upon the deposits made with them, to induce the country banks to select them as depositories of their reserves, was held to cause dangerous accumulations of currency in New York. The banks in New York city themselves recognized the custom of paying interest on deposits as one that imposed an additional burden on the banks and narrowed their profits. Committees appointed by the New York Clearing-House reported against it, but to this day haye never succeeded in abolishing the custom.

Mr. Hulburd recommended that Congress should take measures to secure a central redemption of notes, and forbid the payment of interest upon reserves deposited with banks acting as redemption and reserve agents. The Comptroller also considered the question of the substitution of legal-tender notes for National bank currency, arguing that interest paid by the Government upon the bonds deposited by National banks as security for their circulation was recouped to the Treasury by the taxes paid, with the exception of about three millions of dollars. The taxes at this time consisted of a license tax of two dollars upon each $\$ 1,000$ of capital, of one-half of one per cent. upon deposits and capital in excess of United States bonds held, of one per cent. upon circulation, and a tax upon dividends or, if dividends were not declared, upon profits. In addition, there were stamps upon checks, notes and bills of exchange, and many other documents which were handled by the banks. These taxes were collected part by the Collectors of Internal Revenue and part by the United States Treasurer. The Comptroller stated that the small difference between the amount of interest paid upon the United States bonds held by the banks and the amount returned by taxation was more than made up by the fact that the National banks held about a hundred millions of legal-tender notes, which amounted to a loan of that amount to the Grovernment without interest. This argument appears to have been sound at that time when the credit of the United States was not so good as it has since become. 
In 1868 fourteen National banks had failed and been placed in the hands of Receivers, and a number had gone into voluntary liquidation. Twelve were organized that year, five were new, one a State bank converted, and six were in place of other National banks that had gone into liquidation.

\section{A Bank of Redemption Proposed.}

The difficulty about redemptions began to be felt in a new way. The law provided that National banks might close their affairs by the votes of their stockholders, owning two-thirds of their stock, and that such banks might, after one year had elapsed from the date of their liquidation, retire their circulation by the deposit of lawful money and withdraw their bonds. The law in this latter respect was permissive rather than mandatory, and seems to have been passed with the idea that it would not do to let the banks get out of the system too easily. It was soon found that a bank under it could go out of the National system and cease business or become a State bank, leaving its national circulation outstanding and making no effort to retire its circulation or withdraw its bonds. As there were no redemptions, the bank might thus obtain the benefit of its circulation for an indefinite period without subjecting itself to the restrictions of the National Banking Law. The bank taking this course deprived new organizations of circulation to which they were entitled. The attention of Congress was called to this, and the Comptroller suggested that redemptions might be rendered more practical by the establishment in New York city of a bank with a capital of from ten to fifteen millions of dollars, the stock of which should be held by the National banks, which bank should redeem the notes of all the National associations. The expense of these redemptions might, it was also pointed out, be paid by the profits of the banking business to be carried on by the institution. The practice of certifying checks, and the use of National bank capital and credit in New York city in stock speculations, began to attract attention. It was estimated that $\$ 70,000,000$ of capital and $\$ 112,000,000$ of credit were used in this way. There had, for several years, been much stringency in the money market in the fall of the year, sometimes almost amounting to panic. This culminated, in 1869, on Black Friday.

The Comptroller, in 1868, refers to this condition of things, and suggests as a remedy that a certain portion of the legal-tender notes should be kept as a reserve in the Treasury and issued to banks depositing United States bonds. At a later date in February, 1874, James Buell, President of the Importers and Traders' National Bank, of New York, in an interview with the Banking and Currency Committee, ascribed this recurring stringency in the fall to the fact that inadequate redemption of National bank notes led to their collection in the financial centres during the most of the year; that when the crops had to be moved, the sudden demand from the country banks caused a contrac. 
tion in New York. If, on the other hand, redemption at one-quarter of one per cent. discount in New York had been compulsory, these notes would have been sent home to be issued only as legitimate business required. He said that the crops under the present system were moved by contraction of the currency instead of by an expansion, as would be the case were redemptions enforced. This might have been true under the conditions existing from 1868 to 1878 , but owing to the great increase in Government paper, the Redemption Agency at Washington has not fulfilled this expectation.

\section{LEGISLATION OF 1869.}

On March 3, 1869, Congress remedied one or two defects in the National Banking Law. Instead of requiring banks to make reports on fixed days in January, April, July and October, the law as amended required the Comptroller to call for reports of their condition on some past day five times during the year. This prevented the bank from taking measures to prepare itself for making a good report. Reports of dividends and earnings were also required to be made semi-annually, and certification of checks, unless funds were on deposit to meet them, was forbidden under penalty of forfeiture of charter. On April 6,1869 , it was made criminal for any person to aid or abet officers of National banks in any of the acts made punishable by previous law.

During 1869 nine banks were organized; eight of them were new, and one a State bank converted. The Comptroller said that the operation of the law requiring reports to be made for past days was satisfactory, and that under it the reports gave a much better representation of the ordinary transactions of the banks than the reports under the previously existing law. The abuse of retaining circulation by banks in voluntary liquidation was again adverted to as well as the necessity of a central redeeming agency and the custom of paying interest on deposits. The Comptroller recommended uniformity in the manner of paying the taxes then paid by National banks. Part were paid to the Treasury, and part to the collectors of internal revenue. He suggested that if the legal-tender notes were withdrawn that there would be no objection to free banking and a withdrawal of the present limit upon the aggregate anount of National bank circulation.

\section{Proposed Resumption of Specie Payments.}

Discussions upon the subject of specie payments in this and previous years indicate that the general idea in regard to resumption was that retirement and cancellation of the legal-tender notes would follow resumption.

George S. Coe, in 1868, in a letter to the Hon. J. V. L. Pruyn, of the House of Representatives, upon the natural road to specie payments, advocated a law making contracts upon a gold basis legal, leaving the legal-tender notes to be absorbed in payments to the Government. 
James Gallatin, of New York, in the same year addressed to Andrew Johnson, President of the United States, a letter entitled "Hard Money and Free Trade," in which he enumerated many of the plans for resumption and improving the finances at that time advocated. There was one to issue two thousand millions of six per cent. bonds payable principal and interest in gold, in which all the indebtedness of the United States, including legal-tender notes, was to be funded. One per cent. of the interest was to be paid to the States in lieu of taxation.* R. J. Walker's plan was to obtain a $\$ 250,000,000$ gold loan in Europe to resume specie payments. $\dagger$ Another plan was to sell demand notes payable in gold at the highest possible premium, and thus absorb the legaltender notes. Hon. John D. Van Buren suggested paying 7 3-10 eurrency interest instead of six per cent. in gold. The Comptroller of the Currency wanted all National bank notes redeemed at a common centre. Mr. Gallatin's own plan was to legislate as little as possible, trust to the natural laws of trade, preserve the public faith and practice economy and retrenchment. He was in favor of a loan for such time and at such a rate of interest as would enable the Secretary to sell it at par for gold, but fix no day for resumption.

\section{Operations OF the Sistem IN 1870-Legislation.}

During the year ending November 1, 1870, thirty-seven banks were organized. In the beginning of the year, practically the full amount of circulating notes at that time authorized, viz., $\$ 300,000,000$, had been issued. New banks could only be organized by procuring the surrender of a portion of the circulating notes of banks already in existence. The holding of circulation became a privilege which could be sold by the banks that possessed it at a premium. Banks that went into voluntary liquidation were in no hurry to redeem their notes. New institutions had therefore to buy their circulation from other banks that had secured a privilege for more than they wanted, paying frequently a premium of as high as six per cent. The unequal distribution of the privilege among the States attracted much attention under such circumstances, and it was asserted in Congress that there had been an error in the construction of the law under which the distribution was made, which had brought about the inequality.

The year 18\%0 was fruitful in legislation, and attempted legislation affecting the National banks. The bill for consolidating and funding the debt into bonds bearing five, four and a half and four per cent., then became a law. The original measure, as introduced and finally passed in the Senate, contained sections which established free banking, and for the resumption of specie payments through the agency of the National banks. The plan was that the National banks already in existence should deposit the new bonds in equal proportions of fives,

* To compensate the States for depriving them of the right to tax bank stock.

+ This plan was the one virtually adopted in preparation for resumption in 1879. 
four and a halfs and fours as security for their circulation, in place of the six per cent. bonds then held for the purpose. The circulation of new National banks was to be based entirely upon the new bonds, which they could buy at par. The only limit to the issue of increase of National bank circulation was the amount of legal-tender notes outstanding, which were to be retired as the National bank notes were issued. The honor and difficulty of the resumption were thus to be thrown upon the National banks. They declined the task sought to be imposed upon them. There was much opposition to the measure, on the ground that the Government was taking advantage of the banks to compel them to subscribe, whether or no. It was a force bill. Their advocates in the Senate, and particularly in the House, opposed the provision, and in the House had sufficient strength to defeat it. In the light of subsequent events, it might be claimed that the measure was really a blessing in disguise, and if the banks and their advocates had been gifted with more foresight, they would have been in favor of the measure. The bonds might have appreciated in their hands, the system might have had the prestige and glory of bringing about the resumption of specie payments, and the legal-tender note would perhaps have been permanently retired.

\section{Mr. ShermaN's SpeEch.}

At least Mr. Sherman* anticipated much benefit to the National banks from the bill. Even to its harshest feature he thought they had no valid objection. He said:

"The last three sections of the bill apply to the National banks, * * * they are mere creatures of law, *** they hold their existence at the pleasure of Congress. *** We may to-morrow, if it promotes the public interest, withdraw their authority. *** They hold of our securities $\$ 346,000,000$; nearly all of these bear six per cent. interest in coin. We will not deprive them of any of them; we will not deny them even the payment of six per cent. gold interest, as long as they are the holders of these bonds. But they hold the franchise of issuing paper money guaranteed by the United States, which constitutes the circulation of our country; and we say that enjoying that franchise, we now stipulate with them for the reduction of interest on the bonds they hold. The provisions of the bill are not arbitrary, they are not harsh; they do not take from the National banks any rate which they enjoy, except one confessedly at our pleasure. If they are not content to enjoy their franchise on the terms proposed, they can retire. *** The last section is intended to be a free banking law, opening wide the door to the organization of National banks to any extent, only upon the condition that an equal amount of greenbacks shall be retired as the new notes are issued. The only limit on it is the amount of greenbacks now outstanding, and when they are exhausted, it will be for Congress to determine whether we shall go further. *** As bank notes are issued, United States notes will be retired, thus changing the burden of resumption from the United States to the banks by their voluntary consent."

Referring to the danger of the defeat of the part of the measure relating to National banks through their opposition, Mr. Sherman said:

* Sherman's Speeches, p. 258. 
"National banks would be very unwise indeed to make an issue on this question. If any man here is a friend of the National bank system I can claim to be. I was here at its cradle, introduced the original banking bill and advocated it, and also introduced the amendment to it, conducted it and saw it passed. * * * They ought not to obstruct this measure ; their interest is promoted by it." * * *

After the defeat of the sections, he said:

"I wish now to record my deliberate judgment, that in this conclusion, to which we have been compelled to arrive by the action of the House, we are doing the National banks a great injury, which will impair their power and influence umong the people, and that the opposition of the National banks to this provision will do more to weaken and destroy them than anything that has transpired since their organization."

On the other hand it may be said that while Mr. Sherman, with the exceptional foresight of a statesman, might see all the future advantages promised to the National banks, the view taken by the banks was warranted by the uncertainty of Government credit, and the bugbear of specie resumption, which was not then generally regarded as so easy of accomplishment as it afterwards proved. The banks, moreover, were justified in their opposition, by the fact that there was no market for the four and a halfs and fours for several years afterwards.

Their interests were further considered in three separate measures, which became laws. One of these extended the penalties of the act of June 3,1864, for misdemeanor of bank officers, to the officers of National banks organized under the act of February 25, 1863. The second provided for an additional issue of national currency to the amount of $\$ 54,000,000$, and the withdrawal of $\$ 25,000,000$ from banks located in States that had more than their proportion for redistribution among banks organized in localities having less. This act also provided that associations might change their location from States where they could not receive notes to States where they could do so, and for the organization of gold banks. The third compelled banks already in liquidation to retire their outstanding circulation by the deposit of lawful money within sixty days from the date of the act, and banks thereafter going into liquidation to deposit lawful money for similar purpose within six months from the date of the vote of their stockholders closing the institution. It also provided that banks in liquidation for consolidating with other National banks need not retire their notes.

Of the thirty-seven banks organized up to November, 1870, thirtyone were to receive their circulation from the increase allowed by the new act. One gold bank was started in Boston. There does not appear to have been any hurry upon the Pacific Coast to make this law available. The idea was that by substituting a paper currency based on gold for the exclusive gold currency of that section, at least forty millions of gold would be released, which might be an aid to the resumption of specie payments. 
There were, at the close of $18 \% 0$, two hundred and fifty applications for new banks on file, which would require a capital of $\$ 27,000,000$, and a proportionate amount of circulation. Twenty banks in liquidation paid in legal-tender notes and retired their circulation, which when it came in would be available for new banks. The redemptions of mutilated National bank currency were more vigorous than ever before. Up to October 1, $\$ 30,897,518$ had been returned to the Comptroller's office, $\$ 17,048,119$, or more than half, within the year. There were still imperfections in the working of the system that needed to be removed by legislation. The Comptroller recommended that the officers of National banks be required to stamp the word counterfeit upon all notes of that description that came into their hands. He reminded Congress that there was no law compelling banks to make good their capital stock when it became impaired, the only penalty being the stoppage of dividends, that stockholders would not voluntarily make good the loss, and that consequently such institutions lingered on in a sickly condition with no prospect of being useful to the public or to their stockholders.

There was some complaint of the alleged practice of National banks taking illegal interest. In regard to this the Comptroller remarked that the heavy rates of State and national taxation amounting to about five per cent. in all, absorbed so large a proportion of the profits of the banks that they were under great temptation to charge higher rates in order to make reasonable dividends. The payment of interest on deposits was, he said, a practice sanctioned by custom and well intrenched, and would then be hard to abolish, even if its prevention were practicable.

\section{Increase of Circulation-ACT of July 12, 1870.}

The effect of the increase in the limit of aggregate circulation from 300 to 354 millions by the act of July 12, 1870, was seen in 1871, by the organization of 145 new banks in the South and West. The amount of circulation taken in the South was small, and it was estimated that after the West and Northwest were supplied there would still be left twenty or twenty-five millions for Southern banks if they chose to apply for it. Five National banks were this year organized in New Orleansthree of them old State banks and two new institutions. In addition to the 145 banks which took out circulation under the new limit, ten banks were organized in localities having more than the proper proportion of circulation, and obtained circulation surrendered by previously existing banks. Notwithstanding the relief in the South and West, new National banks could not be organized in most of the Eastern and Middle States, no matter how useful they might prove to the public, without buying up from other National banks some portion of the amount allotted to the State in which they were to be located. 
Very few banks availed themselves of the right to change their location from one State to another for the purpose of obtaining circulation, indicating that in the West and South, where they could get circulation, the rate of interest was so high that there was little profit in it, while in the East, where the profit was greater, circulation could not be had. The First National Gold Bank of San Francisco was organized in this year, and the Comptroller expressed the hope that the example would be followed by other organizations of the same kind, when the convenience of the new currency was experienced. The gold bank previously organized in Boston* did very little business, and soon went into voluntary liquidation and closed its affairs. It never put in circulation any of the notes, some $\$ 300,000$ in all, sent to it from Washington.

\section{John JAY Knox Appornted Comptroluer.}

In April, 1872, Mr. Hulburd, Comptroller of the Currency, resigned, and was succeeded by John Jay Knox. The license tax on National banks was repealed after May 1, 1871, and the income tax after December 1, 1871. The former had been in operation from May 1, 1864, and the amount paid by the National banks was $\$ 5,322,688$. The income tax was imposed March 1, 1869, and the banks had paid $\$ 5,539,289$, when it was abolished. Up to November, 1872, 2,061 banks had been organized, of which twenty-one had failed, ninety-one placed in voluntary liquidation, leaving 1,944 in operation. Of the $\$ 54,000,000$ of new circulation authorized to be issued, $\$ 53,917,470$ had been taken by banks in the South and West, and this apportionment still left a deficiency of $\$ 40,000,000$ in the States that had not received their proportion, inasmuch as there was a total deficiency of $\$ 94,000,000$ in $18 \% 0$, when Congress granted the additional $\$ 54,000,000$. The same law required the Comptroller, when the additional circulation was taken up, to make requisition upon certain banks in States having an excess of circulation, and withdraw $\$ 25,000,000$ from them. If this portion of the act had been carried into effect the withdrawal would have been made, $\$ 5,018,000$ from four banks in New York city, $\$ 11,403,000$ from thirty-six banks in the city of Boston, $\$ 2,894,000$ from fifty-three country banks of Massachusetts, $\$ 2,997,000$ from fifteen banks in Connecticut, and $\$ 2,688,000$ from sixteen banks in the city of Providence. By these withdrawals, all the banks in Massachusetts, Rhode Island and Connecticut would be reduced to a uniform limit, not exceeding $\$ 300$,000 each.

The difficulty in carrying out this withdrawal consisted in the lack of means of getting in the notes, even if the banks deposited lawful money in the Treasury for their redemption. If the banks did not respond, the Comptroller could sell their bonds and deposit sufficient of the proceeds in the Treasury. If there was pressure for circulation in the localities entitled to it, the notes withdrawn would be

* Kidder National Gold Bank. 
gathered up and assorted by brokers, who could sell them to the new banks at a premium of from four to six per cent. This practice, which the Comptroller thought should not be oncouraged even indirectly by law, was sure to find exercise under the withdrawal provision of $18 \% 0$ and therefore he recommended an issue of $\$ 5,000,000$ additional circ lation during each year for five years, to banks in States where less than the proper proportion of circulation had been received. In 1872 he further recommended that banks should be authorized to commence business upon the deposit of $\$ 10,000$ in bonds. 


\section{VIII}

PROGRESS OF NATIONAL BANKING SYSTEM, 1872-1878.

Criticism of fixed reserves - Great fire in Chicago - Locking up money in New York -Action of clearing-house-United States not preferred creditor of National banks-Evasion of ten per cent. tax law-Marking counterfeit and spurious notes - Panic of 1873 - Issue of clearing-house loan certificates - Panic investigations - Reforms of clearing-house-Forced redemption of notes proposedWithdrawal act of $18 \% 0$, difficulty of execution-Proposed exchequer bank - Act of June 20, 1874-Opinion of Attorney-General-Fluctuations of circulation Operation of Section 4, act of 1874-Large reserves held, 1874-75-Comptroller's report of 1875 - Gold notes in California - Operation of redemption agency Designs and denominations of National bank notes - Discrimination in the taxation of bank shares - Two-cent stamp tax - Usury - Printing of notes - National bank law consolidated in revised statutes - Recommendations in 1876, '77 and' 78 .

\section{The LAw of Fixed Reserves.}

Gold banks were gradually making way in California, as their notes were found a more convenient form of currency. The banks were usually stronger in reserve than the law required. Some objections were from time to time made to the requirement by law of a fixed reserve, inasmuch as the natural laws of business would induce bankers to keep what was necessary. An arbitrary limit was sometimes too great and sometimes too small. The Comptroller replied that the law of reserve did not in the least interfere with good bankers, who would, even if there was no law, at all times keep an adequate reserve, but it. did have a good effect on ignorant and reckless banks.

The Chicago Fire, 1871.

The great fire at Chicago occurred October 8-11, 1871, and the buildings of eighteen National banks were totally destroyed. It was anticipated that they would sustain in many cases an almost entire loss, but after the safes recovered from the ruins were opened it was found that the books, papers, etc., were in a condition to permit the recovery of debts. The loss upon discounted paper was about $\$ 600,000$, and the entire loss experienced was more than covered by the surplus which the banks had accumulated under the provisions of the National Banking Law.

In April, 1871, notwithstanding the law of February 3, 1869, forbidding the locking-up of money, over $\$ 4,700,000$ was drawn out on checks. 
by one depositor of a National bank, which ordinarily would have gone through the clearing-house. The object was to lock up money, but the manner in which it was accomplished did not strictly lay the drawer of the checks liable to the law. The clearing-house association passed resolutions disapproving such transactions.

\section{United States not a Prefkrked Creditor of Failed National} BANKs.

Among the twenty-one banks that had failed and been placed in the hands of Receivers were some that had been depositories of the public money. The National Banking Law required a pro rata distribution of the realized assets of the failed institutions among all its creditors. The Treasurer of the United States raised the question whether an old law of 1797 which made the United States a preferred creditor in the case of bankrupts and insolvents did not continue to apply to insolvent National banks, notwithstanding the provision of the National Banking Law. The question was finally settled in 1882, by the decision of the United States Supreme Court, in the case of the Cook County National Bank of Chicago, that the United States was not a preferred creditor of an insolvent National bank.

\section{Evasion of Ten Per Cent. Tax, and Marking of Counterfeits.}

In some parts of the country, especially in the South, the law imposing a tax of ten per cent. upon State bank circulation and fractional notes was disregarded or evaded. The State of Alabama, in defiance of the provision of the United States Constitution forbidding States to emit bills, issued small notes. Savings banks, municipal corporations, cities and towns and railroad companies, issued receipts and certificates which circulated as money. Many State institutions and individuals assumed the title National, giving the impression that they were National banks, under the restrictions of the national law. The Comptroller called attention to these matters, and also renewed recommendations that the law should be amended to compel National bank officers to mark all counterfeit and spurious notes that came into their possession, to compel banks to restore lost capital or go into liquidation. Some attempts had been made to organize banks by paying capital in stock notes. Up to November $1,1872, \$ 86,695,895$ in mutilated notes had been returned to the office, over sixty-eight millions of it within the last three years.

\section{The Panic of 1873.}

The year 1873 was the tenth year of the existence of the National banking system, and there were 1,980 banks in operation. It is further distinguished by the great financial panic which commenced in Septemberwith the failure of the private banking firm of Jay Cooke \& Co., which had gained great wealth and prestige by its operations in Govern- 
ment securities during and subsequent to the war. Coincident with this failure was that of the First National Bank, of Washington, and that of the National Bank of the Commonwealth, of New York.

\section{Issue of Clearing-House loan Certificates.}

The general distrust caused demands upon the banks by depositors, and the country banks drew upon their city correspondents. Between September 12 and December 26, the aggregate individual deposits were reduced from $\$ 622,685,563$ to $\$ 540,510,602$, and amounts due from reserve agents from $\$ 96,134,120$ to $\$ 73,032,046$. To relieve themselves of the pressure the New York associated banks authorized the issue of clearing-house loan certificates to any bank a member of the clearinghouse, upon its bills receivable and other good assets.* These certificates took the place of cash and cash certificates in the settlement of balances between the banks, and were virtually a loan of the credit of the association to such banks as required it. The measure was effective, there were no other failures, and within two months confidence as far as the banks were concerned was restored. The country, however, did not recover from the general prostration of business which ensued until after the resumption of specie payments in 1879. The public mind was so impressed with the terrible distress prevalent after September, 1873, that the causes of the catastrophe were investigated with great eagerness. A very common view was that the provision of law requiring or permitting National banks to keep a large proportion of their reserves in the financial centres collected a larger proportion of the currency there than could be used for legitimate business. Moreover, the city banks in competition among themselves bid for these deposits from the outside banks, by offering to pay interest upon them. In order to make a profit the banks were forced, in the absence of other opportunities, to loan to speculators, and thus the overtrading and speculation which are so apt to end in financial disaster were encouraged.

\section{Investigation and ACtion of New York Clearing-House.}

The New York Clearing-House Association was seized with a spasm of virtue, and a committee was appointed to report on reforms in the banking business. The committee reported in November, 1873, in perfect accordance with the tone of feeling that led to their appointment, against paying interest or procuring it to be paid on deposits, against certifying checks where there was not a corresponding credit to the drawer; in fact, against all of the well-known and profitable vices of the associated banks. The report was adopted, but when the patient began to recover, all the good resolutions were gradually forgotten, and the old practices were once more tolerated. In fact, it is very doubtful whether the panic was in any way the result of these practices.

* The issue of clearing-house loan certificates was first adopted by the associated banks of New York city in the year 1860 . 
Others thought that if the law had been such as to have required prompt redemption of National bank notes at the reserve centres, the balances would have been largely required for this purpose, and the supply of currency at the centres would also have been diminished by the return of the redeemed notes to the bank that issued them, and that the country banks when demand was made on them by their depositors would have been able to meet it by reissuing their own notes, and would not have been forced to call upon their city correspondents.

\section{Forced Redeirtions Proposed.}

In order to secure such a redemption it was generally admitted that it would be necessary to allow the redeeming banks a discount of from one-eighth to one quarter of one per cent. The Comptroller in his report for 1873 discusses the question of redemption and points out that the National bank note currency had always been equal to the legal-tender note; that if the banks were allowed to redeem them at a discount of one-quarter of one per cent., the public would pay for any supposed benefit to be derived from the measure, at the rate of $\$ 900,000$ per annum if the whole currency were redeemed once in each year, and more if redeemed oftener. He admitted that such a system would result in the return of notes to the country banks at seasons of the year when not needed to be paid out when demand increased, and would give what, at the time, was exceedingly desirable, elasticity to the currency.

\section{'Difficulty in Withdrawal of Circulation.}

It was found impossible to withdraw the $\$ 25,000,000$ of circulation authorized to be withdrawn by the Act of 1870 , from banks in States having more than their proportion, with any prospect of redistributing it to banks in sections entitled to it, unless the latter would pay a premium for getting it redeemed. The Comptroller recommended the issue of $\$ 25,000,000$ of additional circulation instead, and also the organization of new banks upon the minimum deposit of $\$ 10,000$ in bonds. The net profit on circulation to country banks was less than one per cent., and to banks in redemption cities less than one and a half per cent. There was little danger of excessive issue of circulation if free banking were authorized, and to secure proper redemption the amount should be increased until the notes were at a discount of oneeighth of one per cent. in the cities. Two banks were this year placed in the hands of Receivers for illegal certification of checks.

In this year a series of letters were published in New York, written by D. H. Loudon, advocating the establishment of what was to be known as the Exchequer Bank. It was to stand in the same relation to the Government of the United States as the Bank of England to that of England. Like the last-named bank, the Exchequer Bank was to issue circulation against Government debt and gold, was to negotiate 
and fund Government loans, and generally to carry on the financial operations of the Government.

\section{Act of June 20, 1874-Name of Law Changed.}

The talk about redemption and redistribution of the National bank currency which had been going on for years, at last, in 1874, incuced the passage by Congress of the act of June 20, 1874. This act changed the name of the National Currency Act to National Bank Act, and did away with reserve upon circulation, and in lieu thereof established a system of redemption of bank notes at the Treasury Department, the cost of which the banks, instead of the public, were to pay. All the charges for transportation to Washington and for assortment of the notes were at the expense of the associations, which were now also for the first time required to pay the expense of engraving the plates from which their notes were printed, thus changing to this extent the law of 1864, which provided that all expenses of preparing plates and printing notes should be paid from the proceeds of the tax on circulation. Most of the notes sent for redemption came from the cities which had, under the original law, been redemption cities, over one-third of the whole from New York city, indicating that the expense of transportation charged to the banks would have been considerably lighter if the Redemption Agency had been established at New York instead of at Washington. The great feature of the law of 1874 was contained in Section 4 and permitted the banks, whatever their capital, to withdraw their bonds down to a minimum of $\$ 50,000$, by depositing lawful money with the United States Treasurer to retire their circuilating notes. It was intended, most probably, to correct the defect in the act of 1870 , and to facilitate the withdrawal of the $\$ 25,000,000$ provided for in that act, also further insisted upon in the act of 1874; but its effect upon National banks and their circulation has been more far-reaching than was expected, and has given rise to more discussion than almost any other single provision of the National Banking Law, as will hereafter be seen.

\section{RETIREMENT aND REDistribution of CiRculation.}

It had immediate effect in inducing the voluntary retirement of a large amount of circulation by banks. There was at this time a premium of over twelve per cent. in currency upon the six per cent. United States bonds deposited by the banks as security for their circu: lation, and the banks in the localities liable to be called upon for the surrender of the $\$ 25,000,000$, found that by depositing lawful money and selling their bonds, they could realize this premium. An opinion was obtained from the Attorney-General as to the proper way to carry out the withdrawal of $\$ 25,000,000$ as provided by the law of 1874 , that the Comptroller should issue notes to banks entitled to them, and subsequently make requisition for an equal amount upon the banks required 
to surrender their circulation. The Attorney-General suggested that this might result in a temporary issue in excess of the limit of $\$ 354,000$,000 , but so much was coming in by voluntary surrender that there was little danger of overstepping that limit. This course being pursued, there was never any necessity of making requisition, inasmuch as the voluntary surrender supplied sufficient to make good all issues to new banks, and keep the aggregate circulation within the prescribed limit. Under the provisions of Section 4 of the act of 1874 , the outstanding circulation of banks in operation, gradually diminished from $\$ 340,26 \%$,649 in May, 1874, to $\$ 290,002,057$ in June, 1877. From that date it began gradually to increase, and with some fluctuations, attained a maximuin of $\$ 325,018,161$ in 1881 , since which time, it has gradually and persistently decreased. From 1874 to $18 \%$, the currency premium upon United States bonds gradually fell as the time of specie payments approached, and as the value of National bank and legal-tender notes approached a gold basis. As long as the bonds commanded no premium the circulation increased, but when after 1881 a premium on the bonds as measured by the gold standard appeared, the circulation again began to diminish.

\section{Bad Condition of Notes, EfFect of ACT of 1874.}

In his report for 1874 the Comptroller expressed the opinion that the redemption law of 1874 had for its chief object the purification rather than the redemption of the National bank currency. The notes were in notoriously bad condition. That a redemption in legal-tender notes, simply for the purpose of obtaining the latter, was not to be expected, because the legal-tender notes formed the largest part of the circulation and could be readily obtained by those who might need them for the special uses for which they were better than National bank notes. These uses were two, to make legal-tender payments, and to be-held as bank reserves. They were less in demand for the latter purpose since the law no longer required a reserve upon circulation. This was true, and but for the operation of Section 4 of the act of 1874 , the Redemption Agency at the Treasury would have had but little to do after the worn-out currency had been replaced by new notes. That section, however, caused an unforeseen demand for legal-tender notes for a new purpose, their deposit with the Treasurer in order to retire circulation, and withdraw and secure the premium upon bonds. Banks desiring to withdraw their bonds gathered up National bank notes and sent them in for redemption in legal-tender notes, in order to deposit the legal-tender notes to get the bonds. The banks whose notes were redeemed had to send legal-tender notes to replenish the five per cent. fund. There was thus a twofold demand for legal-tender notes arising from the desire of the banks to realize the premium on their bonds, which kept up an exceedingly active redemption of National bank currency, even after all the worn-out and mutilated notes had been replaced 
by new ones. The evil effect of this much-discussed section was partly due to a defect, inherent in any extensive banking system based upon Government securities. Whenever the securities rise in price, unless there are additional issues of circulation,* the profit on circulation becomes so small that the banks prefer to surrender it and take back their securities. Additional issues, as the price of bonds rises, are unsafe. It was more just to the banks to give them the opportunity of withdrawing their bonds and not compel them to sustain a circulation at a loss. The only further question is, could not the two objects of purifying the currency and permitting the banks to withdraw bonds when there was no profit on circulation, have been accomplished without the use that was made of the legal-tender note, which use gave it a prominency and a value with banks and bankers, and the Treasury, which have had much to do with fastening it on the country as a permanent currency. If, instead of requiring the redemption of National bank notes in legal-tender notes, any bank had been permitted to redeem its notes in those of any other National bank, the circulation could have been purified by a clearing system, carried on at the Redemption Ageney, and the reception of the notes of any National bank, except its own, from a bank, for the retirement of its own notes, would in the same way have permitted the withdrawal of bonds as the circulation became unprofitable. The balances only would have been paid in legal-tender notes, or after the resumption of specie payments, in gold.

\section{The Bank Reserves.}

The act of $18 \% 4$ abolished the redemption agencies, but it did not repeal the law permitting banks to keep a certain proportion of their reserves in the reserve cities. A provision requiring banks to keep all their reserves at home passed both the House and the Senate, but was struck out in conference committee. The change in the reserve law reduced the required reserve of legal-tender notes by over $\$ 20,000,000$, but notwithstanding the reduction of the requirement, the banks held reserves more than equal in amount to the former requirement. This indicated that the business of the country had been so reduced since the panic that the currency was at this time redundant. The deposit of legal tender notes in the Treasury to retire National bank circulation had a tendency to expand the circulation, inasmuch as the legaltender notes were not retained in the Treasury as a special deposit, but were placed to the credit of circulation account in the general fund, against which a sufficient reserve was kept. All above the usual reserve were paid out as required. The National bank notes came in for

* That is unless the Government allows a larger percentage of circulation on the bonds deposited when their market value exceeds par. The law permits ninety per cent. of par value of bonds and makes no provision for the market value going above par, although it further protects the notes if the bonds depreciate below ninety per vent. of their par value. 
redemption by degrees, and it was only by the slow process of their redemption that contraction could be brought about.

\section{Taxation of National Bank Shares.}

The rates of taxation imposed on the National banks under State and municipal authority were exceedingly onerous, and the more so as other institutions dealing in money, and in many ways coming in competition with the banks, were not taxed to a corresponding extent. The rates of this taxation imposed on the banks varied in different localities.

\section{CoMPtrolleR's REPORT FOR 1875.}

During the year 1875 one hundred and seven banks, two of them gold banks, were organized, and the total number in operation on November 1 of that year was 2,092. The act of June 20, 1874, was: taken advantage of by 241 banks to retire circulation and withdraw their bonds. In November, 1874, the banks had on deposit for circution $\$ 385,421,750$ of United States securities, of which $\$ 239,440,100$ bore interest at five per cent., and the remainder at six. The six per cent. bonds were at a premium and there was a profit in taking them out and replacing them by fives, issued under the act of 1870 , but nuany of the banks found it more profitable to retire their circulation permanently. The feature of the $\mathbf{1 8 \% 4}$ act for withdrawing circulation from banks in States having more than their legally allotted proportion never went into operation, inasmuch as the act for free banking and the resumption of specie payments passed on January 14, 1875, before there was any necessity of making requisitions on the banks. It repealed all laws limiting the aggregate amount of National bank circulation, and also the laws for the withdrawal and redistribution of circulation. It authorized the unlimited issue of circulation to banks organized or to be organized under the law, but required the retirement of legal-tender notes to the amount of eighty per cent. of the additional National bank notes issued. The operation of the act was to reduce the total volume of the paper currency of the country. In fact, from the date of the act to November 1,1875 , there was a reduction of $\$ 8,763,756$ in legaltender notes, and a reduction of $\$ 6,774,548$ in the volume of National bank notes outstanding, making a total of over $\$ 15,000,000$ of contraction in about nine and a half months. Nine National gold banks had been organized in California with a gold note circulation of $\$ 2,630,000$. The panic of 1873, the effects of which were seriously felt in California, by the suspension of the National Gold and Trust Co., of San Francisco, had a bad effect upon the circulation of these notes. Before that, these notes had an extensive circulation in the mining regions of the Pacific Coast, on account of the saving they effected by their superiority over coin for purposes of remittance. The prejudice existing in that section of the country was strengthened by the troubles of 1873 , and the notes were discredited by the State institutions and private bankers in which 
most of the banking capital of California was invested; so finding it difficult to keep their notes in circulation, some of the banks deposited gold in San Francisco and Washington for their redemption.

\section{Operations of Redemption Bureau.}

The Redemption Agency established in the United States Treasury, under the act of June 20, 1874, received up to November 1, 1875, National bank notes amounting to $\$ 219,336,445$ of which forty-two per cent. were sent in from New York eity. Of those sent in $\$ 19,757,958$ were returned to the banks as still fit for circulation, and the remainder, which included notes of insolvent and liquidating banks, and notes of banks retiring under the act of 1874 , were sent to the Comptroller for destruction. The notes so destroyed of banks in operation were replaced by new notes, sent to the banks to the extent of $\$ 141,962,100$. The banks objected to the expense of the redemptions being assessed upon them, holding that this should be borne by the holder of the note, but to this it was replied that in such case the notes would not be sent in. The Treasury transmitted by express legal-tender notes in payment of the unassorted bank notes sent in for redemption. Many of the banks which sent in the notes preferred to have the proceeds placed to their credit with their correspondents in the redemption cities, and the Comptroller in his report for 1875 suggested that if such transfers could be made by the Treasury at the option of the transmitting bank, a large amount of expense could be saved.

\section{Denominations and Devices of National Bank Notes.}

The first issue of the National bank notes (national currency) consisted of nine denominations, to wit- $\$ 1$ 's, $\$ 2$ 's, $\$ 5$ 's, $\$ 10$ 's, $\$ 20$ 's, $\$ 50$ 's, $\$ 100$ 's, $\$ 500$ 's and $\$ 1,000$ 's. A similar story or legend is engraved on the face of these notes, with vignettes, lathe-work counters, denomination in figures in corners, facsimile signatures of Register and Treasurer of United States, name and location of bank of issue, etc., the faces printed in black. The backs of this issue consisted of a vignette printed in black in the centre, surrounded by a green printing which embraced the denomination of note engraved in lathe-work and other miscellaneous lettering, also two small oval vignettes, one on each end, being the coat of arms of the United States and of the State or Territory in which the bank is located.

$\$ 1$ faces-On face of note, vignette called "Concordia," two female figures clasping hands and standing in front of an altar, over which is the title of the bank. $\$ 1$ backs - On back of note in centre, a vignette, "Landing of the Pilgrims."

$\$ 2$ faces-On left side of note, vignette of a female figure holding a flag, called "Stars and Stripes;" at the right of this vignette is a large figure " 2 " (lathe-work) under which is engraved title of bank. \$2 backs-On back of note in the centre is a vignette representing several 
figures, one of which is Sir Walter Raleigh, called "Introducing Tobacco from America."

\$5 faces-On face of notes two vignettes, on left, "Discovery of Land by Columbus," on right, "Introduction of the Old World to the New." Title of bank in centre. $\$ 5$ backs-On back of note a large vignette, "Landing of Columbus."

$\$ 10$ faces-On face of note two vignettes, left side, "Franklin and Electricity;" on the right, "America Seizing the Lightning." \$10 backs-On back of note a large vignette, "De Soto Discovering the Mississippi."

$\$ 20$ faces-On face of note two vignettes; on left, "Battle of Lexington;" on right, female figure "Loyalty." \$20 backs-In centre of note large vignette, "Baptism of Pocahontas."

$\$ 50$ faces-Two vignettes on face of note; on left, "Washington Crossing the Delaware;" on right, soldier kneeling in prayer ("Victory.") \$50 backs-Large vignette in centre, "Embarkation of the Pilgrims."

$\$ 100$ faces-Two vignettes; on left, naval battle, "Com. Perry's Victory;" on right, female figure with faces, "The Union." $\$ 100$ backsIn centre a large vignette, "The Signing of the Declaration of Independence."

$\$ 500$ faces-Two vignettes on face; on left, "Civilization;" on right, marine scene, "Arrival of the Sirius in New York Harbor, 1838." $\$ 500$ backs-Large vignette in centre of note, "Surrender of Gen. Burgoyne."

$\$ 1,000$ faces-Two vignettes; on left, "Scott entering the City of Mexico;" on right, "U. S. Capitol at Washington." $\$ 1,000$ backsLarge vignette in centre representing "Washington Resigning his Commission."

\section{SERIES OF 1875.}

In the year 1875 the national currency plates of all denominations, which had hitherto been engraved and printed in the city of New York, were brought to Washington, and by order of the Comptroller of the Currency, deposited in the vaults of the Bureau of Engraving and Printing. These plates after undergoing some slight alterations by erasing the engraved signatures of the prior Register and Treasurer of the United States and inserting those of a later period (also adding the imprint of the Bureau of Engraving and Printing) were issued as the "series of 1875."

\section{SERIES OF 1882.}

In the year 1882 quite a change was made in the national currency notes by altering the issue to " series of $1882 . "$

A new design was engraved for the face of \$5's only, with portrait of James A. Garfield; also the new feature of inserting in the border of each note (on face) in six distinct parts the charter number of each bank. This feature was also adopted for the faces of each denomina- 
tion of this series, which included the $\$ 10$ 's, $\$ 20$ 's, $\$ 50$ 's and $\$ 100$ 's; all other denominations of former issues were discontinued. ${ }^{*}$ On backs the black vignettes of former issues were abandoned, and, as a substitute, a geometrical pattern was introduced, and the borders embracing denominations, vignettes, coat-of-arms, etc., retained, and all printed in a brown color, also large charter number printed in green tablets. over the brown printing in the centre.

Except the new design for the face of the $\$ 5$ note the old designs for the faces were retained.

Under this last series the California banks that had special plates, which designated that the notes were payable in gold, had their plates altered to conform to the regular issue. In this early issue of national currency was included a gold-note issue for California banks in denominations of $\$ 5, \$ 10, \$ 20, \$ 50, \$ 100, \$ 500, \$ 1,000$. The designs of the faces were the same as the common issue, with the exception of a slight change of story or legend, as follows: "Redeemable in gold coin, etc."

On the backs the black printing of the large vignette was omitted and a design substituted in its place, printed in salmon color, representing the gold coins of the United States bunched together, inclosed in the brown border.

Out of a total issue of $\$ 668,988,000$ of all denominations, $\$ 235,295,920$ were five dollar notes, $\$ 174,105,070$ tens, and $\$ 105,921,280$ twenties. The $\$ 100$ denomination was next in amount, and then the fifty dollar notes. Only about $\$ 30,000,000$ of ones and twos were issued.

\section{State Discrimination in Taxing National Bank Shares.}

Complaints had now become frequent of the discrimination exercised by State authority in taxing the National banks. The shares of the latter were taxed at their full market value, while those of other moneyed corporations were assessed at less than half their value. A National bank in one of the Eastern cities refused to pay the taxes assessed upon it, on the ground that the shares of a neighboring State bank, although worth several times as much as its own, were assessed at no greater value. The State court before which the case was brought decided that this was no cause of complaint. The banks in New York city appointed a committee to confer with the Tax Commissioners of that State, to endeavor to effect some equitable arrangement as to the taxation of banks.

\section{Two Cent Stamp Check Tax.}

A great source of annoyance to the banking community was the law that a two-cent stamp should be affixed to every check. The banks, National and State, were, it was claimed, subject to the inspection of

\footnotetext{
$* \$ 1$ 's and $\$ 2$ 's were discontinued in 1879 . The act of June 3,1864 , provided that after the resumption of specie payments no National bank notes of a denomination less than five dollars should be issued.
} 
the revenue collectors, in order to see by examination of cancelled checks whether the law was complied with. Objection was made by the National banks to this form of inspection, and the matter haying been brought to the attention of the Secretary of the Treasury by the Comptroller, the latter officer decided that the National banks were subject only to the inspection of the National bank examiners. An inspection showed that in only five cases was there any evidence of intent to evade the check tax. On account of the annoyance, both to the banks and to the office in enforcing this tax, which was greater than the trouble incurred in enforcing all other restrictions of the banking law combined, the Comptroller recommended the repeal of the law requiring stamps on checks.

In the month of October, 1875, the total amount of specie held by all the National banks of the country was $\$ 8,050,329$, which had diminished from $\$ 22,436,761$ about the date of the passage of the Resumption Act on January 14, 1875.

\section{Forfeiture of Interest Where Usury is Charged.}

The subject of usury, charged by the National banks, received consideration by the United States Supreme Court in the case of the Farmers and Mechanics' Bank of Buffalo vs. Dearing, and the decision was that where a National bank makes a loan at a usurious rate of interest, it can recover the principal only, the interest being forfeited. Where the usurious rate of interest has been actually paid, double the amount so paid may be recovered in an action brought within two years, and that National banks were not subject to State usury laws.

Among the 219 millions of dollars redeemed at the Treasury, only 520 counterfeits of all denominations were discovered. Of these 205 were twos, 138 fives, 120 tens, fifty-two fifties, and five one hundreds, amounting in all to $\$ 5,400$. This was an unexpectedly small proportion, and much less than the loss to the public from counterfeits on the Bank of England. The five dollar counterfeit was the most dangerous one, and the plate from which it was printed was finally captured by the Treasury detectives.

\section{Printing of National Bank Notes.}

Previous to the act of March 3, 1875, the notes of National banks were printed by the bank note companies, but that act required the notes to be executed by not less than three plate printings, the last of which was to be done in the Treasury Department. This necessitated the removal of a large number of plates and dies from the custody of the bank note companies to that of the Secretary of the Treasury. The plates, etc., which had been used for printing the notes of banks which afterwards closed, either by failure or liquidation, were, from time to time, destroyed under the supervision of the Secretary of the Treasury and the Comptroller. Originally the method of destroying mutilated 
notes, which had been redeemed, was by fire, but by the act of June 23,1874 , this method was discontinued and that of maceration, or grinding to a pulp with water, substituted.

\section{Evasions of Ten Per Cent. Tax.}

The law imposing a ten per cent. tax upon all State bank circulation was amended by the act of February 8,1875 so as to prevent any evasion, and was made to apply to any person, firm, association, corporation, State bank or State banking association which should pay out the notes of any person, firm, association (other than a National banking association) corporation, State bank or State banking association, or of any town, city or municipal corporation. The payment of bank examiners was fixed by the act of February 19, 1875.

In 1873 Congress consolidated all the laws of the United States in force on December 1, 1873, in the Revised Statutes of the United States, and the National banking laws in force at that date were of course included in that revision. Afterwards all laws passed up to 1878 were included in a further revision of the statutes made by Hon. Geo. T. Boutwell, but his work, though included in the latest edition of the Revised Statutes, never received the approval of Congress.

\section{Recommendations of The CoMPtRolleR's RePORT OF 1875.}

In the Comptroller's report for 1875 a number of amendments to the National Banking Law are recommended, some of which were embodied in a bill introduced in Congress which became a law June 30, 1876. This law authorized the appointment of Receivers by the Comptroller to take charge of the affairs of National banks which became insolvent, either before or after voluntary liquidation. The creditors of a liquidating bank could under it proceed to enforce the liability of stockholders, if necessary, to pay the debts of the association. The law further provided for turning over the assets of an insolvent National bank, after its debts had been paid, to the stockholders. Officers of the United States and of National banks were required to stamp as worthless or counterfeit any fraudulent notes presented at their place of business. All Savings banks in the District of Columbia were placed under the supervision of the Comptroller of the Currency.

At the end of the year 1876, 2,087 banks were in operation. Thirtysix had been organized during the year, and nine had failed. Four hundred and thirty-three banks had taken advantage of the act of June 20, 1874, to withdraw their circulation. There was no further increase in the number of gold banks. The remarkable feature of this, as well as previous years since the panic, was the large amounts of currency held by the banks in the principal cities, indicating great stagnation of business. The reserves held, both by city and country banks, averaged over thirty-three per cent. 


\section{Distribution of the Shares of National Banks.}

The distribution of National bank stock attracted the attention of Congress at the session of $1875-76$, and the House of Representatives passed a resolution requiring the Comptroller of the Currency to furnish a list of stockholders, their residences and the amount of stock held by each. The information furnished in accordance with this resolution showed that the total number of shares was $\$ 6,505,930$, held by 208,486 shareholders; that the average amount held by each was $\$ 3,100$. The law required new organizations to make their shares $\$ 100$ each, but converted State banks retained their shares at the previously existing denomination. Some of the shares were therefore for $\$ 80, \$ 50, \$ 25$, and in some cases as low as ten dollars.

During the year 1877 the number of banks in the system did not increase. Twenty-nine new banks were organizeù, but twenty-six went into liquidation, and ten failed.

\section{Approach of Time for Resuming Specie Payments.}

Nearly three years had elapsed since the passage of the act for the resumption of specie payments. One more year, and the day set for that resumption would arrive. In his report for 1877 the Comptroller refers to the previous periods in the history of the country when specie payments had been suspended and resumed by the banks. During the period substantially beginning with suspension in 1837 , and ending with resumption in 1842, the State banks had held specie amounting on an average, to 31.7 per cent. of their circulation. and eighteen per cent. of their circulation and deposits. The returns for the period from 1850 to 1858 , including the suspension of 1857 , indicated that the State banks, during the eight years, held specie averaging 32.3 of circulation and 16.1 per cent. of circulation and deposits. The returns of the National banks from 1870 to 1877 showed that they held specie amounting to forty-tive per cent. of their circulation, and 16.1 per cent. of their circulation and deposits. The results of a similar comparison, instituted for the same periods, between the State and National banks in geographical divisions of the country, showed results equally favorable to the state of preparation for specie payments, in which the National banks were in 1877 . On November 1, 1877, the legal-tender note had approximated to par, and was then worth 97.3 cents in gold, a gain of about ten per cent. after the passage of the Resumption Act.

\section{Fudctuations of Gold Value of Legal-Tender Note.}

The following.tables show the value in gold of the legal-tender paper dollar, in July of each year, from 1863 to 1877 , and on November 1, 1877 , the value being first estimated in fractions of a gold dollar, and next in grains of gold. 
Value in Fractions of Gold Dollar.

\begin{tabular}{c|c|c|c|c|c|c|c|c|c|c|c|c|c|c|c}
\hline 1863 & 1861 & 1865 & 1866 & 1867 & 1868 & 1869 & 1870 & 1871 & 1872 & 1873 & 1874 & 1875 & 1876 & 1877 & 1877 \\
\hline Cts. & Cts. & Cts. & Cts. & Cts. & Cts. & Cts. & Cts. & Cts. & Cts. & Cts. & Cts. & Cts. & Cts. & Cts. & Cts. \\
$\mathbf{7 6 . 6}$ & $\mathbf{3 8 . 7}$ & $\mathbf{7 0 . 4}$ & $\mathbf{6 6 . 0}$ & $\mathbf{7 1 . 7}$ & $\mathbf{7 0 . 1}$ & $\mathbf{7 3 . 5}$ & $\mathbf{8 5 . 6}$ & $\mathbf{8 9 . 0}$ & $\mathbf{8 7 . 5}$ & $\mathbf{8 6 . 4}$ & $\mathbf{9 1 . 0}$ & $\mathbf{8 7 . 2}$ & $\mathbf{8 9 . 2}$ & $\mathbf{9 4 . 5}$ & $\mathbf{9 7 . 3}$ \\
\hline
\end{tabular}

Value in Gold Grains.

\begin{tabular}{|c|c|c|c|c|c|c|c|c|c|c|c|c|c|c|c|}
\hline 1863 & 1864 & 1865 & 1866 & 1867 & 1868 & 1869 & 1870 & 1871 & 1872 & 1873 & $187 / 4$ & 1875 & 1876 & 1877 & 1877 \\
\hline Grs. & Grs. & Grs. & Grs. & Grs. & Grs. & Grs. & Grs. & Grs. & Grs. & Grs. & Grs. & Grs. & Grs. & Grs. & Grs. \\
\hline 19.8 & 9.9 & 18.1 & 17.0 & 18.4 & 18.0 & 18.9 & 22.0 & 22.9 & 22.5 & 22.2 & 23.4 & 22.4 & 23.0 & 24.3 & 25.1 \\
\hline
\end{tabular}

These tables by no means fully represent the fluctuations in the legal standard of value during sixteen years. The variations cannot be counted by the number of years, nor even by the number of days. They were numerous on each day during the suspension of specie payments, and can only be numbered by tens of thousands. The importers, and other wholesale dealers found, during suspension, that they could realize more profit from the purchase and sale of gold than of the commodities belonging to their legitimate trade. The tendency of such fluctuations is either to bankrupt or to demoralize all persons engaged in ordinary traffic; for, under such circumstances, business of every kind becomes simply a game of chance, based upon the ever-changing value or weight of a false but legalized standard, and persons in every portion of the country abandon their legitimate business and embark in speculation, bringing failure and disgrace upon themselves and losses upon those confiding in them.

Progress of the System to November 1, 1878.

The total number of National banks organized from the establishment of the National banking system on February 25, 1863, to November 1, 1878, was 2,400. Two hundred and seventy-three had gone into voluntary liquidation, and seventy-four had become insolvent, leaving 2,053 doing business at the close of 1878. Nine were National gold banks in California redeeming their notes in gold at their counters and in San Francisco.

\section{Deposit of Legal-Tender Notes to Retire Circulation.}

Before the passage of the act of June 20, 1874, no National bank could reduce its circulation and take up its bonds except by returning a proportionate amount of its own circulating notes, and these were usually difficult to obtain; and prior to the act of January 14, 1875, the total amount of circulation authorized to be issued was limited to 
$\$ 354,000,000$. These acts provided both for a reduction of circulation and withdrawal of bonds at the pleasure of the banks upon a deposit by them of lawful money in sums of not less than $\$ 9,000$, and for an issue of bank notes to any association organized under the National Banking Law.

As the law stood after July 12, 1870, any number of persons not less than five, in any part of the country, night organize a bank with fifty thousand dollars or more capital, and upon the deposit of bonds receive circulation equal to ninety per cent. of the amount of the paid-in capital; but no association, whatever its capital, might receive more than $\$ 500,000$ in circulation. Prior to 1870 , a bank having capital between $\$ 500,000$ and $\$ 1,000,000$ could receive eighty per cent. thereon; between $\$ 1,000,000$ and $\$ 3,000,000$, seventy-five per cent.; if over $\$ 3,000,000$, sixty per cent. These last proportions of circulation were fixed by the act of March 3, 1865. The original National Currency Act of 1863, and the amended act of 1864 , permitted the issue of circulation, if properly secured by bonds, equal to the paid-in capital. The act of July 12 , 1882 , limited the circulation to ninety per cent. of the paid-in capital.

After the enactment of the law of June 20, 1874, permitting the redistribution of fifty-five millions of currency, by withdrawing it from banks located in sections of the United States having more than their proportion and issuing it to banks new and old in those parts of the country having less than their proportion, the banks as a whole voluntarily surrendered $\$ 66,237,283$ of their notes. This indicated that the circulation was not profitable to many of the banks and that they had gladly availed themselves of the privilege granted by the act of 1874 to deposit legal-tender notes to retire their circulation, and withdraw their bonds. They had been prevented from doing this before, by the difficulty of gathering back their own notes from the general mass outstanding.

\section{Holdings of National Bank Shares.}

In 1876 an investigation had been made into the character and condition of the stockholders of the National banks. This was directed by Congress, on account of the charges made that the stockholders were large eapitalists. and that the system was an odious monopoly. The result showed that there were in all seven hundred and sixty-seven persons who each held $\$ 50,000$ or more in National bank stock; that more than one-half of the whole number of shareholders held each less than $\$ 1,000$ in stock, and that taking the whole number of shareholders the average amount held.by each one was but $\$ 3,100$. Of shareholders owning not more than $\$ 1,000$ each, there were 32,235 in Massachusetts alone, 12,784 in New York, 14,621 in Pennsylvania, 1,441 in Kentucky, 2,388 in Ohio, 1,608 in Illinois, 832 in Georgia and 617 in Virginia. It was also shown that citizens of the Western and Southern States held much of the stock in Eastern banks. The stock proved to be very widely 
distributed among people of moderate means. Among the stockholders all political parties were represented, which contradicted the assertions sometimes made of partisan control.

\section{Growth of State Banks.}

In his report for 1878 the Comptroller referred to the fact of the growth in the number of State and private banks, alongside and in competition with the banks of the National system. The amount of interest accruing to the latter upon bonds to secure circulation, less the tax paid upon it, was $\$ 14,544,692$, while the profit derived from the entire issue of notes was less than two and one-half per cent. on their capital.

\section{Requirements and Restrictions of the National Banking ACt.}

The reason for the increase in the number of State banks, regardless of the profit on circulation, was found in the fact that the laws governing the National banks contained numerous and burdensome restrictions, and imposed many and severe penalties for their violation. On the one hand they authorize the issue of circulating notes, but on the other they require that the business of banking shall be conducted under a uniform system, which insures the greatest possible degree of safety to the depositor and the bill holder and prompt and certain convertibility to the circulating notes.

The most prominent requirement of the law was that the capital stock of all National banks should be fully paid in. The organization of banks without capital was one of the great abuses of previous banking systems and many disastrous failures were due to this cause. Special care was exercised in the framing of the National Banking Law to guard against the organization of banks without bona fide capital. Fifty per cent. of the capital of a National bank must be paid in before it can be authorized to commence business, and the remainder must be paid in installments of not less than one-fifth monthly, each installment being certified to when paid by the President and Cashier under oath.

It was frequently asserted by the opponents of the National banks, that a bank may use its circulating notes to organize other banks without real capital. The law carefully guarded against this abuse from the first. The officers and directors are required to certify to the Comptroller the amount of actual money paid into the bank as capital, while subsequent installments of stock must be similarly certified. The law distinctly forbids the pledge or hypothecation directly or indirectly of circulating notes for the purpose of securing money to be paid in on stock, and their use in any way to increase capital. The rigid examinations the Comptroller is authorized to and does cause to be made alınost precludes the possibility of any fraud in this direction remaining long undiscovered. No one except those who accept without proof the theory that dishonest dealing is the rule and not the exception, and somehow is bound to escape detection, can doubt the bona fide payment 
of the capital of National banking associations before the circulation is issued to them. If any case of fraudulent use of circulation is proved those guilty thereof become liable to the severe penalties of the law. Impaired capital is at once made good by pro rata assessment on the shareholders. The interest on the bonds of an association delinquent in this respect is withheld by the Treasurer, and if the delinquency is continued a Receiver may be appointed. The status of the National banking system compared with those of banks in foreign countries shows a proportion of paid-in capital to liabilities larger than in those countries.

\section{Redemption of Notes.}

Next to the precautions to insure the payment of the capital stock, the National Banking Law provides for the convertibility of the note, both for its immediate and ultimate redemption. Its redemption at par on presentation, either at the bank or at the United States Treasury, is secured by special requirements, and the penaity of being placed in the hands of a Receiver for failure. The law of 1863 and the completer act of 1864, both provided for the redemption of the notes at the bank's counter or by a redemption agent to be selected with the approval of the Comptroller in one of a certain number of cities named in the law. These acts also required a reserve in lawful money to be kept on circulating notes. The act of June 20, 1874, relieved the banks of keeping any reserves on circulation and of redeeming their notes at any other place than their own counters and the Treasury redemption agency.

\section{Profits, Dividends and Surplus.}

Another important part of the National Banking Law was that throwing restrictions around the profits and dividends. No National association is permitted to withdraw any portion of its capital stock in dividends. No dividend is allowed to be declared to an amount greater than the net profits remaining after deducting losses and bad debts. Semi-annual dividends are permitted from the net profits, but there is a further requirement that one-tenth of the net profits of each half-year shall, before the declaration of a dividend, be carried to surplus, until this fund shall equal one-fifth of the capital stock. Three uses for profits are thus pointed out: first, to keep the capital unimpaired by meeting losses and bad debts; second, to build up a surplus fund, and third to declare dividends. The surplus accumulated by the banks in October, 1878 , was $\$ 117,000,000$.

\section{Making and Publishing Reports of Condition.}

The requirement that reports of their condition be made from time to time to the Comptroller and published in newspapers accessible to their stockholders and depositors, is another important safeguard thrown around the National banking system. The acts of 1863 and 
1864 required reports of condition quarterly verified by the oath of the President and Cashier simply, in such form as the Comptroller might direct; on the first Mondays of January, April, July and October. These reports were to be published in each case in a newspaper in the place where the bank was located. These first laws also required reports of each bank, on the first Tuesday of each month, under oath of the President or Cashier, giving loans, specie and other lawful money, deposits and circulation. No reports of dividends were specifically required by these acts. The law as to reports was amended by the act of March 3, 1869. The monthly reports were dropped, and the reports instead of being quarterly were to be made for any past date called for by the Comptroller. They were also to be published, in the same form as made to the Comptroller, and in addition to being sworn to by the President or Cashier, they required the attestation of at least three directors. Semi-annual reports of dividends and earnings were also required by the law of 1869 , and special reports of condition from any association when necessary in the judgment of the Comptroller. The reports of condition to the Comptroller and their publication keep each National bank under the scrutiny of an expert official, and also under that of their stockholders, depositors and local rivals.

\section{Examinations of National Banks.}

A further and perhaps equally important safeguard consists in reports of examinations. Examinations are provided for when the capital stock is paid in and the bank first commences business, and these examinations are continued periodically as long as the bank does business; to ascertain by personal inspection that the banks are managed honestly and wisely and according to law. Examinations may be made whenever the Comptroller with the approbation of the Secretary of the Treasury may deem proper. The original law authorized the appointment of examiners who should make these examinations. They have power to put the officers and agents under oath and are required to make full reports. Their functions are in lieu of all other visitorial powers, as far as the banks are concerned, except those vested in the courts.

\section{Compensation of Examiners.}

The pay of these examiners was at first five dollars a day for every day engaged and two dollars a mile for every twenty-five miles travelled, to be paid by the association examined. The law appears to contemplate the appointment of an examiner for each examination, but in practice the same man, having acquired knowledge and skill, was appointed to examine a number of banks, so that the combined compensation would afford him an adequate salary. For convenience, the banks were partitioned into groups, each group being within a certain district. An examiner was appointed for each district, changes being 
made from time to time as was deemed for the good of the service. A corps of trained men was gradually formed available for the Comptroller to use effectually in carrying out the law. The compensation, although still paid by the bank, was changed by the act of February 19, 1875, from five dollars a day and mileage to a regular fee for each bank, according to the amount of capital. The change was of questionable wisdom. It is highly probable that the five dollars a day method insured more thorough examinations. These examinations were unpopular at first, but the results have been most excellent. While they do not absolutely prevent bank disasters and frauds, together with the reports of condition they have reduced the percentage of failure to a very small figure compared with the percentage of failures shown under systems of banking not provided with these checks.

\section{Penalties for Violation of Law.}

The penalties of the National Bank Act are of two kinds. The first is the appointment of a Receiver to wind up the bank's affairs in case of mismanagement and violation of law by its officers and directors not amounting to misdemeanor or felony. The second penalties to which officers and directors are subject are for cases when they personally and presumptuously disregard the law or misappropriate the bank's funds. A Receiver may be appointed for the failure to restore diminished capital, for failure to make good reserve, for failure to redeem notes, for failure to sell shares of own stock taken for debt, for failure to pay up capital or restore it when impaired, for certifying checks unlawfully, for general violation of law, for refusal to pay judgments and for insolvency. When directors are guilty of violations of law for which no special penalty is imposed, a suit may be brought by the Comptroller for forfeiture of the franchise of the bank. If the franchise is forfeited and the officers of the bank by their sudden liquidation cause loss to depositors or stockholders, the directors may be held personally liable for such losses, if they were cognizant of, and acquiescent in the violations of law. Penalties of fine and imprisonment, of from one to fifteen years, are imposed upon officers of the Treasury and banks and bank directors, for countersigning notes unlawfully, for loaning money on United States and National bank notes, for misapplying or stealing or embezzling funds or drawing papers unlawfully, or making false entries or for certifying checks when a depositor has no account. There are also minor penalties for refusing to pay duties to the Government, and for disobeying the Comptroller's call for reports or for an assessment to make good impaired capital stock. 


\section{IX}

CONTEST BETWEEN LEGAL-TENDER NOTE AND NATIONAL BANK NOTE, 1862-1878.

Two measures for furnishing currency for war - Legal-tender act temporary and the National bank currency a permanent measure - Senator Sherman's opinionOpinion of Mr. Spaulding - Obstacles in the way of the banking system - Lack of organization among the banks in 1862 - Bank loans to the Government in 1862 - National system suggested-Could the war have been carried on with bank notes - Legal-tender funding repealed - Comparison of legal tenders and bonds in 1863-Secretary McCulloch's contraction policy - Errors in limiting bank issues - Act of July 12, 1870 - Effect of premiums on bonds - Unfavorable attitude of Congress toward banks - Popular opposition to banks - Fiat money and interchangeable bonds - Greenback convention of 1876 - Bills in House and Senate in 1878 - Other measures -- Interview of Comptroller. of Currency with Banking and Currency Committee - Pamphlets in 1878-Attacks on Resumption Act on the stump - Opinions of financiers and others before Banking and Currency Committee - Operation of Act of July, 1870, for redistribution of bank circulation - Redemption of National bank notes - Act of June 20, 1874, and its operation - Effect of Treasury influence on legal-tender notes - Uniformity of value prevents redemption of bank notes in legal-tender notes - Voluntary retirement of bank circulation - Act of January 14, 1875 - Operation of act of 1875 - Effect of bond premiums.

\section{National Bank Notes and Legal-Tender Notes.}

It will be interesting to pause here in the account of the progress of the National banking system and consider the relation between the legal-tender note and the National bank note from 1862 to the year 1878 , previous to the resumption of specie payments. This is a most important part of the history of banking, as it is the rise and development of the use of paper money issued directly by the Treasury of the United States that has deprived the banks almost completely of the note-issuing function, once their most important power. In a succeeding chapter it will be shown how, in 1862 , there were two measures before Congress, one for the issue of legal-tender notes and the other for a national currency to be issued through the banks. The former was adopted as a temporary expedient because the latter could not be placed under way in time to meet the exigencies of the Treasury, and the National banking system was designed to provide a currency to take the place of the legal-tender notes when the supposed emergency that had ealled the latter into being had passed away. But the National bank 
note never was substituted for the legal-tender note, and great as has been the benefit conferred on the country by National banks, this benefit is not that which was intended. The legal-tender note has risen up and strangled the National bank note at every turn, has prevented the development of the system, and has, by encouraging the issue of other forms of Government paper, left no field for an elastic bank currency. The triumph of the legal-tender note might, however, have been expected. It is only another instance of the Gresham law, the worse currency driving out the better. The recuperative power of the country after the war, the energy and eredit of the Government, have given strength to a bad system. Secretary Chase in 1862 said:

"Little room can remain for doubt that the evils certain to arise from such a scheme of currency (legal-tender notes) if adopted as a permanent system, greatly overbalance the temporary, though not inconsiderable, advantages offered by it."

Senator Sherman in reporting the legal-tender bill from the Finance Conmittee said :

\section{Sherman on the Legal-Tender Bill.}

"We are about to choose between a permanent system, designed to establish a uniform national currency based upon the public credit, limited in amount and guarded by all the restraints which the experience of men has proved necessary, and a system of paper money unlimited as to amount except for the growing necessities of the war. In the consideration we surely should sacrifice all local interests, all pride of opinion; and while acting promptly under the pressure of events, weshould bring to our aid all the wisdom of united counsels, and all the light which the experience of former generations of men can give us. * * * Another practical objection to these United States notes is there is no mode of redemption. They are safe, they are of uniform value; but there is no mode pointed out by which they are to be redeemed. No one is bound to redeem them. They are receivable, but not convertible. They are debts of the United States, but they cannot be presented anywhere for redemption. No man can present them except for the purpose of funding them into bonds of the United States. They are not convertible; they lack that essential element of any currency. * * * The issue of Government notes can only be a temporary measure and is only intended as a temporary measure to provide for a national exigency."

\section{Mr. Spaulding on the Legal-Tender Measure.}

The view taken through the whole discussion of the legal-tender act by Mr. Sherman, Mr. Spaulding and others, was that it was a temporary measure, a war measure, a measure of necessity. Mr. Spaulding, the father of the legal-tender act, not only regarded the legaltender measure as a measure of necessity for the war, but he looked upon the National banking system as the "commencement of a permanent system for providing a National currency that would, if wisely administered, be of great benefit to the people, and a reliable support to the Government in the future." In a letter written to the Comptroller of the Currency in 1873 he said: 
"All the advocates of the legal-tender act while it was pending in Congress, based their arguments for the necessity of its passage as a temporary relief to the Treasury during the war and not as the permanent policy of the Government; on the contrary, the National Banking Law was advocated as a permanent system of banking and currency for the whole country."

\section{National Bank Notes to be a Permanent Currencr.}

In fact, from the history of the legal-tender act and that of the $\mathrm{Na}$ tional Currency Act, it seems to be undeniable that while there was no positive engagement or promise, there was a tacit understanding that the immediate emergency having been relieved by the issue of United States legal-tender notes, the permanent currency of the nation was to be furnished by the National banks. If the National banking system could have been inaugurated and put upon its feet without the intervention of the legal-tender note, there is great probability that it could easily have furnished all the currency needed for carrying on the war. Congress was evidently of the opinion that the banking system would take time to develop, and Chase, with great reluctance, consented to the substitution of the legal-tender act as the chief financial resource.

\section{Obstacles to National Bank Currency.}

The obstacle in the way of making a uniform bank currency a resource was the existing banks doing business under the laws of the several States. In 1862 there were in operation in the United States 1,492 banks, having a circulation of $\$ 183,792,079$, and holding specie and specie funds amounting to $\$ 130,000,000$. The circulation of specie outside of the banks may, perhaps, be placed at $\$ 100,000,000$ additional. The total available circulation of bank bills and specie being thus in the neighborhood of four hundred millions of dollars, one-third, perhaps, being in the States of the Confederacy.

\section{LACK of ORganization among Banks IN 1861.}

There was, however, no organization among the banks of the country by which their united resources could be utilized for a great necessity. The banks of New York city were associated in the clearinghouse and it was possible to obtain unity of action among the banks of Boston and Philadelphia, but none of the bank officers of that day had been accustomed to the large transactions rendered necessary by the war. They did not realize the power and resources of the country behind them. Moreover, the Independent Treasury system of hoarding Government funds in the Government vaults was inimical to the best use of the banks.

Congress, by act of July, 1861, authorized a loan of $\$ 250,000,000$, either in twenty-year Treasury notes with interest not exceeding seven per cent., or in seven-thirty, three-year Treasury notes; and by act of August 5, 1861, authorized six per cent. twenty-year bonds in which to fund the Treasury notes. The expression, seven-thirty, applied to the 
Treasury notes, referred to the annual interest of 7.3 per cent. per annum. The twenty-year Treasury note alternative, in the act of July, 1861, was not availed of, but the seven-thirty notes were largely issued.

\section{LOANS BY THE BANKS IN 1861.}

To place the seven-thirty note loan the banks were appealed to, that is, the associated banks of New York and those of Philadelphia and Boston. These banks on August 15, 1861, made a contract with the Secretary to take $\$ 150,000,000$ of securities in three separate installments, of which the New York banks subscribed for over $\$ 102,000,000$.

The banks really took but little risk, as the matter now appears. They opened subscriptions for the loan, and paid ten per cent. of the subscription in cash to the Assistant Treasurers of the United States, placing the remainder to the credit of the Government on the books of the banks. But they were full of apprehension. The credit of the Government was very low, and if it had not been for this action of the banks it is doubtful if public confidence could have been secured. Fifty millions of dollars were advanced by the banks on August 15, and fifty millions more on October 1 . These loans were secured by seventhirty notes. On November 16, 1861, a third advance of fifty millions was made by the banks in return for an equal amount of six per cent. bonds as security. These loans to the Government exhausted the resources of the banks. If they had been permitted to hold and disburse the Government money, the burden upon them would, no doubt, have been lighter. The Secretary of the Treasury would not, however, permit this. The money was first drawn from the banks and placed in the Treasury and then drawn upon again for the expenses of the Government. Large sums in specie were sent to armies to pay the troops and abroad to buy supplies. The banking machinery was inadequate to the re-collecting of the scattered funds, and specie payments were suspended in December, 1861.

\section{First Suggestion of National Banking System.}

The incapacity of the State banks to act together no doubt first suggested to the Secretary his plan for a National system. If no legaltender notes had been authorized the question arises, How could the banking system have obtained its start, with what kind of money would it have purchased the bonds on which to obtain the required circulation.

\section{Possibility of Carring on War with Bank Notes.}

The experience with the legal-tender notes showed that $\$ 450,000,000$ of these notes were issued. Assuming that one-third of this issue was rendered necessary by the excessive depreciation of the notes at certain periods, and that the depreciation of a national currency founded on bonds would have been very much less, then it may also be assumed that three hundred millions of National bank notes, once in circulation, 
would have accomplished all the work of $\$ 450,000,000$ of legal-tender notes. Under the act of 1863 , the first National Currency Act, the banks were permitted to issue circulation to the par value of the bonds deposited. Three hundred millions of bonds would have sufficed to issue the assumed amount of bank notes. As an actual fact, the New York, Boston and Philadelphia banks did advance one hundred and fifty millions in eash in 1861. If, in exchange for this one hundred and fifty millions six per cent. bonds had been deposited in the Treasury, and an equal amount of notes issued to the banks, who can say that these notes, guaranteed by the Government and backed by the credit of the banks, would not have supplied the place of the first issue of $\$ 150,000,000$ legal-tender notes.

Of course, the banks could not be expected to change their charters for National ones at once; but the notes based on bonds might have been issued by them as State banks. The next one hundred and fifty millions could easily have been issued by the State banks in other parts of the country, following the example of the city banks.

Some such plan was, no doubt, perfectly practicable, and was actually proposed a little later by O. B. Potter. It would, perhaps, have bridged the temporary difficulty for which the legal-tender note appeared the only remedy. The banking system which would have grown up on such a beginning would have been of a more composite nature than the National banking system, but by gradual amendment it might have developed into a much better system for issuing currency as it would not have had the legal-tender note or its successors, the silver certificates and Treasury notes of 1890 , to contend with.

\section{COMPARISON OF EXPEDIENTS.}

These speculations are not without utility in showing the real value of the expedients actually employed. Success is, as a rule, however, regarded as endorsing the means used, and the legal-tender note will always be looked upon as one of the main financial instruments in saving the life of the nation. If it had been kept within the intention of those who were in Congress when it was authorized, it would not have interfered with the subsequent development of the National banking system.

\section{Proposed Funding of Legal-Tender Notes Repealed.}

The legal-tender notes of February, $1862(\$ 150,000,000)$ and of June, $1862(\$ 150,000,000)$, were all fundable at the option of the holders into five-twenty six per cent. bonds. The following words were printed on the back of the note:

"This note is a legal tender for all debts, public and private, except duties on imports and interest on the public debt; and is exchangeable for United States six per cent. bonds redeemable at the pleasure of the United States after five years." 
On March 3, 1863, another act was passed authorizing the issue of one hundred and fifty more millions of legal-tender notes, but containing the provision that the holders of United States notes issued under former acts "shall present the same for the purpose of exchanging them for bonds as therein provided, on or before July 1,1863 , and thereupon the right to exchange the same shall cease and determine."

\section{Legal Tenders and Bonds in 1863.}

Up to March $31,1863, \$ 61,046,500$ of six per cent. bonds had been issued. During 1862 these bonds had been quoted at least half the time below par, and consequently were not readily exchanged for legaltender notes. For the first three months of 1863 they were also below par. On the whole they were not worth as much as legal tenders at a time when there were so much better opportunities to use money. Only $\$ 161,056,000$ legal-tender notes had been issued by March 31,1863 , and $\$ 60,000,000$ of these merely replaced an equal amount of demand notes. The act of March 3, 1863, also authorized the Secretary to issue ten-forty bonds at not more than six per cent. interest. He tried to issue them at five per cent., but the loan was a failure.

The right of refunding legal tenders into six per cent. bonds was withdrawn for the purpose of floating the five per cent. loan, because no one would take bonds at the lower rate of interest when higher rate bonds could be had for the legal-tender note.

That the right of exchange was not thought much of by the public at this time is evident from the fact that although it was to be withdrawn after July 1 , between March 31 and July 1 only $\$ 8,740,800$ in six per cent. bonds were issued. Greenbacks could be more profitably used, even when gold was 155 premium, than to fund them into bonds at par. So the right to fund legal-tender notes into twenty-year bonds quietly lapsed, although the fact of its existence was the principal argument in favor of agreeing to the legal-tender enactment in the minds of many.*

\section{Law Abrogating Right of Funding.}

The law abrogating this right was a breach of contract with the holders of the notes, but it was a contract not valued by the holders. When, however, the bonds began to rise in market value then the Government gained greatly in premiums which would have been lost if the right to fund legal-tender notes in the bonds had been retained.

In 1865 Congress authorized Secretary McCulloch to reduce the volume of legal-tender notes, and their aggregate amount was contracted to

\footnotetext{
*The great mistake-greater than all other mistakes in the management of the war-was the abrogation of the right to fund the greenback currency intogold bonds, as provided for in the two preceding acts. All the other mistakes, civil and military, which occurred during the war were of slight consequence when compared with the mischievous and grave consequences resulting from this one mistake.-"Financial History of the War," by E. G. Spaulding.
} 
$\$ 356,000,000$ in 1867 . The largest amount of legal-tender notes outstanding at any one time was on January 3,1864 , and was $\$ 449,338,902$. The act of June 30, 1864, provided that the total amount issued should not exceed $\$ 400,000,000$, and an additional sum not exceeding $\$ 50,000,000$ for the redemption of temporary loans. In 1867 Secretary McCulloch had reduced the legal-tender notes to $\$ 356,000,000$. They continued at this amount until 1874, when, in response to the demand for more money caused by the panic of 1873 , the aggregate was increased to $\$ 382,000,000$.

\section{Congress Forbids Further Retirement of the Legal Thinders.}

In 1875 the restriction imposed on the increase of National bank circulation above $\$ 354,000,000$ was removed, but also providing that as new circulation was issued to banks increasing their capital or to newly organized banks, the legal-tender note aggregate was to be reduced by an amount equal to eighty per cent. of the new National bank notes issued until such aggregate of legal-tender notes should be reduced to three hundred millions of dollars and no more. The result was that on May 31, 1878, the aggregate had been reduced to $\$ 346,681,016$. On that date a new law was enacted by Congress preventing any further reduction in the amount of legal-tender notes, and the aggregate of such notes has since continued to stand at $\$ 346,681,016$.

\section{Restrictions on the Circulation of National Banks.}

The features of the National Currency Act preventing the National bank notes from taking possession of the field occupied by the legaltender notes during the years from 1865 to 1878 , inclusive, were the provision of the law of 1864 , fixing the limit of notes to be issued to all the banks at three hundred millions of dollars, and the provision of the act of March 3, 1865, that one hundred and fifty millions should be apportioned to associations in the States and Territories according to population, and the other one hundred and fifty millions to associations in the States and Territories according to the existing banking capital, resources and business of each State. The apportionment was not, however, made with exactitude owing to the greater pressure to obtain circulation exerted by some States than by others, and the amounts obtained by the banks in some of the States was much less than the law entitled banks organized in those States to have. When, therefore, a new bank was organized in any one of the latter States, it experienced difficulty in obtaining circulation:

\section{ACt of Julx 12, 1870.}

This caused complaint, and on July $12,18 \%$, a law was passed increasing the aggregate by $\$ 54,000,000$. This was nearly all issued by 1873 , and at the end of this distribution fourteen States and Territories 
had $\$ 80,600,000$ more than their share, while thirty States and Territories had less than they were entitled to by that amount.

These restrictions of law not only prevented the growth of National banks in the South and West, but also prevented the banks in the wealthy Eastern and Middle States from issuing as much circulation as. they would otherwise have done.

\section{Premiums on Bonds Affect Bank Notes.}

From 1865 to 1875 these restrictions prevailed, and when they were removed in the latter year the premium on the United States bonds. deposited to secure the circulation had so increased that there was a great temptation to the banks to retire their circulation and realize the premium. Congress refused to increase the ratio of circulation to bonds as the value of the security augmented, so that many of the banks in parts of the country where money was in demand incurred losses by retaining circulation to the extent of ninety per cent. only upon the par value of bonds worth one hundred and fifteen as early as 1873. The act of 1874 enabled them to deposit legal-tender notes to retire their circulation, and after this date the withdrawal of bonds to realize the premium was very rapid.

\section{Unfavorable Action of Congress.}

Measures tending to maintain the National bank circulation were uniformly rejected by Congress. They were opposed by those who were in favor of the legal-tender note as it was, and by those who desired the enlargement of the legal-tender idea to the extent of having the 'Treasury issue quantities of fiat money. Almost every Congress bills were introduced to effect the substitution of legal-tender notes for National bank notes.

The silver agitation began in 1874 and 1875, and resulted in the restoration of the coinage of the silver dollar in 1878, and the authorization of silver certificates.

The steady attack on the National banking system produced little effect except upon its circulation issuing power, and this declined because the growing premium on the bonds could not be made the basis of additional circulation without the action of Congress, which could not be obtained in the face of the popular agitation of financial heresies prevailing during the period of nearly four years between the passage of the act for the resumption of specie payments in 1875, and the fixed date of resumption on January 1, 1879.

\section{Popular Opposition to Banks.}

Those who sought the repeal of the Resumption Act and a wider issue of irredeemable paper, as well as those who desired the restoration of the coinage of silver dollars, opposed any law that might have pre- 
served or increased National bank circulation. Some of the theories and predictions of that period will be shown in the next few pages.

\section{The Interchangeable Bond Scheme.}

A favorite plan with those who advocated unlimited, irredeemable fiat greenback money, was what was known as the 3.65-bond plan. In one of its phases it was advocated in Congress by General Butler as early as 1869. In its more complete form it proposed that the Government should issue a bond bearing interest at the rate of 3.65 per cent. per annum, both principal and interest payable in greenbacks. The greenbacks were to be payable in the 3.65 bonds, and any holder of the latter could obtain greenbacks for them to the amount of their face value with accrued interest. The rate 3.65 , or one cent per day on $\$ 100$, was considered very ingenious, as it would make the amount of interest due readily calculated by the holder of average intelligence. It was no new invention, however, as a similar principle had been adopted in the issue of the Treasury notes of 1812, which bore interest at the rate of 5 2-5 per cent. per annum, or one cent and a half per day, and the interest upon the seven-thirty notes issued by Secretary Chase was two cents a day. So it might be said that what was good and ingenious about the 3.65 -bond plan was not original.

This scheme was very plausible and taking, and was supposed by many to be a perfect contrivance for making the legal-tender note currency elastic, and at all times correspond with the wants of business and trade. When trade was dull the people would invest their redundant greenbacks in 3.65 bonds, and when brisk and more currency was necessary, it could be obtained by presenting the 3.65 bonds for redemption. One prominent financial writer in the West became most enthusiastic in favor of the plan, and wrote of it in language that has become celebrated, as "embodying a subtle principle which will regulate the movement of the currency as accurately as the motion of the steam engine is regulated by its governor." Simon Newcomb in his A B C of Finance most skilfully exposed the fallacy of this scheme of apparent redemption. He says:

"The principles on which this ingenious system of finance are based need not be confined to money; they can also be applied to navigation so as to prevent shipwrecks. A ship's anchor frequently fails to hold her in a storm, and she may thus be driven on a lee shore. Scores of vessels are wrecked in this way every year. The new plan of anchoring which is open to all the world is this: Dispense with all such uncertain things as anchors, and send your ships out in pairs. Then whenever your two ships-the Eagle and the Ocean Wave-are in danger of being blown on a lee shore in a gale of wind, lash the Eagle firmly to the Ocean Wave so that the wind cannot move her an inch. Then lash the Ocean Wave to the Eagle so that she cannot move either. Then the two ships will bid defiance to the storm, and their crews will look on calmly as they see these unwise captains who trust in anchors drifting by them. You see the principles involved. The Eagle is the greenback, the Ocean Wave the bond. The greenback is based on the bond as the Eagle is lashed to the 
Ocean Wave. The bond is based on the greenback as the Ocean Wave is lashed to the Eagle. And thus we see in navigation as in finance, a 'subtle principle' which will regulate the movement of finance and ships 'as accurately as the motion of the steam engine is regulated by its governor.' "

\section{Action of Greenback Convention, 1876.}

This plan, as well as most others proposed by the greenback advo. eates, involved a retirement of National bank circulation, and this was advocated even by those who would make the paper of the Government equal with gold. The greenback convention held at Indianapolis in 1876, and which nominated Peter Cooper for President, declared that a United States note issued directly by the Government and fundable into bonds bearing interest not exceeding one cent a day on $\$ 100$ and exchangeable for United States notes at par, was the best circulating medium ever devised, and insisted in the language of Thomas Jefferson, that "bank paper must be suppressed, and the circulation restored to the nation, to whom it belongs."

The Prohibition convention in the same year declared that the national Government alone should have the high prerogative of issuing paper money, although such paper money should be redeemable in gold and silver on demand. In 1878 the National Party, the new name taken by the Greenbackers, at Toledo, announced that all bank issues designed to circulate as money should be suppressed, and United States notes should be a legal tender at their stamped value. This was fiat money. In the Forty-fifth Congress two bills were offered in the Senate and fourteen in the House to repeal the Resumption Act. A fifteenth bill to this effect passed the House in November, 1878, by 133 to 120 . It rested in the Senate.

Mr. Townshend, of Illinois, offered a resolution "instructing the Committee on Banking and Currency to inquire into the expediency of withdrawing the National bank circulation and winding up the National banks, and providing the country with greenbacks or other currency of similar character." Mr. Cobb, of Indiana, offered a bill "for the withdrawal of National bank currency and the issue of $\$ 500,000$,000 of legal-tender Treasury notes." Mr. Hunter, of the same State, proposed "to reissue all the greenbacks redeemed under the Resumption Act and pay them out on the public debt." Mr. Hartzell, of Illinois, offered a bill "to substitute greenbacks for the issues of National banking associations," and his colleague, Mr. Fort, proposed a measure to accomplish the same result gradually. Mr. Riddle, of Tennessee, wanted to forbid the organization of new banks, and to prohibit the recharter of those in operation. Mr. Buckner, of Missouri, offered a bill "to retire the National bank notes," which was perfected, reported from the Committee on Banking and Currency, and made a special order for April 23, 1878, but was not then reached for action. 


\section{Views OF THE COMPTROLLER OF THE CURRENCY IN 1878.}

On February 19, 1878, the Comptroller of the Currency, by the request of the Committee on Banking and Currency, gave his views relative to the bill for retiring the circulating notes of National banks, etc. The bill proposed notes in the form "The United States of America are indebted to the bearer in the sum of _- dollars." They were to be legal tender, receivable for all dues, public and private, except for obligations made payable in coin or lawful money under existing laws, and were to be receivable at par for four per cent. bonds. These notes were to be equal in amount to the National bank circulation and exchangeable for it. The Comptroller expressed the opinion that it was doubtful whether vested rights of National banks could be disturbed; that if the National system was abolished, the tax on State bank circulation would be repealed and State banks re-established. He went on to show the advantages of the National system, quoted the opinions of Hamilton, Dallas, Gallatin and Chase as to the dangers of Government paper, and showed the greater safety enjoyed by the public, both as to circulation and deposits, under the National system. The profits of the National banks, as shown by their dividends, were not excessive; their profit on circulation, based on four per cent. bonds, was not more than 1 9-10 per cent.; that the banks had been and would still be of great service in funding the debt of the United States, and that no saving to the Government could be effected by the passage of the bill, inasmuch as the holders of the bonds would still receive interest upon thein.

The committee seemed to be under a vague impression that by assuming the redemption of National bank circulation in the United States notes provided by the bill, the Government would have the right to seize and cancel the bonds upon deposit with it. This vague idea, to the injustice of which some Representatives seemed to be blinded by their prejudice against the banks, formed the basis of most of the schemes for substituting Government paper for National bank notes. The year 1878 was especially prolific of pamphlets and arguments on both sides of the question. Those in favor of carrying into effect the resumption law advocated an honest policy toward the National system. The opposite party found one of their strongest positions was to appeal to and excite in every way the popular prejudice against the banks. J. W. Schuckers and Henry C. Baird, of Philadelphia, and Peter Cooper, were prominent paper-money advocates. On the other side, Prof. Simon Newcomb and Thomas M. Nichol were the authors of cogent pamphlets in favor of coin redemption and honest money.

\section{Atracks on the Resumption Act.}

At this time, with the experience of how quietly and efficiently the Resumption Act went into effect, it seems impossible that men could 
have been so frantically earnest in 1877 and 1878 to secure its repeal at any price. Mr. Schuckers, in 1877, wrote: "The immediate duty is to repeal the Resumption Act-that wicked and infamous enemy of labor, of property, of morals and of order !" The supreme duty was "the duty of effecting an utter and final divorcement between the Government and the banks." He took General Garfield to task for saying that the condition of the country was, on the whole, sound and satisfactory-" but," he exclaims, "what a fearful mockery is this of the desolation and anxiety, and actual want, that reign in tens and hundreds of households throughout the length and breadth of the land, wrought by this infamous resumption robbery. I dare not dwell further here lest my indignation should get the upper hand of my friendship for a man whom I wish always to respect." *

On April 1, 1878, the Banking and Currency Committee of the House commenced taking the testimony in regard to the propriety of repealing the act for the resumption of specie payments. Mr. Buckner was chairman of the committee. Mr. Ewing, of Ohio, was a prominent opponent of the resumption plan, and the majority of the committee were in favor of repealing the resumption law. Mr. Sherman, Secretary of the Treasury, in reply to inquiries, stated that the available gold on hand on resumption day would, he expected, be between $\$ 125,000,000$ and $\$ 140,000,000$, and that he expected only to sustain the legal-tender note issues of the Government. The National banks and State banks and individuals would take care of themselves. Mr. Sherman's testimony continued from April 1 to April 16.

\section{Opinions of Financiers AND OTHERs.}

Mr. Colgate, of New York, was next before the committee, and was of the opinion that gold and greenbacks might be interchangeable on January 1, 1879, or perhaps before, but regarded the prospect of permanent resumption with $\$ 140,000,000$ of coin a doubtful experiment, although all the circumstances were then favorable.

William H. Winder, of New York, said that a convertible currencythat is, a paper currency not a legal tender, convertible into coin on demand-was a monstrous device, wholly in the interest of the foreign creditor, and fatal to domestic productive industries of a debtor country. * * * A law exacting convertibility is an unmitigated evil, with no redeeming trait. $* * *$ It was better to have gold at a premium. A premium of 100 per cent. would be of incalculable advantage to every American productive industry. *** A premium on gold is a bounty on exports and a duty on imports. $* * *$ The volume of paper should be unchanged; and, when this was the case, the premium on gold was due not to the depreciation of the paper, but to a foreign demand for gold,

* Review of General Garfield's speech on Specic Payments in letter of J. W. Schuckers to Hon. Willam D. Kelley, November 22, 1877. Henry C. Perry, Publisher, Philadelphia. 
which, by taking it from the country, decreased the aggregate of money and caused a rise of prices. $* * *$ A paper legal-tender currency for domestic purposes was advantageous on account of its unvarying volume; its steadiness was superlative. A gold volume is of all things on earth the most unsteady, the most fluctuating, the most treacherous. * * * The great legislative wrong was the change of payment of bonds from legal tenders to coin. Lunatics from an asylum could not have worked greater mischief. * * $*$ The sun at noonday was not a more indisputable fact than the impracticability of the resumption of specie payments. * * $*$ Mr. Sherman's whole exposition of the plan was an agglomeration of ifs, ands, and buts and contingencies, that no one would want specie. $* * *$ England was whispering with a serpent tongue into the ear of our Secretary. $* * *$ An English gentleman came to this country* with $\$ 500,000$ to obtain the demonetization of silver. *** He had no occasion to use it. The committee in Congress received him as their Gamaliel. $* * *$ The Secretary could not certainly maintain specie payments if he had gold equal to the paper circulation. $* * *$ The Resumption Act should be repealed. *** No benefit could come from resumption except to the foreigner. $* * *$

Mr. Vermilye, of New York, had supposed that the Resumption Law provided for the absolute redemption of legal-tender notes, but did not see any difficulty in resuming and maintaining resumption. If the reissue caused inconvenience the Secretary could coinmence to retire the notes. $* * *$ The combined legal-tender and National bank notes formed a currency more than was requisite for the wants of business. * * * He would be willing to let the paper money of the country be confined entirely to greenbacks, and let the National bank notes go out of circulation.

John A. Stewart, President of the United States Trust Company, New York : If resumption meant final redemption of legal-tender notes, did not think it could be maintained; but the payment in coin and subsequent reissues were practicable. The people, from curiosity, might want gold at first, but would soon be satisfied. The legal-tender notes were the most convenient. *** Under the Secretary's plan of resumption there would be a healthy expansion of the currency. $* * *$ The house of A. T. Stewart, of New York, had for some weeks past. been paying gold in change to ladies who go there to buy goods. At first they were anxious to get the gold, but afterwards preferred paper.

Richard B. Pullan, of Cincinnati, did not think it practicable to maintain specie payments after January 1, 1879. * * * The National banking system was the main cause of the distress that exists. $* * *$ The banks had cost the people over $\$ 200,000,000$ * * * The avarice and cupidity of the banks would force legal-tender notes, the supe-

* This refers to the alleged visit of Ernest Seyd to this country in 1872. Mr. Seyd was a bimetallist, and he was not in this country subsequent to 1856 . 


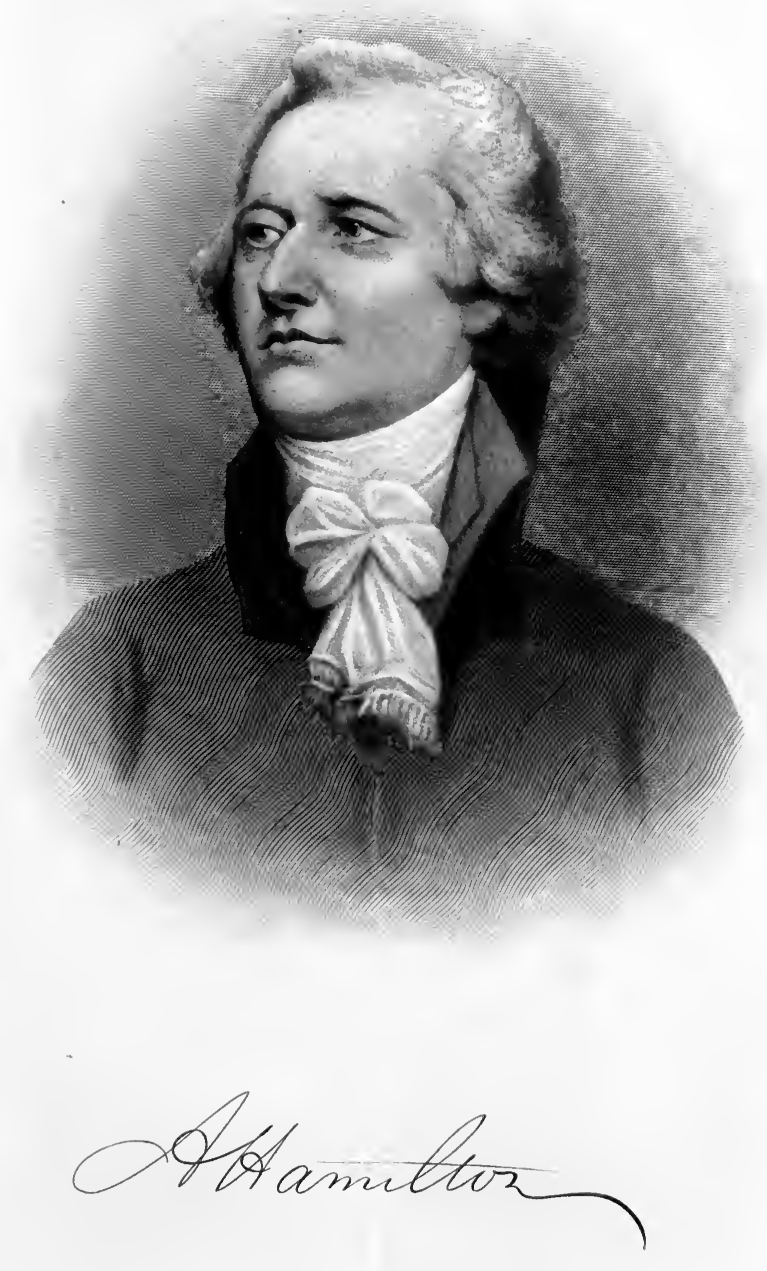


. 
rior currency, out of circulation. * * * There would be great expansion from free issue of National currency.

A. J. Warner, of Marietta, Ohio: Specie payments on January 1, 1879, were not at once practicable and consistent with the general welfare of the country. * * * The people would prefer the larger portion of their currency to be coin. $* * *$ The Secretary, even with the co-operation of the National banks, could not maintain $\$ 650,000$,000 of convertible currency in circulation in the United States. *** The effect of the Resumption Law has been to greatly lessen the total production of the country, and greatly to lessen, if not to stop altogether, the increase of national wealth.

Henry C. Baird, of Philadelphia: The Government and the banks will not be able to sustain resumption after January 1, 1879. * * * The practical way to bring about prosperity was an increase of circulation from $\$ 650,000,000$ to $\$ 2,000,000,000$. * * * Specie pay ments were a relic of barbarism which has long outlived its day and usefuiness. *** The $\$ 2,000,000,000$ of currency would not be a debt of the Government. When asked if it would not have to be paid at some time, Mr. Baird answered, "No, never." * * * The people of the world have been enslaved for thousands of years by the metallic system. * * * The reason the French assignats depreciated was because the English Government and the emigrés together were engaged in counterfeiting the assignats, and the counterfeits were so good they could not be told from the genuine ones.

George S. Coe, of New York: His idea of resumption was, that in 1875, when the law was passed, it was the intention to pay or fund the legal-tender notes and depend on three or four hundred millions of $\mathrm{Na}$ tional bank notes and coin. *** If the restraint of the legaltender act were removed on resuinption, coin would take the place of nearly all if not the whole of the legal-tender notes. * * * Three hundred millions of legal-tender notes and three hundred and fifty millions of National bank notes could be maintained permanently, exchangeable or convertible with the gold held by the Treasury and banks and what would come into the country, and the Secretary could safely resume on January 1.

George Opdyke, of New York: It was practicable and consistent with the pnblic welfare to resume and maintain specie payments on and after January 1, 1879. *** The amount of coin already in the country was ample. $* * *$ In view of the strong confidence of the people in the present paper money, grounded on its perfect security, the banks and the Government would be likely to receive from the people a larger amount of gold than they would draw out.

Joseph Seligman: The paper currency of the country could be kept afloat with the coin in the country. All that was necessary was the confidence of the people that they could get coin when they wanted it; when this was believed the majority of the people would not want coin. 


\section{Opinions of Messrs. Weston, Wright, Heiser and Schuckers.}

George M. Weston, of Maine: Specie payments might be resumed, but they would not be maintained. There was no instance of the maintenance of specie payments where the proportions of paper currency to coin were such as they were then in the United States. A paper money receivable for all public dues and private dues, and not redeemable in coin, fixed in amount and increased every year in a ratio which would approximate the increase of business demands, would be the most perfectly stable money that could be had. ***

Benjamin H. Wright, of Rome, N. Y.: Specie payments may be maintained, but the plan is very crude and imperfect from its origin. It had no sure basis to start on. * * * Its birth was a party caucus, a censurable adjunct of a legislative hall. * * * The Secretary should be authorized to exchange with the National banks coin for legal-tender notes and legal-tender notes for coin.

Henry A. Heiser, of New York: It would be impossible for the Secretary to maintain specie payments with the present volume of the paper currency. * * * The fact that gold was such a novelty would, when resumption day arrived, lead a great number of store-keepers and others to give notice that they had resumed specie payment. Those who received gold from them would put it away, so that there would be a virtual withdrawal of forty millions from eirculation. If there was free circulation of gold and paper fifty per cent. would be coin.

J. W. Schuckers, of Pennsylvania, was the last gentleman who gave his opinion: It was not consistent with the public welfare to resume specie payments on January 1, 1879, nor at any other time. * * * The decline in gold was due to progressive prostration of industry and to "rigging" the exchange market by the bank syndicate. * * * It will be found more difficult to get rid of the nominal premium of onehalf to one per cent. than it was to reduce the premium from eight or ten per cent. down to one. * * * The inconvertible system of money was to be preferred. * * * A really flexible currency does not exist, and a convertible currency cannot be made so. * * * Mr. Sherman overestimates his resources. His plans are very plausible; as the detectors say of good counterfeits, "they are well calculated to deceive." * * * His ultimate and efficient preparation for resumption will not be more than $\$ 45,558,000$. * * * Nothing in the world is more certain than that Mr. Sherman's whole disposable reserve may be drained away from him in twenty to thirty days. * * * The banks could, in a single hour, precipitate twenty-five or thirty millions of coin certificates upon the Treasury. *** When a demand is made on the banks for coin, they must get it from the Treasury. * * * The Resumption Law ought to be repealed with as little delay as legislative forms will permit. 


\section{LAW OF JULY 12, 1870.}

The law of July, 18\%0, as previously stated, authorized an additional issue of fifty-four millions of National bank circulation. This had been almost all distributed by November, 1873. The same law provided that when the additional circulation slould be taken up, the Comptroller should, in order to supply further demands of banks organized or to be organized in States having less than their proportion of circulation, begin to withdraw circulation from banks in States and Territories having more than their proportion. This process was to commence with banks having over one million circulation in all States having an excess, and then proceed pro rata with other banks having a circulation exceeding three hundred thousand in States having the largest excess of circulation, and reducing the circulation of such banks having the greatest proportion in excess, leaving undisturbed any States having a smaller proportion until those in greatest excess should be reduced to the same grade, and continuing until the full amount of twenty-five millions was withdrawn.

Under this law the twenty-five millions would have been withdrawn from four banks in New York city, thirty-seven in Boston, twenty-one in Massachusetts, seventeen in Providence and fifteen in Connecticut. Nothing can illustrate the lack of legislative wisdom more than this measure, so calculated to restrict the free issue of bank notes in response to the wants of business. It was, however, a part of the policy of rigid restraint adopted from 1863 to 1875 , when the limit on bank issues was removed. The very localities where the circulation was most useful were deprived of it. The Comptroller in 1873 asked for the repeal of this provision and recommended that twenty-five additional millions be authorized to be issued to banks in States having less than their proportion.

\section{Redemption of National Bank Notes in Lawful Moner.}

The laws of 1863 and 1864 made the National bank notes redeemable in lawful money, that is in legal-tender notes, the only lawful money before specie payments were resumed. From 1863 to 1873 the amount of outstanding legal-tender notes was largely in excess of the National bank notes in circulation. During the latter year the amounts were $\$ 356,000,000$ legal-tender notes and about $\$ 350,000,000$ of bank notes. There was consequently no redemption of the latter in the former, and there was no elasticity of increase and decrease of the aggregate mass of the two forms of paper currency, in conformity with the fluctuating demands of business. Thus when general business was dull large accumulations of paper money occurred in the financial centers, unduly stimulating speculative enterprises, so that when the general business of the country increased, a scarcity was felt which it was impossible to supply. 
In 1873 the Comptroller concluded that to give the proper elasticity to the National bank note it would be necessary to increase the issues until they were at least one hundred millions in excess of the amount of legal-tender notes. A reduction of the latter notes would have the same effect. If the proper proportion were obtained between the lawful money issues and those of the banks, the bank notes would tend to increase whenever business throughout the country demanded more money. Whenever they became redundant a slight discount at the money centers would force their redemption and prevent such an accumulation as would encourage undue speculation.

\section{ACT of June 20, 1874.}

The act of June 20, 1874 was, perhaps, in part the result of the recommendations of the Comptroller made in 1873, but it contained, contrary to his recommendations, further provisions for enforcing the pernicious redistribution of circulation scheme of the act of 1870 . This had not been carried out because it was not to go into effect until the full $\$ 354,000,000$ of circulation had been issued, and in practice there was always a small margin between the amount actually issued and this limit. Moreover, there was no way of expeditiously gathering up and returning the circulation, which might be called for from any particular bank.

The act of 1874 provided for a redemption agency at the United States Treasury, in lieu of the bank redemption agents previously existing, where National bank notes were to be redeemed in lawful money. It removed the lawful money reserves previously required to be kept on National bank notes. It permitted National banks to withdraw their bonds by depositing legal-tender notes in the Treasury to protect the United States in its assumption of the payment on demand of the bank notes previously secured by the bonds. It required the Assistant Treasurers and designated depositories to gather up and assort bank notes and send them in for redemption. It increased the amount of circulation to be withdrawn from banks in States having more than their proportion to fifty-five millions, and directed the Comptroller to proceed at once to this withdrawal without waiting for the issue of the whole $\$ 354,000,000$ limited aggregate. The same act fixed the legal-tender notes at the increased amount of $\$ 382,000,000$. The banks in operation were each required to deposit with the United States Treasurer an amount of lawful money equal to five per cent. of their circulation, this sum to be in lieu of all reserve on their issues, and also to count as a portion of the reserve required on their deposits.

\section{Operation of Act of June 20, 1874.}

While the act was ostensibly one to require the redemption of the bank notes, yet there could be no real redemption under it or any other law, responsive to the wants of business, so long as the legal-tender 
notes exceeded the National bank notes in amount. This law did, however, subsequently effect a purification of the bank currency, and a rapid circulation of both the legal-tender and the bank notes through causes not contemplated when the act was passed, and the operation of Section four.

\section{EfFect of Treasury Influence.}

The act of June 20,1874, was originated through the influence of certain officials in the Treasury upon that portion of Congress who were in favor of the legal-tender note: This kind of influence is often very much more potent than is generally suspected, and has had much to do with upholding the legal-tender note as against the National bank note. The tendency of all Government bureaus is to magnify their own importance. The position of the National Banking Bureau in the Treasury Department was at the commencement very strong. With Secretaries Chase, Fessenden and McCulloch, the legal-tender note was but a temporary expedient, while the National bank currency was to be the permanent money of the country. With Boutelle and Richardson the importance of the legal-tender note as a financial factor in increasing the power of the Secretary, began to gain on the National bank note. This tendency began to be felt in the subordinate offices. With legaltender notes, the Treasurer's office, which had charge of the preparation, signing, issuing and redemption of these notes, gradually acquired more power. The Treasurer was a much more important official with greatly increased patronage. The handling of the United States notes caused him to be in more frequent consultation with the Secretary. The office of the Comptroller of the Currency did not tend to establish so close relations. In fact, there were from a very early day two factions in the Treasury Department, the legal-tender faction and the National bank faction. The former, whenever they had opportunity, did what they could to prevent the retirement of legal-tender notes and the substitution therefor of National bank currency Many of the most effective arguments against the banks were furnished to members of Congress from this source.

The act of June 20,1874, is an instance of the manner in which the acknowledged necessity of a better redemption of National bank notes was turned into a means of enlarging the functions of the United States Treasurer at Washington. The increase in the amount of legal-tender notes to $\$ 382,000,000$ precluded any real redemption of National currency in them, the more so as the demand for legal-tender notes for bank reserves was reduced by the act. The legal-tender note was of no more value in the market than the bank notes. The redemption feature of the law performed excellent work in purifying the circulation. From June 20, 1874, to January 14, 1875, the date of the act removing all restrictions on National bank currency, a period of seven months, $\$ 62,291,511$ were received at the redemption agency, and dur- 
ing the nine months after January $14,1875, \$ 157,044,934$ were received. The whole expense of these redemptions was borne by the banks, and was a considerable item to be deducted from the diminishing profit on circulation.

\section{Voluntary Retirement of Notes.}

The feature of the act of June 20, 1874, permitting the deposits of legal-tender notes in order to retire circulation and withdraw bonds, caused a sufficient voluntary retirement of notes by banks in States having more than their proportion, to supply all demands in States having less between June, 1874, and January, 1875, when all restrictions on the aggregate amount of bank notes were removed.

\section{ACt of January 14, 1875.}

The act of January 14, 1875, for the resumption of specie payments was the last effort made by Congress to reduce the legal-tender note aggregate. As has been seen the operation of this law did reduce the aggregate of these notes from $\$ 382,000,000$ to $\$ 346,681,016$, when further reduction was stopped by the act of May 31, 1878. From January, 1875 , to November 1, 1876, the additional bank circulation issued amounted to $\$ 18,080,355$, and eighty per cent. of that sum in legaltender notes was retired. But owing to the retirement of circulation by banks desiring to realize the premium on their bonds, the decrease in aggregate bank notes outstanding secured by bonds was $\$ 30,710,732$. Of this sum $\$ 20,910,946$ was, in fact, still in circulation, but secured by an equal sum in legal-tender notes held by the Treasurer, awaiting the presentation of the bank notes for redemption and cancellation. On November 1, 1877, the amount of National bank notes outstanding secured by bonds was $\$ 302,770,619$, and $\$ 13,111,371$ secured by legaltender notes in the hands of the Treasurer. The total amount of new circulation issued since January, 1875 , had been $\$ 34,386,385$, retiring legal-tender notes equal to eighty per cent. thereof, viz., $\$ 27,509,108$. At this date the banks held as security for circulation $\$ 81,984,550$ of six per cent. bonds, $\$ 200,090,500$ of five per cents, $\$ 45,089,700$ of four and a half per cents, and $\$ 15,884,150$ of four per cents.

\section{Premium on Bonds Held to Secure Circulation.}

The premium on the bonds held by the banks on November 1,1875 $(\$ 361,498,150$ par value), was $\$ 64,342,421$. On these bonds the circulation issued, ninety per cent., was $\$ 325,348,260$. The bonds and premium being together worth $\$ 425,840,533$ the banks lost money on a margin of over $\$ 100,000,000$. It was the desire to realize this margin which led them to avail themselves of the privilege of the act of June 20,1874 , to retire their circulation and withdraw their bonds. As the funding operations of the Government continued and premiums on securities grew larger, the impulse to retire circulation increased. The 
banks themselves, no doubt, at times failed to avail themselves of opportunities to benefit by Congressional action, and were too prone to act for their individual interests as against a wider and more united policy, but this was the fault of the system, and indicated the absurdity of the charges often made of combinations among them for mutual profit. The act of June 20, 1874, authorized any National bank desiring to withdraw its eirculating notes in whole or in part, to deposit lawful money with the Treasurer of the United States in sums of not less than nine thousand dollars, and to withdraw a proportionate part of the bonds pledged as security for its notes, and under this act the circulating notes of National banks have been gradually retired, as the profit on circulation declined or any other motive influenced the bank to realize the premium upon its bonds. 


\section{PROGRESS OF THE NATIONAL BANKING SYSTEM FROM 1878 TO 1880.}

Act of January 14, 1875 - Views of the Comptroller on Resumption - History of National bank circulation - Comptroller's report for 1879-Gold obtained for resumption - Refunding of the public debt - Contracts for sales of bonds Public debt of England - Imports of gold - Proposals to substitute legal-tender notes for National bank notes - Value of circulation privilege in 1879 - Illegal certification of checks - Comptroller's report for 1880-Gold certificates.

\section{The Resumption of Specie Pafments.}

The year 1878 was the sixteenth year of the existence of the National banking system. The act of January 14, 1875, had provided for the resumption of specie payments upon January 1, 1879. As this time approached desperate efforts were made to repeal the act. The New York associated banks, in view of the near approach of specie payments, in order to facilitate the success of resumption as far as possible, adopted the following propositions for the guidance of the several banks:

First.-Decline receiving gold coins as special deposits, but accept and treat them only as lawful money.

Second.-Abolish special exchanges of gold checks at the clearinghouse.

Third.-Pay and receive balances between banks at clearing-house either in gold or United States legal-tender-notes.

Fourth.-Receive silver dollars upon deposit only under special contract to withdraw the same in kind.

Fifth.-Prohibit payments of balances at clearing-house in silver certificates or in silver dollars, excepting as subsidiary coin in small sums (say under ten dollars).

Sixth.-Discontinue gold special accounts by notice to dealers to terminate them on January 1, 1879.

\section{Report of Clearing-House Commitee.}

The committee of the clearing-house which adopted these propositions said:

"At present there is a marked distinction made in the daily transactions of banks, between their deposits of gold and their deposits of currency, by treating the former as a special fund payable in kind. It must be evident that if this discrimina- 
tion continues to be made after resumption, it will prolong the idea of the inferiority of circulating notes after they have been declared to be restored to an equality with gold by becoming interchangeable, and will therefore falsify the proclamation of the Government. It will not only be a practical denial by the banks of the sincere purpose of the Government to maintain its resolution, but by affording protection and facility to those who draw coin from the Treasury, will place the moral force and power of the banks in direct opposition to the effort of the Government.

To make resumption effective the banks must cordially co-operate by practically treating lawful currency and gold coin as equivalent in value, as they did before the war, declining to receive all deposits of gold as subject to special contract as hitherto, and accepting it only as lawful money. They should also abolish all existing arrangements in which gold coin is preferred, by giving notice that they will expire on the first of January next, the day of resumption, and terminate all special gold exchanges at the clearing-house.

If the Government, also, forbearing all further legislation on the subject, will discontinue the issue of gold certificates at the Treasury, and regard gold coin as practically the equivalent of lawful money in all its disbursements, the distinction which has so long existed between coin and currency will rapidly fade away and natural law will reassert its beneficent dominion over our financial affairs. Resumption of the coin standard being assured, it is entirely safe to let the circulating notes find their true place as their constitutional merits and the demands of trade and the public interests may naturally determine. But resumption of the coin standard can be successfully reached only by the fearless disbursement of gold both by the banks and the Government, and by such unreserved and confident action as will manifest to the public that they are working harmoniously together, and feel the utmost assurance of its practicability and permanence."

\section{Assistant Treasurer of United States Madf a Member of Clearivg-House.}

The Assistant Treasurer of the United States at New York was also made a member of the clearing-house under the following arrangement:

First.-Hereafter drafts drawn upon any bank represented in the Clearing-House Association in the city of New York, received by the Assistant Treasurer of the United States in that city, may be presented to such bank at the clearing-house for payment.

Second.-Hereafter drafts drawn upon the Assistant Treasurer at New York may be adjusted by him at the clearing-house, and the balance due from the United States may be paid at his office in United States notes or clearing-house certificates.

Third.-After the first of January next payment of checks presented to the Assistant Treasurer by any bank connected with the clearinghouse may be made by him in United States notes.

The propositions formulated for the guidance of banks by the associated banks of New York were formally adopted by the associated banks of Boston, and exerted a great influence upon the conduct of all the banks in the United States.

\section{CoMPTROLLER's VIEWS ON RESUMPTION.}

The Comptroller of the Currency in his report said in reference to approaching resumption, in answer to the objection to resumption com- 


\section{monly made, that it would not be possible for the banks to provide for the redemption of their deposits in gold coin:}

"Those who take this view proceed on the assumption that the banks will be called upon to pay their deposits in specie. This was not true during any former period of specie payment, and is less likely to be true under the National banking system than under any previous system of banking. The banks in this country, from their first organization, have, in times of resumption, as well as of suspension, received from their dealers current bank notes and have paid out the same. This is true to-day in England, Scotland, Germany and France, in all of which countries the bank note is preferred, as a rule, to either gold or silver.

Only a small portion of the bank circulation of the country, at any period prior to 1863 , was either safe or convertible, yet this circulation, poor as it was, was freely received by the banks outside of the commercial cities, and was paid out by them to their depositors, so closely identified were the interests of the one with the other. The notes which were returned from the commercial centers for redemption were readily paid out and circulated at home, and the demand for specie, wherever it existed, was almost entirely owing either to an excess of currency or to a want of confidence in the institutions which issued it.

The people throughout the country now know that the National bank notes are safe, and that if these notes are not paid at the counters of the banks issuing them, they will be paid at the Treasury Department in lawful money, and that the securities held for their redemption are amply sufficient for that purpose.

No reason, therefore, exists why the people who, in the last fourteen years, have not lost one dollar through the use of bank notes, should decline to receive such notes in payment of their deposits. These notes are not only guaranteed by the Government, but they are received by it in payment of all taxes and other dues except duties on imports, and are disbursed by it in payment of all demands except interest on the public debt, and the redemption of National bank notes.

The National banks hold eight hundred and eighty millions of loans made to the people, and each bank is required by law ' to take and receive at par, for any debt or liability to it, any and all notes or bills issued by any lawfully organized National banking association.' There are, therefore, eight hundred and eighty millions of the liabilities of the people due to the National banks-a sum largely exceeding the whole amount of deposits - which may be paid in the notes of any or all of the National banks in the country.

The National bank notes are, therefore, very different in character from the heterogeneous bank notes formerly issued by the authority of the several States.

Moreover, the deposits of the banks are largely owned by their own shareholders and by their borrowers; and surely business men, who look to the banks for accommodations, and stockholders, whose profits depend upon their successful management, will be the last to conspire to injure their credit.

Deposits consist chiefly of bank credits and are derived largely from the discount of commercial paper, and are paid mainly by transfers on the books - not with either coin or currency. Throughout the country all large payments are made, not with money, but with checks. In the principal cities these payments are accomplished through the operations of clearing-houses. During the last twenty-four years the exchanges of the New York clearing-house were four hundred and fifty-four billions, while the balances paid in money were less than nineteen billions. The average daily exchanges during the whole period were more than sixty-one millions, while the average daily balances paid in money were but two and a half millions, or but four and one-fifth cents upon the dollar.

Inmediately after resumption in England, in 1821, there was but little demand for gold, and the same was true in France after resumption by the Bank of France 
in 1850, and in this country after the resumptions of 1838 and 1858. All thought of demanding actual payment in specie will vanish as soon as resumption is assured, and those timid bankers who fear that coin will be demanded for every dollar of deposits can reassure themselves by an agreement with their dealers that their deposits shall be payable as at the present time in 'current funds,' which will then consist of legal-tender notes and the notes of specie-paying banks."

\section{Gold and Silver in the United States.}

The Comptroller in his report issued in November, 1878, refers to the estimate of the Director of the Mint in 1877, of the amount of gold and silver coin and bullion in the country, and by adding importations and deducting exportations, and amount used in the arts, arrives at the conclusion that there was on June 30, 1878, $\$ 332,443,947$ in gold and silver coin and bullion in the country, of which $\$ 244,353,390$ was in gold coin and bullion and $\$ 88,090,557$ in silver coin and bullion. Of this the National banks held on June 29, $\$ 29,251,403$.

\section{History of National Bank Circulation.}

In the report of 1878 , also, the Comptroller concisely summed up the history of National bank circulation in order to show its exact standing at so important an epoch as that then approaching.

"The act of February 28, 1863, and the subsequent act of June 3, 1864, authorized the issue of three hundred millions of National bank circulation, which was increased by the act of July 12,1870 , to three hundred and fifty-four millions. The act of June 20,1874, authorized any bank desiring to withdraw its circulating notes, in whole or in part, to deposit lawful money with the Treasurer of the United States in sums of not less than nine thousand dollars and to withdraw a proportionate part of the bonds held as security for such notes; and the act of January 14, 1875, repealed all provisions restricting the aggregate amount of National bank circulation, and required the Secretary of the Treasury to retire legal-tender notes to an amount equal to eighty per cent. of the National bank notes thereafter issued until the amount of such legal-tender notes outstanding should be three hundred millions of dollars and no more. That portion of the above act which required a reduction of United States legal-tender notes was repealed by the act of May 31,1878, which provides :

'That from and after the passage of this act it shall not be lawful for the Secretary of the Treasury, or other officer under him, to cancel and retire any more of the United States legal-tender notes; and when any of said notes may be redeemed, or be received into the Treasury under any law, from any source whatever, and shall belong to the United States, they shall not be retired, cancelled or destroyed, but they shall be reissued, and paid out again and kept in circulation; provided, that nothing herein shall prohibit the cancellation and destruction of mutilated notes, and the issue of other notes of like denomination in their stead as now provided by law.'

Subsequent to the passage of the act of June 20, 1874, and that of January 14, 1875 , which authorized the retirement and reissue of National bank notes at the pleasure of the banks, the circulation steadily decreased in volume until the year 1877 , the total decrease being $\$ 30,869,655$, since which time there has been a small increase." 
The following table exhibits the decrease and increase since 1867, giving the total outstanding circulation on November 1, of each year, on June 20, 1874 and January 14, 1875 :

\begin{tabular}{|c|c|c|c|}
\hline & & June $20,1874 \ldots \ldots \ldots \ldots \ldots$ & $\$ 349,894,182$ \\
\hline & $300,002,234$ & November $1,1874 \ldots \ldots$ & $351,927,246$ \\
\hline er $1,1869$. . & $299,910,419$ & Ja & $351,861,450$ \\
\hline eer $1,1870$. . & $302,607,942$ & & 345, \\
\hline & & & 321 , \\
\hline $1872 .$. & $341,512,772$ & nber 1,1877 . & $316,775,111$ \\
\hline ovember & $348,382,046$ & November $1,1878$. & $320,991,795$ \\
\hline
\end{tabular}

From the passage of the act of June 20, 1874, to November 1, 1878, $\$ 79,910,488$ of legal-tender notes were deposited in the Treasury for retiring National bank circulation, and $\$ 74,095,965$ of bank notes were redeemed, cancelled and destroyed. From the passage of the act of January 14, 1875, to May 31, 1878, when further cancellation of legaltender notes was prohibited, $\$ 44,148,730$ of additional National bank circulation was issued, and $\$ 35,318,984$ of legal-tender notes, equal to eighty per cent. of the additional bank notes, were retired and destroyed, leaving $\$ 346,681,016$ outstanding, at which amount they have remained unchanged.

The Comptroller made no recommendations in regard to legislation by Congress in his report of $18 \% 8$.

\section{COMP'TROLLER's REPORT FOR 1879.}

In his report for 1879, including data up to December 1 of that year, the Comptroller discusses the relations of the National banks to the resumption of specie payments and the refunding of the National debt, which had recently received a new impulse through the issue of four per cent. bonds by Secretary Sherman. In reference to the resumption of specie payments the Comptroller called attention to the fact that "the act of January 14, 1875, required the Secretary of the Treasury on and after January 1, 1879, to redeem in coin the United States legaltender notes then outstanding on their presentation for redemption at the office of the Assistant Treasurer of the United States in the city of New York, in sums of not less than fifty dollars.

At the time of the passage of this act the leading industries and general business of the country were greatly depressed. The agricultural classes were largely in debt and the failure of mercantile establishments and manufacturing corporations in the three years previous represented more than $\$ 500,000,000$. During the succeeding years an era of economy supervened, agricultural products greatly increased, and the balance of trade was turned largely in favor of the United States-the excess of exports for the fiscal year 1876 being more than seventy-nine millions of dollars, in $\mathbf{1 8 7 7}$ more than one hundred and fifty-one millions, in $\mathbf{1 8 7 8}$ more than two hundred and fifty-seven millions, and for the year ending September 30, 1878, more than two hundred and ninety-four millions. For 1878 the excess was more than three 
times as great as the excess of 1876 , and more than two-thirds greater than that of 1877 .

\section{Sale of Bonds for Resumption Purposes.}

The Resumption Act not only fixed the day of resumption, but authorized the Secretary, in order to prepare and provide therefor, to use any surplus revenues not otherwise appropriated, and to sell at not less than par in coin any of the bonds of the United States described in the act of July 14, 1870. Under this act the Secretary in 1877 sold at par in coin fifteen millions of four and a halfs and twenty-five millions of fours, and in April, 1878, he sold fifty millions of four and a half per cents at a premium of one and a half per cent. The coin in the Treasury continually increased, so that on the day of resumption the Secretary held over one hundred and thirty-five millions $(\$ 135,382,639)$ of gold coin and bullion, and in addition over thirty-two millions of silver coin and bullion $(\$ 32,476,095)$, the gold alone being nearly forty per cent. of the United States notes then outstanding.

The banks in the eities of New York and Boston strengthened the hands of the Government by their action in 1878, an account of which has been heretofore given. The Assistant Treasurer of the United States in New York became a member of the clearing-house, thus facilitating the business of the banks with the Government, and the banks agreed to receive United States notes not only for their ordinary balances but in payment of interest upon the public debt and of other coin obligations of the Government. The banks of the country at the date of resumption held more than one-third of the outstanding Treasury notes; but they had so much confidence in the ability of the Secretary to maintain resumption that none were presented by them for redemption. The people also who held more than three hundred millions of the issues of the National banks, based upon the bonds of the nation, preferred such notes to coin itself. There was therefore no demand for payment of the notes of the Government, and the gold coin in the Treasury increased more than thirty-six millions in the ten months succeeding the date of resumption.*

\section{Refunding of the Public Debt.}

In regard to the National banks and the refunding of the public debt, the Comptroller said that the great war debt of the United States was contracted in less than four and a half years. In 1835 the country was entirely out of debt and on January 1,1861 , the whole public debt amounted to $\$ 66,243,721$ only. During the next six months it increased at the rate of about four millions a month, being on July 1, 1861, $\$ 90,580,873$. During the next year it increased at the rate of more than thirty-six millions a month, and at the close of the fiscal year ending July 1,1862 , it was $\$ 524,176,142$. At the end of the succeeding year it

*Comptroller's report, 1879. 
was $\$ 1,119,772,138$, having more than doubled. During the following year it increased nearly seven hundred millions, amounting on July 1 , 1864 , to $\$ 1,815,784,370$. During the next nine months, to the close of the war, April 1, 1865, the debt increased at the rate of about two millions a day, or sixty millions a month, and for the five months next thereafter at the rate of about three millions a day or ninety millions a month, reaching its maximum on August 31, 1865, at which date it amounted to $\$ 2,845,907,626$, and was composed of the following items:

Funded debt.

Matured debt..........................................

Temporary loans.......................................

Certificates of indebtedness...............................

Five per cent. legal-tender notes........................

Compound interest legal-tender notes... .................

Seven-thirty notes.

United States notes (legal tenders) .......................

Fractional currency...................................

Suspended requisitions uncalled for

Total.

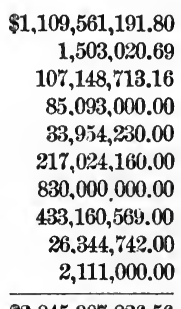

$\$ 2,845,907,826.56$

The temporary obligations of the Government are shown by the table to be more than one thousand two hundred and seventy-five millions of dollars. This immense amount was funded within the three years which followed the close of the war; and the skill and good judgment displayed in so doing can only be fully appreciated by those who are familiar with the difficulties and delicate conditions under which the work was accomplished. The temporary loans, certificates of indebtedness, seven-thirty notes and all the other items of the temporary debt, were either paid before and at maturity, or were funded into the five-twenty six per cent. bonds, more than one thousand six hundred millions of which were issued.

The acts of July 14, 18\%0, and January 20, 1871, authorized the issue of bonds for the purpose of funding the five-twenty six per cents. The former act authorized the issue of fifteen hundred millions of bonds, two hundred millions of which were to be five per cents. payable ten years after date, at the pleasure of the United States, three hundred millions of four and a half per cents. payable in fifteen years, and one thousand millions of four per cents. payable in thirty years from the date of their issue. These bonds were not to be sold for less than their par value in coin and the proceeds were to be applied to the redemption of the five-twenty bonds. The latter act increased the amount of the five per cents. to five hundred millions, but restricted the whole issue to the amount originally authorized, viz., fifteen hundred millions.

The whole amount of the funded debt on January 1, 1871, was $\$ 1,935,342,700$ of which $\$ 1,437,097,300$ consisted of five-twenty six per cent. bonds and $\$ 194,56 \%, 300$ of ten-forty five per cent. bonds. On August 1, 1871, nearly sixty-six millions of new five per cent. bonds had been subscribed for, chiefly by the National banks. During the same 
month an agreement was entered into by the Secretary with Jay Cooke \& Co. for the sale of the remaining two hundred millions of said bonds and in the month of January, 1873, similar arrangements were made for the sale of a large additional amount. The remainder of the five hundred millions $(\$ 178,548,300)$ was sold during the next three years, the Secretary of the Treasury stating in his report of December 6, 1875, that he had "the pleasure of announcing to Congress that the funding of five millions of six per cent. bonds into those bearing five per cent. interest had been accomplished."

\section{Contracts for the Sale of Bonds.}

On August 24, 1876, a new contract was made by the Secretary with A. Belmont \& Co. and associates, for the sale of the three hundred millions of dollars in four and a half per cent. bonds authorized. In this contract the Secretary reserved the right to terminate it by giving ten days' notice to the contractors, and under the contract calls were made prior to March 4, 1877, for the redemption of one hundred millions of six per cents.

In May, 1877, Secretary Sherman, availing himself of the privilege secured in the contract, gave notice that he would limit the sale of four and a half per cents to two hundred millions; and additional subscriptions were rapidly made until that amount was taken.

The avails of one hundred and eighty-five millions of these bonds were applied to the redemption of five-twenty sixes, the remaining fifteen millions being held for resumption purposes.

On June 9, 1877, a contract was made with a syndicate for the sale at par in coin of the four per cent. bonds authorized by the refunding act, with the right to terminate the contract at any time after December 31,1877 , by giving ten days' notice to the contracting parties. In 1877 seventy-five millions of the four per cents were sold, and in 1878 more than one hundred and twenty-five millions. During the first four months of 1879, over four hundred and ninety-seven millions of additional fours were disposed of, of which more than one hundred and forty-nine millions were disposed of at a premium of one-half of one per cent. Of this amount one hundred and twenty-one millions were taken by the First National Bank, of New York, and associates, and the remainder by other National banks. These, with the sales of forty millions of refunding certificates, completed the refunding of all the bonds of the United States which were redeemable.

\section{Sales of Bonds Under the Refunding and Resumption Acts.}

The sales of United States bonds from 1871 to 1879 , under the refunding acts, were five hundred millions of fives, one hundred and eighty-five millions of four and a halfs, and $\$ 710,345,950$ of four per cents; in all more than one thousand three hundred and ninety-five millions of dollars. 
There were also sold for resumption purposes after March 1, 1877, under authority of the act of January 14, 1875, for the resumption of specie payments, twenty-five millions of fours, and sixty-five millions of four and a half per cents; fifty millions of the latter being at a premium of one and a half per cent.

The reduction of the interest-bearing debt of the United States from its highest point on August 31, 1865, to Novenber 1, 1879, was $\$ 583$,886,594 .

At its highest point the annual interest on the debt was $\$ 150,977$,697 , and in 1879 it was reduced to $\$ 83,773,778$. The refunding operations of 1877-1879 effected an annual reduction of interest amounting to $\$ 14,290,416$, and were at the time without parallel in financial history.

\section{Public Debt of Great Britain.}

The public debt of England in January, 1793, amounted to $\$ 1,191$, 145,000. At that date began the great expenditures caused by the wars of the French Revolution and with Napoleon, extending from 1793 to 1816 .

Statement of British Debt, 1793-1816.

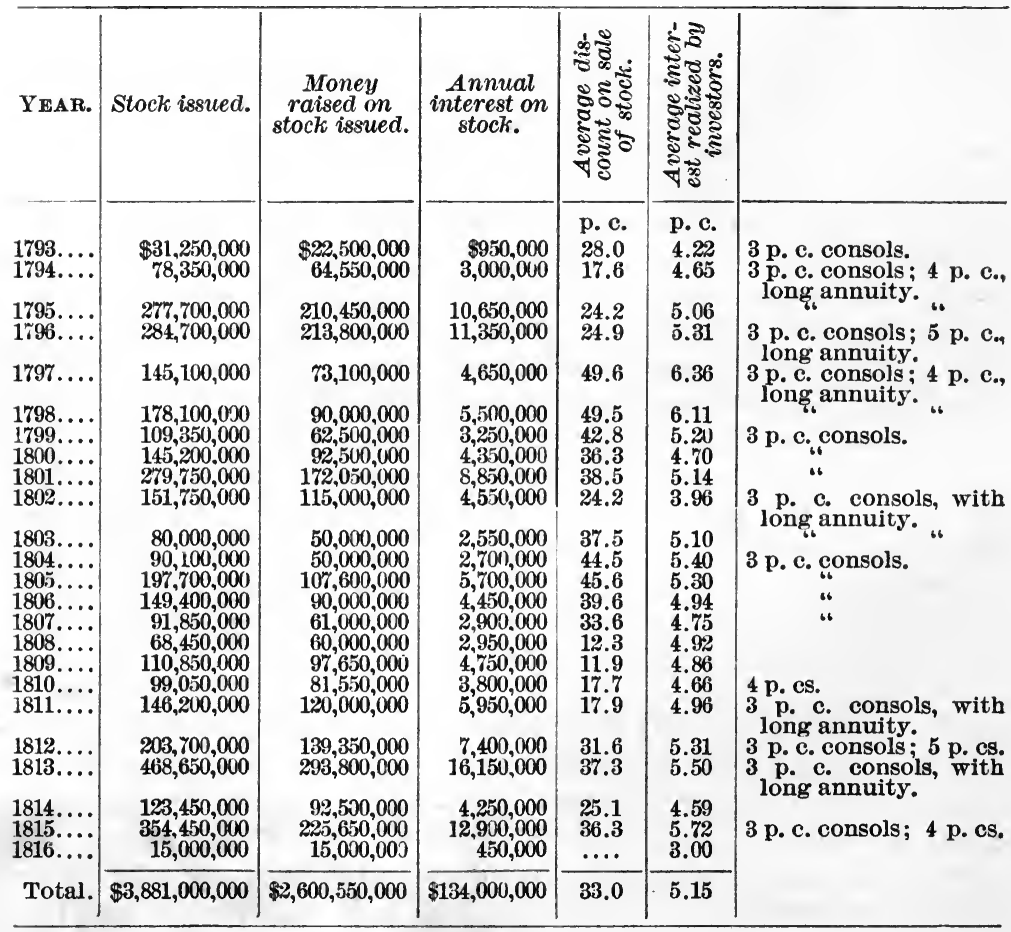


Between these dates stocks and annuities to the amount of 3,881 millions of dollars were placed on the market at rates of interest varying from three to five per cent. The average rate of discount at which the stock was sold was thirty-three per cent., and the average rate of interest paid on the money actually received from the sale was five and fifteen-hundredths per cent. In 1817 the total debt including exchequer bills and exchequer bonds was $\$ 1,040,543,610$, the annual interest on which was $\$ 142,750,195$. The total debt in 1875 had diminished to $\$ 3,876,741,930$, with an annual charge for interest and cost of management of $\$ 135,472,400$. In 1878 there appeared a slight increase, the amount of the debt then being $\$ 3,888,90 \%, 980$, with interest and cost of management amounting to $\$ 142,063,756$. The preceding table gives interesting information as to the rates at which the British debt was placed upon the market during the years 1793-1816, inclusive, showing the rates actually realized by investors, or what is the same thing in this case, the interest paid by the British Government for the money actually received. The pound sterling is counted as five dollars.

Proposed Substitution of Legat-Tender Notes for National BaNk CURrency.

In the year 1879, with the resumption of specie payments, there began a large influx of gold into the United States. The banks, however, did not increase their stock of gold in proportion. There were many propositions afoot for the substitution of Treasury notes for National bank notes. The Comptroller urgently recommended that the banks increase their gold coin to at least one hundred millions of dollars, and to insure this increase recommended that notes of the smaller denominations be withdrawn from circulation. The addition of coin to the circulation of the country would have had the effect of reducing the amount of paper money when in excess of the wants of business and to send home for redemption both legal-tender and National bank notes. The accumulation of the legal-tender notes in dull times in the money centers would lead, as it did, to constant agitation of the subject in Congress, because of the fancied connection between the dull times and the scarcity of currency away from the money centers. Then was the time to secure a currency that would act automatically, the best currency being that which most readily adapts itself to the wants of business, although the cost may be greater, because, notwithstanding the first expense, an elastic paper money is the cheapest in the end.

The Comptroller saw the danger to the National banking system and to the finances of the country from an increase of Treasury notes, and very strenuously argued against any action by Congress that would permit it.

In order to save the net amount of about twelve millions of dollars interest paid by the Government to the National banks upon the bonds 
deposited to secure their circulation, it was proposed to abolish the National banking system and issue additional Treasury notes. He prophesied that the abolition of the National banking system would be followed by agitation for the repeal of the tax prohibiting State bank circulation, and said:

"The South desires the repeal of this tax because it believes that such repeal will be followed by the organization of numerous banks under State charters, which will issue circulation that, for a time at least, will stimulate the business of that section of the country. The East and North and a portion of the West desire it, for a different reason, perhaps, in the event of the abolition of the National banking system, namely, to prevent the issue of Government notes, because they believe that a system of State notes, at the worst, can only injure the credit of individuals, while the unrestricted issue of United States notes may be followed by a new suspension of specie payments, and injure not only every kind of private business, but also the credit of the nation."

If the ideas of the Comptroller at this time had been found capable of being put into practice in the face of the political elements striving for cheaper money, the National banks would, in the end, no doubt, have furnished the paper currency of the United States.

\section{Value of Circulation Privilege in 1879.}

In 1879 the Comptroller calculated the value of the circulation privilege to the National banks as follows: The banks then held $\$ 7,22 \%, 700$ of called bonds, five and six per cents, upon which interest had ceased. The other five and six per cents held by the banks would become payable in a little over a year, with the exception of the Pacific railroad currency sixes, of which they held only $\$ 4,465,000$. These bonds, when payable, he assumed, would all be exchanged for others bearing a lower rate of interest. Supposing all should be converted into four per cents, the annual interest received on their bonds by the banks would be $\$ 9,822,666$. If the capital invested in bonds were loaned directly upon commercial paper or upon bonds and mortgages at eight per cent., it would yield $\$ 29,722,656$, instead of the amount received as interest on the bonds deposited to secure circulation. The circulation received on the four per cents would, at eight per cent., earn $\$ 24,884,084$, and this added to the $\$ 9,822,666$ interest received on the four per cents would make a total income to the banks from their bonds and circulation of $\$ 34,706,750$, which exceeds the sum the banks could earn by loaning the capital invested in four per cent. bonds by about five millions of dollars only; or, in other words, this differense of five millions of dollars is the real profit the banks derive from circulation, and was, in $18 \% 9$, only one and three-tenths per cent. upon the capital invested in bonds. That this profit was not any great inducement to the investment of capital in National bank stock is shown by the fact that at this time there were 1,005 State banks and 2,634 private bankers in the country who found banking more profitable outside of than in the National banking system. 


\section{Illegal Certification of Checks.}

The certification of checks illegally by some of the National banks in New York city attracted public attention this year. The history of this was that on February 19 and March 3, 1869, two extraordinary acts were passed by the Fortieth Congress in reference to the business of banking. The first prohibited the loaning of money upon United States or National bank notes as collateral security, for the purpose of contracting the currency, and the second prohibited the certification of checks drawn upon any National bank unless the drawer actually had the money on deposit in such bank. The penalty for the violation of the first section was a fine of one thousand dollars and a forfeiture of one-third of the money loaned. The officer or officers of the bank were also liable to a further penalty equal to one-fourth of the money loaned. The penalty for the illegal certification of checks was forfeiture of the charter of the bank. This last penalty was found inadequate to stop the illegal certification of checks. It seemed an unsuitable remedy, as it necessitated the closing, it might be at great loss to innocent stockholders, of institutions otherwise of benefit to the community and perfectly solvent. The House, therefore, on June 19, 1870, passed another act imposing a fine of of not more than five thousand dollars and not more than five years' imprisonment, or both, upon the officers of a bank who should illegally certify checks. This bill passed the House almost unanimously, but failed in the Senate. The practice, however, was checked and was not renewed to any great extent until 1879, when the Comptroller took action to check it by ordering special examinations in order to procure evidence, if any such existed, upon which to base suits for forfeiture of charter. This had the expected effect of again checking the practice.

\section{CoMPtRolLER's RePORT FOR 1880.}

In his report for 1880 the Comptroller gave an account of the operations of the National banks after the resumption of specie payments, referring to the increase in loans and the reduction of interest rates. $\mathrm{He}$ also made some comparisons with the operations of the banks of England and France. In summing up he said:

"This brief outline of some of the transactions of the National banks covers the most important period of the financial history of the country, and shows the immense advantage experienced from having during the years following the great war an excellent banking system. The system was established, not for the benefit of the stockholders of the banks, but for the benefit of the people. Its ample basis of unimpaired capital, its large surplus, its large cash reserves, its secured circulation, its protection to depositors and its general management, must commend it to every student of political economy ; and it is among the most gratifying of political signs that during the late exciting campaign, while both parties have claimed the credit of having brought about a return to specie payments, neither party has urged the abolishment of the system. The National banks have now entered upon a new 
career. The machinery is in excellent working order, and but little legislation is needed to perfect it into a homogeneous system which will be part and parcel of the nation."

How little these expectations were fulfilled will be seen in future pages. In fact, the very next year an attack was begun upon the system, which has been kept up with great pertinacity in one or more directions until the national currency issued by the banks has been almost entirely superseded by the direct issues of the Government, and the usefulness of the National banks and their safety and solvency have been impaired by unwise flnancial legislation. In the report of 1880 , the Comptroller discussed the rates of taxation, the losses of the banks as compared with their surplus, dividends and earnings, and renewed previous recommendations for the repeal of the tax on capital and deposits, and of the two-cent stamp tax on bank checks. The National Bank Act authorized the use as reserve of clearing-house certificates representing specie or lawful money specially deposited for the purposes of any clearing-house association. The law also allowed the issue of certificates of deposit for legal-tender notes by the Secretary of the Treasury. They were issued in denominations of $\$ 5,000$ first in 1873 . On June 30,1875 , there were outstanding $\$ 59,045,000$, of which the banks held $\$ 47,310,000$. June $30,18 \% 6$, there were $\$ 33,140,000$ outstanding, the banks holding $\$ 29,330,000$. On June 30,1879 , the amount was reduced to $\$ 29,330,000$, of which the banks held (June 14) $\$ 25,180$,000 . On October 1,1880 , these certificates were reduced to $\$ 9,885,000$, the banks holding $\$ 7,655,000$. The rapid redemption of these certificates after resumption was due to the demand for United States notes. They had been used for effecting clearings for which they were most convenient. Grold certificates, also first issued by the Treasurer in 1865, were used for clearing-house purposes. On June 30, 1875, there were $\$ 21,796,300$ of these certificates outstanding, the National banks holding $\$ 12,642,180$. The Treasury discontinued the issue of gold certificates December 1, 1878, and the outstanding amount decreased so that the banks no longer found them available.

These two sources of convenient documents, representing legaltenders and gold, suitable for effecting clearings having failed, and gold coin having rapidly accumulated, the banks in New York established a depository for gold coin for the convenience of the clearing-house. This was the Bank of America, which issued the first bank certificates of deposit on October 14, 1879. The full capacity of the vault was $\$ 39,550,000$. Of these certificates the National banks on October 1 , 1880 , held $\$ 36,189,000$. Similar depositories of gold coin, for which clearing-house certificates were issued, were agreed upon by the clearing-house banks of Boston, Philadelphia and Baltimore. This device saved the risk and inconvenience of transporting the coin itself from bank to bank in the payment of clearing-house balances.

The small profit on circulation tended to take away the property of 
elasticity from the National bank circulation, and the Comptroller recommended that upon the deposit of the necessary amount of bonds the banks be permitted to issue circulation to an amount equal to their paid-in capital. A bill for this purpose was then pending in Congress, and the Comptroller stated that the National bank circulation could, if the banks deposited the necessary bonds, under present law be increased seventy millions of dollars. He did not think, therefore, that there would be a very great increase, but thought that at certain seasons of the year the permission given in the bill would be desirable. He said there was a certain class of banks with capital exceeding five hundred thousand dollars that would find it convenient during the fall season when currency was in demand to increase their circulation, notwithstanding the high price of bonds.

The Comptroller called attention to the requirement of existing law that all National bank notes be signed by the President or Vice-President, and the Cashier of the issuing bank. A number of banks had sought to relieve their officers of the labor of signing notes by having the necessary signatures lithographed, and the Comptroller recommended a law requiring the written signature of at least one bank officer, and imposing a penalty for evasion. 


\section{HISTORY OF THE NATIONAL BANKING SYSTEM FROM 1881 TO 1884.}

Legislation of 1881 - Forcing National banks to buy bonds - Proposed repeal of act of June 20,1874-Synopsis of bill of 1881 - Veto of bill - Withdrawal of bonds by banks-Attitude of the Treasurer of the United States - Extension of bonds in 1881 - Renewal of National bank charters-Extension act of 1882-Organization of new banks - Bank failures in 1882 - Losses by National bank insolvency Contraction of National bank currency - Comptroller's plan for reducing interest on bonds - Over-certification of checks - Legislation of 1883-84.

\section{National Bank Legislation of 1881.}

The year 1881 opened with the consideration by Congress of legislation very important to the National banks. A large portion of the public debt, bearing interest at the rate of five and six per cent., was to mature on or before July 1, and it was necessary to provide for the refunding of the principal part of these bonds. A bill was prepared authorizing the issue of four hundred millions of three per cent. bonds redeemable after five and payable after ten years from the date of issue, and also certificates to the amount of three hundred millions of dollars redeemable after one year and payable after ten years, also bearing three per cent. interest. These bonds were to be sold and the proceeds used to pay the maturing bonds, or they might be exchanged for them, the rate of interest being adjusted. The National banks held about two hundred and ten millions of dollars in the maturing bonds.

A section was appended to the refunding bill for the purpose of obtaining as large a market as possible for the new bonds among the National banks. This section provided that after May 1, 1881, when the fives matured, the new three per cent. bonds should be the only United States securities receivable as security for National bank circulation. It was provided that bonds deposited to secure circulation, upon which interest had ceased, should be withdrawn within thirty days from such cessation of interest or the bank might be placed in the hands of a Receiver. Under the act of June 20,1874, the retirement of circulation in order to withdraw the bond or bonds securing it was a simple matter, inasmuch as the bank could deposit legal-tender notes equalling the circulation with the Treasurer of the United States, the Government becoming responsible for the redemption of the notes. Before June 20, 1874, the withdrawal of bonds had been a more difficult 
matter, because it had been necessary for the bank desiring to do so to gather up its circulation, the very notes themselves, and return them to the Comptroller of the Currency. As the notes of each particular bank became seattered all over the country, it was almost an impossibility to gather them up within any reasonable time. The act of June 20,1874 , had been passed to remedy this difficulty and to facilitate a redistribution of the currency among the different sections of the country. Practically a National bank desiring to withdraw its bonds would borrow of its correspondent the legal-tender notes necessary to retire the circulation based thereon, the deposit would be made with the United States Treasurer, who would turn over the bonds to the correspondent bank. The latter would sell the bonds, reimburse itself, and return the balance to the borrowing bank

\section{Proposed Repeal of the ACt of June 20, 1874.}

Another provision of the bill before Congress was to repeal the act of June 20,1874, and thus leave to the banks that would soon be obliged to withdraw maturing bonds, only the extremely impracticable resource of gathering up their own notes and sending them in for retirement. This they would have to do within the thirty days after maturity, or failing to do so they would be placed in the hands of Receivers to be closed and liquidated according to law. The banks could, if they did not care to gather up their circulation, purchase the new bonds and exchange them for the maturing bonds. As the majority of these institutions had all their resources loaned out in the usual course of business, they were not prepared to advance the money necessary to buy the new bonds in order to substitute them for the maturing bonds. Their only other resource was to borrow the money for the purpose. With the outlook that thousands of banks would in the event of the passage of the bill be seeking to borrow money for the same purpose, there was danger that a panic would be produced in the money market. There was still another thing that many banks might do to avoid the difficulty which the proposed bill seemed to place them in, and that was to reduce their bonds to the minimum required by the act of June 20, 1874, viz., $\$ 50,000$, in advance of the passage of the bill. But to prevent this action the minimum was raised by the bill to onethird of the capital stock.

\section{Synopsis OF THE BILL OF 1881.}

The bill prevented the banks from depositing legal-tender notes to retire circulation, and compelled them to gather up the circulation itself in order to withdraw their maturing bonds. It increased the minimum of bonds they were obliged to keep on deposit, and compelled them to buy a certain amount of bonds at par, the rate of interest on which was so low that it was uncertain whether the bonds would remain at par in the market or not. On January 25, 1881, the Finance Committee of 
the Senate invited Mr. Sherman, the Secretary of the Treasury, Mr. Upton, the Assistant Secretary, and Mr. Knox, the Comptroller of the Currency, to give their views on the bill. Mr. Sherman expressed the opinion that the loan could not be negotiated at three per cent. interest, and produced tables to sustain his view. Mr. Knox said:

"Section five of the funding act of 1881 deranges the whole machinery of free banking. It prevents the banks from increasing and reducing their circulation at pleasure and provides in effect for a permanent deposit of bonds amounting to onethird of the capital of each bank. It also provides that if a bank has too much circulation it shall keep it, and if it has too little it should not increase it unless it shall deposit bonds which are almost certain to be worth less than par. It subjects the banks to an almost certain loss and compels them to continue to submit to the loss when they might at times retrieve or diminish it by depositing lawful money in the Treasury and again coming into possession of their own bonds if the market price should be sufficient to justify a sale."

The interview continued several days. The Treasurer of the United States, Mr. Gilfillan, declared himself in favor of the repeal of the act of June 20, 1874. He asserted that in some instances the privilege of depositing legal-tender notes to retire circulation had been used for speculative purposes, and that it had caused loss to the United States in printing new bank notes taken out immediately in place of those retired. The bill, including the fifth section, finally passed both houses of Congress, but was vetoed by President Hayes on March 3, 1881.

\section{Withdrawal of Bonds by Banks.}

The banks, alarmed by the impending passage of the bill which would prevent the free withdrawal of their bonds by depositing legaltender notes, and compel them to gather up their circulation with great inconvenience to themselves and to the whole country, took advantage of the time remaining and deposited legal-tenders. The number of banks taking this course was 141, located in twenty-four States, and the amount of legal-tenders deposited by them was $\$ 18,764$,434 , as shown by the following table:

\begin{tabular}{|c|c|c|c|c|}
\hline States and Crties. & $\begin{array}{l}\text { No. of } \\
\text { banks. }\end{array}$ & Amount. & States and Crties. & $\begin{array}{l}\text { No. of } \\
\text { banks. }\end{array}$ \\
\hline Philadelphia.......... & 6 & $\$ 2,590,800$ & New York city....... & 9 \\
\hline Pennsyivania......... & 14 & $2,083,300$ & New York............ & 23 \\
\hline Boston ............... & 4 & $1,034,100$ & New Jersey.......... & $\mathbf{5}$ \\
\hline Massachusetts......... & 2 & 81,000 & Indiana.............. & 10 \\
\hline Connecticut .......... & 10 & $1,675,400$ & Missouri.............. & 3 \\
\hline Montana................. & 1 & 36,000 & Virginia.............. & 1 \\
\hline District of Columbia. & 1 & 72,000 & Ohio................. & 19 \\
\hline Rhode Island......... & 2 & 385,200 & Minnesota............ & 3 \\
\hline Nebraska............. & 2 & 171,900 & Kentucky............. & 1 \\
\hline 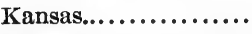 & 2 & 81,000 & Michigan............. & 1 \\
\hline Illinois............... & 10 & 845,900 & Iowa................ & 4 \\
\hline Maine................. & 2 & 135,000 & Vermont.............. & 3 \\
\hline North Carolina....... & 1 & 135,000 & Wisconsin............ & 1 \\
\hline Maryland............. & 1 & 72,000 & & - \\
\hline
\end{tabular}

Amount. $2,843,849$ $1,931,600$ 837,000

$1,080,000$ 164,745 45,000

$1,402,630$ 135,000 310,900 27,000 100,460 463,500 21,150

Totals 
One-third of the bonds so withdrawn were subsequently redeposited. For some months afterwards the total amount of bonds redeposited by the banks making these withdrawals was less than seven millions of dollars. There was no evidence obtained that there was any combination among the banks to deposit legal-tenders and withdraw bonds for the purpose of deranging the money market, although the fact of such a combination was often asserted by those hostile to the banks. If the bill had passed there were nearly seventy millions of bonds held by the banks which would have been subject to compulsory withdrawal, and that only eighteen millions were actually withdrawn in anticipation is of itself a proof that there was no combination.

\section{Position of the United States Treasurer.}

Why this compulsory and unnecessary feature of the bill was introduced is somewhat of a mystery, but it seems to have been in some way the result of a spirit of hostility to the National bank circulation, and of a desire to substitute Treasury notes and Government paper for such circulation. The Treasurer of the United States had been hostile to Section four of the act of June 20,1874, from the very beginning of its operations, and had endeavored to construe it most unfavorably to the banks. He first sought to compel small banks with a capital of less than one hundred and fifty thousand dollars, which, under the previous law had been required to maintain a minimum deposit of bonds equal to onethird of their capital, to increase that sum to fifty thousand dollars. The question raised by him was referred to the Attorney-General, who decided that fifty thousand was the minimum for those banks only whose capital was of such amount that one-third thereof would equal fifty thousand dollars or more, but that where the capital stock of a bank was such that one-third of it was less than fifty thousand dollars, then such one-third of the capital was the minimum deposit of bonds for such bank.

Defeated in his construction of law in this case, Treasurer Gilfillan raised another point after the veto of the funding act of 1881 . Before May 23, 1881, he as well as his predecessors in office had, as a matter of convenience both to the banks and the Government, permitted the redemption of bonds called for payment by the following method. The banks sent a power of attorney authorizing the Comptroller to withdraw the bonds and the Treasurer of the United States to assign them to the Secretary of the Treasury for redemption on account of the bank, as much of the proceeds of the bonds as might be necessary to be used to retire the circulation secured by the bonds, the latter being never out of the hands of the officers of the Treasury Department. The banks were thus relieved from the necessity of first sending in money to retire their circulation and the Government was enabled to get its bonds with more promptitude. On May 23 Treasurer Gilfillan declined longer to allow this method of withdrawal and redemption, alleging 
that the proceeds of the bonds were coin, and not legal-tender notes, and that Section four of the act of June 20,1874, required deposits for the retirement of eirculation to be made in legal-tender notes orily. This question was likewise referred to the Attorney-General. The AttorneyGeneral decided that Government notes are promises to pay dollars and for such promises the thing promised may be substituted by the promiser, and that coin of the United States is a legal tender in all payments.

These endeavors of the Treasurer to throw obstructions in the way of the free redemption and issue of National bank notes were defeated, but it is certain that if the act of June 20,1874 , had been repealed, or if the narrow constructions sought to be put upon it by the Treasurer had prevailed, the refunding operations of 1881 would have been performed with far greater inconvenience.

\section{Continuance of Five and Six Per Cent. Bonds in 1881.}

The refunding bill of 1881 having failed to receive the President's signature, another course was taken by the new Administration of President Garfield, who succeeded President Hayes on March 4, 1881, in regard to the maturing debt of the United States. Mr. Windom, the Secretary of the Treasury, adopted a plan for extending these bonds at a reduced rate of interest. On March 1, 1881, five per cent. bonds amounting to $\$ 469,320,650$ were outstanding redeemable at the option of the Government after May 1, 1881, and six per cent. bonds amounting to $\$ 202,266,550$ were also outstanding redeemable after July 1, 1881. On April 11 the whole amount of six per cent. bonds was called for payment on July 1, 1881, but to holders of all the six per cent. bonds permission was given to have their bonds continued at the pleasure of the Government with interest at three and a half per cent. per annum, provided they should so request and the bonds should be received by the Treasury on or before May 10,1881, the time being subsequently extended until May 20. There were presented for continuance \$178,055,150 out of the $\$ 202,266,550$ of outstanding sixes. The remainder, $\$ 24,211,400$, were paid upon presentation, interest having ceased. On May 12 a similar offer was made to the holders of the five per cent. bonds, the limit of time for presentation for extension being fixed on July 1, 1881. On the latter date notice was given of the payment on October 1, 1881, of the registered fives, whose holders had not availed themselves of the privilege of continuance. The total amount of fives continued was $\$ 401,504,900$, and the amount paid $\$ 67,815,750$. Of the maturing sixes $\$ 61,901,800$ were held by the banks and $\$ 53,741,600$ were continued at three and a half per cent. Of the maturing fives $\$ 172,-$ 348,350 were held by the banks. All of these were continued, and on November 1 the holdings of fives continued at the lower rate of interest had increased to $\$ 187,634,550$. On the whole the veto of the refunding bill of 1881 by President Hayes appears to have been a wise exercise of the power resting in him. The rate of three per cent. fixed for the 
bonds authorized by the bill was not warranted by the state of the markets or the borrowing power of the United States. The effort in the bill to give the bonds a forced circulation at the expense of the National banking system, if persisted in, would most probably have utterly deranged the money market and discredited the bonds. The three and a half per cent. rate adopted for continuing the sixes and fives was probably a little more than the true figure at which the Government could have borrowed upon new bonds duly authorized, but not more in excess than the expense of floating a new loan.

\section{Extension of Corporate Existence of the National Banks.}

In his report for 1881 the Comptroller called the attention of Congress to the fact that the corporate existence of the first organized National bank would expire on January 1, 1882, and that on and before February 25, 1883, the corporate existence of 393 National banks would expire. He recommended the enactment of a law for the extension of the charter of the banks about to expire. The first currency act creating the National banking system, which became a law February 25, 1863 , contained a provision that the corporate existence, or succession, of each bank should be for the period mentioned in its articles of association, but not exceeding twenty years from the date of the act. Some few banks in their articles of association fixed periods rather less than the twenty years from the date of the act and these were the ones whose corporate existence expired before February 25, 1883. The act of June 3, 1864, which superseded the act of February 25, 1863, and Section $\mathbf{5 1 3 6}$ of the Revised Statutes, provided that the banks organized under those acts should have a corporate existence for twenty years from the date of their organization certificate.

The recommendation of the Comptroller was that an act be passed authorizing any National bank with the approval of the Comptroller, at any time within two years prior to the date of the expiration of its corporate existence, to extend its period of succession for twenty years by amending its articies of association. The necessary amendment to the articles of association was to be agreed to by the vote of shareholders owning two-thirds of the stock and duly certified to the Comp. troller. The object was that the responsibility for extension might rest with the Comptroller and to enable him to examine throughly as to the condition of the bank. The Comptroller further suggested that if, for any reason, Congress should not favorably consider a bill for extending charters, the banks could still under existing law renew their existence if they so desired, and in the absence of prohibitory legislation many of them would undoubtedly on the expiration of their charters organize new associations with nearly the same stockholders as before and would then apply for and obtain from the Comptroller of the Currency certificates authorizing them to continue business for twenty years from the dates of their new organization certificates. Such a course of procedure 
would have been perfectly legal, and the Comptroller had no discretionary power in the matter. The Attorney-General on February 23, 1882 , rendered an opinion in which he decided that the National banking laws did not prevent the stockholders of an association, the corporate existence of which had expired, from organizing a new association with the same name. Nor was there anything in the banking laws to prevent an expiring National association being converted into a State bank, and that bank subsequently reconverting into a National bank with the name of the expired National association.

\section{Passage of the Extension Act of July 12, 1882.}

Soon after the assembling of Congress in December, 1881, a bill was introduced for the extension of the corporate existence of National banks, embodying the recommendations of the Comptroller. It was amended in many particulars and passed the House on May 30, 1882, by a vote of one hundred and twenty-five to sixty-seven. It was still further amended in the Senate, passing that body June 22, 1882, by a vote of thirty-four to fourteen. It again passed the House on the report of the Conference Committee, July 10, one hundred and ten to seventy-nine, one hundred and one not voting, and was approved by the President July 12, 1882.

The act provided for the extension of the corporate existence of all National banks for twenty years, by the amendment of their articles of association. It provided that the Comptroller upon receipt of the application of the bank and the anendment certified by the association, shall cause a special examination to be made to determine its condition, and authorized him to grant his certificate for the proposed extension if the condition of the association is found to be satisfactory. It provided that any shareholder not assenting to the amendment of the articles of association may give notice in writing to the directors within thirty days of the date of the certificate of approval of the Comptroller that he desires to withdraw from said association, in which case he was authorized to receive the value of his shares, to be determined in a specified way. The law also provided that in any association organized to take the place of an expiring association, and retaining the same name, the shareholders of the old association shall be entitled to preference in the allotment of shares of the new association in proportion to the number of shares held by them in the old. The circulating notes of an association extending its corporate existence, issued to it previous to such extension, were to be retired gradually by redemption, but at the end of three years lawful money was to be deposited to retire all such circulation as might at the end of that period remain outstanding, and any gain that might arise from any notes that might for any reason fail to be presented for redemption should enure to the benefit of the United States. Notes of a new pattern were to be issued to the extending bank to render them easily distinguishable 
from the old. Banks whose charters expired that did not avail themselves of the privilege of extension were to give notice of liquidation and deposit lawful money according to law. Such expiring banks as might require time to liquidate their affairs were permitted to continue their corporate existence for that sole purpose. The new notes issued were prepared with special provisions against counterfeiting. The five dollar note bore for its vignette a portrait of President Garfield, and those of other denominations had the charter number of the bank printed six times in the margin. The colors were brown and green.

\section{Extension of National Bank Charters.}

By November, 1882, thirty banks had extended their corporate existence under the law, and nearly all those organized under the first Currency Act of February 25, 1863, had given notice of their intention to extend. The total number of banks whose charters had expired up to November 1, 1882, was eighty-six. Of these fifty were placed in voluntary liquidation by their stockholders previous to the date of the expiration of their charter, and all but two previous to the enactment of the act of extension on July 12, 1882. The stockholders of forty-five of the fifty liquidating banks organized new associations with the same names, those of four new associations with a different name, and one did not perfect a new organization. The corporate existence of six of the eighty-six banks expired without any action having been taken by their stockholders for their liquidation, but they were revived for that purpose by Section 7 of the extension act. The united stockholders of three of the six banks perfected new organizations with the same name, in the case of two others the stockholders organized new associations with different names, while in the remaining case the stockholders took no action. The remaining thirty of the eighty-six banks expiring up to November 1, 1882, extended under the new law. The following tables show the dates of expiration of charters of all National banks up to the year 1900, with the exception of the eighty-six already mentioned.

Organized under Act of February 25, 1863.

Date of Expiration.

No. of banks.

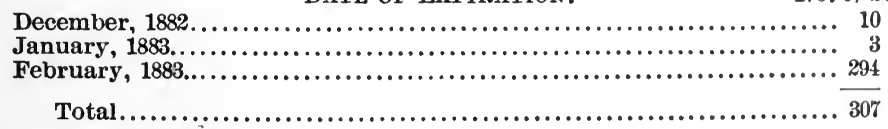

Organized under Act of June 3, 1864.

\begin{tabular}{|c|c|c|c|}
\hline YEAR OF EXPIRATION. & $\begin{array}{l}\text { D. of } \\
\text { nks. }\end{array}$ & YEAR OF EXPIRATION. & $\begin{array}{l}\text { No. of } \\
\text { banks. }\end{array}$ \\
\hline $1884 \ldots \ldots \ldots \ldots \ldots \ldots \ldots \ldots$ & 249 & $1893 \ldots \ldots \ldots \ldots \ldots \ldots \ldots \ldots$ & . 39 \\
\hline $1885 \ldots \ldots \ldots \ldots . . . . . .$. & 734 & $1894 \ldots \ldots \ldots \ldots \ldots$ & 68 \\
\hline $1886 . .$. & 19 & ....................... & 83 \\
\hline .................... & 6 & 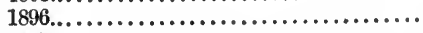 & 24 \\
\hline & 11 & 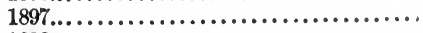 & 29 \\
\hline 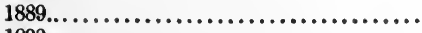 & 3 & 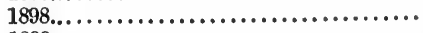 & 27 \\
\hline 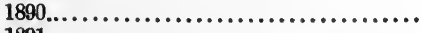 & 63 & 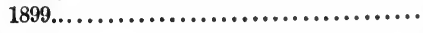 & 43 \\
\hline & 105 & & \\
\hline & 105 & tal. & \\
\hline
\end{tabular}




\section{Organization of New BaNks.}

The foregoing indicates the various motives controlling in the continuance of business under the National law of those having their capital invested. Before the enactment of the extension act the banks whose charters expired while uncertainty of its final passage prevailed, were forced to take action in order to continue business, and this explains why so many of these banks went into voluntary liquidation and organized new banks with the same name but with a different charter number. But the passage of the extension act did not furnish or remove all motive for taking this course in preference to the more simple method of extending the charter. In the case of many banks the stockholders owning the controlling interest in the stock either were or fancied themselves to be handicapped by having a large amount of stock in the hands of people who were of no value to the business of the bank. In the course of twenty years, as active men of business died out, their stock went to their heirs who often took no interest in the bank further than to draw dividends, kept no account there and brought no business to the institution. In these cases the controlling stockholders found they could get rid of what they styled dead wood, by liquidating the old bank, paying off the undesirable stockholders and organizing a new bank, in which all the stock might be held by themselves and those they regarded as desirable associates from a business point of view.

Before the passage of the extension act there was nuthing to prevent the new organization taking the name of the old, and to be to the public virtually though not technically the same bank. But while the extension act was before Congress, some complaints were received from the stockholders frozen out by this method, and a provision was inserted in the act preventing the retention of the name of the old bank by the new unless the allotment of the new stock was the same as before the reorganization. The name was a somewhat valuable asset and this provision of the act stopped many schemes of the kind mentioned, although it did not altogether prevent reorganizations for the purpose of a new distribution of stock. LIn many instances the controlling interest preferred to take a new name rather than be loaded up with undesirable associates. The advantage of extension of charter over reorganization was that the surplus was retained in the first case, while in the latter it had to be distributed among the stockholders.

\section{Comptroller's REPORT FOR 1882.}

In his report for the year 1882 the Comptroller makes some reflections upon the future of National bank currency. He said, after recommending that the issue of circulation to National banks be enlarged to ninety per cent. of the current market value of four and four and a 
half per cent. bonds, "If, however, it shall be the policy of the Government to accumulate the revenue in place of largely reducing it, thus rendering it necessary to continue the rapid reduction of the debt, even if it is to be purchased at the price fixed by the holders, it is of the greatest importance that the basis on which the bank currency is issued should be enlarged so as to include some other form of security besides Government credit. $* * *$ The National banking system was established with a view to uproot other and evil systems, and nothing but the heroic legislation of taxing bad issues of circulation out of existence, which was passed in the interests of the Government during a great war, could have accomplished this purpose. By increasing the rate of issue upon the bonds pledged by the banks as security for their circulation, or by reducing the tax upon bank notes, or by a proper refunding of the debt, and reducing the revenue derived in many instances from unjust and burdensome taxation, the system may continue for twenty-five years or until the maturity of the four per cent. bonds ; but it is far better that the right to issue notes should be gradually discontinued than that so good a system should be used to bring again upon the country the very evils which were experienced before its organization twenty years ago." *

\section{Bank Failures in 1882.}

During the year 1882 there were several failures of conspicuous National banks in Newark, New Jersey, Buffalo, New York, and in Boston. The Comptroller said in regard to bank failures and liquidations that since the commencement of the National banking system eightyseven banks have been placed in the hands of Receivers and four hundred and twenty banks have voluntarily closed their business by the votes of shareholders owning two-thirds of their stock. Seven of the banks in voluntary liquidation failed to pay depositors and were placed in the hands of Receivers.

\section{Losses By National Bank'Insolvency.}

The loss to creditors of eighty-seven National banks placed in the hands of Receivers had, up to that time, been about seven millions of dollars. The average annual loss had therefore been about $\$ 400,000$

* EDITOR's NoTE.-Mr. Knox, in his report for 1882, argued against the advisability of permitting the National banks to issue notes based on the security of their general assets and a safety fund (see report of the Comptroller of the Currency for 1882, p. 16). He afterwards changed his views, and was the author of a bill permitting the issue of notes to the extent of seventy-five per cent. of capital, thirty-five per cent. to be secured by bonds, thirty-five per cent. by gold coin or bullion or silver bullion, five per cent. to be secured by the general assets and a safety fund. ("Rhodes' Journal of Banking," February, 1890, p. 140.) The following statement in regard to the views of Mr. Knox is from "National and State Banks," by Horace White, p.14; ("Sound Currency," Vol. IV):

"The late Mr. Knox, whose authority is far greater than mine on any banking question, argued in his report as Comptroller of the Currency for 1882 against the safety-fund plan. *** Mr. Knox changed his views on this subject completely a few years before his death, as he told meand others." 
in the business of a system of banks having an average eapital of $\$ 450$,000,000 , and which has been responsible for the keeping of deposits averaging from day to day during twenty years over eight hundred millions of dollars, or expressed in percentage, an annual loss of onetwentieth of one per cent. The Comptroller also spoke of the delays caused by litigation in the closing of insolvent banks, saying :

"In many of these cases no conclusion can be reached until the matter has been brought before the courts of last resort. The dockets of the supreme courts in most of the States, and that of the Supreme Court of the United States, are crowded, and when an appeal is made to these tribunals years often elapse before a case can be reached. Owing, however, to the decisions already made, the forms of procedure, under the laws governing National banks, are better understood, and in collecting assets, in allowing offsets, and enforcing the liability of stockholders, the inducements to protract litigation, either upon the part of ordinary debtors of the bank or of the stockholders assessed for their personal liability, are becoming less and less."

\section{Excessive Bank Loans.}

In his report for 1882 , as in previous reports, the Comptroller called attention to the difficulty of enforcing the provisions of the law restricting loans to ten per cent. of the capital stock of a bank. He said:

"In cities where large amounts of produce are received and stored, it is represented that it is impossible for banks to transact this class of business if restricted to the legal limit. It is true the limitation does not apply to loans upon produce in transit where drafts are drawn upon existing values; but if produce is stored instead of being shipped, large loans cannot be made except in violation of law. In such case the Comptroller has no means of enforcing the law except by bringing a suit for forfeiture of charter, and this course might result in great embarrassment to business as well as loss to many innocent stockholders of the banks."

He recommended an amendment to the law relieving legitimate loans upon produce or warehouse receipts and some other classes of collateral, as well as United States bonds, from the limitation fixed in the law.

\section{Contraction of National Bank CuRrency in 1883.}

In the year 1883 the contraction of the National bank circulation due to the rapid payment of the debt of the United States began to be very noticeable. During the year ending November 1,1883 , more than one hundred and five millions of the public debt were called in and paid, and all of the remaining three and a half per cents were called for payment and had ceased to bear interest. Notwithstanding the fact that 262 new banks were organized with a capital of $\$ 28,654,350$, depositing $\$ 9,375,550$ of bonds as security for circulating notes, the aggregate amount of bonds on deposit for that purpose had diminished from $\$ 362,490,650$ to $\$ 352,907,300$, a reduction of $\$ 9,583,350$. More than forty millions of three and a half per cent. bonds held by the banks a year previous had been withdrawn or called for payment, the threes had increased less than twenty-two millions, and the fours and four and a halfs less than nine millions. 
The extension act of 1882 had contained a section authorizing the Secretary of the Treasury to issue three per cent. bonds in exchange for three and a half per cents, the new bonds not to be called for payment until all bonds payable at the option of the Government bearing a higher rate of interest had been called. The National banks had availed themselves of the exchange to a great extent, hoping to postpone thereby the day of payment of the bonds held by them, and of the two hundred and sixty-five millions of threes outstanding on November 1, 1883, the banks held more than two-thirds. Already at that date forty millions of the threes had been called, eighteen millions of which were held by the banks. The Comptroller said that unless there shall be legislation by the present Congress reducing the receipts of the Government, it is probable that the United States bonds will continue to be paid at the same annual rate, and at this rate all the threes will be called during the next three years. This will reduce the bonds from three hundred and fifty-three millions to one hundred and fifty-one millions, and cause a contraction in the National bank currency of about sixty millions per annum. This large contraction will be counteracted somewhat by the substitution by some banks of fours and four and a halfs for threes, but there may also be a reduction in the amount of long bonds by those banks that may desire to realize the premium when, in their opinion, the maximum has been reached in the market.

\section{Plan of the Comptroller for Reducing Interest on Bonds.}

The Comptroller proposed, in order to avoid so rapid a contraction of the National bank currency, a plan first suggested by him in his report for 1882. He said that if the whole public debt were reduced to a uniform rate of three per cent., the present high rate of premium on bonds would almost entirely disappear, and the volume of circulation would respond more readily to the demands of business. The temptation to sell such bonds for the purpose of realizing the premium would no longer remain. A proposition for refunding all the bonds not payable at the pleasure of the Government into three per cents, was made at the last session of Congress. It was that inducements be offered to the holders of the four and four and a half per cent. bonds to surrender them to the Government, receiving in payment therefor three per cent. bonds having the same dates of maturity as the bonds surrendered. The new three per cent. bonds issued would themselves bear a small premium, and it is believed that the holders of four per cents would consent to such an exchange if accompanied by an offer of not more than fifteen per cent. premium. The amount of premium upon this class of bonds, say seven hundred millions in all, would at fifteen per cent. be one hundred and five millions of dollars, and this preniium could be paid from the surplus revenues of the Government as the bonds are surrendered for exchange, thus in effect reducing the debt of the Government one hundred and five millions by a prepayment of in- 
terest which must be paid at the greater rate each year until their maturity. The benefits of this plan both to the holder of the bonds and to the Government are apparent. The holders would receive in the shape of fifteen per cent. premium on their bonds a portion of their interest in advance, which would be available to them for loans at rates greatly exceeding the rate at which the Government can borrow money, or at present less than three per cent. The Government would by this use of its surplus be enabled to save a portion of the interest which it would otherwise be compelled to pay hereafter. The principal objection to this proposition is that the Government would pay to the holders a large premium upon their bonds, but it is evident that in two or three years after the three per cents are paid, if there is no reduction in the revenues, the surplus will enormously increase, unless the long bonds are then purchased by the Government at a rate to be fixed by the holders thereof, which will be a rate much higher than that now proposed.

This was a favorite proposition with the Comptroller for a number of years. The correctness of his views was subsequently proved in the years when the Government in order to use its surplus was compelled to pay high premiums for four and a halfs and fours in order to relieve itself of its surplus money. If the proposition had been adopted in 1882 or 1883 , it is now extremely easy to realize what benefit it would have proved to the Government. It may be said, however, that such a proposition which, on the face of it, seemed to be a gratuitous benefit to one class of people would meet with opposition in Congress sure to defeat it. The kind of legislation which gives a present good in exchange for a future one, is difficult to obtain from a popular legislative assembly. The average voter could not be made to see but that the immediate payment to bond holders far outweighed the more distant benefit to the Government. The idea was afterwards embodied in the Aldrich bill before the Senate. The time had, however, gone by for the greatest benefits to be received from its enactment into law.

\section{Comptroller's Opposition to Treasury Notes and Silver Certificates.}

The Comptroller also in the report of 1883 combated the proposition that Treasury notes and silver certificates should be substituted for the retired bank-note currency. He contended that as the Government already was embarrassed by its surplus revenues it would be embarrassed still more were an additional issue of Treasury notes to be authorized. It would place in the Treasury circulating notes to swell its resources, when already the most important subject before Congress is the reduction of a redundant revenue and the employment of the surplus of an overflowing Treasury. If it were possible to issue additional Treasury notes when the revenues of the Government are so much greater than the expenditures, and simultaneously with the yearly ad- 
dition of silver dollars now authorized by law, it is evident that such steps would lead from a gold to a silver standard. The gold balance belonging to the Treasury is large, but the silver balance has increased rapidly, and the laws now in force will continually increase the silver and reduce the gold. The issue of additional Treasury notes will weaken the Treasury, and be likely to create doubts on the part of some of the holders as to the ability of the Government to pay gold on demand, and the Government by declining to pay in gold, thus taking from the holder the option of payment, may at any time bring the nation upon the silver standard, advancing the prices of products and demonetizing the entire gold coin of the country. In such a crisis the reserve of gold in the Treasury will be continually diminished on the one hand by the presentation of its notes for payment, while its revenue, on the other hand, will not be increased by customs duties paid in gold, as at present, but by the return of silver dollars and silver certificates, which will sooner or later drive every dollar of gold coin out of circulation, bringing upon the country a much greater contraction than that which the issue of Treasury notes is now proposed to avert.

\section{Over-Certification of Checks.}

In August, 1883, it was rumored that the failure of a firm of brokers had resulted in a loss to the stockholders of the Wall street National Bank by an over-certification or acceptance of checks, and an examination by the Comptroller proved an over-certification of the checks of the firm in excess of their account to the extent of nearly $\$ 200,000$. Legal steps were taken against the bank, the teller who certified the checks was indicted and held for trial. The bank, to avoid forfeiture of charter and appointment of a Receiver, went into voluntary liquidation and converted into a State bank. The Comp'roller recommended the establishment of a stock clearing-house to enable the business which caused over-certification of checks to be done as readily by other methods.

\section{LEGISLATION OF 1883-1884.}

During the first session of the Forty-eighth Congress, meeting in December, 1883, three bills looking towards the increase of National bank circulation were introduced in the Senate. One by Senator McPherson giving the banks the right to take out circulation to the par value of the bonds on deposit. One by Senator Sherman giving circulation on bonds bearing interest in excess of three per cent; viz., fours, four and a halfs and Pacific railroad sixes, to the amount of ninety per cent. of the par value of the bonds plus the interest that would accrue up to the time of their redemption in excess of three per cent. Thus a four per cent. $\$ 10,000$ bond in 1884 would have twenty-three years to run until 1907. The interest over three per cent. would be one per cent., or $\$ 100$ per annum, amounting in twenty-three years to $\$ 2,300$. 
This added to the par value $(\$ 10,000)$ of the bonds would give $\$ 12,300$ as a basis for circulation. Ninety per cent. of this would be $\$ 11,070$. As time passed and the bond approached maturity the interest in excess of three per cent. would diminish. The $\$ 11,070$ of circulation, although ninety per cent. of the security in 1884, would be a greater per cent. as the security diminished. Mr. Sherman's bill therefore provided that the circulation should never exceed ninety-five per cent. of the security calculated in any year. Another bill embodying the Comptroller's suggestion to exchange fours and four and a halfs for threes, paying a premium to the holders of the former from the Government surplus, was introduced by Senator Aldrich. None of these bills became laws, although the McPherson bill was favorably reported to the Senate by the Finance Committee to which all these measures were referred, and finally passed the Senate and was favorably reported by the House Committee on Banking and Currency. 


\section{XII}

\section{HISTORY OF THE NATIONAL BANKING SYSTEM, 1884-1891.}

Henry W. Cannon appointed Comptroller - Panic of 1884-Action of clearinghouse - National bank failures in New York - Form of clearing-house loan certificates - Over-certification of checks - New York law - Legal-tender certifcates - Interest on deposits - Demand loans as a resource in panics-Comptroller's report for 1885 - Liquidation of failed banks - W. L. Trenholm appointed Comptroller - Decrease in National bank circulation - Organization of National banks from 1882-1887 - Redemption of three per cent. bonds - Comptroller's report for 1887-Government deposits in National banks - Surplus revenues used in the purchase of bonds - National bank failures in 1888-E. S. Lacey appointed Comptroller - Suburban banks - Indian Territory banks Legislation recommended - Reduction of circulation - Panic of 1890 - Failures of Panama Canal Company and the French Copper Syndicate-Baring failure -Action of banks in New York, Boston and Philadelphia - Bond purchases.

\section{The Crisis of 1884.}

In April, 1884, Henry W. Cannon succeeded John J. Knox as Comptroller of the Currency. Almost immediately upon his assuming office Mr. Cannon had to encounter the difficulties of the financial crisis of May, 1884. In his report for that year the Comptroller said :

"Owing to the large number of mercantile failures which had occurred during the year 1883, considerable financial uneasiness was felt at the beginning of 1884 , and the year opened inauspiciously by the appointment of a Receiver for the New York and New England Railroad. Following closely upon this were the troubles of the Oregon and Transcontinental Company, and the appointment on January 12 of a Receiver for the North River Construction Company. The months of February, March and April were characterized by many commercial failures, rumors affecting the credit of various corporations and a further depreciation in the price of stocks and bonds, and, in fact, of all products and commodities.

This feeling of uncertainty and uneasiness as to values culminated on May 6 with the failure of the Marine National Bank, of New York city, whose President was a member of the firm of Grant $\&$ Ward. The failure of this firm immediately followed, and owing to the prominence of some of its members and its large liabilities, exceeding $\$ 17,000,000$, its failure caused great excitement that had not subsided when, on May 13, the President of the Second National Bank, of New York, was discovered to be a defaulter to the extent of $\$ 3,185,000$. Although this defalcation was immediately made good by the directors of the bank, and did not therefore result in its suspension or failure, such a shock was given to credit and to the confidence of the public in all institutions and firms supposed to have loaned money upon such railroad and other securities as had greatly decreased in value or whose managers were supposed to be directly or indirectly interested in speculation in Wall Street, 
that there was great pressure to sell stocks and securities, and an active demand upon the banks for deposits. This condition of affairs came to a crisis on May 14, in the suspension of the Metropolitan National Bank, the failures of Donnell, Lawson \& Simpson, Hatch \& Foote, and several other bankers and brokers. These failures were followed on May 15 by that of the Newark Savings Bank and the suspension of Fisk \& Hatch and others. Failures and suspensions continued through the months of May and June, including those of the Wall Street Bank, the Philadelphia and Reading Railroad, the West Shore Railroad, C. K. Garrison, M. Morgan's Sons, and of other bankers and brokers.

The suspension of the Metropolitan National Bank on May 14 caused great excitement. All stocks and securities called upon the New York Stock Exchange were greatly depreciated under the pressure to sell, and it was practically impossible for banks to collect their call loans, as their borrowers could not obtain money by the sale of their securities except at ruinous sacrifices ; neither could they borrow elsewhere; and it was impracticable and impolitic to throw upon the market the mass of securities held as collateral for the call loans of the associated banks. If it had been done it is probable that a suspension of gold and currency payments by the banks throughout the country would have followed in the general panic that would have been inevitable.

\section{Action of Clearing-House Banks.}

In this emergency the members of the New York Clearing-House Association, realizing that an immediate demand for deposits would be made by their country correspondents, called a meeting at the clearing-house on the afternoon of May 14, and the following plan for settling balances at the clearing-house was unanimously adopted :

Resolved, That in view of the present crisis, the banks in this association, for the purpose of sustaining each other and the business community, resolve:

That a committee of five be appointed by the chair to receive from banks, members of the association, bills receivable and other securities to be approved by said committee, who shall be authorized to issue therefor to such depositing banks, certificates of deposit bearing interest at six per cent. per annum, not in excess of seventy-five per cent. of the securities or bills receivable so deposited, except in case of United States bonds, and said certificates shall be received in settlement of balances at the clearing-house.

After consultation with the officers and directors of the Metropolitan National Bank, a committee of examination was appointed to visit the bank and to ascertain if some plan could not be arranged to permit it to open again for business. The greater part of the securities of the bank were found to be of such a character that loan certificates could safely be issued upon them, and in this way the Metropolitan National Baink was enabled to resume business on May 15 and settle its balances at the clearing-house. The prompt action of the associated banks and the resumption of the Metropolitan National Bank greatly assisted in allaying excitement and staying the panic, and although confidence was not immediately restored, and the banks in New York were largely drawn on by their country correspondents, reducing their reserves for a time below the legal limit, and although on account of the great depreciation of values, and stringency of the money market occasioned by the want of confidence, other failures of State banks, private bankers and mercantile firms occurred in New York and throughout the country, there was no suspension of gold and currency payments at any point, and the issue of loan certificates was confined to the banks of New York city, and these banks were soon enabled to collect their loans and made good their reserves." 


\section{Failures of Natronal Banks in New York.}

The Comptroller called attention to the fact that but one National bank failed in New York city and one suspended, while the estimated liabilities of the State banks and private bankers failing in the same city exceeded thirty-two millions of dollars. Only eleven National banks failed throughout the United States during the panic of 1884, although more than one hundred banking firms and institutions other than national were obliged to succumb.

\section{Form of Clearing-House Loan Certificates.}

The clearing-house loan certificates issued during this panic by the committee appointed for the purpose, were in the following form :

[No. - ]

$[\$ 10,000$.

LOAN COMMITTEE OF THE NEW YORK CLEARING-HOUSE ASSOCIATION.

New York, May 15, 1884.

This certifies that the -__ National Bank has deposited with the committee securities in accordance with the proceedings of a meeting of the association held May 14, 1884, upon which this certificate is issued. This certificate will be received in payment of balances at the clearing-house for the sum of ten thousand dollars from any member of the clearing-house association. On the surrender of the certificate by the depositing bank above named, the committee will indorse the amount as a payment on the obligations of said bank held by them, and surrender a proportionate share of collateral securities held therefor.

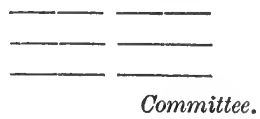

The greatest amount of these certificates outstanding on any one day was on May 20, 1884, when they amounted to $\$ 21,885,000$. After that date they were issued in limited amounts only, and on June 7 their further issue was discontinued. Of the eighty-two banks, members of the clearing-house association, only twenty took out these certificates, and several of the banks so taking them out did so simply as a precautionary measure and did not use them. The total amount issued was $\$ 24,915,000$, and about $\$ 7,000,000$ of these were issued to the Metropolitan National Bank. On and after June 10 balances at the clearinghouse were paid in lawful money. The principal security upon which these certificates were issued was mercantile paper. On July 1 all of the loan certificates, with the exception of those which had been issued to the Metropolitan National Bank, had been returned to the committee and cancelled and the securities taken up. This bank had owing to its suspension and the lack of confidence caused thereby been compelled to liquidate almost its entire deposit account, reducing it from $\$ 11,294$,000 on May 15 to $\$ 1,338,000$ on September 30 . Owing to this enormous 
liquidation of deposits, the Metropolitan National Bank was unable to collect its loans and realize upon its securities with sufficient promptness to cancel its loan certificates by July 1 , and as they bore interest at six per cent. and were secured by ample collaterals, the associated banks were willing to carry them as a loan. The bank finally went into voluntary liquidation and its loan certificates were gradually paid off as the securities deposited as collateral were enabled to be marketed.

\section{Over-Certification OF Checks.}

As before stated eleven banks were placed in the hands of Receivers during the year 1884. Of these the most noticeable was the Marine National Bank, of New York city. This failure was caused by the dealings of the bank with the firm of Grant \& Ward, whose indebtedness under various forms to the association exceeded six times the capital of the bank. The practices between the firm and the bank were very loose and with strong suspicion that the law against over-certification had been violated.

The act of July 12, 1882, Section 13, provided a more severe penalty for over-certification of checks, making any officer, clerk or agent who should willfully violate the law relative to over-certification, or resort to any device to evade the law, guilty of a misdemeanor and liable to a fine of $\$ 5,000$ or imprisonment for not more than five years, or both. Many of the New York city banks immediately took advice of their attorneys, who sent in opinions as to the effect of Section 13 of the law. It was held in these opinions that certification of a check was a form of acceptance, and that the right to make a general acceptance was not interfered with, reliance being placed upon the third clause of Section 5,136 of the Revised Statutes of the United States which grants power to the National banks to make contracts. Many of the banks acting upon the opinions of their attorneys changed the form of certification. Instead of the form previously used, which was simply the word "good" written or stamped with the signature of the teller, checks were then stamped "accepted," with the date and signature of the teller. The question as to whether a check stamped " accepted" was in violation of the law against over-certification was referred to the AttorneyGeneral, who rendered an opinion in reply to the points laid before him. In reply to the first question, whether a bank had the right to accept checks drawn upon it unless the drawer had the amount stated in the check actually on deposit in the bank, he replied in the negative. To construe otherwise, he held, would be to allow a device to evade the provisions of law. In reply to a second question, whether an acceptance under such circumstances would create a liability to the bank for money borrowed and as such be subject to the limitation of loans to one-tenth of the eapital stock, the Attorney-General held the negative inasmuch as the acceptance under such circumstances would be a loan of credit and not of money. To a third question, whether such an 
acceptance to an amount greater than the capital of the bank would not be a violation of Section 5,203 of the Revised Statutes which forbids the bank to become indebted in excess of its eapital except in certain cases, the Attorney-General replied in the affirmative.

The teller of the Wall Street National Bank who had been indicted in 1883 was brought up for trial and plead guilty, but alleged that he acted under the direction of his superior officers. The judge suspended sentence to admit of evidence as to this charge against the officers. Evidence being brought by the District Attorney, the officers of the bank were held for trial by a United States Commissioner.

Certification of checks was in use among the New York city banks long before the National system was established, and for thirty years before the establishment of the clearing-house. Its effect was to make the bank liable for the customer's check so certified and thereby increase its currency and credit. Where the customer's account was ample the effect of the certification was to set apart a portion thereof equal to the check certified as a special fund for meeting the check. This convenient method of enhancing credit became an abuse when banks began to certify checks as good drawn by customers who had nothing to their credit at the time when the check was drawn. The bank thus loaned its credit to the customer, expecting to be repaid by some future deposit. This process of loaning bank credit on certified checks was exceedingly profitable to the banks and was especially convenient in speculative business. Thus a stock broker would buy a line of stocks with a check certified by his bank, and on sale of his stocks make his account good with the proceeds, or if a sale was not immediately made, make his account good with a loan upon the stocks as collateral. The banks doing this business were necessarily very often at the complete mercy of their dealers, and losses were frequently made when the brokers failed in their speculations. The same facilities were also extended to dealers in produce who often required temporary accommodations of money to take up bills of lading for produce shipped to them from the interior, which they desired to transfer from cars and warehouses for shipment abroad. It would seem that in so far as the business for which certification of checks above the account drawn against was deemed necessary was a legitimate and safe business, whether in stocks or produce, some other method implying less risk to the bank and its stockholders might easily have been applied.

\section{New York Law as to Certification.}

Certification of checks in excess of account was not forbidden by the banking law of the State of New York, and the State banks of the city had, in this respect, an advantage over the National banks. The bank officers who allowed over-certification did so from a desire for profit to the bank, and at the same time were most particular as to the character and trustworthiness of those with whom they had such deal- 
ings. Where losses occurred from over-certification they were probably not greater in proportion to the whole mass of such business than the losses that occur in the case of loans of any other class. The matter was finally arranged by making a loan in regular form to those who had been accustomed to the former method of over-certification. It is doubtful whether the real security was any greater or more trustworthy than before.

\section{Certificates for Legal-Tender Notes.}

Section 5,192 of the Revised Statutes of the United States provided that clearing-house certificates representing specie or lawful money specially deposited for the purposes of any clearing-house association, shall be regarded as lawful money in the possession of any association belonging to such clearing-house holding and owning such certificate ; and Section 5,193 provides that the Secretary of the Treasury may receive United States notes on deposit, without interest, from any National banking association in sums not less than $\$ 10,000$, and issue certificates therefor in denominations of not less than $\$ 5,000$, which certificates may be counted as part of the lawful money reserve, and may be accepted in the settlement of clearing-house balances at the places where the deposits therefor were made.

The legal-tender note certificates were first issued in the fiscal year 1873. On June 30,1875 , there were outstanding $\$ 59,045,000$ of these certificates, of which the National banks held $\$ 47,310,000$. On June 30,1876 , the amount outstanding was $\$ 33,140,000$, of which the banks held $\$ 27,955,000$. On June 30,1879 , the amount had been reduced to $\$ 29,330,000$, and on June 14, of the same year, the banks held $\$ 25,180$,000 . The annount outstanding on September 30,1884 , was $\$ 15,945,000$, and the National banks held on that day $\$ 14,200,000$.

\section{Gold Certificates Authorized.}

The issue of gold certificates was authorized by the fifth section of the act of March 3, 1863, and they were used as soon as issued for clearing-house purposes. The first issue was made November 13, 1865, and on June 30,1875 , there were $\$ 21,796,300$ outstanding, of which the National banks in New York city held $\$ 12,642,180$. The issue of these gold certificates was discontinued on December 1, 1878, and the amount. outstanding on June 30,1879 , had decreased to $\$ 15,413,700$, and on October 1,1880 , to $\$ 7,480,100$. The amount outstanding on October 3 , 1882 , was $\$ 4,907,440$, of which the National banks held $\$ 4,594,300$. The issue of gold certificates having been thus discontinued by the Government and the amount of gold coin having rapidly increased, the banks in New York found it necessary to establish a depository for gold coin for the convenience of the clearing-house. This depository was the Bank of America, by which certificates of deposit were first issued on October 14, 1879. The amount of such certificates outstand- 
ing on January 1, 1880, was $\$ 25,610,000$, and on October 1, 1883, was $\$ 22,955,000$. The largest amount of coin on deposit was on January 21,1882 , viz., $\$ 45,330,000$, the capacity of the vault having been enlarged.

The act of July 12, 1882, again authorized the issue of gold certificates by the Government, and this explains the immediate decrease of the certificates issued by the Bank of America. Of the latter certificates the National banks of New York eity held on October 2, 1883, $\$ 20,345,000$; and on September $30,1884, \$ 15,123,000$. On the latter date the same banks held $\$ 47,217,710$ of gold certificates issued by the Government. The act of July 12, 1882, also provided that silver certificates should be available as a part of the lawful money reserve of National banks, and that no National banking association should be a member of a clearing-house that did not receive silver certificates in payment of clearing-house balances.

\section{Payment of Interest on Deposits.}

The practice of paying interest upon deposits had become an almost universal custom among banks. It was customary for the country banks to pay interest on current accounts, and also to issue certificates of deposit bearing interest, the latter usually stating upon their face that no interest will be paid upon the same unless the deposit remains for a certain specified time. Banks in the cities where a large portion of the reserves of the country banks are kept, have paid interest upon the daily balance of accounts of their country depositors, New York city being the centre where large sums of money accumulate in easy times, made up of the accounts of country banks and of those of correspondents in other reserve cities, all subject to interest on current account.

\section{Demand Loans as a Resource in Panics.}

It has been thought that the payment of interest has a tendency to abnormally increase this accumulation, which in turn encourages speculation in stocks, as the banks paying interest are obliged to find some use for the money deposited with them. As this money is liable to be called at any time, it is necessary to make call or demand loans, and dealers in stocks called on the stock exchange, which theoretically can be sold at any time, are enabled to obtain money for speculation by pledging these stocks for collateral and agreeing to repay the sum advanced on demand. During the panic or culmination of a financial crisis these so-called demand loans have been found to be far from a reliable resource. After the panic of 1873 the members of the New York Clearing-House Association discussed the abolition of interest on current accounts. On June 4, 1884, after the panic in May, the clearing-house association endeavored to have its members agree to discontinue the payment of interest on daily balances, but persistent opposi- 
tion of some of the members defeated the arrangement. The united action of the clearing-house association would, no doubt, have great weight, but so long as it is the universal custom of banks, State and National, and of private bankers throughout the country, to pay such interest, the banks of New York would lose by ceasing to do so.

\section{COMPTROLLER'S REPORT FOR 1885.}

In his annual report for 1885 the Comptroller called attention to the large increase in the number of banks organized with a capital of $\$ 150,000$ and under. From July 1, 1879, to July 1, 1882, the number of banks of this class organized was 232 , while from July 1, 1882, to July 1,1885 , the number of the same class of banks organized was 548 . The reason of this increase was the reduction in the amount of United States bonds that a bank was required to deposit before commencing business. Under the law prior to 1874 banks were required to have at all times on deposit, whether they issued circulation thereon or not, bonds equal in amount to one-third of their capital stock. By the act of June 20, 1874 , and the construction put upon it by the Department of Justice, no bank, whatever its capital, was required to keep on deposit more than $\$ 50,000$ in bonds, and where one-third of the eapital stock was less than $\$ 50,000$ such one-third was the maximum requirement. The act of July 12, 1882, retained the maximum requirement in any case at $\$ 50,000$, but banks having a capital of $\$ 150,000$ or less were required to deposit one-quarter only of such capital. The reduction of the bond requirement at once induced a large number of private banking firms and State banks in the West, Northwest and Southwest to enter the National banking system. It became more and more apparent that the National system would not be dependent upon its circulation feature for its continued existence. The Comptroller said :

"It is believed that the National banking system will be continued even if the associations organized under it cannot issue circulation at a profit, inasmuch as the experience under the system has shown it to be a system well adapted to advance the best interests of the public as well as of the banks. This statement is made without prejudice to banks organized under the statutes of those States which contain provisions and restrictions similar to those of the National banking law. In many of the States, however, the banking laws are defective, and it is almost positive that legislation cannot made them homogeneous, nor could the working of the laws passed by thirty-eight States be so harmonious and useful as the working of one general law applicable to all banking institutions enacted by Congress."

\section{Liquidation of Failed Banks.}

In his report for 1885 the Comptroller also called attention to the results of the liquidation of one hundred and four banks that had failed up to that time. He said that these results show in a very interesting manner to what extent it may be safe to permit banks under the National system to issue circulation unprotected by a deposit of United States bonds. Of these 104 banks seventy have been finally elosed, 
and for these the results are absolute. The remaining thirty-four are still in process of liquidation, but have progressed so far that the final result can be estimated with comparative accuracy. The dividends paid to all these banks from the proceeds of their general assets amount to $\$ 28,379,080$. They had an aggregate capital of $\$ 28,858,900$, upon which, under the law, they could have issued on deposit of the necessary bonds, ninety per cent., or $\$ 19,673,010$, of circulation. If at the time of their failure the law had permitted an issue of circulation to the amount of ninety per cent. of capital, unsecured except by a first lien on the general assets of the 104 banks mentioned, the note holders of fifty-eight would have experienced no loss. If the law had authorized an unsecured issue equal to seventy per cent. of the capital, the notes of seventy-one of these banks would have been redeemed from the proceeds of their general assets. At forty per cent. the notes of ninety would have been paid in full, and upon an unsecured issue of twenty-five per cent. of capital loss to note holders would have occurred in the case of five banks only, or about $\$ 62, \mathrm{C} 00$ in all.

The experience with these 104 banks shows almost conclusively that if their issues to the amount of sixty-five per cent. of their capital had been secured by a deposit of bonds to an equal amount, the remaining twenty-five per cent. might have been issued without other security than a first lien upon the general assets, and if a safety fund had been in existence it would, in the case cited, have been drawn upon to the extent of $\$ 62,000$, upon a total circulation amounting to $\$ 5,464,700$.

\section{Mr. Trenholm Appointed Comptroller.}

Early in 1886 Hon. W. L. Trenholm succeeded Mr. Cannon as Comptroller of the Currency. Mr. Trenholm was the sixth incumbent of the office. His predecessors were Hon. Hugh McCulloch, afterwards Secretary of the Treasury; Hon. Freeman Clarke, Hon. Hiland R. Hulburd, Hon. John Jay Knox and Hon. Henry W. Cannon.

\section{Decrease of National Bank Circulation.}

During the year 1886 eight National banks failed, but failures included no banks of any great importance. There was no new legislation during the year 1886 relating to National banks except one enactment enabling banks to increase their capital stock by vote of twothirds of the shareholders, and to change their names and places of business within certain limits. The year was, however, remarkable for the largest decrease of National bank circulation that had as yet occurred in any one year, amounting to $\$ 56,593,533$. This was owing to the rapid payment of the class of bonds held by the banks as security for circulation. On June 30,1884 , there were of the three per cent. bonds redeenable at the option of the Government, $\$ 224,612,150$ outstanding and $\$ 172,412,550$ of these were held by the banks. By June 30,1885 , the total of threes had been reduced to $\$ 194,190,500$, and 
those held by the banks to $\$ 142,240,850$; by June 30,1886 , the total threes had fallen to $\$ 144,046,600$, of which the banks held $\$ 107,782,100$. There were two influences at work, one to reduce the amount of fours and four and a halfs and the other to increase them. The high premiums prevailing for these bonds induced many of the banks holding an excess over the minimum required by law to sell out the excess and retire their circulation based upon it. The organization of 172 new banks during 1886, each depositing the amount of bonds required by law, tended to keep up the aggregate of bonds on deposit. No new bank would buy threes subject as these bonds were to almost immediate call, but for their permanent deposit sought either fours or four and a halfs, the former in preference.

\section{Banks ORganized FRom 1882 to 1887.}

From 1882 to 1887 there were 991 banks organized with a capital of 111 millions, on which they would have been entitled to receive $\$ 99$,999,000 in circulation if bonds had been obtainable. As a matter of fact these banks deposited only $\$ 23,892,100$ in bonds, entitling them to $\$ 21,495,110$ in circulation. The deposit of bonds was only about three millions of dollars in excess of the minimum required by law. During these years the percentage of excess of bonds deposited gradually diminished. Through 1886 and 1887 the three per cent. loan was called for redemption, causing a very large reduction of circulation in the latter year also.

\section{Redemption of Three Per Cent. Bonds.}

The history of this redemption was as follows. As has been seen in the previous pages the three per cent. loan was authorized to be issued to take up the three and a half per cents., by the act of July 12, 1882. There were altogether $\$ 305,581,250$ of threes issued, although the largest amount outstanding at any one time, on August 7, 1883, was $\$ 305,529,000, \$ 52,250$ having been redeemed before the last issue was made. On August 16, 1883, the largest amount ever held by the National banks as security for circulation was on deposit, viz., $\$ 202,386$,750. On October 31,1886 , only $\$ 64,242,550$ remained uncancelled and these were called during the first half of 1887 . The calls for the bonds held by the banks came faster than the banks could replace them with other bonds. The interest upon the threes of course ceased as soon as they were called for redemption, and the language of the law in regard to deposits for circulation required the bonds to be interest bearing. In the clause of the law requiring the bond deposit to be maintained at a minimum, registered bonds only were mentioned, nothing being said about their being also interest bearing. Taking advantage of this ambiguity in the law, it was contended by certain banks which desired to wait for a more favorable time for substituting other bonds, that when a deposit of registered interest-bearing bonds was once made the 
requirement of the law was complied with, and that banks could not against their will be compelled to replace such bonds with others, or to retire the circulation based upon them, because without action on their part and even without their consent, the Government had called their bonds for redemption and had thereby acquired the right to cease paying interest. The question was referred to the Attorney-General for decision and he rendered an opinion that bonds on which interest had ceased could not lawfully be held as security for circulation.

\section{Bank FaIluRes Reported IN 1887.}

In his report for the year 1887 the Comptroller announced the failures of eight National banks, the most important being that of the Fidelity National Bank, of Cincinnati, Ohio. This bank was reduced to insolvency through the reckless management of its board of directors, who suffered certain of their number to divert its funds and credit from their legitimate purposes to the support of a speculation in wheat in Chicago. In the progress of this enterprise many provisions of law were violated, and false statements were made as to the capital, surplus and business of the bank. There was, however, no open evidence to discredit the institution until on June $20, \$ 200,000$ of its drafts went to protest in New York city. An examiner then found the bank insolvent. The proved claims amounted to nearly four millions of dollars.

The Comptroller in his report for 1887 recommended the embodiment of the National banking laws in a new code with such improvements and amendments as experience had shown to be necessary. He presented for the consideration of Congress a bill containing two hundred and forty-three sections. This bill did not become a law.

\section{Deposit of Public Moneys with the Banks.}

In October, 1887, the Secretary of the Treasury, with the view of diminishing the danger from the surplus revenues which caused an abnormal accumulation of cash in the Treasury, resolved to increase the amount of public moneys deposited with selected National banks. These banks when selected as public depositories had always been required to deposit with the department United States bonds as security, and were in addition required to keep a reserve upon them equal to the reserve kept on other deposits. The banks when approached upon the subject of increasing the deposits were unwilling to receive them, when required to furnish four and a half per cent. bonds as security in face value ten per cent. above the amount of deposits, and four per cents., equal in face value to the deposits. They held that the security required was too great to render the deposits profitable. The Secretary, therefore, decided that banks depositing one million dollars in four and a half per cents. might receive one million dollars of public money, and those depositing one million dollars of four per cent. bonds might re- 
ceive eleven hundred thousand dollars of public money. As circulation could only be obtained to the extent of ninety per cent. of the face value of these bonds, this regulation of the Secretary operated to reduce cireulation of the banks during the year 1888. During the four months succeeding October, 1887, over eight millions of dollars in bonds were transferred from the account of security for circulation to the account of security for public moneys. These deposits were increased during four months only, and after January, 1888, no new depositories were designated. The money was not taken out of the Treasury and paid into the banks, but consisted of internal revenue collections that were deposited with the banks as made by the collectors. For this reason many banks, after depositing a million in bonds, found that they had to wait a considerable time before the full amount of public moneys to which they were entitled was received.

\section{Purchase of Bonds with Surplus Revenue.}

Another influenee that caused a still greater withdrawal of bonds deposited as security for circulation was the purchase of four and four and a half per cents. by the Treasury. The threes having all been called, and the surplus of revenues still increasing, on April 17 a circular was issued inviting proposals for the sale of bonds to the Government. During the seven months ending with October, 1888, four per cent. bonds amounting to $\$ 50,402,650$, and four and a half per cent. bonds amounting to $\$ 33,242,600$, were purchased at various rates of premium. During the same period there were withdrawn by the banks from their deposits to secure circulation $\$ 22,142,872$ in bonds. The pressure to withdraw bonds was so great that the limit of lawful money permitted to be deposited to retire circulation in any one month, viz., $\$ 3,000,000$, was reached for three months in succession. The premium paid for four per cents. varied from 123 to 130, and for four and a halfs from 106 to 109.

\section{National Bank Failures in 1888.}

Eight National banks were placed in the hands of Receivers during the year 1888. The Metropolitan National Bank, of Chicago, was the largest of the failures. The net decrease of circulation of the National banks during the year was $\$ 16,848,739$. The number of new National banks organized during the year was 132 .

\section{Edward S. Lacei Appointed Comptroller.}

In $1889 \mathrm{Mr}$. Trenholm retired from the Comptrollership, and was succeeded by the Hon. E. S. Lacey. In his report for 1889 he states that 211 banks had been organized during that year, with an aggregate capital of $\$ 21,240,000$. He further says:

"The location of these new associations is a matter of much interest, as tending to show that local prejudices are giving way, and that the increase is most con- 
spicuous proportionately in the States and Territories toward which immigration is now chiefly tending, without reference to other conditions which have heretofore operated unfavorably to the growth of the system. Texas, with thirty-six banks, leads all the others in respect to the number organized, but if relative population is considered, is exceeded by the State of Washington, with thirteen banks. The increase of sixteen banks in Pennsylvania makes a total of 328 , the largest number in any State. Massachusetts leads in the amount of capital stock and New York in deposits and volume of business. If population be considered the State of Massachusetts has the largest amount of capital per capita invested in National banks, closely followed by the new State of Montana. A consideration of the facts connected with the business of the year seems to verify the statement that the system established by the National Bank Act is not only adapted to the changed conditions developed by the lapse of a quarter of a century, but it is also suited to the wants of widely separated States, living under varied social conditions and transacting business in accordance with customs as dissimilar as climatic and race differences can produce upon this continent."

\section{Banks in Suburbs Absorbed in Reserve Cities.}

Another interesting subject to which Comptroller Lacey called the attention of Congress was that of suburban banks contiguous to reserve cities. He said:

"The rapid growth of our large cities is causing them to absorb outlying suburbs and contiguous towns. In these latter are frequently located National banks of small capital, organized for the accommodation of local tradesmen and not at all adapted to the business of banks in reserve or central reserve cities. In cases where annexation brings these smaller banks within the limits of reserve cities, perplexing questions arise as to title, capital and reserve. For example, during the present year the towns of Lake and Hyde Park were annexed to the city of Chicago. Located in this territory were five National banks ; the National Live Stock Bank, capital $\$ 750,000$; the Drovers' National Bank, capital $\$ 250,000$; the First National Bank, of Englewood, capital $\$ 100,000$; the Calumet National Bank, capital $\$ 50,000$, and the Oakland National Bank, capital $\$ 50,000$. There are now located within the city of Chicago two associations with the title 'First National Bank.' "

Three of the associations referred to possessed a capital of less than $\$ 200,000$, although the law requires associations organized in cities with over 50,000 population to have at least that capital. The same difficulties arose as to the reserves to be kept, and as to whether such suburban banks become city banks by the growth of the city, and'can act as reserve agents. The Comptroller did not award to these banks any additional powers on account of their having accidentally been taken into a large city.

The organization of banks in the Indian Territoryiraised a question, and the Attorney-General decided that National banks could not be organized there, because the treaties with the Indian Nations invested them with self-government to an extent that rendered the National banking laws inoperative.*

*This decision is not applicable at present, as there are now fifteen National banks in the Indian Territory. 
The net decrease of National bank circulation during the year ending November 1, 1889, was $\$ 22,159,043$.

The Comptroller recommended the following amendments to the law: (1) The minimum deposit of bonds to secure circulation should be fixed at ten per cent. of the capital stock in respect to all having a capital of $\$ 300,000$ or less, and for all banks having a greater capital a minimum deposit of $\$ 30,000$ in bonds should be required. (2) Circulation should be issued to the par value of the bonds deposited. (3) The semi-annual duty on circulation should be so reduced as to equal one-fourth of one per cent. per annum. In his report for 1889 the Comptroller refers to these recommendations of the previous year. They were made before the assembling of the Congress then in session, and prior to the passage of the silver-purchase act of July 14, 1890. The passage of this bill authorizing the issue of notes based on silver bullion was generally accepted as indicating the adoption of a new and permanent policy on the part of the general Government, and as tantamount to a declaration that the National banks are not to be made use of in the immediate future to supply the additional circulation required. This opinion was strengthened by consideration of the fact that bills formulated with great care and early introduced in Congress, providing for an increased and permanent issue of bank notes, had not been seriously considered in the Congressional committees having jurisdiction of the subject matter.

\section{Marked Decline in National Bank Circulation.}

During the five years ending October 31,1890 , the aggregate circulation of the National banks was reduced from $\$ 276,304,189$ to $\$ 124$,958,736 , a net decrease of $\$ 151,345,453$, while the increase in the number of National banks for the same period was 138. No new bank legislation was enacted during the year 1889-1890. During the two years ending November, 1890, there were eleven failures of National banks. The year 1891 was remarkable for the number of National banks which became insolvent, twenty-five being placed in the hands of Receivers. Of these the failures of thirteen banks in Kansas and Nebraska were due to bad crops in those States. The Comptroller said:

"The failures for the current year have been numerous, many having been characterized by gross mismanagement and some by criminality of an aggravated character, yet nothing has been developed which indicates that the confidence in National banks on the part of the general public, which is the growth of an experience of twenty-nine years, is ill founded. It is idle to suppose that absolute immunity from failure can be secured by the operation of any law which fails to provide for absolute and complete Government guaranty. That failures will be far more numerous during some years than during others is to be expected. This is true of every variety of business activity. The banks of the country are the mere agencies through which the commercial and business activities of the people are conducted, and of necessity the losses which attend these operations are reflected in the profit and loss account of these agencies." 


\section{The Panic of 1890.}

There was great monetary stringency during the year; up to midsummer it had been a year of more than average business activity. It was apparent in the early spring to the observant that unfavorable conditions existed, the evil effects of which might be expected in the near future. Agricultural interests were in an unsatisfactory condition, and overtrading and unhealthful expansion were apparent. During the year the building of railroads had been prosecuted with unusual vigor, making necessary the placing of large lines of securities. Immense sums before available as loanable capital in New England and the Middle States, had taken a fixed form by reason of investments in the Mississippi Valley and the Pacific Coast, in city and suburban property, in loans represented by farm mortgages, and in the stocks and bonds of unnumbered corporations organized for the purpose of conducting various kinds of manufacturing operations, and supplying water, light and rapid transit to the inhabitants of many rapidly growing cities and villages. Not only did these enterprises attract capital from the Atlantic States, but English investors brought to this country vast sums for the purpose of grouping together and recapitalizing corporations engaged in manufacturing, industrial and commercial pursuits. This unexampled movement of capital toward the West not only divested the Atlantic States in a large degree of the loanable funds available for the relief of those engaged there in manufacturing and other lines of business, but it also unduly stimulated speculative operations in real estate in the West, laying the groundwork for a future collapse in prices when the supply of money should be cut off. The various banking institutions located in the region of the country affected by the speculative spirit became necessarily more or less involved in the operations of their local customers. They found themselves early in the summer of 1890 carrying large lines of loans representing investments in various forms of corporate enterprises in untried fields, and dependent for success upon the growth of towns and cities not yet realized. The banking business of the country was, therefore, in an unduly extended condition on the approach of midsummer, and the banks in many cases were dependent upon rediscounts with their correspondents to carry the heavy loans with which they were burdened. While in this condition the transfer of funds to this country from England and the Continent became reduced and flnally ceased. Not only was the supply of fresh funds from this source cut off, but it was discovered that during the late spring and early summer months, as well as later on, vast amounts of American securities held abroad were forced upon the New York market by European holders for the purpose of preparing for a collapse expected to result from similar conditions of undue expansion existing abroad. The continental countries had already passed through a period of liquidation and loss consequent upon the failure of the 
Panama Canal Company and the French Copper Syndicate. England, by reason of unusually large investments in all parts of the world, and especially in the Argentine Republic, was surely approaching an excep. tionally severe monetary stringency. As an evidence of this and the consequent disposition to increase the stock of gold there held, in order to strengthen their cash resources, during the months of June, July and August, 1890, the net exportation of gold coin and bullion from the United States exceeded $\$ 14,000,000$, and for the period extending from January 1, 1890, to August 31, 1891, the net exportations of gold amounted to $\$ 75,405,613$. While these causes were operating to prevent the necessary relief from reaching us from Europe, the demands upon the banks in New York and other large reserve cities rapidly increased, producing a reduction in the amount of deposits, and an increase in the amount loaned to and rediscounted for the interior banks. The gross deposits of forty-six National banks in the city of New York show a falling off of $\$ 44,831,356$ between February 28 and May 17, $1890 ; \$ 13,519,527$ of this representing a reduction in the balances due to interior banks and those located in other reserve cities, while the reduction in loans and discounts was less than $\$ 10,000,000$. The New York banks were, however, enabled to so strengthen their position during the months of June and July, that marked stringency was delayed until August. It eulnninated about the middle of November, when the failure of a leading firm of brokers, the embarrassment of one large State bank and the failure of another, occurred in New York

\section{The Baring Failure in London.}

These events were simultaneous with the announcement of the embarrassment of the Baring Brothers, of London, and the fact that a syndicate had been formed headed by the Bank of England through whose agency the liabilities of the Barings were guaranteed to the extent of about $\$ 75,000,000$. The unsatisfactory condition of monetany affairs in England, and the desire to be prepared for the effect of the announcement of the failure of Baring Brothers, induced the Bank of England to borrow $£ 3,000,000$ in gold from the Bank of France in addition to $£ 1,500,000$ received from Russia upon the sale of Treasury bonds. Among the unfavorable conditions existing in the United States in addition to the undue expansion and resulting speculative investments which have already been noted, was the greatly reduced yield in 1890 of wheat, oats and corn, and the greatly reduced prices which prevailed for these cereals. The importation of foreign commodities in 1890 also exceeded in value that of any previous year, due no doubt to the new tariff act which took effect on October 6. To relieve this severe monetary stringency the Secretary of the Treasury increased his purchases of United States bonds so as to almost entirely exhaust the available surplus in the Treasury. During the three and one-third 
months from July 19 , to November 1 , 1890 , over $\$ 99,000,000$ was disbursed for 'United States bonds and the interest thereon. Although much relief was afforded by the disbursement of these large sums, the monetary stringency was caused to a greater degree by want of confidence and a curtailment of credits than by lack of circulating medium.

\section{Action of Banks in New York, Boston and Philadelphia.}

During this period of stringency the banks in the cities of New York, Philadelphia and Boston were subjected to the most pressing demands, and after a very careful consideration it was decided by the associated banks in those cities that the exigency required the resort to the issue of clearing-house loan certificates to settle clearing-house balances. The meeting of the clearing-house association in New York city adopted a resolution on November 11, 1890, similar to that adopted in 1884 , given on a preceding page of this chapter. They also passed in addition, in order to provide for the retirement of the loan certificates in case the collaterals pledged should prove insufficient, the following resolution, by which all the banks virtually entered into a pool to sustain each other:

"Resolved, That any loss resulting from the issue of loan certificates shall be borne by the banks comprising the clearing-house association pro rata of capital and surplus, and this resolution shall be ratified by the directors of the respective banks members of the association, and a certified copy of such consent delivered to the chairman of the loan committee."

The amount of loan certificates issued by the loan committee of the New York Clearing-House Association was $\$ 16,645,000$. The first issue was made November 12,1890 , and the entire issue was retired February 7,1891 . The largest amount outstanding at any one time was $\$ 15,205$,000, on December 13, 1890.

The Boston Clearing-House Association passed a resolution appointing a loan committee on November 17, 1890. It was similar to that passed by the New York Clearing-House, except that interest on the certificates was fixed at 7.3 per cent. per annum, instead of six as in the New York resolution. The resolution of ratification passed in Boston differed from that in New York in having the loss, if any, borne by the banks pro rata to the amounts sent to the clearing-house during the year instead of pro rata to capital and surplus.

When a bank applied for and received loan certificates it was required to deposit the necessary securities and also to execute and deliver an obligation in the following form:

"The —— Bank has this day received of —_L Loan Committee of the Boston Clearing-House Association loan certificates issued by said committee in pursuance of a vote of said association passed November 17, 1890, to the amount of - thousand dollars, and has deposited with said committee the securities, a statement whereof is hereto annexed, and said Bank receives said loan 
certificates on the terms set forth in said vote, and agrees to pay the amount of said certificates with interest thereon as provided in said vote."

In Boston loan certificates were first issued on November 19, and the last on December 6, 1890. On the latter date the issue reached its maximum of $\$ 5,065,000$. The last of the issue was retired on January 6,1891 . The Philadelphia Clearing-House took action on November 18, 1890, adopting the following resolution:

" Resolved, In accordance with the resolution of September 24, 1873, as amended October 18,1873 , the clearing-house will issue loan certificates to banks applying and receive them in payment of balances."

The general standing resolution of September 24 and October 18, 1873, under which this action was taken, is as follows:

"For the purpose of enabling the banks members of the Philadelphia ClearingHouse Association to afford proper assistance to the mercantile and manufacturing community and also to facilitate the inter-bank settlements resulting from the daily exchanges, we, the undersigned, do bind ourselves by the following agreement on the part of our respective banks, viz.:

First.-That the clearing-house committee be, and they are hereby, authorized to issue to any bank member of the association loan certificates bearing six per cent. interest on the deposit of bills receivable and other securities to such an amount and to such percentage thereof as may in their judgment be advisable. These certificates may be used in the settlement of balances at the clearing-house, and they shall be received by creditor banks in the same proportion as they bear to the aggregate amount of the debtor balances paid at the clearing-house. The interest that may accrue upon these certificates shall be apportioned monthly among the banks which shall have held them during that time.

Second.-The securities deposited with the said committee shall be held by them in trust as a special deposit pledged for the redemption of the certificates issued thereupon, the same being accepted by the committee as collateral security, with the express condition that neither the clearing-house association, the clearing-house committee nor any member thereof, shall be responsible for any loss on said collaterals arising from failure to make demand and protest, or from other neglect or omission, other than the refusal to take some reasonable step which the said depositing bank may have previously required in writing.

Third.-On the surrender of such certificates or any of them by the depositing bank the committee will endorse the amount as a payment on the obligation of said bank held by them, and will surrender a proportionate amount of securities except in case of default of the bank in any of its transacticns through the clearing-house ; in which case the securities will be applied by the committee, first, to the payment of outstanding certificates with interest; next, to the liquidation of any indebtedness of such bank to the other banks members of the clearing-house association.

Fourth.-The committee shall be authorized to exchange any portion of such securities for others, approved by them, and shall have power to demand additional security at their own discretion.

Fifth.-That the clearing-house committee be authorized to carry into full effect this agreement, with such rules and regulations for the practical working thereof as they may deem necessary; and any loss caused by the non-payment of loan certificates shall be assessed by this committee upon all the banks in the ratio of capital.

Sixth.-The expenses incurred in carrying out this agreement shall be assessed upon the banks in equal proportion to their respective capital.

Seventh.-That the clearing-house committee be, and they are hereby, authorized 
to terminate this agreement upon giving thirty days' notice thereof at any stated meeting of the clearing-house association.

The clearing-house committee having been by the preceding agreement authorized to issue loan certificates, resolved on November 5, 1890 , to exercise this power; whereupon the banks desiring to take out loan certificates were required to furnish resolutions of their directors empowering the hypothecation of securities, under which the issue of loan certificates, signed by not less than three members of the committee, was commenced on November 19, 1890, and ceased on May 22, 1891 , the total issue being $\$ 9,655,000$. The maximum amount outstanding was on January 9,1891 , viz., $\$ 8,870,000$. The certificates were all retired during 1891, except $\$ 170,000$ issued to the Keystone and Spring Garden National banks, which failed in May, 1891.

\section{Bonds Purchased by the Government.}

The history of the bond purchases from the date of the circular of April 17, 1888, shows that up to Oetober 31,1890 , a total of $\$ 330,872$,150 had been purchased, of which sum $\$ 164,307,400$ were four per cents and $\$ 166,564,750$ four and a half per cents. During the year ending October 31, 1891, the purchase of four per cents was discontinued; in the month of January, $\$ 8,645,850$ having been added to previous purchases, making a total of four per cents of $\$ 172,953,250$. On October 9,1890 , the Treasury issued a circular offering to redeem four and a half per cents in advance, interest being added to the face of the bond up to and including August 31, 1891. Similar circulars were issued December 6, 1890, June 2, July 2, August 24, September 2 and September 16, 1891. The total redemptions of four and a half per cent. bonds under these circulars were $\$ 33,966,150$, which added to those previously purchased of this class of bonds, makes the total purchased and redeemed $\$ 200,530,900$. The total purchase and redemption of both fours and four and a halfs amounted to $\$ 373,484,150$ from April, 1888 . The circular of July 2, 1891, provided that four and a halfs called for redemption might be continued at two per cent. The amount of bonds so continued was $\$ 25,364,500$. The National banks, when the great refunding operations began in 1881, lasting ten years, until September, 1891 , had bonds deposited to secure circulation amounting to $\$ 360,488$, 400. During the ten years from July, 1881, to July, 1891, new banks deposited about forty-two millions of dollars in bonds. On October 31,1891 , the National banks had bonds to the amount of $\$ 152,750,950$; deducting the bonds deposited during the ten years leaves $\$ 111,016,550$. Therefore, to the banks in existence in 1881, the refunding operations caused the reduction of their bond holdings in the sum of $\$ 249,471,850$, and a corresponding reduction of their circulation. That the system should have survived so great a reduction of the basis upon which it was supposed to rest, indicates that other merits than that of issuing a sound circulation were the cause of its survival. 


\section{XIII}

PROGRESS OF THE NATIONAL BANKING SYSTEM, 1892-1899.

Decline in National bank circulation - Silver-purchase acts of 1878 and 1890 - Panic of 1893-Bank failures - Clearing-house loan certificates - Decline in banking profits - Consolidation of banks - State and National banks in New YorkPresidential campaign of 1896 - Condition of the National banks in 1892 and 1896 compared - Gold holdings of the banks - Increase of deposits and clearings - Per cent. of dividends paid by failed banks - Use of checks and credit instruments - Branch banks recommended - Issue of notes by the Government and the banks - Revenues received from the National banks - Comptroller's report for 1898 .

\section{Silver-Purchase ACTS OF 1878 aNd 1890.}

The diminution of the circulation of National banks, which has been commented upon in previous chapters, had, no doubt, for its chief cause the high premium at which Government bonds, the only basis upon which circulation could be issued, were quoted in the market. But this diminution would not have been so rapid if it had not been for the policy of the United States in regard to silver. Soon after the passage of the Resumption Act of 1875, the agitation began for the restoration of the coinage of the standard silver dollar of 412.5 grains, or the "dollar of the daddies," as it was affectionately called by its advocates. The Secretary of the Treasury was directed by the act of February 28, 1878, to purchase and coin into silver dollars silver bullion not less in market value than two millions of dollars and not more than $\$ 4,000,000$ worth each month. Under this act, up to July 14, 1890, when the act of February, 1878, was repealed, silver bullion was purchased as follows:

Total cost of silver bullion purchased under act of $1878 \ldots \ldots \ldots \quad \$ 308,199,162$

Total dollars coined.................................. $378, \mathbf{1 6 6 , 7 9 3}$

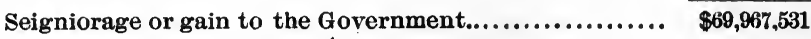

The dollars themselves did not circulate very freely because the act of 1878 authorized the deposit of the actual coins in the United States Treasury and the issue of silver certificates of deposit. These silver certificates soon filled the gap caused by the reduction of the National bank currency, and to a certain extent crowded the latter out of circulation.

The act of July 14, 1890, which superseded the act of February 28, 
1878, authorized the issue of an additional kind of paper money termed Treasury notes, to be used in the purchase of silver bullion at its market price, at the rate of 4,500,000 ounces per month. There were by November, 1892 , about $\$ 325,000,000$ in silver certificates and $\$ 116,000$,000 of these new Treasury notes-a total of nearly $\$ 450,000,000$ of new paper currency - thrown into circulation during fourteen years.

It seems most reasonable that but for this flooding the channels with this immense mass of paper money, the notes of the National banks would not have diminished so rapidly as they did notwithstanding the rapid payment of the national debt. In December, 1878, the total outstanding circulation of National banks in active operation was $\$ 303,000,000$, while in December, 1892 , it was about $\$ 146,000,000$ only-a falling off of $\$ 157,000,000$.

If the Government had refrained from coining or purchasing silver, and from issuing silver certificates and Treasury notes, it is safe to say that the National banks would have kept up their circulation to a much higher point, even if they had not increased it. The premiums upon the bonds would have ruled much lower and allowed a reasonable profit upon their use as a basis for bank notes. Even if the banks could not have furnished an adequate circulation based upon bonds, legislation might have modified the regulations surrounding National bank issues, so as to have enabled the banks to furnish all the paper money really required by the business of the country.

The year 1892 was a comparatively uneventful one, though it was one of general prosperity. Hon. A. B. Hepburrn was appointed Comptroller of the Currency in the place of Hon. Edward S. Lacey, who resigned the office to become President of a bank in Chicago.

The organization of new National banks went on rapidly, one hundred and sixty-three, with a capital of $\$ 15,285,000$, commencing business during the year. Seventeen National banks failed during the year, of which the Maverick National Bank, of Boston, was the most prominent on account of its capital and the amount of its liabilities.

The recommendations made by the Comptroller for modification of existing laws were confined to matters of detail, and no new laws or amendments of old ones were passed by Congress.

\section{Panic of 1893.}

In the early part of 1893 there was another change in the office of the Comptroller of the Currency, James H. Eckels being appointed in the place of Hon. A. B. Hepburn. The year will always be unfortunately celebrated for one of the worst financial crises that has occurred in the business history of the United States. The United States Treasury had become almost the sole source of the immense volume of paper currency upon which the business of the country was done. The volume of the currency had become so great that the year commenced with great expectations of a business larger in volume and more profit- 
able than ever before. In April, however, doubts began to be entertained of the power of the Government to maintain the gold payment of all this paper money when presented for redemption, and lack of confidence in the Treasury began to spread to the financial institutions of the country. The depositors in the banks became doubtful of their power to pay on demand, and began to draw out their deposits. Nor did they use the money so drawn out in the usual manner by loaning it to others. The banks in their turn were unable to make loans to their customers who required money to carry on their business. The entire financial inachinery of the country became deranged, and business almost stopped. The Comptroller of the Currency, in his report for 1893, gave the following account of the effect of this condition of things upon the National banks :

"An analysis of the suspensions and failures which occurred shows that during the year 158 National banking associations were compelled to suspend business, being 4.09 per cent. of the number of existing associations. Their capital stock aggregated $\$ 30,350,000$, or approximately 4.3 per cent. of the paid-in capital stock of all the banks in the system. Of the banks which suspended sixty-five, or 41.14 per cent. with a total capital stock of $\$ 10,935,000$, were insolvent, and required the appointment of Receivers ; eighty-six, or 54.43 per cent., with a capital stock aggregating $\$ 18,205,000$, were able to resume business, and seven, or 4.43 per cent., with a capital stock of $\$ 1,210,000$, were placed in charge of examiners in expectation of resumption."

The table on the opposite page, taken from the report of the Comptroller of the Currency for 1893, shows the effects of the crisis of that year upon the National banking system.

\section{Issue of Clearing-House Certificates.}

During the stress of the crisis the same expedient for relieving the necessities of the money market resorted to during previous crises was again resorted to by the banks in New York, Boston, Philadelphia, Baltimore and other cities in which clearing-houses were established. This was the issue of clearing-house loan certificates, the form and method of issuing which have been described in a previous chapter.

The following figures taken from the report of the Comptroller of the Currency show the movement and amount of the issue of loan certificates in 1893 in the cities named:

\begin{tabular}{|c|c|c|c|c|c|}
\hline & $\begin{array}{l}\text { Date of } \\
\text { issue of } \\
\text { first cer- } \\
\text { tificate. }\end{array}$ & $\begin{array}{l}\text { Date of largest } \\
\text { amount out- } \\
\text { standing. }\end{array}$ & $\underset{\text { standing. }}{\text { Largest }}$ & $\begin{array}{l}\text { Date of } \\
\text { surren- } \\
\text { der of } \\
\text { last cer- } \\
\text { tificate. }\end{array}$ & $\begin{array}{c}\text { Amount } \\
\text { outstand- } \\
\text { ing Oct. } 31 .\end{array}$ \\
\hline $\begin{array}{l}\text { New York...... } \\
\text { Philadelphia.... } \\
\text { Boston........... } \\
\text { Baltimore...... } \\
\text { Pittsburg....... }\end{array}$ & $\begin{array}{l}\text { June 21 } \\
\text { June 16 } \\
\text { June 27 } \\
\text { June 27 } \\
\text { Aug. 11 }\end{array}$ & $\begin{array}{l}\text { Aug. } 29 \text { to Sep. } 6 \\
\text { Aug. } 15 \ldots \ldots \ldots \ldots . .1 \\
\text { Aug. } 23 \text { to Sep. } \\
\text { Aug. } 24 \text { to Sep. } \\
\text { Sep. } 15 . . . . . . . . .\end{array}$ & $\begin{array}{r}\$ 38,280,000 \\
10,965,000 \\
11,445,000 \\
1,475,000 \\
987,000\end{array}$ & 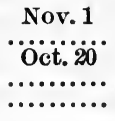 & $\begin{array}{r}\$ 3,835,000 \\
\ldots . .345,000 \\
\quad 332,000\end{array}$ \\
\hline Total......... & .......... & 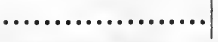 & $\$ 63,152,000$ & & \\
\hline
\end{tabular}


Statement showing by States and geographical divisions the number and capital stock of National banks which suspended during the year ended October 31, 1893, together with the number and capital of those which resumed, failed, and were placed in charge of examiners.

\begin{tabular}{|c|c|c|c|c|c|c|c|c|}
\hline \multirow{2}{*}{$\begin{array}{c}\text { States AND TERRI- } \\
\text { TORIES. }\end{array}$} & \multicolumn{2}{|c|}{ Suspensions. } & \multicolumn{2}{|c|}{ Resumptions. } & \multicolumn{2}{|r|}{ Failures. } & \multicolumn{2}{|c|}{$\begin{array}{l}\text { In charge of } \\
\text { examiners. }\end{array}$} \\
\hline & No. & Capital. & No. & Capital. & No. & Capital. & No. & Capital. \\
\hline $\begin{array}{l}\text { New Hampshire-- } \\
\text { Total Eastern States }\end{array}$ & 2 & $\$ 250,000$ & $\cdots$ & ........ & 2 & $\$ 250,000$ & .. & ........... \\
\hline 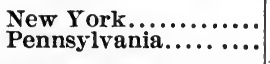 & $\begin{array}{l}2 \\
1\end{array}$ & $\begin{array}{r}500,000 \\
50,000\end{array}$ & $\because$ & …...... & $\begin{array}{r}2 \\
. . \\
\end{array}$ & $\begin{array}{c}500,000 \\
\ldots \ldots \ldots\end{array}$ & $\ddot{i}$ & $\cdots \ddot{\$ 50,000}$ \\
\hline Total Middle States... & 3 & $\$ 550,000$ & .. & $\ldots \ldots \ldots$ & 2 & $\$ 500.000$ & 1 & $\$ 50,000$ \\
\hline 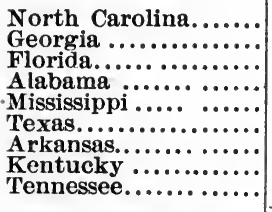 & $\begin{array}{r}2 \\
4 \\
2 \\
4 \\
1 \\
12 \\
1 \\
6 \\
6\end{array}$ & $\begin{array}{r}\$ 300,000 \\
675,000 \\
200,000 \\
550,000 \\
60,000 \\
1,480,000 \\
500,000 \\
2,300,000 \\
2,750,000\end{array}$ & $\begin{array}{r}2 \\
1 \\
\ddot{3} \\
\ddot{6} \\
\ddot{5} \\
2\end{array}$ & $\begin{array}{r}\$ 300,000 \\
250,000 \\
\dddot{4000,000} \\
\dddot{400000} \\
430,000 \\
\ddot{2}, 2000,000 \\
2,000,000\end{array}$ & $\begin{array}{l}\dddot{3} \\
2 \\
2 \\
1 \\
1 \\
6 \\
1 \\
1 \\
4\end{array}$ & $\begin{array}{r}\dddot{\$ 25,000} \\
200,000 \\
150,000 \\
60,000 \\
1,050,000 \\
500,000 \\
50,000 \\
750,000\end{array}$ & $\begin{array}{l}\ddot{.} \\
\ddot{0} \\
\ddot{0} \\
\ddot{0} \\
\ddot{0}\end{array}$ & 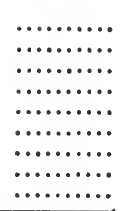 \\
\hline Total Southern States & 38 & $\$ 8,815,000$ & 19 & $\$ 5,630,000$ & 19 & $\$ 3,185,000$ & •. & $\cdots \cdots \cdots \cdots$ \\
\hline 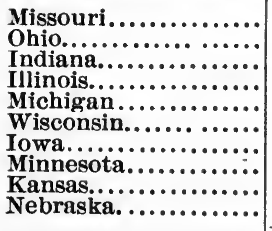 & $\begin{array}{l}\mathbf{3} \\
\mathbf{2} \\
\mathbf{7} \\
\mathbf{4} \\
\mathbf{3} \\
\mathbf{5} \\
\mathbf{6} \\
\mathbf{5} \\
\mathbf{8} \\
\mathbf{6}\end{array}$ & $\begin{array}{r}\$ 1,300,000 \\
180,000 \\
1,000,000 \\
2.150,000 \\
215,000 \\
625,000 \\
575,000 \\
2,400,000 \\
880,000 \\
800,000\end{array}$ & $\begin{array}{l}3 \\
\mathbf{1} \\
\mathbf{4} \\
\dddot{1} \\
\mathbf{5} \\
\mathbf{5} \\
\mathbf{5} \\
\mathbf{4} \\
\mathbf{3}\end{array}$ & $\begin{array}{r}\$ 1,300,000 \\
80,000 \\
450,000 \\
\cdots \times 000 \\
65,000 \\
625,000 \\
525,000 \\
2,400,000 \\
480,000 \\
350,000\end{array}$ & $\begin{array}{l}\ddot{1} \\
\mathbf{3} \\
\mathbf{4} \\
\mathbf{2} \\
\ddot{1} \\
\ddot{3} \\
\mathbf{3}\end{array}$ & $\begin{array}{r}\$ 1000,000 \\
550,000 \\
2,150,000 \\
150,000 \\
\cdots \ddot{50,000} \\
\cdots \dddot{300,0000} \\
450,000\end{array}$ & $\begin{array}{l}\ddot{ } \\
\ddot{0} \\
\ddot{0} \\
\ddot{0} \\
\ddot{1} \\
\cdots\end{array}$ & 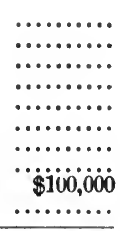 \\
\hline Total Western States. & 49 & $\$ 10,125,000$ & 31 & $\$ 6,275,000$ & 17 & $\$ 3,750,000$ & 1 & $\$ 100,000$ \\
\hline 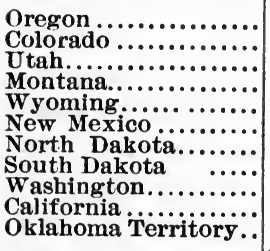 & $\begin{array}{r}6 \\
16 \\
3 \\
10 \\
2 \\
2 \\
3 \\
3 \\
3 \\
14 \\
6 \\
1\end{array}$ & $\begin{array}{r}\$ 800,000 \\
3,600,000 \\
250,000 \\
1,875,000 \\
250,000 \\
225,000 \\
400,000 \\
225,000 \\
1,755,000 \\
1,200,000 \\
50,000\end{array}$ & $\begin{array}{r}5 \\
14 \\
3 \\
2 \\
1 \\
\ddot{1} \\
\ddot{1} \\
4 \\
5 \\
1\end{array}$ & \begin{tabular}{r}
$\$ 700,000$ \\
$3,300,000$ \\
250,000 \\
300,000 \\
200,000 \\
$\cdots \cdots \cdots$ \\
\hdashline$\ldots, \cdots$ \\
125,000 \\
$\mathbf{4 2 5 , 0 0 0}$ \\
$\mathbf{9 5 0 , 0 0 0}$ \\
50,000
\end{tabular} & $\begin{array}{l}1 \\
2 \\
\ddot{7} \\
1 \\
1 \\
3 \\
2 \\
7 \\
1 \\
\cdots\end{array}$ & $\begin{array}{r}\$ 100,000 \\
300,000 \\
1,075,0000 \\
50,000 \\
175,000 \\
400,000 \\
100,000 \\
800,100 \\
250,000 \\
\ldots \ldots \ldots .\end{array}$ & $\begin{array}{l}\because \\
\ddot{i} \\
\ddot{i} \\
\ddot{3} \\
\ddot{3} \\
\ddot{0}\end{array}$ & 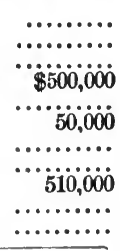 \\
\hline $\begin{array}{r}\text { Total Pacific States } \\
\text { and Territories... }\end{array}$ & 66 & $\$ 10,610,000$ & 36 & $\$ 6,300,000$ & 25 & $\$ 3,250,000$ & 5 & $\$ 1,060,000$ \\
\hline Total United States. & 158 & $\$ 30,350,000$ & 86 & $\$ 18,205,000$ & 65 & $\$ 10,935,000$ & 7 & $\$ 1,210,000$ \\
\hline
\end{tabular}

The issue of loan certificates in 1893 greatly exceeded that of previous years. In 1873 and 1884 they were issued only by the New York Clearing-House Association, the total amount issued in 1873 being $\$ 26$,565,000 and in $1884 \$ 24,915,000$.

Although the banks were prohibited by law from using their credit to issue notes, other corporations and individuals issued large quanti-. 
ties of orders, checks and other forms of credit instruments, which greatly relieved the demand for actual currency.

The effects of the panic upon banks and financial institutions other than National banks were much more serious than upon the members of the National banking system, as will be seen from the following table, compiled by the Comptroller of the Currency:

\begin{tabular}{|c|c|c|c|c|c|c|c|c|c|}
\hline \multirow{2}{*}{ Cluass. } & \multirow{2}{*}{$\begin{array}{l}\text { Num- } \\
\text { ber in } \\
\text { exist- } \\
\text { ence } \\
\text { July 1. } \\
1893 .\end{array}$} & \multicolumn{2}{|c|}{$\begin{array}{l}\text { Suspen- } \\
\text { sions. }\end{array}$} & \multicolumn{2}{|c|}{$\begin{array}{l}\text { Resump- } \\
\text { tions. }\end{array}$} & \multicolumn{2}{|c|}{ Failures. } & \multicolumn{2}{|c|}{$\begin{array}{l}\text { In charge } \\
\text { of national } \\
\text { bank exam- } \\
\text { iners. }\end{array}$} \\
\hline & & No. & $\begin{array}{c}\text { Per } \\
\text { cent. }\end{array}$ & No. & $\begin{array}{l}\text { Per } \\
\text { cent. }\end{array}$ & No. & $\begin{array}{c}\text { Per } \\
\text { cent. }\end{array}$ & No. & $\begin{array}{c}\text { Per } \\
\text { cent. }\end{array}$ \\
\hline 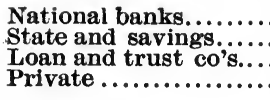 & $\begin{array}{l}* 3,857 \\
5,024 \\
(?) \\
3,950\end{array}$ & $\begin{array}{r}158 \\
219 \\
19 \\
177\end{array}$ & $\begin{array}{l}4.09 \\
4.36 \\
(?) \\
4.48\end{array}$ & $\begin{array}{r}86 \\
54 \\
2 \\
23\end{array}$ & $\begin{array}{l}2.23 \\
1.07 \\
(?) \\
.58\end{array}$ & $\begin{array}{l}65 \\
\ldots . \\
\cdots\end{array}$ & $\begin{array}{l}1.68 \\
\ldots \ldots . \\
\ldots \ldots .\end{array}$ & $\begin{array}{l}7 \\
\ldots \ldots \\
\cdots \cdots\end{array}$ & $\begin{array}{l}.18 \\
\ldots \ldots . \\
\ldots \ldots . .\end{array}$ \\
\hline Total............... & 12,831 & 573 & $\cdots \cdots$ & 165 & $\ldots \ldots$ & 65 & $\ldots .$. & 7 & ...... \\
\hline
\end{tabular}

* June 1, 1843.

The above table does not show the full effects of the 1893 panic. A careful compilation of the bank suspensions in 1893 shows that from January 1 to December 31 there were over 900 banks of all classes which either suspended temporarily or failed entirely.

\section{Slow Recovery from the Financial Crisis.}

In the year following the $\mathbf{1 8 9 3}$ panic there was a check to the organization of new National banks, the number organized to October 31 being only fifty, with capital of $\$ 5,285,000$. This was the smallest number of banks organized as well as the minimum capital in any year since 1879. There were 3,756 banks in operation with $\$ 672,671,365$ authorized capital, represented by 7,955,0761/3 shares, giving to each bank in the system an average capital of $\$ 179,092$, with 2,117 shares and seventy-six shareholders. As compared with the previous year circulation showed a net decrease of $\$ 1,741,563$. The charters of forty-one National banks were extended during the year ending October 31, 1894, while seventy-nine banks, with an aggregate capital of $\$ 10,475,000$, had passed out of the system by voluntary liquidation, and twenty-one, with a capital of $\$ 2,770,000$, had been placed in the hands of Receivers. Ten banks, with a capital of $\$ 1,575,000$, which were previously in the hands of Receivers, had been restored to solvency. Of the six banks whose charters expired by limitation, five were succeeded by new associations with capital stock aggregating $\$ 600,000$.

Though bank failures continued to more than an average extent for soine years succeeding the crisis of 1893 , the people who had withdrawn deposits from the National banks in that year apparently soon changed their minds. From $\$ 1,764,456,177$ on December 9,1892 , the individual 
deposits of the National banks declined to $\$ 1,451,124,330$, but by October 2,1894 , they had increased to $\$ 1,728,418,819$, or only about $\$ 36,000,000$ less than the high figures of 1892 . The specie held on December 9,1892 , was $\$ 209,895,260$, and $\$ 237,250,654$ on October 2,1894 .

\section{Decline in Banking Profits-Consolidations.}

For the year included in the report for 1894 the Comptroller stated that the net earnings were only 5.6 per cent., the lowest ever recorded with the exception of 1878 and 1879. The dividends paid were five per cent., the smallest since the beginning of the system. Owing to the stagnation in business circles many banks had either liquidated or had reduced their capital, and the propriety of consolidating a number of rival banking institutions was discussed by the Comptroller-this plan having already been adopted in several cities. In the subsequent years the tendency toward a reduction of capital in proportion to the deposits held became quite marked, and the consolidation of National banks was reported in many of the large cities as well as in the smaller places. As a result of this latter movement some banking institutions have suddenly leaped into a foremost position in respect to the volume of their business.

During the year ending October 31, 1894, twenty-one National banks had been placed in the hands of Receivers, the aggregate capital of these banks being $\$ 2,770,000$, and their total liabilities $\$ 9,409,356$.

\section{Use of Credit Instruments in Retail Trade.}

An investigation made by the Comptroller in 1894, relating to the use of checks and other credit instruments in retail trade, showed that in total transactions of about $\$ 6,000,000$ covered by the returns, 58.9 per cent. was paid in ehecks and store orders, and 41.1 per cent. in money. This deduction was made from the funds received on deposit by National banks from several classes of retail merchants. It has been generally estimated that, taking transactions of all kinds, between ninety and ninety-two per cent. of the business of the country is carried on by means of checks and other evidences of credit.

\section{Benefits of the National Banking System.}

The Comptroller reported in 1894 that the total tax paid to the Government by the National banks amounted to $\$ 145,234,650.46$, and the profits inuring to the Government from unredeemed circulation were $\$ 2,770,615.47$, or a total revenue of $\$ 148,005,265.93$ derived from the National banks. Deducting the expenses of the Comptroller's bureau, amounting to $\$ 15,365,963.75$, the net actual profit which the Government has derived from these institutions is $\$ 132$,639,302.18. Besides the banks had cared for funds of the Treasury amounting to $\$ 5,356,625,891$ without expense or loss to the the Government, and by thus saving transportation charges which 
would have been incurred by the actual transfer of the money to the different sub-Treasuries, added to the net profits detailed above a sum sufficient to bring the total up to more than $\$ 168,000,000$, as the direct benefit of the National banks to the Treasury of the United States. The Comptroller also cited the following as further benefits which the banks had conferred on the Government and people :

(1) The saving in heavy discounts on the bank currency prevalent before the establishment of the National banking system.

(2) The saving in rates of interest on loans and discounts.

(3) The saving in the making of exchange.

(4) The saving to customers in charges for making collections.

He estimated the discount on the $\$ 200,000,000$ of State bank notes outstanding at the outbreak of the Civil War, at from one to five per cent., while the National bank notes are of uniform value in all parts of the country.

A number of recommendations in regard to amendments of the banking and currency system were suggested in the report for 1894 .

\section{COMPTROLLER's RePORT FOR 1895.}

On October 31, 1895, there were 3,715 National banks in operation having an authorized capital stock of $\$ 664,136,915$, represented by 285 ,190 shareholders, making for each bank in the system an average capital stock of $\$ 178,772$, the number of shares to each 2,136 , and the number of shareholders 77 . The total circulation outstanding at this time was $\$ 213,887,630$. There were organized during the report year fortythree banks, located in twenty different States, with an aggregate capital stock of $\$ 4,890,000$. The corporate existence of seventy-one banks, with a capital stock of $\$ 10,662,000$, had been extended during the year. Four banks, with a capital stock of $\$ 300,000$, had left the system on account of the expiration of their charters, and fifty-one banks, with a capital stock of $\$ 6,093,100$, had gone into voluntary liquidation. Receivers were appointed for thirty-six banks, with an aggegate capital of $\$ 5,235,020$. It will thus be seen that, counting the new banks and those going out of business, there was a net loss of forty-eight in the number of banks, and a reduction of capital employed, from this cause, amounting to $\$ 6,738,120$.

\section{State and National Banks in the State of New York.}

An inquiry made by the Comptroller to show the relations existing between the various State banking institutions and the National banks of the State of New York, resulted in bringing out the following information. The special call made on the National banks for statements of balances with State, private and Savings banks and loan and trust companies, showed average daily eredits of the fifty National banks of New York city for the month of June to be $\$ 61,380,569$, due to State banking institutions, and an amount on July 11, 1895, of $\$ 54,485,412$, 
while the daily balances due the National banks averaged for June $\$ 1,526,842$, and on July 11 amounted to $\$ 1,586,258$. The total for the 334 National banks in the State averaged daily balances for these banks during June $\$ 72,039,062$; amount on July $11, \$ 66,029,740$; average daily balances due from State institutions for June, $\$ 2,563,840$, and on July $11, \$ 2,742,659$.

Included in the special call was a request for data concerning the receipts and withdrawals of every kind in which these banks participated. For the fifty National banks of New York city the average daily receipts for June were $\$ 124,503,693$; receipts on July 11 were $\$ 121$,061,669 . For the remaining 284 banks the average daily receipts for June were $\$ 11,988,577$, and on July 11, $\$ 11,980,788$. Withdrawals from the fifty National banks of New York city for June averaged $\$ 119,308$,833 a day, and on July 11, $\$ 122,769,213$. Withdrawals from the 284 banks outside of New York city averaged for June $\$ 13,914,367$ per day, and for July 11 were $\$ 12,006,343$. Combining all the reports for both items made the average daily receipts of the 334 banks for June $\$ 136,492,270$, and withdrawals $\$ 133,223,200-$ a daily balance in favor of the banks of $\$ 3,269,070$, or $\$ 98,072,100$ for the month. On July 11 receipts aggregated $\$ 133,042,452$ and withdrawals $\$ 134,775,556$, reversing the balance to $\$ 1,733,104$ of withdrawals over receipts.

From the information gained by these investigations the Comptroller stated that the interests of State and National banks were shown to be not antagonistic, but that the two classes of institutions sustained harmonious business relations.

\section{Recommendations OF THE COMPTROLLER.}

Various recommendations for the improvement of the National banking laws, embodied in previous reports, were renewed in the report for 1895, and among others the following :

"The issue of circulating notes to the par value of bonds deposited to secure the same, and the reducing of the per cent. of semi-annual tax levied upon such notes, has been urged by all the Secretaries of the Treasury who have touched upon the subject at all, and by every Comptroller from the time of and including Comptroller Knox. The provision of the law prohibiting the former and the provision of the law governing the amount of the latter, however, are still unchanged upon the statute book."

He called attention to the fact that as the law existed the profits to be made on the issue of circulating notes was so small as to offer no inducement to the banks to exercise the privilege.

In regard to substituting National bank notes for the legal tenders issued by the Government, he said:

"The experience of this and other countries conclusively demonstrates that the best and most rational note issues are those put forth by banks properly and safely conducted. It likewise demonstrates that issues made direct by governments are always expensive and under every circumstance a source of danger to such govern- 
$\checkmark$

ments and loss to their people's business interests. No clearer proof of this could be had than that furnished by the difficulties which we have witnessed on the part of this Government in its efforts to maintain the full credit of its practically limitless amount of demand obligations."

The Comptroller also recommended that in order to aid in securing elasticity in the National bank-note currency, Section 9 of the act of July 12, 1882, regulating the issue and retirement of circulation to banks within a fixed period of time, should be repealed. This section limits the retirement of National bank circulation by a deposit of lawful money to $\$ 3,000,000$ in any calendar month, and also provides that "no National bank which makes any deposit of lawful money in order to withdraw its circulating notes shall be entitled to receive any increase of its circulation for the period of six months from the time it made such deposit of lawful money for the purpose aforesaid." In effect this provision in the law frequently makes it impossible to render even the relief to the money market in times of stringency which would otherwise be possible, and also forces a certain amount of the notes to be kept outstanding although not demanded by business requirements.

\section{Presidential Campaign of 1896.}

The year 1896 was a memorable one in American politics, the campaign being fought almost entirely on the money question. In their platform the Republicans declared for the maintenance of the existing gold standard, in the absence of an international agreement for coining gold and silver at a fixed ratio, while the Democrats declared for the free and unlimited coinage of both gold and silver at a ratio of 16 to 1 . There were defections from both parties, the Republicans losing support in those States where the silver-mining industries were strong, and the Democrats losing in nearly all parts of the country, but this loss was partly offset by an alliance with the Populists. The campaign was one of great bitterness, resulting in the election of the Republican candidate. With the disappearance of the agitation in regard to the standard of value, the business condition of the country, which had been unsatisfactory since the financial crisis of 1893 , gradually improved.

\section{Progress of the National Banking System.}

The Comptroller's report for 1896 showed that up to October 31 of that year twenty-eight banks were organized, or eighteen per cent. of the yearly average. Their aggregate capital was $\$ 3,245,000$. The corporate existence of twenty-six National banks, with $\$ 3,153,800$ capital, was extended during the year. One bank, with $\$ 100,000$ capital, left the system by reason of the expiration of its charter, but was succeeded by a new association with a like amount of capital. Thirty-seven banks, with $\$ 3,745,000$ capital, went into voluntary liquidation, and twentyseven, with an aggregate capital of $\$ 3,805,000$, were placed in the hands of Receivers. 


\section{Comparison of Condition, 1892-1896.}

On September 30, 1892, the aggregate resources, as also the aggregate liabilities, of the National banks rose to the highest mark in the history of the system up to that time, viz., $\$ 3,510,094,89 \%$. On the side of liabilities, individual deposits stood at $\$ 1,765,422,983$, and on the side of resources, loans and discounts were $\$ 2,171,041,088$, being then respectively the maximum amounts ever registered, either before or since September 30, 1892. Along the lines of these two items of receiving deposits and lending money, representing the principal functions of banking in this country, the greatest fluctuations occurred during the years under consideration. The itemoof deposits showed very little variation in amount from September 30,1892 , to May 4,1893 , when it was $\$ 1,749$,930,81\%. After the latter date, however, it shrunk suddenly and rapidly to $\$ 1,556,761,230$ on July 12,1893 , and on October 3,1893 , touched $\$ 1,451,124,330$, the lowest point since December 11, 1889. From this shrinkage of deposits, amounting to nearly $\$ 300,000,000$, from May 4 to October 3, there was a rapid and steady recovery, until on October 2, 1894 , just a year after the date of lowest depression, they were $\$ 1,728$,418,819 , or but $\$ 21,000,000$ less than on May 4, 1893. T'here was thereafter for a brief period a slight decrease in the volume, but it rose again on July 11,1895 , to $\$ 1,736,022,006$, falling again to $\$ 1,648,092,868$ on February 28, 1896, and standing at $\$ 1,668,413,507$ on July 14, 1896. Between this date and October 6, 1896, decrease was marked, being nearly $\$ 71,000,000$, leaving the deposits at the latter date at $\$ 1,597$,891,058 .

The resources of the banks showed loans and discounts to the amount of $\$ 2,161,401,858$ on May 4, 1893 . They had fallen on July 12 to $\$ 2,020$,483,671 , and on October 3 to $\$ 1,843,634,167$. It is noticeable that after this date there was a steady expansion of loans and discounts until October 2, 1894, when the amount was $\$ 2,007,122,191$.

On September 30, 1892, the lawful money reserve of all the banks, consisting of specie, legal money notes, and certificates for legal-tenders deposited, amounted to $\$ 32 \%, 000,000$; on December 9,1892 , it was $\$ 318,000,000$; on March $6,1893, \$ 313,000,000$, and on May $4,1893, \$ 322,-$ 000,000 . The variations during this period, it thus appears, were slight; but through the extraordinary demands of depositors occurring suddenly and unexpectedly after May 4 the reserve on July 12, 1893, fell to $\$ 289,000,000$, the banks being compelled to pay $\$ 193,000,000$ of deposits during that period, $\$ 141,000,000$ of which were provided by the calling in of loans and discounts, which the banks, under the force of such withdrawals, were compelled to demand.

The drain of deposits continued after July 12, and by October 3, 1893, $\$ 105,000,000$ more had been withdrawn, these and prospective withdrawals being provided for by the collection of $\$ 17 \%, 000,000$ of loans and discounts, with the result that the reserve on hand reached on 
October $3, \$ 346,000,000$. After October 3,1893 , with returning confidence, deposits were rapidly returned to the banks and there was gradual expansion of loans and discounts, though in smaller proportion. There was again an increase in reserve. From $\$ 346,000,000$ on October 3 it went to $\$ 414,000,000$ on December 19,1893 ; to $\$ 433,000,000$ on February 28,1894 , touching on May 4, 1894, $\$ 452,000,000$, the highest point it had ever reached. It decreased to $\$ 439,000,000$ on July 18 , to $\$ 402$,000,000 on October 2 , and $\$ 374,000,000$ on December 19,1894 . On July 11,1895 , the amount stood at $\$ 382,000,000$, after which it fell to $\$ 340$,000,000 on September 28, 1895, since which time, and up to October 6 , 1896, the reserve on hand remained steady. The variations are measured by a limit of $\$ 12,000,000$ between the highest and lowest amounts held.

The amount of circulating notes of the National banks outstanding on September 30, 1892, was but $\$ 143,423,298$. The increase thereof was very slight and gradual, due mainly to the compulsory obligation of new banks to deposit bonds, up to July 12,1893 , when it stood at $\$ 155$,070,821 . Under the stress of a currency famine the issues expanded by October 3,1893 , to $\$ 182,959,725$, but thereafter steadily decreased, falling to $\$ 169,337,071$, on December 19,1894 . With the new issue of bonds, the lessened price of bonds, and an apparent increased margin of profit in issuing notes, the volume began to increase, until on October 6,1896 , it amounted to $\$ 209,944,019$, or about $\$ 66,000,000$ greater than on September 30, 1892.

In the matter of capital stock the maximum in the history of the system was reached on December 9,1892 , being $\$ 689,698,017$ for 3,784 banks. This amount had decreased to $\$ 688,701,200$ on May 4,1893 , while the number of banks had increased to 3,830 , the largest number doing business at any time previous or since. After May 4, 1893, there was an almost steady decrease in capital stock as well as in the number of banks, and on October 6, 1896, there were but 3,676 banks doing business with a capital of $\$ 648,540,325$, a falling off of 154 in the number of banks and of over $\$ 40,000,000$ in capital stock. In the face of this substantial decrease in the number of banks and their capital stock they had, on October 6,1896 , a surplus fund of $\$ 247,690,074$, and net undivided profits of $\$ 88,652,759$, making a total of $\$ 336,342,833$ as compared with an aggregate of $\$ 340,524,178$ on September 30,1892 , of which $\$ 238,871,424$ was surplus fund and $\$ 101,652,754$ net undivided profits.

\section{Gold Holdings of the Banks.}

An investigation made with reference to the kinds of money and currency in all classes of banks at this time was only partially satisfactory, only 5,723 banks reporting out of a total of all classes amounting to 12,962 . It was shown that the 3,458 National banks reporting had gold holdings amounting to $\$ 155,073,604$, and the State and other banks, 
$\$ 34,484,737$. From these returns the Comptroller estimated the total of gold and gold certificates held by all the banks on July 1, 1896, at $\$ 302,793,367$.

\section{Increase in Banks, Deposits and Clearings.}

Owing to the fact that the making of returns to the Comptroller of the Currency by banks other than National is a purely voluntary act, the statements of such institutions are always incomplete, as a large number of banks make no report. Upon the partial returns received, however, the Comptroller reported that the whole number of all classes of banks in the country had grown from 1,825 in 1863, to 9,456 in 1896 , and the deposits had increased from $\$ 586,412,948$ to $\$ 4,-$ $874,601,975$. The bank clearings of New York city in the same time increased from $\$ 14,867,597,849$ to $\$ 29,350,894,884$ in 1896 .

\section{Per Cent. of Dividends Paid bx Failed National Banks.}

The lowest per cent. of dividends paid by any failed National bank from the organization of the first bank up to October 31, 1896, the affairs of which had been fully closed, was a little over fourteen per cent. This was greatly below the average, which is about seventy-five per cent. From the beginning of the system to October 31, 1896, 330 banks, or about six and one-half per cent. of all created, had failed, having total capital of $\$ 55,775,920$. Of these failures 149 , representing $\$ 22,745,020$ capital, had occurred in the four years next preceding the date of the 1896 report.

Further Investigation in Regard to the Use of Checks and OTHER CREDit Instruments.

Reference has been made heretofore to the investigations made by the Comptroller in regard to the use of checks and credit instruments, and the unsatisfactory nature of the results, owing to incomplete returns. With better methods of securing information, the investigation was continued in 1896, with greater success. A tabulation of statements received from 5,530 banks showed that their deposits consisted of gold 0.6 per cent.; silver, 0.5 per cent.; currency, 6.3 per cent., and checks, 92.5. The Comptroller stated that from the face of the returns the conclusion was to be drawn that $6 \% .4$ per cent. of the retail trade of the country is transacted by means of credit paper; that 95.3 per cent. of the wholesale is so carried on ; 95.1 per cent. of business other than mercantile, and 92.5 per cent. of all business. After eliminating all factors which were considered as bearing on the question, the Comptroller concluded that at least eighty per cent. of the business of the country is carried on by means of checks, drafts and other credit instruments.

In a report of a committes of the House of Commons, of Great Britain, the operations of the banking house of $\mathrm{Mr}$. Slater were given 
for the year 1856, showing the proportion of money to eredit instruments in transactions representing $£ 1,000,000$. This report showed that in the operations of this bank gold and silver entered to the extent of less than three per cent. ; Bank of England notes seven per cent., and credit instruments ninety per eent. Of the payments gold and silver formed one per cent. ; bank notes two per cent., and credit instruments ninety-seven per cent.

Sir John Lubbock, in a paper published in the "Journal of the Royal Statistical Society," of London, in 1865, reported that out of $£ 19,000,000$ credited to the London customers of his bank, $£ 408,000$ consisted of bank notes; $£ 79,000$ of country notes; $£ 118,000$ of coin, and $£ 18,395,000$, or 96.8 per cent., of checks and bills.

Gen. James A. Garfield, in speaking on the Resumption Act in the House of Representatives, November 16, 1877, stated that while Chairman of the Committee on Banking and Currency in 1871, he requested the Comptroller to secure for him data on this subject. Regarding the results of this inquiry, he said:

"I selected three groups; the first was the city banks, the second consisted of banks in cities of the size of Toledo and Dayton in the State of Ohio. In the third group, if I may coin a word, I selected the 'countriest' banks, the smallest that could be found, at points away from railroads and telegraphs. The order was that those banks should analyze all their receipts for six consecutive days, putting into one list all that can be called cash-either coin, greenbacks, bank notes or coupons-and into the other list all drafts, checks or commercial bills. What was the result? During those six days $\$ 157,000,000$ were received over the counters of the fifty-two banks, and of that amount $\$ 19,370,000$-twelve per cent. only-was in cash, and eightyeight per cent., that vast amount representing every grade of business, was in checks, drafts and commercial bills."

Reports made to the Comptroller in 1896 showed that on July 1 of that year the deposits in 5,530 banks were made up as follows:

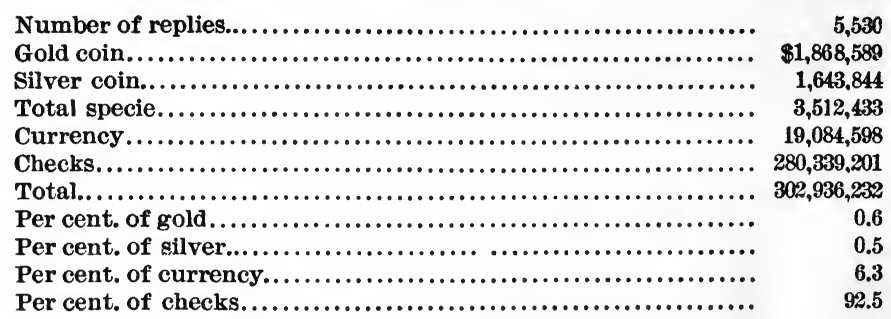

\section{BraNCH BaNKS Recommended.}

As the Supreme Court of the United States had decided that National banks were prohibited from establishing branches, the Comptroller suggested that an amendment to the law should be passed permitting National banks to locate branches in places not having a National bank already established. As this privilege would be open to all banks in the system, he did not think that the objection that it 
would tend to create a monopoly was well founded. It is probable, however, that as the privilege would have been taken advantage of chiefly by the banks of large capital, the ultimate result would have been to increase the influence of the larger institutions and to restrict the organization of local banks.

\section{Issue of Notes BY THE Government AND THE BANKS.}

It had been necessary to issue bonds in 1894, 1895 and 1896 for the purpose of providing gold for the redemption of the demand obligations of the United States, and in view of this the Comptroller again called attention to the expense and difficulty of maintaining these notes at par, and expressed the opinion that a point must " be finally reached when banks shall issue all of the credit currency of the country and stand wholly responsible, instead of the Government, for its redemption in gold coin whenever and in whatever quantities presented." $\mathrm{He}$ supplemented his arguments with a table prepared by the Chief of the Loans and Currency Division of the Treasury Department.

\section{Cost of the gold reserve, including liability for principal of bonds sold and interest thereon to their maturity.}

Principal of bonds sold for resumption purposes:

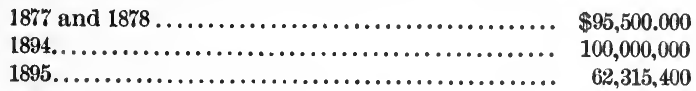

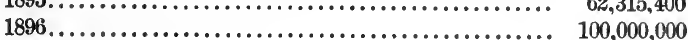

Total principal........................ $\overline{\$ 3 \tilde{5} 7,815,400}$

Interest at 4 per cent. on the average amount of the free gold in the Treasury from January 1 , 1879 , to January 1,1895 .

$93,440,000$

Interest from January 1, 1895, to July 1, 1907, on $\$ 95,500,0004$ per cent. bonds of $1907 \ldots \ldots \ldots \ldots \ldots \ldots$ Interest from January 1, 1895, to February 1, 1904 on $\$ 100,000,0005$ per cent. bonds.

Interest from February 1, 1895, to February 1, 1925 on $\$ 62,315,4004$ per cent. bonds.................. Interest from February 1, 1896, to February 1, 1925, on $\$ 100,000,0004$ per cent. bonds.................

Total cost, including liability, except United

States notes outstanding................... Add amount of United States notes still outstanding................................. $346,681,016$

Total cost and liability. $\$ 1,081,881,562$

If the United States notes had been funded on January 1,1879 , into the thirty-year four per cent. bonds of 1907 , then being sold, the total cost to the Government therefor, including interest from January 1,1879 , to July 1,1907 , would be as follows :

Principal of bonds

Interest from January 1,1879 , to July $1,1907 \ldots \ldots \ldots .395,216,340$ 741.897 .340

Difference in favor of converting the United States notes into bonds. 
He contrasted this statement with the following table, showing the profits which the Treasury had derived from the National banks:

\section{Revenue received by the Government from National banks from 1863 to October 31, 1896.}

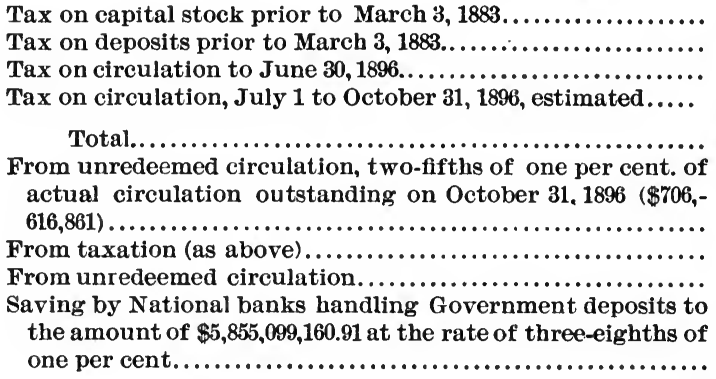

Deduct expenses of Comptroller's office, appropriated for by

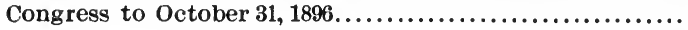

Total profit to Government.
$\$ 7,855,887.74$

$60,940,067.16$

$79.390,680.89$

$617,225.34$

$\$ 148,803,861.13$

$\$ 2,826,466.00$

$148,803,861.13$

$2,826,466.00$

$21,956,621.85$

$\$ 173,586.948 .98$

$16,147,700.00$

$\$ 157,439,248.98$

Despite the strong arguments made against the legal tenders, however, Congress showed no disposition to pass a law for their retirement, although in the following year the proposal that when redeemed in gold they should be reissued only for gold, began to meet with some favor. This would, in effect, convert the legal-tenders into gold certificates.

In his report for 1897 Comptroller Eckels reviewed the history of National bank legislation, and made a strong plea for the retirement of the legal-tender notes issued by the Government and the substitution of a bank-note currency based on the assets of the banks. For the year covered by this report forty-four banks were organized, with an aggregate capital of $\$ 4,420,000$. As a result of failures and liquidations the number of active banks decreased sixty-two and the capital decreased $\$ 11,090,500$ as compared with the data contained in the previous year's report. Thirty-eight National banks were placed in the hands of Receivers for the report year 1896. The year was remarkable for the large amounts collected from insolvent banks- $\$ 13,169,781$ as compared with a total of $\$ 75,935,925$ during the entire thirty-four years the system had been in operation.

\section{Distribution of National Bank Shares.}

Of the $6,337,114$ shares of National bark stock issued up to July 5, $1897,5,464,037$ were held by residents of the States in which the banks are located, 873,077 by non-residents, of which 21,729 shares were owned by residents of foreign countries. The number of shares owned by women was $1,418,542$. There were 281,225 shareholders, of which $2 \% 0^{2}$ - 
149 were natural persons, 101,944 being wom $\_n$. Corporations held 11,076 shares. The average investment by each shareholder was about $\$ 2,250$. It was shown that 169,948 persons or corporations held stock of the par value of $\$ 1,000$ or less; 79,756 over $\$ 1,000$ or less than $\$ 5,000$; $29,541, \$ 5,000$ or less than $\$ 30,000$, and $1,980, \$ 30,000$ or over. This report showed the falsity of the assertion that the National bank shares were principally held by large capitalists or that the system was monopolistic. Over sixty per cent. of the shares was held in lots of $\$ 1,000$ or less. Besides the distribution of shares among women the report of this year showed that there were 499 women employed by the National banks.

\section{COMPTROLLER'S REPORT FOR 1898.}

On January 3, 1898, Hon. Charles G. Dawes entered upon his duties as Comptroller of the Currency, succeeding Hon. James H. Eckels. A large part of the report of the new Comptroller for the year ending October 31, 1898, was devoted to a discussion of the issue of bank notes based on a first lien against the general assets of the banks. He contended that this would result in great loss to depositors, and published a number of carefully-prepared tables to support this view. He also opposed the principle of making the note holders preferred creditors of failed banks, although nearly all banking authorities are agreed that the claims of note holders should take precedence of those of depositors, and for the reason that a holder of a bank note is not a creditor of the bank from choice, but by business custom he is almost compelled to accept current forms of money, although they may not be a legal tender. The deposit of funds in a bank, however, is a purely voluntary act, and discretion may be exercised in selecting the bank believed to be strongest. The National Banking Act makes the notes a first lien on the assets by requiring that a portion of the assets, in excess of the notes issued, shall be invested in Government bonds for the benefit of the note holders, and that a further portion of the assets shall be placed with the Treasury in the shape of a redemption fund. In addition the law gives the Government a paramount lien on the assets of failed banks, so that it may recoup any possible loss should the bonds deposited to secure circulation not sell for enough to redeem the notes.

\section{The National Banks in 1898.}

From the date of the granting of the first certificate of authority, June 20,1863 , to the end of the year covered by the reportfor 1898 , there had been 5,151 National banking associations organized-an average for each year of 147. On October 31,1898 , there were in active operation 3,598 banks, having an aggregate authorized capital stock of $\$ 624,552$,195. The total outstanding eirculation amounted to $\$ 239,546,281$, of which $\$ 210,045,456$ was secured by United States bonds, and the remainder, $\$ 29,500,825$, by lawful money deposited with the Treasurer of the 
United States for account of liquidating and insolvent National banking associations and those reducing circulation. The increase during the year in amount of circulation secured by bonds was $\$ 6,119,776$, and the increase in total circulation, including the notes of liquidating and insolvent National banking associations and those reducing circulation, $\$ 9,582,771$.

The number and eapital of the 3,598 banks in operation on October 31,1898 , in each geographical division were as follows : Five hundred and éighty-two banks, with capital stock of $\$ 155,231,620$, in the New England States ; 961 banks, with capital stock of $\$ 193,887,122$, in the Eastern States; 539 banks, with capital stock of $\$ 64,788,200$, in the Southern States ; 1,045 banks, with eapital stock of $\$ 158,653,100$, in the Middle States ; 348 banks, with capital stock of $\$ 31,699,100$, in the Western States, and 123 banks, with capital stock of $\$ 2(1,065,000$, in the Pacific States.

In point of number of banks in active operation, Pennsylvania, New York, Massachusetts, Ohio, Illinois and Texas led with 428, 327, $263,254,219$ and 197, respectively. According to eapital stock, Massachusetts was first, with $\$ 91,627,500$, New York second, with $\$ 82,944,940$, Pennsylvania third, with $\$ 73,359,390$, followed by Ohio, with $\$ 45,535$,967 , Illinois, with $\$ 36,746,000$, and Texas, with $\$ 19,515,000$.

During the report year there were organized fifty-six banks, located in twenty States and two Territories, with aggregate capital stock of $\$ 9,665,000$. Of this number eight were in Pennsylvania, seven in Ohio, six in Iowa, five in Illinois, four each in New York and Texas, three in Indian Territory, two each in California, Kansas, Missouri and New Jersey, one each in Alaska, Delaware, Indiana, Kentucky, Maryland, New Hampshire, North Carolina, South Carolina, Virginia, Wisconsin and Oklahoma Territory.

In geographical divisions the number of banks organized during the year was as follows : New England States, 1, with capital stock $\$ 50,000$; Eastern States, 16 , with aggregate capital, $\$ 1,185,000$; Southern States, eight, combined capital, $\$ 620,000$; Middle States, twenty-two, total capital, $\$ 3,960,000$; Western States, six, capital aggregating $\$ 300,000$, and Pacific States, three, capital, $\$ 3,550,000$. California was first in amount of capital stock of banks organized during the year, having $\$ 3,500,000$; Illinois had $\$ 2,250,000$; New York, $\$ 525,000$, and Indiana, $\$ 500,000$, the total capital of banks in each of the other States ranging from $\$ 460,000$ down to $\$ 50,000$.

The corporate existence of twenty National banking associations having capital stock of $\$ 2,145,000$, total circulation $\$ 844,875$, and located in twelve States, was extended during the year as follows : New York five, Pennsylvania three, Illinois and Massachusetts two each, and the following one each : Delaware, District of Columbia, Indiana, Kentucky, North Dakota, South Dakota, Vermont, and Washington. Of the total capital, New York aggregated $\$ 585,000$, Massachusetts $\$ 350,000$, 
Pennsylvania $\$ 210,000$, Illinois and North Dakota $\$ 150,000$ each, and Delaware, District of Columbia, Indiana, Kentucky, South Dakota, Vermont, and Washington $\$ 100,000$ each. Under the act of Congress approved July 12, 1882, providing for the extension of National banking associations, the corporate existence of 1,670 banks, having an aggregate capital stock of $\$ 407,531,115$, had been extended. Of these, New York has 244, Massachusetts 231, Pennsylvania 208, Ohio 114. The number of banks in each of the other States ranges from seventyfive down.

By reason of the expiration of corporate existence, three banks, having an aggregate capital stock of $\$ 534,000$, and total circulation of $\$ 165,000$, left the system during the year. They were located in Illinois, Kentucky, and Pennsylvania. Those in the last two States were succeeded by new associations with capital stock of $\$ 250,000$, and cireulation amounting to $\$ 67,500$.

In the ten years from 1899 to 1908 , inclusive, the corporate existence of 1,134 banking associations, with capital stock amounting to $\$ 162$,418,150 , and circulation $\$ 44,293,753$, will expire by limitation.

The number of banks leaving the system during the report year of 1898 by voluntary liquidation was sixty-nine, one of which subsequently passed into the hands of a Receiver. The sixty-eight banks which liquidated had a total capital stock of $\$ 12,509,000$, and circulation amounting to $\$ 2,184,958$.

\section{Maximum National Banking Capital.}

In the midsummer of 1893 the capital stock of the National banks reached the maximum, $\$ 699,034,665$.* Since that date, up to October $31,1898,223$ banks had been organized with an aggregate capital of $\$ 27,505,000$, and 100 increased their stock in the sum of $\$ 8,612,000$. In the same period, by failures, reductions of capital stock, and voluntary liquidations, $\$ 110,599,490$ had been eliminated, leaving $\$ 624,552,195$ on October 31, 1898. While 316 banks, with capital of $\$ 43,991,100$, liquidated voluntarily, twenty-five per cent. of the number were consolidated with other associations. These liquidations and reductions of stock were the inevitable results of constantly decreasing dividends. During the year ended March 1,1893, the average rate of dividends paid to the shareholders of National banks was 7.5 per cent.; in the following year, 6.8 per cent.; in $1897,6.7$ per cent. ; and in $1898,6.96$ per cent. The competition for deposits has developed the very general custom of paying high rates of interest thereon. The prevailing low rates of interest on loans and discounts have also lessened the returns to stockholders. For the year ended June 30, 1898, the tax on National-bank circulation was $\$ 1,901,817$, and the total amount paid to the Government as tax on circulating notes, $\$ 83,313,202.25$.

* Comptroller's Report, 1898, p. XLV. The maximum stated on the following page is taken from the official statistics. 


\section{The National Banks in 1899.}

On June 30, 1899, there were 3,583 National banks in operation, having $\$ 604,865,327$ capital, $\$ 248,146,167$ surplus and $\$ 94,175,584$ undivided profits. The total resources were $\$ 4,708,833,904$, and individual deposits, \$2,522,157,508. Circulating notes outstanding amounted to $\$ 199,358,382$. In 1873 the circulation stood at over $\$ 340,000,000$. Individual deposits passed the one billion mark for the first time in 1881, and in 1898 exceeded $\$ 2,000,000,000$, the total resources in the latter year rising to four thousand millions, the largest total ever recorded up to that time. Capital stock reached its maximum-\$689,600,000-in 1892, and has steadily declined to $\$ 604,800,000$ on June 30,1899 . As the country increases in wealth it appears to be a natural tendency for the banking capital to decline, the depositors supplying more of the loanable funds. The surplus has almost uniformly increased each year, and the amount reported on June $30,1899-\$ 248,146,16 \%$-was the maximum. There has been a loss in the number of banks in recent years. On October 3,1893 , there were 3,781 banks against only 3,583 on June 30, 1899.

The National banks of the United States have failed to provide the country with a paper currency because of the competition of the Government in that field, and for the further reason that under existing law there is no substantial profit to a National bank issuing circulation. But in their deposit and discount functions they have been most successful, and it is doubtful if any system of banking permitting the free organization of banks of small capital has ever been safer or of greater benefit to productive industries.

Condition of the National Banks of the United States, June 30, 1899.

RESOURCES.

Loans and discounts. $\$ 2,492,234,584.52$

Overdrafts........................................

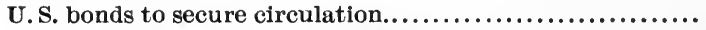

$15,724,395.38$

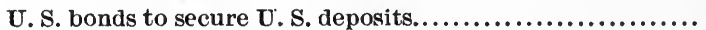

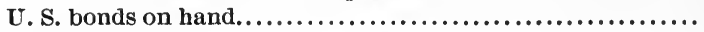

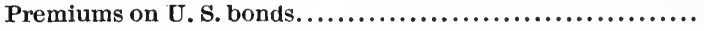

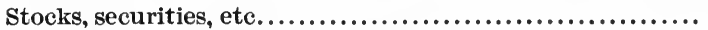

Banking house, furniture and fixtures.

$228,870.310 .00$

$\mathbf{7 8 , 4 9 7 , 0 4 0 . 0 0}$

$21,031,310.00$

$17,715,752.92$

$305,428,927.40$

$78,905,167.54$

Other real estate and mortgages owned...................

Due from National banks.

$30,477,935.92$

$223,873,819.92$

$56,634,310.02$

Due from State banks and bankers.......................

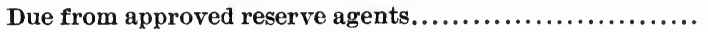

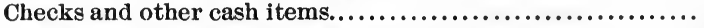

Exchanges for clearing-house.

$406,668,464.82$

$25,631,637.24$

$203,003,934.53$

$19,55 \%, 261.00$

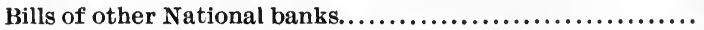

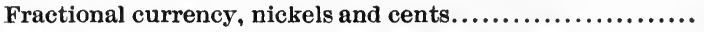

Specie.

$1,107,699.27$

$356,822,046.19$

$116,337,935.00$

$18,590,000.00$

$10,095,518.01$

U. S. certificates of deposit.............................

Five per cent. redemption fund..........................

$1,629,855,16$

Total 
Liabilities.

\begin{tabular}{|c|c|}
\hline \\
\hline \multicolumn{2}{|l|}{ Capital stock paid in ......................... } \\
\hline 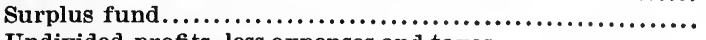 & $248,146,167.55$ \\
\hline Undivided profits, less expenses and taxes..... & $94,175, \mathbf{0 8 4 . 6 4}$ \\
\hline National bank notes outstanding.............. & $199,358,382.50$ \\
\hline State bank notes outstanding....... & $53,108.50$ \\
\hline Due to other National banks............ & $598,340,332.85$ \\
\hline Due to State banks and bankers......... & $334,064,533.98$ \\
\hline Dividends & $7,735,327.07$ \\
\hline Indivi & $2,522,157,508.99$ \\
\hline U. S. deposits........................... & $70,481,616.36$ \\
\hline Deposits of U. S. disbursing officers...................... & $5,831,775.01$ \\
\hline Notes and bills rediscounted....................... & $2,154,782.17$ \\
\hline Bills pay & $6,078,284.90$ \\
\hline Liabilities other than those above............................. & $15,391,173.52$ \\
\hline
\end{tabular}

It will be seen from the foregoing table that the total specie holdings of the National banks on June 30,1899 , were $\$ 356,822,046.19$. Of this amount $\$ 137,690,618.39$ was gold coin, $\$ 23,152,390$ gold Treasury certificates, $\$ 148,495,000$ in gold clearing-house certificates, $\$ 8,361,974$ silver dollars, $\$ 32,578,638$ silver Treasury certificates, and $\$ 6,543,425.80$ silver fractional coin. The holdings of the two metals were:

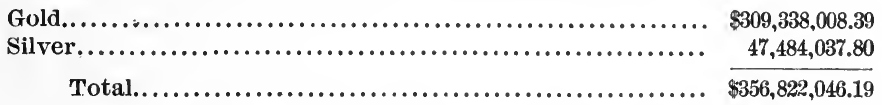

From the beginning of the National banking system up to June 30 , 1899 , there had been 5,196 banks organized, of which 1,245 had gone into liquidation, and 368 had become insolvent, leaving 3,583 in operation.

For the purposes of the Bureau the Comptroller divides the States into the following classifications: New England States-Maine, New Hampshire, Vermont, Massachusetts, Rhode Island and Connecticut; Eastern States-New York, New Jersey, Pennsylvania, Delaware, Maryland, District of Columbia ; Southern States-Virginia, West Virginia, North Carolina, South Carolina, Georgia, Florida, Alabama, Mississippi, Louisiana, Texas, Arkansas, Kentucky, Tennessee ; Middle States-Ohio, Indiana, Illinois, Michigan, Wisconsin, Minnesota, Iowa, Missouri; Western States-North Dakota, South Dakota, Nebraska, Kansas, Montana, Wyoming, Colorado, New Mexico, Oklahoma, Indian Territory ; Pacific States-Washington, Oregon, California, Idaho, Utah, Nevada, Arizona, Alaska.

Of the total capital of the National banks in existence on June 30, $1899, \$ 144,028,970$ belonged to banks in the New England States, $\$ 190$,175,175 to those in the Eastern States, $\$ 63,943,765$ to banks in the Southern States, $\$ 157,474,317$ to banks in the Middle States, $\$ 29,906,100$ to the banks in the Western States, and $\$ 19,337,000$ to banks in the Pacific States. Individual deposits were distributed as follows: New England States, $\$ 361,905,802$; Eastern States, $\$ 1,167,394,397$; Southern States, $\$ 180,507,964$; Middle States, $\$ 619,243,010$; Western States, $\$ 122,372,369 ;$ Pacific States, $\$ 70,733,965$. 


\section{XIV}

\section{REVIEW OF NATIONAL BANK LEGISLATION.}

Secretary Chase's report of 1861 -Drafting the National Currency Act-Legal tender act-Debate on legal-tender bill-Tax bill-National Currency ActDebate on Currency Act-Amendments-Criticism of sections-Opposition of State banks - Bill passes Senate-Secretary of the Treasury on bond negotiations - Repeal of provision of law for funding legal-tender notes into bondsCurrency bill in House-Debate in House-Bill passes House and becomes a law-Defects of act of 1863-Comptroller McCulloch's report of 1863-President Lincoln on Currency Act.

\section{Providing Funds to Meet the Expenses of the Civil War.}

Secretary Chase, in his report to Congress of December 9, 1861, found it necessary to ask for additional means to meet the demands on the Treasury, and suggested two plans. The first contemplated the gradual withdrawal from circulation of State bank issues and the substitution therefor of United States notes payable in coin on demand ; and the second the issue of notes under national direction to institutions and associations, the redemption of such notes in coin to be secured by the pledge of United States bonds and other needful regulations. The first plan had already been partially adopted by the issue of demand notes. The Secretary suggested that the issue of these notes might be extended to an amount equal to the average circulation of the country, and the withdrawal of State bank circulation accomplished by a moderate tax thereon. He was, however, more favorably inclined to the second plan, and thought it had greater advantages without the dangers of the first.

Hon. E. G. Spaulding, in his " Financial History of the War," says, on page 11, that after reading the report of Secretary Chase and finding that the Secretary forbore to recommend the issue of United States Treasury notes to circulate as money, and that he did recommend the national currency bank bill, he (Mr. Spaulding) as chairman of the sub-committe of the Committee on Ways and Means, addressed a note to the Secretary requesting him to furnish the draft of a bank bill for a national currency based on a pledge of public stocks as recommended in his report, and received the following reply:

Treasury Department, December 18, 1861.

SIR : I have the honor to acknowledge the note of the Committee of Ways and Means of this date, covering the note of yourself as chairman of the sub-committee, 
requesting him to furnish the draft of a bill for a national currency based upon the pledge of public stocks. The Secretary of the Treasury, who is now in New York, will give your request his prompt attention on his return.

With great respect,

Geo. Harrington, Acting Secretary of the Treasury.

To Hon. E. G. Spaulding,

Ch. of Sub-Com. of Ways and Means, H. R.

On the return of the Secretary from New York it was ascertained that no national currency bank bill had been prepared. The Secretary then requested $\mathrm{Mr}$. Spaulding to prepare a bill at as early a day as possible. Mr. Spaulding, as chairman of the sub-committee, immediately set to work at his rooms at the National Hotel, preparing the first draft of the bill, which was then copied by George Bassett, Clerk of the Ways and Means Committee. This was during the Christmas holidays, Congress adjourning over two or three days at a time without doing much business, no quorum being present. On December 24 Mr. Spaulding wrote a letter to Mr. Corning, then at Albany, informing him that he was making a draft of the national currency bank bill, and requesting that he would forward a copy of the New York free banking law passed in 1838, with amendments thereto, for the use of the committee. Mr. Corning promptly complied with this request and returned the following reply:

Albany, December 26, 1861.

Mr DEAR SIR : I am, this morning, in receipt of your favor of the 24th inst. I send you by this day's mail a copy of our bank laws, with amendments passed since 1856. This matter as recommended by Secretary Chase will not, in my judgment, meet the approval of our State, hence I think much care should be had in drawing up the bill.

Yours, very truly,

Hon. E. G. SPAUlding, Washington.

Erastus Corning.

When the framework of the bill was nearly completed it was submitted to Mr. Hooper, the only other member of the sub-committee then in Washington, Mr. Corning having gone to Albany. Mr. Hooper rendered valuable assistance in perfecting the bill. He incorporated in it some provisions which the experience of Massachusetts had shown to be valuable.

The bill was finally completed soon after Christmas. A few days afterward the bill thus hastily prepared by Mr. Spaulding was sent by him to the Public Printer, and two hundred copies printed for the use of the Committee on Ways and Means and the Secretary of the Treasury, with the view of having it more maturely considered in the general committee, amended and corrected and finally to be reported to the House. This bill formed the basis of the bank bill which was adopted more than a year afterwards.* The foregoing is the statement

* Upon mature consideration and further examination Mr. Spaulding came to the conclusion that the bank bill, containing sixty sections, could not, with the State banks opposed to it, be passed through both bouses of Congress for several months, 
of one of the principal actors on the financial stage of 1861, and there is no reason to doubt its accuracy. But there is reason to believe also that the matter of drafting a currency bank bill was also referred to Edward Jurdan, then Solicitor of the Treasury. The probability is that the Secretary did not avail himself of the result of the labors of the Solicitor, finding that Mr. Spaulding had completed his draft. An examination of the bill as finally adopted indicates that after an examination of the free banking laws of the several States, the features most approved in practice were taken from each. To this nucleus were added provisions giving further security to the proposed circulating notes, and also further provisions for a proper governmental supervision of the banking business such as experience had shown to be necessary. There were also included in the original draft some suggestions that had been made for attracting the State banks to the new system as well as to induce the friends of the State banks to support the bill. Though at this time more interesting than useful, it is easy to analyze the original banking act of 1863 and find whole sections taken bodily from the free banking laws of New York, Ohio and Michigan.

The bill was introduced by Mr. Hooper, of Massachusetts, on Friday, July 11, 1862, read twice and referred to the Committee on Ways and Means.

Mr. Hooper also introduced a resolution providing that 5,000 extra copies of the bill be printed. This was referred to the Committe on Printing; and, on July 15, when this committee reported the resolution to the House, its consideration was opposed by Roscoe Conkling and, on motion of Frederick A. Conkling, it was laid on the table.

\section{Legal-Tender Notes Proposed.}

A bill to authorize the issue of Treasury notes, payable on demand, was introduced by Mr. Spaulding on December 30, 1861, and referred to the Ways and Means Committee. It was first reported by Mr. Spaulding on January 7, but failed then to receive consideration. It authorized $\$ 100,000,000$ of demand notes; and, when reported again by $\mathbf{M r}$. Spaulding, on the next day, was referred to the Committee of the Whole on the State of the Union and ordered to be printed. On Wednesday, January 22, 1862, Mr. Spaulding introduced, as a substitute for the previous bill, the first bill providing for the issue of legal-tender notes. It came up for consideration on January 28.

In explaining the measure Mr. Spaulding referred to the suggestions in the Secretary's report, and said that the condition of the country was very different from what it was two months previous. In the

and that so long a delay would be fatal to the Union cause. Mr. Spaulding therefore changed the legal-tender section, intended originally to accompany the bank bill, into a separate bill, with alterations and additions, and on his own motion introduced it into the House by unanimous consent on December 30, 1861.-- "Financial History of the War," by E. G. Spaulding. 
meantime, specie payments had been suspended. The Secretary had not recommended demand notes. He had recommended a national currency to be issued by banks. A bill to carry out the suggestion had been prepared and was in the hands of the Ways and Means Committee. The committee had, however, come to the conclusion that, however advişable this plan might be in providing a way for funding United States stocks, it could not be made available soon enough to meet the impending necessities of the Government.* The new system would necessarily go into operation slowly.

An estimate of expenses for the year ended July, 1863, made by Mr. Spaulding, exceeded that of Secretary Chase's report by $\$ 300,000,000$; but Mr. Spaulding said that the Secretary now agreed with his estimate. Unless this bill passed, the bonds of the United States could not be sold except at a ruinous discount, and the present available means were so reduced that the Government must stop payment in a few days.

The necessity of the case was conceived by the majority in Congress to justify them in authorizing legal-tender notes instead of demand notes or National bank currency, and the Secretary of the Treasury, apparently against his will, was forced to accede to the legal-tender proposition as the only one on which it was practicable at that time to obtain legislative action.

\section{System of Bank Currency Contemplated by Secretary Chase.}

Secretary Chase's plan for a bank currency based on bonds does not appear to have been presented in the simple form in which he conceived it. He seems to have contemplated no destruction of existing State bank corporations, but merely to require them to substitute for their own currency a national currency secured by United States bonds - a tax on State bank circulation being the force by which this change was to be brought about. The change which Mr. Chase appears to have desired to accomplish was the investment of the entire State banking capital then existing in United States bonds, which were to be deposited as security for the new circulation. If no limit had been fixed on the issue of national circulation by each institution except the amount of bonds it could secure and deposit, the circulation furnished in this way would have been adequate to the demands of the Government, and it would have furnished an unlimited market for bonds. It was not necessary that the first bill should contain any other provisions. Restrictions could have been imposed as needed by subsequent legislation. This original national currency measure seems to have been calculated to have accomplished within a reasonable time the purpose for which it was intended, if it had not been overloaded at the outset. There was, however, in Congress much jealousy of any

* Secretary Chase's recommendation had been based upon a large amount of specie in the country. 
interference with the State banks and banking systems, and it is possible that the Secretary's plan, even if introduced in its simplest form, might have proved unacceptable.

\section{Debate on the Legal-Tender Bill.}

In the debate on the legal-tender note bill, Mr. Hooper set.forth the advantages of the national curreney bill at some length, and with a tone of predilection in its favor, but seems to have agreed with his colleagues that it could not go into operation in time to meet the present emergency. Secretary Chase finally gave his reluctant consent to the legal-tender bill in these words: "I came with reluctance to the conclusion that the legal-tender clause is a necessity; but I came to it and support it earnestly. I do not hesitate since I have made up my mind. * * * The conclusion I have arrived at is that it is important to the success of the measure." It seems to have been a bitter pill to him. In his letter to the Ways and Means Committee, of January 29, 1862, he merely says: "The provision making United States notes a legaltender has doubtless been well considered by the committee, and their conclusion needs no support from any observation of mine." The letter in which this last quotation is contained was all that was first produced in the House. The evasive character of Mr. Chase's declaration in this letter was noted. Roscoe Conkling asked Mr. Spaulding to state whether the Secretary was for or against this bill with the legaltender provision in it. Mr. Spaulding answered that he was anxious to have it passed in its present form, and, after some hesitation, produced a private letter to himself, of which the first quotation was a part. The Secretary apparently preferred not to put himself on record, if possible, in favor of the bill.*

Mr. Conkling regarded the legal-tender bill as a scheme to introduce the banking bill, which he criticized as hostile to the existing State banks, and at the same time deprecated any plan that would provoke the hostility of this portion of the business community which, in New York city, had, out of a capital of $\$ 119,000,000$, advanced $\$ 100,000,000$ to the Government.

Mr. Kellogg, of Illinois, defended the legal-tender bill from the imputation that it would be dishonest to compel the banks to take these notes. He thanked God that there were but few banks in Illinois. They had, most of them, been obliterated, as they ought to be. Being reminded that they were Western "wild-cat" concerns, he retorted that the "wild-cat" concerns of Illinois were carried on by Eastern

*In a letter to Mr. Spaulding on February 3, 1862, Secretary Chase said: "Mr. Seward said to me on yesterday that you observed to him, that my hesitation in coming up to the legal-tender proposition embarrassed you, and I am very sorry to observe it, for my anxious wish is to support you in all respects. It is true that I came with reluctance to the conclusion that the legal-tender clause is a necessity, but I came to it decidedly, and I support it earnestly."-"Financial History of the War," by E. G. Spauiding. 

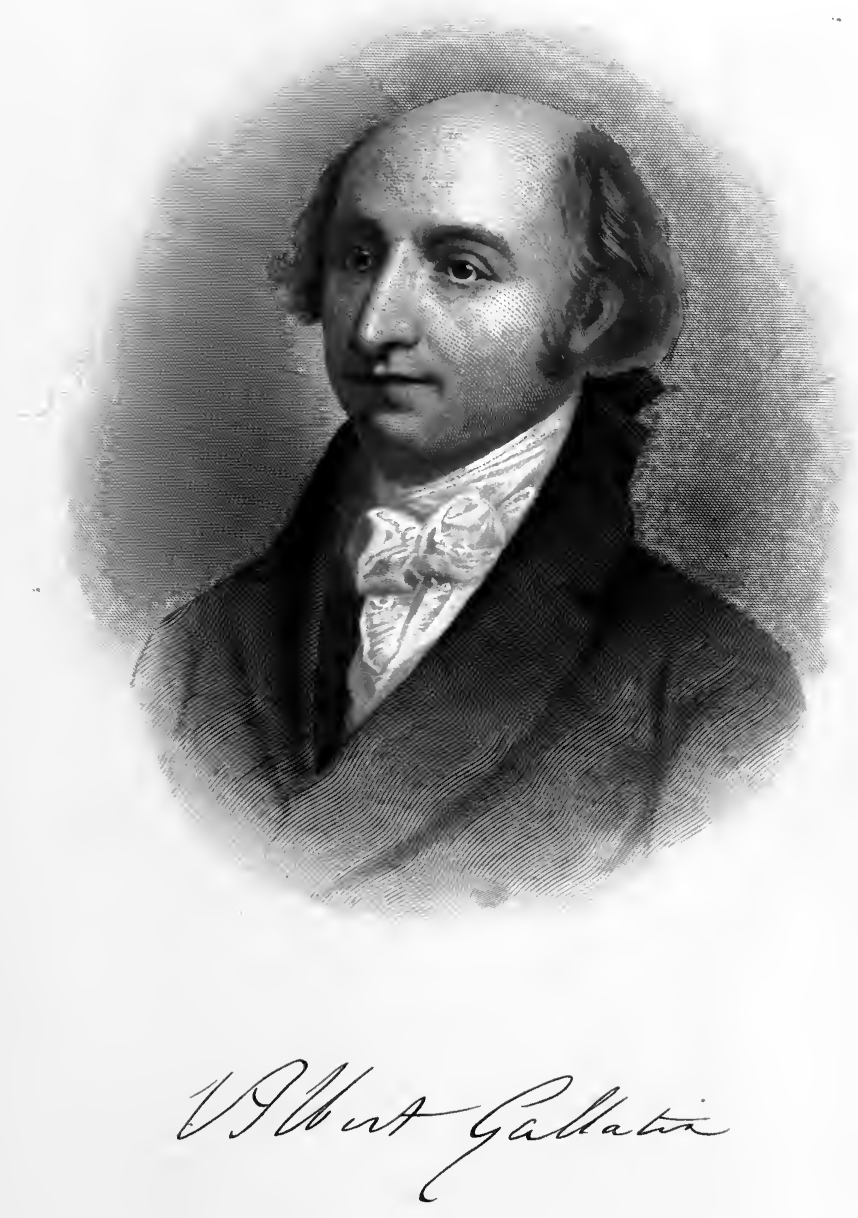


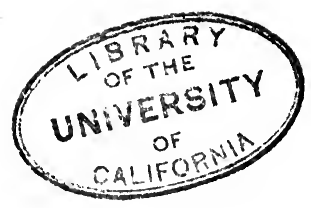


speculators. He'asked Mr. Sheffield, of Rhode Island, who had interrupted him: "Where is the Central Bank of Rhode Island, a specimen article of "wild-cat' banks ?"

The reply was, that "the Governor of Illinois got control of it, put it in his pocket and carried it off."

Mr. Kellogg retorted that "the Governor not only pocketed the bank, but also money from the Treasury of Illinois. He went to Rhode Island, got his hand in with that bank, and learned his trade before he pocketed the funds of the State."

Mr. Stevens said that the banks were unable to loan any more to the Government. They had suspended specie payments and no one expected resumption until the close of the war.

\section{Proposed Taxation of State Bank Notes.}

On January 8, 1863, Senator Sherman took up and discussed the bill previously introduced by him for taxing bank bills and fractional currency. This measure had been introduced in accordance with the recommendation of the Secretary of the Treasury on the ground that the circulation issued by State banks interfered with the issue of legaltender notes, and with funding the United States debt in bonds. The proposition was to tax bank bills in denominations of over one dollar, two per cent., and fractional eurrency of less denominations than one dollar, ten per cent., and Mr. Sherman admitted that the object of the bill was to induce the withdrawal of bank paper in order to substitute the national currency which, at that time, was the legal-tender note. In this discussion Mr. Sherman supported the view that the issue of notes by State banks was contrary to the Constitution.

The National Currency Act was introduced by Mr. Hooper on January 7 , and referred to the Ways and Means Committee. The next day Mr. Stevens, chairman of that committee, reported adversely; but, not having the bill to be read, the report was objected to. He again reported it on the same day, and its consideration was postponed until Friday, January 16. From this time on the subject appears to have been dropped in the House, although new bills of the same purport were from time to time introduced. In the meantime the matter was being discussed in the Senate.

\section{National Bank Bill Introduced in the Senate.}

On Monday, January 26, 1863, the National banking bill, which finally became a law, was introduced by Senator Sherman, and referred to the Finance Committee. Mr. Sherman remarked that there were some features in the bill a little different from those introduced in the House of Representatives. On February 2, notice was given by Mr. Sherman that he had been expecting to report the bill with sundry amendments, and that he would call it up on the following Wednesday and ask for early action. It was not, however, called up until Monday, 
February 9, when, after a motion to postpone, which was defeated by a vote of twenty-one to twenty, its consideration was proceeded with section by section. The first amendment adopted was, that the Comptroller and Deputy Comptroller should not be either directly or indirectly interested in any institution issuing currency under the act. There was not much discussion of the language of the bill, until the last section was reached, when a substitute was proposed providing for the conversion into National associations of State and Territorial banks. This caused some debate as to the power of a Territory to create banks, and Mr. Lane, of Kansas, said that both Kansas and Nebraska Territories, under their organic acts, could not authorize banks, but there were a number of spurious establishments claiming a sort of existence, and he did not wish that these should have the privilege of the new National bank law. The section was then so amended as to exclude the Territorial banks. The point whether State banks should become National without a State-enabling act was also discussed. It appears to have been agreed that Congress did all that was necessary by providing a way for the State banks to go into the system. The question of their relation to the State was one to be left to the decision of each individual bank.

\section{Circulation Proposed for State Banks.}

Mr. Harris, of New York, prepared a section which enabled State banks, without giving up their status as such, to deposit bonds and receive National currency.

Mr. Powell, of Kentucky, desired to provide that no National banks should be organized in any State without the consent of that State. He made a long constitutional argument upon this point, but nobody seems to have taken the trouble to reply to Mr. Powell.

Mr. Sherman objected to Mr. Harris' amendment on the ground that it would cause a lack of uniformity in the character of the banks to be organized under the new system. He then explained the limitedliability clause as being the same as that embodied in the laws of New York and in those of most of the States, and also, in reply to a question of Mr. Doolittle, explained the clause in the law giving priority of claims for circulating notes. He stated that the United States, under the law, would redeein the notes of insolvent National banks, and to reimburse itself hold the bonds and, likewise, had a prior lien on all the other property of the bank.

Mr. Powell, who was evidently disappointed at the ill success of all his State rights propositions, introduced an amendment "that the National banks should keep twenty-five per cent. of the reserve on their notes in gold and silver coin."

Mr. Sherman incautiously answered and gave Mr. Powell the opportunity he desired to make a general criticism on the final proposition of the Government. 


\section{Speech of Senator ShermaN.}

On February 10 Senator Sherman entered into an elaborate speech in favor of the bill in which he stated the main arguments in favor of, and the objections to, the measure, among those who were in sympathy with the Union. He said:

" Since December, 1861, though the proposition ran counter to many local interests, it had steadily gained in favor with all classes of citizens. Under the existing condition of affairs the Government required exceptional means and there were but four expedients among which to choose: First, to use the local currency of the banks; second, to increase the issue of United States notes; third, to organize a system of National banks, or fourth, to sell the bonds of the United States in open market. There were fatal objections to local bank currency, of which the want of security, of uniformity, and the depreciation in value and consequent loss were the chief. The notes of the United States were a better currency than the notes of the local banks, but were objectionable from the fact that their elasticity depended entirely upon the expenditures of the Government, and were at one time redundant, and at another deficient, as Government expenditures were large or contracted, and therefore the amount of them in circulation did not necessarily bear any relation to the business wants of the people. At the present time the great danger was from the undue expansion of these issues. The mere introduction in the House of a bill to issue three hundred millions additional had caused the premium on gold to rise twelve per cent. in six days-from thirty-six to forty-eight per cent.- and within three weeks to nearly sixty per cent. These notes are redeemable and although fundable into bonds they can only be used during the war. When peace comes they will be entirely funded into bonds, and cause then a rapid contraction in prices. They are made the basis of State bank issues, which have increased from one hundred and twenty to one hundred and sixty-seven millions within the year. Great objection is made to the attempt to tax local circulation, but there is no other way to reduce its inflation. The local banks have always been hostile to a national currency. When specie payments are suspended the power to issue a bank note is the power to coin money. The history of the country is full of the disastrous consequences of a system of local banks. The security provided for the currency to be issued under the bill is ample. The United States guarantees the payment of the notes and holds a first lien on all the property of the bank. The new currency will be uniform in appearance and ralue throughout the United States. The banks furnish a market for United States bonds, and as security for their circulation they must deposit bonds of a par value ten per cent. in excess of the circulation they issue. The demand for the bonds will keep up the Government credit. It is not a scheme to break down the local banks. Every one of them can avail themselves of the provisions of the law and receive benefits from the change. The bill will furnish a uniform currency in which to pay taxes. It will create a unity of interest between the people, the stockholders and the Government. It will encourage a feeling of nationality. The uniformity of the notes will guard against frauds and counterfeits. The banks will be depositories of the public money. The wisdom of the establishment of a National system of banking is consistent by precedent in this and other countries."

United States notes were thought preferable by many because they are a debt bearing no interest, and the issue of bonds will increase the interest-bearing debt.

In reply to this Mr. Sherman remarked that "the debt is not so appalling, inasmuch as under the taxation authorized it will be paid in 
forty years. The dangers of unlimited paper money are vastly greater than those of a funded debt. The National banking system of taxation proposes a well regulated sinking fund, and care and economy will enable the country to continue this war, even under the enormous burdens now proposed."

Mr. Howard, of Michigan, desired that the certificates of organization of National banks be published with the laws of the United States. This amendment was at first agreed to, but Mr. Sherman moved its reconsideration and it was finally rejected. Mr. Howard then proposed that thirty per cent. of the capital should be paid in specie. This was also rejected.

Mr. Harris proposed three sections to be added by which State banks holding and depositing fifty per cent. of their capital in United States bonds were to receive circulation on the same in the proportion of eighty per cent. of the par value of the bonds. These amendments were agreed to.

Mr. Henderson, of Missouri, desired that the minimum capital stock be $\$ 300,000$ instead of $\$ 50,000$. This after some debate was rejected, and Mr. Powell proposed that the banks should, twelve months after the war ceased, be required to redeem notes in gold and silver. This was rejected.

\section{State Banks Defended.}

Mr. Collamer, of Vermont, argued that the destruction of State banks, which was the necessary effect of the bill, would be utterly disastrous to society, inasmuch as the operations of the State banks were inextricably interwoven with the business of every community. The passage of the bill would be followed by another taxing State bank circulation two per cent. This tax of the United States interfered with the right of the State to tax its own banks, and the United States could just as well destroy State schools by taxation, if it had the right to destroy State banks by that means. The United States Supreme Court had decided that a State could create a bank to issue paper money, although such bank could not issue State money, and also that the States had no right to tax a bank created by the United States. The United States has no more right to tax a State bank than the States have to tax a United States bank. The only fund the States have for schools is derived from their banks, and Mr. Collamer considered the provisions for the redemption of the notes as hardly worth the paper they were written on. If United States bonds should depreciate the banks would want all the notes to be presented at the Treasury for redemption. The proposed two per cent. tax upon State bank circulation would wind up the State banks. He said that the exemption of the National banks from State taxation, while the State banks were liable to it, and the proposition at the same time of a United States tax upon the circulation of both classes of banks, was unjust to the State 
banks. He believed that the old institutions would be forced out, and that no new banks would be created under the bill. Mr. Collamer also complained that too much power was given to the Comptroller and Secretary of the Treasury.

Mr. Sherman replied to Mr. Collamer and held that the State banks would not be destroyed. If they desired circulation, under the new bill they could get it. If they did not, they could carry on their operations without circulation. The States could not now tax United States bonds on which this currency was to be based. The tax on the new circulation brings a revenue to the United States from the bonds without taking anything which they now possessed from the States. Mr. Sherman contended that the State banks need not call in their loans, nor change their discounts for anything in this bill. Among other amendinents inserted was one to include Chicago, Providence and St. Louis among the redemption cities.

Mr. Powell renewed his old amendments in reference to a reserve of twenty-five per cent. in specie, and requiring the resumption of specie payments within twelve months after the close of the war, but they were both again rejected.

Mr. Davis, of Kentucky, was opposed to the bill as a war upon the State banks.

Messrs. Wilson and Doolittle defended it. It passed the Senate Thursday, February 12, 1863-yeas, 23; nays, 21.

\section{Report of The Secretary of the Treasury, 1862.}

The original legal-tender note bill contained a provision authorizing the holders of all of these notes to fund them in the United States fivetwenty six per cent. bonds. This privilege of funding was held by the Secretary to interfere to a considerable extent with his efforts to place the bonds in the market. In his report of December 4, 1862, he estimated that the public debt on July 1,1863 , would amount to $\$ 1,122$,297,403 . The Secretary estimated that loans to the amount of $\$ 60$,000,000 would be required for sixty days. He further estimated that if the loans he was authorized to issue were sold for coin it would require $\$ 75,000,000$ in bonds to raise the first $\$ 60,000,000 ; \$ 90,000,000$ in bonds to raise the second $\$ 60,000,000$; and $\$ 120,000,000$ in bonds to raise the third $\$ 60,000,000$. This constant depreciation of United States securities would result-in their utter discredit. He next considered the advisability of the reception of suspended State bank bills, instead of specie, in payment of bonds. The sacrifices in this method, he thought, would be as great as in the plan of issuing United States bonds for coin, inasmuch as the demand for the State bank bills would make them as difficult to get as coin. If there was no expansion in their amount, or if, as was not probable, the State bank issues could be unduly stimulated, their value would depreciate and a loss equal to or greater than that incurred in the sale of bonds for coin would result. 
The United States notes which had been issued on December 1 amounted to $\$ 222,932,111$ out of an authorized issue of $\$ 250,000,000$. Of this, $\$ 23,760,000$ had been received in exchange for the United States fivetwenty sixes. The Secretary recommended an additional limited issue of United States notes. He first claimed that there was a redundancy of circulation caused by the issue of State bank circulation during the year from $\$ 130,000,000$ to $\$ 167,000,000$, and that the United States notes were being made the basis of this increased circulation. He recommended the reduction of the circulation of the State banks, and the adoption of the National banking measure. He also said that an act of the last session authorized the Secretary to issue bonds of the United States, already often mentioned as five-twenties, to the amount of $\$ 500,000,000$, and to dispose of them for coin or United States notes at the market value thereof. In the same act authority was given to issue $\$ 250,000,000$ of United States notes, and any holder of such notes to the amount of $\$ 50$ or any multiple of $\$ 50$ might exchange them for the five-twenty bonds at par.

The effect was to make negotiations of considerable amounts impossible, as considerable amounts are seldom taken except with the view to realize at a profit, and resales at a profit are impossible, as bonds can always be obtained at par in United States notes. He therefore recommended the repeal of this provision, or, if the provision was retained, that Congress should authorize him to issue bonds more favorable to the takers-either bonds of longer time or of higher rate of interest.

Congress, in accordance with the recommendation of the Secretary of the Treasury, repealed the provision of law making United States notes fundable into five-twenty bonds, such repeal to take effect after July 1, 1863.

\section{Discussion of the National Currency Bill in the House.}

On February 12, 1863, a messenger of the Senate announced to the House that among other bills the National Currency Bill had passed the Senate, and it was on the same day referred to the Committee on Ways and Means. On the 13th it was ordered to be printed, and on the 19th it was taken up for discussion.

Mr. Spaulding proceeded to explain the bill at length, setting forth its objections and advantages. He did not think it would afford any present relief; that the system would go into operation slowly; and that it would not, to any considerable extent, supersede the necessity. for the issue of Treasury notes. The State banks are firmly established. It will take a long time to supplant them. At the close of the war, when the Government is firmly established, and its authority aceepted in all the States, the system will be most valuable in providing a way for the funding of the public debt, and establishing a permanent system of national currency. 
Mr. Harris opposed the bill for the reason that he believed it would result in inflation and disaster to the Government credit.

Mr. Noell proposed to refer the bill to the Comınittee on Judiciary for a report as to what extent it would interfere with the rights of the States.

Mr. Benton, of New York, stated that "the subject of finance is one of the great questions we are called upon to meet." In giving his support to the bill he would run counter to his previous convictions. He did not, however, believe that existing banking institutions would be injured by it; if he did his patriotism would compel him to give it his support at a time when it was necessary to strengthen and enlarge all the powers of the Government. He quoted from the letter of a banker in his district who, while believing the bill antagonized the local banks, was willing to undergo a personal hardship to advance the public good.

Mr. Baker defended the State banks and opposed the bill because its passage meant the total annihilation of the State banking system. He feared it would force the immense State banking institutions into an attitude of dissatisfaction with the Government. He deprecated the power intrusted to the Comptroller of the Currency and the Secretary. He thought the measure wholly unnecessary.

Mr. Noble discussed the constitutional question, and was of the opinion that the framers of the Constitution did not intend to authorize anything to be made a legal tender in payment of debts but the good old constitutional currency of gold and silver. He regarded the national currency in the same category with legal-tender notes and thought all the paper money schemes of the Government were destructive.

Mr. Alley moved to amend the bill by reducing the semi-annual taxes on circulation to one-half of one per cent. He believed it was for the interests of the bankers to have the measure adopted. He thought the Government circulation should not go on competing with that of the State banks. The tax proposed on national currency of two per cent. per annum was too great. Reduce it one per cent., leaving the provision of two per cent. tax upon circulation in the Finance Bill as it was, and the banks would have a strong inducement to enter the National system.

Mr. Hooper then moved the previous question.

Mr. Conkling and others objected, but it was overruled. The main question was ordered, and after one or two dilatory motions the bill was ordered to a third reading and passed the House by a vote of seventy-eight to sixty-four. It was not amended in the House, and the bill became a law by the signature of the President on February 25, 1863. It taxed the circulation of National banks two per cent. per annum, but imposed no tax upon capital or deposits, nor did it contain any provision authorizing the States to tax National banks. 
A later act passed March 3, 1863, imposed a tax of two per cent. per annum on the circulation of State banks when such circulation exceeded a certain proportion to capital, and of one per cent. per annum upon all other circulation outstanding. Average deposits in excess of average circulation ontstanding were taxed one-eighth of one per cent. semi-annually. National banks were to pay the same tax as State banks, but the manner of collection was different. Fractional issues were taxed ten per cent. per annum.

\section{Limits of National Bank Circulation.}

The limits of circulation were:

Capital not over $\$ 100,000$. Circulation allowed 90 per cent.

Capital over $\$ 100,000$ and not over $\$ 200,000$, allowed 80 per cent.

Capital over $\$ 200,000$ and not over $\$ 300,000$, allowed 70 per cent.

Capital over $\$ 300,000$ and not over $\$ 500,000$, allowed 60 per cent.

Capital over $\$ 500,000$ and not over $\$ 1,000,000$, allowed 50 per cent.

Capital over $\$ 1,000,000$ and not over $\$ 1,500,000$, allowed 40 per cent.

Capital over $\$ 1,500,000$ and not over $\$ 2,000,000$, allowed 30 per cent.

Capital over $\$ 2,000,000$ and not over $\$ 10,000,000$, allowed 25 per cent.

This provision of the general tax bill of March 3, 1863, superseded the provision in the National banking bill, and reduced the tax on National bank notes from two per cent. to one per cent. per annum when within the limits named in the act. A National bank could, under a section of the bank act, receive circulation equal to the amount of its capital stock. Upon ninety per cent. of this it was taxed at the rate of one per cent. per annum, and on the remaining ten per cent. it would have to pay two per cent. If its deposits exceeded its circulation it paid one-quarter of one per cent. on such excess. These taxes were intended to bear equally on both classes of banks. The act also permitted the issue of circulation to National banks to the extent of ninety per cent. of the current market value of the bonds deposited, not, however, exceeding the par value of such bonds. This gave banks with a capital of $\$ 100,000$ an opportunity of receiving circulation to an equal amount on $\$ 100,000$ of bonds, if such bonds were at a premium of twelve per cent. If the bonds were at par they could get $\$ 100,000$ of circulation by putting up about $\$ 112,000$ in bonds. It virtually gave them an opportunity of investing a small part of their deposits in United States bonds until they could get circulation.

While, therefore, under the Currency Act, they had an opportunity to obtain circulation to a greater extent than ninety per cent. of their capital, yet the provisions of the tax law virtually restricted them within that limit.

Recommendations of Mr. MCCulloch.

Hon. Hugh McCulloch, Comptroller of the Currency, in his report to Congress of November 28, 1863, stated that up to that date $134 \mathrm{Na}$ - 
tional banks had been organized under the National Currency Act. Up to the date of the Comptroller's report no circulation had been issued to any of the State institutions. The work of preparing the national circulation had been attended with unlooked-for delays, but that after the banks already organized were supplied, which would probably be accomplished within the next two months, all associations would be furnished with notes within thirty days from the time the bonds were deposited with the Treasurer.

The National Currency Act, although admirable in its leading features, was not altogether symmetrical in its arrangement, nor even clear, if it was consistent in all its provisions, and the Comptroller therefore recommended that the act should be carefully revised. There was ambiguity in regard to the articles of association and organization certificates, and amendments were necessary in the provisions having reference to the increase of capital stock, and in those having reference to the withdrawal of bonds, and the security which might be taken for loans. The section imposing a limit of ten per cent. of capital upon loans should be struck out; and an amendment should be made increasing the limit of the number of directors from nine to thirteen, and requiring that only two-thirds of the directors should be residents of the State-that the officers and directors of insolvent National banks should be made personally liable for the debts of the banks, and should be punished criminally unless an investigation should prove that the affairs of the institution had been honestly administered. This last measure should be adopted in place of the individual liability of stockholders. Further amendments were the reduction of the amount of stock required to be held by a director, as a qualification, and the repeal of the section requiring additional securities to be deposited in the case of depreciation of United States bonds. No bank should be permitted to commence business with a less capital paid in than $\$ 50,000$. There was no provision in the law for the voluntary closing of National banks. The rate of interest to be charged by the National institutions should be made uniform in all the States; and the penalty for usury should be a forfeiture of the interest instead of a forfeiture of the debt, and this uniform rate of interest should be seven per cent. A section should be inserted authorizing the banks to make semi-annual dividends, and before making dividends they should be required to carry to surplus a certain proportion of their net profits. In regard to the provision introduced by Mr. Howard, which made it the duty of the Comptroller to furnish national currency to State banks, upon their deposit of United States bonds, the Comptroller remarks "that is difficult to conceive of a measure more likely to bring the national currency system into conflict with the States and into disrepute with the people," and recommends the repeal of the section. Mr. McCulloch adds that with the suggested amendmends to the act it is not supposed that the National banking system will be an absolutely perfect one, but it is supposed that it will 
afford to the people a better bank-note circulation than any heretofore devised.

The.President, in his message of December 8, 1863, says: "The enactment by Congress of a National banking law has proved a valuable support to the public credit $* * *$ some amendment may be necessary to perfect the existing law." 


\section{$\mathrm{XV}$}

\section{CURRENCY ACT OF JUNE 3, 1864.}

Rally of the State bank opposition - Amendments introduced - Criticisms and debate section by section in the House-Mr. Hooper's speeches-Fails in the House - Another bill introduced in the Senate by Senator Sherman - Again introduced in the House - Amendment of taxation section - Passage of bill Taken up in Senate-Debate in Senate on amendments seriatim - Passage of bill with amendments - Conferences and agreement between House and Senate - Bill signed by the President.

\section{Proposed Amendments of the National Currency ACt.}

There were three bills introduced amending the banking act. The first was reported in the Ways and Means Committee by Mr. Hooper on March 1, 1864. It was taken up on March 23. The bill was read in the Committee of the Whole. The first question raised was, whether the Comptroller should be under the direction of the Secretary of the Treasury and appointed by the President on his recommendation. This was thought by some to interfere with the President's power to appoint. On Mr. Stevens' suggestion the words " on recommendation of the Secretary of the Treasury" were stricken out.

Mr. Hooper then said that the bill was not to establish but to amend the laws governing the National banking system. This system was not inimical to the State banks. Most of the amendments were of a verbal character to make the meaning of the law more clear and distinct and to avoid a misunderstanding and different construction, but there were some important and substantial amendments. One purpose of the amendments is to remove objections of the State banks to the present law. The section introduced about the Bank of Commerce, of New York, provides the only way in which that bank can enter the system. His preference would be to strike the individual liability clause from the bill, as the creditors have sufficient security in the paid-up capital. The note holders are absolutely secure, and the creditors for amounts beyond the capital can as well look out for themselves as can the stockholders. Another amendment is to require each one of the banks to redeem its own notes in some one of the redemption cities as well as at its counter; another is to make the uniform rate of interest seven per cent.; another the increasing of minimum capital to $\$ 100,000$ and requiring fifty per cent. to be paid up before commencing business; another that each director must hold ten shares of stock. 
The House adjourned until March 24, when consideration of the bill was renewed in Committee of the Whole.

\section{Arraignment of Secretary Chase's Policy.}

Mr. Brooks spoke against the bill. He defended the State banks and said that the introduction of this measure was a confession of the failure of the act of 1863. He arraigned Secretary Chase's policy and abscribed to it the failure of the State banks to meet the wants of the Government. I hold in my hand, he said, a pamphlet by the son of Albert Gallatin, who says that if Mr. Chase had not misused the 170 millions of gold received from the banks, the war could have been carried on upon a hard-money basis. He entered at length into the inflation of prices caused by the paper money issues, and criticized the twelve different places of redemption, and charged that the whole system led to corruption and favoritism.

Mr. Kernan criticized the features of the bill which authorized the Comptroller to withhold his certificates from associations when he suspected that the stockholders had not formed the association for a legitimate purpose; also that provision which gave the appointment of Receivers to the Comptroller, which power Mr. Kernan thought should be in the courts. He also regarded it as a grievance that the National banking capital was to be exempted from State taxation. He quoted from the report of Mr. Van Dyke, Comptroller of the State of New York, in regard to the reduction of the property subject to State taxation, by exemptions from taxation granted by United States laws, particularly the exemption of United States bonds, and the proposed exemption of National banking capital. Mr. Kernan did not oppose the bill, but wished these matters pointed out by him corrected.

Mr. Pruyn thought the banking department of the Government should be far removed from the influence of politics. He proposed that the Comptroller should be independent of the Secretary of the Treasury; that he should be appointed by the President, and that his office should be in New York city.

$\mathrm{Mr}$. Hooper in answer to Mr. Brooks referred to the fact that a banking bill had been prepared by Mr. Gallatin, son of Aibert Gallatin, and remarked that he was willing that it should be substituted for the present one.

When the provision relative to the requirement of minimum capital of $\$ 100,000$ was reached, Mr. Kasson, of Iowa, suggested an amendment allowing a minimum of $\$ 50,000$ in towns with a population of not more than 5,000 , under the authority of the Secretary of the Treasury.

On March 25 the bill was again taken up. Mr. Brooks desired that some representatives of the banking interests of New York city should appear before the House with certain amendments proposed by them. Mr. Hooper objected, and explained that Mr. Lyman, head of the New 
York Clearing-House, Mr. Gallatin and eight or ten others, had spent nearly a whole afternoon with the Committee on Ways and Means, and had submitted their amendments, most of which were very judicious, and which had in fact been adopted by the committee previous to the interview. The only amendments recommended by them, not adopted by the committee, were the ones having reference to the removal of the Comptroller's office to New York city. On this day it was found that a quorum of the House was not present, and the whole of the remaining time, until adjournment, was taken up in bringing in the absent members and hearing their excuses.

\section{Banks of $\$ 50,000$ Capital Proposed.}

The bill was again taken up on March 29. The amendment permitting banks to be organized, under certain conditions, with a capital of $\$ 50,000$ was adopted. Mr. Pruyn desired to amend the law so as to make an association a body corporate from the date of the publication of the notice of the execution of its organization certificate. There was some debate on the subject of striking out the power to loan on real estate security, but this was not agreed to ; also on adding the power to deal in foreign coin, and on striking out the provision to require a director to be a citizen of the United States.

Mr. Eldridge wanted every one liable to be enrolled in the National forces made eligible as a director. It was agreed to that the directors should hold office until their successors should be elected and qualified, and the provision in regard to publication of directors was amended so that such publication might be made in the paper published nearest to the city or town in which the bank was located, provided no paper was published in that place. The Comptroller was also given the power to withhold his certificate, authorizing the commencement of business, when he had reason to suspect the stockholders of any newly organized association contemplated anything other than legitimate banking.

Mr. Holman wished to increase the severity of the provision in regard to the liability of stockholders by making them liable ratably for all the debts of the bank; and this failing to meet the approval of the House, he moved to make the director's personally responsible for all such debts. This also failed, as did Mr. Ganson's motion to make the liability of stockholders apply only to stockholders of banks which issued circulation. The law was also amended to require the deposit of not less than $\$ 30,000$ in bonds before the commencement of business, and also to permit the Secretary of the Treasury to issue registered bonds in place of coupon bonds deposited. The issue of circulation to the extent of eighty-five per cent. on five per cent. bonds, which at that time were valued at par in currency, was also provided for, and the signatures of the Register and Treasurer were authorized to be printed on the notes. Mr. Ganson wished to have the law permit National banks to issue notes under $\$ 5$. It was objected to this that the Secre- 
tary and the Treasurer proposed to supply the demand for small notes with the legal-tender issues, but Mr. Ganson's amendment was carried with the proviso that the small notes should not exceed one-sixth of the total issues, and that when specie payments were resumed no note under $\$ 5$ should be emitted.

Mr. Brooks intended to make the Comptroller independent of the Secretary of the Treasury, on the ground that he distrusted the Secretary of the Treasury, intimating further that favoritism had been shown in certain of the financial transactions of the Government.

Mr. Holman wished to compel the sale of real estate taken by the bank within six months after its coming into the possession of the institution. This was rejected.

\section{Fixing the Rate of Interest to be Charged.}

Mr. Blaine moved to make the rate of interest the same as the legal rate in the State in which the bank was located. This was opposed by Mr. Stevens, who contended for the uniform rate of seven per cent., but after some discussion Mr. Blaine's amendment was agreed to. After the amendment of Mr. Holman, providing for the recovery of interest over six per cent. was also agreed to, Mr. Shannon moved that the bill be returned to the Ways and Means Committee, inasmuch as the last amendment took all the value out of it. When it again eame up Mr. Stevens proposed to strike out Mr. Blaine's amendment and substitute the provision fixing seven per cent. as the maximum rate. Mr. Blaine contended for his own amendment passed the previous day; and in referring to the threat of the Ways and Means Committee that they would withdraw the bill unless sustained on the point they contended for, he said : "I believe the country will survive if this bill never passes. I believe the country will survive without this 300 millions of curreney, as we now do."

Mr. Holman was very anxious to make the rate six instead of seven per cent., and, after some discussion, Mr. Blaine proposed as a compromise, interest at the rate fixed by law in the State where the bank is located, provided this rate does not exceed seven per cent. per annum.

Mr. Pike, of New Hampshire, expressed himself as preferring an additional issue of greenbacks to National bank notes. He thought the system was about as important to the Government as dry clothes to a man struggling in the water.

Mr. Alley moved to provide that no State should have the right to reduce the interest below seven per cent. as far as National banks were concerned.

Mr. Kasson, of Iowa, contended that uniformity could not be secured so long as the regulation of interest was left to the States, but Mr. Pike, of New Hampshire, said that he did not believe that uniformity of currency would result from National bank notes anyway. He asked: "Will a bill of the First National Bank, of Idaho, redeemable in San 
Francisco, pass current in Philadelphia-no one believes it." He thought the constitutional legal-tender note, on which the Governinent does not pay a dollar of interest, would be driven out.

Mr. Cole, of California, did not believe in having two legal rates of interest.

Mr. Miller, of New York, thought it would be a mongrel system.

Notwithstanding these objections Mr. Stevens' substitute, providing a uniform maximum rate of interest of seven per cent., passed.

Mr. Hooper suggested that clearing-house certificates should be lawful money, but Mr. Stevens was opposed to this until Mr. Hooper explained that it was for convenience in handling coin.

\section{Provisions For REDEMPTION.}

Charleston and Richmond were added to the list of redemption cities, and Mr. Pendleton, of Ohio, introduced an amendment providing that three-fifths of the twenty-five per. cent. reserve might be kept in balances in New York, Boston and Philadelphia. This was rejected.

Mr. Price thought that all banks should be required to keep an additional twenty-five per cent. reserve in bank. He contended that the checks in the bill were not intended for honest banks, but for "wildcat" banks, adventurers and speculators.

Mr. Hooper objected, and said that good drafts on central places were preferable to coin.

Mr. Price said there was no coin in the bill.

Mr. Hooper: Lawful money is the expression. We trust there will be a resumption of specie payments.

Mr. Price : I hope the gentleman will live long enough to see the day.

Mr. Griswold wished to insert Troy, N. Y., and Mr. Blaine, Portland, Me., as redemption cities.

Mr. Stevens : Let the amendment pass. I move to insert Stumpton next.

Portland and Troy were inserted, as also Buffalo.

Mr. Wilson, of Iowa, moved to strike out all the redemption cities, except New York. He thought that one place of redemption would keep the bills of the western bankers at par. Mr. Stevens thought New York should be struck out.

Mr. Hooper was opposed to Mr. Wilson's amendment suggesting that the fifteen redemption cities would find it for their interest to have all bills at par in New York.

Mr. Brooks moved to insert Brooklyn, and said that the newly organized National banks in St. Louis issued the currency of the newly organized National banks in Wisconsin, and vice versa, and that the brokers of St. Louis redeemed the St. Louis notes at one-quarter and one-half per cent. discount, and that this was already one of the practical operations of the bank law. He thought they should strike out 
the seventeen bids for notes in different parts of the Union and come to New York, the monetary centre.

Mr. Alley remarked that as the notes were receivable for all public debts, the rate of exchange could not be greater than the cost of transportation-at the outside not over one-half of one per cent.

Mr. Randall, of Pennsylvania, said that he had always resisted centralization, and he now resisted the financial centralization contemplated by Mr. Wilson's amendment.

Mr. Wilson said that none but a western man could understand the evil of high exchange. They had paid as high as fifteen per cent. on western money, and he feared that unless redeemed in New York the National bank bills of the West would be at a discount of two or three per cent.

Mr. Alley believed that the high exchange between the East and the West grew out of the depreciation of western money, but Mr. Wilson responded that the exchange was two, three, five and ten per cent. in the case of bills of good western banks.

Mr. Stevens moved to strike out New York city and insert the words, "and the note of each National banking association shall be received by every other National association at par."

$\mathrm{Mr}$. Morrill thought that if Mr. Wilson's amendment was insisted on it would defeat the bill.

Mr. Hooper proposed to leave it optional with the banks to redeem their circulation in New York at a discount of one-fifth or one-quarter of one per cent., or at par, as the House may fix it.

Mr. Wilson did not agree to this, but said he wanted to make the redemption at New York compulsory.

Mr. Hooper's amendment was renewed by Mr. Davis. Surprise was manifested that Mr. Wilson, a representative from the West, should offer to part with the privilege the western banks had of redeeming at home, and wish to make them tributary to New York city. Mr. Wilson replied, saying it was no privilege to a merchant in Iowa, who wanted to pay a debt in New York, to have Iowa notes redeemable in St Louis.

Mr. W. J. Allen, of Illinois, asked whether it was intended to drive out all circulation issued by State authority. This movement for centralization is but a reinauguration of the old National banking system under the auspices of Nicholas Biddle. Are we to be treated with the same plate of soup in this time of our direst trouble which nauseated the stomach of the nation when Jackson was at the helm of State? We have no Jackson now, but we have a man at the wheel of power whose early education, in a financial point of view, was dreadfully neglected, as I suppose. He knew there was a machine at work making money. How long did it work without some sort of aid? My friend Mr. Mallory suggests greasing. I adopt the term. I am no State bank man. I belong to a party opposed to all banks. I have been in favor 
of those commodities called gold and silver. Even though I was a State bank man I could not favor this bill. I want information, I want to be educated financially. I am in the same condition about this that I think the President of the United States is.

Mr. Kasson thought that places of redemption at the foci of trade would be more in accordance with the course of trade. Much would be left to the discretion of the Comptroller in approving redemption places.

Mr. Price, of Iowa, noved to amend by joining Philadelphia and Boston with New York as places where balances were to be kept.

Mr. Eldridge, of Wisconsin, desired to know what was meant by redemption. In Kentucky redemption is pay in whiskey and tobacco. In Wisconsin they pay in some places in badgers; in other places in shingle blocks; in other places in white fish. He believed it had been said of this paper that "it knoweth not that its redeemer liveth."

$\mathrm{Mr}$. Cravens moved to insert Indianapolis with New York.

Mr. Hooper said that the Comptroller of the Currency, who was from Indiana, asked him particularly not to insert Indianapolis.

Mr. Price still insisted on joining Boston and Philadelphia with New York, and said, in reference to numerous redemption places, that "a redemption that covers up creation is no redemption at all."

Mr. Wilson asked if that expression was strictly orthodox.

Mr. Eldridge then moved to make notes redeemable in coin, which excited the opposition of Mr. Shannon, who wanted to know when Mr. Eldridge and his Democratic brethren would cease croaking and harping. It would be but a few years when specie payments would be resumed. The committee rose March 31, 1864. The bill was taken up next day and the provision in regard to redemption cities was left without amendment. When the section as to the declaration of dividends was read, Mr. Law, of Illinois, proposed to limit dividends to eight per cent. per annum, and that, after the surplus of twenty per cent. was paid up, all net profits over eight per cent. were to be paid into the United States Treasury for the benefit of the pension fund. He did not believe that any bank predicated on paper would succeed He was surprised that Mr. Hooper, from the Hub of the Universe, a place having more specie than any other place, a hard-money man, should have thought it advisable to engineer this thing through the House. He said that a similar institution predicated on State stocks had been tried in Indiana and Illinois. The institution went down. He proceeded to illustrate: "A steamboat on the Ohio put in at a wood-yard on the Illinois shore for wood. A man sat smoking his pipe, careless of all that was going on." (Here the hammer fell.) Mr. Law begged to finish his story. Mr. Price said: "I propose to let that fellow sit there." Mr. Law continued: "How much do you ask for that wood?" "Two dollars and a half a cord.' "Will you take Illinois paper ?" 'Yes, cord for cord.'" 
On Mr. Stevens' motion the word net was struck out before profits in the section.

Mr. Hall moved to strike out the words "or if there be no newspaper in the place, then in the newspaper published nearest thereto." Mr. Hall thought no bank should be organized in a town where there was no newspaper. In the nineteenth century the newspaper should come first and then the bank.

Mr. Eldridge thought each bank should be required to run a newspaper.

A motion was introduced by Mr. Kalbfleisch to add to the thirtyfifth section a provision for National banks to deal in each other's stock, which was lost.

\section{Paying Out Notes Below Par.}

When the provision relative to National banks paying out no bank money that was below par, or no money of banks not redeeming their notes in lawful money, was reached, Mr. Hooper moved that they should be permitted to do so only after July 4, 1865, and on suggestion of $\mathrm{Mr}$. Beaman he agreed to extend it until July 4, 1866. He explained that the section applied to the paying out only of the notes. They could be received by the National banks.

Mr. Stevens thought that it was unjust, both to the State and to the National banks, to prohibit them from paying out the notes. $\mathrm{He}$ thought that under it the National banks would not receive much of the State money, and that it would compel merchants, who receive such money in their business, to resort to the State banks to make their deposits, and he said that many bankers had expressed themselves to him as against the section, to which Mr. Hooper replied that the insertion of the amendment of July 4, 1866, had made it satisfactory to the bankers. Mr. Hill remarked that this provision was virtually a repudiation of State bank notes.

Mr. Kasson, on the other hand, said that the provision permitted the National banks to take such currency as they chose, and that its effect would be to cause the gradual redemption of State bank notes; that it was in effect similar to laws which already controlled many of the State banks, and that it ought to be the law.

Mr. Stevens thought that the States might retaliate and prevent their banks from taking National bank notes.

Mr. Morrill moved to add the words "unless the association has issued all its own circulation allowed by law," which he thought would overcome the objection to the provision, but the whole section was finally struck out on Mr. Stevens' motion.

Mr. Kalbfleisch, of New York, moved to strike out of Seetion 41 the words "in lieu of all other taxes," inasmuch as he wished to give the States power to tax the National banks, and Mr. Griswold suggested that this effect would be produced if the section were made to read "in 
lieu of all other national taxes," and to add that such associations should be subject to taxation of real and personal estate, the same as persons residing at their respective places of business are taxable by State and municipal laws.

\section{State Taxation of National Banks.}

Mr. Hooper hoped that this amendment in regard to State taxation would not be adopted. He understood it came from Albany, and that there was a proposition before the New York Legislature for taxing National banks. On this Mr. H. W. Tracy, of Pennsylvania, moved that a proviso be added "that no provision contained in this act, or in any act of Congress authorizing the bonds referred to in the sixteenth section of this act, shall be so construed as to prohibit a State from imposing such taxes upon the dividends of the several banking associaciations organized therein under this act as shall to the Legislature thereof seem just and equitable."

Mr. Hooper held that the law as it stood did not prohibit a State from taxing the personal property of an individual which is invested in the bank, but simply prohibited taxation of the bank itself.

Mr. Eldridge stated that individuals composing the corporation were in many cases inaccessible, and that if no provision for the taxation of these new institutions is inserted in the bill, the banking capital of the country would take refuge from taxation in the National system.

Mr. Morrill argued that the exemption from State taxation was just, simply because the capital of the National banks was invested in United States bonds, which were not taxable by the States. These banks were taxed by the United States on their circulation for license and on their income. It is a fallacy to argue them exempt from taxation.

Mr. J. C. Allen was in favor of State taxation, and saw no reason why investors in United States bonds should not be taxed.

Mr. Grinnell held that if power to tax were given to the States they would tax these new banks out of existence.

Mr. Washburn, of Massachusetts, was in favor of taxing even United States bonds, although opposed to giving the States the right to tax the banks.

An inclination to tax United States bonds being manifested by several members of the House, Mr. Stevens said: "It seems to me gentlemen have not sufficiently reflected on this proposition. I do not suppose therc is any member of this House who is for violating our pledges made to the nation. Now, sir, these banks are to have no circulation except what is based on United States bonds, and not quite to the amount of the bonds, but within ten per cent. of it." He denied that banks chartered by the Government could be taxed by the State, and if the amendment to this effect should pass, the State could tax the banks out of existence. On this the provision was rejected. 
G. W. Hotchkiss, of New York, then moved a provision that "nothing herein shall exempt any association organized under the act from the same State and municipal taxation imposed on other corporations in the States where such associations are located." Mr. Hotchkiss did not regard the fact that United States bonds were invested in the banking business as an argument that such banking business should not be taxed. He was in favor of taxing both the United States bonds and the banking business.

Mr. Wilson believed that Congress had the sole power to tax the National banks, and that it could not even delegate that power to the States. Mr. Hotchkiss asked him to permit the insertion of the words "in lieu of National taxation," and let the subject of State taxation be vested in the courts.

Mr. Broomall remarked that the law did not require the banks to invest all their capital in United States bonds-could not the portion that was not so invested be taxed?

Mr. Kasson said this was not a tax bill, but that there was a tax bill in preparation which would tax the National banks heavily enough.

Mr. Broomall thought then that the words, "in lieu of all other taxes," should be stricken out.

Mr. J. C. Allen was opposed to exempting either United States bonds or banks; the tax amendments proposed were then rejected.

On April 2 the Treasurer of the United States was relieved from destroying the notes of liquidated banks in the same manner as wornout or mutilated notes.

\section{Proposed Conversion of State Banks into National Banks with Same Articles of Association.}

Mr. Hooper proposed the introduction into the forty-fourth section of a provision that a State bank could convert into a National association, and yet retain its own articles of association, even if such articles might be contrary to the new law.

Mr. Randall opposed this on the ground that it was in effect State legislation in favor of the Bank of Commerce, of New York.

Mr. Alley wished to provide that the liability of stockholders of all associations should be limited to the amount invested in their stocks.

Mr. Stevens objected to the amendment as encouraging debate; he wanted to get on with the bill.

Mr. Allen opposed any letting up on a personal liability clause.

Mr. Alley then moved an amendment that the stockholders of all other associations under the act shall not be personally liable. This was rejected.

Mr. Broomall asked that the provisions of the State charters of State banks becoming National banks should be annulled. He wanted State banks to cease to be State banks when they became National banks. In answer to inquiries of Messrs. Holman, of Indiana, Pike, of New 
Hampshire, and Brown, of Wisconsin, Mr. Hooper explained that the object of his amendment to Section fifty-four was to permit the Bank of Commerce to go into the system, and he proposed it as a substitute for the sixty-third section, which provided specially for that bank, for the reason that a general provision might seem less objectionable than a special one. He knew of no other bank than the Bank of Commerce which would be affected by his amendment.

Mr. Stebbins eulogized the Bank of Commerce, its services to the Government, and its high character. He remarked that the object of the bill was to perfect the act of 1863 , and the sixty-four sections in it were the result of the thoughtful deliberations and reflections of the Comptroller of the Currency, adopted, after further consideration, by the Ways and Means Committee. He had, therefore, uniformly voted for the propositions of that committee.

Mr. Alley moved that all the privileges extended to the Bank of Commerce, including the freedom from double liability, should be extended to the stockholders of other associations. He reasoned that as the bill holders were provided for, the depositors could take care of themselves, and that there was no necessity for making stockholders liable for more than the amount invested in their stock.

Mr. J. C. Allen spoke in favor of retaining the liability clause in the law.

Mr. Price contended that the effect of Mr. Hooper's amendment was to make two classes of banks. He was interrupted by the fall of the haminer.

Mr. Stevens moved that the committee rise. This was agreed to. He then moved when the committee sit again that all debate on the pending section be closed in one minute.

Mr. Alley's attempt to have stockholders' liability struck out failed.

Mr. Holman then moved that the stockholders' liability under the act shall not be impaired.

Mr. Boutwell moved that any State bank holding stock in another bank may continue to hold that stock after it becomes a National bank, and $\mathrm{Mr}$. Hooper amended the forty-fifth section about the security required for United States deposits in National banks designated as depositories, by inserting the words "and otherwise" after bonds.

Mr. Holman asked whether the words "and otherwise" did not mean any security other than bonds, which the Secretary might require, and what other security Mr. Hooper had in view; to which Mr. Hooper replied that by the present arrangement or rules of the department the Secretary requires a personal bond in addition to the deposit of United States stock, and it was to permit this custom to continue that the words are inserted. Mr. Holman said that the United States deposits should not exceed the par value of the bonds, but this proposal was not favorably received. 


\section{Deposits of Government Funds in the Banks.}

Mr. Boutwell then moved to amend the section in regard to United States depositories of public money, which, as it stood, provided that all the public moneys with the exception of receipts for customs should be deposited with them, so as to make them financial agents merely. Mr. Boutwell's object was to have the banks employed as financial agents in the negotiation of bonds whenever the Secretary might require their aid, but he thought the public moneys should, as a rule, be deposited in the Treasury and not with the banks.

Mr. Stevens was of the opinion that Mr. Boutwell's amendment was very mischievous. If the banks giving the required securities were not in effect places for the public deposits it would be better to have no banks at all. To require all the taxes to be deposited in the sub-Treasury, out of the way of the country, would, he thought, create trouble and inconvenience. Mr. Ward supported Mr. Boutwell, and eited the disasters eonsequent on deposits in State banks.

Mr. Morrill remarked that the ashes of the old bank and sub-Treasury controversy will be very interesting, but there was hardly time for their enjoyment. He opposed Mr. Boutwell.

Mr. Kalbfleisch, of New York, moved to change the word "may" to "shall," so that the Secretary "shall" require the security. He said it was a very simple amendment. Mr. Grinnell thought it was, and therefore opposed it. Mr. Boutweli's amendment was, however, agreed to.

Mr. Brooks moved to compel the designated depositories to send all circulating notes of National banks to redemption cities for redemption. He wished the new system to be at least as good as the old Biddle Bank. The amendment was rejected.

The forty-sixth section as to protest of notes not redeemed on presentation was amended so as to permit the President or Cashier of the redemption agencies, as well as the President and Cashier of the issuing bank, to waive protest. Agreed to.

Mr. Wilson again made an effort to have redemptions confined to New York, Boston and Philadelphia, but the amendment was again rejected. After the reading of the forty-seventh and forty-eighth sections the committee arose and the House adjourned until Monday, April 4.

On April 4, Mr. Hooper moved to amend Section fifty so as to make the money paid into the Treasury by Receivers of National banks subject to the order of the Comptroller of the Currency, and also to have claims proved to the satisfaction of the Comptroller. Both agreed to.

Mr. Price moved to strike out the fifty-eighth section, providing penalties for mutilating notes. This did not meet with approval.

Mr. Hooper made verbal amendments in the sixtieth section and changed the sixty-second so as to permit associations to change their 
names within six months. Mr. Brooks asked if this amendment did away with the provision providing banks to be numbered, one, two, three, etc., and permitting them to take their old names. Mr. Hooper said that was the intention; this had Mr. Brooks' approval.

Mr. Holman moved to amerd the sixty-second section by adding " that all the property and effects of the association organized under this act (except bonds issued by the United States which may be expressly exempt from taxation) shall be subject to the same taxation and for the same purpose as other property of the State in which the association may be organized." This was rejected, and Mr. Hooper then moved to strike out the sixty-third section and substitute for it a provision, exempting executors, administrators and guardians from personal liability.

Mr. Nelson wished to add a provision that the circulating notes of State banks secured by the pledge of United States stocks should be receivable for public dues, the same as those of National banks, and that State banks should be subject to the inspection and examination of the Comptroller of the Currency. Mr. Stevens said that all that was necessary to show how the proposition of Mr. Nelson would operate was to read from the statement of circulation of New York banks, Ballinger Bank, capital, $\$ 10,000$, circulation $\$ 72,000$. This excited some feeling among the New York members, and Messrs. Kalbfleisch and Kernan said that all the circulation of New York banks was secured by deposits of stocks.

As an offset to Mr. Stevens' statement about the Ballinger Bank, Mr. Brooks read irom a statement of a National bank in New York city, with a capital of $\$ 300,000$, showing that it had Government deposits amounting to $\$ 1,431,791$; that it had all this Government money without interest, and at the same time its statements showed that it had loaned to the Government $\$ 500,000$ of its own money at five per cent.

Acsording to Mr. Hcoper the explanation of this was that the bank mentioned by Mr. Brooks had been acting as the agent of the Government in the negotiation of the five-twenty loan, and that the deposits on hand were simply the accumulated moneys received in payment of bonds, which they had not yet had an opportunity of remitting to the Treasury.

Mr. Cox then attacked the general proviso introduced by Mr. Hooper, as a substitute for the sixty-third section, under which the Bank of Commerce was to come into the system.

\section{Withirawal of State Bank Circulation.}

Mr. Ward proposed that a State bank be required to withdraw its State circulation. He did this to prevent too great inflation, and stated that the amount of paper circulation in loyal States, in which he counted legal-tender notes, certificates of indebtedness, seven-thirty notes, one 
and two year notes, and State bank circulation, amounted to $\$ 992,369$,376 , and that the addition of the contemplated issue of National bank notes would make a total circulation of about 1,300 millions.

\section{The Interest Section Adopted.}

Mr. Blaine returned to the interest section. He desired to have it provide that the rate of seven per cent. should be the legal rate for a National bank in all States where no rate was established, but that each bank should be bound by the State law where such State law existed. He remarked that this had already been voted down, the objection being that it would destroy the uniformity of the system, but as subsequently several provisions had been adopted which very seriously infringed upon that uniformity, he hoped this would also be adopted. He referred particularly to the provision in regard to the Bank of Commerce, and said: "If I invest in a bank in New England I incur a double personal liability, but if I invest in a bank in New York I do not."

After Mr. Wilson had moved that the proviso requiring that the rate fixed by the State should not exceed seven per cent., Mr. Blaine's amendment was passed by the House.

Mr. Van Valkenburg moved that nothing in the act should be so construed as to prevent taxation by the States of the capital stock of a National bank, in the same manner as property of other corporations is taxed for State and municipal purposes.

\section{Denunciation of the National Banks.}

Mr. Holman, in speaking on this amendment, insisted that the capital of National banks should not be withdrawn from State taxation. He charged that 900 millions of favored capital, the earnings, or rather the spoils, of directors and stockholders, made out of this war, is to be relieved from the burdens of the Government. The power and wealth thus created and protected at the very outset must become a fearful agent of centralism-a power stronger than the Government, a protector of wealth, an oppressor of labor, a monster dangerous to public liberty. To remove the objection to Mr. Van Valkenburg's resolution, which seemed to allow taxation of United States bonds, he moved to tax dividends and all other property, except United States bonds.

Mr. Pruyn sustained Mr. Van Valkenburg's amendment as placing the National banks on the same footing as to taxation, on which the Legislature of New York had placed its own banks. It was a tax on the franchise.

Mr. Davis, of Maryland, thought the bill might as well be dropped if permission was given to the States to tax National banks at their pleasure.

Mr. Kernan endeavored to show that under the amendment States can only tax the interests of individuals in the banks, and that State taxation would then press equally on State and National institutions. 
Mr. Davis, of Maryland, contended that there could be no uniformity or equality if the States had the right to tax, as the rule of taxation varied in the different States, and the rule of taxation of different forms of capital in the same State. There was nothing to prevent a State from taxing a horse at one rate, a cow at another, a hog at a third, insurance companies at a fourth, manufacturing companies at a fifth, State banks at a sixth and National banks at a seventh.

Mr. Mallory thought that while a horse was taxed at one rate and a cow at another, still the rate was the same for all horses, or for all cows. It would therefore be the same for all banks. He was unable to believe that the National banks should be exempt. They received six per cent. in gold on their bonds, which was equal to ten per cent. in currency, and they had an opportunity to make at least twelve per cent. more by the issue of circulation. It seemed to him that if the States were not given the power to tax the banks it would be a step in the direction of destroying the States.

Mr. Morrill, of Vermont, thought that the power to tax the National banks given to the States would make the bill a nullity. The States might as well have the power to tax the public buildings or United States ships. If they could tax them at all they could tax thein out of existence. He was in favor of National banks to the fullest extent that justice might require, and since these banks escaped taxation by the States they should bear a higher proportion of national taxation than other personal property in the States.

Mr. J. C. Allen reverted to his old argument against the exemption of capital invested in United States bonds, and was in favor of giving the fullest power of taxation to the States.

Mr. Davis, of New York, proposed to have the Secretary of the Treasury transmit to the Treasurers of the several States reports of the taxes collected from each National bank therein, and also to remit onefourth of the amount collected to such Treasurers. He was of the opinion that while the States might not have the right to tax National banks, yet something was due to them.

Mr. Strouse was in favor of taxation.

\section{State Taxation Amendment.}

Mr. Hotchkiss moved to add to Mr. Van Valkenburg's amendment the words " and no State shall impose any tax upon said associations, or their capital, eirculation, dividends, or business, at a higher rate of taxation than shall be imposed by the said State upon the same amount of moneyed capital in the hands of individual citizens of such State." He did not believe that the new system would be so odious that the States would desire to tax it out of existence. Do not forget that this is the only system we are going to have. Bankers inform me they must all come under it. The State of New York has a banking capital of $\$ 110,000,000$ and without a provision permitting States to tax National 
banks this would be entirely exempt from State and municipal taxation.

Mr. Eldridge thought that the principal objection of those opposed to State taxation was, that they did not wish National institutions to be taxed by the States fo: fear the latter would destroy them. If this was the case and there was so much hostility to the bill, as this state of things indicated, the bill had better be dropped.

Mr. Van Valkenburg accepted Mr. Hotchkiss' amendment.

Mr. Davis replied to Mr. Eldridge that the Government did not exist by the will of the people of the States, but by that of the people of the United States. There is no hostility to the people in refusing to allow the people of one State to say whether a National bank shall or shall not exist within its borders. There could be no rule of taxation in States where banks are not allowed.

Mr. Mallory, of Kentucky, responded to Mr. Davis. He did not know what the people would become when your armies shall have crushed out all the liberty that remains in this country.

Mr. Hotchkiss added a proviso that no State tax shall be imposed on any portion of the capital stock invested in United States bonds. This brought out Mr. J. C. Allen again who, as usual, was opposed to making any exemption on account of the investments in United States securities.

\section{Executors, Administrators, etc., Relieved from Liability.}

On April $5 \mathrm{Mr}$. Hooper moved that the debate in the committee be limited to one minute. He then offered his substitute for the sixtythird section, relieving executors, administrators, guardians and trustees from personal liability.

Mr. Davis added a proviso to Mr. Van Valkenburg's amendment that no State taxes should be imposed upon capital stock invested in United States bonds.

Mr. Davis, of New York, reiterated his suggestion that the Secretary of the Treasury should each year furnish a statement of the taxes paid by the National banks in each State to the Treasurer of that State. Both these amendments were rejected.

Mr. Hooper's amendment regarding guardians, executors, etc., was agreed to.

Mr. Price moved that no association could pay out any money which did not circulate at par. This was adopted.

Mr. Washburne then moved to strike out the enacting clause, to kill the bill. This was rejected.

Mr. Holman moved a substitute for the bill, viz. : To repeal the act of February 25, 1863, and to provide for the liquidation of associations created under it. The last section reserving the right to Congress to alter or amend was then read. Mr. Brooks said it was the only good one in the bill. He moved an additional section that associations shall 
be required to retain the gold interest received on their bonds to secure circulation until the accumulation amounted to six per cent. of the reserve of country banks and ten per cent. of the reserve of city banks. In support of his views Mr. Brooks read a letter from Waldo Flint, Esq., President of the Eagle Bank, of Boston. This amendment was not agreed to. Mr. Brooks then moved two additional amendments; one, providing that whenever two-thirds of the directors of a National bank converted from a State bank should deem its further continuance inexpedient, it might be placed in liquidation; and the other forbidding National banks from doing a Savings bank business. In regard to the latter Mr. Hooper asked if the New York State banks were forbidden to do a savings business. Mr. Brooks was not sure, but Mr. Hooper believed it was the practice. Both of Mr. Brooks' amendments were then rejected.

On April 5 the bill, having been finally read in the Committee of the Whole, was reported to the House. Mr. Stevens moved to strike out the whole of it and insert a substitute which was identical with the original bill, with the exception that in place of Mr. Blaine's amendment making the rate of interest to be taken by a National bank the same as that of the State in which it was located, the provision permitting a uniform rate of seven per cent. had been inserted. The amendment permitting taxation of National banks by the State was also omitted from Mr. Stevens' substitute.

\section{Prejudice Against National Banks.}

Mr. Steele, of New York, was opposed to the bill. He remarked that a good while ago there grew up in this country a National instition called the United States Bank. Old Hickory Jackson said it was of unlawful origin, contrary to the spirit of our institutions and dangerous to the liberties of the people. He swore "by the Eternal," and it disappeared.

If that bank, with its thirty millions of capital, was so dangerous to liberty, and required the wonderful energies of a Jackson to put it down, what shall be said of this mammoth with its capital of three hundred millions? It may be used to control elections, and if so used what would happen? It would become necessary that some enthusiastic, self-sacrificing patriot with courage enough to speak out and call for a Jackson to overthrow it, and let a greater than Jackson appear, what could he do. A whole army of Jacksons would be impotent against such an institution. (Yet, according to mathematical demonstration, if one Jackson was enough to overthrow an institution of thirty millions, ten Jacksons ought to prove sufficient for one of three hundred millions.)

After some discussion a vote was postponed until the substitute could be printed. The House then adjourned. 


\section{Mr. Hooper's Speech in Favor of the Bill.}

The bill was taken up on the 6 th, and Mr. Hooper made the closing speech, and said in substance: Since he had been criticized for saying the State banks had outlived their usefulness he had been reminded of their services in the Revolutionary War, but had yet to learn that any were then in existence. In 1812 the use of their notes had caused much inconvenience and trouble. The State banks of New York, by the urgent advice of James Gallatin, who has been referred to as a representative of a great class of financiers in this country, suspended specie payments in December, 1861. The Secretary of the Treasury was urged to use their notes, but refused. This was in his (Mr. Hooper's) opinion the reason why Mr. Gallatin had said in his pamphlet that if Mr. Chase had managed matters right " the State banks could have gone through the crisis successfully, administering this Government as a hard money Government to carry on a hard money war."

He (Mr. Hooper) had been criticized for opinions in favor of a sounder currency advocated in some former works of his on the subject. These works were written in a time of peace and prosperity, but the arguments used then were sound, and are now sound. In the same work he had said that if paper money is ever useful in a country it is in times of great emergency. When the banks suspended specie payments in December, 1861, it seemed to hirn that the great emergency had come. In the use of State bank circulation he feared consequences similar to those of 1812, when one travelling from New York to Washington found his money increase as he went, and when he reached Washington, although travelling expenses were higher than now, he had more money than when he started. This state of things was sadly reversed on the return journey. Owing to the depreciation of State currency the Government often received less than fifty per cent. coin value for its loans. Mr. Calhoun at this time said that the Government issued its paper bearing six per cent. interest, and for every hundred dollars of it took sixty dollars in depreciated State bank paper, and then suggested that the Government issue its own notes making them a legal tender, exercise its constitutional powers against the State banks and tax them out of existence.

He reminded the New York bankers that after suspension in 1861 their boasted State bank currency stood no better in the eye of the law than "wild-cat" currency, which he took to mean irredeemable bank notes. The New York banking law contained some very excellent provisions, and some that were objectionable. He considered it objectionable that twenty-five banks with a capital of $\$ 1,932,968$ could issue circulation amounting to $\$ 5,998,088$. The experience of 1812 should make all feel grateful to the Secretary of the Treasury that he had firmly refused to take State bank notes. It has been asserted that the law of last year was unendurable because it had been found necessary to 
amend it. The law was, on the contrary, a good one. It had some imperfections which it was proposed to amend. Its passage established a most important principle, and the brief experience of a single year has been satisfactory. The State banks are opposed to the bill, because they are deriving large profits from their depreciated circulation. They use the legal-tender notes as a basis for the expansion of their own issues, as in 1856 and 1857 they did the influx of gold from California. It may, with as much propriety, be said that the gold of California caused the suspension of 1857 , as that the financial plans of the Secretary have been the cause of the present depreciated condition of the currency. It has been asked why does not the Government diminish its paper circulation. The only consequence of such diminution at. the present time would be that the State banks would issue so much more of their irredeemable paper. Those banks are watching for every opportunity to expand their issues. There is no expense to them in this but the cost of paper and printing, and the trouble of signing the notes. On the contrary the National banks are restricted as to the amount of curreney they shall issue, and the rate of interest they shall charge. The Secretary of the Treasury cannot hope to control depreciation of the currency unless the issues of the State banks can be regulated. It is in his (Mr. Hooper's) opinion as indefensible in principle to issue a piece of paper money without the Government impress as it would be to issue a piece of metallic money without that impression. The laws regulating the issue of paper should declare the issue of any other notes, except those authorized by the Government of the United States, to be as great a crime as counterfeiting the coin of the country. This bill is not inimical to State banks. They can all come under it, and the object in supporting the bill is to bring them all under it. $\mathrm{He}$ hoped the Government would exercise its power of taxation to the fullest advantage in order to control the issue of the paper circulation of the country. Patriotism alone should lead the State banks to surrender the regulation of the currency to the Government. To the question, "Why should not the Government issue its own notes," he replied that it was unfair to the State banks to compel them to retire their circulation and lose the profit upon it, to make way for Government issues; but under the National law, in lieu of their retired circulation, Congress gave them a chance to go into the National system and issue circulation under it.

He believed that specie payments would soon be restored were the retirement of State bank eirculation accomplished. When this happened the Government notes would be withdrawn, so that specie would then be the only money of the country. If the right to issue paper money were confined to the Government, and there were no National bank notes, he feared that the legal-tender notes would not be withdrawn, and that they would continue permanently an irredeemable currency. Government notes can only be issued in payment of the 
debts of the Treasury, and therefore such a currency must at times be less than the requirements of business. He reiterated his claim made in the course of debate that without any specific authority to the States to tax the banks, the incomes of individuals interested in such banks were taxable under the State laws, and that to give the States power to tax the National banks was to grant the power to destroy them. If such a provision is attached to the bill, he should oppose it.

Most of the amendments were then voted down.

The tax provision and Mr. Blaine's amendment as to interest were passed. This seems to have disgusted Mr. Hooper and many of the friends of the bill, and Mr. Stevens moved that it be laid on the table, which was done by a vote of ninety to forty-four on April 6, 1864.

On April $8 \mathrm{Mr}$. Sherman, in the Senate, by unanimous consent, obtained leave to introduce Senate Bill No. 224, to provide a national curreney. He said it was the same bill perfected in the House of Representatives, but a misunderstanding or disagreement of its friends defeated it. This was referred to the Finance Committee.

\section{Bill Amended and Passed bx the House.}

On April 11 Mr. Hooper introduced House Bill No. 395, to provide a national currency, etc., and on the 16th the bill came up for consideration. Mr. Hooper stated that the only change was in the forty-first section about taxation. The amended section was as follows:

"Provided that nothing in this act shall be construed to prevent the market value of the shares in any of the said banking associations held by any person or body corporate, created by State law, being included in the valuation of the aggregate personal property of such person or State corporation in assessing any tax imposed by any State or municipal authority on the aggregate personal property of all persons subject to the authority of such State or municipality."

Mr. Washburne moved to amend this by restricting banks from loaning on real security. This was accepted by $\mathrm{Mr}$. Hooper and passed. Mr. Fenton then proposed to amend the taxation section as follows:

"And that nothing in this act shall beconstrued to prevent the taxation by States of the capital stock of banks.organized under this act, the same as the property of other moneyed corporations for State or municipal purposes, but no State shall impose any tax upon such associations or their capital, circulation, dividends, or business, at a higher rate of taxation than shall be imposed by such State upon the same amount of moneyed capital in the hands of individual citizens of such State, provided that no State tax shall be imposed on any part of the capital stock of such association invested in the bonds of the United States deposited as security for its circulation."

This amendment was passed, and on April 20 the bill was passed after an attempt to reconsider, made by Mr. Brooks, and another to table by Mr. Holman, had been defeated by a vote of seventy-eight to sixty-three. 
On the next day the Senate made the House bill a special order for April 26. On April 8 a similar bill had been introduced in the Senate and referred to the Committee on Finance. On the 20th Mr. Sherman reported it, and it was made a special order for the next Tuesday, the 26th. On the 26 th both measures were taken up. The amendments of the Finance Committee were voted upon as they were reached in the reading. In the first section the words "by, and with the advice and consent of the Senate," were struck out. Mr. Fessenden explained that it interfered with the power of removal by the President. It was held that in all other cases the power to appoint included the power to remove, and he saw reasons why, in ease of unfaithfulness, the President should have power to remove the Comptroller of the Currency during the recess. He also saw reasons why the Comptroller should be politically independent. It was thought best to strike out the words. If the House wished to retain them it could be settled in conference committee.

Mr. Buckalew, of Pennsylvania, thought removal should be on reasons to be reported to the Senate; but Mr. Fessenden remarked that the words would not interfere with the power of removal, as, although the reasons might not be satisfactory to the Senate, this would produce no effect on the previous act. Mr. Pomeroy said the Senate could then refuse to confirm the successor, on which Mr. Fessenden replied such course would only make confusion. Mr. Howard thought that the President's power of removal should not be interfered with. He must be responsible for his acts to the people.

\section{Provisions of the Bill Explained by Mr. Sherman.}

Mr. Sherman then made a general explanation in regard to the bill. He said that nearly all the provisions contained in the law of last year were in the present measure. There had been many changes-most of them, however, were changes of detail, transpositions, and verbal modifications, making the law more effective and easy of execution. There were, however, six or seven important propositions which would be likely to attract the attention of the Senate. The first provided centers of redemption. The old law required redemption only at the counter of the bank. The second was as to taxation of the banks. The old law left doubts as to whether they could be taxed by State or municipal authority. The general impression was that they could not, and the present law is intended to define this. The amendment of the Finance Committee proposes that these banks shall be taxed by State and municipal authority, and that the stockholders themselves shall be taxed on their stock as upon personal property. A third important amendment. is that permitting the conversion of State banks. The fourth is in regard to the rate of interest. The House bill fixes it at seven per cent. The old act left the legal rate to the State control. The Finance Committee have put it back, substantially as it was last year, leaving the 
rate to be fixed by State law. The fifth important amendment relates to the kind of stocks that may be used as a basis for banking. Under the old act any kind of bonds could be received on deposit. Under this nothing but registered bonds held in trust could be so received. $\mathrm{Mr}$. Henderson asked if the five per cent. bonds could be used. Mr. Sherman said, yes, notes to a certain percentage of their par value can be issued, and there must always be a difference of ten per cent. between the market value and the circulation received. The Comptroller can call for money or new securities to make up any difference. The sixth important amendment is the permission to issue a certain proportion of notes under five dollars, which last was the lowest denomination under the old law. Mr. Sherman did not mean to discuss the measure unless compelled to do so by the course of debate. He had done this a year ago and the experience of one year had made him confident that the system could be made a success. He also explained, in reply to a question of Mr. Collamer, that the double personal liability was to extend to stockholders of converted State banks.

\section{A Certain Bank Exempted from Double Liability of ShaREHOLDERS.}

A provision as to the Comptroller's bond was amended so as not to require freeholders as sureties. Verbal amendments were made in sections six and nine. Section six contained a provision that the stockholders of banks with a paid-in capital of five millions should be liable only to the amount of their stock. It was amended to make the requirement $\$ 5,000,000$ of paid-in stock and a surplus of twenty per cent. Mr. Sherman said the purpose of this amendment was to enable the Bank of Commerce of New York city to enter the system under exceptional conditions and to confine the exception to that bank alone. This institution was the largest bank in the United States. It had no circulation. Its articles of association or co-partnership were said to have been framed by Chancellor Kent in 1839. It was organized with a view to supersede the old Bank of the United States. The directors did not object to the liability clause of the act and wished to go into the system, but were restrained by their articles of association which made it necessary that any change, whereby a stockholder should be rendered liable in his individual capacity for the debts of the association, should be made only by the consent of every stockholder. The stockholders number 2,500 and are settled all over the world, and it is impossible to obtain their consent. The directors and managers of the bank desire to come in ; they are very strong, holding $\$ 16,000,000$ of Government securities ; they have been friends of the Government and they loan it their money freely.

Mr. Collamer thought that the provision for the accumulation of surplus made every bank keep up one of twenty per cent. In reply Mr. Sherman said that the purpose was to require the Bank of Com- 
merce to keep up the twenty per cent. surplus in addition to that required by the act.

Mr. Grimes, of Iowa and Mr. Henderson, of Missouri, proposed making no exception of the Bank of Commerce.

Messis. Sumner and Fessenden supported Mr. Sherman.

Mr. Cowan remarked that the Bank of Commerce was an exceptional case, even under the banking laws of New York.

Mr. Wilson, of Massachusetts, inquired why any personal liability clause was necessary. He did not think the Government should look after the interest of depositors and creditors, but Mr. Pomeroy thought it was the easiest liability clause that was ever contained in a bill.

Mr. Sherman thought it was not only an easy liability, but an easy one to enforce. He would not give a cent for a lawyer that could not collect what was due from each stockholder. The amendment of the committee passed.

The next amendment was in Section fifty-two permitting National banks to reduce their capital and withdraw their bonds to an amount not below the minimum by delivery of their circulating notes to the Comptroller.

The next change, in Section twenty-six, authorized the Secretary to permit an exchange of bonds, if he were of the opinion that such a change could be made without prejudice to the United States.

Mr. Henderson wanted to know if this amendment would permit the substitution of any bonds that may hereafter be issued by the United States.

Mr. Sherman: It is simply to allow the change of one class of bonds for another.

Mr. Henderson: That is, any bonds hereafter issued.

Mr. Sherman: The fourth section of the act described the kind of bonds which may be used-United States bonds bearing interest payable in gold. This amendment was agreed to.

\section{Rejal Estate Taken to Secure Previously Existing Debt.}

Several verbal amendments followed and Section twenty-eight was then so amended as to allow a bank to hold real estate mortgaged to it in good faith for debts previously contracted. Mr. Sherman assured Mr. McDougall that this gave banks no right to loan on real estate, but if a debt is contracted they may, in order to secure it, take a mortgage on that description of property.

Section thirty was then amended so as to permit National banks to take the rate of interest allowed by the laws of the State or Territory where the bank is located, and no more, and when no rate is fixed by the law of the State or Territory, the bank may take, reserve, or charge a rate not exceeding seven per cent.

Section 40 was amended to allow State bank officers to inspect the list of stockholders of National banks. 
The tax section was then reached, and the provision in regard to the taxation of National banks was reported by the Finance Committee as follows :

"That nothing in this act shall be construed to prevent the market value of the shares of any of the said associations, held by any person or body corporate, from being included in the valuation of the personal property of such person or corporation in the assessment of all taxes imposed by or under State authority for State, county or municipal purposes, but not at a greater rate than is assessed upon other moneyed capital in the hands of individual citizens of each State, and all the remedies provided by State laws for the collection of such taxes shall be applicable thereto ; provided also that nothing in this Act shail exempt the real estate of associations from either State, county or municipal taxes to the same extent, according to its value, as other real estate is taxed."

\section{State Taxation of National Banks.}

Mr. Chandler, of Michigan, objected to striking out from the section as it came from the House the proviso exempting capital invested in United States bonds from taxation. He thought the change made by the committee gave the right of unlimited taxation to the States.

Mr. Fessenden said that the Committee on Finance had considered and reconsidered the matter with the view not to kill the bill, but to make it acceptable to the people of the States. The committee thought that the proviso adopted by them would be benficial to the system. He thought it came to the very simple question who should tax the stock, not the circulation, not the deposits, not that which relates exclusively to banking purposes, and operates for banking purposes, but which operates upon so much actual property invested by the individuals owning the property and residing in the States upon that particular amount of property. The proposition as it came from the House of Representatives is delusive. It says, you may tax stock in the hands of individuals, but exempts what is invested in banks. We do not break faith in permitting bank stocks to be taxed even if invested in United States bonds. When United States bonds are exempted they are simply exempted as property, but not as property invested in the banking business. Those entering into the banking business are permitted to deposit their bonds just as they might be required to deposit specie or other property. The power of the States to tax is limited by the amendment of the committee. "They must tax this property thus invested, precisely as they tax other personal property, and to no greater extent." These were substantially the views which had guided the committee in coming to this conclusion. Mr. Chandler insisted that most of the States protect their systems from local taxation by imposing a State tax in lieu of all other taxes. Mr. Fessenden said the Senator was mistaken; that in New Hampshire and many other States after the bank had paid a specific tax for the privilege of banking, the stockholders were liable to taxa- 
tion on the value of their shares-not the market value. If above par it is assessed just as any other personal property is assessed.

Mr. Chandler responded and among other things said he had no theories. It was his judgment as a practical banker and as a practical business man that this taxation would kill this bill.

Mr. Fessenden said it was astonishing what differences of opinion existed among practical men. He had conversed with several-not persons so practical as his friend, but still claiming to be practical bankers and interested in the subject-and their opinions were entirely different from Mr. Chandler's.

Mr. Chandler: The Senator from Maine seems to sneer at practical business knowledge. I tell the Senator that if he had a little more on his committee it would be better for his committee.

Mr. Fessenden: We made a great mistake in not having the Senator from Michigan upon it, but we are getting along very well without him.

Mr. Chandler: The Senator from Michigan can stand on his own merits.

Mr. Fessenden: The Senator from Michigan is the only Senator who boasts of his practical knowledge every time he addresses the Senate.

Mr. Chandler: I have got about enough of this gentleman's lecturing, and I will thank him to lecture some one else the next time. He thought that in a time of great emergency nothing should be done to defeat the measure which, without its tax feature, would gain the support of the banking capital and sustain the credit of the Government. He insisted this tax would kill the bill.

Mr. Sumner remarked that whether Mr. Chandler's proposition was practical or not he was sure it was patriotic, and whatever is patriotic contains the best elements of the practical. He was opposed to allowing the States to tax the National banks, as it destroyed the character of uniformity for these great institutions. He thought the system should not be subjected to any such conditions.

Mr. Sherman contended that the measure as it came from the House was ineffective as to taxation. It was contradictory and could not be construed. He was in favor of taxing these institutions heavily with the support of the national Government, but was opposed to that part of the section which gave the power of taxing them to the State. There could nothing result but great inequality and diversity of taxation.

Mr. Henderson, of Missouri, was opposed to the bill, but in favor of the State taxation proposition. In the first place, that it may defeat the bill, and in the second place that at any rate it is mere justice.

It was again taken up on April 28.

Mr. Pomeroy moved to strike out the committee's tax proposition, and insert "That nothing in this act shall be construed as exempting the capital stock of an association beyond the amount invested in United States bonds and deposited with the United States Treasurer as 
part of its capital, or as security for circulating notes, from being sub ject to the same rate of State and municipal taxes as is imposed upon other personal property of the State or city, or town, in which the association is located." Mr. Pomeroy said that his amendment would tax the corporation direct, and not the stockholders, whom it might be difficult to reach.

Mr. Chandler agreed with Mr. Pomeroy.

Mr. Howe saw no reason why the capital of a National bank should be exempt from State taxation because United States bonds were put up to secure circulation, but he thought the State should not be crippled by depriving them of the power to tax the property of National banks.

Mr. Collamer said that the fact of depositing United States bonds for circulation did not deprive the national Government of the right to tax the National banks, neither would it be a breach of contract to allow the States to tax them. He contended that the taxation of shareholders was no tax on capital stock. Whoever puts in United States bonds and takes bank shares no longer owns the bonds. The bank then owns them. The one who puts them in cannot be obliged to pay the income tax on them as he did before. The main question is whether the banks shall be left to State taxation. He took it that this bill would sequester all banking capital in the States and bring such capital under the National system. If, then, the States were not permitted to tax these banks, what would be the effect? For example, take the tax for the poor, for schools, highways and bridges. By fortuitous circumstances you may in each town find some man of wealth. His money is mostly invested in bank or other corporation stocks. This law passes without a State taxation provision. Your wealthy man puts his money in National bank stock. The town levies a highway or bridge tax. The people pay-some in money and some in labor. Some one looks at the tax list. Where is Mr. Stiles, our wealthiest man? he is not on the list at all. Does he pay anything for building our bridges and roads? Does he contribute anything for the support of town schools? Does he do anything to suport the expenses of the government of the State ? Does he help pay interest on the State debt incurred in the defense of the Union? No, sir, not at all. Why is this? It is the law of the land that the wealthiest man among us is exempt from these contributions, which the rest of us feel and have to pay.

The debate then went on between Messrs. Chandler, Henderson, Fessenden, Anthony, and Sprague. The general opinion of the Senators from New England was that individual holders of shares should be taxed upon them as they were on other personal property. Mr. Chandler said there has never been a greater emergency in the history of the Government. We are not receiving from the ten-forties more than half of the daily expenses incurred. What greater inducement can you hold out to poor and rich alike to take these bonds" than to exempt them 
from taxation beyond a certain per cent.? If we cannot save the country without limiting taxation shall we not do it? Sir, I have not got the Constitution on the brain. I believe that this great Government has got the power of salvation within itself. I believe it is constitutional to do whatever is necessary to save the Constitution and the Government. Some men who have got the Constitution on the brain cannot do anything to save this Government. I have not that, thank God!

Mr. Johnson, of Maryland, thought that by depriving States of the power to tax property within their borders they might be deprived of power to pay their debts. Under circumstances less stringent many of the States had failed. If the States became bankrupt the power of the Union for good is at an end.

Mr. Chandler believed that the Constitution gave Congress the power to tax the State bank circulation out of existence. He would vote for the withdrawal of all paper except that of the Government.

\section{Views of Senator Sumner.}

Mr. Sumner regarded the question as a very simple one. The country has gone forth to meet a great rebellion organized in the name of State rights. Every effort to increase the army, to increase the navy, and to increase our financial resources, is met by objections in the name of State rights. It is hard to meet State rights, not only on the battlefield but in the Senate chamber. The complaint has been that the bill would sequester property from State taxation, but what is this sum of three hundred millions proposed as the capital of the National banks, which it is said will be sequestered, as compared with the enormous amount of property sequestered from State taxation in the shape of material for the army and navy. Milton has pictured that statesmanship which was able "to advise how war may best uphold, moved by her two main nerves, iron and gold, in all her equipage."

No Senator proposes to complain because we protect the nerve of iron, but complaints are registered because we propose to protect the much more delicate nerve of gold.

$\mathrm{Mr}$. Sumner proceeded at length into a consideration of the constitutional argument, which he based principally on the decision of the United States Supreme Court in the case of $\mathrm{McCulloch}$ against the State of Maryland as to the propriety of refusing the States the right to tax National bank circulation.

Mr. Fessenden said that the Senator from Massachusetts had given a running commentary on a decision of the Supreme Court, with which lawyers were tolerably familiar, in connection with a little poetry. The whole of his argument was poetical in that the Senator drew on his imagination for the application of what he had read, inasmuch as in his, Mr. Fessenden's, judgment, it had no earthly application in the matter of law to the subject before the Senate. Giving the States the 
right to tax National banks within their borders creates no inequality in interest, in business, or in anything in which they are concerned. It is not in question whether the States can tax National banks, but whether the national Government can give them permission to do so. It is a simple question of expediency. It has been argued that this system is a thing of a year or two, simply for the emergency of the war. Does not the Secretary of the Treasury dream, and does he not believe, that it is to extend through all time; if so it is a matter of peace, as much as of war, and we must take into consideration what will be the case when peace comes.

After a colloquy between Senators Sumner and Fessenden, chiefly of a personal character, Mr. Sherman spoke on the amendment, illustrating further his views in regard to National taxation of banks and his opposition to State taxation. He claimed that the exemption from taxation of United States bonds gave the same opportunity now to rich citizens to evade taxation as they would have if the States were denied the right to tax National banks. He dwelt very strongly on the inequality which would result from the different tax laws of the various States, and claimed that the amendment of the Finance Committee was imperfect in that it would not reach non-resident stockholders.

After some further argument in the nature of criticism of views already advanced by Senators, the Senate adjourned to April 2\%.

The bill was again taken up on April 30, and the debate on Section forty-one was continued. Mr. Clark, of New Hampshire, was in favor of State taxation.

Mr. Lane, of Kansas, wished that the States should have the power to tax so that if the time came when the people no longer wanted the banks they could be destroyed.

Mr. Sumner desired to amend the law so that it would state that the shares of stockholders should not be subject to State, county or municipal taxation.

Mr. Cowan remarked upon the immense profits the National banks might receive under the law, and that State taxation could not, under such circumstances, be opposed on the ground of hardship.

Mr. Johnson, of Maryland, said that the profits which the law gave these banks the opportunity of obtaining were so large that all banking capital would seek employment under the system, and if the States were prohibited from taxing them there was danger of impairing State credit, which, in his opinion, was of as much importance as national credit. He referred to the decision of the Supreme Court in McCulloch against the State of Maryland, and contended that the court had admitted the right to tax the shares and real estate of a National bank although they denied the right to tax the franchise. It was both unconstitutional and inexpedient to exempt National bank capital from taxation because invested in United States bonds. 
Mr. Pomeroy's amendment was rejected by a vote of twenty-eight to eleven.

\section{State and Municipal Taxation of National Banks.}

Mr. Howard, of Michigan, then offered an amendment that the bank shares be taxed for the purposes of the State at the place where the bank was located. The object was to prevent any evasion by non-resident shareholders. He argued that if unlimited power were given to tax shares a State might destroy a National bank as surely as by taxing its franchise. He said the question of State right to tax shares was not involved in McCulloch vs. Maryland, and on this Mr. Johnson remarked that the question was necessarily involved in the case, but that as a matter of fact the judges had admitted the right of the States to tax shares and real estate.

Mr. Hale opposed Mr. Howard's amendment on the ground that the personal property of a citizen of one State would, under it, be taxed in another.

When the bill was again taken up Mr. Chandler moved to insert a provision that all State, county and municipal taxes should not exceed the amount of taxes authorized by the State upon its local banks. Inasmuch as the States were limited by the amendment of the Finance Committee in the taxation of National banks to an amount not exceeding the taxes assessed upon other moneyed capital in the hands of individual citizens, Mr. Chandler wished to prevent the States from discriminating against them by laying a less tax on their local banks than was laid on money in the hands of individual citizens. The amendment of the committee was then agreed to.

Section fifty-three was next taken up and Mr. Henderson, of Missouri, wished to amend it so as to enable any individual, as well as the Comptroller of the Currency, to bring suit for the forfeiture of charter in case of violation of law by the directors. He did not, however, press his amendment, and the other amendments suggested by the committee were agreed to, without debate, and the Senate adjourned.

The bill was again taken up on May 2, in order to permit the introduction of new amendments by Senators. Mr. Davis suggested that real estate taken for debt should not be held for longer than five years, and also that a bank should be required to pay specie within six months from the close of the war. Upon this last amendment a long discussion ensued upon the relations of the Government and the State banks. Mr. Davis endeavored to show that the Government was responsible for all inflation of the currency. The National Currency Bill was then dropped for that day.

\section{Further Discussion of The Question of Taxation.}

It was taken up again on May 5 , and the amendments voted on in the Committee of the Whole were taken up one by one. There was con- 
siderable debate on the rate of interest section. Some wanted to make a uniform rate of seven per cent., and others to reduce it to six per cent. The debate brought out the fact that there were some States where no rate was fixed, and in such eases where the normal rate for money was high National banks would be placed at a disadvantage by being limited either to six or seven per cent. The section was therefore on Mr. Fessenden's suggestion withdrawn.

Mr. Sumner opened the debate on the bill. He showed the great inflation of State bank curreney from 1862 to 1863 . In New England it had increased from $\$ 39,306,000$ to $\$ 65,516,000$; in the Middle States it had increased from $\$ 50,865,000$ to $\$ 75,044,000$, and this without taking into account the inflation of the same currency throughout the Western States. He thought the State system must yield to the National system. He said there had been warnings not to slay the goose that laid the golden eggs, meaning by this goose the State banks; but all those who use this illustration forget that there is another bird which lays eggs, such as no State banks can lay, not merely of gold, but of victory. It is the National credit, which Senators seem willing to abandon, if not to slay.

Mr. Chandler followed and claimed that the tax would defeat the bill. He had a profound respect for the members of the Finance Committee as lawyers and statesmen, but for their practical business knowledge he had the same respect that they had for his legal attainments.

Mr. Fessenden replied that he did not feel disposed to attempt to answer the speeches made by the two gentlemen, but he was not inclined to rest under these imputations. (Mr. Sumner had, in the course of his remarks, eited Patrick Henry speaking, at the time when Washington's armies were reduced to the extreme of distress at Valley Forge: "Where is the man who would not have thrown open his fields, his barns, his cellars, the doors of his house, the portals of his breast, to receive the meanest soldier in that famished band? Where is the man? There he stands, but whether he has the heart of an American in his bosom you are to judge. [Patrick Henry pointed to John Hook, who was pressing a vexatious claim for supplies taken for the use of the starving troops.] "What notes of discord do I hear?" continued the orator. "They are the notes of John Hook, bawling through the patriot camp, 'Beef! Beef! Beef!'” And now, said Sumner, we are doomed to listen to a similar cry. We do not hear Beef! Beef! Beef ! but they say what means the same thing, State taxation! State taxation! State taxation!)

At this Mr. Fessenden naturally took offense, considering it a reflection upon himself and others who sustained the tax measure. He thought that the majority of the Finance Committee, the gentlemen in the House of Representatives, among whom were Mr. Hooper, Mr. Sumner's own colleague, the twenty-eight in the Senate who had voted for this tax measure, the Comptroller of the Currency and others who 
sustained a reasonable degree of State taxation, should not be represented as shouting Beef! Beef! Beef!'with State taxation in it. $\mathrm{He}$ remarked that he had letters from bankers of high standing who sustained the tax. He then turned his attention briefly to the practical knowledge of $\mathrm{Mr}$. Chandler, and replied that his allegation as to the danger of the States taxing National banks out of existence was obviated by the limit which had been provided in the section.

The bill was again taken up on the 6 th, the tax question being still a subject of debate.

\section{Secretary Chase's Views on State Taxation.}

Mr. Sherman read a letter from Mr. Chase, Secretary of the Treasury, in which he replied to an argument used by Senator Johnson in the course of debate, that if the States had constitutional power to tax the real estate of Federal banks within their borders they consequently must have power to tax their shares by making the distinction that real estate was held under the law titles of the State and should therefore be subject to State taxation, but that personal property and credits, shares, etc., of the National banks will derive their value and title from National laws and should therefore be subject to National taxation only. Mr. Sherman wished to get a vote on the bill.

The tax as it came from the committee with Mr. Chandler's amendment, forbidding the States to make any distinction in the taxation of National banks and that of their own local institutions, was finally passed by a vote of twenty-nine to eight. The further amendments were then agreed to without division. The Senate then returned to the interest section, which had been withdrawn for revision, but it was not yet ready. Mr. Hale then amended Section nine so as to disqualify a director whose required shares were hypothecated for any loan or debt. It had previously read "for any loan or debt due to his own bank." Agreed to.

Mr. Chandler moved to insert a clause permitting one-half of the twenty-five per cent. reserve of the banks in redemption cities, other than New York, to be kept in associations in New York, Philadelphia and Boston.

Mr. Sherman thought that if National banks were required to redeem at par in New York, while 1,600 State banks were required to redeem at their own counters only, the system would fail. This requirement as to a central redemption of National bank notes should be postponed until after the State banks were absorbed by the system or went out of existence. Mr. Sherman contended that the same rate of exchange should not be established throughout the country, inasmuch as express charges were greater from one point than from another.

Mr. Chandler's amendment was rejected. 


\section{Fixing the Rate of Interest.}

The interest section was then taken up in the following form, after the revision of the committee: "The rate established by the laws of the States or Territories where the bank is located and no more, and when no rate is fixed by the laws of the State or Territory, the bank may take, receive, reserve, or charge, a rate not exceeding seven per cent."

Mr. Sherman amended by inserting after "no more," the words, "except that where by the laws of any State a different rate is limited for banks organized under State law, the rate so limited shall be allowed for organizations established in any such State under this act." The interest section as revised by the committee and amended by Mr. Sherman was agreed to.

Mr. Chandler made a motion to strike out all redemption cities, except New York, Boston and Philadelphia.

Mr. Henderson: To strike out all but New York. Rejected.

Mr. Sherman objected to putting all the wealth of the country in one city where a mob might destroy it, the most uncertain-(a Senator, disloyal) - I will not say disloyal, but the most uncertain place in the country. It can only be done after the State banks are absorbed.

Mr. Chandler's amendment was agreed to by a vote of fifteen to fourteen. He then moved another amendment to allow a discount of one-quarter of one per cent. on the notes redeemed in the cities named.

On Mr. Fessenden's suggestion Mr. Chandler's last amendment was made compulsory and agreed to. There was then some discussion upon the limit of the circulation to be issued.

Mr. Henderson wished to limit it to the amount already issued.

\section{Substitute Measure Offered BY Mr. Doolittle.}

Mr. Doolittle introduced as a substitute a measure intended to reduce State bank circulation to the amount of the paid-in cash capital or the amount issued on United States bonds with a penalty of one per cent. per month on any excess over this limit. He desired to permit State and National banks to stand upon the same footing so far as taxation was concerned. He thought that the other advantages given to National banks would induce the State banks to enter the system without the compulsion of inequality of taxation. He deprecated any war on the State banks, and thought that if State banks were to be wiped out it were better to substitute Government paper.

Mr. Henderson had seen no good reasons given for the passage of the bill. Mr. Sherman had given none; Mr. Fessenden had given none. The Secretary of the Treasury had given what he called reasons, and Mr. Henderson proceeded to show that they were feeble and inconsequent. He continued in a very long speech, in which he reviewed the entire subject of the banking and financial history of the country. He 
regarded the evils that would result from this system as great. It would neither enable the Secretary to negotiate a loan, nor will it make a uniform currency in this country, unless it be a currency uniform in its worthlessness and corrupting influences. This seems to have exhausted the Senate for the time. It adjourned May 6, 1864, to take up the matter again on the 9 th.

Mr. Trumbull was in favor of Mr. Henderson's amendment. He concurred in most that was said, but Mr. Henderson's amendment was lost.

The question now came up on Mr. Doolittle's amendment. In substance this was to limit banking circulation to the issues now outstanding of both State and National banks. All new issues were to be redeemable in gold or silver. The National Bank Act was to be revoked, except the provision permitting State banks to have circulation upon deposit of United States bonds, and the circulation of all banks was to be reduced to an amount equal to the capital stock, or the excess was to be secured by Government or State stocks within certain limits of time. Mr. Doolittle read a letter from George S. Coe, of New York, in which he said, among other things: "You have struck the keynote. Your plan is the only one which the old State banks, as a body, would for a moment consider, and to it I believe they would give the most favorable regard."

Mr. Sherman criticized Mr. Doolittle's plan with much severity and acumen. He regarded it as repealing the charters of all State banks on the one hand, and in return giving them the monopoly of all benefit under the National system.

Mr. Hale, of New Hampshire, thought Mr. Doolittle's amendment would be more explicit and clear if put in the form "that all those instruments heretofore known as State constitutions be and are hereby abolished."

Mr. Doolittle finally withdrew his amendment to offer it at some other time.

Mr. Sherman then offered an amendment to the thirty-second section upon a motion to reconsider. He explained that if his amendment prevailed it would require each country bank to select a redemption agent where it would redeem its notes at par, in one of the cities named in the thirty-first section, but each of the centres of redemption must redeem in New York at par. To those west of the Alleghany Mountains an allowance of one-fifth of one per cent. was to be made, but to those east of that line no discount was to be allowed. After some colloquy Mr. Sherman's amendment was allowed to lay over for revision.

Mr. Collamer moved to make the National currency receivable for all salaries, debts, and dues from the United States to individuals, corporations, etc., except interest on the debt, and redemption of National currency. This was adopted. Also that each association should take 
at par the notes of every other association. Passed. Also that associations designated as depositories should take national currency at par. Agreed to. Also that each association should hold the amount paid it as interest on its bonds to secure its circulation as a reserve until all of its reserve was coin, and specie payments were resumed. There was much discussion on this amendment. Messrs. Collamer, Johnson and Henderson, being in favor of it, and Messrs. Sherman and Chandler against it. The Senate then adjourned.

When the bill was again taken up Mr. Collamer's motion was still under consideration, and much further debate ensued between the same gentlemen as on the previous day. It was finally rejected by a vote of seventeen to fourteen. Mr. Collamer then desired to limit capital stock, as well as circulation to three hundred millions.

Mr. Sherman, however, regarded the limit on eirculation as a limit on eapital. The amendment was agreed to. Mr. Sherman's amendment in regard to redemptions then came up. He increased the discount allowed to one-quarter of one per cent. It was adopted.

Mr. Sprague amended Section ten so as to permit two-thirds of the stockholders to call a meeting for postponed election of directors if the directors failed to do so. This was agreed to. Also that an association should have a receipt for bonds transferred, which was agreed to.

\section{Proposal to Base Circulation on the Market Value of Bonds.}

Mr. Powell moved to make the circulation ninety per cent. of the current market value in gold in United States bonds deposited. Rejected by seventeen to eleven.

Mr. Cowan, of Pennsylvania, wished to give a Receiver power to enforce the full liability of stockholders immediately on taking possession of assets.

After some discussion between Mr. Cowan, Mr. Sherman, and Mr. Johnson, Mr. Sherman proposed to give the Receiver power to enforce the liability if it was found necessary. This was adopted.

Mr. Cowan proposed to strike out all relating to increase of capital stock, arguing that this provision might tempt banks to invest circulation in bonds for the purpose of obtaining circulation to purchase more bonds, etc. This, after some explanations from Mr. Sherman, he modified by striking out the section which placed it in the power of the Comptroller of the Currency to permit banks to exceed the maximuin fixed in their articles of association. Agreed to.

Mr. Henderson wished to change the twenty-sixth section so as to compel banks to put up additional security if the market price of bonds ever fell below the price ruling at the time they were deposited. This was lost. He also wished to provide that banks should put up not less than fifty per cent. in bonds before commencing business. On explanation he withdrew this and moved to strike out the proviso by which banks of $\$ 50,000$ capital should be organized. This was agreed to. 
Mr. Henderson then moved to strike out the forty-fifth section permitting National banks to be used as Government depositories. Lost.

Mr. Sprague moved that the agent of an association should witness the destruction of its notes. This was agreed to.

Mr. Buckalew's motion to strike out the provision for small notes was rejected.

Mr. Doolittle offered an amendment providing that State banks that did not reduce their circulation to 150 per cent. of capital could not use United States notes as legal-tender, and should also be taxed on excessive circulation. Rejected.

Mr. Powell then moved to substitute a bill to repeal the act of February 25,1863 . Rejected, by a vote of thirty-one to six. The bill then passed by thirty to nine.

On May 17 the House ordered the Senate amendments to be printed.

On May $23 \mathrm{Mr}$. Hooper attempted to call them up, but the Legislative bill took preference, and the House adjourned when the National Currency Bill was again reached. It came up again on May 24, and after a motion to lay the Senate amendments on the table, they were taken up and all concurred in with the exception of the fifteenth about taking up bonds upon which no circulation had been issued; the twenty-second limiting capital stock to three hundred millions; the thirty-sixth, inserting Leavenworth among the redemption cities, and the thirtyseventh, striking out Portland and putting in Providence and Buffalo.

At this point Mr. Stevens said that the House had so amended the bill as to render it worthless. He moved to lay it on the table. This was defeated seventy-two to fifty-five.

Mr. Cox read a letter from J. Andrews, President of the Board of Control of the State Bank of Ohio, objecting to the bill as oppressive of that institution. The letter showed circulation of thirty-six branches on the first Monday in April, 1862, $\$ 8,105,500$; first Monday in April, 1863, \$6,630,416; first Monday in April, 1864, $\$ 5,512,685$.

The letter stated that the bank could not get in its notes in time enough to avoid the taxes which had been imposed, and suggested that the outstanding issues should be exempted from the tax, which should only be imposed on subsequent issues.

Mr. Sherman's amendment to Section thirty-two in regard to providing for redemptions in New York city, and making a distinction between the banks east and west of the Alleghanies, was not concurred in. Also Section forty-one, the Senate tax amendment, was not concurred in.

A committee of conference was appointed which consisted of Messrs. Hooper, Washburn, and Mallory on the part of the House, and Messrs. Sherman, Porter, and Johnson on the part of the Senate. The conference committee came to an agreement and reported May 31, 1864. The commitieo modified the tax section to the form in which it appears in the act. The bill was signed by the President June 3, 1864. 


\section{XVI}

NATIONAL BANK LEGISLATION, 1864-1892.

Act of June 3, 1864- Inequalities in the distribution of circulation - Withdrawal of bonds by banks in liquidation - Trying to account for the panic of $1873-$ Remedies proposed-Veto of the inflation act-Repeal of law requiring reserve on circulation - Proposed resumption of specie payments - The greenback theory - Further retirement of legal tenders prohibited - Extension of corporate existence - Lack of commercial redemption of notes - Indisposition of Congress to enlarge the circulation privilege.

\section{ACTs of March 3, 1865.}

Section twenty-one of the act of June 3, 1864, permitted the issue of notes to a National bank to the extent of ninety per cent. of the current market value of the United States bonds deposited, but not to exceed ninety per cent. of the par value if the rate of interest upon the bonds was not less than five per cent. The proportion to capital was 100 per cent., so that a bank might deposit bonds in excess of capital and receive circulation equal to capital. On March 3, 1865, this section was amended, and the limit of circulation in proportion to capital was changed to ninety per cent. for capital of $\$ 500,000$ and less; eighty per cent. on capital between $\$ 500,000$ and $\$ 1,000,000$; seventy-five per cent. on capital between $\$ 1,000,000$ and $\$ 3,000,000$, and sixty per cent. upon all over $\$ 3,000,000 . *$ By the same act the aggregate authorized circulation of $\$ 300,000,000$ was to be apportioned among the States and Territories-one-half according to the representative population and the other half according to the existing banking capital, resources and business of each State and Territory. On the same day another act was passed which taxed the circulation of State banks out of existence by imposing a duty of ten per cent. on the notes of such banks paid out by any National banking association, State bank or State banking association after July 1, 1866, and also authorized the Comptroller of the Currency to give preference to such State banks in good standing and having a paid-up capital of $\$ 75,000$, as might make application to become National associations prior to July 1,1865 . That is, these banks were for a limited time to be authorized to begin business as National banks and receive circulation in preference to new organizations.

* Under the existing law (1899) the circulation of all banks is restricted to ninety per cent. of the par value of the bonds, and is further limited to ninety per cent. of the paid-in capital of the bank. 
"There was some doubt as to the effect of the two laws of Marsh 3, 1865, upon each other: They were contradictory, in that if the one giving preference to State banks was carried out it would evidently prevent the strict execution of the apportionment provided by the other. And a strict execution of the apportionment provision might leave many of the State banks applying for conversion without circulation, inasmuch as most of the banks in a situation to avail themselves of the law were located in the Eastern and Middle States, and were so numerous as to require far more circulation than the apportionment would give to those sections of the country.

The Comptroller of the Currency and the Secretary of the.Treasury construed the law preferring State banks as taking precedence of the distribution law, and allowed the conversion of State banks to go on regardless of the rule of apportionment. This rule was disregarded even after July 1, 1865, when the prescribed limit of State bank conversions had passed, and by July, 1867, the whole amount of circulation had been issued to converted State banks regardless of their location. The result was that the circulation of banks in the Eastern and Middle States was much in excess of what they were entitled to receive under the apportionment law, while the banks in the Western and Southern States had received much less than their proportion. In the light of later events there is no doubt that the West and South had all the circulation they had then eapital to obtain; and that, if the amount issued in the Eastern and Middle States had been restricted to the sum allowed by the apportionment law, the excess would have remained uncalled for by banks in the States entitled to it.

\section{INEqUalities IN THE Distribution of Circulation.}

The panic of September, 1869, known as Black Friday, and the subsequent investigation in Congress, aroused great financial excitement, and popular attention was attracted to the vast accumulations of currency in the East, especially in New York city, and its use in the stock and gold speculations which had culminated so disastrously. The feeling that some legislation was necessary, existing among the people, was strongly reflected in Congress. The lines were drawn between those who favored sound measures and those who were opposed to anything except an increase of the paper currency. From 1866, the heresy of inflation had continued to gain ground. There were many who held the contraction policy of Mr. McCulloch to be the cause of the panic of 1869; and predictions of similar disasters in the future, unless the plan of inflation were adopted, were numerous. "Money to meet the demands of trade" was the very plausible cry. In February, 1870, the House of Representatives adopted a resolution instructing the Committee on Banking and Currency to bring in a bill increasing the currency by at least $\$ 50,000,000$. The inequality of the distribution of National bank circulation could not fail to attract attention under the 
circumstances, and it doubtless served the conservative element in good stead in their effort to defeat measures for an indefinite increase of the legal-tender note circulation. The demand for action could not be set aside, and all that remained was to respond to it in a way that would afford satisfaction and yet defeat the dangerous projects of the inflationists. General Garfield was Chairman of the Committee on Banking and Currency, and he reported a bill providing for an additional issue of National bank notes, for the withdrawal of a portion of the excessive issues to banks in the Eastern and Middle States, and a redistribution of the amount withdrawn among banks to be organized in the West and South; for the removal of banks located in States having more than their proportion of circulation to States having less than the same, and for the retirement of the three per cent. loan certificates outstanding as fast as the new bank circulation was issued. These three per cent. certificates, amounting to $\$ 45,000,000$, were held by the banks as reserves, and virtually increased the volume of legal-tender notes by their amount. So that the provision withdrawing them as the new bank circulation was issued prevented any increase of the aggregate circulation. The bill also contained a provision restricting the currency to be issued to any bank thereafter organized, whatever its capital, to $\$ 500,000$, but permitted the establishment of National banks which were to redeem their issues in gold, without limit, to the aggregate amount of such gold-note circulation, except that no one bank could issue more than one million of dollars.

The bill was thus calculated to suit, or at least silence, all parties. To the inflationists who contended that more notes were necessary, and who came mainly from the West and South, it gave an issue of \$54,000,000 new bills and a redistribution of $\$ 25,000,000$ of old currency, which the West and South could have if they really needed it. And, what was more pleasant to them, it was done at the expense of the envied East, which had not only to give up $\$ 25,000,000$ of their ill-gotten circulation, but likewise had to surrender $\$ 45,000,000$ of temporary loan certificates. On the other hand the conservative bankers of the East were willing enough to yield the $\$ 25,000,000$ which they suspected would never be required of them, and the three per cent. certificates that would, of course, without any inflation, be replaced by legal-tender notes. The National gold bank scheme was a palliative to the ultra hard-money men, who were numerous anong those in political opposition to the Administration. The gold banks might be of service in California, and they gave to the citizens of other parts of the country the opportunity of indulging in a private resumption of specie payments whenever they saw fit.

The bill became a law July 12, 1870. The demand for circulation indicated that some legislation of this kind was necessary, though not to the extent asserted. By November, 1871, $\$ 24,773,260$ of the additional amount provided had been issued to banks in States having less 
than their proportion; but, in November, 1874 , there were still $\$ 2,241$,019 of the $\$ 54,000,000$ which had not been absorbed, and it was unnecessary, apparently, to call in the $\$ 25,000,000$ from States having more than their proportion for redistribution.

\section{Withdrawal of Bonds by Banks in Liquidation.}

Section forty-two of the Act of June 3, 1864, had permitted National banks to place themselves in liquidation by the vote of stockholders holding two-thirds of their stock. After one year from the date of the vote the bank could withdraw its bonds by depositing lawful money with the United States Treasurer to retire its notes. There was nothing mandatory about this, and many banks in liquidation were in no hurry to retire their circulation and withdraw their bonds seeing they could still draw interest on them. They thus enjoyed indefinitely the benefit of their circulation without the necessity of providing for its redemption.

This did not meet the views of Congress, and by the act of July 14, 1870 , banks then in liquidation were required to deposit lawful money within sixty days, from the date of the law, and banks thereafter liquidating were obliged to provide for their notes within six months under severe penalties. This had the effect of releasing the circulation to new and active associations. The limit on aggregate circulation allowed in several of the States having been reached and in some cases exceeded, new associations in such localities had previously much difficulty in obtaining circulation. Whenever any was released by liquidation and failure it was eagerly gathered up and sent in for redemption. In fact the demand was so great that the circulation of banks which had failed or were in liquidation commanded a premium from those banks wishing to obtain a portion of the quota allotted to the State in which they were located. The gathering up of notes of any one bank from among the great mass in circulation was found to be an exceedingly difficult undertaking. Many banks wishing to reduce their circulation could not get their own notes to send back, and it is probable that, if it had become necessary to have enforced the provision of the law of 1870 requiring the withdrawal of $\$ 25,000,000$ from banks in the Eastern and Middle States, the practical difficulty of gathering up their notes would have forced a sale of a large portion of their bonds.

\section{Certificates of Deposit for Legal-Tender Notes.}

During the years 1871 and 1872 there was a cessation of important legislation relating to National banks. In 1872 a bill was passed authorizing the issue of United States certificates of deposit for legal-tender notes to be used as bank reserves, and a bill passed the Senate authorizing banks to make loans to one-tenth of their capital and surplus instead of one-tenth of capital as theretofore, but did not become a law. In September, 1873, occurred the great financial crisis ushered in by the 
failure of Jay Cooke \& Co. When Congress met in December it reflected the intense financial excitement of the time, and the country looked to it for relief. Senator Sherman, Chairman of the Senate Committee on Finance, stated that over sixty different propositions, either in the form of bills or petitions, had been received by the committee. The state of the currency previous to the panic was as follows: The various legaltender acts had authorized an issue of $\$ 450,000,000$ of legal-tender notes, of which amount $\$ 50,000,000$ had originally been regarded as a reserve for the redemption of temporary loans, but had been permanently retired when the temporary loans were funded, reducing the limit of the legal-tender note issue to $\$ 400,000,000$. Under the authority of the law of April 12, 1866, Secretary McCulloch had diminished the amount in circulation to $\$ 356,000,000$, when further contraction was prohibited by the law of February 4, 1868.* In addition to the legaltender notes the law allowed a possible issue of $\$ 354,000,000$ of National bank notes, most of which were actually in circulation.

During the panic it was urged upon the Secretary of the Treasury that the $\$ 44,000,000$ of legal-tender notes retired by Secretary McCulloch should be treated not as permanently retired, but as a reserve to be issued when called for by great emergencies; and yielding to this view, Secretary Richardson under the great pressure of the times issued $\$ 26,000,000$ of this so-called reserve in exchange for United States bonds. That no more of it was issued was due to the fact that no more United States bonds were offered.

\section{Diversity of Opinion Regarding the Panic.}

Congress and the people were divided as to the causes of the panic and the remedies competent to relieve the attendant distress. Those who believed that the trouble was to be ascribed to a restricted currency were, if not the most numerous, the most clamorous. Their arguments were that the limitation of the paper money of the country to $\$ 710,000,000, \$ 356,000,000$ of legal-tender and $\$ 354,000,000$ of National bank notes, had prevented an increase of circulation which it was contended should normally keep pace with the growth in the population and business of the country. Not only had this arbitrary limit remained fixed and immovable for a decade, but the funding of some of the forms of temporary debt which, with these notes, had served the purposes of money, brought about a veritable contraction of the currency in the face of population and business constantly increasing. The evidences of this progress were the number of lines of railway either finished or in process of construction, the development of manufacturing interests upon every side, and the great extension of trade and commerce. These enterprises had to stagnate because there was not

* "It was an unreasonable apprehension of what might be the effect of this contraction, rather than what it was, that raised the outcry against it."- "Men and Measures of Half a Century," by Hugh McCulloch, p. 212. 
money enough in circulation to keep them in a condition of healthful vitality. It was patent to all that failures occurred because those who had incurred the risks of projects of importance to the public did not have and could not procure the currency to meet necessary payments. The National banking system received its share of animadversion. The banks in the West and South had not received their part in the distribution of circulation allowed by law, while those in the East had been unduly favored. The scarcity of money was most severely felt in the West and South. The circulation of a country, it was claimed by many, should have a certain proportion per capita to the population, and this per capita proportion should be greater in sparsely settled than in densely populated communities. The per capita proportion in the United States was much under what was allowed in France and England. It was claimed that on general principles the smaller the aggregate of money in circulation the greater its value, and the more difficult it became for the debtor classes to obtain it to pay their debts, and it was contended that prices fell with contraction and rose with the expansion of the currency.* An increase of prices was what was wanted to restore confidence. Anything tending to contraction was to be resisted.

On the other hand it was asserted that there was really no lack of circulating medium, and that the financial disasters had not been brought about by any inadequacy in the aggregate volume of money. The trouble was due to the assumption of debt for the purpose of creating products in various forms and of various kinds for which there was no immediate demand. Debts were incurred to build railroads in regions where there was as yet no trade and over which the travellers were few, and which could not pay even the interest on the cost of their construction for years to come. Goods were manufactured of a description which already existed in plenty and which consequently could not be sold in time to meet the engagements incurred in their making. Individuals and companies had borrowed money and locked it up in enterprises which made no returns. The money itself was in existence, but was in the hands of those who felt no inducements to lend it to the debtors upon their depreciated property. The increase of the circulating medium by issues of Government paper could afford no relief. It could only be paid out to ereditors of the Government, bond holders or others. If those who needed relief had Government bonds or other sound security they could obtain money upon them at

* "For more than fifty years I have been a careful observer of the course of trade and the general range of prices in the United States, and of the causes which have affected the market value of our agricultural and manufacturing productions. I have known prices to be advanced by foreign demand, or by temporary deficiency of supply, but more frequently by speculation, induced and fostered by redundant currency. I have known prices to decline by the reaction of speculation, and by diminution of the home or foreign demands; but I have never known our farm products or manufactured goods to fail to bring what they were worth, at home or abroad, by reason of insufficient supply of money or its representatives."- "Men and Measures of Half a Century," by Hugh McCulloch, p. 212. 
the banks. From over-trading and over-production the value of many forms of security had depreciated in the market, some, perhaps, more than was warranted. This could not be obviated by increased issues of paper, but time must be given to enable people to discriminate between what was good and what was bad. Further, it was believed that much of the speculation out of which the difficulty had grown was due to irredeemable paper, the fluctuations in which as measured by the gold standard had offered peculiar inducements to speculators, and that a permanent cure could only be hoped for by a return to specie payments.

The permanent resumption of specie payments was thought impossible by some as long as the balance of trade was against the United States. Some proposed a United States bond bearing interest at the rate of 3.65 per cent., which should be convertible into legal-tender notes at the option of the holder, while at the same time the legal-tender notes could, at any time, be exchanged for the bond. This, it was asserted, would give elasticity to the Government issues.

In short, one party held that the panic was not the fault of the currency, though the latter might be improved by a return to specie payments, while the other scouted specie payments and maintained that an additional issue of greenbacks would afford a cure for the ills of the time.

\section{Veto of the Inflation Bill by President Grant.}

Congress had to do something or pretend to do something, and the debate continued month after month, while the country was doubtless gaining strength by the delay.

Senator Sherman said that the Finance Committee were part in favor of unqualified inflation, a part in favor of a return to specie payments. The latter did not agree as to the means by which such payments were to be brought about. The first bill presented by the committee was an attempt to reconcile the divergent views. It was a short bill of six sections. The first fixed the limit of legal-tender notes at $\$ 382,000,000$, which was the amount then outstanding, including the $\$ 26,000,000$ issued by Secretary Richardson during the panic. The inflationists wanted $\$ 400,000,000$, and the others $\$ 356,000,000$. The second section provided for the redemption after July 1, 1876, in gold coin or United States five per cent. bonds, of legal-tender notes when presented at New York or Washington in sums of $\$ 1,000$, or some multiple thereof. The notes when so redeemed might be reissued. The third provided for the reapportionment of National bank circulation to give the South and West an amount proportionately equal to the bank circulation outstanding in New York and the East. For every $\$ 1,000,000$ additional bank circulation issued $\$ 700,000$ of legal-tender notes were to be retired and the banks were to keep three-quarters of their reserve at home and retain one-fourth of the coin interest on their bonds. 
This bill amended to allow an issue of $\$ 400,000,000$ legal-tender notes and $\$ 410,000,000$ of National bank currency, passed both houses, but was vetoed by President Grant. It was manifestly an impracticable measure. The constant reissue of legal-tender notes and their funding into United States bonds would have increased the funded debt without retiring the notes. It served its turn in giving Congress something to occupy it during the period of greatest excitement and until cooler counsels prevailed.

\section{Repeal of the Law Requiring a Reserve on Circulation.}

Another bill was introduced in the House which finally became a law on June 20, 1874. This measure principally concerned National bank circulation. It repealed the provision requiring reserve upon circulating notes and provided for redemption at the Treasury of the United States, each bank to keep on hand with the Treasurer a fund equal to five per cent. of its notes. This law also required the Comptroller of the Currency to proceed at once to withdraw the $\$ 25,000,000$ of circulation required by the act of 1870 to be withdrawn from the East and to distribute it to banks organizing in the South and West, and this was to be done notwithstanding the fact that the whole $\$ 54$,000,000 of additional circulation provided by the act of 1870 had not yet been issued.

To overcome the practical difficulty of banks returning their own eirculation, the law permitted them to provide for the redemption of their notes by the deposit of lawful money. The immediate effect of this provision was the voluntary retirement of a large amount of circulation and withdrawal of bonds by many of the banks in the Eastern and Middle States, indicating that even in that section of the country the demand for additional currency was not so great as had been supposed. The banking law of June 3, 1864, required all National banks of a capital of $\$ 90,000$ or upward to deposit with the United States Treasurer an amount of bonds not less than one-third of such capital whether circulation was issued or not, and in no case could the minimum of bonds held be less than $\$ 30,000$. The act of 1874 reduced the required minimum of bonds for banks of large capital to $\$ 50,000$ by permitting any association to reduce its bonds to this amount.

The feature of the law allowing banks in operation to retire their eirculation by a deposit of lawful money, was first suggested in a letter of the Comptroller of the Currency to Mr. Sherman, Chairman of the Finance Committee of the Senate, dated December 4, 1873. In this letter it was stated that many applications had been received for the organization of banks without circulation, and suggested that this could be accomplished by reducing the minimum of bonds required to be deposited to $\$ 10,000$, and permitting banks already in existence who did not wish to issue notes, to retire their circulation by a deposit of lawful money. The Comptroller says that as far as he is aware there can be 
no objection to such a bill. This proposition was debated to some extent in the Senate, but was dropped without action, and the provision of retiring circulation by deposit of lawful money was embodied in the bill, which became a law as above stated.

The portion of the act of June, 1874, requiring the Comptroller to withdraw circulation from banks, located in sections of the country having more than their proportion of circulation, was superseded by the free banking act of 1875 before there was any opportunity to put it in practical operation. Doubtless it would never liave proved of much value. The circulation might have been withdrawn from some of the States, but there would have been little demand for it in others. Three hundred and eighty-two millions of legal-tender notes stood in the way of any great increase of the National bank currency.

\section{Decline of THE INFLation Sentiment.}

By the end of 1874 there was some reaction from the general feeling in favor of inflation of the currency that had prevailed after the panic. It was plain that the expansion party in Congress could not secure any addition to the legal-tender issues. The operation of the act of 1874 would, it was plain, cause contraction rather than an increase of $\mathrm{Na}$ tional bank circulation. The circulation surrendered by the eastern banks lay idle in the Treasury as the banks in the South and West did not appear to want it. There was also a strong party in favor of doing something to bring about the resumption of specie payments.

A bill for this purpose was reported by Mr. Sherman on December 21,1874 . When it was called up the next day, such hasty action was deprecated by Messrs. Schurz, Bayard and Thurman, but by a vote of thirty-nine to eighteen, the Senate decided to consider it. Mr. Sherman explained that there were three plans of specie resumption advocated, first by a steady contraction of the legal-tender notes issues; second by funding the legal-tender notes in bonds, and third resumption by graduated payments, redeeming the notes in gold at their quoted market value, and by degrees paying more and more for them until at length they were brought to par in gold. Mr. Sherman himself was in favor of the second plan, but he was aware that it would be impossible to secure sufficient support for any one of the three.

The bill he had reported contained some of the principles of these plans, and proposed resumption by three graduated steps : 1st the redemption of the fractional currency in silver ; $2 \mathrm{~d}$ the free issue of $\mathrm{Na}$ tional bank notes and the proportional withdrawal of legal-tender notes, and $3 \mathrm{~d}$ a future fixed day of payment in coin. These provisions were acceptable to the ultra hard-money men, with the exception that the bill left it uncertain whether the legal-tender notes withdrawn by the issue of National bank currency were permanently retired. On this point Schurz, Bayard and Thurman were anxious to be informed, but Mr. Sherman declined and professed to be unable to give any opinion. 
His answer was, that if the bill did not settle it time would show. This very uncertainty made it acceptable to the other party who saw in it a chance for the expansion both of legal-tender and bank-note circulations. At least it was a safe bill for a politician to vote for as he could explain it to mean contraction or expansion according as his enquiring constituent was of one or the other way of thinking. The bill passed December 21, the same day it was taken up.

\section{Resumpition Ac' of January 14, 1875.}

In the House it was reached on January 7 , and was passed without debate under the previous question. The call for the previous question was sustained upon the promise of Mr. Maynard, Chairman of the Banking and Currency Committee, who had charge of the bill, to the minority that gentlemen would have leave to print any amendments or remarks they might have desired to make on the bill in the "Record." As the defeat of the measure was hopeless, this promise was accepted by the politicians as all that was necessary to make their record right. While Mr. Maynard's promise was all right as far as it went, it was soon found that it was only good so far as he was concerned. When the bill was passed, many other members objected to printing amendments and. speeches which had not been offered or made in actual debate, and in spite of Mr. Maynard's pleas that the majority would honor his promise, the House would not consent to permit the printing of the post facto amendments and arguments. The bill became a law January 14, 1875. The free banking section of the specie resumption bill removed all limit upon the aggregate amount of National bank circulation, and provided that as additiona notes were issued to the National banks to the amount of $\$ 1,000,000$, legal-tender notes to the extent of $\$ 800,000$ should be retired. During this session of Congress laws were enacted removing the limit of circulation which a National gold bank might issue, further restricting the issue of paper money by individuals and corporations other than National banks, and regulating the pay of National bank examiners.

\section{The Greenback Theorx.}

Up to the date of the Resumption Act, no serious attacks were made upon the National banking system. The National bank note seemed to enjoy an equal degree of popularity with the notes of the Government. In 1869 General Butler had advocated a plan for retiring National bank circulation and making irredeemable Government notes the exclusive currency of the country. It was received with no favor, and in all the subsequent financial discussions up to and including that of 1875 , the advocates of inflation had looked with equal favor upon an expansion of legal-tender notes and one of National bank notes. During the period between 1875 and 1879 , when resumption was to take place, a change occurred. It is plain that the free banking law gave 
the opportunity to secure all the currency that the wants of business in any part of the country might require. If there was a demand for currency, as the inflationists urged, here was an unfailing well from which the demand might be supplied. It is true that legal-tender notes were retired as National currency expanded but not in the same degree, and there was thus a gradual inflation of the aggregate amount of paper money. Business did not revive to the extent expected, prices did not rise, and times continued to be hard. Although the banks could obtain currency to issue, they could not obtain such security for loans as seemed good to them. The popular feeling seems to have reacted against the banks. They could issue currency but would not loan it as freely as the offerers of poor security desired. The hard times were ascribed to the Resumption Law, to the contraction of the legal-tender notes, to everything except the condition of exhaustion which had followed the panic of 1873. The National bank medium did not produce quick enough results, something else was wanted. Every Congress between 1875 and 1879 was fertile in measures for substituting greenbacks for National bank notes, and for abolishing the National banking system. The South generally aimed to effect the destruction of the system by repealing the tax upon State bank circulation, thus restoring the State systems, while the greenback advocates usually hailed from the West.

The Comptroller of the Currency in his address to the American Bankers' Association at Saratoga in 1879, said, "that there were not six members from the Eastern and Middle States who were in favor of the issue of the greenback as the only paper currency of the country; and from the Southern States, so far as he could learn, there was not one member in favor of such substitution."

\section{Further Retirement of Legal Tenders Prohibited.}

The main argument of the greenback party for the substitution was the saving in interest to be effected by the Government from issuing its own money. Most of the plans proposed to issue large additional amounts of legal-tender notes to be used in retiring and cancelling the United States bonds deposited by the National banks, regardless of the fact that such bonds could not be redeemed before they matured. These measures seemed to assume that the Government could dispose of the bonds it held in trust for the banks without any regard to the rights which the National banks had in common with other bond holders. The only thing effected in Congress was the enactment of the law of May 31, 1878, by which any further reduction of the legal-tender notes was prohibited. From 1875 to May 31, 1878, National bank notes to the amount of about $\$ 44,000,000$ had been issued, and legal-tender notes had been reduced from $\$ 382,000,000$ to $\$ 346,681,016$, at which last amount they have since continued. The retirement of National bank notes more than kept pace with their issues, and the aggregate amount 
was reduced from $\$ 351,861,450$ on January 14,1875 , to $\$ 320,991,795$ in November, 1878. There was, therefore, under the free banking law of 1875, during the time the provision for retirement of legal-tender notes continued in full force, a total contraction of the paper money of the country of about $\$ 66,000,000$-much greater than the contraction under Secretary McCulloch in 1866 . This contraction cannot, however, be said to have been forced by the law, but was the natural expression of the real condition of business at that period.

In 1876 an act was passed amending the provisions of the original bank act in regard to the appointment of Receivers. Previously there had been no way to wind up a National bank unless it refused to redeem its notes or committed one of several specified violations of law. A bank might be utterly insolvent and yet not have committed any of the specified acts for which a Receiver might be appointed. The new law enabled the Comptroller to close a bank on account of insolvency, and also gave him control of banks in voluntary liquidation which might fail to meet their debts. It provided also for turning over the remaining assets of banks whose debts had been fully paid by the Receiver to their stockholders. Only laws relating to minor points were passed between $18 \% 6$ and 1882 .

The original banking act of February 25, 1863, had permitted banks to fix in their articles of association the day upon which their corporate existence should commence, and for what term of years it should continue, which term, however, was not to exceed twenty years from the date of the law. If this law had continued in force all National banks, whenever organized, would have terminated not later than February 25, 1883. This law was superseded by the act of June 3, 1864 , but, in the meantime, some 300 banks had been organized. Some of them took eighteen, some nineteen years, but the majority the full term allowed by the law. The charters therefore commenced to expire in 1881 and continued to do so at different dates in 1882 and 1883, until February 25 of the latter year. The act of 1864 provided that banks organized under it should have existence for twenty years from the date of their organization, which was the date of their organization certificate. This change virtually made the system perpetual, as new banks could be organized as the old ones expired. This process necessitated the winding up of the old banks, and was also objectionable in some cases in that it did not give the Comptroller sufficient power of supervision of the process of transferring the assets of the expiring association to the new bank, and involved much trouble in the retirement of circulation and the transfer of bonds. The attention of Congress was called to the matter, and a bill was introduced by $\mathrm{Mr}$. Crapo, Chairman of the Banking and Currency Committee of the House, for the extension of the charters of the banks which were about to expire. 


\section{Extension of the Corporate Existence of National Banks.}

The introduction of this bill was the signal for all who were opposed to the National banking system, as it stood under existing law, to offer such amendments as they thought necessary to improve its defects or to curb its alleged powers for evil. The bill, as it finally became a law, provided that stockholders owning two-thirds of the stock might extend their association with the approval of the Comptroller of the Currency to be granted after a special examination of its condition. There were provisions for protecting the minority stockholders who might not wish to extend the bank, also for protecting minority stockholders of banks which were placed in liquidation for the purpose of organizing new associations. $\mid$ One member, who thought National banks had too great advantages in the United States courts, introduced a clause for the purpose of putting them on the same footing in this respect as State banks and private bankers. The old circulating notes of extended associations were to be all redeemed and destroyed, and the new circulation issued by them was to be of a new and different design; so that the profit arising from notes lost and destroyed during the period of the first charter of the bank, which the law declared should belong to the Government, might be accurately determined. The cost of preparing the plates from which their notes were printed was to be paid by the banks. Banks that did not extend had their franchise extended for winding up their affairs. Banks with a capital of $\$ 150,000$ or less were permitted to organize with bonds amounting to one-fourth of their capital. There were several provisions in regard to the issue and retirement of circulation. Banks that retired their notes by the deposit of lawful money could not take out new notes until the lapse of six months, and not more than three millions of dollars of lawful money could be retired in any one month. The act also provided for the issue of three per cent. bonds in exchange for the bonds bearing three and one-half per cent. The issue of gold certificates was authorized and silver certificates were made available for reserve, and National banks were forbidden to belong to a clearing-house where silver certificates were not taken in payment of balances; and last, fine and imprisonment were made the penalty for the unlawful certification of checks.

In March, 1883, a law was passed repealing the taxation of bank capital and deposits, leaving circulation only subject to semi-annual duty.*

\section{Redemption of National Bank Circulation.}

The original National Curreney Act of February 25, 1863, made no provision for the redemption of circulation at redemption agencies in the principal cities, but simply required that every bank should redeem its circulation at its own counter, keeping a reserve upon its deposits

* The War Revenue Act of 1898 imposed a tax on the capital and surplus of bankers. 
and circulation of twenty-five per cent., of which reserve three-fifths might be kept deposited with associations in nine principal cities named in the act. Sections thirty-one and thirty-two of the act of June 3, 1864, established two classes of redemption cities, New York alone being in the first class. The banks in the cities of St. Louis, Louisville, Chicago, Detroit, Milwaukee, New Orleans, Cincinnati, Cleveland, Pittsburg, Baltimore, Philadelphia, Boston, Albany, Leavenworth, San Franciscoand Washington, were required to select in New York city, an association subject to the approval of the Comptroller of the Currency at which they, each of them, would redeem their circulating notes at par. The banks located outside of the cities named, and since known by the general title of country banks, were required to select in some one or more of the cities named, including New York, an association or associations subject to the approval of the Comptroller of the Currency, at which they, each of them, would redeem their circulating notes. It may be noted here that although the act of March 3, 1865, which provided that every National banking association, State bank, or a State banking association, should pay a tax of ten per cent. on the amount of notes of any State bank or State banking association paid out by them after July 1, 1866, had great weight in compelling the majority of the existing State banks to convert into National banks, yet there were a large number of the State banks in New York and other large Eastern cities so strong that the mere suppression of their right to issue circulation would not of itself have induced them to become National banks.

Hon. Hugh McCulloch, Comptroller of the Currency, was at first apprehensive of too rapid an increase in the number of the National banks, ${ }^{\circ}$ because he was of the opinion that too many new National banks, in addition to the old State banks already existing and refusing to convert into National organizations, would greatly overstock the country with banking facilities. He, therefore, in every possible way sought to encourage the conversion of the State banks into National institutions. He used his utmost influence to induce the Legislatures of the States in which the State banks were mostly located to pass enabling acts to facilitate conversion from the State to the National system. By 1864 the principal States had passed such enabling acts and there was a strong prospect that all of the States would do so. The large city banks, confiding in their deposit and discount business, were still in many cases loath to enter the system; and it was the construction put by the Comptroller of the Currency upon Sections thirtyone and thirty-two of the Currency Act of 1864, requiring the selection of redemption and reserve agents at the money centers, which did more to finally drive these banks into the National system than the suppression of their circulation by the act of March 3, 1865. The sections referred to do not distinctly provide that the redemption agents selected must be National banks; but inasmuch as the Comptroller of the Currency refused to approve any other than National banks as such agents, 
the large State banks saw at once that unless they could legally become the redemption and reserve agents of their country correspondents, these correspondents would be likely to transfer their accounts to the National banks, and consequently felt obliged to enter the National system or to give up a large share of their business. It was well understood by the authors of the National Currency Act, that some system of practical and effective redemption was necessary for the preservation of a healthy currency and as a safeguard against redundancy. The original redemption law provided a large number of eities at which each National bank might select its redemption agencies. As a matter of fact, it was found that the great majority of the country banks selected for the redemption of their notes, agencies in New York city, Boston and Philadelphia.

\section{National Bank Notes not Subject to True Commercial REDEMPTION.}

At the very first and for almost the whole period of the existence of the National banking system lawful money of the United States, in which the National bank notes were legally redeemed, has been in excess of the amount of the National bank notes themselves. The result of this has been that from the beginning of the system there has been no true commercial redemption of the National bank note. The provisions, both in regard to redemptions of circulation and the maintenance of a large reserve for such purpose, were intended by the authors of the act, very evidently, for a condition of things when the National banks should issue the bulk of the currency of the country. They did not contemplate that there would be any other lawful money than the original legal-tender notes and gold and silver, and that the great increase in our currency which has been caused by the issue of silver certificates, Treasury notes and other forms of lawful money* besides the legal-tender note, would be caused by the issue of additional National bank curreney. By means of these enlarged issues of lawful money the National bank note has been kept in the background, and because the money in which it was to be redeemed was more plentiful than the notes to be redeemed, the National bank currency has never been freely presented for redemption. Owing to this fact the currency became very much worn and mutilated as well as dirty and defaced. The difficulty of getting back their notes which was encountered both by the banks that went into voluntary liquidation and by the others that desired to retire a portion of their circulation, made it necessary to adopt some plan for securing regular redemption of the notes. The act of June 20, 1874, therefore, abolished all lawful money reserves on National bank circulation and established a bureau in the Treasury Department for the redemption of the National bank cur-

* Though the silver certificates are not strictly lawful money, they are practically so, as they represent the coin dollars which are a full legal tender. 
rency. At the same time this law permitted any association that desired to withdraw its bonds to do so by depositing lawful money for the ultimate redemption of its circulating notes. The premium on bonds, beginning to appear in 1874, and the gradual increase in the amount of lawful moneys of the United States, soon began to force out of use and cause a reduction in the amount of National bank currency outstanding; and the National Redemption Bureau of the Treasury Department has been doing an active business in redeeming and retiring the notes of National banks almost since the date of its first organization.

Although the Redemption Bureau at Washington superseded the redemption agents that before the year 1874 had been maintained by each bank in some one of the so-called redemption cities, the act creating it did not interfere with the privilege of banks keeping a portion of their reserves with agents approved by the Comptroller of the Currency in such cities. These reserve cities were divided into two classes. The banks in New York city, being the only city in the first-class, were obliged to keep their entire required reserve in their own vaults. The banks in cities of the second-class were permitted to keep one-half of their reserve in banks in New York eity, and one-half in their own vaults. Under this system, country banks, so-called, that is banks located outside of any of the reserve cities, the total required reserve of which was fifteen per cent. of deposits, kept three-fifths of such fifteen per cent. in banks selected and approved by the Comptroller, in the reserve cities, and the remaining two-fifths in cash at home. Banks in reserve cities of the second-class, required to keep a reserve of twentyfive per cent. of their deposits, were permitted to keep twelve and onehalf per cent. in banks in New York city, and twelve and one-half per cent. in their own vaults. The tendency of this it was thought was to cause an undue accumulation of the reserves of the banks in New York city banks. To counteract this in a degree the act of March 3, 1887, was passed, which provided for the creation of other reserve cities of the first class, the banks in which, like those in New York, should keep their total cash reserves of twenty-five per cent. on their deposits at home.

This act provided that whenever three-fourths of the National banks located in any city of the United States, having a population of two hundred thousand people, made application to the Comptroller of the Currency to have such city made a central reserve city, or reserve city of the first-class, similar to New York city, the Comptroller might grant such request. Similarly a request from three-fourths of the National banks in any city of fifty thousand inhabitants, would authorize the Comptroller to make that city a reserve city of the second-class. Under this law Chicago and St. Louis became central reserve cities, and a number of other cities became reserve cities of the second-class.

It is a question whether the effect of this law in diverting any large portion of the reserves of the banks, as a whole from New York city, 
was in any respect noticeable. The cities which availed themselves of it certainly laid themselves under a stricter provision of law in regard to reserve than they had been previously obliged to observe.

On July 28, 1892, an act was passed making it obligatory upon every National bank to redeem all notes issued to or received by it, even if such notes were lost or stolen from the bank and put in circulation without the signature, or on the forged signature, of the President, Vice-President and Cashier.

\section{Currency, Funding and Banking Act of March 14, 1900.}

On March 14, 1900, the President signed a bill entitled "An Act to define and fix the standard of value, to maintain the parity of all forms of money issued or coined by the United States, to refund the public debt, and for other purposes." It declared the gold dollar to be the standard of value and made it the duty of the Secretary of the Treasury to maintain all forms of money coined or issued by the United States at a parity with the standard. A separate division of issue and redemption was created in the Treasury Department to which was transferred $\$ 150,000,000$ of gold coin and bullion, to be used for redemption purposes. United States notes and Treasury notes issued under the act of July 14, 1890, were made payable in gold, the former to be retained in the division of issue and redemption until exchanged for gold and not in any case to be paid out to meet deficiencies in the revenues, and Treasury notes as redeemed or received in the ordinary course of business to be retired and cancelled, their place to be supplied by silver dollars or certificates. The limit of the subsidiary silver coinage was raised to $\$ 100,000,000$. Changes were also made in the denominations of silver certificates, with a view to increasing their general circulation.

The new law reduced the minimum capital of National banks to $\$ 25,000$ in towns not exceeding 3,000 inhabitants, increased the circulation to the amount of paid-in capital and to the par value of the bonds deposited, reduced the tax on circulation to one-half of one per cent. per annum, and limited the circulation of each bank of the denomination of $\$ 5$ to one-third of its total issue.

Provision was also made for funding the five per cent. bonds of 1904, the four per cents of $190 \%$ and the three per cents of 1908 into thirty year two per cent. bonds, payable principal and interest in gold. 


\section{XVII}

\section{FINANCIERS OF THE CIVIL WAR PERIOD.}

Salmon P. Chase, Lincoln's first Secretary of the Treasury - John Sherman, author of the Resumption Act - Hugh McCulloch, the first Comptroller of the Currency and twice Secretary of the Treasury - Elbridge G. Spaulding, the "Father of the Greenbacks."

\section{Men Who Shaped the Financial Policies of the Civil War} PERIOD.

It may be said that the National banks and the legal-tender notes are two of the important heritages of the war of 1861-65. Both were born of the necessities of that epoch, and while it was proclaimed that the legal-tender notes were only a temporary expedient, they still occupy a prominent place in the circulating medium of the country more than thirty years after the close of the war, and twenty years after the accomplishment of resumption. In carrying on the great financial operations of the war-which perhaps are without parallel in history-there were men who took such a conspicuous part as to render their careers of interest to students of American banking. Secretaries Chase, McCulloch and Sherman are entitled to a place in the financial history of that time by reason of their prominence, either in shaping legislation or in carrying out the financial policies of the Government. Mr. Chase is justly entitled to the honor of officially proposing the National banking system, and Mr. McCulloch was the first Comptroller of the Currency and twice Secretary of the Treasury. Mr. Sherman was the author of the Resumption Act, and as Secretary of the Treasury carried out its provisions. He was also closely identified with the legislation by which the National banks were established.

Mr. Spaulding, the "Father of the Greenbacks," is another prominent figure of that period whose work is fully referred to throughout this volume. It should be remembered that Mr. Spaulding was not a "greenbacker" in the modern sense. He was a banker by profession, and a firm believer in the gold standard. Brief biographies of Secretaries Chase, McCulloch and Sherman and of Mr. Spaulding follow.

\section{Salmon P. Chase.}

As Secretary of the Treasury during most of the Civil War period, it fell to the lot of Mr. Chase to conduct the financial operations inci- 
dent to that great conflict. He was also the author of the National banking system, though the details of the plan were wrought out by others. His policy as Secretary of the Treasury has been criticized in many respects, particularly his failure to make proper use of the banking machinery in disbursing the proceeds of the loans made by the banks of New York, Boston and Philadelphia at the beginning of the war. In his Recollections ex-Secretary Sherman says:*

"The Secretary of the Treasury had ample and complete authority given him by the Act of July, 1861, to borrow money on the credit of the Government, but he could not deal with the system of State banks then existing in the several States. He was forbidden by the Sub-Treasury Act of 1846 to receive notes of State banks, and was required to receive into and pay from the Treasury only the coin of the United States; but by the act of August 5, 1861, he was permitted to deposit to the credit of the Treasurer of the United States, in such solvent specie-paying banks as he might select, any of the moneys obtained from loans, the moneys thus deposited to be withdrawn only for transfer to the regularly authorized depositories, or for the payment of public dues, including certain notes payable on demand, as he might deem expedient. He had, however, no authority to receive from individuals or banks any money but coin.

The coin received from the Boston, New York and Philadelphia banks, in payment of their subscriptions to the Government loans, to the amount of nearly $\$ 150$,000,000 , had to be sent to every point in the United States to meet public obligations, and when thus scattered, was not readily returned to the banks, thus exhausting their resources and their ability to loan again."

Mr. McCulloch, the first Comptroller of the Currency, and afterwards twice appointed Secretary of the Treasury, says in regard to the failure of Mr. Chase to make use of bank checks in disbursing the Government funds: $\dagger$

"For a considerable time, even after the war had begun, the specie standard was maintained, and hopes were indulged that the war might be prosecuted on a specie basis. These hopes were dissipated by the action of Secretary Chase in his dealings with the New York, Philadelphia and Boston banks, which had agreed to advance to the Government on its 7.3 notes $\$ 150,000,000$ ( $\$ 50,000,000$ in August, $\$ 50$,000,000 in October, and $\$ 50,000,000$ in November, 1861), under the expectation that the Treasury drafts for the money would be presented through the clearing-houses and be paid without large reductions of their coin. The Secretary did not, however, feel at liberty to meet their expectations, and the drain upon their coin reserve soon became so heavy that they were forced to suspend specie payments. Their suspension was soon followed by the suspension of nearly all the banks in the country."

Mr. McCulloch and Mr. Sherman both had the highest regard for the abilities of Mr. Chase. In his "Men and Measures of Half a Century" (p. 184), the former says, in speaking of Secretary Chase:

"He was the manager of the finances from March, 1861, to July, 1864, and by their successful management during that gloomy and momentous period he established a lasting claim upon the respect and gratitude of his countrymen. To him, more than to any other single man, always excepting Abraham Lincoln, are they indebted for the preservation of the national unity."

* "John Sherman's Recollections," p. 269.

+" Men and Measures of Half a Century," by Hugh McCulloch, p. 135. 
Mr. Chase was at first strongly opposed to making the Treasury notes a legal tender, but finally consented to this expedient. In the case of Hepburn $v s$. Griswold he delivered the opinion of the United States Supreme Court to the effect that these notes were not a legal tender in the payment of debts contracted prior to the passage of the act. This opinion was afterwards reversed by an enlarged court.

The relation of Secretary Chase to the finances of the Civil War period are given in detail elsewhere in this work. An outline of the principal events of his career is given in the following sketch:

Salmon Portland Chase was born in Cornish, N. H., January 13, 1808. In April, 1820, he went to Ohio, becoming a member of the family of his uncle, Philander Chase, Episcopal Bishop of Ohio. At that time the country was but little developed and the means of transportation were primitive. He reported that in 1822 it required the equivalent of a bushel of wheat to carry a letter 160 miles. About this time his uncle was offered the presidency of the Cincinnati College, which young Chase entered as a freshman. As the income of the college was unsatisfactory he was not able to remain there long, and was compelled to return home, his uncle having decided to leave Cincinnati. On the return journey he was accompanied part of the way by the Bishop, but at Kingston, on the Hudson, they separated. Of the rest of the trip he says:*

"I was taken down the river and was put on board the boat for Albany. From Albany I went to Troy, and there learning the way to Bennington and Brattleboro, started to make across the mountains homeward. My scanty purse did not contain enough to pay stage fare and I walked, getting an occasional ride from some farmer going my way."

Soon after returning home he was engaged to teach school at Roxbury, the compensation being $\$ 8$ a month and board. After two weeks he was compelled to give up the school, as his management of it was not considered successful by the local board. In 1824 he entered Dartmouth College, and later taught school at Reading, Vt., this time with success. After graduating he went to Washington and endeavored to establish a classical school, but the attempt failed. He was finally engaged as principal of a seminary there, and in 1827 began the study of law in the office of William Wirt. A year later he was one of those who drew up a petition for the abolition of slavery in the District of Columbia. He was admitted to the bar December 21, 1829, and in the following March located at Cincinnati. An edition of the "Statutes of Ohio" which he compiled, was highly praised by such eminent jurists as Kent and Story. In 1832 he voted for Wirt for President, his vote being given to him for personal reasons and not because he sympathized with the anti-masonic movement represented by Wirt's candidacy. He voted for Harrison in 1836 and 1840, personal consid-

* "Life and Public Services of Salmon P. Chase," by J. W. Schuckers. 19 
erations largely influencing these votes also. His political convictions were destined, however, to take definite form as a result of approaching events.

The destruction of the printing office of James G. Birney caused him to denounce mob violence. He did not sympathize with Birney's abolition sentiments, but upheld the right of free speech and a free press. He was engaged as counsel to defend an alleged fugitive slave in 1837 , and took part in an anti-slavery convention at Columbus in 1841. While he was not an abolitionist he opposed the further extension of slavery. He was elected to the United States Senate as a Democrat February 22, 1849, and in 1855 was elected Governor of Ohio, as a Republican, and was also re-elected to this position. February 2, 1860, the Republicans elected him to the United States Senate. $\mathrm{He}$ had many supporters for President in 1860, but worked earnestly for Lincoln when the latter was nominated. On January 3, 1861, he had an interview with Mr. Lincoln at Springfield, and was tentatively offered the position of Secretary of the Treasury. He took his seat in the Senate on March 4, 1861, and two days later President Lincoln, without consulting him, appointed him Secretary of the Treasury, the Senate unanimously confirming the nomination. He resigned his office June 29, 1864, the resignation being accepted on the following day. Apparently the resignation was due to a controversy over the appointment of a Sub-Treasurer at New York, but it is believed that the ambition of Mr. Chase to be President was the real cause of his leaving the cabinet. On December 6, 1864, he was nominated as Chief Justice of the United States Supreme Court, the nomination being confirmed without reference. Mr. Chase died in New York May 7, 1873.

About the time of his resignation he was compelled to borrow $\$ 25$,000 to meet his necessary expenditures. He had handled millions of public funds, but was himself comparatively poor. The efforts of his daughter, the former wife of Governor Sprague, of Rhode Island, to save the homestead of Secretary Chase from being sold, have been frequently referred to in the press in recent years.

Mr. McCulloch, an expert witness, speaks of Mr. Chase's services in the highest terms. Mr. Lincoln is reported to have said of him: "Of all the great men $I$ have known Chase is equal to about one and a half of the best of them."

In the light of the estimates of men of such authority as Lincoln and $\mathrm{McCulloch}$, who were entirely familiar with all the difficulties surrounding the conduct of the Treasury in those times, the superficial criticism of Secretary Chase so freely indulged in by financial writers loses most of its weight. His mistakes were such as most men might have made. His achievements were such as few men could have excelled. 


\section{JohN Shwrmax.}

Because of his work in restoring specie payments Mr. Sherman has been violently denounced by the advocates of an irredeemable currency. He has been declared by them to be a traitor to his country, a conspirator in the employ of foreign "gold syndicates," and has been condemned in the most extravagant language conceivable. Perhaps no greater tribute to his worth and ability could be produced. From the breaking out of the Civil War until his retirement from public life in 1898, Mr. Sherman has occupied a leading place in the country's history. His relation to financial affairs is fully set forth in this work. As the author of the Resumption Act, and as the Secretary of the Treasury under whose direction the operations of the act were carried on, he was instrumental in re-establishing the currency of the United States upon a specie basis, which had been destroyed by the Civil War.

His later financial views were favorable to a retention of the legaltender notes sustained by an ample coin reserve. He suggested more than twenty years ago that these notes when once redeemed in coin should be reissued only for coin-a proposition that has been recently revived and favorably received. This makes the legal-tenders virtually gold certificates, and remoyes one of their most objectionable features. The Act of July 14, 1890, for the purchase of silver bullion was generally known as the Sherman Act, but it was a compromise measure of which Mr. Sherman was one of the authors. He was opposed to the free coinage of silver, which was an issue in the presidential campaign of 1896. A brief biographical sketch of ex-Secretary Sherman follows.

John Sherman was born at Lancaster, Ohio, May 10, 1823, his ancestors being among the very early New England settlers, coming to this country from England. Roger Sherman, distinguished in Revolutionary history, belonged to another branch of the same family. After receiving a fair education, he began the study of law at Mansfield, Ohio, and in 1844 was admitted to the bar. In 1854 he was elected to Congress as a Whig, and was successively elected to every Congress from then up to and including the elections held in 1860. When Mr. Chase was made Secretary of the Treasury in 1861, Sherman was elected to succeed him as United States Senator from Ohio. He entered the Senate March 23, 1861, and was also elected for the succeeding term, and in 1872 elected for the third time. In 1877 he was appointed Secretary of the Treasury by President Hayes. He was a prominent candidate for President at the Republican National Convention of 1880, when James A. Garfield was nominated. Upon the election of the latter Mr. Sherman was chosen as Senator in place of Garfield, who had been elected to that office. In 1886 he was again elected to the Senate for the fifth time. On the death of Vice-President Hendricks he was chosen as President pro tem. of the Senate. In 
1892 he was elected to the Senate for the sixth time. Mr. Sherman's appointment as Secretary of State by President McKinley, and his resignation of that office, are matters which need only be mentioned at this time.

His opinion in regard to the necessity of passing the legal-tender act, as a war measure, will be of interest. He said :

"The legal-tender act, with its provision for coin receipts to pay interest on bonds, whatever may be said to the contrary by theorists, was the only measure that could have enabled the Government to carry on successfully the vast operations of the war." *

Mr. Sherman was certainly one of the ablest financiers of the period during the Civil War and subsequent to it, and his work in restoring the paper currency to a specie value in $\mathbf{1 8 7 9}$, as well as his identification with the National Bank Act and the refunding operations, will insure him a permanent place in the ranks of notable American financiers.

\section{Hugh McCulloch.}

There are two reasons which distinguish Mr. McCulloch from the other gentlemen who have held the office of Comptroller of the Currency or Secretary of the Treasury. He was the first Comptroller of the Currency, organized the bureau and inaugurated the National banking system, and he was twice appointed Secretary of the Treasury. Besides, he was a highly successful banker, and in the ability shown in the management of the public finances he has had few equals.

Hugh McCulloch was born at Kennebunk, Me., December 7, 1808, and in 1833 went west and settled at Fort Wayne, Ind., where he became Cashier and Manager of the branch of the State Bank of Indiana. Upon the expiration of the bank's charter in 1857, and the organization of its successor, the Bank of the State of Indiana, he became its President, and under his management the institution achieved a high reputation, continuing to redeem its notes in specie even during the severe panic of $\mathbf{1 8 5 7}$.

* Mr. McCulloch did not at first support the National banking system, but afterwards became one of its strongest friends. In 1863 he visited Washington, though he did not see Secretary Chase, but ealled at his office and left his card. Shortly afterward, on his return home, he found several telegrams requesting his presence in Washington, and also a letter from Mr. Chase urging him to accept the office of Comptroller of the Currency. On the resignation of Secretary Fessenden, in March, 1865, he was appointed Secretary of the Treasury, continuing in office till 1869. From 1871 till 1878 he was engaged in banking in London. In October, 1884, he was appointed Secretary of the Treasury by President Arthur, holding the office till the change of Administration in the following March. His death occurred at his home in Maryland, May 24, 1895. 
Mr. McCulloch believed that the United States notes were a war necessity, although he did not think it necessary to make them a legaltender. He declared that the notes would be valued according to the public faith in the ability of the Government to redeem them. After the close of the war he began retiring the greenbacks, but the cry of contraction was raised and the process stopped. The value of his services in funding the temporary obligations issued during the war was very great. His reports as Comptroller of the Currency and Secretary of the Treasury are replete with sound information on banking and finance. If his policy had been carried out, the legal-tender notes would have been paid off and permanently retired soon after the war ended.

Elbridge G. Spaulding.

The name of Mr. Spaulding is identified with the legal-tender notes issued during the Civil War in the United States. His relation to the financial events of that time may be traced in the history of that period. He drew up the original draft of the National Banking Act, but concluded that it could not be made effectual in time to meet the exigencies of the situation in which the Government was then placedan opinion shared by some of the ablest and most patriotic men of the time. He did not believe in greenbacks as a permanent currency, but favored their retirement after the close of the war, and advocated a bank currency redeemable in gold. On introducing the legal-tender act he stated that it was a temporary war measure - a measure of necessity, and not of choice, that it would insure a loan to the Government without interest. This measure was entitled "An Act to authorize the issue of United States notes and for the redemption and funding thereof, and for funding the floating debt of the United States." The notes issued under the first and second acts were convertible into United States bonds, and Mr. Spaulding greatly deplored the repeal of this provision in later years. In an address at the Centennial Exposition at Philadelphia in 1876, Mr. Spaulding said:

" The National Bank' Act requires that each National bank which issues national currency shall redeem it on demand 'in lawful money of the United States.'

In a normal condition of the country this requirement means gold coin, the value of which is regulated by Congress. Unfortunately, eleven years after the close of the war, the temporary 'war currency' issued in the form of greenbacks, still lingers as an evil element, and is declared by law to be 'lawful money,' so that the banks can and do redeem their circulating notes in this depreciated greenback currency. This is practically no redemption at all."

He then referred to the establishment of the Redemption Bureau at Washington, and said:

"This operation furnishes clean notes for those that are worn and defaced, but it is in no sense an efficient redemption, and can not be made so until the Government takes out of the way its irredeemable greenback currency."

These views were expressed before resumption, and when the greenback was depreciated. But in a preface to his "Financial History of 
the War," written on October 1, 1875, after the passage of the Resumption Act, he says, referring to the taking effect of the act:

"A constitutional standard of value having been thus established, the Government, desiring to return to its legitimate function of coining money and regulating its value, will ultimately wish to rid itself of the trouble and risk incident to the issuing a paper currency and redeeming it in gold, and will finally repeal the legal-tender act. This will leave the business of free banking where it belongs, open to all citizens, to be carried on upon a gold basis, under proper legislative restrictions. It would probably be better for all concerned if the legal-tender act should be repealed at an earlier day, and at the same time provide for retiring the greenbacks by the issue of five or six per cent. compound interest notes, fundable in two and three years into five per cent. ten-year gold bonds."

He thus stated the fundamental principle in regard to maintaining paper currency in circulation at par with gold:

"The wit of man, during the last hundred years, has not been able to contrive any method by which a paper currency can be circulated on a par with gold, unless it can be conveniently converted into gold coin on demand. It is not enough that 'the whole property of the country' is held liable to ultimately pay the greenbacks. Such security, though ample, is too general and intangible for the purpose. This "whole property' can only be reached and applied through the slow process of taxation."

Elbridge Gerry Spaulding was born in Summer Hill, Cayuga county, New York, February 24, 1809. His ancestors were among the earliest of the Massachusetts colonists. Both his grandfather and father fought in the American Revolution. He studied law at Batavia, and afterwards at Attica, New York, and was admitted to the bar, removing soon after to Buffalo. He became interested in the Bank of Attica and the Farmers and Mechanies' Bank of Batavia. Both banks were removed to Buffalo. The latter institution was reorganized as the Farmers and Mechanics' National Bank, and Mr. Spaulding became its President, holding this position until his death-the bank going into liquidation in November, 1897.

In 1836 Mr. Spaulding became city clerk of Buffalo, and in 1841 was elected an alderman and served as chairman of the finance committee. In 1847 he was elected by the Whigs to be Mayor of Buffalo, and in the following year was elected to the State Legislature. He was elected to Congress in 1849, and as a member of that body opposed the extension of slavery. In 1853 he was elected State Treasurer of New York, and was re-elected to Congress in 1858 and again in 1860 . He was identified with the Republican party in State and National politics.

At the Centennial Exposition at Philadelphia in $\mathbf{1 8 7 6}$ he delivered a notable address on "One Hundred Years of Progress in the Business of Banking," and was the author of a "History of the Legal-Tender Paper Money Issued During the Great Rebellion."

Mr. Spaulding died at his home in Buffalo, New York, May 5, 1897. 


\section{XVIII}

\section{NATIONAL BANK STATISTICS.}

The following tables give the complete official statements of the National banks for each year from 1863 to 1899 , compiled from the Annual Reports of the Comptroller of the Currency. Up to and including 1869.the statements are for some day in the month of October, and from 1879 to 1897 , for a day in December. For 1898 the staiement is as of September 20 . It will be seen that the figures approximately represent the condition of the National banks at the close of the respective years. In all cases cents are omitted from the tables.

National Banks, 1863-1899.

\begin{tabular}{|c|c|c|c|c|}
\hline CLASSIFICATION. & $\begin{array}{c}1863 . \\
66 \text { banks. }\end{array}$ & $\begin{array}{c}1864 . \\
508 \text { banks. }\end{array}$ & $\begin{array}{c}1865 . \\
1,513 \text { banks. }\end{array}$ & $\begin{array}{c}1866 . \\
\text { 1,644 banks. }\end{array}$ \\
\hline \multicolumn{5}{|l|}{ RESOURCES. } \\
\hline Loans and discounts........ & $\$ 5,466,088$ & $\$ 93,238,657$ & $\$ 487,170,136$ & $\$ 603,314,704$ \\
\hline U. S. bonds to secure cir'n. & ............. & ............ & ............ & $331,843,200$ \\
\hline U. S. bonds and securities. & $5,662,600$ & $108,064,400$ & $427,731,300$ & $94,974,650$ \\
\hline Other stocks, bonds, etc... & 106,009 & $1,43 \pm, 739$ & $19,048,513$ & $15,887,490$ \\
\hline Due from Nat'l \& other b'ks & $2.625,597$ & $34,017,026$ & $107,372,212$ & $122,861,291$ \\
\hline Real estate, furniture, etc. & 177,565 & $2,202,318$ & $14,703,281$ & $17,134,002$ \\
\hline Current expenses.......... & 53,808 & $1,021,569$ & $4,539,525$ & $5,311,253$ \\
\hline Premiums paid............. & 2,503 & & $2,585,401$ & $2,493,773$ \\
\hline Checks \& other cash items & 492,138 & $7,640,169$ & $72,309,854$ & $103,684,249$ \\
\hline Bills of Nat'l \& other b'ks. & 764,725 & $4,687,727$ & $16,247,241$ & $17,437,779$ \\
\hline Specie.................... & (a) $1,446,607$ & (a) $44,801,497$ & $18,072,012$ & $9,226,831$ \\
\hline Legal tenders \& frac'l cur. & & & $189,988,496$ & $205,793,578$ \\
\hline Total ................... & $\$ 16,797,644$ & $\$ 297,108,195$ & $\$ 1,359,768,074$ & $\$ 1,526,962,804$ \\
\hline \multicolumn{5}{|l|}{ Liabilities. } \\
\hline Capital stock ................ & $\$ 7,188,393$ & $\$ 86,782,802$ & $\$ 393,157,206$ & $\$ 415,472,369$ \\
\hline Surplus fund................ & (............. & $2,010,286$ & $38,713,380$ & $53,359,277$ \\
\hline Undivided profits........... & 128,030 & $5,982,392$ & $32,350,078$ & $32,593,486$ \\
\hline Nat'l bank notes outstan'g & ............. & $45,260,504$ & $171,321,903$ & $280,253,818$ \\
\hline State bank notes outstan'g & (............ & ............ & ........... & $9,748,025$ \\
\hline Individual deposits........ & (b) $8,497,681$ & (b) $122,166,536$ & (b) $500,910,873$ & $564,616,777$ \\
\hline U. S. deposits............... & ............ & .............. & $48,170.381$ & $30,420,819$ \\
\hline Dep'ts U. S. disb. officers.. & .............. & ............. & ............. & $2,979,955$ \\
\hline Dne Nat'l \& other banks.. & (c) 981,178 & $34,862,384$ & $174,199,998$ & $137,518,274$ \\
\hline Other items .... & 2,360 & 43,289 & 944,053 & (n............ \\
\hline Total .................... & $\$ 16,797,644$ & $\$ 297,108,195$ & $\$ 1,359,768,074$ & $\$ 1,526,962,804$ \\
\hline
\end{tabular}

(a) Including other lawful money.

(b) Including other deposits.

(c) Including State bank circulation ont standing. 
National Banks, 1863-1899-Continued.

\begin{tabular}{|c|c|c|c|c|}
\hline CLASSIFICATION. & $\begin{array}{c}1867 . \\
1,642 \text { banks. }\end{array}$ & $\begin{array}{c}1868 \\
\text { 1,643 banks. }\end{array}$ & $\begin{array}{c}1869 . \\
1,617 \text { banks. }\end{array}$ & $\begin{array}{c}1870 . \\
1,648 \text { banks. }\end{array}$ \\
\hline \multicolumn{5}{|l|}{ RESOURCES. } \\
\hline Loans and discounts........ & $\$ 609,675,214$ & $\$ 657,668,847$ & $\$ 682,883,106$ & $\$ 725,515,538$ \\
\hline U. S. bonds to secure cir'n. & $338,640,150$ & $340,487,050$ & $339,480,100$ & $344,104,200$ \\
\hline U. S. bouds to secure d'pts. & $37,862,100$ & $37,360,150$ & $18,704,000$ & $15,189,500$ \\
\hline U. S. bonds and securities. & $42,460,800$ & $36,817,600$ & $25,903,950$ & $23,893,300$ \\
\hline Other stocks, bonds, etc... & $21,507,881$ & $20,693,406$ & $22,250,697$ & $22,686,358$ \\
\hline Due from redeeming agts.. & (.............. & (n............ & $56,669,562$ & $64,805,062$ \\
\hline Duefrom other Nat'l b'ks.. & $95,217,610$ & $102,278,547$ & $35,393,563$ & $37,478,166$ \\
\hline Due from State Bks \& Bkrs & $8,389,226$ & $7,848,822$ & $8,790,418$ & $9,824,144$ \\
\hline Real estate, furniture, etc. & $20,639,708$ & $22,747,875$ & $25,169,188$ & $28,021,637$ \\
\hline Current expenses........... & $5,297,494$ & $5,278,911$ & $5,646,382$ & $6,905,073$ \\
\hline Premiums paid........... & $2,764,186$ & $1,819,815$ & $2,092,364$ & $3,251,648$ \\
\hline Checks \& other cash items & $134,603,231$ & $143,241,394$ & $108,809,817$ & $13,229,403$ \\
\hline Clearing-house exchanges. & (.............. & (n.............. & - n............ & $76,208,707$ \\
\hline Bills of other National b'ks & $11,841,104$ & $11,842,974$ & $10,776,023$ & $17,001,846$ \\
\hline Bills of other banks........ & 333,209 & 222,668 & n........... & (.............. \\
\hline Specie................................ & $12,798,044$ & $13,003,713$ & $23,002,405$ & $26,307,251$ \\
\hline Legal-tender notes........... & $a 100,550,849$ & $92,453,475$ & $83,719,295$ & $80,580,745$ \\
\hline Fractional currency......... & (............. & $2,262,791$ & $2,090,727$ & $2,150,522$ \\
\hline Three per cent. certificates. & (n............ & $59,080,000$ & $45,845,000$ & $41,845,000$ \\
\hline Compound interest notes.. & $56,888,250$ & $4,513,730$ & .............. & .............. \\
\hline Total ................... & $\$ 1,499,469,060$ & $\$ 1,559,621,773$ & $\$ 1,497,226,604$ & $\$ 1,538,998,105$ \\
\hline \multicolumn{5}{|l|}{ Liabilities. } \\
\hline Capital stock ................. & $\$ 420,073,415$ & $\$ 420,634,511$ & $\$ 426,399,151$ & $\$ 435,356,004$ \\
\hline Surplus fund....................... & $66,695,587$ & $77,995,761$ & $86,165,334$ & $94,705,740$ \\
\hline Undivided profits.......... & $33,751,446$ & $36,095,883$ & $40,687,300$ & $46,056,428$ \\
\hline Nat'1 bank notes outstan'g & $293,887,941$ & $295,769,489$ & $293,593,645$ & $296,205,446$ \\
\hline State bank notes outstan'g & $4,092,153$ & $2,906,352$ & $2,454,697$ & $2,091,799$ \\
\hline Dividends unpaid........... & (............. & ............. & ............... & $2,242,556$ \\
\hline Individual deposits........ & $540,797,837$ & $580,940,820$ & $511,400,196$ & $507,368,618$ \\
\hline U. S. deposits................... & $23,062,119$ & $17,573,250$ & $7,112,646$ & $6,074,407$ \\
\hline Dep'ts U.S. disb. officers.. & $4,352,379$ & $4,570,478$ & $4,516,648$ & $4,155,304$ \\
\hline Due to National banks..... & $93,111,240$ & $99,414,397$ & $95,067,892$ & $106,090,414$ \\
\hline Due to other b'ks \& bk'rs.. & $19,644,940$ & $23,720,829$ & $23,849,371$ & $29,200,587$ \\
\hline Notes rediscounted.......... & ............. & .............. & $3,839,357$ & $4,612,131$ \\
\hline Bills payable..... & ............. & ...... & $2,140,363$ & $4,838,667$ \\
\hline Total .................. & $\$ 1,499,469,060$ & $\$ 1,559,621,773$ & $\$ 1,497,226,604$ & $\$ 1,538,998,105$ \\
\hline
\end{tabular}

(a) Including fractional currency. 
National Banks, 1863-1899-Continued.

\begin{tabular}{|c|c|c|c|c|}
\hline CLASSIFICATION. & $\begin{array}{c}1871 \\
1,790 \text { banks. }\end{array}$ & $\begin{array}{c}1872 . \\
1,940 \text { banks. }\end{array}$ & $\begin{array}{c}1873 . \\
1,976 \text { banks. }\end{array}$ & $\begin{array}{c}1874 . \\
2,027 \text { banks. }\end{array}$ \\
\hline RESOURCES. & - & & & \\
\hline Loans and discounts......... & $\$ 818,996,311$ & $\$ 885,653,449$ & $\$ 856,816,555$ & $\$ 955,862,580$ \\
\hline U. S. bonds to secure cir'n. & $366,840,200$ & $384,458,500$ & $389,384,400$ & $382,976,200$ \\
\hline U. S. bouds to secure d'pts. & $23,155,150$ & $16,304,750$ & $14,815,200$ & $14,714,000$ \\
\hline U. S. bonds and securities. & $17,675,500$ & $10,306,100$ & $8,630,850$ & $15,290,300$ \\
\hline Other stocks, bonds, etc... & $23,061,184$ & $23,160,557$ & $24,358,125$ & $28,313,473$ \\
\hline Due from redeeming agts.. & $77,985,600$ & $86,401,459$ & $73,032,046$ & $80,488,831$ \\
\hline Due from other Nat'l b'ks.. & $43,313,344$ & $42,707,613$ & $40,404,757$ & $48,100,842$ \\
\hline Due from State Bks \& Bkrs & $13,069,301$ & $12,008,843$ & $11,185,253$ & $11,655,573$ \\
\hline Real estate, furniture, etc. & $30,070,330$ & $33,014,796$ & $35,556,746$ & $39,190,683$ \\
\hline Current expenses.......... & $7,330,424$ & $8,454,803$ & $8,678,270$ & $5,510,566$ \\
\hline Premlums paid.............. & $5,956,073$ & $7,097,847$ & $7,987,107$ & $8,626,112$ \\
\hline Checks \& other cash items & $13,784,424$ & $13,696,723$ & $12,321,972$ & $14,005,517$ \\
\hline Clearing-house exchanges. & $114,538,539$ & $90,145,482$ & $62,881,342$ & $112,995,317$ \\
\hline National bank notes........ & $13,085,904$ & $19,070,322$ & $21,403,179$ & $22,532,336$ \\
\hline Fractional currency........ & $2,061,600$ & $2,270,576$ & $2,287,454$ & $2,392,668$ \\
\hline Specie........................ & $29,595,299$ & $19,047,336$ & $26,907,037$ & $22,436,761$ \\
\hline Legal-tender notes............ & $93,942,707$ & $102,922,369$ & $108,719,506$ & $82,604,791$ \\
\hline U. S.certificates of deposit & …......... & $12,650,000$ & $24,010,000$ & $33,670,000$ \\
\hline Three per cent. certificates. & $21,400,000$ & $4,185, \cap 00$ & & (............. \\
\hline Dep. with U. S. Treasurer. & (n)............ & (n.......... & (n......... & $21,043,084$ \\
\hline Total ...................... & $\$ 1,715,861,897$ & $\$ 1,773,556,532$ & $\$ 1,729,380,303$ & $\$ 1,902,409,638$ \\
\hline \multicolumn{5}{|l|}{ LIABILITIES. } \\
\hline Capital stock ................. & $\$ 460,225,866$ & $\$ 482,606,252$ & $\$ 490,266,611$ & $\$ 495,802,481$ \\
\hline Surplus fund................ & $101,573,153$ & $111,410,248$ & $120,961,267$ & $130,485,641$ \\
\hline Undivided profits........... & $48,630,925$ & $56,762,411$ & $58,375,169$ & $51,477,629$ \\
\hline Nat'l bank notes outstan'g & $318,265,481$ & $336,289,285$ & $341,320,256$ & $331,193,159$ \\
\hline State bank notes outstan'g & $1,886,538$ & $1,511,396$ & $1,130,585$ & 860,417 \\
\hline Dividends unpaid........... & $1,393,427$ & $1,356,934$ & $1,269,474$ & $6,088,845$ \\
\hline Individual deposits........ & $596,586,487$ & $598,114,679$ & $540,510,602$ & $682,846,607$ \\
\hline U. S. deposits.................. & $14,829,525$ & $7,863,894$ & $7,680,375$ & $7,492,307$ \\
\hline Dep'ts U. S. disb. officers.. & $5,399,108$ & $5,136,597$ & $4,705,593$ & $3,579,722$ \\
\hline Due to other Nat'l banks.. & $118,657,614$ & $124,218,392$ & $114,996,666$ & $129,188,671$ \\
\hline Due to State b'ks \& bk'rs.. & $38,116,950$ & $34,794,963$ & $36,598,076$ & $51,629,602$ \\
\hline Notes rediscounted.......... & $4,922,455$ & $6,545,059$ & $3,811,487$ & $6,365,652$ \\
\hline Biils payable............ & $5,374,362$ & $6,946,416$ & $7,754,137$ & $5,398,900$ \\
\hline Total ......... & $\$ 1,715,861,897$ & $\$ 1,773,556,532$ & $\$ 1,729,380.303$ & $\$ 1,902,409,638$ \\
\hline
\end{tabular}


National Banks, 1863-1899-Continued.

\begin{tabular}{|c|c|c|c|c|}
\hline CLASSIFICATION. & $\begin{array}{c}1875 \\
2,086 \text { banks. }\end{array}$ & $\begin{array}{c}1876 . \\
2,082 \text { banks. }\end{array}$ & $\begin{array}{c}1877 \text {. } \\
2,074 \text { banks. }\end{array}$ & $\begin{array}{c}1878 \text {. } \\
2,055 \text { banks. }\end{array}$ \\
\hline RESOURCES. & & $\cdot$ & & \\
\hline Loans and discounts........ & $\$ 962,571,807$ & $\$ 929,066,408$ & $\$ 881,856,744$ & $\$ 826,017,451$ \\
\hline U. S. bonds to secure cir'n. & $363,618,100$ & $336,705,300$ & $343,869,550$ & $347,812,300$ \\
\hline U. S. bouts to secure d'pts. & $13,981,500$ & $14,757,000$ & $13,538,000$ & $49,110,800$ \\
\hline v. S. bonds on hand......... & $16,009,550$ & $31,937,950$ & $28,479,800$ & $44,255,850$ \\
\hline Other stocks, bonds, etc... & $31,657,960$ & $31,565,914$ & $32,169,491$ & $35,816,810$ \\
\hline Due from reserve agents... & $81,462,682$ & $83,789,174$ & $75,960,087$ & $81,733,137$ \\
\hline Due from other Nat'l b'ks.. & $44,831,891$ & $44,011,664$ & $44,123,924$ & $43,144,220$ \\
\hline Due from State banks...... & $11,895,551$ & $12,415,841$ & $11,479,945$ & $12,259,856$ \\
\hline Real estate, furniture, etc. & $41,583,311$ & $43,498,445$ & $45,511,932$ & $46,728,147$ \\
\hline Current expenses........... & $9,218,455$ & $9,818,422$ & $8,958,903$ & $7,608,128$ \\
\hline Premiums paid.............. & $9,442,801$ & $10,811,300$ & $8,841,939$ & $6,978,768$ \\
\hline Cash items........................ & $11,238,725$ & $10,658,709$ & $10,265,059$ & $9,985,004$ \\
\hline Clearing-house exchanges. & $67,886,967$ & $68,027,016$ & $64,664,415$ & $61,99^{2}, 286$ \\
\hline Bills of other banks........ & $17,166,190$ & $17,521,663$ & $20,312,692$ & $19,392,281$ \\
\hline Fractional currency........ & $2,901,023$ & $1,146,741$ & 778,084 & 496,864 \\
\hline Specie.......................... & $17,070,905$ & $32,999,647$ & $32,907,750$ & $34,355,250$ \\
\hline Legal-tender notes......... & $70,725,077$ & $66,221,400$ & $70,568,248$ & $64,672,762$ \\
\hline U. S. certificates of deposit & $31,005,000$ & $26,095,000$ & $26,515,000$ & $32,520,0010$ \\
\hline Due from U. S. Treasurer. & $19,202,256$ & $16,359,491$ & $16,493,577$ & $17,940,918$ \\
\hline Total ..................... & $\$ 1,823,469,752$ & $\$ 1,787,407,093$ & $\$ 1,737,295,145$ & $\$ 1,742,826,837$ \\
\hline \multicolumn{5}{|l|}{ LIABILITIES. } \\
\hline Capital stock ............... & $\$ 505,485,865$ & $\$ 497,482,016$ & $\$ 477,128,771$ & $\$ 464,874,996$ \\
\hline 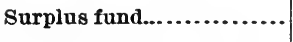 & $133,085,422$ & $131,390,664$ & $121,618,455$ & $116,402,118$ \\
\hline Undivided profits ............ & $59,204,957$ & $52,327,715$ & $51,530,910$ & $44,040,171$ \\
\hline Nat'l bank notes outstan'g & $314,979,451$ & $292,011,575$ & $299,240,475$ & $303,324,733$ \\
\hline State bank notes outstan'g & 752,722 & 608,548 & 470,540 & 400,715 \\
\hline Dividends unpaid........... & $1,353,396$ & $1,286,540$ & $1,404,178$ & $1,473,784$ \\
\hline Individual deposits......... & $618,517,245$ & $619,350,223$ & $604,512,514$ & $598,805,775$ \\
\hline 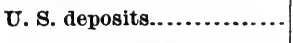 & $6,652,556$ & $6,727,155$ & $6,529,031$ & $40,269,825$ \\
\hline Dep'ts U. S. disb. officers.. & $4,232,550$ & $4,749,615$ & $3,780,759$ & $3,451,436$ \\
\hline Due to National banks..... & $119,843,665$ & $122,351,818$ & $115,773,660$ & $120,261,774$ \\
\hline Due to State banks.......... & $47,048,174$ & $48,685,392$ & $44,807,958$ & $41,767,755$ \\
\hline Notes rediscounted.......... & $5,257,160$ & $4,553,158$ & $4,654,784$ & $3,228,132$ \\
\hline Bills payable.......... & $7,056,583$ & $5,882,672$ & $5,843,107$ & $4,525,617$ \\
\hline Total ................... & $\$ 1,823,469,752$ & $\$ 1,787,407,093$ & $\$ 1,737,295,145$ & $\$ 1,742,826,837$ \\
\hline
\end{tabular}


National Banks, 1863-1899-Continued.

\begin{tabular}{|c|c|c|c|c|}
\hline CLASSIFICATION. & $\begin{array}{c}1879 . \\
\text { 2,052 banks. }\end{array}$ & $\begin{array}{c}1880 \\
2,095 \text { banks. }\end{array}$ & $\begin{array}{c}1881 \\
2,164 \text { banks. }\end{array}$ & $\begin{array}{c}1882 . \\
2,308 \text { banks. }\end{array}$ \\
\hline RESOURCES. & & & & \\
\hline Loans and discounts......... & $\$ 933,543,661$ & $\$ 1,071,356,141$ & $\$ 1,169,177,557$ & $\$ 1,230,456,213$ \\
\hline U. S. bonds to secure cir'n. & $364,272,700$ & $358,042,550$ & $368,735,700$ & $357,047,650$ \\
\hline U. S. bouds to secure d'pts. & $14,788,800$ & $14,726,500$ & $15,715,000$ & $16,314,000$ \\
\hline U. S. bonds on hand........ & $40,677,500$ & $25,016,400$ & $31,884,000$ & $15,492,150$ \\
\hline Other stocks and bonds.... & $38,836,369$ & $48,628,372$ & $62,663,2.18$ & $66,998,620$ \\
\hline Due from reserve agents... & $102,742,452$ & $126,155,014$ & $123,530,465$ & $122,066,106$ \\
\hline Due from National banks.. & $55,352,459$ & $69,079,326$ & $77,633,902$ & $76,073,227$ \\
\hline Dne from State banks.... & $14,425,072$ & $17,111,241$ & $17,644,704$ & $18,405,748$ \\
\hline Real estate, etc........ & $47,992,332$ & $47,784,461$ & $47,445,050$ & $46,993,408$ \\
\hline Current expenses..... & $7,474,082$ & $4,442,440$ & $4,647,101$ & $5,130,505$ \\
\hline Preminms paid.. & $4,150,836$ & $3,288,602$ & $3,891,728$ & $6,472,585$ \\
\hline Cash items.............. & $10,377,272$ & $14,713,929$ & $17,337,964$ & $16,281,315$ \\
\hline Clearing-house exchanges. & $112,172,677$ & $229,733,904$ & $217,214,627$ & $155,951,194$ \\
\hline Bills of other banks......... & $16,406,218$ & $21,549,367$ & $24,190,534$ & $25,344,775$ \\
\hline Fractional currency..... & 374,227 & 389,921 & 366,361 & 401,314 \\
\hline Specie................ & $79,013,041$ & $107,172,900$ & $113,680,639$ & $106,427,159$ \\
\hline Legal-tender notes........... & $54,715,096$ & $59,216,934$ & $60,104,387$ & $68,478,421$ \\
\hline U.S. certificates of deposit & $10,860,000$ & $6,150,000$ & $7,930,000$ & $8,475,000$ \\
\hline Due from U. S. Treasurer. & $17,054,816$ & $17,125,822$ & $18,097,923$ & $17,954,069$ \\
\hline Total ................... & $\$ 1,925,229,617$ & $\$ 2,241,683,829$ & $\$ 2,381,890,866$ & $\$ 2,360,793,467$ \\
\hline \multicolumn{5}{|l|}{ LIABILITIKS. } \\
\hline Capital stock .................. & $\$ 454,498,515$ & $\$ 458,540,085$ & $\$ 465,859,835$ & $\$ 484,883,492$ \\
\hline Surplus fund................. & $115,429,031$ & $121,824,629$ & $129,867,493$ & $135,930,969$ \\
\hline Undivided profits........... & $47,573,820$ & $47,946,741$ & $54,221,816$ & $55,343,816$ \\
\hline Nat'l bank notes outstan'g & $321,949,154$ & $317,484,496$ & $325,018,161$ & $315,230,025$ \\
\hline State bank notes outstan'g & 322,502 & 258,499 & 241,701 & 207,273 \\
\hline Dividends nnpaid........... & $1,305,480$ & $6,198,238$ & $6,372,737$ & $6,805,057$ \\
\hline Individual deposits......... & $\mathbf{7 5 5 , 4 5 9 , 9 6 6}$ & $1,006,452,852$ & $1,102,679,163$ & $1,066,901,719$ \\
\hline 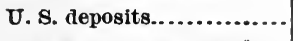 & $6,923,323$ & $7,898,100$ & $8,796,678$ & $9,622,303$ \\
\hline Dep'ts U. S. disb. officers.. & $3,893,217$ & $3,489,501$ & $3,595,726$ & $3,786,262$ \\
\hline Due to National banks..... & $152,484,079$ & $192,413,295$ & $197,252,326$ & $194,491,260$ \\
\hline Due to State banks..... & $59,232,391$ & $71,185,817$ & $79,380,429$ & $77,031,165$ \\
\hline Notes rediscounted.......... & $2,116,484$ & $3,354,697$ & $4,122,472$ & $6,703,164$ \\
\hline Bills payable......... & $4,041,649$ & $4,6: 36,876$ & $4,482,325$ & $3,856,056$ \\
\hline Total .................... & $\$ 1,925,229,617$ & $\$ 2,241,683,829$ & $\$ 2,381,890,866$ & $\$ 2,360,793,467$ \\
\hline
\end{tabular}


National Banks, 1868-1899-Continued.

\begin{tabular}{|c|c|c|c|c|}
\hline CLASSIFICATION. & $\begin{array}{c}1883 . \\
2,529 \text { banks. }\end{array}$ & $\begin{array}{c}1884 . \\
2,664 \text { banks. }\end{array}$ & $\begin{array}{c}1885 . \\
2,732 \text { bank8. }\end{array}$ & $\begin{array}{c}1886 \text {. } \\
2,875 \text { banks. }\end{array}$ \\
\hline RESOURCES. & & & & \\
\hline Loans and discounts........ & $\$ 1,307,491,250$ & $\$ 1,234,202,226$ & $\$ 1,343,517,559$ & $\$ 1,470,157,681$ \\
\hline U. S. bonds to secure cir'n. & $345,595,800$ & $317,586,050$ & $304,776,750$ & $228,384,350$ \\
\hline U. S. boyds to secure d'pts. & $16,846,000$ & $16,740,000$ & $18,012,000$ & $21,040,900$ \\
\hline U. S. bonds on hand......... & $13,151,250$ & $12,305,900$ & $12,665,750$ & $10,576,200$ \\
\hline Other stocks and bonds.... & $71,609,421$ & $73,449,352$ & $77,533,84.1$ & $81,431,000$ \\
\hline Due from reserve agents... & $126,999,606$ & $121,161,976$ & $139,239,444$ & $142,117,979$ \\
\hline Due from National banks.. & $77,902,785$ & $69,459,884$ & $79,452,309$ & $88,271,697$ \\
\hline Due from State banks...... & $19,402,047$ & $18,329,912$ & $18,553,946$ & $21,465,427$ \\
\hline Real estate, etc............. & $49,540,760$ & $49,889,936$ & $51,963,062$ & $54,763,530$ \\
\hline Current expenses........... & $4,878,318$ & $9,670,996$ & $9,416,971$ & $10,283,007$ \\
\hline Premiums paid......... & $8,647,252$ & $11,923,447$ & $11,802,199$ & $15,160,621$ \\
\hline 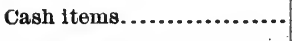 & $17,491,804$ & $11,924,152$ & $12,810,187$ & $13,218,973$ \\
\hline Clearing-house loan cer'fs. & (............. & $1,870,000$ & 630,000 & ............. \\
\hline Clearing-house exchanges. & $134,545,273$ & $75,195,955$ & $92,351,296$ & $70,525,126$ \\
\hline Bills of other banks........ & $28,809,699$ & $22,377,965$ & $23,178,052$ & $26,132,330$ \\
\hline Fractional currency........ & 427,754 & 456,778 & 415,082 & 447,833 \\
\hline Trade dollars............... & ............ & (............. & $1,670,961$ & $1,827,364$ \\
\hline Specie........................ & $114,276,158$ & $139,747,079$ & $165,354,352$ & $166,983,556$ \\
\hline Legal-tender notes........... & $80,559,796$ & $76,369,555$ & $67,585,466$ & $67,739,828$ \\
\hline U. S. certificates of deposit & $10,840,000$ & $19,040,000$ & $11,765,000$ & $6,195,000$ \\
\hline Five per c. fund with Treas. & $\ldots \ldots \ldots$ & $\ldots \ldots \ldots$ & & $10,056,128$ \\
\hline Due from U.S. Treasurer. & $16,865,938$ & $15,442,306$ & $14,981,021$ & 975,376 \\
\hline Total.................. & $\$ 2,445,880,917$ & $\$ 2,297,143,474$ & $\$ 2,457,675,256$ & $\$ 2,507,753,912$ \\
\hline \multicolumn{5}{|l|}{ LIABILITIES. } \\
\hline Capital stock paid in....... & $\$ 511,837,575$ & $\$ 524,089,065$ & $\$ 529,360,725$ & $\$ 550,698,675$ \\
\hline Surplus fund................. & $144,800,252$ & $146,867,119$ & $150,155,549$ & $159,573,479$ \\
\hline Undivided profits............ & $58,787,945$ & $70,711,369$ & $69,229,645$ & $79,298,286$ \\
\hline Nat'l bank notes outstan'g & $304,994,131$ & $280,197,043$ & $267,430,837$ & $202,078,287$ \\
\hline State bank notes outstan'g & 181,121 & 174,645 & 133,932 & 115,352 \\
\hline Dividends unpaid............ & $7,082,682$ & $1,331,421$ & $1,360,977$ & $1,590,345$ \\
\hline Individual deposits......... & $1,106,453,008$ & $987,649,055$ & $1,111,429,914$ & $1,169,716,413$ \\
\hline U.S. deposits................. & $10,026,777$ & $10,655,803$ & $12,058,768$ & $13,705,700$ \\
\hline Dep'ts U. S. disb. officers.. & $3,768,862$ & $3,749,969$ & $3,005,783$ & $4,276,257$ \\
\hline Due to National banks..... & $200,867,280$ & $187,296,348$ & $216,564,533$ & $223,842,279$ \\
\hline Due to State banks.......... & $84,776,421$ & $72,572,384$ & $85,060,162$ & $91,254,533$ \\
\hline Notes rediscounted......... & $8,248,562$ & $8,433,724$ & $9,932,828$ & $9,159,345$ \\
\hline Bills payable................. & $4,106,297$ & $3,415,524$ & $1,951,598$ & $2,444,958$ \\
\hline Total ................... & $\$ 2,445,880,917$ & $\$ 2,297,143,474$ & $\$ 2,457,675,256$ & $\$ 2,507,753,912$ \\
\hline
\end{tabular}


National Banks, 1863-1899-Continued.

\begin{tabular}{|c|c|c|c|c|}
\hline CLASSIFICATION. & $\begin{array}{c}1887 . \\
\text { s,0\%0 banks. }\end{array}$ & $\begin{array}{c}1888 \\
\text { s,150 banks. }\end{array}$ & $\begin{array}{c}1889 \\
3,326 \text { banks. }\end{array}$ & $\begin{array}{c}1890 . \\
\text { \$,573 banks. }\end{array}$ \\
\hline \multicolumn{5}{|l|}{ RESOURCES. } \\
\hline Loans and discounts........ & $\$ 1,583,941,484$ & $\$ 1,676,554,863$ & $\$ 1,811,686,891$ & $\$ 1,932,393,206$ \\
\hline U. S. bonds to secure cir'n. & $186,431,900$ & $162,820,650$ & $143,434,700$ & $139,688,150$ \\
\hline U. S. bouds to secure d'pts. & $42,203,000$ & $48,949,000$ & $41,681,000$ & $27,858,500$ \\
\hline U. S. bonds on hand........ & $6,988,550$ & $6,374,400$ & $3,740,350$ & $2,075,600$ \\
\hline Other stocks and bonds.... & $90,775,413$ & $102,276,898$ & $1.11,344,480$ & $116,609,301$ \\
\hline Due from reserve agents... & $132,959,765$ & $156,587,199$ & $164,889,765$ & $160,220,682$ \\
\hline Due from National banks.. & $98,227,065$ & $107,175,402$ & $118,206,354$ & $111,573,147$ \\
\hline Due from State banks...... & $21,995,356$ & $24,217,165$ & $28,143,681$ & $28,434,882$ \\
\hline Real estate, etc.............. & $58,825,168$ & $63,436,066$ & $70,694,191$ & $78,060,490$ \\
\hline Current expenses........... & $10,600,817$ & $11,342,192$ & $11,902,368$ & $13,434,642$ \\
\hline Premiums paid............... & $18,797,205$ & $16,681,256$ & $15,847,602$ & $14,568,760$ \\
\hline Cash items................... & $13,326,455$ & $14,140,858$ & $15,134,700$ & $15,057,481$ \\
\hline Clearing-house exchanges. & $85,097,330$ & $91,765,292$ & $103,719,453$ & $88,818,299$ \\
\hline Clearing-house loan cer'fs. & . & n........ & $\ldots \ldots \ldots$ & $13,395,249$ \\
\hline Bills of other banks........ & $23,447,294$ & $21,728,238$ & $20,388,807$ & $18,832,221$ \\
\hline Fractlonal currency........ & 554,906 & 628,387 & 720,462 & 755,021 \\
\hline Trade dollars......... & 328 & 763 & $\ldots \ldots \ldots$ & n............. \\
\hline Specie.................... & $159,240,643$ & $172,734,278$ & $171,089,458$ & $190,063,006$ \\
\hline Legal.tender notes........... & $75,361,975$ & $82,555,060$ & $84,490,894$ & $82,177,126$ \\
\hline U. S. certificates of deposit & $6,165,000$ & $9,220,000$ & $9,045,000$ & $5,760,000$ \\
\hline Five pero.fund with Treas. & $8,168,503$ & $7,141,434$ & $6,276,659$ & $6,069,110$ \\
\hline Due from U. S. Treasurer. & $1,068,117$ & $1,246,391$ & $1,239,867$ & $1,093,947$ \\
\hline Total $\ldots \ldots \ldots \ldots$ & $\$ 2,624,186,330$ & $\$ 2,777,575,799$ & $\$ 2,933,676,687$ & $\$ 3,046,938,825$ \\
\hline IIABILITIES. & & & & \\
\hline Capital stock paid in....... & $\$ 580,733,094$ & $\$ 593,848,247$ & $\$ 617,840,164$ & $\$ 657,877,225$. \\
\hline Surplus fund.............. & $175,246,408$ & $187,292,469$ & $198,508,794$ & $214,965,633$ \\
\hline Undivided profits ............ & $79,899,218$ & $88,302,639$ & $97,050,091$ & $111,772,985$ \\
\hline Nat'l bank notes outstan'g & $164,904,094$ & $143,549,296$ & $126,039,541$ & $123,038,785$ \\
\hline State bank notes outstan'g & 98,676 & 82,354 & 81,006 & 77,328 \\
\hline Dividends unpaid........... & $1,343,963$ & $1,267,930$ & $1,289,651$ & $1,167,262$ \\
\hline Individual deposits......... & $1,235,757,941$ & $1,331,265,617$ & $1,436,402,685$ & $1,485,095,855$ \\
\hline U. S. deposits............... & $38,416,276$ & $46,707,010$ & $39,224,588$ & $24,922,263$ \\
\hline Dep'ts U. S. disb. officers.. & $4,515,024$ & $4,415,608$ & $4,672,950$ & $4,456,472$ \\
\hline Due to National banks..... & $223,088,927$ & $252,291,134$ & $267,159,449$ & $253,082,126$ \\
\hline Due to State banks..... & $98,809,344$ & $108,001,606$ & $123,713,409$ & $121,438,255$ \\
\hline Notes rediscounted......... & $16,268,247$ & $14,844,303$ & $15,723,378$ & $25,598,405$ \\
\hline Bills payable............... & $5,105,112$ & $\mathbf{5 , 7 0 7 , 5 8 1}$ & $5,970,976$ & $11,501,225$. \\
\hline Jlearing-house loan cer'fs. & (n............ & .............. & $\ldots \ldots \ldots \ldots$ & $11,945,000$ \\
\hline Total ............ & $\$ 2,624,186,330$ & $\$ 2,777,57 \dot{5}, 799$ & $\$ 2,933,676,687$ & $\$ 3,046,938,825$ \\
\hline
\end{tabular}


National Banks, 1863-1899-Continued.

\begin{tabular}{|c|c|c|c|c|}
\hline CLASSIFICATION. & $\begin{array}{c}1891 . \\
\text { 3,692 banks. }\end{array}$ & $\begin{array}{c}1892 . \\
\text { s,784 banks. }\end{array}$ & $\begin{array}{c}1893 \text {. } \\
\text { s,787 banks. }\end{array}$ & $\begin{array}{c}1894 . \\
\text { s,737 banks. }\end{array}$ \\
\hline REBOURCES. & & & & \\
\hline Loans and discounts......... & $\$ 2,001,032,625$ & $\$ 2,166,615,720$ & $\$ 1,871,574,769$ & $\$ 1,991,913,123$ \\
\hline U. S. bonds to secure cir'n. & $153,838,200$ & $166,449,250$ & $204,809,350$ & $195,735,950$ \\
\hline U. S. bonds to secure d'pts. & $19,186,500$ & $15,321,000$ & $14,436,000$ & $15,051,000$ \\
\hline U. s. bonds on hand......... & $4,279,750$ & $4,148,600$ & $3,049,000$ & $20,760,350$ \\
\hline Premiums on bonds...... & ............. & $\ldots \ldots \ldots \ldots$ & ............. & $16,130,000$ \\
\hline Other stocks and bonds.... & $128,440,959$ & $153,648,180$ & $159,749,363$ & $197,328,354$ \\
\hline Due from reserve agents... & $196,319,537$ & $204,948,159$ & $212,630,636$ & $234,331,340$ \\
\hline Due from National banks.. & $124,827,315$ & $142,623,106$ & $108,265,460$ & $124,798,322$ \\
\hline Due from State banks...... & $32,4: 25,379$ & $34,403,231$ & $28,682,998$ & $30,962,557$ \\
\hline Real estate, etc.............. & $84,049,386$ & $88,221,052$ & $92,322,060$ & $98,659,789$ \\
\hline Current expenses......... & $13,279,136$ & $14,204,970$ & ............. & ............. \\
\hline Premiums paid......... & $14,695,279$ & $13,913,289$ & $13,806,470$ & (.............. \\
\hline Cash items.................... & $17,939,023$ & $16,755,332$ & $13,519,016$ & $13,051,055$ \\
\hline Clearing-honse exchanges. & $108,243,483$ & $110,522,668$ & $71,943,165$ & $80,869,202$ \\
\hline Bills of other banks...... & $20,225,104$ & $20,488,781$ & $21,497,840$ & $18,522,596$ \\
\hline Fractional currency......... & 837,175 & 893,909 & 988.602 & 885,072 \\
\hline Specie................... & $207,898,034$ & $209,895,260$ & $251,253,648$ & $218,041,222$ \\
\hline Legal.tender nótes............ & $93,854,354$ & $102,276,335$ & $131,626,759$ & $119,513,472$ \\
\hline U. S. certificates of deposit & $8,765,000$ & $6,470,000$ & $31,255,000$ & $37,090,000$ \\
\hline Five perc. fund with Treas. & $6,682,280$ & $7,282,413$ & $8,876,042$ & $8,5+2,386$ \\
\hline Due from U.S. Treasurer. & $1,047,684$ & $1,268,405$ & $2,029,141$ & $1,289,077$ \\
\hline Total ................... & $\$ 3,237,866,210$ & $\$ 3,480,349,667$ & $\$ 3,242,315,326$ & $\$ 3,423,474,873$ \\
\hline LIABILITIES. & & - & & \\
\hline Capital stock paid in........ & $\$ 677,356,927$ & $\$ 689,698,017$ & $\$ 681,812,960$ & $\$ 666,271,045$ \\
\hline Snrplus fund........... & $228,221,530$ & $239,931,932$ & $246,739,602$ & $244,937,179$ \\
\hline Undivided profits........... & $108,116,263$ & $114,603,884$ & $100,288,668$ & $95,887,436$ \\
\hline Nat'l bank notes outstan'g & $134,792,873$ & $145,669,499$ & $179,973,150$ & $169,337,071$ \\
\hline State bank notes outstan'g & 74,118 & 74,176 & 75,059 & 66,290 \\
\hline Dividends unpaid....... & $1,503,539$ & $1,308,137$ & $1,217,903$ & $1,130,390$ \\
\hline Individual deposits........ & $1,602,052,766$ & $1,764,456,177$ & $1,539,399,795$ & $1,695,489,346$ \\
\hline U. S. deposits................ & $14,478,542$ & $9,673,349$ & $10,391,466$ & $10,151,402$ \\
\hline Dep'ts U. S. disb. officers.. & $3,955,227$ & $4,034,240$ & $3,469,398$ & $3,865,339$ \\
\hline Due to National banks..... & $292,480,956$ & $323,339,449$ & $298,>05,834$ & $334,619,221$ \\
\hline Due to State banks.......... & $149,334,721$ & $160,778,117$ & $151,313,715$ & $180,345,566$ \\
\hline Notes rediscounted.......... & $16,325,642$ & $1 \dot{5}, 775,618$ & $11,465,546$ & $7,682,509$ \\
\hline Bills payable................. & $7,994,514$ & $9,318,249$ & $14,388,362$ & $11,471,551$ \\
\hline Other liabilities............ & $1,178,586$ & $1,688,817$ & $2,973,863$ & $2,220,523$ \\
\hline Total ...... & $\$ 3,237,866,210$ & $\$ 3,480,349,667$ & $\$ 3,242,315,326$ & $\$ 3,423,474,873$ \\
\hline
\end{tabular}


National Banks, 1863-1899-Continued.

\begin{tabular}{|c|c|c|c|c|}
\hline CLASSIFICATION. & $\begin{array}{c}1895 . \\
\text { s,706 bank8. }\end{array}$ & $\begin{array}{c}1896 . \\
\text { s,661 banks. }\end{array}$ & $\begin{array}{c}1897 . \\
\text { s,607 banks. }\end{array}$ & $\begin{array}{c}1898 . \\
3,585 \text { banks. }\end{array}$ \\
\hline REso & & & & \\
\hline Loans and discounts......... & $\$ 2,041,499,137$ & $\$ 1,901,160,110$ & $\$ 2,100,350,318$ & $\$ 2,172,519,610$ \\
\hline U. S. bonds to secure cir'n. & $210,479,500$ & $239,346,340$ & $222,020,750$ & $224,628,840$ \\
\hline U.S. bouds to secure d'pts. & $15,358,000$ & $15,868,000$ & $45,367,100$ & $83,926,230$ \\
\hline U. S. bonds on hand......... & $8,655,900$ & $8,406,550$ & $14,915,800$ & $30,614,010$ \\
\hline Premiums on bonds........ & $16,698,340$ & $17,641,942$ & $18,555,489$ & $18,971,197$ \\
\hline Other stocks and bonds.... & $193,383,321$ & $189,701,636$ & $217,582,980$ & $255,198,927$ \\
\hline Banking house, etc......... & (.............. & $78,325,325$ & $79,254,940$ & $79,386,337$ \\
\hline Real estate, etc............... & $104,272,211$ & $27,736,020$ & $29,852,102$ & $30,484,417$ \\
\hline Due from National banks.. & $131,007,238$ & $125,382,562$ & $168,825,189$ & $159,128,045$ \\
\hline Due from State banks...... & $33,341,627$ & $32,141,784$ & $48,012,498$ & $46,324,878$ \\
\hline Due from reserve agents... & $203,002,116$ & $219,966,660$ & $309,569,861$ & $320,002,050$ \\
\hline Cash items......................... & $12,939,318$ & $13,138,402$ & $14,933,428$ & $16,828,942$ \\
\hline Clearing-house exchanges. & $86,557,507$ & $84,976,088$ & $118,415,838$ & $110,286,935$ \\
\hline Bills of other banks........ & $17,114,290$ & $18,583,392$ & $18,859,116$ & $19,649,723$ \\
\hline Fractional currency........ & 925,289 & 925,400 & 925,465 & $1,023,834$ \\
\hline Specie.................. & $206,712,410$ & $225,540,708$ & $252,163,552$ & $293,874,158$ \\
\hline Legal-tender notes........... & $99,209,423$ & $118,893,612$ & $112,564,875$ & $110,038,300$ \\
\hline U. S. certiflcates of deposit & $31,440,000$ & $37,080,000$ & $45,840,000$ & $16,810,000$ \\
\hline Five perc. fund with Treas. & $9,194,625$ & $10,411,548$ & $9,761,568$ & $9,795,055$ \\
\hline Due from U.S. Treasurer. & $1,744,071$ & $1,889,686$ & $1,442,901$ & $4,019,551$ \\
\hline Total......... & $\$ 3, \mathbf{4 2 3}, \mathbf{5 3 4 , 3 2 8}$ & $\$ 3,367,115,772$ & $\$ 3,829,213,776$ & $\$ 4,003,511,044$ \\
\hline LIABILITIES. & & & & \\
\hline Capital stock paid in....... & $\$ 656,956,245$ & $\$ 647,186,395$ & $\$ 629,655,365$ & $\$ 621,517,895$ \\
\hline Surplus fund.... & $246,177,563$ & $247,339,567$ & $246,416,688$ & $247,555,108$ \\
\hline Undivided profits .............. & $94,501,758$ & $95,792,337$ & $95,293,663$ & $93,015,097$ \\
\hline Nat'l bank notes outstan'g & $185,151,344$ & $210,689,985$ & $193,783,985$ & $194,483,765$ \\
\hline State bank notes outstan'g & 63,504 & 60,393 & 60,335 & 55,907 \\
\hline Due to National banks..... & $302,721,578$ & $317,860,025$ & $445,061,154$ & $446,417,454$ \\
\hline Due to State banks.......... & $167,303,670$ & $168,635,982$ & $232,877,503$ & $251,917,900$ \\
\hline Dividends unpaid............ & $1,091,869$ & 952,120 & 943,274 & $1,008,410$ \\
\hline Individual deposits......... & $1,720,550,241$ & $1,639,688,393$ & $1,916,630,252$ & $2,031,454,540$ \\
\hline U. S. deposits..................... & $9,699,120$ & $11,822,671$ & $39,939,047$ & $70,187,368$ \\
\hline Dep'ts U. S. disb. officers.. & $4,059,468$ & $3,597,205$ & $4,012,185$ & $4,977,832$ \\
\hline Notes rediscounted......... & $11,359,771$ & $8,099,591$ & $3,161,796$ & $6,084,815$ \\
\hline Bills payable............. & $20,492,304$ & $12,805,832$ & $7,722,623$ & $11,283,332$ \\
\hline Other liabilities.... & $3,405,889$ & $2,585,271$ & $13,655,901$ & $23,551,615$ \\
\hline Tota & $\$ 3,423,534,328$ & $\$ 3,367,115,772$ & $\$ 3,829,213,776$ & $\$ 4,003,511,044$ \\
\hline
\end{tabular}


National Banks, 1863-1899-Continued.

\begin{tabular}{|c|c|c|c|}
\hline & 1899. & & 1899. \\
\hline RESOURCES. & 3,595 banks. & LIABILITIES. & 3,595 banks. \\
\hline Loans and discounts........... & $\$ 2,496,751,251$ & Capital stock... & $\$ 605,772,970$ \\
\hline Overdrafts............................. & $19,231,907$ & Surplus fund.................. & $248,449,234$ \\
\hline U. S. bonds for circulation... & $229,639,610$ & & \\
\hline U. S. bonds for deposits...... & $80,976,980$ & Undivided profite.............. & $102,066,430$ \\
\hline U. S. bonds on hand............ & $19,328,220$ & National bank circulation.... & $200,345,567$ \\
\hline Premiums on U. S. bonds..... & $17,626,212$ & State bank circulation......... & 53,108 \\
\hline Stocks, securities, etc........ & $320,437,066$ & & \\
\hline Banking house, etc............ & $79,064,021$ & Due to National banks........ & $575,169,387$ \\
\hline Real estate, etc................. & $30,255,465$ & Due to State banks........... & $334,258.085$ \\
\hline Due from National banks..... & $212,431,744$ & & \\
\hline Due from State banks........ & $59,288,465$ & Due to reserve agents......... & $19,440,496$ \\
\hline Due from reserve agents...... & $414,126,660$ & Dividende unpaid.............. & $1,137,392$ \\
\hline Checks and other cash items. & $17,414,999$ & & 2450725595 \\
\hline Clearing-house exchanges.... & $154,800,514$ & Individual deposits.......... & $2,450,725,595$ \\
\hline Bills of other banks........... & $20,077,605$ & U. S. deposits................... & $72,826,840$ \\
\hline Fractional currency.......... & $1,121,297$ & Dep'te U. S. disb. officers...... & $6,053,440$ \\
\hline Specie......................... & $338,571,383$ & & \\
\hline Legal-tender notes............. & $111,214,651$ & Notes rediscounted............ & $4,365,777$ \\
\hline U. S. certificates of deposit... & $16,540,000$ & Bllls payable.... & $9,945,237$ \\
\hline Five perct. fund with Treas.. & $10,116,130$ & & \\
\hline Due from U.S. Treasurer.... & $1,340,945$ & Other liabilities................. & $19,745,568$ \\
\hline 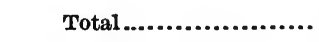 & & ........ & \\
\hline
\end{tabular}



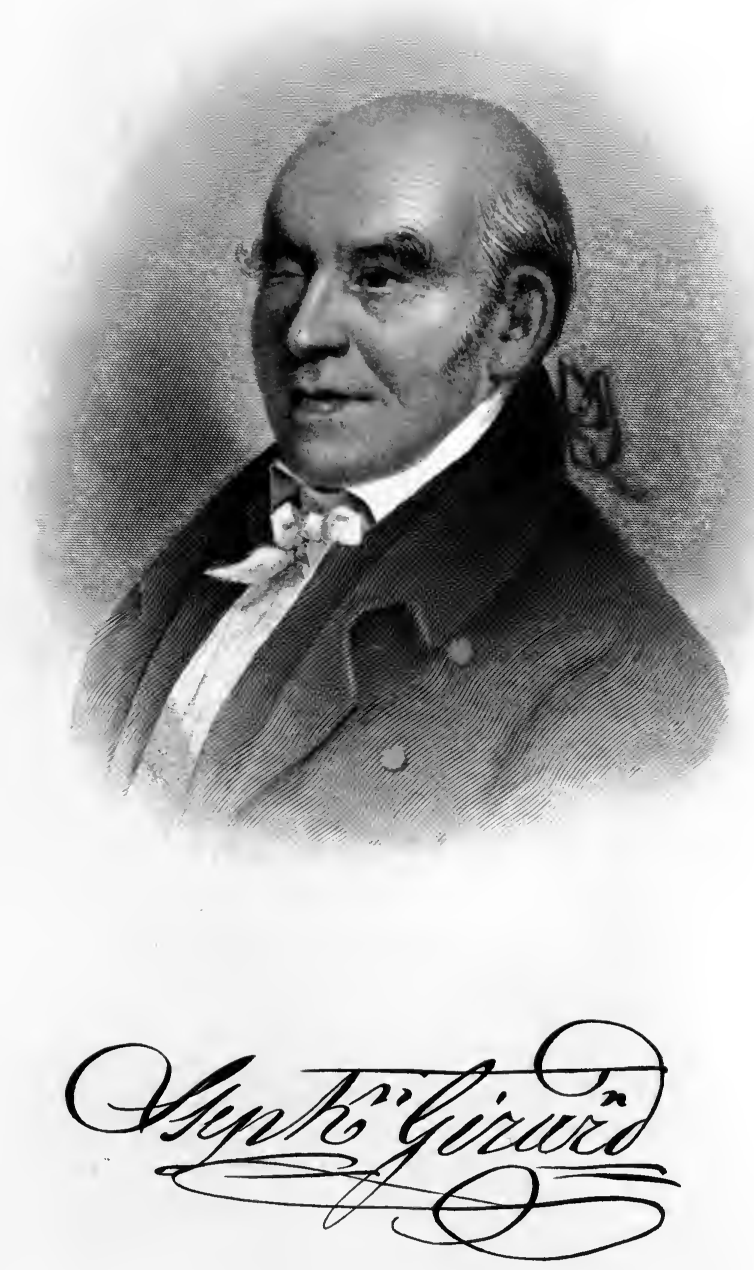
$\ominus$ 


\section{PART II}

\section{BANKING UNDER STATE LAWS.}

\section{I}

\section{STATE BANKS IN THE UNITED STATES.}

Establishment of the first State banks - Difficulty of procuring statistics - Condition of banks from 1811-1829 - Banks of the United States and State banks, 18111840 - State banks from 1834-1898 - Financial heresies from 1811 to 1861 - Various laws under which banks were organized - Losses through bank failures States as bank stockholders - Early proposal to tax State bank notes - Failures of State banks.

\section{Development of the State Banking Systems.}

In no particular has the progress of the United States been more marked than in the improvement of its banking systems. Much stress has been laid upon the losses caused by State bank notes prior to the Civil War, and it is probable that these losses have been greatly exaggerated. But the State banks of to-day are generally different from what they were in those times. They are, as a rule, quite as well managed and operating under as rigid laws and as careful official supervision as the National banks.

The historian searching for materials will usually find no difficulty in obtaining minute accounts of all the wars that have devastated the earth, but will find long intervals of silence in regard to the peaceful developments of mankind. So it is in banking history-the failures and losses seem to have been recorded with painstaking accuracy, but the great and incalculable benefits which banks have conferred upon the business of the country are seldom mentioned. It is well to bear these considerations in mind in reading the history of the early State banks, and to remember that while there were undoubted losses from the imperfections inherent in the diverse banking systems well-nigh inseparable from the primitive conditions of those times, the State banks existing before the Civil War were, nevertheless, of great benefit to the commerce and industries of the country. The "red dog" and "wildcat" currency of these banks is generally held up as an ex- 
ample of the impropriety of permitting banks to issue notes, but the banks which always redeemed their notes, even after the Government suspended specie payments, seem to have been forgotten.

\section{First State Banks Organized.}

The first banks in the United States were organized in Pennsylvania, Massachusetts and New York. The Bank of North America, in Philadelphia, although organized under a charter granted by the Continental Congress, received a charter from the State of Pennsylvania on April 1, 1782. This was a perpetual charter, but was repealed in 1785, and renewed from time to time until 1864. Charters were also granted to this bank by other States, notably by Massachusetts in 1782-irassachusetts granted a charter to a bank of its own, namely, the Massachusetts Bank, located in Boston, on February 7, 1784. The Bank of New York began business in 1784 under articles of association drawn by Alexander Hamilton, and was, subsequently, on March 21, 1791, chartered by the New York Legislature. The Federal Constitution was under consideration, but had not gone into actual operation when these banks commenced business.

The first Bank of the United States was chartered February 25, 1791, exactly seventy-two years before the date of the National Currency Act, which took effect February 25, 1863, and about a month before the charter was granted to the Bank of New York by the Legislature of that State.

The ideas of the time as to the sovereignty of the Federal Government and that of the States in relation to banks of issue, were such that there seems to have been a greater contest as to the right of the United States to charter banks of issue than there was as to the rights of the States to exercise the same power. The prohibition in the Constitution of the emission of bills of credit by the States seems to have been regarded as applying only to bills issued solely on the credit of the State, and to have referred to the issue of bills by the State Treasuries before, during and after the Revolutionary War, which, in many instances had resulted so disastrously. There seems to have been no idea that the bills of a chartered bank came under this category, even if the State held stock in the bank, although this question afterwards arose.

\section{State Bank Statistics.}

The first systematic effort to obtain and compile statisties showing the condition of all the banks in the United States, the need of which had long been felt, was in the passage, in July, 1832, of a resolution by the House of Representatives, directing the Secretary of the Treasury to lay before the House yearly thereafter, such statements relating to the banks organized under State laws as could be obtained from the several State officials. Previous to the passage of this resolution, such information upon this subject as was made public was obtained princi- 
pally by individual effort, any general information of the condition of the banks being procured with great difficulty, and such statistics even as were obtained being found very imperfect. Mr. Niles, in publishing in the "Register" a table derived from the report of Secretary Crawford of 1820, giving the capital, circulation, deposits and specie of the banks in 1819, said: "It will be seen that the preceding returns are very imperfect, as for instance, the capital paid in in Maryland is given at $\$ 86,290$, whereas it is nearly eight millions of dollars. Several of the other items, I know from various documents in my possession, are pretty nearly correct, yet some are also much deficient."

Mr. Gouge, in his "Short History of Paper Money and Banking in the United States," * also says, that "efforts, extending over seven years, to collect the accounts of the banks of the country, had proved so unsatisfactory in results, and so little success had crowned the labors of Mr. Crawford, Mr. Gallatin and Mr. Niles in the same direction, that it was not thought worth while to arrange for publication the materials that had been procured. To collect and arrange the accounts of five or six hundred banks which are or which liad been scattered through twenty-four States and two or three Territories, would be no easy task."

In the report of Secretary Crawford on the condition of the banks, January 3, 1836, there is printed, on page 216, a statement taken from " Blodgett's Economica," giving an estimate of the number of banks in the several States, their capital, circulation and specie, in various years from 1774 to 1804 ; but an accompanying note says that probably many of the amounts given are largely conjectural. The statement is printed below in a condensed form, and is the only one containing information of any kind as to the condition of the banks in the years named. In this table the amounts are expressed in millions of dollars:

\begin{tabular}{|c|c|c|c|c|c|c|c|c|c|}
\hline YeAR. & 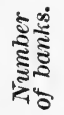 & 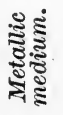 & 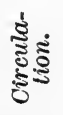 & $\frac{\tilde{\Xi}}{\tilde{\Xi}}$ & YEAR. & 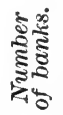 & 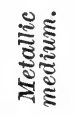 & 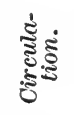 & 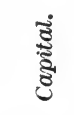 \\
\hline 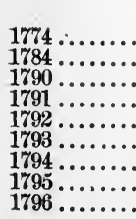 & $\begin{array}{r}\cdots 3 \\
4 \\
6 \\
16 \\
17 \\
17 \\
23 \\
24\end{array}$ & $\begin{array}{r}\text { Mill. } \\
\$ 4.0 \\
10.0 \\
9.0 \\
16.0 \\
18.0 \\
20.0 \\
21.5 \\
19.0 \\
16.5\end{array}$ & $\begin{array}{r}\text { Mill. } \\
\$ 2.0 \\
2.5 \\
9.0 \\
11.5 \\
11.0 \\
11.6 \\
11.0 \\
10.5\end{array}$ & $\begin{array}{r}\text { Mill. } \\
\$ 2.1 \\
2.5 \\
12.9 \\
17.1 \\
18.0 \\
18.0 \\
19.0 \\
19.2\end{array}$ & $\begin{array}{l}1797 \ldots \ldots \\
1798 \ldots \ldots \\
1799 \ldots \ldots \\
1800 \ldots \ldots \\
1801 \ldots \ldots \\
1802 \ldots \ldots \\
180 . \ldots \ldots \\
1804 \ldots \ldots\end{array}$ & $\begin{array}{l}25 \\
25 \\
26 \\
28 \\
31 \\
32 \\
36 \\
59\end{array}$ & $\begin{array}{r}\text { Mill. } \\
\$ 16.0 \\
14.0 \\
17.0 \\
17.5 \\
17.0 \\
16.5 \\
16.0 \\
17.5\end{array}$ & $\begin{array}{r}\text { Mill. } \\
\$ 10.0 \\
9.0 \\
10.0 \\
10.5 \\
11.0 \\
10.0 \\
11.0 \\
14.0\end{array}$ & $\begin{array}{l}\text { Mill. } \\
\$ 19.2 \\
19.2 \\
21.2 \\
21.3 \\
22.4 \\
22.6 \\
26.0 \\
39.5\end{array}$ \\
\hline
\end{tabular}

Secretary Crawford, in his report on the currency, made to Congress in February, 1820, $\dagger$ estimated the capital, specie, circulation and loans of the banks of the country, for the years 1813,1815 and 1819 , as follows: 


\begin{tabular}{|c|c|c|c|c|}
\hline YEAR. & Capital. & Specie. & Circulation. & Loans. \\
\hline 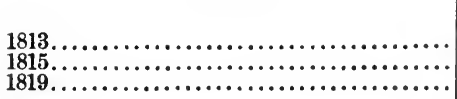 & $\begin{array}{l}\text { Millions. } \\
\$ 65.0 \\
88.0 \\
125.0\end{array}$ & $\begin{array}{l}\text { Millions. } \\
\$ 28.0 \\
16.5 \\
21.5\end{array}$ & $\begin{array}{l}\text { Millions. } \\
\$ 62 . \text { to } \$ 70 . \\
99 . \text { to } 110 . \\
45 \text {. to } 53 \text {. }\end{array}$ & $\begin{array}{l}\text { Millions } \\
\$ 117.0 \\
150.0 \\
157.0\end{array}$ \\
\hline
\end{tabular}

In this report he also gives a statement of the bank capital for the years 1814 to 1817, by States, "so far as it was known at the Treasury." This statement he believed to be substantially correct, for the reason, as stated by him, that it was based upon the applications made to the Treasury Department for compositions of the stamp duty of about one per cent., which duty was, by an Act of Congress of August 2, 1813, imposed upon the amount of notes issued by incorporated or unincorporated banks. The act further provided that, in lieu of this duty, the Secretary of the Treasury might agree with any of the banks to an annual composition of one-half of one per cent. upon the amount of the annual dividends made by them to their stockholders. The aggregates of bank capital given in the years named are as follows: 1814, $\$ 80,378,504 ; 1815, \$ 88,185,823 ; 1816, \$ 89,380,709 ; 1817, \$ 125,676,446$.

In respect to the bank capital given for the year 1817, Mr. Crawford says that, after deducting the amount of permanent accommodation enjoyed by stockholders in their respective banks, the active bank capital of the United States may be fairly estimated at a sum not exceeding seventy-five millions of dollars. Referring to the custom then prevalent of paying bank capital with stock notes, he says.

"Such, it is believed, has been the process by which the capital of most of the banks has been formed, which has been incorporated since the commencement of the late war. as since that time banks have been incorporated not because there was capital seeking investment, not because the places where they were established had commerce and manufactures which required their fostering aid, but because men without active capital wanted the means of obtaining loans which their standing in the community would not command from banks or individuals having real capital and established credit. Hence the multiplicity of local banks scattered over the face of the country in particular parts of the Union, which by the depreciation of their paper have levied a tax upon the communities within the pale of their influence exceeding the contributions paid by them."

Mr. Crawford also gives a table, by States, showing the condition of the banks for the year 1819, which table, however, he admits to be imperfect, and in which the items of capital, eirculation and specie, for the banks in the State of New York (the only ones given), are stated to be on the authority of a report made by a committee of the New York Legislature. The aggregates of the principal items of the State banks as taken from Mr. Crawford's report, together with those of the Bank of the United States as taken from a report of its condition in October of the same year, are stated on the following page: 


\begin{tabular}{r|c|c|c|c|c}
\hline & Capital. & Loans. & Deposits. & $\begin{array}{c}\text { Circula } \\
\text { tion. }\end{array}$ & Specie. \\
\hline $\begin{array}{r}\text { State banks. .............. } \\
\text { Bank of the Ưnited States. }\end{array}$ & $\frac{\$ 72,340,770}{34,973,828}$ & $\frac{\$ 73,623,596}{29,932,668}$ & $\frac{\$ 11,192,155}{5,494,417}$ & $\frac{\$ 35,770,903}{3,810,111}$ & $\frac{\$ 9,828,745}{3,254.479}$ \\
Total.................... & $\$ 107,314,598$ & $\$ 103,556,264$ & $\$ 16,626,592$ & $\$ 39,581,014$ & $\$ 13,083,224$ \\
\hline
\end{tabular}

In $1831 \mathrm{Mr}$. Gallatin made an estimate of the number, capital, circulation, deposits and specie of the banks in the United States for the years 1811, 1815, 1816, 1820 and 1829, and also a similar estimate for the Bank of the United States for the first and the last two of the years named. These estimates have been combined in the following table:*

State Banks.

\begin{tabular}{|c|c|c|c|c|c|}
\hline Yhars. & $\begin{array}{c}\text { Number } \\
\text { of banks. }\end{array}$ & Capital. & Circulation. & Deposits. & Specie. \\
\hline 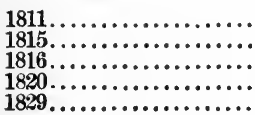 & $\begin{array}{r}88 \\
208 \\
246 \\
307 \\
329\end{array}$ & $\begin{array}{r}\$ 42,610,600 \\
82,259,590 \\
89,822,4224 \\
102,110,611 \\
110,192,268\end{array}$ & $\begin{array}{r}\$ 22,700,000 \\
45,500,000 \\
68,000,000 \\
40,641.574 \\
48,274,914\end{array}$ & $\begin{array}{r}\ldots \ldots \ldots \ldots . \\
\ldots \ldots \ldots \ldots . \\
\$ 31,244,959 \\
40,781,119\end{array}$ & $\begin{array}{l}\$ 9,600,000 \\
17,000,000 \\
19,000,000 \\
16,672,263 \\
14,939,643\end{array}$ \\
\hline
\end{tabular}

Bank of the United States.

\begin{tabular}{|c|c|c|c|c|c|}
\hline YeARS. & $\begin{array}{l}\text { Number } \\
\text { of banks. }\end{array}$ & Capital. & Circulation. & Deposits. & Specie. \\
\hline $\begin{array}{l}1811 \ldots \ldots \ldots \ldots \ldots \ldots \ldots \ldots \ldots \\
1820 \ldots \ldots \ldots \ldots \ldots \ldots \ldots \ldots \ldots \\
1829 . \ldots \ldots \ldots \ldots \ldots \ldots\end{array}$ & $\begin{array}{l}1 \\
1 \\
1\end{array}$ & $\begin{array}{r}\$ 10,000,000 \\
35,000,000 \\
35,000,000\end{array}$ & $\begin{array}{r}\$ 5,400,000 \\
4,221,770 \\
13,048,984\end{array}$ & $\begin{array}{l}\dddot{\$ 4}, 705,5 i i \\
14,778,809\end{array}$ & $\begin{array}{r}\$ 5,800,000 \\
3,147,977 \\
7,175,274\end{array}$ \\
\hline
\end{tabular}

Mr. Gallatin gives a list of 328 banks in operation in 1830 , with an aggregate capital of $\$ 110,101,898$ (exclusive of the Bank of the United States); and of 129 banks, having a capital of $\$ 24,312,339$, which had failed or discontinued business since January, 1811. A list of thirtysix banks whose capital was not known is also given. He further gives a statement of the discount on bank notes during the suspension of specie payments from 1814 to $181 \%$. $\dagger$

"Eliott's Funding System" $\ddagger$ gives, on page 984, a statement of the number, capital, circulation, loans and deposits of the banks of the country on January 1 , for various years from 1811 to 1840 , which is frequently quoted and often erroneously credited to various writers on finance. (See top of following page for statement.)

It is stated by Mr. Elliott \| that fifty-five banks, with an aggregate capital of $\$ 67,036,265$ and circulation of $\$ 23,57 \%, 752$, failed in 1841 . The total bank capital of that year is stated by him at $\$ 317,642,692$, and the circulation at $\$ 121,665,198$; and he also states that in nearly erery instance the capital of those banks which failed was entirely lost.

* "Considerations on the Currency and Banking Systems of the United States," Philadelphia, 1831, pp. 45, 49 and 53.

+ Finance Report, 1876, p. 199.

\# House Ex. Doc. No. 15, 1st Sess. 28th Congress.

" "Elliott's Funding Sytem," p. 1,176. 


\begin{tabular}{|c|c|c|c|c|c|c|}
\hline Y EAR. & $\begin{array}{c}\text { Number } \\
\text { of } \\
\text { banks. }\end{array}$ & $\begin{array}{l}\text { Loans and } \\
\text { discounts. }\end{array}$ & Specie. & Circulation. & Deposits. & Capital. \\
\hline 1811. & 89 & $\ldots \ldots \ldots \ldots$ & $\$ 15,400,000$ & $\$ 28,100,000$ & & $\$ 52,720,601$ \\
\hline $1815 \ldots$ & 208 & ......... & $17,000,000$ & $45,500,000$ & & $82,259,599$ \\
\hline $1816 \ldots$ & 246 & .......... & $19,000,000$ & $68,000,000$ & & $89,822,422$ \\
\hline 1820 . & 308 & & $19,820,240$ & $44,863,344$ & $\$ 35,950,470$ & $137,210,611$ \\
\hline $1830 \ldots$ & 330 & $\$ 200,451,214$ & $22,114,917$ & $61,323,898$ & $55,559,928$ & $145,192,268$ \\
\hline 1834. & 506 & $324,119,499$ & •........ & $94,839,570$ & $75,666,986$ & $200,005,944$ \\
\hline 1835. & 558 & $365,163,834$ & $43,937,625$ & $103,69 ?, 495$ & $83,081,365$ & $231.250,337$ \\
\hline 1836 . & 567 & $457,506,080$ & $40,019,594$ & $140,301,038$ & $115,104,440$ & $251,875,292$ \\
\hline 1837. & 634 & $525.115,702$ & $37.915,340$ & $149,185,890$ & $127,397,185$ & $290,772,091$ \\
\hline 1838 . & 663 & $485,631,687$ & $35,184,112$ & $116,138,910$ & $84,691,184$ & $317,636,778$ \\
\hline $1839 \ldots$ & 662 & $492,278,015$ & $45,132,673$ & $135,170,995$ & $90,240,146$ & $327,132,512$ \\
\hline $1840 \ldots \ldots \ldots \ldots$ & 722 & $462,896,523$ & $33,105,155$ & $106,968,572$ & $75,696,857$ & $358,442,692$ \\
\hline
\end{tabular}

The act of June 23, 1836, which made it the duty of the Secretary of the Treasury to select and employ, as depositories of the public money, banks incorporated by the several States, required that each bank should furnish to him as often as he might require, but not exceeding once a week, statements setting forth their condition and business ; and that the Secretary should at the commencement of each session lay before Congress a statement of the number and names of the banks employed as depositories of the public money, with their condition, and the amount deposited in each, as shown by the returns received by him. This act also provided that no bank should be selected which did not redeem its notes and bills in specie on demand, nor which should, after July 4, 1836, issue or pay out any note or bill of a less denomination than five dollars. The act further provided that thereafter no notes or bills of any bank which issued currency of a less denomination than five dollars should be received in payment of any debt due to the United States. Prior to the passage of this act, and also under its provisions, compilations of the reports of the deposit banks were prepared at the Treasury Department and transmitted to Congress at sundry times. Many of these statements are published in the reports of the Secretaries, from 1834 to the date of the passage of the SubTreasury Act of August 6, 1846.

The following statement, derived from the report of Secretary Woodbury for September 21, 1836, exhibits the condition of thirty-six of these banks on June 1, and of eighty-nine on November 1, 1836 : *

\begin{tabular}{|c|c|c|}
\hline RESOURCES. & $\begin{array}{c}\text { June } 1,1836, \\
\text { s6 banks. }\end{array}$ & $\begin{array}{c}\text { Nov. } 1,1836, \\
89 \text { binks. }\end{array}$ \\
\hline Loans and discounts.. & $\$ 108,498,037.74$ & $\$ 163,972,830.24$ \\
\hline Stocks.............. & n........... & $5,184,908.45$ \\
\hline 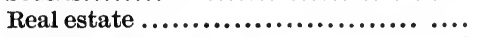 & $1,892,342.27$ & $3,051,490.95$ \\
\hline Due from other banks................. & $17,867,869.49$ & $26,662,669.70$ \\
\hline 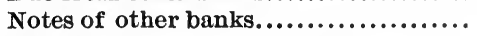 & $10,982,790.42$ & $16,412,324.57$ \\
\hline Specie............................... & $10,450,415.13$ & $15,520,202.42$ \\
\hline 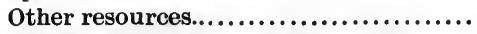 & $12,563,613.63$ & $13,038,523.88$ \\
\hline Totals. & & $\$ 243,842,950.21$ \\
\hline
\end{tabular}

* Finance Report, 1829-'36, p. 758. 


\section{Lta BILITIES.}

\begin{tabular}{|c|c|}
\hline Capital.. & $\$ 46,418,092.83$ \\
\hline Profits on hand........ & $6,926,825.14$ \\
\hline Circulation................. & $27,967,152.40$ \\
\hline Public deposits............. & $41,023,952.66$ \\
\hline Other deposits............... & $16,044,573.40$ \\
\hline Due to banks..................... & $17,110,822.36$ \\
\hline Other liabilities................... & $6,763,654.39$ \\
\hline
\end{tabular}

Totals. $\$ 162,255,068,68$
$\$ 77,576,449.67$
$11,048,695.90$
$41,482,897.82$
$49,377,986.30$
$26,573,479.65$
$24,083,161.28$
$13,700,279.59$
$\$ 243,842,950.21$

The following tables exhibit the aggregate of the principal items of the Bank of the United States and of the State banks, so far as can be ascertained, for various years, from 1811 to 1840 :

Bank of United States.

\begin{tabular}{|c|c|c|c|c|c|}
\hline & Capital. & Loans. & Deposits. & Circulation. & Specie. \\
\hline $1811 \ldots \ldots \ldots \ldots \ldots \ldots$ & $\$ 10,000,000$ & & & $\$ 5,400,000$ & $\$ 5,800,000$ \\
\hline 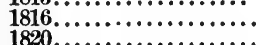 & $\ddot{350 i n ̈ o ̈ o ̈ ~}$ & & & & \\
\hline $\begin{array}{l}1820 . \\
1830 .\end{array}$ & $\begin{array}{l}35,000,000 \\
35,000,000\end{array}$ & $\begin{array}{r}\$ 31,401,158 \\
40,663,805\end{array}$ & $\begin{array}{l}\$ 6,568,794 \\
16,045,782\end{array}$ & $\begin{array}{r}3,589,481 \\
12,924,145\end{array}$ & $\begin{array}{l}3,392,755 \\
7,608,076\end{array}$ \\
\hline ........ & $35,000,000$ & $54,911,461$ & $10,838,555$ & $19,208,379$ & $10,039,237$ \\
\hline 1835. & $35,000,000$ & $51,8 \cap 8,739$ & $11,756,905$ & $17,339,797$ & $15,708,369$ \\
\hline $1836^{\circ}$. & $35,000,000$ & $59,232,445$ & $5,061,456$ & $23,075,422$ & $8,417,988$ \\
\hline 18 & $35,000,000$ & $57,393,709$ & $2,33 \%, 409$ & $11,447,968$ & $2,638,449$ \\
\hline 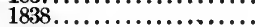 & $35,000,000$ & $45,256,571$ & $2,616,713$ & $6,768,067$ & $3,770, \times 42$ \\
\hline $1039{ }_{103 \ldots \ldots \ldots \ldots \ldots \ldots \ldots \ldots}$ & $35,000,000$ & $41,618,637$ & $6,779,394$ & $\begin{array}{l}0,982,621 \\
5,980\end{array}$ & $4,153,607$ \\
\hline 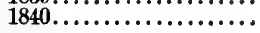 & $35,000,000$ & $36,839,593$ & . 3,338,521 & $6,695,861$ & $1,469,674$ \\
\hline
\end{tabular}

State Banks.

\begin{tabular}{|c|c|c|c|c|c|}
\hline & Capital. & Loans. & Deposits. & Circulation. & Specie. \\
\hline 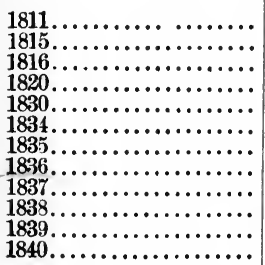 & $\begin{array}{r}\$ 52,601,601 \\
82,259,590 \\
89,822,422 \\
137,110,611 \\
145,192,268 \\
200,005,944 \\
231,250,337 \\
251,875,292 \\
290,772,091 \\
317,636,778 \\
327,132,512 \\
358,442,692\end{array}$ & 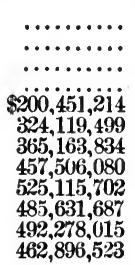 & 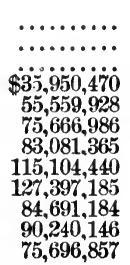 & $\begin{array}{r}\$ 28,100,000 \\
45,500,000 \\
68,000,000 \\
44,863,344 \\
-61,332,893 \\
94,839,570 \\
103,692,495 \\
140,301.038 \\
149,185,890 \\
116,138,910 \\
135,170,995 \\
106,968,572\end{array}$ & $\begin{array}{l}43,937,695 \\
40,019,954 \\
37,915,940 \\
35,184,112 \\
45,132,673 \\
33,105,155\end{array}$ \\
\hline
\end{tabular}

The table shown on next page * exhibits the principal items contained in the returns of the State banks of the country, yearly, from 1834 to 1863 , and for each period of ten years from 1863 to 1893 , and for the period of five years from 1893 to 1898 .

An examination of the foregoing statistics indicates that during the period from 1790 to 1811, when the first Bank of the United States was in operation, the growth of State banks was very slow, there being but eighty-nine of such institutions in operation in the latter year. Im-

\footnotetext{
* It is necessary to state that the returns made to the Comptroller of the Currency by State banks are purely voluntary, and therefore the statistics compiled from such returns are very incomplete. They represent, however, the best information available in regard to the State banking institutions.
} 
mediately upon the expiration of the charter of the Federal bank, in 1811, an enormous crop of State banks came into existence, and in 1815 there were two hundred and eight of them.

State Banks, 1834-1898.

\begin{tabular}{|c|c|c|c|c|c|c|}
\hline Year. & $\begin{array}{l}\text { No. of } \\
\text { bank8. }\end{array}$ & Capital. & Loans. & $\begin{array}{l}\text { Individual } \\
\text { deposits. }\end{array}$ & $\begin{array}{l}\text { Circula- } \\
\text { tion. }\end{array}$ & Specie. \\
\hline $1834 .$. & 506 & $\$ 200,005,944$ & $\$ 324,119,499$ & $\$ 75,666,986$ & $\$ 94,839,570$ & \\
\hline 1835. & 704 & $231,250,337$ & $365,163,834$ & $83,081,365$ & $103,692,495$ & $\$ 43,937,625$ \\
\hline 1836. . & 713 & $251,875,292$ & $457,506,080$ & $115,104,440$ & $140,301,038$ & $40,019,594$ \\
\hline $1837 .$. & 788 & $290,772,091$ & $525,115,702$ & $127,397,185$ & $149,185,890$ & $37,915,340$ \\
\hline $1838 \ldots$ & 829 & $317,636,778$ & $485,631,787$ & $84,691,184$ & $116,138,910$ & $35,184,112$ \\
\hline $1839 . . .$. & 840 & $327,132,512$ & $492,278,015$ & $90,240,146$ & $135,170,995$ & $45,132,673$ \\
\hline $1840 \ldots \ldots$ & 901 & $358,442,692$ & $462,896,523$ & $75,696,857$ & $106,968,572$ & $33,105,155$ \\
\hline $1841 \ldots \ldots \ldots \ldots$ & 784 & $313,608,959$ & $386,487,662$ & $64,890,101$ & $107,290,214$ & $34,813,958$ \\
\hline $1842 \ldots \ldots$ & 692 & $260,171,797$ & $323,957,569$ & $62,408,870$ & $83,734,011$ & $28,440,423$ \\
\hline $1843 \ldots . .$. & 691 & $228,861,948$ & $254,544,937$ & $56,168,623$ & $58,563,608$ & $33,515,806$ \\
\hline $1844 \ldots \ldots$ & 696 & $210,872,056$ & $264,905,814$ & $84,550,785$ & $75,167,646$ & $49,898,269$ \\
\hline $1845 \ldots . .$. & 707 & $206,045,969$ & $288,617,131$ & $88,020,646$ & $89,608,711$ & $44,241,242$ \\
\hline $1846 \ldots \ldots$ & 707 & $196,894,309$ & $312,114,404$ & $96,913,070$ & $105,552,427$ & $42,012,095$ \\
\hline $1847 \ldots \ldots$ & 715 & $203,070,622$ & $310,282,945$ & $91,792,533$ & $105,519,766$ & $35,132,516$ \\
\hline $1848 \ldots .$. & 751 & $204,838,175$ & $344,476,582$ & $103,226,177$ & $128,506,091$ & $46,369,765$ \\
\hline $1849 \ldots \ldots$ & 782 & $207,309,361$ & $332.323,195$ & $91,178,623$ & $114,743,415$ & $43,619,368$ \\
\hline $1850 \ldots \ldots$ & 824 & $217,317,211$ & $364,204,078$ & $109,586,585$ & $131,366,526$ & $45,379,345$ \\
\hline $1851 \ldots$ & 879 & $227,807,553$ & $413.756,799$ & $128,957,712$ & $155,165,251$ & $48,671,048$ \\
\hline $1853 \ldots$ & 750 & $207,908,519$ & $408,943,758$ & $145,553,876$ & $146,072,780$ & $47,138,592$ \\
\hline $1854 . .$. & 1,208 & $301,376,071$ & $557,397,779$ & $188,188,744$ & $240,689,207$ & $59,410,253$ \\
\hline $1855 \ldots$ & 1,307 & $332,177,288$ & $576,144,758$ & $190,400,342$ & $186,952,223$ & $53,944,546$ \\
\hline $1856 \ldots$ & 1,398 & $343,874,272$ & $634,183,280$ & $212,705,662$ & $195,747,950$ & $59,314,063$ \\
\hline $1857 \ldots$ & 1,416 & $370,834,686$ & $684,456.887$ & $230,351,352$ & $214,778,822$ & $58,349,838$ \\
\hline $1858 \ldots \ldots$ & 1,422 & $394,622,799$ & $583,165,242$ & $185,932,049$ & $155,208,344$ & $74,412,832$ \\
\hline $1859 \ldots$ & 1,476 & $401,976,242$ & $657,183,799$ & $259,568,278$ & $193,306,818$ & $104,537,818$ \\
\hline $1860 \ldots$ & 1,562 & $421,880,095$ & $691,945,580$ & $253,802,129$ & $207,102,477$ & $83,594,537$ \\
\hline $1861 \ldots$ & 1,601 & $429,592,713$ & $696,778,421$ & $257,229,562$ & $202,005,767$ & $87,674,507$ \\
\hline $1862 \ldots$ & 1,492 & $418,139,741$ & $646,6 \pi 7,780$ & $296,322,408$ & $183,792,079$ & $102,146,215$ \\
\hline $1863 \ldots$ & 1,466 & $405,045,829$ & $6 \pm 8,601,863$ & $393,686,2226$ & $238,677,218$ & $101,227,369$ \\
\hline $1873 .$. & $\cdots$ & $42,700,000$ & $119,300,000$ & $110,800,000$ & 200,000 & $3,000,000$ \\
\hline 1883. & 754 & $102,500,000$ & $322,400,000$ & $335,000,000$ & 200,000 & $17,400,000$ \\
\hline $1893 \ldots$ & 3,579 & $250,800,000$ & $757,500,030$ & $709,900,000$ & .......... & $137,000,600$ \\
\hline $1898 \ldots$. & 3,965 & $233,587,353$ & $813,749,803$ & $912,365,406$ & ........... & $66,510,993$ \\
\hline
\end{tabular}


The contest between the first Bank of the United States and the State bank party, which resulted in the overthrow of the former, has been considered in another chapter, and notwithstanding the establishment of the second Bank of the United States in 1816, State banks had become permanently fixed. The detailed histories of banking in the several States will show to what excesses the State bank party carried their ideas.

\section{Erroneous Ideas in Regard to Bank Notes.}

The creation of wealth by means of bank notes was the great heresy of the period between the years 1811 and 1861 , as the creation of wealth by Government issues and fiat has been the chief financial heresy since that date.

The early State banks of the Eastern States were organized and managed generally on sound business principles. There was real wealth and a thriving commerce which rendered them a necessity. Having something of a monopoly, their profits were large. But their success was warped into the service of those whose ideas were less sound, and was cited as proof that all that was necessary under the primitive conditions existing in the newer settled States was a liberal issue of bank paper. In the lack of individual moneyed capital, banks were started based on capital created by the State, by the issue of bonds, or upon land, which was abundant and cheap. To start a bank and issue notes, with little or no regard for their .redemption in cash, was so easy a way of acquiring the property of others that even honest men became sharpers, and dishonest men invented every conceivable method of misleading the public with biking devices. The legislatures sought to control this tendency, but were frequently led by crude ideas to make matters worse. Even the protective laws they did enact were hard to enforce. The idea that redit money, instead of being an instrument of wealth wais in vert truth wealth itself, had taken a strong hold of the minds of the pullie, and legislators could not get over the notion that by chartering banks, with capital created by the State, or permitting individuals to start bayks on capital which was only capital by courtesy, they were incressing the wealth of the public by the exact amount of the bank notes issued. The inevitalle results followed, and the disasters of ensive financial crises gradually taught the public something. of the dofigers of uncontrolled banking issues. The older States, having had mưch experience in their colonial existence, were the first to learn how to control the management of banking capital. Among so many States and Territories there were always some where the laws were loose and ineffective, and there was room in those for the bank expert to exercise his dangerous knowledge of the credulity of the public, and its desire of apparent gain. 


\section{How Banks Were Organized in the Various States.}

The State banks of the period from 1811 to 1861 were either institutions composed of private stockholders, who furnished all the capital, working under certain regulations laid down in special charters, or in general banking laws, or they were entirely capitalized and managed by the State, or they were constituted partly with State and partly with private capital, the management being similarly divided.

Which one of these systems was the best has been left very much in doubt. In some States the purely State management of a State bank resulted most disastrously, as in Kentucky, Illinois, Tennessee, Florida, Mississippi and Alabama, while the State banks of Ohio and Indiana were well managed and solvent institutions. In Kentucky, Illinois and Tennessee there was more than one bank managed by the State in succession, and the success of these banks varied in the same State. Neither did private State banks with special privileges do much better. The laws and regulations governing the institutions did not seem to have much to do with their success or failure. If a bank was really needed, to carry on a legitimate trade and commerce, it was most generally a success, but if started under never so good auspices, where not needed, it generally ended disastrously. Thus a banking system succeeded well in Louisiana under almost identical laws with those of banking systems in Alabama, Mississippi and Florida, which were most ridiculous failures. The banking laws of Michigan were very similar to those of New York, but the banks in the latter State were generally successful while those of Michigan became a by-word and a hissing. These discrepancies were somewhat due to the difference in the enforcement of the several laws, but not altogether ; because as long as banks were allowed to be started where there was no legitimate business for them, no power on earth could force them to do a legitimate business however wisely that business was defined in the law.

When the Civil War broke out in 1861, order was beginning to come out of the general confusion in regard to banking which had prevailed in many of the States. The advantages of a general banking law as opposed to special charters were almost universally acknowledged. The necessity of some special security for and supervision of the issue of currency was beginning to be seen.

Of course it is a question whether the development of State banking currency in the right direction would have benefited the country as much as the National banking system with its currency has done. Speculation in this line, however, may not be unprofitable. If instead of issuing legal-tender notes, and afterwards sweeping State bank currency out of existence by a prohibitive tax to make way for a new class of banks, United States bonds had been permitted by the United States Government and by all the States to be the basis of the currency issue by the State banks, it is possible that a better permanent currency 
would have been obtained, and that the greenback and silver dollar heresies would never have arisen to plague the people.

\section{Losses By State Bank Failures.}

The losses to the public under the various State systems of banking were undoubtedly large, as may be gathered from the detailed history of the several States. Exactly how large will never be known, because the records of the period, in this respect, are surprisingly incomplete. The information for the period from 1789 to 1864 can only be obtained from the following sources: "Blodgett's Economica," "Elliott's Funding System," "Thompson's Bank Note Reporter and Counterfeit Detector," "Hunt's Merchants' Magazine" and the "Bankers' Magazine," "Niles' Register," "Considerations on the Currency and Banking System of the United States," by Albert Gallatin, reports made by the Secretary of the Treasury to Congress since 1832, and the reports of the Comptroller of the Currency. From all these sources nothing more than a partial estimate can be made, but it is probable that the loss to note holders was about five per cent. per annum, and the losses to depositors and stockholders cannot be definitely ascertained. Probably, however, the loss to note holders was the principal loss, as the free issue of bank notes under the laws of most of the States permitted the payment of deposits in these notes whenever called for. The runs on the banks were not made by the depositors, but by note holders. The loss to stockholders was, no doubt, less than might appear if we compare banks of the period before 1864 with those now in existence. Capital then was apt to be only partially paid up. In the worst class of banks where the greater part of the losses occurred, it probably consisted of stockholders' notes of little or no value. 'The losses experienced by depositors in State banks becoming insolvent at the present time are no criterion by which to judge of the losses by failures of State banks under the old regime. A depositor before 1864 could generally get notes of his bank for his check if nothing else, and these he could use unless there was a run on his bank. Even then he could use them at a discount.

Without seeking to minimize the losses under the State banking systems of the past, it is undoubtedly the case that as great a stress has been laid upon them as they will bear.

The circulating notes of the State banks were subject to violent expansion in times of confidence, and as sudden a contraction when distrust occurred. This was due to the lack of a uniform control upon issues. The cost of exchange was also immensely increased by the lack of uniformity in the credit of the banks in the several States at the commercial centers.

To sum up the State banking systems as they existed before the organization of the National banking system, it will be well to quote the language of Mr. Woodbury, Secretary of the Treasury, in his 
report for 1836 , as to what was lacking to make them safe and serviceable:

"If all the States would unite in adding a few judicious limitations on the amount of discounts as compared with capital and deposits, and on the safe kind of security to be taken for them, with the requirement of frequent publicity of their condition in detail, and of rigid accountability to periodical examinations by legislative authority, the time is not distant when our currency would become stable; indeed it deserves consideration whether under such circumstances the whole monopolies of banking might not with public advantage be entirely abolished and the.banking privilege under the above restrictions, securities, limitations and requirements, particularly if the personal liability of the stockholder be added, might not safely be thrown open to all."

\section{States as Holders of Bank Stocks.}

Many of the States, chiefly Southern and Western, authorized banking corporations with the State as part or sole stockholder, and similar to the organizations in the States to which reference has already been made. In nearly all of the States, banks specially chartered were the favorite organizations. The amount of currency issued was frequently twice, and in many instances three times, the amount of the nominal capital of such banks. These charters were thus very valuable, and the State Legislatures were besieged by applicants for such special privileges. Governor Snyder, of Pennsylvania, in 1813, vetoed a bill granting charters to twenty-five banks, with an aggregate capital of nine millions. In the ensuing year a bill was passed, by a two-thirds vote over the second veto of the Governor, authorizing forty-one banks, with an aggregate capital of seventeen millions, of which only one-fifth part was required to be paid in. Of this number thirty-seven went into operation. Many of these institutions had but a nominal capital, consisting chiefly of notes given by the stockholders for the amount of their shares. Such banks had usually but an ephemeral existence, and fifteen of the number which were organized in Pennsylvania failed within four years of the date of their organizations. In other cases charters of banks authorized by the New England and Southern States were disposed of to non-residents, who organized banks of circulation with little or no capital, and the citizens of other remote States suffered great loss from the worthlessness of such bank issues. As late as $\mathbf{1 8 5 4}$ the circulation of one of the principal Western States consisted chiefly of notes issued by two banks in Georgia, which circulated upon the personal credit of two or three of their non-resident stockholders, and without any reference to the character and management of the banks which issued them.

Mr. Gallatin, referring in 1831 to the condition of the banks at an early day, says :

"The dissolution of the Bank of the United States deprived the country of a foreign capital of more than $\$ 7,000,000$ invested in the stock of that institution, and which was accordingly remitted abroad during the year that preceded the war. * * The creation of new State banks in order to fill the chasm was a natural consequence 
of the dissolution of the Bank of the United States, and, as is usual under such circumstances, the expectation of great profits gave birth to a much greater number than was wanted. From January 1, 1811, to January 1, 1815, not less than one hundred and twenty new banks were chartered and went into operation, with a capital of about forty, and making an addition of near thirty millions to the banking capital of the country."

He estimates the notes in circulation in 1811, including the notes of the Bank of the United States, at $\$ 28,100,000$; in 1815 , before the suspension of specie payments, at $\$ 45,500,000$; and in 1816 , at $\$ 68,000,000$; the increase in the circulation during the first fifteen months after the suspension of specie payments being about fifty per cent. In 1820 this amount had been reduced to $\$ 44,863,000$. He further says :

"So great a reduction in the issues of the banks could not have been effected without a corresponding diminution of their discounts. Debts contracted during the suspension of specie payments, and while the currency of the country was depreciated, became payable at par. The distress, therefore, that took place at that time may be clearly traced to the excessive number of State banks incorporated subsequent to the dissolution of the first Bank of the United States and to their improvident issues. The numerous failures which had preceded the year 1819 , or have since taken place, have also been principally due to the same causes. We have an account of one hundred and sixty-five banks that failed between January 1, 1811, and July 1, 1830 ; the capital of one hundred and twenty-nine of these amounted to more than $\$ 24,000,000$, stated as having been paid in. The whole amount may be estimated at near thirty millions, and our list may not be complete. The capital of the State banks now existing amounts to about 110 millions. On a total capital of 140 millions, the failures have amounted to thirty millions, or more than one-fifth of the whole. Of the actual loss incurred we can give no account. There are instances in which the stockholders, by paying for their shares in their own notes, and afterward redeeming their notes with the stock in their name, suffered no loss; and this fell exclusively on the holders of bank notes and depositors." *

As early as 1831 it was proposed to tax out of existence the issues of State banks. On this point Mr. Gallatin says: $\dagger$

"Congress has the power to lay stamp duties on notes, on bank notes and on any description of bank notes. That power has already been exercised; and the duties may be laid to such an amount, and in such a manner as may be necessary to effect the object intended. This object is not merely to provide generally for the general welfare, but to carry into effect in conformity with the last paragraph of the eighth section of the first article, those several and express provisions of the Constitution. which vest in Congress exclusively the control over the monetary system of the United States, and more particularly those which imply the necessity of a uniform currency. * * * Congress may, if it deems it proper, lay a stamp duty on small notes which will put än end to their circulation. It may lay such a duty on all bank notes as would convert all the banks into banks of discount and deposit only, annihilate the paper currency, and render a Bank of the United States unnecessary in reference to that object. But if this last measure should be deemed pernicious or prove impracticable, Congress must resort to other and milder means to regulate the currency of the country." $\ddagger$

* "Considerations on the Currency and Banking System of the United States," p. 50.

†Ibid., p. 75.

\#ustice Story, in his dissenting opinion in the case of Briscoe and others vs. The Bank of the Commonwealth of Kentucky (XI Peters, 349), says: "The States may cre- 


\section{The New York Free Banking Law.}

After the New York free-banking law had been perfected by various amendments, and subsequent to 1850 , a number of the States, among which were Massachusetts, Vermont, Connecticut, New Jersey, Ohio, Indiana, Illinois, Wisconsin, Tennessee, Virginia and Louisiana, adopted the system which had proved so satisfactory in New York. The Massachusetts and Louisiana acts, in addition to the many excellent features of the New York act, required an ample reserve to be kept on hand, and also contained other restrictions, which were subsequently embodied in the National Bank Act. In nearly all the States which adopted the free-banking system, charters for banks were still granted which authorized the issue of circulating notes without security and in excess of capital. These were more profitable, and therefore in most of the States but few banks were organized under general laws. In other States the best features of the New York law were omitted. The shareholders were not made personally liable ; the security required was not sufficient; the notes were issued in proportion to the stock and bonds deposited, and not in proportion to the cash capital ; no provision was made for the prompt redemption of the notes at any commercial center, and a majority of the directors and shareholders were frequently non-residents. Many of the organizations were not banks, in any true sense of the word, but were associations without capital, located at places not easily accessible, and owned by non-residents who availed themselves of ill-considered legislation to convert their bonds into currency at rates higher than the market value-drawing the interest on their bonds, but transacting little or no business at the place of issue. When the bonds depreciated in value, and any considerable amount of notes were presented at their counters for redemption, the banks failed, the securities were sold by the authority of the States, and the avails were distributed among the note holders.

The Governor of Indiana, referring to such banks, says in his message for 1853 :

"The speculator comes to Indianapolis with a bundle of bank notes in one hand and the stock in the other; in twenty-four hours be is on the way to some distant point of the Union to circulate what he denominates a legal currency authorized by the Legislature of Indiana. He has nominally located his bank in some remote part of the State, difficult of access, where he knows no banking facilities are required, and intends that his notes shall go into the hands of persons who will have no means of demanding their redemption."

The Governor of Michigan, in his message for the same year, says:

"At present we are giving charters to the issues of banks about which we actually know nothing, in whose management we have no participation, and are thus

ate banks, as well as other corporations, upon private capital, and may rightfully authorize them to issue bank bills or notes as currency, subject always to the control of Congress, whose powers extend to the entire regulation of the currency of the country." 
literally paying a large tribute for what generally in the end proves to be a great curse."

Governor Ford, in a message to the Legislature of New Jersey, says:

“ In many cases our banks, although ostensibly located in New Jersey, have their whole business operations conducted by brokers in other States. The facility with which they may be organized and located, without reference to the wants of the community or the business of the place, is destructive to all the legitimate ends of banking."

The New York "Journal of Commerce," in June, 1853, referring to the same subject, says:

"The operators in these schemes have turned to the West, and, under the freebanking laws of Indiana, Illinois, and Wisconsin, are prepared to flood the channels of circulation with their notes. It is not Western capital that is seeking profitable employment, nor is it Eastern capital invested at the West. Not a dollar of the new currency will be issued where it is likely to be presented for redemption."

The rates of exchange between the money centers and points in the South and West were necessarily high under the old State banking systems. Exchange on New York city in $\mathbf{1 8 5 9}$ averaged from one and a half to two per cent., and in 1860 one per cent. This was due to the diversity in the credit of the State banks and the lack of uniformity of value in their notes.

\section{Failures of the Early State Banks.}

In 1782 the first State bank in Massachusetts was authorized. From 1805 to 1810 the bank notes in the State were depreciated and very unstable in value, and a number of the banks failed. In 1814 nearly all of the banks outside of New England were compelled to suspend specie payments, and most of them were either closed or continued with great loss to their creditors. In 1829 the Farmers' Bank of Belchertown suspended, with a capital of $\$ 100,000$; the Sutton Bank, with a capital of $\$ 100,000$, and the Brighton Bank with a capital of $\$ 150,000$ failed. In 1836 the Nahant Bank, of Lynn, with a circulation of $\$ 242,965$, failed. From 1837 to 1840 the Chelsea, the Kilby, Middling, Interest, La Fayette, Franklin, Commonwealth, Middlesex, of Cambridge, American, Commercial, Fulton, and Hancock banks failed.

It is claimed that during the period from 1837 to 1844, thirty-two banks suspended, the circulation of which was redeemed, with the exeeption of the Roxbury Bank.

From 1844 to 1855 only two banks failed; in 1857 one more was added, but it is understood that the circulating notes of these three were redeemed in full. The total failures in Massachusetts during the whole period was fifty-two.

The first State bank organized in Rhode Island was in 1791. In 1809 the Farmers' Exchange Bank, of Gloucester, failed, with a circulation of $\$ 580,000$, and assets of but $\$ 86.46$; in 1829 the Farmers and Me- 
chanics' Bank, of Pawtucket, failed. No loss was sustained because of its circulating notes. In 1832 the Burrville Bank failed, with a circulation of $\$ 49,000$, which was finally redeemed without interest. The other creditors and the shareholders received nothing. In 1836 the Scituate Bank failed, but redeemed its circulation in full, and thereafter reopened. In 1843 the Rhode Island Agricultural Bank failed, and a part of its circulating notes was finally redeemed. In 1857 five banks failed, and in 1858 three others, some of which redeemed their circulation in full while others defaulted. The total failed banks in Rhode Island was thirteen.

In 1792 the first State bank was organized in Connecticut. In 1825 the Eagle Bank failed, with a circulation of $\$ 1,163,237$, and assets estimated at the time of failure to be worth $\$ 300,000$. The result was a large loss to note holders. The Derby Bank also failed, with a circulation of $\$ 80,000$, entailing almost a total loss.

In 1799 the first bank was organized in Maine. By 1829 the Castine, the Hallowell and Augusta banks, with a total circulation of $\$ 460,000$, failed. Before this time the Wiscasset, the Kennebec and the Passamaquoddy banks had also failed. A large amount of the circulation of these banks was a total loss to note holders. From 1837 to 1839 the Globe Bank, the Washington County Bank, the Frankfort Bank, the Stillwater Canal Bank and the Bank of Oldtown, failed, with heavy losses except to note holders. Eleven other banks failed prior to 1854, of which it is stated the circulation was redeemed in full. In that year the Shipbuilders' Bank and the Canton Bank failed, with heavy losses to the holders of their notes. In 1855 the Mousam River Bank and the Grocers' Bank failed. Most of the circulation of these two banks was redeemed. In 1856 one other bank failed, and in 1857 five others, but their circulation was largely redeemed. The total failed banks in Maine during this period was thirty-seven.

The Sanford Bank. which failed in 1861, up to January 1, 1863, had only paid a small amount of its circulation ; the Norombega Bank, of Bangor, had redeemed its circulation, but no information is given as to other liabilities; the Atlantic Bank, which failed in February 1860, had redeemed its circulation, but no other information is given; the Mariners' Bank. of Wiscasset, had redeemed its circulation, and had remaining some real estate, the proceeds of which could be applied to the payment of other creditors.

The first State bank was organized in New Hampshire in 1792. By 1809 the Cheshire, the Hillsboro and the Coos banks had failed, with heavy losses on circulation. Between 1839 and 1845 the Concord Bank failed, with a circulation of $\$ 88,000$ and deposits of $\$ 70,000$; the Wolfboro Bank, with a circulation of $\$ 38,000$, and the Lancaster Bank, with a circulation of $\$ 48,000$, also failed. But a small amount of the circulating notes and no other claims were paid by these banks. During this period eight other banks failed, some of which redeemed their cir- 
culation in full. The total of failures in New Hampshire during the period was fourteen.

In 1862 the bank officials of New Hampshire reported that the Weare Bank, which had suspended at Hampton Falls, with a capital of $\$ 50,000$, and with assets amounting to $\$ 104,341$, from which it had collected about $\$ 44,000$, had nearly redeemed its circulation. The Exeter Bank, which failed in 1860 , was reported to have been nearly liquidated.

In 1806 the first bank was organized in the State of Vermont. It was an institution the capital of which was supplied by the State. In 1812 it failed, causing a loss of over $\$ 200,000$ to the State, but the note holders and other creditors were paid in full when its affairs were finally closed in 1845. In 1839 the Essex Bank failed, with a circulation of $\$ 66,262$ and deposits of $\$ 3,798$. But a small portion of the circulation was paid from the assets of this bank. In 1862 the Black River Savings Bank had paid final dividends amounting to 65.82 per cent. on its liabilities, while the affairs of the Middlebury Savings Bank were nearly closed, but with almost a total loss to creditors.

In the State of New York the first bank chartered was in 1791. In the years before 1831 the following banks had failed: In 1819, Bank of Niagara, capital $\$ 400,000 ; 1820$, Bank of Hudson, capital $\$ 300,000$; 1825, Bank of Washington and Warren, capital $\$ 400,000$; Bank of Plattsburg, capital $\$ 300,000 ; 1827$, Aqueduct Association, capital $\$ 90$,$000 ; 1829$, Bank of Columbia, capital $\$ 160,000$; Middle District Bank, capital $\$ 500,000 ; 1830$, Franklin Bank, capital $\$ 500,000$.

The failed banks whose liabilities were secured by the Safety-Fund system are as follows:

Bank of Buffalo, capital $\$ 200,000$, circulation $\$ 111,234$; Commercial Bank of Buffalo, capital $\$ 400,000$, circulation $\$ 174,782$; City Bank of Buffalo, capital $\$ 400,000$, circulation $\$ 127,845$; the Wayne County Bank, capital $\$ 100,000$; Commercial Bank, of New York, capital $\$ 500$,000 ; Commercial Bank, of Oswego, capital $\$ 250,000$; Watervliet Bank, capital $\$ 250,000$; Clinton County Bank, capital $\$ 200,000$; Lafayette Bank, eapital $\$ 500,000$; Bank of Lyons, capital $\$ 200,000$; Bank of Oswego, capital $\$ 150,000$. All the liabilities, including circulation of the above banks, were paid in full from the safety-fund deposit. The liabilities of the banks amounted to $\$ 3,000,000$, but only $\$ 138,277$ was realized from their assets.

Subsequent failures were: The Canal Bank, of Albany, with a capital of $\$ 300,000$, circulation $\$ 185,531$; Lewis County Bank, capital $\$ 100,000$, circulation $\$ 150,000$, with no other liabilities; Yates County Bank, capital, $\$ 100,000$, circulation $\$ 148,958$; Bank of Orleans, capital, $\$ 200,000$, circulation $\$ 200,000$. The Canal Bank paid no creditors except note holders. The Yates County Bank and the Bank of Orleans paid the largest part of the note holders. The failure of the Lewis County Bank was complete. 


\section{Failures Under the New York Free Banking System.}

Under the free banking system inaugurated in 1838, there were fiftyseven failures, which resulted as follows, viz:

\begin{tabular}{|c|c|c|}
\hline NAME OF BANK. & $\begin{array}{l}\text { Circulation } \\
\text { outstanding. }\end{array}$ & $\begin{array}{l}\text { Rate } \\
\text { paid }\end{array}$ \\
\hline Tenth Ward Bank.$\ldots \ldots \ldots \ldots \ldots \ldots \ldots \ldots \ldots \ldots \ldots \ldots$ & $\$ 11.303$ & \\
\hline Bank of Tonawanda................................... & 15,485 & 68 \\
\hline Millers' Bank of Clyde... & 45,090 & 94 \\
\hline 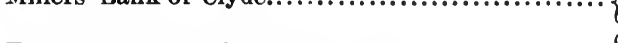 & 137,380 & Par \\
\hline Farmers' Bank of Seneca County. & $\begin{array}{l}27,343 \\
22,234\end{array}$ & 74 \\
\hline City Trust and Banking Company.. & 1,200 & Par \\
\hline Chelsea Bank................................. & 695 & 25 \\
\hline Allegany County Bank.. & 23,346 & 50 \\
\hline & 3,051 & 36 \\
\hline Bank of A merica, Buffalo..... & 69,9200 & 76 \\
\hline Bank of Commerce, Buffalo......................... & 65,025 & 76 \\
\hline & 31,766 & \\
\hline 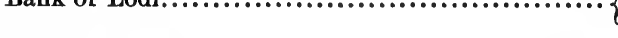 & 8,846 & \\
\hline Bank of Olean... & 50,124 & 74 \\
\hline & 3,224 & \\
\hline Bank or western NeW rork...... & $\begin{array}{l}74,393 \\
16,325\end{array}$ & 75 \\
\hline Binghamton Bank................. & 8,960 & 79 \\
\hline Cattaraugus County Banl & 53,019 & 77 \\
\hline & 6,181 & \\
\hline Erie County Bank.......... & 37,413 & 60 \\
\hline Mechanics' Bank, Buffalo....... & 19,7200 & 78 \\
\hline & 66,235 & 63 \\
\hline Merchants' Exchange Bank. & 47,760 & \\
\hline Phœenix Bank, Buffalo............................... & 27,490 & 73 \\
\hline 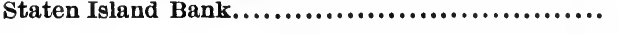 & 19,702 & \\
\hline St. Lawrence Bank. & $\mathbf{4 0 , 4 7 5}$ & \\
\hline Union Bank, Buffalo.......................... & $\begin{array}{l}19,499 \\
46,150\end{array}$ & \\
\hline 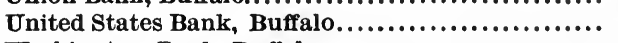 & 41,627 & $\begin{array}{l}81 \\
77\end{array}$ \\
\hline Washington Bank, Buffalo............................ & 19,235 & Par \\
\hline New York Banking Company....................... & 11,240 & 42 \\
\hline State Bank of New York, Buffalo $\ldots \ldots \ldots \ldots \ldots \ldots \ldots \ldots$ & 2,890 & 30 \\
\hline Farmers' Bank of Orleans.............................. & 24,825 & Par \\
\hline Clinton Bank......................................... & 2,682 & 60 \\
\hline 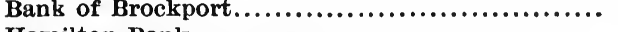 & 25,000 & 80 \\
\hline 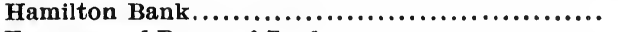 & 8,245 & Par \\
\hline Farmers and Drovers' Bank............................ & 5,971 & Par \\
\hline Atlas Bank, Clymer................................. & 129,998 & 75 \\
\hline & 48,202 & 97 \\
\hline 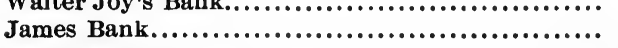 & 50,700 & Par \\
\hline 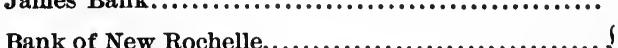 & 80,000 & 91 \\
\hline Bank of New Rochelle........... & 5,113 & Par \\
\hline Farmers' Bank of Onondaga ......................... & 81,000 & 85 \\
\hline Merchants and Mechanics' Bank, Oswego............. & 88,000 & 77 \\
\hline Eighth A venue Bank............................... & 100,000 & 94 \\
\hline Bank of Carthage..................................... & 53,643 & Par \\
\hline Empire City Bank, New York......................... & 110,464 & Par \\
\hline
\end{tabular}




\begin{tabular}{|c|c|}
\hline NAME OF BANK-Continued. & $\begin{array}{c}\text { Circulation } \\
\text { outstanding. }\end{array}$ \\
\hline Exchange Bank, Buffalo............................... & \\
\hline State Bank, Sacketts Harbor........................ & 48,462 \\
\hline 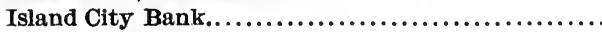 & 99,528 \\
\hline Hamilton Exchange Bank $., \ldots \ldots, \ldots, \ldots, \ldots, \ldots, \ldots$, & 43,016 \\
\hline 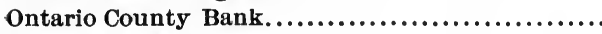 & 49,063 \\
\hline Pratt Bank of Buffalo $\ldots \ldots \ldots \ldots \ldots, \ldots \ldots \ldots, \ldots \ldots \ldots$ & 31,000 \\
\hline Chemung County Bank................................ & 58,167 \\
\hline Pine Plains Bank $., \ldots, \ldots, \ldots, \ldots, \ldots, \ldots, \ldots, \ldots, \ldots, \ldots$ & 66,956 \\
\hline Dairymen's Bank...................................... & 91,470 \\
\hline Agricultural Bank, Herkimer....................... & 80,528 \\
\hline 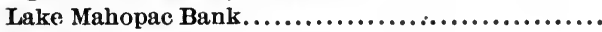 & 40,400 \\
\hline 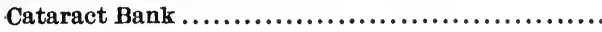 & 51,556 \\
\hline Bank of Albany................. & 65,673 \\
\hline Bank of the Capitol............. & 73,449 \\
\hline 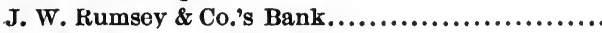 & 31,150 \\
\hline 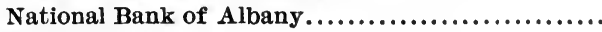 & 64,150 \\
\hline Medina Bank.................... & 100,168 \\
\hline Brockport Exchange Bank... & 41,516 \\
\hline
\end{tabular}

Of this total of fifty-seven failed banks under the free banking law of 1838, twenty-nine were within the first five years, and had an aggregate circulation of $\$ 12,233,374$. Their securities, consisting of stocks, bonds and mortgages, were sold for $\$ 953,371$, entailing a loss of $\$ 601$,966. The avails of these twenty-nine banks were only seventy-four per cent. of the circulation, with nothing for the other creditors. The losses to the note holders occurred only in the case of those banks which had deposited State stocks other than those of New York. Of the entire number failing, but twenty-three redeemed their circulating notes in full. At the end of 1862, the Reciprocity Bank, of Buffalo, was in the hands of a Receiver. The circulation at date of failure amounted to $\$ 159,577$. The affairs of the Bank of Orleans and the Yates County Baniz were still unsettled.

\section{Failures in Indiana.}

From 1852 to 1857 , and prior to the panic, fifty-one of the ninetyfour free banks and private institutions in Indiana are reported as having failed, with almost entire absence of payment to note holders or other creditors. The amount of circulation and other liabilities have not been obtained for these banks. During 1863 the circulation of the Bank of North America at Clinton was redeemed at the Southern Bank of Terre Haute at ninety cents. The circulation of the State Stock Bank at Peru was redeemed at the Bank of Goshen at eighty-five cents, and the circulation of the New York and Virginia State Stock Bank was redeemed at par. The circulation of the following banks was redeemed by the Auditor of the State from securities which had been deposited with him: Bank of Albany at ninety cents, Bank of Albion at par, Bank of Gosport at par, Bank of Perryville at par, Bank of South Bend at par, Boone County Bank (genuine) at par, Bank of T. Wads- 
worth at ninety-one cents, Bank of Rockport at par, Central Bank at. par, Farmers' Bank of Jasper at ninety-one cents, Kalamazoo Bank at par, State Bank of Marion at ninety cents, Savings Bank of Indiana. (genuine), at sixty-nine cents; Wayne Bank, at Logansport, at par; Wayne Bank, at Richmond, at par, and Agricultural Bank, at par. In the notice of the Auditor of the State it is set forth in italics that. persons sending notes "will take particular notice" that no other suspended bank notes are redeemed at his office.

The bank reports from Minnesota show that on January 1, 1863, the circulation of the Bank of Rochester was being redeemed at sixteen and a quarter cents on the dollar, Chisago County Bank at nineteen and a quarter cents, Filmore County Bank, twenty cents; Bank of Owatonna, twenty and three-quarter cents; Exchange Bank, twenty one and a quarter cents; Central Bank, thirty cents; Nicollet County Bank, thirty-five cents; Bank of the State of Minnesota, seventy cents; Bank of St. Paul, ninety-eight cents, while the circulation of the Bank of Redwing was provided for at par.

\section{Michigan's Early Banking Experience.}

The banking system of the State of Michigan prior to 1863 was, as practiced, entirely based upon frauds. It is current history that the Bank Commissioners were carefully watched with a view to transporting specie from banks already examined to those which it was supposed they were about to visit. Gold and silver never before circulated so freely or traveled so rapidly, and if the same well-filled boxes or bags were found in several banks in succession, some official was ready to swear that the bona fide ownership was vested in the present possessor. Sometimes it passed the commissioner by rapid transit on the road; sometimes it was transported by night; sometimes, arriving too late, it was handed in at the back door of the banking house while an examination was in progress. But there were some banks that had no amount of even borrowed specie. The Bank of Sandstone, for instance, never had any specie, and although its liabilities exceeded $\$ 38,000$, it had no assets of any kind at the time when it was reported upon. The Exchange Bank of Shiawassee had in the safe but seven coppers and a very small amount of paper, while it had bills in circulation to the amount of $\$ 22,267$. The Jackson County Bank was discovered by the commissioners to have many large and well-filied boxes, but on being opened and examined it was found that while the top was covered with silver dollars there was nothing below but nails and glass. The only box containing silver brought into the room and sworn to by a director present as the property of the bank was afterward the subject of an action by the director against the Receiver of the bank for its recovery, claiming it as his own individual property. A settlement of the bank's affairs proved that, with an indebtedness of some $\$ 70,000$, it had not more than $\$ 5,000$ of available assets. It was reported by the Bank 
Commissioners in December, 1839, that only three chartered banks, with one branch bank, and four organized under the general law, out of sixty recently established, were then in existence. The report of the Attorney-General of the State, made at the same time, enumerates fortytwo banks under injunction, and exhibits the condition of their affairs so far as ascertained. His report is an exhibition of a large amount due creditors, with little or no available assets with which to liquidate. It is estimated that the circulition outstanding, which was a total loss to the note holders of the State, was not less than $\$ 1,000,000$.

Illinois, Indiana and Wisconsin passed free-bank laws in 1851, 1853 and 1855 , respectively. Few of the banks organized under these laws escaped disastrous failure, either prior to 1857 or in the panics of that year and of 1861. Immense loss was entailed upon all of their creditors. At these two periods most of the banks of the Southern and Western States failed, either because their business was transacted without any actual supply of capital or from reckless management.

It is stated in "Elliott's Funding System," page 1,176, that in 1841, out of banks having a capital amounting to $\$ 317,642,692$ and circulation of $\$ 121,665,198$, fifty-five banks, with a total capital of $\$ 67,036,265$ and a circulation of $\$ 23,577,752$, failed. In nearly every instance the capital of these banks was entirely lost.

In the financial report for 1838 the balance of public deposits due from banks which had suspended specie payments amounted to $\$ 2,345$,535, including the Commercial Bank, of Buffalo, the Mobile branch of the Bank of Alabama, the Planters' Bank, of Mississippi, at Natchez, the Agricultural Bank, of Natchez, the Bank of Kentucky at Louisville, the Franklin Bank of Cincinnati, the State Bank of Indiana, the Bank of Michigan at Detroit, and the Farmers and Mechanics' Bank at Detroit.

The following list of 129 banks, with capital amounting to $\$ 24,212$,339 , and thirty-six banks of which the capital was not known, are banks enumerated by Hon. Albert Gallatin, previously Secretary of the Treasury, in "Considerations on the Currency and Banking System of the United States" :

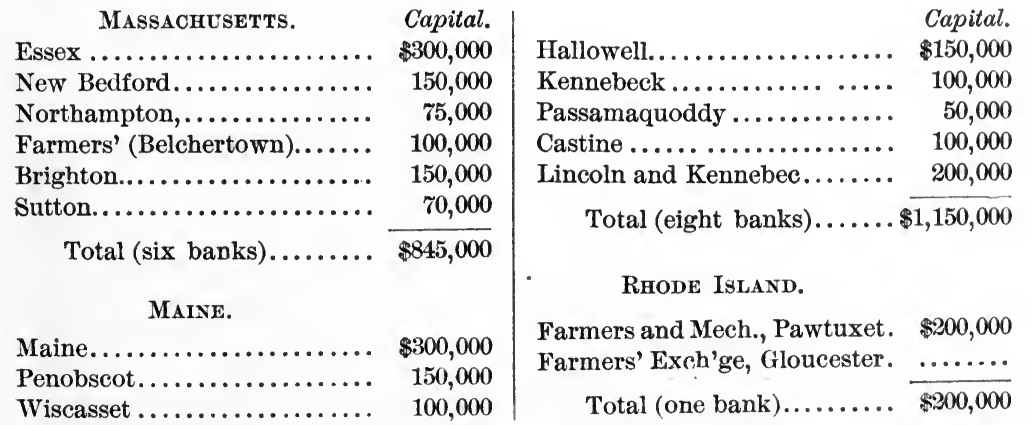




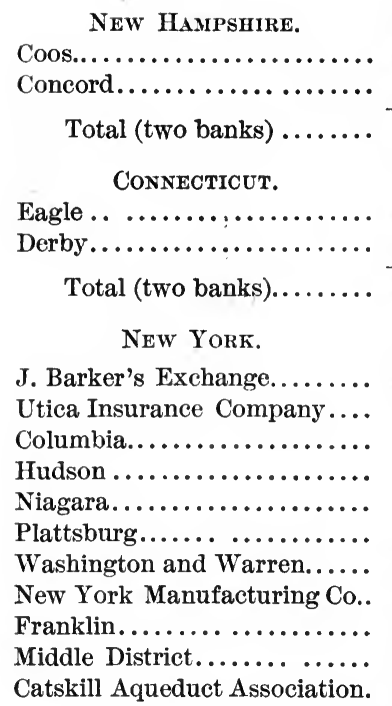

Total (ten banks). .$\overline{\$ 3,378,676}$

New JERSEY.

Jersey City Bank.

Paterson ....................

State Bank, Trenton..........

Protection and Lombard......

Franklin ..................

Monmouth ...................

Manufacturing................

Salem and Philadelphia.......

Hoboken

Total (seven banks).

$\$ \overline{1,142,400}$

\section{Pennsyluania.}

Washington. ...............

Farmers and Mechanics' of Greencastle................

Farmers and Mechanics' of

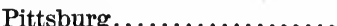

Juniata.................

Marietta and Susquehanna Trading Company..........

Pennsylvania Agricultural and Manufacturing Bank........

Delaware Bridge..............

Allegheny ..................

Beaver......................

Swatara..................

Center ....................

Huntingdon
Capital. $\$ 100,000$ 29,600 $\$ 129,600$

$\$ 500,000$ 100,000 $\$ 600,000$

$\$ 495,250$

100,000

167,650

110,000

108,000

300,000

400,000

700,000

510,000

487,776

........

$\$ 200,000$

160,000

92,400

200,000

300,000

40,000

150,000

......

.........

$\$ 92,070$

74,485

65,337

164,478

239,430

110,102

99,715

144,807

78,985

75,075

159,610

123,122
Northumberland, Union and Columbia ............... \$116,980

Northwestern Bank......... $\quad 77,688$

Union of Pennsylvania...... 124,792

Silver Lake............... $\quad \mathbf{6 4 , 8 8 2}$

Fayette, New Salem .......... .......

Harmony.......................

Wilkesbarre Branch...................

Total (sixteen banks).... $\overline{\$ 1,811,558}$

Delaware.

Farmers and Mechanics' of Delaware............... \$45,000

Total (one bank)........ $\overline{\$ 45,000}$

\section{Maryland.}

Elkton ... .............. $\$ 110,000$

Conococheague............. 157,500

Cumberland ............. 107,862

Somerset \& W.............. $\quad 90,000$

Somerset............... 195,850

Caroline................ 103,045

Havre de Grace............ 132,0\%5

City................... 838,540

Planters' Prince George County $\quad 86,290$

Total (nine banks)...... $\overline{\$ 1,821,162}$

District of Columbia.

Columbia................. $\$ 901,200$

Union of Alexandria......... $\quad 340,000$

Central................... 252,995

Franklin............... 163,265

Total (four banks)...... $\overline{\$ 1,657,460}$ VIRGINIA.

Ohio County ............. $\$ \$ 60,000$

Charleston M. and C. Co...... 32,580

Winchester.............. 122,930

Monongalia.............. $\quad 25,000$

Farmers and Mechanics', Harper's Ferry............. $\quad 19,480$

South Branch............. 25,000

Farmers', Merchants and Mechanics', Jefferson County.. Warrentown................

Leesburg Union..............

Loudoun County.............

Total (ten banks)....... $\overline{\$ 421,415}$

North Carolina.

Fayetteville

Bertie
26,425

60,000

20,000

30,000 


\begin{tabular}{|c|c|}
\hline $\begin{array}{l}\text { South Carolina. } \\
\text { Cheraw................... }\end{array}$ & $\begin{array}{l}\text { Capital. } \\
\$ 20,000\end{array}$ \\
\hline Hamburg.................... & ........ \\
\hline Total (one bank).......... & $\$ 20,000$ \\
\hline GEORNIA. & \\
\hline Darien............. & $\$ 480,000$ \\
\hline Total (one bank).......... & $\$ 480,000$ \\
\hline
\end{tabular}

Planters' Bank.. ............ \$200,000

Bank of Louisiana.......... $724,000^{\circ}$

Total (two banks)....... $\overline{\$ 924,000}$

Alabama.

Planters and Merchants' Bank. \$164,175

Tombeckbe............... 156,937

Steamboat............... 16,000

Total (three banks)....... $\overline{\$ 337,112}$

Tennessee.

Fayetteville Transfer.........

Farmers and Mechanics' of

Nashville...............

Nashville and branches.......

Tennessee Bank (old)..........

Three branches of Tennessee

Bank

Nashville branch of Tennessee

Bank.

Rogersville branch of Tennessee Bank..............

Total (four banks and five branches)

\section{KentuCKY.}

Farmers and Mechanics' of Lexington (stock and notes at par).

Versailles....................

Kentucky and branches.......

Flemingsburg .............

Limestone..................

Shepherdsville...............

Hinkston Exporting Company.

Newcastle..................

Cynthiana...................

Center Bank of Kentucky.....

Union of Elizabethtown .......

Farming and Commercial Bank

Greenville.

Newport.

Southern Bank of Kentucky...
$\$ 2,229,782$

$\$ 110,000$

180,200

994,560

371,107

300,000

206,775

67,140

$\$ 489,700$

111,180

$2,756,220$

61,626

135,825

55,880

50,120

40,520

47,900

120,000

39,400

37,219

46,640

54,700

117,222
Farmers' of Harrodsburg.....

Farmers' of Somerset......... Lancaster Exporting Company Insurance................. Barbersville................. Cumberland Bank of Burkville Burlington.................

Bank of Columbia............

Frankfort ...................

Georgetown

Greensburg. .

Green River.

Christian Bank

Bank of Henderson.

Bank of Washington...........

Commercial Bank of Louisville

Mount Sterling .............

Morgantown................

Monticello . .

Farmers' Bank of Jessamine..

Owingsville ................

Petersburg Steam Mill........

Farmers' Bank of Gallatin ....

Farmers and Mechanics' of Logan ...................

Farmers and Mechanics' of Shelbyville ...............

Farmers and Mechanics' of Springfield................

Winchester Commercial.............. Commonwe'lth Bank.(2,000,000 Nominal) Total (eighteen banks).... $\$ \overline{\$ 4,307,431}$ Онго.

Miami Exporting Company, Cincinnati ............... Columbia, New Lisbon........ Granville Alex'n Society...... Farmers' Bank of New Salem. German of Wooster........... Muskingum ................ Farmers and Mechanics' of Cincinnati.............. 184,776 Cincinnati............... 216,430 Dayton Manufacturing....... 61,622 Lebanon-Miami Banking Company.................. 86,491 Urbana Banking Company.... $\quad 49,685$ Farmers and Mechanics' Manfacturing, Chillicothe....... Hamilton.................. Zanesville Canal and Manufacturing Company.
Capital. $\$ 81,000$ 22,379 39,900 ........

n......

.........

.......

(.........

........

.........

$\ldots \ldots$.

(.........

........

.........

(n..... ....... $\ldots \ldots \ldots$ $\ldots \ldots$ $\$ 468,966$ 50,000 12,002 57,000 25,000 97,800 


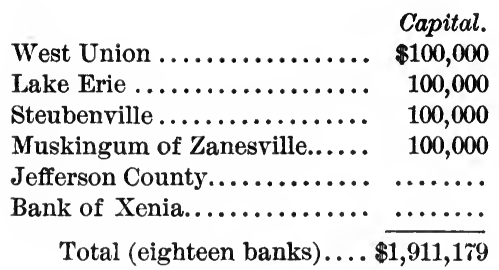

\section{INDIANA}

Farmers and Mechanics'..... \$130,000 Bank of Vincennes........... 12r,624

Total (two banks).
ILLINOIS.

Capital.

$\begin{array}{lr}\text { Illinois....................... } & \$ 105,720 \\ \text { Edwardsville............... } & \mathbf{5 7 , 1 9 0}\end{array}$

Total (two banks)....... $\overline{\$ 162,910}$ Missouri.

Bank of Missouri............. $\$ 250,000$

Bank of St. Louis.......... $\quad 150,000$

Total (two banks)....... $\stackrel{\$ 400,000}{ }$ Michigan.

Monroe .................. \$10,000

\section{RECAPITULATION.}

One-hundred and twenty-nine

banks ................\$24,212,339

Thirty-six banks............. Not known

Failed Banks Other than National, 1864-1896 (Cents Omitted).

\begin{tabular}{|c|c|c|c|c|c|}
\hline YEAR. & $\begin{array}{l}\text { Number } \\
\text { of } \\
\text { failures. }\end{array}$ & Capital. & $\begin{array}{l}\text { Nominal } \\
\text { assets. }\end{array}$ & Liabilities. & $\begin{array}{l}\text { Dividends } \\
\text { paid. }\end{array}$ \\
\hline 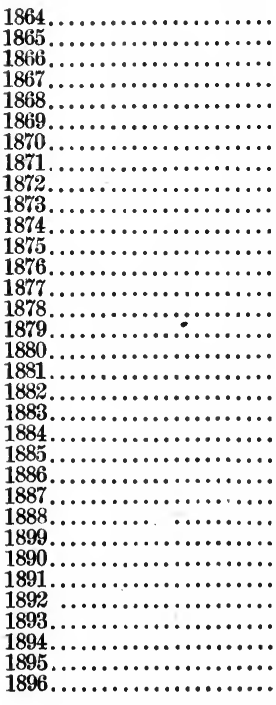 & \begin{tabular}{r|}
2 \\
5 \\
5 \\
3 \\
7 \\
6 \\
1 \\
7 \\
10 \\
33 \\
40 \\
14 \\
37 \\
63 \\
70 \\
20 \\
10 \\
9 \\
19 \\
27 \\
54 \\
32 \\
13 \\
19 \\
17 \\
15 \\
30 \\
44 \\
27 \\
261 \\
71 \\
115 \\
78 \\
\end{tabular} & $\begin{array}{r}\$ 125,000 \\
275,000 \\
260,000 \\
276,381 \\
100,000 \\
\ldots, 2,000 \\
220,000 \\
470,000 \\
907,000 \\
770,000 \\
2,413,900 \\
961,000 \\
2,491,250 \\
3,, 250,193 \\
1,370,465 \\
452,200 \\
436,750 \\
545,000 \\
870,000 \\
1,718,536 \\
1,099,400 \\
254,000 \\
931,590 \\
745,500 \\
363,250 \\
2,169,568 \\
2,071,300 \\
578,840 \\
16,641,637 \\
3,112,447 \\
3,906,350 \\
3,400,642\end{array}$ & 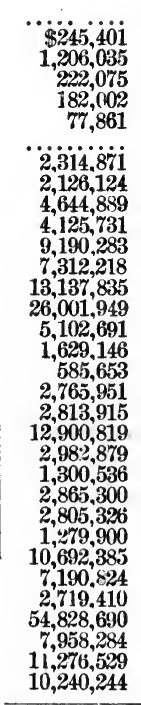 & $\begin{array}{r}\$ 225,66 \dot{2} \\
890,112 \\
138,821 \\
148,886 \\
361,961 \\
50.000 \\
2,654,187 \\
3,059,318 \\
6,938,653 \\
4,562,879 \\
12,365,475 \\
9,206,429 \\
15,223,785 \\
27,269,520 \\
5,253,307 \\
1,311,799 \\
1,785,890 \\
2,608,489 \\
3,193,747 \\
15,508,389 \\
4,883,454 \\
1,140,824 \\
3,074,622 \\
3,342,336 \\
2,147,059 \\
11,385,584 \\
6,365,198 \\
3,227,608 \\
46,766,818 \\
7,218,319 \\
9,010,584 \\
7,513,837\end{array}$ & 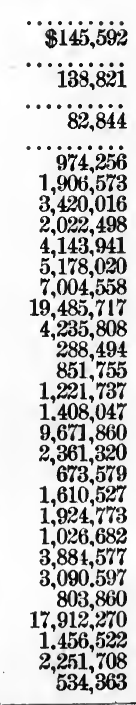 \\
\hline $\begin{array}{r}\text { Total } \ldots \ldots \ldots \ldots \ldots \ldots \\
\text { Not dated................... }\end{array}$ & $\begin{array}{r}1,164 \\
70\end{array}$ & $\begin{array}{r}\$ 53,187,259 \\
445,000\end{array}$ & $\begin{array}{r}\$ 212,725,771 \\
, 1,586,419 \\
\end{array}$ & $\begin{array}{r}\$ 218,833,563 \\
1,796,424\end{array}$ & $\begin{array}{r}\$ 99,711,330 \\
377,396 \\
\end{array}$ \\
\hline Grand total........ & 1,234 & $\$ 53,632,259$ & $\$ 214,312,190$ & $\$ 220,629,988$ & $\$ 100,088,726$ \\
\hline
\end{tabular}

The reports of insolvent State banks show that 158 banks paid dividends to creditors of 100 per cent.; 128 paid 75 per cent. and over, but less than 100 per cent.; 184 paid 50 per cent. and over, but less than 75 per cent.; 203 paid 25 per cent. and over, but less than 50 per cent., and 192 made payment of less than 25 per cent. 


\section{II}

\section{NEW ENGLAND STATES.}

Primitive banking in New England was based chiefly upon real estate; in some cases the notes were emitted by the Colonies and in others they were issued by associations of individuals, frequently with the same result-depreciation of the notes and loss to their ultimate holders when the banks were closed up. It was not long before the heresy concealed in these early banking schemes became apparent, and most of the New England Colonies were not slow to apply the lessons of experience. Restrictive acts were passed both by the Colonies and the mother country. There was a gradual evolution of the banking system, until finally the banks of that section of the country established a reputation generally superior to those in other States. In 1814 they maintained specie payments, although suspension was general elsewhere.

The term bank, as applied to the first of these institutions organized, signified rather a common fund, or heap, and not an ordinary commercial bank. Some of the Colonies issued notes and loaned them on real estate mortgages; and though these loans were restricted to five years, many of them were renewed, some not being repaid for over thirty years. As land was the principal security which the colonists had, it is not surprising that they sought to make it the basis of their currency instead of specie or the titles to those commodities which in a highlydeveloped State constitute the most desirable form of security, but which are greatly limited in supply in a pioneer community.

\section{MAINE.}

The first bank chartered by the General Court of Massachusetts, to do business in the district of Maine, was organized at Portland, June 15,1799 , and was named the Portland Bank. Its capital was $\$ 100,000$, with the privilege of increasing to $\$ 300,000$, at the pleasure of the stock holders. This privilege was improved, and the whole amount authorized was taken up.

All this capital was probably not paid in in cash, as there was considerable poverty in the community, resulting from the destruction of the town by fire in October, 1775. The reports made upon banks in 
1820 indicated a considerable loan to stockholders secured by the pledge of their stock. This bank prospered for a time, but met with serious financial disasters in 1808, and was closed up with a loss of twenty-five per cent. of the capital.

On June 23, 1802, the Maine Bank, of Portland, was chartered, with a paid-in capital of $\$ 300,000$, which was afterwards reduced to $\$ 200$,000 . This bank was closed in 1813, when the charter expired.

At the session of the General Court in 1802 the Lincoln and Kennebec Bank, of Wiscasset, was chartered with a capital of $\$ 200,000$. The Saco Bank, at Pepperellboro, was chartered March 8, 1803.

The population of Maine in 1800 appears to have been about 152,000 , widely separated and scattered along the shore; engaged in lumbering, fishing, building of ships, navigation and trading with the West Indies and States of the Union.

The depression following the War of the Revolution and the troubles arising from an unsettled currency, did not prevent a large increase in the shipping of the State, and there was great activity in competing with English shipping for the carrying trade. But there does not seem to have been any great call for banking facilities during the period from 1803 to 1812. The repeal of the "Embargo" in 1809 had, undoubtedly, set free the shipping of Maine, which had engaged once more in competing for the carrying trade. There was a considerable revival of business in the State, and as early as January 23, 1812, twenty banks received charters from the General Court of Massachusetts, six of which were situated in Maine-the Bath Bank, of Bath, the Cumberland Bank, of Portland, the Hallowell and Augusta Bank, the Wiscasset Bank, the Kennebec Bank and the Saco Bank.

A law was enacted in 1812 fixing an annual tax of one per cent. on the capital stock of all banks. In 1813 six new banks of $\$ 100,000$ each, were established; namely, the Lincoln, Kennebunk, Bangor, Augusta, Gardiner and Waterville, all of whose charters expired on October 1, 1831.

The official documents of the General Court of Massachusetts on December 17, 1814, show returns from twelve Maine banks, having a capital stock of $\$ 1,846,000$. Of that amount, $\$ 823,625$ was secured by real estate and bank stock, indicating that four-ninths of the capital of the banks was made up of the promises to pay of individual stockholders, rather than actual cash. The return shows $\$ 581,466$ bills in circulation, and that $\$ 730,561$ of bills had been redeemed within the six months prior to the return.

\section{Methods of Redeening Bills.}

Prior to 1819 the redemption of bills in Boston had rested with agents of the individual banks, who both interested themselves in putting the bills in circulation and sometimes in their redemption. It was a constant source of trouble, and the utmost skill had to be used to 
keep these bills from being returned to the banks. Maine was so far removed from Massachusetts that it finally became necessary to collect all the Maine bank bills held by the Boston banks and send a man with a team down the shore to exchange these bills for specie. It was no uncommon sight to see the team in the inn yards with kegs filled with specie and two dogs guarding the treasure. There is no account of any attempt being made to rob this specie collector-a striking instance of the honesty of the inhabitants of Maine in the early part of this century.

So great was the loss of interest in the collection of these bank bills from the remote districts, that in 1809 the leading merchants of Boston signed a paper agreeing to take no country bank bills after that date. This circular set forth in considerable detail the wrongs which they suffered in consequence of receiving these bills, and their determination to take them no longer.*

\section{Maine Admited Into The Union.}

In 1820 Maine became a separate State, and the first report to the Legislature upon the subject of banking was a result of the examination by a committee of the Legislature of the Hallowell and Augusta Bank. The committee particularly found "the amount of loans made to stockholders on their individual notes secured by the pledge of their stock in the bank, to be $\$ 121,373$, real estate and debts secured by real estate, to the nominal amount of $\$ 48,110.38$; "from which it appears that the whole capital stock of the bank, and the additional amount of $\$ 19,483.38$, was invested in real estate and in permanent loans; but this was not all. The committee found that the institution held notes and other debts secured by names, to the amount of $\$ 84,-$ 388.23 , a large part of which had existed for a long time, had been subject to no checks and was thought by the committee to have been of no more avail than its loans on stocks.

"The semi-annual dividends appear to have been uniformly declared, with the balance against the bank, in profit and loss account; and the reason assigned for making the dividends under such circumstances was that the institution had no other means of collecting the interest on stock notes."

In 1824 the Bangor Bank had sixty-five per cent. of its capital loaned on a pledge of stock therein, the Bath Bank eighty per cent., the Hallowell and Augusta Bank forty-three per cent., the Kennebec Bank seventy-six per cent., the Passamaquoddy Bank sixty-seven per cent. and the Waterville Bank eighty-two per cent.

In 1827 the Legislature found it advisable to appoint a committee to secure evidence of the number of fictitious persons who appeared on the books as stockholders with notes as collateral. In 1831 a general bank law was passed. In 1834 there were thirty banks doing business 
in the State, representing a capital of $\$ 2,931,000$; the capital stock represented by notes secured by bonds and mortgages appears to have fallen to $\$ 119,550$-an evidence of great improvement in the financial standing of the community, and an indication that capital was represented by something more tangible than promises to pay of stockholders.

\section{Operations of The SUfFolk System.}

Under the general arrangement made with the New England banks about 1819 for the redemption of their bills by the Suffolk Bank of Boston, each bank was pledged to place a permanent deposit of not less than $\$ 2,000$, drawing no interest, the amount required varying, of course, with the capital and business of the bank. The Suffolk Bank, in consideration of such deposit, redeemed the bills and returned them to the bank issuing the same whenever they reached a fixed sum, provided the bank kept a deposit sufficiently large, independently of the $\$ 2,000$, to redeem the bills; and if at any time the excess should be greater than the permanent deposit, the Suffolk Bank could send home the bills for specie redemption. This method of redeeming bank bills caused a great deal of discontent, which manifested itself in various ways.

In the winter of 1835 a remonstrance was presented to the Legislature against the enforced redemption of bills by the Suffolk Bank system. The following words appeared in this remonstrance:

"After the Legislature has granted a charter to a bank, before such corporation dare to go into operation or issue a single dollar (bill), it must send a deputation to Boston, and laying down the bags of tribute money at the feet of the President of the Suffolk Bank, receive from him permission and the terms upon which it may operate."

The circulation of bills in 1835 amounted to $\$ 2,380,114$, showing an increase of nearly $\$ 1,700,000$ in a year, while the specie reserve had fallen from $\$ 208,000$ in 1830 to $\$ 186,000$ in 1835 ; but, on the other hand, the loans had increased from $\$ 2,888,000$ in 1830 to $\$ 6,357,000$ in $1835-$ conditions clearly pointing to inflation and an unhealthy state of excitement in the mercantile world. Although in 1838 some of these unhealthy conditions existed, the beginning of the end was in sight; the return to normal and healthy conditions of business life, as evidenced by the banking returns.

This agitation against the Suffolk system continued to be felt all through the State for some years. Commissioners appointed by the Governor reported; on January 25, 1837, that "they found fourteen, out of the fifty-five banks in the State, had ceased to make permanent deposits in Boston."

Despite the reports of a committee recommending the passage of an act prohibiting the maintenance of a reserve fund to redeem the bills in Boston, the Legislature refused to take any action in the matter. In 1835 the Legislature passed an act prohibiting the circulation of 
any bills smaller than five dollars; and in 1836 a bill providing for no bill smaller than five dollars or between five and ten dollars or between ten and twenty dollars. This had the result of encouraging the circulation of bills of banks of other States.

\section{Suspension of Specie Payments.}

In May, 1837, the banks of Maine suspended specie payments. There were then fifty-five banks in the State, with a total capital of $\$ 5,458,750$.

In 1841 the banking law was carefully revised by the Legislature, and many important safeguards added. In the same year forty-two banks reported a capital of $\$ 3,514,000$. Ten banks scaled their capital stock $\$ 547,500$. Two banks surrendered their charters having $\$ 50,000$ capital stock, making a total reduction of $\$ 857,500$. This was the first official recognition of the losses sustained by the banks in the crisis of 1837. The diminution of banking capital since 1838 had been $\$ 1,904,750$. The average circulation for the last six months of that year was $\$ 1,414$,564 , and the average monthly redemption $\$ 559,433$, "showing that the whole circulation of the banks passes through the Suffolk Bank nearly five times a year. $* * *$ This amount is paid without a draft upon specie, but by the course of trade, which places ample funds in Boston for the purpose, and still has left a balance there in our favor of half a million of dollars."

The report for 1842 showed that while stockholders had lost about $\$ 2,000,000$, note holders had lost not more than $\$ 175,000$.

The commissioners' report for 1848 stated that only two banks in the State had not entered the Suffolk system-the Calais and Mercantile Banks. They said:

"We do not censure their course, but their bills are from three to six per cent. discount. The Frontier Bank, the nearest neighbor of the Calais Bank, and a wellmanaged institution, can maintain but a very limited circulation; its bills being in good credit at Boston, are sought for foreign payments, while the depreciated paper of the Calais Bank supplies almost the entire home circulation for the county of Washington."

In 1856 the highest number of State banks was reached, being seventy-seven in number, with a capital of $\$ 8,107,485$.

In September, 1857 , specie payment was suspended in Maine, and the report of the Bank Commissioners notes that all but three of the banks sustained themselves in good credit. They say:

"'The 'Suffolk system,' though not recognized in our banking law, has proved to be a great safeguard to the public; whatever objections may exist to the system in theory, its practical operation is to keep the circulation of our banks within the bounds of safety."

When the National Banking Law was passed in 1863 there were in the State sixty-nine banks, with $\$ 8,008,000$ capital and $\$ 6,019,156$ circulation. Nineteen banks gave notice during 1864 of their intention to surrender their charters, and in $\mathbf{1 8 6 5}$ sixty-eight banks are reported as 
either closing under the Act of 1863 or converted under the Act of 1865 , so that the banks of discount organized under the laws of Maine practically ceased to exist in $\mathbf{1 8 6 5}$.

State Banks.

\begin{tabular}{|c|c|c|c|c|c|c|}
\hline YEARS. & $\begin{array}{l}\text { No. of } \\
\text { bank8. }\end{array}$ & $\begin{array}{l}\text { Loans and } \\
\text { discounts. }\end{array}$ & Specie. & $\begin{array}{l}\text { Capital } \\
\text { stock. }\end{array}$ & Circulation. & Deposits. \\
\hline $1834 \ldots$ & 29 & $\$ 4,359,874$ & $\$ 137,420$ & $\$ 2,931,000$ & $\$ 1,358,914$ & $\$ 704,079$ \\
\hline $1839 \ldots$ & 50 & $6,913,471$ & 241,951 & $4,771,500$ & $1,909,097$ & 927,281 \\
\hline $1844 \ldots \ldots \ldots$ & 35 & $4,279,331$ & 223,769 & $3,009,000$ & $1,606,663$ & 927,498 \\
\hline $1849 \ldots$ & 32 & $5,275,171$ & 339,231 & $3,098,000$ & $2,252,764$ & $1,119,252$ \\
\hline $1854 \ldots$ & 60 & $12,114,697$ & $1,163,522$ & $6,393,369$ & $4,623,906$ & $3,816,104$ \\
\hline $1859 \ldots$ & 68 & $11,815,127$ & 663,754 & $7,408,945$ & $3,886,539$ & $2,472,993$ \\
\hline $1863 \ldots \ldots$. & 69 & $13,658,172$ & 747,145 & $7,983,000$ & $6,488,478$ & $5,076,107$ \\
\hline $1875 \ldots \ldots \ldots$ & 3 & 292,596 & ............. & 225,000 & 3,609 & 106,209 \\
\hline
\end{tabular}

In 1878 there was one State bank reported in existence, having $\$ 75,000$ capital, $\$ 1,594$ circulation, $\$ 25,859$ deposits and $\$ 84,385$ loans and discounts. The others had been absorbed into the National banking system or had gone out of business.

\section{National Banks.}

Figures in thousands of dollars.

\begin{tabular}{|c|c|c|c|c|c|c|c|c|c|}
\hline DATE. & 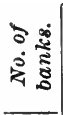 & $\begin{array}{l}\text { Loans } \\
\text { and dis. } \\
\text { counts. }\end{array}$ & $\begin{array}{c}U . S . \\
\text { bonds. }\end{array}$ & $\begin{array}{c}\text { Cash } \\
\text { and cash } \\
\text { items. }\end{array}$ & Capital. & Surplus. & $\begin{array}{l}\text { Undi. } \\
\text { vided } \\
\text { profits. }\end{array}$ & 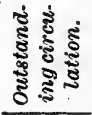 & $\begin{array}{c}\text { Indi. } \\
\text { vidual } \\
\text { deposits. }\end{array}$ \\
\hline $1863 \ldots . .$. & 1 & $\$ 5$ & $\$ 51$ & $\$ 11$ & $\$ 50$ & ......... & ...... & & $\$ 19$ \\
\hline $1868 \ldots . . . . .$. & 61 & 10,189 & 9,915 & 1,664 & 9,085 & $\$ 1,197$ & $\$ 637$ & $\$ 7,470$ & 5,076 \\
\hline $1873 . . . . . .$. & 63 & 13,523 & 9,449 & 1,939 & 9,440 & 1,892 & 1,468 & 7,783 & 6,494 \\
\hline $1878 \ldots \ldots . .$. & 72 & 13,560 & 10,192 & 1,684 & 10,760 & 2,389 & $1,23 \tilde{\jmath}$ & 8,313 & 5,956 \\
\hline $1883 \ldots \ldots . . .$. & 72 & 18,778 & 9,290 & 2,074 & 10,485 & 2,575 & 1,410 & 8,080 & 10,032 \\
\hline $1888 \ldots . . . .$. & 75 & 20,192 & 5,131 & 1,888 & 10,660 & 2,550 & 1,394 & 4,403 & 11,065 \\
\hline $1893 . . . . . .$. & 83 & 21,342 & 4,437 & 1,484 & 11,221 & 2,699 & 1,611 & 3,754 & 12,890 \\
\hline $1898 \ldots . . . .$. & 82 & 21,546 & 5,931 & 1,616 & 11,071 & 2,699 & 1,581 & 4,746 & 17,421 \\
\hline
\end{tabular}

\section{SAVINGS BANKS.}

Prior to 1852 there were four Savings banks organized in Maine. The first was the Portland Savings Institution in 1819. In 1834 it had received $\$ 154,193.12$ from 1,585 persons. In the reverses of $1837-8$ it failed, after a severe run, being unable to realize upon its mortgages and bank stock.

The Saco and Biddeford Savings Institution was chartered in $\mathbf{1 8 2 7}$, the Gardiner in 1834, and the Augusta in 1848. In 1852 these banks 
had an aggregate deposit of $\$ 235,726.11$. From this on their deposits constantly increased and became an important factor in the material growth and prosperity of the State.

In 1852 three Savings banks were chartered, the Bangor, Bath and Portland.

In 1856 there were 4,947 depositors and $\$ 919,571.85$ of deposits in the Savings banks.

In 1858 the deposits amounted to $\$ 923,397.78$, with an increase of fifty depositors over 1856, showing how slight an effect the panic of 1857 had upon the Savings banks at that time.

In 1855 Savings banks were first made subject to examination by the State Commissioners, whose official existence began with discount banks in 1840 .

In 1869 the Legislature passed an act regulating the incorporation and powers conferred upon Savings banks, and limiting their rights under their existing charters by general law. This act has been only slightly modified, and that particularly in the limitation of investments, the original act providing only that "no loans are to be made on security of names alone, nor directly or indirectly to any trustee, nor to a firm of which any trustee is a member."

In 1871 the Savings Bank Examiner published for the first time a schedule of bonds and stocks held by the Savings banks. He reported the number of banks had increased to forty-nine, and the number of depositors to 79,411 , and the deposits to $\$ 22,787,802$.

In 1872 an act was passed creating a tax of one-fourth of one per cent. every six months upon the net deposits of Savings banks, excepting Government bonds, corporation stocks otherwise taxed, and real estate, and provided that dividends should not exceed six per cent. per annum.

It may be interesting to note in this connection that with the growth of the Savings banks, the taxes have steadily increased from $\$ 119,767.58$, for the year 1872 , to $\$ 394,016.12$ in 1898 . The taxes at present levied are greatly in excess of the average taxation on all other classes of property in the State, and average about five-eighths of one per cent. on the average deposits, too great a load for the Savings banks to carry, considering the high price they have to pay for all first-class bonds.

In 1873 the Bank Examiner gave in detail not only a schedule of bonds and stocks, but a list of the securities held by each Savings bank as collateral for loans.

In 1877 the laws relating to Savings banks were revised and consolidated, and a clause enacted permitting a Justice of the Supreme Court of the State, upon proper representation, to reduce the amount due each depositor of a Savings bank so as to divide a loss pro rata among the depositors. This has proved a wise provision, because it enables an insolvent bank to clean up and put itself on a sound basis within a very few weeks, and thus save the depositors a long period of anxiety about the safety of the whole of their deposits. 
In the latter part of $187 \%$ a panic, confined wholly to the Savings banks, began in the State of New York, and passing eastward, reached the State of Maine in January, 1878. This was a crucial test of the strength of these institutions. So great was the stress that most of the banks were obliged to take notice from depositors, and State laws in some instances were found insufficient. This panic lasted during the whole year of $18 \% 8$. The strongest banks felt the strain almost equally with the lesser banks. But for the large amount of loans to individuals and corporations within the State, who were able to place their loans with the discount banks, the Savings banks would have had hard work to pay their depositors, and few, if any, would have been able to meet the demand made upon them. The loss of deposits up to November, 1878 , amounted to $\$ 3,779,046$.

On February 23 of this year the body of J. W. Barron, Treasurer of the Dexter Savings Bank, was found in the vault, bound and gagged, death following his discovery. A curious theory was started about a year after, that his death was self-inflicted, but experts failed to find any evidence of defalcation or any other reason for suicide, and two noted crooks, Stain and Cromwell, have since been convicted and are serving sentence as his murderers.

Between September, 1877, and September, 1878, thirteen Savings banks were compelled to avail themselves of the relief law of 1877 , and have their deposit accounts reduced. Most of these losses were restored to the depositors within a few years.

With the close of the year 1879 all traces of the panic in the Savings banks disappeared. There was only a slight decrease in deposits for this year, and every year succeeding has shown-with the exception of 1893-an increase in the deposits, and even in that year there was a loss of only $\$ 136,000$.

The following table shows the growth of Savings banks in Maine from 1879 to 1899 :

\begin{tabular}{|c|c|c|c|c|c|}
\hline Years. & $\begin{array}{l}\text { Number } \\
\text { of banks. }\end{array}$ & $\begin{array}{l}\text { Number of } \\
\text { depositors. }\end{array}$ & $\begin{array}{c}\text { Total } \\
\text { deposits. }\end{array}$ & $\begin{array}{l}\text { Amount of } \\
\text { reserve fund. }\end{array}$ & $\begin{array}{l}\text { Av. deposit } \\
\text { for each } \\
\text { depositor. }\end{array}$ \\
\hline $\begin{array}{l}1879 \ldots \ldots \ldots \ldots \ldots \ldots \\
1884 \ldots \ldots \ldots \ldots \ldots \ldots \ldots \\
1889 \ldots \ldots \ldots \ldots \ldots \ldots \ldots \\
1894 \ldots \ldots \ldots \ldots \ldots \ldots \ldots \\
1899 \ldots \ldots \ldots \ldots \ldots \ldots\end{array}$ & $\begin{array}{l}59 \\
54 \\
55 \\
51 \\
51\end{array}$ & $\begin{array}{r}75,443 \\
105,680 \\
132,192 \\
155,704 \\
\cdots \cdots \cdots\end{array}$ & $\begin{array}{r}\$ 20,978,139 \\
32,913,835 \\
43,977,085 \\
54,531,223 \\
62,583,434\end{array}$ & $\begin{array}{l}\$ 519,721 \\
1,098,431 \\
1,778,935 \\
2,189,256 \\
2,150,993\end{array}$ & $\begin{array}{r}\$ 278 \\
311 \\
332 \\
350 \\
\ldots\end{array}$ \\
\hline
\end{tabular}

In 1883 the Legislature approved an act organizing the Portland Trust Company and the Somerset Loan and Building Association. These were the pioneers of two systems of banking which have become important features in the State.

The total resources of the trust and banking companies as reported April 29,1899 , amounted to $\$ 10,023,364$, and the Savings banks to $\$ 65,932,906$, representing a total of $\$ 75,956,270$. 
One thing is noticeable in studying the tables which are annexed hereto showing the resources of the discount banks other than the Savings and other banking associations in the State, and that is that the State of Maine appears to be so far removed from the centre of speculation and panic resulting therefrom, that there is but little change in the condition of the banks after 1857 resulting from panies. The amount of banking capital in proportion to the population is very large, and there has been no run on the discount banks, and with the exception of 1878 no serious run or panic in the Savings banks.

The National banks, Savings banks, trust companies and loan and building associations, have total resources of $\$ 118,854,367$ in 1899 against $\$ 2,198,247$ in 1820 held by the banks then existing.

In the early banking history of the State there were some banks fraudulently organized. These were, however, exceptional, and as the Governor remarked in his message of May, 1845, the banks of Maine were probably as free from imperfections as those of any State in the Union, which fact he ascribed to the provisions of the banking law which fixed a limit on circulation and the extent of the indebtedness of directors, and providing that the stockholders should be liable for the debts of the bank, for official returns under oath, and for periodical inspection by Bank Commissioners.

\section{NEW HAMPSHIRE.}

\section{State Banks in New Hampshire.}

A company was formed in New Hampshire about 1735, and issued notes somewhat on the plan of the Merchants' Association, of Boston, but as the provisions for the payment of the notes were deemed inadequate, their eirculation was prohibited in Massachusetts. These notes were payable in New Hampshire, Massachusetts, Connecticut and Rhode Island bills, or in silver, gold or hemp, "at the unknown price they may be at Portsmouth, in New Hampshire, anno 1747, whereby his Majesty's good subjects will be great sufferers, should they part with their goods and substance for them or accept them in payment." *

The first bank in New Hampshire was the New Hampshire Bank, of

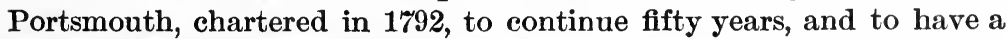
capital of $\$ 160,000$, and be managed by a President and seven directors. It continued to be the only bank in the State until after 1800, but from 1802 to 1806 several other banks were chartered. †The Concord Bank, of Concord, was ehartered in 1806, and was to run for twenty years. Soon after the charter was obtained a quarrel broke out between two parties into which the incorporation was locally divided-one representing the North and the other the South end of the town. The differences could not be reconciled, and two banks were started under

* Felt, "Maseachusetts Currency." + "Annals of Portsmouth," Mr. Davis, 1825. 22 
the same charter, each claiming to be the sole and only genuine institution.* There was a great bitterness of feeling between the two which found expression in constant plots against each other. A favorite plan was for one to gather up the bills of the other and make a run upon it for specie. The North-end bank seems to have kept possession of the charter, as the other end at length became exasperated enough to try to enforce its alleged rights in the courts. A suit was brought by one of the prominent South-enders, and a bill of complaint prepared containing one hundred causes of grievance. The celebrated Jeremiah Mason was retained to conduct the proceedings. He did not appear to think much of the case or the party who employed him, and suggested to his client that, as he had got into gentleman's company, he must pay gentleman's prices. This hint appears to have rendered the litigant more willing to accept a compromise which Mr. Mason succeeded in bringing about. This put a stop to the policy of annoyance, and shortly after the South-enders obtained a charter for themselves, and were known as the Merrimac County Bank. This remarkable case of twin stars in the banking galaxy of New Hampshire indicates how broad were the prerogatives given by a charter, especially when there were no penalties for enforcing its provisions.

\section{Banks Required to Make Reports.}

When the chartered banks became more numerous, it became necessary for the State to exercise some control, and an Act was passed June 21,1814 , which required annual reports to be made by the banks to the State authorities.

In 1831 there were twenty-one banks in the State with a capital of $\$ 2,065,310$ and circulation of $\$ 1,107,901$. In January, 1832 , acts were passed requiring the banks to make reports and also prohibiting the emission and circulation of bills of small denominations. On July 4, 1838 , owing to the cessation of specie payments and the consequent disappearance of small change, this last provision was suspended until July 1, 1840. The same act of suspension contained a provision that all loans on pledge of capital stock should be considered as reducing the capital, and circulating notes were not to be issued above amount of capital remaining after all such loans were deducted from it. This act was rendered necessary by the practice largely indulged in by stockholders of paying their subscriptions with stock notes, or what amounted to the same thing, of immediately borrowing back what they had paid in, in specie. The reports were to have been made within six days from the first Monday in June. Most of the New Hampshire banks at this date redeemed their notes in Boston at the Suffolk Bank.

In 1841, Governor Page believed that too many banks had been incorporated in the State, and said that throughout the nation peculation and fraud of such aggravated character had been committed by

$$
\text { *N. Bouton, "Hist. Concord." }
$$


those to whom the management of these institutions was intrusted as to become truly alarming. Most of the banks in New Hampshire had fulfilled their appropriate duties to the community with a considerable degree of fidelity. He referred to the approaching expiration of many bank charters, and said that the Legislature would have the opportunity of imposing important restrictions. Under the charters granted, the stockholders were liable as partners for the debts of the institution. In 1843, when many applications for renewal of charter were made, Governor Hubbard hoped this security would not be given up. In 1845 the number of banks in the State had by failure and liquidation been reduced to seventeen, with a capital of $\$ 1,587,488$, and circulation of $\$ 1,124,531$, as against twenty-six in 1841 , with a capital of $\$ 2,735,000$ and circulation $\$ 1,229,708$. In 1843 the circulation of State banks had gone down to less than $\$ 1,000,000$.

Among the banks which failed was the Concord Bank, which as has been mentioned, was chartered in 1806. By the original act the stockholders were jointly and severally liable for the payment of the bills issued by the institution, but when the charter was renewed in 1824 this section was omitted. Its capital was $\$ 100,000$ and its charter had been renewed twice by the Legislature and did not expire until 1846 . The Bank Commissioners in 1841 stated that no examination of the affairs of the institution had been made from 1812 to that time. In 1839 a statement of the debts due the bank was made by the Cashier and laid before the directors. This was the only statement ever laid before the board, and gave them the first intimation of certain large debts due the institution of which they had not before been aware. In 1840 the directors got certain parties to give a bond for $\$ 30,000$ to the Suffolk Bank to secure the latter for redeeming the bills of the Concord Bank, and to indemnify these bondsmen, gave them over $\$ 50,000$ of the best securities in the institution. This bond, not being satisfactory to the Suffolk Bank, was changed for one given by certain stockholders, and the securities to indemnify these stockholders were increased to over $\$ 80,000$. On obtaining this bond, the Suffolk Bank stopped redeeming, having over $\$ 29,000$ of the bank's bills already redeemed. After deducting the bills in the Suffolk Bank, for which it had given bond, there were outstanding $\$ 59,000$ in bills. The deposits, individual and bank, were about $\$ 70,000$. Out of $\$ 196,000$ bills receivable, the Cashier had borrowed directly $\$ 40,000$, and as surety with individuals and companies with which he was interested, about $\$ 90,000$ more. This management indicates the inevitable failure, and there appears to have been no way of punishing such gross misappropriation of the funds of the bank, except to take the depreciated property of the individuals concerned. At the time of its failure the bank had about $\$ 683$ in specie.

The crisis of 1809 caused several failures, and the notes of these banks were quoted in Boston at a discount of from thirty to sixty per cent. The Lancaster Bank, organized in 1833, had $\$ 50,000$ capital stock, 
only $\$ 12,500$ of which was paid up in cash, stockholders' notes being given for the balance. In 1837 the bank had $\$ 48,000$ outstanding circulation.

In the case of the failure of the Wolfborough Bank, it was found that one individual had borrowed $\$ 105,000$ out of a total loan of $\$ 142,000$, without any security except a lien upon previously mortgaged real estate. Its actual available means were about $\$ 19,000$ as against $\$ 132,000$ of liabilities. When the bank was incorporated, in 1834 , the entire capital, $\$ 100,000$, was paid in in cash by the subscribers, but was returned to them on the same day as a loan secured by a pledge of the bank's stock. The crisis of 1837-39 reduced the number of banks from twenty-eight in the latter year to seventeen in 1845.

In 1847 Governor Colby thought the New Hampshire Banking Law aristocratic in its operation, and that the unlimited liability of the stockholders forced the whole business into a sort of legalized co-partnership of the rich. He thought the laws should be modified to give more opportunity for investments in the banking business.

When the National banking system went into effect in 1863 , there were fifty-two State banks in operation in New Hampshire having $\$ 4,678,700$ capital, $\$ 4,192,034$ circulation, $\$ 1,725,866$ deposits and $\$ 356$,000 specie. By 1870 all but three of the State banks had entered the National system.

As early as 1799. a law was passed prohibiting private banking, and notes were payable unconditionally at place of issue. A later act made them payable in specie on demand. On July 5, 1837, a law was approved providing for a Board of Bank Commissioners to supervise the banks of the State. When the banking laws were revised in 1842, unchartered banks were still prohibited, and notes were to be payable in specie on demand. No notes were to be issued of a less denomination than one dollar, and the circulation was limited to four-fifths of capital stock. If a bank failed to pay in specie it thereby forfeited its charter. Quarterly reports of condition were to be made by the banks. By the act of June 27, 1857, banks were prohibited from commencing business until all the capital has been paid up in cash.

State Banks.*

\begin{tabular}{|c|c|c|c|c|c|c|}
\hline YEARS. & $\begin{array}{l}\text { No. of } \\
\text { banks. }\end{array}$ & $\begin{array}{l}\text { Loans and } \\
\text { discounts. }\end{array}$ & Specie. & $\begin{array}{l}\text { Capital } \\
\text { stock. }\end{array}$ & Circulation. & Deposits. \\
\hline $1834 \ldots . . . . .$. & 24 & $\$ 3,450,820$ & $\$ 354,390$ & $\$ 2,454,30$ ४ & $\$ 1,068,145$ & $\$ 314,971$ \\
\hline $1839 . \ldots \ldots .$. & 28 & $4,476,442$ & 187,961 & $2,939,500$ & $1,510,691$ & 522,036 \\
\hline $1844 \ldots \ldots \ldots$ & 19 & $2,760,009$ & 137,253 & $2,008,298$ & $1,021,914$ & 394,778 \\
\hline $1849 \ldots \ldots \ldots$ & 23 & $3,779,509$ & 155,707 & $2,178,000$ & $1,508,608$ & 443,629 \\
\hline $1854 \ldots \ldots \ldots$ & 36 & $6,891,621$ & 176,434 & $3,626,000$ & $3,079,548$ & 775,410 \\
\hline $1859 \ldots \ldots \ldots$ & 52 & $8,591,688$ & 255,278 & $5,016,000$ & $3,271,183$ & $1,187,991$ \\
\hline $1863 \ldots \ldots . .$. & 52 & $7,513,369$ & 356,000 & $4,678,700$ & $4,192,034$ & $1,725,866$ \\
\hline
\end{tabular}

* After 1863 the State banks were practically merged into the National system. 
The State banks of New Hamphire have been almost wholly merged into the National system, or have gone out of business, but there are a number of Savings banks operating under State laws. Their history is given in the following pages.

\section{National Banks.}

Figures are in thousands of dollars.

\begin{tabular}{|c|c|c|c|c|c|c|c|c|c|}
\hline DATE. & 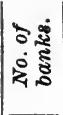 & $\begin{array}{l}\text { Loans } \\
\text { and dis. } \\
\text { counts. }\end{array}$ & $\begin{array}{c}U . S . \\
\text { bonds. }\end{array}$ & $\begin{array}{c}\text { Cash } \\
\text { and cash } \\
\text { items. }\end{array}$ & Capital. & Surplus. & $\begin{array}{l}\text { Undi- } \\
\text { vided } \\
\text { profits. }\end{array}$ & 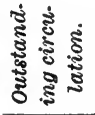 & $\begin{array}{c}\text { Indi- } \\
\text { vidual } \\
\text { deposits. }\end{array}$ \\
\hline $1863 \ldots$ & 1 & $\$ 37$ & $\$ 63$ & ...... & $\$ 100$ & ...... & $\ldots \ldots$ & ......... & .......... \\
\hline $1868 \ldots$ & 40 & 4,264 & 5,932 & $\$ 830$ & 4,785 & $\$ 501$ & $\$ 420$ & $\$ 4,255$ & $\$ 2,063$ \\
\hline $1873 .$. & 42 & 6,535 & 5,521 & 800 & 5,135 & 910 & 582 & 4,556 & 2,899 \\
\hline $1878 \ldots$ & 46 & 6,547 & 5,561 & 867 & 5,740 & 1,031 & 539 & 5,048 & 3,166 \\
\hline $1883 .$. & 49 & 8,537 & 6,351 & 1,026 & 6.155 & 1,198 & 560 & 5,278 & 4,983 \\
\hline $1888 \ldots . .$. & 49 & 10,150 & 4,127 & 1,194 & 6,205 & 1,497 & 735 & 3,277 & 6,362 \\
\hline $1893 \ldots . .$. & 51 & 10,919 & 3,864 & 869 & 6,130 & 1,548 & 769 & 3,255 & 7,931 \\
\hline $1898 . .$. & 51 & 11,258 & 4,780 & 1,041 & 5,830 & 1,419 & 545 & 3,494 & 9,928 \\
\hline
\end{tabular}

\section{SAVINGS BANKS.}

Probably no State has had such a varied experience with Savings banks as New Hampshire. The mutual Savings bank has been in existence since the beginning of these institutions in 1823, the guaranty or stock Savings bank since 1871, and the Savings bank department of trust companies since 1885 . Investments were practically unrestricted until 1893, and legislation for the control of Savings banks and the regulation of the character and amount of their purchases was fitful until two years later. The Savings institutions of New Hampshire have paid the highest rate of dividends and the largest tax on deposits of any Savings banks in the country. The deposits have been the most per capita of any State in the Union, and for several years New Hampshire stood fifth in rank in the United States in the amount of her savings deposits, being exceeded only by New York, Massachusetts, Connecticut and California. The State has received more in taxes from the Savings bank deposits since 1863 than from any other one source, and in $\mathbf{1 8 9 3}$ the deposits of the Savings banks were quadruple the value of all the railroad property of the State, including rolling stock and equipment, four times the value of the manufacturing plants of the State, and equal to two-thirds of the value of all the lands and buildings of the State. The Savings bank tax on resident deposits is divided among the towns of the State in the proportion that the deposits of their inhabitants bears to the total deposits, and before the reduction of the tax in 1895 it was sufficient in nearly all the towns to pay their 
State tax. The tax on non-resident deposits goes to the literary fund, and has been a most valuable contribution to the common schools.

\section{Effects of the Panic of 1893.}

The panic of 1893 , owing to the character of the investments, menaced every Savings bank of the State as like institutions have at no time and in no place been menaced; and for a period of a few months it was not thought possible for more than a few of the strongest institutions to weather the storm. Yet a large majority of the banks passed safely through the crisis, and there are several of these institutions to-day which in solidity and strength are not surpassed by any similar institutions in the country. For the decade from 1880 to 1890 there was a great augmentation of Savings banks and Savings institutions, occasioned by the belief that guaranty or stock Savings banks would be a source of great profit to the stockholders. Charters were granted by the Legislature beyond the needs of the people and the wants of the community, and deposits flowed into the State becanse of the high rate of dividends paid. There was a rivalry of Savings banks to secure deposits, and they were invited by advertisements of the guaranteed rates of dividends paid. Following the summer of 1893, institution after institution was put under injunction until more than one-fourth of the entire number were in the hands of the court; yet there was not during all this time any general run on the Savings banks of the State. The weak banks and the unnecessary institutions went into liquidation, while the strong banks passed through the storm with public confidence unimpaired. It required this experience to convince the Legislature that large dividends and large revenue from taxes were not the sole indications of prosperity and stability, and that well-guarded lines of investments and well-devised rules of control were as obligatory on the State as the chartering of these institutions.

\section{The First Savings Banks Chartered.}

Seven years after the first Savings bank was chartered in this country two were chartered by the New Hampshire Legislature, the Portsmouth Savings Bank, at Portsmouth, and the Strafford Savings Bank, at Dover. Philanthropic motives were the basis of their inception. Manufacturing establishments were multiplying in the State, families were drawn from the rural communities to the villages because of the opportunities for employment; men, women and children were working in the mills and during such employment were receiving and spending larger wages than could be obtained on the farm. There were periods of business adversity which threw these people out of employment, and improvidence in prosperity brought as a sequel suffering in times of financial depression. Pauperism was prevalent, and as a cure of the evil Savings banks were started. They were to teach the people 
habits of thrift and independence, and well they have served the purpose of their creation.

Four years earlier, in 1819, the first attempt was made in New Hampshire to obtain a charter for a Savings bank, the petition coming from the citizens of Portsmouth. A bill was introduced in the house and passed that body, but was defeated in the Senate. There is nothing in the records of the Legislature or in the newspapers of the times to indicate why the bill failed to receive the approval of the Senate, but in 1823, when the charter for the Portsmouth Savings Bank was passing through its various stages in the house, a leading member remarked that as the principles of the bill were new and required some consideration, he moved that it be referred to the judiciary committee. It was probably conservatism in dealing with the untried that postponed for four years the chartering of Savings banks in New Hampshire. The petitions for both the Portsmouth and Strafford Savings Banks were presented at the same session in 1823, and the bills for both passed without debate in either body of the Legislature, and were approved by the Governor respectively June 26 and July 1 . The Portsmouth Savings Bank received its first deposit August 20, 1823, and the Strafford Savings Bank February 28, 1824. They are still in existence, and are two of the strong Savings banks of the State.

These two charters were granted in perpetuity, but the practice thereafter was not uniform. For a time the limit of twenty years was placed upon these grants, and they were renewed by the Legislature upon expiration until 1883, when all Savings bank charters were made perpetual. From 1823 to 1871 all charters were mutual, the depositors receiving all the profits and bearing all the losses incident to the investment of their deposits. These charters contained few, if any, restrictions beypnd limiting the holdings of real estate and prohibiting the issue of currency and the payment of any compensation to the officers except to the Treasurer or Secretary. The corporation was authorized to make by-laws, and some of the early Savings banks were given authority to receive deposits of money and "other personal property" under such conditions as the by-laws might prescribe. It is possible that there was a contemplation that the strong box of the Savings bank would be used as a safety-deposit vault for the storage of plate and other valuables, but if so, there does not appear to have been any general use of the same for this purpose, or that the banks derived any profit therefrom. The books and accounts were to be open to the inspection of the Governor of the State, any Justice of the Supreme Court of Judicature, or to any committee of the Legislature appointed for that purpose by either house.

From 1823 to 1838 six additional Savings banks were chartered, only two of which are now in operation. The Exeter Savings Bank, at Exeter, was the third Savings bank in the State to be chartered, in 1828 , and it was the first to fail and close its doors. No supervision of 
the Savings banks was attempted by the State until the Exeter Bank got into difficulty about the year 1841. The Legislature of that year passed a joint resolution making it the duty of the Bank Commissioners of the State, who then had supervision of discount banks, to make an examination of the Savings banks whenever directed by the Governor, and report their findings to him. The Governor was also authorized to appoint, with the advice of the council, one or more suitable persons as trustees to take possession of any Savings bank not properly conducted by its own officers, and to close up its affairs. In accordance with this authority, Governor Hubbard, in 1842, appointed three trustees to take possession of the Exeter Savings Bank. These trustees, having qualified, made a demand upon the officers of the Exeter Bank for its property, but their right to take possession was disputed by the Savings bank officers. The State trustees immediately filed a bill in equity to obtain possession of the property, and a temporary injunction was granted by the court restraining the corporate trustees from meddling with the property of the bank until a hearing could be had. At the hearing in December of that year, the injunction was dissolved, the bill dismissed, and the State trustees reported the facts to the Governor, announcing that by the decision of the court they were relieved of any further duty in the premises. Although the State trustees failed to get possession of the property of the Exeter Savings Bank, its affairs were soon after wound up by its own officers.

The failure of the Exeter Savings Bank checked the granting of charters for Savings banks for several years. In the years 1842 and 1844 applications were made for charters for the Amoskeag Savings Bank at Manchester, the Somersworth Savings Bank at Somersworth, and the Walpole Savings Bank at Walpole. Although the bills for these charters passed the House, they were defeated in the Senate. In 1845 the Somersworth Savings Bank obtained a charter for a term of twenty years, and in 1849 the Walpole Savings Bank was incorporated, but did not then take advantage of its charter, and it was not until 1852 that the Amoskeag Savings Bank secured its charter, although in 1846 a charter was granted for a Savings bank at Manchester, to be called the Manchester Savings Bank.

\section{Growth of Savings Bank Deposits.}

The growth of deposits for the first twenty-five years of the history of Savings banks in New Hampshire was very slow. In 1850 the total deposits were only $\$ 1,600,000$. Forty-three years later, in 1893, the total deposits of the Savings banks alone were, in round numbers, $\$ 75,000,000$, while the savings deposits of trust companies amounted to two million dollars more. June, 1893, was the high-water mark of Savings bank deposits in New Hampshire. Since then, owing to the panic of that year, unfortunate investments in the West, the necessary reduction of dividends owing to the decrease in interest rates, and the large 
tax imposed by the State on Savings bank deposits, there has been a large decrease in the volume of deposits, together with the failure of quite a number of Savings institutions. From 1850 to 1893 there was a steady increase of deposits, with the exception of four years, 1858, 1874, 1878, and 1879. The number of Savings banks in 1850 was twelve; in 1893 there were seventy. In 1850 the total deposits of the Savings banks of the State were $\$ 1,600,000$. In 1893 there were twenty-three Savings banks that had deposits of over one million dollars each; ten with deposits of over two millions; five with deposits of over four millions, and one with deposits of over seven millions. In 1850 there were 13,000 open accounts in the Savings banks proper. In 1893, there were 174,000 . In 1850 the average to each account was $\$ 125$; in 1893 it was $\$ 425$. In 1850 the deposits averaged to each person in the State $\$ 5.16$; in 1893 the average was $\$ 200$. For a period of several years prior to 1893 New Hampshire had the largest amount of Savings bank deposits per capita of any State in the Union.

In 1898 there were but fifty-two Savings banks in active operation, and the total amount of deposits was, in round numbers, $\$ 50,000,000$; twelve Savings banks had more than one million deposits each, six had over two millions deposits, five over three million deposits, four over four million, two over five million, and one over seven million. There were thirty Savings banks, and trust companies with Savings bank departments, that were under temporary or permanent injunction of the court. Some of these are undergoing reorganization; but the remainder are in voluntary or forced liquidation. There are six trust or banking companies with Savings bank departments that are now in operation, and their savings deposits amount to $\$ 1,842,578.37$. The number of open accounts of the Savings banks proper in 1898 was 120,382 , and the number of these accounts in the savings departments of trust or banking companies was 6,131 . Of these accounts in the Savings banks those aggregating $\$ 500$ or less were 93,009 ; those over $\$ 500$ but not exceeding $\$ 1,000$ were 14,495 ; over $\$ 1,000$ but not exceeding $\$ 2,000,8,679$; over $\$ 2,000$ but not exceeding $\$ 5,000,3,648$; over $\$ 5,000$ but not exceeding $\$ 10,000,491$; over $\$ 10,000$, sixty. In the savings departments of the trust companies the size of the accounts is relatively the same.

The charters for the mutual Savings banks provided for a corporation which elected trustees, to whom was given the management of the institution. These trustees were elected annually, and in turn chose the President and Treasurer and executive officers of the bank. The trustees were selected as a rule from among the successful business men of the community, and as they received no compensation for their services the office of trustee came to be regarded as an honorary position, conferring a certain mark of distinction and public confidence. In the early history of these institutions the deposits were mainly the savings of people of small incomes who were not qualified to make judicious 
,

investment of their savings. The volume of deposits was small, and the burden and responsibility resting upon the trustees was light. The general management of the banks was conservative. Years later, when the deposits aggregated millions, and the Savings banks were used by people of means as a place of deposit and investment, the labor devolving upon the trustees became, in some instances, quite a tax, and the duty that was once cheerfully borne because of the philanthropic character of these institutions was delegated to the executive officers or to committees, or to the Treasurer, or neglected altogether. It was then seen that the provisions of the charters that trustees should not receive compensation for their services worked to the disadvantage of the banks. But it was not until 1881 that this prohibition in the charters was remedied by the Legislature, and the Savings bank trustees were authorized to pay themselves and the President of the bank reasonable compensation for services rendered.

\section{Organization of Guaranty Savings Banks.}

Repeated failures of Savings banks through the neglect of trustees to attend to their duties was one of the reasons assigned for the establishment of guaranty Savings banks, so-called. The first of this class of Savings banks was chartered in 18\%1. The charters provided for a permanent paid-in guaranty fund, to be at all times equal to ten per cent. of the deposits, which could not at any time be reduced below that percentage. and no part of it could be withdrawn except by permission of the Bank Commissioners. Two classes of depositors were createdthe owners of the guaranty fund or capital stock, who were called special depositors, and the general depositors, who were the same as depositors in mutual Savings banks. To these special depositors was given the control of the management of the bank, and they elected the trustees who invested its funds. All profits in excess of a fixed rate of dividend to the general depositors went to the stockholders, or owners of the guaranty fund. In nearly all the charters for guaranty Savings banks the rate of dividends to the general depositors could not be less than four per cent., a defect which was afterwards cured by general legislation. One of the earliest of these Savings banks was so successful in its investments that it not only paid the guaranteed rate of dividend to the general depositors, but extraordinary profits to its stockholders. Its success led to a large number of applications for this class of charters, not a few of them coming from localities where there was no demand for additional Savings bank facilities. It was urged in behalf of this class of banks that the owners of the stock or guaranty fund, having a financial interest in the success of the institution, would be more careful in making investments, and that in addition to the protection afforded to the general depositors by the guaranty fund, there would be less failures because of the conservative management thus secured. It was a taking argument with the Legislature, and for nearly 
two decades this was the only kind of Savings bank charter granted. It was about this time that the Savings banks were beginning to invest in the West, where high rates of interest were paid. Rates on western loans to the eastern investor ranged all the way from seven to twelve per cent., and after paying four or five per cent. dividend to the general depositors there was a large amount of profit to the stockholders. So long as these high rates prevailed in the West and good judgment was exercised in making investments, the guaranty Savings banks seemed to justify their creation, but in the long run it was found that the stockholders were more earnest to make profits on the capital stock they had invested than to look after the safety of the general deposits which they guaranteed. Soon came suspension and failure.

In 1895 a test was made in the Legislature against the granting of any more guaranty Savings bank charters, and since that time all charters for Savings banks have been of the mutual character. In 1893 the Bank Commissioners protested against the granting of trust company charters with Savings bank privileges, and since that time charters for transacting a discount bank business and a Savings bank business have been kept separate. None of the guaranty Savings bank charters granted since 1889 have been used by the incorporators. This class of Savings banks was popular for a period of twelve years. What might have been their history under wise laws regulating the investments of Savings banks, it is impossible to tell. There is to-day no demand for such charters. In the condition of affairs that existed from 1871 to 1893 it is now clear that they never ought to have been chartered. The experience of New Hampshire has demonstrated that the original theory of a Savings bank is the correct one in practice.

\section{Trust Companies.}

In 1885 began the chartering of trust companies, so-called. The early ones were created for the purpose of doing a western loan business, but the provisions of the charters were so liberal that they were soon construed as giving authority to do, in addition, both a local discount and Savings bank business. The capital invested was the sole protection of these varied interests. Some of the larger ones not only bought and sold western loans, guaranteeing a considerable amount of those sold, and issued debentures on their own securities placed in trust, but also invited and secured quite a line of business and savings deposits. In 1889 the commissioners procured the passage of a law requiring these companies to conduct their Savings bank business as a separate department, and making it amenable to the Savings bank laws of the State, which especially required them to create a guaranty fund out of their earnings.

As soon as these charters were construed as giving authority to do both a Savings bank and discount business there were a number of applications made for them from small towns having no banking facilities 
and desiring both a discount bank and a Savings bank. With four exceptions the charters granted were used solely for these two purposes. The commissioners opposed the granting of this form of charter, and in 1893 successfully defeated an attempt to secure another at the hands of the Legislature. The applicants were obliged to accept two distinct charters, one for a discount bank and one for a Savings bank, neither of which was used. Since then no attempt has been made to secure one of these charters. The reports of those now in existence show two distinct departments, the investments of the savings department being in accord with the law regulating investments; and the court has held, in the case of those in liquidation, that the savings depositors had a prior lien on the assets of that department. There are now six of them in operation; but their aggregate deposits are less than $\$ 2,000,000$, nearly half of the aggregate being in one institution.

\section{LIMITATIONS UPON INVESTMENTS.}

As remarked in the introductory paragraph of this article, legislation in New Hampshire for the government of Savings banks and the regulation of their investments was fitful up to the year 1895. If a Savings bank got into difficulty through the mismanagement or dishonesty of its officers, or through improper investments, the next Legislature was besought to enact a specific law to remedy the particular trouble. These spasmodic statutes were added to, amended and repealed as influence was brought to bear upon the Legislature. Severe penalties were imposed for certain palpably dishonest transactions, but it was not until 1869 that any attempt was made to regulate the investments of Savings banks. Then a law was passed requiring one-half of the deposits of any Savings bank to be invested in securities within the State. Five years later this was supplemented by an act which forbade Savings banks investing any part of their deposits in the stock of any railway or manufacturing corporation. These two acts remained unchanged until 1881, when they were repealed, and in place thereof the following law was passed :

"No Savings bank shall loan to any person or corportion, firm and its individual members an amount in excess of ten per cent. of the deposits and accumulations of such Savings bank, nor purchase or hold both by way of investment and as security for loans the stocks and bonds of any corporation to an amount in excess of such ten per cent."

For the next ten years this was the only limitation placed upon Savings bank investments, and this decade was the one in which the mania for western investment was at its height.

The law of 1869, which forbade the investment of more than onehalf of the deposits outside of the State, was seldom enforced, and soon became a dead letter. The law of 1881 was practically no restriction upon investments. The limitation of investments in stocks and bonds to ten per cent. of the deposits, while it prevented the putting of all 
the eggs into one basket, did not shut out a class of purchases which were entirely foreign to the business of a Savings bank.

The earliest western ventures of Savings banks were in farm loans, and in this for a time a profitable business was transacted. If these investments had been confined to a limited area in the West, and had been made with the same care that like loans were made at home, little trouble would have resulted therefrom ; but so large were the early returns and so profitable were these investments to both corporations and individuals, that Savings bank officers began to look upon all western loans and securities as equally good, and the funds of New Hampshire Savings banks were sought for the promotion of all kinds of enterprises in the West. During this period the deposits grew from about thirty million dollars to seventy million dollars. The Savings banks were generally paying five per cent. dividends to their depositors. The State was reaping a handsome income from its tax on Savings bank deposits. Interest and dividends on western securities were regularly paid, and the people of the State were led to believe that this seeming prosperity had a sure foundation. Although the Bank Commissioners sounded a warning note as early as 1888, and repeated their admonitions in each successive report, it was impossible to secure legislative action until disaster had overtaken the banks. An attempt was made in 1891 to secure the co-operation of the banks in the passage of legislation which the best of financiers deemed to be necessary ; but nothing came of it, and a tentative measure introduced early in the session for the purpose of calling attention to the subject was indefinitely postponed without debate, about the middle of the session. The Bank Commissioners, however, went before the joint committee of both branches of the Legislature, which had in charge the work of the commissioners appointed to revise and codify the statutes, and asked them to insert some restrictions in the revision of laws. It was towards the close of the session. The time was too short in which to frame a detailed investment law, and this committee confined itself to making certain limitations of investments and certain prohibitions.

Mild as were its provisions, it was strenuously objected to by some of the Savings bank officials, and would have been strongly opposed in the Legislature if opportunity had been afforded for discussion. The committee on revision of the statutes did not submit its report until the closing week of the session. That report comprised nearly three hundred amendments to existing laws, and it had to be adopted or rejected in its entirety, or the legislative session prolonged for several weeks. Included with these amendments were the Savings bank provisions referred to above, and thus the first effective restrictions on Savings bank investments were secured.

The change in public sentiment during the next four years was rapid; and although the Legislature of 1893 did nothing for the relief of the Savings banks, the Legislature of 1895 was rpe for action. That 
year the Bank Commissioners prepared two bills, which were presented to the Legislature by the chairman of the board, who was a member of the House-one regulating the management of Savings banks, and the other defining their investments. Both bills were passed in substantially the form in which they were presented, and are the law to-day with only slight modifications. Almost no opposition was made to their passage, for it would have been fruitless if it had been attempted. A large number of Savings banks were under injunction, and there had been a large withdrawal of deposits therefrom. The investment law has worked, in the main, very satisfactorily. Very few complaints have been made of its operation. Its provisions are much more liberal than the Massachusetts statute, and offer larger latitude for investments outside the State. This is necessarily so, because there is not the home demand for money in New Hampshire that there is in Massachusetts.

It was this lack of local demand for money which first sent the Savings bank officers to the West for investments. It is too early even now, although six years have intervened since the panic of 1893, to write dispassionately of the western investments for New Hampshire Savings banks. Much has been said in a eritical spirit of these investments which is not justified by the facts. Savings bank officers and western people have been very frequently unjustly criticized. That the business was overdone and frequently recklessly done, cannot be disputed. This was equally true, though in smaller amounts, of investments nearer home. The first experience of individuals and corporations in the West were so generally successful and profitable that one after another conservative financiers connected with the Savings banks of New Hampshire yielded to the general impulse and purchased of this class of securities. Like any popular mania it could not be restrained until trouble was brought forcibly home to the investors. The Savings banks were able to pay a higher rate of dividends than were paid by those of other New England States. This satisfied the depositor, and he joined with the bank officials in deprecating legislative interference with the investments of Savings banks. The towns of the State were receiving a larger tax from the Savings banks than was levied in any other State. This revenue enabled the towns to pay their State tax and in some instances almost the county tax as well. If the Savings bank investments were to be restricted, said the Savings bank officials, then the Savings bank tax should be reduced, to put New Hampshire Savings banks on a plane of equality with those of adjacent States. Representatives from the towns of the State in the Legislature objected to the reduction of the tax because it lessened the revenue with which they paid their State obligations.

In this condition of affairs, when the Savings banks seemed each year to be growing larger and stronger, there was little thought of danger and no disposition to guard against it. The Savings bank managers seemed drifting with the tide. They invested their own private funds 
in the same class of securities that they invested the depositors' money. When the trouble came it overtook them as well as the institutions they were managing. It is to their credit that with the largest opportunity for illegitimate gain, very few instances were shown where any Savings bank officer profited by his connection with western investments at the expense of the depositor.

\section{State Supervision of Savings Banks.}

State supervision of banking institutions was first established in 1837, and then related only to the discount banks of New Hampshire. Ten years later the Bank Commissoners were required by statute to annually examine Savings banks and report their condition. No specific power was lodged for many years in the hands of the Bank Commissioners, and for a long time there were no laws relating to the control of Savings banks or their investments which they were required to enforce. Their duties were merely to make an examination of these institutions and report their findings to the Legislature, or to the Governor. For a number of years their supervision was merely perfunctory. This was due in part to the small number of Savings banks, their slow growth, and the greater number and importance of the discount banks, whose affairs they were also required to examine. The pay of the commissioners was small, consisting of a per diem and mileage which for a long time was collected by them of the Savings banks at their examinations. The Savings bank officers for many years regarded these examinations as an impertinent interference, and were inclined to pay more liberally if the commissioner was uninquisitive and took a speedy departure than if he too closely questioned into their conduct of business. The terms of the commissioners were at various times one, two, or three years, with reappointments the exception rather than the rule. There was no continuity of their work, owing to the fact that a change of State administration frequently made an entire change in the personnel of the commission.

From 1837, when the Bank Commission was ereated, until 1887, a period of fifty years, it was without an office in which to file its papers or do its work. When an examination was actually made the papers were treated as the private property of the commissioners and were either destroyed or lost. In 188\%, when new appointments of commissioners were made, there was not a scrap of paper on file anywhere to show what the Bank Commissioners had done outside of the published reports, and the Bank Commission had not even a set of these. In 1883 the first step was taken by the Legislature to make the office more effective, when it was provided that the commissioners should be paid by the State instead of by the banks, thus making them independent of the institutions they were called upon to examine; and two years later provision was made for an office at the capital, but the commissioners did not avail themselves of it until 1887. It was not until 
1889 that the commission was put upon a permanent basis for systematic and continuous work. Then provision was made for a board of three commisioners who should serve for a term of three years, the first appointments being for one, two and three years respectively, so that the term of no two commissioners would expire the same year. They were paid an adequate annual salary and their actual travelling expenses. Two of the three first appointments made after this act were re-appointments of the then commissioners, a practice which has prevailed with only two exceptions since that time. The work that has been performed by this continuing board is shown by their reports, and is to be found in the statutes of the State. The office is now considered the most important one in the State, and a high degree of efficiency is expected by the public. Their examinations are no longer regarded as intrusions by Savings bank officers, and they are now generally attended by one or more members of the board of trustees. Their recommendations to the Legislature carry more weight than those of any other board in the State. Since 1895 they have secured practically all the legislation they have asked, and have been instrumental in preventing much unwise legislation. Through their efforts the system of bookkeeping of the Savings banks has become uniform, and the records to be found in their office contain a minute history of every Savings bank in the State since $188 \%$.

There is much of interest which might be written of the history of New Hampshire Savings banks during their early period, but it is in nowise uncommon to the story of the growth of these institutions anywhere. In the scope of this article the intent has been mainly to trace their development and to sketch those features which have been exceptional to New Hampshire. There is also the story of individual banks, which would be interesting reading in different periods, but beyond the limits of this sketch. There have been able financiers at the head of some of these institutions, as an examination of their securities will show. The legislation of recent years enacted for the protection of the Savings banks came largely from study of the experience of these men. If the failures of New Hampshire Savings banks have been exceptional in number in the last decade, so has been the recovery from the troubles which at one time beset them. With few exceptions, the service rendered by the officers has been inadequately paid. The laws of the State have been liberal enough in this respect; but while the deposits expanded beyond the conception of the philanthropists who originated the Savings corporation, the trustees in rewarding themselves and their executive boards have clung closely to the original theory of a benevolent institution. There will be fewer institutions hereafter, but they will be stronger. This is not wholly due to recent experiences. It is the tendency of the times. The present means of transportation and improved mail facilities have done away with the necessity of Savings banks in many country towns. The banks in the larger centers can not only serve larger areas of terri- 
tory, but can pay for that skill and training so essential to financial success. The depositors of New Hampshire have at no time lost faith in these institutions. With the revival of business activity has come an increase of deposits. The general decline of interest rates, and the general reduction of Savings bank dividends in all parts of the country, are satisfying depositors that the Savings banks of New Hampshire are investing money as profitably as like institutions of other States. The growth of deposits, drawn as they mainly are from the wage-earners, will hereafter be normal. There will be a considerable increase shortly from the payments of dividends of banks now in liquidation, which are not included in the tables for 1898. It will be some time before the aggregate reaches the maximum of 1893 ; but the growth will be healthy, and the increase natural. No other State has contributed so much, in proportion to its population, of the savings of its people to the development of the country, for the investments of these institutions cover a large range of territory. They are permanent monuments of the industry and thrift of New Hampshire people. Safeguarded as they now are, their accumulations will hereafter, as heretofore, contribute both to the needs of the depositors in the day of adversity and to the material prosperity of the State and the nation.

\section{New Hampshire Savings Banks.}

Table showing the number, condition, and progress of the Savings banks of New Hampshire in each period of five years from 1850 to 1898, inclusive.

\begin{tabular}{|c|c|c|c|c|}
\hline YEAR. & $\begin{array}{l}\text { No. of } \\
\text { banks. }\end{array}$ & $\begin{array}{c}\text { No. of } \\
\text { depositors. }\end{array}$ & $\begin{array}{c}\text { Amount of } \\
\text { deposits. }\end{array}$ & $\begin{array}{c}\text { Average to } \\
\text { each } \\
\text { depositor. }\end{array}$ \\
\hline 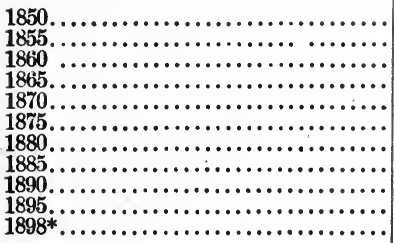 & $\begin{array}{l}12 \\
17 \\
26 \\
29 \\
45 \\
68 \\
67 \\
68 \\
72 \\
67 \\
52\end{array}$ & $\begin{array}{r}13,031 \\
21,300 \\
30,828 \\
43,572 \\
70,918 \\
96,938 \\
89,934 \\
121,216 \\
159,782 \\
163,702 \\
122,223\end{array}$ & $\begin{array}{r}\$ 1,641,543 \\
3,341,256 \\
4,860,024 \\
7,831,335 \\
18,759,461 \\
30,214,585 \\
28,204,791 \\
43,827,356 \\
65,727,019 \\
66,746,702 \\
49,997,654\end{array}$ & $\begin{array}{l}\$ 1 / 5 \\
156 \\
157 \\
179 \\
264 \\
327 \\
313 \\
361 \\
411 \\
407 \\
409\end{array}$ \\
\hline
\end{tabular}

* Only banks in active operation included. Fifteen banks under injunction are in liquidation or undergoing reorganization. Not all of the shrinkage of 1896 to 1897 is permanent. The greater part of the deposits is still in banks. Some of it in those in liquidation will be withdrawn upon payment of dividends and deposited elsewhere in the State. There will be a large increase from this source within a few years to swell the accounts of active banks. Probably $\$ 8,000,000$ of deposits in banks under injunction will be redeposited in the State after withdrawal. It seemed better to estimate what would thus be redeposited than to include any deposits in banks under injunction with those in active operation in completing the figures for 1898. 


\section{VERMONT.}

Owing to the lack of specie and good bank bills in circulation, and the large amount of counterfeit and depreciated paper of various kinds which found its way into the hands of the people, the business interests of the State suffered severely from 1781 to 1806 . Temporary relief was afforded by a limited issue of bills of credit by the State, but the distress continued to be acute. But the people were opposed to creating a State bank, a proposition for that purpose having been defeated in 1787 by a vote of 456 to 2197. In 1803 the Legislature granted charters to two banks, but the bills were vetoed by the Governor and Council. The grounds upon which executive approval was withheld were because it was declared that the issue of bank bills would drive specie out of circulation and expel it from the country, and would foster speculation, and

"Because banks, by facilitating enterprises both hazardous and unjustifiable, are natural sources of all that class of vices which arise from the gambling system, and which cannot fail to act as sure and fatal, tho' slow poisons, to the republic in which they exist."

It was also asserted that banks tended to draw off the dependence of debtors from their own exertions as means of payment, and to rely on incurring new debts to discharge the old. Not only was there hostility to a bank owned by the State, but to the organization of banks by individuals. It is interesting to note that with the growth and development of the State this hostility gradually became less and finally disappeared. The prejudice against banks seems to be strongest in those communities where such institutions are most needed to promote industry and trade, and is but little known in those countries that have reached a high degree of wealth and civilization.

There was a growing perception of the difficulties in the financial situation cansed by the increase in circulation of bills issued by banks in various States, whose soivency no one could determine, and in $\mathbf{1 8 0 6}$ a bill was passed by the Legislature incorporating the Vermont State Bank, owned by the State and managed by a board of thirteen directors chosen by the Legislature. Offices were established at Woodstock and Middlebury and afterwards at Burlington and Westminster. These branches were subsequently consolidated with the bank at Woodstock.

The Treasurer of the State advanced about $\$ 500$ to buy plates and paper for manufacturing notes, which was all the capital the bank had. No bills were to be issued in excess of the specie on hand until that should amount to $\$ 25,000$, after which an issue amounting to three times the specie was authorized, up to $\$ 300,000$. It seems that prospective borrowers advanced the bank $\$ 25,000$ in specie, in return for notes, dollar for dollar, and when the required amount was reached 
the bank was able to lend them its notes. The issue of notes was begun in February, 1807, and by September 30 the bank had loaned $\$ 139,757$. These bills were of the denominations of 50 cents, 75 cents, $\$ 1, \$ 1.25, \$ 1.50, \$ 1.75, \$ 2$ and $\$ 5$.

In order to facilitate the collection of debts due to the bank, the Cashiers were practically given the powers of a court of record and authorized to enter judgments summarily and issue execution on all debts due more than three days. In 1810 loans were restricted to twice the specie on hand, and in no case to exceed $\$ 1,000$ to any one person or company. The bills were made a legal tender for taxes and in redemption of property sold for taxes, but the affairs of the bank were tending toward insolvency and these expedients were ineffective. In 1812 a land tax of one cent per acre was assessed to pay the bills of the bank, which was being closed up as rapidly as possible, but the final liquidation did not take place until 1845. It is estimated that the loss to the State in conducting the bank was about $\$ 200,000$; other creditors were paid in full.

In 1817 a charter was granted to a bank at Windsor, with a capital of $\$ 150,000$, but as the charter contained a clause making stockholders liable for all demands against the bank which should not be paid within three days from the time they became due, the organization of the bank was not completed. A charter wa $\approx$ obtained in the following year without this provision. The Windsor and Burlington banks, incorporated in 1818 , had $\$ 100,000$ and $\$ 150,000$ capital respectively. In 1821 the Brattleboro Bank was incorporated with $\$ 100,000$ capital, and from 1824 to 1827 several other banks were chartered, there being ten in existence in the latter year. There was not at this time any general statute governing the organization and management of banks, but they were regulated by the respective charters. They were allowed to begin business upon paying in a nominal amount of their capital. The banks were required to pay their bills and other liabilities on demand in specie, and were prohibited from dealing in goods or real estate. Interest charges were limited to six per cent., and the total debts of the banks could not exceed their deposits and three times their capital. This practically limited the circulation to three times their capital. For any excess of indebtedness the directors were made liable, and as a further security to the public they were required to give bonds to the State Treasurer, usually in the sum of $\$ 8,000$ for the faithful performance of their duties.

\section{Banking Under the SAFETy-Fund System.}

In 1831 an act was passed modelled closely upon the "Safety-Fund Act," of New York. Its leading object was to ereate a fund out of which the creditors of any bank that should become insolvent might be paid. For this purpose each bank thereafter chartered was required to pay into the State Treasury the sum of four and one-half per cent. 
upon the amount of its capital stock, in six annual installments. In case the fund was reduced by the failure of any banks it was to be made up by assessments by the State Treasurer upon the several banks, not exceeding three-fourths of one per cent. in one year. The fund, until used for the purpose designated, was to remain the property of the respective banks contributing, and the balance of the income from its investment, after deducting the expenses of Bank Commissioners, for whose appointment provision was made, was to be paid to such banks, annually ; and on the expiration of the charter of any bank its contribution to the fund, if not required to indemnify the creditors of any other bank which had become insolvent, was to be returned by the Treasurer.

This act also provided that no bank should go into operation until at least one-half the eapital was paid in. In other particulars the banks were to be governed by their charters, which were renewed under the act of 1831 without important modification. In place of the annual tax of six per cent. upon dividends, which the State had previously imposed, a tax of ten per eent. on profit was substituted. The act of 1840 imposed still further stringent regulations upon the business of banking, requiring that before beginning business one-half of their capital should be paid in in gold or silver. Severe penalties were prescribed for violation of the act in the issue of notes and making loans. The banks were all placed under the inspection and supervision of the Bank Commissioner.

This law proved satisfactory in its operations and raised the standard of banking throughout the State.

In 1842 the General Assembly passed an additional act relating to banks, the important part of which was a provision that banks thereafter chartered might be relieved from the contribution to the safety fund if the directors should execute satisfactory bonds conditioned that they should "at all times pay and redeem according to law all bills issued by such bank, and should pay and refund all deposits made in such bank when such payments were demanded." This act also required not only that one-half of the capital should be paid before the bank went into operation, but that the other half should be paid in within two years. Loans to directors, stockholders and single individuals were also more strictly limited than theretofore.

Another part of the act provided for a fixed tax of one per cent. per annum upon capital in lieu of the tax of ten per cent. on profits, but remitted this tax to such banks as should "keep a sufficient deposit of funds in the city of Boston, and should at that eity uniformly cause its bills to be redeemed at par." This seems to have been the first official recognition and encouragement of the so-called Suffolk redemption system by the State. The extension of the advantages of this exemption from tax to the other banks, provided they should give bonds, together with the natural advantages accruing from the system itself, 
eventually brought them all into the redemption system, though as late as 1848 three of them still refused to maintain the required deposit at Boston. By 1850, however, all were in line.

In 1839 the Essex Bank failed, and the Bank Commissioner reported that its assets and the amount of the safety fund then available were insufficient to pay the circulation, amounting to $\$ 66,262$. A committee of the General Assembly, reporting on the failure of this bank, in 1842, took the ground that where failures had been caused by fraudulent acts of the directors, the note holders should look to the bondsinen of the directors for reimbursement and not to the safety fund, the latter being for the protection of the holders of notes issued by banks whose officers had not violated the conditions of their bonds.

In 1840 an act was passed limiting the circulation to twice the paidup capital instead of three times its amount as formerly allowed.

The Free Banking Act of 1851 permitted the organization of banks of $\$ 50,000$ and not more than $\$ 200,000$ capital, and allowed them to issue notes on a pledge of United States stocks and certain State stocks, deposited with the State Treasurer. This law was somewhat less stringent than the preceding ones, and there were but four banks organized under it. While this law was in existence some thirteen banks procured charters permitting them to transact business under the more stringent act of 1840. They preferred to voluntarily impose upon themselves conditions which would inspire public confidence rather than to take advantage of the greater freedom of the new act. The panic of 1857 showed that these banks were on a solid foundation, for although their circulation was reduced one-half in sixty days they continued (with one exception) to pay specie on demand.

With the taking effect of the National Banking Act State banks in Vermont gradually ceased to exist.

State Banks, 1834-1885.

\begin{tabular}{|c|c|c|c|c|c|c|}
\hline YEARS. & 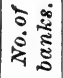 & $\begin{array}{l}\text { Loans and } \\
\text { discounts. }\end{array}$ & specie. & $\begin{array}{l}\text { Capital } \\
\text { stock. }\end{array}$ & Circulation. & Deposits. \\
\hline $1834 \ldots$ & 17 & $\$ 1,870,813$ & $\$ 50,958$ & $\$ 921,815$ & $\$ 1,463,713$ & $\$ 180,792$ \\
\hline $1839 \ldots$ & 19 & $2,888,812$ & 129,319 & $1,325,530$ & $1,966,812$ & 308,349 \\
\hline $1844 \ldots$ & 17 & $2,225,245$ & 92,562 & $1,137,500$ & $1,743,807$ & 289,079 \\
\hline $1849 \ldots$. & 24 & $3,613,227$ & 120,798 & $1,826,975$ & $2,322,962$ & $330,19 \tilde{5}$ \\
\hline $1854 \ldots .$. & 40 & $6,572,9 \overline{5} 1$ & 196,680 & $3,275,656$ & $3,986,709$ & 745,170 \\
\hline $1859 \ldots$. & 46 & $6,946,523$ & 198,409 & $4,029,240$ & $3,882,983$ & 787,834 \\
\hline $1864 \ldots$ & 38 & ................ & ............ & $\star 3,834,000$ & .............. & .......... \\
\hline $1875 \ldots$ & 5 & $1,524,978$ & ......... & 252,500 & ............ & $1,590,038$ \\
\hline $1880 \ldots$ & 5 & $1,308,626$ & .......... & 350,000 & ............. & $1,728,844$ \\
\hline $1885 \ldots$ & 8 & $1,804,989$ & .......... & 455,000 & ............ & $2,480,946$ \\
\hline
\end{tabular}


After 1887 the Government statistics do not include any State banks in Vermont. They had been by this time practically absorbed into the National banking system.

National Banks, 1864-1898.

Figures in thousands of dollars.

\begin{tabular}{|c|c|c|c|c|c|c|c|c|c|}
\hline YEARS. & 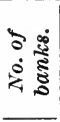 & $\begin{array}{c}\text { Loans } \\
\text { and dis. } \\
\text { counts. }\end{array}$ & $\begin{array}{c}U . S . \\
\text { bonds. }\end{array}$ & 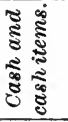 & Capital. & Surplus. & $\begin{array}{c}\text { Undi- } \\
\text { vided } \\
\text { profits. }\end{array}$ & $\begin{array}{c}\text { Out. } \\
\text { standing } \\
\text { circula. } \\
\text { tion. }\end{array}$ & $\begin{array}{c}\text { Indi- } \\
\text { vidual } \\
\text { deposits. }\end{array}$ \\
\hline $1864 .$. & 10 & $\$ 804$ & $\$ 1,852$ & $\$ 311$ & $\$ 1,400$ & $\$ 2$ & $\$ 69$ & $\$ 1,083$ & $\$ 309$ \\
\hline $1869 \ldots$ & 40 & 6,524 & 7,467 & 932 & 6,810 & 879 & 431 & 5,901 & 1,901 \\
\hline $1874 \ldots$ & 42 & 10,421 & 8,239 & 1,011 & 7,863 & 1,671 & 537 & 6,840 & 4,051 \\
\hline $1879 \ldots \ldots$ & 47 & 10,048 & 8,678 & 1,011 & $8,4 \div 0$ & 2,058 & 542 & 6,999 & 3,806 \\
\hline $1884 .$. & 49 & $11, \overline{554}$ & 6,590 & 861 & 8,011 & 1,629 & 626 & 5,776 & 4,922 \\
\hline $1889 .$. & 49 & 13,331 & 3,382 & 609 & 7,466 & 1,741 & 723 & 2,636 & 7,112 \\
\hline $1894 .$. & 49 & 12,674 & 3,637 & 870 & 7,005 & 1,626 & 839 & 2,960 & 8,912 \\
\hline 1898.. & 49 & 11,628 & 4,954 & 917 & 6,885 & 1,508 & 853 & 3,720 & 9,704 \\
\hline
\end{tabular}

Savings Banks and Trust Companies.

There are in operation in Vermont forty-one Savings bank and trust. companies, the latter institutions having capital stock, while the Savings banks are operated on the mutual plan without capital. Some of the institutions combine the functions of a Savings bank with those of a trust company. Investments are most carefully guarded by the law and the result has been highly satisfactory. In his report for 1898 the Inspector of Finance says that for fifteen years only one trust company had been placed in the hands of a Receiver, while there had been but one failure prior to that period; and no mutual Savings bank of the State ever failed.

Growth of Savings Banks, 1850-1898.

\begin{tabular}{|c|c|c|c|}
\hline YEARS. & Number of & Due depositors. & $\begin{array}{l}\text { Increase in periods } \\
\text { of five years. }\end{array}$ \\
\hline 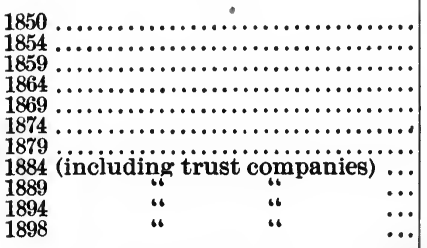 & $\begin{array}{r}6 \\
14 \\
12 \\
10 \\
10 \\
13 \\
16 \\
24 \\
31 \\
40 \\
41\end{array}$ & $\begin{array}{r}\$ 199,376 \\
901,789 \\
940,840 \\
1,952,500 \\
2,301,940 \\
5,011,831 \\
6,753,104 \\
13,724,291 \\
17,801,328 \\
27,966,855 \\
34,071,721\end{array}$ & $\begin{array}{r}\$ 702,413 \\
39,051 \\
1,011,660 \\
349,440 \\
2,709,891 \\
1,741,273 \\
6,971,186 \\
4,077,036 \\
10,165,527 \\
\ldots \ldots \ldots . .\end{array}$ \\
\hline
\end{tabular}




\section{MASSA CHUSETTS.}

In order to forestall a plan for establishing a fund or bank of eredit projected by individuals in the Colony in 1714, Massachusetts issued $£ 50,000$ in bills in that year. These bills were placed in the hands of trustees to be loaned out in sums of $£ 50$ to $£ 500$, at five per cent. on safe mortgages on real estate, one-fifth part of the principal payable each year. The loans were to be paid in five years, but were apparently renewed, as some of them were outstanding for thirty years. In 1716 an additional issue of $£ 100,000$ was made and $£ 50,000$ more in 1721 , the terms under which loans were made varying somewhat from those prescribed in the original act. These emissions caused a rise in the value of silver compared with the paper currency.

The people of the province of Massachusetts before the Revolutionary War, as has been seen in a previous chapter, had shown a disposition to engage in banking in something like the modern sense, when Colman proposed his land bank. This tendency which, perhaps, would have led to the establishment of a bank modelled on the Bank of England, was checked by the act of Parliament forbidding the incorporation of stock companies.

The Revolutionary War was not favorable to financial projects, but near its close, on March 8, 1782, the State of Massachusetts granted an act of incorporation to the Bank of North America, of Philadelphia, this institution having then been in existence for two months. The latter bank was so successful that the Massachusetts Bank was organized in Boston, and obtained a charter from the Legislature on February 7, 1784. This was the first local bank established in the State, and the second in the United States. The capital was limited to $\$ 300,000$, of which $\$ 253,500$ had been paid in when it commenced business on July 5 of that year. The par value of its shares was at first $\$ 500$, made purposely high to sustain the aristocratic pretensions of the founders of the institution and keep the shares out of the hands of the people. The bank purchased for its place of business the building known in those days as the Manufactory House, with 125 feet of land fronting on Common, now Tremont street, and 225 feet on the east side of Hamilton place. The price was four thousand dollars. The same property is now said to be valued at over $\$ 5,000,000$. The specie of that day consisted of guineas, johannes, louis d'ors, and moidores in gold, and crowns, half erowns, pistareens and English shillings in silver.

Nothing was said in the original charter in regard to the issue of. notes, but the bank issued notes in denominations of $\$ 1.50, \$ 2.50, \$ 3.50$ and $\$ 4.50$, also of $\$ 6, \$ 7, \$ 8, \$ 9, \$ 15, \$ 25, \$ 30, \$ 35$ and $\$ 40$.

As early as 1840 the Massachusetts Bank issued notes printed on fibre paper, the same in principle as that used by the United States to print its Treasury and other notes. On commencement day at Harvard, in 
the last century, the Governor, President of the Senate, Speaker of the House, and the President of the bank, always sat on the platform together.

During the 109 years which have elapsed since this bank was established, it has passed but three dividends, the first at the close of the War of 1812 , the second during the financial crisis of 1837 , and one since it became a National bank. To compensate for these omissions extra dividends have been declared. Up to June 1, 1874, a period of ninety years, the ratio of its losses to the total amount loaned was but four one-hundredths of one per cent. In the eighty years of its existence as a State bank, from 1784 to 1864 , the whole amount of circulating notes issued by it was $\$ 4,674,177$, of which the amount lost or not presented for redemption was $\$ 22,111$, or not quite one-half of one per cent.

The next charter was granted by the State in 1792 , to the Union Bank, of Boston, which was organized with a specie capital of $\$ 1,200$,000 , of which $\$ 400,000$ was subscribed by the State. During the interval, from 1784 to 1792 , the currency was in bad condition, small bills having nearly driven specie out of circulation. In the latter year, as already stated, the Legislature prohibited the issue of any notes less than five dollars. Provision was made for legislative examinations of the Union Bank, and it was also made the depository of the funds of the Commonwealth. In this charter as well as in most of those subsequently granted, the banks receiving them were required to loan certain sums to the State at fixed rates of interest. The Union Bank, for instance, was required to loan not exceeding $\$ 100,000$ to the State at five per cent.

In 1795 Massachusetts incorporated two more banks, the Nantucket with a capital of $\$ 40,000$, and the Merrimac at Newburyport. Both of these banks, by a special provision, were allowed to issue notes of a denomination as small as two dollars. Five banks in all were incorporated up to 1799. In that year a restraining law was passed prohibiting the establishment of unincorporated banks, and the further issue, except by the Nantucket Bank, of notes of a less denomination than five dollars. In consequence of this law the State was inundated with small bills from other States, and the permission was soon given to the Massachusetts banks to emit small notes.

\section{Semi-AnNual Reports Required.}

In 1803 a law was enacted requiring the banks to make semi-annual returns of their condition to the Governor and Council, to be signed by the directors ; and by a supplementary law of 1805 the reports were required to be sworn to. Returns made June, 1805, showed sixteen banks then in operation, with an authorized capital of $\$ 5,760,000$, of which $\$ 5,460,000$ had been paid in. Only one other bank was chartered from this time until 1811. The currency had again become very inferior, notes as small as twenty-five cents being in circulation in large numbers, and as a consequence specie had again nearly disappeared. There were 
many failures of New England banks during the financial pressure of 1808-9, but those of Massachusetts resting on a firmer basis, mainly escaped with a sudden contraction of their note issues. The discount in Boston on New England bank notes ranged in 1809 from ten to sixty per cent., and in Philadelphia many of them were at a discount of fifty per cent., or more. To remedy this evil the Legislature of Massachusetts, on January 1, 1810, enacted a law, fixing a penalty of two per cent. a month, payable by the bank to the bill holder, for a failure or refusal to redeem their notes on presentation.

Two banks were chartered in 1811, one of which was the State Bank of Boston, with an authorized capital of $\$ 3,000,000$, the State reserving the right to subscribe for $\$ 1,500,000$ additional. This subscription was, however, never made. A similar provision was made in all the charters granted subsequent to 1793 , usually retaining the right of the State to subscribe to about one-third of the stock. By the partial exercise of this right Massachusetts had become interested to a considerable extent in the banking business, in 1812 holding about $\$ 1,000,000$ in bank stock, out of a total banking capital in the State of about $\$ 8,000,000$. In 1811 also, nearly all the banks were newly chartered, the new franchises reducing the amount of circulating notes that might be issued from twice the amount of the capital to fifty per cent. in excess of the capital. In 1812 the first tax was laid on bank capital, the amount being one-half of one per cent.

\section{Strength of the Banks in 1814.}

The Massachusetts banks were in 1814 twenty-one in number. Although this year, owing to the financial distress consequent on the war with England, was disastrous to the State banks throughout the United States, none of those in Massachusetts suspended, this being attributable in great measure to the severe penalty imposed for non-payment of their notes. By maintaining specie payments the Massachusetts banks were able to attract coin from other States where specie payments were suspended.

The whole number of banks chartered previous to January 1, 1825, was forty-nine, with an authorized capital of $\$ 20,800,000$. Of this number nine had failed, or discontinued business, or had never availed themselves of their charters. Reductions of capital of many of the others had also taken place, leaving forty banks in operation with an authorized capital of $\$ 14,305,000$, of which $\$ 13,300,000$ had been paid in : so that at the close of the first forty-one years of banking in Massachusetts, not less than eighty-two per cent. of the whole number chartered, together with seventy per cent. of the capital authorized, still remained in existence. In 1825 the amount of circulating notes authurized to be issued was reduced to the capital paid in.

In the four years from 1825 to 1828 some thirty-six banks were incorporated, and fourteen others were authorized to increase their capi- 
tal, representing in all $\$ 9,075,000$ of new banking capital. But the demand for cash to meet the requirements of this rapid expansion in banking could not be met, and neither of the two banks chartered in 1827 went into operation, and but six of the fourteen chartered in 1828, and of these six two failed within two years.

\section{The Banking Law of 1829.}

The first really comprehensive banking law of Massachusetts was enacted February 28, 1829, and was to apply to all banks thereafter organized and to those increasing their capital or extending their charters. Under this law banks were required to have fifty per cent. of their capital bona fide paid in in specie before commencing business. It also prohibited loans to shareholders until their subscriptions were entirely paid in, and limited the amount of loans on pledges of its own stock to fifty per cent. of the capital. The limit of circulating notes was increased to twenty-five per cent. in excess of the paid-in capital, and debts due to or from any bank, exclusive of deposits, were restricted to twice the amount of such capital, the directors being held personally liable for any excess. On January 1, 1837, there had been organized in all, including the old banks rechartered, 138 banks, with an authorized capital of $\$ 40,830,000$. Of this number four had never gone into operation, while of the remaining 134 no less than thirty-two had either failed or surrendered their charters in consequence of the financial panic of that year. The nominal capital of the banks that failed was $\$ 5,500,000$; their liabilities were $\$ 11,283,960$, of which $\$ 3,133,129$ was for circulation and $\$ 1,577,738$ for deposits. The loss to shareholders was estimated at $\$ 2,500,000$, and to the public at three-quarters of a million more, making a total loss of about three and one-quarter millions of dollars, or about thirty per cent. of their entire indebtedness. During the fiftytwo years from 1784 to 1836 ten banks only had failed or discontinued business, the total losses to shareholders and the public probably not exceeding one-third of a million dollars.

\section{The Panic of 1837.}

For several years prior to 1836 there had been undue expansion, and many banks were organized with little or no capital. Their plan was to borrow specie for one day to the amount of half the authorized capital, and after it was duly counted by the Bank Commissioners, and oaths made by the directors that it was to be held as the capital of the bank, it would then be returned to the lenders and its place supplied by the notes of the stockholders. This process would be followed by the issue of notes. Circulation and deposits showed a large increase in September, 1836, compared with 1830 , but the proportion of specie held was smaller than ever before. As a number of banks had been organized on borrowed specie or fictitious capital, they were in a poor condition to weather the impending storm, and failures became fre- 
quent. One bank closed with $\$ 111,000$ notes outstanding, and only $\$ 36.71$ cash on hand. Specie payments were suspended on May 12, 1837, by the Boston banks, and resumption did not become general throughont the State until August, 1838. From 1837 to 1844 thirtytwo banks failed or discontinued business as a result of the crisis.

One of the valuable results of this crisis was the adoption in 1838 of a system of official examinations of banks, through the agency of a Board of Bank Commissioners, who were required to make annual examinations of every bank and special ones whenever required by the Governor of the State. This board was abolished after five years, but the law of 1851 provided for a Bank Commissioner with substantially the same powers.

There was a slow recovery from the crisis of 1837, but the experience gained during that time appeared to have been salutary. From 1840 to 1855 but two banks failed, both paying their notes in full.

In 1843 banks were prohibited from paying out over their counters other notes than their own.

The Massachusetts banking law relating to the chartered banks was gradually improved, as experience dictated, and at the time of the war was perhaps, as has been said by an eminent writer-whose synopsis of the law is given below-one of the best banking laws ever produced. No individual could hold more than one-half of the stock of any bank. No person could be a director of more than one bank. No person could be a director whose stock was pledged for debt. Neither the debts nor the credits of a bank could exceed twice the capital stock paid in, except for deposits and for debts due to and from other banks. Directors were personally liable for violations of this clause, unless they dissented or were absent, in which case they must notify the Bank Commissioners of the State forthwith. No bank could pay out any notes but its own, or issue any notes directly or indirectly, except at its own banking house, or issue any notes with the understanding that they should be kept out a certain length of time. No bank could borrow money to be repaid in anything except specie or its own notes. In case of bank failure the note holders were to be paid first. Each bank was required to keep fifteen per cent. of specie as a reserve against both circulation and deposits, but country banks might reckon their balances in Boston banks payable on demand in specie. This specie reserve law was passed after a hard struggle in 1858. It was copied from the Louisiana act of 1842 , but the amount of the specie was only one-half that required in Louisiana. When gold was paid out it must be paid by weight. This was an old law of 1803 re-enacted at every revision of the banking laws down to and including 1860 . There was a provision that if any new banks were chartered with any greater privileges than those enjoyed by the old banks, the same privileges should extend to the latter. This proviso was inserted in the act of 1828 and in every subsequent revision. 
By the act of 1849 , when any bank stopped payment stockholders were rendered individually liable in proportion to their stock for the redemption of the bank's notes.

The act of 1828 provided that at elections for bank directors each stockholder should be entitled to one vote for the first share, and to one vote for every two additional shares, provided that no person had more than ten votes. This was re enacted in the revision of 1835 but dropped in that of 1860 .

\section{Free Banking Law of 1851.}

A free banking law was enacted in 1851 similar in its provisions to that of the State of New York. Not more than seven banks were ever organized under it, the system of chartered banks occupying the field down to the commencement of the National banking system. The State did much to facilitate the conversion of State into National associations upon the establishment of the National banking system. The first institution to avail itself of the new law was the Safety Fund Bank of Boston, in 1863, under the title of the First National Bank of Boston. The conversions progressed so rapidly that in October, 1865, but a single bank remained doing business under a State charter. Of the 183 State banks existing in 1863, four had discontinued business, and 1'78 had become National banks.

From 1850 to 1857 fifty-eight banks were organized, with $\$ 14,400,000$ capital, and by the increase in the capital of existing banks the total of new banking capital was raised to $\$ 18,745,000$. Though most of the banks suspended specie payments in 1857 , and were compelled to make large reductions in their loans and circulation owing to the crisis of that year, there was but one bank failure-an evidence of the improvement made in the banking system in the twenty years preceding.

The banking capital of the State banks reached its maximum $-\$ 67$,544,200-in 1862, being distributed among 138 banks.

A compilation of the statistics of the dividends paid by the Massachusetts banks in the last half of each of the thirty-two years from 1808 to 1839 inclusive, was given in "Hunt's Merchants" Magazine" for 1840. It is separated into two parts because the State imposed a tax of one per cent. per annum on bank capital in 1813, the first part for the five years ending with 1812 , and the other for the remaining twentyseven years. For the first period the average semi-annual dividends paid by all the banks was $\$ 3.72$ upon each one hundred dollars of capital, while for the twenty-seven years following the imposition of the bank tax the average semi-annual rate was $\$ 2.96$ per hundred. Taking the whole period of thirty-two years together, the semi-annual average was about three and one-tenth per cent. The average annual rate of dividends for the whole period, assuming that the dividend for the first six months of each year did not differ materially from that of the last six months, was, therefore, six and one-sixth per cent. per annum. The 
average annual dividends of the National banks of Massachusetts from 1870 to 1876 was nine and six-tenths per cent.

\section{The Suffolk Banking System.}

\section{Mr. D. R. Whitney, in his History of the Suffolk Bank, says:}

"The business man of to-day knows little by experience of the inconvenience and loss suffered by the merchant of sixty years ago arising from the currency in which debts were then paid. Receiving payment in bank notes, he assorted them into two parcels, current and uncurrent. In the first he placed the notes issued by the solvent banks of his own eity; in the other the bills of all other banks. Upon these latter there was a discount varying in amount according to the location and credit of the bank issuing them. How great the discount he could learn only by consulting his 'Bank Note Reporter,' or by inquiring at the nearest exchange office. He could neither deposit them nor use them in payment of his notes at a bank. The discount on them varied from one per cent. upwards, according to the distance the bills had to be sent for redemption and the financial standing of the bank by which they were issued. Many banks were established in remote places, mainly for the purpose of making a profit on circulation. The more distant they were from the business centres the more expensive it was to send their bills home for redemption, and the more difficult it was for the general public to know their true financial condition."

This state of things in New England led by degrees to the establishment of what is known as the Suffolk Bank system of redemptions.

The charter of this institution was granted in 1818, and was to continue until 1831. In addition to the regular business of discounting commercial paper, the directors turned their attention to buying and selling foreign exchange and dealing in United States stock and dollars. This branch of their business was closed up in 1826, and after that date the bank turned its attention to receiving and redeeming the bills issued by the New England banks. This business grew out of the fact that the directors saw that they could buy the notes of the country banks at a discount and make a profit by sending them home for redemption. It was a pure matter of business in which the desire of benevolently sustaining the currency had no part. The New England Bank, of Boston, had previously carried on the same business to some extent. The Suffolk Bank appears to have extended it by entering into a sort of forced compact with the country banks. The Suffolk Bank agreed to receive the notes of any country bank which would make with it a permanent deposit of $\$ 5,000$, with such further sums as might be required to redeem its bills taken by the Suffolk Bank, and also to give the country bank the privilege of receiving back its own bills at the same discount at which they had been taken by the Suffolk Bank. The bills of the banks that would not make the deposit with the Suffolk Bank were sent home for redemption at par in specie. The effect of this proposition cut both ways. Such banks as made the permanent deposit, etc., with the Suffolk found that although the latter bank was benefited by the increased amounts it had to loan, their own circulation was raised nearly to par, and secured a currency which was of great benefit to them. The banks 
which refused to accept the terms found their notes at such a large discount in Boston as enabled the Suffolk Bank to make a considerable profit in sending them home for redemption. The system thus grew up without any act of the Legislature, simply from the force of circumstances and the fact that the managers of the Suffolk bank knew how to take advantage of them, both for the benefit of the bank and the community.

At first the competition between the Suffolk and New England banks reduced the discount on notes of Massachusetts banks, which had previously been at a discount of one per cent. to one-half of one per cent., and the profits became so small that the directors were forced to reduce the expenses of the bank. There was great animosity to the institution displayed by those country banks which had refused to make the required deposit and whose bills were sent home for specie.

The unaided effort of the Suffolk Bank had by 1822 proved inadequate to prevent the circulation of the country banks from superseding the notes of the Boston banks in their own eity, and with the view of securing some circulation for their own notes in April, 1824, a cormmittee was appointed by the Suffolk to confer with the other Boston banks and secure their co-operation. This letter stated "that of the whole incorporated banking capital of New England, amounting to less than twenty millions of dollars, the eleven banks in this city possess ten million one hundred and fifty thousand. That estimating the circulation of the country banks at only seventy-five per cent. of their capital, which they believe to be a moderate computation, these banks furnish seven million five hundred thousand dollars of the circulating medium, while the banks in the city with a capital equal to all the rest, keep in what may be fairly termed permanent circulation only three hundred thousand dollars." The letter stated that the Suffolk Bank had in the previous three months received nearly one million dollars in country paper, the greater part of which had been sent home for redemption or redeemed by agents in Boston at par, and nothwithstanding the unfavorable season and bad state of the roads, the bank was no loser by the operation. As the benefit to the Boston circulation would be common to all the banks, the Suffolk committee thought that the risks of redemption should likewise be shared among them. The committee recommended that a fund be raised by the several banking institutions for the purpose of sending bills home for redemption.

This communication led six other of the Boston banks to associate themselves with the Suffolk, and to contribute jointly a sum of $\$ 300,000$ to carry the plan into effect. All the country money received by any of the banks was sent to the Suffolk, which agreed to take it "at the same or less discount than the New England Bank, or other banks in Boston received it, and should send it home for redemption." The Suffolk Bank, as agent of the association, commenced the business of receiving country money under the agreement on May 24, 1824. The 
country banks became much excited, and called the associated banks the Holy Alliance and the Suffolk the "Six Tailed Bashaw." "But they soon became convinced" says Mr. Whitney in his history of the bank, " that a promise to pay printed on the face of a bank note, meant a promise to pay specie on demand; that such a demand was likely to be made upon them at any time; and that the associated banks, with the Suffolk as agent, were not to be frightened or turned out of their course by sarcastic words." The foreign money business continued to increase from year to year.

\section{Essence of the Suffolk Plan.}

* The general arrangement made with the New England banks, which opened an account with the Suffolk Bank for the redemption of their bills was as follows: Each bank placed a permanent deposit with the Suffolk Bank of $\$ 2,000$ and upwards, free of interest, the amount depending upon the capital and business of the bank. This sum was the minimum for banks with a capital of $\$ 100,000$ and under. In consideration of such deposit the Suffolk Bank redeemed all the bills of that bank which might come to it from any source, charging the redeemed bills to the issuing bank once a week, or whenever they amounted to a certain fixed sum; provided, the bank kept a sufficient amount of funds to its credit, independent of the permanent deposit, to redeem all of its bills which might come into the possession of the Suffolk Bank; the latter bank charging it interest whenever the amount redeemed should exceed the funds to its credit; and if at any time the excess should be greater than the permanent deposit, the Suffolk Bank reserved the right of sending home the bills for specie redemption. As soon as the bills of any bank were charged to it, they were packed up as a special deposit, and held at the risk and subject to the order of the bank issuing them. In payment the Suffolk Bank received from any of the New England banks with which it had opened an account, the bills of any New England bank in good standing at par, placing them to the credit of the bank sending them on the day following their receipt.

The banks of New England were divided into two classes-those keeping a deposit with the Suffolk Bank and redeeming their bills at its counter, and those which kept an account with some other Boston bank, with which an arrangement was made for the redemption of their bills. The Suffolk Bank did not require the New England banks to keep a deposit with it as a condition precedent to receiving their bills at par. On the contrary, it received at par the bills of all sound New England banks, whether they kept an account with it or not. It only required that they should redeem their bills at some convenient place on penalty of having them sent home for specie. For the bills of the former class of banks the Suffolk had security in the form of

* "The Suffolk Bank," by D. R. Whitney. 
deposits and collections. For the bills of the other class it had no security except the good faith of the banks acting as their agents.*

For some years preceding 1855 , an impression got out that the business was very profitable to the Suffolk Bank, and the country banks thought by establishing an institution in Boston, in which they were the stockholders, they could secure this profit for themselves. "There was also," says Mr. Whitney, "the old feeling of ill-will among the weak banks, which had been compelled to keep their circulation within bounds."

The Bank of Mutual Redemption was chartered in that year, but did not go into operation until 1858. It met with some opposition from the Suffolk and other Boston banks, but was finally successful in gaining a large share of business, and the Suffolk Bank in November, 1858, withdrew from the business, leaving it all to the Bank of Mutual Redemption.

"It was the underlying principle of the Suffolk Bank system that any bank issuing circulation should keep itself at all times in a condition to be able to redeem it ; that it should measure the amount by its ability so to do; and that the exercise at any time of the right to demand specie of a bank for its bills was something of which the issuing bank had no right to complain. The directors enunciated this principle when they first entered into the foreign money business, in their controversy with the agent of the Springfield Bank in 1824; they acted upon it during the whole existence of the system, and they gave up the business because the exercise of the right was made use of effectually, by banks hostile to the system, to place the Suffolk in a false position before the public. Yet the bank had not labored in vain; it found the currency of New England in a chaotic state; but by putting this principle into practice it had brought order out of confusion, and had compelled the banks to keep themselves stronger than they otherwise would, and to live up to a principle the justice of which they could not deny, although the practice of it might cause them to forego some seeming immediate profits, and to this latter cause must be attributed much of the hostility it provoked." +

\section{Comparison of Redemptions UNder the SuFfolk and National SYSTEMS.}

In 1857 the redemption of notes by the Suffolk Bank was almost $\$ 400,000,000$, as against $\$ 137,697,696$, in 1875 , the highest amount ever reported under the National banking system. The redemptions in 1898 were only $\$ 66,683,467$, at a cost of $\$ 1.29$ per thousand. The cost of redemption under the Suffolk system was ten cents per $\$ 1,000$, which does not appear to include transportation. If this item is deducted from the cost of redeeming National bank notes, it would reduce it to about ninety-four cents. This difference is accounted for by the relatively small amount of redemptions by the Treasury, and the increased expense incident to the necessity of official checks by the Government, and by the higher salaries paid. But allowing for these differences, the fact is established that private enterprise could be entrusted with the work of redeeming the circulating notes of the banks, and that it could

* "The Suffolk Bank," by D. R. Whitney. + Ibid. 
thus be done as safely and much more economically than the same service can be performed by the Government.

The amount of New England bank notes redeemed at the Suffolk Bank from 1841 to 1857, was as follows, in millions of dollars :

\begin{tabular}{|c|c|c|c|}
\hline $\begin{array}{r}\text { Millions. } \\
\ldots \ldots \ldots 109\end{array}$ & $\begin{array}{l}\text { Date. } \\
1846 . . . \ldots \ldots \ldots \ldots 141\end{array}$ & $\begin{array}{l}\text { Date. } \quad \text { Millions. } \\
\text { 1850.......220 }\end{array}$ & Date. Millions \\
\hline ........105 & $1847 \ldots \ldots \ldots \ldots \ldots 165$ & $1851 \ldots \ldots \ldots \ldots \ldots 243$ & $1855 \ldots \ldots$ \\
\hline ..126 & $1848 \ldots \ldots \ldots \ldots . \ldots 178$ & $1852 \ldots \ldots \ldots \ldots \ldots 245$ & 1856. \\
\hline .137 & $1849 . \ldots \ldots \ldots \ldots \ldots 199$ & $1853 \ldots \ldots \ldots \ldots \ldots 288$ & 1857. \\
\hline
\end{tabular}

Since the establishment of the National banking system the redemptions have averaged about $\$ 54,000,000$ a year.

State Banks.

\begin{tabular}{|c|c|c|c|c|c|c|}
\hline YEARS. & 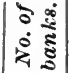 & $\begin{array}{l}\text { Loans and } \\
\text { discounts. }\end{array}$ & Specie. & $\begin{array}{l}\text { Capital } \\
\text { stock. }\end{array}$ & Circulation. & Deposits. \\
\hline $1803 \ldots$ & 7 & $\$ 3,857,491$ & $\$ 1,079,928$ & $\$ 2,225,262$ & $\$ 1,565,189$ & $\$ 1,522,271$ \\
\hline $1813 .$. & 16 & $10,234,409$ & $5,780,798$ & $8,895,000$ & $2,186,137$ & $6,903,593$ \\
\hline $1823 \ldots$ & 34 & $15,638,247$ & $1,033,375$ & $11,650,000$ & $3,128,986^{\circ}$ & $3,122,058$ \\
\hline $1833 \ldots .$. & 102 & $45,261,008$ & 922,309 & $28,236,250$ & $7,889,110$ & $3,716,182$ \\
\hline $1838 \ldots$. & 120 & $48,206,809$ & $2,394,624$ & $34,630,000$ & $9,400.513$ & $9,621,217$ \\
\hline $1843 \ldots$. & 103 & $42,993,291$ & $7.298,815$ & $31,089, \ngtr 00$ & $9,219,267$ & $10,213,887$ \\
\hline $1848 \ldots .$. & 112 & $53,110,100$ & $2,578,030$ & $32.985,000$ & $13,196,029$ & $8,094,970$ \\
\hline $1853 \ldots \ldots .$. & 143 & $87,187,177$ & $3,731,765$ & $49,050,175$ & $25,620,472$ & $19,007,651$ \\
\hline $1858 \ldots \ldots \ldots \ldots . . . .$. & 174 & $104,423,472$ & $11,112,716$ & $61,819,825$ & $20,839,438$ & $32,076,006$ \\
\hline $1862 \ldots$ & 183 & $127,592,511$ & $9,595,530$ & $67,544,200$ & $28,957,630$ & $44,737,490$ \\
\hline
\end{tabular}

National Banks.

Figures are in thousands of dollars.

\begin{tabular}{|c|c|c|c|c|c|c|c|c|c|}
\hline YEARB. & 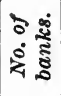 & $\begin{array}{l}\text { Loans and } \\
\text { discounts. }\end{array}$ & $\begin{array}{c}\text { U. } S . \\
\text { bonds. }\end{array}$ & $\begin{array}{l}\text { Cash and } \\
\text { cash items. }\end{array}$ & Capital. & surplus. & $\begin{array}{c}\text { Undi. } \\
\text { vided } \\
\text { profits. }\end{array}$ & $\left|\begin{array}{c}\text { ont. } \\
\text { standing } \\
\text { circula- } \\
\text { tion. }\end{array}\right|$ & $\begin{array}{c}\text { Indi- } \\
\text { vidual } \\
\text { deposits. }\end{array}$ \\
\hline $1863 .$. & 1 & $\$ 104$ & $\$ 50$ & $\$ 25$ & $\$ 150$ & & $\$ 1$ & & $\$ 92$ \\
\hline $1868 . .$. & 207 & 109,128 & 76,500 & 29,830 & 79,882 & $\$ 16,036$ & 3,868 & $\$ 56,756$ & 62,798 \\
\hline $1873 \ldots$ & 217 & 156,116 & 69,978 & 25,683 & 90,852 & 23,925 & 11,451 & 58,453 & 72,469 \\
\hline $1878 \ldots$ & 236 & 150,356 & 87,112 & 25,571 & 95,215 & 22,820 & 4,511 & 61,676 & 80,614 \\
\hline $1883 \ldots$ & 246 & 194,175 & 74,292 & 29,117 & 96,602 & 25,363 & 7,273 & 65,400 & 116,026 \\
\hline $1888 . .$. & 253 & 230,988 & 34,455 & 34,091 & 96,141 & 27,655 & 8,325 & 25,158 & 144,302 \\
\hline $1893 . .$. & 269 & 239,184 & 31,055 & 23,164 & 99,467 & 30,382 & 10,381 & 27,205 & 156,164 \\
\hline $1898 \ldots .$. & 263 & 272,608 & 32,777 & 30,949 & 90,477 & 29,433 & 11,930 & 23,963 & 222,787 \\
\hline
\end{tabular}

Savings Banks.

There are no State banks of discount in Massachusetts, but banking facilities are supplied by the National banks, by Savings banks and trust companies. The Savings banks are, in general, similar to 
all the mutual institutions in the New England and Middle States. Their investments are strictly regulated by law and their management is under careful official supervision of a Board of Bank Commissioners. Reports from these banks were first required in 1834, at which time there were twenty-two banks, 24,256 depositors and $\$ 3,407,773$ deposits, an average of $\$ 140$ to each account. In 1898 there were 185 banks, $1,406,722$ depositors and deposits amounting to $\$ 488,642,923$, an average of over $\$ 347$ to each account. The accompanying table graphically represents the growth of Savings banks in Massachusetts from 1834 to 1898:

\begin{tabular}{|c|c|c|c|c|c|}
\hline YeARS. & 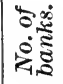 & $\begin{array}{c}\text { No. of } \\
\text { accounts. }\end{array}$ & $\begin{array}{l}\text { Amount of } \\
\text { deposits. }\end{array}$ & $\begin{array}{l}\text { Average } \\
\text { to each } \\
\text { account }\end{array}$ & $\begin{array}{l}\text { Expense } \\
\text { of man- } \\
\text { agement. }\end{array}$ \\
\hline 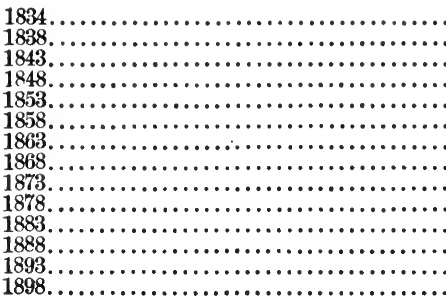 & $\begin{array}{r}22 \\
30 \\
31 \\
41 \\
60 \\
86 \\
95 \\
115 \\
175 \\
168 \\
168 \\
176 \\
185 \\
185\end{array}$ & $\begin{array}{r}24,256 \\
33,063 \\
43,217 \\
69,894 \\
117,404 \\
182,655 \\
272,219 \\
383,094 \\
666,229 \\
674,251 \\
806,010 \\
983,202 \\
1,214,493 \\
1,406,722\end{array}$ & $\begin{array}{r}\$ 3,407,773 \\
4,869,393 \\
6,935,347 \\
11,970,448 \\
23,370,102 \\
33,914,972 \\
56,883,828 \\
94,838,836 \\
202,195,343 \\
209,860,641 \\
252,607,631 \\
315,185,093 \\
399,995,070 \\
488,642,569 \\
\end{array}$ & $\begin{array}{r}\$ 140 \\
147 \\
160 \\
171 \\
199 \\
185 \\
208 \\
247 \\
303 \\
311 \\
313 \\
320 \\
329 \\
347\end{array}$ & $\begin{array}{r}\$ 11,968 \\
18,329 \\
20,777 \\
36,405 \\
59071 \\
105,039 \\
140,713 \\
297,527 \\
547,518 \\
606,550 \\
650,247 \\
783,158 \\
1,010,639 \\
1,202,708\end{array}$ \\
\hline
\end{tabular}

\section{Trust Companies.}

As the National banks are prohibited from making loans on real estate, the demand for such accommodations in States having no State banks must be met by some other class of institutions. In Massachusetts there are Loan, Safe Deposit and Trust Companies, which make loans on real estate and do a banking and trust company business. Their capital may not exceed $\$ 1,000,000$ nor be less than $\$ 200,000$, and must be fully paid in before commencing business. They are restricted in making loans and investments, and are required to keep a reserve of fifteen per cent. upon deposits payable on demand or on ten days' notice, and their real estate loans are confined to the New England States and New York. Objection has been made to them on the ground that in some cases they have been organized as feeders to National banks to permit them to engage in a class of business which they could not carry on under the Federal laws. It is not disputed, however, that they satisfactorily perform many other valuable functions outside the scope of commercial banking, and that they are, upon the whole, of substantial advantage to the business interests of the State. There were thirtyfour of these companies doing business on October 31, 1898, and they held in their banking departments deposits amounting to $\$ 118,743,979$, with other liabilities of $\$ 22,873,531$, and total assets amounting to $\$ 141$,617,510. Eleven of the companies have established trust departments, the liabilities of which amounted to $\$ 12,677,357$ on the date mentioned. 


\section{RHODE ISLAND.}

Though Rhode Island is the smallest State in the Union, it stands first with reference to its per capita banking resources. As in other Colonies the experiment of issuing paper curreney was tried, what was called the "first bank" of $£ 40,000$ having been emitted in 1715 . These bills were loaned on real estate at five per cent. for ten years. There were several successive issues, and as the notes depreciated the demand for an increased supply continued to grow.

In 1791 the Providence Bank was incorporated, its authorized eapital being $\$ 250,000$, which was soon increased to $\$ 400,000$. There was nothing said in the charter about the issue of notes, and no limit was placed on the indebtedness. Stockholders were liable only to the amount of their shares. Officers were given summary powers over the property of delinquent debtors through what was known as the bank process. This permitted a bank to order the clerk of a court to issue writs of execution and attachment against the property of those persons whose notes or instruments were payable or negotiable at the bank and were unpaid for ten days after demand of settlement had been made. This enabled the banks to collect their debts without the formality and expense of legal proceedings. They rendered judgments themselves and only invoked the aid of the courts in carrying out their decrees. In 1836 Thomas W. Dorr, afterwards the leader of Dorr's Rebellion, made a successful fight in the Legislature for the repeal of this law, and thereafter banks were obliged to employ the same means as individuals in collecting their debts.

The Bank of Rhode Island was ehartered in 1795 , with $\$ 100,000$ capital, and by 1805 there were thirteen banks in existence with a total capital of about $\$ 1,500,000$. The Farmers' Bank, of Gloucester, which failed in 1809 , nominally had $\$ 100,000$ capital, but only about $\$ 19,000$ was paid in, and from this amount was withdrawn the sum which the directors had paid, leaving the actual capital but little more than $\$ 3,000$.

\section{Novel Plan of Issuing Circulation.}

The following transaction is reported : One of the directors bought out eleven others for $\$ 1,300$ each, paying for their stock with the bank's funds. He then borrowed of the bank on his note $\$ 760,265$, to be paid whenever the holders of a majority of the stock should demand payment, but with the provision that as he himself held the majority of the stock he should determine when the notes were to be paid. When the bank failed its tangible assets were $\$ 86.46$, and it had about $\$ 580,000$ in bills outstanding.

This failure was exceptional, however, and was the only one prior to 1829. Very few of the early banks in Rhode Island were a source of loss to the public. 
In 1809 the banks were compelled by law to make and publish reports. Prior to this the methods employed to prevent fraudulent management were by frequent examinations by committees selected from the board of directors. Up to 1820 there was no restriction on the issue of notes, but in that year the circulation was limited to the paid-in capital. Most of the banks, however, were inside this limit before the law was passed.

As the banks were unhampered for years in their circulation privileges, possessed extraordinary powers for the collection of their debts, and were not compelled to pay a bonus to the State and were free from taxation, their number multiplied rapidly. The total number in operation in 1826 was forty-four, and their authorized capital was $\$ 10,350,000$.

\section{Liabilities of Stockholders and Directors.}

The early bank charters limited the liability of stockholders to the amount of their shares, but by a subsequent act an additional individual liability was imposed on the directors who had violated the provisions of the banking law. The charters granted in 1833 provided for unlimited liability of shareholders, after the property of the corporation had been exhausted.

An additional act in relation to banking was passed in 1836 . It placed the minimum capital at $\$ 50,000$, one-half of which must be paid in before commencing business, and the balance within six months. This act also provided for a Board of Bank Commissioners to examine and receive reports from the banks. The board was abolished and revived again in 185\%. In the interval the banks were required to make regular semi-annual reports to designated State officials. The dates were fixed for these reports. Likewise the banks were "fixed" for them. They accumulated specie sufficient to make a good showing in anticipation of the event. At the annual examination in October, 1835, forty-four banks, with a circulation of $\$ 1,160,788$, had $\$ 486,574$ of specie in their vaults. Three months later, when an unexpected examination was made, the same banks were found to have $\$ 1,294,292$ circulation and but $\$ 197,550$ in specie.

The banks found it necessary to suspend specie payment in 1857 , but each bank was obliged to receive its own notes on deposit and pay interest upon them. In 1859 the proportion of circulation to capital was. limited to sixty-five per cent. for all banks. It had been since 1837 graduated according to capital. There was but one bank failure in the panic of 1837 , and this bank actually failed the previous year, having arranged for the redemption of its notes. It afterwards reopened. There was also one failure in 1843. From 1857 to 1859 the number of banks was reduced through failures and liquidations from ninety-eight. to ninety.

When the National Banking Act went into effect most of the State banks were gradually merged into the new system. 
It will be seen that the Legislature of Rhode Island dealt with the banks in an enlightened manner, and as a result the financial institutions of the State attained a high degree of excellence.

State Banks.

\begin{tabular}{|c|c|c|c|c|c|c|}
\hline YEARS. & 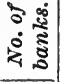 & $\begin{array}{l}\text { Loans and } \\
\text { discounts. }\end{array}$ & Specie. & Capital stock. & Circulation. & Deposits. \\
\hline $1834 \ldots$ & 58 & $\$ 9,607,285$ & $\$ 467,407$ & $\$ 8,041,132$ & $\$ 1,251,435$ & $\$ 2,273,237$ \\
\hline 1839. & 62 & $12,895,325$ & 462,002 & $9,868,773$ & $1,886,108^{\circ}$ & $1,554,905$ \\
\hline $1843 \ldots$ & 62 & $11,779,080$ & 382,645 & $10,133,213$ & $2,886,570$ & $1,577,266$ \\
\hline 1848. & 62 & $14,501,940$ & 320,581 & $10,037,241$ & $2,698,495$ & $1,260,499$ \\
\hline $1853 . .$. & 77 & $22,844,911$ & 359,699 & $15,917,429$ & $4,895,529$ & $2,238,856$ \\
\hline $1858 .$. & 83 & $24,065,894$ & 732,622 & $20,070,741$ & $2,644,195$ & $2,624,226$ \\
\hline $1863 .$. & 88 & $30,579,988$ & 505,270 & $20,890,129$ & $6,413,404$ & $5,376,414$ \\
\hline $1868 .$. & 20 & $\ldots \ldots \ldots \ldots$ & ......... & $3,052,050$ & ............. & …......... \\
\hline $1873 .$. & .. & $4,155,211$ & .......... & $3,149,950$ & 24,594 & $1,060,379$ \\
\hline $1878 .$. & 15 & $4,031,790$ & .......... & $3,227,850$ & 16,466 & $1,138,598$ \\
\hline $1893 \ldots$ & 6 & $1,603,590$ & ........... & 916,675 & ............ & 909,777 \\
\hline $1898 . . . .$. & $6^{*}$ & $1,093,897$ & 13,151 & 916,675 & 974 & 760,547 \\
\hline
\end{tabular}

* $\mathbf{T}$ wo in liquidation.

\section{National Banks.}

Figures are in thousands of dollars.

\begin{tabular}{|c|c|c|c|c|c|c|c|c|c|}
\hline YEARS. & 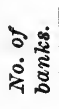 & $\begin{array}{c}\text { Loans } \\
\text { and dis- } \\
\text { ccunts. }\end{array}$ & $\begin{array}{c}U . S . \\
\text { bonds. }\end{array}$ & $\begin{array}{l}\text { Cash and } \\
\text { cash items. }\end{array}$ & Capital. & Surplus. & $\begin{array}{c}\text { Ondi- } \\
\text { vided } \\
\text { profits. }\end{array}$ & $\begin{array}{c}\text { Out. } \\
\text { standing } \\
\text { circula. } \\
\text { tion. }\end{array}$ & $\begin{array}{c}\text { Indi- } \\
\text { vidual } \\
\text { deposits. }\end{array}$ \\
\hline $1864 \ldots$ & 1 & $\$ 534$ & $\$ 531$ & $\$ 209$ & $\$ 500$ & & .......... & $\$ 363$ & $\$ 231$ \\
\hline $1869 \ldots$ & 62 & 22,485 & 14,710 & 2,381 & 20,365 & $\$ 1,672$ & $\$ 1,237$ & 12,409 & 5,789 \\
\hline 1874... & 62 & 28,160 & 14,932 & 2,171 & 20,505 & 4,082 & 1,642 & 12,991 & 7,931 \\
\hline $1879 \ldots$ & 61 & 24,320 & 16,803 & 1,918 & 20,010 & 3,527 & 1,066 & 13,277 & 7,646 \\
\hline $1884 \ldots$ & 63 & 30,178 & 15,627 & 2,464 & 20,540 & 4,001 & 1,483 & 13,686 & 11,562 \\
\hline $1889 \ldots$ & 60 & 36,009 & 4,041 & 1,407 & 20,284 & 4,418 & 2,042 & 3,425 & 16,037 \\
\hline $1894 \ldots . . .$. & 59 & 35,789 & 7,501 & 1,686 & 20,237 & 5,174 & 1,263 & 6,525 & 19,596 \\
\hline $1898 \ldots . .$. & 57 & 34,515 & 8,030 & 1,901 & 19,337 & 4,808 & 1,327 & 6,797 & 20,963 \\
\hline
\end{tabular}

\section{Savings Banks and .Trust Companies.}

The underlying principles governing the Savings banks of Rhode Island are similar to those of the other New England States. They have no capital and are managed by trustees for the benefit of depositors. Careful supervision is exercised over their management by the State, and their investments are limited by law. The history of their growth from 1853 to 1898 is concisely given in the following table : 
Savings Banks, 1853-1898.

\begin{tabular}{|c|c|c|c|c|c|}
\hline YeARS. & 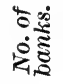 & $\begin{array}{c}\text { Number } \\
\text { of deposi- } \\
\text { tors. }\end{array}$ & $\underset{\text { deposits. }}{\text { Amount of }}$ & $\begin{array}{c}\text { Average } \\
\text { to each } \\
\text { depositor. }\end{array}$ & $\begin{array}{c}\text { Average } \\
\text { per } \\
\text { capita. }\end{array}$ \\
\hline $1853 . . . \ldots \ldots \ldots . .$. & 12 & 16,989 & $\$ 3,308,769$ & $\$ 194$ & $\$ 22$ \\
\hline $1858 \ldots \ldots \ldots \ldots \ldots$ & 20 & 27,643 & $6,349,621$ & 239 & 43 \\
\hline $1863 . \ldots \ldots \ldots \ldots \ldots \ldots$ & 21 & 40,827 & $11,128,713$ & 275 & 63 \\
\hline 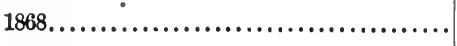 & 25 & 63,501 & $24,408,635$ & 384 & 131 \\
\hline $1873 \ldots \ldots$ & 37 & 93,124 & $46,617,183$ & 500 & 214 \\
\hline $1878 \ldots . . . \ldots$. & 39 & 93,053 & $44,266,882$ & 475 & 171 \\
\hline $1883 . . . \ldots \ldots$ & 38 & 114,762 & $50,127,806$ & 416 & 181 \\
\hline $1888 \ldots \ldots \ldots$ & 38 & 123,102 & $57,699,884$ & 468 & 189 \\
\hline $1893 . \ldots \ldots \ldots$ & 35 & 130,610 & $69,053,724$ & 528 & 199 \\
\hline 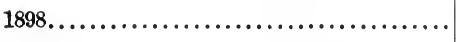 & 35 & 140,815 & $70,589,065$ & 503 & 183 \\
\hline
\end{tabular}

In his annual report for 1898 the State Auditor and Insurance Commissioner said that a comparison of the Savings bank returns with those of the previous year showed an increase of $\$ 1,154,609$ in deposits, most of which came from small depositors. The number depositing less than $\$ 500$ had increased 1,865 , while those depositing $\$ 1,000$ and upwards had increased but 716. This would seem to disprove the statement frequently made by political agitators that the rich are getting richer and the poor are getting poorer. Nor is the State of Rhode Island exceptional in this respect. Wherever Savings banks exist it will be seen that their deposits have been increasing at a continuous and rapid rate, and that the gains are, as a rule, distributed among a. large number of depositors. In other States where the Savings bank system has never gained a foothold, it will be found that the building and loan associations largely supply their places, not only providing assistance in purchasing homes for those in moderate circumstances, but furnishing a profitable method of investment. While there have been many failures of these organizations in some of the States, they are being gradually placed under more stringent regulations and their management is improving.

In November, 1898, the trust companies of the State held deposits amounting to $\$ 23,684,020$. Their capital and surplus exceeded $\$ 4,000$,000. But little of their funds are loaned on real estate mortgages, most of them being placed on personal and collateral security and in State, Government, municipal and other bonds.

Contrary to the policy adopted in New York, the deposits in the Savings banks of Rhode Island are subject to an annual tax of forty cents on each $\$ 100$, and the deposits of trust companies are similarly taxed. 


\section{CONNECTICUT.}

The Colony of Connecticut experimented with circulating notes long before any banks were chartered in the State. In 1709 the Colony emitted bills to the amount of $£ 8,000$, for the purpose of meeting expenses. In 1732 the General Court granted a charter to the "New London Society United for Trade and Commerce," which soon issued circulating notes in imitation of Colonial bills and brought about the speedy repeal of its charter.

It was towards the close of the century when the bank note first came into use in the State, by the establishment of the Hartford Bank. The people had recently seen the folly of Government currency, and this bank was established largely to fill the need for currency to buy and move the crops during the fall and winter.

On February 27,1792 , its capital was fixed at $\$ 100,000$, divided into 250 shares of $\$ 400$ each.

On May 14 petition for an act of incorporation was made to the General Assembly. The petition was granted, and the charter provided that no person (except the State of Connecticut) should hold more than thirty shares.

The holders of one and two shares were entitled to one vote at stockholders' meetings; holders of from two to ten shares, one vote for every two shares; and holders of more than ten shares, one vote for every four shares. There were nine directors, only three-fourths of whom could be eligible for re-election each year. In addition to its capital of $\$ 100,000$ the State could take forty shares at par and have the appointment of two directors.

The bank opened for business August 8, 1792, with the following men as directors: Jeremiah Wadsworth, John Caldwell, John Morgan, George Phillips, Barnabas Deane, Timothy Burr, James Watson, Caleb Bull and Ephraim Root.

At this time there were few other banks in America. In Philadelphia there was the Bank of North America, chartered in March, 1782; in New York the Bank of New York, chartered in 1791; in Boston the Bank of Massachusetts, chartered in 1784; in Providence the Providence Bank, which began business in October, 1791.

Thus the Hartford Bank, the Union Bank of New London, and the New Haven Bank, all chartered at about the same time, were among the earliest banks in the United States, and they all exist to-day (1899), with a long and honorable career of usefulness to their credit.

The incorporation of these banks was speedily followed by others. In 1795 the Middletown Bank was chartered; in the following year the Norwich Bank, and by 1828 seventeen banks had been chartered, fifteen of which were then in existence. These early charters usually provided that notes or bills might be issued to an amount not exceed- 
ing, in the whole, fifty per cent. over and above the capital stock of the bank and the amount of its deposits. In practice this limit was rarely even approached, and Connecticut bank currency was always held in high esteem.

On June 16, 1792, the Hartford Bank took the lead in introducing the decimal system of notation, when its directors resolved that their notes should be payable in "dollars." On August 26, 1792, it was announced that paper offered for discount should be expressed in dollars and cents. Five years later, in July, 1797, this change in notation was made at the office of the Treasurer of the State.

In 1814 Connecticut banks were able to maintain specie payments, although most of the banks in the South and West had suspended. Nor was there any injury to their repute until 1825, when the first bank failure occurred-the Eagle Bank, of New Haven-due to gross mismanagement. In the same year the Derby Banking and Fishing Company failed, after a few months' exploitation at the hands of New York parties, who had obtained control of its charter.

Until 1836 the conduct of the banks was left almost entirely to the discretion of their officers, subject to such restrictions as were imposed by their respective charters.

At a session of the General Assembly held at New Haven in May, 1836, the following resolution was adopted:

"Resolved by this Assembly: That the Treasurer of this State, the Comptroller of Public Accounts, and the Commissioner of the School Fund, be, and they hereby are, appointed a committee to examine into the banks of this State, and to ascertain by inspection or otherwise, the management and their mode of doing business, and whether the same is according to, and within the provisions of their charters, and whether their business is done in a manner to accommodate the public-and to ascertain if any increase of bank capital is needed in this State." * * *

The committee was also vested with power to send for persons and papers and to examine under oath all officers, agents or servants of any bank.

In response to the committee's request the thirty-one banks rendered a statement of their liabilities and of their means and resources to meet the same, showing in the aggregate as follows:

Resources.

Real estate owned by the banks, viz.:

Banking houses.......................... \$165,993.32

Other real estate $\ldots \ldots \ldots \ldots \ldots \ldots \ldots \ldots \ldots \ldots \ldots \ldots . \quad 13,609.80$

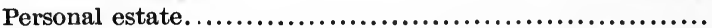

Bills of other banks in this State.............. \$220,411.71

Bills of other banks out of this State.......... 119,167.79

Balances due from other banks ...........................

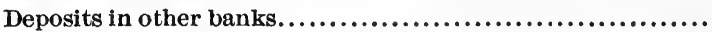

Gold, silver and other coin in the banks....................

Stock of the banks....................................

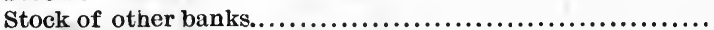

Other stocks.

$\$ 179,603.12$

$15,759.86$

$339,579.50$

$374,802.82$

$127,684.64$

$426,290.51$

$13,700.00$

$37,484,67$

$373,058.50$

Bonus paid.

$71,116.19$ 
Resources-Continued.

\begin{tabular}{|c|c|}
\hline & \\
\hline 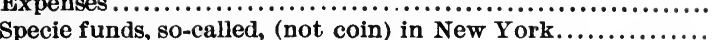 & \\
\hline 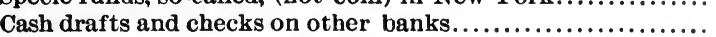 & $10,792.72$ \\
\hline Bills discounted and debts due the banks, viz.: & \\
\hline From corporations............................ $\$ 295,523.75$ & \\
\hline From individuals............................ $13,066,404.85$ & $13,361,928.60$ \\
\hline Other property not before specified..... & $1,905.72$ \\
\hline Total resources..... & $\$ 15,609,966.28$ \\
\hline Liabilities. & \\
\hline Capital stock paid in, transferable $\ldots \ldots \ldots \ldots \ldots \ldots . \$ \$ 7,882,460.00$ & \\
\hline Capital stock not transferable................... $\quad 796,847.50$ & $\$ 8,679,307.50$ \\
\hline Bills of the banks in circulation............................. & $4,094,681.71$ \\
\hline Balances due to other banks............................ & $457,650.27$ \\
\hline Deposits not bearing interest $\ldots \ldots \ldots \ldots \ldots \ldots \ldots \ldots . \$ 1,832,714.80$ & \\
\hline Deposits bearing interest....................... $\quad 90,028.60$ & $1,922,743.40$ \\
\hline 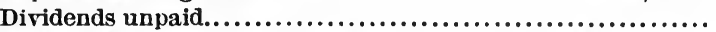 & $36,655.76$ \\
\hline 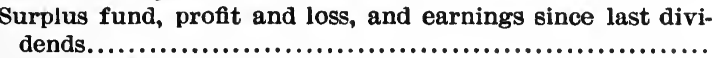 & $415,557.94$ \\
\hline Bonus due from banks................................... & $1,624.17$ \\
\hline id liabilities not above specified.. & $1,273.46$ \\
\hline Variation in accounts......................................... & 189.35 \\
\hline Due in New York ...... & 220.14 \\
\hline & \\
\hline
\end{tabular}

The committee visited thirty of the thirty-one banks and the three branches, and stated that "the soundness and solvency of all the banks examined by us is, in our judgment, unquestionable. We believe that the public may place entire confidence in their ability to meet all their engagements; and inasmuch as the present is a time of suspicion and distrust in pecuniary concerns, we feel bound to express ourselves fully on this point. We think nothing short of a state of general bankruptey can deprive any of our banks of the means of redeeming all their bills."

\section{Loans Made Outside the State.}

From 1836 to 1840 great complaint seems to have been made because some of the banks loaned much of their funds out of the State, and even in the more remote parts of the United States.

The supply of banking capital in New Haven and some of the larger towns was much greater than the demand for loans, and the temptation was strong to make loans in New York and elsewhere, thereby securing an extensive and profitable circulation of the bills of the bank.

The Special Legislative Committee of 1836 pointed out that these loans were often made at rates of interest or discount ranging from seven to eighteen per cent., although the charters of the banks limited the rate to be charged on loans to six per cent.

The banks claimed in defense of their action that their charters contemplated but six per cent. as the rate on loans, but permitted them to deal in "bills of exchange," on which they were not restricted as to rate. 
Upon the recommendation of the special committee, Bank Commissioners were appointed in 1838 to make annual visits to the banks and to inspect their operations. The Board of Bank Commissioners has existed from that date, and in 1842 the Savings banks of the State were also placed under their supervision.

For several years after the appointment of the commissioners they repeatedly called attention to mistakes of management which some of the banks were making. In some cases excessive loans had been made to directors ; in other cases loans had been made upon the pledge of a bank's own stock to such an extent as to materially reduce the actual capital available for the assistance of the mercantile conmunity ; and in some instances dividends had been paid which had not been clearly earned, and which resulted in the temporary impairment of the capital of the bank.

A decided improvement in these respects took place between $\mathbf{1 8 4 0}$ and 1850, and the solvency of Connecticut's banks was everywhere recognized.

The law of 1835 prohibited the circulation of one and two dollar bills within the State, but bank bills of Massachusetts and Rhode Island composed a considerable portion of the currency in the northern and eastern counties of Connecticut. The banks in those counties refused to aid in violating the law by receiving them, even for the purpose of returning them to the banks for redemption. Thus they continued in eirculation longer than bills of other denominations, and much to the injury of the legal curreney in that vicinity. At this time the "banks redeemed their bills in New York or Boston, or both, and the redemption of bills took place in these cities to an extent probably one hundred fold greater than at their own counters." Thus it had become unnecessary for the banks to keep in their vaults any large amount of coin.

The total amount of specie in the vaults October 1,1836 , was $\$ 426$,290.51 , and on March 31,1837 , was $\$ 415,386.10$. In six months prior to April 1, 183\%, two-thirds of the circulating bills were redeemed once in thirty days, and one-third once in forty-five days.

$*$

In 1827 an act had been passed which rendered valid all prior loans on which discount or interest had been taken according to Rowlett's Tables. These tables were made up on the basis of a year of 360 days, and their use caused considerable controversy. However, in 1838 these tables were made the standard for future transactions, although the Bank Commissioners, * in their report of 1839 , doubted the "expediency of establishing Rowlett's Tables as the legal standard," and recommended that the laws of 1838 be repealed. However, the very great 
convenience of a 360-day year in computing interest soon became recognized, and its use became general.

\section{Loans to Directors on a Pledge of Stock.}

An abuse that was quite persistent for some years was the loaning of large amounts to directors without adequate security, or often on the pledge of the bank's own stock.

The law of 1837 provided, curiously enough, that a director should not be indebted in a sum exceeding $\$ 9,000$ over and above the sum which stood in his name. And under this law it actually occurred that in the case of a few small banks the directors were indebted to an amount in excess of the entire capital stock.

To correct such conditions it was repeatedly urged that the loans to directors be limited to a fixed percentage of the capital stock, and a law to this effect was finally passed, it even going so far as to prohibit any loan to any " company or corporation of which such director is a member or stockholder." This provision caused much inconvenience, and was afterwards repealed. At the present time (1899) the limit for any one director is placed at five per cent. of the capital and surplus of the bank.

In 1839 certain irregularities were disclosed in the conduct of the Jewett City Bank, to which three of its directors had become indebted to an amount exceeding its actual capital. This condition was soon remedied, however, and the bank was re-established in the public confidence.

\section{Maintaining Specie Payments.}

In October, 1839, Philadelphia banks suspended specie payments. Their suspension, after having by an extraordinary measure of finance drawn a large amount of funds from New York and New England, produced general alarm and distrust in the integrity of the Connecticut banks. The suspension of nearly every bank in the States south and west of Pennsylvania, and also in Rhode Island, immediately followed.

New York and New England banks determined to maintain specie payments, and in doing so produced a state "of pecuniary distress, more intense, more general and more embarrassing than any that had before occurred in our country." * Bank notes were returned for redemption with unprecedented rapidity, while the banks' funds were considerably diminished "by the retention of their funds in the suspended banks, as well as by the urgency of the claims of their debtors for indulgence." +

The course of the loans, circulation and specie of the banks was as follows: 


\begin{tabular}{|c|c|c|c|}
\hline 1839. & Loans. & Circulation. & Specie. \\
\hline 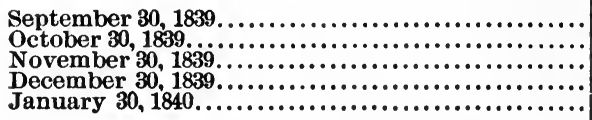 & $\begin{array}{r}\$ 11,199,878 \\
10,345,044 \\
9,803,703 \\
9,602,362 \\
9,596,582\end{array}$ & $\begin{array}{r}\$ 3,821,291 \\
2,551,203 \\
2,025,840 \\
1,872,793 \\
1,886,140\end{array}$ & $\begin{array}{r}\$ 458,733 \\
515,193 \\
481,697 \\
470,693 \\
484,433\end{array}$ \\
\hline
\end{tabular}

One-third of the entire circulation, or $\$ 1,270,088$, was returned to the banks within thirty days after the suspension of the Philadelphia banks. No Connecticut bank failed, however, and the Bank Commissioners refer to the situation in the following terms:

"This contraction of the ordinary currency of our community, accompanied by a necessary curtailment of bank accommodations, pressed heavily on all classes of our citizens and the banks, although suffering under the pressure of their own liabilities, were held responsible for the pecuniary embarrassments of the community. Under these adverse circumstances our banks have sustained their credit and consequent ability for future usefulness."

At this time the law authorized the banks of the State "to issue post notes payable to order, and at a time subsequent to issuing the same."

This description of paper was not issued by Connecticut banks after 1837 , since the practice had been brought into disrepute by the banks of other States substituting this class of notes for current circulation, and forcing large issues on the market under the pretext of affording relief to the commercial community.

A few Connecticut banks had, however, invested to some extent in the depreciated paper of banks of other States.

Thus in 1839 post notes of two of the Philadelphia banks had been purchased to the amount of $\$ 360,000$. The suspension of the Philadelphia banks and their consequent refusal to pay these notes at maturity, resulted in some embarrassment to the Connecticut institutions and furnished a corrective for the policy of buying such paper, which policy was at best of doubtful propriety.

During these "panic" years the greatest losses sustained by the banks were due to the large amount of funds placed in the hands of E. M. Morgan \& Co., brokers, and to bad loans made in 1836 and 1837 in the western part of New York State.

\section{SUFFOLK SYSTEM OF REDEMPTION.}

At this time the banking system of New England stood very high in public esteem. The arrangement for the redemption of bank bills known as the "Suffolk Bank System" was in force, and was exerting a healthful and conservative influence on the banks.

Under this plan the several banks maintained deposit balanees to their credit with the Suffolk Bank, which redeemed at par all their 
notes, charged them to the accounts of the banks of issue, and periodically sent home the notes thus redeemed.

In the quaint phraseology of the time the situation is thus described: "Any estate in the southwest part of Connecticut is now given for the bank issues of the opposite point, with as much safety and readiness as though it was located at the door of the receiver, the whole being at par at the Suffolk Bank, consequently with every bank redeeming there."

In the years closely following the crisis of 1837 not one bank failure occurred in Connecticut, nor was there even a solitary case of suspension nor of inability to redeem their bills at the Suffolk Bank, where about one-eighth of the circulation was redeemed each week.

Indeed, since 1792, during the first fifty years of banking in Connecticut, but two failures occurred, viz., the Derby Banking and Fishing Company, in 1825, and the Eagle Bank at New Haven in the same year.*

Throughout the entire country there had been about two hundred bank failures thus far in the history of the United States. In many instances the failures were due to improper loans made to directors, and to this fact may be traced the general disposition which prevailed in 1840-50 to limit the amount of such loans by law.

A feature of this period which tended to injure the repute of the circulating notes of the banks, was the issue by the Housatonic Railroad Company of its post notes and demand notes, which circulated as currency. On April 13, 1843, such notes were outstanding to the amount of $\$ 259,575$. $\dagger$ In May of the same year $\$ 5,000$ of the company's notes were protested, and were not paid within twenty days after such notice. The company was unable to obtain further subscriptions from its stockholders, and its affairs were in a very critical state. Under these conditions its circulating notes became a source of annoyance, and to some degree a menace to the banks, by inspiring a lack of confidence in their own well-secured bank notes.

\section{Expansion of Circulation and Loans.}

The last half of the year 1843 and the year 1844 witnessed a rapid expansion by Connecticut banks, as may be seen from the following table:

*There was a clause in the charter of this bank *** that various ecclesiastical and educational societies might at any time subscribe shares at par, with their funds, which shares should not be transferable, but should be withdrawable on six months' notice. In the first case of trouble, of course, the question arose whether these were deposits or shares in the capital, involving the question whether the owners were debtors or creditors in bankruptcy. In the case of the United Society against the Eagle Bank, it was held that the society could not, after the insolvency of the bank, withdraw its shares or recover the amount as a debt of the bank. Its position was that of a stockholder." Sumner's "History of Banking," p. 171.

+ Funded by issue of seven per cent. bonds in 1844 . 


\begin{tabular}{|c|c|c|c|}
\hline & Circulation. & $\begin{array}{l}\text { Due from } \\
\text { banks and } \\
\text { brokers in } \\
\text { New York. }\end{array}$ & $\begin{array}{l}\text { Bills dis- } \\
\text { counted. }\end{array}$ \\
\hline 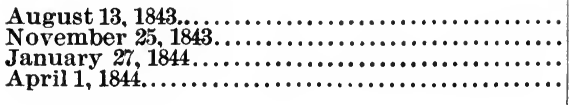 & $\begin{array}{r}\$ 2,712,542 \\
2,875,400 \\
\mathbf{2 , 9 3 6 , 8 5 8} \\
\mathbf{3 , 6 2 8 , 5 6 9}\end{array}$ & $\begin{array}{r}\$ 1,486,126 \\
1,221,053 \\
1,197,286 \\
1,172,344\end{array}$ & $\begin{array}{l}\$ 9,539,246 \\
10,060,735 \\
10,103,514 \\
10,913,205\end{array}$ \\
\hline
\end{tabular}

On April 1, 1844, the loans and the circulation had reached a higher point than had been attained since March, 1839. During these years the recklessness of States, banks and individuals had thrown most busi ness interests into despair. Capital was unemployed and accumulated rapidly in New York, where for the most of it no interest was allowed. With enterprise lagging and the demand for money slight, loans were made in New York at as low rates as three and four per cent.

The first of January, 1844, as compared with 1841 and 1839, shows to what extent the depression in trade and the accompanying contraction in discounts and circulation affected all the banks in the United States :

\begin{tabular}{lcrr} 
& \multicolumn{1}{c}{1889.} & 1841. & \multicolumn{1}{c}{1844.} \\
Discounts................. & $\$ 492,278,015$ & $\$ 308,543,723$ & $\$ 207,277126$ \\
Circulation................ $135,170,995$ & $80,864,821$ & $55,688,792$
\end{tabular}

Early in 1844 the spirit of enterprise awoke, speculation became more general, and its effects on the banks of Connecticut became quite marked.

During the following year the aggregate circulation became larger than at any former period; yet it did not reach the amount allowed by law.

The banks were allowed by their charters to circulate once and a half the amount of their capital stock and deposits. The whole amount of banking capital was $\$ 8,475,630$; hence the legal limit was $\$ 12,713$,445 , besides what they were entitled to have on their deposits ; but as a matter of fact the circulation was only about one-third the amount to which their capital alone entitled them.

The Suffolk Bank system of redemption imposed a salutary check upon excessive circulation and made it impossible for the banks to sustain as large note issues as they were legally entitled to.

Thus the system imposed restrictions upon bank issues far more effectual and rational than any law could have effected.

The years 1846-48 were prosperous ones for Connecticut banks. In 1846 their dividends averaged seven and one-quarter per cent. for the year.

In 1847 a tendency was manifest to divide earnings too closely and to maintain too small a specie reserve.* The claim was still made that the banks went "abroad for paper to the neglect and inconvenience of our

* The law of 1848 required a specie reserve in vault of ten per cent. of crrculation. 
own citizens." While this claim may have been well based in certain eases, yet it is true that at times the supply of loanable funds was greatly in excess of the requirements of Connecticut merchants and manufacturers.

The charters of several banks provided that the State, the School Fund or ecclesiastical societies might become stockholders at any time by paying the par value of the shares. In this way the State secured the right to one or more directors in several banks, and the Commis sioner of the School Fund was by law authorized to examine each bank in which that fund had any stock. In 1847 the total capital of the banks was $\$ 8,726,381$, owned as follows:

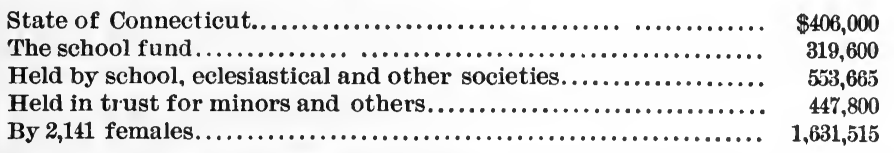

The whole number of stockholders was 6,270 , with an average holding of $\$ 1,206$ of stock.

In 1848 a law was passed requiring banks to keep in their vaults specie to the amount of ten per cent. of their circulation. This was readily done, since more specie came in over the counters than was required in payments. People preferred bills.

\section{General Banking Law of 1852.}

During the next four years there was considerable agitation in regard to the banking system of the State, culminating in 1852 in a general banking law, under which five banks organized the following year, viz., the Uncas, the Saugatuck, the Bank of Hartford County, the Bank of Litchfield County, and the Bank of Commerce, at New London.

The main feature of this general law was in its provision for the issue of currency against a deposit of specified public stocks to be made with the Treasurer of the State, from whom the bank would then receive an equal amount of bills. The banks were also obliged to retain a portion of their capital for redemption purposes.

Thus there developed two banking systems side by side. The old chartered banks issuing a credit currency on the one hand, and the new associated banks with their specially-secured circulation.

The stimulus to trade given by the gold discoveries in California had aided in a very general expansion by the banks, which had added largely to their lines of discount and circulation. In the summer of 1851 there was a decided pressure in the money market, which was met by most of the banks without inconvenience. However, in March, 1853, two small banks failed; the Eastern Bank, of Killingly, and the Woodbury Bank. These failures were due to the failure of a New York broker, in whose hands a large amount of the assets of both banks had been placed 
In 1855 there were sixty-seven banks in the State, of which thirteen were organized under the General Banking Law,* with a combined capital of $\$ 2,948,169$; while the chartered banks numbered fifty-four, with a capital of $\$ 14,197,282$. In the following year the number of banks increased to seventy, with a capital of about nineteen millions of dollars.

At this period in the history of the State much attention was paid to legislation touching the banks. In 1855 it was enacted "that the loans and discounts of any bank to persons out of the State shall not, at any time, exceed in the aggregate one-fourth part of its capital stock actually paid in, bills in circulation, and moneys on deposit, at the time."

The rate of interest charged on loans was also a matter of frequent consideration by the General Assembly. From time to time the Bank Commissioners recommended that the rates of exchange on items payable at a distant place be fixed by law.

By the act of 1854, the rate of interest which the banks might pay on deposits was restricted to four per cent. This was repealed the following year, but in 1862 a new law was enacted, which forbade the payment of any interest. This too was repealed later.

\section{The Panic of 1857.}

The financial panic of 1857 severely tested the resources of all the banks. For many years Connecticut bank notes had been eagerly sought after for circulation in Ohio, Indiana and other Western States, and at the beginning of the panic large amounts of Connecticut bank currency were in use in other States.

Beginning with a sudden decline in the price of public securities, the failure of the Ohio Iife and Trust Company' and a few other large institutions, the results of a too rapid expansion soon became manifest in a general want of confidence in the circulation of banks, whose notes were presented for redemption with great urgency.

On July 1 the circulation of the banks of the State was $\$ 10,411,000$. On January 1,1858 , it stood at $\$ 4,130,265$, a contraction of over $\$ 6,000$,000 in the space of six months, the greater part of which occurred in August, September and October, when the panic was at its height. During this period nearly all the banks continued to redeem their notes in New York and Boston, and to pay them in specie at their own counters until October 14, when the general suspension of New York and Boston banks took place. On the following day most of the Connecticut banks suspended specie payments, $\uparrow$ although they still maintained their redemptions in New York and Boston. In their 1859 report the Bank Commissioners remark: "The ability of the banks to sustain themselves, without breaking down their customers, under a contrac-

* All the banks organized under the "Free Banking Act" were incorporated in 1855 by General Act.

+ There were a few notable exceptions of banks which maintained specie payments through this trying time. 


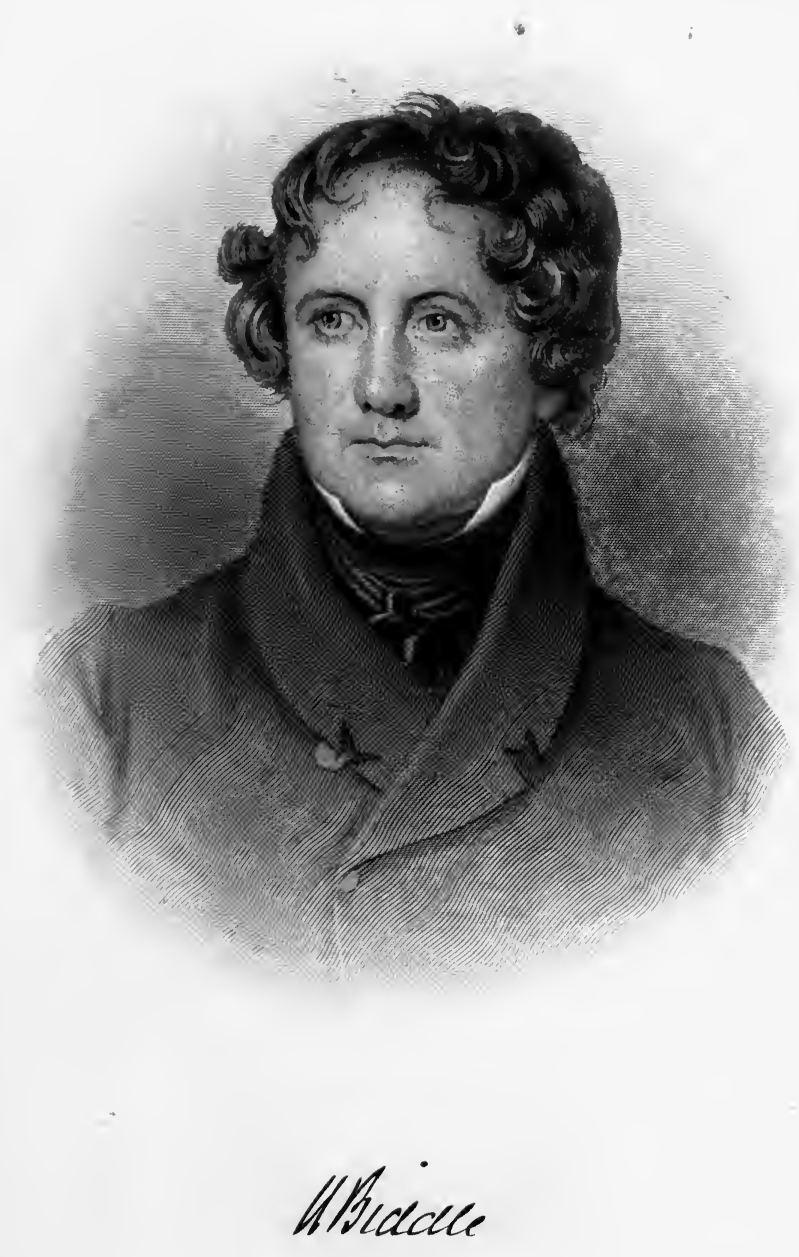


$\Leftrightarrow$ 
tion so unprecedented, exhibited a degree of soundness and stability which must place them high in the confidence of the public of this and other States."

During this period seven banks, out of a total of seventy-three, were placed in Receivers' hands; some of them, however, resumed business after a temporary suspension.

Many of the banks held large amounts of suspended debts, upon which there was eventually considerable loss, involving in some cases impairment of capital stock and its consequent reduction, or at best the passing of dividends for a few years.

A direct result of the panic was the enactment in 1858 of a law limiting the circulation of the banks to seventy-five per cent. of their capital. This law simply made legal and binding a limitation which had never been exceeded by the banks, save in the year 1853, when the circulation reached eighty per cent. of the capital. Under the Suffolk Bank system of redemptions it was impossible for the banks to force an unnatural and undue amount of bills into circulation. Business usage and commercial laws had safeguarded the people quite as effectually as the legislation of the General Assembly.

In 1860 panic conditions extended far and near, but specie payments were maintained in New York and New England, though a general suspension prevailed in the extreme South and as far north as Philadelphia. The following year was one of anxiety, and on December 31, 1861, the New York banks suspended; and although no run had occurred on the banks of Connecticut, they adopted the same expedient.

\section{Loans Made to the Government.}

At the outbreak of the Civil War, when the first loan of $\$ 50,000,000$ was successfully effected, the banks of Connecticut loyally came to the assistance of the Government, and by May, 1862, these banks had taken of the national loan, on their own account, the sum of $\$ 6,500,000$. In addition to this they subscribed for $\$ 1,308,100$ of the State of Connecticut loan of $\$ 2,000,000$, issued to pay the expenses of preparing and dispatching troops to Washington.

With the establishing of the National banking system in 1863 came a very general transition of the Connecticut banks from the State to the Federal system. In April, 1863, the capital of the State banks was $\$ 21,849,148$. In April, 1865 , it had been reduced to $\$ 13,073,850$, and in May, 1866, the situation was as follows:

MAY, 1866.

Capital.

Ninety National and State banks........................

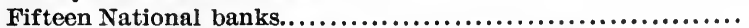

Thirty-two banks, changed from State to National system un-

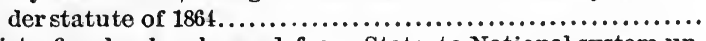

Thirty-five banks, changed frcm State to National system un-

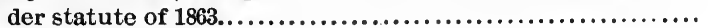
Eight State banks.

$\$ 26,182,243$ $2,760,000$

$10,449,373$

$10,986,930$ $1,985,920$ 
The eight State banks remaining in 1866 were placed at a great disadvantage as compared with their rivals in the National system, by the operation of the prohibitive tax of ten per cent. on State bank notes. The circulation of course was rapidly retired from $\$ 1,275,732$ in 1866 , to $\$ 29,918$ in 1873 , while during the same period the National bank circulation had increased to nearly $\$ 18,000,000$.

The following table reveals the rapid growth of the National system during the year 1865 :

\begin{tabular}{|c|c|c|c|c|c|c|c|}
\hline $\begin{array}{c}1865 \\
\text { FIRST Mon- } \\
\text { DAY IN- }\end{array}$ & 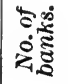 & Capital. & $\begin{array}{l}\text { Circula- } \\
\text { tion. }\end{array}$ & $\begin{array}{c}\text { Total } \\
\text { liabilities. }\end{array}$ & $\begin{array}{l}\text { Specie and } \\
\text { legal } \\
\text { tenders. }\end{array}$ & $\begin{array}{l}\text { Loans and } \\
\text { discounts. }\end{array}$ & Deposits. \\
\hline $\begin{array}{l}\text { January.... } \\
\text { April....... } \\
\text { July } \\
\text { Octöe...... }\end{array}$ & $\begin{array}{l}23 \\
38 \\
70 \\
81\end{array}$ & $\begin{array}{r}85,673,909 \\
12,492,929 \\
21,281,070 \\
23,990,020\end{array}$ & $\begin{array}{r}\$ 3.999,876 \\
4,88 \div .943 \\
7,329,036 \\
\mathbf{9 , 8 1 5 , 5 2 7}\end{array}$ & $\begin{array}{r}\$ 17,409,044 \\
30.717,306 \\
49,927,532 \\
58,705,819\end{array}$ & $\begin{array}{r}\$ 823,292 \\
1,461,992 \\
2,563,862 \\
3,128,924\end{array}$ & $\begin{array}{l}\$ 5,074,996 \\
10,924,637 \\
19,521,347 \\
23,556,157\end{array}$ & $\begin{array}{r}\$ 3,492.528 \\
6,164,725 \\
9,310,691 \\
11,059,70 \%\end{array}$ \\
\hline
\end{tabular}

These banks had State bank notes outstanding in October, 1865, amounting to $\$ 6,162,463$.

The earnings of National banks in Connecticut show a marked decline during the last twenty years, as the following table of percentages indicates :

$\begin{array}{lccccc} & 1874 . & 1878 . & 1894 . & 1898 . \\ \text { Earnings to capital and surplus................. } & 9.6 & \mathbf{6 . 4} & 4.1 & 4.5 \\ \text { Dividends to capital and surplus.............. } & 8.1 & 6.4 & \mathbf{5 . 0} & \mathbf{5 . 0} \\ \text { Dividends to capital.......................... } & 10.3 & 8.1 & 6.7 & 7.0\end{array}$

The depression following the panic of 1873 resulted in many losses for the banks.

From September 1, 1875, to September 1, 1879, Connecticut National banks charged off $\$ 4,606,174$ of bad debts, while during the same period the losses of all the National banks in the United States amounted to nineteen per. cent. of their entire capital. Yet in spite of losses the bank failures were few and insignificant.

The panic of 1884 was successfully weathered, and during the more recent trials of 1893 not a bank closed up in either the National or State system, and the only afterclap of the panic was seen in 1895, in the failure of the First National Bank, of Willimantic, and the Dime Savings Bank in the same town.

In their report made in 1894, the Bank Commisioners comment as follows on the condition of the banks during the panic of the previous year: "Not a single instance of suspension or default or even a suspicion of weakness has been displayed by any of the banks."

The following tables illustrate the growth of the State banks and National banks of Connecticut, from their earliest record to the present time : 
State Banks.

\begin{tabular}{|c|c|c|c|c|c|c|}
\hline YeARs. & $\begin{array}{l}\text { No. of } \\
\text { banks. }\end{array}$ & $\begin{array}{l}\text { Loans and } \\
\text { discounts. }\end{array}$ & Specie. & $\begin{array}{l}\text { Capital } \\
\text { stock. }\end{array}$ & Circulation. & Deposits. \\
\hline $1834 \ldots$ & 28 & $\$ 8,307,824$ & $\$ 118,640$ & $\$ 6,851,909$ & $\$ 2,407,496$ & $\$ 1,167,964$ \\
\hline $1839 .$. & 31 & $12,226,947$ & 502,180 & $8,832,223$ & $3,987,815$ & $1,285,867$ \\
\hline $1844 \ldots$ & 31 & $10,842,955$ & 445,430 & $8,292,238$ & $3,490,963$ & $1,847,447$ \\
\hline 1849. & 36 & $14,043,096$ & 575,656 & $8,928,264$ & $4,511,570$ & $1,831,291$ \\
\hline $1854 \ldots$ & 63 & $28,292,321$ & $1,207,381$ & $15,597,891$ & $11,219,566$ & $3,910,160$ \\
\hline 1859. & 74 & $27,856,785$ & 989,920 & $21,512,176$ & $7,561,519$ & $5,574,900$ \\
\hline $1864 \ldots$ & 61 & $28,569,876$ & $1,198,372$ & $20,606,962$ & $11,869,701$ & $9,996,643$ \\
\hline 1869. & 7 & $2,353,568$ & 24,304 & $1,610,000$ & 37,337 & $1,243,750$ \\
\hline $1874 .$. & .. & $2,754,632$ & 9,903 & $1,450,000$ & 29,425 & $1,525,957$ \\
\hline $1879 .$. & 4 & $1,745,180$ & $\star 158,661$ & $1,350,000$ & 19,506 & $1,256,679$ \\
\hline 1884. & 6 & $3,515,980$ & *304,933 & $1,850,000$ & 19,356 & $2,284,664$ \\
\hline 1889. & 8 & $4,776,747$ & $\nmid 317,245$ & $2,340,000$ & 9,550 & $4,063,279$ \\
\hline $1894 .$. & 8 & $4,693,186$ & $\nmid 429,269$ & $2,340,000$ & .............. & $4,494,445$ \\
\hline $1898 \ldots$ & 8 & $5,356,901$ & †ร29,824 & $2,240,000$ & ....... & $5,922,325$ \\
\hline
\end{tabular}

* Currency, specie and cash items.

$\uparrow$ Specie and currency.

Trust Companies Doing a Banking Business.

\begin{tabular}{|c|c|c|c|c|c|c|}
\hline YEARS. & Capital. & $\begin{array}{c}\text { Total } \\
\text { liabilities. }\end{array}$ & $\begin{array}{c}\text { Cash } \\
\text { on hand. }\end{array}$ & $\begin{array}{l}\text { Loans and } \\
\text { discounts. }\end{array}$ & $\begin{array}{c}\text { Total } \\
\text { resources. }\end{array}$ & Deposits. \\
\hline $1872 \ldots .$. & $\$ 536,750$ & $\$ 1,726,372$ & $\$ 42,024$ & $\$ 1,277,460$ & $\$ 1,726,372$ & $\$ 1,119,145$ \\
\hline $1882 \ldots . .$. & 926,600 & $3,866,706$ & 124,749 & $2,434,359$ & $3,866,706$ & $2,611,191$ \\
\hline $1892 \ldots . .$. & $1,161,600$ & $6,450,872$ & 146,006 & $3,788,347$ & $6,450,872$ & $4,576,197$ \\
\hline $1898 \ldots . .$. & $1,245,000$ & $8,806,773$ & 400,408 & $4,103,173$ & $8,806,773$ & $6,576,327$ \\
\hline
\end{tabular}

National Banks.

Figures in thousands of dollars.

\begin{tabular}{|c|c|c|c|c|c|c|c|c|c|}
\hline DATE. & 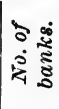 & $\begin{array}{c}\text { Loans } \\
\text { and dis- } \\
\text { counts. }\end{array}$ & $\begin{array}{c}U . S . \\
\text { bonds. }\end{array}$ & $\begin{array}{c}\text { Cash } \\
\text { and cash } \\
\text { items. }\end{array}$ & Capital. & Surplus. & $\begin{array}{c}\text { Undi. } \\
\text { vided } \\
\text { profits. }\end{array}$ & 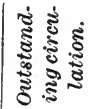 & $\begin{array}{c}\text { Indi- } \\
\text { vidual } \\
\text { deposits. }\end{array}$ \\
\hline $1863 . . . . . . .$. & 2 & $\$ 308$ & $\$ 179$ & $\$ 45$ & $\$ 314$ & $\ldots . .$. & $\$ 7$ & & $\$ 378$ \\
\hline $1868 . . . . . . .$. & 81 & 28,259 & 22,934 & 3,812 & 24,624 & $\$ 3,858$ & 1,633 & $\$ 17,347$ & 12,429 \\
\hline 1873.... & 80 & 35,809 & 20,724 & 3,661 & 25,325 & 6,782 & 1,823 & 17,854 & 13,706 \\
\hline $1878 \ldots$ & 82 & 30,809 & 22,711 & 4,167 & 25,505 & 6,215 & 1,311 & 17,471 & 15,741 \\
\hline $1883 \ldots$ & 88 & 42,183 & 19,879 & 4,439 & 25,927 & 6,870 & 1,940 & 17,111 & $2<, 542$ \\
\hline $1888 \ldots$ & 84 & 43,818 & 12,026 & 4,426 & 24,194 & 6,925 & 1,903 & 7,871 & 27,505 \\
\hline $1 \times 93 . . . . . . .$. & 84 & 43,870 & 8,165 & 3,990 & 22,999 & 7,775 & 2,937 & 6,999 & 28,675 \\
\hline $1898 . . . . . . .$. & 80 & 45,221 & 9,430 & 4,021 & 21,181 & 7,968 & 2,487 & 7,443 & 37,952 \\
\hline
\end{tabular}




\section{SAvings Banks.}

In 1819 the first Savings bank in the State was incorporated as the Society for Savings, at Hartford. This was followed by the Norwich Savings Society in 1824, the Middletown Savings Bank in 1825, the Savings Bank of New London in 1827, and the New Haven Savings Bank in 1838.

In 1842, when these institutions first came under the supervision of the Bank Commissioners, their number had increased to nine, with deposits aggregating $\$ 1,690,960.18$, owned by 13,018 depositors, having an average deposit of $\$ 129$. In only a few instances was the amount of a single deposit in excess of $\$ 1,000$, and in all such cases notice was given to the depositor to reduce it to that sum.

In view of the present holdings of Savings banks in public securities, it is interesting to note that in 1843 the Bank Commissioners recommended the passage of a law providing "that no future purchase shall be made of any State, city, bank, insurance or other stocks, post notes or bonds;" and it was enacted by the General Assembly " that no loans of the moneys or funds* of any Savings bank or Savings society be hereafter made unless the same be secured by mortgage of real estate in this State, unincumbered, equal in value to double the amount of the loan secured thereon, except to an amount not exceeding in the whole ten per cent. of the amount actually on deposit in such Savings bank or Savings society for the time being."

In 1847 a law was passed which prohibited any Savings bank from reserving as a contingent fund a greater sum than $\$ 15,000$. Seven years later the deposits of the Society for Savings in Hartford had become $\$ 2,435,196$, and the insufficiency of a $\$ 15,000$ contingent reserve for such an institution became apparent.

The law at present (1899) limits the surplus (or contingent fund) to ten per cent. of the deposits. It provides that not exceeding twenty per cent. of deposits and surplus may be invested in notes secured by stock or bond collateral; that not exceeding twenty per cent. may be invested in the joint and several obligations of two or more parties, all residents of the State; it permits the investment in a selected list of public securities, in deposits in incorporated banks of New York, Massachusetts or Rhode Island, and loans secured by mortgage on unincumbered real estate in the State worth double the amount of the loan.

The most disastrous Savings bank failure that Connecticut has witnessed was that of the Townsend Savings Bank of New Haven, which failed in September, 1874, after a career of fourteen years. On January 1,1873 , its deposits and surplus were $\$ 3,871,964$. On January 1 , $1874, \$ 3,617,423$. During the summer of 1874 there was a constant drain of deposits, and in September, when the bank was placed in the estate. 
hands of Receivers, its deposits had been reduced to $\$ 2,784,023.86$. The final dividend was paid in 1887 , and the total amount returned to the 12,000 depositors amounted to $\mathbf{4 5 . 7}$ per cent. of the original claims.

At the present time (1899) there is an increasing disposition to discriminate in favor of small depositors, for whose use the Savings banks were primarily intended. Indeed, as long ago as in January, 1883, the New Haven Savings Bank adopted a graduated scale of interest rates, paying four per cent. upon deposits of $\$ 2,000$ and less, and three per cent. upon all sums in excess of that amount.

The Savings banks of the State have withstood with credit the several panics of 1873, 1884 and 1893 .

In July, 1893, there was a steady withdrawal of deposits from many banks. In many cases it continued for some weeks and showed no signs of abating. To protect all the depositors the banks had recourse to their rule requiring a three months' notice before the withdrawal of deposits, and thus stopped the foolish run on certain banks which were absolutely sound, but whose securities would otherwise have had to be sacrificed at panic prices. The following table illustrates the growth of the Savings banks during the last fifty years:

\begin{tabular}{|c|c|c|c|c|c|}
\hline YEARS. & $\begin{array}{l}\text { Number } \\
\text { of banks. }\end{array}$ & $\begin{array}{c}\text { Total } \\
\text { deposits. }\end{array}$ & $\begin{array}{l}\text { Number of } \\
\text { depositors. }\end{array}$ & $\begin{array}{l}\text { Average } \\
\text { deposit. }\end{array}$ & $\begin{array}{l}\text { Rate of in. } \\
\text { terest paid. }\end{array}$ \\
\hline $1847 \ldots \ldots$ & 9 & $\$ 3,113,250$ & 22,663 & $\$ 137.37$ & 5 and $51_{2}$ \\
\hline $1858 \ldots \ldots \ldots \ldots . . . .$. & 35 & $14,052,181$ & 66,709 & 210.67 & 6 \\
\hline $1868 . . . . . . .$. & 55 & $41,803,681$ & 149,919 & 278.87 & 6 and 7 \\
\hline $1878 \ldots . .$. & 86 & $72,515,468$ & 199,795 & 363.12 & $4,41_{2}, 5$ and 6 \\
\hline $1888 \ldots . .$. & 85 & $105,850,079$ & 287,776 & 367.92 & 4 and $4 \frac{1}{3}$ \\
\hline $1898 \ldots . . . . . . . . . . . .$. & 89 & $163,482,498$ & 375,810 & 435.01 & 4 and $4 t_{2}$ \\
\hline
\end{tabular}




\section{III}

\section{* EASTERN STATES.}

Pennsylvania and New York were the seats of the first banking institutions organized in the United States, and they continue to be two of the foremost banking States of the Union up to the present time. The history of banking in New York is of especial interest in view of the experience with the safety-fund system and the close parallel of the banking system to that under which the National banks operate. Maryland is noted for the rarity of bank failures, and in Delaware the State continues as a partner in the ownership and control of a bank, the experiment in this line having been more fortunate than in many other States. New Jersey has some historic banks whose existence dates. almost from the beginning of the present century.

While some of these States have not escaped the disasters that were elsewhere attendant upon the evolution of banking, their financial institutions have been for many years, as a rule, under careful legal restrictions, and their management has been conservative. The annual transactions of the New York Clearing-House banks alone are stupendous, yet they are carried on without loss to the public.

\section{NEW FORK.}

The history of banking in the State of New York naturally divides: into three periods. The first is from the adoption of the Constitution of the United States in 1789 to 1829 . This may properly be called the period of chartered banks. The next period extends from 1829 until 1838 , and is that of the institutions known as the safety-fund banks. These banks were chartered banks, but they were, in a manner not previously known, bound together into a banking system by the provisions of the Safety Fund Law of 1829. The free banking system went into operation in 1838, and continues until the present time. Although the period from 1829 to 1838 has been characterized as that of the safetyfund system, because during that time this system held the prominent place, yet it will be seen that for many years after 1837 the safetyfund system continued to exist alongside of the free banking system.

- The division of the country into geographical sections has been made to conform to that adopted in the reports of the Comptroller of the Currency in recent years. 
While the above general division gives some aid in fixing the principal features of banking in the State of New York chronologically, there are two other most important matters that have to be placed in their proper relation to these periods before the various events can be judged in their true light. One of these concerns the so-called restraining acts, and the other the Civil War and the organization of the National banking system. The philosophy of the restraining acts involves a study of the whole question of State interference with the right of private individuals conducting the banking business. The organization of the National banking system interfered not only with the right of private individuals conducting a banking business, but also with the rights of associations chartered by the State to exercise their full rights under the State charters. These influences were not, of course, peculiar to the State of New York. There were and still are restraining acts in other States, and the National Currency Act affected the rights of banks chartered by other States as well as those chartered by the State of New York.

In the history of New York at the time of the adoption of the Federal Constitution, from 1789 to 1800 , the business of the State did not require any very great amount of banking assistance; but as business increased rapidly, and chartered banks grew in number, and men began to find out how profitable the use of their credit was, individuals, finding nothing to prevent, either singly or as ordinary partners or associates, without troubling the Legislature, went into the business and began to issue notes.

Naturally, there was no check on fraud and tricks, and naturally also the banks that had taken the trouble to secure a charter from the State, and had paid something for it, began to object to this invasion of their privileges.

The legislators of the State, influenced on one side by the outcry arising among their constitutents on account of the frauds perpetrated under the cloak of irresponsible banking, and on the other by the demands of banks which had paid for their charters, gradually enacted laws, until in 1818, it became illegal for any person or body corporate, except such bodies corporate as were expressly authorized by law, to keep any office for deposits, for discounting notes, or for issuing any evidence of debt to circulate as money.

There is no doubt, however, that the banking business as conducted by individuals was, considering the large numbers engaged in it, conducted as honestly as by corporations. Both among individual banks and the chartered banks there were failures and frauds. There was much agitation from time to time, on the part of those who considered that their rights as free and equal citizens were invaded, to secure its repeal. Gradually it dawned upon the public mind that even chartered banking was not altogether irreproachable, and that the defect grew, not so much out of a difference in the mainer of carrying on banking by indi- 
vidual citizens and by chartered banks, as out of a want of proper safeguards, and restrictions to be imposed by law on both.

All this took time. But the spirit of American institutions, to allow the largest liberty in business consistent with the good of all, at length prevailed and the restraining acts were finally repealed in 1837. Immediately afterwards the Free Banking Act was passed, permitting any citizen or association of citizens who would comply with certain requirements of the law to go into the business of banking, including the right to issue promissory notes to circulate as money. Since that date there has been no discrimination exercised by the State of New York favoring any of its citizens above others as to carrying on the banking business. The laws relative to banks passed since 1837 have had for their object either to increase the revenues of the State or to insure greater safety to the public.

In 1863 the National Curreney Act became a law but it did not meet with any great degree of success until after the imposition in March, 1865, of the prohibitory tax of ten per cent. upon State bank notes. Then the State banks in New York as well as in other States began to convert themselves into National banks. Deprived by Federal power of the important privilege of issuing circulating notes under State law, they fell in line under the protection of the law that still allowed them that privilege.

Many distinguished statesmen have declared that the right of a State under the Federal Constitution to charter a bank to issue circulating notes was beyond the power of the State under the compact entered into in the Constitution of the United States. But the right was asserted by the several States and acted upon and has never been successfully contested in the courts. Therefore, when in 1865 , the prohibitory tax on State bank notes was imposed by Congress, its constitutionality was at onee tested in the courts and the law was finally decided to be constitutional by the Supreme Court of the United States.

New York in 1863 had an excellent banking system; the banks under it were sound and solvent and issued a satisfactory and safe currency. The Federal interference fell more heavily on the banks of New York than on those of many of the other States. It was felt to be more of a usurpation and less necessary than it might be in other States where banking methods were not so carefully and wisely guarded. Out of this there grew a slightly hostile spirit in the legislation imposing taxation on National banks within the State. By degrees, however, the United States courts rendered decisions that made it impossible to tax National banks differently to banks carrying on a similar business under State law. Trust companies were then chartered that, while doing a business competing with ordinary banks, are yet so different in many respects that the Supreme Court of the United States has regarded them as a separate class of institutions, rightfully subject to another rate of taxation. This discrimination in taxation of in- 
stitutions which, as the banks claim, do a similar business, has, therefore, been one of the consequences of the National Currency Act impinging on the Free Banking Law of the State of New York. The history of the safety-fund system shows that the operation of this fund has been very much misapprehended. It has been looked upon as a failure, whereas so far as a fair trial was allowed, it was a great success.

\section{The Chartered Banks.}

The first act passed by the Legislature of the State of New York establishing a bank was that of April, 1782, incorporating the Bank of North America and at the same time preventing the establishment of any other banking corporation within the State. The Bank of North America had its charter from the Congress of the Confederated Colonies, and this contained a provision forbidding the bank to establish branches within the several Colonies without the consent thereof. The act of the New York Legislature in 1782 was merely confirmatory, as far as the State of New York was concerned, of the charter granted by Congress.

It had the effect of preventing any other bank from obtaining an act of incorporation until 1791. The Bank of New York, which since 1784 had been doing business under articles of association drawn by Alexander Hamilton, secured a charter on March 21, 1791. In the meantime, in 1789, the present Constitution of the United States had gone into effect, and the powers granted to the Bank of North America by the Congress of the Confederation had not been made use of by that institution, which had obtained and worked under another charter granted by the State of Pennsylvania. Hamilton regarded the Bank of North America as having compromised its charter as a National bank by accepting the Pennsylvania charter, and he doubtless influenced the legislators of New York to disregard the restraining act of 1782 in favor of a new incorporation.

The Bank of New York was the third organized bank in the United States. It was authorized to have a capital of $\$ 1,000,000$, and could contract debts, including those on account of circulating notes, to three times the amount of its capital. It was organized with a capital of $\$ 900,000$-divided into shares of $\$ 500$ each, a subscription by the State to 500 shares subsequently increasing its paid-up capital to $\$ 950,000$. It commenced business under its new charter on May 2, 1791. This charter was amended by several acts of the Legislature, and by the act of April 6, 1808, it was extended until the second Tuesday in May, 1820. Before this date, on April 2, 1813, its corporate existence was again extended until the first Tuesday in June, 1832. By this last act the Comptroller of the State was to subscribe $\$ 15,000$ to its stock for the benefit of common schools. The treasurer of Hamilton College was permitted to subscribe $\$ 15,000$, while Union and Columbia Colleges had the right to subscribe $\$ 20,000$ each if they desired. In 1832 its charter was 
again extended until 1852 and its capital increased to $\$ 2,000,000$. Wher. this period elapsed it reorganized under the Free Banking Law with the same capital, and on January 6, 1865, it became a National bank, its capital having previously been increased to $\$ 3,000,000$.

Between the date of incorporation of the Bank of New York and that of the declaration of war with Great Britain, in June, 1812, nineteen banks, including the Bank of New York, were chartered by the Legislature with an authorized capital of $\$ 18,215,000$. Among these banks were the Manhattan Company, Merchants', Mechanics', Bank of America, and City Bank, of New York city; the New York State and the Mechanies and Farmers', of Albany, and the Bank of Utica. Seven of those named, including the Bank of New York, became National banks, while three of them are at present leading banks organized under State laws, and all except one are now in existence and have maintained high credit from the date of their organization to the present time. Twenty-four additional banks were chartered between 1812 and 1829 , the date of the passage of the Safety-Fund Act, the amount of capital of all the chartered banks being then $\$ 25,105,000$, of which amount $\$ 13,770,000$ was authorized for banks in New York city. In 1841 the whole number of incorporated banks in the State as distinguished from those established under the Free Banking Act of 1838, was ninety-five, with a capital of $\$ 36,401,460$. After the passage of the General Banking Law of 1838 , no new acts incorporating separate banks or for the extension of existing charters as they expired were passed, and the incorporated banks as their existence terminated either wound up or organized under the Free Banking Law. With the exception of one or two institutions having perpetual charters, the rights of all as incorporated banks had lapsed by the year 1866 .

The system forbidding the exercise of banking powers except under an act of the Legislature gave the monopoly of the business to those who could obtain charters, and the supposed profits of the business caused many contests for these prizes, which were usually conducted upon a strictly political basis.

The first act in the nature of a restraining act was that of 1782 , by which the Bank of North America was given the exclusive right of banking in the State. This, however, became a dead letter by 1791, when the Bank of New York was chartered. In 1792 the Bank of Albany was established with a capital of $\$ 240,000$, and, in 1793 , the Bank of Columbia, at Hudson, where a company from Rhode Island proposed to open a foreign trade and establish a whale fishery business. The capital of the last-named bank was to be $\$ 160,000$.

\section{Chartering of the Manhattan Company.}

In 1799, when both branches of the Legislature were in the hands of the Federalists, it was not probable that they would permit their opponents to obtain authority to organize a banking institution. The 
banking business in New York city was at this time monopolized by the Bank of New York and a branch of the Bank of the United States. There was, therefore, a very profitable field for another institution. The moving spirit in the Bank of New York was Alexander Hamilton. He drafted its constitution and controlled its policy, though holding no other official position than that of a director. Aaron Burr, his political enemy, was a stockholder in the bank. He had repeatedly made unsuccessful attempts to obtain a charter for a rival institution. The yellow fever had raged in the city with greater virulence in 1798 than in previous years, and this was generally ascribed to unwholesome water. This gave to Burr's scheming mind the opportunity which he sought. A bill was prepared incorporating a company for the purpose of supplying the city of New York with pure and wholesome water. The capital was to be $\$ 2,000,000$, but lest it might not be found practicable to einploy the whole of it at once in the water-works, the company was given the privilege of employing all surplus capital in the purchase of public stocks or in any other moneyed transactions and operations not inconsistent with the laws and Constitution of the United States or of the State of New York. The charter was to be a perpetual one. Aaron Burr, who was a member of the Legislature in 1799, drew the bill and secured its passage. He was opposed to Hamilton and the Federalists, and sought to weaken them by raising up a rival to the Bank of New York and the branch Bank of the United States. The bill passed the Legislature and likewise the Council of Revision which, under the first Constitution of New York, had to pass upon every new law, without any suspicion of its containing banking privileges. This is not so surprising considering the necessary popularity of a measure for preventing the return of the dreaded yellow fever. The charter was thus granted on April 2, 1799, and the water-works were begun the same spring. By the close of 1801 twenty miles of wooden pipes had been laid and 1,400 houses supplied. The water was pumped from wells into a reservoir. These works continued to supply the city until 1840.*

Notwithstanding this compliance with one part of the charter the principal business of the company was done under the other. In the first year of its existence $\$ 1,000,000$ was employed in banking. The water-works were dropped when the Croton Aqueduct was completed, and the company became purely a banking institution, though the company still nominally maintains its "water-works," consisting of a well

\footnotetext{
* It is of additional interest to note that while the Manhattan Company is to-day known wholly as a banking institution, it is required to maintain a water committee, who annually report that no application for a supply of water has been denied; and as an assurance of the continued maintenance of its supply. there is always present at the annual meeting a pitcher of water freshly drawn from its tank. Whether the directors or the stockholders test its quality by really drinking it, is one of the secrets of an honored corporation into which the writer deemed it in questionable taste to pry.-"A Historic Institution," by John Kendrick Bangs; "Harper's Magazine," May. 1899.
} 
from which water is pumped into a tank by a small engine, the plant being located at Reade and Centre streets. While the company has not fulfilled the apparent purpose of its organization, it has been for more than a hundred years a staunch banking institution. The method of obtaining the charter was in keeping with the system by which such favors were then obtained. Burr, however, did not profit by his trickery, for when the affair was made public there was great indignation, and at the next election Burr and his party were defeated.

So far the political power in the State had been in the hands of the Federalists ; but, in 1803, the Republicans had come into power; and in that year application was made to the Legislature for the charter of the New York State Bank, at Albany. The applicants for the charter alleged that the Bank of Albany was owned by Federalists, and was so managed as to be oppressive to business men who were Republicans. They also petitioned the Legislature that the charter for the bank should grant to them, exclusively, the salt springs in the State for, say, sixty years, on the condition that the price of salt at the salt-works should not exceed five shillings per bushel, and that they should pay annually to the State $\$ 3,000$ for the first ten years, $\$ 3,500$ for the second ten years, and $\$ 4,000$ annually thereafter. The bill was reported, with a clause granting the exclusive right to the salt springs; but this clause was subsequently stricken out, and the charter granted with an authorized capital of $\$ 460,000$.

The Merchants' Bank, of New York, applied for a charter at the same session at which the charter of the State Bank was granted. Through the influence of the Clintons and Livingstons, the charter for the State Bank at Albany was granted. * "The ground taken in its favor was that the only three banks in the State of New York-the Bank of Columbia, at Hudson; the Bank of Albany, and the Farmers' Bank, near Troy-were all in the hands of the Federalists. The Republican character of this new bank and the passage of its charter were both secured by admitting all the Clintonian members of the Legislature to subscribe for a certain number of shares. The prevailing party in the Legislature refused a charter to the Merchants' Bank, already in operation under articles of copartnership, and also to a moneyed corporation applied for by the friends of Burr." The Merchants' Bank, of New York, disappointed in obtaining a charter in 1803, had continued business under its articles of association. A fresh application for a charter had been made in 1804; but, instead of granting one, the Legislature of that year passed an act prohibiting banking by unincorporated companies, under severe penalties, declaring notes or other securities for the payment of moneys in such companies void, and giving the Merchants' Bank one year in which to wind up its affairs.

"Similiar acts for the restraint of private banking had recently been passed in Massachusetts, copied from the old act of Parliament of 1741, the first enforcement

* Hildreth's " Hist. U. S.," Vol. V, p. 477. 
of which in New England had almost produced a rebellion. The stockholders of the Merchants' Bank, not discouraged, again made their appearance at Albany. The leading Democrats, from their concern in the Manhattan and other banks, were not only deeply interested in keeping up a monopoly, but they also considered it quite intolerable that an association of Federalists should presume to ask a Democratic Legislature for a bank charter. After very hot debates and a violent altercation, in which two Senators, both having the title of judge, came to actual fisticuffs within the senatorial precincts, the bill of incorporation passed the Senate by a majority of three votes." *

A scandal connected with the passage of this bill was the exposure of two Senators who, through another Senator, had accepted stock in the bank with the understanding that it was to be taken off their hands at twenty-five per cent. advance.

No further serious contests over bank charters occurred until 1812. Governor Tompkins in his message, in January, 1812, refers to applications for new banks with a capital of eighteen and one-half millions of dollars. There was already an existing banking capital in the State of $\$ 13,000,000$, authorized to contract debts to the extent of $\$ 39,000,000$. The Governor objected to the multiplication of banks, and alleged that the collection of the specie of the country in their vaults made it more convenient to be sent out of the country.

In the spring of 1812 the stockholders of the Bank of the United States made application for a charter of a branch to be established in New York city, to be called the Bank of America. There were allegations of bribery in connection with the passage of the bill through the House, and to prevent its passage by the Senate Governor Tompkins, under authority of a clause in the constitution of 1817 , on March 27 prorogued the Legislature for sixty days by a special message. He urged that a bank with so Iarge a capital was unnecessary, and that sufficient proof had been furnished him to show that the bank applicants had used or attempted to use corrupt means to secure the charter.

\section{The Bank of America Chartered.}

The Legislature met again on May 21, 1812, and on the 22d the Bank of America bill was called up in the Senate. A motion to recommit was. lost by a tie vote. Many dilatory motions were made and lost by a vote of sixteen to fifteen, and on May 24 the bill passed by the same vote, and became a law June 2, 1812.

As the bill passed, the bank was to pay $\$ 400,000$ to the State, and was bound to loan to the State at any time it might require it $\$ 1,000,000$ at five per cent. and an additional $\$ 1,000,000$ at six per cent. The capital stock was to be paid in- $\$ 5,000,000$ in stock of the Bank of the United States and $\$ 1,000,000$ in cash. Books for subscription were therefore opened in ten States. The bonus to the State and the loans required by the charter were remitted by the acts of March, 1813, and February 26, 1819, on the stipulation that the capital should be reduced to

* Hildreth's "Hist. U. S.," Vol. V, p. 548-50. 
$\$ 4,000,000$ and then to $\$ 2,000,000$. It was afterwards increased to $\$ 3,000,000$.

The charters granted from 1791 to 1812 generally contained provisions authorizing the colleges of the State (Hamilton, Union and Columbia) to subscribe for portions of the stock, and the State itself was sometimes authorized to be a subscriber.

None of the banks chartered prior to 1816 were required to pay their notes in specie. The first bank required to do this was the Bank of Niagara, at Buffalo, incorporated in 1816. Afterwards this provision was inserted in all charters.

\section{New Banking Plan Proposed.}

Of the banks chartered before 1829 the charters of over thirty were, without regard to the date of their organization, made to expire in the years from 1831 to 1833 . Mr. Forman, in his plan for a safety-fund system, said that this was done because intelligent men foresaw evils which might arise from the plan of incorporating independent banks, and believed that, by limiting all charters to about the same time of expiration, it would become possible for them to adopt some general system of regulations which would secure a sounder circulation and better management.

A clause was inserted in the constitution of 1821 , which required the assent of two-thirds of both branches of the Legislature in order to incorporate a moneyed institution, with the intention of obviating some of the evils which had grown out of the contest for bank charters. The only effect of the restrictive clause was to increase the evil by rendering necessary a more extended system of corruption.

The restraining act of 1804 , to which reference has been made, passed with the special object of preventing the Merchants' Bank of New York from continuing business without legislative enactment, prohibited any person under a penalty of one thousand dollars from subscribing to or becoming a member of any corporation for the purpose of receiving deposits or of transacting any other business which incorporated banks may or do transact by virtue of their acts of incorporation. This restraining law is said to have been passed through the aid of influential men who controlled and were interested in banking corporations then in existence. This law, as is seen, prohibited associations of persons from doing a banking business, but it did not specifically prohibit individuals or incorporated institutions from engaging in banking and issuing notes, which they did in denominations as low as six, twelve, twenty-five, fifty and seventy-five cents, as well as bills of greater value. At the close of the War of 1812 this had become an evil of great magnitude. Among those engaging in this business were the Bankers' Exchange Bank, Utica Insurance Company, Little Falls Aqueduct Association, Catskill Aqueduct Association, small notes of Benj. Rathbone, Calvin Cheeseman, and a host of individuals and corporations, 
tavern-keepers, glass-makers, merchants, turnpike companies, etc. To put a stop to this the restraining act of 1818 was passed, which provided that no person, association of persons, or body corporate, except such bodies-corporate as were expressly authorized by law, should keep any office for the purpose of receiving deposits or discounting notes or bills, or for issuing any evidence of debt to be loaned or put in circulation as money. The law of 1804, thus amended, remained upon the statute books for thirty-two years, and, after various unsuccessful attempts, was finally repealed in 1837 , one year before the passage of the Free Banking Law.

\section{New York Safety-Fund System of Chartered Banks.}

In 1828 the charters of the greater number of incorporated banks in the State were to expire within the next four years, among them those of eight large banks in New York city, and these institutions were making a combined effort to obtain from the Legislature a renewal of their charters "without conditions or restrictions," or, as the bank men expressed it, "with clean charters." * In order to effect their purpose the banks exerted themselves to secure the election of members of the Legislature favorable to them, and also gained all the further influence they could by favoring such schemes for internal improvements as were popular in different localities. Those in the Legislature who favored branch canals and roads in their sections of the State joined with the members in favor of banks to insure the success of their several projects. In his letter to Hon. A. C. Flagg on this subject, Abijah Mann states that, being a member of the Legislature in 1828, he, in order to prevent the obtaining of charters without conditions, proposed that each of the new charters should contain a provision making the stockholders personally liable for the debts of the banks. The motion was made on the occasion of the passage of a bill to extend the charter of the Bank of Geneva, and was lost, but had its effect afterwards to double the amount of their stock, as by the constitution of the State, of 1821, a two-thirds vote of the Legislature was required to pass an act incorporating a bank. It was found that, even with the assistance of the advocates of the internal improvement schemes, the charters could not be renewed in the face of the opposition which had sprung up. On the final vote upon these measures many of them were lost by the lack of only one or two votes. Two-thirds of the members of the Assembly numbered 84, and many of the bills received 83 votes. $\dagger \mathrm{Mr}$. Mann ascribes this lack to the absence of Mr. Carrier, his colleague from Herkimer county, "who," he says, "was a merchant in favor of banks, but was an honest and independent man. He became at last satisfied, when the vote was taken, that the interests of the State and its treasury were in great danger, whereupon he suddenly left Albany to attend to his merchandise."

\footnotetext{
* Abijah Mann.
}

† Assembly Journal, 1829, pp. 11, 12, 13. 


\section{Governor Van Buren's Proposals.}

Governor Van Buren, in his message to the Legislature in 1829, says that out of forty incorporated banks in the State, thirty-one would expire within four years, chiefly within the next two years. He thought it would not be possible to get along without banks, nor would it do to depend on a Federal bank. It was necessary to pursue one of two courses, to renew the charters of the existing banks, when known to be sound, or to take measures to incorporate new institutions to take the place of those about to expire. A State bank controlled entirely by the State would probably end in disaster as similar institutions in other States had done, but a State bank with branches controlled by private stockholders, and in which the rights of the State as a stockholder were the same as those of individual citizens, would probably be better than the present system. There was not, however, any way of getting rid of the present system without the risk of immense damage to the business of the State as the result of the liquidation of so many banks, and therefore it inust be retained. The efforts of the Legislature should be directed to securing its safety and stability. The expiration of so many charters, and the applications for renewal and for new incorporations, gave the Legislature the opportunity to secure the agreement of the banks to measures which would effect their safety and stability. Bonuses he opposed as tending to weaken the institutions which paid them. The personal liability of stockholders tended to lower the character of those who went into the banking business. He, however, had received suggestions from disinterested sources which, if carried out, would, in his opinion, insure safety to the circulation and an enviable soundness to the banks. He then outlined the safety, or bank fund system, in general terms.

On January 26, 1829, Mr. Van Buren addressed a letter to the Assembly, in which he says, in answer to requests for information called out by the portion of his message referring to the bank funds, that he had requested Mr. Joshua Forman, * of Syracuse, who had first suggested the matter to the Governor, to write out his plan in detail. Mr. Van Buren therefore enclosed in his letter a letter from Mr. Forman of January 21,1829 , enclosing his plan, which was carefully and ably elaborated.

Mr. Forman commenced by mentioning the evils of the existing system-how banks were organized without capital and managed without honesty. When honestly organized, they were often bought up by swindlers who, maintaining a fictitious credit by making unearned dividends, sold out the stock to innocent holders after plundering the good assets. There was no control or check upon the issue of circulation; and by excessive expansion, succeeded by sudden contraction, the

* Mr. Forman Suggested Erie Canal, 1808, Roberts, N. Y., 530. 
business of the country was exposed to continually recurring periods of financial disturbance. The evils and loss resulting from the irregular and injudicious management of solvent banks even exceeded those incurred by the failures. He argued that the proper proportion of circulating medium is intimately connected with the actual products and commodities of a country. Paper money redeemable in coin in proper amount is as good as coin. Undue issues have the effect of increasing prices in the same way as an undue proportion of coin in circulation, without the power that coin has of regulating its volume by going to other countries. An increase of prices makes it unprofitable to export goods in payment of foreign debts, and the gold and silver on which the paper money is based are exported for that purpose. There being no outlet for home products, the market is glutted and stagnation of business ensues. The circulating notes of the banks, no longer needed when there is no business, are returned for redemption. The banks press their debtors. Prices then fall, as everyone is anxious to sell. As they sink in price, commodities are exported, relieving the home inarket; and prices rise again, gold and silver return, the banks again put out excessive issues, and the same round is repeated.

\section{Mr. Forman's Suggestions for Regulating the Banking Business.}

Mr. Forman proposed, in order to regulate the bank issues, to first insure the payment of capital, to limit loans and discounts, to prevent issue of bills other than those payable on demand, to prevent speculation by bank officers in the depreciation of their paper, and the transferring of assets to preferred creditors in anticipation of insolvency. He proposed a Board of Commissioners to be chosen either by all the banks, or appointed by the State, or by the State and banks jointly. He preferred that they should be appointed by the banks, as he thought the State should interfere as little as possible. These commissioners were to inspect the business of all the institutions, and were to enforce all the legal regulations. The commissioners were to be answerable to the Governor of the State for their conduct, and could be removed by him for sufficient cause. Inasmuch as the banks under the restraining acts and their charters had the exclusive right to issue circulation, with all the accruing profits, he thought it but right that they should be severally bound to secure the safety of such circulation. He proposed a fund, "to be raised from an annual payment of all the banks, according to capital, to be applied to the payment of the debts of such banks as shall fail ; to go on accumulating until it shall amount to $\$ 500,000$ or $\$ 1,000,000 . "$ When diminished by payments it was to be brought up by further contributions. The State was to incorporate no other banks except those willing to come under this system. The commissioners were to receive the subscriptions of stock of each newly-iıcorporated bank and certify that it was actually paid in to the Secretary of State. 
The banks under the law were not to be taxed as corporations, but the stock of individual stockholders was to be subject to taxation. $\mathrm{He}$ says :

" The propriety of making the banks liable for each other was suggested by the regulations of the Hong Merchants in Canton, where a number of men, each acting separately, have by a grant of the Government the exclusive right of trading with foreigners, and are all made liable for the debts of each in case of failure. The case of our banks is very similar; they enjoy in common the exclusive right of making a paper currency for the people of the State, and by the same rule should in common be answerable for that paper. This abstractly just prunciple, which has stood the test of experience for seventy years, and under which the bond of a Hong merchant has acquired a credit over the whole world not exceeded by that of any other security, modified and adapted to the milder features of our republican institutions, constitutes the basis of the system."

He thought banks should be confined to discounting short-time paper, to be paid at par without promise of renewal. The most surprising suggestion in Mr. Forman's plan is, however, that the banks should be compelled to invest their capital in safe public stocks or put it out at interest on bonds and mortgages upon productive real estate of double the value for long periods, and not employ it in their ordinary business. This he considered a most essential feature, although it may seem singular to many; but, as he feared it could not be apapplied to the existing banks, he only mentions it in order to state the whole case. The banks that adopt this plan would do business purely on their own credit, without touching their eapital, which would remain as a permanent support to that credit. To the objection that the banks would have no specie by this plan with which to redeem their bills, he answers that in payment of loans a due proportion of specie would flow in, and that good management would then preserve a proper proportion.

\section{Author of the Safety-Fund Plan.}

This investment of eapital in stocks and mortgages is the princip'e afterwards adopted as the basis of the free banking system. Abijah Mann, in his letter to Hon. A. C. Flagg, claims the idea as his, and says he obtained it from conversations with Mr. Benton in regard to the English joint-stock banks. Mr. Mann rather ignores Mr. Forman in his pamphlet. He says the safety-fund system was said to have been suggested by Judge Forman, of Onondaga county. Mr. Mann was a member of the Legislature of 1829. Mr. Forman's plan was sent to the Legislature by the Governor, and the Assembly ordered thrice the usual number of copies in such cases printed. It is hardly possible that Mr. Mann could have failed to have seen Mr. Van Buren's letter, in which he gives Mr. Forman credit for the suggestion of the safety fund, or Mr. Forman's plan itself. If he saw the letter it would appear that he overlooked the suggestion therein contained as to the investment of capital stock in public stock and bonds and mortgages, which he afterwards 
claimed as his own idea derived from the practice of English joint stock banks, with which he first became acquainted in conversation with Mr. Benton. Mr. Forman's plan is remarkable for the soune and conservative views in regard to banking and finance contained therein, being much in advance of those usually held by the majority of public men at that time.

The letter of the Governor and the plan of Mr. Forman were taken into consideration by the Committee on Banking Corporations,* and in the report of the latter, bringing in a bill founded almost entirely on Mr. Forman's letter, although omitting some of his best suggestions, they ignore Mr. Forman entirely, and treat the bill as their own. Judge Paige was chairman of this committee. Mr. Mann speaks of the bill as Judge Paige's bill. The report reads that the committee flatter themselves that they have hit on a measure that will possess the invaluable recommendation of creating a complete and infallible security to creditors, and will impart a solidity and currency to the bank paper of the State not equalled by any in the world; and also that its provisions will be practically acceptable to the banks. $\dagger$ The bill was reported February 13, 1829. The hopeful statement in the committee's report, that the bill would meet the approval of the banks, is rendered doubtful by the fact that it was strenuously opposed. by the banks of Albany and New York city although popular with the country banks. This opposition was almost fatal. Mr. Mann says :

"I sought an interview with Judge Paige, and told him that his bill was as dead as Julius Cæsar unless something could be done to change the current and save it. It so happened by the laws contained in the charters, that country banks had the right to take seven per cent. in advance upon discounts, while the banks in Albany and New York were generally restricted to six per cent. For this discrimination there was no longer any reason, if any ever existed, and it was agreed between us that I should propose an amendment to the bill to place them all upon the same footing, and allow them seven per cent. on all paper having more than sixty-three days to run. * * * The amendment was proposed and adopted without debate. *** The next morning the patriotic representatives of the Aibany banks appeared in the lobby with brilliant countenances and congratulated me with exuberant joy on the condition of the State and the rest of mankind. They had ciphered out the value of that "pious fraud ' over night, and possessed their souls in peace."

The New York banks, thus deserted by their Albany allies, were unable to prevent the passage of the bill. Mr. Mann, in his letter, seems to delight in portraying himself as the good-natured benefactor of banking institutions, which in his heart he regarded with aversion and contempt. Although representing himself as indispensable to the passage of the bill, yet he speaks contemptuously of another feature of it, as follows: "The law operated a few years under the guardianship of Bank Commissioners, who, General Root said, were placed there like cur dogs to watch a meat market, and were as easily subsidized by suitable food." 
The Assembly passed, on March 18, the Safety-Fund Act by a vote of seventy-four to thirty-one. Although very materially modifying the existing banking system, it did not require a two-thirds vote, as it incorporated no new bank. The bill was introduced in the Senate March 20 , referred to a committee, and reported on the 24th.* A letter was read in the Legislature from the Presidents and Cashiers of several of the New York banks, which, although deserted by their Albany allies, still opposed the bill, inasmuch as the privilege of charging seven per cent. on discounts was not of the same advantage to them, praying the Legislature for permission to withdraw their petitions for renewal of charter if the bill became a law, being satisfied that they could not continue business if it passed. This did not have the desired effect; it was regarded as a threat, and perhaps made some of the Senators more determined in favor of the measure. It passed March 31, with slight amendment, which was concurred in by the Assembly, and the bill became a law April 2, 1829.†

The distinctive feature of this law was that requiring the establishment of a common fund by a provision requiring every banking corporation thereafter created or whose charter should be renewed or extended to contribute annually a sum equal to one-half of one per cent. of its capital stock paid in, the payments to be continued until every such corporation had contributed to an amount equal to three per cent. of its capital stock. The fund was to be in charge of the Comptroller and Treasurer, and was to be kept separate from the funds of the State. It was to be invested by the Comptroller, and the income from the same, after paying the expenses of the Bank Commissioners created by the law, was to be returned to the contributing banks in proportion to their contributions. Whenever the fund was reduced by payments on account of insolvency, the several banks were required to continue their annual contributions until the limit of three per cent. of the aggregate capital of all the banks was reached.

\section{Banks Placed Under Supervision.}

Another feature of the system was the appointment of three Bank Commissioners to supervise and inspect the several banks, and report annually to the Legislature the result of their investigations. It was supposed that in a commission consisting of three persons each would be a check upon the others. To effect this purpose the Governor and Senate were to appoint one commissioner, the banks in the southern portion of the State another, and the remaining banks a third.

These commissioners were required, either one or more of them, to make an examination of each bank in the system once in four months, and any three corporations could request them to make a special examination of any bank which they had reason to believe required it. The commissioners were not to be personally interested in any bank. No

* "Niles' Register," A pril 11, 1829.

+Senate Journal, 1829. 
new bank could commence business until the payment of its capital stock had been proved by oath to their satisfaction. The banks could issue notes to double the amount of their capital, and their loans were not to exceed two and a half times their stock. The Chancellor, in cases of insolvency, was to determine the amount of debts of the bank, the amount of its assets, and the amount to be paid from the fund. Suspension of specie payments for ninety days was one ground for insolvency.

The law in regard to the manner of the appointment of commissioners was changed in 1837 , when the selection of all three was given to the Governor and Senate.

Hon. Millard Fillmore, Comptroller of the State of New York, in his report for 1849 , says :

"This, of course, brought them within the vortex of the great political whirlpool of the State, and the place was sought for and conferred upon partisan aspirants without due regard in all cases to their qualifications to discharge the delicate trust committed to them. This state of things, under the administration of both the great political parties of the State, continued until 1843, when the Legislature abolished the office and conferred the power of examining these banks upon this office whenever there was reason to suspect that a bank had made an incorrect report, or was in an unsafe or unsound condition to do banking business."

The stock of the safety-fund banks was distributed by agents selected from the neighborhood of the institutions, and was in many instances divided among the political friends or favorites of the agents. The Bank Commissioners, in their report for 1837 , say of this :

"The distribution of bank stocks created at the last session has in very few, if any, instances been productive of anything like general satisfaction. In most instances its fruits have been violent contention and bitter personal animosities, corrupting to the public mind and destructive of the peace and harmony of society."

The commissioners, in despair at the situation and the general com. plaints, proposed that the stock should thereafter be sold at auction.

\section{The New System in Operation.}

Contributions to the fund were first made in 1831 . In 1832 the report of the Bank Commissioners indicates that there were then fifty-two banks in operation under the safety-fund system, and twelve others not subject to it. They mention a large and continuous increase in circulation of the banks from January 1, 1829, to January 1, 1832, that of the banks outside of New York city and Long Island having risen from $\$ 4,508,056$ in 1829 to $\$ 8,622,277$ in 1832 . There was also a corresponding increase in capital stock. They say:

"The very large amount of circulation of the banks outside of tho city of New York, compared with that of the last year, is attributable in part to the use of capital belonging to the canal fund, in part to the establishment of new banks, and partly to a general overtrading in the country, somewhat encouraged by the facilities afforded by those banks." 
The canal fund, which amounted to about two millions of dollars, was deposited with banks.

The stocks of the new banks were sought for with much eagerness both by investors at home and from other States. The latter were induced to purchase because of the popularity and supposed safety of the safety-fund system, and the former by the hope that the demand from abroad would force the stock to a premium which they could realize by selling out after holding the stock a short time. Contests for the control of the institutions had the effect of increasing the number of subscriptions, and the * commissioners speak of the number of applications for new acts of incorporation as far exceeding any prudent calculations of profitable investment. They intimate, however, that the demand for gold for export indicated an approaching severity of pressure on the banks, and view with apprehension a future suspension of specie payments. The law permitting the banks to issue notes to double the amount of their capital would permit a possible aggregate circulation of $\$ 50,000,000$, although the necessity of redemption in specie had kept down the actual circulation to $\$ 14,000,000$. If specie payments were suspended the commissioners feared an exorbitant increase. They reported that their examinations of the various banks under their control showed them to be in good condition.

The pressure anticipated in the commissioners' report of 1832 culminated during the year 1834. In the report of the Bank Commissioners for 1835 they speak of the financial crisis just passed as of a character political rather than commercial. The existence of deep pecuniary suffering at a time when there were abundance of products, an unusual supply of the precious metals, and the country a creditor in the com mercial world, was anomalous. This condition of distrust was ascribed to the removal of the deposits from the Bank of the United States, bank curtailments, the neccessity of paying duties in cash, overtrading and excessive bank issues. There were grossly exaggerated accounts of actual distress, misrepresentation of facts, solemn and confident predictions of impending ruin in the public papers, all coming from high authority. The New York banks were special objects of attack. Insolvency was insinuated and directly charged, the people were appealed to to save themselves by demanding specie for bank notes, and the ruin of the safety fund was prophesied.

The country banks were not required to redeem then notes except at their own counters, and when their paper accumulated in the cities it was at a slight discount. The law did not permit the country banks to buy up their own notes, and it had become customary for the Albany and New York banks to purchase these notes when offered and send them home for redemption. The country banks kept very little specie at home, and generally kept their funds in the cities, and consequently redeemed the notes when presented by drafts upon their deposits in the

* Commissioners' Report, 1832. 
eities. In the height of the pressure, a refusal to purchase the country notes on the part of the banks usually doing this business placed them at a serious discount, though there was no refusal to redeem when presented at the issuing bank. The strength of the banks outside the cities is indicated by the fact that they reduced their circulation two millions by redemptions within sixty days.

In 1835 the number of banks under the safety-fund law was seventysix, with a capital of $\$ 26,231,460$, that of other banks in the State being $\$ 5,175,000$. The total circulation of the safety-fund banks was $\$ 14,-$ 464,023 , against which they held in specie $\$ 5,561,745$, and specie funds in city banks $\$ 4,944,877$. The banks appear to have been very strong at this period. The bank fund had reached $\$ 400,000$, and no drafts on it were anticipated. The income from it was to be distributed among the contributing banks.

\section{Proposed Retirement of Small Bills.}

The commissioners in 1835 considered the question of the withdrawal of small bills under five dollars from circulation as a measure tending to insure a large stock of specie in the hands of the people. The amount of such bills in circulation was estimated at $\$ 4,000,000$; and while desirable that this portion of the circulating medium should be superseded by specie, which it was estimated would take its place to the extent of $\$ 2,000,000$ at most, there were difficulties which required a careful consideration. In 1834 the act of Congress changing the relation between gold and silver had gone into effect, and by it, as is well known, gold was so considerably over-valued that silver would not circulate. As gold was the only metal available, and as there were no gold pieces as yet coined under two-and-a-half dollars, it would be impossible to supersede the small bills until gold dollars were coined and came into circulation. The commissioners recommended that the circulation of one-dollar notes should stop after six months, of twos after twelve months, and of threes after eighteen months.

The dividends of the banks averaged 7.81 per cent., those of the country banks being larger than those of banks in the cities. The contributions to the safety fund were not charged off as losses in declaring dividends, but treated as funds of the banks.

On March 31, 1835, an act was passed forbidding further circulation of bills under two dollars after September of that year, of bills under three dollars after March, 1836, and of bills under five dollars after September, 1836. The suspension of issues of small bills was very unpopular, as in the scarcity of silver coin and gold coin of small denominations they were a real necessity, and it became one of the principal questions in the contest between the political parties in the State for election of Governor in 1836. Mr. Seward, who ran against Governor Marcy, was known as "Little Bill" Seward. Although defeated, the triumphant party saw the necessity of yielding to what was evidently a 
popular demand based on necessity, and May 16, 1837, a law was passed superseding the provisions of the law of 1835 for a limited term. In other words, one dollar bills were allowed to be put in circulation until two years after February, 1838, twos until July 1, 1840, threes and fours until January 1, 1841 . The same limits were fixed for the circulation in the State of small bills of banks located outside of the State, and severe penalties were imposed for any violation of the law.

\section{Suspension of Specie Payments.}

In May, 1837, the New York banks, in common with those throughout the United States, suspended specie payments, and the Legislature, on May 16, legalized the act for one year, but made it obligatory on the banks to receive each other's notes.

The banks of the State resumed specie payments in the spring of 1838 , before the end of the year granted by law. The suspension in 1837 and the resumption in 1838 were participated in by the banks throughout the United States; but the New York banks did not take part in the second suspension, which took place in the fall of 1839.

\section{The Free Banking Law.}

In 1837 the Free Banking Law of New York went into operation, and the banks under it came into some competition with the safety-fund or chartered banks. During 1839 the latter curtailed their loans to the amount of $\$ 15,512,000$, and their circulation was diminished by nearly $\$ 9,000,000$. A considerable depreciation of the notes of the country banks began early in the fall of 1839 from the discontinuance of a voluntary arrangement by which they had been purchased by the city banks in New York eity. The city banks were induced to abandon this arrangement on account of the necessity of retaining control of their own funds and the immense amount of the country notes thrown on them for redemption. The discount on these notes was from two to six per cent. and caused much confusion in the exchanges. To remedy this state of things and prevent their recurrence, the law of May 4, 1840 , required all banks, safety-fund and free banks, outside of New York, Brooklyn and Albany, to appoint agents in the cities of New York and Albany for the redemption of their notes at a discount not exceeding one-half of one per cent.

From the year 1829 to the year 1841, covering a period of twelve years' duration, the safety fund was not drawn upon, as no chartered bank became insolvent during that time.* The first failure of a bank under the system was that of the Wayne County Bank, of Palmyra, due to the culpable conduct of its President. The Chancellor was applied to in December, 1840, for a temporary injunction to close the institution, and this was subsequently made permanent. Its circulation alone amounted to $\$ 139,392$. It was then discovered that the law made 
the safety fund responsible not only for the circulation, but for all the debts of the insolvent bank.*

The commissioners say : "This peculiar feature of the law does not seem until recently to have been generally understood either by the public at large or even by those engaged in the business of banking; and great doubt is entertained in regard either to its justice or its expediency." They add: "The Safety-Fund Act was primarily designed to secure bank-note holders and not depositors or other creditors."

The whole capital then subject to the law was $\$ 32,551,460$, which gave an annual payment of $\$ 162,795.73$. The fund on January 1,1841 , was $\$ 861,643$, and the number of safety-fund banks ninety. It is true that Mr. Forman, in his letter formulating the plan, uses the term, "debts of the bank;" but, as he just before dwells particularly upon circulating notes, it is probable that it was the debts on this account he had in view, the more so as he distinctly mentions from $\$ 500,000$ to $\$ 1,000,000$ as the limit of the fund, which he never could have imagined sufficient to meet all the debts of insolvent institutions.

From this oversight or misunderstanding arose the disasters which afterwards overtook the safety-fund system. If, as was the probable intention of its suggestor, the fund had only been drawn on for the redemption of the circulation of the banks that became insolvent, it would have been amply sufficient for the purpose, as will hereafter be seen. When it was found that all the debts of every description were to be paid from it, a fictitious credit seems to have been given to the chartered institutions, which was used by some of them in recklessly contracting debts for the emolument of their managers. In 1842 an act was passed devoting the safety fund exclusively to the redemption of circulating notes; but within the six months previous to the passage of this law, six banks, with a circulation of $\$ 1,408,000$, had failed, and injunctions were obtained by the creditors of these institutions to prevent any payments from the fund to redeem the circulation of banks subsequently becoming insolvent until all the debts of banks failing prior to 1842 had been paid. The act of 1837 authorized immediate redemption of bills, but required one-third of the safety fund to be reserved for debts. The question was further complicated, inasmuch as the act of 1842 permitted the solvent safety-fund banks to pay in their future contributions for the next six years in bills of the insolvent banks, with an allowance of interest to the bank of seven per cent. on the sum paid until the time when it would have become due. Ten banks in all had become insolvent at the date of the passage of the law of 1842 , and this law required the bank fund to be applied to the payment of their notes in the order of their failure. As the banks could pay in notes of any of the insolvent banks, and thus immediately get a benefit from them, there seemed to be a serious inconsistency in the law, as well as a great deficiency in the fund. The Comptroller, in 1845, and 
also in 1846, recommended that a stock, bearing six per cent. interest, should be issued, to be redeemed from future payments to the fund, which should be used to immediately pay all the clams upon that fund. In many of the failures which occurred it was found that there had been issues of notes largely in excess of those allowed by law, and that the commissioners had been, in making their regular examinations, deceived by fraudulent devices and by perjury on the part of bank officials. There was no penalty for illegal issues of notes, nor for deceiving the commissioners. Some of the officers were, however, indicted for perjury. In July, 1843, an act was passed which required all future issues of notes by the safety-fund banks to be printed, countersigned and registered by the Comptroller, to whom all plates were to be turned over, to remain in his custody. All notes outstanding were to be redeemed and sent to the Comptroller for destruction, and were gradually to bo superseded by the countersigned and registered notes.

\section{Condition of The SAfety Fund IN 1845.}

In his report for 1845 the Comptroller sums up the condition of the fund at that time as follows: It was estimated that the amount required to pay the debts of insolvent banks was $\$ 1,017,000$. There was in the fund $\$ 179,193$, leaving to be provided for $\$ 837,806$. There had already been paid from the safety fund $\$ 1,502,170$, and this, with the further amount of $\$ 1,017,000$ estimated to be due, made a total charge on the fund by the failure of ten banks of $\$ 2,519,170$. In his report for 1846 Comptroller Flagg shows that the total contributions to the fund were, up to September $30,1845, \$ 1,885,536.99$, and the redemptions of notes were $\$ 1,769,922$, showing the fund to have been ample security for the circulation of the insolvent banks.

\section{Comparison of the Safety-Fund and Free Banking Systems.}

In this report the Comptroller compares the safety-fund and free banking systems and says: "In the security of the public under each system, our experience in the failure of ten safety-fund banks, and about three times as many of free banks, proves that the contributions of one-half of one per cent. annually on the capital of the safety-fund banks have thus far afforded as much protection as the deposits with the Comptroller, by the free banks, of a sum nominally equal to all the bills issued by them. It will be seen by reference to a statement under the head of insolvent free banks, that the loss to bill holders on the supposition that all the securities had been stocks of this State and bonds and mortgages, would have been over sixteen per cent., while the actual loss has been nearly thirty-nine per cent. The loss by safetyfund banks to the first holders (from delay in payment and consequent depreciation) was from twenty to twenty five per cent.; and there has been a loss of four years' interest to subsequent purchasers, whereas in the case of the free banks, the securities were sold and the proceeds 
paid to the bill holders within a few weeks after the failure of the bank." If the Banking Fund Act of 1829 had provided only for the redemption of circulating notes, as is the case with the act for free banking, all the notes of the safety-fund banks which have failed would have been paid at par by the contributions made to the safety fund from 1841 to 1845. And if the present plan of registering notes (to prevent lllegal issues) had also been in operation the result would have been still more favorable, as fraudulent issues have been redeemed from the safety fund to the amount of $\$ 700,000$.*

The Comptroller, in his report of December 31, 1847, states that, under the act of 1843 , all the unregistered notes of the safety-înd banks had been redeemed and destroyed except $\$ 716,620$, which were still outstanding. At this time the future contributions of all the safety-fund banks were mortgaged to meet the bank fund stock issued in payment of the debts of the banks which had failed during the years 1841-42, and that, in case of an additional failure there could be no resort to it, so that the circulation of the safety-fund banks, amounting to $\$ 16,926$,918, rested solely on the solvency of each bank issuing the notes. The Comptroller feared that, as the debt of the State diminished by operation of the sinking fund, it would be impossible for banks desiring to operate under the free banking system to obtain the stocks necessary as a basis of circulation. He suggests that a safety fund ample to protect bill holders might be accumulated by requiring each bank to pay in to the Comptroller als amount equal to ont-half of one per cent. upon the circulating notes to be issued for the term of its charter. Thus a bank chartered for twenty years, with a capital of $\$ 100,000$, could issue $\$ 150,000$; and, if it desired to issue the full amount, would under the proposition, pay in at once $\$ 15,000$. The sums thus paid in to be placed at interest by the Comptroller for the benefit of the fund; with paidup capital and ten per cent. of circulation in the safety fund to be held and husbanded, he believed the currency would be amply secured as required by Section 6 , Article 7 of the constitution, which provides that all bills or notes put in circulation as money shall be registered, and shall have ample security for their redemption in specie. It would require the consent of each of the free banks to carry out this method of a safety fund, and they ought therefore to be given the option of entering into such an arrangement or depositing stock and bonds and mortgages as at present. It is thus seen that in 1847 the same difficulty was felt in regard to the permanency of the circulating notes of the New York tree banking system, based on stocks, as has since arisen in regard to the circulating notes of the National banks.

HoN. Millard Fillmore's Opinion of The SAfety-Fund System.

The Hon. Millard Fillmore, Comptroller in 1848, in his report of December 30, of that year, says that the safety fund itself had long

+Ex. Doc. No. 77. 1st sess. 30th Cong., page 211 . 
since been exhausted, and future contributions to it mortgaged by the issue under the act of 1845 of $\$ 900,828.47$ of six per cent. State bonds with which the debts of the insolvent banks in excess of the fund had been paid. Since 1829 the contributions to the fund had been $\$ 1$, 876,063 , the whole circulation redeemed from the insolvent banks was $\$ 1,548,558$, leaving a surplus of $\$ 327,505$, which, with the amount obtained for the six per cent. State stock, had been swallowed up to meet other debts of the institutions. "It is therefore apparent," says Mr. Fillmore, "that the safety fund would have proved an ample indemnity to the bill holder had it not been applied to the payment of other debts of the bank than those due for circulation." He thought it reasonable and proper for banks to contribute to a fund to make circulation secure, but saw no reason why such a fund should be created for the purpose of securing depositors and other creditors. The law, even in 1842, simply preferred bill holders; if there were any surplus it could still be applied to the payment of other debts. He recommended that the fund should be sacredly devoted to the bill holder and to no other purpose.

In 1848 there were seventy-eight incorporated safety-fund banks in operation and two branches. The charters of all were to expire by 1866. By the act of May 16, 1837, these banks were allowed to issue circulation in proportion to capital, as follows :

\begin{tabular}{|c|c|c|}
\hline Circulation. & Circulation. & Circulation. \\
\hline$\ldots \$ 150,000$ & $\ldots . \$ 225,000$ & \\
\hline .... 160,000 & .... 250,000 & 700,000 \\
\hline ... 175,000 & $\ldots . .300,000$ & $1,000,000$ \\
\hline $200,000 \ldots \ldots \ldots \ldots \ldots 200,000$ & $500,000 \ldots \ldots \ldots \ldots . .350,000$ & $\begin{array}{l}1,490,000 \ldots \ldots \ldots \ldots \ldots 1,000,000 \\
2.000,000 \ldots \ldots \ldots \ldots \ldots 1200,000\end{array}$ \\
\hline
\end{tabular}

By the act of April 12, 1848, banks with a capital of over $\$ 200,000$ were allowed to issue circulation to the full amount of their capital ; but for this additional issue they were required to deposit security with the Comptroller in the same manner as the free banks.

The safety-fund system was not finally terminated until 1866 , by which date the charters of all the incorporated banks had expired. The Legislature passed an act in that year providing that the amount of the safety fund remaining after all claims upon it were discharged should be paid into the treasury of the State.

\section{Why the Safety Fund Was Not a Complete Success.}

The system did not meet with the success that the principle would seem to warrant, and this was chiefly due to the attempt to make all the debts of the insolvent banks chargeable to it. The heaviest failures took place before the change was made in the law by which the circulating notes alone were redeemed from the safety fund. 'The history of the fund from 1829 to 1866, a perıod of nearly forty years, indicates that if, from the first, the contributions of the incorporated banks had been 
applied to redeeming the notes of the insolvent institutions, they would have been ample for the purpose, and would have made the circulation of the safety-fund banks more secure than that of the banks under the free banking system. If the law requiring the Banking Department to control the printing and register and issue to the banks their currency had been a part of the original act, it would have prevented illegal issues to the amount of $\$ 700,000$ which were redeemed from the safety fund ; and, instead of a surplus of about $\$ 13,000$, placed in the State treasury under the law of 1866, there would have been a surplus of nearly a million dollars at that time. In other words, owing to defects in the practical application and operation rather than in the principle of the safety-fund act, the banks, under the system, were called upon to contribute about a million dollars more than they would had the defects referred to been seen and obviated at the outset.

\section{The Free Banking Srstem.}

The restraining acts, preventing any one from engaging in the business of banking without obtaining a special charter from the Legislature of the State, had caused much feeling among the people, especially after the panic of $\mathbf{1 8 3 5}$, and this found voice in the numerous petitions to the Legislature for the passage of a law ereating a general system of private banking.* These petitions were referred to a select committee of the Senate, which reported March 18, 1837. In their report the committee enumerated the evils of the existing system of banking. They referred to the insecurity of the bills issued by the chartered banks, the losses which had resulted from the frequent suspensions, and the discounts at which many of the bills passed. Inasmuch as banking operations could not be carried on without a charter, the obtaining of such charters had become a notorious field for fraud and for political corruption. Charters were obtained through dishonest combinations, made between members of the Legislature interested in them and members interested in other doubtful schemes, and thus laws were passed detrimental to the interests of the people. There were also frauds in the distribution of the stock of the newly chartered institutions. Some few were admitted to the privilege, more were refused; and thus great excitement and bitterness among the eitizens were aroused, which brought about constant complaints and demands for new charters. The committee spoke of the existing system as a monopoly, under which some issued their notes and obtained interest on them, while the majority of citizens, when they issued notes, had to pay interest on them. Reference was made to the fact that the reason why Van Buren, then President, had, when Governor of New York, advocated the safety-fund system, was because he hoped it would mitigate some of the evils of the banking monopoly in the hands of the chartered banks. He had, during the eight years he was in the * Senate Doc. No. 55, March 18, 1837. 
New York Senate, steadily opposed the granting of bank charters, voting against thirty-two out of thirty-three charter bills presented for adoption. The safety fund had not met expectations. During the panic of 1835 it had scarcely been heard of as a means of upholding eredit, and the credit of the State had been loaned to the amount of six millions to uphold the system. The committee referred to the success of the Scotch joint-stock banks, and ascribed it to the unlimited personal liability of the stockholders and directors. In conclusion, they recommended, as conducive to the safety of a free banking system, three things-a paid-up capital, publicity of the shareholders' names, and an unlimited personal liability - and reported a bill of seventeen sections in which these three features were prominently embodied.

\section{History of the Free Banking Law.}

Abijah Mann was elected a member of the Legislature in November, 1838 , and in 1868 a correspondence took place between him and the Hon. A. C. Flagg relative to the history of the introduction and passage of the Free Banking Law in the New York Legislature, and also incidentally in regard to some points in the history of the safety-fund system. Governor Marcy, in his message of January 2, 1838, referring to his former recommendation to repeal the restraining acts, expresses fear of the injurious consequences which would result from granting to individuals the unrestrained license to issue paper. He thought that the objections to the unqualified repeal of the restraining acts would be removed if the issues could be limited to the amount of a fund provided for their certain and prompt redemption: He did not point out any definite way of accomplishing this, and seemed to have in view some improved safety-fund plan. He recommended free banking, with proper restrictions, to secure the safety of the public. Mr. Mann, in his letter to Mr. Flagg, states that two bills were first presented to the Assembly, one drawn by Mr. Verplanck and the other by John C. Spencer, both of which were opposed by Mr. Mann, who pointed out their radical defects, but said that, if it was determined to pass a general banking law he thought one might be framed which could be endured, and mentioned the principle of requiring deposits of New York State stocks to the amount of the circulation issued, so that every bank note should be, in effect, simply a certificate in the hands of the holder that he was entitled to a share in the bond equal in amount to the note. Mr. Mann's views had such weight that a committee of nine, with him as chairman, was appointed to draw a new bill. Mr. Mann, as he himself states, had been a member of Congress during the last four years of General Jackson's Administration (from 1833 to 1837) and walked in his footsteps in the controversy with the Bank of the United States. He had been one of the committee appointed to examine that bank in 1834, and, while performing that duty, was brought into contact with Mr. Benton. In 
conversation with him Mr. Mann learned of the system pursued by jointstock and individual bankers in England, of investing the greater part of their capital in Government stocks upon which money could always be raised when circumstances rendered it necessary.

The committee desired Mr. Mann to draw up the bill with provisions similar to those suggested by him in debate, and he did so, omitting, however, any provision for the formation of associations, intending, as he says, to place the business of banking in the hands of corporations, with special charters. Mr. Mann thought a provision allowing any one to form associations would be a violation of the constitution of the State. The committee were not satisfied with the omission, and the provision was finally inserted by Mr. Mann at their request. The bill, as drawn, required New York State stocks as the only acceptable basis for circulation; but, in the House, an amendment was added permitting the deposit of bonds and mortgages to some extent. Some of the theories advocated in debate were similar to those held in later days in regard to the National banks. A Mr. Wylis Hall maintained, in a solemn argument, that, if the notes of one bank were amply secured, as many more could be made as were wanted, viz., by using the notes of the first to buy securities to obtain notes for the second, and so on ad infinitum. This is identical with the scheme of a certain Mr. O'Neil, who, it was alleged in a campaign document issued by the Greenback party in 1877-78, had established a inultitude of National banks by this process.

\section{Issue of Notes on State Securities.}

The bill, with the amendment permitting the deposit of bonds and mortgages as securities, became a law on April 18, 1838. * It consisted of twenty-six sections. Under it associations might be formed to carry on the business of banking, and might receive and issue circulation upon depositing with the Comptroller of the State stocks of the State of New York, or of the United States, or of any State, which was or should be made equal to a five per cent. stock, or bonds and mortgages on improved and productive real estate worth, exclusive of the buildings thereon, double the amount secured by the mortgage and bearing interest at a rate not less than six per cent. per annum. The circulation was to be printed and registered, under the direction of the Comptroller, and issued by him to the banks to an amount equal to the securities deposited. The banks could deposit stocks only, in which ease the circulation was printed to indicate it was so secured; or, they might deposit half stocks and half bonds and mortgages, when that fact was also printed on the note. The associations received the annual interest on their securities so long as they redeemed their notes at their own coun-

\footnotetext{
*The system had a bad start. Within five years after the law was passed twentynine banks that had organized under it failed, and the deposited securities realized on!y seventy-four cents on the dollar of the outstanding notes.--" National and State Banks," Horace White; "Sound Currency," II, r.
} 
ters. If an association refused to redeem its notes the Comptroller warned its managers, and if it refused for ten days after such warning, its securities were sold and the notes redeemed from the proceeds by the Comptroller. The State was in no way bound for the notes. The plates were kept by the Comptroller. The shares of the association were deemed personal property. There were several restrictions as to powers of the association, and creditors or shareholders holding debts against, or shares in it could request the Chancellor of the State to make an examination of its affairs. Reports had to be made, under oath of the President or Cashier, to the Comptroller on the first Monday in January and July of each year. It contained no provision making stockholders liable for the debts of the association unless they had bound themselves to that effect in their articles of association.

The New York Free Banking Act has generally been regarded as the first practical exponent of the principle of a bank circulation secured, as to its ultimate redemption, by collaterals placed beyond the power of the bank, in the custody of the Government. It has been seen that. Mr. Mann claims to have derived the idea from the practice of English joint-stock bankers, who, however, were the custodians of their own securities. The idea, in the form adopted in the New York Free Banking Law, was not new, but had been suggested years before. Nor was the New York Free Banking Law the first to carry the idea into practice, as the Michigan Free Banking Law of March 15, 1837, passed over one year before, contained requirements similar in principle intended to give ample security not only for the circulating notes, but for all the deposits. The Michigan law was more comprehensive and complete than the New York law in many particulars; and, if the State of Michigan had been in condition to enforce its law with a rigor equal to that with which the New York law was enforced, the public would, perhaps, have been as well protected.

In November, 1840, seventy-one associations were in operation under the Free Banking Law with a circulation of $\$ 5,367,976$, secured by State stocks and mortgages amounting to $\$ 6,620,580$, of which $\$ 4,535,550$ were stocks and $\$ 2,085,030$ mortgages on real estate. The State stocks were those of Indiana, Arkansas, Illinois, Michigan, New York, Alabama, Kentucky, Maine and Missouri.

\section{Friction Between the Two Classes of Banks.}

It appears, from the report of the Bank Commissioners of January, 1841 , that immediately there was some friction developed between the chartered and the free banks. The latter made every effort to force their notes into circulation. Many of them used their funds to buy their own notes and those of the chartered banks in New York city at a discount, thus compelling the chartered banks to reduce their circulation. This practice also had the effect of breaking up the prevailing system of purchase of ecuntry notes by the city banks, and resulted 
in the immediate depreciation of the notes of the banks in most parts of the interior from two to six per cent. This state of things continued through 1839 . On March 4, 1840, a law was passed by the Legislature requiring all the banks outside of the cities of Albany, New York and Brooklyn to appoint an agent in Albany or New York to redeem their notes at a rate of discount not exceeding one-half of one per cent. This law produced a steadiness and uniformity of value in the country paper never known before. By virtue of another law passed in 1840 , the free banks were subjected to the inspection of the Bank Commissioners, and the Comptroller was restricted to receiving stock of New York State. The stocks of other States held prior to this act were, however, permitted to be transferred and re-deposited at their market value, but all new deposits of such stocks, and even of United States stocks, were prohibited. The provision of this law requiring inspections was regarded by the banks as unconstitutional, and they submitted to the inspection under protest, with the exception of one, which refused to permit the commissioners to make an examination. Against the latter legal proceedings were instituted. The commissioners thought it probable that associations were formed under the general law in excessive numbers ; that many banks had obtained the mortgages which they deposited as securities on condition of making accommodation loans on long time to the parties who had furnished the mortgages, and that thus they became powerless to afford legitimate banking facilities. They remark that the free banks, from the fact that they cannot reach the securities deposited with the Comptroller, are obliged to retain the funds they may derive from the issue of circulation within their control so as to be able to redeem the notes when presented, and are, therefore, as a rule restricted to discounting good business paper having a short timeonly to run. In March, 1841, twenty of the free banks failed to redeem their notes, and eighteen were placed in the hands of Receivers ; only two permantly resumed business. The Bank Commissioners in 1842 state that only forty-six free banks were then in operation. The reason that more were not placed in charge of Receivers was that the law did not permit the appointment of a Receiver for simple insolvency, and a few of these insolvent banks managed to keep up the redemption of their notes in New York and Albany. They ascribe the difficulties among the free banks to the "diminution of confidence which took place in the market value of many of the State securities other than New York deposited with the Comptroller." In many cases the stocks had been purchased by the banks at very high prices on credit, with no means of future payment. The great defect of the law, in the opinion of the commissioners, was the permission to deposit stocks of States other than New York. They speak highly of the Free Banking Law when banks are established under it with a capital of their own for the purpose of doing a legimate business.

In 1843 the commissioners say : "During the past year the banking 
associations under the general law have sustained themselves with remarkable success, and we are aware of no instance in which they have failed, since the last annual report, in redeeming their notes promptly at home or by their agents." The law as modified obviated the danger from depreciation of State stocks ; and, while the profits of the free banks were not as great as those of the chartered institutions, yet investments in them were made with less risk to the stockholder, and the bill holder was better protected. At this time the Supreme Court of the State decided that a sight draft drawn by these associations was uttra vires and invalid even in the hands of a bona fide holder, and could not be enforced against the bank. The commissioners recommended the Legislature to grant this power. This was the last report of the Bank Commissioners. The office was abolished in 1843, and the duties turned over to the Comptroller of the State.

In 1844 the Comptroller reported that up to that date ninety-three free banks had deposited securities and received circulation while eight had voluntarily closed business and redeemed their circulation. Twentysix had failed and their circulation had been redeemed by the Comptroller at an average discount of about twenty-five per cent. The remaining banks had securities with the Comptroller consisting of New York State stocks amounting to $\$ 1,774,434$, United States stocks, $\$ 52,000$, and stocks of Michigan, Indiana, Illinois, Arkansas, Alabama, Kentucky and Maine, with $\$ 17,731$ cash deposited, amounting at face value to $\$ 3,744,829$, but then valued by the Comptroller at $\$ 2,745,156$. They also had bonds and mortgages amounting to $\$ 1,525,540$. The United States stocks were, it seems, deposited in misapprehension of the law which in $\mathbf{1 8 4 0}$ forbade the deposit in future of any except stocks of New York, with the object of enhancing the value of the New York State stocks. The Comptroller recommended that the restriction be removed as to United States stocks.

\section{IMPERFECTIONS IN THE METHODS OF REDEMPTION.}

The Comptroller called the attention of the Legislature to the fact that "during the past year a number of applications have been made for the establishment of individual banks at points remote from the general channels of business and where no necessities seemed to exist for banking facilities." He referred to a bank in Warwick of which the nominal President resided in Connecticut and the whole business conducted by a person in New York who under a power of attorney from the President acted as banker and agent. "The redemption at a discount of one-half of one per cent. allowed by law is probably one of the principal inducements for establishing banks of this description. The notes are signed and circulated in the city of New York; and, by fixing the place of redemption at some inaccessible point, the holder is compelled to go to the office where the note was really issued in Wall street and pay one-half of one per cent. for its redemption." 
The Comptroller refers to the fact that, under the Suffolk Bank system, the notes of the country banks of New England are redeemed at par in Boston, and suggests that the country banks of New York should be compelled to redeem their notes at par in New York eity. $\mathrm{He}$ estimated the annual redemptions in the State at $\$ 100,000,000$, and that the people thus paid a tax amounting annually to $\$ 500,000$ to sustain the State banks. In the case of twelve of the insolvent free banks, the Comptroller had not been able to collect from their assets, exclusive of securities for their circulation, sufficient to pay the costs of the proceedings against them. Bonds and mortgages do not appear to have been a bad security in some cases, inasmuch as a mortgage of $\$ 10,000$ deposited as security for circulation of the Washington Bank of New York sold for $\$ 12,391.53$ above all expenses.

\section{Printing of Notes Placed Under Offictal Control.}

Up to 1843 the incorporated banks had enjoyed, and in some cases abused, the privilege of procuring and keeping the plates from which their notes were printed, and the only check upon the amount of the issues they might make was their honesty and regard for law. The act of April, 1843, required every chartered bank to take an account of its circulation outstanding on July 1, 1843, and make report of the same to the Comptroller of the State under oath. As fast as such notes were redeemed and destroyed, the Comptroller, who by the same act became the custodian of the plates, caused to be printed and registered and issued to the bank new notes equal to the notes satisfactorily proved to him to have been destroyed. Thus by degrees all the circulation of the chartered, as well as of the free banks, came to be issued by the Comptroller, and a check was put upon fraudulent and excessive issues by the incorporated banks. By the act of 1848, chartered banks were authorized to issue a larger amount of circulation in proportion to capital than the law had previously permitted, and for the increase were required to deposit securities in the same manner as the free banks, the circulation issued to them on the deposit of securities being designated on the face of the notes, to distinguish it from the ordinary circulation of these banks. These restrictions, and the greater credit of the free bank or secured circulation, as well as the difficulty of obtaining new charters, led the incorporated banks to reorganize under the free banking system as their charters expired.

\section{Circulation of the Banks in 1848.}

In 1848 the number of free banks was fifty-three, and of individual bankers fifty-one, with an aggregate circulation of $\$ 9,993,762$ against securities amounting to $\$ 10,640,182$. Of these securities $\$ 7,627,092$ were New York State stocks, $\$ 114,000$ United States stocks, $\$ 1,514,979$ bonds and mortgages, and the remainder, except $\$ 49,906 \mathrm{cash}$, consisted of stocks of Illinois, Arkansas, Indiana, Alabama and Michigan. In 1848 
the Legislature made a change in the law, requiring that thereafter only New York stocks made equal to six per cent. and bonds and mortgages bearing seven per cent. interest on real estate to the extent of two-fifths of the value of improved real estate, exclusive of the buildings thereon, could be received as security for circulation.

Millard Fillmore, Comptroller, in his report dated December 30, 1848, made just after his election as Vice-President of the United States, states that the average amount for which bonds and mortgages held as security for circulation had sold during the previous ten years was 67.71 per cent., while five per cent. New York State stock had sold at an average of 92.86 per cent. He recommended legislation providing for the gradual withdrawal of the bond and mortgage security and the substitution of New York State stocks. This report also contains a suggestion which is of interest, as in some degree outlining a system similar to the National banking system. He said it would be highly beneficial if the plan of basing bank circulation upon stock security could be introduced in all the States; and that, if the United States would make the notes of State banks secured by State stocks receivable for public dues, it would give such noies a credit co-extensive with the United States. Section 62 of the National Banking Law of February 25, 1863, contained a provision authorizing notes to be issued by the Comptroller of the Currency to State banks depositing United States bonds with the Treasurer of the United States; and these notes, like the notes of National banks, were receivable for public dues. $\mathrm{Al}$ though this provision was never carried into effect, having been repealed in 1864, yet its insertion in the original act was perhaps due to the suggestion of Mr. Fillmore in his report as Comptroller of the State of New York.

In 1857 the free banks were put to a severe test by the financial crisis of that year. There was a general suspension of specie payments on October 13, and on the 26th of the preceding September the notes in circulation amounted to $\$ 27,122,904$. Over $\$ 7,920,000$ of the notes of the country banks had accumulated in New York city.

On November 7, 1857, the clearing-house passed a resolution requiring the country banks to pay this amount in monthly installments of twenty per cent., with interest at six per cent., commencing on January 1, 1858. Their outstanding circulation, outside of the $\$ 7,920,000$ held in New York, was to be redeemed as usual after November 20, 1857. This plan was carried out in five months, and the entire debt of $\$ 7,920,000$ was paid, netting the city banks $58-9$ per cent. interest. In order to accomplish the result the country banks appear to have borrowed to make the twenty per cent. payments; and, having secured their notes, returned them to the Comptroller at Albany, and took out their securities, from the proceeds of which they paid the loans. Between October 1, 1857 , and April 1, 1858 , securities amounting to $\$ 4,325$,000 had been drawn out. The payments were effected with a very 
slight reduction of discounts and, consequently, less pressure on the business community. In his report for 1858 the Superintendent of the Banking Department remarked that, in previous crises, the suspension of specie payments had been the signal for an increase of their issues by the banks; but, in this instance, there had been a gradual and steady reduction, amounting to $\$ 4,412,746$ between September 26,1857 , and March 13, 1858, at which latter date the total amount outstanding was $\$ 22,710,158$. All attempts to obtain a law excluding bonds and mortgages failed, notwithstanding frequent recommendations of the Comptroller and Bank Superintendent to this effect.

The suspension of specie payments by the New York city banks soon after the beginning of the Civil War is referred to at length in another part of this work.

\section{Revision and Consolidation of the Banking Laws.}

In 1880 an act was passed by the Legislature providing for the appointment of three commissioners to compile and revise all statutes of the State of New York affecting banks, banking and trust companies. Under this act Governor Cornell appointed George B. Sloan, David C. Van Cott and Willis S. Paine. Mr. Sloan was afterwards succeeded by William Dowd, and Mr. Van Cott ceased to act as a member of the commission. The revision of the banking laws, as submitted by this commission became a law July 1, 1882.

Again, in 1891, in accordance with a plan for revising and consolidating the general laws of the State, the Commissioners of Statutory Revision submitted a draft for a new banking law to the Legislature. The bill passed the Assembly, but owing to the dead-lock in the Senate, failed to reach the Governor. It was again presented to the Legislature in 1892, and became a law on May 18, 1892. This is substantially the law now governing the banks of the State. One of the new provisions of the act was to make the stockholders of all banks liable to double the amount of their shares. The law had before only imposed a liability upon banks issuing notes. As practically all the banks issued circulation, this provision was wide enough in its application until the Federal law taxing State bank notes went into effect. By the law of 1892 banks of discount in New York and Brooklyn were required to have a reserve fund of not less than fifteen per cent. of their aggregate deposits. Other banks were required to have a reserve of ten per cent. It will be seen that this law gives the State banks an advantage over the National banks, the latter being compelled to keep a reserve of twenty-five per cent. in New York city and fifteen per cent. outside the reserve cities of the State.

\section{State and National Banks in New York.}

In some of the New England States the State banks have been superseded by the National institutions, but this has not been the case 
in New York. The National banking system was largely modelled on the New York banking law, and, therefore, there was no particular incentive to the State banks to change their form of organization on the ground of greater safety. In recent years the high premium on Government bonds has practically destroyed the profits on circulation, and some of the National banks of New York city do not issue notes at all; so that there is no longer any advantage on that score. The Superintendent of Banks reported in 1898 that when the National Banking Act went into effect in 1863 there were 309 State banks in operation, while five years later there were but forty-five. Since 1868 most of the years have shown an increase in the number of banks, the total being 212 in 1897. On September 20, 1898, there were 325 National banks operating in the State. The total resources of the State banks of deposit and discount are much less than those of the Savings banks and trust companies, while the number and importance of the private banking firms, in New York city especially, are proportionately greater than elsewhere in the United States.

Banking institutions operating under State laws are under careful supervision of the State Banking Department, and are required to make and publish frequent reports of their condition and to submit to a thorough examination by official examiners. The standard of management is generally high, and disastrous failures are rare.

State Banks, 1834-1899.

\begin{tabular}{|c|c|c|c|c|c|c|}
\hline YEARS. & $\begin{array}{l}\text { No. of } \\
\text { banks. }\end{array}$ & $\begin{array}{l}\text { Loans and } \\
\text { discounts. }\end{array}$ & Specie. & $\begin{array}{l}\text { Capital } \\
\text { stock. }\end{array}$ & Circulation. & Deposits. \\
\hline $1834 \ldots . .$. & 78 & $\$ 57,689,704$ & $\$ 2,657,503$ & $\$ 27,755,264$ & $\$ 17,820,402$ & $\$ 19,119,338$ \\
\hline $1839 \ldots$ & 96 & $68,300,486$ & $6,602,708$ & $36,801,460$ & $19,373,149$ & $18,370,044$ \\
\hline $1844 \ldots$ & 142 & $70,025,734$ & $10,086,542$ & $43,649,887$ & $16,335,401$ & $32,229,293$ \\
\hline $1849 \ldots$. & 179 & $81,911,412$ & $5,481,874$ & $44,362,869$ & $22,509,982$ & $33,849,963$ \\
\hline $1854 \ldots$ & 312 & $203,008,077$ & $14,169,905$ & $79,018,980$ & $32,573,189$ & $75,554,481$ \\
\hline $1859 \ldots$ & 300 & $200,577,198$ & $28,335,984$ & $110,258,480$ & $28,507,990$ & $110,465,798$ \\
\hline $1863 \ldots$ & 308 & $178,922,536$ & $37,803,047$ & $108,668,297$ & $39,182,819$ & $200,824,756$ \\
\hline $1869 \ldots$ & 52 & $47,743,597$ & $1,397,744$ & $18,205,924$ & 831,919 & $60,517,891$ \\
\hline $1874 \ldots . . .$. & .... & $71,017,418$ & .............. & $26,306,290$ & 78,773 & $62,425,178$ \\
\hline $1879 \ldots \ldots$ & 71 & $53,537,343$ & ................ & $19,318,200$ & 37,378 & $52,188,451$ \\
\hline $1884 \ldots \ldots$. & 87 & $92,254,126$ & ................ & $22,115,700$ & 63,658 & $109,466,498$ \\
\hline $1889 \ldots \ldots$. & 145 & $148,821,967$ & .............. & $27,765,700$ & 8,065 & $180,826,561$ \\
\hline $1894 \ldots \ldots \ldots$ & 205 & $163,641,484$ & .................. & $32,584,710$ & ....... & $184,191,806$ \\
\hline $1899 \ldots \ldots$. & 208 & $191,370,544$ & $24,728,319$ & $29,545,700$ & ....... & $270,033,433$ \\
\hline
\end{tabular}


National Banks, 1863-1898.

Figures are in thousands of dollars.

\begin{tabular}{|c|c|c|c|c|c|c|c|c|c|}
\hline DATE. & 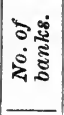 & $\begin{array}{c}\text { Loans } \\
\text { and dis. } \\
\text { counts. }\end{array}$ & $\begin{array}{c}U . S . \\
\text { bonds. }\end{array}$ & $\begin{array}{c}\text { Cash } \\
\text { and cash } \\
\text { items. }\end{array}$ & Capital. & Surplus & $\begin{array}{l}\text { Undi. } \\
\text { vided } \\
\text { profits. }\end{array}$ & 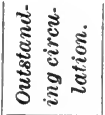 & $\begin{array}{c}\text { Indi- } \\
\text { vidual } \\
\text { deposits. }\end{array}$ \\
\hline $1863 .$. & 7 & $\$ 422$ & $\$ 748$ & $\$ 167$ & $\$ 985$ & ...... & $\$ 6$ & & $\$ 432$ \\
\hline 1868... & 304 & 232,192 & 101,036 & 196,364 & 114,655 & $\$ 25,023$ & 13,514 & $\$ 67,069$ & 278,352 \\
\hline $1873 \ldots \ldots . .$. & 276 & 279,953 & 74,359 & 130,585 & 108,260 & 31,133 & 16,871 & 57,686 & 223,377 \\
\hline $1878 . .$. & 280 & 235,593 & 101,181 & 126,426 & 89,094 & 25,026 & 13,325 & 47,795 & 223,000 \\
\hline $1883 \ldots . . . .$. & 315 & 344,213 & 55.730 & 157,345 & 86.894 & 34,064 & 17,298 & 43,119 & 308,139 \\
\hline $1888 \ldots . . . .$. & 322 & 402,942 & 40,073 & 183,217 & 85,893 & 43,741 & 19,448 & 23,595 & 360,916 \\
\hline $1893 \ldots \ldots$. & 334 & 397,389 & 38,733 & 120,619 & 87,826 & 56,297 & 27,683 & 32,150 & 354,632 \\
\hline $1898 \ldots \ldots . .$. & 324 & 155,337 & 86,661 & 165,723 & 82,995 & 57,608 & 26,142 & 31,272 & 529,495 \\
\hline
\end{tabular}

The New York Clearing-House Association.

It is said that Albert Gallatin was the first to suggest the adoption of the system of making bank clearances now employed by the banks of New York city. Mr. Gallatin died in 1849, so that his suggestions were probably not those which were adopted. In November, 1851, a letter appeared in the "New York Journal of Commerce," the writer being Geo. D. Lyman, a clerk in the Bank of North America, in which it was suggested that one bank be selected as a medium of exchange, and that all city banks keep an account with it, and send their gross exchanges to it at some regular hour each morning. At a meeting of those interested, on August 16, 1853, a committee was appointed to draft a plan. This plan was published in the Bankers' Magazine for September, 1853, signed by George D. Lyman, receiving teller of the Bank of North America. On September 13, 1853, the clearing plan was adopted in detail, and Mr. Lyman was made Manager.

The first clearing was made in the basement of No. 14 Wall street, October 11, 1853; soon after the place for making the clearings was changed to 82 Broadway, and later to the Bank of New York, 48 Wall street. In 1875 the association moved to Nassau and Pine street, and in 1896 took possession of its own building in Cedar street. The establishment of the clearing-house obviated many inconveniences in making exchanges, and also improved the standard of bank management by compelling weekly reports and by exercising supervision over the banks admitted to membership in the association.

When the clearing-house association was organized it consisted of fifty-two banks, that had a combined capital and surplus of $\$ 49,000,000$, and deposits aggregating $\$ 39,000,000$. Their loans were $\$ 97,000,000$, and their cash on hand (gold) amounted to $\$ 9,700,000$. There. were no Government notes then. The banks had outstanding, however, their own notes, amounting to $\$ 9,500,000$. 
New York Clearing-House Association, Transactions for Forty-six Years.

\begin{tabular}{|c|c|c|c|c|c|}
\hline 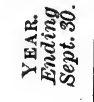 & 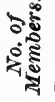 & $\begin{array}{l}\text { EXCHANGES. } \\
\text { Amount brought to } \\
\text { Clearing-House. }\end{array}$ & $\begin{array}{l}\text { BALANCES. } \\
\text { Paid in Money. }\end{array}$ & $\begin{array}{c}\text { AVERAGE } \\
\text { Daily Exchanges. }\end{array}$ & $\begin{array}{c}\text { AVERAGE } \\
\text { Daily Balan- } \\
\text { ces. }\end{array}$ \\
\hline $1854 \ldots$ & 50 & $\$ 5,750,455,987.06$ & $\$ 297,411,493.69$ & $\$ 19,104,504.94$ & $\$ 988,078.06$ \\
\hline $1855 \ldots$ & 48 & $5,362,912,098.38$ & $289,694,137.14$ & $17,412,052.27$ & $940,565.38$ \\
\hline $1856 \ldots$ & 50 & $6,906,213,328.47$ & $334,714,489.33$ & $22,278,107.51$ & $1,079,724.16$ \\
\hline $1857 \ldots$ & 50 & $8,333,226,718.06$ & $365,313,901.69$ & $26,968,371.26$ & $1,182,245.64$ \\
\hline $1858 \ldots$ & 46 & $4,756,664,386.09$ & $314,238,910.90$ & $15.393,735.88$ & $1,016,954.40$ \\
\hline $1859 \ldots$ & 47 & $6,448,005,956.01$ & $363,984,682.56$ & $20,867,333.19$ & $1,177,943.96$ \\
\hline $1860 \ldots$ & 50 & $7,231,143,056.69$ & $380,693,438.37$ & $23,401,757.47$ & $1,232,017.60$ \\
\hline $1861 \ldots$ & 50 & $5,915,742,758.05$ & $353,383,944.41$ & $19,269,520.38$ & $1,151,087.77$ \\
\hline $1862 \ldots$ & 50 & 6,871,443,591.20 & $415,530,331.46$ & $22,237,681.53$ & $1,344,758.35$ \\
\hline $1863 \ldots$ & 50 & $14,867,597,848.60$ & $677,626,482.61$ & $48,428,657.49$ & $2,207,252.39$ \\
\hline $1864 \ldots$ & 49 & $24,097,196,655.92$ & $885,719,204.93$ & $77,984,455.20$ & $2,866,405.19$ \\
\hline $1865 \ldots$ & 55 & $26,032,384,341.89$ & $1,035765,107.68$ & $84,796,040.20$ & $3,373,827.71$ \\
\hline $1866 \ldots$ & 58 & $28,717,146,914.09$ & $1,066,135,106.35$ & $93,541,195.16$ & $3,472,752.79$ \\
\hline $1867 \ldots$ & 58 & $28,675,159,472.20$ & $1,144,963,451.15$ & $93,101,167.11$ & $3,717,413.80$ \\
\hline $1868 \ldots$ & 59 & $28,484,288,636.92$ & $1,125,455,236.68$ & $92,182,163.87$ & $3,642,249.95$ \\
\hline $1869 \ldots$ & 59 & $37,407,028,986.55$ & $1,120,318,307.87$ & $121,451,392.81$ & $3,637,397.10$ \\
\hline $1870 \ldots$ & 61 & $27,804,539,405.75$ & $1,036,484,821.79$ & $90,274,478.59$ & $3,365,210.46$ \\
\hline $1871 \ldots$ & 62 & $29,300,986,682.21$ & $1,209,721,029.47$ & $95,133,073.64$ & $3,927,665.68$ \\
\hline $1872 \ldots$ & 61 & $33,844,369,568.39$ & $1,428,582,707.53$ & $109,884,316.78$ & $4,638,255.54$ \\
\hline $1873 \ldots$ & 59 & $35,461,052,825.70$ & $1,474,508,024.95$ & $115,885,793.58$ & $4,818,653.67$ \\
\hline $1874 \ldots$ & 59 & $22,855,927,636.26$ & $1,286,753,176.12$ & $74,692,573.97$ & $4,205,075.73$ \\
\hline $1875 \ldots$ & 59 & $25,061,237,902.09$ & $1,408,608,776.68$ & $81,899,470.26$ & $4,603,296.65$ \\
\hline $1876 \ldots$ & 59 & $21,597,274,247.04$ & $1,295,042,028.82$ & $70,349,427.51$ & $4,218,377.94$ \\
\hline $1877 \ldots$ & 58 & $23,289,243,701.09$ & $1,373,996,301.68$ & $76,358,176.06$ & $4,504,905.90$ \\
\hline $1878 \ldots$ & 57 & $22,508,438,441.75$ & $1,307,843,857.24$ & $73,785,746.54$ & $4,273,999.53$ \\
\hline $1879 \ldots$ & 59 & $25,178,770,690.50$ & $1,400,111,062.86$ & $82,015,539.38$ & $4,560,622.35$ \\
\hline $1880 \ldots$ & 57 & $37,182,128,621.09$ & $1,516,538,631.29$ & $121,510,224.25$ & $4,956,008.60$ \\
\hline $1881 \ldots$ & 60 & $48,565,818,212.31$ & $1,776,018,161.58$ & $159,232,190.86$ & $5,823,010.36$ \\
\hline $1882 \ldots$ & 61 & $46,552,846,161.34$ & $1,595,000,245.27$ & $151,637,935.38$ & $5,195,440.54$ \\
\hline $1883 \ldots$ & 63 & $40,293,165,257.65$ & $1,568983,196.15$ & $132,543,306.76$ & $5,161,128.93$ \\
\hline $1884 \ldots$ & 61 & $34,092,037,337.78$ & $1, \mathbf{5} 24,930,993.93$ & $111,048,981.55$ & $4,967,201.93$ \\
\hline $1885 \ldots$ & 64 & $25,250,791,439.90$ & $1,295,355,251.89$ & $82,789,480.38$ & $4,247,069.39$ \\
\hline $1886 \ldots$ & 64 & $33,374,682,216.48$ & $1,519,565,385.22$ & $109,067,588.94$ & $4,965,899.95$ \\
\hline $1887 \ldots$ & 64 & $34,872,848,785.90$ & $1,569,626,324.77$ & $114,337,209.13$ & $5,146,315.82$ \\
\hline $1888 \ldots$ & 64 & $30,803,686,609.21$ & $1,570,198,527.78$ & $101,192,415.11$ & $5,148,191.89$ \\
\hline $1889 \ldots$ & 63 & $34,796,465,528.87$ & $1,757,637,473.47$ & $114,839,820.23$ & $5,800,783.74$ \\
\hline $890 \ldots$ & $64^{\circ}$ & $37,660,686,571.76$ & $1,753,040,145.23$ & $123,074,139.12$ & $\mathbf{5 , 7 2 8 , 8 8 9 . 3 6}$ \\
\hline $891 \ldots$ & 64 & $34,053,698,770.04$ & $1,584,635,499.88$ & $111,651,471.39$ & $5,195,526.21$ \\
\hline
\end{tabular}


New York Clearing-House Association, Transactions for Forty-six Years-Continued.

\begin{tabular}{|c|c|c|c|c|c|}
\hline 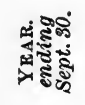 & 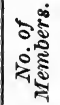 & $\begin{array}{l}\text { ExchaNges. } \\
\text { Amount brought to } \\
\text { Clearing-House. }\end{array}$ & $\begin{array}{c}\text { Balances. } \\
\text { Paid in Money. }\end{array}$ & $\begin{array}{c}\text { A VERAGE } \\
\text { Daily Exchanges. }\end{array}$ & $\begin{array}{c}\text { A VERAGE } \\
\text { Daily Balan- } \\
\text { ces. }\end{array}$ \\
\hline $1892 \ldots$ & 64 & $\$ 36,279,905,235.59$ & $\$ 1,861,500,574.56$ & $\$ 118,561,781.82$ & $\$ 6,083,335.18$ \\
\hline $1893 .$. & 64 & $34,421,380,869.50$ & $1,696,207,175.52$ & $113,978,082.31$ & $5,616,580.05$ \\
\hline $1894 \ldots$ & 65 & $24,230,145,367.70$ & $1,585,241,633.52$ & $79,704,425.55$ & $5,214,610.63$ \\
\hline $1895 \ldots$ & 67 & $28,264,379,126.23$ & $1,896,574,349.11$ & $92,670,095.49$ & $6,218,276.55$ \\
\hline $1896 \ldots$ & 66 & $29,350,894,883.87$ & $1,843,289,238.66$ & $96,232,442.24$ & $6,043,571.27$ \\
\hline $1897 \ldots$ & 66 & $31,337,760,947.98$ & $1,908,901,897.67$ & $103,424,953.62$ & $6,300,006.26$ \\
\hline $1898 \ldots$ & 65 & $39,853,413,947.74$ & $2,338,529,(16.43$ & $131,529,418.97$ & $7,717,917.54$ \\
\hline $1899 \ldots$ & 64 & $57,368,230,77133$ & $3,085,971,370.53$ & $189,961,029.04$ & $10,218,448.24$ \\
\hline $\begin{array}{l}\text { Total } \\
46 \text { yrs. }\end{array}$ & & $\$ 1,231,423,418,499.23$ & $\$ 58,640,345,106.12$ & $\$ 87,115,590.26$ & $\$ 4,162,727.69$ \\
\hline
\end{tabular}

SAvings Banks.

The Savings banks of New York State have greater resources than any of the other banking institutions operating under the laws of the State, and they are almost as large as the resources of the discount banks and trust companies combined. On January 1, 1899, there were 130 Savings banks in the State, and their total resources were $\$ 923,420,861$. Their deposits amounted to $\$ 816,144,36 \%$.

The first Savings bank incorporated by the New York Legislature was the Bank for Savings, of New York city, incorporated in 1819.* In the following year the Albany Savings Bank was chartered.

These banks are semi-benevolent in character, and are intended to furnish a safe place for the deposit of the surplus earnings of those who work for wages, and those in humble circumstances. Both the deposits and the surplus earnings are exempt from taxation. There are no shareholders, and all the funds are held in trust for the benefit of depositors.

The management is vested in a board of trustees, who serve without pay, except for certain specific services. They are prohibited from borrowing from the bank or becoming surety for any borrower.

Investments are limited to real estate mortgages on property within the State, worth twice the amount loaned, and to high-class bonds. The restrictions in regard to investments practically assure the safety of the sums so invested. Deposits from any one person may not exceed $\$ 3,000$. Savings banks do not deal in exchange or commercial paper or make collections, nor do they receive deposits subject to check. Payments are made on orders accompanied by pass books.

* On the nights the Bank for Savings was open for business the Treasurer used to carry the deposits home in a little hair-covered trunk, the bank then not owning a safe. That trunk is now one of the bank's most prized possessions.- "New York Evening Post," Dec. 31, 1897. 
Savings Banks, 1858-1899.

\begin{tabular}{|c|c|c|c|c|}
\hline YEARS. & $\begin{array}{l}\text { No. of } \\
\text { banks. }\end{array}$ & No. of accounts. & Deposits. & $\begin{array}{l}\text { Average } \\
\text { to each } \\
\text { depositor. }\end{array}$ \\
\hline $1858 \ldots \ldots . .$. & 54 & 203,804 & $\$ 41,422,672$ & $\$ 203$ \\
\hline $1863 . . . \ldots$. & 71 & 347,184 & $76,538,183$ & 220 \\
\hline $1868 \ldots \ldots . .$. & 102 & 537,466 & $151,127,562$ & 281 \\
\hline $1873 \ldots .$. & 150 & 822,642 & $285,286,621$ & 346 \\
\hline $1878 \ldots \ldots . .$. & 138 & 844,550 & $312,823,058$ & 370 \\
\hline 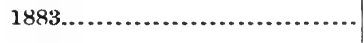 & 127 & $1,095,971$ & $412,147,213$ & 376 \\
\hline $1888 \ldots . . . .$. & 125 & $1,325,062$ & $505,017,751$ & 381 \\
\hline $1893 \ldots \ldots \ldots . . .$. & 124 & $1,593,804$ & $629,358,273$ & 394 \\
\hline $1899 \ldots$. & 129 & $1,865,653$ & $816,144,367$ & 437 \\
\hline
\end{tabular}

A better idea of the magnitude of the business done by these banks may perhaps be gained by a statement of the deposits held by some of the principal Savings banks of New York eity on January 1, 1899.

Bowery Savings Bank........ \$66,326,851

Bank for Savings........... $58,011,545$

Emigrant Industrial Sav. Bank $53,357,950$

German Savings Bank......... 44,033,364
Seamen's Bank for Savings..... \$41,997,415

Greenwich Savings Bank...... 35,765,536

Brooklyn Savings Bank....... 33,202,090

Williamsburgh Savings Bank. . 32,714,161

\section{Trust Companies.}

It has been seen that the State banks of deposit and discount in New York have held their ground in competition with the National banks much better than has been the case in many other States. But a comparatively new rival to the State banks has arisen. This is the trust company, which of late years has shown a tendency to enter the banking field besides performing other profitable functions prohibited to the banks.

Not only are they allowed wider latitude in their operations, but they are not subject to the same restrictions as banks in the matter of reserve and are more lightly taxed. In the city of New York, especially, the trust companies have shown a remarkable growth in recent years. This has been partly due, no doubt, to the immunities and privileges which these institutions enjoy, but the multiplication of industrial combinations, whose organization has been managed by the trust companies, has also been a source of great profit.

From January, 1896, to October, 1899, nineteen trust companies were organized in the State, and four or five more were being formed. Most of these companies are in New York city.

Prices of the shares of eleven companies in New York city in $\mathbf{1 8 9 5}$ averaged $\$ 498$, and in 1899 the average price of the shares of thirteen companies was $\$ 885$. This represented an advance of seventy-five per cent., and an increase of fifty per cent. in twelve months. 
* From 1892 until July, 1899, twenty-two new companies have begun business, of which eleven have been organized since January, 1898. Fifty-two companies reported to the Superintendent of Banks on July 1, 1899. Three others have since opened their doors, five are in process of organization, and two more are in the hands of their promoters. Of the fifty-five now in business twenty-nine are in the old city of New York. Brooklyn adds nine companies to New York's list, while seventeen are scattered through the remainder of the State.

But three trust companies are upon the records of the Banking Department as having failed. In the quarter century, from July, 1874, to July, 1899, the number of trust companies has been increased by forty-three, and their resources have grown from $\$ 57,000,000$ to $\$ 722$,000,000 . Within the same period 215 State banks have been organized, eighty-eight have withdrawn through voluntary liquidation, failure or transfer to the National system ; the total number has increased from eighty-one to 208 , and their gross assets from $\$ 108,000,000$ to $\$ 381,000$,000 . Their assets of 1874 were doubled in 1889 , tripled in 1898 , and multiplied by three and a half in 1899 . The assets of the trust companies in 1874 were doubled in 1882, tripled in 1886, quadrupled in 1889 , grew to five fold in 1892, six fold in 1895, seven fold in 1898, and twelve fold in 1899. Of their earnings in 1898 they distributed less than a fifth to their stockholders in dividends, paid considerable more than a third to their depositors as interest and carried nearly $\$ 6,000,000$ to the account of surplus; that is the development of the trust company.

Trust Companies, January 1, 1899.

RESOURCES.

Bonds and mortgages..........

Stock investments............ Loaned on collaterals...........
Loaned on personal securities,

including bills purchased....

Overdrafts...................

Due from bankers and brokers

Real estate.

Cash on deposit in banks or other moneyed institutions.

Cash on hand..................

Other assets.

Total.

$\begin{array}{r}\$ 34,855,023 \\ 136,561,066 \\ 283,402,821 \\ \\ 29,930,375 \\ 20,907 \\ 1,999,280 \\ 9,322,440 \\ \\ 63,254,393 \\ 8,480,227 \\ 11,378,905 \\ \hline \$ 579,205,442\end{array}$

LIABILITIES.

Capital stock paid in.........\$34,850,000

Surplus fund.............. $54,556,366$

Undivided profits........... $7,845,963$

Deposits in trust........... $197,664,749$

General deposits........... 269,519,509

Other liabilities............ 14,768,853

$\$ 579,205,442$

\section{Historic New York City Banks.}

† The Bank of New York, founded by Alexander Hamilton in 1784, is the second oldest bank in the country. The Bank of North America at Philadelphia, was organized in 1781. The Massachusetts Bank, of Boston, was organized the same year as the Bank of New York, and

* Address of Francis S. Bangs before Trust Company Section American Bankers' Association, Twenty-fifth Annual Convention, Cleveland, Ohio, Sept. 5, 6, and 7, 189.

$+\cdots$ New York Evening Post," December 31, 1897. 
these three banks have acted as each other's correspondents for more than a century. The Bank of New York has occupied its present site at Wall and William streets for more than a century. Gen. Alexander MeDougall was its first President. The bank prides itself on never having passed a dividend except once, and that was in 1837, when it was compelled by law to do so. The next year, however, it paid a double one and so maintained its record.

When the banks were admitted into the clearing-house association upon its organization they were placed according to their age and numbered accordingly. Thus the Bank of New York stands first on the list. The history of the Bank of the Manhattan Company has already been told. With the exception of these two banks-the Bank of New York and the Bank of the Manhattan Company-and a branch of the United States Bank, all the other banks that followed them were organized after the beginning of the present century. The Merchants' Bank was organized in 1805, the Mechanics' in 1810, the Bank of America, the Phenix Bank, and the City Bank in 1812, the Tradesmen's in 1823, the Chemical in 1824, the Merchants' Exchange Bank in 1828, the Gallatin (then known as the National) in 1829, the Butchers and Drovers', the Mechanics' and Traders, and the Greenwich, in 1830, the Leather Manufacturers' in 1832, the Seventh Ward (now Seventh National) in 1833, and the Bank of the State in 1836. The American Exchange National Bank was organized in 1838, the Bank of Commerce in 1839, and the Broadway and the Mercantile Bank in 1849, and the Pacific Bank in 1850. The remainder were organized subsequent to 1850 .

The oldest three bank presidents in active service are: Francis A. Palmer, of the Broadway Bank, the oldest in point of age; George G. Williams, of the Chemical Bank, and Frederick D. Tappen, of the Gallatin Bank. The last named is the oldest bank President in point of service. He entered the Gallatin Bank a junior clerk in 1850 (he was born the year the bank was organized), and rose through every grade to that of President, to which office he was appointed in 1868. The bank has only had two other Presidents during the whole of its existence-Albert Gallatin, 1829-1838, and James Gallatin, his son, 18381868. Mr. Tappen was appointed Cashier on the night of the suspension of specie payments in 1857 .

An interesting story is told of the Gallatin Bank's first President. It was after the panic of 1836 . The banks held a meeting to discuss when they should resume specie payments. A motion was offered to resume after certain notice had been given. Albert Gallatin moved as an amendment that the banks should "resume to-morrow." The amendment was carried, and the banks resumed specie payments on the morrow without trouble.

George G. Williams, President of the Chemical Bank, has had a banking experience of more than fifty years. He entered the service of the bank as junior clerk in 1841, and has been its President since 1878. 
The Chemical Bank was started as a chemical manufacturing company, but in many respects it is regarded as the most famous bank in the country. It has a capital of only $\$ 300,000$, but its surplus is more than $\$ 7,000,000$, and its $\$ 100$ shares sell for nearly $\$ 5,000$ each. Its first office was on the present site of the National Park Bank, opposite St. Paul's Chapel, but in 1850 it moved to its present building.

One of the interesting facts in connection with the history of New York banks and the clearing-house was the refusal of the latter to admit National banks to membership in the clearing-house association when they were first organized under the National Banking Law in 1853, because they were regarded as dangerous institutions. The First National Bank was refused admission at first, but the clearing-house association subsequently rescinded its action, and nearly all the other banks then took out charters under the National Banking Act, many of them being allowed to retain their old names instead of losing their identity by being designated by number. The opposition, however, at first to the National banking law and the banks organized thereunder, was very fierce. One of the most cherished documents in the archives of the Chase National Bank, preserved by President Henry W. Cannon, is a copy of a long printed circular urging the associated banks to stand together for their own protection and the protection of the property confided to their care, "in many cases the all of women, children, the infirn and those who look to us as their only means of support $* * *$ and sound the alarm ere it is too late. Let the associated banks in the three great cities of New York, Philadelphia and Boston, decline all recognition of these institutions, directly or indirectly in their exchanges, and let them at once, at whatever expense, return the notes that they are compelled to receive from the Government to their respective points of issue for redemption. In so doing you will keep the heart of the currency at the great city centres unscathed and whole."

Endorsed on this circular in the handwriting of John Thompson, the founder of the Chase National Bank and its second President, is this memorandum: "This paper, sent out by the then President of the Merchants' Bank, was followed by a resolution of the clearing-house binding its members to treat as uncurrent money all National bank notes and to refuse to exchange with National banks. Thompson's bank was the only one open at that time."

The Thompson's bank referred to in the memorandum was the First National Bank, which was organized by John Thompson. He subsequently sold out his interest in that bank, and later, in 1877, organized the Chase National Bank. His son, Samuel Thompson, was its first President. When he died his father took the presidency for a year, and was then succeeded in 1886 by Henry W. Cannon, ex-Comptroller of the Curreney. 


\section{NEW JERSEY.}

The history of banking in the State of New Jersey begins with the establishment of the Newark Banking and Insurance Company, of Newark, and the Trenton Banking Company, of Trenton.

These two institutions were chartered by the Legislature in the year 1804. The charter of the Newark bank ante-dates that of the Trenton eoncern a little more than nine months, and after the hardships that beset pioneers, these two institutions are in existence to-day and rank with the strongest banking houses in the United States.

The Newark Banking and Insurance Company was born of a necessity arising from the growth of the industrial and business interests of the city of Newark, which was at a disadvantage because of its distance from New York and the lack of facilities for travel. There were no railroads in the State in those early days. Traffic between towns was carried on by means of horse and wagon. The necessity of a bank in Newark, the population of which was rapidly increasing, became so great that some of the city's leading business men organized a company, applied to the Legislature for a charter and in 1804 received it. The company elected as its President, Elisha Boudinot, one of the State's most prominent citizens at that time. He was a physician and a lawyer and for several years served as Supreme Court justice.

The business of the bank began in the parlor of Smith Burnett's residence on Broad street, Newark, and the first depositor was Judge Boudinot himself, who intrusted to the bank three hundred dollars. When the books were closed on the first day's business they showed that $\$ 4,000$ had been deposited.

This money was placed in an iron-bound wooden box for safe-keeping, but cash came in so rapidly during the next four or five days that the directors decided to open an account with the Manhattan Bank, of New York, to which institution the funds were taken and there they remained until the following year, when the company erected a commodious bank building in Newark.

\section{The First Banks Begin Business.}

The Newark Banking and Insurance Company began business with a capitalization of $\$ 800,000$, of which $\$ 350,000$ was paid in, and for the privilege of operating it paid the State a bonus of $\$ 1,482$. The bank's charter ran for a period of twenty years, and when it was extended for the third time the bank changed its name to the Newark Banking Company and became a National bank.

During the sixty years of its existence as a chartered institution the Newark bank's business increased until when it became a National bank its assets amounted to $\$ 2,285,695$.

Of these two pioneer institutions, the Trenton Banking Company 
has had the most important and interesting career. It was organized with a capital of $\$ 600,000$, of which $\$ 214,740$ was paid in.

The first President of the institution was Isaac Smith, who was for eighteen years a Supreme Court justice. He was also a member of the Continental Congress and a Colonel in the Continental army. When the bank was organized the State refused to accept a bonus, reserving the right to subscribe for stock, which was done in 1811 to the amount of $\$ 24,000$, which was carried for the benefit of the public schools. The first loan to the State, amounting to $\$ 32,000$, was made for military purposes December 17, 1813, during the war with England.

Owing to the depression in business which followed the war, this bank in common with all others in the country, suspended specie payments August 31, 1814. The Bank of the United States having been organized as a measure of relief to the business of the country, the Trenton Banking Company, July 15, 1816, subscribed $\$ 40,000$ to the stock of that bank and gave aid in other ways to relieve the general distress, making many local loans for that purpose. The impoverished condition of the community in which the bank was striving to establish itself at that time is shown by the fact that it frequently loaned the city money with which to pay its solitary watchman.

The first counterfeits of the notes of this bank were detected in Newark in 1808, and a counterfeit ten dollar note issued in 1810, and obtained in England, was presented at the bank for payment in 1879. Early in the history of the bank two or three runs for the redemption of its notes were made by its depositors. In 1837 a run on the bank began and there were not enough funds in the vaults to meet the demand. There was no railroad at that time between Trenton and Philadelphia; but something had to be done to save the bank, and Benjamin Fish, one of the directors, drove to the City of Brotherly Love, loaded a wagon with silver, returned to Trenton and unloaded the coin in front of the bank. The sight of the money inspired the excited depositors with confidence and they quickly withdrew, satisfied that the bank had the ability to redeem its notes in coin on demand.

The Trenton Banking Company never organized under the National Banking Law of the United States, but has continued business under its charter from the State of New Jersey, as a bank of discount.

\section{Loan to a Royal Customer.}

An interesting inciden in the history of the bank was the loaning of $\$ 800$ to Prince Lucien Murat, who gave a bracelet studded with diamonds as security. The Prince lived at Bordentown, New Jersey, and when the news of the dethronement of Louis Phillippe reached this country in 1848, and the prospects of the restoration of the Bonaparte family began to brighten, the Prince thought that it would be to his interest to return to France. He was a nephew of the great Napoleon and he confidently expected to gain position and influence under the 
government of Louis Napoleon, who was chosen President of the new republic.

Having no money to pay his passage he offered the bracelet, which had been intrusted to him by Hortense, Queen of Holland, and mother of Louis Napoleon. The bracelet lay in the bank vault a year, when the $\$ 800$, with interest, was paid by a friend of the borrower.

When the National banking system was established and a tax of ten per cent. imposed upon the future issues of circulating notes, by State banks, the circulation then outstanding of the notes of the Trenton bank amounted to $\$ 393,194$, nearly every dollar of which has been returned to the bank and redeemed.

\section{Assistance Rendered the Government.}

No period in the history of the bank was of greater interest to the State of New Jersey, or the nation at large, than that during the Rebellion. The minutes show that April 16, 1861, two days after the bombardment of Fort Sumter, the directors passed a resolution tendering the Governor of the State a loan of $\$ 25,000$ for immediate use in equipping troops. On September 5, 1862, a loan of $\$ 200,000$ was made to the State for the payment of bounties.

As the war proceeded Gov: Charles S. Olden, who was then a director of the bank, was authorized to use all the money of the institution that might be necessary for sending troops to the front. The Governor did so, with the result that the State, at the close of hostilities, owed the bank $\$ 600,000$.

On December 31, 1898, the resources of the Trenton Banking Company amounted to $\$ 2,566,320$.

In 1807, the New Brunswick Bank was chartered with a capital of $\$ 200,000$ of which $\$ 90,000$ was paid in. The bonus paid the State was $\$ 6,000$.

In 1810 the Legislature enacted a law fixing a tax of one-half of one per cent. on all bank capital paid in.

\section{Banks Operating Under State Laws.}

The first banking law enacted by the Legislature of New Jersey was approved by Gov. Aaron Ogden, January 28, 1812. The population of the State had grown rapidly, and the necessity for financial institutions where business men could deposit their funds and negotiate paper became pressing.

The people were wary of private banking institutions and made a strong appeal to the Legislature to enact a law under which banks might be chartered and which would give the depositor some assurance that his interests were reasonably secure.

A bill was presented to the Legislature early in the session of 1812 , providing for the establishment of State banks at Camden, Trenton, 
New Brunswick, Elizabeth, Newark and Morris (now Morristown), the charter of each to run twenty years.

The law provided that the shares of these banks should be fixed at a valuation of fifty dollars each, and that half of the capital subscribed should be reserved for the State. No subscription for stock was to be received from any but citizens of the State for the first five days that the subseription books were open to the public. A commission of reliable citizens was appointed by the Legislature to receive subscriptions for the stock of each bank. If at the end of fifteen days more stock had been subscribed than had been issued, an equitable deduction was to be made from those who had been the largest purchasers. The President and the directors of the institutions were appointed by the Legislature for the first year, at the end of which time the stockholders were to.elect directors who would choose a President of the board. The rate of discount of bills and notes of the banks was not to be more than seven per cent. and dividends were to be declared every six months.

The law provided that the banks should not at any time loan or discount a greater sum than double the amount of the capital stock paid in. It was declared also, that banks could not own vessels, or directly or indirectly be concerned in trade, or the importation or exportation, purchase or sale of any goods, unless pledged to them as security for debts. The latter provision also applied to real estate.

\section{Limitation of the Amount of Indebtedness.}

The amount of indebtedness that the banks might incur was fixed at a sum not to exceed twice the amount of the capital stock paid in, over and above the deposits made with the bank for safe-keeping. In the event of this limit being exceeded, the directors, under whose administration the excess occurred, were held liable for the amount in their individual and private capacities. If there were directors who were not present when the debt was contracted, there was an opportunity for them to escape the liability by notifying the State Treasurer of the fact. The banks were required to make a report of their assets and liabilities each year to the State Treasurer. No notes were to be issued of a less value than three dollars; but a universal demand for currency of a smaller denomination resulted in an amendment to the law in 1813, which enabled the banks to issue notes of the denomination of one dollar.

Encouraged by this action of the Legislature, men with capital and brains went mto the banking business in all parts of the State, and they thrived, in many instances, at the expense of stockholders and depositors. Excepting a few immaterial amendments, the banking law of 1812 stood unchanged until 1850, when the condition of the banks was such as to demand a revision of the statutes relating to the banking business. 
In the thirty-eight years between 1812 and 1850 New Jersey had taken a great stride forward industrially and financially. Railroads were built, canals constructed, towns founded and cities created. Agricultural lands were developed and various enterprises entered into that required the outlay of a vast amount of money. The promoters of these extensive improvements found the banks convenient mediums through which to operate them. In some of the remote parts of the State manufacturing companies and canal corporations did a banking business with the approval of the Legislature, and in some instances used the money of the stockholders and depositors in the furtherance of their own private schemes which were not always successful, and when they failed there were a good many mourners at the funeral.

As the result of these loose methods of doing business the State was flooded with worthless paper, and the authorities finally awoke to the fact that something must be done to clear up the situation. In 1837 a commission was appointed by the Legislature to examine into the condition of the banks in the State, and report to that body.

The report was not very fiattering to the officers of some of the combination manufacturing and banking concerns.

In one instance, in the southern part of the State, it was discovered that a sawmill company were operating a bank as a side issue, and in another instance a company of real estate dealers were doing the same thing.

Although the law required that the bank officials should make an annual report to the State Treasurer of their financial condition, many of them neglected to do so, and the result of the investigation instigated by the Legislature was the winding up of the business of several wildcat concerns and the purification of the financial atmosphere generally.

In 1837 , in common with the banks of other States, the New Jersey institutions suspended specie payment, with the single exception of the Paterson Bank. The Sussex Bank suspended such payment for a few days only.

On March 5, 1842, specie payments were resumed and a law passed warning the banks not to issue notes, bills or drafts prior to August 15 of that year, fixing as a penalty for violation of the law the forfeiture of their charters.

\section{Enactment of a General Banking Law.}

In 1850 what is known as the general banking law of the State was enacted. It authorized the State Treasurer to have printed bank notes of all denominations not less than one dollar, which he might issue to any association of persons formed for the purpose of doing a banking business under the provisions of this act, in exchange for the public stocks of New Jersey, the United States or the State of Massachusetts, dollar for dollar, provided the stocks were productive of a six per cent. 
rate of interest per annum, and he was prohibited from taking such stock at a rate above its par value of not less than one hundred cents on the dollar. Notes for circulation issued under this act and remaining outstanding, were not, at any time, to exceed three million dollars. The banks were authorized, after having executed and signed such notes for circulation, so as to make them obligatory promissory notes payable on demand, without interest, to circulate them as money.

The Treasurer was authorized to give to the bank, transferring stock to him, powers of attorney to recei ve the interest and dividends thereon, which they might apply to their own use. Such powers were to be revoked upon a bank failing to redeem the circulating notes it had issued, or whenever in the judgment of the Treasurer the principal of the stock held by him had become insufficient security; in which case he was to receive dividends on all stocks as well as the interest on all bonds and mortgages deposited by such banking association, and deposit it in some safe bank in the State, in his name, in trust for the association to which it belonged, the deposit to be made on such terms and such rate of interest, not beyond the legal rate, as the Treasurer deemed most conducive to the interest of the association, and to be withdrawn and paid over whenever in his judgment the securities of such association were sufficient to warrant it.

The law provided that instead of transferring public stocks as security for circulating bills, banks might secure one-third of the whole amount of the issue, by making and executing directly to the Treasurer or by transferring to him, bonds and mortgages upon real estate, payable at a period not exceeding one year and bearing interest at six per cent. Before such bonds and mortgages were accepted as security it was required that they have the approval of the Attorney-General.

It was required also that the mortgages be upon improved, productive, unencumbered lands within the State of New Jersey, worth, independent of any buildings thereon, at least triple the amount of the mortgage, and that no mortgage for a greater amount than $\$ 5,000$ should be taken.

In the event of such security becoming insufficient for the payment of the bills and notes issued, the Treasurer was directed to notify the President of the banking association of the fact, and he was required within five days to place in the Treasurer's hands such amount of securities as would secure in full the notes issued. If the President of the banking association neglected to produce the securities in the required time, the Treasurer was authorized to proceed and wind up the affairs of the institution by paying all the circulating notes issued by such association out of the trust funds in his hands for that purpose and selling at public auction the stocks, bonds and mortgages pledged by the members of the association as security.

To defray the eost of making the plates and dies and printing the notes and bills, each bank was required to pay an assessment. A bank- 
ing association was required to have seven members and an aggregate capital stock of not less than $\$ 50,000$ nor more than $\$ 500,000$.

Any creditor or shareholder of a bank whose shares or debts amounted to $\$ 1,000$ could secure an investigation of the affairs of the institution through a master in chancery appointed for that purpose by the Chancellor. In 1851 the law was amended so as to admit of the taking of the stocks of the States of New York, Ohio, Kentucky and Pennsylvania and Virginia as securities.

\section{Organization of Banks UNder THE New LAw.}

When this law went into effect there were in operation in the State under the law of 1812 , twenty-four banks with an aggregate capital of $\$ 3,596,720$; circulation, $\$ 2,548,352$; specie, $\$ 630,734$; deposits, $\$ 1,886$,595 ; bills receivable, $\$ 6,192,575$; notes of and due from other banks, $\$ 1,452,05 \%$. Due to other banks, $\$ 298,570$; balance of profit and loss or surplus, $\$ 543,776$; real estate, $\$ 300,037$; bonds, mortgages, stocks, etc., $\$ 257,568$; suspense account, $\$ 21,889$.

The Treasurer's report for 1851 shows that fifteen banking associations took advantage of the new law. The total amount of securities in the hands of the Treasurer was $\$ 774,145$; circulation, $\$ 767,602$.

In 1852 the number of the banks had increased to nineteen with securities amounting to $\$ 785,420$; circulation, $\$ 766,742$.

When the National Banking Act was passed in 1863 there were twelve State banks with securities amounting to $\$ 1,748,333$, and circulation, $\$ 1,633,513$. The affairs of eight banks were being settled by decrees from the court of chancery and nine had obtained charters from the Legislature, and were winding up their business under the general banking law.

In 1876 there were but two State banks in existence in New Jersey, and their affairs were being settled by the court of chancery. The total amount of their securities was $\$ 3,321$, and their circulation, $\$ 735$.

State Banks Organized Under the General Banking Law of 1850.

\begin{tabular}{|c|c|c|c|c|}
\hline YEARS. & $\begin{array}{l}\text { No. of } \\
\text { banks. }\end{array}$ & $\begin{array}{l}\text { Amount of } \\
\text { securities. }\end{array}$ & $\begin{array}{l}\text { Amount of } \\
\text { circulation } \\
\text { returned and } \\
\text { cancelled } \\
\text { during year. }\end{array}$ & Circulation. \\
\hline $1852 \ldots$. & 19 & $\$ 785,420$ & $\$ 149,209$ & $\$ 766,742$ \\
\hline $1854 \ldots .$. & 15 & 979,595 & 239,615 & 877,742 \\
\hline $1856 \ldots \ldots .$. & 6 & 408,348 & 78,329 & 395,826 \\
\hline $1859 \ldots \ldots \ldots$ & 11 & 842,333 & 165,737 & 795,908 \\
\hline $1860 \ldots$. & 8 & 713,333 & 208,953 & 602,285 \\
\hline $1863 \ldots \ldots \ldots \ldots$ & 12 & $1,748,333$ & 242,630 & $1,633,513$ \\
\hline $1892 \ldots \ldots \ldots \ldots \ldots$ & 2 & 3,321 & .......... & 735 \\
\hline
\end{tabular}




\section{INCORPORATED BANKS.}

At the present time there are twenty-one incorporated or chartered banks in the State, with a capitalization of $\$ 1,738,500$.

The following table shows the condition of the chartered banks at various periods during the past sixty years:

\begin{tabular}{|c|c|c|c|c|}
\hline YEARS. & $\begin{array}{l}\text { No. of } \\
\text { banks. }\end{array}$ & $\begin{array}{l}\text { Loans and } \\
\text { discounts. }\end{array}$ & Specie. & $\begin{array}{l}\text { Capital } \\
\text { stock. }\end{array}$ \\
\hline $1838 \ldots$ & 26 & $\$ 7,093,292$ & $\$ 1,808,712$ & $\$ 5,095,840$ \\
\hline $1850 \ldots . .$. & 24 & $1,452,057$ & 630,734 & $3,596,720$ \\
\hline $1855 \ldots \ldots$. & 22 & $7,746,920$ & 738,595 & $3,935,950$ \\
\hline $1859 \ldots . .$. & 36 & $11,901,085$ & 907,770 & $6,335,322$ \\
\hline $1870 \ldots .$. & 5 & $2,070,353$ & 113,417 & $1,050,125$ \\
\hline $1880 \ldots \ldots \ldots \ldots \ldots \ldots$ & 7 & $2,440,369$ & 128,638 & $1,005,606$ \\
\hline $1890 \ldots \ldots \ldots \ldots$ & 22 & $6,684,593$ & 124,393 & $1,640,822$ \\
\hline $1898 \ldots \ldots \ldots . .$. & 21 & $7,533,497$ & 150,485 & $1,738,500$ \\
\hline
\end{tabular}

National Banks, 1863-1898.

Figures in thousands of dollars.

\begin{tabular}{|c|c|c|c|c|c|c|c|c|c|}
\hline YEARS. & 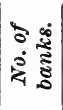 & $\begin{array}{l}\text { Loans } \\
\text { and dis- } \\
\text { counts. }\end{array}$ & $\begin{array}{c}\text { U.S. S. } \\
\text { bonds. }\end{array}$ & $\begin{array}{c}\text { Cash } \\
\text { and cash } \\
\text { items. }\end{array}$ & Capital. & Surplus. & $\begin{array}{c}\text { Undi- } \\
\text { vided } \\
\text { profits. }\end{array}$ & 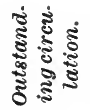 & $\begin{array}{c}\text { Indi. } \\
\text { vidual } \\
\text { deposits. }\end{array}$ \\
\hline & 1 & $\$ 55$ & $\$ 60$ & $\$ 31$ & $\$ 84$ & & $\$ 2$ & & $\$ 108$ \\
\hline $368 \ldots$ & 55 & 19,195 & 11,930 & 3,510 & 11,483 & $\$ 2,245$ & 1,195 & $\$ 9,318$ & 14,165 \\
\hline 1873... & 62 & 26,058 & 12,766 & 3,777 & 13,858 & 3,517 & 1,654 & 10,920 & 17,396 \\
\hline $1878 \ldots . . . . .$. & 68 & 22,572 & 14,248 & 4,001 & 14,033 & 3,703 & 1,375 & 11,279 & 18,584 \\
\hline 1883..... & 69 & 33,349 & 11,214 & 4,623 & 12,203 & 3,824 & 1,703 & 9,351 & 29,700 \\
\hline $1888 \ldots . .$. & 85 & 42,062 & 8,681 & & 13,318 & & & 5,993 & 42,138 \\
\hline $1893 . .$. & 99 & 47,341 & 5,513 & 5,730 & 14,608 & 7,447 & 3,586 & 4,599 & 47,375 \\
\hline $1898 \ldots$ & 104 & 54,262 & 7,482 & 6,126 & 14,487 & 8,301 & 4,639 & 5,031 & 62,128 \\
\hline
\end{tabular}

Prior to 1875 financial institutions of the State were, as a rule, created by special charters granted by the Legislature. The constitution, as amended in 1875, prohibited the granting of special charters and prescribed that the Legislature should enact general laws for the organization of corporations. From 1875 to 1898 the laws relating to the State banks underwent no radical changes.

\section{Revision of the Banking LAws in 1899.}

The banking laws of the State, as revised in 1899, provided that seven or more persons of full age may become a banking corporation. The affairs of every bank shall be managed by a board of not less than five directors, a majority of whom shall at all times be residents of the 
State of New Jersey, who shall be elected annually by the stockholders at their annual meeting and hold office for one year, and until their successors are elected and have qualified. The board of directors of each bank shall from time to time appoint from its members an examining committee, who shall examine the condition of the bank at least once every six months, or oftener, if required by the board, and such committee after each examination shall forthwith report to the board, giving in detail all items included in the assets of the bank which they have reason to believe are not of the value of which they appear on the books and records of the bank, and giving the value, in their judgment, of each of such items. Every bank is obliged to make to the Commissioner of Banking and Insurance not less than four reports during each year.

No bank shall make any loan or discount on the security or on the shares of its own eapital stock, nor be the purchaser or holder of any such shares unless such security or purchase shall be necessary to prevent loss upon a debt previously contracted in good faith; and the stock so purchased or acquired shall within one year from the time of its purchase be sold or disposed of at public or private sale. The total liabilities to any bank of any person or of any company, corporation or firm, for money borrowed, including in the liabilities of a company or firm the liabilities of the several members thereof, shall at no time exceed ten per centum of the aggregate amount of the capital stock of such bank actually paid in, and of the permanent surplus fund of such bank. Every bank shall at all times nave on hand, in available funds, an amount equal at least to fifteen per centum of all its immediate liabilities ; three-fifths of this amount may consist of balances due to the bank from good, solvent banks or trust companies, and two-fifths of such sum shall be held in reserve in cash on hand. It shall not be lawful for any bank, under the provisions of this act, to issue as money or put in circulation as money, any bills or notes.

Whenever any bank shall become insolvent, or shall suspend its ordinary business for want of funds to carry on the same, the AttorneyGeneral or any creditor or stockholder may by petition or bill of complaint setting forth the facts and circumstances of the case apply to the court of chancery for a writ of injunction and the appointment of a Re. ceiver or Receivers or trustees.

In 1891 a Department of Banking and Insurance was established. Its duties are to execute all the laws in force relative to insurance, banking, Savings, trust, guarantee, safe deposit, indemnity, mortgage, investment and loan corporations.

This department of the State government is required to make an annual report to the Legislature of the condition of the institutions over which it has supervision. 


\section{SAVINGS Banks.}

The first Savings bank established in New Jersey was chartered by the Legislature in 1828. It was the Newark Savings Fund Association. Luther Goble was President.

-In the twenty years following, several charters were granted for Savings banks, but only a small percentage of them were taken advantage of.

The banks were required to make an annual report to the Legisla ture, but they neglected to do so and it was not until 1869 that the State authorities were able to compile satisfactory statistics showing the number of Savings banks in the State and their resources.

In 1864 there were nine Savings banks doing business. The rapid increase of population and the prosperity of the industrial classes in the next ten years encouraged the establishment of Savings institutions, and in 1874 the number had increased from nine to forty-two.

The deposits from that time rose from $\$ 3,591,097$ to $\$ 30,710,601$. In 1878 the industries in the State were greatly depressed and the deposits in the Savings banks fell from $\$ 31,974,316$ to $\$ 15,851,490$, and in 1879 they had shrunk to $\$ 14,993,038$.

A revival of business in 1880 brought money to the banks once more and in two years the deposits had increased more than $\$ 10,000,000$.

For seventeen years, dating from 1875 , there was a steady falling off in the number of Savings banks. Many of them went to the wall because of the depreciation of securities and others were put out of business by the withdrawal of money by depositors who, affected by financial panics, became suspicious of them.

In 1875 there were forty-three Saving banks in operation, and in 1892 there were only twenty-four, yet, in the latter year, the deposits were a little more than four million dollars in excess of what they were eighteen years before, which fact indicates that depositors had shifted their savings to the banks in whose substantiality they had faith.

It was not until $\mathbf{1 8 7 6}$ that a general law governing Savings banks was enacted in New Jersey, and it has operated so satisfactorily that it has not been materially amended.

The law requires that no Savings bank shall be established without a certificate of authority from the Commissioner of Banking and Insurance. And the certificate is issued only when the Commissioner has been assured that there is need of a bank in the locality where it is proposed to establish it; that it will be liberally patronized, and that the persons applying for the certificate are of good character and financially responsible.

A majority of the managers must reside in the county where the bank is located and be freeholders in the State. No manager can have any interest, directly or indirectly, in the gains or profits of the bank 
except as a depositor, or borrow any of its funds, or become an indorser, surety or obligor in any manner for money loaned by or borrowed from the bank. The rate of interest and dividends is regulated by the managers so that the depositors receive all the profits of the institution, after deducting necessary expenses and reserving a certain sum as a surplus fund, which, to the amount of fifteen per cent. of the deposits, the managers are authorized to gradually accumulate and to hold to meet any contingency or loss by depreciation of securities or otherwise.

Investments are restricted to bonds of the United States; the State of New Jersey, and the eities, counties, etc., therein; bonds of other States in the United States, or of any city or county thereof, whose net indebtedness is limited by law to ten per cent. of the assessed valuation of the property therein, and first mortgage bonds of railroad companies that have paid dividends regularly on their capital stock for the five years preceding, or the consolidated mortgage bondsissued by any such company to retire its entire bonded debt.

Loans on personal securities cannot be made except upon the additional pledge of specified collaterals having a market value margin of twenty per cent. Not more than fifteen per cent. of the deposits can be so loaned. Mortgage loans may be made up to eighty per cent. of the deposits, on real estate in New Jersey worth fifty per cent. more than the amount loaned thereon, but if the real estate is unimproved or unproductive the margin of value must be seventy per cent. The managers are required to invest the moneys deposited as soon as practicable after their receipt, except that for the meeting of current payments in excess of the receipts they may keep an available fund of not exceeding ten per cent. of the deposits, either on hand or deposited on call in designated banks or trust companies, or loaned on demand on specified collaterals. The aggregate deposit of any corporation or individual is limited to five thousand dollars, exclusive of accrued interest, unless made prior to 1876 , or by order of a court of record or surrogate.

The institutions must be examined once in two years and oftener if deemed expedient by the Commissioner of Banking and Insurance. Reports of condition on January 1 and transactions for the year must be filed annually, within one month from said date, under penalty of two hundred dollars for each day's delay, for which the managers are personally liable.

Savings banks having no capital stock are taxed upon all their property and valuable assets, but the depositors are exempt from taxation on their personal estate to the amount of their deposits.

The following table exhibits the aggregate resources, deposits and surplus of the Savings banks for each of the last thirty-one years, shown in periods of five years : 
Savings Banks, 1869-1899.

\begin{tabular}{|c|c|c|c|c|}
\hline YEARS. & $\begin{array}{l}\text { No. of } \\
\text { banks. }\end{array}$ & Total resources. & $\begin{array}{c}\text { Amount due } \\
\text { depositors. }\end{array}$ & $\begin{array}{l}\text { Surplus } \\
\text { reported. }\end{array}$ \\
\hline $1869 \ldots$ & 14 & $\$ 12,402,732$ & $\$ 11,551,369$ & $\$ 761,171$ \\
\hline $1874 \ldots \ldots \ldots \ldots . . .$. & 42 & $33,259,612$ & $30,710,601$ & $1,398,258$ \\
\hline $1879 . . .$. & 37 & $16,056,609$ & $14,993,038$ & 750,703 \\
\hline $1884 \ldots \ldots \ldots$ & 29 & $30,075,831$ & $28,240,391$ & $1,761,645$ \\
\hline $1889 \ldots \ldots \ldots$ & 24 & $31,895,309$ & $29,094,203$ & $2,724,813$ \\
\hline $1894 \ldots \ldots \ldots . .$. & 25 & $37,729,102$ & $34,266,298$ & $3,235,977$ \\
\hline $1899 \ldots \ldots \ldots \ldots \ldots$ & 26 & $54,719,989$ & $48,852,873$ & $5,565,096$ \\
\hline
\end{tabular}

\section{Trust Companies.}

There are twenty-three trust companies in operation in the State and they are becoming stronger each year. The deposits in the year 1898 show a gain for the year of $\$ 7,547,089$, or over thirty-six per cent. The increase in total resources was over thirty-three per cent. The surplus fund and net undivided profits, which are practically the same, together amount to $\$ 2,161,143$, being $\$ 614,696$ in excess of the total at the close of the year 1897. The following table illustrates the growth of trust companies from 1889 to 1898 :

\begin{tabular}{|c|c|c|c|c|c|}
\hline YEARS. & $\begin{array}{c}\text { No. of } \\
\text { compa- } \\
\text { nies. }\end{array}$ & Capital. & Deposits. & $\begin{array}{l}\text { Surplus and } \\
\text { profits. }\end{array}$ & $\begin{array}{c}\text { Total } \\
\text { resources. }\end{array}$ \\
\hline $1889 \ldots$ & 11 & $\$ 861,250$ & $\$ 3,513,220$ & $\$ 266,551$ & $\$ 4,888,604$ \\
\hline $1890 \ldots$ & 13 & $1,162,500$ & $4,646,315$ & 373,218 & $6,575,190$ \\
\hline $1891 \ldots \ldots \ldots \ldots \ldots$ & 15 & $1,470,000$ & $6,507,678$ & 442,640 & $8,919,723$ \\
\hline $1892 \ldots .$. & 19 & $1,695,000$ & $9,752,510$ & 702,468 & $12,898,700$ \\
\hline $1893 \ldots$ & 19 & $1,800,350$ & $9,997,963$ & 788,858 & $13,624,012$ \\
\hline $1894 \ldots \ldots \ldots \ldots . . . . . . . .$. & 19 & $1,863,375$ & $12,184,394$ & 945,837 & $15,949,126$ \\
\hline $1895 \ldots . .$. & 19 & $1,920,000$ & $15,183,158$ & $1,070,521$ & $19,502,432$ \\
\hline $1896 \ldots$ & 22 & $2,250,830$ & $17,295,869$ & $1,259,984$ & $22,417,128$ \\
\hline $1897 \ldots \ldots \ldots \ldots \ldots$ & 23 & $2,435,000$ & $20,876,380$ & $1,546,446$ & $26,259,730$ \\
\hline $1898 .$. & 23 & $2,856,500$ & $28,423,471$ & $2,161,144$ & $34,972,950$ \\
\hline
\end{tabular}

On January 1, 1899, the combined deposits of the Savings banks, banks of discount and deposit and trust companies were $\$ 85,638,592$, an increase of $\$ 12,337,564$ over the amount reported for the preceding year. The total resources were $\$ 101,532,899$, a gain of $\$ 14,205,171$ over the amount reported on January 1, 1898. 


\section{PENNSYLVANIA.}

Under the colonial form of government, the Province exercised the functions of a bank so far as to issue circulating notes and to make loans to the community. Beginning in 1723 bills of credit were issued and made a legal tender, and the commissioners of the general loan office, charged with their emission, were required to loan a large proportion thereof on sufficient real estate security. This practice was continued by later acts of Assembly, and although large amounts of these bills were issued at different times prior to the Revolution, they seem to have been maintained at par, though several attempts at inflation were only prevented by the negatives of the Governors. of the Province. There is no reason for believing that the colonial currency would have suffered serious depreciation but for the Revolutionary War.

With the growth of commerce, however, the need for a bank became evident, and an attempt was made, as may be learned from a speech made by Robert Morris, in the Pennsylvania Assembly in 1786, to found such an institution. He stated that he and the commercial men of the Province had contemplated the foundation of a bank prior to the war, and had established a credit in Europe for that purpose, from the execution of which design they were prevented by the Revolution.

\section{The First Banks Incorporated by the State.}

The first bank to be chartered by the Assembly of Pennsylvania was the Bank of North America, the plan for which was devised by Robert Morris. This bank was originally chartered by Congress, December 31, 1781, but doubts arising as to the authority of the Continental Congress to grant a bank charter, application was made for State incorporation, which was granted by the act of April 1, 1782. Active hostility to the bank soon developed, and the act of incorporation was repealed September 13, 1785. The bank continued operations under its Federal charter, and a change in popular sentiment resulted in the passage of a new act of State incorporation on March 17, 1787. Under the provisions of this act it was to endure for fourteen years, with a capital stock of not more than two million dollars.

As originally chartered by Congress this bank was to have a capital stock of one hundred shares, of the par value of $\$ 400$ each. The States were to receive its demand notes for taxes and duties, and were requested not to charter any other bank during the pending war. The bank began business January 7, 1782, on which day Robert Morris paid into its coffers $\$ 200,000$ as the subscription of the United States to its stock. Morris afterwards said that, up to September, 1786, the other subscriptions to the bank did not exceed $\$ 70,000$. In 1784-5 the Bank of North America earned fourteen per cent., its capital stock having 
been increased by $\$ 500,000$ in 1784 . Its Pennsylvania charter was renewed for ten years by the act of March 28, 1814 (Pamphlet Laws, p. 280 ), in consideration of the payment to the State of $\$ 120,000$, and its charter was again extended to April 1, 1847, by act of March 21, 1825. This institution is still in existence as a National bank, bearing, however, its original title by special permission of Congress. Its present capital is $\$ 1,000,000$; surplus, $\$ 1,300,000$.* $^{*}$

The Bank of Pennsylvania was incorporated by act of March 30 , 1793 , for twenty years. This bank was to be to Pennsylvania what the Bank of the United States was to the nation. The State subscribed for one-third of the stock, and branches were established at Harrisburg, Reading, Easton, Lancaster and Pittsburg, but these were discontinued about 1810. In that year the State held a million dollars of the stock, and in 1813, and for many years thereafter, a million and a half. In 1796 a serious defalcation, amounting to $\$ 110,000$, with overdrafts to the amount of $\$ 100,000$ more, was discovered in the affairs of this bank. This institution was rechartered for twenty years, from March 4, 1813, by the act of February 14, 1810. By the act of March 20, 1810 (P. L., p. 187) it was provided that whenever the money in the State treasury should exceed $\$ 30,000$, the Governor was directed to invest the surplus in subscriptions to the stock of the Bank of Pennsylvania, provided that no investment be made at any one time for less than the sum of five thousand dollars. This bank failed and went into bankruptey in 1857 , its stock being at that time largely held by charitable associations, trustees, guardians, etc.

The Philadelphia Bank was chartered by the act of March 5, 1804, its capital stock not to exceed two million dollars, and its charter extended to May, 1839, by the act of March 28, 1823.

The Farmers and Mechanics' Bank, of Philadelphia, was chartered by the act of March 16, 1809, its capital stock not to exceed $\$ 1,250,000$. It is still in existence and has been the financial agent of the State for many years.

The act of March 28, 1808 (P. L., p. 185) provided that the members of all banking associations, incorporated or unincorporated, within the Commonwealth should be individually liable for all the debts of their respective associations, but this provision was repealed by Section 5 of the act of March 20, 1810 (P. L., p. 179). Banking companies incorporated under the laws of other States were forbidden to do business in Pennsylvania by the said act of 1808 , and a supplement of 1810 to said act totally forbade any unincorporated banking association from receiving deposits, discounting notes or issuing notes for circulation. This inhibition was suspended by the act of March 21, 1814, but was revived, so far as the issuing of notes was concerned, by the act of March 22,1817 . The entire act of 1810 revived at the expiration of the pro-

* A more extended history of the Bank of North America will be found elsewhere in this work. 
visions of the act of 1814 in 1825, but it was finally repealed by the act of April 3, 1841 (P. L., p. 143).

The banks above named constituted the principal incorporated banks in Pennsylvania up to the date of the passage of the act of March 21, 1814. In 1813, and for many years subsequent thereto, the State held shares of stock in domestic banks as follows : Bank of Pennsylvania, $\$ 1,500,000$; Philadelphia Bank, $\$ 523,300$; Farmers and Mechanics', $\$ 85$,400 ; total, $\$ 2,108,700$.

On these shares the State received $\$ 200,404$ in dividends for the fiscal year 1813, constituting about two-fifths of the entire revenues of the Commonwealth. On the sale of the State's bank stock in 1843 the same was found to have paid an average of nearly six per centum per annum from 1821 to 1843 , and much more at an earlier date.

Before discussing the act of March 21, 1814, and the marked changes in the system of State banking which it inaugurated, it may be well to glance briefly at the financial condition of the State and its people at about that date. Governor Snyder, in his message of December 10, 1813, said :

"Our treasury is more full than on any former period, and the receipts of last year greater than those of any former year; in the treasury remains $* * *$ an unexpended balance of more than $\$ 346,000$."

Despite the war then in progress the general financial condition seems to have been good. The banks of Pennsylvania were few in number and apparently in a satisfactory condition. A committee of the Legislature appointed to examine the banks in which the State was a stockholder reported as follows, in 1812 :

\begin{tabular}{r|r|r|r|r|r}
\hline & $\begin{array}{r}\text { Paper } \\
\text { issued. }\end{array}$ & $\begin{array}{c}\text { Notes } \\
\text { mutually } \\
\text { held.* }\end{array}$ & Cash. & \multicolumn{1}{c}{ Deposits. } & \multicolumn{1}{c}{$\begin{array}{c}\text { Bills } \\
\text { discounted. }\end{array}$} \\
\hline Bank of Pennsylvania....... & $\$ 1,425,203$ & $\$ 506,266$ & $\$ 1,071,136$ & $\$ 1,697,666$ & $\$ 5,088,305$ \\
Philadelphia Bank......... & 713,309 & 231,945 & 305,861 & 734,671 & $2,873,180$ \\
Farmers \& Mechanics' Bank & 814,730 & 337,752 & 345,695 & 927,612 & $2,849,930$ \\
\cline { 2 - 6 } & $\$ 2,943,242$ & $\$ 1,075,963$ & $\$ 1,722,682$ & $\$ 2,359,949$ & $\$ 10,811,715$ \\
\hline
\end{tabular}

* Deducting the notes mutually held from the paper issued, there remains $\$ 1,867,279$ the actual amount of circulation.

It is true - to anticipate a little - that the Presidents of the following banks, viz., the Bank of Pennsylvania, the Bank of North America, the Philadelphia Bank, the Farmers and Mechanies' Bank, the Commercial Bank of Pennsylvania and the Mechanics' Bank united, on August 31, 1814, in a card to the public, explaining that owing to the fact that foreign balances could not be paid in our own products during the pending war, but must be paid in specie, there had, for a long time, been a heavy drain on the banks, which had been increased by a " trade 
in British Government bills of exchange," and hence, to prevent the further exportation of gold, they preferred to voluntarily suspend specie payment then, rather than be compelled to do so when the country was drained of all coin. They promised to resume as soon as possible.

Despite this suspension, the credit of the banks does not appear to have been greatly impaired, and the general outlook seemed much better than might have been expected, considering the war and its resulting evils.

\section{Provision for the Incorporation of Existing Banks.}

Such being the then existent conditions, it is hard to account for the demand that led to the passage of the Act of March 21, 1814, providing for the incorporation of forty-one banks with an aggregate capitalization of some seventeen million dollars. Nothing appears to show that there was any lack of banking facilities, and it॰is to be assumed that the existing banks issued sufficient notes for purposes of circulation. It therefore seems probable that the opponents of this measure were in the right when they claimed that there was no popular demand for its passage, and that it was a piece of jobbery, engineered by speculators.

A similar bill had been passed by both Houses in 1813, but it had been vetoed and defeated by Governor Snyder. He also vetoed the act of 1814, but it was passed over his negative. Before citing the act the following is quoted from his veto message:

"It is a fact well ascertained that immense sums of specie have been drawn from the banks in Pennsylvania and certain other States to pay balances for British goods which eastern mercantile cupidity has smuggled into the United States. The demand for specie has, in consequence, been and still is so great that banks in Philadelphia and in some other parts have stopped discounting any new paper. I ask a patriotic Legislature, Is this an auspicious era to try so vast an experiment? Shall we increase this pressure? Shall we indirectly aid our external and internal enemies to destroy our funds and embarrass the Government by the ereating of forty-one new banks, which must have recourse for specie to that much-exhausted source? Is there, at this time, an intelligent man in Pennsylvania who believes that a bank note of any description is the representative of specie? Is there no just ground for fear that the knowledge that forty-one new banks, having a nominal capital of more than seventeen million dollars, upon the bare payment of one-fifth part shall have the right (inclination to do so cannot be doubted under the predominant spirit of speculation) to throw into circulation an overwhelming flood of paper, will totally destroy the remaining confidence in that medium, and will not the hoarding of specie and a ruinous depreciation of bank notes be the natural consequence of such a state of things ?"

\section{Genkral Provisions of the Act of 1814.}

The act of March 21, 1814 (P. L., p. 154), above referred to, entitled "An Act Regulating Banks," provided that Pennsylvania should be divided into twenty-seven banking districts. The city of Philadelphia constituted one district, to be entitled to three banks; the remainder of Philadelphia county formed another district with two banks; Lancaster county another with five banks, and so on; the twenty-seven dis- 
tricts to have forty-one banks. The names of the different banks and the amounts of their capital stocks, respectively, were given in the act and commissioners were named for each bank, to receive subscriptions to the stock.

The act provided that " the present stockholders in the Mechanics' Bank, of the eity and county of Philadelphia, the Commercial Bank, of Pennsylvania, the Bank of Northern Liberties, the Farmers' Bank, of Lancaster, and the Chambersburg Bank shall, by the commissioners named for said banks, be taken and considered as subscribers thereto so far as the amount of stock respectively and bona fide held by them."

When half the maximum number of shares was subscribed for, and twenty per cent. of the par value thereof was paid in, the banks were to receive letters patent.

Under the provisions of this act the banks might not owe more than double the amount of their paid-in capital stock. The rate of discount was not to exceed one-half of one per cent. for thirty days. Dividends were to be declared at least twice a year, in November and May, but the amount thereof was not to exceed the net profits of each bank. The banks could hold real estate necessary for the convenient transaction of their business, and such as might have been bona fide mortgaged or conveyed to them in satisfaction of debts previously contracted, but banks outside of Philadelphia were not to pay more than $\$ 30,000$ for their banking houses, and banks in Philadelphia were not to pay more than $\$ 50,000$ therefor. No bank was to deal or trade in any manner in any merchandise, nor might any bank purchase any stock whatsoever, except its own stock, or the stock of other incorporated banks in Pennsylvania, Treasury notes or public stock of the United States or any loan proposed by the Government of the United States, or stock in any of the incorporated companies of Pennsylvania for the improvement of roads and inland navigation; provided, the stock and Treasury notes so purchased and loans so made to the Government of the United States shall at no time exceed one-fifth of the stock of the bank; "and the said several corporations shall not deal or trade in any thing but bills of exchange, gold or silver bullion and in the stock and Treasury notes aforesaid." The banks were not to issue notes of a sinaller denomination than five dollars. The issue of notes in the nature of bank notes by individuals or corporations not formed for banking was forbidden.

A tax of six per cent. on the whole amount of dividends declared by the banks during the year was imposed for State purposes, to be increased to eight per cent. should said banks at any time be relieveủ from the tax on bank circulation imposed by the United States in 1797.

By Section 15 of the act the officers of each bank were required to transmit to the Auditor-General, annually in the month of December, a statement of the assets and liabilities of their bank, the amount and rate of dividends, etc., said reports to be submitted to the Legislature 
by the Auditor-General. In 1816 thirty-five banks were in existence, formed under the provisions of this act, and the following statistics thereof are given for said year:

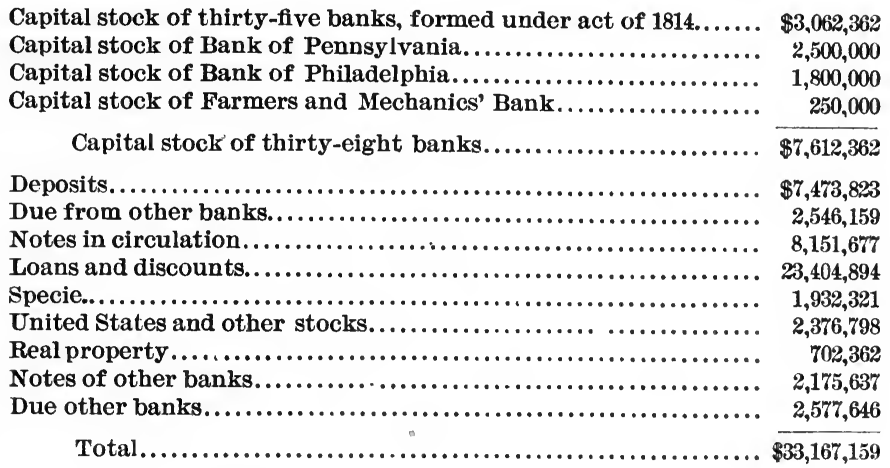

Financial Distress, 1816-1820.

There was great financial distress in the years 1816 to 1820 . At this distance of time the numerous causes therefor seem plain, but the main blame was then placed on the banks of the country. A Connecticut paper of the period pithily stated the causes for the distresses of the time as follows:

"Why is the community so much embarrassed?

Because banks lend money that they have not got to lend,

And because people spend money they have not got to spend.

Rernedy :

Own the money before you lend it !

Earn the money before you spend it!"

Doubtless the troubles of the time were greatly exaggerated by reckless banking, over-issue of bank notes, etc., but we find the bankers of the country assembling in convention at Philadelphia on August 6, 1816, and agreeing to resume specie payments in July, 1817, and the representatives of twenty-three Pennsylvania banks, meeting at Harrisburg on September 12, resolved to abide by the action of the Philadelphia convention. Accordingly specie payments were resumed in 1817, but in 1820 the Secretary of the Treasury said that the convertibility of bank notes with specie, since resumption, had been more nominal than real.

On March 22, 1817, an act was passed prohibiting the issue of notes in the nature of bank notes by others than corporations formed for banking. This was an amplification, as to the issue of notes for circulation, of the earlier act of 1810 .

The clamor against banks not yet abating, the act of March 29, 1819, provided that any bank incorporated under the provisions of the act of 
1814 which should refuse to pay its notes, on demand, in specie, should forfeit its charter, but still be liable, in its corporate capacity, for its debts. The fact of the refusal of the bank to so pay its notes was to be proven before a judge of the court of common pleas who was to certify the same to the Governor, who was then to issue his proclamation dissolving the bank. Section 6 provided that the President or Cashier of any such bank should, under a penalty of $\$ 25$, whenever specie payment was refused of a note of the bank, endorse on the note the date when presented, and the note was then to bear interest at six per centum per annum until paid. These provisions were amplified in the subsequent act of March 25, 1824.

In his message of December 10, 1819, the Governor refers to this act, stating that while no banks have been dissolved under its provisions, " it is probable that their operations may have been in some degree influenced by it. It is understood that several of them have not been able to maintain their issues of paper upon a specie basis, and the stockholders have determined to wind up and dissolve their institutions."

"The Democratic Press," of Philadelphia, of the September preceding, reports the suspension of eleven banks, six of which were in process of dissolution, with a probability that the others would also dissolve, and in February, 1820, the State Treasurer reported that the charters of five specified banks had been declared forfeited.

The hard times of the preceding years having in a measure passed away, in December, 1821, the notes of all the Philadelphia banks were quoted at par, while those of the majority of the country banks were quoted at discounts varying from one-half to one and a-half per cent., only.

The charters granted under the provisions of the act of 1814 were to endure for ten years. In 1823 a bill to rechartor such of the banks of 1814 as were then in existence was defeated, but a similar measure became a law on March 25, 1824. This act substantially re-enacted the main features of the act of 1814 and those of the acts of 1817 and 1819 , with some changes. The tax on bank dividends was raised from six to eight per cent. The charters of twenty-two banks, all that survived of those formed under the act of 1814 (except one bank the charter of which had been extended by special act in 1823), were renewed by this act of 1824 .

In 1825 the reports of twenty-five banks were transmitted to the Legislature, showing the following aggregates : Capital stock, $\$ 8,254$,611 ; notes in circulation, $\$ 3,222,376$; specie, $\$ 1,470,613$.

The amount of circulating medium in 1826 , as reported by a committee of the Legislature, was as follows : Philadelphia bank notes, $\$ 2,054,368$; other banks, $\$ 1,420,519$. These amounts, with an estimate of the specie of all the banks, were estimated to aggregate four millions. 


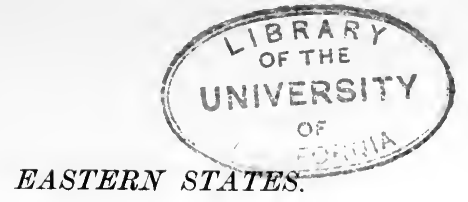

The State of Pennsylvania was by this time fully committed to its great plan for internal improvements, which promised so well, but which ultimately brought the Commonwealth to the brink of ruin. From 1825 to 1853 the State expended some ninety millions of dollars in the construction of internal improvements, receiving during the same period about twenty-five millions from tolls, etc., leaving it with an indebtedness in 1844 of some forty millions; and these works, built at such an immense cost, were afterwards sold for eleven millions on the longest time and easiest terms imaginable. While the railroads and canals were being built, however, and the State was merrily borrowing on every hand, times were almost necessarily good.

The report of the Auditor-General to the Legislature for 1833 showed a total banking capital of $\$ 17,061,944$; notes in eirculation $\$ 10,336,251$; deposits, $\$ 7,708,764$; specie on hand, $\$ 2,898,145$; discounts, $\$ 29,968,408$; real estate, $\$ 1,216,212$. In 1834 bank capital in Philadelphia, exclusive of that of the United States Bank, was $\$ 12,812,875$; country bank capital, $\$ 4,966,689$.

The act of April 1, 1835 (P. L., p. 99) increased the tax on bank dividends according to a sliding scale, beginning with a tax of eight. per cent. on all dividends not exceeding six per cent., and concluding with a tax of eleven per cent. on all dividends in excess of eight per cent. *

Although the revenues of the State aside from loans were barely sufficient to meet the interest charge of the Commonwealth's loans, the credit of Pennsylvania was at its best in 1836. Pennsylvania five per cent. bonds sold for 105, while stock of the Bank of North America was selling for $\$ 450.75$, and stock of the Bank of Pennsylvania at $\$ 518.75$.

There were in 1836 seventeen banks in Philadelphia, and thirty-two elsewhere in the State. The following figures are taken from the report to the Legislature for 1836 : Capital stock, city banks, $\$ 51,180,205$; country banks, $\$ 7,046,630$; total, $\$ 58,226,835$ (this vast increase in bank capital over the amount reported for 1833 is to be accounted for by the incorporation of the Bank of the United States as a State bank with a capital of $\$ 35,000,000$, to be referred to later on); notes in circulation, $\$ 47,148,630$; deposits, $\$ 14,188,753$; specie, $\$ 6,565,869$; discounts, $\$ 96$,531,150 ; real estate, $\$ 1,195,327$.

\section{Bank of the United States Becomes a State Bank.}

The flush times of 1836 may be partially accounted for by the granting of a State charter to the Bank of the United States-the national

* From this point forward legislation involving bank taxation was so frequent and of such a complicated character that the limits of this article will not permit of a discussion thereof. For a full account of bank taxation in Pennsylvania the reader is referred to the writer's "Taxation for State Purposes in Pennsylvania," Kay \& Bro., Phila., or to an address upon bank taxation in that State, also by the writer hereof, read before the annual convention of the New York State Bankers' Association, in July, 1899, and published in the BANKers' MAGAZINE for August, 1899. 
charter of which was about to expire-by the act of February 18, 1836. Section 6 of that act provided that, in consideration of the privileges granted by the act and in lieu of all taxes on dividends, the bank should pay the State two million dollars at thirty days' notice. It was also to advance on a permanent loan, at four or five per cent., the sum of $\$ 6,000,000$, reimbursable in 1868 . If the interest should be fixed at five per cent. the bank was to pay a premium of ten per cent.; if four per cent., then no premium was to be exacted. This was not all. Whenever required by law, the bank was to make the State a temporary loan of a million at four per cent. for not more than a year, it was to make specified subscriptions to the stock of certain corporations, and, finally, it was to pay $\$ 500,000$ for school purposes on June 15,1836 , and $\$ 100,000$ annually thereafter for the same purpose. From 1836 to 1840 the bank paid the State three million dollars in five installments.

Hard as these terms were, the act of 1836 did not pass without strong opposition, and it left an aftermath of charges of corruption, counter charges, investigations, etc. However, the bank's money was very acceptable to the State, as was also the sum of $\$ 2,867,514$ received from the United States on the division of the surplus in the National Treasury, among the States, under the provisions of the act of Congress of June 23, 1836. It was an apparently prosperous year, therefore, that expired on December 31, 1836, but evil days were at hand.

\section{The Panic of 1837-Agitation Against Banks.}

There was great stringency in the money market early in March, 1837. Things went from bad to worse. One hundred and sixty-eight firms failed in New York eity from March 1 to April 18. Finally, on May 10, 1837, the New York banks suspended specie payments, and their example was promptly followed by the other banks of the country. Then, as in 1816-17, the blame for all the distresses of the country was laid upon the banks. A town meeting was held in Philadelphia on May 22, 1837 , at which resolutions condemnatory of the banks were passed, and the delegates to the State Constitutional Convention then in session at Harrisburg were adjured " to introduce into our new constitution the most positive and peremptory provisions against the mad spirit of creating banks, corporations and monopolies, which has heretofore existed in this State." To anticipate a little, it may be here stated that this prayer was granted, and the amendments to the State constitution, promulgated February 22, 1838, included the following:

Art. 1, Sec. 25. "No corporate body shall be hereafter created, renewed or extended with banking or discounting privileges without six months' previous notice of the application for the same, in such manner as shall be prescribed by law, nor shall any charter for the purpose aforesaid be granted for a longer period than twenty years, and every such charter shall contain a clause reserving to the Legislature the power to alter, revoke or annul the same whenever in their opinion it may be injurious to the citizens of the Commonwealth, in such manner, however, that no injustice 
shall be done the corporators. No law hereafter enacted shall create, renew or extend the charter of more than one corporation."

The provisions contained in this section now form parts of Sections 10 and 11, of Article 16, of the present constitution.

To return to the subject of the suspension of specie payment in 1837. An anti-bank convention was held at Harrisburg on July 4, 1837 , which issued an address to the people of the State, in which all the troubles of the time were attributed to "an unchecked and uncontrolled banking system." The distresses of the day are set forth as follows :

"If we turn to the streets of our cities it [the financial distress] is proclaimed in language not to be mistaken. If we traverse our canals and railroads we find the 'panic' prophecy fulfilled; they are indeed a barren waste and bear the indelible marks of premature desertion and decay."

The banks seem to have recovered rapidly from the effects of the crisis of 1837, if the "Philadelphia Herald" of January, 1838 be right in its contention, which it supported by elaborate statistics, that on November 30, 1837, the banks of Pennsylvania had "one dollar of immediate resources for every dollar of immediate liabilities."

To December 2, 1837, seventy-eight banks had been chartered by Pennsylvania since its organization as a State.

\section{Compulsory Resumption of Specie Payments.}

On July 10, 1838, Governor Ritner undertook to compel the banks to resume specie payment by means of a proclanation issued on that date, ordering resumption on August 13, 1838. By a general agreement of banks throughout the country specie payments were resumed on that date, without any excitement and with no runs on the banks, but this action was premature, and in October, 1839, the Pennsylvania banks suspended payments again. On October 23, 1839, the Philadelphia banks united in an address to the people explaining why they had suspended, stating that the original suspension in 1837 was caused by the commercial relations between the United States and Europe, and that the resumption of August, 1838, was premature.

The New York banks did not follow the example of the Philadelphia banks in suspending, but those of the South and West generally did so. There was much recrimination passed between the New York and Pennsylvania banks over the suspension of the latter. The "National Gazette" of November 7, 1839, not only justifies the Pennsylvania banks in their action, but adds:

"We cannot but view the pertinacity with which the New York banks adhere to their resolution to continue specie payment as a kind of fanaticism, or, to say the least, of rashness, which opposes itself both to reason and experience."

The clamor against the banks was resumed, and Governor Porter was importuned on every hand to compel the banks to resume, by 
proclamation, as Governor Ritner had done, but he declined, and gave his reasons for so doing in a message of February 1, 1840. The Legislature, however, passed, and Governor Porter signed, the act of April 3,1840 , requiring the banks to resume on or before January 15, 1841, providing for the forfeiture of their charters if they did not, and levying a tribute of $\$ 3,000,000$ on the banks, in the shape of a loan to the State, in consideration of the State not forfeiting their charters, under the provisions of the act of 1824 , for having suspended specie payments.

A special report to the Legislature made by the Auditor-General in compliance with a resolution specifically requiring this precise information, showed that two marquises, eight counts and countesses, two earls, two lords and twenty-eight knights, barons and baronets were stockholders in the United States Bank of Pennsylvania.

In May, 1840, United States Bank of Pennsylvania stock sold for $72 \frac{1}{1}$ in New York and at 78 in Philadelphia.

The State was now practically at the end of its resources. It was at last apparent that the income from the State works would never repay the money expended on them, and that, if the State debt was to be paid, the people of the Commonwealth must tax themselves to pay it. Accordingly, the act of June 11, 1840 (P. L., p. 612) was passed, very inadequate in its provisions, but yet a step in the right direction.

\section{Fallure of the United States Bank.}

Specie payments were resumed in accordance with the provisions of the act of April 3, 1840, on January 15, 1841, but only for twenty days, for on February 4, 1841, the United States Bank of Pennsylvania closed its doors after having paid out in the redemption of its notes more than six million dollars in specie in the said twenty days. The other Philadelphia banks followed its example, as did other Pennsylvania, the Delaware and some other banks. The directors of the United States Bank of Pennsylvania adopted the following resolutions:

"Whereas, The Bank of the United States, in compliance with its pledge to the public, has made a fair and bona fide effort to resume and maintain specie payments ever since January 15 last, having paid out an amount little, if at all, short of six million dollars in coin or specie funds; and

Whereas, The efforts to maintain specie payment by this bank have been rendered abortive by the intentional accumulation and enforcement of its instant liabilities ; therefore,

Resolved, That this bank is under the necessity for the present of suspending specie payments," etc.

Two weeks afterwards the stock of the bank sold for $25 \frac{1}{2}$ to 28 in New York. It was stated that eleven millions in cash and specie funds were paid out during this futile attempt to resume specie payments.

The banks of Pennsylvania were now in a very serious position, since, under the terms of the stringent act of 1840 their charters were confiscate. Various memorials for relief were presented by them to the 
Legislature, and among these was that of the United States Bank of Pennsylvania. From this document it is learned that that institution had, in the brief term of its existence as a State bank, paid to or for the Commonwealth as follows:

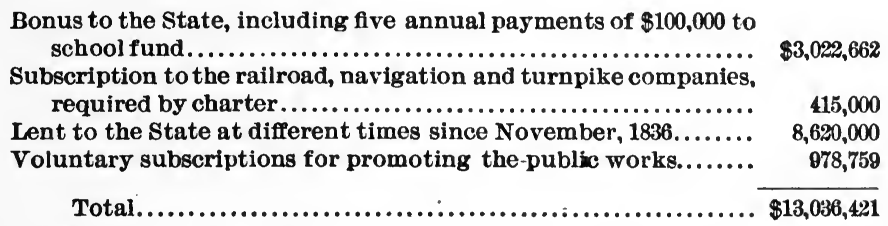

At the time the bank finally suspended payment it was said to have had notes outstanding to the amount of $\$ 2,800,000$, and deposits, at all points, of $\$ 1,100,000$. To dispose finally of the subject of the United States Bank of Pennsylvania it may be here stated that the directors of the said bank made a final assignment on September 4, 1841, agreeably to the permission contained in Sections 18 to 25 of the act of May 4,1841 . In December following its stock sold at four cents. Its affairs were not finally closed out until $1853 . *$

Thus perished one of the greatest financial institutions of this, or any other, century. It was perhaps well that it should cease to exist. Its influence in politics was vast, and doubtless often exerted to corrupt; yet it was a great and in many respects a wise institution; it engineered the finances of the country with much skill, under its various charters for many years, and it finally fell, bravely struggling, the victim of most ignoble foes.

Nicholas Biddle, its master mind, did not long survive the bank with which his name will ever be associated. He died on February 27, 1844, at the age of fifty-eight. He had retired from the presidency of the institution in 1839. Few men have ever been more recklessly calumniated. A man of strict integrity, at any rate in his later years, he probably was not; but it is safe to say that his morals were quite as good as those of his persecutors.

\section{Banks Relieved by the ACt of May 4, 1841.}

The Pennsylvania banks were relieved from their perilous position by Section 17 of the act of May 4, 1841 (P. L., p. 307), which repealed the act of April 23, 1840, and further provided that "All provisions of any other act of Assembly heretofore passed or of any act of incorporation providing for the forfeiture of any charter for or by reason of the non-payment of liabilities on demand, be suspended until further legislative action."

This act of May 4, 1841, which was passed over the Governor's veto, further provided for the borrowing of three million dollars. The banks

* The history of the United States Bank being elsewhere given in this volume, no reference to that institution is made prior to its incorporation as a State bank. 
of the Commonwealth were to be permitted to subscribe to the stock to be issued to this amount, and, on depositing said stock with the Auditor-General, they were to be authorized to issue notes to the amount thereof. The holders of not less than one hundred dollars of these notes, on presenting them to the banks issuing them, respectively, were to receive orders upon the Auditor-General for certificates of stock to the amount of their notes. The banks were to receive one per cent. interest on these notes until redeemed in stock. The notes were to be issued upon the credit and by the authority of the State, and were known as " relief notes." Their issue was a wretched piece of financiering (the idea of which was probably remotely suggested by the General Banking Act of New York, of April 18, 1838, the prototype of the National banking system), and the relief notes depreciated so rapidly that they were at a discount of from ten or twenty per cent. in 1842 . The issue of these notes amounted to $\$ 2,186,550$.

The act of March 12, 1842, required the banks to resume specie payments forthwith. If they refused to pay their notes in specie, on demand, their directors were to be forced by summary process to make assignments of all their property for the benefit of all their creditors. Luckily, by this time the banks had contracted their operations so that it was possible for most of them to comply with the law.

In 1843 the bank capital of the State, not including the capital of certain suspended banks, was $\$ 16,868,555$, as against $\$ 17,061,944$ in 1833 , ten years before, while the discounts in 1843 were $\$ 16,038,916$, as against $\$ 29,968,408$ in 1833 . So much had the financial troubles of the past six years contracted banking operations, notwithstanding the increase of population and of material wealth.

In 1842 the State was unable to meet the interest payments on the public debt, having been unable to place a loan of $\$ 870,000$ authorized by act of July 27, 1842. By authority of that act certificates of stock bearing five per cent. per annum were issued to the bond holders in lieu of interest, and the interest charge was met in the same way during 1843 and 1844. It was not until 1845, by which time the revenues derived from the sweeping tax act of April 29, 1844, began to be received, that Pennsylvania was able to meet her obligations. The stocks in various corporations owned by the State had been sold in 1843 , the bank stock of the par value of $\$ 2,108,700$, selling for $\$ 1,216,453$, the stock of the Farmers and Mechanics' Bank alone bringing par. To dispose finally of the subject of State finances it may be added that the public works, first formally offered for sale under the provisions of the act of April 29, 1844, were not finally disposed of until 1858, when they were sold to the Pennsylvania Railroad Company for a song, that company taking practically its own time, over thirty years, in which to perform the vocal effort.

The bank history of Pennsylvania, during the next few years, was uneventful. Bankers had been taught a severe lesson and they generally 
profited by it. Banking was undergoing a great change. The days of the United States Bank, and of its successor the deposit bank system, were past, the sub-Treasury system having been finally established in 1846. Politics were no more an important factor in banking. Banks were no longer the only moneyed institutions of importance. Railroads and other corporations with large capital were established, with authoritative voices in the financial world. Instead of controlling the business of the country, banks were, henceforth, to become its servants.

In his message of 1847 , Governor Shunk said :

"At present there is reason to believe that our banks are in a comparatively sound condition. Without ascribing this creditable and healthy state of things entirely to the policy which has been adopted of limiting the amounts of banking capital and making bankers individually liable for the payment of their debts, I am persuaded that it has a salutary influence in preserving the soundness of the currency, and that it should be adhered to exclusively."

He refers to the provisions of the act of April 26, 1844, afterwards incorporated in the act of April 6, 1850, referred to below.

The following from the "Philadelphia Ledger" of January 1, 1847, throws some light on banking methods at that time :

"We understand that the Philadelphia Bank has subscribed for 200 shares, or $\$ 10,000$, of the proposed Central Railroad from Harrisburg to Pittsburg. Rumor said yesterday that these subscriptions by our banks would not escape judicial inquiry. * * * Our banks are reaping the profits and enjoying the confidence consequent on five years' legitimate banking, and the departure in this instance, while it is calculated to revive the old anti-bank prejudice, may result in pecuniary loss and the withdrawal of that confidence so essential to banking credit."

At the session of $\mathbf{1 8 4 6}$ a measure was introduced to compel the keeping of bank notes at par in Philadelphia, something like the Suffolk system, and a modification of this plan was embodied in the act of April 6, 1850, hereafter referred to. A resort to the New York free banking method of securing circulation by the deposit of United States and State bonds seems also to have been advocated at this time, for Governor Shunk is found inveighing against that system in his message of 1848, and asserting that "sound banking can only be conducted on money-gold and silver."

The act of April 6, 1850 (P. L., p. 477), entitled "An Act Regulating Banks," was an elaborate codification, in fifty-three sections, of such prior laws relating to banks and banking as had not been repealed, with some new features. This act was to be applicable to "every banking corporation hereafter created by any special act, as well as every bank whose charter is renewed." Its $32 \mathrm{~d}$ Section provided that :

"The stockholders of every such bank, in addition wo the corporate liability, shall be jointly liable to the creditors of said bank, being note holders, in their individual capacities, to the amount of all notes issued." * * * 
The means for enforcing this liability were also provided, A similar provision had been inserted in the act of April 26, 1844 (P. L., p. 419), renewing the charter of the Commercial Bank of Pennsylvania, and in all subsequent acts incorporating banks or renewing their charters.

The act of March 21, 1814, had required the banks incorporated under its provisions to make reports of their condition to the AuditorGeneral, and subsequent acts had required such reports from all banking institutions. The act of April 16, 1850, gave him a supervisory power over all banks, which, extended by subsequent legislation, did not terminate until the creation of the Banking Department in 1891, to which all such powers were transferred.

\section{Provisions for Maintaining Notes at Par.}

The most novel feature of the act of 1850 was the creation of something like the Suffolk bank system. The banks of the eastern part of the State were compelled to keep their notes at par in Philadelphia, while those of western Pennsylvania were required to keep theirs at par in Pittsburg. Banks failing to do this were to pay the State at the rate of two mills per annum on every dollar of the average amount of their circulation, for the time the notes were under par in said eities respectively.

The Cashiers of the banks were to include in their reports to the Auditor-General statements of the length of time that their notes had been under par, respectively, as aforesaid.

Section 30 of this act of 1850 provided:

"It shall not be lawful for any of the said banks to issue or pay out any bank notes other than those issued by itself payable on demand in gold or silver, notes of specie-paying banks of this State which are taken on deposit or in payment of debts, at the counter of the bank, and notes of banks issued under the authority of the act of May 4, 1841 [relief notes], at the option of the person receiving the same, and any violation of this provision shall work an absolute forfeiture of its charter."

Section 26 provided that whenever specie should be demanded by any note holder, one-fifth of the amount of the demand should be paid in American gold coin, if requested, provided such one-fifth amount should not be less than five dollars.

Section 102 of the act of April 19, 1853 (P. L., p. 606), finally prohibited banks from paying out relief notes or using them in any manner in their business, "but they shall cause them to be delivered to the State Treasurer, who shall receive them for debts due the Commonwealth or redeem them in par funds, and shall cause them to be cancelled."

In 1854 there were in Pennsylvania fifty-nine banks with an aggregate capital stock of $\$ 19,635,000$. Of this number nine were Savings banks as follows:

1. The Philadelphia Savings Fund Society, incorporated in 1819. 
2. Western Savings Fund Society, of Philadelphia, incorporated in 1839.

3. Lancaster Savings Institution, incorporated in 1835.

4. Mechanics' Savings Bank, of Harrisburg, formed in 1853.

5. Hanover Savings Fund Society, incorporated in 1849.

6. Shrewsbury Savings Institution, incorporated in 1850 .

7. Lewisburg Savings Institution, formed in $\mathbf{1 8 5 3 .}$

8. Allegheny Savings Fund Company, incorporated in 1849.

9. Somerset Savings Institution, formed in $\mathbf{1 8 4 9 .}$

In $\mathbf{1 8 5 5}$ there were fifty-five banks and fourteen Savings institutions with assets and liabilities, in part, as follows:

Assets.

Discounts.

Specie.

Due other banks...............

Real estate and personal prop.

Bonds, mortgages, etc.........

Stocks.
$\$ 47,511,588$

$6,738,650$

$5,647,642$

$1,128,644$

792,895

913,713
LrabiLITIES.

Capital stock...............\$22,026,596

Circulation............... $16,878,695$

Deposits ................. 24,321,010

The number of banks and Savings institutions was the same in 1856 , and their condition was not materially different from what it was in 1855.

By the act of November 6, 1855, the provisions of Section 30 of the act of 1850 were made applicable to Savings fund, trust and insurance companies, which corporations were, therefore, prohibited from that date, from issuing or paying out bank notes other than those of speciepaying banks of the State, received in the payment of debts or taken on deposit.

Referring to this act in his message of 1856, Governor Pollock pointed out that its provisions would fail of securing the desired effect unless they were extended to cover private bankers and others of that class. He said:

"In many instances the notes of our own banks are collected by private bankers or brokers, and with these, or with specie withdrawn from the banks issuing them, they purchase depreciated and foreign bank paper, which is paid out at par at their counters. By others large loans are negotiated with banks out of the State at less than the usual rate of interest, and their notes-often of less denomination than five dollars and always at a discount, are brought into the State and put into circulation in the manner indicated. *** The effect of this system of private banking has been to limit the circulation of the par paper of our banks and to substitute in its place foreign depreciated and often worthless currency."

\section{The Financtal Crisis of 1857.}

The panic of 1857 is plainly foretold by the great pains taken by the writers of financial articles in the Philadelphia prints of the time, to assure the public that there is really no cause for alarm. The cause first alleged for the growing tightness of the money market was, the tying up in railroad construction of large sums which could not, neces- 
sarily, be readily realized upon; the same cause that largely contributed to the disasters of 1873 .

The panic may be said to have been started by the failure of the Ohio Life and Trust Company, in August. Matters grew worse and worse until, on September 25, 1857, the Bank of Pennsylvania failed, followed by the other Philadelphia, and most of the Pennsylvania banks. The New York banks, however, stood out, and the papers of that eity and State read long and edifying homilies to the Philadelphians on the wickedness of suspending. The "Albany Argus" remarked, critically, that it was " characteristic of Philadelphia to yield to a money crisis." The Philadelphia papers retorted that the New York banks, by draining Philadelphia of her specie, through various devices, had compelled the Quaker City bankers to suspend. Finally, the New York banks, after solemnly resolving that they would no no such thing, suspended in their turn, with the exception of the Chemical Bank. They resumed, however, in December, 1857.

By suspending specie payments the Pennsylvania banks had again incurred the forfeiture of their charters, and it was necessary to pass a relief act. Accordingly a special session of the Legislature was called to assemble on October 6 . The peculiar merit of the laws forfeiting bank charters for not keeping up specie payments seems to have been, that in ordinary times those enactments were not needed to make banks pay in specie, while in times of panic the banks had to suspend, anyhow, and be relieved from the operation of those laws. By act of October 13,1857 , the operation of said enactments was suspended until the second Monday of April, 1858, on which latter date, accordingly, the banks resumed.

The Suffolk system inaugurated by the act of 1850, not having proved entirely satisfactory, the propriety of adopting as a last resource a system similar to the New York free banking method, began to be discussed and finally resulted in the adoption of such a plan in 1860 .

The crisis of 1857 was remarkable as the first one for which the banks were not generally blamed. Governor Pollock, in his message for 1858 , says :

"It is neither just nor proper to charge all our present financial and commercial distress to the banks and their management."

He lays the blame for the troubles of the time principally on the low tariff then in force.

An examination of the bank statements of this period shows nothing radically wrong with banking methods, nor was there anything in the condition of the country which warranted financial alarm. It was a panic rather than a financial crisis.

Nine new banks were incorporated in 1858, all outside of Philadelphia, while but one was chartered in 1859 . 


\section{Establishment of the Free Banking System.}

We now come to the passage of the act of March 31, 1860 (P. L., p. 459), entitled "An act to establish a system of free banking in Pennsylvania, and to secure the public against loss from insolvent banks."

As this law was re-enacted with various changes in the following year by act of May 1, 1861 (P. L., p. 503), further reference will be made to the latter enactment only.

Under the provisions of this act any five or more persons might organize a bank upon complying with certain conditions, with a capital stock of not less than fifty thousand dollars nor more than a million. The Auditor-General was to have notes of a uniform character printed, of denominations not less than five dollars, each note to bear the inscription, "Secured by deposit of public funds." Section 10 provided:

"The banks established under this act, upon legally assigning to and depositing with the Auditor-General the bonds or evidences of debt of this Commonwealth or of the United States, shall be entitled to receive an amount of such circulating notes in blank, of the denominations such as they may require, numbered, registered, countersigned and stamped as herein provided for, the bonds and stocks to be taken at their market value; Provided, that the amount to be invested under the provisions of this act shall not exceed the amount of capital now employed in eorporate banking in this State more than fifteen millions of dollars, until otherwise provided."

Section 12 provided that whenever the securities so deposited should depreciate in value the Auditor-General was to notify the banks depositing the same to either deposit further securities to the amount of the deficiency or to return an equivalent amount of the notes issued to them, respectively. If the securities appreciated notes to the amount of the appreciation were to be issued to the banks depositing said securities.

Section 18 provided that if any bank should refuse to pay its notes of circulation in gold or silver coin, the holders of such notes might cause them to be protested for non-payment, and the Auditor-General, on receiving and filing such protest, was to give notice in writing to the maker of such notes to pay them, and on refusal or neglect to pay the same for twenty days after such notice, the bank was to be notified that it had committed an act of insolvency.

The Auditor-General was to then appoint a committee to ascertain whether the bank had, in fact, omitted to redeem its notes, and if the committee so found, the Auditor-General was to forth with appoint a Receiver to close the affairs of the bank.

Sections 37 and 39 provided the means by which banks created under other acts might organize under the act of 1861 .

The forty-third section provided that the banks should keep in gold or silver coin "or its equivalent" an amount equal to eight per cent. of all their circulating notes of every kind, and whenever the amount of notes outstanding should exceed the proper proportion of the specie on hand, no more notes were to be issued, nor should the liabilities of 
the bank be increased, nor any dividends be declared, until the required proportion should be established.

To recur to the year 1860: The Philadelphia banks had again suspended on November 19, 1860, following the lead of the banks of the South and Southwest. The cause of these suspensions was the ominous aspect of the political outlook. Lincoln's electors had received a majority and the danger of hostilities between the North and South was becoming apparent. The usual relief bill was passed on April 16, 1861 (P. L., p. 341), suspending the pains and penalties of the laws relative to specie payments until the second Tuesday of October, 1861, but when the date named arrived resumption was impossible, and another relief act was passed on April 11, 1862, relieving the banks until the first Tuesday in February, 1863. The Pennsylvania banks, however, had no reason to be ashamed of their inability to resume in 1861. They were nobly striving to keep the Union from suspending. With the banks of Boston and New York they bought 150 millions of Government securities in that year. Subsequent acts extending the time for resuming specie payments were so numerous that no further reference thereto will be made herein.

The free banking system created by the acts of 1860 and 1861 cannot be said to have been a success. Only one bank was formed under it in 1860. The Auditor-General, in his special report on the subject, made to the Legislature on January 3 , 1861, said:

"For some reason existing either in the provisions of the law or the caution of the people in adopting new systems, this plan of reorganizing banking institutions has not received general acceptance. ** * It is better that its acceptance should be gradual rather than sudden. I do not doubt that ultimately, with some modifications of the provisions of the general banking law which experience and a more full examination shall dictate, the system will attract the same favor which it has received in other States."

In 1861 two other banks were incorporated under the free banking system, and yet two more in 1862 . In his report for 1862 , made to the Legislature in January, 1863, the Auditor-General points out the reason why that system is not a success:

"It may, however, well be doubted whether the system devised by the act of March 31,1860 , and its supplement, will ever be extensively adopted so long as the granting of special charters which do not require the circulation to be secured by the deposit of Government securities, shall be continued by the Legislature. The privilege of the special charter is regarded as much more valuable."

It was no difficult matter to secure the passage of an act granting a special charter, in those days, under which charter the bank securing it became subject to the provisions of the general bank act of 1850 and could, therefore, issue its eirculating notes without depositing any securities. Hence it is not strange that banks preferred to incorporate under special charters, especially as there was not, probably, such a public sentiment as would give the banks formed under the 
free banking system a higher standing than that of other banks. Only nine banks were ever incorporated under the provisions of the acts of 1860 and 1861, and the special report of the Auditor-General, made under the provisions of those acts, January 1, 1868, states that "all the banks are returning their circulation and lifting their securities." From this report it appears that the total amount of circulation secured and issued under said acts was $\$ 3,219,668$, of which amount there had been returned and destroyed, on the above date, $\$ 3,070,106$, leaving then in circulation $\$ 149,562$, which amount was reduced in 1866 , as shown by subsequent reports, to $\$ 96,862$ and, in 1870 , to $\$ 79,496$.

\section{Reorganization of Banks Under National System.}

In 1864-5 there was a general desertion from the ranks of the State banks and a consequent enlistment in those of the National banks. A communication from the State Treasurer, dated January 25, 1865, informed the Legislature that fifty-seven State banks, with an aggregate capital stock of $\$ 20,592,388$ had notified him of their intention to become National banks, "leaving but $\$ 6,930,975$ of the banking capital of the Commonwealth under the old law." The report of the same officer, dated January 3, 1866, states that "inquiring of the Comptroller of the Currency, I learn that the National banks of Pennsylvania have a capital of $\$ 46,943,190 . "$

The reason given by the Philadelphia institutions for becoming National banks is said to have been: "The city banks which are considered the fat goose at Harrisburg, to be plucked at pleasure, will be removed from that body forever." It was then supposed that National banks would be exempt from all State taxation.

In 1865 the number of State banks had dwindled to eleven, with nine Savings institutions, having an aggregate capital stock of $\$ 2,790$,995 ; circulation, $\$ 1,831,243.50$; deposits, $\$ 4,461,960.75$; discounts, $\$ 4$,812,195.02; gold and silver, $\$ 348,708.01$.

In November, 1867 , there were but six State banks, not counting Savings institutions; but from this time forward the number of State banks rapidly increased. Twenty-eight were formed in 1871, under the provisions of an equal number of special acts, thirty-four in 1872 and a like number in 1873. These numbers are exclusive of banks the charters of which were renewed, in the said years, by special acts. The adoption of the constitution of 1874, however, which prohibited the formation of corporations except under the operation of general laws, effectively prevented the creation of more State banks under special acts.

\section{Present Condition of the Banks.}

From this period forward the story of the Pennsylvania banks has been in the main that of the other banks of the country; and there remains to speak only of the various laws which have been enacted, affecting them, and to give some figures showing their present condition. 
State Banks.

\begin{tabular}{|c|c|c|c|c|c|c|}
\hline YEARS. & 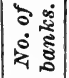 & $\begin{array}{l}\text { Loans and } \\
\text { discounts. }\end{array}$ & specie. & Capital stock. & Circulation. & Deposits. \\
\hline $1834 .$. & 41 & $\$ 31,587,030$ & $\$ 2,909,105$ & $\$ 17,061,944$ & $\$ 10,366,232$ & $\$ 9,819,140$ \\
\hline $1839 .$. & 49 & $37,613,266$ & $3,282,213$ & $23,866,211$ & $11,384,151$ & $8,100,675$ \\
\hline 1844. & 46 & $19,130,127$ & $4,944,383$ & $15,195,857$ & $6,846,741$ & $11,334,202$ \\
\hline $1849 \ldots$ & 45 & $29,296,076$ & $4,020,731$ & $16,011,830$ & $10,083,098$ & $12,727,700$ \\
\hline $1854 .$. & 61 & $48,656,884$ & $4,331,656$ & $19,768,864$ & $17,420,348$ & $22,747,991$ \\
\hline 1859. & 87 & $46,825,266$ & $11,345,536$ & $24,565,805$ & $11,980,480$ & $26,054,568$ \\
\hline $1863 \ldots$ & 94 & $47,248,090$ & $9,467,234$ & $25,917,650$ & $27,689,504$ & $43,038,218$ \\
\hline $1868 \ldots$ & 12 & ................ & ................ & $1,794,090$ & ................. & \\
\hline $1873 \ldots$ & .. & $20,331,359$ & ............. & $7,187,300$ & ............. & $20,761,456$ \\
\hline $1878 .$. & 106 & $22,335,156$ & ............ & $9,187,882$ & 493 & $19,477,173$ \\
\hline 1883. & 81 & $23,207,406$ & ............ & $7,725,006$ & ............. & $27,303,795$ \\
\hline $1888 .$. & 77 & $26,413,454$ & ............. & $7,852,589$ & 71,066 & $30,412,607$ \\
\hline 1893.. & 85 & $36,084,769$ & ................ & $8,819,697$ & ................ & $44,737,284$ \\
\hline $1898 .$. & 89 & $36,680,937$ & .............. & $9,190,695$ & ............... & $52,999,341$ \\
\hline
\end{tabular}

The act under which State banks are now generally incorporated is that of May 13, 1876 (P. L., p. 161), under the provisions of which any three or more persors may organize such a bank, upon complying with the requirements therein specified. The regulations and requirements of the Pennsylvania banking law are similar to those which obtain in most other States. Persons reading this act, however, must remember that the functions therein assigned to the Auditor-General were, by acts of 1891 and 1895, transferred to the Banking Department.

As the law now stands, banks of issue must be incorporated under the provisions of the act of 1861 and its supplements, while the act of May 13, 1876 (P. L., p. 161), Section 6, authorizes the organization of banks to "carry on the business of banking by loaning money, discounting, buying, selling or negotiating promissory notes, drafts, coin, bullion, bills of exchange and all other written evidences of debt or specialties."

It is true that the said section goes on to say "and transact all such other business as shall pertain to the business of banking," but that "other business" is evidently business of the same general character as the kinds of business previously enumerated, it being evident that had the Legislature intended to confer so important a right as that of issuing circulating notes the intention would not have been left open to inference from such general language.

If, therefore, the prohibitory National tax on the circulation of State banks were to be removed, banks incorporated under the provisions of the act of 1876, as all the State banks are, would not be empowered to issue notes for circulation, without reorganizing under the act 
of 1861. This is a fact worthy of remembrance, since all the law books treating of the subject seem to take it for granted that the act of 1861 is no longer in force, apparently because of the repealing clause in the act of 18\%6, which, however, merely repeals inconsistent acts and parts of acts. But the two acts do not conflict. The act of 1861 authorizes the formation of banks of issue, while that of 1876 authorizes the incorporation of banks of discount and deposit only. Of course this is not now a live question, but it may become such in the future.

\section{National Banks.}

Figures are in thousands of dollars.

\begin{tabular}{|c|c|c|c|c|c|c|c|c|c|}
\hline YEARS. & 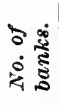 & $\begin{array}{c}\text { Loans } \\
\text { and dis- } \\
\text { counts. }\end{array}$ & $\begin{array}{c}U . S . \\
\text { bonds. }\end{array}$ & $\begin{array}{c}\text { Cash and } \\
\text { cash items. }\end{array}$ & Capital. & Surplus. & $\begin{array}{c}\text { Undi- } \\
\text { vided } \\
\text { profits. }\end{array}$ & $\begin{array}{c}\text { Out }- \\
\text { standing } \\
\text { circula. } \\
\text { tion. }\end{array}$ & $\begin{array}{c}\text { Indi- } \\
\text { vidual } \\
\text { deposits. }\end{array}$ \\
\hline $1863 \ldots . .$. & 15 & $\$ 855$ & $\$ 1,659$ & $\$ 453$ & $\$ 1,080$ & ......... & $\$ 25$ & .......... & $\$ 2,694$ \\
\hline $1868 .$. & 198 & 82,903 & 54,305 & 35,166 & 49,397 & $\$ 12,074$ & 4,686 & $\$ 38,234$ & 75,064 \\
\hline $1873 \ldots$ & 202 & 109,404 & 49,594 & 27,823 & 52,710 & 17,123 & 4,701 & 41,525 & 86,846 \\
\hline $1878 \ldots$ & 234 & 102,338 & 53,189 & 29,327 & 55,663 & $1 \%, 823$ & 4,197 & 40,496 & 84,307 \\
\hline $1883 .$. & 271 & 160,014 & 49,604 & 39,815 & 59,263 & 21,139 & 6,643 & 41,170 & 151,621 \\
\hline $1888 \ldots$ & 313 & 206,733 & 22,438 & 46,394 & 67,030 & 28,218 & 8,333 & 16,536 & 190,494 \\
\hline $1893 \ldots$ & 396 & 233,397 & 26,619 & 37,398 & 73,509 & 39,155 & 10,809 & 22,335 & 212,775 \\
\hline $1898 \ldots$ & 426 & 265,779 & 41,884 & 43,047 & 72,760 & 45,677 & 10,283 & 27,952 & 284,907 \\
\hline
\end{tabular}

\section{Savings Banks.}

Prior to the passage of the act of May 20, 1889 (P. L., p. 246), there was no general law in Pennsylvania by which Savings institutions might be incorporated. Numerous so-called Savings banks had been incorporated under the provisions of special acts, most of them without the characteristics by which such institutions are generally distinguished, but there had been, until the date of the act above named, no general provision for the incorporation of such banks.

Under the provisions of this law any number of persons, not less than thirteen, two-thirds of whom shall reside in the county where the institution is to be located, may, upon complying with the requirements of the act, be incorporated as a Savings bank without capital stock.

Section 17 provides that the deposits of the bank may be invested:

"First.-In the stocks or bonds or interest-bearing notes or the obligations of the United States, or those for which the faith of the United States is pledged to provide for the payment of the interest and the principal.

Second.-In the stocks or bonds of the Commonwealth of Pennsylvania, bearing interest.

Third.-In the stocks or bonds of any State in the Union that has not, within ten years previous to making such investments, by such corporation, defaulted in the payment of any part of either principal or interest of any debt authorized by any Legislature of such State to be contracted. 
Fourth.-In the stocks or bonds of any city, county, town or village of any State of the United States, issued pursuant to the authority of any law of the State, or in any interest-bearing obligation issued by the city or county in which such banks shall be situated.

Fifth.-In bonds and mortgages on unincumbered, improved real estate, situated in this State."

The subject of Savings banks cannot be dismissed without a reference to the Philadelphia Saving Fund Society, probably the earliest Savings institution in the United States, or, at any rate, one of the most notable. This society was first organized as a private association in 1816, it being modelled upon the English Savings banks, then much discussed in British prints. It was incorporated by act of February 25, 1819, and has been in existence as a corporation ever since. The resources of this society were, in 1898 , $\$ 52,893,292$, its deposits $\$ 46,824,-$ 066. It had, in the same year, a surplus fund of $\$ 4,244,586$ and undivided profits of $\$ 1,824,639$. The Society has no capital stock and its earnings are constantly accumulating as a fund to protect depositors against possible loss.

The Western Saving Fund Society, of Philadelphia, incorporated in 1839 , had total resources of $\$ 13,111,328$ in 1898 , with deposits of $\$ 11$,537,970 , a surplus of $\$ 1,145,535$ and undivided profits of $\$ 427,821$.

Statistics in regard to Savings institutions of Pennsylvania, from the first report made by the Commissioner of Banking are as follows:

\begin{tabular}{|c|c|c|c|c|}
\hline YEARS. & $\begin{array}{l}\text { No. of } \\
\text { banks. }\end{array}$ & $\begin{array}{l}\text { Number of } \\
\text { accounts. }\end{array}$ & Deposits. & $\begin{array}{l}\text { Average } \\
\text { to each } \\
\text { depositor. }\end{array}$ \\
\hline …................... & 16 & …........ & $\$ 66,417,794$ & ......... \\
\hline $1893 . . . \ldots . . .$. & 16 & ........... & $66,025,821$ & ........ \\
\hline 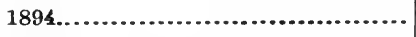 & 16 & 264,642 & $68,522,217$ & $\$ 258.92$ \\
\hline 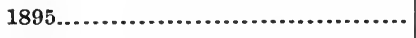 & 16 & 282,677 & $73,937,636$ & 261.56 \\
\hline $1896 \ldots \ldots \ldots . . .$. & 17 & 294,852 & $77,429,347$ & 262.60 \\
\hline $1897 \ldots \ldots \ldots \ldots \ldots$ & 16 & 307,309 & $82,245,532$ & 267.63 \\
\hline $1898 \ldots \ldots \ldots \ldots \ldots \ldots$ & 16 & 322,572 & $88,728,071$ & 275.06 \\
\hline
\end{tabular}

Trust Companies-Taxation.

In Pennsylvania the trust companies are conducted, to a large extent, by the same persons who manage the banks. The bankers frequently take out trust company charters and run such companies in connection with their banks. The two institutions often occupy the same room, the bank's counters on one side, the trust company's on the other. There is a connecting passage at the rear of the room. When business is offered at the bank counter of a character which the law forbids the bank to handle, it is passed over to the trust company's side. The same per- 
sons are directors of each corporation. There are thirty-five trust companies in Philadelphia alone.

While the subject of bank taxation has been purposely omitted from this article, on account of the involved nature of the history of that subject, it may be here said that banks are taxable for local purposes in Pennsylvania only on their real estate. In other words, they are assessed for county, township, borough or city purposes only on their realty. For State purposes they pay, on the basis of a sworn report made to the Auditor-General, a tax of four mills on the aggregate amount of their paid-in capital, surplus and undivided profits, or they may elect to pay ten mills on the par value of their capital stock. These are all the taxes they are liable to. Trust companies are taxable locally in the same way, but for State purposes they pay at the rate of five instead of four mills, and on the actual value of their stock, assets and franchises. The total taxes paid by banks will average six mills on the aggregate amounts mentioned, while those paid by trust companies will average eight and a half mills on the par value of their capital stocks.

Besides the acts for the formation and regulation of banks, hereinbefore mentioned, there is a curious act of May 18, 1893, providing for the formation of co-operative banking institutions, but so far as known no such institution has been formed under the provisions of said act.

The following table gives the statisties of trust companies from the date of the first report made by the Commissioner of Banking :

\begin{tabular}{|c|c|c|c|}
\hline $1892 \ldots \ldots \ldots \ldots$ & $\begin{array}{l}\text { Number. } \\
\ldots \quad 72\end{array}$ & $\begin{array}{c}\text { Capital. } \\
\$ 35,878,744\end{array}$ & $\begin{array}{r}\text { Deposits. } \\
\$ 89,530,104\end{array}$ \\
\hline $1893 . \ldots \ldots \ldots \ldots$ & $\ldots 82$ & $38,308,427$ & $80,060,534$ \\
\hline $1894 \ldots$ & 82 & $39,018,085$ & $96,803,326$ \\
\hline $1895 . . . \ldots \ldots$ & 88 & $39,976,236$ & $103,114,827$ \\
\hline $1896 .$. & 90 & $40,399,990$ & $93,143,838$ \\
\hline 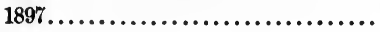 & ... 89 & $37,380,974$ & $107,781,342$ \\
\hline $1898 . \ldots \ldots \ldots \ldots \ldots \ldots \ldots \ldots \ldots \ldots \ldots \ldots \ldots \ldots$ & ... 92 & $36,689,490$ & $123,850,804$ \\
\hline
\end{tabular}

State Banking Department Established.

By act of June 8, 1891 (P. L., p. 217), a Banking Department was constituted, to which all the powers theretofore exercised by the Auditor-General, in connection with banks, except in the matter of their taxation, were transferred, with other powers thereby given. This law was superseded, and the department reorganized by the act of February 11, 1895 (P. L., p. 5), the first section of which provides :

"That there is hereby established a separate and distinct department to be known as the Banking Department, the Commissioner of which said department shall take care that the laws of this Commonwealth in relation to banks, banking companies, co-operative banking associations, trust and safe deposit, real estate mortgage, title insurance, guarantee, surety and indemnity companies, and all other companies of a similar character, Savings institutions, Savings banks, provident institutions and every corporation having power [to receive] and receiving money on deposit, and to mutual Savings funds, building and loan associations, and bond and investment companies incorporated or which may be hereafter incorporated under the laws of this 
State, or incorporated under the laws of any foreign State and authorized, under the laws of this State to transact business herein, shall be faithfully executed; also that the greatest safety to depositors therein and other interested persons shall be afforded; and the said Commissioner of Banking and the said department shall be charged with the supervision of all of said corporations for said purposes; and it shall not be lawful for any foreign corporation to receive any deposit or deposits, or transact any banking business whatsoever in this Jommonwealth until it shall have first filed in the office of the Commissioner of Banking a certified copy of the statement required by law to be filed in the office of the Secretary of the Commonwealth."

While the supervisory powers of the department extend to all classes of corporations desirable to be reached, they do not extend to unincorporated banks nor to private bankers.

Every corporation subject to its inspection, except domestic building and loan associations, is required to pay the Banking Department \$25 per year, and five dollars per hundred thousand dollars of capital stock, or, if the company has no capital stock, then of assets, to defray the expenses of the examinations made by the department. It is believed that the powers conferred upon the Commissioner of Banking are not materially different from those conferred upon similar officers in other States.

\section{DELAWARE.}

Though small in area and never having but a few banks, the banking history of Delaware is by no means unimportant or uninteresting. Many of the States which went into partnership with banks made bad bargains, their experience showing that the commingling of politics and business was not satisfactory. But in Delaware the State has been a partner in a bank since 1807, and the institution appears to have been prudently managed from its organization until the present.

On September 13, 1785, the charter of the Bank of North America, at Philadelphia, was repealed on the ground that the bank as then managed was inconsistent with the public safety. This action was due to the popular prejudice against banks, which was even stronger then than at the present day.

Though continuing to act under its Federal charter, the bank desired incorporation under State laws, as there was some doubt of its right to do business under the former authority. Overtures were therefore made to the State of Delaware, and on February 2, 1786, the Assembly of that Commonwealth passed a bill conferring upon the bank the usual franchises of a corporation. * This charter was readily accepted by the directors of the bank, and if necessary to the transaction of their business, they actually contemplated the removal ot the bank to some point within the State of Delaware. But subsequent events made this step unnecessary. 


\section{Organization of the Farmers' Bank.}

On February 3, 180\%, the Farmers' Bank of Delaware was granted a charter, the preamble to the act of incorporation reciting that "Whereas, the establishment of a bank for the State of Delaware upon a foundation sufficiently extensive to answer the purposes intended thereby, will be conducive to the general interests of the State, and tend to promote the agriculture, commerce and manufactures thereof; therefore," etc.

Its capital was to be $\$ 500,000$, of which $\$ 100,000$ was subscribed by the State, and the remainder apportioned among counties for subscriptions by individuals. The head office was located at Dover, and branches established at New Castle and Georgetown. The management was vested in a board of twenty-seven directors, one-third of whom were appointed by the State. Debts which the bank might contract were limited to twice the capital stock. The authorized capital was afterwards increased to $\$ 1,000,000$ and the actual capital to $\$ 680,000$, and a third branch at Wilmington was added.

The bank never had a monopoly of the circulation of the State, yet always occupied a prominent position in that regard. In 1835, out of a total circulation of $\$ 622,397$, reported in the State, $\$ 339,379$ was issued by the Farmers' Bank. Two years later, out of a total circulation of $\$ 718,948$ by the four banks then in the State, $\$ 386,582$ is that of the Farmers' Bank and its branches. In 1842 there were but three banks in operation-the Farmers' Bank with a capital of $\$ 680,000$ and circulation of $\$ 383,889$, and two others, with an aggregate capital of $\$ 208,470$ and aggregate circulation of $\$ 341,940$. By 1857 the number of banks in the State had increased to eight, with a total circulation of $\$ 1,394,094$, of which $\$ 535,758$ was issued by the Farmers' Bank. This was also the only institution at that time possessing branches, though the Bank of Smyrna had earlier operated a single branch. At the opening of the year 1861 the Farmers' Bank had $\$ 358,586$ outstanding circulation.

In 1866 the Legislature passed an act to enable it to become a National bank; but the directors refused to sanction the change, and it has continued to the present time under its State charter. The State of Delaware owned 8,714 shares of its stock, as shown in the report of the Auditor for 1893 , listed at $\$ 402,840$, from which it derived an income of $\$ 22,000$ during the preceding year. Because of this ownership the State, through its Legislature, appoints three directors for the principal bank and three for each of its branches. The State Treasurer, who is also trustee of the school fund, is required to deposit money belonging to the State or school fund in the Farmers' Bank.

In 1899 the New Castle branch of the Farmers' Bank was discontinued and the capital was reduced to $\$ 581,000$. Besides owning stock in the Farmers' Bank, the State is a shareholder in the National Bank 
of Delaware, of Wilmington, the Union National, of Wilmington, and the National Bank of Smyrna.

There is no general law under which banking corporations can be organized. They must be formed under special charters.

Savings banks are conducted on the mutual plan, and there are also trust companies, the latter practically doing a banking business. The Farmers' Bank is required to make an annual report to the Governor, and the other banks are also required to make and publish statements.

Up to 1847 there had been no broken banks in the State, and in subsequent years failures have been almost unknown.

State Banks.

\begin{tabular}{|c|c|c|c|c|c|c|}
\hline YEARG. & $\mid$ & $\begin{array}{l}\text { Loans and } \\
\text { discounts. }\end{array}$ & Specie. & $\begin{array}{l}\text { Capital } \\
\text { stock. }\end{array}$ & Circulation. & Deposits. \\
\hline $1836 \ldots$ & 3 & $\$ 1,232,830$ & $\$ 173,183$ & $\$ 730,000$ & $\$ 622,397$ & $\$ 480,375$ \\
\hline $1841^{*} \ldots$ & 3 & $1,472,464$ & 155,691 & 881,648 & 860,963 & 312,247 \\
\hline $1846^{*} \ldots$ & 3 & $1,550,321$ & 122,565 & 890,000 & 611,442 & 373,506 \\
\hline $1851 \ldots . .$. & 6 & $2,263,315$ & 188,253 & $1,440,010$ & 833,960 & 558,858 \\
\hline $1856 \ldots . .$. & 11 & $2,906,253$ & 180,051 & $1,493,185$ & $1,192,204$ & 852,164 \\
\hline $1861 * \ldots$ & 8 & $1,970,305$ & 126,614 & $1,088,175$ & 675,278 & 516,393 \\
\hline $1866 \ldots .$. & 5 & ............. & .......... & 780,000 & ............. & .......... \\
\hline $1871 \ldots .$. & 5 & ............... & .......... & 780,000 & .............. & .......... \\
\hline $1888 \ldots . .$. & 2 & 597,098 & ........... & 420,000 & ............. & 455,175 \\
\hline $1893 . .$. & $\cdots$ & $1,808,162$ & ........... & 680,000 & ................. & $1,096,446$ \\
\hline $1897 \ldots$. & 1 & $1,749,721$ & .......... & 680,000 & ............. & $1,119,044$ \\
\hline
\end{tabular}

*Incomplete.

National Banks.

Figures in thousands of dollars.

\begin{tabular}{|c|c|c|c|c|c|c|c|c|c|}
\hline YEARG. & 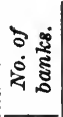 & $\begin{array}{c}\text { Loans } \\
\text { and dis- } \\
\text { counts. }\end{array}$ & $\begin{array}{c}\text { U.S. } \\
\text { bonds. }\end{array}$ & 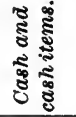 & Capital. & Surplus. & $\begin{array}{c}\text { Undi. } \\
\text { vided } \\
\text { profits. }\end{array}$ & $\mid \begin{array}{c}\text { out. } \\
\text { standing } \\
\text { circula- } \\
\text { tion. }\end{array}$ & $\begin{array}{c}\text { Indi- } \\
\text { vidual } \\
\text { deposits. }\end{array}$ \\
\hline $1864 \ldots \ldots \ldots$ & 1 & $\$ 255$ & $\$ 281$ & $\$ 96$ & $\$ 300$ & ...... & $\$ 6$ & $\$ 124$ & $\$ 150$ \\
\hline $1869 . .$. & 11 & 2,183 & 1,409 & 498 & 1,428 & $\$ 318$ & 81 & 1,186 & 1,436 \\
\hline $1874 \ldots \ldots \ldots$ & 11 & 2,510 & 1,514 & 460 & 1,523 & 429 & 89 & 1,280 & 1,642 \\
\hline $1879 \ldots .$. & 14 & 2,847 & 1,845 & 496 & 1,764 & 463 & 108 & 1,437 & 2,401 \\
\hline $1884 \ldots .$. & 15 & 4,337 & 1,826 & 654 & 1,824 & 645 & 194 & 1,576 & 3,871 \\
\hline $1889 \ldots$ & 18 & 5,624 & 1,341 & 539 & 2,134 & 885 & 285 & 1,149 & 4,685 \\
\hline $1894 \ldots \ldots . . .$. & 18 & 5,316 & 862 & 448 & 2,134 & 973 & 256 & 686 & 4,438 \\
\hline $1898 \ldots \ldots \ldots$ & 18 & 5,725 & 978 & 491 & 2,084 & 984 & 264 & 754 & 5,546 \\
\hline
\end{tabular}




\section{MARYLAND.}

Maryland first issued paper money in 1733. Thereafter almost any object became a sufficient excuse for a new issue. The intervals between emissions varied from one to six years, and the amounts ranged from $\$ 150,000$ to $\$ 1,500,000$. After a term of years, usually about twelve, the notes were to be redeemed, but redemption was commonly made in new notes at fixed rates. The depreciation was usually about six or seven to one of specie.

During the Revolutionary War this paper currency reached its floodtide. The Continental Congress issued at least $\$ 200,000,000$, which distributed itself throughout the States. It did not supersede State money in Maryland; both were made legal tender in 1777. The war expenses necessitated increased State issues to aid the State treasury. In 1797 Maryland issued $\$ 1,300,000$; in 1780 another million followed, and in 1781, a third. The whole mass depreciated greatly, and Continental bills became worthless. Maryland currency at this time was composed of various issues, known as Continental bills, convention bills, provincial bills, State Continental bills, State money, black money and red money. Such a quantity of paper in circulation was naturally calculated to drive out the specie, although in 1781 the considerable sum of $£ 100,000$ was estimated to be still in the State, although it became more and more hoarded.

\section{Incorporation of the First Bank.}

During the last quarter of the eighteenth century the State was undergoing a remarkable industrial development. At the same time the specie in circulation was limited in amount and heterogeneous in character and fluctuating in value. The State bills of credit were gradually passing out of circulation, and the Legislature refused new issues. The circulating medium was becoming more and more contracted. An adequate metallic currency was too expensive. Under these conditions the demand for State bills of credit began to change to one for a bank.

The first attempt to incorporate a bank in Maryland occurred in 1782, when James McHenry introduced into the Senate "An act to establish the credit of a bank" in Baltimore. The bill was considered and passed the Senate; the House of Delegates, however, rejected it.

In 1784 the agitation was revived. The following advertisement appeared in the Baltimore papers :

"Such of the Inhabitants as are desirous of promoting the establishment of a Bank in the Town of Baltimore are requested to meet, * * * when proposals for carrying into immediate effect an institution so essentially necessary to the commercial interests, not only of the town, but of the State also, will be laid before them." 
The townspeople entered heartily into the scheme; proposals for the bank were immediately published and subscriptions solicited. The bank was to be styled the "Bank of Maryland," and the capital stock proposed was $\$ 300,000$, in shares of $\$ 400$, payable in gold or silver. Within ten days 150 shares had been subscribed, so that they were able to proceed to the election of directors.

A lively discussion was carried on between the friends and opponents of the bank until the matter was finally decided by the Legislature. The merchants of Baltimore favored it. The agricultural and speculative elements opposed it; the former, because the short time of loans practically excluded them from borrowing, the rates of discount would be high. They also argued that it would draw capital from the country to the city, and thus check improvement and agriculture. The latter, the speculative class, preferred State issues. It was objected also that it would aid only a few. The 300 shares which were subscribed were distributed among but seventeen persons.

A petition for a charter was presented to the Senate at the November session, 1784. A committee of the House of Delegates reported favorably upon it, and a bill was brought in to charter a bank, but it was finally laid over until the next session of the Assembly, and was. not called up again.

For six years no further attempt was made to start a bank in Maryland. The year 1789 and the early part of 1790 formed a period of considerable depression in the State. A revival, however, began in the spring of 1790, when the extraordinary demand in Europe for food products, resulting from the breaking out of the French Revolution, began to be felt in America.

\section{Lack of Proper Credit Facilities.}

Credit facilities at this time were very meagre, and as a result of these conditions an application was made by sundry citizens to the November session of the Assembly for a charter for a bank to be called the "Bank of Maryland." In this case the petitioners did not organize a partnership under articles of association before applying for a charter. Perhaps this may have been due to a desire to prevent public discussion of the project by enemies of banks who had been so effective in preventing the passage of the charter in 1784. Very slight notice of the bank appears in the papers before it had received a charter.

The assistance of industry and commerce was stated to be the motive in establishing a bank. The bill had little difficulty in passing; the final vote in the House of Delegates was fifty-one affirmative to seven negative. The capital stock was fixed at $\$ 300,000$. Subscriptions were opened in Baltimore, December 10, 1790, and within fourteen days $\$ 200,000$ was subscribed, the amount necessary to be subscribed before the election of directors might occur. During the ensuing year this amount was paid in, and the bank began operations. The remainder 
of the capital stock was called in within the following four years. Subscriptions were paid in foreign gold coins at $6 \mathrm{~s}$. or $6 \mathrm{~s}$. $8 \mathrm{~d}$. the pwt., depending upon the fineness. Few of the notes of the Bank of North America at Philadelphia, and none of those of the banks of New York and Massachusetts had reached Baltimore at this time.

\section{Branch of the Bank of The United States Established.}

An addition to Baltimore's banking capital occurred in 1792, when the Bank of the United States established a branch at that place which usually operated a capital of about $\$ 500,000$.

In 1793 the Maryland Legislature granted a charter to the Bank of Columbia, which was to be located in the District of Columbia. The avowed object of the formation of the bank was to assist in the preparation of the District for occupancy by the national Government. The nominal capital was $\$ 1,000,000$. It immediately passed from the jurisdiction of Maryland.

During the years 1790 to 1800 the Bank of Maryland was able to declare annual dividends of twelve per cent. Its capital was far below what it might with ease have employed. In 1795 an unsuccessful attempt was made to double this capital. As a substitute it was proposed to establish another bank, which might consolidate with the Bank of Maryland, upon the consent of both parties. This clause was stricken out and an entirely separate institution received a charter in 1795 as the Bank of Baltimore, although the Bank of Maryland became a subscriber to its stock.

The capital of the bank was fixed by the Legislature at $\$ 1,200,000$, though the petitioners wanted the limit placed at $\$ 3,000,000$, with provision for increasing it ultimately to $\$ 9,000,000$, as the growing character of Baltimore trade demanded more banking accommodations.

The two banks had an aggregate capital of $\$ 1,500,000$, to which there was added by the United States branch bank at Baltimore about $\$ 500,000$. This amount could be very actively employed in a town whose export trade alone was of an annual value of more than $\$ 9,000,-$ 000 , and which was rapidly growing, to say nothing of other commercial and industrial operations.

\section{DECLINE IN THE EXPORT TRADE.}

Maryland's total exports for 1799 were $\$ 16,300,000$. After this time there was a decrease, due chiefly to the narrowing of the market for American breadstuffs by the restoration of peace in Europe in 1802, and also to the competition of Philadelphia and New York for Baltimore's trade. By 1803 the lowest point had been reached; exports had fallen to $\$ 5,100,000$; there was a general stagnation. The relapse was in large measure charged to Baltimore's lack of banking facilities in comparison wich her sister cities. It was estimated that $\$ 120,000$ of good paper was weekly rejected by the Baltimore banks. The parties 
seeking accommodation were compelled to patronize brokers who charged them excessive rates. Trade was thus driven away. The rivalry with Philadelphia and Alexandria, Va., was very keen. Pennsylvania at this time had six banks, four of which were in Philadelphia, whose total capital was $\$ 10,000,000$; the banking capital of New York was $\$ 6,500,000$, operated by seven banks; yet the trade of these places was normally about the same as Baltimore's. Within ten years the circulating medium of Virginia, Pennsylvania and New York had increased about fifty per cent., it was estimated, whereas in Maryland it had remained almost stationary.

To assist Baltimore from the depression, and to render her more nearly equal to her rivals in banking capital, the Union Bank of Maryland was organized. The articles of association appeared February 24, 1804. On April 10 books were opened for subscriptions of stock, and the amount requisite to enable them to proceed with the election of directors was subscribed in one day. It began business in June, 1804, as a limited partnership or company, and it was thus the first bank in Maryland to begin operations without first having procured a charter.

The capital stock was $\$ 3,000,000$, in shares of $\$ 100$, of which $\$ 2,312$,150 was paid in. Subscription books were opened in the counties, and 500 shares were allotted to each county (1,000 to Anne Arundel) for subscriptions. Senators and delegates were made county commissioners in charge of the subscriptions. Five thousand shares were reserved until after incorporation, so that the State, if it desired, might subscribe.

The articles declared the liability of the company to be limited to their capital stock, but directors were personally liable for dividends declared in excess of profits. Land, ships, and merchandise could be held only as security. The partnership was to terminate in 1825 , unless a charter was received before that time.

\section{BANKs Formed To Aid Agriculture.}

All of the banks thus far established were in Baltimore, and were preëminently for the aid of its commerce and manufactures. The agricultural needs had not yet received the necessary attention. With a view to assisting the farmer class especially, the Farmers' Bank of Maryland was organized in August, 1804, at Annapolis, and a branch bank was located at Easton, and later (1807) another at Frederick.

It started as a private partnership. The articles of association appeared early in August, 1804. A lively discussion was provoked. It was urged that the agricultural interest did not require and could not support such an institution, and that the commerce of Annapolis and Easton was not of sufficient magnitude to need it. At this time the application of the Union Bank for a charter was being opposed by the friends of the old banks, who wished to retain the monopoly of banking. The Bank of Baltimore had been paying regularly from ten to twelve per cent. in dividends, and its stock was quoted at $\$ 500$ (par $\$ 300$ ). 
Union Bank stock was selling at $\$ 8$ to $\$ 10$ advance, though it was still unincorporated. The two new banks were able to obtain charters from the December session of the Assembly, 1804, by banding their forces and working for each other in the Assembly.

At Charlestown, a town created by act of Assembly, and which scarcely had an existence except on paper, a private bank was organized in 1804 under the title of the "Fisherman's Bank of Charlestown." A branch was placed at Turkey Point. The nominal capital was $\$ 1,000$,000. A charter was never obtained. It was largely a means of booming the town.

The renewal of the Continental wars in 1804 again made a market for Maryland products, and Maryland commerce and manufactures, which had sunk so low in 1803, had by 1806 again almost attained that degree of prosperity which was reached in 1799. The export trade in 1806 amounted to $\$ 14,500,000$. On the crest of this wave of prosperity the Mechanics' Bank of Baltimore was chartered in 1806 to give aid especially to practical mechanics and manufacturers. The capital was $\$ 1,000,000$, of which $\$ 640,000$ was paid in, including $\$ 94,625$ subscribed by the State.

Up to 1807 Baltimore and Annapolis, the most populous and leading industrial cities of the State, were the seats of all the banking institutions. In the Farmers' Bank, at Annapolis, one of the aims was to aid agriculture. In 1807 a general extension of banking advantages to the various counties by locating banks in the most important county town, was begun. The first bank thus established was the Hagerstown Bank, in Washington county. Its capital was $\$ 250,000$. In the course of a few years banks were located in nearly all the counties of the State, and on January 1, 1810, there were six chartered banks doing business with an authorized capital of $\$ 6,950,000$, of which $\$ 1,970,355$ had been paid in.

The sources of the legal basis of banking privileges were the common-law right and special charters granted by the State. In some of the States the common-law privilege was from an early date restricted, both to secure the public safety and also on account of the granting of monopoly privileges to special companies. This, however, did not occur in Maryland until 1842. The two systems coexisted throughout the early part of our period, though in 1817 a partial restriction of the conmon-law right occurred, when it was made unlawful for persons to associate for banking purposes without first procuring a charter. The effect of this law was to prevent companies with large capital from engaging in banking without charters, but it did not apply to individuals. Persons issuing notes were in 1831 made subject to the same laws as banks in regard to the denominations of the notes allowed to be issued, but the power to issue remained intact until in 1842 the State removed it by legal enactment.

Free banking under a general law was frequently under debate in 
Maryland during the forties and fifties, and in 1852 a bill was introduced into the Legislature to establish such a law, but its passage was defeated.

\section{a Typical Maryland Bank Charter.}

Excepting the charter of the Bank of Maryland, the charters of all Maryland State banks follow closely the form of that of the Bank of Baltimore, which was established in 1795 , the second bank in the State. Special attention was given by the House of Delegates to the form of the charter, and it served as a type for the charters of later banks.

Various points of similarity between it and the charter of the first Bank of the United States indicate that the latter may have been used to some extent as a model.

The location, eapital, and number of shares were prescribed, and thirty-six persons were designated to receive subscriptions of a stated number of shares in Baltimore and in each of the eighteen counties. The books were to be kept open for subscriptions not less than three days nor longer than three weeks. Stock subscribed was deemed the property of the person in whose name it was taken in spite of all agreements to the contrary. A person was allowed to subscribe not more than twenty shares in one day, though if too many shares were subscribed, the largest subscriptions were to be reduced so that all subscribers might hold some stock. Unsubscribed shares were to be laid open for subscription in Baltimore after four weeks' notice.

Payment of subscriptions was divided into two parts, and the first part was subdivided into thirds, of which the first third was payable to the Commissioners of Baltimore previously to the election of directors, after two months' notice. The directors, when elected, were to eall in the remainder by December 1, 1797, though any subscriber could pay up his stock in full at any time before this limit and draw dividends on the amount paid in. Failure to pay the first third forfeited the right to the share.

The shareholders were to elect annually a board of fifteen directors who were to choose one of their number as President. As soon as 3,000 shares had been subscribed and $\$ 150,000$ paid in specie, the election of directors was to be effected. The bank was allowed to begin operations when $\$ 300,000$ had been paid in specie. The directors were empowered to appoint officers, clerks and servants, and to fix their compensation.

They were created a corporation with the usual powers and the following provisions were to be the fundamental articles of its constitution:

(1) The number of votes to which each stockholder was entitled, was, according to the number of shares he held, in the following proportion: one vote for each share up to two; one vote for every two shares from two to ten; one for every four from ten to thirty; one for every six from thirty to sixty; one for every eight from sixty to one hundred. No one could have more than thirty votes. Shares had to be held three 
calendar months previous to the day of election to confer the right of voting. Stockholders actually resident within the United States and none other were allowed to vote by proxy.

(2) One-third of the directors in office was ineligible for re-election the next year; the director who was President could always be re-elected.

(3) Directors had to be citizens of the United States. No director of another bank could be a director of this bank. There were to be half-yearly dividends of profits. The stockholders were to receive an annual statement from the directors of surplus profits and of debts unpaid at the expiration of the original credit.

(4) Compensation of the President and directors was in the hands of the stockholders.

(5) Nine directors were to constitute a board for the transaction of business.

(6) Six hundred shares of stock, $\$ 180,000$, were to be reserved for the State, of which not over $\$ 90,000$ might be paid in in any one year.

(7) A meeting of the stockholders could be called by sixty or more stockholders representing at least two hundred shares. Ten weeks' notice of the meeting had to be given and its object specified.

(8) Neglect to pay any installment of the capital forfeited the benefit of any dividend having accrued prior to the time of making the payment or during its delay.

(9) Bond of at least $\$ 50,000$, with two or more acceptable sureties, was required of each Cashier or Treasurer.

(10) The corporation could only hold such lands and tenements as were necessary for its accommodation in the transaction of its business, and such as were mortgaged to it as security, or conveyed in satisfaction of debts previously contracted, or purchased at sales upon judgments obtained for such debts.

(11) The corporation could only deal in bills of exchange, promissory notes, gold or silver bullion, or in the sale of the produce of its lands. Six per cent. per annum was the maximum rate for loans and discounts.

(12) A loan of more than $\$ 50,000$ to the State of Maryland, to the United States, or to any State, or of any amount whatsoever to a foreign State, required legislative sanction.

(13) Stock was transferable according to the by-laws of the corporation.

(14) Bills obligatory and of credit made to any person or persons were to be assignable by endorsement; bills or notes of the bank payable to bearer were made negotiable by delivery only.

(15) A prescribed form of oath for directors and Cashier.

(16) If the corporation dealt in any goods contrary to this act, treble the value of the goods so dealt in was to be forfeited.

(17) If loans were made in violation of the twelfth article, three times the anount so loaned was to be forfeited.

(18) The total amount of the debts which the corporation might at 
any time owe, not considering deposits for safe keeping as a debt within the meaning of this provision, might not exceed double the amount of the capital actually paid in. Directors under whose administration any excess occurred were made personally liable for it, in addition to the liability of the corporation. Directors who were absent when the excess was created or who dissented from the resolution creating it, might exonerate themselves by giving notice to the Governor of the State or to the stockholders.

(19) The Treasurer for the Western Shore was to be furnished annually, or oftener if required, with statements of the amount of the capital, the debts due to and from it, the deposits, the notes in circulation, the cash in hand and profits. He was given power to inspect the books and accounts of the bank, so far as was necessary relative to the public safety and the profits belonging to the State, but he was not allowed to inspect private accounts.

(20) The State whenever it held $\$ 66,000$ stock was entitled to appoint two directors, to be elected one each by the House and Senate.

(21) The capital stock and funds of the bank were deemed personal and not real estate.

(22) The bank was prohibited from issuing notes of a less denomination than five dollars.

The duration of the act was limited to twenty years.

The charter of the Bank of Maryland, established in 1790, differed materially from that of the Bank of Baltimore. The privileges granted were greater, and there were no provisions corresponding to the fundamental articles of the charter of the Bank of Baltimore. The subscription of the capital, $\$ 300,000$, was not allotted among the counties. Provisions regarding the capital, payment of subscriptions, voting, election of officers were similar to those of the charter described. A committee of three, chosen quarterly from the directors, was to inspect the accounts of the bank weekly. The liability of stockholders extended only to the amount of the stock. The charter was perpetual.

There were special provisions relating to fraud, robbery and debts. Any officer or stockholder convicted of fraud forfeited his stock to the company, in addition to the remedy which might be had in the name of the company. Forging or counterfeiting was felony, punishable with servitude, seven years or less. Stealing bank notes was punishable as if other goods of the same value had been taken.

No limits were prescribed to the debts of the bank, none to its issues. It was not required to make an annual report to the Legislature.

\section{Some Features of Early Maryland Banking.}

The monopolistic element in banking was especially distasteful in Maryland. A clause of the State constitution discourages monopolies. Two means were adopted to render banks of a public character. First, the State reserved the power in the charter to subscribe a specified 
amount to the capital stock of each bank. As early as 1803 the State utilized this privilege as an investment for its unemployed funds by paying up the amount of 220 shares, out of 600 reserved, in the Bank of Baltimore. The State did not subscribe in all the banks, but by 1811 some stock had been paid up in each of the city banks, and in three county banks. The State subscribed to the stock of no banks established after 1811 . The maximum reached by the State subscriptions was $\$ 540,000$. The revenue which it yielded ranged from $\$ 30,000$ to $\$ 40,000$ per annum. The amount reserved for subscription by the State varied from one-third to one-tenth of the capital.

In a second manner the interest in banks was made general, and they were prevented from becoming too great a power in the hands of a few. The subscription of the capital stock of the early banks chartered by the State Legislature, unless they had been previously organized as partnerships, was apportioned among the twenty-two counties of the State. A committee, usually of three, was appointed to receive subscriptions at the county seat of each county. Persons non-resident in the county could not subscribe until after the lapse of a specified time. Shares remaining untaken at the expiration of the time limit could be subscribed by any one, and if they still remained untaken, they were offered in Baltimore after notice given in the papers.

Of the eleven banks which had been chartered in Baltimore before 1812, six started as private partnerships, though when charters were obtained by most of these, their capital stock was distributed throughout the State for subscription. In 1817 it was forbidden by law to organize a banking company without having first procured a charter. The object of the law was to prevent the rapid increase of banking organizations. However, by this time the establishment of banks throughout the counties had put at rest the cry against the privileged few and against the absorption by the city, of the free capital of the country districts.

The right to issue promissory notes to circulate as money is in no case specifically granted, inasmuch as at this time the common-law privilege of every one to issue, had not been restricted.

The only limit placed upon the issue of notes was that the total of debts which a bank might at any time owe should not exceed twice the amount of the capital actually paid in. This limit was of little effect. Only in one or two cases of the most reckless banking did the debts approach it. The personal liability of the directors for any excess of debts over this amount was, therefore, only an empty form, since there was little probability of reaching this mark in practice. However, the introduction of the principle of personal liability was valuable, and the path to its future use was made easier.

The clause of the charter which required that the capital be paid in legal money proved a very salutary one. Usually one-fourth of the nominal capital was required to be in hand in specie before operations 
could be begun. This compelled the banks organized between 1795 and 1810 to be founded upon a solid capital. Up to this time no evidence can be found that the installments of capital were paid with stock notes.

The business which the banks might engage in was carefully restricted to banking operations exclusively, in which were included the functions of discount, deposit and issue. The holding of real estate was expressly prohibited, except so far as it was necessary to conduct business, and except also land mortgaged or purchased in satisfaction of debt, or held as security. Real estate was not allowed to remain in the possession of the bank more than three years. It was not forbidden to loan upon mortgage security; country banks were expressly permitted to loan upon land. The Mechanics' Bank also was allowed to loan to practical mechanics and manufacturers on property security up to one-eighth of its paid-in capital, but no loan was to be made for more than $\$ 3,000$, nor for longer than two years. Commercial operations were usually especially forbidden to the banks.

The monopoly of banking was not given to the chartered banks, though they enjoyed an advantage over unincorporated banks through their limited liability.

In 1806 a provision was introduced into the charter of the Mechanies' Bank requiring a reservation of one per cent. of its capital from surplus profits as a contingency fund. The principle became common by insertion in other charters, but it did not appear in all. -The fund was not applicable to any particular sort of liability, but to all in general.

In 1793 an act was passed making the forgery, or counterfeiting, or stealing, or knowingly passing such notes of any bank of the United States felony, and punishable as if goods of like value had been stolen. This simply made general the application of the law passed with reference to the Bank of Maryland. In 1797 the same was applied to the forging of checks and orders. Forgery on a bank was made punishable by death in 1806 , but this extreme measure was repealed after two years. No executions occurred under it. The much milder penalty of five to ten years in the penitentiary was fixed upon in $\mathbf{1 8 0 9}$.

The presence in Baltimore of the branch of the Bank of the United States had a salutary effect upon Maryland banks. The policy of the Bank of the United States was always to restrict as far as possible State bank circulation. This was accomplished by the frequent return of the State bank notes received over its counters. Naturally the State banks were strenuous in their objections to what they called the oppression of the "monster" bank, but on the whole the competition was beneficial in reducing issues and in fixing the habit of daily exchanges between the banks.

The directors were usually men engaged in mercantile pursuits who were broadly acquainted in business circles, and who knew the standing of parties liable to call for loans. To secure a broader territory from which to draw its patrons, the Farmers' Bank of Maryland adopted the 
plan of having a director from each county who might be able as an intermediary to extend banking facilities into his county, and who might also have the necessary knowledge of parties of his locality asking the bank for accommodations.

To prevent the banks from falling into the hands of a few individuals, a system of rotation of directors prevailed.

\section{Limitation on Loans to Directors.}

The directors, since they were usually men in mercantile or commercial business, especially appreciated banking facilities, and in many cases they were the ones who most needed discounts, yet there can be no doubt that they enjoyed especial favors at the bank, both in respect to rates and amounts of discounts. In the charter of the Farmers' Bank at Annapolis a clause was inserted which prohibited directors from ' receiving discounts on different terms from others. A second step was immediately taken placing a definite limit to the amount of discounts which directors might receive.

The board of directors for the transaction of business usually consisted of from six to nine, of whom the President was one; but four or five directors were allowed to constitute a board for making discounts only. Discounts were made on two days of the week, and two acceptable sureties were required on each paper. The maximum rate lawful for the banks to charge on loans and discounts was fixed at six per cent. per annum. If information was given and supported to the satisfaction of the majority of the board or quorum of directors that any director or other officer had in any way been concerned in taking usury, he lost his seat. After 1806 this provision was inserted in the charters.

In respect to discount time the provisions in the various charters varied, the country banks as a rule being allowed to discount for a longer time than city banks, and those discounting on real security for a longer time than those taking only personal security. There was no general law on either the time or rate of discounts, but after 1806 each was regulated by a clause of the charter. The Mechanics' Bank discounted notes or bills on personal security for 120 days; on property security the maximum time was two years. For the Hagerstown Bank the discount time was six months. In Baltimore at this time the major part of the loans were upon personal security. It was impossible to obtain collateral for any considerable portion of the business. Loans were made to some extent also upon real security; in the country most loans were secured either primarily or ultimately by real property.

\section{The Scotch System of Cash Credits Introduced.}

A feature peculiar to the Scotch banks was introduced into Maryland by the Farmers' Bank at Annapolis; this was the system of cash accounts. An account of this sort might be opened on application of any farmer, mechanic or manufacturer for sums from $\$ 100$ to $\$ 1,000$, 
whereby the party might draw or pay in any sum not less than $\$ 50$ at any one time, and on which settlements were to be made semi-annually, the party drawing eash to pay interest for what he might owe at six per cent. per annum, to be deducted on opening the account, and to be allowed interest on all sums returned from the time of payment. The party opening the account had to give good personal or real security. The directors were not obliged to lend money on such cash accounts to a greater amount at any one time, than one-fifth part of their capital. An attempt was made in 1804 to introduce this feature into the practice of both the Bank of Baltimore and the Union Bank. A special object of the formation of the Farmers' Bank was the encouragement of agriculture, and this was practically but another method of loaning upon real security, since most of the bank's patrons were farmers with little other available security.

\section{Payment of Interest on Deposits.}

The practice of paying interest on deposits was first introduced in America by the Farmers' Bank of Maryland. Deposits for a period of at least six months drew interest at the rate of four per cent. per annum; three per cent. was paid on deposits drawable on demand. The directors of the Farmers' Bank were empowered to issue notes on such deposits as they might judge prudent, up to the amount of the deposits. The practice of paying interest on deposits became general at a later time.

It has been impossible to ascertain the amount of the circulation of Maryland bank notes at this time. The United States Bank and its branches were efficient in keeping State bank issues in check; also the prohibition from issuing notes of a less denomination than $\$ 5$ acted as a restriction upon issues, in that it kept an amount of small coin always in circulation.

It was usual for the banks to try to maintain an amount of cash on hand equal to one-third of their circulation. This proportion was familiar from the custom of the Bank of the United States and of the Bank of England. There was no. legal requirement in Maryland fixing the amount to be held. The directors were personally liable for dividends declared in excess of profits.

\section{A Period of Expansion, 1810-1818.}

The development of State banking in Maryland proceeded slowly and naturally from the establishment of the Bank of Maryland in 1790 with $\$ 300,000$ capital, up to the end of 1807 , when the total banking capital was $\$ 7,450,000$, including $\$ 500,000$ in the branch of the United States Bank at Baltimore. There had been $\$ 5,500,000$ of this total actually paid in.

From 1806 to 1810 Maryland industries were in an unsettled condition, owing to interruptions by the belligerents of Europe. Trouble- 
some interference, the Berlin and Milan decrees of 1807, and the embargo of 1807, had almost ruined Maryland's export trade. In March, 1809, the embargo was raised, and conditions immediately improved; exports jumped from $\$ 2,700,000$ for 1808 to $\$ 6,600,000$ for 1809 . This period of prosperity was only checked by the War of 1812, and after its termination Maryland trade assumed its normal proportions.

This state of affairs is reflected in the banking history. No increase of banking capital occurred during the years 1806-9. In 1810, coincident with a revival of trade, a period of rapid expansion began, which extended over eight years.

During these eight years banks were located in the industrial centers of the most advanced counties of the State; fourteen of the nineteen chartered during these years were in the counties. There was no increase in the amount of the nominal capital of the old banks.

The increase of banking institutions began in 1810, when the Assembly granted five new charters for banks, of which four were to be located in Baltimore, the fifth at Elkton, in Cecil county. The Baltimore banks were the Marine, the Commercial and Farmers', the Farmers and Merchants', and the Franklin, and they embodied a nominal capital of $\$ 2,700,000$. All of these banks organized under articles of association before applying for charters. The Commercial and Farmers' Bank had been under discussion for some time, and its organization had been decided upon in order to bring banking advantages nearer to the merchants in the upper part of the town. Subscriptions to its stock were well advanced when notice of the projected establishment of the other banks was sprung upon the public by the publication of their articles of association. The State became a subscriber to the stock of each of them.

The discussion evoked by the organization of these apparently uncalled-for banks was not, however, without fruit. To prevent a repetition of this occurrence the General Assembly immediately passed an act "to prevent the increase of banking companies," by which persons were prohibited from associating for the purpose of forming a banking company without first applying for a charter. Each person acting as commissigner for such parties was made liable to forfeit $\$ 2,000$, and each subscriber $\$ 100$. The effect of this was to enable the Assembly to control completely the increase of banking companies, and thus to enable them to check at the start the mania which was growing apace in other States.

Great alarm was occasioned in the State in 1812 , when it was found that a company had dared to organize under articles of association. The City Bank of Baltimore was formed as a private partnership in 1811 , and over $\$ 800,000$ of its stock had been subscribed before it asked for a charter. In 1812 one was granted which fixed the capital at $\$ 1,500,000$, of $\$ 25$ shares, of which 4,000 shares were reserved for the State and 27,600 shares were distributed among the counties for sub- 
scription. The remainder was taken in Baltimore. There is no evidence that the penalty for violation of the law was imposed upon them.

No other banks were chartered in Baltimore until 1835. In 1813 the monopoly of banking in Baltimore was conferred on the banks then existing.

The banks which were organized in the counties were largely to assist the agricultural class, though manufacturing was becoming an important interest, and, especially in the western counties, mining and lumbering operations had already assumed large dimensions.

The Elkton Bank was started with the primary object of aiding the flour trade of that town. And thus special circumstances in each case were of influence. Between 1810 and 1817 sixteen banks were established in twelve counties, having a capital of $\$ 3,450,000$. Three of these, having a total capital of $\$ 550,000$, did not open for business.

From seven banks in 1809 , with a nominal capital of $\$ 7,450,000$, of which $\$ 5,500,000$ had been paid in, the number had risen in 1817 to twenty-two, whose nominal capital was $\$ 14,750,000$, of which $\$ 8,500,000$ was paid in. About $\$ 500,000$ had been withdrawn by the closing of the branch of the United States Bank at Baltimore.

\section{AN INDUSTRIAI EXPERIMENT BY THE BANKS; RECHARTER AND Taxation.}

The period of duration of all the charters granted by the State, except that of the Bank of Maryland, was specified; 1815 was the time of expiration of all the charters given before that date. When the question of recharter arose, Maryland was in the heat of the internal improvement discussion. The popular favor of this policy was strong, and roads, bridges and canals were being planned on a broad and systematic scale to bring all sections of the State within easy communication of their port, Baltimore.

Another circumstance opened up a course of action. A large element of the people was hostile to the banks, either owing to fear of their power or to personal reasons, or to dread of conditions in Maryland similar to those in other States, concerning the horrors of which the periodicals of the day expatiated with the utmost vigor. The people generally agreed that the banks should pay to the State some return for the considerable privileges bestowed upon them. Under these circumstances it was decided to harness upon the banks the construction of some of the new roads in return for the continuation of their expiring charters.

Early in 1813 there was passed an act "to incorporate a company to make a turnpike road leading to Cumberland, and for the extension of the charters of the several banks in this State, and for other purposes." By this act the charters of all the banks in the State were extended to November 1, 1835, upon two conditions-first, that the banks of Balti- 
more and of Washington county subscribed for as much stock as would raise a fund necessary and sufficient to complete the road to Cumberland; secondly, that all the banks of the State paid annually during the continuation of their charters under this act $\$ 20,000$ into the treasury, to be used as a fund for the support of county schools and to be divided equally among the counties. Subscription to the road stock and con. tribution to the school fund were to be made in proportion to capital actually paid in, or that might be paid in from year to year. Managers for the road company were to be chosen by the banks from their stockholders at the rate of one manager for every $\$ 25,000$ of stock subscribed, though each bank subscribing was allowed to appoint one manager. The charters of banks not complying with the terms of this act were not extended. Unless the banks expressed their agreement to it before October 1, 1813, it was to cease to be effective.

The banks did not agree to the proposition, but certain adjustments were made and embodied in a supplement to the preceding act, which passed the Assembly at the December session of 1813, and received the approbation of the banks.

The leading points of difference between the two acts were :

1. The number of banks subscribing to the road was increased. It now included the banks of Baltimore, the Hagerstown, the Conococheague and the Cumberland Bank of Alleghany.*

2. The President and directors, for the time being, of these banks were specifically incorporated "The President, Managers and Company of the Cumberland Turnpike Road."

3. The charters of the banks were continued to January 1, 1835.

4. The annual tax of $\$ 20,000$ for the school fund, apportioned among all the banks of the State, was changed to a tax of twenty cents on the hundred dollars of capital paid in, or paid in thereafter. This provision was to come into operation January 1, 1815. The banks could exempt themselves from this tax by paying to the Treasurer before January 1, 1816, $\$ 200,000$.

5. The fund was pledged for the establishment of a general system of free schools throughout the State, and was to be equally divided among the counties. This fund was to be kept separate from the general funds of the State, and was to be invested, together with the dividends from it, in the shares reserved for the State in the Commercial and Farmers' and the Mechanics' Banks of Baltimore, and an annual report thereof

* It is recorded that the General Asssembly of the State of Maryland autborized the incorporation of the "Cumberland Bank of Allegany" in 1811, and that it began business early in the year 1812. It is also related that when the bank issued its notes, by some misunderstanding as to the orthography of that much-abused word "Allegany," the engraver spelled it "Alleghany," and as the notes had been put in circulation before the error was discovered, in order to avoid the expense of new plates, as well as the inconvenience of calling in the circulation, an act was secured at the June session of the Legislature, in 1812, changing the name to "The Cumberland Bank of Alleghany," which form of title it held to the end of its career.-Robert Shriver, $2 \mathrm{~d}$ Ann. Conv. Md. Bkrs. Assn., Cumberland, June 3, 1897. 
to the General Assembly was required. The road became the property of the banks.

Banks accepting these provisions were continued until 1835; those neglecting them forfeited their charters. On the other hand, the State pledged itself to the banks to impose upon them no other tax during the continuation of this act, and to the banks of Baltimore it promised to grant a charter to no other banking institution to be established in the city or precincts of Baltimore before January 1, 1835.

The banks did not regard the compulsion to subscribe the road stock as a serious burden. It was expected that the tolls would be of considerable amount, and that after a few years the stock would be a valuable resource. All the banks of the State agreed to the act within the specified time limit or shortly thereafter, and were absolved from the penalty of forfeiture of charter.

In 1821 the banks expressed their willingness to undertake the construction of the Boonsborough and Hagerstown turnpike road. This same idea was frequently acted upon thereafter.

The idea of a tax on bank stock to raise a school fund was not new in 1812. In 1810 a bill to tax canal, road and banking corporations for this purpose passed the House of Delegates, but was defeated in the Senate. The tax on bank stock laid by the law of 1813, Chapter 122, continued in force until 1863, and yielded a fund varying in amount from $\$ 30,000$ to $\$ 40,000$ per annum. No other tax was imposed up to 1835, at which time the act expired.

\section{Suspension of Specie Payments in 1814.}

The suspension of 1814 was a general one, but the causes leading up to it were of especial force in Maryland. The demand for specie was increased by the commercial restrictions caused by the blockade of United States ports. Maryland exports, from $\$ 6,833,000$ in 1811, dropped to $\$ 3,787,000$ in 1813 , and $\$ 248,434$ in 1814 . The sudden drop in Maryland's exports of produce in 1814 necessitated other modes of payment for her imports. The Eastern States, too, had imported largely, and specie for repayment was required. The enlargement of the bank circulation in the Middle States had given the Eastern States an advantage; paper money replaced the specie circulation. Excessive issues were called forth by the loans to the National and State Governments, which were necessitated by the war.

The restrictions upon the banks from making large loans to any State without the consent of the General Assembly were removed, and the banks were allowed to loan Maryland up to the amount of their actual capital, and to the United States up to one-third of this amount.

\section{Lack of Proper Restraint on Circulation.}

The transmission abroad in 1811 of over seven million dollars which had been invested in the Bank of the United States, had perhaps some 
influence. The expansion of the State bank currency to fill up the place made vacant by the expiring bank was of much greater importance. The rapid multiplication of banks and the loss of the centralizing influence of the United States Bank almost destroyed entirely the degree of consolidation and unity which had been the effect of the creation of the United States Bank. The banks of the leading commercial eities now exercised this function, but more weakly, since the number of centers was larger and the relations to the other banks were not so stringent. Each bank now dared to issue more than formerly; the facility of getting discounts was increased, and the demand for them became greater. There was an abundance of paper money, but little gold and silver; prices were high. No resistance could be offered to the heavy demand for specie from the Eastern States and Canada, and the South and Southwest, which had been remitting in specie to the Middle States, "closed the profitless traffic." The alternatives were a restriction of discounts and circulation or suspension of specie payments. The following incomplete returns illustrate these facts:

\begin{tabular}{|c|c|c|c|c|}
\hline YEARS. & $\begin{array}{l}\text { No. of } \\
\text { banks. }\end{array}$ & Capital. & Circulation. & Specie. \\
\hline January $1,1811 \ldots .$. & 6 & $\$ 4,895,202$ & $\$ 2,730,000$ & $\$ 850,000$ \\
\hline January $1,1815 \ldots \ldots$ & 17 & $7,832,002$ & $3,970,000$ & 740,000 \\
\hline January $1.1816 \ldots \ldots \ldots \ldots \ldots \ldots$ & 20 & $8,406,782$ & $5,615,000$ & 760,000 \\
\hline
\end{tabular}

Political conditions determined the turn of affairs at this time. During 1814 the British army directed its operations against the Middle and Southern States especially; in August Baltimore was threatened. Such alarm was occasioned that the banks suspended and had their specie conveyed to places of safety.

Baltimore bank notes remained at par or very small discount in Maryland; the notes of the country banks depreciated somewhat more. Immediately after the restoration of peace in 1815, confidence in the bank notes began to rise. In February and March, 1815, Maryland notes generally, excepting those of three or four country banks, were at par within the State, and discount at Philadelphia and New York was only two or three per cent. Considerable pressure was brought to bear on the banks at this time to resume specie payments, but exchange was still high, and besides some of the country banks had extended their circulation to dangerous limits. Altogether they were unwilling to resume.

The resumption of specie payments took place on February, 20,1817.

Preparation for resumption and anticipation of the power of the United States Bank compelled the State banks to strengthen and to restrict issues. This they did by a very severe curtailment of discounts. In January, 1816, the notes in circulation of Maryland banks anounted 
to $\$ 5,615,000$. Within the year they were reduced by $\$ 2,000,000$, or more than one-third. The deposits suffered slight diminution, so that the restriction of discounts must have been at the same rate. The result of this would inevitably have been widespread commercial disaster, but the Bank of the United States met the demand. Within two months its discounts ran up to $\$ 20,000,000$, and by October 31,1817 , they had reached $\$ 33,000,000$. The passage to specie payments, therefore, caused little inconvenience to Baltimore banks, almost as much specie being deposited as was withdrawn.

The plethoric state of the currency was reflected throughout 1815 and 1816 by the high prices. The abundance of money was a matter of comment. All specie disappeared from Maryland at an early date, and the very serviceable regulation, which prohibited the issue of notes of denominations under five dollars, was of necessity repealed in 1814. Notes were the sole currency, even for small change,* until November, $181 \%$.

It is impossible to find out the rates of dividends declared by the banks during the suspension, but the quotations of stock are a good indication of its profit. The quotations for Baltimore bank stock for September 2, 1815, show that the selling price of the shares of nine banks was at an advance of 28.19 per cent. over the price at which the stock was paid in.

The weakest of the country banks, whose notes were greatly depreciated, continued to pay eight per cent.

At the time of suspension specie commanded a premium of ten to twelve per cent. in Baltimore; in August, 1815, the premium had risen to twelve to seventeen per cent.; by November it was nineteen to twenty-two per cent. advance; in August, 1816, it was fourteen to fifteen per cent. premium; after this the premium rapidly declined.

Maryland bank notes fell to five to ten per cent. below par immediately after the suspension. As soon as peace had been declared in 1815 , they recovered and rose to two to five per cent. discount, and soon stood at par in Maryland. By August, 1815, they were at par at home, and at two and a half per cent. discount in Philadelphia and Richmond. In November they were at three per cent. discount in Philadelphia and nineteen to twenty in Boston. Nearly all Maryland notes circulated at par or small discount in Maryland after the first months of 1815. The mass of paper from other States rendered the situation inconvenient and confusing. The notes of each foreign bank had their rates of exchange, varying from time to time, and with the distance of the place of issue. The ignorance of the condition of many distant banks and of the value of their notes, gave rise to another expense upon the public, the note broker. Their service was the purchase and exchange of the unknown and useless notes which were in circulation, but the cost of

* The lowest denomination issued in Maryland was six and one-fourth cents. Niles, April 11, 1818. 
this service was an exorbitant one. The character of the men who entered this pursuit was usually such that the evil possibilities of this office were carefully developed. Endeavor was made to crush them out of existence by expensive licenses. In 1819 Maryland passed a law fixing the license at $\$ 500$ per annum, and requiring bond to the amount of $\$ 20,000$ and an oath to act without fraud and collusion. However, their service was a real one, and without them troubles increased, so that a milder law was soon substituted.

\section{The Fivancial Crisis of 1818.}

The Bank of the United States, immediately after its charter, began to discount freely in order to relieve the pressure upon the State banks. Within eight months after the resumption the discounts of the bank reached $\$ 33,000,000$. The Baltimore branch discounted very freely, and at this place alone the discounts were more than $\$ 8,000,000$.

The condition of the Bank of the United States became a matter of great concern, and it was feared that the reckless administration of the branch at Baltimore would bring it into further peril. Its notes in circulation amounted to $\$ 8,000,000$; its specie was low, never more than one-eleventh of its cash liabilities. Under these circumstances a policy of restriction was decided upon July 10, 1818. Before January, 1820, the discounts of the bank had been reduced $\$ 10,000,000$. The State banks necessarily followed its lead. The Baltimore city banks did not extend their circulation to any considerable degree during the later months of 1817 and the first half of 1818. The restriction which had been begun before the resumption of specie payments was continued during the time of the inflation. The large discounts of the Baltimore branch bank rendered this the easier. During the year 1817 the circulation of the Baltimore banks was reduced from $\$ 2,727,000$ to $\$ 1,742,000$, or about forty per cent.

The report became widely spread early in 1818 that the Baltimore banks were in a critical condition and that a suspension of specie payments was imminent. During the year 1817 the cash liabilities had been diminished from $\$ 4,835,000$ to $\$ 3,440,000$. The banks regarded themselves as sound. The wide extension of discounts at the Baltimore branch bank had likely created the impression that all Baltimore banks had out much paper. In fact, there seems to have been little danger of a suspension. The condition of some of the country banks was different. Most of them were solvent, but at least three had practically never redeemed their notes in specie since 1814.

The irregularities in the administration of the Baltimore branch bank were upon discovery inmediately examined into, and the amount of its discounts was decidedly lessened. Baltimore State banks continued their restriction more gradually throughout $1818,1819,1820$ and 1821.

The drain upon the banks for specie, caused by the more active demand for it North, impelled them to a policy of restriction. The 
brokers were always sensitive to any slight advantage to be gotten by an exchange at the bank of notes for specie. Throughout 1818 notes were returning to the banks for redemption and their specie was being drawn out for sale at an advance. To prevent a decrease of the specie reserves, the Legislature early in 1819 attempted to control the natural rates of exchange. It was made unlawful to buy or sell gold or silver coined for a greater sum in notes than the nominal value of such notes. The penalty for violation was forfeiture of double the sum of gold or silver bought or sold, or imprisonment not exceeding one year. Im. porters of specie were excepted from the action of this provision. These regulations, so far as they referred to the sale of foreign gold and silver coin, were repealed in 1823. The law was, of course, unable to control such transactions; its natural effect was to add to the price compensation for the risk incurred.

\section{Condition of the Banks after the CRises of 1814 aNd 1818.}

The period of 1814-20 resulted in great loss to Maryland banks and effected a reduction of banking capital both by the enforced insolvency of some and by a diminution of the capital of others. The losses of nine country banks and of one city bank resulted in insolvency; other Baltimore banks were compelled to reduce their capital stock.

The locking up of their resources in real estate, due to the low price of grain and consequent agricultural depression which compelled the banks to take securities in payment of money loaned, kept the majority of the country banks from a permanent resumption of specie payments in February, 1817. Most of them resumed temporarily, but were unable to stand the strain. They had issued proportionately more than the city banks. At the same time they were unable to convert their resources into a ready form. The result was that they were in a state of chronic suspension from 1814 to 1820. Throughout 1817-20 their notes were much below par, ranging in discount from ten to ninety per cent., so that even brokers refused to buy them.

In February, 1819, steps were taken to compel these banks to pay specie or forfeit their charters, by the passage of an act which provided that persons obtaining judgment for debt against banks might demand interest at six per cent. per annum from the time when payment was requested. Upon refusal or neglect to pay in specie, any county court might order to be issued a scire facias to show cause why its charter should not be declared forfeited. The court, after investigation, might declare the charter forfeited, and might appoint three commissioners to settle up the affairs of the bank. The interests of other creditors were to take precedence of those of stockholders. Notes of the bank were receivable by the bank for debt at their nominal value. The commissioners were allowed a commission not exceeding five per cent. Banks which had paid specie for their notes from May to October preceding the passage of the act, were exempted from its force until January, 1820. 
Early in 1820 the act was suspended until the beginning of the year 1821 . The suspension of the act protracted for a year the existence of the weak banks. At the end of 1820 eight of the thirteen country banks with a total capital of $\$ 982,622$ signified to the Legislature their intention of closing.

It is impossible to estimate the loss from the failure of these banks. The liability of the stockholders for the amount of their shares most likely availed little, since a large part of the stock had been paid in stock notes, which, in case of failure, were liquidated by the return of the certificates of stock. Thus all loss above, perhaps, the first installment of eapital which was required to be paid in specie or the notes of specie-paying banks, was thrown upon the note holders and depositors. The acceptance of stock of a bank in payment of debts due to it was legalized for the Bank of Caroline, and for the Planters' Bank of Prince George's County. The certificates of deposit of any bank were also made a lawful tender to that bank for debt.

The resources seem to have been of little value in most cases, so that it is probable that considerable stock was lost. Generally note holders suffered much in disposing of their notes at a sacrifice in haste to realize upon them immediately after failure was openly acknowledged.

During the period 1814-20 the Baltimore banks were also undergoing severe losses. The traceable causes of this are found to be maladministration, bad practice and poor investments, operating singly or together. The banks generally were considerably affected by losses through the practice of granting renewals without proper consideration of the changes in the financial ability of the endorsers.

The third cause was general in its effects, and it inflicted loss proportionately on all who were compelled by the law of 1813 and subsequent laws to subseribe to the various improvement schemes. These subscriptions amounted apparently to over $\$ 1,500,000$. The cost of building the roads was always much greater than the computation. They were in no sense a good investment for the banks. The best of these stocks paid no dividends at all for a number of years, and then perhaps they paid two or three per cent. per annum, seldom more; after a few years they ceased to pay at all. This is the history of nearly all of these improvement companies in Maryland.

\section{An Illustration of Reckless Banking.}

The only failure which occurred in Baltimore at this time was that of the City Bank, which failed in 1819. Some account of its affairs will illustrate the extreme form of reckless banking. The Cashier had entire control of the concern, and ran it according to his own ideas. The causes of loss were mainly negligence and embezzlement. Many accounts, especially the largest ones, were not posted up; nearly every one was incorrectly kept; in some cases no account at all was on the books. Individual accounts amounting to hundreds of thousands of 
dollars were not settled for three or more years in some cases. Under such careless supervision embezzlement was easy. All the officers and clerks (except one) had received large discounts; the directors also received discounts without proper security. The overdrafts amounted to $\$ 426,000$.

The immediate occasion of the failure was a call upon it by the branch of the United states Bank at Baltimore, which it could not meet. A run upon it was the result. It extended to other banks, but all resisted it ably except the City Bank, which could only pay its notes under five dollars in denomination in specie.

The assets included the following loans: Cashier, $\$ 166 ; 548$; his friend, $\$ 185,382$; clerk, $\$ 30,000$; another clerk, $\$ 15,082$; and another, $\$ 6,324$. In the $\$ 571,065$ of discounts considered well secured, $\$ 250,000$ or $\$ 300$,000 is included which, at the time of failure, was overdrafts of directors or others. One account amounted to $\$ 97,000$. These were arranged for before the statement to the stockholders was made. The committee estimated the value of the assets at $\$ 760,310$, and the debts due by the bank at $\$ 340,310$, which left a remainder for capital of $\$ 420,000$. The loss of $\$ 400,000$ by the stockholders was the greatest one. The notes were ultimately redeemed, though many were sacrificed through alarm immediately after the failure at rates ranging from ten to twenty per cent. discount. The bank very soon after the failure issued certificates bearing interest at six per cent. per annum in satisfaction of its notes deposited. The loss of interest was of considerable amount; over fifteen years were consumed in the settlement; in 1834 it was continued to 1840 to wind up. A part of the stockholders desired to continue the bank, but it was finally decided to close. Effort was made to convict and punish the embezzling officers, but after a protracted contest it was decided by the court that the action of the defrauders was not punishable.

None of the other banks of Baltimore were driven by their losses to suspension. However, very considerable reductions of capital occurred.

The total loss of banking capital by reduction was more than oneseventh. The State lost as stockholder about $\$ 64,000$, and besides other stock became unproductive. There were doubtless other losses of considerable extent which did not become public, and which were made up from profits instead of a reduction of capital being made.

After the critical period of 1814-20 almost one-half (nine out of twenty-one) of the Maryland banks failed, representing a capital of $\$ 1,821,162$, or more than twenty-two per cent. of the entire active capital. The total loss of capital by failures and reduction was about $\$ 3,000,000$, or one-third of the paid-up banking capital.

Capital Paid in Stock Notes.

It was during the expansion of 1810-17 that the practice first became prevalent in Maryland of paving subscriptions to the stock of banks 
with stock notes. It was charged that this occurred in the case of every bank, except two, which was established in Maryland between 1811 and 1818. The action of these banks in the crises of 1814 and 1818 indicates their weakness. A part of the capital, usually about one-third, was required by the charters of these banks to be paid in gold or silver or the notes of specie-paying banks, before they could begin business. No manner of State inspection was provided to insure obedience to the law. The payment of the remainder of the stock was left entirely in the charge of the directors. The plan followed was briefly this : Allowing that the first installment of the capital was, as required, paid in specie or the notes of specie-paying banks, then the subscriber could obtain discounts to the amount of his paid-up stock; with this he could pay his second installment, and thus on until his entire subscription was paid. If the bank fared well, he enjoyed dividends on the whole amount of his stock ; if it failed, he could absolve his indebtedness to it by paying in his certificates of stock. Thus he had all to gain, and was irresponsible for losses.

The bad condition of some of the country banks from 1816 to 1820 may be ascribed to two chief causes : first, their weak organization; and, second, their loans on real estate. Loans had been secured by farmers during the inflation of 1816-17; in 1817 the prices of agricultural products fell, and the farmers were unable to meet their obligations. The banks, entering upon a restrictive policy, were anxious to retire as much paper as possible; renewal of loans was refused and in many cases the borrower became bankrupt. Much real estate fell into the hands of the banks for which at that time the price was low and ready sale could not be found. With their resources locked up in real estate, they were unable to meet their cash liabilities, and were in almost continual suspension from 1817 to 1820 . Their paper was either at a great discount or ceased to circulate altogether.

In all the banks reforms were needed. Directors and officers were still able to use their positions to secure loans and discounts in extraordinary amounts. The administration of banks at this time was practically controlled by the Cashier. The President was largely a nominal officer, and the one elected to it was supposed to devote but a small portion of his time to its duties. A change in this respect began in 1821, when the Union Bank decided that it would be conducive to better management to have a President who would devote to the office all the time required, and who should receive for his services proportionate recompense.

Considerable danger and loss resulted to the banks from their laxity in permitting the renewal of notes. Some of the charters limited discounts upon real security to a certain percentage of the capital, usually one-eighth; in others no limitation is mentioned. Aside from this, it was the custom among the eity banks to discount chiefly on personal security. The discounts on personal security were to those on real in 
the ratio of 9-12 to 1 . Two names were uniformly required on each paper, one of which had to be of undoubted credit. The banks were too accommodating in permitting renewals; it was common for paper to run four or five years without change in the endorsement. In a time when financial matters undergo such violent convulsions as between 1814 and 1820, the danger of such a practice cannot be exaggerated. Endorsers who were sound in 1814 were very unsound in 1818. The losses of Baltimore banks on bad paper between 1816 and 1821 were enormous, and most all of the banks were seriously affected in this way.*

\section{Banks Purchasing Their Notes at a Discount.}

The varying rates of depreciation of bank notes opened up to the banks the opportunity of buying up their notes at the lowest possible rates. For this purpose special arrangements were entered into with the note brokers, and it was not unusual for a bank to have out agents for this purpose. After 1818 it became illegal for any one to buy, sell or exchange any Maryland bank notes for a less sum than their nominal value, or to employ for the purpose any broker or agent. The forfeit was in each case double the amount of gold, silver or notes so exchanged. The law was ineffective and simply added a risk charge to the price asked for such notes. The practice was common down to the passage of the National Bank Act.

Counterfeiting was rendered easy and successful by the great number of banks, each of which had a different style of note, so that unless one were familiar with the particular characteristics of the notes of each bank theimposition of false notes was easy. The poor quality of paper used and the simple engraving made them easy of imitation and increased the temptation to counterfeit them accordingly. Each newspaper usually contained a list of the counterfeits for the warning of the public. In 1827 the penalty for knowingly passing forged or counterfeit notes was fixed at five to ten years in the penitentiary for the first offence, and ten to twenty years for the second.

The Baltimore banks were driven to stop receiving on deposit depreciated bank notes. They were not allowed by law to receive them

* The following example will illustrate the power of the Cashier at this time and the manner in which favorites were accommodated. In a report of the condition of the Union Bank on August 26, 1819, among the resources was listed an item of $\$ 719$,238.59, made up as follows :

Advanced by the Cashier without the knowledge of the directors $\$ 100,000.00$

Doubtful paper........................................... $357,502.39$

Overdrafts ascertained.................................... 151,293.52

Deficiency in funds unaccounted for...................... 110,442.68

$\$ 719,238.59$

Almost the entire amount proved an utter loss. The bank was saved for the time being by loans from its friends, amounting to $\$ 560,000$ and by passing its dividends. It finally resulted in loss to the stockholders by a reduction of the capital, amounting to $\$ 600,000$, or one-fourth of the whole.-Report to the stockholders of Union Bank for 1820 and 1830. Md. Laws, 18\%1, ch. 166. 
at less than their nominal value, while the risk of the solvency of the issuers and the trouble and expense of collecting and sending them home for redemption fell upon the banks. Demand for specie, too, was in many cases the cause of unpleasant relations. The notes, not only of Virginia, Pennsylvania, District of Columbia and other distant points, but also of some Maryland country banks and those of the United States Bank, if payable at distant points, were refused. This action tended naturally to increase the discount upon such notes, and to retard their circulation; the only recourse was to place them in brokers' hands. The banks suffered materially by refusing them.

Not until June, 1823, did the bainks of Baltimore begin again the receipt of all Maryland bank notes on the same terms as their own, and at the same time Pennsylvania and Virginia notes were received on deposit.

It has been said that the charters of the country banks established between 1810 and 1818 were of less strict nature than the earlier ones. Some of these points of difference will now be mentioned. Usually onethird to one-fourth of the first installment only of the capital was required to be paid in specie; the amount of the first installment varied from one-third to one-half of the capital. The payment of subsequent installments was left entirely with the directors, and thus an opportunity was offered for the use of stock notes. In one case, that of the Centreville Bank, to avoid this the charter required the whole capital to be paid in specie.

The State became a subscriber to the stock of two of these country banks, viz., the Elkton and Hagerstown Banks, but usually the provision was made that whenever the State desired to take stock it might increase the capital of the banks and subscribe. Until subscription was made the State appointed no directors, and usually required no annual reports, since it was only as stockholder that it exercised this supervision. Only five of these country banks were required to send reports of their condition to a State officer. However, by a resolution of the General Assembly, passed in 1818, all the banks within the State were required to transmit an annual report in December to the Assembly.

In some cases even the nominal limit of debts to twice the amount of capital paid in was omitted, and no limit at all was imposed. These were allowed to discount on property security up to one-fifth to oneeighth of their actual capital. The Mechanics' Bank of Baltimore allowed discounts on the security of stock up to three-fourths of the stock paid in. As a consequence of their discounting largely to farmers upon real security, the discount term was increased. Only two were limited to sixty-day discounts; for one the limit was four months, for nine it was six months, for two there was no limit.

Directors were forbidden by most all of the charters to receive discounts on different terms from others. The usual limit of discounts to directors was $\$ 1,000$ in one week, or a total of $\$ 5,000$ in all. The Pres- 
ident and directors were eligible for re-election without limit in the Bank of Somerset and Worcester. In the five charters which were granted in 1817 and 1818 suspension of specie payments rendered the charter void. The insertion of this provision was a result of the continued suspension of Maryland country banks after the general resumption of February, 1816. Six per cent. was fixed as the legal rate of interest and discount, and usury was forbidden; however, interest calculated according to Rowlett's Tables was made valid.

\section{Issue of Notes of Small Denomination.}

The issue of small notes was uniformly prohibited by the charters, but this became a matter of special legislation. In 1821 a general law was passed on this subject, called forth by the violations of charter provisions and previous legislation, which made it unlawful under penalty of $\$ 20$ fine, for any bank to issue or pay out notes or bills of a less denomination than $\$ 5$, or of a denomination intermediate between $\$ 5$ and $\$ 10$. Persons passing such notes of any incorporated or unincorporated company were liable to a fine of $\$ 5$ for each offence. Early in 1820 the banks were freely supplying specie dollars in place of the small notes, but the silver was immediately displaced by notes from the District of Columbia. Finally in September, 1820, the banks decided to receive for five days all notes under $\$ 5$, and thereafter neither to reissue them nor issue new ones, and the townspeople in a general meeting agreed to assist in improving the currency by not circulating such notes.

"An act to impose a tax on all banks or branches thereof in the State of Maryland not chartered by the Legislature," was passed in 1818. It enacted that any bank establishing an office or branch in the State without first obtaining the State's authority, should not issue notes except upon stamped paper procured from a State officer and of the denominations $\$ 5, \$ 10, \$ 20, \$ 50, \$ 100, \$ 500$ and $\$ 1,000$, on which a tax of $10,20,30$ and 50 cents, $\$ 1, \$ 10$ and $\$ 20$, respectively, was imposed; but $\$ 15,000$ annually might be paid in lieu of the above tax. The penalty for establishing such an office was $\$ 500$, and $\$ 100$ was the penalty for circulating notes of such banks unstamped.

The direct object of this law was the taxation of the branch of the Bank of the United States located at Baltimore. The law was urged both on general grounds of hostility to the bank and on account of opposition to it by the State banks, who feared its competition and restraining influence; besides, the opinion was general that an outside bank should not be permitted to enter the State on more favorable terms than the State banks.

The law was declared unconstitutional by the Supreme Court of the United States in 1819 in the familiar ease of McCulloch vs. Maryland, on the ground that it interfered with the execution of one of the implied powers of the Government. 


\section{Speculative Banking Restricted.}

Several restrictive measures were the outcome of the speculative character of banking from 1814 to 1820 . The use of proxies in voting was manipulated to the advantage of ring or machine management, and fraudulent proxies were used. The correction of this abuse was aimed at in the law of 1819 , chapter 134, which forbade the use of proxies to all except the infirm and those living more than ten miles away. No officer, clerk or director could act as proxy, and in any case power of attorney was necessary. Judges of election permitting violation of these provisions were liable to $\$ 2,000$ fine and imprisonment for a year.

Directors were not entitled to receive any accommodations on special terms, and no one could be elected director of a bank whose partner was a director of the same bank. This law was restricted to Baltimore banks, and the assent of the stockholders was necessary to give it force. This it received.

The frauds which were exposed in the management of the City, Union and Mechanics' Banks and the escape of the parties from punishment, led to severe laws on this subject. The law of 1819 fixed the penalty for embezzlement by a bank officer at one to seven years in the penitentiary; for fraudulent abuse of trust the punishment was one to ten years in the penitentiary. In 1821 the penalty in each of these cases was made five to fifteen years in the penitentiary.

\section{The Crises of 1825 and 1828.}

After 1820 there came a reaction from the period of speculation which had preceded. The weak banks passed out of existence; the survivors enjoyed a long period of prosperity without violent disturbance. By 1830 they had recovered from the losses of 1816-21. The United States Bank exercised a controlling influence over them and rendered their operations more guarded and regular. The State banks followed more slowly the restrictions and expansions of the National bank. In Maryland there was not a time in the decade 1820-30 at which the banks had dangerously expanded.

The panic of 1825 was the result of a general spirit of speculation, which reached its greatest magnitude in Europe; in America its special feature was speculation in cotton. An increased tariff also heightened the expectation of prosperity. Demand for credit stimulated the creation of banks again, especially in New England, New York, Pennsylvania and the West. The currency became considerably inflated. Maryland was comparatively affected but little, since the speculation in cotton in this district was not great. Her banking institutions did not receive a single addition. The circulation of the Baltimore banks was increased but $\$ 240,000$ during 1824 , the year of inflation. Within the next six months there was added about $\$ 150,000$, but nothing extreme occurred. 
When the reaction began, about September, 1825, by the fall in the price of cotton and other products, general distress prevailed. Many failures occurred all over the Union, but Maryland suffered proportionately less than any other State. The circulation was uniform and adequate. The contraction by the State banks was not sufficiently rapid to produce disaster; in fact, the discounts of Baltimore banks were greater in January, 1826, than for a number of years preceding, reaching $\$ 3,047,410$. By January, 1827, the amount had been diminished by $\$ 70,000$ by curtailing issues. The entire circulation of Maryland banks was in good credit; none of it was at a discount. This was largely the effect of the frequent settlements required by the United States Bank. A considerable part of the circulation was coin; very few notes under $\$ 5$ in denomination were current, and these were chiefly Virginia bank notes.

The disturbance of 1828 was largely resultant from an extension of circulation by the Bank of the United States. By April, 1828, the money market had become very close, and much specie was being exported. The banks of Maryland had already been compelled to begin a reduction of discounts. At the same time they ceased to receive on deposit, or for the payment of notes, the bills of all banks which were not received in Philadelphia and New York. The quantity of specie at the command of the country banks was so limited that already the redemption of their notes was in many cases a task. The Baltimore banks relieved the stringency as far as lay in their power. In January, 1828 , the circulation and deposits amounted to $\$ 2,996,350$; by January, 1829 , they had increased to $\$ 3,055,980$. The periods of greatest depression were May, 1828, and September, 1828, to July, 1829. By the end of 1829 business had revived and money seemed plentiful; a large part of it was silver.

\section{Banking Expansion of 1829-36.}

Several causes were operative in producing the expansion of banking in Maryland which occurred from 1829 to 1836 . In the first place, the counties which had been gradually progressing during the decade 1820 30 had been practically without banking facilities since the wholesale fall of the country banks in 1819-21. This field was now a ripe one for entrance. Secondly, no new banks had been established in Baltimore since 1812; the monopoly of banking in that city had been conferred on the banks then existing in return for their agreement to build a road from Baltimore to Cumberland. This monopoly expired in 1835. During this period of twenty-three years Baltimore manufactures had developed steadily, and in 1835 works were in construction or contemplation destined to make Baltimore the mart for a wide extent of territory. The improvement in transportation was opening up new industrial possibilities, and Baltimore was zealous to render effective her strong natural position. In 1830 the ery for more banking capital 

CA!IFOP:! 
had already become a strong one. The whole State was dependent for bank accommodations upon twelve banks, of which eight were. in Baltimore. The total capital for the State was $\$ 5,455,000$, exclusive of $\$ 1,500,000$ to $\$ 2,000,000$ employed by the branch of the United States Bank. The counties needed the introduction of facilities at the more advanced points, and the city needed an increased banking capital.

A third cause which was influential in the increase of banks at this time was the termination of the second Bank of the United States. The end of this institution at the expiring of its charter in 1836 was anticipated as early as 1830 . In 1832 President Jackson, by his veto, put at rest all hopes of recharter. As in 1810 , so again in 1832, this was the signal for hosts of applications for new banking charters.

In Maryland the expansion took the forms both of an increase in the number of institutions and also of an augmentation of the capital of several of the old banks. The former movement was much the greater. No banks were chartered in Maryland from 1818 to 1829 . Between 1829 and 1836 seventeen new ones were granted charters and two old ones which had failed in 1821 were revived. Five of the seventeen, however, did not organize and open for business. Nine of the new banks were chartered for Baltimore in 1835; ten were distributed over seven counties. None were created in Baltimore after 1835 for more than a decade, owing to the renewal of the monopoly to the banks then existing until 1845 upon their agreement to make the Boonsboro road.

The total authorized capital of the new banks was $\$ 17,900,000$, though the banks which did not enter upon operations reduced this by $\$ 10,750,000$. The actual increase of capital was $\$ 4,878,900$, or half as much as the pre-existing capital; $\$ 3,788,370$ of this new capital belonged to the five new Baltimore banks.

The new charters were more rigorous in the following respects: The quantity of specie required to be on hand on opening for business varied in different cases from the entire authorized capital to one-fourth of it, and before the bank could open for operations the Treasurer of the Western Shore must have made examination and seen that this amount of specie was in the hands of the bank. It was prohibited, too, to pay installments of stock with discounts obtained by pledge of such stock. Forfeiture of charter on failure to pay their liabilities in specie on demand was a provision of these charters, and interest at twelve per cent. per annum was demandable from the time when payment was demanded and refused.

The expansion of the capital of banks already in operation amounted to $\$ 2,500,000$. The State, too, by selling its right to subscribe in several of the banks effected really an increase of active capital. The right to subscribe to the capital had been reserved by the State in every case in granting the charter, and inasmuch as but a small portion of this amount had ever been subscribed and paid for, it really operated as a limitation of capital. Between 1833 and 1836 the State sold the 
right to subscribe some or all of her reservad shares in three banks at rates varying from $\$ 2$ to $\$ 10$ per share. Stock to the amount of $\$ 625$,000 was thus freed for subscription.

Some mention of the great extension of private banks should be made here. It is impossible to obtain definite information concerning them. The chief function performed by these private banks was that of issue, and after about 1825 this function was exercised by companies of all sorts which could find a market for such wares. With a view to restraining them they were made subject to the same provisions as banks as regards the denominations of their notes. A more effective check was administered in 1842 , when they were prohibited altogether from issuing.

Reviewing the increase of banking capital from 1829 to 1836 , we find that at its beginning there were thirteen banks, with an active capital of $\$ 7,461,372$. These were increased by fourteen banks, whose paid-up stock was $\$ 4,878,000$. The total increase of active capital from the three sources mentioned above was over $\$ 8,000,000, i$. e., the capital was doubled. The Bank of Maryland, by its failure in 1834, detracted $\$ 300,000$. In 1836 there were, then, twenty-six banks, whose nominal capital was $\$ 19,176,000$, of which $\$ 15,465,000$ was paid in.

\section{An Attempt to Establish a Bank of the State of Maryland.}

Throughout the years 1830-33 there was an active discussion of a plan to establish a bank under the direct control of the State government. In 1829 the Legislature appointed a committee to consider the petitions for the bank; it made a careful investigation and reported favorably. The bill received a lengthy discussion, but finally was rejected by a vote of 46 to 23 . Similar committees had the same matter referred to them in the various sessions of 1830-33; invariably the report was favorable, but a bill could never be carried through the Assembly. An attempt to revive the scheme in 1837 was unsuccessful.

\section{UNIFORM REGULATION OF BANKS.}

Up to 1834 the major part of the legislation affecting banks was the charter regulations of the separate banks; very few general laws applicable to all had been passed. The various charters differed considerably in their provisions, as has been shown. A considerable step toward uniformity was taken in 1835 , when all Baltimore banks were made to conform to the charter of the Merchants' Bank, of Baltimore. This charter was given early in 1835 , and new banks which were established in Baltimore after this date were simply brought under its provisions. The old banks came upon the same basis when in 1835 and following years acts were passed continuing their charters. In the case of the banks which had been continued to 1845 by the act of 1821 , in return for their agreement to construct the Boonsboro road, the new regulations could not be introduced until after the termination of the old 
charter. The Marine and the Farmers and Merchants' Banks were extended to 1856; The Mechanics' and the Franklin to 1857; the Commercial and Farmers' and the Baltimore to 1858; the Union to 1859. In return they were to become subject to the regulations contained in the charter of the Merchants' Bank, to relinquish the exclusive right of banking in Baltimore and to suffer additional taxation.

The more important changes which were introduced in the charter of the Merchants' Bank were the following: The President and direetors had to be citizens of Maryland, not of the United States merely, as previously. Issues might not exceed the amount of the capital paid in; the total amount of debts exclusive of issues was limited to the same amount. Formerly the total debts might equal twice the capital. The President and directors in their corporate capacity could not hold any part of the capital of their bank, nor make any loans on a pledge of stock, nor receive the same as collateral security for any money loaned, except for doubtful debts previously contracted. Debts due to a bank by a stockholder had to be settled before he could transfer his stock, unless the President and directors allowed otherwise. Real estate falling into a bank's hands had to be disposed of within five years. The banks were empowered to invest in Maryland, Baltimore and United States bonds. Fifty stockholders controlling 1,000 shares could eall a general meeting of the stockholders.

The Legislature reserved the power to regulate the denominations of bank notes. It required the banks to act as commissioners of loans when desired. In case of suspension of specie payments, interest at twelve per cent. per annum might be demanded, if the assets of the bank were sufficient to pay it; otherwise as much above six per cent. was recoverable as the assets would pay. The law provided for the pro rata distribution of all assets in case of suspension of specie payments.

The country banks were likewise placed upon a common footing by the acts of 1836 and 1842, which extended their charters to dates varying from 1855 to 1860 . All were required to send to the Treasurer an annual report of their condition. Through this act inspection by the State became a protection of the general interests, and was not done by the State as stockholder, inasmuch as the State had only subscribed in two or three of these banks. The payment of the school tax was continued and a new tax, a bonus of $\$ 1.25$ per $\$ 100$ of capital paid in, was imposed. Notes under $\$ 5$ were prohibited, and the State reserved the right to regulate the denominations of issues after 1845. The charters were to become void on failure to pay specie.

\section{INCREASE OF BANK TAXation.}

An additional tax was imposed in each case as the condition of a continuation of the charter after 1845. The banks of Baltimore were required to pay in three annual installments a bonus of $\$ 75,000$, proportioned to the amount of capital of each bank. The country banks 
whose charters were renewed had to pay, as stated above, $\$ 1.25$ for every $\$ 100$ of capital paid in as a bonus to the State.

The new banks which were established during the expansion of 1829-36, were taxed, in addition to the tax for the school fund, $\$ 3.75$ per $\$ 100$ of capital paid in, and at the same rate for additions to capital. In one or two cases the rate varied slightly. These taxes were payable in annual installments within three years.

An attempt was made in $\mathbf{1 8 3 5}$ by the municipal authorities of Baltimore to lay a tax upon the stock of banks. The Legislature decided this to be in violation of its pledge given in the act of 1821, to impose no additional tax until 1845. To prevent discrimination between the banks the city was also forbidden to tax banks incorporated since that act.

In 1841 the State's indebtedness required extra taxation to meet its expenses. All bank stock was taxed at the rate of twenty cents on the $\$ 100$, in addition to taxes on real and other personal property. The banks objected strenuously to this burden, and claimed it was a violation of the State's pledge to impose no further tax until 1845. The loan had been obtained from the banks, now they were taxed to pay it. Considerable trouble was met in the collection of this tax. To facilitate its collection banks which had loaned the State in 1841 were allowed, upon notice to the Treasurer, to issue orders upon the State treasury up to the amount of each one's loan. These were receivable in payment of the direct tax upon bank stock. They were not to be reissued by the Treasurer. Still, collection of the tax continued to be impeded, so in 1843 the bank officers were required to retain from the profits and pay the Treasurer the amount of the tax. However, in January, 1845, the Supreme Court of the United States decided that the banks which had been incorporated prior to the act of 1821, chapter 131, were exempt from the tax during the continuance of their charters. This freed six Baltimore banks from payment of the tax until March 10,1846 , and the money which had been paid in by them was refunded.

A tax of one-half of one per cent. was imposed on all bank stock sold at auction by the act of 1843 .

\section{EFfects of the CRISIs of 1834.}

The crisis which occurred in 1834 was felt comparatively little in the East, and was of short duration. It was precipitated to a great extent by the hostile relations existing between the Administration and the United States Bank. In 1833, when the national deposits were removed, the bank was compelled to contract its discounts suddenly. This occurred before the new State banks which had been chartered were fully organized, hence they were unready to relieve the situation. The branches of the United States Bank, too, were very stringent in their relations with the State banks, and prevented an active response to the demand for discounts. A rapid retrenchment occurred; on January 1, 
1834 , the discounts of the Maryland banks were $\$ 10,273,000$, and the circulation was $\$ 2,071,000$. Within six months the discounts had been reduced by $\$ 1,100,000$ and the circulation by $\$ 800,000$; the specie on hand was maintained at $\$ 630,000$, or one-half the circulation. After June, 1834, the influence of the newly-chartered banks began to be felt and the discount and circulation lines began to rise. The rate of discount dropped rapidly from thirty to thirty-six per cent. per annum to ten to twelve per cent. and lower, and the tightness of the money market was soon relieved.

To this crisis was charged the failure of three banks in Maryland. Maladministration was the cause of bankruptcy in each case; the removal of the national deposits from the United States Bank and the resulting restriction were the occasion of it. The greatest of these failures and the most wide-reaching in its effects was that of the Bank of Maryland. It was the first bank chartered in the State, and it received an exceptionally liberal charter. The State was not a stockholder in it, nor did it render any reports to the Treasurer. Its early administration was vigorous and successful. During the years 1816-24, in common with the other banks, it suffered severe losses, due partly to the character of its officers, who were now conducting it sluggishly in contrast to its former active policy. The bank suspended on March 22, 1834.

Immediately after the failure of the bank its affairs were placed in the hands of a trustee, with whom afterwards two others were associated. Bitter enmity existed between all concerned in the fraud and the trustees.

No report was rendered to the creditors for seventeen months. Finally they became so exasperated that they mobbed the houses of all the parties concerned in the partnership, and there was considerable destruction of property. The mob held sway for five days. Upon petition to the Legislature an indemnity of $\$ 102,550$ was granted to those who suffered by it.

The trustees were in disagreement among themselves. Two of them allowed the acceptance of $\$ 400,000$ from the President of the bank to cover his obligations, after the trust had been conferred. The President pledged his private estate to meet the debts of the bank, and suits against various parties were instituted for sums aggregating over $\$ 600,000$, a large part of which, it was charged, was recovered through unjust influence over the court. By these means sufficient funds were collected to cover all claims against the bank, although it was at first thought the creditors would lose almost everything, but their ultimate losses were small. The greatest loss fell upon those who, in the height of the panic, disposed of their claims at forty to fifty per cent. discount.

The failure of the Bank of Maryland immediately caused runs upon the other banks, but they withstood them without serious difficulty.

The Commervial Bank of Millington failed in 1836. Its nominal 
capital was $\$ 100,000$, and it had been chartered only in 1832 . Its President was a speculator, who immediately before the failure of the Millington bank organized another in Hagerstown on deposits in the old bank as capital. The amount of its assets and debts is unknown.

The Susquehanna Bank, which had failed in 1820, was revived. It sustained the run upon it made at the failure of the Bank of Maryland with difficulty, and soon after succumbed. It must have satisfied its creditors in some way, inasmuch as it resumed business again in 1836. The loss in each of these cases was probably small, since the character of these banks was generally known and their business was very limited.

The Salisbury Bank, which had commenced operations in November, 1830, was compelled to suspend for a time in April, 1834; however, it soon resumed. In the liquidation of debts to banks their notes were receivable, consequently immediately after a failure the debtors of the bank were anxious to purchase at a discount the notes of the insolvent bank to pay their obligation. On this account the Legislature enacted in 1835 that whenever a bank failed to pay on demand in specie, and was in condition to be proceeded against under the act of 1818, Chapter 177 , the notes of the bank were not receivable for debt to the bank unless they had been held by the debtor at the time of failure. The same law provided that to settle the affairs of a bank, if stockholders holding the major portion of the stock so desired, the Chancellor or county court might appoint a trustee, instead of the bank officials. This law was a direct outcome of the Bank of Maryland trouble.

\section{Financial Crisis and Suspension of 1837.}

The period of 1822-37 was one of almost unbroken prosperity in the eastern part of the United States; the difficulties of 1825, 1828 and 1834 were of short duration, and their effects in the Eastern States were not so great. Several circumstances combined to produce the panic of 1837. In the first place, the long-continued prosperity led naturally to a dangerous expansion in industrial enterprises of all sorts. The spirit of speculation had been growing for a decade. In Maryland the special form of speculation was in the various improvement schemes. They were to a great extent local projects, and drew their resources from within her bounds. The public lands were an object of investment generally.

Secondly, the price of cotton had been low for several years, and in 1836 the wheat crop was a failure. The balance of trade had continued against the United States for some years, and specie had been sent abroad to adjust her balances.

A third cause of the crisis was the general apprehension of financial trouble at the closing of the United States Bank and its restriction to enable it to adjust itself to the new conditions.

The Baltimore, Philadelphia and New York banks suspended specie 
payments on May 12, 1837, shortly after the specie circular had been put into operation, which threw back upon the banks their notes for redemption. At the same time shipment of specie abroad continued, and the Government made heavy demands upon the deposit banks. Specie in Maryland commanded a premium of six per cent. To retain it the banks were compelled to suspend.

In Maryland this was altogether a protective measure; the banks were in a sound condition. At the time of suspension they had one dollar in specie in their vaults for every three of notes in circulation, which at that time was regarded as the criterion of soundness. The ratio of specie to circulation and deposits was as one to eight. The country banks were uniformly in as good condition as the city banks. All but four of them had been recently organized, and their operations were not yet far extended.

At the first meeting of the General Assembly after the beginning of the suspension, a committee on the currency was appointed to examine into the solvency of the banks and their ability to redeem their notes ultimately, and to report whether or not they had forfeited their charters by suspending. The committee conducted its examination by means of sworn statements from bank officers in reply to certain general and special questions. These replies were afterwards verified by the committee by a personal investigation of the books of the banks. The cornmittee pronounced the banks without exception to be in a sound and highly creditable condition.

There could, however, be no doubt that the banks had rendered their charters liable to forfeiture. The general law of 1818 declared all charters voidable on suspension. This had been reaffirmed for Baltimore banks, when, by the recharter law of 1834 they became subject to the eleventh and thirteenth sections of the charter of the Merchants' Bank, and for the country banks by the law of 1836 .

The banks expressed their readiness to resume at any time the Legislature might appoint, but they feared the consequences if they were compelled to resume before the banks north of them, to which they were heavily indebted. Maryland banks were owed balances by the banks of the Southern States, which were still in suspension. Their specie would have been drained off to pay their Northern balances, and at the same time they would have had no means of replenishing themselves except by purchase at a heavy premium. On January 1, 1838, the Baltimore banks were in debt to those of New York and Philadelphia $\$ 730,000$. The country banks owed no balances North.

The committee framed its recommendations into a bill, which was passed by the General Assembly in March, 1838. It provided that every bank and Savings institution should transmit to the State Treas urer, once a month during the suspension, a statement under oath of its condition, and likewise to every other bank and Savings institution in the State a similar statement at least once a month during the sus- 
pension. The circulation during the suspension was limited to three times the amount of the specie in the bank's possession, and after resumption they were not allowed to issue more than the amount of their actual capital. No notes nor certificates of deposit of a less denomination than $\$ 5$ were to be issued after May, 1838. The date for resumption was fixed at January 1, 1839, or within thirty days after resumption by the banks of New York, Philadelphia and Virginia, should they resume previously to that date. Banks complying with these conditions were freed from the penalties incurred by the suspension of specie payments and the issue of small notes.

These provisions were made with a view to preparing the banks for resumption. The New York banks were compelled by a State law to resume specie payments by May 10, 1838. The Philadelphia banks followed in August, and those of Baltimore immediately afterward. The resumption caused little inconvenience in Maryland. Discounts were not diminished at all.

\section{The Crisis of 1839.}

The prosperity which had been hoped for did not return with resumption. A year of disaster for the entire country followed, though the South and West especially felt its force. Maryland had become involved in a large and increasing debt through her improvement works, whose cost far exceeded estimation, and from which no returns were being received. In many cases work came to a standstill through lack of funds, and thus a vast amount of public and private capital lay locked up. Banks among others were heavy investors in this sort of stock.

The Bank of the United States, owing to its speculations, had become in a perilous condition, and was laboring to produce another suspension in order to shield itself. On October 10, 1839, it suspended, and all the banks of the Union except those of New England and New York followed. The failure of the Bank of the United States fell very heavily upon Baltimore, where originally over $\$ 4,000,000$ of its capital was subscribed; the whole capital was lost.

Under these circuinstances the banks contracted rapidly. Interest rose to twenty per cent. Just before the suspension the discounts of Maryland banks had stood at $\$ 16,400,000$, and the issues at $\$ 3,400,000$. By January 1, 1840, the discounts had fallen $\$ 2,500,000$ and the issues $\$ 500,000$.

The financial condition of the State, too, was most wretched. In the cause of internal improvement, Maryland had subscribed almost $\$ 12,000,000$, and had become involved in a debt of $\$ 5,500,000$, the interest upon which she was unable at that time to keep up. The public revenue paid the current expenses only. No system of direct taxation was in use in the State, and for several years the inconveniences attendant upon the inauguration of one were felt. The laws taxing real and 
personal property were not enforced in some counties. The negotiation of a loan abroad failed in 1837. In January, 1842, the State was driven to suspend payment of interest on its debt. Between 1837 and 1842 the State borrowed over $\$ 500,000$, principally from the banks. The suspension of interest payment thus directly affected them. At the same time lack of resources necessitated a cessation of work on canals and roads, and the State was again appealed to for help.

To assist the improvement companies, which were in distress, specific powers of issue were granted in a number of cases. The Baltimore and Ohio, the Annapolis and Elkridge Railroad Companies, the Chesapeake and Ohio and the Tidewater Canal Companies, were empowered to issue up to $\$ 4,000,000$ paper variously denominated stock orders, eertificates of debt or toll notes, secured by bonds of the State or of Baltimore or by mortgage of property. Other companies by their charters were allowed to make such issues; many made them without legal sanction. The orders issued by the Corporation of Baltimore and the Baltimore and Ohio Railroad had general circulation, and were the most reliable fractional currency after the disappearance of specie.

An attempt was made in $\mathbf{1 8 4 2}$ to put an end to all issues made without legal sanction. Improvement and other incorporated companies, except such as were allowed to do so by their charters, were prohibited from issuing any sort of paper to circulate as money. The penalty was both corporate and individual liability to pay the full amount issued. At the end of 1842 still more comprehensive legislation was passed, prohibiting every one except banks from issuing anything to circulate as money, under penalty of $\$ 20$ for each offence. Traders forfeited their licenses for passing such notes. Besides the banks, the Baltimore and Ohio, the Annapolis and Elkridge Railroad Companies, and the Chesapeake and Ohio Canal Company were excepted from the operation of this law.

The position of Maryland banks with reference to resumption was similar to that of 1838; they were between two fires, neither Pennsylvania nor Virginia banks were paying in specie, hence they hesitated to take the risk of having their specie drawn off. The Legislature set May 1, 1842, for resumption, and in case of non-compliance the bank forfeited its charter. On March 18, 1842, the Pennsylvania banks resumed, and those of Maryland followed without hesitation.

The banks were uniformly administered with care during the suspensions of 1837 and 1839. There was a gradual expansion of discounts from 1836 to 1839 to meet the needs of patrons whom the stringency was pressing. This expansion was not, however, carried to a degree which imperilled the solvency of the banks. The increase of issues was comparatively small during the suspension of 1837 . The calling in of paper and the reduction of discounts in 1839 was sharp, and caused considerable inconvenience. Between October, 1839, and January, 1840 , discounts were diminished $\$ 2,500,000$, or more than one-seventh. 
Interest rose to twenty per cent. on good paper. Soundness was not sacrificed to profit. The specie reserve was maintained above one-third of the amount of the circulation, even at the expense of purchasing specie at a considerable premium. By January $1,1838, \$ 425,000$ in specie had been purchased since the beginning of the suspension. Some of them had disposed of gold and silver, almost entirely in the form of foreign coins, at a premium.

The dividends made at this time do not indicate excessive profits. The dividends of the twenty-two banks in operation ranged between four and eight per cent. per annum during the years 1837 and 1838.

During the suspension all specie disappeared from circulation, and all the banks were driven to violate the law in receiving and passing notes of less denomination than $\$ 5$. The law which provided for resumption of specie payments allowed the issue of small notes up to onefifth the amount of the capital paid in.*

The Committee on Currency investigated the charge that directors received discounts on more favorable terms than others. The banks all denied that they discounted to directors as such; some acknowledged that they favored directors when their paper was as good as that of others, since they had difficulty in obtaining discounts at other banks. Most of the banks favored their regular patrons when their paper was unquestionable. Of the total discounts on January 1,1838 , of $\$ 15,800$,$000, \$ 2,300,000$ had been made to the directors. The highest discount to any one director was $\$ 121,500$; seven directors had received over $\$ 40,000$ each.

The banks, too, almost unanimously confessed that during the suspension they had discounted to parties on condition that the notes be taken to a distance to be put in circulation. A few, too, had sent out agents, chiefly to Southern points, to buy up their notes at a discount, though the extent to which this was practiced was very small. Although it was prohibited by their charters, the capital of all the banks chartered between 1829 and 1837 , with a few exceptions, was paid partially with stock notes.

As a result of the depression quite a reduction took place in the banking capital of the State, both by voluntary lessening by the stockholders and by failure. Four banks became insolvent.

\section{LIqUidation OF INSOLVENT BanKS.}

These failures led to further legislation in regard to the method of procedure in closing up insolvent banks. The law of 1841 provided that the Governor, upon information that any bank had refused to pay in specie on demand or had issued small notes in violation of law,

* Md. Laws, 1841, ch. 302. The issue of these notes was prohibited after November. 1842. The law of 1844, ch. 111, allowed the issue of notes between five and one dollar in denomination up to ten per cent. of the capital, or at least up to five thousand dollars by each bank. 
should direct the Attorney-General to issue a scire facias against such bank. In this case the county court or any judge of it might by injunction restrain the bank from improperly disposing of its funds, and might appoint a Receiver if it thought best. The court upon proper evidence could adjudge the charter forfeited and appoint threc trustees to settle up the business. Thereupon the property of the bank vested fully in the trustees, and the court might require the bank to execute a deed of assignment to the trustees.

The time consumed in the liquidation of insolvent banks was frequently very long, extending from five to fifteen years in some cases. To prevent the trouble of keeping bank notes this long time, while awaiting dividends of the assets, the Legislature enacted that record might be made of such notes in any court of the State, and the notes themselves might be destroyed by the sheriff.

Considerable reduction was made in the capital of the banks, both on account of losses and also because, in the depression succeeding the panics of 1837 and 1839 , they were unable to employ profitably their entire capitals. The voluntary reduction, together with that from failures, amounted in all to $\$ 2,325,395$; of this amount, at least $\$ 715,000$ was due to loss.

For some years the State had been commuting to money the right to subscribe to the stock of the several banks, and to appoint directors in them. The proceeds were applied to current expenses. The first oc curred in 1828, when the Commercial and Farmers' Bank of Baltimore agreed to pay $\$ 9,5331 / 3$ on condition that the State give up the right to subscribe 286 reserved shares, and also the right to appoint directors. It could still, however, vote on the shares held by it. The right to subscribe 1,000 shares in the Union Bank, 5,000 shares in the Merchants' and 500 shares in the Hamilton were in like manner offered by the State to the banks at prices varying from $\$ 6$ to $\$ 10$ per share. The right to appoint directors in the Farmers and Merchants' Bank was offered to the bank for $\$ 5,000$, the right to vote on the shares being retained.

In 1841 the fight against bill brokers and note shavers was renewed. The first step was to raise the cost of their license to $\$ 3,000$ yearly. The penalty for exchanging and purchasing bills without a license was fixed at $\$ 500$ for each offence. The banks were released from all obligation to redeem their notes in specie for any foreign or domestic broker. The next year these conditions were mitigated to considerable extent by a reduction of the cost of license to $\$ 50$. This was brought about by the inconvenience arising from the mass of depreciated and uncurrent paper money, chiefly of the banks of other States, which by means of the brokers could be exchanged for reliable currency.

In 1837 there was further legislation to prevent the fraudulent manipulation of stock in the election of officers. It provided that stockholders intending to canvass the votes must notify beforehand an officer of the bank; this officer, in turn, had to notify all the stock- 
holders residing in the State. Upon voting, each stockholder had to swear that the stock which he was voting was his bona fide property, or was held by him in some fiduciary relation, and was not transferred to him to increase the number of votes. Persons voting by proxy had to make this oath before some qualified officer of the State. Directors had to make oath that they had not acquired shares to qualify themselves for office. General permission was extended to all the banks in 1844 to make loans upon promissory notes or obligations under seal, secured by mortgage, for any period up to five years at six per cent.

InCRease of Banking Capital, 1843-62.

After the industrial revival which followed the disturbance of 183742 had begun, the inadequacy of Baltimore banking eapital became a matter of common concern among merchants, and various means were adopted within a few years to stimulate its increase. Old banks were allowed to enlarge their capitals; new ones were incorporated, and Savings institutions were changed to regular banks of discount and issue. Some Savings banks were allowed the power of issue. Effort was made to secure the passage of a free banking law.

The formation of new banks proceeded gradually from 1843 to 1862; from 1853 to 1858 the rate of increase was a little greater than before. 'The total number of new banks incorporated, exclusive of those which had been operating before as Savings banks, was seventeen, and the amount of capital allowed them by their charters was $\$ 3,000,000$. One of these banks failed to go into operation, and the charters of two others were repealed by the Legislature, deducting in all $\$ 350,000$ from the total just mentioned. Two of these banks, representing $\$ 800,000$ nominal capital, were located in Baltimore.

Seven Savings institutions were regularly incorporated as banks and allowed all the privileges usually given to banks under the laws of the State. The conversion of Savings banks to regular banks had occurred in two cases previously to this time. The Western Bank of Baltimore had been formed in 1835 from the Mechanics' Saving Fund Society, and at the same time the Fell's Point Savings Bank was authorized to become the Eastern Bank of Baltimore; the latter, however, did not change. The total authorized capital of these seven banks was $\$ 1,800$,000 , of which $\$ 1,400,000$ belonged to the four located in Baltimore. The chief advantages gained by these banks were the power of issue and less restriction in their investments. The Savings banks were generally limited to investing in bonds and securities; some were allowed to discount up to two-thirds the amount of their deposits. In making the change they became subject to the laws controlling banks generally. Two of them were allowed to continue the practice of receiving weekly deposits and paying interest on them up to six per cent. The practice of paying interest on deposits left for a specified time had already become general among the banks. 
It is impossible to conjecture the extent of the business done in Maryland by Savings banks, except so far as their number gives an indication. Though two or three had been incorporated before 1830 , about that time they first became of importance in Maryland. The increase of their number corresponds in time to the increase of the regular banks. Up to 1842 nineteen had been established in the counties and eleven in Baltimore. In most cases they simply invested their deposits and had no capital stock. Between 1842 and 1861 twenty-nine were chartered, eight of which were in Baltimore. Of the total number a capital limit was fixed for sixteen, aggregating in all $\$ 2,800,000$. They were required to send no reports to the State Treasurer, and the magnitude of their operations is unknown. A very small number of failures occurred, only two or three.

\section{Savings Banks Permitted to Issue Notes.}

One peculiar feature of Maryland Savings banks which appears to have developed in no other State, was the right given to some of them to issue notes to circulate as money. This privilege was first conferred by the Legislature in 1844, and by 1860 nine Savings banks had acquired this power. In nearly every case it was the subject of a special act of the Legislature, and was not included in the charter. The limit for issues was usually, as for other banks, the amount of the capital paid in. For the Howard Street Savings Bank it was fixed at one-fourth of the deposits, and one-fourth of the deposits was not subject to withdrawal, but formed a fund for note redemption. The Fredericktown Savings Institution was allowed to issue up to $\$ 30,000$, provided it kept as a redemption fund $\$ 15,000$ in certificates of Maryland, Baltimore, United States or Chesapeake and Ohio Canal stocks. Others were required to keep a redemption fund of State stocks or specie equal to onehalf the issues. In each case the school fund tax was required, twenty cents on the hundred dollars of capital paid in or of notes issued, as the case might be. In one or two cases a bonus also was required, as likewise was an annual report to the Treasurer.

To encourage the growth of banking capital the Assembly made a general law, March 8, 1854, allowing the banks of Baltimore to increase their capitals at times suiting their convenience, simply upon reporting the increase to the State Treasurer and paying the school tax fund. Not less than $\$ 100,000$ might be added at any one time, and the maximum amounts were as follows:

Banks of $\$ 1,000,000$ capital and over might enlarge to $\$ 2,000,000$; banks of $\$ 900,000$ to $\$ 1,000,000$ might enlarge to $\$ 1,500,000$; banks of less than $\$ 900,000$ might enlarge to $\$ 1,000,000$.

Between the time of resumption in 1842 and the passage of the above act the old banks had added $\$ 289,000$ to their capital. Within five years after the act was passed $\$ 1,458,000$ had been added; reductions, however, offset this increase to the amount of $\$ 397,000$. The total increase 
of active banking capital from all sources was $\$ 2,823,000$, from $\$ 9,746$,000 in twenty banks in 1843 to $\$ 12,569,000$ operated by thirty-one banks in 1858. From 1858 to 1862 the reduction was greater than the increase from new banks.

After the period of liquidation which followed the panic of 1839, the banks began again to extend their credit, and in 1847 and 1848 this movement became accelerated under the stimulus of the general industrial prosperity. The enlargement of discounts proceeded regularly until 1854, when a temporary reaction occurred, on account largely of the disturbed condition of financial relations with Europe. After this check the process of expansion continued until 1857. This increase of bank notes, however, to a large extent took the place of the silver coins, which by 1850 had almost entirely disappeared from circulation. From 1850 to 1854 the quantity of money in circulation was too small to perform conveniently its uses, and there was a constant demand for more money. The State attempted to relieve the situation by the charter of new banking companies, by allowing all banks to double their issues, $i$. e., to issue up to twice the amount of their capital paid in, and finally, by the permission granted to certain Savings banks to issue.

The State had always insisted strenuously that the money of denominations under five dollars should be coin, and only under exceptional eircumstances had it departed from this rule. In 1851 silver dollars and half-dollars had become so scarce that some of the banks had again adopted the expedient of issuing notes of denominations under five dollars, and the small notes of banks of other States also circulated in Maryland in considerable numbers. The Legislature in May, 1852, forbade both their issue by Maryland banks after March, 1853, and also the receipt or payment of such notes of banks located outside the State under penalty of tive dollars for each offence. The inconvenience of the lack of small currency was felt on all sides, and quite an agitation was aroused to procure the repeal of the law. The Baltimore City Council by almost unanimous vote requested this action, but without avail. After 1854 the quantity of specie in circulation increased in a marked manner, owing to the influence of the newly-found gold mines.

Throughout the period 1843-57 the quantity of specie in the hands of Maryland banks was always large in proportion to circulation. During these years there was always an amount of specie in the possession of the banks equal to more than half the circulation, and the ratio of specie to circulation and deposits combined was never less than one to four. The following items from the reports of the banks will show these points:

\begin{tabular}{|c|c|c|c|}
\hline YEAR. & $\begin{array}{l}\text { Circulation. } \\
\$ 1.743768\end{array}$ & Deposits. & $\begin{array}{l}\text { Specie. } \\
\$ 2.537 .822\end{array}$ \\
\hline ........ & $2,400,267$ & $3,863,891$ & $2,005,078$ \\
\hline & $3,532,870$ & $5,966,834$ & $2,738,834$ \\
\hline ......... & $4,918,381$ & 8621,052 & $3,405,090$ \\
\hline 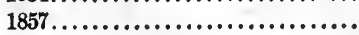 & $5,155,096$ & $9,611,324$ & $3,522,561$ \\
\hline
\end{tabular}


The condition of all the banks was sound, and all redeemed their notes in specie; no Maryland bank paper was at a discount within the State. In New York the notes of Baltimore banks were at a slight discount, about equal to the cost of having them exchanged. The notes of the less well-known banks of the State were quoted in New York at a small discount ranging from one-half to four per cent.

The greatest abuses of the period were, first, the issues of unknown and worthless banks, chiefly Western and Southern, which made their way into all quarters of the country, furnishing a mass of greatly depreciated notes upon the exchange of which the note brokers thrived; secondly, the appalling amount of counterfeiting. The various registers and reporters of counterfeit notes, published monthly or quarterly, gave information to the public of the many counterfeits in circulation.

\section{General Banking Law.}

A general banking law was adopted in 1853 , but it was simply a collection of the laws of the State governing banks, with a few modifications, re-enacted in a single law, and all the banks were made subject to it, both those already existing and those subsequently chartered. The occasion of the passing of the law was the expiration of the charters of twenty banks of the State. These were all continued to 1880, subject to the restrictions of the law. The only new regulations were the following:

1. Regulating voting.

For 1 to 10 shares the holder was entitled to one vote each.

For 10 to 100 shares the holder was entitled to one vote for every two. For 100 and over the holder was entitled to one vote for every five.

2. The President and majority of the directors were to constitute a board for ordinary business and discounting.

3. Discounts and loans for directors were absolutely prohibited, under pain of fine or imprisonment for violation.

4. Interest upon deposits was limited to three per cent. per annum.

5. The State Treasurer was to have a semi-annual statement of the condition of each bank, which was to be published in the county in which the bank was located.

6. The school fund tax was continued.

The free banking principle was entirely omitted; the Legislature continued to hold within its hands the power to extend banking privileges. No special provision was made for the security of bank notes. The regulations of the law were much more minute than those of the free banking bill proposed in 1852.

The act of 1854, chapter 152, should be taken in connection with the above law. By the general law issues, as previously, were restricted to the amount of the capital paid in; by the law of $185 \dot{4}$ banks having a paid-in capital of less than $\$ 250,000$ were allowed to issue up to double that amount. The explanation of this step lies in the fact that the 
amount of currency was found to be inconveniently small; the extension of bank issues was the most available remedy at hand.

\section{Crisis and Suspension of 1857.}

The continual expansion along all lines throughout the entire country during the years 1842-57 culminated in disaster in 1857. The speculative condition of industry stimulated the issues of the banks until in 1857 a climax was reached. The currency, becoming increasingly inflated from 1853 to $185 \%$, was highly conducive to over-trading, overimportation, stock speculation, etc. The reaction was first felt in the Western States in the summer of 1857, and many Eastern firms, creditors of Western concerns, soon failed. Bills on Eastern points were at ten to fifteen per cent. premium. New York was the first Eastern city affected by this panicky state of affairs, but until the middle of October its banks were able to resist suspension. A run began on the deposits of Eastern banks in September, and on September 25 the banks of Philadelphia suspended; on the 26th those of Baltimore did likewise, and the banks of Cumberland, Frederick and other towns followed soon. The deposits of Baltimore banks January 4, 1858, were $\$ 1,683,861$ lower than on the same day of the previous year. This heavy drain upon the specie reserve reduced its amount $\$ 829,359$.

The condition of the banks was sound, but suspension was a matter of self-preservation when the creditor banks of Philadelphia had suspended and those of the South were on the point of doing so. Every facility in the line of discounts within their power was rendered by the banks to relieve the situation. By January 1, 1858, the diminution of discounts was $\$ 902,256$, less by almost half than the withdrawal of deposits. The amount of circulation outstanding decreased $\$ 337,000$. Even after this strain the condition of the Baltimore banks was comparatively strong.

The money market in Baltimore grew tighter toward the end of 1857, and interest was charged at one to one and a half per cent. per month. Exchange on New York was four and a half to five per cent. premium. An effort was made in New York to resume December 13, and discounts were contracted and specie procured for this purpose. The time seemed rather unfavorable, since the exportation of specie at the rate of $\$ 2,000,000$ or $\$ 3,000,000$ a week had succeeded the importation of a few weeks previous. Baltimore bank notes were at par in Maryland, and those of country banks were at very slight discount. The public seems to have exerted very slight pressure upon the banks to resume. The banks, though able to resume at any time, preferred to wait for a general resumption, or at least until after the Philadelphia banks had resumed, the time for which had been set at April 1, 1852. The Virginia banks also resumed about this time.

The greatest nuisance of the suspension was the mass of foreign depreciated paper, which could only be disposed of through the bill 
brokers by paying a large discount. The banks would not receive it; in fact, again, as in the suspension of 1814, the Baltimore banks refused to receive the notes of Maryland country banks, which not only caused great inconvenience, but also reacted upon the banks, causing a greater depreciation of their paper. This condition of affairs offered opportunity to the banks of making arrangements with brokers and of sending out agents to buy up their notes at the lowest possible prices. This scheme was worked not only by the country banks, but also the city banks quietly sent their agents to foreign points for this purpose.

The failure of two country banks, both of Allegany county, resulted from the crisis. The Cumberland City Bank, which had been established in May, 1858, made an assignment on November 26 of the same year. Noteholders and depositors were made preferred claimants. The loss could not have been large.

The Mineral Bank, also located in Allegany county, failed October 5,1857 , with liabilities of $\$ 199,681$. The trustees paid $831 / 2$ cents on the dollar and the expenses of settlement.

\section{The Baltimore Clearing-House.}

Just after resumption in 1858 the banks of Baltimore resolved unanimously to form a clearing-house. It began business Monday, March 8, 1858. In its purpose and operation it is very similar to those of New York, Boston and Philadelphia, though there are differences of detail arising from differences in the magnitude of business transacted.

The chief point of difference from the New York plan was the appointment of one member of the association the depository bank, in whose banking rooms the transactions of the clearing-house were performed, and whose Cashier was manager of the clearing-house. The smaller number of banks elearing and the smaller amount of business cleared in Baltimore, in comparison with other cities, permitted this less specialized form of organization. The number of banks clearing at this time was thirty-one. No clearing-house loan certificates had been issued up to 1864 .

\section{The Suspension of 1860.}

The recovery from the crisis of 1857 was very rapid; the first nine months of the year 1860 was one of the most prosperous seasons in our history. The grain crops were good; the cotton production was unparalleled. After the fall election, however, the attitude of the South created great alarm, and the previous expansion gave way to contraction and preparation for the threatening emergency. Diminished imports brought considerable gold into the country. The banks were strengthening their position. A change of tariff reduced the revenue from this source, and to meet its needs the Government issued $\$ 250,000,000$ in Treasury notes.

The commercial and financial relations of the Northern cities with the 
South were in a very uncertain condition, and Northern creditors were eagerly trying to insure themselves by early settlements of their affairs with Southern correspondents. Immediately after the election the Southern banks felt the withdrawal of their gold, and it was thought that political motives had much to do with the removal of their specie resources to Northern banks. At any rate, the Virginia banks decided that their commercial, financial and political interests demanded that they stop this flow to the North by suspension, which they did November 20. Other Southern banks followed on succeeding days.

This course necessitated the same action upon the part of Baltimore and Philadelphia banks, which were heavy creditors in Virginia and elsewhere in the South. They accordingly suspended November 22. Such a contingency had been anticipated, and preparation had been made for it in Baltimore, but the restriction of the banks was inflicting upon the commercial community the greatest hardships. For several days preceding the suspension it had been almost impossible to negotiate loans upon any terms. This stringency was alleviated after the suspension as far as circumstances permitted, and the public reaped a substantial benefit.

During February and March, 1861, the banks of both Philadelphia and Baltimore prepared for resumption, but the suspension continued in the South, and rendered the resumption of specie payments in Maryland hazardous. Affairs generally, however, soon wore a much more serious aspect, and resumption was indefinitely postponed.

The protracted suspension incident to the Civil War and the entire disappearance of metal money at an early date necessitated legislation in Maryland to prevent the infliction of the penalty prescribed for suspension-forfeiture of charter-and to provide a small currency. In May, 1861, it was made legal for the banks to use notes or certificates of deposit less than one dollar up to ten per cent. of the capital paid in, though any bank might issue $\$ 5,000$ in this manner. The act only applied to banks already having the power of issue, and its duration was limited to two months after the session of the General Assembly in 1861. The following year (March, 1862) this law was repealed, and the banks were allowed to issue up to twenty per cent. of their paid-up capital in notes under five dollars, but none were to be under one dollar in denomination. This law was to terminate May 10, 1864. By the law of 1864 , chapter 13 , the privilege was continued indefinitely.

Article 12, of the Code of General Public Laws, rendering banks suspending liable to forfeiture of their charters, was amended by the act of May 3, 1861, so that no corporation authorized to issue notes for circulation was subject to any forfeiture or penalty for not redeeming in specie before March 11, 1862. On March 8, 1862, the exemption was extended to March 11, 1864.

The great number of counterfeits current led to the repeal of the old law and the substitution of one more carefully worded, so as to prevent 
evasions. The penalty, two to ten years in the penitentiary, was continued.

During the first year of the suspension the discount line of Maryland banks advanced about $\$ 1,500,000$, though the amount of circulation decreased. During 1862, in the midst of inflation, Maryland banks expanded beyond prudence. The discounts increased $\$ 6,500,000$ within the year; the circulation jumped up $\$ 2,900,000$ and the deposits $\$ 6$,100,000. The quotations of stock for January, 1862 and January, 1864, show the effects of the expansion. Whereas in 1862 the stock of most of the Baltimore banks was more or less below par, by 1864 the increased profits from a large circulation had raised them all to a premium. The same process continued throughout 1863 , and in January, 1864, the Baltimore banks were in a condition which would have been risky under any other circumstances than in a general suspension. Loans were increased $\$ 2,200,000$ during the year, and circulation and deposits increased proportionately.

\section{Effects of the National Bank Act.}

The passage by Congress of the National Bank Act, or, as it was entitled, "An Act to Provide a National Currency," primarily a financial scheme to float bonds necessitated by the Civil War, brought before the State banks the question of reorganization. The defects and incompleteness of the first act, passed in February, 1863, rendered its effect upon the State banks comparatively slight. In Maryland but one bank, the Fell's Point, asked permission of the Legislature to reorganize. The law passed in June of the following year was much more effective in producing the desired results, and finally by the taxation of all State bank notes at ten per cent. on July 1, 1866, nearly all the old banks were driven over to the form of National banks.

The question was raised whether or not the State banks might change to National banks without the State's permission. The Fell's Point Bank had taken the precaution to secure this by a special act of the Legislature. The other banks remained under their State charters until after the doubt was put at rest by the passage of an "enabling act" by the General Assembly, March 24, 1865.

The matter was complicated by the fact that the State held considerable bank stock, and was otherwise the creditor of the banks. Further, the State system of free public education was largely dependent upon the receipts from the free-school tax upon banks. In view of these facts the General Assembly was not eager to allow the banks to pass from its control. In 1864 a joint committee of both houses was appointed to make inquiry in regard to the reorganization of the banks under the National Banking Act.

The committee called in the testimony of the Hon. Alexander Randall, the Attorney-General, on the disputed points. First, in regard to the State's claims upon the banks, he decided that as stockholder the 
State had no priority over other stockholders or creditors in event of failure or liquidation. As ereditor in other claims he argued that the State had priority by virtue of its prerogative as sovereign, which priority would be lost if the banks became subject to the national law; furthermore, the State would have no control over them.

The committee asked whether or not the State had power to prevent the reorganization under the National Act. Any such action, the Attorney-General thought, would be an attempt to nullify a law of Congress, and hence unconstitutional.

Being thus unable to prevent the conversion of the State banks into National banks, the Legislature passed March 24, 1865, "An Act to enable any bank, Savings institution or Savings bank of the State to become an association for the purposes of banking under the laws of the United States." This privilege was conferred upon condition that banks making the change first comply with all the requirements of the act of the first session of the Thirty-eighth Congress of the United States, entitled, "An Act to Provide a National Currency," etc. A bank might change if the owners of three-fourths of the stock expressed their consent in writing to that effect, or if at a special meeting of the stockholders, voters holding two-thirds of the stock so desired. At this meeting one vote might be cast for every share, and the State Treasurer voted the State stock. If the stockholders decided to change, the directors, or a majority of them, could execute the organization certificate and such other papers as were necessary, and could perform all other acts necessary for the conversion.

The bank was ordered to present to the Clerk of the Court of Appeals of Maryland a certificate from the Comptroller of the Currency that the bank concerned had become a National bank; this certificate was to be recorded by the elerk, and a copy sent to the Governor, who was to have it published in the locality of the bank. Its charter was considered to be surrendered and its corporate powers to cease, though it could continue to use its corporate name in closing its affairs. No State bank money was allowed to be reissued for more than one year after the surrender of the charter.

Contrary to the opinion of the Attorney-General, all taxes were to be continued as before. All the assets without further transfer were to vest in the association, and it became responsible for all debts incurred previously to the surrender of the charter. Destruction of all plates and dies were provided for.

Within the year 1865 twenty-four banks passed over to the new form; only six State banks were left in 1867; these continued in existence as State banks until after 1871, when at different intervals all became National banks except two, the People's of Baltimore and the Hagers town. A small number of Savings banks, perhaps two, also changed over in $\mathbf{1 8 6 5}$.

Although in the enabling act the State tried to continue in force the 
taxes which had formerly been collected, it was unsuccessful. By 1867 the school fund tax had dropped from about $\$ 35,000$ to $\$ 3,805$, and the banks refused to pay it.

In 1866 it was decided to dispose of the State bank stock, amounting then to $\$ 463,406$, and the Governor, Comptroller and Treasurer of the State were authorized to sell it at not less than its par value, and to invest the proceeds in funded debt of the State.

The chief elements of the system appear in the first charter; (1) special legislation in each case, (2) broad regulations, liberal powers, freedom of action, few restrictions. An eager competition, enforcing prompt attention to contracts, rendered careful administration a necessity for survival. In the first place the ideas adopted were not native to Maryland, but had been worked out elsewhere, notably by the Scotch banks and the first Bank of the United States.

The lack of uniformity in the regulations controlling the various banks was for a long time a source of confusion. This was partially remedied by making all the banks subject to the fundamental principles of the charter of the Merchants' Bank of Baltimore in 1835, and further, by the passage of a general banking law in 1852. State inspection for public security alone, and not by the State as stockholder, was arrived at long after it had been adopted by other States. Stockholders and directors, except in cases of maladministration, were never made personally liable beyond the extent of their shares. There were no preferred claimants in case of insolvency.

The issue of notes was competitive, upon the general credit of the banks. Issue upon the deposit of bonds was rejected to preserve a greater elasticity of the currency and greater possible profits. The payment of interest on deposits was general from an early time, and stimulated to the utmost economical habits on the part of the public. The practice of daily settlements among the Baltimore banks rendered necessary the exercise of the greatest skill and care in administration, and the brisk competition between each other and the branches of the two United States banks, for a large part of the time, was most salutary.

After the period 1814-20, during which the Maryland country banks were in wretched condition, the Maryland banks never ceased to redeem on demand in specie except during times of general suspension. A number of crises were passed with comparatively little inconvenience to Maryland's business men. The cases of insolvency have been remarkably few in Baltimore, three in all, with no loss ultimately falling upon depositors and noteholders. Since 1820 bankruptey has concerned but five county banks; only two of the five were of any consequence, and the loss was small.

The currency was always highly elastic, ultimately secure, excepting the period 1814-20 for the country banks, and convertible upon demand except in time of general suspension. For the shareholders they earned fair dividends, not large, except in the first few years. They collected 
the free capital and turned it to the assistance of every form of industry within the State. A long period of very conservative banking won the entire confidence of the people. The Legislature did not intrude upon the bankers' domain. To this strongly conservative spirit was doubtless due to large extent the success of a system which, owing to its freedom from restrictions, proved deficient under other circumstances.

State Banks.

\begin{tabular}{|c|c|c|c|c|c|c|}
\hline YEARS. & $\begin{array}{l}\text { No. of } \\
\text { banks. }\end{array}$ & $\begin{array}{l}\text { Loans and } \\
\text { discounts. }\end{array}$ & Specie. & $\begin{array}{l}\text { Capital } \\
\text { stock. }\end{array}$ & Circulation. & Deposits. \\
\hline $1834 .$. & 8 & $\$ 8,530,786$ & $\$ 595,505$ & $\$ 5,270,091$ & $\$ 1,433,698$ & $\$ 3,125,035$ \\
\hline 1839. & 22 & $15,844,163$ & $1,679,066$ & $11,419,999$ & $3,798,067$ & $4,219,932$ \\
\hline $1844 .$. & 20 & $10,104,829$ & $3,790,905$ & $9,540,374$ & $2,273,550$ & $4,231,664$ \\
\hline $1849 \ldots$ & 20 & $12,384,850$ & $2,145,013$ & $8,557,732$ & $2,780,476$ & $3,994,162$ \\
\hline 1854 & 25 & $18,358,441$ & $3,405,090$ & $9,558,409$ & $4,918,381$ & $8,621,052$ \\
\hline $1859 .$. & 32 & $21,854,934$ & $3,120,011$ & $12,560,635$ & $3,977,971$ & $9,028,664$ \\
\hline $1863 .$. & 32 & $23,919,669$ & $2,750,183$ & $12,112,309$ & $6,649,030$ & $13,779,279$ \\
\hline 1868. & 8 & ............... & .............. & $2,453,000$ & ............... & .............. \\
\hline $1877 .$. & 15 & $5,787,002$ & ............... & $3,668,475$ & 9,197 & $4,447,021$ \\
\hline 1882. & 10 & $3,940,311$ & & $1,837,025$ & 441 & $3,307,682$ \\
\hline $1887 \ldots$ & 8 & $4,504,221$ & & $1,979,390$ & 69 & $3,799,136$ \\
\hline $1892 \ldots$ & 8 & $3,666,220$ & ............... & $1,612,200$ & (n........... & $3,647,825$ \\
\hline $1897 \ldots . .$. & 12 & $3,060,740$ & .............. & $1,180,670$ & ............. & $3,001,625$ \\
\hline
\end{tabular}

National Banks.

Figures are in thousands of dollars.

\begin{tabular}{|c|c|c|c|c|c|c|c|c|c|}
\hline YEARS. & 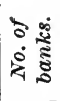 & $\begin{array}{l}\text { Loans and } \\
\text { discounts. }\end{array}$ & $\begin{array}{c}U . S . \\
\text { bonds. }\end{array}$ & $\begin{array}{c}\text { Cash and } \\
\text { cash items. }\end{array}$ & Capital. & Surplus. & $\begin{array}{c}\text { Undi. } \\
\text { vided } \\
\text { profits. }\end{array}$ & $\begin{array}{c}\text { Out. } \\
\text { standing } \\
\text { circula. } \\
\text { tion. }\end{array}$ & $\begin{array}{c}\text { Indi- } \\
\text { vidual } \\
\text { deposits. }\end{array}$ \\
\hline $1864 \ldots$ & 3 & $\$ 1,172$ & $\$ 2,778$ & $\$ 1,066$ & $\$ 1,560$ & $\$ 29$ & $\$ 160$ & $\$ 1,166$ & $\$ 1,900$ \\
\hline $1869 \ldots$ & 31 & 18,219 & 10,945 & 5,554 & 12,740 & 2,045 & 1,088 & 8,807 & 11,798 \\
\hline $1874 \ldots$. & 31 & 23,882 & 10,604 & 6,053 & 13,650 & 2,966 & 1,418 . & 8,845 & 15,747 \\
\hline $1879 . .$. & 33 & 22,509 & 10,503 & 6,856 & 12,795 & 2,989 & 1,009 & 7,369 & 17,936 \\
\hline $1884 \ldots$ & 44 & 32,737 & 9,087 & 6,841 & 14,392 & 3,793 & 1,710 & 7,498 & 23,364 \\
\hline $1889 . .$. & 52 & 37,981 & 2,689 & 5,120 & 14,764 & 4,998 & 1,558 & 1,760 & 27,858 \\
\hline $1894 \ldots$. & 68 & 42,773 & 3,672 & 7,197 & 17,055 & 5,956 & 1,713 & 2,954 & 34,032 \\
\hline $1898 \ldots$. & 70 & 45,568 & 7,120 & 5,981 & 17,044 & 6,897 & 1,589 & 4,153 & 40,277 \\
\hline
\end{tabular}

In 1886 the banking law as enacted in 1870 was extended until 1905. Although bank failures have been exceedingly rare in Maryland, there has been considerable agitation for more stringent laws providing for public supervision of the business. The Maryland Bankers' Association was organized at Baltimore in 1896, its first official act being a strong declaration in favor of the gold standard. 


\section{DISTRICT OF COLUMBIA.}

The municipal government of the District of Columbia has no banking department, and none of the banks in the District are under its supervision. All National associations, Savings banks, loan and trust companies, and other banking institutions, organized under special acts of Congress, are under the supervision of the Comptroller of the Currency and are required to make and publish reports of their condition on the same dates that reports are called for by the Comptroller from National associations throughout the United States. They are likewise subject to examination by National bank examiners.

In addition to the banking institutions and trust companies operating under Federal authority, there are others in the District doing a Savings bank and trust company business under State charters. These institutions are under neither Federal nor municipal supervision, but are subject to the banking laws of the States from which their respective charters were derived and operate as branches with their principal bank in the State.

There are also a number of private banks and banking firms doing business in the District without any special grant of authority other than the payment of an annual license tax to the District government of fifty cents on each thousand dollars of capital employed.

The first bank authorized by law in the District of Columbia was the "Bank of Columbia," which was chartered by an act of the General Assembly of Maryland, passed December 23, 1793, for the purpose, as stated in the preamble, of promoting the agricultural and commercial interest of the State, and facilitating the preparations for the permanent residence of Congress within the Territory of Columbia.

The capital stock was fixed by the act at 10,000 shares of $\$ 100$ each, and the bank was authorized to have succession "until Congress shall exercise jurisdiction in, and assume the government over, the Territory of Columbia, and until they shall by law annul the charter hereby granted."

On February 15, 1811, Congress passed an act incorporating the Bank of Washington, and on March 3, 1817, authorized the incorporation of the Farmers and Mechanics' Bank of Georgetown, the Central Bank of Georgetown and Washington, the Bank of the Metropolis, the Patriotic Bank of Washington, the Franklin Bank of Alexandria, and the Union Bank of Alexandria, and by the same act prohibited any unchartered banking company, or any association, partnership or company of individuals from doing a banking business within the District of Columbia.

In December, 1835, Congress took up the question of the recharter of the banks in the District of Columbia and by resolution appointed a select committee to inquire into their condition.

In the "National Intelligencer" of January 16, 1836, a statement 
was published to the effect that the banks of the District were prepared to meet their liabilities immediately, if necessary, in the following ratio:

Bank of Washington 49.84 per cent. ; Patriotic Bank of Washington 71.81 per cent.; Bank of the Metropolis 46.88 per cent.; Union Bank of Georgetown '78.30 per cent. ; Farmers and Mechanics' Bank of Georgetown 54.52 per cent. ; Farmers' Bank of Alexandria 43.21 per cent., and the Bank of Potomac 51.85 per cent.

For each dollar of liabilities, except capital stock, each bank had assets as follows :

Bank of Washington $\$ 3.30$; Patriotic Bank $\$ 1.64$; Bank of the Metropolis $\$ 1.39$; Union Bank of Georgetown $\$ 2.46$; Farmers and Mechanics' Bank of Georgetown $\$ 3.05$; Farmers' Bank of Alexandria $\$ 1.57$, and Bank of Potomac $\$ 2.32$.

The entire circulation of the seven banks in the District at that time was $\$ 964,799.90$; the specie held by them was $\$ 643,585.52$; their aggregate liabilities, exclusive of capital stock, was $\$ 2,813,925.26$, and their cash funds $\$ 1,492,814.56$. To meet these balances the banks had discount notes amounting to $\$ 3,141,559.95$; real estate $\$ 318,688.25$ and stock $\$ 228,301.93$. Total $\$ 3,688,550.13$, a surplus of $\$ 2,367,439.43$.

Of the banks above named three are still in existence; namely, the Bank of Washington, now known as the National Bank of Washington; the Bank of the Metropolis, now known as the National Metropoli$\tan$ Bank, and the Farmers and Mechanics' Bank of Georgetown, now known as the National Farmers and Mechanics' Bank of Georgetown.

There are also eight other National banks now in active operation.

Bank Statistics, 1834-1874.

\begin{tabular}{|c|c|c|c|c|c|c|}
\hline YEARS. & 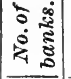 & $\begin{array}{l}\text { Loans and } \\
\text { discounts. }\end{array}$ & specie. & $\begin{array}{l}\text { Capital } \\
\text { stock. }\end{array}$ & Circulation. & Deposits. \\
\hline $1834 .$. & 8 & $\$ 3,693,720$ & $\$ 432,077$ & $\$ 3,337,305$ & $\$ 1,109,389$ & $\$ 1,247,655$ \\
\hline $1835 \ldots$ & 7 & $3,115,524$ & 474,199 & $2,613,985$ & 692,536 & $1,125,618$ \\
\hline $1836 \ldots$ & 7 & $3,1.57,782$ & 643,582 & $2,339,738$ & 961,798 & $1,385,523$ \\
\hline $1837 \ldots$. & 7 & $4,204,512$ & 438,327 & $2,204,445$ & $1,136,557$ & $1,950,736$ \\
\hline 1838. & 7 & $3,109,814$ & 318,354 & $2,175,970$ & 764,822 & $1,222,052$ \\
\hline $1839 \ldots$ & 6 & $3,221,299$ & 415,57: & $1,855,790$ & 950,132 & $1,397,399$ \\
\hline $1840 \ldots$ & 6 & $2,575,613$ & 199,472 & $1,768,074$ & 632,727 & 987,123 \\
\hline $1841 \ldots$ & 6 & $2,000,505$ & 245,629 & $1,745,155$ & 121,975 & 653,386 \\
\hline $1842 \ldots$ & 6 & $1,830,297$ & 114,456 & $1,786,920$ & 111,658 & 707,842 \\
\hline $1843 \ldots$ & 6 & $1,859,904$ & 229,501 & $1,668,307$ & 253,874 & 822,713 \\
\hline $1844 \ldots$ & 6 & $1,978,117$ & 452,055 & $1,659,435$ & 557,279 & $1,391,241$ \\
\hline $1845 \ldots$ & 6 & $2,621,698$ & 456,622 & $1,649,280$ & 535,478 & $1,869,749$ \\
\hline $1853 \ldots$ & 3 & $1,516,641$ & 175,546 & 847,728 & 243,881 & 891,886 \\
\hline $1864 .$. & 4 & ............. & .......... & $1,179,000$ & ............ & .......... \\
\hline $1874 \ldots$ & $\ldots$ & 522,816 & ........... & 73,480 & ........... & 688,338 \\
\hline
\end{tabular}


National Banks, 1863-1898.

Figures in thousands of dollars.

\begin{tabular}{|c|c|c|c|c|c|c|c|c|c|}
\hline YEARB. & 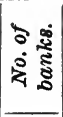 & $\begin{array}{c}\text { Loans } \\
\text { and dis- } \\
\text { counts. }\end{array}$ & $\begin{array}{c}U . S . \\
\text { bonds. }\end{array}$ & $\begin{array}{c}\text { Cash } \\
\text { and cash } \\
\text { items. }\end{array}$ & capital. & Surplus. & $\begin{array}{c}\text { Undi- } \\
\text { vided } \\
\text { profits. }\end{array}$ & 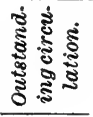 & $\begin{array}{c}\text { Indi- } \\
\text { vidual } \\
\text { deposits. }\end{array}$ \\
\hline $1863 . . . . . .$. & 1 & $\$ 99$ & $\$ 175$ & $\$ 54$ & $\$ 500$ & ......... & $\ldots \ldots$. & & $\$ 31$ \\
\hline $1868 \ldots . . . .$. & 5 & 1,527 & 2,624 & 1,312 & 1,350 & $\$ 235$ & $\$ 260$ & $\$ 1,034$ & 2,121 \\
\hline $1873 \ldots . .$. & 4 & 1,868 & 1,291 & 495 & 1,152 & 284 & 73 & 976 & 1,765 \\
\hline $1878 \ldots . . . .$. & 7 & 1,913 & 1,497 & 606 & 1,507 & 342 & 115 & 1,014 & 2,104 \\
\hline $1883 \ldots . . .$. & 6 & 2,531 & 1,513 & 802 & 1,377 & 339 & 141 & 838 & 3,367 \\
\hline $1888 \ldots . . .$. & 8 & 4,593 & 1,946 & 2,255 & 1,827 & 627 & 274 & 627 & 8,056 \\
\hline $1893 \ldots . . .$. & 13 & 6,552 & 1,375 & 2,915 & 2,827 & 1,405 & 315 & 987 & 8,174 \\
\hline $1898 \ldots . . . . .$. & 12 & 10,363 & 1,961 & 3,148 & 3,027 & 1,367 & 377 & 971 & 15,355 \\
\hline
\end{tabular}




\section{IV}

\section{SOUTHERN STATES.}

The loss of the privilege of issuing notes has been deeply felt by the State banks of the Southern States, and the National banks have never been able to meet the requirements of certain localities for a circulating medium as fully as the former institutions. Since many of the State banks in this part of the country issued a currency that was not only ample in volume, but entirely safe, it is quite natural that there should still be a strong sentiment favorable to the issue of such circulation at the present day. Even among those who believe that the privilege of emitting notes should be confined to National banks, there is more of a disposition to concede the issue upon the commercial assets of the banks than is to be found elsewhere in the conntry. Perhaps close inter-relations of commerce between the States, and the tendency toward more uniform laws and commercial usages, will prevent the restoration of the privilege of issuing circulating notes to the State banks; but on the other hand it may be said that if such functions were restored to these banks, public opinion in the several Southern States would require restrictions that would ensure the safety of the notes, though it would hardly be possible to secure the uniformity provided for by the laws regulating the issue of circulating notes by the National banks.

\section{VIRGINIA.}

The banking system in Virginia, outside of the National banks, is based on the system that existed with the Colonies. The fewest number of banking laws have been enacted, and the legislative acts regulating banking in Virginia are embodied in a short chapter of the Code of 1860, since amended in slight particulars to meet the change of conditions.

While there are no records in Virginia establishing the existence of organized banks in the Commonwealth, before the organization of the Bank of Alexandria by act of General Assembly, November 23, 1792, there are evidences of the demands for banks long prior to that date, and also the passage of certain restrictive acts showing that individuals were attempting to profit by the demands of trade for a circulating medium by doing a banking business on their own account, and as far back as 1730 a bank is reported as having an established business in 
Richmond. In 1777 a special act of Assembly was passed prohibiting "the issue by persons on their own private security of bills of credit or notes payable to bearer." Frequent laws enacted previous to that time pertaining to the punishment of usury, fixing the value at which coins should be received, and providing penalties for excessive discount, show that questions akin to banking occupied the minds of the colonists very early, and that banks in Virginia came tardily to fill a demand that had been pressing for years.

Lack of facilities for exchange was a great clog on the Colonies, and some of their difficulties are expressed in the act of General Assembly of December 14, 1662:

"Whereas, Daylie experience showeth the great damage sustained by divers merchants and other inhabitants of this country by bills of exchange protested, and since the usual advance on goods is fiftie per cent; Bee it therefore enacted, that every person in this country drawing one or more bills of exchange upon any man which shall return the same protested, shall pay to the creditor for his damage by losses of this returne thirty per cent."

In October, 1666, this rate of damage having been found by usage to be excessive, was reduced to fifteen per cent.

\section{Bad Condition of the Coins in Circulation.}

In 1710 the confusion of coins in circulation was so great and so many hardships visited on debtors by reason of heavy discounts, that the General Assembly fixed the value of the coins of Peru, Mexico, Portugal, Flanders and other countries, and made the penalty for refusal to take them, a loss of the debt. It was even necessary to enact a similar law to save the copper coins of the mother country from ruinous discount. "vi"

In 1730 the rate of six per cent., was established as legal interest, and the payment of double the amount loaned was provided as the penalty for a usurious charge. Notwithstanding the already enacted law, and its penalties, it became necessary again in $\mathbf{1 7 1 4}$ to fix the value at which gold coins should be received for debt, and counterfeiting was made high treason visited with death. In 1727 a similar law was passed in regard to silver coins, and a law passed to prohibit the cutting of gold coins into lesser pieces to make change.

But for tobacco the "banking" facilities of the colonists would have been even more inefficient. In the year 1742, in the reign of Good King George II, an act was passed further reflecting the difficul ties of trade without banks of issue :

" And for preventing all mistakes and controversies concerning the allowances to be made upon the paiment of publick, county, and parish levies; Be it enacted, that the levies aforesaid shall be all laid in nett tobacco."

Numerous fines were also paid in tobacco, as evidenced by an act imposing a penalty on masters and overseers of 150 pounds of tobacco who knowingly harbored a slave not their own. 


\section{Difficulties in Using Tobacco for Currency.}

As all public, parish and county dues were payable in tobacco, it became necessary to improve the convenience of handling and storing this commodity, and thus grew up a system of exchange which for ingenuity compares well with later methods, and but for the perishable nature of the basis of the currency would have better stood the test of time.

The colonial government authorized " rolling houses," named from the method in vogue even up to a late day of rolling the tobaccoalong the road in hogsheads to the nearest shipping point. It could be carried to these rolling houses, where under government inspectors it would be weighed, stored and sold, and the public dues be extracted from the proceeds and the balance delivered to the producer.

After all it was difficult to pay dues, fines, etc., in the actual tobacco staple, and acts were passed providing that the inspectors of the warehouses should be obliged to deliver to the person bringing his tobacco for the discharge of any private or public debt, as many promissory notes under the hands and seals of the said inspectors, as should be required for the full quantity of tobacco received by them, "Which notes shall be and are hereby declared to be current \& paible in all tobacco paiments whatsoever, according to the species expressed in the note, whether the county where such inspectors shall officiate or in any other county next adjacent thereto. *** And shall be transferred from one to another in all such paiments, and shall be paid and satisfied by the inspector who signed the same upon demand."

It was further provided that such notes could be renewed, and to counterfeit them was made a felony. If the notes were renewed and the fees paid, the tobacco was sold and the balance of the proceeds, after collecting fees, was turned over to the last holder on demand. Thus it will be seen a large circulating medium was created.

The fault in this system of circulation was the uncertainty and perishableness of its basis. This is illustrated in the records, by the numerous acts passed to provide for deductions from the amount of the face of the notes at re-inspections when the tobacco had deteriorated, the separating of spoiled tobacco from the good, and the burning of spoiled tobacco, all going to show that the last holder of the tobacco notes was likely to be a heavy loser.

This condition was sought to be guarded against by a later act providing that no crop-note older than eighteen months should be legal tender.

The scarcity of specie bore heavily upon the trade of the Colony, and as an encouragement to the colonists to import coin an act was passed in 1755 allowing a rebate of fifteen per cent. on duties paid in coin proven to be money imported for that purpose. In May of the same year the demand for money was so pressing that the General Assembly authorized John Robinson, Treasurer of the Colony, to issue twenty 
thousand pounds of treasury notes, and they were made legal tender for everything "except his Majesty's quit rents." He had to have the best.

The following August the plan of issuing paper money had apparently served so well that four thousand more pounds were emitted "to pay the rewards allowed by law for Indian enemies killed or captured," and twenty thousand pounds "for the protection of his Majesty's subjects against the insults and encroachments of the French." These bore five per cent. interest and were redeemable in five years.

The restricted currency of that day and the demand for the same are also reflected in the numerous acts against usury.

\section{Efforts to Prevent Depreciation.}

All debts were made payable in the current money and the notes naturally soon commenced to depreciate and laws were immediately passed to prevent it and grew more drastic as the depreciation increased. One act provided that where any person should in any suit declare for sterling money except where the debt was payable in sterling, he should be non-suited. The scarcity of a good circulating medium was again set forth one year after the above issues of treasury notes in the preamble to an act providing for the emission of further paper money to the amount of twenty-five thousand pounds, which sets forth: "And, whereas, by reason of the long time allowed for collecting the duties imposed by this act (which from the distressed circumstances of the people) and the great scarcity of gold and silver coin in this colony could not be sooner done," etc.

Yet another step was taken to advance currency reform, but which at the same time makes it apparent that the depreciation of treasury notes was rapid notwithstanding the laws enacted to keep them at par, when in 1757 an act was passed taking up previous issues by a new one.

The preamble to the act states, "And, whereas, the allowing treasury notes to bear interest is found to be very burdensome to the country and not to have answered the good purpose intended by former acts of Assembly, and it will be prejudicial to have notes of different value circulating at the same time. $* * *$ That the Treasurer as soon as can be conveniently done take in all such treasury notes as have been emitted."

This act then provides for the payment of notes previously emitted by the issue of others ranging in value from one shilling to ten pounds.

These notes were largely counterfeited and the evil became so great that the penalty was placed at death "without the benefit of clergy."

The issues were later taken up by reissues, each succeeding issue being larger than the one before.

The difficulty in making change in the Colonies had led to the extensive practice of dividing gold coins with a chisel. And "to prevent the 
evil practice of cutting gold coins into pieces" and to further aid in providing a more convenient circulation "His Majesty graciously permitted the importation at public expense and the use in the Colony of twenty-five thousand pounds in copper coins." The demand for small coins was again sought to be met in February, 1772, when copper halfpence to the value of one thousand pounds were purchased for use in the Colony.

\section{Depreciation of the Continental Currency.}

Commencing with the July Convention of 1775 the Revolutionary fathers in Virginia sought to sustain the fortunes of the Continental forces by further emissions of paper. The intention was that they should be equal to coin, but. rapid depreciation was their history. In May, 1776, paper money of the Commonwealth was made legal tender for all dues and debts and a penalty of twenty-five per cent. on the face value was imposed for demand for discounting the same. An act at the same time prohibited the issue by persuns on their own private security of bills payable to bearer. These first issues as they depreciated were taken up by newer issues at their depreciated value, the issues of 1780 being at the ratio of forty to one for Spanish milled dollars. Loan offices were authorized and notes bearing interest were tried, but these also suffered a rapid depreciation. The rapid depreciation of these notes and their undesirability is shown in the preamble to an act of November, 1781, providing for the settlements of debts on a scale of depreciation, which says:

"Whereas, The paper currency of this State hath from various causes greatly depreciated in its value insomuch that it is not a proper medium of calculation, nor a just standard whereby to adjust and settle debts and contracts, and it has therefore become absolutely necessary to declare that the same shall no longer pass current except in the payment of certain taxes calculated for the express purpose of calling in and redeeming the same."

The depreciation at this time had reached a ratio of one thousand to one, and at that rate they were paid in loan office certificates and passed out of circulation.

The pinch on account of the scarcity of money following the Revolutionary War was so tight that an act was passed in 1782 "to relieve taxpayers," making deer skins well dressed for the purpose of making breeches, commutable with silver at eight shillings per pound for every skin.

In 1785 an act was passed making it unlawful for any person to offer in paynent a private bank bill or note for money payable to bearer, the penalty being a forfeiture of ten times the amount. This act only went into force some months after its passage, showing that there were large quantities of such notes out and that opportunity was given the holders to redeem them without penalty from those who issued them. In $\mathbf{1 7 8 7}$ the payment of taxes in paper money of old 
depreciated issues was so onerous that only one-tenth of the taxes was allowed to be paid in that currency.

There is contributory evidence in the acts of Assembly about this time from which inferences can be drawn making it plain that there were frequent efforts to do a banking business by persons and corporations without authority of the government, but there are no records of any such institutions.

\section{The First Bank Chartered in Virginia.}

'The Bank of Alexandria was the first bank chartered in Virginia. It was established by act of General Assembly November 23, 1792, which in its preamble quaintly indicates the regard in which banks were held in that day :

"Whereas, The experience of commercial nations for several ages past has fully evinced that well-regulated banks are highly useful to society, by promoting punctuality in the performance of contracts, increasing the medium of trade, facilitating the payment of taxes, preventing the exportation of specie, furnishing for it a safe deposit, and by discount rendering easy and expeditious the anticipation of funds, Be it enacted," etc.

There is no record of this ancient institution, whose capital stock was one hundred and fifty thousand dollars. Neither this bank nor the Bank of Richmond appears in the table of banks of that date contained in the appendix to the Comptroller's report for the year 1876 .

The shares of the bank's stock were $\$ 200$ each, payable in installments, and the failure to meet any of the payments caused a forfeiture of the whole.

A stockholder had as many votes as he had shares up to ten, and over that, a vote for every five shares.

The bank had nine directors. It was only allowed to hold such real estate as was requisite for its immediate accommorlation in relation to the convenient transaction of its business. To guard against speculation it was provided that the bank could not buy any public securities or any goods or chattels except such as were sold under the execution of its own claims. The directors met quarterly and were empowered "to regulate the mode of doing business and to appoint and pay officers," to charge six per cent. discount and to make dividends semiannually. The penalty for embezzlement by a director was forfeiture of his stock. Stockholders were only responsible to the amount of their stock, unless the amount of debts should exceed four times the capital, and they would then be liable only after the property of the directors was exhausted. The bank had to report its condition annually to the Governor of the State. One of the most important provisions of this old charter was the special power given to the bank to collect its debts. Persons neglecting to pay negotiable notes could be immediately sued on ten days' notice, judgment secured without right of appeal, nor were the defendants allowed the right to replevy goods 
and chattels taken under the execution. A clause was inserted to show there was not any pledge of public faith or that the General Assembly was bound in any way for its support. The penalty for counterfeiting the notes of this bank was made punishable by death without the benefit of clergy.

The Bank of Richmond was established one month later than the Bank of Alexandria, its charter dating December 23, 1792, and in most particulars following the wording of the first charter. Nothing is known of the history of this bank or the measure of success it attained. The names of the men who were authorized to sell its stock were famous in Virginia mercantile history.

The capital stock of the Bank of Richmond was $\$ 400,000$ in shares of $\$ 200$ each. Eleven hundred shares were allotted to Richmond and 300 each to Norfolk, Petersburg and Fredericksburg, and authority was given to establish a branch bank in any town where 300 shares of the stock were held.

These are the only banks of which any record appears in the acts of Assembly until December 10, 1795, when a special act was passed authorizing the President and directors of the Bank of the United States to establish offices of discount and deposit in the Commonwealth.

\section{Establishment of Banks Under State Control.}

Following this period in banking in Virginia there sprung into life a system of State banking based on the old Scotch system under which a half dozen banks of issue were authorized with numerous branch banks in every part of the State. The charter provisions of these banks were the basis of the few laws that have been enacted in relation to banking since that day.

The first of the banks to be established under State control was the Bank of Virginia, incorporated by the General Assembly January 13, 1804, with a capital stock of one million five hundred thousand dollars in shares of one hundred dollars apportioned 3,750 shares to Richmond, 3,000 to Norfolk, 2,250 to Petersburg, 1,000 to Fredericksburg, 525 to Winchester, 450 to Staunton and 525 to Lynchburg.

The charter provided that the bank should hold real estate and other effects to the value of $\$ 3,500,000$, including the capital stock. The Cashier was required to give bond for $\$ 50,000$. "The total amount of notes thrown into circulation by the bank together with the debts were restricted to four million five hundred thousand dollars, over and above the money then actually deposited in the bank;" that is, the issue could be three for one on its cash capital, and this was the established rate for this class of banks. The directors were made liable in their private capacities for any loss by reason of excess of issue. But in practice these banks rarely issued to the full limit allowed. Their charters allowed them to buy no public stock except their own. They could charge a discount of not more than six per cent. They could make no 
loan to any State or Government except by special act of Assembly. Such an act was passed in 1812 permitting the Bank of Virginia and the Farmers' Bank to loan money to the United States Government, presumably for the War of 1812 .

It was provided that the bank should make annual reports of the condition of its affairs to the Legislature. The notes of these banks were receivable for all payments or dues to the State and all public money lying idle was deposited with them. The State subscribed $\$ 300,000$ to the capital stock of the Bank of Virginia, and borrowed it back at four per cent., payable in ten annual installments. No note could be issued of less than five dollars value and no note was negotiable unless so expressed on its face. A special act was passed the same year of incorporation imposing a penalty of from ten to twenty years for counterfeiting the notes of this bank.

The bank was well managed and was highly successful. Its notes, all payable in gold, had a wide circulation and were at only one-fourth of one per cent. discount in New York. In 1839 it lost $\$ 540,000$ by bad loans made by the paying teller. With some changes in management it gradually recovered from this loss.

All of these banks had branches, and by swapping notes they made it difficult for the brokers to prey upon them.

The Farmers' Bank was chartered February 13, 1812. Its stock was $\$ 2,000,000$, and the State subscribed for 3,334 shares. Fifteen directors were provided for at Richmond, and thirteen for each of the branch banks at Winchester, Lynchburg, Petersburg and Fredericksburg, nine to be elected by the State Legislature for the mother bank, and eight for each of the branch banks, the stockholders to elect the balance. These branches were afterwards increased in number and existed at various points in the State. Each branch issued its own notes of circulation and became a complete bank with all the functions necessary to meet the requirements of the community in which it was established. The branch bank swapped notes with the mother bank and thus promoted a wide circulation.

These mother banks, six in number, were great institutions, and held the complete confidence of the people. The law did not require that they should keep any reserve, and they kept none except the specie held in their vaults to redeem their notes. The relation of the branch banks to the communities in which they existed is illustrated in an address by William L. Royall, before the convention of the American Bankers' Association in Denver in August, 1898 :

"One of the branches of the Farmers' Bank of Virginia was located at Blacksburg, a small village of two or three hundred inhabitants in Montgomery county, which is a blue-grass grazing region of country as fine as any in the world. This branch had a capital of $\$ 60,000$ and a surplus of $\$ 50,000$, that is, it had $\$ 110,000$ of resources. But it had out its notes to the amount of $\$ 146,274$, and it kept in its vaults only $\$ 29,555$ of specie against these notes. With capital, surplus and notes, 
it had, therefore, $\$ 256,000$, but its deposits were but $\$ 7,042$. It had out loans, however, amounting to $\$ 227,000$, which added to the coin on hand about balanced its resources.

Now, this trifling deposit account has a deep meaning. It means that the farmers around, who borrowed the bank's money, did not take their loans in the form of credits on which they checked. It means that they took the bank's notes and put them in their pockets and carried them home and paid them. out to their neighbors, and as everybody had confidence in the bank, whose managers were the leading people of the community, nobody ever thought of going to the bank and demanding redemption of their notes in coin, so that once out they remained out indefinitely and circulated around among the people, performing the function of money as well as the purest of gold dollars. The result was that they could so multiply their capital that they could afford to charge very low rates of interest, and the people generally had an abundance of money at most reasonable rates."

\section{Unchartered Banks Declared Illegal.}

About the time the first banks in Virginia were incorporated the business of banking and the issue of bills were found to be so profitable that numerous private banks and banks of unchartered companies sprang up and their bills reached a wide circulation. An act was passed February 24, 1816, declaring all unchartered banks illegal, and heavy penalties were provided, even to the forfeiture of bills and property. These notes had, however, found their way into wide circulation, and even those acting in good faith found it impossible to recall them quickly and to close the business in the time specified, and it was twice extended, to the Loudoun Company, the Bank of Martinsburg, the Monongahela Bank, the Farmers' Company, the Warrenton Company, the Salem Company, the Leesburg Union Company, the Western Bank, the Charleston Manufacturing and Exporting Company, the Bank of Winchester and other concerns having extensive note issues without right by charter.

No one lost anything by these old State banks in Virginia. The directors in their individual capacity and the property of the bank were made liable for any loss by excess of issue. The bills were placed on the same footing as foreign bills of exchange, "sc that like remedy may be had for the recovery thereof against the drawer."

Half-yearly reports were to be made to the stockholders and annually to the Legislature. The minutes of the bank were to be laid before the Legislature on demand, and a list of the stockholders was to be hung up to public view.

The Bank of the Valley, at Winchester, and the Northwestern Bank were established simultaneously under an act of February 5, 1817, with numerous branches, and in all essential particulars their charters were similar to those before established.

The Merchants and Mechanics' Bank, of Wheeling, was similarly chartered in 1834, and the Exchange Bank, of Norfolk, the last of the State government banks, by a special act of March 25, 1837, with a capital of over three million. The act also comprised a general law 
for the establishment of banks of issue based on State bonds or the bonds of improvement companies guaranteed by the State, and also banks simply of deposit and discount.

Up to this time the only laws governing banks were the acts incorporating the same, and the amendments thereto. The act establishing the Exchange Bank, of Norfolk, increased the banking capital of the Commonwealth by five million dollars, divided among the six banks above-named, the State subscribing to "one moiety" (a half) of the stock of each bank. This act also embraced general regulations for the conduct of banks (see Code of Virginia, 1849), which with the changes made by succeeding Legislatures is the law under which the banks of Virginia have long been incorporated and transact business. These six mother banks, with their branches, at this time comprised the banking system of the State, and with the numerous free banks established between 1837 and 1860, Virginia had a very liberal banking system.

The six banks above named had branches at the places designated as follows: The Bank of Virginia, at Norfolk, Portsmouth, Petersburg, Fredericksburg, Lynchburg, Buchanan, Danville, Charleston and Union (the latter two points being now in West Virginia).

The Farmers' Bank at Norfolk, Petersburg, Fredericksburg, Lynchburg, Winchester, Danville, Farmville, Charlottesville, Wytheville, Alexandria, Louisburg and Blacksburg.

The Exchange Bank at Petersburg, Clarksville, Alexandria, Abingdon, Salem, Weston, Lynchburg and Richmond.

The Bank of the Valley at Romney, Charleston, Leesburg, Staunton, Christiansburg and Moorefield.

The Northwestern Bank (at Wheeling, now West Virginia), at Wellsburg, Parkersburg and Jeffersonville.

'The Merchants and Mechanics' Bank (of Wheeling) at Morgantown and Mt. Pleasant.

Some of the other banks of issue established under the free banking act of March 25, 1837, also had branches.

\section{Provisions in Regard to Circulation.}

The law provided that the total amount of the paper circulation of these banks should never exceed five times the amount of the coin in possession and actually the property of the bank. If the coin of the bank was reduced below one-fifth of its circulation it was required to stop all discounts until the ratio was restored. As a matter of fact some of the banks issued as high as eight to one. These banks were subjected to inspection by committees of the Legislature and sometines examinations did occur. They were made the occasions of a dinner in the directors' rooms and the figures were discussed over the champagne.

The banks at such times kept their coin reserve up by keeping the discounts down. It is reported that at such periods drafts drawn on New York were placed in the safe to make up a balance, and called 
" coin." Be that as it may, there is no case on record where a bank of circulation and deposit failed, and it is claimed by those acquainted with the banking of that day that no one ever lost a dollar by a Virginia bank note previous to the war of 1861 , and they were at a discount of only a quarter of one per cent. in New York.

In addition to the banks mentioned there were many banks that had no circulation, and nothing is known of their history as they made no reports. The acts establishing them are referred to by the compilers of the Code as being "too numerous to mention," and the names are given in long foot notes to pages $338,339,340$, of the Code of Virginia of 1860 .

The period from 1834 to 1860 is referred to by the older bankers as "The halcyon days when there was a bank at every cross roads."

It is claimed that at one time full three hundred banks existed in Virginia. The records indicate that there were at least two-thirds that number in the Commonwealth, which at that time also comprised the State of West Virginia.

\section{The Free Banks of Virginia.}

The free banks comprised a separate class of institutions, of which there were quite a number. The Bank of the Old Dominion at Alexandria, Va., was a good illustration of this class of free banks, that is, it had no State representation on its board of directors and no part of its stock was owned by the State as in the other State banks.

The Bank of the Old Dominion was established March 29, 1851, and when it deposited with the State Treasurer the bonds of the State or securities bearing six per cent. interest guaranteed by it to the amount of $\$ 200,000$-its minimum capital-the bank was authorized to issue notes to the full amount of stock guaranteed, of any denomination not under five dollars. These notes were countersigned by the State Treasurer, and had printed across their face the words "secured by pledge of State securities." These banks not only drew the interest on the bonds and secured a working capital equal to their face value, but the bonds went to a premium of twenty per cent.

It was provided in the charter of the Bank of the Old Dominion and others of the same class that they should have a contingent fund of five per cent. of the cash capital to be accumulated out of the profits, to be held at the bank or any of its branches where accumulated, to meet any losses on its notes. In consideration of the privileges granted by the State every bank had to pay to the State a bonus of one-quarter of one per cent. on its capital stock out of each semi-annual dividend. It will thus be seen that the profits to the State from its banks of circulation were very large.

These banks as a rule were well managed and profitable, and their notes were in great demand, being secured by State bonds, and the notes stood higher than the issue of other States, and a large business 
was done in them by cattle buyers who bought them for use in the West where they had excellent standing.

The Bank of the Old Dominion after the war was over, paid its deposits, redeemed its circulation and paid a dividend to its stockholders. This was the only one of these banks that did so well, although most of them paid their notes to a large extent.

\section{How a Bank's Gold was Saved.}

The Bank of the Old Dominion secured its financial integrity through its discount clerk, Mr. J. W. Lockwood, now the Cashier of the National Bank of Virginia at Richmond.

On the advance of the Federal troops to Alexandria the bank's gold was shipped to Lynchburg, and it was afterwards moved to Richmond in Mr. Lockwood's care.

The demand for gold by the Government was so great that nearly all the banks surrendered their gold and took Confederate securities, and when the end came the banks were swept out of existence with the general destruction.

But not so with the Bank of the Old Dominion, its faithful discount clerk secured its gold and fled with it South at the evacuation of Richmond, and two months later returned it to the board of directors at Alexandria intact along with two thousand dollars in silver, which he buried in a sarcophagus in Charlottesville and dug up after his return.

The President of this bank was William N. McVeigh; P. E. Hoffman was Cashier and G. W. D. Ramsey, a near relative of Gen. Washington, was teller. He was afterwards teller of the First National Bank of Alexandria, and so continued up to eight years ago when he was retired on a pension. He is now ninety-one years of age and when a short time ago was asked for information concerning his banking career, replied in a beautiful hand as steady as a young clerk's. He was a very attentive man of business and would never take his vacation except on legal holidays. He regularly attended the President's New Year receptions at the White House.

The Bank of the Commonwealth at Richmond was another of the notable free banks, with a capital of $\$ 500,000$. Similar banks existed in all the cities and larger towns of the Commonwealth up to 1861, when they practically went out of existence by reason of cheap-note issues, the circulation having jumped from less than ten million in 1860 to more than twice that amount in 1861.

\section{Banks of Deposit and Discount.}

There was still another class of banks in Virginia prior to the Civil War and those were more numerous than any other-banks merely of deposit and discount. A law was enacted in 1838 creating such banks, and while they were regularly chartered few restrictions were imposed and they were conducted on a go-as-you-please plan. The fullest powers 
were given the board of directors in making rules and conducting the affairs of the bank. The failure to pay depositors on demand carried a penalty of ten per cent. on the whole amount from the time of such failure until paid. Provision against speculation, and the rate of discount to be charged were the principal restrictions in the charters.

The Commercial Savings Bank, of Richmond, chartered in 1853, was a sample of this class of banks. Fifteen business men organized a bank and became its directors and owners. They gave their notes for $\$ 2,500$ each and curtailed them $\$ 50$ every month. No dividends were declared. Profits were allowed to accumulate and no one could borrow money without having the name of one of the fifteen as endorser. The bank sometimes had from four to five hundred thousand dollars on deposit and it gave these fifteen men considerable power in the business community. Although four or five of the fifteen failed during its existence, there were accumulations sufficient in the bank to meet the paper of these individuals held by the bank, and when it wound up its affairs the owners drew about seven thousand dollars each of profit.

The City Savings Bank, of Richmond, was an institution of like character. There were many other similar banks of which there is now no record, and many of them were conducted much on the plan of the present building and loan companies. The people lost considerable money by these banks in remote places.

The banks of Virginia in the period from 1837 to 1860 had a prosperous record, keeping on an average ten millions of notes in circulation without loss. They were forced to suspend specie payments in the panic of 1857 , but they tided over their difficulties. They were required by special act of the Legislature to resume specie payments on May 1 , 1858 , and they resumed and continued to pay until the war came on.

The resources and liabilities of the twenty-four banks of circulation and their forty-one branches, on January 1, 1860, were as follows:

\begin{tabular}{|c|c|c|c|}
\hline \multirow{2}{*}{\multicolumn{2}{|c|}{$\begin{array}{l}\text { RESOURCES. } \\
\text { Loans and discounts. }\end{array}$}} & \multicolumn{2}{|l|}{ LiABILITIES. } \\
\hline & & Capital....................... & $16,005,156$ \\
\hline Stocks.......................... & $3,584,079$ & & \\
\hline Real estate................. & $1,019,032$ & Circulation........ & $9,812,197$ \\
\hline ther investments.............. & 433,423 & & \\
\hline Due by other banks......... & $2,756.047$ & Deposits.. & $6,729,0$ \\
\hline Notes of other banks............ & $1,294,093$ & Due other banks & $1,138,327$ \\
\hline items.................... & 29,838 & & \\
\hline ecie $\ldots \ldots \ldots \ldots \ldots \ldots \ldots \ldots \ldots, \ldots$ & $2,913,652$ & Other liabilities. & 34,600 \\
\hline
\end{tabular}

\section{Banking Subsequent to the Civil War.}

The declaration of war between the States closed the most prosperous period of banking in Virginia. All of the banks practically went out of existence with the surrender of Lee's Army at Appomattox.

They had long before transferred their gold to the Confederate Government in place of Confederate securities that were worthless and were wiped out with the "Lost Cause." Most of them went into voluntary 
liquidation with the remnants of their assets that survived the war, and others were forced into a settlement through the courts and by special act of Legislature.

The State was impoverished to the last degree and the people without resources except their battle-swept fields. A very few of its citizens had limited property in the shape of tobacco, and some cotton in storage, but as a rule the people had no assets outside of their real estate.

The National banking system came to the aid of Virginia almost before the cannon that fired the last shot had cooled, and though this system inaugurated by Salmon P. Chase for enlarging the scope of the bond issue for National bank purposes, and the placing of a ten per cent. tax on State banks was regarded as only justified by military necessity - an operation intended to force all financial transactions under the guardianship of the Government, it was at the same time recognized as the salvation of the country, and its arrival was hospitably received.

But money had to be provided to purchase the bonds from the Government on which the circulation of these banks was based. Gold was at a premium of forty-five cents and the bonds worth $\$ 60$ in gold permitted the issue of circulation of $\$ 90$ in National Bank notes. The war was over and the Government strong. The brightest outlook was presented for a rapid appreciation of the bonds, and it is a matter of history that they steadily rose and went to and above par. While the South had no money, the North had it in plenty and rich men sent their agents South to embark in the profitable investment of establishing National banks.

The old local bankers and reliable business men were taken in association with these capitalists, and the business proved very remunerative. The rates of discount were very high-at the beginning as much as one or two per cent. a month. At first the Comptroller did not require the embodiment in the charter of the clause restricting loans to six per cent., and later when he did enforce this provision and a number of the directors of these banks resigned because the business was not profitable enough at that rate, and they were too honest to evade it, others staid in and satisfied their consciences with the plea that they had a right to "buy" outside paper at any price they saw fit. They "bought" paper at these high rates and did a fine business. The original owners of the bonds finally transferred them to others and drew out, as the business became less profitable.

The first of these banks established in Virginia was opened in the United States Custom House in Richmond-all the buildings in the business district, including all the banks with their entire records, having been burned at the evacuation a few weeks before.

It was designated as the First National Bank, of Richmond, with capital stock of $\$ 100,000$. The articles of association were signed April 17,1865 , and the first election of directors occurred in Washington 
April 25, 1865. The capital stock of this bank has been increased from time to time and is now $\$ 600,000$, the largest in Virginia.

The National Bank of Virginia and the Exchange National Bank were chartered the same day, and only a few days after the First National was organized.

The Planters' National Bank, of Richmond, is another of the earliest National banks, having a capital of $\$ 300,000$ and a surplus of $\$ 700,000$. It was chartered December 8,1865 , and was intended to be a successor to the old State institution, the Farmers' Bank of Virginia, but other incorporators a few days before secured a charter under that name, and they adopted the name "Planters." The Farmers' National Bank was later absorbed by the First National.

The Merchants' National Bank, of Richmond, with $\$ 200,000$ capital, is also one of the oldest of the National banks. The People's National Bank, of Lynchburg, the Lynchburg National, the Norfolk National Bank, and the City National Bank, of Norfolk, are also among the oldest National banks in Virginia.

According to the statements compiled from reports to the Comptroller of the Currency, made on September 7, 1899, there were thirtysix National banks in Virginia on that date with a capital stock of $\$ 4,591,000$ and a surplus of $\$ 2,028,800$. Their circulation was $\$ 2,305,675$. The Comptroller's report shows that the National banks in Virginia have steadily grown in number and in capital employed.

The National banks and seventy-two State banks of discount and deposit, eleven Savings banks, and six trust companies, comprise the banking institutions of Virginia.

\section{State Banks Chartered Since the Civil War.}

The first of the present State banks were organized several years after the National banking system was established in Virginia and marked the restoration of business on resources, the result of the energy of a people left in 1861 without capital, and without resources of any kind.

The first banks to be chartered by the Legislature after the war were Savings banks. The Planters' Savings Bank, of Richmond, the Planters' Savings Bank, of Farmville, the Rockbridge Savings Bank, of Lexington, the Farmers and Mechanics' Bank, of Covington, the Botetourt Savings Bank, of Buchanan, and the Virginia Savings Bank, of Richmond, were all chartered within the same month. In March, 1866, the Commercial Savings Bank, of Richmond, the Christiansburg Savings Institution and the Union Bank, of Richmond, were incorporated.

In 1868 the Constitutional Convention was held, and no Legislature met, but in the following years of 1869 and 1870 , a number of banks were chartered with small capital and the circulation of money was largely increased throughout the State. 


\section{Banks Requiren to Make Reports.}

No records were kept of State banks until the year 1885, when a law went into effect requiring all banks to make reports to the Auditor of Public Accounts identically as the National banks make to the Comptroller of the Currency.

The Comptroller notifies the Auditor of Virginia when he is about to make a call for a report from the National banks and the Auditor simultaneously makes a call on the banks of the State for their reports. Failure to make report is punished by heavy fines, and false reporting is punishable by both fine and imprisonment in the penitentiary.

No banking department exists in the organization of the State and no records have been kept, not even the tabulation of these reports from year to year has been made by the State.

The law formerly required all State banks to be chartered by the Legislature, but by a later act it was provided that joint-stock companies and banks could be chartered by the circuit courts.

The requirements to obtain such a charter are of the simplest. Any five or more persons may apply and stating the amount of capital stock, the amount of real estate to be held, the names and residences of the officers of the first year, and the purposes and manner of the business to be conducted, can secure a charter, if the request to the Judge seems reasonable. The fees being smaller than for Legislative charters, most of the banks since the passage of this act have been chartered by the courts.

\section{Simplicity of the Banking LAws.}

There has been the smallest amount of legislation in Virginia relative to banks. The law, like the banks themselves, grew out of the necessities of the case, and all the State banks now in existence hold their charters under the general law of 1838 , with the few modifications that seemed necessary with the change of conditions.

The State banks of Virginia are empowered to conduct any business of any other banks except the issue of bank notes. One of the first of the regular State banks of discount and deposit organized after the war was the Citizens' Bank of Norfolk, chartered by the Legislature in 1867, with $\$ 300,000$ capital. The Bank of Portsmouth was established earlier in the same year. Among the first banks to be chartered by the court under the act above mentioned was the Bank of the State of Virginia, at Richmond, which is typical of its class and is the largest of the Virginia State banks, having a capital of $\$ 500,000$. It received its charter from the circuit court of Richmond January $10,1870$.

These banks are not required under the law to have any reserve, the only guarantee for the depositor being the integrity and the liability of the officers for losses. 
There have been few bank failures in Virginia, such as have failed being due to defalcation rather than mismanagement. Banks in Virginia pay no tax to the State except the regular property assessment on their shares.

On May 31, 1880, Virginia had seventy-six banks, of which twenty were private banks without charter, and two Savings banks. Their combined capital was $\$ 3,036,974$; deposits, $\$ 7,757,202$. July 18,1890 , there were the same number of banks. The capital stock was $\$ 4,591$,048 ; deposits, $\$ 13,767,424$. June 30,1899 , there were eighty-nine banks with capital stock $\$ 5,840,080$; deposits, $\$ 21,106,121$.

State Banks.

\begin{tabular}{|c|c|c|c|c|c|c|}
\hline YEARS. & 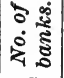 & $\begin{array}{l}\text { Loans and } \\
\text { discounts. }\end{array}$ & Specie. & Capital stock. & Circulation. & Deposits. \\
\hline $1834 .$. & 20 & $\$ 11,752,058$ & $\$ 937,751$ & $\$ 5,694,500$ & $\$ 5,598,392$ & $\$ 2,875,774$ \\
\hline 1839... & 27 & $17,019,567$ & $2,360,423$ & $8,074,456$ & $8,231,918$ & $3,106,136$ \\
\hline $844 \ldots$ & 27 & $14,098,534$ & $2,464,932$ & $10,369,137$ & $5,877,087$ & $2,873,832$ \\
\hline $849 \ldots$. & 35 & $17, \mathbf{3 3 8}, 182$ & $2,392,800$ & $9,686,570$ & $7,825,832$ & $3,719,613$ \\
\hline 1854.. & 55 & $24,913,789$ & $3,271,042$ & $12,796,466$ & $14,298,792$ & $6,513,027$ \\
\hline $859 \ldots$ & 63 & $22,419,512$ & $3,077,687$ & $14,685,370$ & $10,340,342$ & $7,401,701$ \\
\hline $1861 \ldots$ & 66 & $25,866,262$ & $3,017,359$ & $16,486,210$ & $19,817,148$ & $7,157,270$ \\
\hline $86 \%$ & 2 & …............. & …..... & $1,070,000$ & $\ldots \ldots \ldots$ & , \\
\hline $1872 \ldots$ & 27 & …............ & …............ & $2,963,000$ & ............. & ….............. \\
\hline $1876 \ldots$ & 19 & $3,239,140$ & (............. & $1,855,399$ & ............. & $2,628,297$ \\
\hline $1885 \ldots$ & 52 & $8,146,947$ & (............... & $2,881,430$ & ................. & $7,846,492$ \\
\hline $1889 \ldots \ldots$ & 67 & $12,601,775$ & (............... & $3,801,615$ & $\ldots$ & $10,777,116$ \\
\hline $1894 .$. & 84 & $16,206,927$ & ............... & $6,303,844$ & ................. & $13,263,860$ \\
\hline $1899 \ldots$ & 89 & $21,048,228$ & ….......... & $5,840,080$ & ............ & $21,106,621$ \\
\hline
\end{tabular}

National Banks.

Figures are in thousands of dollars.

\begin{tabular}{|c|c|c|c|c|c|c|c|c|c|}
\hline YEARs. & 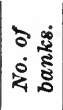 & $\begin{array}{l}\text { Loans } \\
\text { and dis- } \\
\text { counts. }\end{array}$ & $\begin{array}{l}\text { U. S. } \\
\text { bonds. }\end{array}$ & $\begin{array}{l}\text { Cash and } \\
\text { cash items. }\end{array}$ & Capital. & Surplus. & $\begin{array}{c}\text { Undi. } \\
\text { vided } \\
\text { profts. }\end{array}$ & $\begin{array}{c}\text { out. } \\
\text { standing } \\
\text { circula. } \\
\text { tion. }\end{array}$ & $\begin{array}{c}\text { Indi. } \\
\text { vidual } \\
\text { deposits }\end{array}$ \\
\hline $1864 \ldots . .$. & 1 & $\$ 250$ & $\$ 175$ & $\$ 53$ & $\$ 100$ & .......... & $\$ 16$ & $\$ 80$ & $\$ 388$ \\
\hline $1869 \ldots \ldots$ & 16 & 4,044 & 2,583 & 888 & 2,223 & $\$ 169$ & 162 & 2,060 & 2,936 \\
\hline $1874 \ldots . .$. & 20 & 7,046 & 3,744 & 1,149 & 3,535 & 630 & 360 & 2,890 & 5,035 \\
\hline $1879 \ldots \ldots$ & 17 & 6,582 & 3,187 & 1,126 & 2,866 & 793 & 243 & 2,280 & 5,620 \\
\hline $1884 \ldots . .$. & 24 & 11,738 & 3,191 & 2,168 & 3,537 & 1,262 & 593 & 2,281 & 10,796 \\
\hline $1889 \ldots . .$. & 30 & 12,694 & 2,487 & 1,224 & 4,121 & 1,660 & 556 & 1,005 & 10,646 \\
\hline $1894 \ldots . .$. & 37 & 14,918 & 2,670 & 1,679 & 4,846 & 2,708 & 614 & 1,729 & 12,735 \\
\hline $1898 \ldots . .$. & 35 & 15,139 & 4,115 & 2,062 & 4,546 & 2,928 & 559 & 1,715 & 16,402 \\
\hline
\end{tabular}




\section{State and Private Banks.}

A report of the condition of the Virginia banks, other than National, at the close of the fiscal year ended June 30,1899, is as follows:

\begin{tabular}{|c|c|c|c|}
\hline RESOURCES. & private banks. & $\begin{array}{l}\text { Savings } \\
\text { banks. }\end{array}$ & $\begin{array}{c}\text { Trust } \\
\text { companies. }\end{array}$ \\
\hline \multicolumn{2}{|c|}{ Loans on real estate................ $\$ 16,703,762$} & $\$ 2,742,556$ & $\$ 1,601,910$ \\
\hline 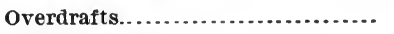 & 80,963 & 14,689 & 1,386 \\
\hline United States bonds............... & 443,830 & n........... & (n............... \\
\hline Stocks, bonds and securities........ & $2 ; 007,920$ & 571,834 & 240,104 \\
\hline Expenses and preminms............ & 94,849 & 21,530 & 6,372 \\
\hline Due from other banks and bankers. & $2,810,858$ & 534,232 & 124,242 \\
\hline Real estate, furniture and fixtures.. & 280,046 & 236,192 & 129,025 \\
\hline Checks and other cash items........ & 427,985 & 73,581 & 2,951 \\
\hline Specie................... & 442,953 & 80,893 & 26,193 \\
\hline Notes and currenoy ............. & 757,120 & 82,286 & 47,344 \\
\hline Other resources..................... & 80,095 & 5.057 & 155 \\
\hline \multicolumn{2}{|c|}{ 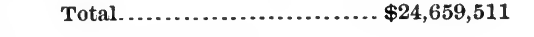 } & $\$ 4,352,850$ & $\$ 2,178,352$ \\
\hline \multicolumn{4}{|l|}{ LIABILITIES. } \\
\hline \multicolumn{2}{|c|}{ Capital stock $\ldots \ldots \ldots \ldots \ldots \ldots \ldots \ldots \ldots$ \$4,687,344} & $\$ 600,341$ & $\$ 552,395$ \\
\hline Surplus fund..................... & $1,367,349$ & 208,108 & 55,000 \\
\hline Other undivided profits.............. & 856,349 & 170,870 & 124,255 \\
\hline Dividends unpaid................... & 80,680 & 13,186 & 7,000 \\
\hline Deposits subject to check........... & $14,430,583$ & $2,074,851$ & $11,001,089$ \\
\hline Other deposits............................ & $2,077,396$ & 1,114 & 408,274 \\
\hline Due other banks and bankers....... & 772,615 & 118,787 & 30,339 \\
\hline Other liabilities...................... & 387,496 & 52,279 & (.............. \\
\hline \multicolumn{2}{|c|}{ Total....................... \$24,659,511 } & $\$ 4,352,850$ & $\$ 2,178,352$ \\
\hline \multicolumn{2}{|c|}{ Number of banks................ } & 11 & \\
\hline
\end{tabular}

Banking in Virginia has prospered generally and shows a steady growth. The clearing-house reports of the city of Richmond give striking evidence of this fact.

There are eight banks holding membership in this association-the First National, the Planters' National, the Merchants' National, the National Bank of Virginia, the State, the City, the Citizens' Exchange, and the Security. The clearings of these banks for the first eight months of the years 1898 and 1899 make an interesting exhibit of prosperity. The amounts are given in tabular form below, and a comparison of the two years shows great growth in the amount of money cleared:

1898.

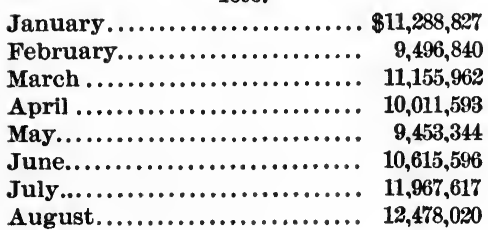

1899.

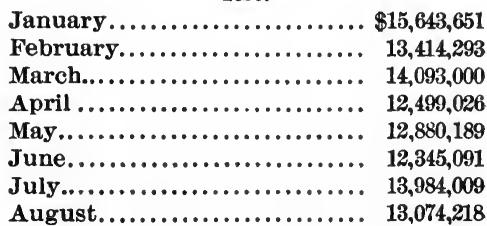


Despite present prosperity the old Virginia banker sighs for the repeal of the ten per cent. tax on State banks of circulation, and the return of the halcyon days from 1834 to 1861, when the State banks maintained a circulation of ten millions of dollars in bank notes-nearly six times the present circulation of the National banks in Virginia; when money was plentiful and easy to get at low rates of interest, and did not vanish to the money centers on the least warning of financial or trade disturbance.

\section{WEST VIRGINIA.}

Prior to the Civil War this State formed a part of Virginia, with which its early banking history is merged. Since the accession of West Virginia to the Union, the banks of the State have made a record of quiet growth and have greatly aided in developing the great natural resources of the State. It is only within the last six or eight years that proper attention has been paid to the gathering of data and the supervision of the banks chartered by the State, and while the information is now full and accurate, it only applies to the present, and not to the past.

There were banks, few indeed in number, within that portion of the original territory of Virginia now comprised within the boundaries of West Virginia long prior to the separation, and a brief reference to them will show the foundation of the present extensive business.

One hundred years ago, as now, Wheeling was the largest town within the territory of the State of Virginia between the Alleghanies and the Ohio, and here the first bank, strictly speaking, west of the mountains, was established by virtue of an act passed by the General Assembly of Virginia in February, 1817, although the town of Wellsburg has a prior claim entitled to consideration. This same act contained provisions for the incorporation of banks in the towns of Clarksburg, Morgantown, Wellsburg, Parkersburg, Beverly and Middlebourne -all, with the exception of Wheeling, mere country hamlets, yet each representing the business center for a wide extent of rich but sparsely settled country. The act named commissioners authorized to receive subscriptions to the capital stock, and those named for the Wheeling bank, the Bank of Northwestern Virginia, were Archibald Woods, John White, George Knox, Noah Zane and Samuel Sprigg. It was further provided that the subscription books should be opened in November, 1817 , and the bank was ready for business in the following spring, its first President being Noah Zane and the first Cashier Thomas Woods. This pioneer institution was so well managed that during the panic of 1837 it was one of the few financial institutions of the country which did not close its doors, but during the war of the rebellion it went out of business and was succeeded by the Exchange Bank, which still exists as the National Exchange Bank. 
The second bank founded in Wheeling was the Merchants and Mechanies', which dates from July 13, 1834, the first President being Roderick McKee. In 1865 the title was changed to the Merchants' National Bank, which went into liquidation in the early seventies. The Bank of Wheeling was founded in 1853, still existing under the same name, and in 1854 the Savings Bank of Wheeling, the first Savings bank in the present limits of the State, was organized. Under various changes of name it still exists, since 1874 as the Commercial Bank. The People's Bank of Wheeling was organized in 1860, and these institutions were the banks of the chief city of the State of West Virginia at the time of its formation through the fortunes of war.

The first banking institution at Wellsburg, for which precedence is claimed in a consideration of the banking business within the limits of the present State, was established about 1813, under the title of the Charlestown Manufacturing and Exporting Company, this implying a mercantile as well as a banking business. The house was probably simply a place of safe deposit for funds. In 1832 a branch of the Northwestern Bank, at Wheeling, was established at Wellsburg. The Northwestern also established a branch at Morgantown at an early period, while small banks had a more or less precarious existence prior to the rebellion at Kanawha Court House, now Charleston, Beverly, Parkersburg, Clarksburg, and at one or two other points. Their business was necessarily restricted, the means of communication for collections and transfers slow and at times uncertain, as there was not a railroad in the State aside from the Baltimore and Ohio, along the northern border, with the branch line from Grafton to Parkersburg, and yet they sufficed for the then exceedingly limited business, for the territory of the future State was sparsely settled and the great majority of its people poor, Wheeling being the only manufacturing town and the chief shipping point.

\section{Growth of the Banking Business.}

The growth of the banks from the possible dozen in 1863 to one hundred and seventeen in 1899, has been a remarkable one, and yet only in keeping with the general prosperity and development of the State. Every important town now has one or more banking institutions, Wheeling heading the list with thirteen, eleven State institutions and two National banks, having aggregate resources of twelve millions of dollars, with monthly clearings of between two and three millions; loans and discounts of $\$ 6,300,000$, cash on hand $\$ 1,350,000$, and deposits of $\$ 8,612,000$. As illustrating the progress of the business in the chief eity of the State in a single twelve months, ending in the summer of 1899 , it may be said that loans increased $\$ 700,000$, cash on hand $\$ 500,000$, resources $\$ 3,000,000$, and deposits $\$ 2,600,000$. These figures are a fair indication for the remainder of the State.

Of that branch of banking in Wheeling coming under the general 
head of Savings banks, the first and probably the only one in the State at the time of its formation was the Wheeling Savings Institution, established during the war of the rebellion. It failed in 1871 as the result of bad management. Other Savings banks established in recent years have been remarkably successful.

Of the banking centers of the State outside of Wheeling the most prominent are Charleston, the State capital, with five banks; Clarksburg, with four; Martinsburg, with four; Parkersburg, with five, and Sistersville, Wellsburg, Morgantown, Mannington, Huntington, Grafton and Fairmont, with three each. Many other towns like Alderson, Bluefield, Buckhannon, Cameron, Charlestown, Hinton, Jackson, Lewisburg, Moundsville, New Martinsville, Piedmont, Princeton, Weston, etc., have two banks each, while there are but few counties, even in the remote mountainous regions, which do not have one or more banks, with correspondents in the larger cities and towns, thus affording facilities for the rapid development of the State which is steadily going forward. Some of these interior banks date far back in the history of the State, examples being the First National Bank of Parkersburg, founded in 1863, the year of the admission of the State into the Union; the Parkersburg National Bank and the Second National Bank of the same city, dating from 1865; the Kanawha Valley Bank of Charleston, organized in 1867; the Merchants' National Bank of West Virginia, at Clarksburg, founded in 1865 ; the First National Bank of Fairmont, organized in 1853, and some others of early date. The great majority of the banks of the State, however, originated in the last fifteen years, and all have found a profitable business, under a management which has resulted in singular freedom from the difficulties arising from such panics as pervaded the country in 1893 . Some of the State banks with but a modest capital do an enormous business.

The State has a complete system of bank examination, the official being appointed annually by the Governor, and his reports are published once a week for two weeks, in the month of October or November, in some paper in the county in which the bank is located, with a provision for special examinations at any time, upon order of the State Board of Public Works.

In the past the banking business of the State, often pursued under unpropitious conditions, has been very successful, and a steady growth in the number and resources of the banks may be safely predicted, for great as has been the development of the State in the recent past, it has but started upon its industrial, manufacturing, mining and mercantile career, and the banking business must and will keep pace with the growing needs of the people. 
State Banks, 1864-1899.

\begin{tabular}{|c|c|c|c|c|c|c|}
\hline YEARS. & 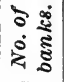 & $\begin{array}{l}\text { Loans and } \\
\text { discounts. }\end{array}$ & Specie. & $\begin{array}{l}\text { Capital } \\
\text { stock. }\end{array}$ & Circulation. & Deposits. \\
\hline $1864 \ldots \ldots \ldots$ & 9 & ............. & ............ & $\$ 2,061,250$ & ........ & $\ldots$ \\
\hline $1868 \ldots \ldots . . . . .$. & 5 & ............. & ......... & 570,200 & .......... & …. \\
\hline $1872 \ldots .$. & 6 & ............. & $\cdots \cdot$ & 540,000 & ......... & ...... \\
\hline $1876 \ldots \ldots \ldots \ldots$ & 10 & $\$ 2,164,247$ & ........... & 659,610 & n......... & $\$ 1,946,715$ \\
\hline $1887 \ldots . .$. & 14 & $3,253,762$ & …......... & 819,855 & $\$ 13,791$ & $2,897,123$ \\
\hline $1892 \ldots \ldots \ldots . . . . .$. & 27 & $4,278,974$ & (.............. & $1,343,537$ & .......... & $4,288,791$ \\
\hline $1897 \ldots . .$. & 66 & $10,439,991$ & ............ & $3,397,210$ & ......... & $10,635,843$ \\
\hline $1898 \ldots \ldots . . . . . . .$. & 75 & $12,609,950$ & ............. & $3,567,812$ & .......... & $13,730,840$ \\
\hline $1899 \ldots$. & 83 & $13,919,330$ & ........... & $\star 3,422,000$ & ......... & $15,097,310$ \\
\hline
\end{tabular}

* Decrease caused by changes to National banks.

National Banks, 1864-1898.

Figures are in thousands of dollars.

\begin{tabular}{|c|c|c|c|c|c|c|c|c|c|}
\hline YEARB. & 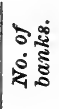 & $\begin{array}{c}\text { Loans } \\
\text { and dis- } \\
\text { counts. }\end{array}$ & $\begin{array}{c}U . S . \\
\text { bonds. }\end{array}$ & $\begin{array}{c}\text { Cash } \\
\text { and cash } \\
\text { items. }\end{array}$ & Capital. & Surplus & $\begin{array}{c}\text { Undi- } \\
\text { vided } \\
\text { profits. }\end{array}$ & 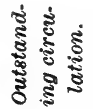 & $\begin{array}{c}\text { Indi- } \\
\text { vidual } \\
\text { deposits. }\end{array}$ \\
\hline $1864 \ldots$ & 2 & $\$ 265$ & $\$ 326$ & $\$ 204$ & $\$ 186$ & $\ldots$ & $\$ 28$ & $\$ 134$ & $\$ 592$ \\
\hline $1868 \ldots . . .$. & 15 & 2,519 & 2,974 & 765 & 2,216 & $\$ 229$ & 97 & 1,971 & 2,544 \\
\hline $1873 \ldots$ & 17 & 4,349 & 2,733 & 620 & 2,596 & 357 & 151 & 2,272 & 2,843 \\
\hline $1878 \ldots . . .$. & 15 & 2,399 & 1,540 & 455 & 1,656 & 406 & 109 & 1,326 & 1,381 \\
\hline $1883 \ldots$ & 19 & 3,522 & 1,591 & 688 & 1,867 & 490 & 139 & 1,382 & 2,803 \\
\hline $1888 \ldots$ & 20 & 4,144 & 817 & 685 & 1,966 & 458 & 157 & 626 & 3,371 \\
\hline $1893 \ldots . .$. & 30 & 6,901 & 1,015 & 1,104 & 2,961 & 765 & 286 & $864^{\prime}$ & 5,622 \\
\hline $1898 \ldots . . .$. & *33 & 8,667 & 1,780 & 1,077 & 3,351 & 898 & 289 & 1,262 & 8,874 \\
\hline
\end{tabular}

*Two since organized.

\section{NORTH CAROLINA.}

The constitution of North Carolina contains nothing on the subject of private or even State banks. In the early colonial days there was a scarcity of gold and silver, and here, as elsewhere, various measures of value were used. Barter commodities were doubtless current from the beginning of the settlement, and, in 1715, the Assembly placed fixed values on corn, wheat, tobaceo, skins, beef, tar and eleven other commodities, and at the price named they were to be received in payment of all debts unless sterling was specified in the note or contract. In 1712 there was serious trouble with the Tuscarora Indians, and the Government found itself in debt. The receipts from the tax on land, 
imposts on vessels, etc., were small, and following the examples of other Colonies the Assembly issued "bills of credit" in 1713. For the first ones there was no provision for payment and no promise to pay. Succeeding issues in later years followed with the usual history of depreciation and substitution. In 1729 the Assembly attempted to improve the financial condition by providing for an issue of bills of credit of which $£ 30,000$ was to be placed in the hands of precinct treasurers to be loaned to the people generally for a period of fifteen years on land security. The interest and part of the principal were to be paid annually, the profits to go toward paying expenses of the Government. But the Lords Proprietors, except Carteret, had sold their Carolina interests to the King and the first royal Governor, Burrington, who came over in 1730, declared this attempt at land banking invalid.

In 1756 the Assembly issued treasury notes bearing six per cent. interest to be redeemed by a poll tax of two shillings and a duty of two pence on all imported liquors for one year, and other similar issues were made from time to time. From 1748 to 1764 there was emitted:

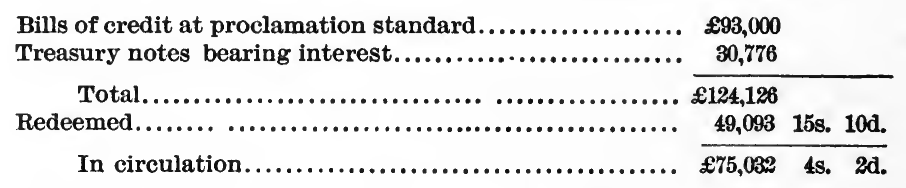

In 1767 the matter of a proper circulating medium for the Colonies was fully discussed in Parliament, and a suggestion was made looking toward the establishment of the Bank of America, as a branch of the Bank of England, which should issue notes and attend to the financial needs of the Colonies, but the idea was never carried out.

In 1791 North Carolina stood ahead of New York in population and importance and fourth in the list of States of the Union, but as yet it had no bank and few laws pertaining to financial affairs. Promissory notes were made negotiable by an act of November, 1762 , which was the first law concerning commercial paper. The next act was " for the security of the Bank of North America" (Philadelphia), and made counterfeiting any note of this bank a felony without benefit of clergy.

\section{First Chartered Banks in the State.}

A few other acts concerning counterfeiting and the collection of debts are found, but nothing of importance until 1804. In this year two banks were chartered. The preamble to the act establishing the first one, the Bank of Cape Fear, reads as follows: "Whereas, the increase of population and commerce in the districts of Wilmington and Fayetteville render it expedient that a bank should be established for their accommodation in the town of Wilmington, be it enacted, etc." The capital stock was not to exceed $\$ 250,000$, divided into shares of $\$ 100$ each. Commissioners were named in the act for opening books of sub- 
scription. Shares were to be paid in gold or silver "one-fourth at time of subscribing, one-fourth within sixty days after the bank shall go into operation, one-fourth within one hundred and twenty days and one-fourth in six months." The corporation was to continue until January 1,1820 , and the bank was to go into operation when $\$ 25,000$ was subscribed. Authority was given for a branch at Fayetteville and the bank was forbidden to take more than six per cent. "for or on account of its loans and discounts." Note issues were limited to $\$ 750,000$ " over and above the moneys actually deposited in the bank for safe keeping." In case of excess the directors were to be individually liable.

The State reserved the right to subscribe, at any time within three years, to an amount not exceeding $\$ 25,000$ of the stock, and in case this amount was taken, authority was given for a corresponding increase in note issues. A provision was also made that this bank might become a branch of any general bank for the State which might hereafter be established.

The charter for the Bank of Newbern contains almost exactly the same provisions. Its capital was to be, however, only $\$ 200,000$. In 1807 the Treasurer was authorized by act of the Assembly "in the name of the State to subscribe in the banks of Cape Fear and Newbern for the number of shares (250) which the State has reserved the right of subscribing for, in each of the said banks."

The act further provided that one-third of the amount be paid immediately out of the public treasury and that interest at four per cent. should be allowed for deferred payments. After all payments were made the Treasurer was further authorized to borrow from the banks to the amount of stock held, and the loan was to be continued until the dividends on the stock had paid the debt. The Treasurer, Comptroller and Secretary, or any two of them, were authorized and empowered to appoint three additional directors for each bank to represent the State, and the notes of the bank were declared to be receivable in payment of all public dues and at the public treasury. In 1809 a law was passed to prevent the circulation of promissory notes or due bills for less than ten shillings, and imposing a fine of five pounds for each offence.

In the same year, for the first time, the currency of the United States was recognized, and it was declared lawful for "the records and all other papers and proceedings to be kept in dollars and cents."

\section{State Bank of North Carolina Established.}

"An act to redeem the paper currency now in circulation and to establish a bank by the name and title of the State Bank of North Carolina" was passed in 1810 . The capital was $\$ 1,600,000$, and the principal bank was to be in Raleigh and branch banks in Edenton, Newbern, Wilmington, Fayetteville, Tarborough and Salisbury. Two hundred and fifty thousand dollars of the stock was reserved for the 
State, to be paid for in gold or silver or "money or certificates of the United States."

The dividends on the stock held by the State were to be applied to redeeming the outstanding paper currency emitted by law in 1783 and 1785. Note issues were limited as usual to three times the capital stock plus the amount of deposits, and no note for a less sum than one dollar was to be issued. Loans to the United States Government were restricted to one hundred thousand dollars and not more than $\$ 50,000$ might be loaned to any State. No loan could be made to any "foreign prince or State" unless authorized by law. The notes were assignable by endorsement, and reports to the Treasury Department were required as demanded, "not exceeding once in three months." The corporation was to continue until 1830 , and during its existence no other bank was to be chartered. A preference in subscriptions to stock was given to the two banks in operation, with the evident hope and expectation that they would become branches of the State institution, but they did not see fit to enter into the arrangement.

Subscriptions to the stock of the bank were disappointing, and in 1811 an additional act was passed with the following explanation:

"Whereas, The subscriptions to the capital stock of the State Bank of North Carolina have fallen short of the sum authorized to be subscribed thereto by the aboverecited act, and it becomes necessary in consequence thereof to modify the conditions upon which by said act the charter of incorporation was granted, in order to enable the State, through the agency of the banks, to effect one of the principal objects had infview in its establishment-the redemption of the paper currency, be it enacted."

The State agreed to allow four per cent. of the dividends accruing on its stock to go to the general benefit of the shareholders, to extend the exclusive charter to 1835 , and further that no tax should be "laid on the capital stock of said bank nor on the dividends to be declared thereon," provided the bank would take up the outstanding paper currency within six months after December 18,1817 . The bank might redeem the said paper in its own notes or in coin at the rate of one dollar for ten shillings. All dividends accruing to the State were to be used in paying the bank for currency redeemed, the public Treasurer was made $e x$ officio director, and severe penalties for counterfeiting were imposed.

The remaining stock was subseribed, but was paid largely in bank notes instead of in coin, and the State issues were not promptly redeemed as had been intended. In 1811 the stealing of bank or promissory notes was made a felony and the passing of forged notes or checks a fraud.

James Johnson, father of Andrew Johnson, President of the United States, was janitor of the bank for a number of years.

\section{Extension and Amendment of Charters.}

At the session of the Assembly in 1814 the charters of the banks of Cape Fear and Newbern were extended to 1835 , and an addition made 
to the capital stock of the former of $\$ 525,000$, and to the latter of $\$ 575,000$. The banks were required to loan the State not exceeding one-tenth of the amount of the capital stock, and $\$ 100,000$ additional stock in each bank was to be reserved for the State, and, as a consideration for the amended charters, the State was to receive $\$ 18,000$ of this stock in each bank without paying anything therefor.

No note under one dollar was to be issued and a tax of one per cent. per annum was to be levied on all stockholders, "except on the stock holden by this State, which shall be paid to the Treasurer of this State by the Presidents or Cashiers of said banks on or before the first day of October in each and every year." The stock reserved in each bank to the amount of $\$ 410,000$ was to be paid for at the convenience of the State. Treasury notes to the amount of $\$ 82,000$ in denominations of five cents, twenty cents, twenty-five cents, thirty cents, forty cents and fifty cents, were to be issued at once and turned over to the banks in payment of the remaining subscription. These bore no interest, were put into circulation by the banks, redeemed by the Treasurer and reissued. In case the State Bank forfeited its charter before redeeming the paper currency outstanding, these banks were to undertake the task, and dividends on the State's stock were to be applied toward payments on the paper redeemed. The charter provided further that branch banks and agencies might be established at such points as the Presidents and directors might determine upon.

\section{Prohibition of Private Note Issues.}

When the Assembly met in November, 1816, its attention was called to a peculiar state of affairs in connection with an unauthorized currency which seemed to be freely circulated. The act in relation thereto reads as follows:

"Whereas, The practice of issuing due bills or small promissory notes, commonly called due bills, by private citizens of this State, and others styling themselves corporate bodies, has increased and continues to increase to an alarming height and degree, highly detrimental to the true interest of the State ; and,

Whereas, The before-recited act has been found insufficient to suppress the evil ; therefore, in addition to the penalties contaíned in that act, and as a further remedy,

$B e$ it enacted, That from and after the passing of this act it shall not be lawful under any pretence whatever for any person or persons, any corporation, school or academy within this State, which now is or hereafter may be established, to issue any bill, order ticket, promissory note, or any other species of security whatever may be its form or name, commonly called due bills, with an intention to evade this act, under the penalty of ten pounds for each and every bill, order, ticket, promissory note, or other species of security, whatever may be its name or form, commonly called due bills, so issued."

A penalty of ten pounds was also imposed upon every person for passing or receiving such a due bill, and for each offence of passing or receiving a check drawn for less than one dollar on any bank, for the benefit of any school, academy, corporation, company or private 
citizen or for such a check drawn on any person. A penalty of one hundred pounds and imprisonment not exceeding six months was to be imposed upon any person or persons, who, without a charter, attempted to do a banking business, and the act repealed as much of the charters of the Fayetteville School Association and the Bertie Manufacturing Company "as might, by construction or implication, authorize them to issue any ticket, order, check, bill or promissory note" for circulation.

In case the corporations mentioned above should refuse or neglect to pay on demand any outstanding obligation, including the classes named, then the holder was entitled to recover twice the amount.

At the same session the Treasurer of the State was directed to issue $\$ 80,000$ in treasury notes in denominations of from five to seventy-five cents, and to place them with the State Bank. The bank was to put them into circulation, and they were to be redeemed from time to time as presented, and might be reissued. These notes were to be receivable for debts and taxes and were to be accepted by the bank as a part payment of the debt due from the State.

The banks of North Carolina evidently did not suffer so much from the War of 1812 as did other financial institutions, as is shown by the fact that on July 1, 1816, the notes of North Carolina banks bore a premium of four per cent. in Philadelphia. Their difficulties came a little later. On April 7, 1819, these notes were at a discount of from two to three and one-half per cent. in New York, but four months later were quoted in Baltimore at from twenty to twenty-five per cent. discount.

The second Bank of the United States began operations on January 1, 1817, and established a branch in Fayetteville, N. C. By June 23, 1818 , the loans and discounts made at this point amounted to half a million dollars.

During the year 1819 only $\$ 943.34$ of the oustanding paper of the State was redeemed, and about $\$ 24,000$ more before 1823 , when, under an act of the Assembly, $\$ 100,000$ additional treasury notes were issued. For the following years there appears to have been little legislation on financial matters. The report of the Treasurer for 1826 shows that individuals held 6,491 shares in the Bank of Newbern, and 6,225 in the Bank of Cape Fear, on all of which a tax of one dollar per share had been paid. Three commissioners were appointed by the Assembly in 1828 to represent the State's interest in meetings of the shareholders of the banks, and were instructed not to give their consent to "any proposition or regulation for the too rapid reduction of the debts to said banks or to the too sudden winding up of the affairs thereof." They were further directed to ascertain whether or not the banks would agree to a consolidation and upon what terms, and report to the next Assembly. By resolution at the same session the Treasurer was forbidden to make any further investment of State funds in bank stock. He had, however, but a short time previous to the meeting of the Assem- 
bly purchased shares in the State Bank at ninety and in Newbern and Cape Fear at eighty, and he reported deposits of State funds in all the banks, $\$ 20,000$ with Cape Fear, $\$ 25,000$ with the State Bank and $\$ 30,000$ with Newbern. The dividend from the State Bank for this year was six per cent., and from Cape Fear and Newbern four per eent., though the last named did not pay dividends after this year and Cape Fear continued only one year longer.

On November 18, the State Bank, in a statement made by Charles Dewey, Cashier, claimed to have loans $\$ 2,500,208.80$, real estate $\$ 180$,758.30 , and specie $\$ 66,280.50$. Notes in circulation were $\$ 996,040.34$, and deposits $\$ 275,522.88$.

\section{CRITICISM OF THE BANKS.}

A report made to the Assembly of 1828-29 sums up the history of the banks, and is severe in its criticism of their management and methods. In the first place, the committee found that in the beginning the capital stock was not paid in gold or silver as provided by the charters, and that soon after the banks went into operation "they contrived to get possession of nearly all the paper money which had been issued on the faith of the State, which, being at the time a legal tender, enabled them to evade demands for specie, which they did, by thrusting this ragged paper at those who presented their notes for specie."

In regard to the act of 1807 which granted additional eapital to Cape Fear and Newbern, the committee says : "It is in evidence to the undersigned that the whole of this additional stock was manufactured by the banks themselves, and that in many instances, favored individuals were permitted to acquire stock by subscribing their names and putting their notes into bank without advancing a single dollar of the actual capital." In regard to the State Bank, the report says that only $\$ 500$,000 of the capital was paid in specie when the institution began business. In 1818 for every dollar of specie on hand the bank had $\$ 12$ of notes in eirculation. Books were opened for the remaining stock and subscribers were allowed to pay in notes of the bank in order to "apply a sponge to a part of the outstanding debt," thus purchasing notes with stock. "The bank itself, by a scribbling process of its own, created the capital, and paid off a portion of its debt by the very act by which it also created its capital. A circumstance, too, which greatly adds to the enormity of the transaction, is that before all the installments became payable, the State Bank, the Bank of Newbern and Bank of Cape Fear entered into a formal resolution, through their delegates assembled at Fayetteville in June, 1819, not to pay specie; and their notes immediately fell to fifteen per cent. below par. Then commenced the system of usury and extortion, which has since been carried on with such unparalleled audacity under the name of exchange."

The committee further said that in case an individual applied for a loan the note was made payable in specie, but the customer would 
receive bills which were at a discount; also that the banks had employed agents in New York and Petersburg to buy up their notes at as great discount as possible. "In the case of the State Bank large quantities of their notes have occasionally been thrown into circulation by themselves in the purchase of cotton. It is in evidence to the undersigned that they laid out at one time $\$ 30,000$ of their notes in the purchase of cotton on which they made a profit of more than $\$ 8,000$. To protect themselves from demands for specie, the banks, at one time, determined to administer an oath to an individual presenting notes in which he was compelled to state that he was not a broker."

All the banks, it seems, had purchased United States notes, and both the State Bank and the Bank of Cape Fear held considerable stock in the United States Bank. "The State Bank appears to have made a most convenient use of this arrangement. It appears from evidence of the late President of that bank, that they have been in the habit of rendering false statements to the Legislature and that in May last, when they stated in their exhibit that they had in hand $\$ 214,000$ in specie, $\$ 140,000$ of it consisted of stock in the United States Bank, so that, instead of keeping the specie in their vaults, to take up their paper, they have vested it in the stock of another bank, and were deriving interest from it. It further appears from the evidence of the same person, that the amount of actual specie now in the State Bank at Raleigh is not more than $\$ 300$ or $\$ 400$, at any rate not exceeding $\$ 1,000$."

This committee used strong language in the entire report and presented a resolution to the Assembly directing the Attorney-General to institute a judicial inquiry, but no further record anywhere appears, so it is probable that the matter was dropped.

A statement of condition for all the banks about this time is as follows:

Resources.

Loans and discounts...........\$4,739,327

Due from banks.............. 245,067

Specie ....................... 157,147

Bills of exchange.............. 532,576

Bills of other banks............ $\quad 42,982$

Real estate................. $\quad 344,608$

Stocks, securities and claims.... $\quad 240,923$

Total.................. $\overline{\$ 6,302,630}$
Liabilities.

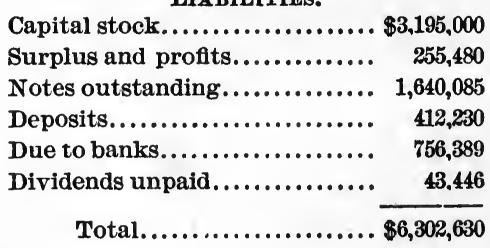

\section{Legislation in Regard to BaNks aNd BaNking.}

Four years before, the note issues had been over three million dollars. At this session of the Assembly an act was passed to enable the State Bank to wind up gradually and another act for the same purpose with reference to the other banks. Under these acts all laws in force were to continue until 1838. None of the banks were to make loans after 1834. No notes under five dollars to be issued after 1832 and none of any denomination after 1834 . Stock to be received in payment of debts 
at value fixed by shareholders and approved by Treasurer. Debts to be called in installments and after January 1, 1834, dividends on capital to begin. The stock in the State Bank was valued in accordance with one provision of this act at $\$ 75$ per share in payment of debts. Cape Fear stock was valued at $\$ 80$ and Newbern at $\$ 65$, though, in the case of the last-named bank, the Treasurer says it is "rather a high estimate."

There were still outstanding in $1830 \$ 118,222$ of the State treasury notes, and the Treasurer estimates that there was in circulation in the State this year $\$ 808,530$ of United States Bank paper. In 1831 a law was passed making it unlawful after July, 1832, for any person to pass or receive any bill for any amount under five dollars unless it was issued by some bank in the State. During this year the State continued to keep deposits in all the banks. The Treasurer in his report comments upon the great "inconvenience arising from a different currency obtaining in different sections of the State." Sheriffs from several counties brought bills from the banks of many States and a settlement was difficult.

The Assembly of 1832 passed an act to establish the Bank of North Carolina, but it was never organized. During this year the Bank of Newbern declined to pay tax on the shares of stock held by the State, and the matter, after being tested in the courts, was decided in favor of the bank. At the beginning of the next session of the Assembly, which met November 18, 1833, the Bank of Cape Fear was rechartered until January 1, 1855; capital, $\$ 800,000$; note issue limited to twice the amount of stock. It must loan the State an amount equal to one-tenth the capital if requested. Statements were to be made to the Treasurer when desired, not oftener than once in six months. The tax to be paid by the bank was twenty-five cents per share. No note under three dollars was to be issued.

An act was also passed to establish the Merchants' Bank of the town of Newbern (capital $\$ 250,000$ ) and the Albemarle Bank in the town of Edenton (crpital $\$ 200,000$ ).

At the same session the Bank of the State of North Carolina was chartered with $\$ 1,500,000$ capital, the State reserving for itself two-fifths of this amount. The other provisions corresponded with those in the new charter for the Bank of Cape Fear. This bank was soon organized, and began operations on September 10. Branches were established at once in Newbern and Tarborough, and the directors decided upon agencies in Milton, Leaksville, Charlotte and Morganton so soon as a necessary amendment to the charter could be secured.

In 1835 the State issued $\$ 400,000$ five per cent. certificates of the denomination of $\$ 1,000 \mathrm{each}$, to run until 1860 , for the purpose of paying for stock in the Bank of the State of North Carolina. The bank established a branch in Fayetteville which was intended "in some degree to supply the place of the United States Branch Bank recently discontinued at that place." 
On November 1 of this year the State had received in dividends of the capital stock of the State Bank $\$ 88$ per share, and of the Bank of Newbern $\$ 70$ per share. Outstanding treasury notes of 1814,1816 and 1823 had been reduced to $\$ 52,511$. During the session of $1836-37$ the charter of the Bank of Cape Fear was continued until 1860. Capital $\$ 1,500,000$ if stockholders desired; the State was to be allowed $\$ 300,000$ of the increase. Representatives of the State were to appoint four directors. Branches were allowed. The President and directors had authority to reduce the stock if it seemed best.

At the same session banking privileges were conferred on the Louisville, Cincinnati and Charleston Railroad Company upon certain conditions. "If South Carolina, North Carolina, Tennessee and Kentucky, or any three of these States shall assent thereto, then the corporators of the Railroad Company may form a separate corporation to be called the Southwestern Railroad Bank." Each stockholder paying $\$ 100$ for a share of the railroad stock was entitled to take one share in the bank at $\$ 50$ until the stock of the railroad amounted to twelve million dollars. The principal bank was to be located in Charleston, and branches and agencies in different States. No note was to be of a less denomination than $\$ 5$ until the railroad was built, and after that nothing less than $\$ 10$. The issue was limited to double the capital. A curious provision in the charter was to the effect that the bank should never permit the railroad company to overdraw. There was also a provision that the share in the railroad company and the share in the bank were " inseparably connected," and one could not be transferred without carrying the other with it. No taxes were to be levied until the railroad was finished.

On January 3, 1839, an act was passed to amend the charter of the Bank of Cape Fear so that stock of delinquent holders might be sold at auction.

\section{Condition of the Banks in 1839.}

A summary of the condition of the banks of the State in 1839 is as follows :

RESOURCES.

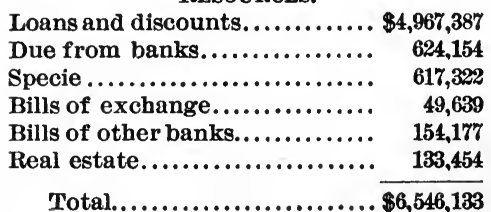

TIABILITIES.

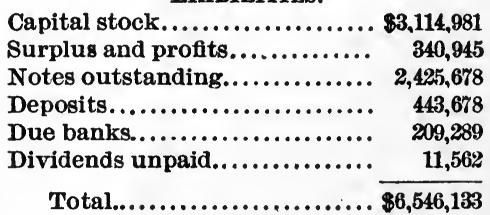

The charter of the Merchants' Bank, of Newbern, was amended on December 26, 1842, so that bills might be issued of any denomination down to "three dollars but not under." The time of holding the annual meeting of stockholders of the Bank of Cape Fear was changed from the first Monday in January to the first Monday in May. 
There was no financial legislation during the sessions of 1844-45. The State Treasurer reports $\$ 48,850$ treasury notes still outstanding. Dividends were paid the State on stock held in the Bank of Cape Fear and the State Bank.

In 1847 the State owed the Bank of Cape Fear $\$ 90,000$ borrowed money. The General Assembly of 1848-49 chartered the Bank of Fayetteville; capital, $\$ 800,000$; shares, $\$ 50$ each, payable in specie or equivalent. When 2,000 shares were subscribed and $\$ 25,000$ paid in the bank was to begin operations. Double liability of stockholders was provided for and the State tax was twelve and one-half cents per share. Debts were limited to twice the capital plus deposits. Notes not paid on demand were to draw twelve per cent. Annual reports to the Legislature were required. The Treasurer at this session was instructed to issue $\$ 200,000$ of certificates to pay the $\$ 90,000$ due the Bank of Cape Fear, $\$ 25,000$ due the Bank of the State and the debt due on account of the Raleigh and Gaston Railroad.

The statement of condition of the banks of North Carolina in 1849 was as follows:

\begin{tabular}{|c|c|}
\hline $\begin{array}{l}\text { RESOURCES. } \\
\text { Loans and discounts............ }\end{array}$ & $2,545,665$ \\
\hline Due from banks................. & 331,479 \\
\hline Specie...$\ldots \ldots \ldots \ldots \ldots$. & 761,582 \\
\hline Bills of exchange............. & 686,227 \\
\hline Bills of other banks.............. & 212,710 \\
\hline Real estate..................... & 59,915 \\
\hline Stocks, securities, etc...... & 193,000 \\
\hline Salaries, expenses, etc... & 2,772 \\
\hline
\end{tabular}

LIABILITIES.

Capital stock..................\$2,008,430

Surplus and profits............ 319,811

Notes outstanding............. $\quad \mathbf{1 , 9 6 5 , 0 8 6}$

Deposits...................... 376,369

Due to banks................ 119,494

Dividends unpaid.............. 4,160

Total..................... $\$ 4,793,350$

\section{INCREASE IN THE NUMBER OF BANKS.}

During the legislative sessions of $1850-51$, the capital stock of the Bank of Cape Fear was increased 5,000 shares, and the amendment to the charter required a branch in Greensboro to be established in six months. The Bank of Washington was also chartered with $\$ 400,000$ capital. The Commercial Bank, of Wilmington, was allowed an increase of capital to the amount of $\$ 50,000$, and the Merchants' Bank, of Newbern, was rechartered to 1880 . A charter was also granted to the Bank of Wadesboro, with $\$ 200,000$ capital. During this session of the Legislature charters were granted for the Milton Savings Institution (\$250,000 capital), the Jackson Savings Institution of Northampton ( $\$ 50,000$ capital), the Raleigh Savings Institution ( $\$ 250,000$ capital) and the Mechanies' Savings Society, of Weldon ( $\$ 20,000$ capital). The charters for all these institutions were very much alike and provided generally that the institutions might receive deposits, but could not "issue any bill, note or other device in the nature of a bank note." Nomoney was to be loaned to a director or officer. A committee of stockholders was required to examine the affairs of the institutions at least once in 
six months and publish a report. No stockholder in debt to the institutions was allowed to transfer his stock until the debt was paid. The State Treasurer or other officer appointed by the Assembly had authority to examine at any time.

At the next session of the Assembly, 1852, the Bank of Charlotte, capital, $\$ 300,000$, the Farmers' Bank of North Carolina (at Elizabeth City), capital $\$ 500,000$, and the Bank of Yanceyville, capital $\$ 200,000$, were incorporated. The Bank of Wadesboro was allowed to increase its capital 4,000 shares.

The increased number of charters granted during these years and the number of acts concerning the collection of debts, the issuing of coupon bonds by the State, etc., show the general improvement and development of the State. In 1854-55 the Bank of Clarendon, at Fayetteville, was incorporated, and also the Bank of Wilmington. Three new Savings institutions were also chartered, located at Wilmington, Washington and Smithville. The Bank of Cape Fear was also rechartered at this session and the Bank of the State of North Carolina in 1857.

In the Treasurer's report for 1858 is included receipts for dividends on bank stock held by the State, $\$ 95,078.75$. Investments in bank stock continued to be the rage, and in $\mathbf{1 8 5 9}$ charters were granted for the banks of Lexington, Salisbury, Miners and Planters' (Murphy), Commerce (Newbern), and for four new Savings institutions. The State Treasurer was authorized to sell bonds to the amount of $\$ 1,360,000$.

\section{History of the Bank of North Carolina.}

*The Bank of North Carolina was the successor of the Bank of the State of North Carolina, as the latter had been of the State Bank of North Carolina. It was attempted to get a recharter of the Bank of the State, but the General Assembly declined to grant acceptable terms. The charter of the Bank of North Carolina was then procured from the General Assembly of 1858-59. Its corporate life was to end on the first day of January, 1890.

The capital stock was $\$ 2,500,000$, of which the literary board, as part of the school fund, was to have $\$ 500,000$ and the University $\$ 200$,000 . Individuals could take the residue. The company could only hold $\$ 7,500,000$ of real and personal estate.

The commissioners to open books were the Governor, Treasurer and Comptroller. If too much was subscribed they were to do the scaling.

The payments were to be in gold and silver coin of the United States or in Spanish milled dollars, in four equal quarterly installments. The capital stock was all paid in a year.

No stockholder could borrow or be a surety until stock was paid in full. 1899.

* Paper by Dr. K. P. Battle, read before the North Carolina Bankers' Association, 
There were to be ten directors-holders of ten shares-the State to have her pro rata share. The public Treasurer was to be one. The other was appointed by the Governor, Secretary of State and Comptroller.

A director could not be director of another bank without the consent of three-fourths of the stockholders.

The directors chose the President out of their number, but the stockholders fixed salaries. Stockholders appointed branches and agencies. Directors assigned the capital to them and elected five directors to each.

The first report was to be made on August 15, 1859, then quarterly, to the public Treasurer, to be published in two Raleigh newspapers.

The directors or stockholders holding one-tenth of the stock could call special meetings.

One share had one vote; up to ten shares, one vote for two shares; ten to thirty shares, one vote for four shares; thirty to sixty shares, one vote for six shares; sixty to 100 shares, one vote for eight shares; 100 to 200 shares, one vote for ten shares; over 200 shares, one vote for twenty shares. The State vote was not scaled.

The bank could deal in gold and silver coin, mint certificates, promissory notes negotiable and payable at the bank or branches, and securities of the United States, of this State, not over one-half the stock. There were to be no certificates of deposits under twenty dollars.

\section{Issue of Circulating Notes.}

Power was given to issue circulating notes not over twice the capital, nor over three times the specie on hand. The notes were to be five dollars and multiples, but the General Assembly reserved the right to enact that there should be none under ten dollars. They should be payable on demand with twelve per cent. damages per annum for refusal.

If the Governor and Council do not advise suspension of specie payments, the bank must pay the public Treasurer four per cent. per annum on entire circulation.

On discounts the bank was allowed one-half per cent. per month in advance. The General Assembly had the right of inspection through a committee.

The Cashier was required to give a $\$ 25,000$ bond. He was to be Secretary and his book evidence.

Embezzlement was felony. Knowing and willful false statement was a misdemeanor. The bank must lend the State not over $\$ 200,000$ at one time on thirty days' notice. Notes must be originally issued at the principal or branch bank, where made payable. Payments to the bank could be made in notes issued anywhere. The tax was thirty cents a share, out of profits-might be increased to one dollar-but not more than a subsequently chartered bank. The General Assembly could tax dividends just as interest and the realty of the bank was taxable as other land. 
The bank might hold real estate for business, and might take mortgages to secure previous debt. Also, take land in payment of a debt. There was no compulsion to sell such land. In 1861 the bank with its seven branches held but $\$ 40,414$ in real estate, and at the close of the war held only $\$ 80,103$.

The State was prosperous in 1859-it being calculated that cotton planters in Edgecombe were realizing six per cent. on their investment in cotton and six per cent. in increase of slaves.

Nearly all the stockholders of the Bank of the State reinvested in the new bank. They got 100 cents on the dollar and a bonus of ten per cent. About five per cent of its notes were never presented. The literary board paid its stock in this way.

The first meeting of stockholders was held in the Senate Chamber on July 20, 1859. Ex-Governor Swain was President, E. B. Freeman, Secretary. The directors elected were George W. Mordecai, B. F. Moore, Charles Manly, George E. Badger, John H. Bryan, J. W. B. Watson, Daniel M. Barringer and Kemp P. Battle. Mr. Mordecai got the largest vote, 3,502 ; all of the directors received four-fifths of the whole. The State stockholders were Treasurer Courts, ex-officio, and M. R. Pool.

\section{BY-LAWS OF THE BANK.}

After electing directors the stockholders proceeded to the adoption of by-laws.

Wednesday was discount day, when the directors, at least threefourths being present, passed on the proposals for loans. Each note must have, except in special cases, two good sureties, residents of North Carolina, or stock collateral. In the latter case the loan must be not over three-fourths in value of the collateral.

The note must be for eighty-eight days, with the understanding that it might be renewed for eighty-eight days longer on payment of onefourth, and so on until the debt was extinguished in about one year. Special loans for six months were possible, but must be paid in full at maturity.

Bills of exchange, foreign and inland, could be discounted by the President and Cashier, but must be reported to the board, as was also the over-due paper. This over-due paper must be sued on in thirty days at farthest.

If paper was not paid nor renewed no name on it could be accepted for any other loan. If a director's name, or the name of his firm, was on the paper, he was not allowed to vote. The discount included the last day of grace and the day of offering. The holidays were Sundays, January 1, July 4, Christmas and Thanksgiving day. January 1 was included because that was negro-hiring day, when customers and offcers must needs be engaging their servants for the year or hiring out those under their charge. 
The books were balanced on the fourth Mondays in January, April, July and October. Dividends were payable on the first Mondays in June and December, and must be advertised in at least two newspapers.

For overdrafts officers were liable to dismissal or must pay the amount out of their salaries, but directors could allow overdrafts secured by pledge of securities. The directors were pledged to secrecy as to all votes. Partners transacting business with the bank must give the names of all the partners. No Cashier or other officer could be concerned in trade or engage in speculation. No Cashier, agent, clerk or teller was allowed to procure a discount, nor be a surety. The President kept one key of the vault and the Cashier the other.

It was the President's duty to be at the bank every day. The bank notes were signed by the President and Cashier. The directors could dismiss the Cashier or any officer at discretion, without assigning cause. The President must report to the stockholders any director allowing his note lying over thirty days.

Three directors were appointed by the President each month to inspect the vault, count cash, examine books, etc., and to report in writing.

The board had power to examine individual accounts, but no single director could do so. Special deposits were received at the risk of depositors. The officers were bound to receive deposits if offered in acceptable funds.

Lost eertificates must be advertised in two newspapers and then oath made as to loss before a duplicate could be issued.

Branches were established at Wilmington, Fayetteville, Tarboro, Windsor, Milton, Charlotte and Morganton.

After the adoption of the by-laws the stockholders, who had their session in the Senate chamber, adjourned. The directors met in a room in the old bank building, now the Episcopal rectory, then the property of the Bank of the State; part of the house being occupied by Mr. Dewey as a residence. Mr. Mordecai was chosen President and Charles Dewey, Cashier of the Bank of the State, was elected Cashier of the new bank. Wm. E. Anderson, who had been clerk, was made teller, and Jordan Womble, Jr., bookkeeper.

\section{Proportion of Gold and Siluver Holdings.}

Though bimetallism was the law, gold was substantially the metal used, the silver being evidently only for small change. In November, 1859 , there was gold, $\$ 683,842$; silver, $\$ 13,148$; gold, fifty-two to one. The largest proportion of silver prior to the war was about one to twenty-five.

On October 20,1860 , the circulation was $\$ 1,311,301$; the specie $\$ 490,714$. Under the terrible pressure by the State Treasury in January, 1862 , the maximum circulation was reached, $\$ 1,673,730$, the specie being $\$ 517,468$ - a little over three to one. Compared with other banks the contrast is striking. In 1859 the Bank of Cape Fear circulation 
was $\$ 1,922,309$, specie, $\$ 481,550$, or four to one; the Bank of Wilmington circulation, $\$ 498,542$, specie, $\$ 66,462$, or over seven to one; Bank of Fayetteville circulation, $\$ 233,375$, specie, $\$ 61,104$, or four to one; Bank of Clarendon, $\$ 336,200$ circulation, specie, $\$ 31,522$, or over ten to one; Bank of Yanceyville, $\$ 390,908$ to $\$ 24,500$ specie, or about eighteen to one; Bank of Washington, $\$ 365,816$ to $\$ 40,671$ specie, or nine to one.

Some of these banks at their maximum disproportion later show : Bank of Washington, at Greensboro, nineteen to one; Bank of Washington, at home, nineteen to one; Farmers' Bank, Greensboro, nine to one; Bank of Fayetteville, nineteen to one; Bank of Clarendon, over thirty to one; Bank of Cape Fear, seven to one; Bank of Wilmington, about thirty-eight to one; Bank of Yanceyville, about twenty to one; Bank of Charlotte, six to one.

Alongside the Bank of North Carolina should be placed the excellent Merchants' Bank of Newbern, with only $3 \frac{1}{2}$ to one.

On October 20,1860, the total liabilities, counting dues to the Bank of the State were $\$ 1,005,313$ deposits, and $\$ 1,311,301$ circulation; total, $\$ 2,316,614$. Whereas the assets were: specie, $\$ 490,714$; loans, $\$ 2,796,081$, and bills of exchange, $\$ 1,328,249$; North Carolina bonds, dues of other banks, $\$ 275,730$. In other words $\$ 4,890,774$ cash and securities to meet $\$ 2,316,614$ liabilities to other than stockholders. Add real estate and the assets reach $\$ 4,944,797$. At the end of the war the bank had $\$ 657$, 500 in North Carolina and $\$ 1,068,032$ in Confederate securities; total, $\$ 1,725,532$. This amount was only two-thirds of the stock, and the owners of that stock did the same, or worse, in their private business, and it must be remembered that State and Confederate currency was all there was, and the bank was forced to use that or stop business. There still remained $\$ 379,141$ specie, and $\$ 1,959,398$ loans and discounts, with $\$ 80,103$ realty; total $\$ 2,418,642$, to meet $\$ 1,194,770$ circulation, and $\$ 344,821$ deposits; total, $\$ 1,549,591$. This showing was not unhopeful but the unknown quantity was the solvency of the loans and discounts. The deposits would have been much larger but in the second year of the war, as Confederate and State currency rapidly depreciated, the stockholders ordered the officers to receive deposits, with the understanding that checks on them should be paid in Confederate currency.

An attempt to convert the bank into a National institution was defeated, and the work of compromising with its creditors, by paying onefourth of their claims in gold, was begun. For this purpose $\$ 100,000$ in gold was deposited in New York. A creditor who held a large amount of the notes attached this sum and the bank was forced into bankruptcy.

But, although the stockholders lost one and a half millions, the school fund one-half million, the University one-fifth of a million, it is contended that the Bank of North Carolina was founded on sound principles, and with its faithful and intelligent officers, would have been 
prosperous and a blessing to the community, if it had not been struck by the terrible tornado of the greatest civil war of all the ages.

\section{Banking During and Subsequent to the Civil War.}

In 1860-61 the forfeit for the failure to redeem notes when presented for payment was removed. The revenue act provides for taxes on stock in the different institutions running from twelve and one-half to sixty cents per share. Charters were granted for banks in Roxboro, Thomasville and Waynesville. At the extra session of the Legislature in 1861 the charter of the Bank of the State of North Carolina was extended. Preparations for the war were being made at this time. On December 20,1862 , authority was given for an issue of five million dollars in State bonds. Banks in Graham and Lincolnton were authorized and the dividends on the bank stock held by the State amounted, for the year, to $\$ 104,710$. In 1863 every private bank was taxed ten per cent. on profits, and every agency of banks incorporated outside the State was taxed $\$ 500$. The State, this year, appropriated $\$ 3,200,000$ for defence, and the Treasurer was authorized to borrow $\$ 3,000,000$ from the banks and issue bonds for the same. The banks were allowed to issue $\$ 1, \$ 2$ and $\$ 2.50$ notes and were not required to redeem in specie if they loaned money to the State. All money over $\$ 100$ held by individuals was taxed one-fifth of one per cent., and during the war the stockholders of banks might at any time change the place of meeting. As the war progressed it sometimes became necessary for the banks to move their books and money from place to place before everything finally went down in the general erash.

The charter of the State Bank was extended in 1865 to 1869 , and in 1866 an act was passed to enable the "banks of this State to close their business." On June 23, the charters of all the banks were repealed so far as any requirements whatsoever concerning the keeping of specie. A scale of depreciation of Confederate money was arranged, and in the general liquidation and preparation for a new beginning, a charter was obtained for a Savings institution in Newbern. During the following year two others were established, and a charter granted for the National Loan and Trust Company, of Raleigh. The act forbidding imprisonment for debt was repealed on February 27 of the same year. The Assembly of 1870 placed the tax on all the banks at five per cent. of the profits, and at the same session the Bank of Raleigh was incorporated.

In 1873 and during the following years the charters granted to several banks allowed them to take as security for loans, liens on crops, even before planting and on the prospective products of mining and manufacturing operations. During the next few years many banks obtained charters, and in 1877 the State required as a franchise tax $\$ 200$ from every bank of $\$ 100,000$ capital, and a corresponding amount for smaller capitals, and the tax on profits was repealed. From 1880 to 
1890 was a period of growth and development for the State, and banks increased in number and importance.

During one session of the Legislature we find thirty-two banks in the list of those "incorporated or had name changed."

The panic following the expansion which began about 1889 in this State was severely felt by the financial institutions, but most of them survived and are now in a state of health and strength. The State Bankers' Association was organized in 1897. There are in the State at the present time twenty-seven National banks, forty-four State banks, and twenty-one private banks, four Savings banks and two trust companies properly speaking. In the summary of conditions given below the trust companies are included with the Savings banks.

State Banks.

\begin{tabular}{|c|c|c|c|c|c|c|}
\hline YEARS. & $\begin{array}{l}\text { No. of } \\
\text { banks. }\end{array}$ & $\begin{array}{l}\text { Loans and } \\
\text { discounts. }\end{array}$ & Specie. & $\begin{array}{l}\text { Capital } \\
\text { stock. }\end{array}$ & Circulation. & Deposits. \\
\hline $1834 \ldots . . .$. & 3 & $\$ 1,807,209$ & $\$ 78,507$ & $\$ 1,372,325$ & $\$ 958,934$ & $\$ 421,012$ \\
\hline $1839 \ldots \ldots$ & 10 & $4,752,584$ & 723,875 & $3,100,750$ & $2,114,140$ & 588,389 \\
\hline $1844 \ldots$. & 10 & $4,452,203$ & 945,645 & $3,225,000$ & $2,081,853$ & 489,687 \\
\hline $1849 \ldots \ldots$ & 15 & $4,937,174$ & $1,326,938$ & $3,407,300$ & $2,955,121$ & 502,518 \\
\hline $1854 \ldots$ & 25 & $10,366,247$ & $1,857,048$ & $4,818,565$ & $7,320,667$ & $1,808,587$ \\
\hline $1859 \ldots$ & 28 & $12,247,300$ & $1,248,525$ & $6,525,200$ & $6,202,626$ & $1,502,312$ \\
\hline $1861 \ldots$ & 31 & $14,080,746$ & $1,059,715$ & $7,863,466$ & $5,218,598$ & $2,034,391$ \\
\hline $1871 \ldots .$. & 3 & .............. & .............. & 327,000 & (.............. & ................ \\
\hline $1887 \ldots \ldots$ & 11 & $1,721,211$ & .............. & 691,410 & ............. & $1,424,785$ \\
\hline $1892 \ldots \ldots$ & 32 & $5,524,727$ & .............. & $2,122,500$ & ….......... & $3,792,462$ \\
\hline $1897 \ldots \ldots$. & 45 & $4,537,989$ & .............. & $2,046,870$ & …........ & $3,412,841$ \\
\hline
\end{tabular}

National Banks.

Figures in thousands of dollars.

\begin{tabular}{|c|c|c|c|c|c|c|c|c|c|}
\hline YEARS. & 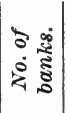 & $\begin{array}{c}\text { Loans } \\
\text { and dis- } \\
\text { counts. }\end{array}$ & $\begin{array}{c}U . S . \\
\text { bond8. }\end{array}$ & $\begin{array}{c}\text { Cash } \\
\text { and cash } \\
\text { items. }\end{array}$ & Capital. & Surplus. & $\left|\begin{array}{c}\text { Undi. } \\
\text { vided } \\
\text { profits. }\end{array}\right|$ & $\mid \begin{array}{c}\text { out. } \\
\text { standing } \\
\text { circula- } \\
\text { tion. }\end{array}$ & $\begin{array}{c}\text { Indi- } \\
\text { vidual } \\
\text { deposits. }\end{array}$ \\
\hline $1865 \ldots$ & 2 & $\$ 24$ & $\$ 61$ & $\$ 54$ & $\$ 68$ & ...... & $\$ 3$ & ....... & $\$ 52$ \\
\hline $1870 \ldots$ & 6 & 1,512 & 923 & 399 & 850 & $\$ 70$ & 120 & $\$ 529$ & 1,562 \\
\hline $1875 \ldots . .$. & 11 & 3,373 & 1,931 & 524 & 2,200 & 219 & 269 & 1,602 & 2,270 \\
\hline $1880 \ldots . .$. & 15 & 4,187 & 2,299 & 579 & 2,501 & 320 & 214 & 1,815 & 2,883 \\
\hline $1885 \ldots .$. & 15 & 4,672 & 1,417 & 729 & 2,064 & 472 & 236 & 993 & 3,238 \\
\hline $1890 \ldots$ & 21 & 6,659 & 920 & 506 & 2,656 & 649 & 378 & 646 & 4,673 \\
\hline $1895 \ldots . . .$. & 27 & 6,314 & 916 & 558 & 2,716 & 780 & 280 & 686 & 4,551 \\
\hline $1898 . .$. & 27 & 6,501 & 1,074 & 765 & 2,691 & 824 & 343 & 681 & 5,936 \\
\hline
\end{tabular}


State, Savings and Private Banks of North Carolina, 1898.

\begin{tabular}{|c|c|c|c|c|}
\hline & State banks. & $\begin{array}{c}\text { Savings } \\
\text { banks. }\end{array}$ & $\begin{array}{l}\text { Private } \\
\text { banks. }\end{array}$ & Total. \\
\hline 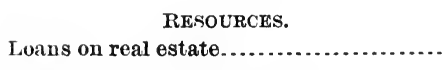 & $\$ 713,353$ & $\$ 216,373$ & $\$ 162,815$ & $\$ 1,092,542$ \\
\hline All other loans and discounts............... & $4,087,320$ & $1,093,729$ & 802,234 & $5,983,284$ \\
\hline 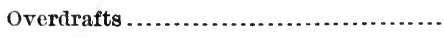 & 86,214 & 530 & 38,902 & 125,647 \\
\hline United States bonds on hand (par value). & 24,000 & 23,300 & (n.......... & 47,300 \\
\hline North Carolina State bonds...... & 38,758 & 39,206 & 2,200 & 80,165 \\
\hline 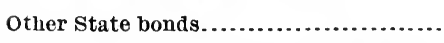 & ........... & ........... & ............ & ........... \\
\hline All other stocks, bonds and mortgages... & 194,458 & 39,978 & 37,452 & 271,889 \\
\hline 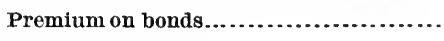 & 2,345 & (n.......... & (n.......... & 2,345 \\
\hline Due from banks........ & 961,103 & 235,190 & 233,004 & $1,429,299$ \\
\hline Banking house.................. & 134,875 & 40,655 & 21,000 & 196,531 \\
\hline Furniture and fixtures................ & 54,289 & 3,469 & 12,805 & 70,561 \\
\hline All other real estate owned............ & 75,481 & 10,311 & 55,020 & 140,813 \\
\hline 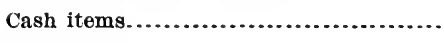 & 144,355 & 3,290 & 23,914 & 171,561 \\
\hline 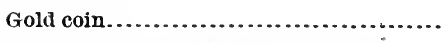 & 139,889 & 40,495 & 17,486 & 197,871 \\
\hline Silver coin and all fractional currency.... & 69,923 & 5,622 & 31,165 & 106,711 \\
\hline National bank notes and other U. S. notes. & 314,003 & 17,762 & 88,684 & 420,449 \\
\hline 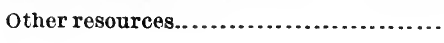 & 33,920 & 148,836 & 7,168 & 189,925 \\
\hline Total. ........................... & $\$ 7,074,293$ & $\$ 1,918,752$ & $\$ 1,533,854$ & $\$ 10,526,900$ \\
\hline $\begin{array}{c}\text { LIABILITIES. } \\
\text { Capital stock paid in.................. }\end{array}$ & $\$ 1,946,060$ & $\$ 280,000$ & $\$ 299.237$ & $\$ 2,525,297$ \\
\hline 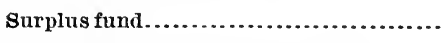 & 270,501 & 26,787 & 79,292 & 376,581 \\
\hline Undirided profits, less expenses..... & 220,721 & 43,473 & 47,471 & 311,666 \\
\hline Dividends unpaid................... & 2,340 & 32 & 699,571 & 2,372 \\
\hline Deposits subject to check........ & $3,721,990$ & 787,355 & 85,145 & $5,208,917$ \\
\hline Due to banks................................. & 92,486 & 9,250 & 7,197 & 186,882 \\
\hline Notes and bills rediscounted...... & 100,965 & n......... & 12,496 & 108,163 \\
\hline Cashiers' checks outstanding............... & 35,618 & 880 & 672 & 48,995 \\
\hline 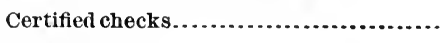 & 8,637 & (........... & 101,909 & 9,309 \\
\hline Bills payable.................. & 183,525 & (n......... & 75,996 & 285,434 \\
\hline Demand certificates of deposit......... & 101,868 & 99,795 & 110,819 & 277,660 \\
\hline Time certificates of deposit............ & 389,560 & 29,216 & 14,043 & $\mathbf{5 2 9 , 5 9 7}$ \\
\hline Other liabilities................. & 16 & 641,961 & ........... & 656,020 \\
\hline Total. & $\$ 7,074,293$ & $\$ 1,918,752$ & $\$ 1,533,854$ & $\$ 10,526,900$ \\
\hline
\end{tabular}




\section{SOUTH CAROLINA.}

The early colonists of Carolina were from Great Britain, many of them of the better class, but in moderate circumstances. The inducements to emigrate were so strong that each year brought new adventurers from every portion of Europe and even from far-off China. To some of the emigrants it was an easy mode of getting rid of home debts and often of criminal prosecutions. The revocation of the Edict of Nantes contributed considerably to the population by furnishing some of the best families to the new colony. Carolina became a general rendezvous of French Protestants. About the same time quite a colony came over from Germany. The Swiss also flocked to Carolina, consequently the population of the new colony was of a heterogeneous character. The early colonists found themselves surrounded by thousands of enraged Indians who had been inhumanly treated by Spaniards who had come over from Cuba and had turned loose the Cuban bloodhounds upon them, tearing to pieces women and children. In retaliation the Indians murdered and scalped the colonists. The pirates from Cuba and the West Indies also committed great outrages upon the colonists. With such surroundings an almost bankrupt people were not in condition to establish a bank. The irresponsible State government flooded the country with an immense amount of almost worthless currency and bills of credit to carry on the Indian and Spanish wars and to meet the other exigencies of the Colony.

For more than half a century the colonists struggled along without a chartered bank. Great Britain had from time to time sent to the colony several cargoes of negroes from Africa which were sold into slavery. These were employed mainly on the coast and sea islands in the cultivation of rice, indigo and vegetables. As there was scarcely any silver or gold coin, the purchase of the negroes had to be paid for with rice, indigo, furs, skins and the like. A considerable amount of coin went to pay for the imported slaves. A few years of peace enabled the planters to successfully cultivate rice, indigo, hemp and other products, with a profitable business in skins, furs and fish.

The merchants and inhabitants greatly prospered. There was a large advance in the price of real estate in Charleston and on the islands around the city, also in the value of slaves, which had become an article of merchandise saddled upon the colony by the mother country.

\section{Land and Loan Bank of the Carolinas Established.}

It was believed that the establishment of a bank would stimulate trade and other industries, and would also be an easy mode of obtaining money and supporting the wants of the State government, as but a small income was derived from the people by direct taxation. The improved condition of things in the Carolinas suggested the feasibility of 
establishing a bank. The first and only bank organized under the Proprietary Government was in 1712, located in Charleston, and known as the Land and Loan Bank of the Carolinas, with a perpetual charter granted by the State Legislature with the privilege of issuing bills to be forever the legal money of the country. Five hundred thousand dollars of currency was issued as fast as it could be printed and loaned out at ten per cent. to such of the inhabitants as could give land or other satisfactory security. This large emission of bank bills doubled the actual value of land, slaves and agricultural products. Bank bills became the circulating medium of the Carolinas. There was a wide difference between the current bank bills and gold and silver coin. The latter never entered into circulation. The bank, however, with all of its abuses and defects, was a great convenience and power in the new, crude, colony, furnishing for a period of sixty years current money receivable for all dues, State and personal. The bank lasted from 1712 to the end of the Royal Government in 1775, a period of sixty-three years. It was a great help to the people in building up the Colony, but was destroyed by the Revolutionary War.

At the beginning of the Revolutionary War, Charleston was the most important shipping port on the American Continent.

The eight years' war of the Revolution left South Carolina in a demoralized condition. Political anarchy prevailed. The herculean effort to throw off the British yoke led her people to endure untold sacrifices. Society was disorganized, and unusual distress prevailed all over the State. The large amount of State and private debts and bank currency was nearly all lost. The law prohibited suits for recovery of debts. When the war was over, South Carolina was left with her rich lands, good climate, a hardy race of men, with the profitable staples of cotton and rice to restore their wasted fortunes. So great was the political disturbance, it required nearly ten years to establish a stable State government. Good crops stimulated trade, and the people in a few years felt the necessity of banking facilities. From the beginning of the State government only State banks were chartered. The paper money consisted exclusively of the notes of banks organized under State laws.

Beginning of the State Banking System.

The first era of banking in the new State of South Carolina was in 1792 when the Bank of South Carolina was chartered by the State Legislature. In the same year a branch of the Bank of the United States was established at Charleston. Five banks were chartered, viz. :

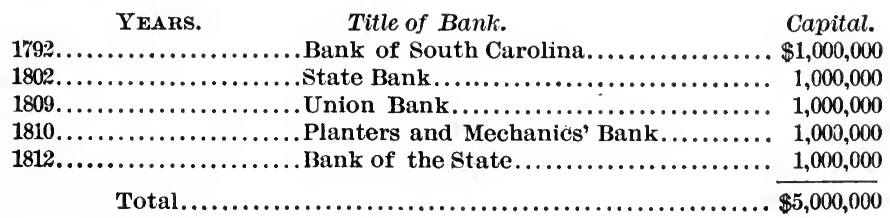


These banks were all located in Charleston, which was at that time the eapital of South Carolina. The banks were ably and honestly managed by the best merchants and bankers of Charleston. Of the large amount of money deposited in those banks and the vast issues of currency, not a dollar was lost until the Civil War of 1861.

\section{The Bank of South Carolina.}

About 1804 the Legislature subscribed $\$ 300,000$ to the bank called the State Bank of South Carolina, but subsequently, in 1812, to relieve the financial distress then prevailing the Legislature chartered the Bank of the State of South Carolina. This bank was to receive on deposit all stocks and bonds and unexpended cash and all taxes collected in future. The title was vested in the President and directors, and the faith of the State was pledged to support the bank and make good all losses. The institution had power to make loans on both real and personal security at seven per cent. interest, payable in advance, the loans to be renewable for periods up to ten years. The bank was to pay the interest on the State debt, and its charter was to run until 1836. The bank realized upon the assets turned over by the State, and its effective capital was in $1819 \$ 1,372,500$. In 1830 the charter was renewed until 1856. In 1830 its available assets were $\$ 3,768,292$, and at this time it had paid $\$ 215,000$ of the principal of the State debt, which, however, had been largely increased by means advanced by the State for internal improvements.

In 1834 , by the apparently brilliant prospects opened by the completion of railroads and the rise in the price of cotton, the Legislature was induced to charter the Charleston, Louisville and Cincinnati Railroad Company, with a capital limited to $\$ 36,000,000$. The State took $\$ 800,000$ in stock, and advanced $\$ 200,000$ in cash, and endorsed the bonds of the company for $\$ 2,000,000$. In 1838 a great part of the city of Charleston was destroyed by fire, and an extra session of the Legislature was called, which authorized the Bank of the State to negotiate a loan of two millions of dollars for the benefit of the sufferers, and the bank obtained the money in England. In 1852 the charter was extended until 1871. The Civil War did not destroy the bank and in $\mathbf{1 8 6 7}$ it still held a large amount of assets, some of which had been rendered of doubtful value, belonging to the State. In 1868 the first Republican (or negro) Legislature passed an act to close the bank, and in 1870 it was placed in the hands of Receivers.

In 1820 there were five banks in the State: The Bank of South Carolina, chartered in 1792 with capital of $\$ 1,000,000$; the State Bank of South Carolina, chartered in 1802 , with capital of $\$ 1,000,000$; the Union Bank and the Planters' Bank, both chartered in 1810, and each having a capital of $\$ 1,000,000$; and finally the Bank of the State of South Carolina, having at that time a capital of $\$ 1,123,15 \%$. This last bank was the fiscal agent of the State. It received all taxes, paid all demands, 
negotiated all loans and received all the assets of the State. There were in South Carolina, as in other States, two opinions about the expediency of conducting all the financial operations of the State through an institution of this kind. No objection, however, seems to have been made to its constitutionality before the courts. The views of the opponents of this institution are indicated in the following quotation from Governor Seabury's message in 1849 :

"The Bank of the State of South Carolina is a dangerous institution, anti-Republican in its character and tendency, and the evils inevitably arising from the crnnection of a monied corporation and the State increase and ramify the longer the rights and privileges of the former are extended. The political history of South Carolina has so long presented the anomalous spectacle of its constituted authorities pertinaciously upholding a State corporation, while it denounced any union between a bank and the Federal Government, I also desire in this place to express my settled conviction that the Bank of the State was founded on a false and pernicious principle; that to grant to the members of a community almost exclusively devoted to rural pursuits unusual facilities for commanding money, is to inflict on them and their posterity an unmitigated evil."

On the other hand we find in a work on South Carolina recently published by the State Board of Agriculture, the following summing up of the history of the bank. Speaking of the closing of the bank in 1870 , the authors of the work remark:

"Thus passed away a powerful institution, which for more than haif a century had exercised exclusive control of the fiscal affairs of the State. Its friends claimed that it had saved, consolidated and made profitable the funds of the State, that it had furnished relief to many citizens and added to the general revenues of the State, improving and developing the towns of the interior. Its profits were employed in paying the interest and in reducing the principal of the public debt. It preserved its capital entire and its funds safe, maintaining the character and the credit of the State in Europe and at home without blot or suspense. Its most violent opponents admitted the ability and integrity displayed in its management, and declared that the abiding confidence of the people in it was a high but dangerous compliment to the purity of the public characters of the State."

The constitutionality of the paper issues of the Bank of the State of South Carolina can not be questioned after the decision of the United States Supreme Court in the case of Briscoe vs. The Bank of the Commonwealth of Kentucky; but this question does not appear to have been raised in South Carolina.

\section{Notable Banks and Bankers of the State.}

Among the public men of South Carolina as legislator and banker, none was better known than Langdon Cheves, Judge of the South Carolina Supreme Court, member of Congress, Speaker of the House and President of the United States Bank. During his presideney of the United States Bank, a branch bank was in successful operation in Charleston, which did a profitable business in sterling and domestic exchange. Mr. Cheves' father lost everything by the war. He appren- 
ticed his son, Langdon, when only ten years of age to a shipping merchant in Charleston.

The large and wealthy private banking house of James Adger \& Co., correspondents of Brown Bros. \& Co., of Liverpool and London, did an extensive and successful business in sterling and domestic exchange. It was for half a century the leading private banking house in South Carolina. James Adger, the senior partner of the firm, was one of the most successful business men that Charleston ever had. From a small beginning he amassed a large fortune; his three sons were his partners.

At the close of the Branch Bank of the United States there arose the necessity of a bank with a large capital to take its place. The old banks in Charleston had not accustomed themselves to handling, to any extent, foreign exchange: they were very conservative in their business. The great staples for Carolina of cotton and rice were chiefly sold for foreign exchange.

\section{The Bank of Charleston Chartered.}

About this time Henry Gourdin was one of the leading merchants and bankers in Charleston. It was mainly through his influence that the Bank of Charleston was established. He was a director in the Union Bank, of which Henry Ravenel was President. In $1834 \mathrm{Mr}$. Gourdin was elected a member of the State Legislature.

It was not known generally that a charter for a bank was to be applied for. There was great opposition to creating a new bank. Judge Colcock, then President of the Bank of the State, was violently opposed to chartering a bank with the proposed large capital. He contended that it would destroy the old banks and have a monopoly of the banking business of Charleston and of the State; he proposed to increase the capital of the Bank of the State. As that bank was fast falling into the hands of ring politicians, the proposition was rejected, and the Bank of Charleston was chartered with a capital of $\$ 3,000,000$. The petitioners for its charter were Ker Boyce, L. M. Wiley, H. W. Conner, Robt. Y. Hayne and Henry Gourdin, all leading merchants and bankers of Charleston. They bought the United States Bank building on Broad street and began business in 1835 with Gen. James Hamilton as President and Arthur Rose as Cashier. With such officers and a strong board of directors, the Bank of Charleston revolutionized the banking business in South Carolina. A close alliance was made with the Bank of Liverpool, the relations of the two banks becoming most intimate and confidential. In a few years the Bank of Charleston ranked in commercial circles of Europe among the foremost institutions of its kind in the United States. Samuel Smith was Manager of the Bank of Liverpool at that time. The Bank of Charleston succeeded to the large business of the Branch Bank of the United States, and with its large capital and good management, the 
bank enabled the merchants to build up the jobbing trade of Charleston, which soon extended to nearly all of the Southern States; the shipping business also greatly increased.

When the war began in 1861 the Bank of Charleston was on the high road of success. Its bills passed currently in every State in the Union. Alas! War leaves nothing but ruin in its ravages. The Bank of Charleston paid all of its depositors and bill holders in full, and was one of the few banks in the South that survived the war. In 1872 it reorganized as the Bank of Charleston National Banking Association, and although it has not a capital of three million dollars now, yet it ranks in credit and usefulness with any bank in the South. Only meagre and unsatisfactory bank reports were published in this State until after the panic of 1837 .

In 1812 there were five State banks with an aggregate capital of \$5,000,000 , which was increased to $\$ 8,800,000$ in 1835 by the organization of the Bank of Charleston, with $\$ 3,000,000$ capital, and the Southwestern Railroad Bank, with $\$ 800,000$ capital. All these banks were located in Charleston. In 1839 there were twelve banks, with $\$ 11,600$, 000 capital, $\$ 5,000,000$ in circulation, and $\$ 2,500,000$ deposits, and by 1859 the capital had increased to $\$ 15,000,000$, the circulation to $\$ 12$,000,000 and the deposits to $\$ 5,250,000$.

At the beginning of the War in 1861 there were twenty-two State banks in South Carolina, with an aggregate capital of $\$ 18,000,000$; circulation, $\$ 10,000,000$; deposits, $\$ 12,000,000$. The banks were so carefully and successfully managed that there had not been a failure of a bank in South Carolina since the close of the Revolutionary War in 1783 .

Early in the War of 1861 C. G. Memminger, Secretary of the Confederate Treasury, a Charleston banker, called upon the banks for $\$ 10$,000,000 of their bills, which were to be returned as soon as the Confederate notes could be printed. The writer of this sketch was a director in the Bank of South Carolina, the first bank that was chartered after the War of the Revolution by the State Legislature. Hetold Mr. Birnie, the President, that if the request was granted it would break all the banks, as the bills of the banks, which were considered better than Confederate notes, would be hoarded. A majority of the directors, however, voted for the issue, which resulted in the destruction of the banks.

\section{Soundness of the State Banks.}

The State bank system in the Southern States before the war was popular and as perfect as anything could be outside of National banks. The laws regulating banks in South Carolina gave satisfaction throughout the country, affording as they did a sound currency and ample accommodation to the people. A Bank of Charleston note was current from Maine to Texas, and even circulated in England and on the Con- 
tinent of Europe. Bank capital in South Carolina was exempt from taxation by State or municipal authorities. This enabled them to declare satisfactory dividends and make loans at low rates of interest. The majority of the banks in South Carolina were located in Charleston. They were banks of issue and all specie-paying.

\section{Destruction Wrovght by the Civil War.}

The disastrous war of 1861-65 was a political earthquake that shook the Southern States from center to circumference, resulting in loss of lives and property beyond computation. The slaves alone of the South represented a money value of three thousand millions of dollars. As many more millions in currency, bank capital, bonds and miscellaneous debts were destroyed by the surrender of Lee. In 1861 a terrible fire swept over Charleston from Ashley to Cooper rivers, and destroyed six million dollars' worth of property. Columbia, the State capital, was literally destroyed by fire in $\mathbf{1 8 6 5}$ when Sherman's army visited that city.

As the war began in Charleston her trade and commerce were the first to suffer its effects, from which it has never fully recovered. When the Confederate authorities evacuated Charleston in 1865, a small force of mounted men was left to burn the cotton, gunboats, provisions and other Confederate property. The burning of the cotton at the Northeastern depot resulted in a terrible calamity. A large quantity of powder was stored there which ignited and blew up the depot, burying in the ruins two hundred men, women and children who were at the depot to get the provisions stored there. The fire spread across the city, destroying millions of dollars' worth of property. The shelling from the Federal gunboats prevented any one living below Calhoun street. In this crisis the mayor appointed Aldermen George W. Williams and W. H. Gilliland to be the bearer to Morris Island of the following communication.

" To the General Commanding the Army of the United States at Morris Island:

SIR-The military authorities of the Confederate States have evacuated this city. I have remained to enforce law and preserve order until you take such steps as you may think best.

Very respectfully, your obedient servant,

Charleston, S. C., February 17, 1865."

Charles Macbeth, Mayor.

The aldermen met General Bennett and delivered the mayor's letter. The services of the Federal troops were secured in extinguishing the fires in various parts of the city. Provisions enough were saved from the flames to feed 20,000 people, whites and blacks, for four months.

As soon as the war was over, the firm of Geo. W. Williams \& Co. resumed business, and without delay erected fifteen large brick warehouses in the burnt districts for the storage of cotton, merchandise and fertilizers, at a cost of $\$ 100,000$. They rebuilt the Charleston Iron Works that gave employment to 200 men and a large cotton-press, which has compressed millions of bales of cotton. They also re-estab- 
lished the banking house which at once made arrangements with Drexel, Morgan \& Co., New York, Brown Bros. \& Co. of London, Bank of Liverpool and Drexel, Harjes \& Co., Paris, to handle their sterling exchange, which amounted to five million dollars per annum. They also did a large business in domestic exchange. So carefully was business done in Charleston that of the large amount of sterling exchange bought there was not a dollar lost.

Soon after the war, cotton, which was the great Southern staple, was shipped to Charleston and sold at fifty cents per pound. This stimulated trade and created a heavy demand for currency. This was needed to move the cotton. Only National banks could furnish currency. Geo. W. Williams \& Co. decided to establish a National bank with a capital of $\$ 500,000$. They had bought sterling exchange in 1861 with Confederate money at 103, and sold it in 1865 at 225. Their New York bankers sold six hundred thousand sterling exchange for them and invested in Government seven per cent. bonds at less than par.

As there was not a bank in South Carolina, Geo. W. Williams \& Co. arranged at Washington to establish the First National Bank of Charleston with a capital of $\$ 500,000$; their senior partner was to be President. There was, however such a demand for his time and services in the mercantile business that he could not accept the office, but became Vice-President. It has been a most successful institution.

In December, 1865, the People's National Bank was chartered with a capital of $\$ 500,000$ afterwards increased to $\$ 1,000,000$.

In 1872 the Bank of Charleston was reorganized as the Bank of Charleston National Banking Association, with a capital of $\$ 600,000$. The capital has been reduced to $\$ 300,000$, but the bank still has the largest capital and business of any bank in the State. The three National banks in Charleston have all been successful.

In 1875, ten years after the war, there were three National banks in Charleston with combined capital of $\$ 2,100,000$ and a few old State banks winding up, not having capital enough to continue business. The capital of new State banks chartered from 1865 to 1875 was less than one million dollars. In 1885 there was a great disposition in nearly every little town in South Carolina to establish one or more State banks, generally called Savings banks, but they all had capital more or less, and in some instances less than more. The depositors received a fair rate of interest. In consequence of the excessive taxation and the large increase of State banks, the three National banks of Charleston reduced their capital from $\$ 2,100,000$ to $\$ 750,000$. Quite a number of National banks in the interior have gone into the State bank system.

In 1874 Geo. W. Williams \& Co. established the Carolina Savings Bank at Charleston with an authorized capital of $\$ 500,000$.

The low rate of interest on Government bonds is causing a reduction of National banks. After the premium paid, they will not yield more 
than $2 \frac{1}{2}$ per cent. interest. The constantly increasing number of trust companies are also serious rivals of the banks.

South Carolina has for the past 100 years been distinguished for sound banking. As has been stated, from 1783 to 1861 there was not the failure of a bank chartered by the State. From 1865 to 1898 there have been comparatively few bank failures. Perhaps no State in the Union has a better record for sound banking.

In 1898 the sixteen National institutions had an aggregate capital of $\$ 1,943,000$, and the eighty-seven State banks (including Savings banks) a capital of $\$ 3,501,000$. The surplus of these banks was $\$ 2,668,000$, and the deposits $\$ 26,335,150$. Fourteen of the State banks and three of the National banks were located in Charleston.

State Banks.

\begin{tabular}{|c|c|c|c|c|c|c|}
\hline YEARS. & $\begin{array}{l}\text { No. of } \\
\text { banks. }\end{array}$ & $\begin{array}{l}\text { Loans and } \\
\text { discounts. }\end{array}$ & Specie. & $\begin{array}{l}\text { Capital } \\
\text { stock. }\end{array}$ & Circulation. & Deposits. \\
\hline $1835^{*} \ldots$ & 4 & $\$ 3,886,441$ & $\$ 754,219$ & $\$ 2,288,030$ & $\$ 2,156,318$ & $\$ 1,600,956$ \\
\hline $1840 \ldots \ldots$ & 14 & $18,347,002$ & $1,847,498$ & $11,584,355$ & $4,439,404$ & $2,279,218$ \\
\hline $1845^{*} \ldots$. & 11 & $14,440,112$ & $1,864,999$ & $11,065,668$ & $4,306,991$ & $1,772,498$ \\
\hline $1850 \ldots$. & 14 & $20,601,137$ & $1,711,902$ & $13,139,571$ & $8,741,765$ & $3,322,132$ \\
\hline $1855 \ldots \ldots$ & 19 & $23,149,098$ & $1,283,284$ & $16,603,253$ & $6,739,623$ & $2,871,095$ \\
\hline $1861 \ldots .$. & 20 & $22,230,759$ & $1,628,336$ & $14,952,486$ & $6,089,036$ & $3,334,037$ \\
\hline $1871 \ldots \ldots$ & 8 & ................ & ............... & $2,800,000$ & ................ & ................ \\
\hline $1876 \ldots \ldots .$. & 6 & 996,088 & ............... & 585,783 & .............. & 899,903 \\
\hline $1881 \ldots \ldots$. & 2 & 457,633 & ................ & 140,000 & ................ & 811,951 \\
\hline $1885 \ldots \ldots$. & 5 & $1,710,779$ & ................ & 500,000 & ............. & $2,341,354$ \\
\hline $1891 \ldots \ldots .$. & 19 & $3,049,089$ & .............. & $1,342,948$ & ................ & $1,737,764$ \\
\hline $1897 \ldots \ldots$. & 17 & $2,263,313$ & ............. & 917,700 & ............... & $1,251,674$ \\
\hline
\end{tabular}

* Incomplete.

National Banks.

Figures are in thousands of dollars.

\begin{tabular}{|c|c|c|c|c|c|c|c|c|c|}
\hline YEARS. & 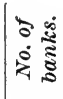 & $\begin{array}{l}\text { Loans and } \\
\text { discounts. }\end{array}$ & $\begin{array}{c}U . S . \\
\text { bonds. }\end{array}$ & $\begin{array}{l}\text { Cash and } \\
\text { cash items. }\end{array}$ & Capital. & Surplus. & $\begin{array}{c}\text { Undi. } \\
\text { vided } \\
\text { profits. }\end{array}$ & $\left|\begin{array}{c}\text { Out. } \\
\text { standing } \\
\text { circula } \\
\text { tion. }\end{array}\right|$ & $\begin{array}{c}\text { Indi- } \\
\text { vidual } \\
\text { deposits. }\end{array}$ \\
\hline $1866 \ldots$ & 2 & $\$ 732$ & $\$ 144$ & $\$ 399$ & $\$ 500$ & $\$ 2$ & $\$ 82$ & $\$ 63$ & $\$ 823$ \\
\hline $1870 \ldots$ & 3 & 1,829 & 375 & 437 & 1,081 & 121 & 79 & 333 & 961 \\
\hline $1873 \ldots$ & 12 & 4,044 & 2,425 & 372 & 3,168 & 339 & 208 & 2,181 & 1,499 \\
\hline $1878 \ldots$. & 12 & 3,766 & 1,620 & 575 & 2,851 & 433 & 203 & 1,290 & 1,649 \\
\hline $1883 \ldots$ & 13 & 4,530 & 1,505 & 640 & 1,885 & 754 & 443 & 1,118 & 2,584 \\
\hline $1888 \ldots .$. & 16 & 5,970 & 1,172 & 646 & 1,773 & 788 & 798 & 420 & 3,096 \\
\hline $1893 \ldots$. & 14 & 6,055 & 625 & 503 & 1,748 & 841 & 690 & 418 & 3,058 \\
\hline $1898 \ldots$ & 16 & 5,907 & 939 & 546 & 1,943 & 750 & 492 & 539 & 3,824 \\
\hline
\end{tabular}


The writer of this sketch has had an experience in banking embracing a period of half a century and has passed through numerous wars and panics. He has never found it more difficult to use money profitably than at this time. The Savings banks have found it necessary to reduce the rate of interest paid depositors to three per cent. in consequence of the difficulty in making satisfactory investments and loans. Rates of interest on approved securities generally approximate to those paid by the Government.

\section{GEORGIA.}

Great Britain had denied to the Colonies the right to emit bills of credit, but after hostilities began between the Colonies and the mother country the business of the Colony was conducted with an issue of colonial currency approximating fifty thousand dollars, which was legal tender for all public and private debts. This currency disappeared, and so far as known no portion of it was redeemed. It doubtless was preserved by hopeful holders as some are yet treasuring the Confederate bonds and the issues of State currency by some of the cotton States, which were payable "six months after a treaty of peace shall have been ratified between the United States and the Confederate States."

\section{Bills of Credit Emitted bx the State.}

Bills of credit were largely emitted by the State of Georgia during the Revolutionary period, and the poorly fed soldiers of the Revolution were paid in this currency, as their descendants were paid in money of like currency in the sixties. After the treaty of peace with Great Britain Georgia redeemed the war issue of colonial currency with a new issue of paper currency at the ratio of one to one thousand. When one considers the amount of the original that must have been lost, destroyed, and fallen into the hands of the enemy, the proportion of redemption was even greater than a discount of 999 per centum. This new currency, however, answered the purpose of money, was a medium of exchange, gave credit and enabled the pioneers to erect a State and build up values that would endure when the stimulus to exertion had ceased to be worth the paper upon which the delusive promises to pay had been printed.

On May 4, 1778, the Legislature of Georgia authorized an issue of legal-tender paper of more value than the class of paper previously issued. The amount was a quarter of a million dollars, or $£ 50,000$, pledging the faith and credit of the State for redemption.

The notes were further secured by lands acquired by the State. Most of these bills were redeemed, some of them as late as the thirties. This circulation was a great relief to a struggling people, and more confidence was reposed in those bills than in any previous currency in circula- 
tion in the history of the Colony. It would be difficult to obtain many genuine bills of the currency circulating in Georgia in the year 1778, but the following is a sample of one of these unredeemed bills of what was known as the "rattlesnake issue." It is printed on rough paper, being three and one-eighth inches by six inches.

Ten years after the emission of this bill the Federal Constitution provided against the issue of bank bills by the States, and Georgia lived up to the inhibition until January, 1862, during the Civil War, when, as will be seen further on, she again resorted to an emission and eirculation of State currency.

Until 1810 the banking transactions in Georgia were all through branches of the Bank of the United States, and thus the State escaped the evils that many other States experienced by chartered banks with large volumes of currency emitted by them. In eseaping the aftermath of repudiation and worthless paper, it is a matter of history that the progress of the State was not particularly noticeable. While other States were building cities, promoting manufacturing industries and building roads and canals, Georgia made no material progress for the decade ending 1810, beyond the stage coach and the wagon.

As dissatisfaction with the Bank of the United States grew, there was also enkindled a sentiment in favor of banks that would be free from Federal supervision and control.

\section{Banks Chartered Under State liaws.}

Anticipating, by three years, refusal of a renewal of the charter of the Bank of the United States, a number of prominent merchants, planters, professional men and tradesmen of Savannah, Ga., in 1807 obtained from the Legislature a charter for the Planters' Bank. 'The charter, however, did not meet the requirements of a majority of the projectors, and an organization was not then effected. The city of Augusta, on the Savannah River, was then, and for forty years later, a decided rival of Savannah, and the project of a bank was taken up, culminating in December, 1810, by the Legislature chartering the Bank of Augusta, with a capital of $\$ 300,000$, which capital was twice increased thereafter, until in 1826 its capital stock was one million two hundred thousand dollars, of which the State of Georgia had reserved stock to the amount of $\$ 200,000$, and ten years ago the State Treasurer was instructed to cease to carry on his books the stock of the Bank of Augusta as live assets, thus wiping out $\$ 80,000$.

The Savannah projectors obtained a new charter for the Planters' Bank in 1810, with an authorized capital stock of one million dollars, one-tenth of which, or 1,000 shares, was reserved to the State.

For five years the Bank of Augusta and the Planters' Bank, of Savannah, were the only chartered banking institutions in the State, but the State was infested with all sorts of bills of credit, issued by individuals, partnerships and associations of various kinds, demoralizing in tendency 


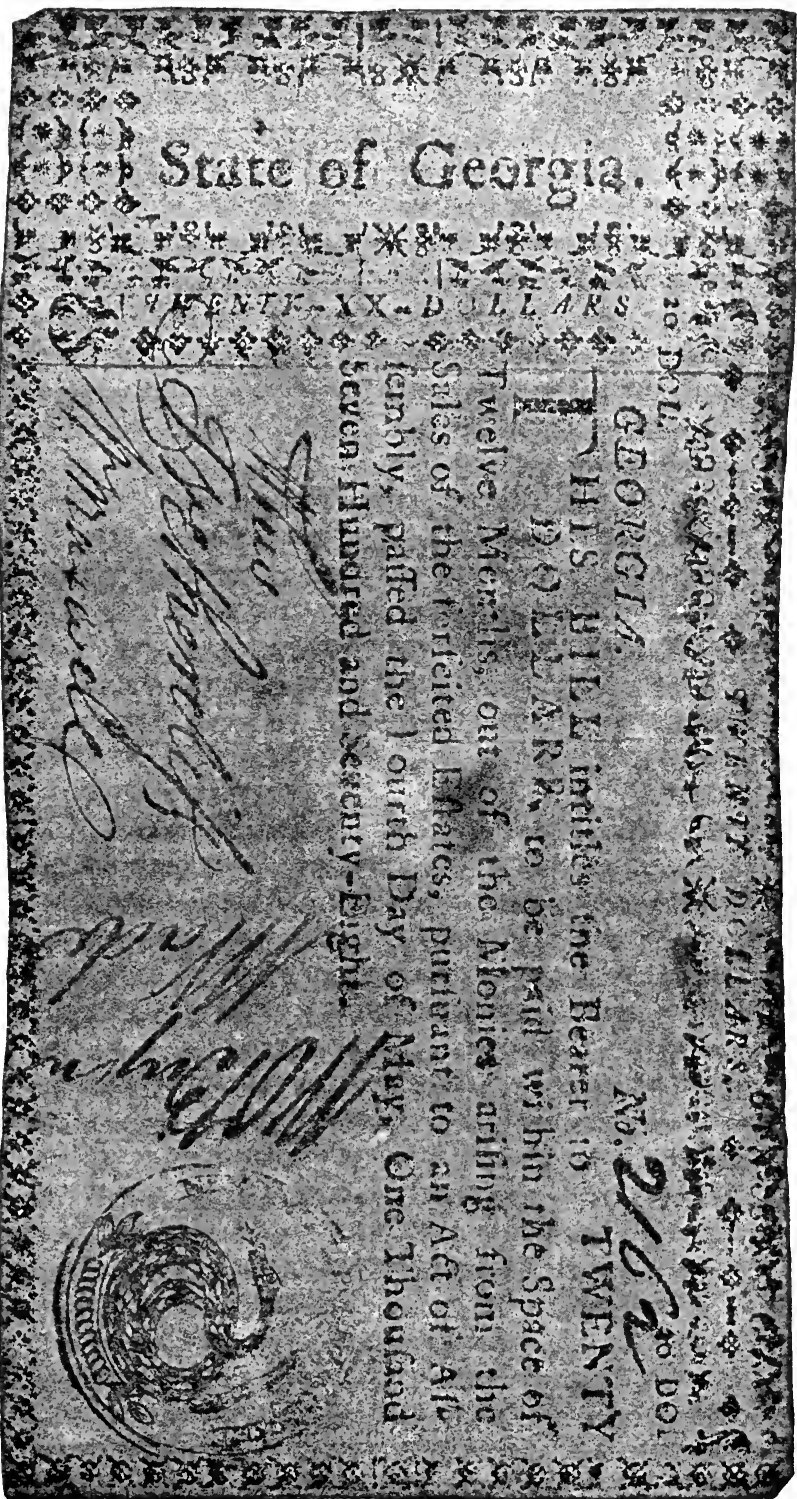




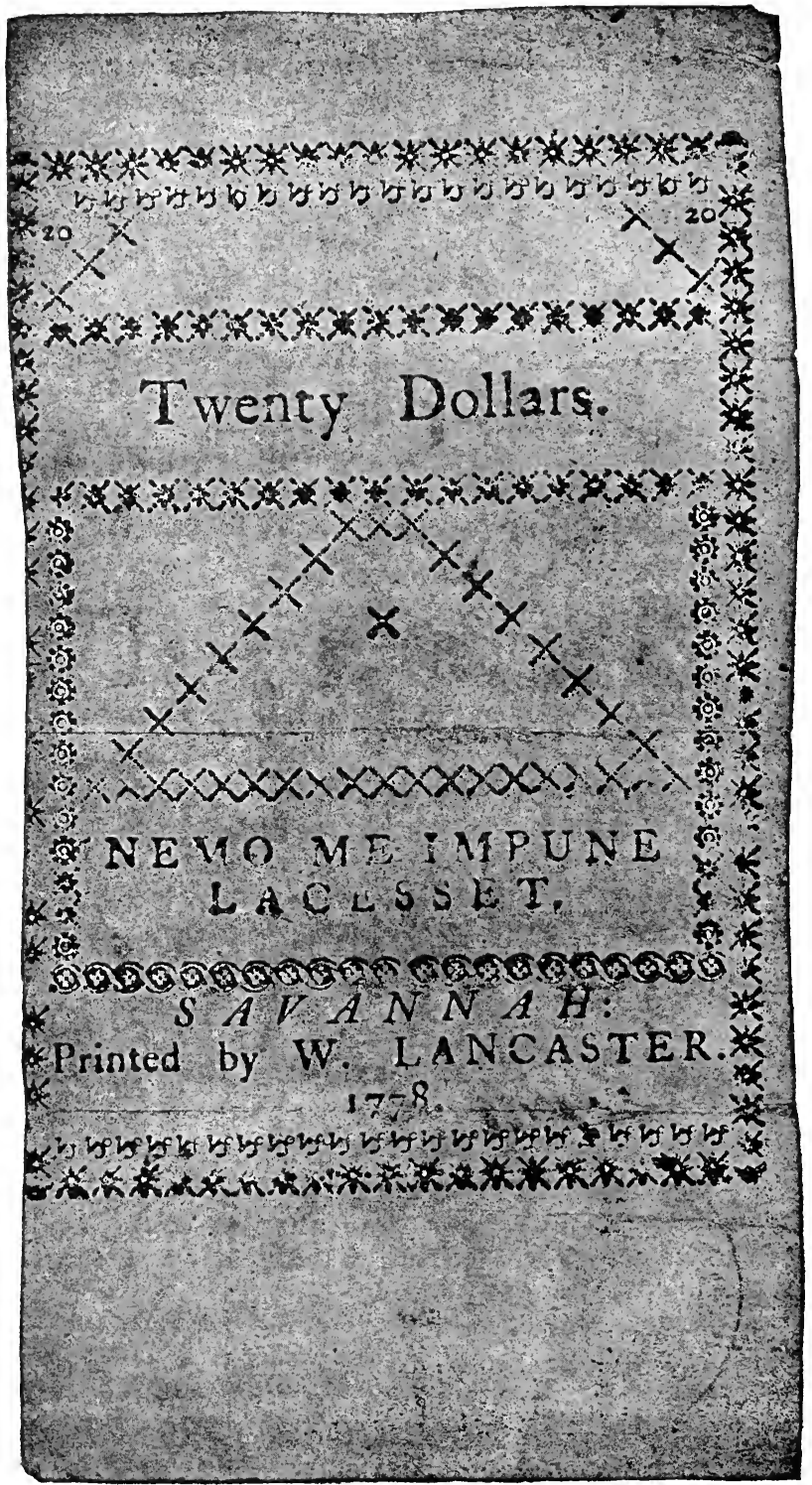


and calculated to impair the general scope of the chartered banks. It was sought to correct the abuse, if not wholly to destroy it, by legislative enactment in 1815, for at that session a tax of eight per cent. was laid upon all bills issued by other than chartered banks, and for all subsequent issues of the kind a tax of twenty per cent. was laid. The act required the emitters of such bills to make returns under a penalty of $\$ 500$.

During this period of 1810-15, while the second war with Great Britain was in progress, specie payments had been suspended, and the issue of small bills had tended to the withdrawal of coin and subsidiary coinage. But, contrary to the terms of the charters of the banks then doing business in the State, to-wit : the Bank of Augusta and the Planters' Bank, of Savannah, suspension of specie payments was frequent, and by them and other chartered banks later on during their existence, but in every instance Legislatures passed enabling acts, and no bank ever lost a charter, the Legislature invariably coming to the relief of the banks. In 1857, and again in 1860, when the Legislature had legalized the suspension of specie payments, and the Governor had interposed vetoes in each instance, the bills were passed over his veto.

December 16, 1815, the Bank of the State of Georgia, of Savannah, was incorporated with a capital stock of one and a half million dollars $(\$ 1,500,000)$, of which the State reserved six thousand shares, or six hundred thousand dollars, nearly one-half, and one year later the Bank of Darien, with a capital stock of one million dollars, was chartered, the State taking one-half.

\section{Organization of a Bank by the State.}

The State of Georgia in 1828 evolved out of its holdings in these four banks, the idea of a central bank, without capitalization other than the shares it owned in the four banks it had chartered, and the bonds, notes and other instruments of indebtedness due the State, to which it added moneys then in the hands of the State and moneys that might accrue to the State from all other sources. The professed object of the bank was to loan money to the people; the real object was to evade the provision of the constitution that prohibited the emission of bills by the State. This prodigy was known as the Central Bank, and was located at Milledgeville, then the capital of the State. It continued in active operation until 1842, but it required fourteen years thereafter to collect its assets. For many years the profits of the Central Bank enabled the State to conduct its internal affairs without laying taxes, and for a portion of the time, taxes, when imposed, were nominal; but this appearance of prosperity was fictitious. Its stock in the four banks mentioned had to be disposed of, loans were resorted to, and eventually the State had to issue bonds to redeem its outstanding bills. One of the dominant and anticipated popular features of the Central Bank was to make loans to the people of the various sections 
of the State, but complaints were numerous of inequality and favoritism in the placing of loans, which did much to enntribute to the unpop. ularity of the Central Bank.

\section{Operations of the Branch Bank of the Untted States.}

Going back to 1816 the chartering of the second Bank of the United States was the signal for the re-establishment of one of its many branches at Savannah. Congress had passed a law providing for the resumption of specie payments from February 20, 1817, after a sevenyears' suspension. The chartered banks of Georgia no doubt came as near compliance with the law as did the banks of most of the other States of the Union, but all sorts of evasions were resorted to and the local banks were in perpetual conflict with the United States Bank, the latter seeking to compel specie payment, and the former as persistently availing themselves of every tactful scheme, subterfuge and device to avoid paying out specie. Bills of the chartered banks were protested, but as the local sentiment was with the home banks, it was difficult and often impossible to retain counsel to press the claims of the Federal bank. The Legislature was finally invoked by the chartered banks, and in 1820 that body repeaied so much of the law providing for the resumption of specie payments so that it would not apply to a refusal of specie to the United States Bank by the chartered banks of the State; a year later further legislation was had that voided the interest upon the bills of the chartered banks held by the Federal bank for refusal of specie. This was repealed in 1824, but as hostilities were renewed between the Bank of the United States and the chartered banks, the law was re-enacted two years later.

From 1815 down to 1835 a number of banks were chartered, most of which had small capital, but all had the privilege of issuing bills to three times the amount of their capital stock. Between the depressing years 1833 to 1840 most of these banks disappeared, to the general sorrow of their depositors and holders of their bills of eredit; anong the general wreck were some of the more pretentious banks, such as the Darien Bank, with its capital of $\$ 1,000,000$ and $\$ 3,000,000$ in bills, and the Merchants and Planters' Bank, of Augusta, with a capital of $\$ 300$,000 and nearly $\$ 1,000,000$ of outstanding currency, whose charter a committee of the Legislature recommended in 1833 , should be forfeited, as the bank had been illegally organized, and had conducted. its business illegally from the time it had obtained its charter in 182\%. For four preceding years legislative committees had made the most glowing reports of it, recommending it to the confidence of the people and to the Legislature.

The banks that did most for internal improvements and the material progress of Georgia were the Georgia Railroad and Banking Company, of Augusta, and the Central Railroad and Banking Company, of Savannah. They were of great benefit to the State, and weathered all 


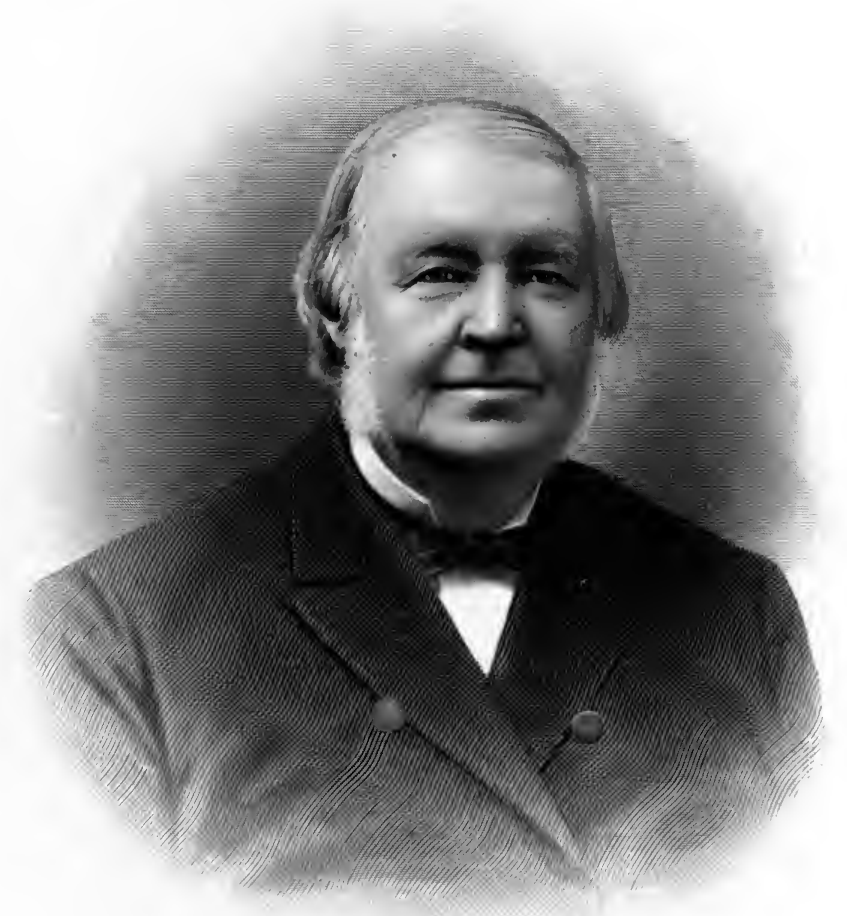

Hengh hibulloch 

financial storms, even rising superior to the depression and ravages of war, and meeting all their obligations, including their outstanding currency. To the Georgia Railroad and Banking Company was due the construction of the first railroad in Georgia, which was from Augusta to Athens, via Union Centre, and under its auspices the first railroad construction in the State was along this line, since that early period being extended to Atlanta, not then a settlement, but now the principal city of the State.

The Central Railroad and Banking Company first obtained a charter December 20,1833, as the Central Railroad and Canal Company, of Georgia. Finding that under this charter it was not desirable to build a canal, as the railroad era had begun, and railroads were no longer experimental, an amended charter was obtained December 14, 1835, from the Legislature for the Central Railroad and Banking Company, of Georgia, and incorporating in the charter the privileges of doing a banking business. The pioneers in this incorporation were W. W. Gordon, a lawyer, Mayor of the city and a member of the Legislature at the time of the passage of this act; he was the father of Gen. W. W. Gordon, now residing at Savannah; Thos. Purse, a merchant, member of the Board of Aldermen of Savannah, afterwards State Senator and Mayor of the city, and father of Capt. Daniel G. Purse, President of the Savannah Board of Trade. Mr. Gordon was the first President of the company, and Thos. Purse, first Superintendent of the road, under whose superintendency it was constructed. Mr. Gordon died before the road was completed; Mr. Purse survived the war. He was the inventor of the time-table as applied to roads, and was for many years one of the bank directors, both he and Mr. Gordon being members of the first board of directors. Mr. Purse was the originator of the banking idea, which was not looked upon so favorably by Mr. Gordon at the time the enterprise was projected.

The Central Railroad and Banking Company, of Georgia, had an authorized capital of three million dollars, one-half of which it was permitted to use for banking purposes. The project had the material support of the local banks, for when the eity of Savannah subscribed for $\$ 500,000$ of the stock, the Planters' Bank tendered a loan of $\$ 50,000$, the Bank of the State of Georgia $\$ 50,000$, and the Marine and Fire Insurance Bank $\$ 25,000$, all without interest, to enable the city to meet the first installment that was required of it as a stockholder when entering its subscription. Out of this joint railroad and banking institution has grown the extensive system of railroads from Savannah to and through the interior.

The Central Railroad and Banking Company rehabilitated its devastated lines after the war, met all its obligations, and until the majority of the stock found its way into Wall Street, a bond of the Central Railroad and Banking Company, of Georgia, was considered to be as good as a bond of the United States. 
The banking feature of the corporation has not been exercised for the past four years, but all its obligations were fully met before it ceased to exercise that privilege of its charter, the latter having been extended for thirty years by Legislative enactment Septeinber, 23, 1870.

An interesting feature of the banking history of Savannah, dating from April, 1848, at which time it was the banking center of the State, may be seen by the following : Savannah, with a population of 13,573 , of which 7,250 were white, had twenty-four bank officers. The banks then doing business in the city were :

The Bank of the State of Georgia, capital $\$ 1,500,000$, of which the city held $\$ 750,000$. This bank had branches at Augusta, Eatonton, Athens, Washington and Greenboro, with agencies at Macon and Griffin. The Planters' Bank, with a paid-up capital of $\$ 535,400$. The Marine and Fire Insurance Bank, paid-up capital $\$ 400,000$. It had an agency in Macon. The Central Railroad and Banking Company of Georgia, paid-up capital of $\$ 2,549,165$, of which $\$ 205,000$ was appropriated for banking purposes. This bank had a branch in Macon up to 1841, when the branch was wound up. The Saving Institution for Savings, established in 1844. It was under the fostering care of the Bank of the State of Georgia.

For the ten years ending May, 1848, these banks declared dividends as follows :

The Bank of the State of Georgia, fifteen semi-annual dividends, it intermitted two in 1842, one in 1843 and two in 1844. The average per centum per annum for seven and one-half years was 6.4 ; the whole ten years average perannum 4.8 per cent. For the twenty-one years preceding 1838 the average annual dividends were seven per cent. The losses of this bank from 1838 to 1842 were heavy, hence omissions of dividends in 1842, 1843 and 1844.

The Planters' Bank, without intermission, declared twenty semiannual dividends of four per cent. except in 1842 and 1843 , when they were but three per cent.; in 1847 the semi-annual dividends were $41 / 2$ per cent. each; the annual average for ten years was 7.7 per cent.

The Marine and Fire Insurance Bank declared nineteen semi-annual dividends, intermitting one in December, 1842. These dividends were all four per cent. except the one of June, 1843, which was three per cent. The average for ten years was 7.5 per cent. per annum.

The Central Railroad and Banking Company from June, 1836, to June, 1839, averaged dividends of nine per cent. per annum; from December, 1839 , to December, 1840 , its average was 4.7 per cent. on bank and road stock. It declared no dividends from 1841-47, but from June, 1848 , to December, 1849, a period of eighteen months, its annual average dividend on bank and road stock was $4 \frac{1}{3}$ per cent.

In 1849 the following banks were in active existence in the State:

At Augusta: Augusta and Insurance Banking Co., capital $\$ 375,000$, with branch at Savannah; Georgia Railroad and Banking Company, 
capital $\$ 375,000$; Branch Bank of the State of Georgia, capital $\$ 450$,000 ; Bank of Augusta, capital $\$ 650,000$; Mechanies' Bank, capital $\$ 500$,000 , and the Brunswick Bank, capital $\$ 200,000$.

At Milledgeville: Bank of Milledgeville.

At St. Marys: Bank of St. Marys, and at Savannah the banks just mentioned.

"In 1851 there were twenty-three banks in operation. Not only among them, but among the first four banks also, suspensions of specie payment were frequent, and though the law imposed a penalty for the suspension to the extent of the forfeiture of the charter of the bank suspending, the customary and inevitable result was that the Legislature legalized suspension and relieved the bank of its forfeiture. Public sentiment seems to have overwhelmingly justified the course of the banks." *

\section{Destructive Results of the War.}

Between the years 1849 and 1861, few of the banks fell by the wayside, but the crucial period of the war swept all of them away with two or three exceptions. The failure of the Confederate States to secure a place in the constellation of nations, the loss of slave property, the destruction of homes and property, as a result of Sherman's march through Georgia, the repudiation of the bills emitted by the State and the chartered banks of the State, all combined to make the richer classes poor and the poorer classes poverty stricken, so that when Savannah had capitulated to the land forces of Sherman, which had devasted the interior, supplies had to be issued to white and black; some masters were as empty-handed as their former slaves.

Under such conditions banks, not having anything tangible to lean upon, went down in a general bankruptey. Confederate bonds as collateral were worthless, and had they been worth the paper upon which they were printed, it would have made no difference; the Federal offcers, acting under orders, took possession of the banks, and while they safeguarded all other bank property, Confederate money and Confederate bonds, and all currency or collaterals predicated upon Confederate success, were indiscriminately given to the flames. Some bank officials in Savannah managed to escape with their bank assets and collaterals, such as were movable, before the city was occupied, to be captured in the interior of South Carolina, and in such instances what little specie, legitimate assets and deposits as were found were returned, but no paper with the word "Confederate" on it was ever returned.

It is related by Mr. Augustus Barie, Cashier of the Merchants and Planters' Bank, of Savannah, that when Sherman's approach became dangerously near the eity, what little specie the bank had, all the collaterals and special trust deposits were removed from the city, but it was all captured by the Federals at Columbia, S. C. Some months later the bank's effects were returned to Savannah. Mr. Barie says he examined the packages with fear and trembling, not hoping to find them intact.

* Address of John K. Ottley before Fifth Annual Convention Ga. Bkrs. Assn. 
Among the trust deposits the English Vice Consul had $\$ 10,000$ of bonds, which he had been apprehensive he would never hear from. Mr. Barie says the package had been opened and examined, but not otherwise disturbed, and he had the pleasure of returning the securities to the owner. Mr. Barie added, "when I discovered this I made up ny mind that whatever might be thought and said in general of the Yankees, some of them I knew were honest."

The liability clause against stockholders in banking corporations, making all liable for the entire indebtedness of the corporation, was taken advantage of by a few shrewd bargain-drivers from the East. The bills of the defaulting banks were bought up at prices ranging from three to eight cents on the dollar, and as close bargains as possible were driven, but in most cases adjustments were had by compromise; in some instances this class of stockholders, who had anything to transfer, managed to get their little property out of their hands.

With Georgia's ports blocked, her youth and manhood at the front, with coin driven from the country, the banks, as a rule, conducted by men too old or too infirm to be in the field, the issue of paper bills and fractional currency was universally resorted to. Not only the chartered banks of the State, but the State itself issued curreney for much of which it accepted Confederate bonds. Cashiers were worked day and night signing bills to be sent on to the Confederate capital in exchange for bonds of the Confederacy. A few specimens of these bills are introduced herewith. The banks of Augusta, Macon, Savannah, and the State of Georgia, from Milledgeville, emitted bills, all the banks issuing a fractional currency.

In all cases the bills were printed on plain white paper, and in many instances the quality of the paper and character of the printing were much inferior to the ordinary drug labels of to-day. Here are a few of the samples:

Certificate of Deposit.

2

THE AUGUSTA SAVINGS BANK.

Tims \& Rust has deposited in this Bank TWO DOLLARS, payable in current or Confederate notes.

Augusta, Ga., Dec. 9th, 1861.

W. W. CuY, Treas.

H. H. Hickman, Prest.

50.

50.

Mechanics' Bank will pay the bearer on demand Fifty Cents.

50. Augusta, Ga., Jan. 1st, $1862 . \quad$ T. B. Bishop, for Cashier.

50.

STATE OF GEORGIA.

No. 611.

Macon, Ga.

This certifies that there has been deposited in the Georgia Savings Bank, Sept. 15th, 1865, in Confederate Treasury Notes, One Dollar, payable to the bearer at the option of the bank in Confederate Treasury or current bank notes.

R. W. Cubbedge, Cashr.

J. C. Riant, Prest. 
Will pay 50 cents to bearer on demand.

Redeemable in sums of $\$ 5$ and upwards. Savannah, Ga., January 1st, 1862.

W. B. Tinslex, Cashier.

The Central Railroad \& Banking Co. of Georgia will pay the bearer Two Doli.ARs in Confederate Treasury Notes, when presented in sums of Five Dollars and upwards.

Savannah, December 19, 1861.

JNo. R. WILder, for Cashier.

\section{ONE THE BANK OF THE STATE OF GEORGIA ONE}

Acknowledges to owe One Dollar to the bearer, redeemable in Confederate Treasury Notes, when presented in sums of Five Dollars and upwards.

SavanNah, May 12, 1864.

W. Cumming, Cashier.

And here are presented four specimens of differently worded bills issued by the State, from the then capital of Georgia, Milledgeville, currency issued in 1862, 1863 and 1864 :

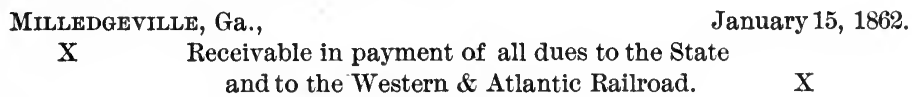

$$
\text { No. } 442 \pi \text {. }
$$

THE STATE OF GEORGIA

Will pay bearer Ten Dollars, redeemable in eight per cent. State Bonds or specie, six months after a treaty of peace, or when the banks of Savannah and Augusta resume specie payment, if before that time.
P. Thweatt, Compr. Geni.
JNo. Jones, Treasr.

No. 7206

Milledgeville, Jan. 1st, 1863.

$\$ 1$.

The State of Georgia will pay the bearer One Dollar at the Treasury, in Confederate Treasury Notes when presented in sums of Five Dollars and upwards.

J. M. Beale, for Comp. Genl.

S. J. HOWARD, for Treas.

Milledgeville, Ga.,

February 1st, 1863.

in payment of all dues to the State, and to the Western \& Atlantic Railroad.

No. 7306.

THE STATE OF GEORGIA

Will pay bearer One Hundred Dollars in specie or six per cent. bonds of this State six months after a treaty of Peace shall have been ratified between the United States and the Confederate States.

T. J. Bloovworth, for Compr. Genl.

JNo. JoNes, Treas.

Milledgeville,

THE STATE OF GEORGIA

April 6th, 1864.

Will pay the bearer Twenty Dollars at her Treasury on the 25th day of December next, in Confederate Treasury Notes, issued after the 1st of April, 1864; if presented within three months after maturity, otherwise not redeemable except in payment of public dues.

Y. D. Tinsley, for Compr. Genl.

R. J. MCCARNY, for Treasurer.

This last series was issued in denominations of $1,2,3,4,5,10$ and 20 dollars. 
All this currency issued by the State was repudiated by act of the Legislature, the justice of which action has always been questioned. The writer was shown, while collecting data for this review, a package containing $\$ 10,000$ of this State currency, for which the owner had paid fifty per cent. premium, and he said that he had never opened the package since he purchased it until the day he exhibited it to the writer. That package was the result of his earnings for nearly a lifetime, and yet when the war closed it was not worth the price of a meal, and worthless as it was, it would have been destroyed had it fallen into the hands of Federal army officers.

The banks in Georgia that weathered the war can be counted on the fingers of one hand without exhausting all the fingers. Among the Augusta banks the Georgia Railroad and Banking Company survived; in Savannah the Central Railroad and Banking Company, of Georgia, lived on; the Marine Bank of Savannah paid its bills, but it may be said, not uncharitably, of it, that it held conservatism paramount to sectional loyalty, for while other local banks freely exchanged their bills of credit with the Confederate States for bonds, in some instances as rapidly as Cashiers, writing day and night, could sign their names, the Marine Bank was more cautious and did not overwork its clerical force to advance Confederate interests.

With peace and the rehabilitation of the State government; with the ports of Savannah and Brunswick opened again to unrestricted commerce, and with the resumption of interior and inter-State railroad communications, Georgia began to rapidiy recuperate from her enervated condition. New life was infused into railroad construction and traffic, and with the revival of work on the cotton plantations, in the turpentine forests, and in the lumber industry, capital was attracted to the State, and banking on a sounder basis took the place of the wilder practices in the days when every bank Cashier could inflate the currency at a nod from the board of directors. . The Federal law imposing a ten per cent. tax on bills, except those issued by National banks, accomplished what the State.could not accomplish, although the tax laid by the latter was double. No bank in Georgia has felt brave enough, even if it desired, to issue bills of credit, and one of the results is that the chartered banks of Georgia rank high for their conservative conduct of banking affairs, failures being very rare among them.

\section{Restoration of Prosperity to the State.}

Since the war, with a development of the field, the forest, the quarry and the mine, Atlanta, scarcely known before the war, and not a factor in the banking history of the State prior to the war, is now the capital of the State, a railroad center, the most populous city of Georgia, and the principal banking metropolis of the State, the paid-up capital of her banking institutions having passed the three million mark, or nearly one-fifth of the paid-up capital employed in the entire State. 
The deposits of the Atlanta banks aggregate nine million dollars, or more than one-fourth of the amount of deposits in all the banks of Georgia.

Savannah, whose banking eapital was almost wiped out by the war, comes next with a banking capital of nearly two and three-quarter millions, and deposits aggregating eight million dollars.

Augusta with nearly one million dollars capital, and four million of deposits; Macon with a capital of over one and a half millions and three millions of deposits; Columbus banks have a paid-up capital of over half a million and over a million and a quarter of deposits, while in the thriving cities and towns of the State outside of the five principal cities mentioned, are prosperous banks with capital ranging from twenty-five thousand to one hundred and fifty thousand dollars, and in the aggregate with over seven million paid-up capital and deposits approximating nine millions more.

Of the 227 banks doing business in Georgia, but twenty-six are National banks, eighteen are Savings institutions, the remaining 183 being incorporated banks or private bankers. The entire paid-up capital of these banks is in the aggregate $\$ 16,000,000$ with deposits aggregating $\$ 34,000,000$.

The safeguards thrown around the chartered banks are such as to reduce failures to the minimum. The laws governing banks in Georgia are so modelled as to invite greater confidence in them. Some of the later and better features of the laws governing banking institutions in Georgia are due to the vigilance displayed, and the active interest taken in the matter, by the Georgia Bankers' Association through its executive council. The founder of the Georgia Bankers' Association is Mr. Mills B. Lane, Vice-President of the Citizens' Bank of Savannah. The Bankers' Association was organized at Macon, September 14, 1892, with ninety-six banks represented. M. B. Lane was chosen President, J. W. Cabaniss, President of the Exchange Bank of Macon, Treasurer, and L. P. Hillyer, Cashier of the American National Bank at Macon, Secretary. Mr. Hillyer has been re-elected at each succeeding meeting of the association, which convenes annually.

The Bankers' Association, at its inception, took strong ground for the repeal of the Sherman silver law, and has since been undeviating in its support of sound money, and in its advocacy of such legislation, Federal and State, as would best contribute to the stability of the banks and the security of creditors. It has all along favored the repeal of the ten per cent. tax on the circulation of State banks when strengthened by such legislation as will make their currency as safe as the National bank currency. This association has increased its membership until at the annual meeting, which was held at Warm Springs, in June, 1899, its active membership comprised 130 banks.

The five principal banking cities of the State are represented by clearing-houses at Atlanta, Savannah, Macon, Augusta and Columbus. 


\section{Summary of the Georgia Banking Laws.}

Some of the principal features governing banking in Georgia may be thus briefly summarized :

In the absence of a contract seven per cent. is the legal interest, but eight per cent. may be named in a contract; the excess of legal rate is forfeited. There is no "market overt" in Georgia.

Three days of grace is in force, and it has not been thought advis. able to press upon past Legislatures a bill looking to the repeal of same.

Banks are limited to a premium of one per cent. on exchange sold.

Charters for banking institutions are obtained by application to the Secretary of State, fee $\$ 50$; amending charter, fee $\$ 25$; renewal of charter, fee $\$ 100$. The life of a charter is thirty years with right of renewal for thirty years.

Not less than $\$ 50,000$ of capital, in shares of $\$ 100$, must be subscribed in good faith; not less than twenty per cent. must be actually paid in before applying for a charter, and in no case less than $\$ 25,000$ must be paid in cash before filing a declaration. Individual liability upon stockholders over and beyond the par value of original stock held equal in amount to the face value of the said stock. Constitutional prohibition against purchasing stock in competing corporations.

Loans to officers and directors in the aggregate must not exceed twenty-five per cent. of the capital stock, and not to exceed ten per cent. of the capital stock can be loaned to any one officer or director, nor may a bank loan any of its funds to any person on the endorsement of any of its officers or its directors.

The issue of bills of credit is authorized under strict provisions, under the supervision of a commission composed of the Governor, the Comptroller-General and the Treasurer of the State, the engraving being under the direction of the commission, and the bills signed by the Comptroller-General. The issue of these bills is limited to one and onethird times the capital stock. To secure the redemption of this currency, one-half of the capital stock in specie or Federal currency is required to be held as reserve, and the other half of the stock must be deposited with the State in the shape of Government, State, county and municipal bonds, not below par, one-half of the deposit to be represented by Government or valid State bonds. Examinations and published statements of chartered banks are provided for.

Bank stocks, and not their capital, are taxable; the stock is taxed in the hands of shareholders (and this includes National banks), Cashiers being required to list and pay the same. The property of banks is taxed direct. A State tax of ten dollars is levied on bank Presidents, but county and municipal authorities are probibited from levying any additional tax or professional license on them.

Stockholders who have transferred their stock six months prior to a bank's failure are relieved from liability. 
An incorporated manufacturing or mining company, owning property to the value of $\$ 25,000$ over and beyond its liens or secured debts, may be given authority to do a Savings bank business, but not a general banking or discount business; depositors are limited to $\$ 1,000$ in their account and a minimum deposit is ten cents. Depositors are allowed to withdraw on notice of not less than three months. Married women and minors are allowed to deposit in the Savings banks of Georgia, and their deposits are not subject to the control of husband, parents, guardian or trustee, but may be withdrawn by such wife and minor. No further deposits are permitted when their sum equals the value of property beyond secured debts on the date the deposit is offered.

State Banks.

\begin{tabular}{|c|c|c|c|c|c|c|}
\hline YEARB. & 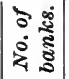 & $\begin{array}{l}\text { Loans and } \\
\text { discounts. }\end{array}$ & Specie. & Capital stock. & Circulation. & Deposits. \\
\hline $1835 .$. & 23 & $\$ 7,714,851$ & $\$ 1,781,835$ & $\$ 6,783,308$ & $\$ 3,694,329$ & $\$ 1,014,674$ \\
\hline $1840 \ldots$ & 39 & $13,783,221$ & $3,300,694$ & $15,098,694$ & $5,518,822$ & $1,985,413$ \\
\hline $1846 \ldots$ & 22 & $5,549,232$ & $1,104,235$ & $8,970,789$ & $2,471,264$ & $1,318,266$ \\
\hline $1851 .$. & 18 & $11,286,342$ & $1,938,512$ & $13,050,198$ & $9,820,874$ & $2,414,794$ \\
\hline $1856 \ldots$. & 24 & $16,758,403$ & $1,955,966$ & $11,508,717$ & $10,092,809$ & $2,525,256$ \\
\hline $1861 .$. & 18 & $12,046,173$ & $1,631,997$ & $10,357,200$ & $6,040,775$ & $2,764,407$ \\
\hline $1869 .$. & 1 & ............. & & 300,000 & ............. & ............... \\
\hline $1876 \ldots .$. & 8 & $1,000,138$ & ............ & 756,700 & ............ & 320,177 \\
\hline $1881 \ldots$ & 21 & $5,889,301$ & ............ & $2,534,775$ & ................ & $4,634,538$ \\
\hline $1887 \ldots$ & 25 & $9,864,984$ & ............ & $10,295,840$ & ............. & $6,392,996$ \\
\hline $1892 \ldots$ & 51 & $12,130,226$ & ............. & $5,961,595$ & ............ & $8,380,370$ \\
\hline $1897 \ldots$ & 41 & $8,785,980$ & & $3,926,900$ & ............. & $6,389,932$ \\
\hline
\end{tabular}

\section{National Banks.}

Figures are in thousands of dollars.

\begin{tabular}{|c|c|c|c|c|c|c|c|c|c|}
\hline YEARS. & 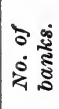 & $\begin{array}{c}\text { Loans } \\
\text { and dis. } \\
\text { counts. }\end{array}$ & $\begin{array}{c}U . S . \\
\text { bonds. }\end{array}$ & $\begin{array}{l}\text { Cash and } \\
\text { cash items. }\end{array}$ & Capital. & Surplus. & $\begin{array}{c}\text { Undi- } \\
\text { vided } \\
\text { profits. }\end{array}$ & $\begin{array}{c}\text { Out. } \\
\text { standing } \\
\text { circula. } \\
\text { tion. }\end{array}$ & $\begin{array}{c}\text { Indi. } \\
\text { vidual } \\
\text { deposits }\end{array}$ \\
\hline $1865 \ldots$ & 1 & $\$ 97$ & $\$ 40$ & $\$ 219$ & $\$ 100$ & ......... & $\$ 15$ & ....... & $\$ 350$ \\
\hline $1870 \ldots . .$. & 8 & 2,504 & 1,646 & 1,057 & 1,815 & $\$ 239$ & 295 & $\$ 1,148$ & 1,682 \\
\hline $1875 \ldots$ & 12 & 3,108 & 2,151 & 1,071 & 2,663 & 459 & 251 & 1,735 & 1,557 \\
\hline $1880 \ldots$ & 13 & 3,692 & 2,323 & 862 & 2,221 & 432 & 180 & 1,940 & 2,012 \\
\hline $1885 \ldots$ & 16 & 5,383 & 1,902 & 1,226 & 2,472 & 813 & 337 & 1,571 & 3,335 \\
\hline $1890 \ldots$ & 30 & 10,724 & 1,068 & 1,199 & 3,906 & 1,164 & 796 & 822 & 6,335 \\
\hline $1895 \ldots$ & 29 & 8,147 & 1,231 & 822 & 3,516 & 1,037 & 776 & 925 & $\mathbf{5 , 6 9 8}$ \\
\hline $1898 \ldots$ & 29 & 9,971 & 1,561 & 1,374 & 3,916 & 1,312 & 760 & 1,036 & 7,283 \\
\hline
\end{tabular}


The Legislature in 1898 passed a law providing for a commission composed of two bankers, one Senator and two Representatives to revise the banking laws of Georgia, and report the best system for regulating the business of banking in the State. In view of this action, further amendatory legislation may be looked for along safe and conservative lines.

\section{FLORIDA.}

Florida was a part of the Louisiana purchase. The act of Congress of March 30, 1822, established the Territorial Government. It was not admitted to the Union as a State until 1845. During its existence as a Territory Florida had a banking experience which, in excitement and interest, is unrivalled by that of few of the States and Territories. Up to 1833 several banks had been chartered by the Territorial Legislature, including the Bank of Florida, the Central Bank (which succeeded the former institution), the Bank of West Florida, Merchants and Planters' Bank, of Magnolia, the Commercial Bank, the Bank of Pensacola and the Union Bank of Florida. All of these seem to have received some aid and assistance from the Territory - the Bank of Pensacola to the amount of $\$ 500,000$ in bonds guaranteed by the Territory, the Southern Life Insurance and Trust Company (chartered in 1835), to the amount of 400 certificates of $\$ 1,000$ each, and the Union Bank bonds amounting to three millions of dollars.

\section{Plan on Which the Banks Were Organized.}

The scheme of all these banks appears to have been similar to that adopted in many of the Southern States at this period. The capital fixed at a certain amount, divided into shares usually of $\$ 100$ each, was to be offered to the people generally for subscriptions. These subscriptions were to be paid, a small portion in cash, which might or might not be called for by the directors, the remainder in mortgages on real estate and negroes-the security being supposed to be worth double the amount of the mortgage - the interest on these mortgages to form a permanent income to the bank. On the strength of this security, the Territory or State was to advance its credit to the bank in the shape of bonds guaranteed by the Territory or State, the bank assuming the payment of the principal and interest of such bonds. The proceeds of the bonds were the available means of the bank, and the theory appears to have been that a large portion of these proceeds was to be loaned to the stockholders on the security of their stock, to enable them to improve their lands and to raise such crops as would allow them to pay the interest on their mortgages, and thus afford the bank means of paying the interest on the debt as it came due, and of creating a sinking fund for the payment of the principal at the maturity of the bonds. 
The history of this kind of banking in Louisiana, Mississippi, Florida and other States seems to show that while the plan was plausible and theoretically safe, most of those who were engaged in carrying it out had their own individual interests in view or were ignorant and reckless in regard to banking principles. The stock was never fairly distributed, the real estate security offered was never fairly appraised. Favorites were awarded large amounts of stock for which mortgages on doubtful property were accepted. The bonds issued by the State were disposed of without regard to legal requirements, and the money received loaned to those who had received the stock without reserving sufficient to form a reserve to protect the credit of the bank from immediate demands. One radical defect was the connection of what was really a system for using the State and Territorial credit to make loans on long time to its citizens to enable them to improve their real estate with a system of banks for issuing circulating notes. The bonds issued were on long credit, and the interest on the loans on real estate, if they had been judiciously made and the amounts received been judiciously used by the Receivers would, perhaps, have provided for the bonds; but the issues of paper money by the same institution could only be loaned on the same security already given for former loans, as almost all the real estate of any value was mortgaged for stock and involved the banks in speculations and consequent losses beyond their power to meet. It was found, too, that these loans so easily obtained were generally regarded as gifts, and the borrowers did not, as a rule, bring their cotton and other products to the banks, but sold them to outside merchants, neglecting thus to pay their interest.

\section{The Union Bank of Florida.}

The history of the Union Bank of Florida, the largest of the institutions in that Territory, which have already been named, illustrates the foregoing points. It was chartered by an act of the Governor and Legislative Council of the Territory of Florida, which became a law on February 12, 1833-about ten years after the organization of the Territory. It was to have a capital of $\$ 1,000,000$, with the privilege of increasing to $\$ 3,000,000$. Commissioners were to be appointed to receive subscriptions and, when 3,000 shares of $\$ 100$ each were subscribed the Governor was to appoint twelve directors, to remain in office until February 1,1834 , after which date seven directors were to be annually elected by the stockholders, and the remaining five were to be appointed by the Governor. The subscribers were not to pay any part of their shares in money, but to secure their subscriptions by bonds and mortgages on real estate and property which was to be worth twice the amount for which it was pledged. The bank was to borrow its whole capital, and to enable it to do so bonds were to be issued to the bank signed by the Governor, for the payment of which, principal and interest, the faith of the Territory was pledged. The bank, however, was 
to pay the interest and principal as it came due, and no provision further than pledging the faith of the Territory was made for their payment in the event of the bank failing to pay; but all the profits of the bank were to be applied to the payment, and after they were all paid then one-half of the surplus profits was to belong to the Territory. Books of subscription for the stock were to be opened at Tallahassee, Pensacola, St. Augustine, Jacksonville, Marianna and Key West, but were only opened at Tallahassee, Pensacola and Marianna. The subscription commenced on April 10, 1833, and the books were closed January 22, 1835. Eleven thousand four hundred and eighty-five shares were subseribed by 118 individuals, and 9,177 shares were allotted to ninety-four subscribers. The board of directors was appointed when 3,000 shares had been subscribed. John G. Gamble, of Tallahassee, became President of the bank, and was chiefly instrumental in its organization. His son, Major Robert Gamble, now residing at Tallahassee, contributes the following interesting account of the plan of organization:

"The board of directors was authorized to issue bonds, to be guaranteed by the Territory, to the amount of three million dollars. The subscribers to the stock were mostly planters, who were permitted to secure their subscriptions by mortgages upon their lands and slaves, and to withdraw in the bank's paper currency a sum equal to two-thirds of the appraised value of the mortgaged property, paying therefor interest as upon a loan at the rate of eight per cent. per annum. The expectation was that two per cent. of this interest bestowed in a sinking fund would, by the time the charter should expire, extinguish the loans. The bonds having been issued and indorsed, in 1836 President Gamble went to Europe to place them, readily disposing of one million. During his absence the board of directors, assuming that he would have no difficulty in disposing of the remainder of the bonds, issued the paper of the bank so far beyond its realized capital as to alarm the purchasers of the bonds, prevent further sales thereof and impair the credit of the institution at home. The depreciation of the bank's paper enabled the stockholders to cancel their obligations to the bank and release their mortgaged property without great loss, and the loss fell chiefly upon the bondholders."

In April, 1834, the bank received 360 bonds of $\$ 1,000$ each from Governor William P. Duvall, and in the following September contracted with parties in New York to dispose of 1,000 bonds of the Territory of Florida. The remaining 640 bonds necessary to make up the amount were obtained from Governor Eaton on February 10, 1835 . These bonds became due the first quarter, in January 1,1858 , and the remaining quarters on January 1, 1860, 1862 and 1864, respectively. A capital of $\$ 1,000,000$ being thus obtained the bank commenced business on January 16, 1835. By January 2, 1836, the return made to the Legislature showed liabilities amounting to $\$ 1,728,605$, of which $\$ 335,150$ was for circulating notes issued. Their loans showed $\$ 589,832$ loaned on stock. The committee of the Legislature, reporting on the bank in 1840, says:

"The charter intended that two-thirds of the money borrowed by the sale of bonds should be loaned on long mortgages to the subscribers who had taken up the 
shares and given their property as security or pledge for the payment of the bonds when due, and that the remaining third should remain in bank to perform a legitimate banking business. The sum borrowed $(\$ 1,000,000)$ properly distributed and prudently managed was at the time quite sufficient to have relieved the planting interest from pressing embarrassment and to have performed all the purposes reasonably required by merchants. Regardless of these considerations and all principles of prudence and sound policy, the Union Bank, with an apparently singular impatience, not only distributed its borrowed capital among stockholders and others upon terms which preciuded its being repaid within any reasonable time, but it also extended these imprudent loans upon the capital based upon circulation and deposits."

\section{CoNDITION OF THE BANK IN 1837.}

The bank had in $1837 \$ 110,000$ cash means to meet $\$ 675,704$ of immediate liabilities. The act of incorporation provided that at any time after the bank had been in operation one year the capital might be increased to $\$ 3,000,000$ and additional bonds to an equal amount obtained from the Territory. Books were opened in October, 1837, for the new subscriptions. There was no difficulty in obtaining them. At the time of the first subscription there was some doubt about the bank's obtaining capital, and the people were indifferent. The idea of a bank founded on borrowed capital had before been ill understood; now it was perfectly comprehensible. The charter of the bank was an Eldorado; it authorized a further issue of $\$ 2,000,000$ in bonds. The first 1,000 bonds had been readily, spontaneously, unexpectedly converted into money, could there be any doubts as to the sale of the rest? Between October and February 404 persons had subscribed their names for shares in various amounts aggregating, instead of two, eight millions of dollars. Out of 19,812 new shares allotted at this time, eighty-eight old shareholders, then holding 8,897 of the 10,000 old shares, received 17,156 . On January 1, 1838, Governor R. K. Call executed 2,000 bonds of $\$ 1,000$ each, which were delivered to the bank in March. When, afterwards, an inquiry was made as to the manner in which the seal of the Territory was attached to these bonds, John P. Duvall, Secretary of the Territory, who was supposed to have custody of the seal, inade affidavit that he did not affix such seal, but that on entering his office one morning he observed a number of circular pieces of paper on the floor and, on inquiry, found that his office had been occupied by the Governor and others until one or two o'clock at night executing the bonds, and that to prevent the seal being in his custody the Governor gave orders to his private secretary to lock up the seal. The bonds were known as faith bonds and * were to be sold at not less than par. There was much dispute as to what was meant by par-one party contending that it meant specie in New York and the other (the bank) that it meant par in Tallahassee. The President of the bank was made agent for the sale of the bonds and visited various points in Europe where he disposed of 1,280 of the bonds and realized $\$ 1,374,901$ in Florida bank paper. Six-

* Affidavit of John P. Duvall, February 1, 1842. 
teen more bonds were sold, and the remaining 704 were left on sale but were never directly sold, being at length hypothecated for debts of the bank. The money thus secured was loaned on stock and to stockholders, it being claimed that great favoritism was shown. On January 1,1840 , the loans on stock aggregated $\$ 1,830,642$.

\section{INTERVENTION OF THE Federal Government.}

In 1839 and 1840 the banking operations of the institutions chartered by the Territory attracted the attention of the Government of the United States, and the President referred to the question of the legal right of a Territory to charter a banking corporation in his message to Congress. On December 30, 1839, the United States Senate passed a resolution requesting the President to obtain from the authorities of the Territory information about the issue of Territorial bonds and incorporations. In his message of January, 1840, Governor Reid called the attention of the Legislature to the matter and the Legislature appointed a committee to examine and obtain the necessary information. The report of the committee was very unfavorable to the bank, but as the latter had still some resources remaining, and as there was reason to suspect some members of the committee of personal animus, the managers of the bank were able to make what was at least a plausible reply. One asseveration made by them, while it in no way excuses the gross mismanagement all through of the affairs of the concern, does at least show that in the creation and inception of the institution, its present enemies had been in its favor and had even approved some of the methods they later affected to deplore. The bank officers in their reply asserted that the chairmen of both committees of the Legislature, when the bank was in funds, shared and appropriated to themselves the proceeds of sixty thousand dollars of the bonds. The committees reporting unfavorably to the bank in the year 1840, were those of the House. The Senate as a body took a different ground.

Before the bonds issned to the bank could be sold, it was found necessary to obtain the opinions of legal authorities as to the right of a Territorial Government to incorporate a bank and to issue bonds. The Territorial Government was inaugurated by an act of Congress dated March 30, 1822, which was amended by the act of March 3, 1823. By the act of March, 1823, bills passed to tax the inhabitants of the Territory did not become laws until they had been reported to Congress by the Governor and received the sanction of Congress, but this was repealed in 1828. By an act of Congress passed in 1826, the members of the Council were to be elected by the people instead of being appointed by the President of the United States.

Opinions were obtained from Chancellor Kent, Horace Binney, Daniel Webster and Peter Jay. It was agreed by these eminent lawyers that the Territorial Government had the right to incorporate a bank and to issue bonds subject to the disapproval of Congress. But 
if Congress did not disapprove they were valid, and all acts done under them were valid. If Congress disapproved, all acts done previous to such disapproval which involved innocent parties, were valid. The bonds issued to the banks were, therefore, decided by these authorities to be valid.

The liability of the State of Florida for the payment of the bonds issued by these banking institutions and upheld by the credit of the Territory, was a question which returned to vex the people of the State for many years, and in 1850 Governor Brown refers, in a message to the Legislature, to a large number of these bonds which had come into his hands, and called attention to the release of the mortgaged property of stockholders of the two institutions named, upon their depositing such bonds with the officers of the same, and recommends a legislative inquiry into the matter.

\section{Early Banking Legislation.}

From 1839 to 1845 (the year in which the Territory became a State), several general laws were enacted puporting to regulate, in part, the banking business, then chiefly in the hands of the local agents of bankers or banking concerns located in other States. These agencies were either so profitable, or were so difficult to control, that a desire for local banks again arose, and in 1851 the State Bank of Florida was granted extraordinary privileges in an elaborate charter; but notwithstanding its pretensions it appears never to have been practically established, for in December, 1855, the Bank of the State of Florida was granted an equally elaborate and comprehensive charter, in the preamble of which appears the recital that "Whereas, The State of Florida is without the benefit of any banking institutions," etc. In the interim, however, the Legislature had enacted (in 1853) a general banking law, whereby the State Comptroller was empowered to provide "such quantity of circulating notes, in the similitude of bank notes, in blank * * * as he may from time to time deem necessary," to be delivered to and issued by private bankers or banking associations upon the deposit with the Comptroller of certain described securities. During the years intervening until the Civil War era, large numbers of banks were chartered and some became firmly established, but no official supervision, or collection of statistics or other information concerning them appears to have been required or made.

In his message to the Legislature on November 22, 1858, Governor Madison S. Perry stated that the law had at first made the deposited stocks the only security for noteholders, but that by subsequent amendment the stockholders were made liable pro rata according to the amount of their shares. He thought that when a panic was impending the stockholders would dispose of their shares to men of straw, and recommended that this liability should not only apply to those who held stock at the time of the failure of a bank, but to those who had 
been stockholders for the twelve months next preceding such failure or suspension.

Whether Governor Perry's proposed amendment was euacted, or his apparent lack of confidence in the integrity of his fellow-citizens (and particularly those of them who were engaged in the banking business) was justified by actual conditions then or previously existing, would constitute inquiries of doubtful present utility. Before such suggested changes in the law could be fairly tested, the nutterings of the impending eivil conflict drove all thoughts of enterprise and progress out of the public mind, and the annihilation of values which ensued during and subsequent to the war period left little use for banks or bankers, or material with which to conduct banking operations.

The period immediately following the Civil War was one of considerable political and commercial disturbance, and for some years the banking business of the State was conducted by private bankers and small associations of capital, in the chief business eenters, without State supervision or authorization, and without a uniform system of laws or practice.

\section{The Present Banking Law.}

A general banking law was enacted by the Legislature of 1889, and under its provisions periodical reports to the Comptroller are required, from the data contained in which that official annually prepares and publishes a table of statistics for the year, embracing all of the State banks, both Savings and commercial. The first State bank organized under this law was incorporated August 20,1889. A report of the condition of the existing State banks is appended.

\section{Statistics of Florida State Banks Established under General and Special} Acts of the Legislature.

\begin{tabular}{|c|c|c|c|c|c|}
\hline Number. & Years. & $\underset{\text { paid in. }}{\text { Capital }}$ & $\begin{array}{c}\text { Surplus and } \\
\text { undivided } \\
\text { profts. }\end{array}$ & Deposits. & $\begin{array}{c}\text { Loans, } \\
\text { discounts } \\
\text { and } \\
\text { overdrafts. }\end{array}$ \\
\hline $15^{*} \ldots \ldots$ & 1890 & $\$ 490,000$ & $\$ 19,896$ & $\$ 1,387,742$ & $\$ 1,193,333$ \\
\hline $15 \nmid \ldots \ldots \ldots . .$. & 1891 & 445,000 & 39,111 & $2,545,583$ & $2,584,018$ \\
\hline $11 \neq \ldots \ldots \ldots \ldots$ & 1892 & 335,000 & 56,240 & $1,001,871$ & 728,517 \\
\hline $18 \ldots \ldots \ldots$ & 1893 & 434,110 & 80,935 & 909,482 & 843,889 \\
\hline $19 \ldots \ldots \ldots$ & 1894 & 477,500 & 99,380 & 930,842 & 935,755 \\
\hline $21 \ldots \ldots \ldots$. & 1895 & 570,800 & 96,342 & 955,841 & 942,829 \\
\hline $19 \ldots \ldots$ & 1896 & 550,000 & 153,558 & $1,079,129$ & $1,075,846$ \\
\hline $238 \ldots \ldots \ldots \ldots$ & 1897 & 775,000 & 186,990 & $1,796,179 \|$ & $1,585,786$ \\
\hline $20 \ldots \ldots \ldots \ldots$ & 1898 & 690,000 & 161,830 & $1,988,797 \pi$ & $1,665,053$ \\
\hline
\end{tabular}

* One bank chartered did not go into operation.

$\uparrow$ Two banks in hands of Receivers; one changed to National bank.

¥ One bank consolidated with a National bank.

Four banks established under special charters.

|| Including $\$ 90,886$ Savings deposits. IIncluding $\$ 109,570$ Savings deposits. 
There were two Savings banks in 1890 , reporting $\$ 40,000$ capital and $\$ 98,254$ deposits. In 1893 there was but one bank, with a capital of $\$ 20,000, \$ 1,212$ surplus and profits and $\$ 107,658$ deposits. By 1898 the surplus and profits had increased to $\$ 12,241$ and the deposits to $\$ 175,428$.

State Banks.

\begin{tabular}{|c|c|c|c|c|c|c|}
\hline YEARS. & 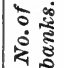 & $\begin{array}{l}\text { Loans and } \\
\text { discounts. }\end{array}$ & specie. & $\begin{array}{l}\text { Capital } \\
\text { stock. }\end{array}$ & Circulation. & Deposits. \\
\hline $.1835 \ldots$ & 2 & $\$ 233,209$ & $\$ 14,312$ & $\$ 114,320$ & $\$ 133,531$ & $\$ 67,215$ \\
\hline $1839 .$. & 7 & $4,686,543$ & 188,288 & $2,322,552$ & 867,009 & 820,324 \\
\hline $1861 \ldots$. & 2 & 424,262 . & 55,071 & 425,000 & 116,250 & 108,606 \\
\hline $1885 \ldots$ & 1 & 70,765 & ......... & 50,000 & ............ & 48,568 \\
\hline $1892 \ldots$. & 9 & 441,930 & ........ & 238,550 & ......... & 599,513 \\
\hline $1897 \ldots . .$. & 24 & $1,591,270$ & ........... & 800,150 & .......... & $1,697,218$ \\
\hline
\end{tabular}

National Banks.

Figures are in thousands of dollais.

\begin{tabular}{|c|c|c|c|c|c|c|c|c|c|}
\hline YEARS. & 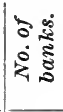 & $\begin{array}{c}\text { Loans } \\
\text { and dis- } \\
\text { counts. }\end{array}$ & $\begin{array}{c}U . S . \\
\text { bonds. }\end{array}$ & $\begin{array}{c}\text { Cash } \\
\text { and cash } \\
\text { items. }\end{array}$ & Capiłal. & Surplus. & $\begin{array}{l}\text { Undi. } \\
\text { vided } \\
\text { profits. }\end{array}$ & 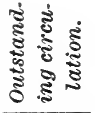 & $\begin{array}{l}\text { Indi- } \\
\text { vidual } \\
\text { deposits. }\end{array}$ \\
\hline $1874 \ldots$ & 1 & $\$ 5$ & $\$ 30$ & $\$ 30$ & $\$ 38$ & $\ldots$. & $\cdots$. & $\$ 27$ & $\$ 11$ \\
\hline $1879 \ldots .$. & 1 & 73 & 90 & 26 & 50 & 2 & 6 & 45 & 100 \\
\hline $1884 . . .$. & 3 & 432 & 93 & 109 & 150 & 16 & 11 & 82 & 496 \\
\hline $1889 \ldots$ & 13 & 2,459 & 492 & 277 & 950 & 131 & 106 & 239 & 2,352 \\
\hline $1893 \ldots \ldots . .$. & 17 & 3,501 & 442 & 565 & 1,300 & 288 & 267 & 325 & 3,217 \\
\hline $1898 \ldots . . .$. & 15 & 3,045 & 739 & 799 & 1,150 & 513 & 134 & 331 & 5,102 \\
\hline
\end{tabular}

\section{ALABAMA.}

Alabama was originally part of the Mississippi Territory carved out of the Louisiana purchase, and was admitted into the Union as a State December 14, 1819. But as early as 1816 a territorial charter had been granted for the Planters and Mechanics' (afterwards Merchants') Bank at Huntsville, and in 1818 a bank was also chartered at St. Stephens, and the Bank of Mobile in the same year. In 1823 the notes of the Huntsville banks were in bad credit and the Huntsville Bank and the Planters and Merchants' Bank closed. The constitution expressly provided that the State might embark in the banking business for the benefit of the citizens. At this period the opinion prevailed that a bank was a great engine for developing the resources of a new country. The example of Mississippi, admitted to the Union in 1817, was before the eyes of the first Legislature, and it was implicitly believed that it only 
required the enactment of suitable laws to make money abundant and easy to obtain. The success of the second Bank of the United States and of many chartered corporations in the several States in paying large dividends to their private stockholders inspired confidence that if the business were controlled by the State the benefits would be equally divided among all the citizens instead of being absorbed by a favored few. It was the instinctive democratic opposition to monopolies of every kind that in the simplicity of inexperience hit upon this method.

The constitution provided that one State bank might be established with as many branches as the Legislature deemed necessary. The State was to hold two-fifths of the stock, the remainder being subscribed for by the citizens. The stockholders and the State were to manage the bank and be liable for its debts in proportion to the stock held. Half the capital stock subscribed was to be paid in in gold and silver coin before the bank could commence business, and the money so paid was not to be less than $\$ 100,000$. The Legislature was also authorized to make provision for all banks already in existence to become branches of the projected State bank.

* At the very first session of the General Assembly a law was enacted and approved on December 21, 1820, "To incorporate the subscribers to the Bank of the State of Alabama." At this time Cahawba was the capital of the State, and as long as it continued to be the capital it was to be the seat of the central bank. The limit of capital was fixed at two millions of dollars, two-fifths of which $(\$ 800,000)$ were reserved for the State, and three-fifths to be raised by the subscriptions of citizens. To carry into effect the necessary preliminaries, superintendents were named in the law, charged with opening subscriptions of the following amounts in the places named. The total amount offered was $\$ 500,000$, of which $\$ 105,000$ was offered at Caha wba, $\$ 105,000$ at Huntsville, $\$ 70$,000 at Claiborne, $\$ 50,000$ at Tuscaloosa, $\$ 50,000$ at St. Stephens, $\$ 30,000$ at Courtland, $\$ 25,000$ at Montgomery, $\$ 25,000$ at Mobile, $\$ 20,000$ at Blakeley and $\$ 20,000$ at Demopolis.

At this date the population of Alabama, was 127,901, of which number about 85,000 were whites and the remainder mostly slaves. The principal industry of the State was agriculture, and cotton was the chief staple. The crop raised in the United States in 1801 was a little over 100,000 bales of 300 pounds each. By 1821 the crop was 370,000 bales and by $1831,1,039,000$ bales. The price in the same period, while gradually diminishing with the increase of supply, had never been less than eleven cents per pound. The hope of great returns from the development of the cotton industry and other collateral pursuits was as sanguine as that excited in California by the discoveries of gold, and the necessity of a circulating medium and of credit to turn the land and

* Many of the facts contained in this sketch are from a paper on the "History of the State Bank of Alabama," read before the Alabama Bankers' Association in 1891. 
its products into lasting wealth pressed heavily upon a most energetic white population. That the bank was a failure is a matter of no great surprise, as in all probability there was not $\$ 500,000$ in gold and silver coin in the State of Alabama that could be subscribed to the stock as the terms of the law creating the bank required.

The institution was known, after the style of the Bank of the United States, as "The President, Directors and Company of the Bank of the State of Alabama." It was to be governed by thirteen directors, an unlucky number as it turned out, annually elected by the stockholders. The voting was scaled according to the shares held, also copying the plan of the Bank of the United States-one share only being held entitled to one vote, ten shares to five votes, one hundred shares to twenty votes, while the holders of five hundred shares or more could not cast over thirty votes. The Superintendents could not obtain the necessary subscriptions, and the bank, evidently started on sound financial principles, except perhaps for the participation of the State as a stockholder, never commenced business. It was an almost exact copy of the second Bank of the United States, in which the Federal Government held one-fourth of the stock, and which proved both successful and profitable to its stockholders. That the lack of capital and specie was the cause of the failure is shown by the subsequent banking experience of the State.

\section{Second Attempt to Establish a State Bank.}

Determined to have the banking facilities for the development of the natural resources in which they justly had so strong a faith, the people through their representatives enacted another law on December 20, 1823, to establish "The Bank of the State of Alabama."

The object of the bank, as stated in the preamble to the act, was to provide for the safe and profitable investment of the funds of the State, and to secure an extended and undepreciating currency. The first bank had depended for its success upon the subscription of actual money to its stock. The result had shown that while rich in the possibilities of development, Alabama did not yet have sufficient of the precious metals, the basis of successful business, as yet within her borders. To remedy this and to obtain a circulating medium, with that touching faith in the unlimited power of execution of a people's government, characteristic of our forefathers in the new States, and which has not yet departed from the minds of many of the people, this new bank act required that the capital, no limit being imposed. should be furnished by the general credit, that is, by the State itself. The other portions of the act were similar to those of the first bank law.

The capital was to be provided by the State in the following manner: First, from the proceeds of the sales and rents of the University lands, not to exceed one hundred thousand dollars. These lands had been set apart to found a university, and of course, no better invest- 
ment for the funds of the University could be found than the stock of the State bank. Next, the proceeds of the three per cent. fund, which was a fund acquired by the sale of 1,620 acres of land granted by Congress for the seat of government of the State. Next, the proceeds of the lease of certain sait springs and all other public funds that might come into the possession of the State. These sources of capital were not objectionable, but in addition thereto another expedient was placed in the hands of the Governor and five commissioners (afterwards reduced to three). This was to issue stock of the State, not to exceed $\$ 100,000$ in amount, redeemable in ten years at not more than six per cent. interest. It appears probable that the original intention of this issue of stock was to secure in advance the proceeds of the University lands authorized to be made part of the capital of the bank, but it was the entering wedge for a reckless use of the credit of the State that caused much subsequent disaster. There was a necessity for banking facilities, and if the power and credit and resources of the State had been wisely used, within proper limits, the benefits would have been unalloyed. So great was the necessity, no doubt, that the State could have afforded to pay six per cent. interest for a reasonable time to secure a circulating medium for its citizens. Alabama State banking was, however, an unfortunate example of the great danger that attends such efforts made with the best intentions on the part of a State government in a new and poor community, entirely dependent upon the future for its prosperity.

The first $\$ 100,000$ in bonds having been sold and the proceeds applied to the capital of the bank, on January 12 , 1828, another $\$ 100$,000 of bonds, with interest at six per cent. and redeemable in twenty years, were authorized to be sold by the Governor, Comptroller, Treasurer and the President of the bank. On January 15, sixteen sections of land donated by Congress for schools were authorized to be sold, and about $\$ 1,300,000$ was received and paid to the bank. In 1833 another law was passed by which the remainder of the funds derived from the University lands amounting to $\$ 500,000$ were invested in the capital of the bank. The bond-selling plan having been adopted was continued until $\$ 14,000,000$ in all were issued as shown by the following table:

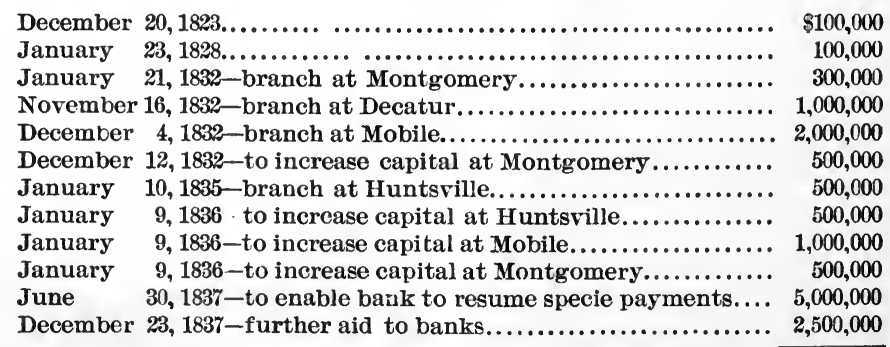

Total.................................................. $\$ 14,000,000$ 
The conditions of these bonds varied, some were payable at the pleasure of the State, some in twenty and others in thirty years. The interest was in most cases six per cent., though some of the bonds bore five per cent. The corporate name of the bank was, "President and Directors of the Bank of the State of Alabama." It had power to deal in real and personal property, to do a general banking business, and to issue circulating notes, the only limit to the latter being the discretion of the President and the directors. The President and directors, thirteen in all, again the unlucky number, were elected annually by the joint vote of the General Assembly. Five directors and the President constituted a quorum for business. They could appoint and remove the Cashier and other officers, and neither they nor the bank officers could endorse for each other or for outside parties. The notes were issued in all denominations, above and below one dollar-shinplasters of 61 cents, 121 cents, twenty-five cents, fifty cents and seventy-five cents being common, redeemable in sums of five dollars. The loans made by the bank were apportioned among the several counties of the State. Bonds were given by the officers for the faithful performance of their duties. These oaths increased in severity as time went on and the temptations to mismanagement apparently increased. They contained obligations to faithfully discharge their trust, to observe the usury acts, to refrain from betting at any "gaming table such as cards, dice, billiards, or any table known as A B C or E O, or any faro bank, or any other table of like description;" that they were not ineligible on account of being indebted to the bark in excess of the limit preseribed by law, and after 1839 they swore that they would not become indebted to the bank in any way. The limit of indebtedness of the President and each of the directors was not at first illiberal, being $\$ 10,000$ at the central bank and the same at each of its branches, except Mobile, where the limit to each was $\$ 20,000$ - sixty thousand dollarsin all. The total limit was subsequently reduced to $\$ 35,000$.

The bank when it first commenced business was located at Cahawba and subsequently in 1826, it accompanied the Government of the State when the capital was changed to Tuscaloosa.

\section{Condition and Management of the Bank.}

Including the proceeds of land sales, the funds received from the University of Alabama, and the moneys from the sales of State stocks, the total amount received by the bank was $\$ 15,859,420$, enough one would think to have started and maintained a most respectable and solvent institution. Of this sum, however, $\$ 7,500,000$ was the proceeds of stocks issued simply to keep the bank above water during the financial crisis of 1837. The bank does not appear to have paid even the interest on the stock issued for its benefit. The statement of its condition in 1826, shows it to have had at that time a capital of $\$ 253,000$; notes in circulation $\$ 273,000$; deposits $\$ 164,000$, with a discount line of $\$ 449,000$, and 
cash $\$ 250,000$, including $\$ 141,000$ in specie. It was thus apparently a sound and solvent institution three years after its inception. In 1837, however, the bank does not make so good a showing. On June 1, of that year, its capital was $\$ 7,889,886$, notes in circulation $\$ 4,600,000$ and deposits $\$ 6,700,000$. To meet these liabilities it had $\$ 492,000$ in specie; notes discounted $\$ 17,694,000$, with amount due from branches, $\$ 1,200$,000 . Of the bills discounted $\$ 6,300,000$ were afterwards found to be bad debts. This was a bad showing for eleven years' business.

The policy which led to this deplorable state of things necessitating the issue of $\$ 7,500,000$ more State bonds in December, 1837, was one of the most remarkable political favoritisms. The President and directors had complete and unchecked control over the management of the bank. The capital was not their own, and they were responsible only to the members of the General Assembly who annually elected them. These latter again were tempted to use the power and means of the bank to secure their election and re-election. The provision of law requiring the distribution of loans among the counties of the State made the elected legislators the channels through whom loans could be obtained by their constituents. The President and directors in the main bank and in each of its branches varied from fourteen to six, and received salaries besides the privileges lawful and unlawful of their positions, and the total number to be elected each year was between sixty and seventy. These offices became the object of much electioneering by all kinds of greedy adventurers, who promised the members of the General Assembly to give them liberal bank discounts in return for their election as directors. The legislators were tempted to give their votes to the highest bidder, in order to be able to pass along the bank favors to their influential constituents. Re-election to the General Assembly was thus secured year after year. The candidates for the directory were most liberal in their treatment of the legislators. On one occasion, while one of these annual elections was pending, a member of the House of Representatives died; each member of the House, as was usual, wore crape on his arm for thirty days. This badge indicated the legislators to the candidates for bank honors, and the former were treated with the greatest hospitality. A backwoodsman, in Tuscaloosa, seeing this, put crape on his arm, and was feasted royally for several days on the strength of it before his ingenuity was suspected.

The most fortunate candidates were those of a generous, convivial nature, who did not fear to make liberal promises. A hotel keeper in Tuscaloosa, believing that if he were a director it would greatly enhance the popularity of his hotel, succeeded in securing an election. His foresight was justified and his hotel crowded. The other hotel keepers of the capital were obliged to follow his example, and soon all five were members of the board of directors of the Bank of the State of Alabama, and often "controlled with absolute and imperious sway the destiny of the bank." They were called the "Culinary Sanhedrim," and met 
around an oval table, still preserved as historic in one of the banks now doing business in Tuscaloosa.

John L. Tindall, the President of the bank, was a man anxious to manage its affairs properly. He was noted for his quiet humor and ready wit. On one occasion, presiding at a meeting of the directors, when the hotel keepers were in the majority, and a large number of bills had passed for discount, approved by one or the other of the five, a small note was offered and no one seemed to know the maker. It was about being rejected when President Tindall, looking enquiringly at each of the hotel keepers in succession, without visible response, remarked very quietly, "This man must have camped out last night."

No director could expect the vote for his re-election of a member of the General Assembly whose note he refused to discount. They had also to discount the notes of those recommended by the legislators. One of the latter in 1832 obtained discounts to the amount of $\$ 24,000$ on fictitious notes. He fled on discovery of the fraud to Texas, and prospering there repaid the money to the bank in the year 1839 .

The operations of the bank until 1837 do not appear to have excited any apprehension in the minds of the public. Times were so good from 1826 to 1836 that the direct taxes of the State were abolished. No one had any difficulty in getting all the money he needed. The cotton crops were good and brought good prices. The price of land naturally increased and every one felt rich. There was, however, an undercurrent to all this. Thinking men were becoming apprehensive of the results when loans were made so recklessly to directors and members of the Legislature. Laws were frequently passed restricting and forbidding these advances, but they were annulled as often by other laws. In 1839, after this class of indebtedness was largely reduced the amount due from directors alone was nearly $\$ 780,000$. In 1837 an imminent catastrophe was averted by the issue of $\$ 7,500,000$ bonds of the State. By 1841 the rumors of bank frauds had become so alarming that when the Legislature met a resolution was introduced in the House by R. Jennison, Jr., of Tuscaloosa, ordering an investigation of the affairs of the bank by a select committee. A similar committee was ordered by the Senate and the two were made a joint committee. A special act gave this joint committee full powers. Under this act the House part of the commitmittee reported that "they have discovered the existence of a disgraceful league to plunder the banks and swindle the people of the State. Men high in office, members of the Legislature, and bank directors are supposed to be implicated. *** With all these facts before them the Senate has seen fit to dissolve their portion of the committee. This renders it impossible for us to act efficiently and we therefore tender our resignation." The journal of the joint committee containing the testimony, with all the other papers, was handed to the Governor and by him placed in the hands of the Secretary of State for secrecy. It is supposed to have been consumed in the fire which destroyed the Capitol at 
Montgomery in 1849. This was a confession that men were involved of too great power in the State to be safely punished by ordinary methods.

The charter of the State Bank expired January 1, 1845, and the institution then went into liquidation. It had four branches, three established in 1832 and one in 1835. These branches were closed by action of the Legislature in 1842-43. On the one hand the operations of the bank left the State burdened by an indebtedness of $\$ 14,000,000$, on which interest to the amount of $\$ 16,840,000$ was paid before the liquidation of the bonds. In addition there was absorbed property of the schools and university amounting to $\$ 1,600,000$ on which the State annually pays interest. On the other hand the expenses of the State government were paid by the bank for ten years, and during that period the people of the State were almost altogether relieved from direct taxation. At the session of the Legislature of 1847-48 the direct taxes were restored in time to save the State from the disgrace of the threatened repudiation of its bonds. The affairs of the State Bank were finally wound up in 1868.

While the experience of the people of Alabama with their bank is not so encouraging as to be held up as an example, yet in fairness it may be said that the development of the resources, and the consequent wealth of Alabama, is in some measure indebted to the bank. Badly managed as it was, the entire loss, including interest on the bonded debt created, did not exceed $\$ 35,000,000$. Estimating the relief from direct taxation for ten years at $\$ 4,000,000$ per annum, and the payment of the expenses of the Government, it cannot be said that the people of Alabama did not receive some compensation for the expenditure. They passed the most critical period of their development without the retarding pressure of taxation.

State Banks.

\begin{tabular}{|c|c|c|c|c|c|c|}
\hline YEARS. & $\begin{array}{l}\text { No. of } \\
\text { banks. }\end{array}$ & $\begin{array}{l}\text { Loans and } \\
\text { discounts. }\end{array}$ & specie. & Capital stock. & Circulation. & Deposits. \\
\hline $1834 \ldots$ & 5 & $\$ 6,381,595$ & $\$ 477,992$ & $\$ 4,308,207$ & $\$ 2,054,471$ & $\$ 1,108,468$ \\
\hline $1839 \ldots$. & 7 & $25,842,884$ & $1,687,046$ & $11,996,332$ & $6,779,678$ & $4,919,598$ \\
\hline $1844 \ldots . .$. & 1 & $1,478,016$ & 613,729 & $1,500,000$ & 124,031 & 558,213 \\
\hline $1849 \ldots .$. & 1 & $3,564,189$ & 618,131 & $1,500,000$ & $1,679,196$ & $1,160,064$ \\
\hline $1854 \ldots$ & 3 & $5,865,142$ & $1,125,954$ & $2,100,000$ & $3,171,487$ & $1,671,448$ \\
\hline $1859 \ldots .$. & 6 & $9,058,379$ & $3,371,956$ & $3,663,490$ & $6,651,117$ & $3,830,607$ \\
\hline $1861 \ldots$. & 8 & $10,934,060$ & $2,715,119$ & $4,976,000$ & $5,055,222$ & $3,435,685$ \\
\hline $1869 \ldots .$. & 2 & ................ & ............ & $1,000,000$ & ........... & ............ \\
\hline $1887 \ldots .$. & 7 & $1,723,835$ & ............. & 735,000 & …......... & 934,266 \\
\hline $1892 \ldots .$. & 13 & $1,109,166$ & ............ & 748,050 & ............. & 705,691 \\
\hline $1897 \ldots \ldots$. & 11 & $1,575,081$ & ............ & 751,900 & …....... & 951,609 \\
\hline
\end{tabular}


National Banks.

Figures are in thousands of dollars.

\begin{tabular}{|c|c|c|c|c|c|c|c|c|c|}
\hline YEARS. & $\begin{array}{l}\text { No. of } \\
\text { banks. }\end{array}$ & $\begin{array}{l}\text { Loans } \\
\text { and dis. } \\
\text { counts. }\end{array}$ & $\begin{array}{c}U . S . \\
\text { bonds. }\end{array}$ & $\begin{array}{c}\text { Cash } \\
\text { and cash } \\
\text { items. }\end{array}$ & Capital. & Surplus. & $\begin{array}{l}\text { Undi. } \\
\text { vided } \\
\text { profits. }\end{array}$ & $\begin{array}{l}\text { Out- } \\
\text { standing } \\
\text { circula- } \\
\text { tion. }\end{array}$ & $\begin{array}{c}\text { Indi- } \\
\text { vidual } \\
\text { deposits. }\end{array}$ \\
\hline $1865 .$. & $* 2$ & ....... & ....... & ...... & ....... & ...... & $\ldots$. & ...... & ....... \\
\hline $1870 \ldots . .$. & 2 & $\$ 526$ & $\$ 311$ & $\$ 108$. & $\$ 400$ & $\$ 15$ & $\$ 74$ & $\$ 265$ & $\$ 312$ \\
\hline $1875 \ldots . .$. & 9 & 1,455 & 1,612 & 463 & 1,635 & 182 & 80 & 1,401 & 957 \\
\hline $1880 \ldots . .$. & 9 & 2,236 & 1,556 & 421 & 1,518 & 221 & 144 & 1,320 & 1,319 \\
\hline $1885 \ldots$. & 10 & 3,266 & 1,217 & 589 & 1,835 & 291 & 213 & 990 & 2,143 \\
\hline $1890 \ldots$ & 30 & 9,743 & 1,549 & 932 & 4,294 & 1,010 & 645 & 1,070 & 7,025 \\
\hline $1895 \ldots . .$. & 26 & 6,549 & 1,291 & 677 & 3,485 & 582 & 524 & 1,009 & 5,636 \\
\hline $1898 \ldots, .$. & 26 & 6,682 & 1,101 & 1,030 & 3,205 & 659 & 528 & 809 & 6,953 \\
\hline
\end{tabular}

* No report.

In 1836 the Planters and Merchants' Bank, of Mobile, was chartered for twenty years (but failed in 1842), with $\$ 500,000$ capital. It was permitted to issue notes to twice the amount of its capital. About this time there was a general increase of the capital of the banks, for which purpose bonds were to be sold by the State. There was also a considerable expansion of circulation, amounting for the State bank and its branches to $\$ 9$ of notes to $\$ 1$ of specie. Their suspension was inevitable, and when it came it was legalized by the Legislature, as in most other States. Extension laws were passed for the benefit of debtors, but their results were far from what had been expected.

\section{. Present Banking Law of the State.}

The incorporation of banks in any other manner than that prescribed in the constitution is prohibited by that instrument. Bills and notes must be redeemed in gold and silver, and no law can be passed sanctioning the suspension of specie payments. While the State banks do not now issue circulation, in case that privilege should be restored this provision of the constitution would prevent the evil that was the most destructive of the security of such circulation. Knowing that they would be relieved of the penalties of suspension, the State banks in nearly all the States suspended without hesitation on the first signs of financial stress. The State is prohibited from owning stock in any bank, or from giving or loaning its credit to a bank. A minimum capital of $\$ 50,000$ is required, one-half of which must be paid in before commencing business. 


\section{MISSISSIPPI.}

Up to 1809 the circulating medium of Mississippi consisted of Spanish coin, doubloons, dollars, halves, quarters, pistareens and picayunes. * The first paper currency consisted of cotton receipts given at the public gins for cotton brought and deposited there to be ginned. A statute of the Territory provided that when a planter handed his cotton to the public gin, a receipt should be given him, and the ginner was obliged under heavy penalties to deliver the cleaned cotton baled to the holder of the receipt within four months. The law also made the receipts negotiable, and they passed freely from hand to hand.

In 1809 the Bank of Mississippi at Natchez was chartered by the Territorial Commissioners to run for twenty-five years; the directors were to be individually responsible for any issue of bills in excess of three times the capital stock, then amounting to $\$ 100,000$. From the outset the bank was wisely and judiciously conducted and its bills were never dishonored. It continued as a private corporation until 1818, when its powers were extended by the Legislature and it was created a State bank with a capital limited to $\$ 3,000,000$ - the State to subscribe one-quarter and to appoint one-third of the directors. The new charter was to continue until 1840 , and in the meantime no other banking institution was to be incorporated by the State. Provision was also made for three branches and more if the directors should deem them necessary. Its capital in 1830 was $\$ 930,600$ and no complaint had ever been made of the institution. In that year, however, the Legislature, disregarding its solemn pledge given in 1818 that no other banking institution should be chartered, established the Planters' Bank of Mississippi, with a capital of $\$ 3,000,000$, and made it the financial agent of the State. The managers of the Bank of the State of Mississippi, dreading the evils which they feared would result from speculation in negroes and wild lands, then so prevalent, concluded to wind up that institution.

Of the $\$ 4,000,000$ of capital of the Planters' Bank, the State subscribed one-half and issued two millions of dollars in bonds, bearing six per cent. interest in payment therefor. The bonds were sold at a premium of $\$ 250$,000 , which was deposited in the bank as a sinking fund from which, together with the dividends accruing on the stock of the bank belonging to the State, the interest on the bonds was to be paid. As long as the State interests in the bank were kept distinct from other financial projects, this investment was apparently a prosperous one. The bank paid annual dividends of ten per cent. until September, 1839, when the sinking fund had increased to $\$ 800,000$. The State, however, transferred its interest to the Mississippi Railroad Company, and most of the large sinking fund was subsequently lost-leaving only about $\$ 60,000$, which was increased

*Claiborne's Mississippi Province, State and Terr., Vol. I. p. 300. 
by the commissioners by as much more from collections made from the assets of the Planters' Bank. During the prosperous times preceding 1835 the banking capital of the State increased to $\$ 12,000,000$, which so encouraged the legislators that during the session of 1835 banks and railroads with an aggregate capital of about $\$ 17,000,000$ were chartered.

In 1837 the number of banks had increased to eighteen, with capital of about $\$ 13,000,000$, more than $\$ 5,000,000$ circulation and $\$ 24,000,000$ of loans. The Mississippi Union Bank was chartered in 1838, to have a capital of $\$ 15,500,000$, to be "raised by means of loans to be obtained by the directors of the institution." The State then was induced to authorize an issue of $\$ 15,000,000$ in five per cent. bonds to be loaned to the bank, for the payment of which the faith of the State was pledged. Five millions of these bonds were issued to the bank in 1838 and a further equal amount in 1839. The first installment of bonds was negotiated by the commissioners of the bank through Mr. Biddle, the President of the Pennsylvania Bank of the United States, and $\$ 5,000,000$ was received therefor in installments.

\section{Alleged Infringement of the Bank's Contract.}

In accordance with the provisions of the third section of the act incorporating the Planters' Bank, 500 State bonds of $\$ 1,000$ each were issued in 1831, and sold by three commissioners appointed by the Governor. The bonds were made payable to and indorsed by one of the commissicners, and the principal and interest were made payable at the Phenix Bank, of New York city. The charter of the Planters' Bank was amended February 5, 1833, and a further issue of State bonds bearing six per cent. interest to the amount of $\$ 1,500,000$ was authorized and likewise sold in New York city. By the act incorporating the bank it was provided that if the dividends on the stock failed to pay the interest on the bonds, any amount atdvanced by the bank was to be charged by it to the account of the State. When the stock in the bank, owned by the State, was transferred to the Mississippi Railroad Company, it obligated itself to pay the interest on the bonds, and the principal with the exception of about $\$ 250,000$. The Planters' Bank paid the interest up to March 25, 1841 , at which time $\$ 166,792.22$ was due the bank from the State on account of these bonds. The interest was paid by the bank in London in sterling, and this it seems was considered by the State an important infringement of the contract.

The bonds issued to the Mississippi Union Bank consisted of 2,500 bonds of $\$ 2,000$ each executed in June, 1838, and delivered to the managers of the bank. One million two hundred and fifty thousand dollars were made payable in twelve years and $\$ 3,750,000$ in twenty years from February 5, 1838. The bonds were made payable in dollars, current money of the United States with interest at five per cent., payable semi-annually at the place stipulated in the bonds. 


\section{Payment of the Bonds Opposed.}

In 1841 the interest on all of the State bonds-both those issued in behalf of the Planters' Bank amounting to $\$ 2,000,000$ and those issued in behalf of the Union Bank amounting to $\$ 5,000,000$ was in default, through the inability of the Planters' Bank, the Mississippi Railroad Company which had succeeded to the interest of the Planters' Bank, and the Mississippi Union Bank. The holders of the bonds wrote many letters of inquiry and expostulation to the Governor of the State, assuming that inasmuch as the creatures of the State through whom and for whom the bonds of the State were negotiated had failed, that the State would, without hesitation, for its own credit and honor, provide for the payment of the interest and principal. To all these holders a letter was sent by Governor McNutt dated July 14, 1841, in which he informed the holders that "the State, therefore, denies all obligation to pay the bonds"-for the reason that they were not sold in accordance with the constitution and laws of the State. Before going further into the details of the reasons given by the Governor, the following abstract of a report of a select committee of the Legislature made in February, 1842, will show distinctly the history of the issue of the bonds in behalf of the Mississippi Union Bank. It appears that a clause in the Constitution of the State of Mississippi provides that no law shall ever be passed to raise a loan of money upon the credit of the State for the payment or redemption of any loan or debt, unless such law be proposed in the Senate or House of Representatives and be agreed on by the majority of the members of each house and entered on their journals with the yeas and nays taken thereon, and be referred to the next succeeding Legislature, and published three months previous to the next regular election in three newspapers of the State, and unless the next Legislature duly passes the said law.

\section{The Mississippi Union Bank.}

On February 5, 1838, the Legislature passed an act which had, in compliance with the constitution, been passed by a former Legislature, in 1835 and duly published, to incorporate the Mississippi Union Bank. By Section 5 of this act the faith of the State was distinctly pledged for the security of the principal and interest of a loan of fifteen millions five hundred thousand dollars to furnish funds to enable the bank to operate. The Governor of the State, to effect this loan, was required to issue bonds of the denomination of $\$ 2,000$ each, payable in twelve, fifteen, eighteen and twenty years, at five per cent. interest. Subscription books were to be opened for $\$ 15,500,000$ of stock in $\$ 100$ shares and to be kept open ten months. Owners of real estate in Mississippi were alone allowed to subscribe and to secure subscriptions, they were to give mortgages on property satisfactory to the directors, which property was, in all cases, to be equal to the subscrip- 
tion. Ten dollars in cash was to be paid on each share when the directors might require it. When 5,000 shares were subscribed the Governor was to appoint provisionally fifteen directors to hold office one year. After the books were elosed and it appeared that $\$ 500,000$ had been paid on the original stock of the bank, the institution was to commence business, and lastly, when the directors were appointed and their President elected, and the Governor of the State notified of this, he was then to execute to the bank bonds in proportion to the amount subscribed and secured to the satisfaction of the directors until the whole $\$ 15,500,000$ in bonds should be furnished. All the foregoing was provided for in Section 5 of the act of incorporation.

The act also provided that both principal and interest of the bonds should be paid by the bank, and the bulk of its profits was to be set aside for this purpose. On February 15 it seems the Legislature passed a supplemental act requiring the Governor to subscribe for 50,000 shares of the stock of the bank in behalf of the State, to be paid for out of the State bonds to be issued to the bank. This was done, and it was claimed that this supplemental act, passed without due regard to the requirements of the constitution, was the one under which the five millions of bonds were issued. In other words, no bonds whatever were issued and negotiated under the constitutional act, but that the $\$ 5,000$,000 issued were under the supplemental act solely, and therefore unconstitutional and void. It was claimed that the supplemental act repealed all the more important provisions of the constitutional act. In addition to claiming that the bonds were issued under an unconstitutional act, the committee refers to certain details of the negotiation of the bonds by commissioners of the bank with Nicholas Biddle, President of the Bank of the United States, and alleged these arrangements were in violation of the terms of the instructions to dispose of the bonds at not less than par and that Mr. Biddle, in the whole transaction, was guilty of intentional and willful fraud. The committee concluded by saying that the people of Mississippi have taken a stand similar to that occupied by Washington, Jefferson, Madison and Franklin, and a host of worthies who struggled through the gloomy revolutionary period. "They are not controlled by selfish or mercenary motives. The low and groveling consideration of dollars and cents has nothing to do with the merits of the question. Their honest obligations they will fulfill should they have to divest themselves of the comforts and necessaries of life to do so. Higher and holier motives than mere pecuniary considerations actuate them. They have determined that they will never submit to an invasion of their constitution by either a foreign or domestic foe. The rights secured to them under that sacred instrument they will maintain at all hazards; and relying on the correctness of their principles and the justice of their cause they will, with confidence and cheerfulness, submit to the verdict of posterity."

After the general election in November, 1841, it was claimed that the 
payment or disavowal of the bonds was made a test question and that the majority was in favor of disavowal or repudiation.

Another committee reported that "they were satisfied of the justice of the determination of the freemen of Mississippi never to pay the principal and interest of those bonds or to recognize the Mississippi Union Bank as a legal institution, and that in so doing they declare in favor of a principle honorable to themselves and beneficial to their offspring. They thereby declare that the few cannot bind the many without their consent, and set a lasting example before those who may come after them of the fruitlessness of the attempt to grasp and carry out unwarranted powers, calculated to affect their private rights and to endanger the civil liberty of themselves and their children. Freemen jealous of their rights have ever by care, vigilance and energy arrested the course of aggression and avoided the baleful results of slavish apathy."

Governor Tucker, in his message of January 1, 1844, speaks of a revival of business after a depression of prices during 1842 and 1843 never before experienced. He ascribes this revival, " not to fortuitous circumstances or by speculative operations or to expansion of a paper medium of currency ; nor is it believed to be owing to any act of legislation of this State, or of the United States, or even of any portion of the world favorable to commerce. Necessity has imposed on the votaries of idleness, prodigality, baseless speculation, banking and gambling, habits of industry and economy. Hence the revival of business is the natural result of industry, economy and time which have (aided by the bankrupt law), swept off a large portion of the debts and embarrassments of the people created by the disasters of past idleness, prodigality, gambling and banking operations." Governor Tucker also puts the bonds of the State issued to the Planters' Bank on adifferent footing from those issued to the Mississippi Union Bank.

In his message of January 4, 1842, Governor McNutt intimates that if proper investigation be had that even the Planters' Bank bonds may be found to have been irregularly issued; but Governor Tucker in 1844, considered these bonds, with the interest thereon, debts of the State created within the forms and by the permission of the fundamental law of the State, and that good faith to the State's engagement, as well as to the constitution requires that the same shall be paid when due or at least without unreasonable delay. He also considers the sinking fund of the Planters' Bank and effects of the Mississippi Railroad Company, which are the only resources of the State except taxation, form a frail dependence for the payment of debts-and therefore virtually recommends taxation to pay these bonds and other debts of the State. $\mathrm{He}$ regards, however, the Mississppi Union Bank and the five millions of bonds issued to it as unconstitutional. Subsequently, Governor Brown also in his message was in favor of taking measures for the payment of the Planters' Bank bonds; but in regard to those issued to the Miss- 
issippi Union Bank he takes the same view as his predecessors, and claims that being irregularly issued they are not the debt of the State, that Mississippi has not repudiated her debt, but has simply decided at the ballot box that these bonds are not her debt.

It appears, however, from an unprejudiced view of the whole evidence, that both the Planters' Bank and the Mississippi Union Bank were contemplated as a means of facilitating business within the State and the latter was evidently planned with the intention of permitting every citizen to participate in its benefits. The immense capital was divided into shares of $\$ 100$ each, to which only citizens of the State were permitted to subscribe on the easy terms of a cash payment of ten dollars, even the ealling for this was discretionary with the directors. In order that the directors might not be obliged to call even for this small cash payment, the State furnished to the bank the means of raising the cash required to equal its whole capital. If the scheme had been carried out strictly according to the original plan it is plain that some 100,000 citizens or more could each have subscribed for a share or two, and that for the real estate security given by them for their shares on the security of their shares would have each received a loan from the fund derived from the sale of the State bonds. This plan was beyond dispute made legal in accordance with the constitution of the State. It was passed by the Legislature of 1837 , published as required by the constitution, submitted to the people who, with full knowledge elected another Legislature, which in 1838 again enacted the same law. After this measure became a law, the Legislature by some malevolent intention as intimated by the report of one committee, or by some felicity as intimated by that of another, passed a supplementary bill. It is probable that the Legislature, the Governor, or none of those concerned, saw any serious harm in directing that a portion of the bonds, which the constitutional law authorized, should be treated as a subscription of the State to some of the stock of the bank. The original law did not make it necessary to the organization of the bank that the whole $\$ 15,500,000$ of stock should be taken by the people. The original law only required a subscription of $\$ 500,000$ when the various other steps, appointment of directors, election of President, notification of Governor and issue of bonds in proportion to bonds subscribed, could be taken in order. It is possible the Legislature thought the process of issuing bonds would be too slow if it could only keep pace with the subscription of shares by individuals. each of whom was to execute a mortgage on real estate satisfactory to the directors.

\section{Legality of THE State's Subscription.}

At first sight, the feature of the supplementary act authorizing the Governor to subscribe to $\$ 5,000,000$ of stock was apparently contrary to the provision of the law constitutionally passed, that the stock should be subscribed for by owners of real estate in Mississippi only. But it 
may have been held that the State was an owner of real estate in Mississippi, and could therefore subscribe for the stock. Doubtless too, the individual subseribers could pay up their shares to their full value in cash without any violation of the law, and why not the State when it gave bonds which were equivalent to the cash. All this may have seemed plausible to the Legislature, and convinced them they were merely passing a bill to explain and render effective the original act. The defect, if it was a defect, seems to have consisted in the fact that they made it appear that the bonds were to be issued in payment for a subscription to the stock, whereas the intention of the original law seems to have been to have the State give the bonds not for stock, but for a certain share in the profits of the bank, remaining after interest on bonds was paid, and the bonds given for stock were not the bonds intended to be given under the constitutional act. Technically, therefore, the action in repudiating these bonds may be defended. But the authorities of the State never impugned the validity of the bonds on this ground until after the failure of the Mississippi Union Bank and the default in interest.

In his message of January 5, 1841, Governor McNutt refers to this bank as irretrievably ruined, and that it will be hereafter totally unable to pay the interest on the $\$ 5,000,000$ bonds issued in 1838 . He does not refer to it as illegally chartered, but invariably speaks of its charter as a settled matter. He intimates that there may have been illegality in the details of the sale of the $\$ 5,000,000$ of the $\$ 15,500,000$ issued, yet he does not deny that they were constitutionally issued to the bank. He warns all persons against negotiating a second $\$ 5,000,000$ issued to and in possession of the bank, unless they pay down for them in specie in terms "authorized by the charter of the bank." In fact as he was the Governor who executed and issued the bonds, he was in some degree estopped from asserting any constitutional invalidity. In this message he intimates that there was a similar irregularity in the sale of the Planters' Bank bonds, in fact puts the bonds issued to both banks on a similar footing. He advocates repudiation in his message. In July, 1841, when he wrote his letter to the foreign holders of the bonds, he still says nothing of the supplementary act, and although he mentions it in his message of 1842 as being the act under which the bonds were issued, he does not claim any irregularity in the execution and issue of the bonds, but only in the negotiation and sale thereof. He may have been loath to admit his own carelessness in the transaction. The report of the select committee of the Legislature in February, 1842, however, claims distinctly that the bonds were issued under the sole anthority of the supplemental act.

\section{LEgality OF THE BondS UPHELD.}

The question of the execution, issue, negotiation and sale of the bonds was judicially tested in the courts of Mississippi, in * Campbell

* Claiborne's Ilist. Miss., Vol. I, Chap. 33. 
vs. Union Bank (6 How.), and in State of Mississippi vs. Johnson (25 Miss. Rep., 625). The respective decisions were rendered by Judge Sharkey and Chief Justice Smith. In both eases the law was held to be constitutional and the bonds binding on the State. The Legislature, however, took no action toward the payment either of the Union Bank bonds or of those issued to the Planters' Bank, which were not disputed, and finally a constitutional amendment was passed forbidding the payment of any of them. Political excitement ran high, and both Judge Sharkey and Judge Smith were accused of being influenced by personal and political motives in their decisions.

It must also be remembered that at this period the ideas in regard to the effect of charters and banking operations generally were vague and crude. A very large number of banks were chartered, and there were an almost equal number of unchartered institutions. The basis of all was real estate, and the belief was that the bank was a machine which could transmute real estate into a circulating medium. With a real estate basis it was expected that the banks would be able to maintain the credit of their notes by always being prepared to redeem in specie those that were presented. Most of the charters contained a provision of forfeiture in case specie payments were not maintained. Governor McNutt, by proclamation, declared the charters of a large number of banks forfeited. It was further believed that on dissolution of the corporation by forfeiture, debts due to and from it were extinguished, and all real estate belonging or pledged to the institution reverted to its original possessors. Thus the easiest way to settle the tangle of indebtedness and difficulty that was usually the consequence of these early banking operations was believed to be to declare the charters forfeited. This view was only changed by legislation. The Briscoe bill was passed by the Legislature to facilitate the disentanglement of the difficulties resulting from the financial crisis, and Judge Guion appended an amendment which declared that debts due to or from a corporation were not abrogated by forfeiture of charter, and provided for trustees to wind up such institutions. During this period, Robert J. Walker, afterwards Secretary of the Treasury of the United States, was prominent in Mississippi as a lawyer, politician and land speculator. He, it is said, borrowed most of the sinking fund of the Planters' Bank to aid him in his speculations, and when called upon to pay the same, offered Mississippi treasury warrants then worth but fifty cents on the dollar. He, however, always took strong ground in favor of sustaining the credit of the State, and advocated the payment of the bonds.

The banking scheme was adopted as a means of developing the resources of the State. At its inception it was sustained and thought well of by all. When, through mismanagement, greed and perhaps fraud, it failed, then the majority who had approved the inception of the plan tried to throw off their responsibility, because by the very 
nature of the scheme it had offered opportunities to a grasping minority of which they had not hesitated to avail themselves.

In 1840 several laws restricting banking were passed, prohibiting unauthorized banking; banks were required to pay in specie and to limit their circulation to three times the specie on hand. The credit of the paper currency was exceedingly bad at this time.

State Banks, 1834-189\%.

\begin{tabular}{|c|c|c|c|c|c|c|}
\hline YEARS. & 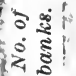 & $\begin{array}{l}\text { Loans and } \\
\text { discounts. }\end{array}$ & Specie. & $\begin{array}{l}\text { Capital } \\
\text { stock. }\end{array}$ & Circulation. & Deposits. \\
\hline $1834 \ldots . . . . . . . .$. & 1 & $\$ 5,461,464$ & $\$ 113,220$ & $\$ 2,666,805$ & $\$ 1,510,426$ & $\$ 545,353$ \\
\hline $1838 \ldots \ldots . . . . . .$. & 26 & $28,999,984$ & 766,360 & $19,231,123$ & $7,472,334$ & $4,638,669$ \\
\hline $1851 \ldots \ldots \ldots \ldots$. & 1 & 112,275 & ........... & 118,460 & 161,930 & 4,500 \\
\hline $1855 \ldots . . . .$. & 1 & 352,739 & 8,063 & 240,165 & 221,760 & 42,738 \\
\hline $1858 \ldots \ldots . . . . .$. & 2 & 393,216 & 591 & $1,110,000$ & 169,400 & 49,781 \\
\hline $1868 \ldots . .$. & 2 & ............. & ............ & 400,000 & ............ & .............. \\
\hline $1887 \ldots . . . . . . . .$. & 9 & $1,288,478$ & .......... & 759,650 & $\ldots \ldots \ldots$ & $1,102,906$ \\
\hline $1892 \ldots . .$. & 55 & $6,348,189$ & ............ & $3,115,836$ & ........... & $5,190,963$ \\
\hline $1897 \ldots \ldots . . . .$. & 83 & $8,513,828$ & …..... & $3,581,225$ & ............ & $7,673,246$ \\
\hline
\end{tabular}

National Banks, 1865-1898.

Figures are in thousands of dollars.

\begin{tabular}{|c|c|c|c|c|c|c|c|c|c|}
\hline YEARS. & 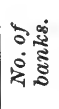 & $\begin{array}{c}\text { Loans } \\
\text { and dis- } \\
\text { counts. }\end{array}$ & $\begin{array}{c}U . S . \\
\text { bonds. }\end{array}$ & $\begin{array}{c}\text { Cash } \\
\text { and cash } \\
\text { items. }\end{array}$ & Capital. & Surplus. & $\begin{array}{c}\text { Undi- } \\
\text { vided } \\
\text { profits. }\end{array}$ & 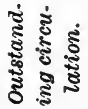 & $\begin{array}{c}\text { Indi. } \\
\text { vidual } \\
\text { deposits. }\end{array}$ \\
\hline $1865 \ldots . . . .$. & 1 & $\$ 16$ & $\$ 57$ & $\$ 70$ & $\$ 50$ & .... & $\$ 6$ & $\ldots$. & $\$ 86$ \\
\hline $1882 \ldots$ & 1 & 132 & 75 & 52 & 75 & $\ldots$ & 9 & $\$ 68$ & 108 \\
\hline $1888 \ldots . . . .$. & 12 & 2,647 & 393 & 400 & 1,105 & $\$ 242$ & 93 & 293 & 1,379 \\
\hline $1893 \ldots \ldots .$. & 12 & 2,358 & 339 & 305 & 1,055 & 457 & 107 & 305 & 1,221 \\
\hline $1898 \ldots . . .$. & 10 & 2,475 & 277 & 317 & 855 & 402 & 150 & 227 & 2,250 \\
\hline
\end{tabular}

Under the present banking system of the State the banks are required to make reports four times a year to the Auditor of Public Accounts, under penalty of forfeiting their right to do business on failure to comply with this requirement. These reports must be published in some newspaper where the bank is located. Loans to any one person or firm are restricted to one-fifth of capital, and the receiving of deposits when the bank is known to be insolvent is punishable by imprisonment.

The State and National banks of Mississippi will compare favorably with those of any State in the Union. Failures among them have been exceptionally rare, and they have successfully withstood panics that were disastrous to the banks of the country generally. 


\section{LOUISIANA.}

March 14, 1818, Louisiana had authorized a subscription of $\$ 500,000$ toward the capital of $\$ 2,000,000$ in the Louisiana State Bank. The State was to appoint six out of eighteen directors. The bank was required to pay a bonus of $\$ 100,000$ to the State, in consideration for which "the stock and real estate belonging to the said bank shall forever during the continuance of its' charter, be exempt from the payment of any State tax." Inasmuch as only $\$ 100,000$ was ever actually subscribed, and as both bonus and exemption from taxation were also characteristics of subsequent charters to other banking institutions, this bank can hardly be considered as a State institution.

\section{Successful Operations of the BanK of Louisiana.}

April 7, 1824, the Bank of Louisiana was chartered with a capital of $\$ 4,000,000$, one-half of which was subscribed by the State. For the State subscription the issue of five per cent. bonds was authorized at the rate of $\$ 100$ in bonds for every $\$ 83_{\frac{1}{2}}$ of stock, payable at intervals of from ten to twenty-five years from their dates. These were to be sold by the bank for specie. The interest was to be paid from the dividends upon the bank stock, any deficiency that might occur being paid by the bank and charged to the account of the State. Of the thirteen directors six were to be appointed by the Governor on behalf of the State. Five branches were required to be opened.

In 1826 the General Assembly seems to have become provoked at the delay in declaring dividends and insisted upon the declaration of a dividend upon the State stock at least. The difficulty experienced in controlling the institution led to the appointment of a seventh director on the part of the State and an act requiring semi-annual dividends of profits. In 1827 the profits accruing to the State were sufficient to permit $\$ 300,931$ of the bonds to be called in and paid, which was authorized by a resolution of March 24 of that year.

In 1844 the Treasurer of the State was authorized to sell 12,000 shares of the stock of the Bank of Louisiana for the purpose of raising funds to pay the bonds, $\$ 1,200,000$, falling due in 1844 and 1849 . The bank itself purchased the bonds, becoming thereby obligated to redeem both series of bonds, which it punctually did. The remainder of the stock was also directed to be sold in $\mathbf{1 8 4 4}$ for the purpose of meeting other bonds falling due.

\section{The Union Bank of Louisiana.}

In 1832 the State incorporated the Union Bank of Louisiana, with a capital of $\$ 7,000,000$. This was an institution established on precisely the same foundation as the Union Banks of Florida and Mississippi 
mentioned elsewhere. The subscribers of the stock paid in nothing, merely giving a mortgage to cover the amount of subscription; and the actual capital was derived from the proceeds of the $\$ 7,000,000$ bonds issued by the State for the purpose. Six of the twelve directors were appointed by the Governor on behalf of the State. The State reserved the right to borrow from the bank $\$ 500,000$ at interest, and each stockholder was entitled to a credit equal to one-half the amount of his shares. The State for its guaranty was to receive one-sixth of the profits of the institution. The bank seems to have been managed no better than the most of the property banks of the same style in operation in other States. It failed in $\mathbf{1 8 4 2}$ with its assets in such shape that the collection of anything from them was a slow and difficult matter. The proceeds, as realized, were turned toward the payment of the interest and principal of the $\$ 7,000,000$ bonds issued by the State on behalf of the bank. January 18, 1853, the Union Bank deposited with the Treasurer $\$ 21,000$ to secure the State against any loss for twenty-one bonds not returned. These-the last of the issue-were afterwards returned and cancelled.

The State also issued in aid of the Consolidated Association, bonds to the amount of $\$ 2,004,000$; and in aid of the Citizens' Bank additional bonds to the amount of $\$ 8,000,000$, of which $\$ 7,188,000$ were finally sold. Both these institutions were upon precisely the same basis as the Union Bank, $i . e$., the sale of the bonds issued by the State was to furnish the actual capital, and the stockholders were to secure their subscriptions by mortgages on real estate. In the case of the Consolidated Association, the State, for its guaranty, was considered as stockholder for $\$ 1,000,000$. Dividends were to be declared only as the bonds were paid, and in the same proportion. The profits till then were to be retained as a sinking fund to meet the redemption of the bonds. The case was the same with the Citizens' Bank, except that the interest of the State in the net profits was one-sixth, as in the case of the Union Bank. Both these institutions were put in liquidation in $\mathbf{1 8 4 2 .}$

By 1858 the bonds issued by the State for the Citizens' Bank had been reduced from $\$ 7,188,000$ to $\$ 5,300,000$, for which the State still retained a first mortgage on the $\$ 14,000,000$ real estate of the stockholders mortgaged by them to secure their stock. In the years $1842-1848 \$ 1,000$,000 had been raised by assessments upon the stockholders. In 1852 the Citizens' Bank was reorganized upon an entirely new basis, the distinctive feature of which was the separation of the bank into two departments-a banking department and a mortgage department. Immediately the banking department assumed an important place among the banking institutions of the State-its circulation reaching $\$ 3,089$,000 by January, 1860.

The State definitely renounced the banking business in its constitution of 1852 by the clause: "The State shall not subscribe for the stock of, nor make a loan to, nor pledge its faith for the benefit of any cor- 
poration or joint stock company created or established for banking purposes."

From the following table can be gathered something of the course of these banks in respect to their circulation:

\begin{tabular}{|c|c|c|c|}
\hline DATE. & $\begin{array}{c}\text { Circulation } \\
\text { Louisiana Bank. }\end{array}$ & $\begin{array}{l}\text { Circulation } \\
\text { Union Bank. }\end{array}$ & $\begin{array}{c}\text { Circulation } \\
\text { Citizens' Bank. }\end{array}$ \\
\hline July, $1835 \ldots \ldots \ldots \ldots \ldots \ldots \ldots$ & $\$ 751,987.00$ & $\$ 1,428,045.00$ & 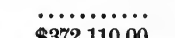 \\
\hline Jan. 23, 1837.................. & $841,190.00$ & $1,476,445.00$ & $\$ 372,110.00$ \\
\hline Dec. $23,1837 \ldots \ldots \ldots \ldots \ldots \ldots$ & $398,000.00$ & $1,564,580.00$ & $410,545.00$ \\
\hline Dec. $3,1838 . . . \ldots \ldots \ldots \ldots \ldots \ldots$ & $141,742.00$ & $967,410.00$ & $161,995.00$ \\
\hline Oct. $21,1839 . \ldots \ldots \ldots \ldots \ldots \ldots \ldots$ & 292,72200 & $638,470.00$ & $428,450.00$ \\
\hline Feb. $1,1840, \ldots \ldots \ldots \ldots \ldots \ldots \ldots \ldots$ & $261,747.50$ & $964,630.00$ & $308,725.00$ \\
\hline Dec. $5,1840 . \ldots \ldots \ldots \ldots \ldots \ldots \ldots$ & $25 \%, 552.00$ & $981,695.00$ & $\ldots \ldots \ldots$ \\
\hline Mar. $26,1842 . . \ldots \ldots \ldots \ldots \ldots \ldots$ & $276,277.50$ & $447,170.00$ & ........... \\
\hline Jan. $1,1843 . \ldots \ldots \ldots \ldots \ldots \ldots \ldots$ & $341,216.50$ & $148,325.00$ & ...... \\
\hline Jan. $1,1844 \ldots \ldots \ldots \ldots \ldots \ldots \ldots$ & $673,389.50$ & $68,335.00$ & .......... \\
\hline Jan. 1, 1845................... & $776,644.50$ & $30,580.00$ & .......... \\
\hline June $1,1845 . \ldots \ldots \ldots \ldots \ldots \ldots \ldots$ & $998,567.50$ & 29.455 .00 & .......... \\
\hline April $25,1846 . \ldots \ldots \ldots \ldots \ldots \ldots$ & $1,351,500.00$ & $27,010.00$ & .......... \\
\hline Jan.,1847....................... & $965,777.00$ & $26,350.00$ & $947,163.00$ \\
\hline Jan., 1848...................... & $1,026,640.00$ & $26,135.00$ & .......... \\
\hline Nov., 1848..................... & $1,126,782.00$ & $26,005.00$ & $246,975.00$ \\
\hline Nov., $1849 . \ldots . \ldots \ldots \ldots \ldots \ldots . .$. & $1,222,217.00$ & $25,985.00$ & $11,176.00$ \\
\hline 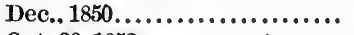 & $852,909.00$ & $25,795.00$ & $11,061.00$ \\
\hline Oct. $30,1852 . \ldots \ldots \ldots \ldots \ldots \ldots \ldots$ & $1,249,484,00$ & $25,520.00$ & $6,027.00$ \\
\hline
\end{tabular}

\section{Louisiana Bank ACT of 1842.}

The act of 1842 is generally regarded by experts as a model one in many respects. This opinion is expressed by Horace White, * who says:

"The State of Louisiana had her full share of bank misery in 1837 and later. Her banks suspended specie payments, and so remained until 1842. In that year the State passed a banking law which was, in nearly all respects, a model for other States and countries.

The principal features of this law were the requirements (1) of a specie reserve equal to one-third of all its liabilities to the public; (2) the other two-thirds of its liabilities to be represented by commercial paper having not more than ninety days to run; (3) all commercial paper to be paid at maturity; and if not paid, or if an extension were asked for, the account of the party to be closed and his name to be sent to the other banks as a delinquent; (4) all banks to be examined by a board of State officers quarterly or oftener ; (5) bank directors to be individually liable for all loans or investments made in violation of the law, unless they could show that they had voted against the same if present; (6) no bank to have less than fifty shareholders, having at least thirty shares each ; (7) any director going out of the State for more than thirty days, or absenting himself from five successive meetings of the board, to be deemed to have resigned, and his vacancy to be filled at once; (8) no bank to pay out any notes but its own; (9) all banks to pay their balance to each other in specie every Saturday, under penalty of being immediately put in liquidation; (10) no bank to purchase its own shares or lend on its own shares more than thirty per cent. of the market value thereof.

This law had one feature which cannot be approved. It allowed some loans to be made on mortgage security, but it restricted such loans to the bank's capital. No part of the deposits could be lent except on commercial paper maturing within ninety days. I judge that not many mortgage loans were made by the Louisiana banks,

* "National and State Banks;" "Sound Currency," Vol. II, p. 5. 
since none of them suspended in the panic of 1857 , although most of the banks of the country were temporarily closed by that catastrophe. Mortgage loans are all right in themselves, but they are no part of the banking business. I think that the Louisiana Bank Act of 1842 was eminently scientific. It was the first law passed by any State requiring a definite amount of specie to be kept as a reserve. The Louisiana law required no pledged security * for the circulating notes of banks, nor did it put any limit on the amount of their issues. All this was covered, and amply covered, by requiring thirty-three per cent. of specie against all liabilities, whether deposits or notes, the balance of the assets to be in mercantile paper having not more than ninety days to run.

Under this law, Louisiana became in 1860 the fourth State in the Union in point of banking capital and the second in point of specie holdings. I think, however, that the requirement of a thirty-three per cent. reserve of coin (or, as we say now, of "lawful money") was excessive, and that the twenty-five per cent. in larger cities and fifteen per cent. in other places, required of National banks, is ample. It is a matter of history that the Louisiana Bank Act of 1842 was strictly and intelligently enforced until the city of New Orleans was captured during the Civil War."

State Banks.

\begin{tabular}{|c|c|c|c|c|c|c|}
\hline YEARS. & $\begin{array}{l}\text { No. of } \\
\text { banks. }\end{array}$ & $\begin{array}{l}\text { Loans and } \\
\text { discounts. }\end{array}$ & Specie. & $\begin{array}{l}\text { Capital } \\
\text { stock. }\end{array}$ & Circulation. & Deposits. \\
\hline $1835 \ldots$ & 41 & $\$ 37,388,839$ & $\$ 2,824,904$ & $\$ 26,422,145$ & $\$ 5,114,082$ & $\$ 7,106,628$ \\
\hline $1840 \ldots$ & 47 & $49,138,700$ & $2,847,497$ & $41,736,768$ & $4,345,533$ & $5,415,230$ \\
\hline $1845 \ldots$ & 28 & $18,417,669$ & $8,282,981$ & $19,670,580$ & $2,099,331$ & $8,418,764$ \\
\hline $1850 \ldots$ & 28 & $18,602,649$ & $6,979,772$ & $14,257,520$ & $5,069,867$ & $8,210,705$ \\
\hline $1855 \ldots$ & 19 & $27,142,907$ & $6,570,568$ & $20,179,107$ & $6,586,601$ & $11,688,296$ \\
\hline $1860 \ldots$ & 13 & $35,401,609$ & $12,115,431$ & $24,496,866$ & $11,579,313$ & $19,777,812$ \\
\hline $1865 \ldots$ & 10 & .............. & ................ & $7,671,800$ & ............... & ................ \\
\hline $1870 \ldots$ & 12 & ............... & & $7,801,500$ & ................ & . \\
\hline $1875 \ldots$ & 5 & $4,449,312$ & ................ & $3,792,300$ & 9,447 & $6,149,202$ \\
\hline $1880 \ldots$ & 10 & $6,108,888$ & ............... & $4,458,198$ & 8,712 & $7,086,841$ \\
\hline $1885 \ldots$. & 4 & $4,036,049$ & .............. & $2,582,200$ & 8,617 & $5,816,536$ \\
\hline $1890 \ldots \ldots$ & 6 & $6,235,170$ & ................ & $2,130,200$ & 8,577 & $7,486,897$ \\
\hline $1897 \ldots . . .$. & 20 & $5,845,302$ & ............ & $2,413,150$ & ........ & $5,942,957$ \\
\hline
\end{tabular}

Requirements of the Present Banking Law.

Banks of circulation, discount, deposit, safe-deposit, Savings banks and trust companies may be organized by any number of persons more than five. The minimum capital is $\$ 10,000$, the amount being graded up to not less than $\$ 100,000$, according to the population of the place where the bank is located. Savings banks must have $\$ 50,000$ capital. Shareholders' liability is confined to the extent of their shares. Capital must be paid up in full in specie within twelve months after a bank commences business.

* The present law (1899) requires that circulating notes must be secured by a pledge of public stocks with the Auditor of Public Accounts. State bank notes are not issued, however, owing to the prohibitive Federal tax. 
"Every bank is required to have on hand at all times, in specie, an amount equal to one-third of all their other cash and liabilities, and for the other two-thirds of said liabilities an equal amount in specie, specie funds, bills of exchange, or discounted paper maturing within ninety days and not renewable. Should the specie, specie funds and short paper fall below the proportions of the cash liabilities, and remain so for a period of ten days, it shall not be lawful to make any loans or discount whatever until the bank shall again have the reserve above required." *

All banks are required to make and publish quarterly statements of their condition.

\section{National Banks.}

Figures are in thousands of dollars.

\begin{tabular}{|c|c|c|c|c|c|c|c|c|c|}
\hline YEARS. & 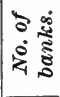 & $\begin{array}{l}\text { Loans and } \\
\text { discounts. }\end{array}$ & $\begin{array}{c}U . S . \\
\text { bonds. }\end{array}$ & $\begin{array}{c}\text { Cash and } \\
\text { cash items. }\end{array}$ & Capital. & Surplus. & $\begin{array}{c}\text { Undi- } \\
\text { vided } \\
\text { profits. }\end{array}$ & $\mid \begin{array}{c}\text { Ont- } \\
\text { standing } \\
\text { circula- } \\
\text { tion. }\end{array}$ & $\begin{array}{c}\text { Indi- } \\
\text { vidual } \\
\text { deposits. }\end{array}$ \\
\hline $1864 \ldots$ & 1 & $\$ 168$ & $\$ 300$ & $\$ 2,343$ & $\$ 500$ & $\ldots$ & $\$ 76$ & $\$ 166$ & $\$ 2,210$ \\
\hline $1868 \ldots$ & 2 & 1,004 & 1,208 & 993 & 1,300 & $\$ 62$ & 105 & 1,059 & 1,124 \\
\hline $1873 \ldots$ & 9 & 9,108 & 3,900 & 2,490 & 4,750 & 297 & 300 & 3,335 & 7,512 \\
\hline $1878 \ldots$ & 7 & 5,341 & 1,781 & 2,139 & 2,875 & 573 & 340 & 1,385 & 4,839 \\
\hline $1883 . .$. & 8 & 9,467 & 2,577 & 2,378 & 3,225 & 1,102 & 414 & 2,240 & 8,136 \\
\hline $1888 \ldots$ & 13 & 12,419 & 2,234 & 3,730 & 3,425 & 1,508 & 395 & 1,327 & 11,912 \\
\hline $1893 . .$. & 20 & 16,501 & 1,152 & 2,188 & 3,935 & 2,496 & 673 & 1,034 & 13,549 \\
\hline $1898 . .$. & 19 & 14,316 & 1,228 & 3,495 & 3,160 & 2,736 & 622 & 748 & 16,503 \\
\hline
\end{tabular}

\section{TEXAS.}

The existence of Texas under so many different kinds and conditions of government, and the environments of country and of people, have been such as to leave upon every characteristic an impress peculiarly Texan, and among others, to make its banking history unique. The Texas we know to-day represents the growth of the inherent spirit of independent statehood through the intermediate conditions of Spanish dependence, Mexican statehood, Texan independence, and final coalition with the United States.

In this sketch it has not been thought necessary to go further back than to that memorable period when the sturdy sons of Texas, after a struggle of unparalelled heroism, achieved independence, and despite the armed aggressions of Mexico, established and for nine years maintained an independent republican government, with all the machinery of Congress, courts and attendant financial complications.

Texas shook off the grasp of Mexico by the decisive battle of San

* Report of the Comptroller of the Currency, 1893, Vol. I, p. 214. 
Jacinto, and came before the world, penniless as to actual cash, but rich in an almost boundless public domain, and possessing a boundless determination.

\section{Finances of the Republic of Texas.}

As was no more than natural, the earnest attention of the provisional government was turned to the borrowing of money as the quickest and best means of relieving the financial distress. Indeed, the entire history of the Republic is checkered with efforts to coin its natural wealth into available sinews of war with which to maintain the liberty of the country against continued menace and occasional aggression from Mexico.

One of the first acts of the Republic was the appointment of Messrs. Thomas F. McKinney and Samuel M. Williams as commissioners to borrow, in the United States, a million dollars, with instructions to pledge or hypothecate the public lands and the public revenues for the same.

Subsequently similar efforts were put on foot in other directions and from them grew incidents most vitally affecting the history of the country both in its political and banking life, incidents which though serious enough at the time and serious indeed to the people of the Republic, are to-day amusing in many respects.

Messrs. McKinney and Williams were among the most enterprising men of the day. They gave of their private means to aid their country and their names are closely associated with Texas history and with the story of Texas finances.

Every available means to raise the needed money was employed. Borrowing was not the only expedient attempted at the time. Aside from direct loans, the public lands were the main dependence, though Texas land scrip found few buyers.

On January 27,1836 , an act was passed authorizing the issuance of one hundred and fifty thousand dollars in treasury notes, a specification on the face of which declared that they would be received in payment for lands and other public dues, or be redeemed with any moneys in the treasury not otherwise appropriated.

Despite a depleted treasury and all other obstacles, Texas continued the fight against the trained armies of Mexico. The battle of San Jacinto became history. Santa Anna was captured and Texas was free.

The first Congress of the Republic of Texas met October 3, 1836, in the town of Columbia, and on the 22d of the same month, Gen. Sam Houston, already duly elected by the people, was inaugurated President. During this same Congress the first step toward banking legislation was recorded by the young Republic.

\section{Provision for Organizing a Bank.}

On December 10, 1836, an act was passed requiring the President to appoint a commissioner "for the purpose contemplated in the tenth 
article of the charter of the Bank of Agriculture and Commerce, granted to Samuel M. Williams by the Legislature of Coahuila and Texas, in April, 1835, in order that the parties may exercise and enjoy their privileges under said act."

This charter was granted under Mexican regime, but Texas evidently intended to revive it, and possibly to continue the system, the next section of the Texas act " authorizing and empowering the Secretary of the Treasury to negotiate a loan from any bank or banks that may be established in this Republic, of sufficient amount for the payment of all just claims held by McKinney and Williams, against this Government."

On December 16, 1836, came "an act to incorporate the Texas Railroad, Navigation and Banking Company ;" its capital stock was fixed at five millions, with a permissible increase to ten millions, and granting the right of connecting the waters of the Rio Grande and the Sabine River by international canal, with the privilege of unlimited canal and railroad branches. The bank feature provided that the institution should not go into operation " until the bank had a specie capital of $\$ 1,000,000$ paid in," and it was further provided that the charter should lapse unless a $\$ 25,000$ good faith bonus should be paid in gold and silver within eighteen months after the act went in force. It appears that the $\$ 5,000$,000 stock was subscribed promptly, and the $\$ 25,000$ was tendered in Texas treasury notes before referred to, which by law were at that time receivable for all public dues. The Treasurer issued a written acknowledgment of the tender, but refused to receive the notes. And thus this ambitious scheme came to a halt.

The next session of this Congress saw no banking legislation, though there vas some discussion of projects for the incorporation of "a joint stock company for the erection of a hotel and bath house at Velasco, with banking privileges; the same at Houston; the Internal Improvement and Banking Company, of Texas; the Red River and Aransas Bay Railroad, Navigation and Banking Company; a Bank of the Republic of Texas."

Texas finances were at a low ebb. Audited treasury drafts were worth but fifteen per cent. Among other expedients was discussed the creation of banks founded on Texas bonds. Henry Smith, the Texas Treasurer, favored such a plan. However, in opposition to his recommendation, on June $\mathbf{9}, \mathbf{1 8 3 7}$, an act was passed authorizing the issuance of promissory Government notes, receivable for all public dues, to the amount of $\$ 500,000$.

\section{A Government Bank Proposed.}

During the third Congress, December, 1838, President Mirabeau B. Lamar, formally recommended the establishment of a National bank, founded on the credit and resources of the Republic, to be controlled. by the Government, the directors to be elected by joint ballot of both 
houses, and the President and Cashier to be appointed by the President of the Republic. The "resources" of Texas, President Lamar conceived te be "the public domain," and this he proposed to pledge. The bank should be the Government's fiscal agent, a regulator of exchange, a bank of deposit, loan and discount, and a bank of issue as well, and it "would, of course, be extended by branches established at every convenient and suitable part of the Republic."

A bill to incorporate "The Bank of the Republic of Texas," in conformity with the President's views, was introduced, discussed hotly, and on January 21, 1839, was tabled by a vote of sixteen to fourteen.

In $1840 \$ 7,000,000$ Texas bonds were "nearly" floated in France, which local history says was to be used in the establishment of a National bank, but fortunately negotiations were broken off before the final arrangements were completed, and the loan was never consummated.

\section{Negotiations Upset By a Herd of Swine.}

While negotiations were pending in France, Fate was fighting against them in Texas, in the shape of a herd of swine owned by an Austin hotel keeper. The French Minister, M. de Saligney, had a fine horse. The pigs found their way into the stable and ate the corn dropped from the manger. The French servant, driving them out, killed one. Mr. Bullock, the owner of the pigs, at once registered his resentment by giving the servant a sound thrashing. M. de Saligney complained to the Texas Government. Mr. Bullock was arrested and pending trial was released, with the Secretary of the Texas Treasury on his bond. M. de Saligney happened in the hotel. Mr. Bullock ejected him. Another complaint, another arrest and another release, with the Treasurer as bondsman. The matter had by this time grown from its first proportions as a personal disagreement and became a matter of public importance. It was every where discussed, in the newspapers, on the streets and in Congress. Everyone upheld Mr. Bullock and his pigs. The Government actually sent to France and asked the recall of the French Minister. Thus the thing became of international moment. It happened that M. de Saligney was closely related to the French Minister of Finance, with whom rested the consummation of the loan which was to lift Texas out of her financial troubles and put her National bank on foot. Negotiations were abruptly broken off. What the results would have been had that loan been made, one can only conjecture; but a well-posted writer of the day says that as "the geese saved Rome, so Mr. Bullock's pigs saved Texas."

\section{Texas Annexed to the United States.}

The finances of the young republic continued to be a source of worry to the Texas patriots. Meantime private manipulation of the stock of the Texas Railroad, Navigation and Banking Co., netted some 
$\$ 60,000$ to private speculators, but the enterprise itself never materialized.

On March 1, 1845, the President of the United States approved a joint Senate and House resolution for the annexation of Texas, and on July 4,1845 , the people of Texas assented to the proposed annexation, and adopted a State constitution which was approved October 2, 1845. Repudiation and scaling of State liabilities were discussed at length; laws looking in that direction were passed, and finally an act was passed cutting off interest on all debts of the old Republic after July 1, 1850.

\section{Evolution of Texas Currency.}

As a Mexican State, Texas currency was gold and silver, and occasional notes issued by banks in the United States. The population was small and currency scarce, Almonte, the Mexican historian, recording the fact that not ten per cent. of all sales made were for cash. $\mathrm{He}$ says: "Purchases are made on credit, or for barter, which gives the country, in its trading relations, the appearance of a fair."

One medium of exchange of this period has gone down to history as the "hammered dollar." Mexico, emancipated from the rule of Spain, retained a considerable amount of Spanish silver, and this, in the form of dollars, remained in circulation, though with the royal effigy battered out of all recognition thereon, by an official "hammering," which served the double purpose of testifying the Mexican sentiment toward Spain and also put the coin in condition, by the defacing of its stamp, so that it " remained at home." After the breaking out of the Revolution "hammered money" was to a great extent displaced by bank notes from the United States, but the shaky condition of these banks in the ' 30 's made them a treacherous medium. Shinplasters and fractional currency were issued at intervals between 1837 and 1840. Treasury drafts for irregular amounts sometimes figured as currency, bearing a promise of ten per cent. interest. In 1838 a series of non-interest-bearing treasury notes were issued. These were partially printed in scarlet and were familiarly known as "red backs." They were never worth more than $37 \frac{1}{2}$ per cent. of their face, and in 1842 they were worth but two cents on the dollar, and were often altogether refused.

The natural temperament of the pioneer Texan was favorable to the loftiest flights of financial fancy, and numerous remarkable schemes were entertained, but the tremendous bank explosions occurring in the United States early in the history of the Texan Republic appear to have rendered them cautious, for the only large banking scheme they actually put on foot was the Commercial and Agricultural Bank. This, inaugurated while Texas was a State of the Mexican Government, was intended as a bank of the Department of the Brazos. It was to have $\$ 1,000,000$ capital in shares of $\$ 100$. When $\$ 300,000$ were subscribed directors were to be chosen. It was to continue twenty years and might have 
branches. Interest at eight per cent. on six months and ten per cent. on longer loans might be asked, and only the eapital of the bank might be responsible for its own loans.

Its operations should commence when $\$ 100,000$ had entered its vaults, and it should be subject to annual examination by an executive commissioner.

On December 14, 1837, the Texas Congress passed an act prohibiting the issue or circulation of promissory notes by any person or persons in Texas, under a penal fine of $\$ 5$ to $\$ 50$, for every offence. The tender of any such notes in payment was also prohibited. Yet on February 3, 1841, Congress authorized McKinney \& Williams (the Commercial and Agricultural Bank projectors), to issue their notes to the amount of $\$ 30,000$ for circulating money, explaining in the act that it was done because McKinney \& Williams had made large advances to the Government at an early period in its existence.

This act was followed by another providing that "all laws granting to any individual, individuals or corporations the authority to issue either bills or promissory notes to pass or circulate as money, are hereby repealed."

This act deprived the Commercial and Agricultural Bank of the power to issue and circulate its own money.

\section{Banks Prohibited by the Constitution.}

The first constitution adopted after the admission of the State to the Union contained this clause: "No corporate body shall hereafter be created, renewed or extended, with banking or discounting privileges."

That clause has been an integral part of the Texas constitution ever since, with the exception of the brief period when the reconstruction element was in power, and shows the effect produced on the people of Texas by their experience with United States banks.

There was no bank in actual operation in Texas during the existence of the Republic, but subsequently the old Commercial and Agricultural Bank was put on foot, though no one knows just how, for the provision requiring it to certify that " $\$ 100,000$ had entered its vaults," does not seem to have been complied with. However, it commenced operations in Galveston in 1846, and at once established a branch at Brownsville.

\section{Circulation of Bank Notes on the Credit of Individuals.}

From 1846 to 1852 the banking affairs of the State presented an interesting picture. Texas laws contained drastic inhibitions against the issue of bank notes, but the spirit of this legislation was shrewdly evaded as is evidenced in the case of the house of R. \& D. G. Mills, of Galveston, who about this time put in circulation in Texas a large number of notes issued by the Northern Bank of Mississippi, at Holly Springs, and endorsed by R. \& D. G. Mills. Without this endorsement they would never have gained currency in Texas, as the Holly Springs con- 
cern was recognized as of unstable character, while the Mills house was the richest commercial house in Texas, and was regarded with unshaken confidence.

"Mills' money" became a recognized currency throughout Texas, and different authorities estimate the amount in circulation in the early fifties at from $\$ 40,000$ to $\$ 300,000$. This money was, by the people, generally held to be "as good as gold, or even better."

On February 7, 1852, the "State Gazette," of Austin, chronicled the suspension of the house of R. \& D. G. Mills, and a panic convulsed the entire State. Communication was slow and information unreliable. Things turned out better, however, than at first reported, for this great house, though it had suffered losses, recuperated almost immediately, and was in successful operation at the time of the breaking out of the Civil War.

\section{Banking During the Reconstruction Era.}

The caution of the people of the State in regard to banking institutions continued to exert an influence on Texas legislation as long as Texans remained in power, but when the "reconstruction" forces came in their first act was the adoption of a constitution in which, for the first and only time in the history of the State, the bank-prohibiting clause was omitted. This constitution was adopted in 1869, and the "reconstruction" Legislature of 1871 took advantage of the chance offered and passed "an act concerning private corporations," which was approved December 2, 1871.

Among many liberal provisions this act declared:

"Any five or more persons may organize themselves into a Savings association, and shall be permitted to carry on the business of receiving money on deposit, and to allow interest thereon, giving to the persons depositing credit therefor; and of buying and selling exchange, gold, silver, coin, bullion, uncurrent money, bonds of the United States, of the State of Texas, and of the city, county and school district in which any association shall organize; of loaning money on real estate and personal security at such rate of interest as may be agreed upon; and of discounting negotiable notes and notes not negotiable; and on all loans made may keep and receive the interest in advance."

The capital stock was limited to not less than $\$ 50,000$ or more than $\$ 500,000$ in $\$ 100$ shares, ten per cent. to be paid when subseribed, and the balance subject to call. Each bank was required to have not less than five nor more than nine directors, who should annually appoint a President, Cashier and Secretary. A majority of the stock must be subscribed and a certificate of the name, location, stock, stockholders, and date of organization made by the President and Secretary, acknowledged before a notary public, recorded in the county, and a copy thereof and of the by-laws, filed with the Secretary of State. No bank chartered under this law could assume or retain any corporation or association name already existing. Semi-annual reports to the Secretary of 
State were required. Dividends of net profits were to be declared each first of January and July.

In 1873 there was an act of the Legislature amendatory of the above act, by virtue of which the corporations formed thereunder were validated, it appearing that the act of 1871 had been passed without an enacting clause.

It seems that several institutions took advantage of the banking clause, and the Farmers and Merchants' Bank, of Paris; the Red River County Bank, of Clarkesville; the Fannin County Bank, of Bonham, and the Paris Exchange Bank, were organized thereunder, and reported to the Secretary of State.

Almost immediately thereafter the "reconstruction" element was overthrown and "home rule" restored in Texas. One of the first acts under the new order was the adoption of a new constitution, and Section sixteen of Article sixteen of that instrument provided that "No corporate body shall hereafter be created, renewed or extended with banking or discounting privileges." Through all the changes the Texas constitution has since undergone this section has been preserved.

It will be seen, therefore, that State banks in Texas have been peculiar and noteworthy institutions, yet so far as can be discovered the only advantage they possessed lay in the meager distinction of their unique character as State banks in a State where such institutions are expressly and repeatedly prohibited. Officially their existence has been practically unknown at the State Departments, and their semi-annual reports have caused a mild surprise in the minds of clerks to whom they have come in the changing course of official life at the State capitol.

No record has been kept of their reports, and the only mark they have made on the pages of history is the dedication of a dusty little file box to their use in the Secretary of State's office, and an occasional reference to them in the office report.

The continued existence of these banks is explained by Section eighteen of Article sixteen of the constitution, which expressly provides that "the rights of property and of action which have been acquired under the constitution and laws of the Republic and State shall not be divested."

\section{REPoRts OF The State BANKs.}

No reports are in evidence earlier than 1888, and those preserved show that the Fannin County Bank was the only one with regular reports on file from that date to July 1,1898 . Since the latter date no reports appear, and there is no record and no official information to show what has become of the banks. From private sources, however, it is learned that the Farmers and Merchants' Bank, of Paris, failed in May, 1897. The Red River County Bank, of Clarkesville, has since been chartered as a National bank, and the Paris Exchange Bank became a National bank in 1898. 
The first and last accessible statement of the Fannin County Bank may be found of interest.

Semi-Annual Statement of the Condition of the Fannin County Bank, December 31, 1888.

RESOURCES.

Loans and discounts........... \$77,843

Overdrafts.................. $\quad \mathbf{5 , 4 2 0}$

Advances on cotton............ $\quad \mathbf{7 9 , 6 0 1}$

Real estate................... 6,442

Bank building and fixtures....... 6,439

Bank stock.................. $\quad 3,000$

Due from banks and bankers.... $\quad \mathbf{5 6 , 5 7 0}$

Cash on hand

Total.

$\$ 302,986$
LIABILITIES.

Capital stock paid in........... $\$ 100,000$

Surplus fund................ 20,000

Undivided earnings............ 1,024

Due other banks............. 1,482

Deposits.................... 180,480

Total.................\$302,986

Semi-Annual Statement of the Condition of the Fannin County Bank, June 3, 1898.

RESOURCES.

Loans and overdrafts..........\$176,860

Bank building and fixtures...... $\quad 6,792$

Other real estate............... 4,842

Stocks and bonds............... $\quad 4,075$

Cash and exchange....,........ 179,810

Total.
LIABILITIES.

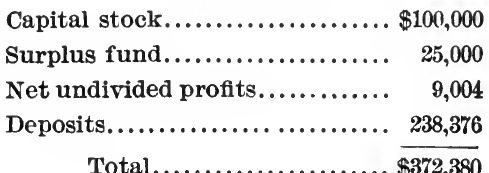

In justice to the bank it may be said that this statement is endorsed under oath by the President, as being the forty-ninth semi-annual statement filed, though not half that number are on evidence in the Secretary of State's office. The Fannin County State Bank became a National bank January 1, 1899, having at that date completed twenty-five years of active business life under its old State charter. Thus the last of the State banks in any way officially known at the capitol has ceased to exist as such.

Of the old banking concerns put on foot so many years before the war, local historians state that the Commercial and Agricultural Bank was chartered for but twenty years, and ran its course in that time, Messrs. McKinney and Williams subsquently devoting their attention to other financial enterprises and leaving each a reputation closely interwoven with the history of the State.

When the Civil War came upon the country the great commercial house of R. \& D. G. Mills had substantially diverted their large means away from the banking channel of finances, and the crisis of the nation found them with immense landed possessions and the owners of over a thousand slaves. From thenceforth they figure no more in the banking fields of Texas.

Immediately prior to the war the demands for exchange were filled by the large commercial houses, many of which were in fact virtually private banks. Most of the exchange at this period seems to have been drawn on John H. Brower, of New York, and the heaviest drafts were 
undoubtedly made by B. A. Shepard, of Houston, and S. M. Swenson, of Austin. Mr. Swenson afterwards removed to New York, where he died in 1896, leaving an estate valued at about $\$ 15,000,000$.

B. A. Shepard subsequently became a prominent private banker in Houston, one of the foremost, in fact, in the State, and is still regarded as a Nestor in the financial history of Texas.

Among the banks now existing, the First National Bank of Houston and the First National Bank of Galveston appear to divide honors in the record for antiquity, and the bank of Ball, Hutchings \& Co., of Galveston, also ranks among the celebrated financial institutions of the State.

After the Civil War the banking history of Texas differed but little from that of other States. In recent years National banks have multiplied, and among the numerous private banks which have come into existence are quite a number styling themselves Savings banks.

There is no way of getting statistics of these institutions. The State takes no official cognizance of them, and no public reports are required from them.

There are one hundred and ninety-three National banks in the State. The Comptroller of the Currency reports that these banks have aggregate resources of $\$ 86,841,755.26$.

State Banks.

\begin{tabular}{|c|c|c|c|c|c|c|}
\hline YEARS. & 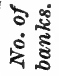 & $\begin{array}{l}\text { Loans and } \\
\text { discounts. }\end{array}$ & Specie. & Capital stock. & Circulation. & Deposits. \\
\hline $1875 \ldots$ & 5 & $\$ 422,106$ & ............. & $\$ 306,443$ & ............ & $\$ 436,632$ \\
\hline $1880 \ldots \ldots \ldots \ldots$ & 5 & 845,139 & ............ & 630,000 & ............ & 759,105 \\
\hline $1887 \ldots \ldots \ldots \ldots$ & 9 & $1,444,712$ & & 761,098 & ............. & 976,851 \\
\hline $1892 \ldots \ldots \ldots \ldots$ & 4 & 798,255 & ............ & 450,000 & ............ & 662,940 \\
\hline $1897 \ldots . . . . . . .$. & 4 & 811,513 & .............. & 450,000 & ............. & 646,931 \\
\hline
\end{tabular}

National Banks.

Figures are in thousands of dollars.

\begin{tabular}{|c|c|c|c|c|c|c|c|c|c|}
\hline YEARS. & 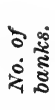 & $\begin{array}{c}\text { Loans } \\
\text { and dis- } \\
\text { counts. }\end{array}$ & $\begin{array}{c}U . S . \\
\text { bonds. }\end{array}$ & $\begin{array}{c}\text { Cash and } \\
\text { cash items. }\end{array}$ & Capital. & Surplus. & $\begin{array}{c}\text { Undi. } \\
\text { vided } \\
\text { profts. }\end{array}$ & $\begin{array}{c}\text { out. } \\
\text { standing } \\
\text { circula. } \\
\text { tion. }\end{array}$ & $\begin{array}{c}\text { Indi. } \\
\text { vidual } \\
\text { deposits. }\end{array}$ \\
\hline $1866 \ldots . .$. & 4 & $\$ 209$ & $\$ 439$ & $\$ 439$ & $\$ 428$ & $\$ 4$ & $\$ 36$ & $\$ 170$ & $\$ 626$ \\
\hline $1873 \ldots . .$. & 7 & 1,180 & 1,025 & 699 & 925 & 180 & 79 & 670 & 1,044 \\
\hline $1878 \ldots . .$. & 11 & 1,508 & 825 & 687 & 1,050 & 296 & 76 & 533 & 1,516 \\
\hline $1883 \ldots .$. & 43 & 10,099 & 1,927 & 2,200 & 3,652 & 1,049 & 683 & 1,462 & 8,003 \\
\hline $1888 \ldots . .$. & 100 & 24,689 & 3,034 & 4,033 & 11,806 & 2,777 & 1,129 & 2,313 & 15,785 \\
\hline $1893 \ldots . .$. & 222 & 44,828 & 5,549 & 6,064 & 23,596 & 4,938 & 2,332 & 4,611 & 25,748 \\
\hline $1898 \ldots . .$. & 196 & 42,838 & 6,107 & 7,000 & 19,205 & 5,230 & 2,171 & 4,419 & 37,895 \\
\hline
\end{tabular}


ARKANSAS.

The first recorded act of the first Legislature of the State of Arkansas, passed in 1836, and approved by Governor J. S. Conway, October 26 of the same year, appears upon the statutes as "an act to establish the Real Estate Bank of the State of Arkansas."

The law provided that the bank should have an "original" eash capital of $\$ 2,000,000$, and as the State had no such fabulous sum to start the business with, it was arranged that the amount should be raised by loans or negotiations on the security of real estate at its cash value, with the guarantee of the public credit, in the issuance of $\$ 2,000,000$ bonds by the State in favor of the bank and transferable by the endorsement of the bank President and Cashier. These bonds were supposed to be paid by the bank, but the State was their surety.

There was to be established a principal office in Little Rock, and branches in Washington, Columbia and Helena.

All citizens of the State, bona fide land owners, were eligible to subscribe for the stock, their subseriptions to be secured by mortgage and bond at least equal to the stock subscribed. Subscriptions were limited to 300 shares, and subscribers were entitled to a credit of one-half the amount of stock subscribed for by each.

Subscription books were to be opened the following March for $\$ 2,250$,000 of stock in shares of $\$ 100$ each, to be divided equally between the head and branch offices.

The subscription books being closed the Governor was to appoint two directors and the stockholders to elect seven directors at each of the four bank locations, the terms of office being annual. One of the appointed and one of the elected directors of each bank, with the several Presidents, duly elected, should constitute a central board to meet in Little Rock and take charge of the business of the institution. And thus was the lumbering machine put in motion.

\section{Bank of the State of Arkansas Incorporated.}

It will be noticed that an excess stock of $\$ 250,000$ was opened on the books and subscriptions were taken at other than the banking centers. This may be accounted for by the second act of the same Legislature. This measure was an act to incorporate the Bank of the State of Arkansas, at Little Rock, with branches at Fayetteville and Batesville, the capital stock to be $\$ 1,000,000$, to be raised by the sale of State bonds, loans or negotiations together with such other funds as " may now or hereafter belong to or be placed under the control and direction of the State."

This bank was to be conducted by a President and twelve directors to be appointed by joint vote of the Legislature.

The bank was also authorized to deal in bullion, gold and silver coin 
and do a general bank and exchange business. Notes, bills, or liabilities were to be issued as soon as $\$ 50,000$ had been paid into the vaults, and all loans were limited to $\$ 10,000$ to each borrower.

Out of the bonds issued by the State in aid of the State Bank came the notorious "Holford bond" question, which vexed the State for many years. These bonds were hypothecated by the bank to the Ohio Valley Trust Co., of Cincinnati, $\$ 1,000,000$ of bonds being passed as security for a loan of $\$ 250,000$. Payment was made on the loan from time to time, until some $\$ 115,000$ had been paid. Meantime the bonds were placed in New York and re-hypothecated, until eventually they lodged in the vaults of the Holfords, of England.

Demand was made for full payment of the face of the bonds and the State resisted. During the rule of the reconstruction element the bonds were taken up and funded, but one of the first acts of legislation after the reconstruction element was ousted was their repudiation in so far as excess of the actual cash benefit derived from them by the original loan.

The Real Estate Bank was organized and authorized to lend its funds upom farm lands as security, and the avenues for looseness of method and laxness of execution, for mistake and confusion, afforded by the plan of its organization could lead to but one result. The careers of both these banks were short and disastrous, as might have been expected, and the extent of disaster was magnified by the brevity of their existence, the wonder being how so much wreck and ruin could have been heaped up in so short a time. In the light of their multiplied follies some good may have been accomplished in the great object lesson they presented to the balance of the world and to future generations, but it was a bitter experience for Arkansas.

After the passing of the State banks and prior to the Civil War there were no individual or other forms of organized deposit banks in the State. Banking enterprise in Arkansas had received a blow from which it was slow to recover. Everything looking to the establishment of a bank was regarded with suspicion and distrust.

At this period such facilities as were of actual necessity in the way of places of deposit, as well as the facilities for furnishing exchange, were supplied by the principal merchants in the leading towns.

The first regular banker in Arkansas was S. H. Tucker, who went into the banking business exclusively in 1865 . His business was located in Little Rock, and with that city he was identified until his death, which occurred in 1894.

Shortly after Mr. Tucker began business for himself in Little Rock, the banking house of Bucksmart \& Co. was started in Pine Bluff, the county seat of Jefferson county. Mr. Tucker was also interested in this concern.

At about this same time John J. Hornor, of Helena, the county seat of Phillips county, and one of the most prosperous towns on the 
Mississippi River, opened a banking office at that place; and then was established the bank of Stoddard Brothers \& Co., of Little Rock.

\section{Beginning and End of a Famous Bank.}

The opening of these banks was followed by the advent of the National banks, with the Merchants' National Bank, of Little Rock, first in the field, and one of the landmarks of the period. Inaugurated in the midst of the corrupt reconstruction regime, it partook of the character of its environments, acquired an unsavory flavor, and as a financial venture on a legitimate basis it was never a success. At one time during its most flourishing period it had but two genuine depositors.

The organization of the First National Bank, of Fort Smith, followed, and in their order the others which have since come upon the field.

The fate of the Merchants' National Bank, of Little Rock, above referred to, is a story of more than ordinary interest and stands out as a prominent point in the financial history of the Southwest.

The business, the name and the enterprise of this bank were taken up by Logan $\mathrm{H}$. Roots, one of the shrewdest and most successful men of the day. He moved it to new and elegant quarters in the business center of the city - and with it went the undesirable reputation it had won under the questionable manipulation of former days.

Realizing what the trouble was, its astute President had it rechristened, and the First National Bank, of Little Rock, was the result. With Logan H. Roots at its head and his brother, P. K. Roots as Cashier, the bank entered upon a career of prosperity which soon made it indeed " the First" National Bank, not only of Little Rock, but of the entire State. The bank progressed and the Roots' wealth multiplied until Logan $\mathrm{H}$. Roots was ranked as a millionaire. Ill-health came and he retired from active control of the bank, and Horace G. Allis took charge.

The new President was of a unique character. He was formerly of Pine Bluff, where he had been in the bank of C. M. Neel. In Little Rock he figured as auditor of the Little Rock and Fort Smith Railroad, then as President of the Gazette Printing Company, and after a brief connection with St. Louis banking interests returned to Little Rock to take charge of the First National Bank there. Various public enterprises engaged his attention, and soon his name was in every mouth, his praises on every tongue:

A man of prepossessing personal appearance, of unquestioned ability and endowed with the dash of a fearless character, whether viewed from a physical or an intellectual standpoint, he rode high on the wave of popularity, and when the crash came the whole country was shaken.

Logan $\mathrm{H}$. Roots died in the midst of a desperate effort to save the shattered bank, leaving his widow possessed, even yet, of great wealth. Horace $G$ Allis retired within Federal walls at Brooklyn, N. Y., and a 
score of prominent Little Rock business men were crippled or went into bankruptcy. The recipient of executive elemency, Horace G. Allis, returned to Little Rock, organized an expedition and disappeared in the snows of Alaska.

\section{State Has No Banking Laws.}

As to banking laws, Arkansas has none. The State has never passed any since its picturesque efforts in 1836 . Of course, there have been frequent attempts, but, fortunately perhaps, none of the aspiring solons have as yet succeeded in engrafting their ambitious efforts upon the statutes of the State. Such attempts have multiplied in recent years and the public lives in suspense whenever one of Arkansas' modern Legislatures convenes.

At present there are eight National banks and ninety-eight State and private banks in the State. With the exception of thirty-four, all these banks have been established within the past ten years. Twenty years ago there were but six banks in the entire State outside of Little Rock, and there were then only three in that city. But four of the banks that were in existence twenty years ago are alive to-day.

There has been organized but one Savings bank in the State-a real Savings bank that has confined its operations to that line of business, and that is the Little Rock Trust Company. With this one exception the banking of the State has been organized along the lines of commercial banks. It is utterly impossible to furnish a detailed statement of the bank business in specified periods, there being no law of any kind to require reports from State or private banks.

There is no clearing-house in the State, though for some time the banks of Little Rock have been giving weekly clearances to the commercial agencies. Neither in the agencies nor in the banks, however, has any record been kept whereby figures can be satisfactorily and quickly secured.

The Little Rock Board of Trade has kept a record of bank clearances since January, 1895. This record shows the clearances for January, $1895, \$ 370,295.89$; balances, $\$ 67,854.03$.

A comparative statement of the Little Rock banking business, compiled from this source is here appended.

\begin{tabular}{|c|c|c|c|c|c|}
\hline \multirow{2}{*}{ FIRST WHEK. } & \multicolumn{2}{|c|}{ CLEARANCES. } & \multicolumn{3}{|c|}{ BALANCES. } \\
\hline & January. & July. & January. & July. & Annual. \\
\hline $1895 \ldots .$. & $\$ 370,295.89$ & $\$ 322,224.85$ & $\$ 67,854.03$ & $\$ 45,908.27$ & $\$ 16,202,706.00$ \\
\hline $1896 \ldots$ & $360,014.67$ & $208,623,23$ & $68,752.23$ & $67,616.20$ & $16,304,815.08$ \\
\hline $1897 \ldots \ldots \ldots \ldots \ldots$ & $331,226.93$ & $266,336.40$ & $59,509.58$ & $33,827.21$ & $16,633,591.53$ \\
\hline $1898 \ldots . . . . . . . . . . .$. & $432,835.68$ & $250,306.66$ & $71,607.70$ & $45,186.42$ & $17,631,462.31$ \\
\hline $1899 \ldots \ldots$. & $395,503.20$ & .............. & $60,002.12$ & ............ & ...................... \\
\hline
\end{tabular}


The banking field in Arkansas to-day is certainly one of which the State may be proud, especially when consideration is had as to the checkered past. There is no State which for its opportunities has more or better banks than Arkansas.

State Banks.

\begin{tabular}{|c|c|c|c|c|c|c|}
\hline YEARS. & 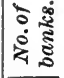 & $\begin{array}{l}\text { Loans and } \\
\text { discounts. }\end{array}$ & Specie. & $\begin{array}{l}\text { Capital } \\
\text { stock. }\end{array}$ & Circulation. & Deposits. \\
\hline $1838 \ldots$ & 3 & $\$ 374,791$ & $\$ 96,455$ & $\$ 413,105$ & $\$ 8,100$ & $\$ 87,242$ \\
\hline $1841 \ldots$. & 10 & $3,838,694$ & 203,813 & $3,532,706$ & 995,905 & 146,018 \\
\hline $1845 \ldots$. & 10 & $2,352,617$ & 35,940 & $3,002,706$ & 410,442 & 140,813 \\
\hline $1875 \ldots$. & 1 & 72,112 & ......... & 50,000 & ............... & 78,246 \\
\hline $1887 \ldots$ & 6 & 510,390 & .......... & 265,000 & ........... & 593,264 \\
\hline $1892 \ldots$. & 28 & $2,320,547$ & ......... & $1,223,894$ & ........... & $2,233,188$ \\
\hline $1897 \ldots . .$. & 32 & $2,785,395$ & ......... & $1,342,995$ & ............ & $2,785,129$ \\
\hline
\end{tabular}

National Banks.

Figures are in thousands of dollars.

\begin{tabular}{|c|c|c|c|c|c|c|c|c|c|}
\hline YEARS. & $\begin{array}{l}\text { व: } \\
\text { : }\end{array}$ & $\begin{array}{c}\text { Loans } \\
\text { and dis. } \\
\text { counts. }\end{array}$ & $\begin{array}{c}U . S . \\
\text { bonds. }\end{array}$ & $\begin{array}{c}\text { Cash } \\
\text { and cash } \\
\text { items. }\end{array}$ & Capital. & Surplus. & $\begin{array}{c}\text { Undi. } \\
\text { vided } \\
\text { profits. }\end{array}$ & 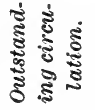 & $\begin{array}{c}\text { Indi- } \\
\text { vidual } \\
\text { deposits. }\end{array}$ \\
\hline $1866 \ldots$ & 2 & $\$ 244$ & $\$ 252$ & $\$ 118$ & $\$ 200$ & $\cdots$ & $\$ 24$ & $\$ 130$ & $\$ 172$ \\
\hline $1873 .$. & 2 & 229 & 255 & 63 & 205 & $\$ 21$ & 19 & 182 & 126 \\
\hline $1878 . \ldots . .$. & 2 & 274 & 326 & 75 & 205 & 32 & 8 & 184 & 250 \\
\hline $1883 . \ldots$. & 5 & 1,103 & 457 & 218 & 455 & 70 & 58 & 297 & 1,097 \\
\hline $1888 \ldots \ldots$. & 7 & 2,768 & 616 & 325 & 950 & 191 & 105 & 369 & 2,180 \\
\hline $1893 . . . . .$. & 9 & 2,194 & 250 & 354 & 1,100 & 380 & 101 & 225 & 1,267 \\
\hline $1898 . .$. & 7 & 2,443 & 317 & 291 & 1,070 & 266 & 71 & 226 & 2,150 \\
\hline
\end{tabular}

\section{KENTUCKY.}

The necessities of the pioneer population were met at first by barter, but little money being in circulation; then some staple product, as in the case of furs, where the coon skin or beaver was taken as the unit of value, and exchanges were made on that basis; later, when agriculture developed, some prime crops became the medium of exchange and unit of value. Inheriting the practice from Virginia, where tobacco was for a long time in the nature of a legal tender, receivable for taxes, church tithes, and the like, it was given the same function in Kentucky; not as in Virginia, by law, but by popular consent and practice. Later, there was a system of depositing tobacco and other non-perishable arti- 
cles not of ready sale in a merchant's warehouse, for which receipts were given. These receipts were assignable and passed readily in the community, serving the function of money. Another form of circulating medium was the land warrant, which, by purchase or service, would be issued by the State for a stated number of acres, to be located upon any of the vacant land of the State. These, being made assignable, passed equally with the warehouse receipts in business transactions, and were, indeed, regarded as superior to them. The amount of specie in circulation was small. The decimal system of Jefferson had been adopted in 1792 , with the silver dollar as the unit, at a ratio to gold of fifteen to one. But this was an overvaluation of silver and had the effect of retiring from circulation, by exportation, the bulk of the coin of that metal, which commanded a higher price as bullion than as currency, and in 1802, by order of the President, the coinage of silver dollars was stopped. The chief coin in circulation was the Spanish milled dollar, with smaller French and English coins and subdivisions of the Spanish dollars, made by cutting into two, four and eight pieces, which had their proportional values in circulation. There was practically no paper money in circulation. The notes or fiat money issued by the general Government had fallen out of circulation from depreciation or retirement, and the result of the issue stood as a menace and a warning against a repetition of such experiment.

\section{The First Incorporated Banks.}

Although the growth of the new State of Kentucky in population, agriculture and trade, demanded corresponding increase in currency, the Legislature of Kentucky gave no encouragement to the establishment of banks, doubtless owing to disasters in European banks, which had shaken confidence in such institutions. The shippers of produce to New Orleans would sell their cargoes and receive bills of exchange on New York. These they would take or send by sea, and with the proceeds buy dry goods or other merchandise to be sent by wagon to Pittsburg and thence by water to Louisville or other towns on the Ohio. Under the guise of establishing an insurance company, for the purpose of insuring the cargoes of the Mississippi against accident and loss, the Legislature passed an act, approved December 6, 1802, incorporating the Kentucky Insurance Company, of Lexington, into the charter of which was clandestinely inserted a clause investing it with banking privileges of the most dangerous character. It was authorized to acquire and hold corporate property to the amount of $\$ 150,000$, to issue stock to the amount of $\$ 100,000$, and to take and give bonds, bills and notes in the course of its business, and receive and pass them by assignment. But the conceived purpose of the bill was, after it became a law, discovered to be the following additional clause : "And such of the notes as are payable to bearer shall be negotiable and assignable by delivery only." 
Thus was established, without due discussion or the adoption of a mature plan with well-guarded provisions against initial errors and subsequent amendments of still graver objection, the first bank of issue and circulation in Kentucky, entailing woes as dire as the most vivid imagination could depict. Not only did the bank-for such it was, despite its misleading name-avail itself of the power to issue its notes payable to bearer, but by an amendment passed two years after obtaining its charter its incorporators were authorized to issue notes "to amount due them, the money in their vaults, the property, real, personal and mixed, they may own, and their capital stock." A more vicious and dangerous system of banking cannot be conceived. The immediate result was to cause a fictitious prosperity, to induce speculation, create large dividends and stimulate the chartering of other banks of equally as great or greater objection.

The old Bank of Kentucky, having no connection with that of the same name now at the head of such institutions in Kentucky, was chartered by an act approved December 7, 1806, and had engrafted upon it features which were even more objectionable than those of its predecessor, in coupling the State with its capital stock and credit as a stockholder and reserving to itself the right to name proportionally the directors, thus making a political as well as a financial institution. The State had agreed to take the notes of the bank for all public dues, but, in 1808, authorized the bank to pay auditors' warrants in specie and charge six per cent. interest on the amounts so disbursed, which operated as a discrimination against the bank paper and injured its credit. The financial erisis which followed the War of 1812 compelled the bank to suspend specie payment and though it resumed in 1815 and continued in excellent credit, in the meantime the suspension led to further tinkering by the Legislature, which only made matters worse for the people. The Legislature authorized an increase of its capital stock to $\$ 3,000,000$, and, in 1815 , authorized any debtor to replevy his debt for one year if his creditor refused to take his pay in the notes of the suspended bank.

\section{Bad Effects of the Stay Laws.}

This was the beginning of that unfortunate legislation designed to protect debtors from the payment of creditors which, for ten or twelve years, plunged the State into the most disastrous financial complication, bankrupted her citizens by the thcusands and produced the most violent political agitation. The staying of debts, the effort to protect debtors from their creditors, became the dividing question between political parties, and led to the formation of a new Court of Appeals, contending with the old for jurisdiction and precedence, and for a time threatened to involve the people in a fratricidal war. Before the storm culminated, the theory of fiat money, of making money valuable by making it abundant, was pushed to its extreme experimental issue, and 
its results should be a warning to all modern theorists who contend that Congress or the State can create money, or that something can be made out of nothing.

At the time of the chartering of the insurance company, previously mentioned, there was much hostility to banks, and if it had been publicly declared that the charter was to permit the incorporation of an institution with banking powers it could not have been got through the Legislature.* By 1804 the oversight had been discovered. Public attention was concentrated on the institution by the fact of its paying eight per cent. semi-annual dividends, which fact caused its stockholders and supporters to be denounced as a moneyed aristocracy. In that year an effort was made to repeal its banking privileges, but the bill to this effect was vetoed by the Governor. Its right, under its charter, extended until 1818, but in 1806, the Legislature chartered the Bank of Kentucky + with a capital of $\$ 1,000,000$. The banking powers of the insurance company were interfered with and finally superseded by this new institution, which, having virtually a monopoly of the banking business within the State, was in good credit, paid liberal dividends and in its turn incurred the hatred of those who looked upon its prosperity as a symptom of aristocracy, incompatible with republican institutions.

In 1817-18 the feeling against permitting this institution to continue longer to enjoy its monopoly took tangible form, and forty independent banks were chartered with a capital of $\$ 10,000,000$, and with power to issue their notes, payable on demand, over and above the specie in their own vaults, to an amount equal to three times their capital stock, less their indebtedness, and were permitted to redeem their notes in the paper of the Bank of Kentucky. These charters were issued on January 26, 1818, but in November of the same year a pressure for specie on the part of the Bank of the United States caused them all, including the Bank of Kentucky, to suspend specie payments. The directors of the newly created banks were, it is said, men destitute of experience or knowledge of financial affairs, and in some instances devoid of common honesty. During the summer of 1818 the State had been flooded with their paper. The tendency to speculation, rife at this time, was encouraged by the facility with which loans could be obtained. The money was expended in all kinds of rash enterprises, and the action of the Bank of the United States, rendered necessary by its own instinct of self-preservation in calling in its loans and presenting bills for redemption in specie, gave the impulse which caused these banks to collapse like bubbles, carrying with them the speculations based on their issues. As an indication that the weakness of the newly chartered banks had more to do with their failure than the severity of the pres-

* A contrary opinion is expressed by Gen. Basil W. Duke in his "History of the Bank of Kentucky."

+ This was not the present Bank of Kentucky, but an earlier institution of that name, and known as the "first" or "old" Bank of Kentucky. 
sure, the Bank of Kentucky resumed on December 10. The amount of specie drawn from the Ohio banks, as stated in a contemporary letter during the year preceding June 26, 1819, was about $\$ 800,000$. The branch bank at Cincinnati called upon the local banks for payment of loans amounting to $\$ 700,000$, in installments of twenty per cent. every twenty days. The effect of the financial crisis was that every one was in debt and means of payment difficult to obtain. In February, 1819, the charter of the Bank of Kentucky was extended to 1841, and on December 16 of that year an act of relief was passed over the Governor's veto to suspend sales under executions for sixty days, and subsequent acts extended the right of replevying property taken under execution to two years. The pressure became greater and there was a public outcry for relief.

\section{Bank of the Commoniwalth Chartered.}

The Legislature of 1820-21, to afford the relief so generally demanded, on November 29, 1820, chartered the Bank of the Commonwealth of the State of Kentucky, with a capital of $\$ 2,000,000$ and with branehes in each judicial district. It was popularly known as the People's Bank, and a supplemental act, December 22, 1820, authorized the bank to issue circulating notes to the extent of $\$ 3,000,000$. The public faith was pledged for the redemption of its circulation and certain bonds south of the Tennessee River were set aside as a guarantee fund. This paper was not made a legal tender, but was made payable and receivable for all public debts, dues and taxes; and if a creditor refused to receive its bills he became exposed to the operation of the replevin or stay law. The notes were issued by twelve trustees. They were to be loaned out to the citizens, but the loans to single individuals were limited to $\$ 2,000$. One-half of the clear profits of the bank was set apart as an educational fund and one-half of the profits of each branch was devoted to the use of some educational institution in the district in which the branch was located. At the time of the establishment of the Bank of the Commonwealth the Bank of Kentucky was in good condition, well managed, paying its notes in specie and its stock was at par. By the terms of its charter the right was reserved to the Legislature of electing such number of directors as would insure the control of the board. Fearing that the experienced and eonservative President and board of directors, who had hitherto so prudently managed the Bank of Kentucky, might feel it their duty to reject the issues of the new institution, the Legislature exercised its right and superseded the old board by men pledged to receive the notes of the new bank for debts due the Bank of Kentucky. This action effected the ruin of the latter bank, depreciating its stock fifty per cent. and compelling it to suspend spccie payments. Its charter was finally repealed by the Legislature on December 5,1822 , at the same time that it annulled the charters of the banks created in 1817. 
By March 22, 1822, the notes of the Bank of the Commonwealth had fallen to $62 \frac{1}{2}$ cents on the dollar, and they continued to fall in value until they passed at a small fraction of their face value, and creditors were left to accept a fraction of their debts in full payment or go without payment for two years, running the risk of new delays and the bankruptey of their securities. The question of the constitutionality of the stay law came in the meantime before the courts. The judiciary of the State were not affected by the popular feeling which had forced the Legislature to enact these measures, and the decision of Judge James Clarke, of the lower court, was against the constitutionality of the replevin feature of the law which the court held interfered with the validity of contracts. This decision raised a storm of popular fury and the case was varried to the Court of Appeals, where Judge Clarke's decision was sustained. The contest finally led to the passage of a law repealing the act under which the Court of Appeals was created and the constitution of a new court, but the authority of the old court was ultimately established. On February 11, 1829, notes of the Bank of the Commonwealth to the amount of $\$ 300,000$ were, by order of the Legislature, publicly burnt at Frankfort.

In connection with the Bank of the Commonwealth of Kentucky the question, whether the bills of this bank were such bills of credit as are forbidden by that clause of the Constitution of the United States which provides that States shall not emit bills of credit, came before the United States Supreme Court. The charter of the bank provided that it snould be established in the name and in oehalf of the Commonwealth of Kentucky and should be under the direction of a President and twelve directors to be chosen by the Legislature, and moreover, that it should be exclusively the property of the Commonwealth. The Supreme Court had, in Craig vs. State of Missouri, previously decided that bills of the State of Missouri, issued through loan offices were unconstitutional; a creature of the State, with a capital subscribed solely by the State and managed by State officers, nust come under the same rule. Further, all the profits on the authorized issue of $\$ 3,000,000$ of circulating notes were to accrue to the State. The question arose in a suit brought by the bank to collect a promissory note which had been discounted in bills of the bank, the defense being no consideration given for the note, inasmuch as the alleged consideration was in bills of the bank, which were in effect bills of credit issued by the State, and therefore unconstitutional and void. It was further insisted that the act of the Legislature incorporating the bank was similarly defective. The lower court decided in favor of the bank, and the defendants appealed to the Supreme Court of the United States, where it was held that the act incorporating the bank was not unconstitutional, and that the notes issued by the institution were not bills of credit of the State.

After the liquidation of the Pank of Kentucky and Bank of the 
Commonwealth of Kentucky, the State had to depend for paper money on the notes of the branches of the Bank of the United States at Lexington and Louisville, and the bills of banks located outside its borders. The Democratic party was then dominant in Kentucky and had every confidence that Jackson would prove victorious in his contest with the Bank of the United States and that the National bank would fail to obtain a renewal of its charter. In anticipation of the withdrawal from the field of the United States Bank the Legislature determined to establish State banks to supply the place of that institution. In the session of 1833-34 charters were granted to three banks-a new Bank of Kentucky with a capital of $\$ 5,000,000$, the Northern Bank of Kentucky with a capital of $\$ 3,000,000$, and the Bank of Louisville with a capital of $\$ 5,000,000-\$ 13,000,000$ possible capital in all, although the actual aggregate paid-in capital never exceeded $\$ 9,030,000$. It is stated that $\$ 1,150,-$ 000 of the capital of the Bank of Louisville was subscribed in four days, two-thirds of it by Eastern capitalists. The Bank of Kentucky was to have six branches, and of its capital of five millions the State was to subscribe one million in five per cent. bonds, payable at the pleasure of the State after thirty years, and one million more to be made up from the accumulation of annual dividends, unless the State should choose to pay it in sooner. The State tax on the banks was to be not less than twenty-five nor more than fifty cents per share. It appears to have been fixed at forty cents in 1834. About this time the removal of the Government deposits from the Bank of the United States began to be felt, and the Kentucky banks appear to have received their proportion of the deposits of public money made with the State banks.

\section{Suspension of Specie Payments in 1837.}

The share of Kentucky in the surplus revenue distribution authorized by the act of Congress of June 23,1836 , was nearly $\$ 2,000,000$, but three installments only amounting to about $\$ 1,500,000$ were received. The Legislature, in February, 1837, decreed that this money should be distributed among the three banks for the benefit of the State on certain conditions, the profits being set aside for educational purposes. In May of that year the financial pressure became so great from the drain on the depository banks to pay the installments of the surplus revenue that the banks began to suspend specie payments. Up to May 8 there were 352 suspensions and business failures in New York alone. Stock of the State of New York went down to seventy, and New England Bank stock to ninety-six. On May 9, 10 and 11, the banks of New York, Philadelphia and Baltimore suspended. The banks of Pittsburg and Cincinnati followed suit. On May 18 a run commenced on the banks at Louisville and $\$ 45,000$ was drawn out on that day. The next day the Kentucky banks suspended, although having $\$ 1,900,000$ in specie against $\$ 3,300,000$ in circulation. Inasmuch as the United States moneys drawn from the Kentucky banks to pay the installments of surplus 
were redeposited with them by act of Legislature, they did not suffer so much on this account as banks in other States. The suspension of specie payments caused scarcity of small change and scrip and shin plasters of small denominations were issued by towns, corporations and individuals. Among others, the Maysville City Council issued several thousand dollars of scrip in denominations of 61 cents, $12 \frac{1}{2}$ cents, twenty-five cents, fifty cents and $\$ 1$, redeemable in bank notes in amounts of $\$ 5$.

The State was at this time in the midst of a scheme of internal improvements, upon which about $\$ 1,000,000$ was being spent annually. The people generally were involved in private speculations, based upon the idea that the then buoyant prices would be permanent, and both public and private credit had been strained to the utmost.*

Although by the terms of their incorporation the Kentucky banks by their suspension of specie payments forfeited their charters, the Legislature legalized their acts and did not interfere with them. Many of the suspended banks soon resumed payments, those in Kentucky in August, 1838, but in October all again suspended. Specie was at a premium of from eight to eleven cents, but small change was plentiful in Kentucky, dimes and half-dimes readily passing for $12 \frac{1}{8}$ and 61 cents. During the year the Kentucky banks lost $\$ 505,000$ in specie and the Bank of Kentucky suffered through the action of the Schuylkill Bank, of Philadelphia, which as agent of the Kentucky bank issued $\$ 1,299$,700 of its stock without authority and without return. To meet this loss the Legislature authorized the bank to set aside all individual profits, all future earnings over amount required to pay five per cent. dividends, and all amounts which might be recovered from the Schuylkill Bank. Against the latter bank a judgment of $\$ 1,300,000$ was eventually recovered, but as the total assets of the concern did not exceed $\$ 400,000$ the total loss was not far from $\$ 1,000,000$. There was another general suspension in 1839 , with the exception of a few banks in the East. In 1842 the Kentucky banks resumed specie payments, at which time their aggregate circulation was $\$ 2,800,000$, which was gradually extended until in 1850 it had reached $\$ 6,683,000$.

The latter part of 1841 and the year 1842 marked a period of great financial distress in the State, and heavy sacrifices of property were made during the forced liquidation of debts. Efforts to re-establish a Bank of the Commonwealth were defeated, though the existing banks were required to extend relief. By the close of 1844 prosperity had returned to the business interests of the State.

In 1838 the Southern Bank of Kentucky was chartered by the Legislature with a capital of $\$ 2,000,000$, of which a certain portion was required to be subscribed before the bank could commence operations. The financial difficulties of that period prevented the obtaining of the necessary subscriptions, and although in 1842 the Legislature reduced 
the amount of the requirement the charter remained in abeyance until 1852, when it was amended and the bank went into operation with a eapital of $\$ 1,300,000$. Four other banks with large capitals were at this time chartered by the State, of which two failed in 1854. In its session of that year the Legislature proposed to incorporate six new banks, but one bill having been vetoed by the Governor the others were not pressed. In addition to the chartered banks there seem to have been other banking institutions in operation in Kentucky. Including chartered banks, twenty-seven failed in 1854, but in 1856 there were thirty-four banks and branches still in operation.

\section{History OF THE BANK OF KentuCKY.}

Of the three large banks chartered by the Legislature of 1833-34 only one is now in existence-the Bank of Kentucky. The Northern Bank of Kentucky went into liquidation in 1898, and in 1899 the Bank of Louisville was merged into the Southern National Bank. High taxes in recent years had greatly impaired the ability of these institutions to earn satisfactory dividends. The Bank of Kentucky now has (1899) $\$ 1,645,000$ capital and $\$ 1,103,000$ surplus. This institution was chartered February 22, 1834, for thirty years, with $\$ 5,000,000$ capital, and by the act of February 15, 1858, the charter was extended twenty years, and for a further period of twenty-five years on October 1, 1884. By the act of Mareh 8, 1843, the stock of the Commonwealth was reduced from $\$ 2,000,000$ to $\$ 1,000,000$, and by legislative permission in 1842 and 1861 the capital stock, exclusive of that paid for by the Commonwealth, first to the sum of $\$ 3,700,000$ and subsequently to $\$ 3,000,000$. The bank was organized in January, 1835, and bought from the branch bank of the United States in Louisville the house in which it has ever since conducted its business. It was the first building erected by the Federal Government in Louisville.

Subscriptions of stock by the Commonwealth were to be paid in installments by the issue of bonds or scrip, the bank being required to redeem them without charge, out of its dues to the State. Business was. to be commenced when $\$ 300,000$ in gold and silver had been paid in. The powers and duties of the institution were defined in the second section of the charter, and were such as were usually granted to banking corporations. In addition to the head office at Louisville six offices. were provided for, and additional branches were allowed by subsequent legislation. Notes were restricted at first to denominations of $\$ 5$, but in 1843 and 1848 power was given to issue bills of a less denomination; the right was prohibited in 1858, but was again granted in 1861. By the act of 1858 the circulation was restricted to the amount of paid-in capital.

Section five of the charter provided that the bank should not at any time "suspend, fail, or refuse payment in gold or silver of any of its notes, bills, or other obligations due or payable or any moneys on de- 
posit," on penalty of forfeiture of its corporate privileges. But like other banks it suspended in 1837, and the Legislature relieved it of the penalty incurred.

The management of the bank was intrusted to a board of eleven directors, eight of whom represented the stockholders and three the Commonwealth of Kentucky, the latter appointed by the Governor. The President and directors were authorized to appoint a Cashier and nine directors for each of the branches; but the directors of the branches were given authority to choose one of their own body as President and to appoint a clerk and such other officers as the President and directors of the principal bank might direct. No dividends were to be declared until there had been accumulated a surplus of $\$ 20,000$ for each million dollars of the capital of the bank actually paid in, and the surplus or contingent fund was never to be reduced below that ratio on all stock paid for. Dividends of the profits over and above this contingent fund were to be declared at the principal bank on the first Monday in January and July of each year.

While the amount of capital to be employed at the principal bank and branches was to be under control of the directors, it was provided that not more than two-fifths of the paid-in capital should be employed at Louisville unless authorized by the Legislature, and the bonds or scrip paid in by the Commonwealth should not under this provision be considered as capital paid in until sold and the cash received by the bank. The first $\$ 500,000$ paid in by individuals, companies and corporations might lawfully be employed as banking capital in the city of Louisville, the residue as paid in to be employed in the establishment of branches until three-fifths of all the capital stock paid in should be employed in the branches, and thereafter three-fifths of what should be paid in was to be used at the branches, and the remainder in the principal bank.

Taxation was to be twenty-five cents on each one hundred dollars of paid-in stock, payable on the first of July in each year. This was to be in full of all tax or bonus. The Legislature might increase or diminish the tax, but it was not at any time to be fixed at an amount greater than fifty cents on each $\$ 100$ of paid-in capital.

On January 26, 1835, John I. Jacob was elected President, and George L. Gwathmey, Cashier. Mr. Jacob was President of the branch Bank of the United States at Louisville at the date of the expiration of the charter of the parent institution. On June 17, at the request of the directors, the President submitted a report outlining the policy of the bank. He favored a careful restriction of circulation and advocated the distribution of loans among as large a number of punctual and solvent persons as practicable.

The circulation of the notes at this time appears to have been confined to the State and to Pittsburg, Wheeling, Cincinnati, Madison and partially through Indiana. Such notes as circulated in the East had a 
constant tendency to return to the parent bank for redemption in specie or eastern funds. In view of this the President recommended that the resources of the bank should be kept in an available condition.

A dividend of four per cent. was declared on July 4, 1836, although the country was then on the verge of the crisis which culminated in the following year.

\section{General Inflation of Bank Circulation.}

The period immediately preceding the crisis of 1837 was one of inflation, the circulation of the State banks having risen from $\$ 61,000,000$ in 1830 to $\$ 149,000,000$ in 1837 . In former years a restrictive influence had been exercised by the Bank of the United States, but this institution was now itself near its impending end. There was up to this time but little effective legislative restraint upon inflation. In New England a wholesome check was exercised by the operations of the Suffolk system of redemption. By section four of the charter of the Bank of Kentucky, and similar regulations in the charters of other banks incorporated by the Legislature, it was provided "that said banks shall not at any time owe, whether by bond, bill, note or other contract, an amount exceeding twice the amount of the capital actually paid in, exclusive of sums due on deposit," but a large margin was yet permitted by this provision for an issue of notes which, in periods of stringency, might be in excess of the capacity to convert them into specie.

The bank at this period rendered substantial assistance to a number of public improvement enterprises. On April 14, 1837, Mr. Jacob resigned as President, and James Guthrie was appointed for the unexpired term. At the succeding annual election W. H. Pope was elected.

On May 6,1837 , the circulation of the principal bank was $\$ 2,430$,000 and that of the branches $\$ 1,505,000$. Though the Kentucky banks suspended on May 19, they had at the time about $\$ 1,900,000$ in specie against $\$ 3,300,000$ in circulation and might have resisted suspension for several months. A policy of curtailment was adopted and it was decided by the Bank of Kentucky not to purchase bills of exchange on any point without the State of Kentucky, nor to receive, except in payment of debts, any notes of banks outside the State. After the storm had passed these restrictions were relaxed and the bank began to extend its usual accommodations. On February 28, a resolution was adopted to the effect that the notes under discount and bills of exchange should not exceed $\$ 6,000,000$, and that the business of the branches should not then exceed : 
On August 13, 1838, the Kentucky banks resumed specie payment. Financial troubles again arose in 1839, and on October 16 there was another general suspension, resumption not taking place until June, 1842. As usual the banks were relieved from the penalty incurred by their suspension.

The transfer agency of the Bank of Kentucky at Philadelphia was changed on July 30,1839, from the Schuylkill Bank to the Bank of the United States. While acting as transfer agent there had been issued from the Schuylkill Bank spurious and fictitious stock of the Bank of Kentucky to the amount in nominal value of $\$ 1,250,000$. There was long litigation over this transaction, the Bank of Kentucky finally recovering a judgment for $\$ 1,343,000$, but as the assets of the Schuylkill Bank were only $\$ 430,000$ it lost about $\$ 1,000,000$.

Though these losses caused a heavy depreciation for a time in the bank's stock, it rose again to a premium in a few years. This was largely due to the energetic and skillful management of Virgil McKnight, who was elected President in 1840. While occupying this position he made it a rule never to lend money without full knowledge of the purposes for which it was to be used. It was not enough for him to know that the collateral was ample to secure the loan.

The act of March 8, 1843, relieving the bank from the penalty incurred by suspension of specie payments, contained a provision requiring the bank to make certain loans to citizens in each of the ten Congress districts. These conditions were accepted. Also in accordance with the act the bank in that year surrendered $\$ 1,000,000$ of bonds to the State and reduced its capital by a like sum. The number of directors was reduced to eight, six to be chosen by the stockholders and two appointed by the State.

On May 21, 1846, the bank advanced $\$ 25,000$ to the Governor to be used in transporting State troops for service in the war against Mexico.

The bank now began to experience great prosperity, resulting from good management and the improved business conditions.

At a meeting of the stockholders in June, 1858, the provisions of the act of February 15, 1858, extending the charter of the bank for twenty years from October 1, 1864, were accepted. A branch of the bank was established at Hickman by resolution of April 19, 1859, with $\$ 150,000$ capital.

The panic of 1857 , which was severe in many parts of the country, and which caused great alarm in Kentucky, produced no ill effects on the banks, all of them continuing to pay in specie even after the New York banks had suspended.

\section{Proposed Increase of Circulation.}

A communication from the Legislature dated January 21, 1861, was addressed to the President of the bank, stating that the committee by which it had been signed had been instructed "to communicate with 
the banking institutions of the State in order to ascertain whether or not any legislative action is necessary to enable the said banks to furnish to the community a larger circulating medium," and requested the opinion of the officials of the Bank of Kentucky on that subject.

In the absence of the President two directors were appointed to represent the bank. They reported that the probable circulation of the banks was then about $\$ 8,000,000$. They estimated that the entire bank circulation of the United States was $\$ 180,000,000$, and assuming that Kentucky was entitled to one-thirtieth of this, "she has already a larger currency than her share." The bank circulation of Kentucky was far in excess of that of either Indiana or Ohio, though each of these States exceeded Kentucky in population and wealth. Tennessee, about on a par with Kentucky in these respects, had but $\$ 3,000,000$ of bank circulation. The directors of the bank further said:

"From these comparisons we draw the inference that Kentucky now has as large a circulating medium as can be kept afloat, and that any attempt to increase its volume must result in its rapid return to the banks for redemption in gold. The foregoing inference is fully confirmed by the actual bank movement of the present season. During the fall months this bank discounted paper and bought bills with much liberality. We presume all the other banks of the State did the same. Our circulation, in consequence, for a time ran up with rapidity. But the notes would not stay out; they soon began to pour back faster than they had been issued, and in spite of our utmost efforts the circulation of this State is now at a lower point than at any time since the panic of 1857 . The present contraction inflicting such severe pressure on the public is therefore in no degree due to an unwillingness on our part to increase our issues, but has followed persistent efforts to increase them."

Regarding the measures proposed for relief, which were substantially confined to the suspension of specie payments and an increase of banking capital, the directors said:

"Of suspension an immediate and disastrous result would be the destruction of the high credit that our money now enjoys in the neighboring States, and its instant return for redemption in some shape. This redemption, which could not be refused without ruinous depreciation, would hamper the banks, exhaust their immediate resources, and paralyze further efforts to relieve home necessities. * * *

Secondly, will an increase of banking capital enlarge the circulating medium of the State? Political economy teaches that the volume of a currency which a country can sustain is not an accidental or unlimited quantity, but is controlled by economic laws, and depends on the public wealth, credit, industry, commercial activity, and other productive forces. Of course, whenever the circulating medium consists in part of credit in the shape of paper money, an adequate capital as well as skillful and honest bank management are requisite bases on which the public confidence may repose. But these bases being granted, the amount of money that can be kept in circulation will depend on the circumstances above enumerated.

A comparative statement of the banking capital and circulation of this State for some of the last years will illustrate our position :

$185 \%$.

Capital............ \$10,433,400

Circulation.......... 13,485,585
1859.

$\$ 12,141,725$

$14,345,696$
1860.

$\$ 12,660,670 \quad \$ 13,429,725$

$13,520,207$
1861.

$10,26 \%, 202$ 
Comparing 1861 with 1857 :

Capital has increased.............................. \$2,996,325

Circulation has decreased........................ 3,218,383

Compared with 1859 :

Capital has increased............................. \$1,288,000

Circulation has decreased....................... 4,078,494

Compared with 1860:

Capital has increased........................... \$ \$69,055

Circulation has decreased........................ 3,253,005

Proving that in this State the increase of banking capital has not enlarged the circulating medium. The statistics of other communities exhibit the same results.

We think there is no further legislation needed in regard to the increase of the circulating medium."

\section{Disturbances Incident to the Civil War.}

In October, 1861, the Legislature authorized any principal bank to suspend temporarily any branch when from the proximity of the invaders of the State it was considered unsafe to continue business. The banks of issue having consented to loan to the citizens of the State $\$ 1,000,000$, to be governed by the act of 1843 , the Legislature passed an act on $M a r c h ~ 8,1862$, relieving the banks from the penalties for suspension of specie payments and authorizing them to pay out United States legal-tender notes.

The banks of the State having agreed to loan the Military Board of the State $\$ 2,000,000$ in amounts proportionate to their respective capital, the directors of the Bank of Kentucky, on October 11, 1861, placed $\$ 300,000$ to the credit of the State Treasurer for the use of the board. Owing to the disturbances incident to the war several branches of the bank were closed, and in January, 1866, a resolution was passed to discontinue all branches except the one at Frankfort, and this policy was carried out in three or four years. The bank ceased to perform the functions of a bank of issue with the taking effect of the act imposing a tax of ten per cent. on State bank circulation. In $1872 \mathrm{Mr}$. McKnight was succeeded as President by Henry A. Griswold, and a resolution was adopted in 1872 to invest the surplus in United States bonds. $\mathbf{M r}$. Griswold died on December 30, 1872, and in May of the following year Thomas L. Barret was elected to succeed him as President.

The effects of the panic of 1873 were severely felt in Louisville and elsewhere, but President Barret opposed the suspension of currency payments by the bank. On September 29 he submitted a statement of the condition of the bank, with an expression of his full confidence in its ability to pay all claims against it, and "its clear duty not to suspend payment of anything or in any respect.".

This sketch of the Bank of Kentucky would be incomplete without mention of its colored porter and messenger, Carey Logan. He entered the service of the bank in 1841, being then a slave, and outlived every 
officer and director connected with it at that date. He was devoted to the institution and his pride in it knew no bounds. The only occasion on which he was known to murmur was when the offices of the bank: were being altered and improved. The old man then shook his head and muttered disapproval of modern innovation. In 1892, at the age of eighty years, he was incapacitated for service, but he was continued on the pay roll of the bank, and in addition the President was authorized to pay fifty dollars a month for his comfortable support. The resolutions spread upon the minutes of the bank at his death, which occurred December 21, 1893, contain the following tribute :

"It is a remarkable fact and worthy of official record, that although he conld neither read nor write, yet for years prior to the organization of the clearing-house, he, as the bank's messenger, collected from other banks and merchants of the city money, checks and drafts in amounts aggregating millions of dollars, without the loss of a cent to the bank or a mistake of any kind which was ever discovered."

The foregoing facts in relation to the Bank of Kentucky are from an interesting "History of the Bank of Kentucky," by Gen. Basil W. Duke.

\section{The Louisville Clearing-House-Crisis of 1890.}

The Louisville Clearing-House was organized November 24, 1875, and began operations January 3, 1876. In the summer of 1890 the usual monetary stringency caused by the demand for currency to move the crops was considerably increased by the extraordinary volume of products in that year, especially the cotton crop, which was the largest ever grown in America, and was aggravated by some popular apprehension due to changes in the tariff schedule. While nothing in the nature of a financial panic was the result, there was yet much uneasiness entertained by banks and business men generally, and precaution was deemed necessary to avert possible disaster. The banking institutions of Louisville united through the clearing-house association, and at a meeting on December 6, 1890, a resolution was unanimously adopted for the appointment of a committee to pass on applications for relief and to extend such aid as might be deemed expedient, all the banks binding themselves to make good any loss that might ultimately result from accommodation afforded, in proportion as their respective capital, surplus and deposits bore to the aggregate loss. This resolution had immediately the effect intended, and all apprehension in Louisville was quieted. It unquestionably contributed very largely to restore confidence in Kentucky and the neighboring Southern States.

While the monetary stringency of 1890 soon passed away, it resulted in a good many financial disasters to Louisville. A number of large commercial and manufacturing concerns were forced to the wall, resulting in the failure of the Falls City Bank, the Masonic Savings Bank and the private banking house of Theodore Schwartz \& Co., the two latter the most disastrous failures and more widespread in their effects than any that ever occurred in the history of the city. 


\section{New Tax Law Becomes Operative.}

In May, 1886, the new tax law on banking capital, known as the Hewitt law, went into effect. Prior to that time banks paid a tax into the State Treasury of fifty cents on each one hundred dollars of stock held and paid for in such institutions, which was in full of all tax or bonus, and became a part of the sinking fund of the Commonwealth. The Hewitt law provided that banks should pay seventy-five cents on their capital and the State rate of taxation, whatever it might be on their surplus, less ten per cent. of their capital, and also to pay the municipal tax on any real estate they might own and use for banking purposes, and this was to be in full of all taxation. The bill provided that all banks who would give up their chartered rights of fifty cents on the one hundred dollars and accept the provisions of the Hewitt law should not be disturbed any more on the subject of taxation during the continuance of their respective charters. The banks were required by the law to call a meeting of their stockholders and to take a vote upon the proposition, and if accepted by the stockholders to certify the same to the Governor of the State, and that all banks so voting in favor should be considered as having entered into a contract with the State of Kentucky which should be binding until the charters of the banks accepting should expire. Under this belief and with a willingness on the part of the banks to pay more tax than they had been required to pay, all the banks in the city of Louisville and nearly all in the State of Kentucky promptly accepted the law and cheerfully paid their taxes under its requirements.

The adoption of the new constitution in 1891 radically changed the laws of the Commonwealth, and especially so in relation to assessment and taxation, and in the necessary revision of the statutory laws it assumed to wipe out the contract made by the State with the banks under the Hewitt law. As soon as the new constitution went into effect, the city of Louisville, under the provisions of the act for the government of cities of the first class, proposed to levy on each bank, trust company and title company a license tax, which should not be less than four nor more than six per cent. on their gross earnings exclusive of rent from real estate paying a tax to the city. The banks, being strong in their faith that they had a contract with the State under the Hewitt law, resisted the payment of the tax proposed by the city. They organized and employed counsel to defend their rights, in the meantime making an agreement with the sinking fund commissioners and city authorities to pay into the sinking fund an amount equal to four per cent. of their gross earnings, taking the sinking fund's note bearing interest at the rate of four per cent. per annum, with the understanding that if the proposed tax should be declared illegal the city should pay back to the banks the money thus paid, with four per cent. interest, and if the matter was decided against the banks they were simply to surrender 
the notes which they had taken to the sinking fund commissioners to cancel. In this way the city was not kept out of its expected revenue, and it showed a willingness on the part of the banks not to do anything which would cripple or hamper the city in its financial arrangements. The Court of Appeals, after a long and careful investigation of the case, when it reached that body, finally decided in favor of the banks, four of the court approving and three dissenting, and the banks were fully sustained all along the line in their efforts to hold the State to as binding a contract as was ever made or entered into in the opinion of the banks.

If the tax on banking capital sought to be imposed under the new constitution ever goes into effect so far as the banks in the city of Louisville are concerned, they can never live under its provisions. It must inevitably result in driving many of them, especially the smaller and weaker banks, out of existence, and those who may survive can only exist by raising discount rates so high that it will greatly retard the growth and commercial prosperity of the eity.

In the matter of taxation on banking capital, the banks have been fairly and liberally dealt with in the past. The tendency of legislation, however, and of the times in this State, as it seems to be everywhere else, is toward excessive and burdensome taxation upon monetary institutions. The fine-spun theories of some of these lawmakers that taxation should be equal on all classes of property are beautiful to contemplate, but when a bank is compelled to pay an assessment of $\$ 100$ on every $\$ 100$ of its bills receivable and the agriculturist to pay a $\$ 30$ assessment on a $\$ 100$ acre of beautiful blue-grass land, the glaring inequalities of the position are apparent. The complaint on the part of the banks is not against the inequality of taxation, but against the inequality of valuation. This theory of taxation, if persisted in, can only result in forcing capital to seek other channels for fair remuneration upon its investments and harm must come to the commercial interests and material welfare of the city of Louisville and the State of Kentucky.

\section{Banking Institutions in Louisville.}

There are sixteen banks in Louisville, of which nine are State institutions and seven National. The aggregate capital is $\$ 8,500,000$, surplus, $\$ 1,000,000$. The aggregate deposits, $\$ 22,000,000$; the aggregate average loans, $\$ 23,500,000$. This does not include the trust companies or building and loan associations, in which a very large amount of capital is invested. There are five trust companies in Louisville, three of them large and very strong, prosperous institutions, but as they are not required by law to make any published reports of their condition, the correct figures of their deposits and loans cannot be given. Their capital is $\$ 3,200,000$.

The First National Bank was chartered in 1863, and was the first National bank south of the Ohio. 


\section{Financial Crisis of 1893.}

The financial panic that swept over the country in 1893 did not exempt Louisville from a share of its disasters. During the period of great prosperity that antedated the panic, the people had gone into many important enterprises in which large sums of money were invested. When the crisis came these great enterprises were forced into the hands of Receivers, and the stocks and bonds of these enterprises became in most instances practically unmarketable. This caused great distress among local investors as well as heavy loss. Several of the banks were compelled to close their doors, some of them never to reopen. Few cities suffered more from the financial storm that swept over the land. While several of the banks could not hold out, the most of them were strong and ready for any emergency that might arise, and, in fact, the business community only suffered a temporary loss of the usual facilities afforded; and it is a tribute to the banks of the city that outside of a few who were weak and had to succumb to the pressure brought to bear upon them in their weakness, the majority stood the test under circumstances that tried the strength of the best and without resorting to what even New York was compelled to do-issue clearing-house certificates and cease paying out currency except in small amounts, which proved to the world that the banking institutions of Louisville were as strong and safe as those of any other city.

State Banks.

\begin{tabular}{|c|c|c|c|c|c|c|}
\hline YEARS. & $\begin{array}{l}\text { No. of } \\
\text { banks. }\end{array}$ & $\begin{array}{l}\text { Loans and } \\
\text { discounts. }\end{array}$ & Specie. & $\begin{array}{l}\text { Capital } \\
\text { stock. }\end{array}$ & Circulation. & Deposits. \\
\hline $1835 \ldots$ & 2 & $\$ 861,511$ & $\$ 2,284$ & $\$ 792,423$ & $\$ 87,564$ & $\$ 7,828$ \\
\hline $1840 \ldots$ & 17 & $10,522,464$ & $1,261,500$ & $9,329,088$ & $3,940,333$ & $1,049,648$ \\
\hline $1845 \ldots$ & 19 & $9,781,013$ & $2,648,706$ & $8,203,428$ & $4,934,098$ & $2,024,181$ \\
\hline $1850 \ldots$ & 16 & $11,637,207$ & $2,683,373$ & $7,030,000$ & $6,682,524$ & $2,209,035$ \\
\hline $1855 \ldots$ & 34 & $17,307,567$ & $4,152,988$ & $10,369,717$ & $8,628,946$ & $3,011,719$ \\
\hline $1860 \ldots$ & 45 & $25,284,869$ & $4,984,141$ & $12,216,725$ & $14,345,696$ & $5,144,879$ \\
\hline $1865 \ldots$ & 38 & ............... & .............. & $11,587,025$ & ............... & .............. \\
\hline $1870 \ldots$ & 55 & ................. & & $16,649,256$ & ............... & ............ \\
\hline $1877 \ldots$ & 54 & $19,319,718$ & & $12,037,493$ & 268,975 & $10,825,141$ \\
\hline $1882 \ldots$ & 60 & $20,586,505$ & & $10,859,887$ & 217,684 & $14,531,655$ \\
\hline $1887 \ldots$ & 71 & $20,895,907$ & & $11,555,686$ & 35,976 & $16,852,350$ \\
\hline $1892 \ldots$ & 162 & $41,435,926$ & .......... & $19,220,852$ & 48,345 & $31,283,511$ \\
\hline $1897 \ldots . .$. & *190 & $32,237,938$ & ............ & $15,546,739$ & ............. & $25,008,521$ \\
\hline
\end{tabular}




\section{National Banks.}

Figures are in thousands of dollars.

\begin{tabular}{|c|c|c|c|c|c|c|c|c|c|}
\hline YEARS. & $\begin{array}{l}\text { No. of } \\
\text { banks. }\end{array}$ & $\begin{array}{c}\text { Loans } \\
\text { and dis. } \\
\text { counts. }\end{array}$ & $\begin{array}{c}U . S . \\
\text { bonds. }\end{array}$ & $\begin{array}{c}\text { Cash } \\
\text { and cash } \\
\text { items. }\end{array}$ & Capital. & Surplus. & $\begin{array}{l}\text { Undi. } \\
\text { vided } \\
\text { profits. }\end{array}$ & $\begin{array}{c}\text { Out. } \\
\text { standing } \\
\text { circula. } \\
\text { tion. }\end{array}$ & $\begin{array}{c}\text { Indi. } \\
\text { vidual } \\
\text { deposits. }\end{array}$ \\
\hline $1864 \ldots .$. & 1 & $\$ 83$ & $\$ 352$ & $\$ 142$ & $\$ 200$ & $\$ 4$ & $\$ 20$ & $\$ 99$ & $\$ 136$ \\
\hline $1868 .$. & 15 & 3,107 & 3,022 & 819 & 2,835 & 264 & 207 & 2,330 & 1,416 \\
\hline $1873 \ldots .$. & 36 & 9,599 & 7,655 & 1,297 & 8,221 & 751 & 565 & 6,783 & 4,040 \\
\hline $1878 \ldots .$. & 48 & 12,428 & 9,805 & 1,926 & 9,957 & 1,444 & 627 & 7,734 & 5,836 \\
\hline $1883 . .$. & 65 & 22,456 & 11,902 & 2,735 & 12,568 & 2,362 & 834 & 9,434 & 13,579 \\
\hline $1888 \ldots . .$. & 69 & 27,798 & 5,886 & 2,606 & 13,754 & 3,379 & 1,103 & 3,080 & 14,299 \\
\hline $1893 . . . .$. & 81 & 27,887 & 5,327 & 2,956 & 14,463 & 3,732 & 1,244 & 3,549 & 14,624 \\
\hline $1898 \ldots . .$. & 75 & 24,075 & 8,950 & 2,918 & 11,065 & 2,870 & 706 & 5,262 & 21,234 \\
\hline
\end{tabular}

\section{TENNESSEE.}

Tennessee requires no filing of bank reports with the Comptroller of the State Treasury, and the compilation of a complete and accurate banking history of the State is a task presenting great difficulties, as the records at hand are very meagre.

When North Carolina relinquished her rights to the territory now comprising the State of Tennessee--an act made legal by the Congress of the United States, approved June 11, 1796, by George Washingtonthe only currency in circulation in this section of what was then known as the West was the notes of the first Bank of the United States. Foreign coins of silver, issued by almost all the nations of the world, and gold coins of larger denominations were, with the notes of the Bank of the United States, the circulating medium. Most of this coin was clipped or punched, and it was no uncommon occurrence to receive in the course of trade, shillings and pistareens cut in half, when change was scarce, which passed as current for half shillings and half pistareens.

The principal business was transacted by barter in such articles as tobacco, bullets, whiskey, wheat, and coon skins. There seemed to be no fixed value, except the notes of the Bank of the United States, with its assets of nearly $\$ 15,000,000$ - of which $\$ 5,000,000$ was in specie.

From the skins of animals, once a legal tender for all debts, both State and individual, the people craved for an evolution, to culminate in the issuance of bank notes, to be authorized by the State. The poorer classes would accept it as a blessing. They argued that if the 
law made it a legal tender it would pass as readily as gold and silver. What the populace wanted was money, and the sequel will show conclusively that when the discontinuance of the issuance of bank notes under State jurisdiction, occurred in 1863, the people had money-such as it was-and many of them have that identical money now.

Under colonial permit, the Congress of the United States had flooded the country with a paper curreney that was, in course of time, utterly worthless. This seemed to be a proper system, nevertheless, for an old Territory, just emerging into the dignity of new statehood.

\section{The State's First Banking Experience.}

The first experience the State of Tennessee had with banking, on its own responsibility, was in November, 1807, when the General Assembly established the Nashville Bank. It was the logical outcome of earnest solicitation from the leading merchants and traders of Nashville, and the State, whereby it was claimed that the business of the State required more money to aid the merchants in increasing their stocks of goods, and to enable the farmers to move their crops to market. The capital stock was fixed at $\$ 200,000$, in shares of $\$ 50$ each. The charter of the bank was twice extended, the last time until 1838, when its capital was increased to $\$ 400,000$. On February 14, 1818, Stephen Cantrell was elected President in Place of Josiah Nichol, who resigned. Wilkins Tannehill was the Cashier.

Josiah Nichol was a native of Ireland. He was one of the proprietors of King's Salt Works, at Abingdon, Virginia. He moved first to Knoxville, and in 1808 to Nashville, where he was, until his death, one of the leading merchants and most highly respected citizens. He died suddenly, of cholera, May 31, 1833. He was President of the Nashville Bank for several years before 1818, when he resigned, as is stated. In August, 1827, he was made President of the branch of the Bank of the United States, at Nashville, a position he held at the time of his death. He was a man of the highest sense of honor.

In 1817 the Legislature authorized the organization of banks at Winchester, Shelbyville, Rogersville, Murfreesboro and Gallatin. These banks were offered the privilege of uniting with the Bank of the State of Tennessee, at Knoxville, of which Hon. Hugh L. White was President, or with the Nashville Bank. An arrangement was made by the banks mentioned to unite with the Nashville Bank, and they became branches of that institution, with a combined capital of $\$ 2,400,000$. On March 31, 1823, the Nashville Bank and branches burned over $\$ 250,000$ of circulation, to enhance the value of their bank notes. This bank continued until 1827 , when it was liquidated with a small loss to its stockholders.

The last statement to be found of the Nashville Bank was published on June 20, 1819, and is as follows: 
Report of the Nashville Bank and Branches, June 20, 1819.

\begin{tabular}{|c|c|c|c|c|c|}
\hline & $\begin{array}{l}\text { Specie on } \\
\text { "hand. }\end{array}$ & Discounts. & $\begin{array}{c}\text { Individual } \\
\text { Deposits. }\end{array}$ & $\begin{array}{c}\text { Circula- } \\
\text { tion. }\end{array}$ & $\begin{array}{l}\text { Capital } \\
\text { paid in. }\end{array}$ \\
\hline Nashville............ & $\$ 65,786$ & $\$ 692,591$ & $\$ 147,468$ & $\$ 140,476$ & $\$ 511,960$ \\
\hline Murfreesboro................ & 37,177 & 204,898 & 26,322 & 110,770 & 105,510 \\
\hline Rogersville................. & 22,948 & 87,461 & 6,703 & 32,268 & 65,890 \\
\hline Shelbyville ......................... & 67,663 & 231,062 & 18,039 & 165,763 & 96,555 \\
\hline 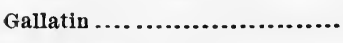 & 17,625 & 171,762 & 10,543 & $\mathbf{7 2 , 6 9 0}$ & 113,825 \\
\hline winchester .................... & 53,548 & 208,796 & 4,878 & 145,149 & 100,820 \\
\hline Total.......................... & $\$ 264,747$ & $\$ 1,596,560$ & $\$ 213,943$ & $\$ 667,116$ & $\$ 994,560$ \\
\hline
\end{tabular}

Condition of the Banks of Tennessee in 1819.

ResourCes.

Loans and discounts..........\$2,214,729

Due from other banks......... $\quad 218,060$

Specie....................... $\quad 343,884$

Other stocks and bonds........ 18,905

Real estate................. 40,423

Total................. $\overline{\$ 2,836,001}$
LIA BILITIES.

Cash paid in . . . . . . . . . . . . $\$ 1,545,866$

Circulation................. 898,129

Deposits, public.............. 17,003

Deposits, private.............. 262,866

Due other banks............. 29,884

Undivided profits............ 82,253

Total.................. $\overline{\$ 2,836,001}$

The Farmers and Mechanics' Bank, of Nashville, was one of the banks chartered by the Legislature in 181\%. On June 18, 1819 it was the first bank to suspend specie payment, having been required to pay out over $\$ 30,000$ in specie in two months. On account of this suspension the circulation of paper money in Tennessee was a very difficult undertaking. Two years after the suspension of specie payment silver and gold was from fifteen to eighteen per cent. above par, while the notes of the Farmers and Mechanics' Bank, the Fayetteville Bank and other banks, were from forty-five to seventy-five per cent. discount.

In 1823 the United States and Virginia bank notes were thirty-one per cent. premium in Tennessee, and specie thirty per cent. premium, while the notes of the banks of this State could hardly be passed.

The State held its first stock in a bank styled "The President, Directors and Company of the Bank of the State of Tennessee," which was chartered November 20,1811 . The capital of the bank was $\$ 400,-$ 000 , in shares of $\$ 50$ each. The State subscribed $\$ 20,000$, and showed its lack of faith in the venture by reserving the right to withdraw its stock at the end of ten years.

The parent bank was located at Knoxville, with Hugh Lawson White (at one time a prominent candidate for President of the United States), as President. Branches were established at Clarksville, Jonesboro and Columbia. It was restricted to an issue of no smaller a denomination than $\$ 5$. The rule of value governed then as now, and the good (or 
best) money, silver and gold, was hoarded, and to meet the wants of the people for change the bank was permitted to limit its lowest issues to one dollar notes. Mutilated silver coin was used as small change.

\section{Branch of the Bank of the United States Established.}

In 1816 the second Bank of the United States was chartered by Congress "on account of the unsatisfactory condition of the finances and circulating medium of the country." It was suggested by the directors that a branch be established at Nashville. Out of $\$ 27,633,049$ of stock held by this bank, Nashville had subscribed $\$ 53,463$. As soon as it reached the public ear that foreign capital was proposed for banking. purposes, the Legislature imposed a privilege tax of $\$ 50,000$ on any office or branch of any bank not chartered by the State, for each and every year, before they were allowed to conduct the business of banking in the State.

This act was declared unconstitutional by the Supreme Court of the United States, and was afterwards repealed by the Legislature. Nashville held several public meetings before the consent was gained, but finally, in August, 1827, the branch was established in a bank building on the corner of College street and the Public Square, with Josiah Nichol as President and John Somerville as Cashier, The Bank of the United States was in operation until 1832, when Andrew Jackson's veto placed it in liquidation.

\section{Early Bank Failures.}

From January 1, 1811, to July 1, 1830, the following-named banks in Tennessee had either failed or discontinued business:

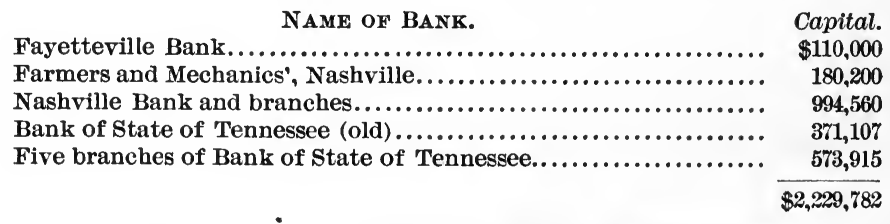

\section{Second Bank of the State of Tennessee.}

The first financial panic known to Tennessee was during the year 1820. Joseph McMinn was then Governor of Tennessee. He evidently agreed with the masses that the surest cure for a panic was money-no matter as to the kind or quality-but money; and to carry out his idea he convened the Legislature. The first act of that body was to enact a law, July 26, 1820, entitled "An act to establish a Bank of the State of Tennessee, for the purpose of relieving the distress of the country and improving the revenue of the State."

The course of time developed the fact, as was declared by Governor William Carroll, in his message to the Legislature in 1833, "that the establishment of banks, for the purpose of relieving the people from 
pecuniary distress is, in most cases, ruinous to those who avail themselves of such relief."

The capital of the second "Bank of the State of Tennessee" was fixed at $\$ 1,000,000$, which was to be predicated upon funds belonging to the State, and warranted by the proceeds of the sales of the public lands. No provision was made for the redemption of the bank's notes in specie, but stock bearing six per cent. interest, to the amount of $\$ 250,000$ was authorized and was to be sold at par.

\section{ANDREW JACKson's HARD-Money Views.}

Andrew Jackson was very much in evidence on this occasion, and he took a prominent stand against the provisions of this act. While he denounced it as 'jeing a violation of Section 10 of the First Article of the Constitution of the United States, which declares that "No State shall coin money or enit bills of credit, or make anything but gold and silver a legal tender in payment of debts," in his memorial to the Legislature, he continues:

"Bills issued on any other basis, save that of specie, must prove inefficient and abortive ; owing to its having no other basis than that of property, and not being convertible into specie, it can never be estimated as an equivalent; it will not engross public confidence, but must depreciate; and if it passes as a medium of exchange at all, its value must in a great degree be nominal."

He then refers to the Mississippi financial scheme, the Mississippi stock and Treasury notes issued by the United States, as well as "all those cases in which State authorities have undertaken to put in circulation bills of credit having a corresponding foundation."

This is one of the few occasions when "Old Hickory's " logic was of no avail. The Legislature passed the bill, and the Bank of the State of Tennessee was organized. Bills to the amount of $\$ 500,000$, of the denomination of not less than $\$ 5$ nor more than $\$ 100$ were allowed to be issued. This ruling was afterwards modified so as to permit an issuance of fractional notes of $\$ 1, \$ 2$ and $\$ 3$, to the amount of $\$ 75,000$.

The bank started out, under a clear sky, with every evidence of bright prospects ahead, as no facility was withheld by the State government to prevent the most prosperous success of this financial scheme. Agencies were established in every county of the State (formed previous to the year 1819), with authority to make loans to citizens, not to exceed $\$ 500$ each for any single loan, on twelve months' time, upon mortgages, upon real estate or personalty, to be worth twice the amount of the loan to be effected.

The Treasurers of East and West Tennessee, as well as all fiduciary officers of the State, were ordered to place all funds in their possession belonging to the State in this bank. The bank notes and bills of credit were soon at a discount. Other banks, even in this State, declined to accept them in the regular course of business, and they were taken in exchange for notes of the Bank of the United States at ten per cent. 
discount. Beyond the borders of Tennessee the notes were hardly negotiable, and were frequently purchased by money dealers at a discount of fifty per cent.

A large amount of the money, distributed to agents over the State, was lost by defaleation. The Cashier of the Nashville Bank was discovered to be a heavy defaulter in 1832. The losses were:

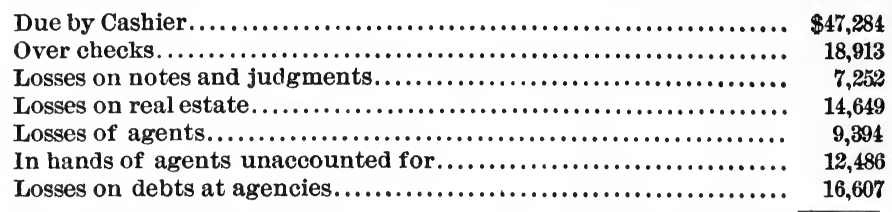

Total................................................ $\overline{\$ 126,585}$

The total defalcation of the Cashier was $\$ 67,695$. The overdrafts permitted to be made were from those high in authority, while the bookkeeping had been disgracefully neglected, and on some accounts postings had not been made from eight to ten years.

\section{The Union Bank of Tennessee.}

In 1832 the General Assembly, at the suggestion of Governor Carroll, abolished the Bank of the State of Tennessee-ordering that all State funds in its possession be placed in the Union Bank of Tennessee, which was then in process of organization. This bank was chartered by the Legislature October 18, 1832, and anong its provisions was a declaration that the capital stock should be limited to $\$ 3,000 ; 000$. The stock was subscribed, $\$ 500,000$ by the State of Tennessee, $\$ 967,000$ in Nashville, $\$ 140,000$ in Columbia, $\$ 59,200$ in Jackson, $\$ 14,000$ in Franklin, and $\$ 6,500$ in Memphis, by December 10, and by December 13 the subseriptions amounted to $\$ 1,773,000$. The total amount subscribed was $\$ 2,273,000$, which included the State's subscription of $\$ 500,000$. On January 29,1833 , the directors elected George W. Gibbs President, and A. Van Wyck was later elected Cashier.

General Gibbs, who was one of the leading financiers of that period, sold the $\$ 500,000$ State of Tennessee bonds (issued to the Union Bank), in Baltimore City at five per cent. premium, thus realizing a profit to the bank of $\$ 25,000$. These bonds were issued in equal installments, payable in fifteen, twenty, twenty-five and thirty years, bearing five per cent. interest-an investment by the State that would hardly bring such a premium at the present day.

The Union Bank had covenanted with the State to pay into the State treasury annually one-half of one per cent. on the capital stock paid in, as a bonus to the State. Notes issued by the bank were to be received by the State in payment of taxes and all debts due to the State. Under these most favorable auspices the doors of the bank were opened for business March 4, 1833. A large proportion of the 
stock was held by Eastern capitalists, Philadelphia alone having subscribed for 16,000 shares.

On July 29, 1834, Jno. M. Bass was elected President of the Union Bank, and continued as such for a quarter of a century. During his presidency the panic of 1837 occurred.

The Union Bank, with its five branches, battled manfully under the leadership of Jno. M. Bass, and came out victorious, and until the year 1865 was one of the most useful and profitable financial institutions of the country. In that year the bank went into liquidation.

The Planters' Bank was incorporated by the Legislature November 11,1833 , with six branches, with an authorized capital of $\$ 2,000,000$. Its first President was Edward B. Litchfield, with Nicholas Hobson as Cashier. In 1837 Mathew Watson was made President, with the same Cashier. In 1854 Dempsey Weaver was made Cashier of the Planters' Bank, a position he held uninterruptedly until 1865, when the bank, on account of the passage of the National Bank Act, was forced into liquidation, and Mr. Weaver was appointed Receiver, and so continued until the bank was wound up.

\section{InCorporation of the Bank of Tennessee.}

On January 19, 1838, the Legislature launched the third State bank, under the title of the Bank of Tennessee. The act sets forth that "the faith and eredit of the State are pledged" to support the venture. A capital of $\$ 5,000,000$ was to be secured as follows : from the common school fund, the sales of the Ocoee land, the State surplus revenue, and the balance to be acquired on the credit of the State, either in specie or in funds to be converted into specie. The plan was to realize the convertible funds, by an issuance of $\$ 2,500,000$ of six per cent. thirty-year State bonds to be sold at not less than their par value.

"The faith and credit of the State" at this time did not come up to its rating as highly as the Legislature supposed, for after strenuous efforts by the officials in charge, the American Life Insurance and Trust Company, of New York, purchased $\$ 1,000,000$ of the bonds, and the remaining bonds, $\$ 1,500,000$, were eventually cancelled. The directors, after considerable difficulty, established branches at Athens, Clarksville, Columbia, Knoxville, Memphis, Murfreesboro, Rogersville, Shelbyville, Somerville and Trenton, and afterwards at Sparta.

This bank was a political institution, and politicians virtually controlled its management. It opened its doors for business in February, 1838, with William Nichol as President and Henry Ewing as Cashier. William Nichol was born in Abingdon, Virginia, in 1800. He was the first President of the Bank of Tennessee (in 1838). When the ground upon which the capitol is built, at Nashville, was purchased in 1843, by the city, to induce the removal of the capital to Nashville, the city's sredit was so low that he gave his own note for the property, to close the sale. The city afterwards assumed the debt, which was $\$ 30,000$. 
The board of directors were appointed every two years by the State. Col. Willoughby Williams was President of the parent bank, at Nashville, for some time prior to March 2, 1843, when he resigned and was succeeded by Felix Robertson, and then A. O. P. Nicholson, and in January, 1854, by Cave Johnson, who served until 1860, when he resigned, and was succeeded by Granville P. Smith, and afterwards by G. C. Torbitt, father of the "Torbitt issue," which was, after the war, a source of vexation to the holders of Bank of Tennessee money. When the bank went into operation the capital, it is said, was divided as follows:

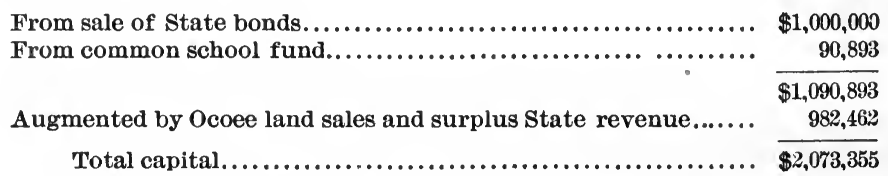

At this time the banking capital of the State exceeded $\$ 10,000,000$.

Specie payment was resumed January 1, 1839, but the banks reckoned without their specie, and another suspension occurred the following October.

At this time Governor Polk's message is replete with economic ideas backed by the strongest arguments to discourage any increase in banking capital. Referring with deep regret to the suspension of specie payment, he says, "the only and permanent relief is to be found in habits of economy and industry, and the productive labor of our people."

January 1, 1843, resumption of specie payment was effected, and in the succeeding ten years banking in Tennessee was very successful and profitable. This was especially noticeable in the three old banks-the Bank of Tennessee and the Union and the Planters' Bank. The notes of these three banks passed current throughout the State, but were at a discount beyond the State's borders.

An arrangement was made at Nashville whereby the notes of the Bank of Tennessee and branches were redeemed at the parent bank at Nashville.

Under the National bank system the banks are permitted (1899) to issue only ninety per cent. in circulation of the bonds held by the Comptroller of the Currency. Under the old State system the banks were allowed to issue three dollars for every dollar of coin in their vaults. The branches were situated in out-of-the-way places, far away from railroad and river transportation, and as a former custom the notes were made payable at these branches, and issued by the parent bank at Nashville and the branches at Memphis and Knoxville. In discounting the paper the branch notes were usually paid out under the supposition that the notes issued would not reach the branches for redemption before the maturity of the paper. Experiments were frequently made in the following manner. The parent bank at Nashville would 
diseount a piece of paper, for which it would probably pay the notes redeemable at the Rogersville branch. Frequently the date of discount was written or stamped upon these notes, and the Cashier at the Rogersville bank would keep a minute of how long the money was in circulation before being presented for redemption. Men conducting private banks in Nashville frequently travelled over the State on horseback to the branch banks to withdraw gold for the bank notes they had accumulated. Their profit was the premium they earned on their specie, and the gains made on their purchases of uncurrent money in Nashville, which was almost always largely in excess of par notes. Redeeming the branch notes at Nashville, paying interest on the bonds of the State and internal improvement, and bonds for the school fund, besides paying the interest on the State stocks-amounting in all to a payment of about $\$ 275,000$ annually-while its annual profit netted $\$ 175,000$, showing a deficit of about $\$ 100,000$ annually; and the capital having dwindled down to $\$ 2,500,000$ from $\$ 3,225,000$, Governor Brown in 1849 demanded that the burdens on the Bank of Tennessee should be lightened, or the institution should be liquidated. This advice was not heeded.

\section{Free Banking Law Adopted.}

In 1851-52 the Legislature adopted what was known as the free banking law. This law was almost the same as the law then in force in New York. Quite a number of banks were organized under this law on fictitious capital, and "wildeat" banks were as plentiful as grasshoppers. The issuance of bank notes of a high order of engraving seemed to be the order of the day. The rule of $\$ 3$ to $\$ 1$ in specie seemed to be obsolete, and the redundancy of currency was enormous. There were, of course, exceptions to this bad system of banking.

In 1853, Governor Andrew Johnson, in his message to the General Assembly, did not hesitate to condemn the wretched system of banking the State had gradually fallen into, and he suggested the liquidation of the State Bank. The same idea prevailed in his message of $\mathbf{1 8 5 5}$ and 1857. In his last message is a report from the directors of the bank in which they state that "they have come to the conclusion, and from a settled conviction, that the best interests of the State require that the Bank of Tennessee should be put in liquidation and its affairs closed at as early a period as the convenience of the citizens will allow."

This ridiculous system of banking, which pervaded every State in the Union, had its weight in producing the panic of 185\%. If the recommendation of Governor Johnson had been heeded a large reduction of the State debt could have been secured.

By common consent nearly all the banks of Tennessee suspended specie payment and began to curtail their business, which was continued until 1861, when the sinews of war were needed, and the Legislature passed a law compelling the banks to increase their circulating 
medium. In 1861 the circulation of the Bank of Tennessee was $\$ 1,313$ 728. In 1862 it reached $\$ 4,710,666$.

\section{Approach of the Civil Conflict.}

On November 26,1860 , a number of merchants and citizens of the State addressed a communication to General William A. Quarles, Supervisor of the banks of Tennessee, asking his opinion regarding the suspension of specie payment, and whether the banks would be able to weather the political and commercial storm which was imminent. $\mathrm{He}$ advised a temporary suspension, suggesting that the banks should permit a liberal but prudent line of discounts and renewals; that they should furnish exchange at a maximum rate of one and one-half per cent. and that they should also furnish small sums of coin, sufficient for the wants of trade, for their customers. He furnished the following report, showing assets of $\$ 11,833,175$ and deposit and circulation liabilities, including amount due banks, $\$ 5,247,931$-an excess of assets over liabilities of $\$ 6,585,244$ in the three old banks of the State.

Exhibit of Report of Supervisor of Banks of Tennessee, November, 1860.

\begin{tabular}{c|r|r|r|r|r|r}
\hline NAME OF BANK. & $\begin{array}{c}\text { Specie and } \\
\text { exchange. }\end{array}$ & $\begin{array}{c}\text { Due from } \\
\text { Treas- } \\
\text { urer. }\end{array}$ & $\begin{array}{c}\text { Due from } \\
\text { State } \\
\text { banks. }\end{array}$ & $\begin{array}{c}\text { Notes and } \\
\text { bills. }\end{array}$ & $\begin{array}{c}\text { Circulation } \\
\text { and } \\
\text { deposits. }\end{array}$ & $\begin{array}{c}\text { Due to } \\
\text { banks } \\
\text { and } \\
\text { bankers. }\end{array}$ \\
\hline Bk. of Tenn. and br's. & $\$ 1,062,296$ & $\$ 52,451$ & $\$ 156,000$ & $\$ 3,859,411$ & $\$ 1,768,639$ & $\$ 53,160$ \\
Union Bk. and br's... & 536,711 & $\ldots \ldots \ldots$. & $\ldots \ldots \ldots .$. & $2,619,682$ & $1,579,488$ & 28,644 \\
Planters' Bk. and br's. & 667,545 & $\ldots \ldots \ldots$ & $\ldots \ldots \ldots$. & $\mathbf{2 , 8 7 9 , 0 7 9}$ & $1,701,069$ & 119,931 \\
\hline
\end{tabular}

He also stated that public confidence had been destroyed, and that every dollar of specie withdrawn from the banks made it necessary under the law to contract their circulation to the extent of three dollars. Such a course would have ruined the country.

Finally, the State bank system as a currency-supplying feature for the commercial world was virtually eradicated by the war between the States-it is to be hoped with no possibility of it ever again being restored.

Thousands upon thousands of dollars of State and private bank notes are in the hands of the citizens of the South to-day-a living witness of the financial crime perpetrated against the people by the acts of State Legislatures, in favoring the issuance of bank notes by the State and stock banks of the United States.

When the Federal army entered the State of Tennessee, the bankers migrated toward the south via Chattanooga, on horseback, in buggies, carriages, wagons, or by river and rail. A number of the officers of the Bank of Tennessee, and its branches, followed the bank south, where its specie was deposited in Atlanta.

Governor Isham G. Harris, a prominent figure in State politics (at 
this time styled the War Governor of Tennessee, afterwards United States Senator from Tennessee, until his death, in 1898) kept in touch with the Bank of Tennessee, and its branches, until the close of the war, when for a while he was a refugee in Mexico. The assets of the bank, in a very battered condition, were turned over to Governor William G. Brownlów, at Nashville. Of its $\$ 16,000,000$ assets, $\$ 8,000$,000 had been converted during the war into Confederate State eight per cent. bonds.

Banking during the war was by no means a sinecure. Many private banking and State institutions carried their money South, and did their banking business from their side pockets. The Cashier or President had with him a statement from his individual ledger. Their asssets were deposited in Richmond, Va., Mobile, Ala., Atlanta, Ga., or Charlotte, N. C. When a customer wrote to or called upon them for a portion of his balance, or the entire amount, they would give the party a check against the bank's account at Atlanta, or some other point, for the sum desired. They would then mark opposite the balance the amount drawn by the depositor.

The Northern Bank of Tennessee, at Clarksville, established in 1854, and still carried on at the place of its nativity, though by new officers, never suspended specie payment. As long as gold could be obtained its notes were redeemed in gold, and when the greenback was declared legal tender, the notes of this bank were redeemed in that currency. D. N. Kennedy was President, and James L. Glenn, Cashier, for nearly forty-five years. Both of these gentlemen have retired from the sole ownership of the bank, and the old institution is beginning its fortysixth year with new stockholders and officers, with every prospect of continued success. It is believed this bank is the only ante-bellum bank of this State now in existence.

The Union Bank of Tennessee was placed in liquidation under Jos. W. Allen, one of Tennessee's most faithful financiers, who had been agent of the Bank of Tennessee, at New Orleans, for twenty-five years.

It has been charged that the largest proportion of the available and good assets of the Bank of Tennessee were lost by the failure of the Tennessee National Bank, of Memphis, which was organized June 5, 1865 , with $\$ 100,000$ capital. A Receiver was appointed May 21, $186 \%$. It was the fifth bank of the National banking system to fail, and the losses were exceedingly heavy.

In the capture of New Orleans General N. P. Banks, under general order No. 202, issued August 17, 1863, seized balances due the banks of the South, and the assets of the Southern Confederacy, deposited with the banks of New Orleans. Among those assets were balances due the following-named banks of Tennessee, to-wit:

Ocoee Bank, Cleveland......................................... \$8,000

Bank of West Tennessee, Memphis................................ $\quad 90,887$

Chattanooga Savings Institution.............................. 1,833

Planters' Bank of Tennessee, Nashville......................... 101,462 
Bank of Tennessee and Branches.

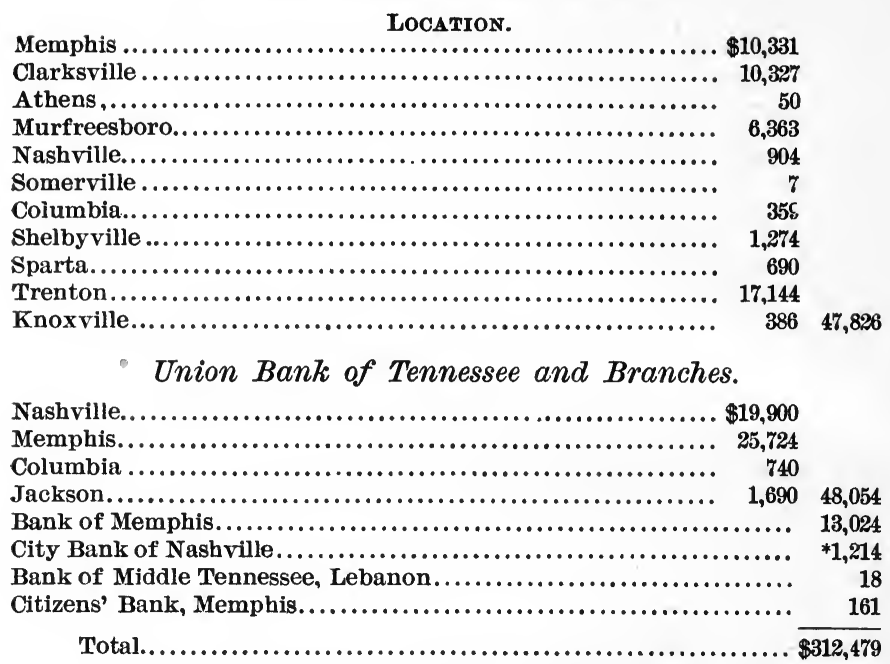

*This amount returned to City Bank, Nashville, May 19, 1865.

This report furnishes an idea of the losses by the banks of the South. The whole amount of Confederate funds seized at New Orleans was $\$ 689,491$, and of this amount $\$ 312,494$ belonged to banks in Tennessee.

\section{Bank of Tennessee Placed in Liquidation.}

In February, 1866, a bill was passed by the Tennessee Legislature to place the Bank of Tennessee in liquidation, and to wind up its aftairs. In accordance with this act Governor Brownlow nominated Samuel Watson, of Cheatham county, W. T. Berry, H. G. Scovel, A. Lovering, A. V. S. Lindsey and John Baird, as directors to wind up the Bank of Tennessee. Upon Samuel Watson fell the burden. He was the President of the Bank of Tennessee, "in liquidation," and trustee of its affairs. Some difficulty having occurred about the bond of Mr. Watson, which would amount to millions of dollars under the law as trustee, the Chancery Court at Nashville, to obviate the difficulty, appointed him Receiver, with a bond of $\$ 50,000$. His report to the court exhibited assets amounting to $\$ 12,478,483$. In this amount were included the following items:

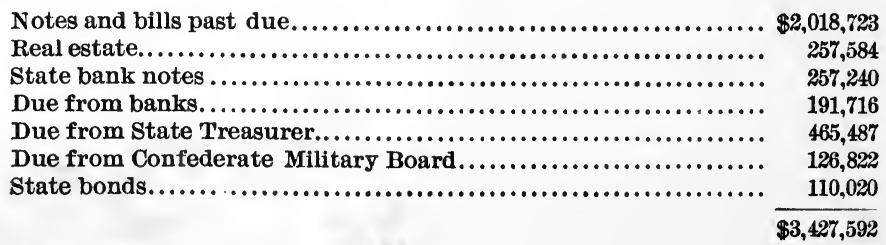


The rest of the assets were composed of Tennessee war bonds, Confederate bonds, Confederate certificates and Confederate treasury notes.

In 1875 he made a statement to the court, exhibiting the details of winding up the bank and its branches. His report was approved. The school fund of Tennessee was made a preferred creditor in the final settlement. This act was declared illegal in suits brought both by the new issue noteholders and the depositors of the bank.

The principal question regarding these notes was, "Were they issued in aid of the rebellion? that is, the Confederate war." In December, 1875, the Supreme Court of Tennessee held that the notes in controversy were not issued in aid of the rebellion, and that as to the question of the ownership of the assets of the Bank of Tennessee, they belonged to the note holders and not to the school fund and the depositors. Finally the whole matter of paying the note holders was settled by an act of the Legislature, March 29, 1883, which provided for the issuance of certificates of indebtedness to the amount of $\$ 1,000,000$ by the Governor, Comptroller and Treasurer of the State, in the sums of one dollar, five dollars and twenty dollars, " as may be found most convenient." These certificates were to bear the date of their issuance, and to be payable to the person to whom issued, or bearer, and receivable for taxes due the State to the amount of one-fifth for each year for five years. It was to be shown on their face that they were issued as a substitute for the notes of the Bank of Tennessee.

An attempt was made by a meeting of the creditors or note holders of the bank, in Nashville, September 7, 1883, at which $\$ 600,000$ of the notes were represented, to reject the State's proposition on account of five years' delay, but the action of the meeting did not prevent the carrying out of the provisions of the act of the Legislature.

The depositors of the Bank of Tennessee and its branches, have never to this day realized a dollar of the balances due them, while the speculators who had purchased the notes of the bank at a heavy discount (thousands of dollars of the new issue having been purchased at five cents on the dollar), were paid dollar for dollar for the face of the notes in Tennessee certificates of indebtedness.

\section{Proposed Revival of the Bank of Tennesee.}

With all this financial folly and injustice staring the people of Tennessee in the face, an attempt was made in 1875 , while the notes of the Bank of Tennessee were still unredeemed, headed by the Comptroller of the Treasury of Tennessee, to re-establish the Bank of Tennessee. The proposition was to issue $\$ 5,000,000$ in State bonds, upon which it was supposed could be realized $\$ 4,500,000$ by placing the bonds at ninety cents on the dollar. This was to be the capital of the new bank. It was suggested that three dollars in notes should be issued for each dollar of capital, which would establish a circulating medium of $\$ 13,500$,000 , with about as much doubt as capital, regarding its circulating 
quality. But the people who were gazing with saddened eyes upon this old bank's pass books, and those who had parted with their Bank of Tennessee notes in exchange to the speculators, in many cases at ninety-

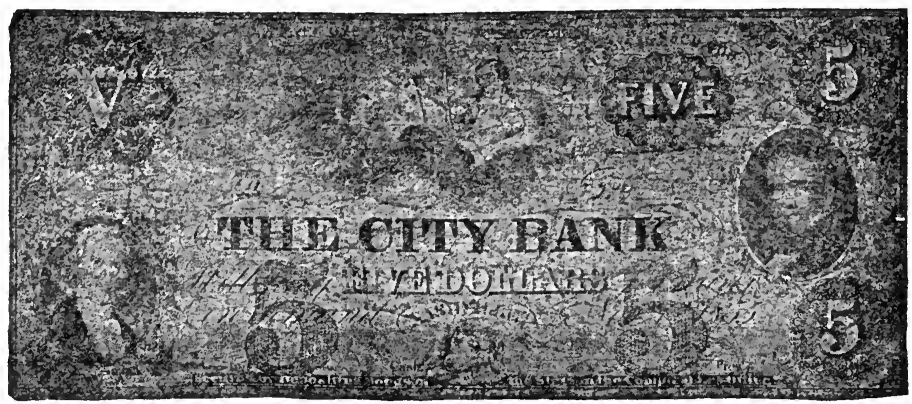

five per cent. discount, did not look favorably upon a repetition of the financial troubles they had so recently met with, firmly believing that as a circulating medium State bank notes, except on a specie basis, will

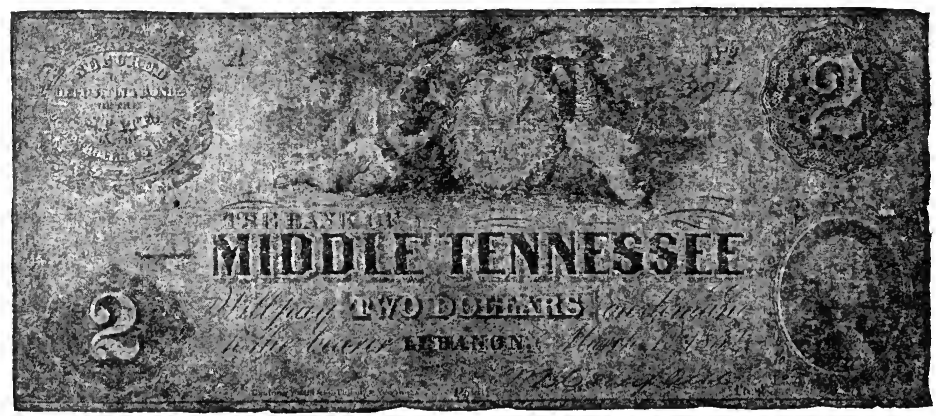

always prove a failure, even if they escape the ten per cent. tax levied upon State bank issues by the United States Government.

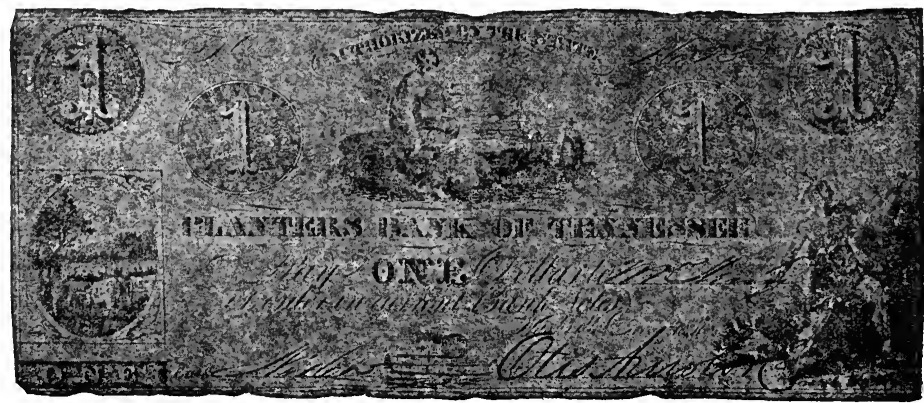




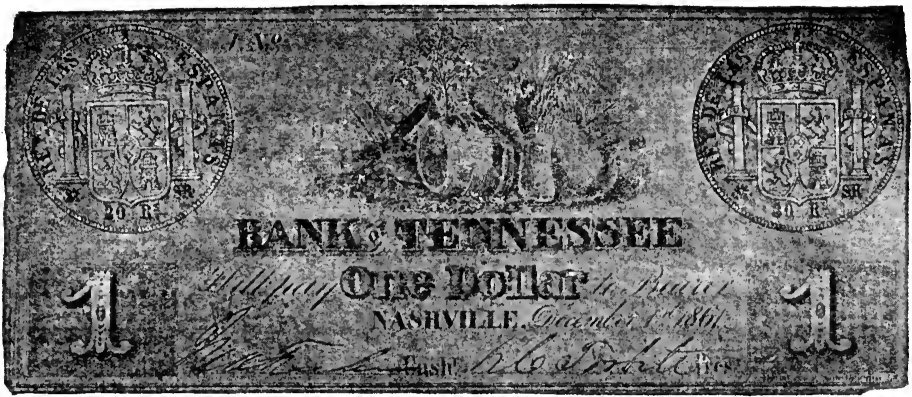

\section{Bankivg in the Principal Cities of the State.}

Memphis has always been one of the most careful banking cities in the State. It was a young but thriving city when the first banks of Tennessee were organized.

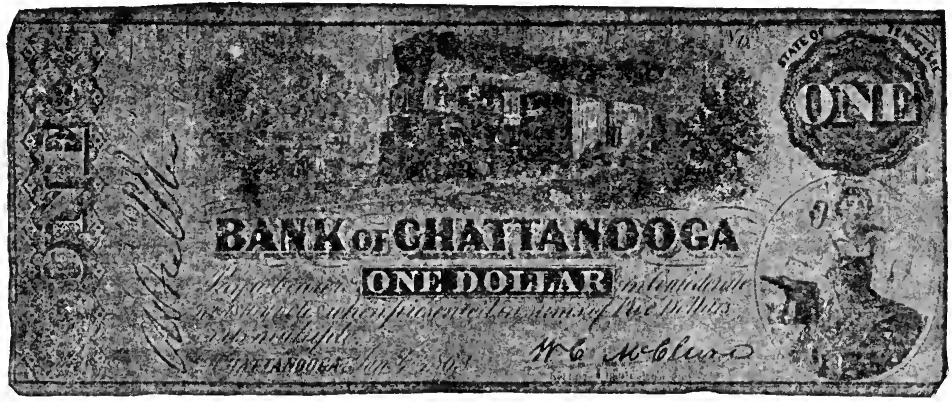

The Farmers and Merchants' Bank was chartered in 1837, and continued to be flourishing until 1849, when it failed and went into liquidation. Its first President was Robert Lawrence, who was succeeded by Seth Wheatly, afterwards by Jeptha Fowlkes. The Bank of Tennessee, chartered in 1838, had a branch in Memphis, also the Union and

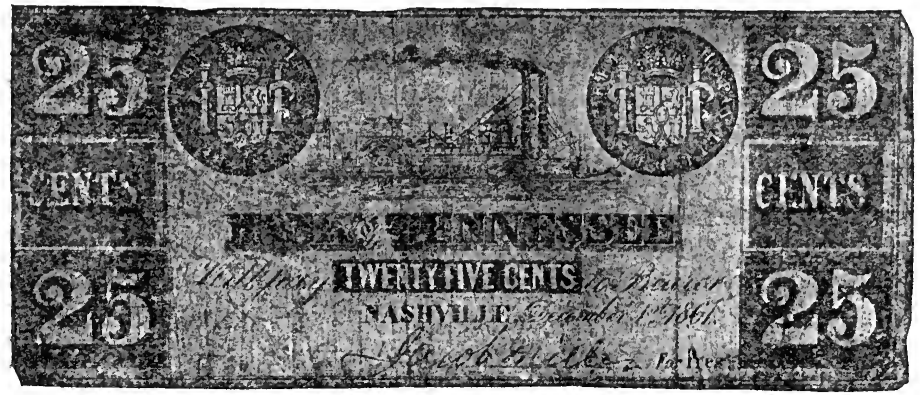


Planters' Bank. Prior to 1840 these branch banks, with the Farmers and Merchants', did the entire banking business for a large section of country contiguous to Memphis. During the period between 1840 and 1850 , a number of brokers engaged in banking. Among them were Fowlkes and Adams, Carroll \& Co., Cameron \& Casey, Cherry, Caldwell \& Co., and J. B. Kirkland. The Merchants' Bank, Bank of West Tennessee, Gayoso Savings Bank, Southern Bank, Bank of Memphis, Citizens' Bank, and others were among the once prosperous banks that are now extinct. (These names are selected from an old copy of Dye's Bank Reporter.)

But few of the notes of the banks at Memphis were at par. The Bank of Tennessee, Union Bank, Planters' Bank, and the Bank of West Tennessee notes were nearly always accepted, but all money circulating in the shape of bank notes was looked upon with suspicion.

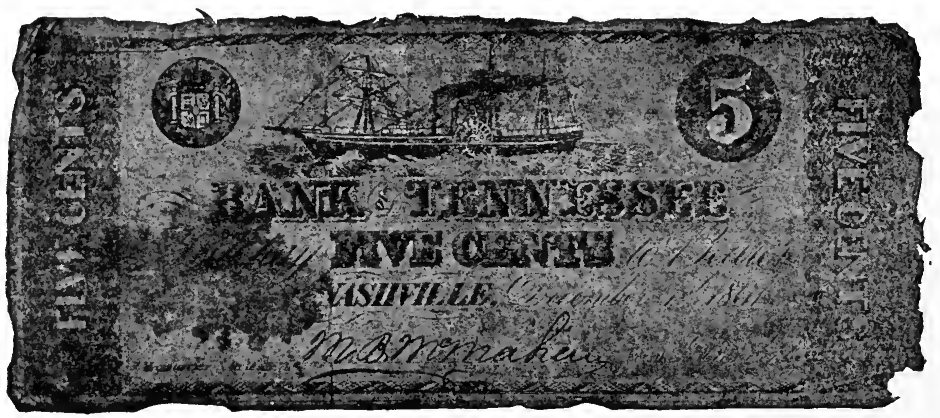

This fear of holding paper money frequently led to excessive and reckless speculation, and many fortunes were made with the money of the times, but more were lost for the want of a sound-money system.

The war of the rebellion wrecked all the banks of Memphis, but when peace was declared the merchants and capitalists arranged to furnish means to meet the wants of their extensive trade by opening private and National banks. Probably no city in the country has a more solid and substantial financial banking record than the city of Memphis. The panics of 1873 and 1893 , though proving a serious obstacle to profits in banking, left but little indication of damage to the banks of Memphis. They stood like the rock of Gibraltar, and came out of the wreck bearing an untarnished record, and strengthened from the fact that they had earned the confidence of the people, and had established the reputation and ability to meet any and every emergency. Even in times of pestilence and panic, Memphis, without resorting to clearing-house certificates, has maintained her credit, and her bankers have met every obligation. The five National, ten private and State and Savings banks and trust companies of Memphis, January, 1899, showed the following condition: 


\begin{tabular}{|c|c|c|}
\hline & $\begin{array}{c}\text { Slate, private, } \\
\text { and Savings } \\
\text { banks. }\end{array}$ & $\begin{array}{c}\text { National } \\
\text { banks. }\end{array}$ \\
\hline Capital... & . $\$ 1,203,500$ & $\$ 2,350,000$ \\
\hline Surplus and profits.... & 359,420 & 560,077 \\
\hline Ind.deposits.......................... & $4,318,030$ & $7,784,666$ \\
\hline Total.. & $\$ 5,880,950$ & $\$ 10,694,743$ \\
\hline
\end{tabular}

This shows a total capital surplus and deposits of $\$ 16,575,693$.

Nashville had five banks in 1861, organized under the general banking laws of the State, viz.: The City Bank, which was the property of Dyer Pearl and his brother, E. G. Pearl; the Traders' Bank, the Merchants' Bank, the Bank of Commerce, and the Bank of the Union. Not one of these banks survived the war.

Nashville now has three National and four private banks, Savings banks and trust companies, their condition in January, 1899, being as follows:

\begin{tabular}{|c|c|c|}
\hline & $\begin{array}{c}\text { National } \\
\text { banks. }\end{array}$ & $\begin{array}{c}\text { State, private } \\
\text { and Savings } \\
\text { banks. }\end{array}$ \\
\hline 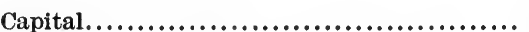 & $\$ 2,000,000$ & $\$ 400,000$ \\
\hline Surplus and profits........................... & 266,683 & 87,283 \\
\hline 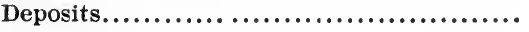 & $6,442,291$ & $1,672,413$ \\
\hline Total... & $\$ 8,708,974$ & $\$ 2,159,696$ \\
\hline
\end{tabular}

This gives a total capital, surplus and deposits of $\$ 10,860,670$.

During the panic of 1893 Nashville had one of the most disastrous National bank failures that has occurred in the South. Most of the banks were forced into suspension, but there has been a substantial recovery from this condition.

Knoxville prior to the war was well equipped with banks. Besides the branch of the Bank of Tennessee, and a branch of the Union Bank, the following local banks were in operation: The Bank of East Tennessee, Bank of Knoxville, Ocoee Bank, Miners and Manufacturers' Bank, and the Farmers' Bank. The Bank of East Tennessee failed, and the people met with a severe loss, as its circulation had been issued to a considerable amount. All of these banks were closed by the war. Knoxville now has five National banks and four State and private banks, their condition being as follows:

\begin{tabular}{|c|c|c|}
\hline & $\begin{array}{l}\text { National } \\
\text { banks. }\end{array}$ & $\begin{array}{l}\text { State and } \\
\text { private banks. }\end{array}$ \\
\hline Capital..... & $\$ 700,000$ & $\$ 283,450$ \\
\hline Surplus... & 391,950 & 21,156 \\
\hline Deposits............ & $3,470,821$ & 335,000 \\
\hline Total.. & $\$ 4,562,771$ & $\$ 639,606$ \\
\hline
\end{tabular}

The only National bank in Tennessee that ever failed and afterwards returned a dividend to its stockholders was the State National Bank, of Knoxville, which paid to stockholders a dividend of nearly eighty-five per cent.

Chattanooga also had her supply of banks in the ante-bellum days. Besides the branches of the Bank of Tennessee and the Union Bank, 
there were the following banks: Bank of Chattanooga, Lookout Savings Bank, and the Chattanooga Savings Institution. These banks were throttled with the rest of Tennessee's financial institutions, by the hand of war.

Since 1865 the following banks have mostly gone into voluntary liquidation: City National Bank, Merchants' National Bank, Fourth National Bank, City Savings Bank, People's Bank, Penny Savings Bank, and two or three smaller concerns, with small assets and liabilities. Chattanooga now has three National banks and five State and private banks, with capital, surplus and deposits as follows:

\begin{tabular}{|c|c|c|}
\hline & $\begin{array}{c}\text { National } \\
\text { banks. }\end{array}$ & $\begin{array}{c}\text { State and } \\
\text { private banks }\end{array}$ \\
\hline 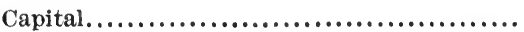 & $\$ 650,000$ & 475,000 \\
\hline Surplus ..... & 395,264 & 30,563 \\
\hline Deposits .......................... & $2,498,086$ & $1,510,023$ \\
\hline Tot & $\$ 3,543,350$ & $\$ 2,015,586$ \\
\hline
\end{tabular}

The war ending brought to their homes those who had been in the Confederate army, or as refugees for four years, to find only the greenbacks issued by the United States Government for war purposes, and National bank notes, as the circulating medium. Private banks were soon organized in portions of the State, and the National banking system was soon fully established. No record can be found to in any way furnish a list of those banks-not National-which were established in the latter part of 1865 , and of later date.

The following statement of the State banks, private banks, Savings banks and trust companies of Tennessee, to December 31, 1898, is as correct as can possibly be furnished with the information at hand:

\begin{tabular}{|c|c|}
\hline $\begin{array}{l}\text { RESOURCES. } \\
\text { Loans and discounts............. }\end{array}$ & \\
\hline Bonds and real estate.......... & $3,045,664$ \\
\hline Cash and due from banks...... & $5,073,800$ \\
\hline
\end{tabular}

LIABILITIES.

$\begin{array}{rr}\text { Capital stock. ................ } & \$ 6,407,010 \\ \text { Surplus and profits............ } & 1,294,262 \\ \text { Deposits and certificates...... } & 14,249,628 \\ \text { Due to other banks........... } & 122,624 \\ \text { Total } \ldots \ldots \ldots \ldots \ldots \ldots \ldots . & \$ 22,073,524\end{array}$

Laws Relating to the Establishment of Banks.

The present system of State and private banking in Tennessee, while it does not equal that of some other States, is so far safe, and when out of the whirlpool of panies, very profitable. The law authorizes the establishing of the following classes of banks: Discount, Saving banks and trust companies. Besides, there are private banking firms unchartered, who are, for the sake of distinction, styled brokers.

All charters in Tennessee are obtainable from the Secretary of State. No special amount of capital stock is required or named in the charter. The President and Cashier must certify to the Comptroller of the State Treasury, under oath, the amount of eapital stock. The management of the bank is in the hands of the President and board of directors, 
who usually select the Cashier and Assistant Cashier, and are required at certain periods to investigate the affairs of the bank. The stockholders are held liable only for the amount of stock they have subscribed. The banks are required to make a statement for publication semi-annually, but no provision is made for filing these statements with the Comptroller of the Treasury of Tennessee, and no penalty is attached for failure to publish the reports.

Tennessee has no bank supervisor or examiner, and there are no restrictions thrown around the character of loans, and no amount of cash reserve or accumulation of surplus required. The law contains nolegal provisions governing the receipt of deposits, neither is the payment of interest on deposits disallowed. In many instances interest on deposits is paid by all classes of banks.

Section thirty-one, article two of the constitution, reads:

" The credit of this State shall not be hereafter loaned or given to, or in aid of any person, association, company, corporation or municipality, nor shall the State become the owner, in whole or in part, of any bank, or a stockholder with others in any association, company, corporation or municipality."

It is therefore impossible for the State, without an alteration of the constitution, to be interested cither as a stockholder or owner of a bank. There is no law prohibiting branch banks, and in some few cases branch banks are in successful operation.

The only medium by which any information regarding the condition of the banks of Tennessee can be furnished the public, is in their semiannual statements, which the law requires shall be published in a newspaper in the town or city where the bank is located.

An ad valorem tax is levied on the capital of banks. At one time an effort was made to class banking as a privilege, for which a privilege tax should be collected, but of late years the privilege tax has been remitted, and the bank's capital taxed as other property. There is no special legal course provided for closing up the business of insolvent banks, but all procedures shall be in the manner provided by law for the application of property of natural persons to the payment of their debts, engagements or contracts. No restrictions are applicable to the investment of Savings bank funds, and such bonds purchased for investment are not required to be of the issue of the State of Tennessee, or the counties or municipalities of the State. Should a law of this character be enacted by the General Assembly, it would keep at home the thousands of dollars sent out of the State each year, or semi-annually, to meet the interest on State, county or city bonds.

The compiler has selected a few samples printed herein of the bank notes issued in Tennessee under the old 'State bank system, as a mere reminder of the legacy left to the present generation, in the shape of a circulation of a worthless character, which is very much in evidence against the issuance of State bank money. 
National Banks of Tennessee that have Failed from 1863 to Dec. 5, 1898.

\begin{tabular}{|c|c|c|c|c|c|}
\hline NAME OF BANK. & $\begin{array}{c}\text { Date of } \\
\text { organization. }\end{array}$ & Capital. & Total assets. & $\begin{array}{c}\text { Offsets } \\
\text { allowed } \\
\text { and } \\
\text { settled. }\end{array}$ & $\begin{array}{l}\text { Loss on } \\
\text { assets. }\end{array}$ \\
\hline Tennessee Nat., Memphis.. & June 5,1865 & $\$ 100,000$ & $\$ 471,991$ & ......... & $\$ 380,383$ \\
\hline Nat. Bank Shelbyville....... & Oct. 20,1874 & 50,000 & 150,681 & ......... & 122,751 \\
\hline Commercial Nat., Nashville... & July 22,1884 & 500,000 & $2,521,952$ & $\$ 86,139$ & 846,322 \\
\hline Second Nat., Columbia........ & Apr. 23, 1887 & 100,000 & 388,354 & 21,872 & 163,801 \\
\hline State Nat., Knoxville*...... & Aug. 28, 1889 & 100,000 & 247,293 & 3,580 & ......... \\
\hline First Nat., Dayton............... & July 10,1890 & 50,000 & 103,355 & 3,026 & 54,231 \\
\hline First Nat., Johnson City....... & Dec. 24,1888 & 50,000 & 151,272 & 3,429 & 101,837 \\
\hline
\end{tabular}

* Returned to stockholders, $\$ 83,375$.

National Banks in Voluntary Liquidation from 1863 to Dec. 5, 1898.

\begin{tabular}{|c|c|c|c|c|c|}
\hline \multirow[b]{2}{*}{ NAME OF BANK. } & \multirow[b]{2}{*}{$\begin{array}{c}\text { Date of } \\
\text { liquidation. }\end{array}$} & \multirow[b]{2}{*}{ Capital. } & \multicolumn{3}{|c|}{ Circulation. } \\
\hline & & & Issued. & Retired. & $\begin{array}{c}\text { Out. } \\
\text { stand. } \\
\text { ing. }\end{array}$ \\
\hline First Nat., Knoxville............... & Oct. 22,1872 & $\$ 100,000$ & $\$ 80,910$ & $\$ 80,208$ & $\$ 702$ \\
\hline Merchants' Nat., Memphis............... & Aug. 30, 1873 & 250,000 & 225,000 & 222,598 & 2,402 \\
\hline Second Nat., Nashville................ & July 8,1874 & 125,000 & 92,920 & 91,810 & 1,110 \\
\hline City Nat., Chattanooga................... & Sept. 10, 1874 & 170,000 & 148,001 & 147,289 & 712 \\
\hline First Nat., Gallatin...................... & Oct. $\quad 1,1875$ & 75,000 & 45,000 & $\$ 4,665$ & 345 \\
\hline First Nat., Bristol................. & July 10, 1876 & 50,000 & 45,000 & 44,748 & 252 \\
\hline Fourth Nat., Memphis.................... & July 19,1879 & 125,000 & 45,000 & 43,845 & 1,155 \\
\hline Mechanics' Nat., Nashville.............. & Jan. 13,1880 & 100,000 & 90,000 & 87,550 & 2,450 \\
\hline National Bank, Pulaski........... & July 23,1882 & 70,000 & 43,700 & 42,646 & 1,054 \\
\hline Merchants' Nat., Nashville............... & June 30,1883 & 300,000 & 141,200 & 139,440 & 2,760 \\
\hline Third Nat., Nashville............... & Feb. 20,1884 & 300,000 & 167,600 & 164,240 & 3,360 \\
\hline Farmers' Nat., Franklin............ & Jan. 24, 1885 & 50,300 & 10,740 & 10,620 & 120 \\
\hline German Nat., Memphis....... & May 6,1885 & 175,300 & 120,100 & 112,415 & 7,685 \\
\hline First Nat., Columbia....... & July 14,1885 & 100,000 & 66,800 & 64,298 & 2,502 \\
\hline Nat. Bank, Lebanon......... & Aug. 30, 1886 & 50,000 & 24,550 & 23,515 & 1,035 \\
\hline Second Nat., Lebanon............... & Sept. 18,1889 & 50,000 & 11,250 & 10,000 & 1,250 \\
\hline First Nat., Cardiff............ & May 25, 1891 & 50,000 & 11,250 & 10,860 & 390 \\
\hline Giles Co. Nat., Pulaski........... & Jan. 12,1892 & 100,000 & 22,500 & 19,204 & 3,296 \\
\hline Merchants' Nat., Chattanooga.... & Sept. 24, 1892 & 250,000 & 45,000 & 40,080 & 4,920 \\
\hline Fourth Nat., Chattanooga............ & Aug. 10, 1893 & 150,000 & 44,200 & 38,970 & 5,230 \\
\hline Farmers and Merch. Nat., Clarksville. & Oct. 19,1893 & 100,000 & 22,100 & 17,150 & 4,950 \\
\hline Farmers and Merch. Nat., Union City. & Jan. 10, 1894 & 100,000 & 22,350 & 18,300 & 4,050 \\
\hline
\end{tabular}


State Banks.

\begin{tabular}{|c|c|c|c|c|c|c|}
\hline YEARS. & $\begin{array}{l}\text { No. of } \\
\text { banks. }\end{array}$ & $\begin{array}{l}\text { Loans and } \\
\text { discounts. }\end{array}$ & Specie. & $\begin{array}{l}\text { Capital } \\
\text { stock. }\end{array}$ & Circulation. & Deposits. \\
\hline $1834 \ldots$ & 1 & $\$ 2 ; 117,371$ & $\$ 86,455$ & $\$ 1,243,827$ & $\$ 1,520,880$ & $\$ 125,486$ \\
\hline $1839 \ldots \ldots$ & 22 & $10,021,729$ & $1,177,969$ & $6,488,192$ & $2,607,830$ & 863,472 \\
\hline $1844 \ldots$ & 23 & $9,122,796$ & $1,109,909$ & $8,536,567$ & $2,345,193$ & $1,186,749$ \\
\hline $1849 \ldots$ & 22 & $8,564,013$ & $1,117,479$ & $7,086,943$ & $3,291,762$ & $1,061,840$ \\
\hline $1854 .$. & 28 & $11,846,879$ & $1,983,790$ & $6,599,872$ & $6,821,836$ & $2,200,922$ \\
\hline $1859 \ldots$ & 39 & $13,262,766$ & $2,863,018$ & $8,361,357$ & $6,472,822$ & $4,659,809$ \\
\hline $1864 .$. & 5 & ............. & ............... & $5,205,700$ & .............. & ................. \\
\hline $1868 \ldots$ & 1 & (............... & & 100,000 & & ............. \\
\hline $1872 \ldots$ & 7 & (n............. & . & $1,594,000$ & .............. & …........... \\
\hline $1887 .$. & 27 & $6,525,539$ & ............. & $2,924,254$ & .............. & $5,590,552$ \\
\hline $1892 \ldots$ & 63 & $7,821,378$ & ............. & $4,017,967$ & .............. & $6,105,364$ \\
\hline $1897 \ldots \ldots$. & 51 & $5,234,642$ & .............. & $2,585,697$ & .............. & $5,241,765$ \\
\hline
\end{tabular}

National Banks.

Figures are in thousands of dollars.

\begin{tabular}{|c|c|c|c|c|c|c|c|c|c|}
\hline YEARS. & 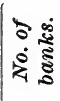 & $\begin{array}{l}\text { Loans and } \\
\text { discounts. }\end{array}$ & $\begin{array}{c}U . S . \\
\text { bonds. }\end{array}$ & $\begin{array}{c}\text { Cash and } \\
\text { cash items. }\end{array}$ & Capital. & Surplus. & $\begin{array}{c}\text { Undi- } \\
\text { vided } \\
\text { profits. }\end{array}$ & $\begin{array}{c}\text { Out. } \\
\text { standing } \\
\text { circula. } \\
\text { tion. }\end{array}$ & $\begin{array}{c}\text { Indi- } \\
\text { vidual } \\
\text { deposits. }\end{array}$ \\
\hline $1864 \ldots$ & 3 & $\$ 87$ & $\$ 485$ & $\$ 554$ & $\$ 340$ & $\ldots$ & $\$ 100$ & $\$ 127$ & $\$ 939$ \\
\hline $1869 \ldots$ & 13 & 3,321 & 1,999 & 853 & 2,017 & $\$ 193$ & 239 & 1,145 & 3,309 \\
\hline $1873 \ldots$ & 23 & 5,154 & 3,450 & 1,102 & 3,101 & 433 & 252 & 2,668 & 4,250 \\
\hline $1878 \ldots$ & 25 & 4,735 & 3,567 & 1,855 & 3,080 & 479 & 211 & 2,427 & 5,273 \\
\hline $1883 \ldots$ & 30 & 10,475 & 3,264 & 1,915 & 4,315 & 810 & 384 & 2,568 & 8,419 \\
\hline $1888 \ldots$ & 42 & 19,850 & 1,873 & 2,418 & 7,715 & 1,616 & 872 & 1,254 & 11,241 \\
\hline $1893 \ldots$ & 52 & 18,336 & 1,664 & 2,674 & 9,400 & 2,109 & 1,048 & 1,224 & 10,456 \\
\hline $1898 \ldots$ & 49 & 20,471 & 2,574 & 2,772 & 8,435 & 1,831 & 884 & 1,737 & 17,827 \\
\hline
\end{tabular}

NoTÐ.-In compiling the history of banking in Tennessee the writer has referred to the following authorities :

Report of Commissioner of Labor (U. S.) 1886.

Phelan's History of Tennessee.

History of Nashville, by J. Wooldridge, 1890.

Acts of the Tennessee Legislature, 1811, 1817, 1820, 1832-33, 1853, 1861-62, 1866, 1883.

Reports of Comptroller of the Currency of the United States, 1876, 1878, 1886, 1898.

Files of the "Clarksville Jeffersonian" from 1844 to 1861.

The Bankers' Directory, January, 1899 ; Bradford Rhodes \& Co.

Executive Documents No. 101, Forty-ninth Congress, first session, subject "Funds Seized at New Orleans, August 17, 1863."

He also returns thanks to Hon. William M. Farrington, Memphis, and Major E. C. Lewis, Mr. John M. Bass, Mr. Edgar Jones and Mr. Joseph W. Allen, all of Nashville, for valuable information furnished. 
* MIDDLE STATES.

Some of the States embraced in what is now known as the Middle West, but which a few years ago comprised the frontier of the country, had a very unsatisfactory experience with banks of issue. It was here that the currency known as "wildeat" and "red dog" flourished and fell, leaving behind it a reputation that still renders ineffectual all arguments for restoring the privilege of issuing notes without special security. For in the popular mind the memory of the banks that did not pay is still fresh, while institutions like those managed by George Smith, in Wisconsin and Illinois, and by Hugh MeCulloch, in Indiana, have been forgotten. In this section of the country, as in others, there was much unsound banking in the era preceding the war between the States, but there were many conspicuous exceptions (notably in Ohio and Kentucky in addition to those mentioned) proving the value of capability and integrity of management under any system. Since those early days there have been great changes in the general condition of the population, and these changes are reflected in the improved standing and management of the banks. This part of what was the West a generation ago is now as conservative as New England. In agricultural wealth and in all the resources which constitute the greatness of a country, the States embraced in this division rank close to the head of all those comprised in the Federal Union.

\section{OHIO.}

The citizens of Ohio early recognized the advantages of association under State authority in the transaction of business, and hence sought the empowering of associations for various purposes. The first Legislature of the State, on April 15, 1803, incorporated the Miami Exporting Company, granting it a charter for forty years. The principal object for which it was organized was the transportation of agricultural products to the markets, particularly to New Orleans. "Its charter, however, granted banking privileges," and on March 1, 1807, it aban-

*The division of the country into geographical sections has been made to conform to that adopted in the reports of the Comptroller of the Currency in recent years. 
doned all other objects and embarked in the banking business. It was located in Cincinnati, and was perhaps the first bank in Ohio, certainly the first under State authority. The nominal capital of this bank was $\$ 500,000$, divided into shares of $\$ 100$ each, payable $\$ 5$ in cash and the remainder in produce and manufactures, such as the President and directors might be willing to receive. It issued notes which were redeemed in the notes of other banks.

On February 10, 1808, the Legislature incorporated the Bank of Marietta, in response to the request of Rufus Putnam, Benjamin Ives Gilman, William Skinner and others, "the better to enable them to carry on the purposes of the institution," and on the 18th of the same month the Bank of Chillicothe, with a capital of $\$ 100,000$, and the Bank of Steubenville were incorporated.

The Muskingum Bank, of Zanesville, was authorized by the Legislature of 1810-11, the Western Reserve Bank, of Warren, by that of 1811-12, and the Farmers and Mechanies' Bank, of Cincinnati, by that of 1812-13, their several charters to continue until 1818. These banks were created by special acts, the main features of which were the same.

\section{Unauthorized Circulation Prohibited.}

February 8, 1815, the Legislature passed "An act to raise revenue from the banks and to prohibit the unauthorized issuing and circulating of bank paper." All banks, whether chartered or unincorporated, were required to pay the State four per cent. upon all dividends declared by them. The law provided for the collection or enforcement of the claim, should any bank fail to comply with the requirements of the act. The same act provided that it should be unlawful for any one, individual or company, to issue notes unless authorized by law, and provided as a penalty for the violation of this law, that every person so offending, on conviction, "Shall be imprisoned for the space of one year and fined in any sum not exceeding five thousand dollars, at the discretion of the court." These provisions were not to be applicable to banks which had begun business previous to January 1, 1815, until after January 1, 1818. On January 27, 1816, the Legislature enacted a law to regulate banks and banking, and to prohibit the issuing and circulating of unauthorized bank paper, beginning a war against unauthorized banks and bank currency that was waged by the State during the continuance of State banks issuing currency.

\section{Suspension DUe to the War of 1812.}

A condition of general distress and financial difficulty followed the War of 1812, and many banks were compelled to suspend business. Rufus King, in "American Commonwealths," says: "In Ohio and other Western States the circulating notes of all banks were below par; notes of the best Ohio banks were at a discount in New York of from eight to fifteen per cent." 
Salmon P. Chase, writing of this period, said:

"The numerous banks, which had been chartered before and during the war, and which continued to spring into existence in every part of the State, supplied an abundant medium. Speculation, stimulated by every incentive, ran into wild and extravagant excesses. Improvements of every kind, under its strong propulsion, advanced with enormous rapidity. But this innatural state of things could not long continue. Men who had contracted debts found, when called upon for payment, that the means were wanting. Banks which had made excessive issues found themselves unable, at all times, to redeem their paper on demand, and the currency of course began to depreciate. Things were rapidly verging to this state, when the branches of the Bank of the United States, which had been chartered by Congress in 1816, were established at Cincinnati and Chillicothe. These branches issued notes to a considerable amount, and the presence of this convertible paper, doubtless, tended to hasten the depreciation of the State currency. By receiving the notes of the State banks, also, until large quantities had been accumulated, and then calling on them to redeem their paper, the branches effectually tested the solvency of these institutions. Few could endure the ordeal. The notes of nearly all the local banks continued to sink lower and lower in the scale of depreciation, and the paper of several became absolutely worthless."

To relieve the situation the Legislature sought to increase the number of banks and by act of February 23, 1816, six new ones were incorporated and seven existing institutions authorized to continue under the provisions of this act. The new banks provided for were: the Franklin Bank, of Columbus: the Lancaster Bank, of Lancaster; the Belmont Bank, of St. Clairsville; the Commercial Bank, of Lake Erie, in the village of Cleveland; the Bank of Mt. Pleasant, at Mt. Pleasant, and the Bank of West Union, at West Union. The charters of the following banks were continued by the same law: The Lebanon Miami Banking Company, the Bank of Cincinnati, the Urbana Banking Company, the Columbiana Bank, of New Lisbon; the Farmers and Mechanics' Bank, of Chillicothe, and the German Bank, of Wooster. It also provided that the Miami Exporting Company might avail itself of the provisions of the act and continue banking under its authority. The charters of these banks were to continue until 1843. This law provided that the affairs of each institution organized under its provisions should be managed by a board of thirteen directors, of whom the President should be one, and a majority of whom should constitute a quorum for the transaction of business. Each bank was to set off one share to the State for each twenty-five shares of its capital stock, on or before September 1, 1816, and to continue to do so as new stock might be created and sold. Each share set apart to the State should be entitled to the same dividend as allowed other stockholders, "collectively as one dollar is to twenty-five dollars." This provision was made in lieu of taxes, and all banks availing themselves of the provisions of this act and operating thereunder were "exempt and free from payment of any tax to be imposed and collected by any other law of the State." 


\section{Legislation Regulating the Banking Business.}

February 5, 1819, the Legislature passed "An act to regulate judicial proceedings where banks and bankers are parties, and to prohibit issuing bank bills of a certain description." No bank or banker within the State should issue or receive notes or bills payable on a future day, but all such were to be "held to be payable on demand." It also prohibited the issuing, passing or receiving of bills of less denominations than one dollar.

The Legislature attempted to make the money of the banks good by legal enactment through the passage of a law, February 8, 1819, to prohibit the paying or receiving of any bank note or bank notes at less than the amount expressed in the body of the same, and every person so offending was to be deemed guilty of misdemeanor and upon conviction thereof, be fined in any sum not exceeding five hundred dollars. This law was repealed January 24, 1820. On February 18, 1820, an act was passed to enforce payment by banks and to prohibit the issuing of bills payable at a future date.

Enactments were passed on February 2, 1821, February 2, 1822, and January 28,1824 , to facilitate the collection of debts or claims against banks or bankers. The last enactment also reiterated the prohibition against issuing bills payable at a future date.

By act of February 5, 1825, all banks created or incorporated by the act of February 23, 1816, were reinvested with such stock as had been set off and vested in the State, and instead thereof each bank was required to pay to the State two per cent. on all dividends made by it previous to the passage of this act, and four per cent. on all dividends which should thereafter be made by such bank, until otherwise provided by law. It required the directors or a legal majority of them to notify the Auditor of State of their acceptance of the terms of this act and their compliance therewith and to furnish the Auditor with a statement of all dividends made previous to the passage of this act.

\section{Branch of the United States Bank Prohibited.}

March 14, 1836, was passed "An act to prohibit, within this State, any branch, office or agency of the United States Bank, as recently chartered by the Legislature of Pennsylvania;" wherein it was provided, "That, whereas, the general welfare of this State forbids the establishment, within its limits, of any branch, office or agency of said bank," etc. That it should be unlawful for any body corporate, created by law of the State, or person or persons to act as agent or representative for such bank, or to circulate any notes or bills, as money, issued by the Bank of the United States. To make the act effective heavy fines were imposed for a violation of its provisions. This act was repealed January 28, 1838, and a new one passed February 9, 1839, prohibiting the establishment of any branch of any bank within the State 
without the consent of this State, which law remained in force until March 12, 1845.

On March 14, 1836, a law was enacted prohibiting the issuing of bills of less denomination than three dollars after July 4, 1836, and any bills of less denomination than five dollars after July 4, 1837. But on March 13,1838 , the above act was repealed and banks were authorized to issue notes of less denomination than five dollars, but not less than one dollar. By the last-named act it was provided, "That the several banks incorporated by the laws of the State be and they are hereby required to resume specie payments by July 4, 1838, provided the banks of New York, Philadelphia and Baltimore have resumed by that time." And if any bank should fail to comply with the requirements and not resume specie payments, it should be discredited at the treasury of the State and its notes should not be received by county treasurers for "taxes, tolls, or other public dues of the State."

But the enactment of laws by one Legislature for the purpose of authorizing and regulating banking and currency and the repeal of such enactments by the succeeding Legislature and the substitution of other enactments for the same purposes and the same objects failed to correct the evils of either banking or currency or to prevent the failures of banks.

February 16, 1838, an act was passed prohibiting the exercise of banking functions, including the issue of notes, except by banks incorporated by a law of this State.

By an act of February 9, 1839, the issuing of any bill of less denomination than three dollars after July 4, 1839, and after October 1, 1839, of less than five dollars or of a denomination between five and ten dollars, was prohibited, under penalty of fifty dollars for each offense.

\section{The Banking Law of 1839.}

On February 25, 1839, the Legislature passed an act providing for the appointment of a Board of Bank Commissioners and for the regulation of banks within the State of Ohio. This law provided for the appointment of Bank Commissioners of the State of Ohio, one for two years, one for four years and one for six years, and at the expiration of their terms the appointments were to be for six years. They were to receive as compensation three dollars per day, "while actually engaged in their appointments," and three dollars for every twenty-five miles of necessary travel, but "shall receive no per diem compensation during the time employed in travelling." It was made the duty of the commissioners, or one of them, to visit every banking institution in the State at least once in each year without previous notice to such institution, and make a thorough examination thereof. Their powers were ample to carry out the provisions of the law. It was the duty of the commissioners to make an annual report of their proceedings and investigations to the Legislature on or before the third Monday of each reg- 


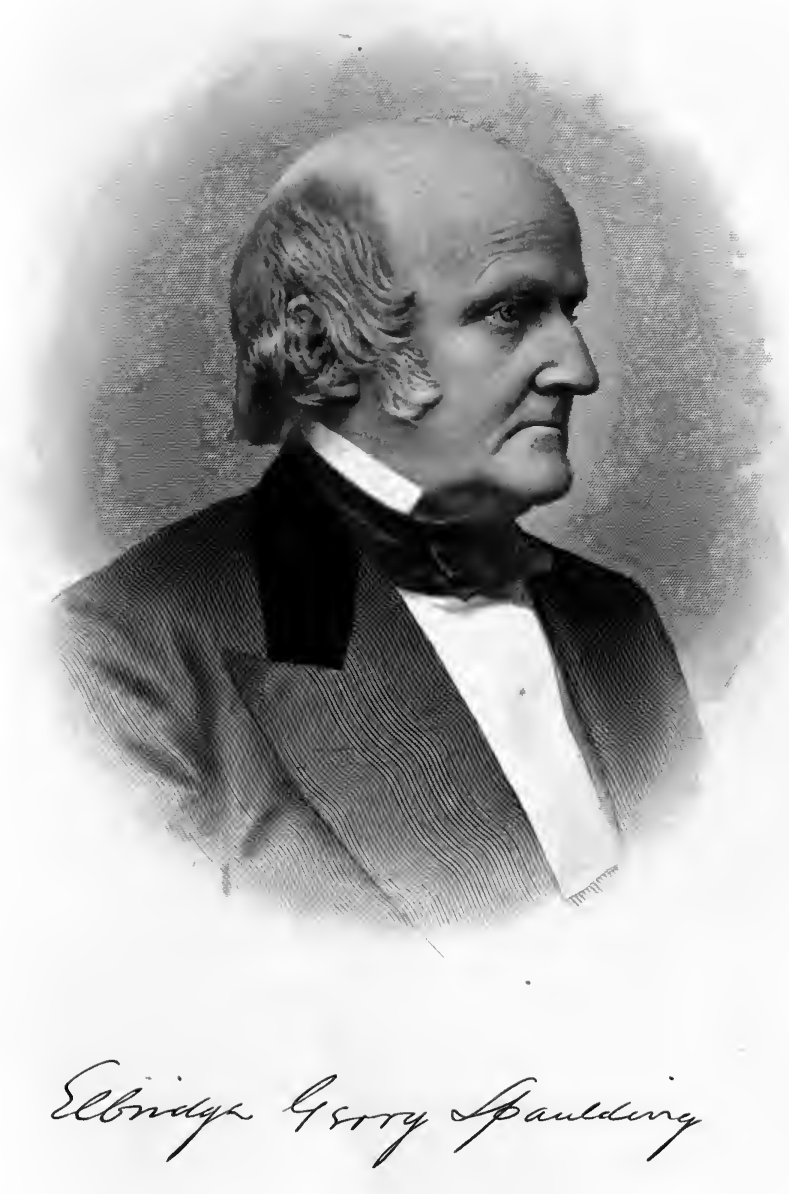


ular session. The commissioners were liable to prosecution for a failure or neglect of duty, and were forbidden to disclose the name of any debtor of any banking institution or the private accounts of depositors. If any banking institution through its officers refused to permit the examination, or to furnish such evidence or assistance as the commissioners needed in the examination, it should forfeit its charter.

It required all banking institutions to, at all times, pay their notes in gold and silver coin or the current notes of other banks; if they should for a period of thirty days in any one year, fail to pay their notes in gold or silver, the commissioners should, in the manner prescribed, proceed to close up such institution.

It prohibited the appointment of any one to be a commissioner who was a stockholder of or who was indebted to any moneyed institution having banking powers.

On March 23, 1840, the Legislature enacted another amendment to the law of January 27,1816 , endeavoring to drive from circulation all unauthorized issues of currency. It also, by this act, prohibited the issuing of bills of less denomination than five dollars. The penalty for the violation of the above enactment was the forfeiture of its charter by the bank violating.

On the same date an amendment was made to the act providing for the Board of Bank Commissioners, defining the powers of the board and specifying the duties of banks and bank officers in their relation to the board, fixing the compensation for the board and providing the penalty for failure upon the part of the banks to comply with the requirements of the act.

An act was passed February 18, 1842, to enforee the resumption and continuance of specie payments by banks, to provide for the appointment of Receivers for failed banks, and to define the powers and duties of such Receivers. This also prohibited the buying of or speculating in claims against the bank by the Receivers or Bank Commissioners. It further provided that if any Receiver or Bank Commissioner "shall convert to his own use, embezzle, loan or fraudulently dispose of any money or effects of such insolvent banks he shall upon conviction be imprisoned in the penitentiary and kept at hard labor, not more than ten years nor less than three years." It further defined the duties of the commissioners, requiring them, or one of them, to visit the banks at least once in each six months.

\section{General Revision of the Banking Law in 1842.}

A general law to regulate banking in Ohio was enacted March 7, 1842 , which was intended to remedy the evils resulting from the deficiencies of former legislation and to embody the wisdom derived from experience. It provided that no association of persons should be incorporated to carry on the business of banking within this State without being first regularly formed, and having made application to the Legis- 
lature for an act of incorporation; required notice of such application to be published in some newspaper of general circulation in the county for at least thirty days next preceding the session of the General Assembly to which application was to be made. It defined the powers of the bank and prohibited it commencing business until all its capital should be paid in gold or silver; required the capital stock to be examined by the Bank Commissioners and certified to the Register; required the officers to take oath and defined their powers and duties; provided for punishment for violation by an officer or agent of any of the provisions of the preceding specifications; provided for declaring dividends, the proportion of circulation to eapital, and the manner of issuing circulation, the payment of expense of commissioners and registration, the rate of interest, for a special tax on capital and circulation, for the creation of a safety fund, for the receiving of the notes of other banks, rules for transfer of stock, the posting for public inspection of the names of stockholders; made the President, directors and officers liable for the loss of capital and mismanagement, and regulated the denomination of notes. On the same day the Legislature passed an act to prevent fraudulent currency, and another to amend the act of February 18, providing for Bank Commissioners and for the regulation of banks within the State, and to enforce resumption and continuance of specie payments. The act of February 18, 1842, was further amended by an act of January 25, 1843.

Each session of the Legislature, either upon recommendation of the Governor, or the promptings of patriotism, undertook to remedy the evils of the currency system. The enactment of the most stringent laws against unauthorized banking and bank currency, and the increasing of banks by authorizing additional charters, did not prevent the circulating of unauthorized currency nor the failure of banks. These brought distress and resulted in general paralysis of business by the withholding from the community of the principal agent necessary to its transactions.

\section{Opposition to the Bank of the United States.}

The establishment of a branch of the United States Bank in Cincinnati, January 12, 1817, and one at Chillicothe on October 13, of the same year, designed possibly to give strength and stability to the general financial system, proved rather to be a source of irritation, not only to the bankers of the State but also to the Legislature. What was begun as a war of competition between the banks, became a war of extermination when taken up by the Legislature. On February 8, 1819, the Legislature adopted a resolution levying a tax of $\$ 50,000$ upon each branch or office of the Bank of the United States in Ohio; and provided that if payment should be refused, the collecting officer should enter the bank and by force secure the amount, which was done in the case of the Chillicothe branch. The bank appealed to the United States 
Circuit Court, which ordered that the money be returned. The matter was carried to the Supreme Court of the United States and decided in favor of the bank.

\section{Difficulties in Adjusting Taxes.}

The question of taxation was one that exercised the ingenuity of legislators and State officials. It was sought in several ways to secure a basis of valuation that would be accepted by the banks and at the same time make it a stable and profitable source of revenue to the State. First there was levied a certain per centum upon the dividends paid, and next there was the setting aside of a portion of the stock as the property of the State, and then finally a return of this stock to the banks and again requiring the payment of a certain per centum upon dividends paid. These afford illustrations of the methods of experiment employed in the matter of bank taxation. The State officials appear to have experienced considerable difficulty in collecting the taxes from the banks. The reports of the State Auditors give frequent notice of their inability to collect the taxes due and the consequent embarrassment to the department.

\section{Why the Banks Suspended Specie Payments in 1837.}

The suspension of specie payments was a matter of frequent occurrence and a cause of grave concern to Legislature, banks and community. The Legislature in December, 1837, by resolution required the Auditor of State to procure from the banks a general statement of their condition under twenty different questions, or specifications, one of which was, "What were the causes which led them to suspend specie payments and at what period they expect to resume them?"

Replying to the above questions, M. Garathy, Cashier of the Lancaster (Ohio) Bank, said:

"The causes which led to the suspension of specie payments by the Ohio banks, in May last, were so notorious at the time the suspension took place, that we did suppose they were known to every one. But it seems to be otherwise; and we will therefore give, in as brief a manner as possible, the reasons, as we suppose, which induced the suspension.

At the time the Ohio banks declined the redemption of their bills with specie, they were apprised that the banks of the States north and south, east and west, had generally, if not universally, suspended specie payments. The Ohio banks were well aware that a continuance of specie payments, under such a condition of things, would subject them to heavy and constant drafts on their coin ; and that, too, by banks of other States, which had closed their doors to this mode of payment. They deemed it gross folly-nay, worse, highly criminal, to continue a course of operation which must result in abstracting, to their full amount, the precious metals from Ohio, while so far as they could see, no corresponding benefit would result therefrom. In this condition of the monetary affairs of the country, and with the further embarrassment arising from the refusal of the land offices to receive bank paper in payment of the public lands, the Ohio banks felt it to be an imperative duty to adopt the course they did, for the purpose of guarding against consequences which they foresaw must prove 
fatal to the banks, and disastrous to the best interests of the State. The suspension of specie payments by the Ohio banks was nearly simultaneous, and without concert, showing that similar views and similar feelings influenced them to the course they took.

To that part of the resolution which requires an opinion as to the time when the banks expect to resume specie payments, a simple declaration that we do not know, might be deemed an insufficient answer. * * *

The refusal at the land offices of the notes of specie-paying banks, when for fifteen or twenty years they had been received, and without a reason being assigned for the refusal, was eminently calculated to discredit bank paper with the public generally. It is a fact notorious to the most casual observer, and which it were useless to attempt to disguise, even if we felt inclined to do so, that the measures of the Secretary of the Treasury, since July 1, 1836, in reference to western bank paper, have resulted, whether so intended or not, in exciting a general distrust of paper money ; and the unfortunate compulsory suspension of specie payments, which followed soon after, completed the mischief which the Secretary began. If the specie circular * were rescinded, the bank paper made receivable in payment of public lands, the confidence of the public in bank notes would be at once restored, and the western banks. could and would commence the payment of specie for their notes forthwith; but to attempt a resumption while the country is so deeply in debt, and under the now discredited condition of paper money, would bring on a state of things which no benevolent mind could contemplate but with feelings of deep regret."

Reports were received from thirty-four banks, generally sustaining the views expressed in the above quotation. This appears to be the first general record of the condition of the banks of the State, being a statement of their condition in December, 1837. It shows that these thirtyfour banks were capitalized at $\$ 13,700,000$, and had paid in $\$ 11,331,618$ of capital and had a circulation of $\$ 6,221,136$.

\section{Organization aNd Operation of The EarLY Banks.}

During the twenty years following the passage of the general enactment of 1816, numerous banks were organized. The Dayton Manufacturing Company, with banking powers had been authorized, August 18, 1814, and continued in business until 1831, at which time some change was made in its affairs and thereafter it was known as the Dayton Bank. It is claimed to be the lineal antecedent of the Winters National Bank of the present. At Mount Vernon the Owl Creek Bank was organized April 10, 1816. It is said to have been a private bank, and failed in 1831. The Bank of New Philadelphia was organized November 13, 1816, and failed a few years later. The Bank of Hamilton, at Hamilton, was authorized December 19, 1817, and continued to do business until February 9, 1842. At Xenia the Bank of Xenia was authorized in 1819, the Bank of Geauga, at Painesville, in 1830, and continued until 1863 ; the Franklin Bank, of Cincinnati, was organized and commenced business in 1833, and the La Fayette Bank, of Cincinnati, in 1834, both of which are still doing business. The Bank of Circleville was authorized in 1834 and liquidated in 1854. The Bank of 
Manhattan was authorized March 25, 1836, to do business at Toledo, and appears to have been the first bank at that place. The Ohio Life and Trust Company was chartered February 12, 1834, with an authorized capital of $\$ 2,000,000$; it w?s located in Cincinnati with a branch office in New York.

Of the first banks the Miami Exporting Company had a successful career for many years, but finally declined and failed January 10, 1842. The Farmers and Mechanics' Bank, of Cincinnati, failed the following day. The Bank of Marietta continued business by extension of its charter until January 1, 1843, when it went into voluntary liquidation, . by reason of the expiration of its charter, but before its affairs had been finally closed the law of February, 1845, had been enacted, and it was succeeded by the Marietta branch of the State Bank, in the same room and with the same President. In 1863 the branch bank was merged into the Marietta National Bank and continued until February 16, 1876, when it went into final liquidation. The Muskingum Bank, of Zanesville, had a very successful career, and continued to do business until the expiration of its charter in 1843. It is claimed for this bank that it and a bank in Pittsburg were the only ones in the United States that did not repudiate and refuse to pay their notes during the panic of 1837 .

The Western Reserve Bank, of Warren, while not the first bank in the State, has perhaps had the longest existence. Chartered by the Legislature of 1811-12, it commenced business November 12, 1813, and by renewal of its charter continued business until December 31, 1842, when it proceeded to close up its affairs. It procured its second charter as an independent bank under the law of 1845, in July of that year; and in turn became the First National Bank of Warren, July 31, 1863, again renewed its charter in 1883, and is still doing business, having an unbroken succession of more than eighty-five years.

\section{Unsatisfactory Experience with Notes Secured BY CoM- MERCIAL Assets.}

The year 1842 closed one period of history in banking in Ohio, for by the law of 1816 the charters were to expire January 1, 1843 . Numerous banks had been incorporated within that period, some of which had been successful but many failed. A feeling of general distrust prevailed during a good portion of the time and much difficulty and inconvenience were experienced in the transaction of the business of the country. The banks gave no security for their circulation beyond their general assets, and when a bank failed the notes were in many cases found to be worthless. This frequently occurred even when ordinary prudence had been exercised in the management of the bank, because of the inability of borrowers to meet their obligations as well as the inability of the officers to realize on property, the assets of the bank of necessity undergoing shrinkage. Another aggravating source of distrust was the 
failure of banks which from results appear to have been organized purely for speculation. One of the most flagrant examples is the Bank of Gallipolis. In 1839 a gentleman claiming to be a capitalist from Buffalo, with two others, arrived in Gallipolis and proceeded to organize the Bank of Gallipolis. These gentlemen were very plausible in their appearance and representations and soon succeeded in starting the bank with a capital of $\$ 200,000$. The directors authorized an issue of $\$ 175,000$ of circulation, and it is said that so far as the books of the bank show that was all that was ever issued. When the bank failed, perhaps two years later, it was discovered that the gentlemanly managers had had printed and issued $\$ 1,200,000$ without the knowledge of the directors. This currency was scattered all over the South and West. These bank notes as products of the engravers and printers' art compared favorably with the work of the present. There are still some of them in existence and inquiry is frequently made as to their value.

In 1834 the Lafayette Bank, of Cincinnati, was organized and among the names of the directors appears that of Salmon P. Chase, who was chosen secretary for the board; and the records of the meetings of the directors, made by him, are still in the possession of the bank. Other prominent bankers of that period were Trumann P. Handy, of Cleveland, who appeared as Cashier of the Commercial Bank of Cleveland in 1837. Also James P. Espy, who was elected Cashier of the Franklin Bank, of Columbus, January 18,1827, which position was later filled by his son James Espy, now of Cincinnati.

On February 21, 1843, an act was passed to amend the law of March 7,1842 , by prohibiting any person from serving as director in more than one bank at any one time, and providing that "no judge of any court of record in this State or clerk of any such court, or sheriff of any county, shall be eligible as a director of any such banks. $* * *$ Nor shall any loan be made for a longer period than six months, nor any note purchased that has a longer time to run than six months from the date of purchase." It also regulated dividends, defined duties of directors, provided for their release from individual liability, required directors to examine the bank at least once in each six months, fixed stockholders' liability, provided for a Receiver in case of failure and defined his duties, prohibited banks and bank officers from dealing in public stocks of any kind, and provided that the State of Ohio should have a lien upon the real estate of the directors and stockholders of any insolventbank, "for the benefit of the creditors of such bank." It also provided for the renewal of the charters of a number of banks. On March 6, 1844, provision was also made for renewal and amendment of the charters of a number of banks enumerated in the act.

The financial difficulties of the period beginning in 1837 had affected the State government as well as the banks and the people. The State was engaged in building canals, and had of necessity placed its securities upon the market. It had also borrowed $\$ 500,000$ from the Frank- 


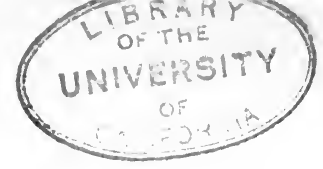

MIDDLE STATES.

lin Bank, of Columbus, and $\$ 581,000$ from the Chillicothe Bank, of Chillicothe, with which to meet its payments on this work, and found itself unable to further meet its obligations. In the Legislature opposition had developed against the continuance of these improvements, and an effort was made upon the part of this opposition to repudiate the obligations of the State. With this division in the sentiment of the Legislature and its consequent effect upon the State securities, and without funds to meet its maturing obligations, it seemed as if dishonor and ruin must be the result. It was in this crisis that a distinguished citizen who had served the State as a member of the Legislature for many years, and in other capacities, came to the State's rescue. Hon. Alfred Kelley, upon his own responsibility and the strength of his integrity, raised nearly a quarter of a million of dollars and saved the credit of the State. In 1844 he was again elected a member of the Legislature. Mr. Kelley had been a leader in nearly all movements for the public welfare and internal improvements. There had been a strong demand during the past several years for the creation of a banking and currency system that would provide a stable circulation and promote the credit of the financial institutions. It was natural, therefore, to look to Mr. Kelley for some effort in that direction. In the period between the date of his election and the meeting of the Legislature he had prepared a bill "to incorporate.the State Bank of Ohio, and other banking companies," which, as Chairman of the Currency Commission, he introduced on January 7, 1845. The committee in reporting the bill, said:

"The committee entertains no doubt that a very large majority of the people of the State anxiously desire the enactment, by the present General Assembly, of some law authorizing the establishment of banks which will furnish them with a safe and convenient currency, afford reasonable facilities for obtaining money to meet the wants of commercial and manufacturing operations, and at the same time hold out proper inducements to those who have money to invest in banking institutions. * * * In framing this bill the committee have constantly in view the great landmarks of entire security to the bill holder, reasonable security to dealers with the banks, and proper inducement to the capitalist, whether great or small, to invest his disposable means in banking."

\section{Provisions of the Act of 1845.}

The Legislature passed the bill February 24, 1845. It provided that it should be lawtul for any number of "natural individual persons, not fewer in number in any case than five, to associate and form companies for the purpose of carrying on the business of banking, each in such place in this State as shall be designated in the articles of association, subject to the contingencies, restrictions, conditions and liabilities prescribed in this act." The aggregate amount of capital stock of all the companies authorized by this act was fixed at six millions, one hundred and fifty thousand dollars. This did not include the eapital of existing banks that might be authorized to continue business by accepting the 
conditions of the act. It divided the State into twelve districts, for the purpose of giving a fair distribution of the privileges of the act, and fixed the maximum number of banks to which each district should be entitled, created a Board of Commissioners composed of John W. Allen, Joseph Olds, Daniel Kilgore, Alexander Grimes and Gustavus Swan, and provided for their qualification and succession; required the Governor to call the first meeting, fixed Columbus as the place of meeting, and directed the commissioners to select one of their number as president; required certificates setting forth the name of the company, the city, village or town where it was to do business, the amount of capital stock and the number of shares, the name and place of residence and number of shares held by each member, the time when such company shall have been formed, and whether the company had elected to do business as an independent banking company, or as a branch of the State Bank of Ohio. The certificate was to be properly acknowledged, recorded by the county recorder and a copy filed with the Secretary of State. The capital stock of any branch of the State Bank should not be less than one hundred thousand dollars, and of an independent bank not less than fifty thousand dollars. The law provided for the deposit of security for circulation and the payment of stock, also for the Board of Commissioners to examine certificates, and defined their duties. It also provided for the appointment of a Board of Control for the branches of the State Bank of Ohio, defined their qualifications, and stipulated the time and place of meeting, fixed their compensation and created them a body corporate until May 1, 1866, and thereafter until the affairs of the several branches should be closed up. All notesissued and intended to circulate as money were to be made payable at the office of the branch and required to be paid in gold or silver coin, the lawful currency of the United States, or either, at the option of the branch, on demand. It provided the ratio of circulation of branches of the State Bank, which should be: "On the first hundred thousand dollars or any lesser amount of its capital, not more than twice the amount of such capital; on the second hundred thousand dollars, or part thereof, not more than one and a half times the amount of such capital over one hundred thousand; on the third hundred thousand dollars or part thereof not more than one and a quarter times the capital over two hundred thousand; on the fourth hundred thousand dollars, or part thereof, not more than once the amount of such eapital over three hundred thousand, and on any amount of capital over four hundred thousand dollars not more than three-fourths of such capital over four hundred thousand, and on its portion of the safety fund an amount equal thereto.

It also provided the manner of delivery of notes and their return when mutilated; required each branch to pay ten per cent. on the amount of its circulation to create a safety fund, which should be invested, and defined the liability of stockholders and directors. Should 
any branch refuse to redeem its notes it was to be deemed insolvent. In case of insolvency each branch was required to contribute in proportion to its circulation to a fund for redeeming the notes of the failed bank. Independent banks were required to deposit certificates of funded debts of this State or the United States to the amount of their stock. The Treasurer of State was to furnish circulation for banks, and authorized to procure the necessary engraved plates. Should any independent banking company fail to redeem its notes the Treasurer of State was authorized to sell stock and redeem the outstanding circulation. It made it the duty of the Auditor, Treasurer and Secretary of State, or a majority of them, as often as once in each year, to appoint some suitable person in the vicinity of each independent banking company, who should not be a stockholder in any bank of this State, who had the power to make a thorough examination into all the affairs of the bank which he might be appointed to examine, and such agent was required to make a detailed report of the condition of such bank to the Auditor of State.

The general provisions provided for the division of the capital into shares of one hundred dollars each, representation of stockholders at election, the number (not less than five or more than nine), and qualification of directors, their term of office, and how vacancies should be filled, and that banking companies should be bodies corporate until May 1, 1866, and thereafter until their affairs are closed up; authorized the issuing of notes of one, two, three, five, ten, twenty, fifty and one hundred dollars each and fixed the ratio of each; and provided for the redemption of the notes of both independent and branch banks. It required each banking company to have on hand at all times in gold or silver coin, or their equivalent, one-half of which at least should be in gold and silver coin in its vaults, an amount equal to at least thirty per centum of its outstanding notes of circulation; fixed the time for declaring dividends, and required statements to be made twice each year and filed with the Auditor of State; required each company to pay the State six per cent. on its net profits in lien of all taxes to which it should otherwise be subject; fixed the limit to which loans might be made to any person or firm; prohibited the paying out of any depreciated notes, and regulated the penalty for any violation of this act by any officer or director. then provided for the continuance of existing banks upon accepting the terms and conditions of this act.

The enactment of this law opened the way for the establisment of a system of banks that supplied a circulating medium entitled to the confidence of the people and with such safeguards about its preparation and emission as to protect it against unauthorized issues. Numbers of banks whose charters had expired in 1843 and were in process of liquidation, availed themselves of the provisions of the act to become branches of the State Bank of Ohio or independent banks; while some of the old banks whose charters had been renewed by special legislation continued 
under their former charters. For several years business prospered, and the Commonwealth enjoyed the benefits of a uniform and sound currency. The first general report, as evidenced by the public records, was of the conditions of the banks November 15, 1846. At that date there were nine independent banks, seventeen branches of the State Bank and eight old banks. The independent banks had a capital of $\$ 376,170$; the branch banks, $\$ 1,496,787$, and the old banks, $\$ 3,953,750$, making a total authorized banking capital of $\$ 5,826,677$. In 1847 the number of banks had increased to ten independent, twenty-five branch and eight old banks; in 1848 to fifty-six and to fifty-seven in 1850.

\section{Further Acts to Prevent Unauthorized Banking.}

The providing of a sound and uniform currency did not prevent the issuing of unauthorized bank notes and the circulation of issues of other States, and to try to control this the Legislature on March 21, 1845, passed an act prohibiting any one from engaging in the business of banking without express authority of a law of this State; and again, on January 22, 1846, an act to prevent unauthorized banking and the circulation of unauthorized bank paper. This prohibited any exchange broker, money broker or incorporated company bringing into the State for purposes of circulation as money any notes issued by any bank or banking company out of this State. It provided further, "nor shall any broker or incorporated company receive them knowing them to have been brought into the State; provided, however, that this shall not be construed to prevent the receipt of such notes if the bank issuing is at the time redeeming its notes in gold and silver and they came into the State in the regular course of business."

\section{Enactment of a Free Banking Law.}

On March 21, 1851, the Legislature passed an act to authorize free banking. Section 1 provides: "That any number of natural persons, not less than three, may engage in the business of banking, with all the rights, privileges and powers conferred by and subject to the restrictions of this act."

This act further provided for certificates to be made by the incorporators, giving name of company and the name of place where the business was to be carried on, the amount of capital, the names and residence of stockholders and the time when formed. When properly executed it should be recorded by the recorder of the county and a copy transmitted to the Secretary of State. Capital could not be less than twenty-five thousand dollars nor more than five hundred thousand dollars. When any company had complied with the regulations the Governor, Auditor and Secretary of State were authorized to issue a. certificate of incorporation.

The Auditor of State should have notes engraved and forward them to the banks upon the deposit of specified securities, consisting of any 
public stock issued or to be issued by the State of Ohio or the United States. The notes were to be signed by the President and Cashier of the bank. The stock was declared personal property upon which the bank should have a lien for debts due it. It also provided for the election of directors, defined their qualifications and term of office, fixed the denomination of notes and their proportion, required the banks to receive the notes of other banks at par and to keep on hand, in gold and silver coin or their equivalent, thirty per centum of the amount of outstanding circulating notes; provided for the sale of securities to redeem circulation, defined stockholders' liability and made it the duty of the Auditor, Treasurer and Secretary of State or a majority of them as often as once in each year to appoint some suitable person in the vicinity of each banking company, who should not be a stockholder in any bank of the State, to examine the bank and make a detailed report to the Auditor of State.

Between the date of the passage of the Free Banking Law and November 15, 1851, when occurred the next recorded statement of the banks, twelve had been organized under its provisions, and there were then twelve independent banks, forty-one branch banks, five old banks and twelve free banks, with an aggregate capital of $\$ 7,949,356$.

The new constitution of 1851 contains the following provision: "No act of the General Assembly authorizing associations with banking powers, shall take effect until it shall be submitted to the people, at the general election next succeeding the passage thereof, and be approved by a majority of all the electors, voting at such election." Similar provisions are to be found in the constitutions of several other States.

Again the question of taxation appears to have forced itself upon the Legislature, and on April 13, 1852, it provided by enactment for the return, under oath, by the President and Cashier, to the county auditor, the average amount of notes and bills discounted or loans made during the year, "on which the bank has reserved, received or is entitled to receive any profit, at their actual value in money, which should constitute the basis for taxation."

This did not, however, settle the question, for the Auditor of State in his report of February 12, 1853, said: "But few of the banks of Ohio have paid the taxes assessed against them under the provisions of the act of April 13, 1852. This delinquency is not a matter of accident, but is attended by circumstances which betray the existence of a conspiracy to trample upon and override the very authority which gave the conspirators their corporate existence."

\section{Forged Notes Discovered in Circulation.}

Great care had been exercised in all recent acts in those provisions regulating the furnishing of circulating notes to prevent fraudulent or unauthorized issues. However, during the summer of 1853 the business community was startled by finding in circulation a quantity of the 
notes of the free banks of Ohio, printed on genuine plates, with forged signatures of the officers of the banks and of the Registrar, who was required to number and countersign them. As the law made it the business of the Auditor of State to provide the notes, he naturally felt his responsibility for their appearance. For a long time every effort to find the ones who had put them in circulation failed; but finally it was discovered that the engraving establishment had been betrayed by the person entrusted with the printing of them. This individual eventually confessed, and with four accomplices was tried in the criminal court of Hamilton county and sentenced to imprisonment in the penitentiary. The old plates were abandoned, new ones procured, and the old circulation withdrawn.

\section{Heroic Treatment of Banks Refusing to Pay Tax.}

On March 14, 1853, the Legislature enacted a law to tax banks not only upon their capital but also upon their loans. This was stigmatized as the "crowbar law," because the county treasurer was authorized, in the event of refusal to pay the tax, to enter the vaults of the bank and by force to secure the money. This was done in the ease of the Commercial Bank, of Cleveland, the money being secured and stored in the vaults of an insurance company. Application was made to the United States court, by writ of replevin, and the money secured by the United States marshal forcing the doors of the vault of the insurance company. The law was declared unconstitutional.

During 1854 many of the banks and private bankers failed, and those authorized by the various laws of the State were reduced by six; and by 1855 the old banks had disappeared, with one exception, and the number of State banks was reported at fifty-nine. The general panic of 1857 caused the failure of many banks, largely private ones, and a few of the authorized ones. The Ohio Life and Trust Company failed in August, 1857, and its failure was, perhaps, one of the immediate causes of the panic. It failed because of some irregularity of the Cashier of its New York office. It had been very successful and enjoyed an enviable reputation. Many of the Ohio banks kept theirNew York account with this institution, and its failure was a heavy blow to them. It is said that this failure, at one time, threatened the existence of the State Bank of Ohio.

Acts were passed April 8 and 14, 1857, to amend the law of February, 1845, and again on March 14, April 5 and May 1, of 1859, but none of them changing the purpose or general provisions of the law. On April 11, 1856, an act was passed supplementing the Free Banking Act of 1851, but was repealed April 6, 1859 .

\section{Inauguration of the National Banking System.}

The outbreak of the Civil War with disturbances of existing conditions and the enactment of the National Bank Act, with the high rate 
of taxation upon State bank issues, drove the currency of State banks out of circulation. Most of them availed themselves of the provisions of the act and became National banks; some continued until the expiration of their charters in 1866 and liquidated. This closed another period in the history of banking in Ohio. The banks authorized under the laws of 1845 and 1851 were uniformly successful and furnished a currency for the people, not one dollar of which was ever lost by the holder thereof. So nearly perfect were the provisions of the act of 1845 as prepared by Mr. Kelley, that they received but little modification when presented to the Legislature, and comparison with the National Bank Act will show a marked similarity in many sections. This may, perhaps, be explained by the fact that Mr. Chase was closely identified with the preparation of the latter, and was familiar with the former.

During the period just mentioned there were identified with the banking interests of Ohio, Judge Swan, Alfred Kelley and J. J. Janney, of Columbus; Amasa Stone and T. P. Handy, of Cleveland; Jonathan Harshman and Valentine Winters, of Dayton; J. H. Grosbeck and James Espy, of Cincinnati. Others who began their careers as bankers during this period are Wm. G. Deshler and P. W. Huntington, of Columbus; W. A. Goodman, whose name appears as Cashier of the Ohio Valley Bank in 1859, and G. P. Griffith, of Cincinnati; John F. Whitelaw, of Cleveland; S. W. Moore, of Delaware; J. H. Winters, of Dayton; A. H. Miller, of Fremont, and C. A. Phelps, who was Cashier of the Springfield Bank in 1859-all of whom are still identified with banks of the State.

Within the year 1863 twenty National banks were authorized and doing business in Ohio, having a capital of $\$ 2,363,000$; by 1864 the number had increased to eighty-two with an aggregate capital of $\$ 9,772,-$ 000 ; and by 1865 to one hundred and thirty-four, with a capital of $\$ 21$,146,000 , and a surplus of $\$ 1,834,000$. It is worthy of note that of the sixty-six National banks organized in 1863 nearly one-third, twenty, were in Ohio; the First National Bank, of Youngstown and the First National Bank, of Fremont, being numbers three and five, respectively. There were at this time thirty-six State banks in Ohio, with a capital of $\$ 811,500$, and "permanent reserve" of $\$ 138,863$; also numerous private banks. With the National bank notes there circulated freely the Government notes, called greenbacks, furnishing a convenient and acceptable currency. The suspension of specie payments with the outbreak of the war had been universal, so that all banks were upon an equal footing so far as specie payments were concerned. The National banks were regarded as having an advantage over State and private institutions in their profits because of the income received from their bonds deposited to secure their circulation. They also enjoyed the reputation of being more secure because of supervision by the Government. The State banks were mostly confined to villages and country 
towns, for the reason that the capital limitation prevented the organization of National banks in the smaller communities where the demand for banking capital did not require so much as the minimum limit, $\$ 50$,000 , while the State permitted organizations with half that amount.

\section{Effects of the Panic of 1873.}

The banks participated in the general prosperity which followed the close of the Civil War and the subsequent reign of "war prices." The panic of 1873 was the first general reversal and several banks failed, others suspended, resuming after the universal excitement attendant upon the first stages of the panic had subsided. Thirteen banks were compelled to quit business, their affairs being settled, in some cases, with great loss to depositors. They were not, however, attended with the widespread disaster which was consequent upon the failure of the banks of the earlier periods when the effects of failure fell upon the note holders as well as depositors, and when the banks gave no security for the redemption of their notes.

There was but one bank failure in Ohio from 1863 to 1873 , the Fredricktown Bank, of Fredricktown, Knox county, which went into bankruptcy December 24, 1869.

The conditions following the recovery from the effects of the panic were favorable to general prosperity and the banks shared in the improved conditions. In the country towns and villages money was not plentiful, yet appeared to be ample for the needs of business ; that is, if any one had anything for sale he could get the money for the article if he were willing to accept the price the purchaser was willing to pay. Measured by this test there was sufficient for the needs of business. The banks were not able to supply the demand for loans and consequently found a ready market for their funds at good rates of interest. In the towns the prevailing rates were ten to twelve per cent., while the cities charged from six to eight and in some cases more. If the inability of the banks to accommodate all applicants for loans be the proper test as to the supply of money, then it was not plentiful.

On April 24, 1877, the Legislature enacted a law to authorize free banking, subject to the approval of a majority of the voters of the State, as required under the constitution of 1851 , but failing to receive such approval it did not become operative.

On April 29, 1879, the Legislature repealed the provisions of the Free Banking Act of 1851 providing for and regulating the issuing of circulation, as they were inoperative because of the tax imposed upon State issues by the general Government. Also that provision requiring the banks to be examined by a person chosen by the Auditor, Secretary and Treasurer of State.

The resumption of specie payments on January 1, 1879, had no perceptible effect upon the business of the banks. The knowledge that resumption had taken place and that coin could be had seemed to 
satisfy every one and none cared to bother with it, the currency being more convenient.

For several years following, only an occasional failure was reported but caused no uneasiness and was of little moment except to those interested as creditors. In 1884 twelve Ohio banks failed as a result of the financial disturbances of that year. In 1885 there were five failures, all private banks; in 1886 but one failed, a private bank; and in 1887 there were three failures, two private banks and one National bank, the Fidelity National Bank, of Cineinnati, with liabilities of $\$ 4,328,619$. This failure was caused by the speculations of its Vice-President. This was the most extensive failure of recent years, and possibly the greatest ever occurring in Ohio. The bank had been operating but a short time. Organized in February, 1886, it was placed in the hands of a Receiver in June, 188\%. No bank in the State ever started under more favorable conditions, and none, perhaps, ever made more rapid growth; and but for the speculations of its officials it might have become a strong and permanent institution. While this failure affected a good many people, it had no influence of any moment upon the banking interests of the State. General conditions were conducive to prosperity and the banks were apparently prospering. When the panic of 1893 came few anticipated trouble or feared its continuance or wide extent. Yet twenty-seven banks were added to the list of failures as the result of that year's experience. Fifteen private banks were unable to stand the demands made upon them; and seven State banks, four Savings banks and one National bank, for like reasons, suspended business and their affairs were wound up by Receivers. Several other banks were compelled to suspend temporarily, but were able to resume after a short period of suspension.

\section{Growth of THE BaNkINg Business in OHIO.}

Some idea may be had of the growth of banking in Ohio by a comparison of the number of banks and the amounts of capital at different dates during the years since the inauguration of the National banking system. In 1865 there were 134 National banks with a capital of $\$ 21$,146,000 and surplus of $\$ 730,000$; there were thirty-six State banks with a capital of $\$ 811,500$ and "permanent reserve" of $\$ 138,363$. In 1875 there were 173 National banks; capital, $\$ 29,644,000$ and surplus, $\$ 6,347$,000. There are no records for that year of the State banks. In 1885 there were 203 National banks with a capital of $\$ 36,710,000$ and surplus of $\$ 6,400,000$; thirty-eight State banks with a capital of $\$ 1,962,000$ and surplus of $\$ 392,046$. In 1895 there were 247 National banks with a capital of $\$ 45,445,000$ and surplus of $\$ 12,809,000$, and 131 State banks with a capital of $\$ 9,210,000$ and surplus of $\$ 1,435,669$. In 1898 there were 254 National banks; capital, $\$ 44,865,000$, surplus, $\$ 12,976,000 ; 161$ State banks, capital, $\$ 13,793,996$, and surplus and undivided profits of $\$ 6,650$, 029 , and 302 private banks with $\$ 9,954,548$ capital and $\$ 1,425,277$ surplus 
and undivided profits, making a total of 1717 banks with $\$ 68,613,538$ capital and $\$ 21,051,306$ surplus, in round numbers, $\$ 90,000,000$ of banking capital. In 1865 the National banks doing business in the State had a circulation of $\$ 14,731,000$; in 1875 , $\$ 22,855,000$; in $1885, \$ 19,011,000$; in $1895, \$ 13,513,000$; and in $1898, \$ 16,880,000$.

Since the introduction of the National system there have been organized in Ohio 361 National banks, of which 107 have gone into liquidation, thirteen only of which have failed. During the same period three State banks, six Savings banks and ninety-six private banks have failed, making 124 failures during the period from 1863 to 1898, inclusive.

At the close of 1898 the banks of the State were in a healthy condition and strong in available funds. The general business situation at this time was exceptionally good. Most of the city banks and many of the country banks pay interest on deposits and as a consequence money is placed with them even at low rates, resulting in an enormous aggregate of deposits. Though a condition of general prosperity prevails at the time this sketch is written, and the manufactories are all running, many of them both day and night; yet the demand for accommodation is so moderate that the banks find it difficult to obtain investments for their funds and rates of interest are lower than ever before in the history of banking. Competition for investments is so keen as to, perhaps, still further reduce the prevailing rates.

\section{Savings Banks.}

The first authorized Savings bank, or society for savings, as it was called, was, perhaps, the Society for Savings, of Cleveland, incorporated by act of the Legislature, March 22, 1849. Three other institutions of the same nature were incorporated during the same session; the Hocking County Savings Institute, at Logan; the Savings Fund Society, at Woodsfield, and the Pickaway County Savings Institute, at Circleville.

The historian of the Society for Savings, of Cleveland, says that the first suggestion of a society for savings in Cleveland came from Chas. J. Woolson, in a private conversation with Samuel H. Mather, in his office in the summer of 1848. These gentlemen were both from New Hampshire, and when they met, New England, its people and its institutions were a frequent topic of conversation. On this occasion Mr. Woolson, speaking of the success and the benefits of New England Savings banks, said: "Why not have a savings bank in Cleveland? I believe one could be established here that would be a success, and a great benefit to the community." From this conversation came the subsequent movement which resulted in the Society for Savings. The first deposits were received August 2, 1849. At the end of two and a half years the deposits amounted to $\$ 80,482$, and the number of depositors to 484 . While the outlook was not bright, the board of trustees were very hopeful, and one in the exuberance of his feelings, declared, " the time would come when the deposits would amount to $\$ 300,000$ !" In 1849 Mr. Mather 
was elected Secretary and Treasurer and continued to serve as such until 1884, when he was succeeded by Luther Allen. At the end of the fifth year of its existence it had grown until the deposits were $\$ 265,095$, and the number of depositors were 1,787.

It passed through the various panics and financial depressions which are so prominent a part of the financial history of the country, without any serious difficulty and met all its obligations. By 1860 its deposits had increased to $\$ 403,370$, and its depositors to 3,175 ; by 1870 its deposits were $\$ 3,237,220.10$, and its depositors, 9,409 ; by 1880 , deposits $\$ 9,247,230$, and depositors, 22,584 ; in 1890 , deposits, $\$ 19,145,274$, and depositors, 41,378 , and at this time (1899) its deposits are $\$ 30,472,264$; its undivided profits, $\$ 372,265$; surplus, $\$ 2,000,000$, and its depositors, 53,879. In 1886 Col. Myron T. Herrick was elected Secretary and Treasurer, and continued such until the death of Mr. Mather, who had been elected President in 1884, when Mr. Herrick was chosen President and still continues at the head of what is one of the leading Savings institutions of the country.

\section{Legislation Providing for Incorporation of Savings Banks.}

On April 16, 1867, the Legislature enacted a general law for the establishment of societies for savings. Any number of natural persons not less than five might incorporate a society for savings in such county by making their certificate, setting forth the purpose, the name by which it should be known and the place where the business was to be done. Certificates to be approved by a Board of Commissioners composed of the Auditor, Treasurer and Secretary of State. When approved by the Board of Commissioners the Governor was to issue a proclamation authorizing the persons to commence and carry on the business of a Savings society. It provided for officers, the manner of their election and qualification, term of office and the time for annual meeting. Authorized them to receive deposits, but limited the amount that might be received from any one person to $\$ 2,500$. They were authorized to loan money on real estate, and acquire and hold real estate for the convenience of their business. The act required an annual report to the Board of Commissioners, and authorized the deposit and withdrawal of funds by minors and women.

On February 16, 1873, an act was passed which embodied the main features of the foregoing and provided that for the purpose of carrying on the business of said corporation, and for the security of the depositors, it should be the duty of the persons named in the certificate of organization, and such others as might become stockholders in the corporation, to raise and form a capital of not less than fifty thousand dollars to be paid in as should be required by the board of trustees. But at least one-half of each subscription should be paid in before the corporation should commence business and the remainder from time to time as the trustees might require. 
It also provided for the repeal of the act of April 16, 1867, with its amendments, but provided that such repeal should not prejudice the rights acquired by such institutions as were operating under said act, but that they might continue their business under the provisions of this act by signifying their desire to the Secretary of State.

Under this law the Savings banks of to-day are operating as commercial Savings banks. The records of the State do not give any information as to their business as Savings banks, merely publishing their reports along with the other incorporated banks of the State, there being nothing to indicate what portion belongs to the Savings and what to the commercial department. The last annual report of the secretary of the Ohio Bankers' Association gives the number of Savings banks in the State to be ninety, with capital of $\$ 6,693,876$, and surplus and undivided profits of $\$ 5,643,746$. These ninety banks are included in the one hundred and sixty-one before enumerated as State banks.

The Savings banks are an important factor in the prosperity of the communities where located and at the same time largely perform the functions of the commercial bank. The field of the Savings bank has in recent years been invaded by organizations styled building and loan associations, which assume many of the prerogatives of banks, receiving deposits and paying interest thereon, and loaning money, mostly upon real estate. These institutions enjoy some peculiar privileges acquired by legislation for their benefit. They pay no taxes except it be upon the articles of furniture necessary for the conducting of their business, and are exempt from internal revenue taxes. They may borrow money to supply their needs and may loan upon such security as may be approved by the board of directors. They thus become strong competitors for the business of the banks.

On May 21, 1894, the Legislature by enactment repealed the law of February 24, 1845, which authorized the State Bank of Ohio and its branches and also independent banks. Hence Ohio to-day has the modified form of the Free Banking Law of 1851, the law of 1873 providing for savings and loan associations (from which our Savings banks get their authority) and the general incorporation laws of the State. Under one or another of these three systems the incorporated banks are now doing business. They are not subject to examination by the State but are required to make a report, to the Auditor of State, of their condition before commencing business on the first Monday of April and October of each year.

The private banks constitute a large and important part of the banking institutions of the State, operating without many of the restraints which govern the incorporated banks, but when guided by the same wisdom and skill they are equally successful. They are not required to make reports to any one, except such as are required for the purposes of taxation. consequently no data can be had concerning their operations. 
State Banks.

\begin{tabular}{|c|c|c|c|c|c|c|}
\hline YEARS. & $\begin{array}{l}\text { No. of } \\
\text { banks. }\end{array}$ & $\begin{array}{l}\text { Loans and } \\
\text { discounts. }\end{array}$ & Specie. & $\begin{array}{l}\text { Capital } \\
\text { stock. }\end{array}$ & Circulation. & Deposits. \\
\hline $1835^{\star}$ & 24 & $\$ 9,751,973$ & $\$ 1,707,835$ & $\$ 5,819,692$ & $\$ 5,221,520$ & $\$ 2,090,065$ \\
\hline 1839. & 34 & $16,520,360$ & $2,616,814$ & $10,153,846$ & $8,157,871$ & $2,680,604$ \\
\hline $1844 .$. & 8 & $2,968,441$ & 792,483 & $2,167,628$ & $2,246,999$ & 505,430 \\
\hline 1849. & 54 & $14,912,665$ & $3,155,362$ & $6,584,220$ & $9,491,037$ & $4,567,783$ \\
\hline $1854 .$. & 68 & $17,380,255$ & $2,319,064$ & $8,013,154$ & $9,839,008$ & $7,693,610$ \\
\hline $1859 .$. & 53 & $11,171,343$ & $1,845,441$ & $6,707,151$ & $8,040,304$ & $4,389,831$ \\
\hline $1863 .$. & 55 & $12,298,400$ & $3,023,285$ & $5,674,000$ & $9,057,837$ & $11,697,818$ \\
\hline $1868 .$. & 4 & ................ & ............. & $1,550,000$ & $\ldots \ldots \ldots$ & (.................. \\
\hline 1872. & 8 & ................ & & $1,200,000$ & & ................ \\
\hline $1877 \ldots$ & 44 & $5,689,786$ & , & $2,259,819$ & $\cdots$ & $4,671,582$ \\
\hline $1882 \ldots$ & 27 & $5,090,123$ & & $1,374,300$ & & $5,351,661$ \\
\hline $1887 \ldots$ & 46 & $9,696,155$ & .............. & $3,079,695$ & ............. & $10,314,788$ \\
\hline $1892 \ldots \ldots$ & 77 & $23,695,033$ & ............... & $6,492,605$ & ….......... & $24,518,054$ \\
\hline $1897 \ldots \ldots$ & 131 & $37,620,591$ & .............. & $10,814,300$ & ............. & $37,047,393$ \\
\hline
\end{tabular}

* Incomplete.

National Banks.

Figures are in thousands of dollars.

\begin{tabular}{|c|c|c|c|c|c|c|c|c|c|}
\hline YEARS. & 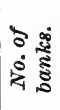 & $\begin{array}{c}\text { Loans } \\
\text { and dis- } \\
\text { counts. }\end{array}$ & $\begin{array}{c}\text { U.S. } \\
\text { bonds. }\end{array}$ & $\begin{array}{c}\text { Cash } \\
\text { and cash } \\
\text { items. }\end{array}$ & Capital. & Surplus. & $\begin{array}{c}\text { Undi- } \\
\text { vided } \\
\text { profits. }\end{array}$ & $\begin{array}{c}\text { Out. } \\
\text { standing } \\
\text { circula- } \\
\text { tion. }\end{array}$ & $\begin{array}{l}\text { Indi. } \\
\text { vidual } \\
\text { deposits }\end{array}$ \\
\hline $1863 .$. & 20 & $\$ 2,516$ & $\$ 1,493$ & $\$ 1,126$ & $\$ 2,363$ & ....... & $\$ 69$ & ........ & $\$ 2,896$ \\
\hline $1868 .$. & 135 & 30,924 & 27,521 & 8,524 & 21,556 & $\$ 3,402$ & 1,916 & $\$ 18,272$ & $23,60^{\circ}$ \\
\hline $1873 .$. & 168 & 54,407 & 27,613 & 8,866 & 28,843 & 5,659 & 2,635 & 22,848 & 33,914 \\
\hline $1878 \ldots$ & 163 & 44,172 & 26,002 & 10,178 & 27,287 & 5,316 & 2,477 & 19,952 & 30,266 \\
\hline $1883 .$. & 200 & 76,324 & 29,008 & 15,198 & 35,183 & 6,033 & 3,487 & 23,148 & 59,615 \\
\hline $1888 .$. & 219 & 92,125 & 18,808 & 17,187 & 39,949 & 8,313 & 4,032 & 10,725 & 73,710 \\
\hline $1893 \ldots$ & 242 & 111,040 & 17,457 & 16,788 & 45,645 & 12,117 & 5,284 & 13,881 & 84,440 \\
\hline $1898 .$. & 252 & 124,842 & 26,095 & 17,074 & 44,865 & 12,976 & 4,387 & 16,680 & 120,512 \\
\hline
\end{tabular}

\section{INDIANA.}

Indiana presents the anomaly of having been a State organizing the most admirable system of banking of any State in the Union, and also of having a banking system at one time so vicious that under it the banks bankrupted nearly the whole people. The State Bank of Indiana, and its successor, the Bank of the State of Indiana, stood all the tests of financial panics from 1834 until the banks were all absorbed by 
the National banking system without closing their doors for a minute, or losing a dollar to bill holders, depositors or stockholders. It is a proud distinction for Indiana that its State bank was long the model bank of the country. So well was its affairs managed that in a period of twenty-two years of actual business, the profit to the State on its $\$ 800,000$ of stock amounted to three and a half million dollars.

\section{Banking Under the Territorial Government.}

Under the Territorial Government, lasting from 1800 to 1816, there was no law providing for private banks, but the first effort at banking in the Territory was a private bank established at Vincennes. It was a bank of discount and deposit only, and its career was creditable to those who managed it. Similar banks were also opened at Madison, Corydon and Lawrenceburg. In the early stages Indiana had to depend for its eurrency on the issues of banks in Ohio, United States Bank notes and Spanish milled dollars. This want of an adequate circulating medium seriously hampered business, and in 1814 the Territorial Legislature chartered the Bank of Vincennes with a capital of $\$ 500,000$, and the Farmers and Mechanies' Bank, of Madison, with a capital of $\$ 750,000$. The stock for these two banks was rapidly subscribed, as the charters were very liberal. It was provided in the charter of the bank at Madison that the State at any time might subscribe for a large portion of its stock. These banks were authorized to issue bills in denominations of one, five, ten and twenty dollars, which was afterwards changed so as to permit the issue of two and three dollar bills. They entered upon business at once, and their issues soon relieved the stringency and business greatly revived.

\section{Provision of the State Constitution.}

The State constitution was adopted in 1816. It provided for the continuance of the charters of the two banks mentioned, and that the Legislature might, at any time, adopt either of those banks as a State Bank. The general provision for the establishment of banks read as follows:

"There shall not be established or incorporated in the State any bank or banking company, or moneyed institution, for the purpose of issuing bills of credit, or bills payable to order or bearer : Provided, That nothing herein contained shall be so construed as to prevent the General Assembly from establishing a State Bank, and branches, not exceeding one branch for any three counties, and to be established at such place within such counties as the directors of the State Bank may select: Provided, There may be subscribed and paid in specie, on the part of individuals, a sum equal to thirty thousand dollars."

On January 1, 1817, the Bank of Vincennes was adopted by the Legislature as a State Bank. The powers of the corporation were enlarged and an increase of one million dollars in the eapital stock authorized. Of the ten thousand shares of new stock thus authorized, 
three thousand seven hundred and fifty were to be reserved for the State, to be subseribed for from time to time by the Governor. Private individuals, companies and corporations were authorized, under certain restrictions, to subscribe for the remaining new shares of stock. The bank was empowered to conditionally adopt the Farmers and Mechanics' Bank, of Madison, as one of its branches, and to establish other branches also. Branches were established at Brookville, Corydon and Vevay. The State never did subscribe or pay for the shares of stock reserved for it.

The bank, thus enlarged, and with such increased powers, entered upon an era of mismanagement that soon wrought widespread ruin. It

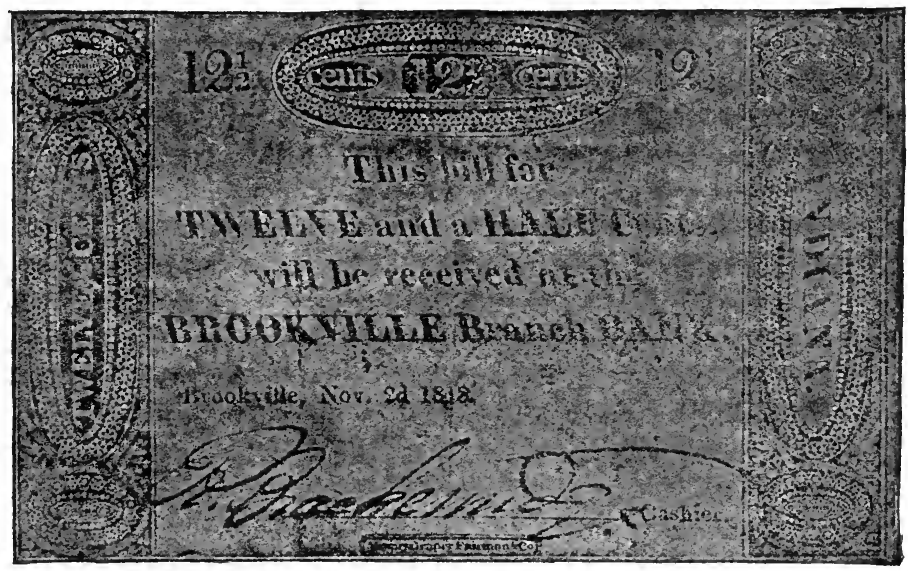

issued bills far in excess of its power of redeeming, contracted debts double the amount of its deposits, declared and paid large dividends to the stockholders, while refusing to redeem its notes in specie as required by its charter, and finally embezzled $\$ 250,000$ placed in the bank as a special deposit by an agent of the United States. These, and other acts caused the Legislature, in 1821, to order a suit brought to annul the charter. The bank fought the case through the Supreme Court, but that court finally adjudged the bank guilty of all the charges made against it, and annulled the charter. The branch at Madison paid all its obligations, and continued to operate as a separate institution, but depositors and bill holders of the parent bank, and of the other branches never received anything, there being but $\$ 34$ in the vault when the court closed its doors. The bank, while in existence, issued notes as low as six and a quarter cents. Its notes for the purpose of change were for six and a quarter, twelve and a half (see specimen printed above) and twenty-five cents. The collapse of the bank ended banking business in the State, so far as banks of issue were concerned, with the exception of the Farmers and Mechanics' Bank, at Madison, which 
maintained its credit, and on the expiration of its charter was authorized by the Legislature to continue business until 1834, when the State Bank was chartered. In the intermediate time merchants, millers and others issued notes, which passed for eurrency in the immediate neighborhood, but were not current anywhere else. This improvised currency helped local traffic, but there was a great stringency, the only relief being the funds brought in by purchasers of public lands, and that was very slight, for this money soon found its way back to the Government.

\section{The State Bank of Indiana Chartered.}

In 1834 the State was entering upon its great system of internal improvements, which was designed to include railroads, canals and turnpikes. To engage in this work the State borrowed several millions of dollars, but it was evident that a more abundant circulating medium would have to be provided, and the growing opposition to the Bank of the United States foreshadowed the early fall of that great institution. The State Bank of Indiana was therefore chartered, which proved to be one of the great banks of the country. It was to have a capital of $\$ 1,600,000$, of which the State was to take one-half. Great inducements were offered to individuals to subscribe the other half, the State offering to loan all subscribers to the stock $\$ 31.25$ on each share subscribed for, the shares being for $\$ 50$. Even with this extraordinary inducement, the State had to be canvassed from one end to the other to secure the necessary subscribers to the stock. The largest individual subscription was $\$ 5,000$. The State was divided into ten districts for branches, and provision was made in the charter for three more, which was afterward increased until the number of branches reached seventeen, the State taking stock in the new branches until its holdings amounted to about $\$ 1,500,000$. The parent bank was supervisory in its nature, its banking powers being exercised through the branches. It had absolute power over the branches, and could limit their business or close them entirely if it was considered that they were operating so as to endanger the other branches. Each branch was liable for the debts of the other branches.

\section{Methods of Organization and Management of the Bank.}

The bank was authorized to receive deposits, buy and sell gold, silver, bullion, and foreign coins; discount commercial paper and issue bills payable to bearer. The bank was not at any time to suspend specie payment, on a forfeiture of twelve and one-half per cent. interest. on all bills refused to be redeemed in coin. The branches were to be mutually responsible for the redemption of all the bills issued, but each branch was to hold its own profits. No notes were to be issued of a less denomination than five dollars, and the State reserved the right to raise this limit to ten dollars, nor was the bank permitted to receive and 
place in circulation bills of other banks of a smaller denomination. The State reserved the right to elect the President and four of the seven directors of the parent bank, and one-half of the directors of the branches, the individual stockholders electing the other directors. On all applications for loans of $\$ 500$ and upward it was required that at least five of the seven directors should concur before the loan was made. No loan to exceed $\$ 5,000$ was to be made without the consent of the parent bank.

Indiana was then an agricultural State, and the great object of the bank was to encourage the development of the agricultural resources of the State, hence a rule was adopted that under no circumstances would a loan to exceed $\$ 300$ be made to a merchant, or $\$ 500$ to a manufacturer. Great care was exercised in making loans, even of the smallest amount, and diligent inquiry was made as to the standing of a proposed borrower, not so much as to his wealth, as to his sobriety, integrity and industry. It has been claimed as a result of this carefulness, that the bank in twenty-five years of doing business, and loaning many millions, did not lose $\$ 50,000$ from bad debts. The bank was a complete monopoly. During its existence no other bank of issue could operate in the State. Its capital had to be specie, and was gradually increased until in 1841 it amounted to $\$ 2,500,000$, but in 1843 the State reduced its holdings by withdrawing about $\$ 500,000$.

\section{Action of the Bank in the Panic of 1837.}

The bank was opened for business on November 20, 1834, and its profits for the first five months were about two and one-half per cent. It had hardly got under way when the financial panic of 1837 struck the country. The bank had been one of those designated to receive the United States deposits removed from the United States Bank by order of President Jackson, and was holding about half a million of those deposits. Suddenly the deposits were recalled. The original seattering of the money had induced in the West an era of wild speculation, and the banks had freely loaned all they could command, and when the order came to return the Government deposits, and to return thein in specie, it caused consternation. When the crash of 1837 came the State Bank of Indiana held $\$ 1,500,000$, which it paid in the usual course of business. The first installment of this deposit $(\$ 80,000$ in gold) was conveyed in a stage-coach to Washington by J. F. D. Lanier. When this money was delivered, the Secretary of the Treasury (Levi Woodbury) said to Mr. Lanier that his bank was the only one in the country holding Government deposits that had offered to pay any specie at all.*

The first effect of the panic was to cause the banks to reduce their loans, and this caused much hardship especially in a newly settled State. In May of 1837 the New York banks suspended specie payments, and the *"National and State Banks;" "Sound Currency," Vol. II, No. 1, p. 4. 
State Bank of Indiana was forced to follow, ${ }^{*}$ although it clained that it held specie enough to redeem its notes, but as it also held large amounts in the notes of those banks which had suspended, for self-preservation it was compelled also to refuse specie. The Governor commended this action, as did the Legislature. In connection with other banks specie payments were resumed in August, 1838, but the resumption did not last long, but in 1840 in accordance with the orders of the Legislature resumption again took place.

No bank in the country stood higher than did the State Bank of Indiana during the panic. In all the Western and Southern States its notes commanded a premium, and in the East were taken at a very small discount. $\dagger$ This high standing was all the more remarkable from the fact that when the bank was organized it was by men unused to banking business. Prior to that time Indiana had never had a great financial institution; she was far away from the center of financial control, and her citizens had had no experience in the management of such institutions. The "specie circular" of President Jackson added to the financial distress in Indiana. The breaking down of her great system of internal improvements was the last in this chapter of misfortune, but the bank maintained its credit through all, and preserved the people from final and irretrievable bankruptcy. Its loans were made in small amounts, and scattered over the entire State, thus affording the greatest possible measure of relief. The bank generally carried an ample specie reserve, never falling below twenty per cent. of its immediate liabilities and usually being much greater. Prior to the California gold discoveries in 1848, this reserve was chiefly in silver.

The first President of the bank was Samuel Merrill, who had been Treasurer of State for twelve years. When the bank was organized there was no thought of politics in connection with it, but politics soon began to show itself. Merrill was a Whig, and in the session of the Legislature in 1843-44, the Democrats having a majority, succeeded after a large number of ballots, in ousting him and electing Judge James Morrison. For the good name of the bank, and its future success, it was well that the choice fell on Judge Morrison, as he was a man of the greatest probity. In 1853 Morrison in turn gave way to Ebenezer Dumont, at another revolution of the political wheel.

At the organization of the bank the directors adopted a uniform style for the buildings, so that the parent and all the branches had buildings of similar architecture. They were two stories high, the lower story being used as a sort of basement. In front was a portico, the roof being supported by corinthian columns. Some of those buildings are still in existence, and are used for banking purposes.

\footnotetext{
* Deposits that were made specially payable in coin were so paid during suspension and specie was also paid out for change.

+In 1839 "Niles' Register" gave Indiana notes at five to six per cent. discount in New York.
} 
State Bank of Indiana.

\begin{tabular}{|c|c|c|c|c|c|}
\hline & 1835. & 1840. & 1845. & 1850. & *1855. \\
\hline RESOURCES. & & & & & \\
\hline Loans and discounts............ & $\$ 1,434,790$ & $\$ 2,912,619$ & $\$ 1,830,181$ & $\$ 1,709,935$ & $\$ 1,024,648$ \\
\hline Bills of exchange......... & 376,175 & 704,628 & $1,197,435$ & $2,414,951$ & $3,654,132$ \\
\hline Real estate, etc........... & 19,510 & 204,805 & 348,169 & 364,233 & 177,825 \\
\hline Due from other banks... & 759,660 & 335,505 & 638,699 & 598,014 & 929,425 \\
\hline Notes of other banks... & 572,073 & 195,724 & 84,188 & 355,535 & 292,736 \\
\hline Other securities.......... & ........... & $1,092,963$ & 663,133 & 224,842 & 238,203 \\
\hline Specie................ & 797,811 & $1,022,963$ & $1,079,368$ & $1,197,880$ & $1,223,199$ \\
\hline LIABILITIEs. & & & & & \\
\hline Capital stock.......... & $\$ 1,199,778$ & $\$ 2,690,000$ & $\$ 2,878,894$ & $\$ 2,082,950$ & $\$ 2,150,107$ \\
\hline Surplus................. & 170,000 & 275,839 & 375,239 & 750,678 & $1,228,301$ \\
\hline Public deposits......... & $1,124,007$ & 79,227 & ........... & ........... & \\
\hline Individual deposits... & 379,543 & 309,248 & 359,265 & 556,432 & 599,177 \\
\hline Due other banks....... & 23,415 & 154,423 & 45,656 & 112,175 & 120,666 \\
\hline Circulation............ & $1,534,020$ & $2,835,902$ & $3,667,495$ & $3,548,267$ & $3,397,251$ \\
\hline
\end{tabular}

* After 1855 the bank began to wind up its affairs, as the Legislature had refused to renew its charter.

\section{OPPosition TO THE BANK.}

Notwithstanding the great success of the bank, and the immense profits which accrued to the State on its stock, a feeling of hostility to the institution grew up. The State was Democratic in politics and the Democrats were followers of Jackson. His hostility to the United States Bank created a similar hostility to that of Indiana, but it was not strong enough to accomplish anything until the constitutional convention of 1850 met. It then developed strength enough to get a clause in that instrument denying the State the right to own any bank stock. To show the immense profits of the bank, the following table of dividends paid is given. These dividends were the average of all the branches, some of them being much more profitable than others:

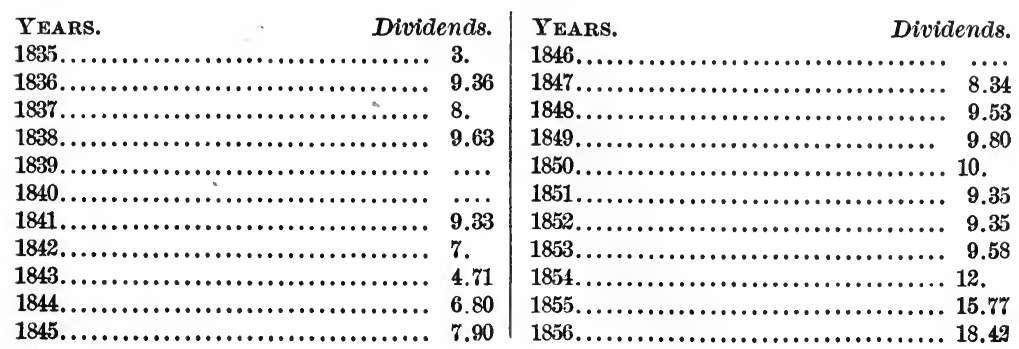


During its existence the bank was the depository of the United States' officers of Indiana, as well as of the funds of the State, and usually had on deposit large amounts from these sources. When the affairs of the bank were finally wound up, the profit of the State on its connection therewith amounted to $\$ 3,500,000$.

\section{General Banking Law Adopted.}

The constitution of 1850 changed very materially the banking clause in the old one. That clause was simple and direct, while the new was complex, and its immediate results were great disaster and disgrace to the State. From a banking system that was a model, it opened wide the door for a system that was vicious in every part. It gave the Legislature the authority to enact a general banking law, permitting banks to be established upon filing with the Auditor of State the bonds or other evidences of debt, of the Federal Government, or of any of the States. These bonds were to be held as collateral security for the notes to be issued. It also authorized the Legislature to charter a bank with branches, without such security. This was the beginning of a series of disasters that well-nigh engulfed the people in ruin.

Under this constitution the Legislature in $\mathbf{1 8 5 3}$ enacted a general banking law. This law provided that on filing with the Auditor of State the bonds of the Government or of any State, the persons so filing could establish a bank of discount and deposit, and also issue bills to the amount of $\$ 100$ for every $\$ 110$ face value of the bonds so filed. In the meantime the charter for the State Bank was drawing to a close, although it had several years yet to run. As early as 1854 the politicians actively began the work of preventing a renewal of the charter. Those interested in the bank tried to stem the current, but it was too strong for them, and they began to look toward going out of business on the expiration of their charter. The Governor of the State, Joseph A. Wright, was vehement in his opposition to banks of all kinds, and had vainly interposed his veto to the general banking law of 1853 . He was also opposed to a renewal of the charter and joined forces with those who were endeavoring to prevent it.

\section{Bank of the State of Indiana Chartered.}

When it developed that the charter would not be renewed then the real schemes of the politicians who were opposing it came to light. They went before the Legislature and asked for a charter for a bank to be known as the Bank of the State of Indiana. Governor Wright opposed this measure just as strenuously as he had done the others, but the bill granting the charter was passed in $\mathbf{1 8 5 5}$. The Governor promptly vetoed it. In the closing hours of the session it was passed over his veto. On the passage of the bill, the Governor, who was present in the Senate chamber, took the platform and made a most violent speech, charging that the bill had been passed by the most shameful corrup- 
tion. This speech caused the greatest sensation throughout the State, and the bank charter was one of the issues in the next campaign. The Governor appealed to the courts to prevent the organization of the bank, but the bank was sustained.

When the Legislature met in 1857 the Governor renewed his attacks on the charter, using in his message the following language:

"The means and appliances brought to bear to secure the passage of this charter would, if exposed to the public gaze, exhibit the nakedest page of fraud and corruption that ever disgraced the Legislature of any State. While men of pure and honorable sentiment were led into its support in the belief that the approaching close of the existing bank required them thus early to provide a successor, others supported it upon the promise of stock, equivalents in money, or pledges as to the location of branches. To make up the constitutional vote in its favor the names of members were recorded on its passage who were at the moment absent, and many miles distant from the capital."

The Legislature ordered an investigation of the charges contained in the message, and a voluminous mass of testimony was taken. A majority of the committee reported that many dishonorable things had been resorted to to prevent a renewal of the charter of the old bank, and to secure that of the new, and recommended that the charter be revoked. The speculators, however, were strong enough to prevent this, and the organization of the new bank went on.

The charter provided for a parent bank with twenty branches, and places were fixed for the opening of books for the subscriptions to the capital stock, and persons named to take such subscriptions. The books were opened and the stock subscribed immediately. In no place were the books kept open more than fifteen minutes. In every case the person authorized to take the subscriptions had a list in his hands, and transcribed the names in the books, and then they were closed.

The stock was nearly all taken by men unused to banking, and who were without adequate means to carry on a successful banking institution. The subscriptions were made for speculation, but proved to be a "white elephant." Finally, negotiations were opened for a purchase of the branches of the old bank, and this was accomplished on the agreement that Hugh McCulloch, President of the branch at Fort Wayne, should become President of the parent bank. This brought into the new concern most of those who had grown up with the old bank, and with their experience and the great financial ability of President McCulloch the bank entered upon a career of high honor, and proved a worthy successor to the State Bank. The charter was similar in its provisions to that of the old bank, the most important change being that the State no longer had the right to name any of the directors nor the President.

Successful Resistance of the Panic of 1859.

The bank began business in 1857 with twenty branches. Like its predecessor it fell on evil times soon after its organization. The panic 
of 1837 came two years after the organization of the State Bank, and in 1859, before the Bank of the State had been in operation quite two years, a great financial panic swept over the country, precipitated by the failure of the Ohio Life Insurance and Trust Company. Every bank in the East, except the Chemical Bank, of New York, suspended specie payment, and all in the West except the Bank of the State of Indiana, and the Bank of Kentucky. The Indiana bank weathered the storm and redeemed all its obligations in gold as fast as they were presented. Many of the branches of the Bank of Kentucky were at remote points from the railroads, and could not be easily reached by the brokers and other bill holders, but those of the Bank of the State of Indiana were within easy reach and holders rushed for the specie, but all demands were promptly met.

Bank of the State of Indiana.

\begin{tabular}{|c|c|c|c|c|c|}
\hline & 1858. & 1859. & 1860. & 1862. & $\dagger 1864$. \\
\hline RESOURCES. & & & & & \\
\hline Loans and exchange.......... & $\$ 5,154,548$ & $\$ 6,213,659$ & $\$ 7,790,315$ & $\$ 3,857,428$ & $\$ 4,118,658$ \\
\hline Real estate, etc................... & 257,035 & 316,930 & 263,949 & 241,210 & 169,315 \\
\hline Due from other banks........ & 982,731 & 716,631 & $1,152,119$ & $1,342,104$ & 763,209 \\
\hline Other securities.......... & (n............ & ............. & ............. & 407,218 & 930,839 \\
\hline *Bills of other banks... & 338,189 & 264,964 & 217,429 & $1,233,122$ & $1,258,501$ \\
\hline Specie....................... & $1,685,894$ & $1,411,500$ & $1,917,368$ & $3,472,369$ & $1,417,957$ \\
\hline LiabiLities. & & & & & \\
\hline Capital stock.......... & $\$ 2,486,259$ & $\$ 2,988,431$ & $\$ 3,323,850$ & $\$ 3,354,200$ & $\$ 2,775,000$ \\
\hline Surplus............... & 348,382 & 553,259 & 738,905 & $1,005,852$ & $1,345,663$ \\
\hline Due other banks..... & 146,750 & 81,663 & 45,991 & 260,000 & 91,241 \\
\hline Deposits............. & 986,468 & 834,188 & $1,186,870$ & $2,033,795$ & $2,755,688$ \\
\hline Circulation........... & $4,502,348$ & $4,303,286$ & $5,753,610$ & $4,975,332$ & $1,501,865$ \\
\hline
\end{tabular}

* Includes United States notes.

$\dagger$ Before the reports of 1864 were made most of the branches had been converted into National banks, and others were preparing for the conversion. All but three became National banks.

Every private bank in the State, except two at Indianapolis and one at Fort Wayne, went down in the panic. Gold was at a premium and New York exchange in great demand. The Bank of the State sold exchange on New York, often getting $\$ 125$ premium on a draft for $\$ 1,000$. Thus, in two great financial storms which wrecked most of the financial institutions of the country, Indiana banks maintained their financial standing. The Bank of the State fell heir to the business rules and methods of the old State Bank. The State, however, was growing in the importance of its manufacturing and mercantile interests, and the new bank became more liberal in loaning to those industries, but it kept as the main object of its fostering care the movement of crops. 
The charter required regular reports to the Auditor of State, showing the condition of each branch, and the parent bank had the same supervisory authority over the branches that had been exercised by its predecessor. When the question of organizing a National banking system was under discussion the Indiana Bank opposed the movement, claiming that it was able to carry on its business and meet all demands. It did continue to do business until all of the branches but three were re-organized into National banks. Two of the three remaining changed into private banks and are still maintained as such, ranking high in credit. The other liquidated and resigned its charter.

\section{A Different Kind of Banking.}

Now we must turn to a darker page in the financial history of Indiana. During the interval between the failure of the Bank of Vincennes in 1821, and the charter of the State Bank in 1834, the State was practically without banks, except private institutions for deposit and the Farmers and Mechanics' Bank, of Madison. Two or three companies had been chartered to do an insurance business and under a strained construction of a clause in their charters they conducted a quasi banking business, issuing bills of small denominations payable to bearer. The standing of the companies was good and their bills circulated freely, and so far as is known, all were redeemed. During the progress of the work on the internal improvement system, merchants, millers, plank-road companies, and even colleges, issued bills. Those issued by the plank-road companies and colleges were eventually redeemed, but most of the others proved worthless. The State also went. into the business of issuing bills, and put out a million or so of treasury notes, in denominations of five, ten and twenty dollars. The notes were made receivable for taxes, and bore interest. They depreciated very rapidly, finally selling as low as sixty cents on the dollar, but before they were all finally redeemed they appreciated until they were worth two for one. These notes were generally called "red dog," while those for smaller sums, issued by plank-road companies and others were designated as "blue pup."

The greatest blow, however, to Indiana's credit and the darkest page in her financial history was inaugurated under the general banking law of 1853. This bill, like that for the charter of the Bank of the State, was vetoed by Governor 'Wright, but was passed over his veto. It was loosely drawn, and opened wide the door for fraud. It was speedily taken advantage of by daring speculators, and banks sprung up like mushrooms everywhere. Not all those who established banks under this law were corrupt or dishonest, and some of the banks redeemed all their obligations in full, but a great majority of the banks were established without any reliable security for the bill holder, and none at all for the depositor, while others never opened any banking house. In one instance a farmer was President and kept the 
funds of the bank in a potato barrel in his cellar. In another the Cashier, a blacksmith, had a box under his anvil for a vault.

\section{Halcyon Days of Wildcat Banking.}

The organizers of a bank were required to deposit with the Auditor of State the bonds of the United States or of some State. At that time the bonds of several of the States, especially those in the South, were at a discount. A few men would get together, purchase the bonds of some State at a discount, file them with the Auditor, and receive authority to establish a bank. With that authority they could enter upon the manufacture of paper money by the wholesale. They were permitted to have the custody of the plates and dies from which their bills were printed, and notwithstanding the law required that the bills should be countersigned by the Auditor, there were practically no guards to prevent them from issuing bills ad libitum, and in many cases bills were issued to an amount two or three times greater than the value of the bonds deposited ; then bank, officers and directors would disappear, leaving the bill holders to mourn. A thousand or two dollars in cash was all that was required to start a bank. This was needed to pay for engraving the plates and printing the bills. An embryo banker would go to New York with a thousand dollars, order an engraver to make the plates and print $\$ 50,000$ in bills. He would next visit a broker and negotiate for $\$ 50,000$ of the bonds of some State, get them at a discount, and instruct the broker to send them to Indianapolis in care of the Auditor of State, the price to be paid on their delivery at Indianapolis. He would then go to Indianapolis with his $\$ 56,000$ of new bills, get the Auditor to countersign them, and pay for the bonds with the bills and have a surplus left. Thus a new bank would be established, without banking-house, furniture or anything else. Thus one man with $\$ 10,000$ bought bonds and established banks until he had a circulation of $\$ 600,000$ of paper, and was drawing interest on more than that amount of bonds. When the crash finally came the bills were bought up at a large discount, presented to the Auditor and the securities redeemed, the banker retiring from business with a large fortune. The law required that all banks established under it should receive the bills of all the other banks, in discharge of debts, but it was practically a nullity.

Such a flood of paper money, with no substantial backing could not help proving disastrous. The bills rapidly depreciated, and notes taken one afternoon at eighty cents might be quoted the next morning at sixty-five, or even lower; thus all values and all business were deranged. Several times the honest bankers made an effort to stem the tide of dishonesty, but their efforts were all in vain. Every merchant and business man had to provide himself with a periodical known as the "BankNote Reporter," that he might keep informed as to the fluctuations of the bills. The banks were authorized to issue notes of various denominations 
from one dollar to five hundred dollars, but could not issue bills for less than $\$ 5$, to an amount greater than one-quarter of the total issue. As a rule almost the entire issue would be confined to bills for five dollars or less. Such was the flood of small bills that all coin was driven out and the Legislature undertook to remedy the matter by limiting the issue of small bills to one-twentieth of the total issue, which was afterwards again raised to one-sixth. The banks were required to redeem their notes in specie. On failure to do so the State Auditor could serve notice and then redeem from the bonds on file with him.

\section{Rapid Increase in Number of Banks and Circulation.}

Within two years nearly one hundred banks were started with a total circulation of more than nine and a half million dollars. Fifty-six of them collapsed before the end of the first year of their existence, representing a circulation of nearly three millions. In 1855 the Legislature undertook to remedy the matter by amending the law limiting the circulation to six million dollars, and requiring that all stockholders should be bona fide residents of the State, and also that the deposit of securities should be ten per cent. in market value in excess of the issue. All banks failing to meet the requirements of the new law were required to go out of business. This cut off a number more of them, and the number grew less each year. The financial panic of 1857 drove more of the banks to the wall, and those remaining finally redeemed all their notes. The securities of the broken banks were disposed of and their bills redeemed by the Auditor, most of them at a discount.

Free Banks in Indiana.

\begin{tabular}{|c|c|c|c|c|c|}
\hline & 1854. & 1856. & 1858. & 1860. & *1862. \\
\hline RESOURCES. & & & & - & 1 \\
\hline Loans and exchange............ & $\$ 1,306,466$ & $\$ 1,841,360$ & $\$ 1,082,757$ & $\$ 1,239,498$ & $\$ 1,0 \mathrm{i} 0,219$ \\
\hline 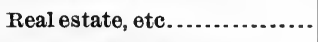 & 52,750 & 80,373 & 50,209 & ․ $\quad 59,883$ & 80,158 \\
\hline Due from sther banks........ & $1,879,745$ & 427,8 & 124,211 & 156,912 & 189,872 \\
\hline Bills of other banks........... & 638,121 & 340,112 & 130,715 & 105,198 & 153,240 \\
\hline 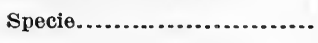 & 807,395 & 318,918 & $\mathrm{C}_{201,872}$ & 171,840 & $\dagger 467,166$ \\
\hline LIABILITIES. & & & & & \\
\hline 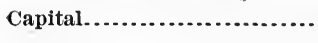 & $\$ 6,148,837$ & $\$ 2,128,867$ & $\$ 1,523,328$ & $\$ 1,287,640$ & $\$ 1,144,585$ \\
\hline 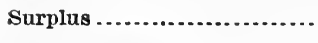 & ............. & 44,030 & 71,379 & 62,193 & 100,012 \\
\hline Due other banks......... & $57 ? 8,329$ & 123,436 & 27,882 & 25,079 & 43,531 \\
\hline Deposits ........... & $1,613,510$ & $1,363,294$ & 733,135 & 841,066 & $1,087,918$ \\
\hline Circulation ......... & $5,219,100$ & $1,310,905$ & $1,043,597$ & $1,210,262$ & $1,161,265$ \\
\hline Bonds to secure circulation.. & $5,131,827$ & $1,415,670$ & $1,448,170$ & $1,328,605$ & $1,288,375$ \\
\hline
\end{tabular}

* In 1863 the banks began to organnize under the National law.

† Includes United States notes. 
Organization of Banks Under the National System.

The first National bank in Indiana, was organized May 11, 1863. It was one of the first in the United States. It was organized by the late William H. English, and was successful until 1884, when it went into voluntary liquidation. Within one year after the National banking law went into effect seventy banks were organized in Indiana, most of the branches of the Bank of the State, and many private banks entering the system. There are now one hundred and twelve in the State. Indiana has been fortunate in that it has experienced no great banking wrecks. There have been some National banks that have failed, the Indianapolis National, which closed its doors in 1893, being the worst failure that has occurred in the State. Up to the present time (1899) the depositors of that bank have received about sixty per cent. of their claims.

\section{Private Banks and Bankers.}

There was no law in Indiana requiring private banks to report to the Auditor of State until 1872. Several large banks had been in existence for many years. In 1873 seven organized under the new State law. This number has gradually increased until they now number about thirty. Their growth is shown in the following table:

Private Banks.

\begin{tabular}{|c|c|c|c|c|c|}
\hline & 1878. & 1883. & 1888. & 1893. & 1898. \\
\hline REsOURCES. & & & & & \\
\hline Loans and discounts.......... & $\$ 2,050,183$ & $\$ 2,832,663$ & $\$ 4,024,382$ & $\$ 8,333,060$ & $\$ 10,498,978$ \\
\hline Bonds, stocks, etc........... & 120,073 & 28,900 & 169,114 & 607,670 & $1,304,639$ \\
\hline Real estate, etc................ & 13,141 & 191,976 & 233,512 & 462,216 & 600,755 \\
\hline Due from other banks....... & 397,177 & 615,169 & 817,732 & $1,228,113$ & $3,252,046$ \\
\hline *Specie ..................... & 357.920 & 370,049 & 456,927 & $1,615,402$ & $1,839,593$ \\
\hline LiABILITIES. & & & & & \\
\hline Capital stock.......... & $\$ 1,228,600$ & $\$ 1,179,800$ & $\$ 1,850,000$ & $\$ 1,509,150$ & $\$ 1,416,500$ \\
\hline Surplus .............. & 100,778 & 205,058 & 299,618 & 638,968 & 623,185 \\
\hline Due other banks........ & (........... & 4,153 & 20,899 & 54,772 & 197,806 \\
\hline Deposits.......................... & $1,623,200$ & $2,654,140$ & $3,473,630$ & $6,689,717$ & $11,987,053$ \\
\hline
\end{tabular}

* Includes United States and National bank notes.

From the earliest times there have been individual or partnership banks that have not been under legislative control. . As early as 1815 the Territorial Legislature was called upon to enact a law, providing that any person doing business as a bank of deposit, should promptly pay all demands made upon it, in coin or in the bills of a chartered bank. It was provided that on failure to do so complaint could be made to the Auditor of State, and if the bank still failed after five days' notice he 
could wind it up. The panic of 1857 closed all the private banks in the State but two in Indianapolis and one at Fort Wayne. In 1872 a law was passed for the incorporation of private banks, and since then the system has rapidly grown. There must be at least five stockholders and a capital of not less than $\$ 25,000$ paid up. Reports of their condition must be made to the Auditor twice a year, and he may personally or by an appointee make an examination as often as he deems desirable, and may take possession on a failure to comply with the law. The President and Cashier are required to file a bond with the Auditor.

\section{Savings Banks and Trust Companies Authorized.}

Until within the last few years Indiana has practically had no Savings banks. As early as 1830 a law was enacted providing for the establishment of such institutions, and some attempts were made in that direction. The same law provided for the organization of building, savings and loan associations, and they took the place of Savings banks. In 1869 a carefully prepared and digested law for the establishment of Savings banks was enacted, and a few banks have been operating under it. In 1893 trust companies were authorized, and several have been organized containing a savings department.

\section{Savings Banks.}

Prior to 1869 there was no State supervision of Savings banks. In that year a law was enacted requiring the Auditor of State to make an examination of such banks at least once in every two years. The first examination and report was made in 1872 . There were then nine such banks in the State. In 1898 there were but five. From 1877 to 1898 their gain in deposits has been as shown below:

\begin{tabular}{|c|c|c|c|c|c|}
\hline & $187 \%$. & 1882. & 1887. & 1892. & 1898. \\
\hline RESOURCES. & & & & & \\
\hline 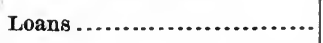 & $\$ 1,288,563$ & $\$ 1,445,392$ & $\$ 2,182,385$ & $\$ 2,933,970$ & $\$ 3,532,680$ \\
\hline Real estate, etc......... & 26,667 & 80,296 & 90,632 & 165,361 & 190,551 \\
\hline Bonds on hand......... & 36,866 & 216,798 & 267,332 & 470,644 & 727,269 \\
\hline 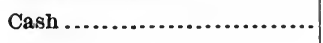 & 208,866 & 161,158 & 333,495 & 932,180 & $1,178,184$ \\
\hline LiABILITIES. & & & & & \\
\hline Deposits ........................... & $\$ 1,447,168$ & $\$ 1,753,255$ & $\$ 2,554,478$ & $\$ 4,073,128$ & $\$ 5,048,943$ \\
\hline Surplus.......................... & 44,512 & 120,698 & 182,562 & 330,809 & 495,850 \\
\hline
\end{tabular}

The reports at the close of 1899 indicated a gain of about $\$ 650,000$ in deposits compared with 1898 . There are 21,000 depositors in these banks.

\section{Trust Companies.}

In 1893 a law was enacted authorizing the organization of trust companies. In that year two were organized and began business. In 1898 
the number had increased to six, with $\$ 1,910,000$ capital and $\$ 260,000$ surplus and profits. Deposits were $\$ 1,885,099$. By the close of 1899 there were fourteen companies reporting, with two more organized but not yet doing active business. Their deposits amounted to $\$ 3,675,000$, and total resources exceeded $\$ 7,000,000$. Though of recent origin, these institutions have shown a considerable growth, their deposits having grown from the figures above named from a total of but $\$ 147,400$ in 1894 .

\section{Distinguished Bankers of Indiana.}

The most distinguished banker of Indiana was the late Hon. Hugh McCulloch.* He was born in Kennebunk, Maine, December 7, 1808. He received his education in the schools of that place and at Bowdoin College. His health failing him he left college without graduating, and began teaching school. He studied law and then sought a home in the West. He chose Madison, Indiana, as his home, it then being the largest and wealthiest city in the State, and located there in 1833. The northern part of the State was just then attracting attention owing to the prospects for the building of a canal from Lake Erie to the Ohio River, through Indiana. He finally concluded to remove to Fort Wayne, and there practice his profession. The State Bank had been recently chartered and one of its branches was to be located at Fort Wayne, and with that institution he becanne identified, and thereafter gave his life to banking and financial pursuits.

He became President of the Fort Wayne Bank after serving an apprenticeship as teller and Cashier. As President he was required to visit Indianapolis frequently, to hold consultations with the Presidents of the other branches, and this brought him into close contact with the leading bankers of the State. When the charter of the State Bank was about to expire, its successor, the Bank of the State of Indiana, proposed to purchase the branches of the old bank. They found the purchase could be made on one condition only, and that was that $\mathrm{Mr}$. McCulloch should be made President of the head bank. This was finally agreed to, and under his management the new bank became one of the most successful institutions in the country. During the panic of $\mathbf{1 8 5 7}$ he refused to let any of the branches suspend specie payments, and by this means the bills of the bank commanded a premium throughout the West and South.

He was naturally proud of the great moneyed institution of which he was the head, and when, in 1862, it was proposed to pass a National Banking Law, he opposed it strenuously, visiting Washington to work against it. He held that his bank could meet all its obligations, notwithstanding the stringency produced by the war, and thought others ought to do the same. The bill became a law, however, and while he was on an Eastern trip, the next year, he was suddenly surprised at the offer from Secretary of the Treasury, Chase, of the position of

* See p. 292. 
Comptroller of the Currency under the new law. His views in regard to the expediency of a National Banking Law had undergone a marked change. Not that he had lost faith in his own bank, but because he saw the necessity that the people should be supplied with some safe, reliable currency. To accept the offer of Secretary Chase meant a large pecuniary sacrifice, but after some hesitation he concluded to accept and give the Government the benefit of his wide experience. His name at the head of the new system at once gave it strength among the moneyed men of the country. He served in the office until March, 1865, when, on the resignation of William Pitt Fessenden, he was made Secretary of the Treasury by President Lincoln. He was re-appointed by President Johnson and served throughout his term. He then engaged in banking in New York and London. In 1884, when Mr. Gresham retired from the office of Secretary of the Treasury, Mr. McCulloch was again called to that high position, making his third appointment as head of the Treasury, and by as many different Presidents.

J. F. D. Lanier was another Indiana banker who won fame in financial circles. He was a native of North Carolina, and was of Huguenot stock. His ancestors fled from France on the revocation of the Edict of Nantes. One of his ancestors married a sister of John Washington, the first of that family to come to Annerica, while another married the sister of Mary Ball, the mother of George Washington. Mr. Lanier's grandfather fought with Gen. Wayne at the great battle with the Indians on the Maumee, and his father commanded Fort Warne during the War of 1812. Mr. Lanier was educated at Eaton, O., and at Newport, Ky. In 1817 his father removed to Madison, Ind., and entered upon a business career that proved very unfortunate, and he died insolvent, but his son afterwards paid all his debts in full. At Madison, Mr. Lanier began the study of law, finally graduating at Transylvania Law School, in Kentucky. He began the practice at Madison, and soon became successful. In 1824 he was appointed Assistant Clerk of the State House of Representatives, at a salary of $\$ 3.50$ per day. This brought him the acquaintance of many of the leading men of the day.

His law practice enabled him to accumulate some money, and when the State Bank was chartered in 1833, he became the largest individual stockholder in the Madison branch, of which he was made President. In 1837, when the Government called for the return to Washington of the Government funds held by the various banks, Mr. Lanier was selected as the agent of the State Bank to take $\$ 80,000$ in gold to Washington. He went by steamer to Wheeling, and from there across the mountains alone in a stage coach chartered for the purpose. In 1849 he went to New York and associated himself with Richard H. Winslow, for the purpose of engaging extensively in railroad building. Out of this connection grew the well-known banking house of Winslow, Lanier $\&$ Co. They were the first to offer railroad bonds on the market at New York. Their business in that line grew rapidly, and they frequently 
placed a million dollars' worth of bonds daily. In six years they negotiated the bonds which built more than ten thousand miles of railroads. In $1859 \mathrm{Mr}$. Lanier took hold of the work of re-organizing the Pittsburg and Fort Wayne road, which had gone down in the panic, and carried it through so successfully that it soon became one of the best paying roads in the country. In $1865 \mathrm{Mr}$. Lanier visited Europe, and at the request of the Secretary of the Treasury, acted on behalf of the Government in interesting foreign capitalists in our bonds. He visited all the money centers of Europe, and so successful was he in setting forth the resources of the country that foreign bankers no longer refused to invest in United States bonds. Three years later he again visited Europe on behalf of the Government to aid in an effort to float a five per cent. loan, and was again eminently successful.

Mr. Lanier never lost his interest in Indiana. In 1847 the State was practically bankrupt, being burdened with a large debt for internal improvements, and for several years had defaulted the interest. Most of the bonds were held in Europe, and Mr. Lanier was selected by the Legislature to proceed to Europe and lay a proposition for settlement before the holders of the bonds. He was given bonds and State stocks to the amount of several million dollars, all duly signed, and such was his reputation for integrity that no one thought of asking for even his personal bond. In 1863, when the State Legislature refused to appropriate money to pay the interest on the State debt, Mr. Lanier and his partner promptly furnished the Governor with several hundred thousand dollars. They had helped Governor Morton before with funds to meet the exigencies of the war, and advanced large sums to him from time to time as long as the war lasted.

Samuel Merrill, the first President of the State Bank of Indiana, was a Vermonter by birth. He came to Indiana while yet a young man, locating at the little town of Vevay, on the Ohio River. There he studied law and began the practice. In 1822 he was elected Treasurer of State, by the Legislature. The capital of the State was then at Corydon, where he entered upon the discharge of the duties of his office. When Indianapolis was selected as the future capital he removed the archives of the State to that place, in a wagon, driving through an almost unbroken forest, through which no roads had been made. He was twelve days on the journey. He was a careful, methodical man, and the old books of his office, which are still preserved, are models of correct bookkeeping. He served as State Treasurer for twelve years, and resigned on being elected President of the State Bank by the Legislature. The banking business was new then in Indiana, but the known probity of Mr. Merrill at once gave the new institution a high standing among the people. There were no railroads in the State and but few of any kind. The prime object of the bank was to encourage the agricultural development of the State. The branches were scattered far apart, but Mr. Merrill made frequent visits 
to them, carefully examining into their condition. He not only examined as to the character of the loans made, but laboriously went over all the accounts. Such rigid investigation prevented any defalcations had there been any desire upon the part of any of the officers to rob the bank. Under his administration the bank was unusually prosperous notwithstanding it had to pass through the great financial crisis of 1837-40.

Polities at last interfered, and he was displaced by the Legislature to make room for one of the political faith of the majority in the Legislature. On leaving the bank he was elected President of the Madison and Indianapolis Railroad, which was then in process of construction. It was the first attempt at railroad building in the State and met with engineering difficulties at the very start, but such was the energy of Mr. Merrill, and such the ability with which he managed its affairs, that the road was successfully completed, and its stock sold at a premium of thirty per cent. After he relinquished the management the stock went down until it was finally sold at a song.

He was a warm personal friend and admirer of the late Henry Ward Beecher, and was one of those instrumental in getting that great divine as pastor of a church in Indianapolis. He was a man of great charity, and was at the head of all the charitable organizations of the city of his home. It is told of him that while President of the State Bank he was in the habit of soliciting from everybody old clothing to give away to those in need. He had a room in the bank where a pile of this elothing was always kept. One day on entering the bank in a hurry he threw a handsome new cloak he had just had made for himself, on the pile of old clothes. Shortly afterwards a mendicant came in asking for help. Mr. Merrill told him to go into the room and help himself. When it came time to close the bank Mr. Merrill went for his cloak, as it was a very bitter day in winter, but found that the mendicant had helped himsel to it. Mr. Merrill was a great friend of education. On his arrival at Indianapolis, there was no one competent to teach school, and he opened a school which he taught while serving as Treasurer of State.

Among the pioneer bankers of Indiana Calvin Fletcher took and held a very high place to the hour of his death. He was born in Vermont, in 1798. His early education was obtained under difficulties. Up to 1815 it consisted of about two months each year in the schools in the neighborhood of his father's residence. Then for two years he worked as a laborer and spent his earnings in attending the academies at Randolph and Royalton, in his native State. At the age of nineteen he determined to seek a home in the West. In two months he worked his way, mostly on foot, to Urbana, Ohio. Arriving there he was without money or friends, or even acquaintances. He obtained employment as a hired hand on a farm, for a short time, and then as a school teacher. That fall he entered a lawyer's office to study law.

In 1821 the Indians had ceded their lands in Indiana, and the new town of Indianapolis had been laid off as the future capital. Mr. 
Fletcher put his young wife, and all his earthly possessions, in a wagon and started for the new capital, through an almost trackless forest. $\mathrm{He}$ was fourteen days on the road, camping out each night. He put out his sign as an attorney, and did not wait long for clients. He was elected to the State Senate and served in that body for seven years. When the State Bank was chartered he was appointed by the Legislature as one of the four men to organize the bank, and also to act as Sinking Fund Commissioner. This last position was one of great importance to the State, and of great responsibility. By its charter the bank was required to pay to the commissioner the dividends and profits due the State on its stock in the bank, together with the tax levied against the stock of the individual holders and the interest paid by the bank on the $\$ 500,000$ loaned by the State to the stockholders. The amounts so received were to be invested to provide a fund for the payment of the bonds issued by the State to procure the money with which to establish the bank.

He held that position for seven years, when he resigned to accept the Presidency of the Indianapolis branch of the bank, a place he continued to hold for sixteen years, until the charter expired. All this time he had been conducting a very large and lucrative law practice, and had carefully invested the proceeds, making him for those days, and for Indiana, a very wealthy man. On winding up the affairs of the branch bank he and Mr. Sharpe, who had been Cashier, opened a private bank, which for many years was one of the great moneyed institutions of Indianapolis. Some years after his death it became embarrassed and was compelled to close its doors. Mr. Fletcher was intense in all he did. He was a hater of slavery, and was never too busily engaged to refuse to listen to the story of a black man escaping from slavery, and to such he always gave liberal aid. During the war he with other Indiana bankers advanced large sums to the State to aid in arming and forwarding troops.

\section{National Banks.}

Figures are in thousands of dollars.

\begin{tabular}{|c|c|c|c|c|c|c|c|c|c|}
\hline YEARS. & 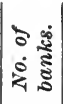 & $\begin{array}{c}\text { Loans } \\
\text { and dis- } \\
\text { counts. }\end{array}$ & $\begin{array}{c}U . S . \\
\text { bonds. }\end{array}$ & $\begin{array}{l}\text { Cash and } \\
\text { cash items. }\end{array}$ & Capital. & Surplus. & $\begin{array}{c}\text { Undi- } \\
\text { vided } \\
\text { profts. }\end{array}$ & $\begin{array}{c}\text { out. } \\
\text { standing } \\
\text { circula. } \\
\text { tion. }\end{array}$ & $\begin{array}{c}\text { Indi- } \\
\text { vidual } \\
\text { deposits. }\end{array}$ \\
\hline $1863 \ldots$ & 9 & $\$ 478$ & $\$ 700$ & $\$ 274$ & $\$ 865$ & .......... & $\$ 6$ & .......... & $\$ 784$ \\
\hline $1868 \ldots . .$. & 70 & 14,609 & 14,056 & 3,322 & 12,767 & $\$ 2,184$ & 802 & $\$ 10,990$ & 8,00 ? \\
\hline $1873 \ldots$. & 92 & 27,147 & 16,920 & 3,300 & 17,632 & 4,248 & 1,110 & 14,472 & 14,023 \\
\hline $1878 \ldots$ & 94 & 20,498 & 14,209 & 4,802 & 15,035 & 4,116 & 1,295 & 11,436 & 13,840 \\
\hline $1883 \ldots . . .$. & 98 & 28,745 & 11,020 & 5,685 & 14,029 & 3.717 & 1,519 & 8,595 & 23,542 \\
\hline $1888 . . . . .$. & 94 & 27,938 & 6,446 & 5,624 & 11,965 & 3,591 & 1,631 & 4,084 & 24,503 \\
\hline $1893 \ldots . . .$. & 115 & 31,110 & 5,445 & 6,726 & 13,787 & 4,704 & 1,867 & 4,557 & 26,496 \\
\hline $1898 \ldots . . .$. & 112 & 34,452 & 8,464 & 7,595 & 14,167 & 4,596 & 1,123 & 4,191 & 44,608 \\
\hline
\end{tabular}


State Banks.

\begin{tabular}{|c|c|c|c|c|c|c|}
\hline YEARS. & $\begin{array}{l}\text { No. of } \\
\text { banks. }\end{array}$ & $\begin{array}{l}\text { Loans and } \\
\text { discounts. }\end{array}$ & Specie. & Capital stock. & Circulation. & Deposits. \\
\hline $1835 \ldots$ & 10 & $\$ 531,843$ & $\$ 751,083$ & $\$ 800,000$ & $\$ 456,065$ & $\$ 127,236$ \\
\hline $1840 \ldots$ & 13 & $4,581,486$ & $1,021,490$ & $2,595,221$ & $2,985,370$ & 372,784 \\
\hline $1845 \ldots$ & 13 & $2,834,421$ & $1,120,013$ & $2,105,212$ & $3,101,000$ & 320,303 \\
\hline $1850 \ldots$ & 13 & $3,912,796$ & $1,285,406$ & $2,082,910$ & $3,304,260$ & 663,462 \\
\hline $1855 \ldots .$. & 59 & $9,305,651$ & $1,894,357$ & $7,281,934$ & $3,165,856$ & $2,289,605$ \\
\hline $1860 \ldots \ldots$ & 37 & $7,675,861$ & $1,583,540$ & $4,343,210$ & $5,390,246$ & $1,700,479$ \\
\hline $1865 \ldots \ldots$ & 18 & .............. & ............. & $1,065,000$ & ............ & ............. \\
\hline $1872 \ldots$. & 8 & ............. & ............... & 948,000 & ............... & ….......... \\
\hline $1877 \ldots \ldots$ & 13 & $1,446,249$ & ............ & 876,100 & ............ & $1,057,058$ \\
\hline $1882 \ldots \ldots \ldots$. & 17 & $2,071,240$ & ........... & 964,800 & ........... & $2,210,438$ \\
\hline $1887 \ldots \ldots$ & 32 & $3,485,264$ & ............ & $1,676,600$ & ........... & $3,126,849$ \\
\hline $1892 \ldots \ldots \ldots . . .$. & 72 & $8,172,222$ & ............ & $3,586,700$ & ............ & $7,654,964$ \\
\hline $1897 \ldots .$. & 96 & $9,564,127$ & ............ & $4,875,900$ & ............ & $9,970,813$ \\
\hline
\end{tabular}

\section{ILLINOIS.}

The history of the early banks of Illinois is pretty much the same as that of the banks of all the western country, the development of which was contemporary with that of Illinois. For the most part these pioneer financial institutions were founded for the accommodation of the dreaming speculators of the new Territory, who foresaw the coming greatness of the future State, but whose impractical minds were not capable of computing the amount of labor and time necessary to bring about the results they so confidently expected, and which really came in a marvelously brief period of time.

Following the sophistry of the politicians of early Illinois, the historical writers of the State have, for the most part, attributed to the banks much of the distress caused by the premature and visionary schemes which handicapped the State during its infancy, but in this they are hardly just. The first banks were bad enough, but their weaknesses were the direct result of imperfect and often dishonest legislation. Having by faulty enactments created unstable institutions, it became the fashion of the early politicians to meet the popular ery against them with denunciation of all banks, and statutes were enacted that were hostile to them. Thus the early banks came into disrepute, and to this day there remains something of the prejudice brought about by the political discussions had previous to the enactment of the present State banking law.

Previous to the War of 1812 , there was no occasion, practical or 
fancied, for a banking institution in Illinois. The early French settlements were communistic in their character. They were founded by the trading companies and the missionaries, and they trafficked with no one but the Indians and the parent settlements along the Mississippi. The trade was confined to the pelts of wild animals, and by these were measured the value of the few commodities purchased. It was not until the settlers from the East commenced to come into the country that a demand for money was created, and this demand was based largely upon the desire to speculate upon the growth of the new State. Capital was needed to carry out the plans that were already being formed for metamorphosing the wilderness, and banks, with the future prosperity of the country as their most prominent asset, were suggested as a source from which to obtain the needed money. At this time the only currency in circulation in the Territory was that which had been paid to the Illinois volunteers, but this was sufficient to give the people an extravagant notion of the utility of bank notes.

\section{The Bank of Iluinois Established.}

In 1813 a bank was started at Shawneetown and three years later it became an incorporated bank by a special act of the Territorial Assembly. It was incorporated as "The President, Directors and Company of the Bank of Illinois," and John Marshall, David Apperson, Samuel Hays, ILeonard White and Samuel R. Campbell were appointed as commissioners to receive subscriptions for the institution. The law incorporating the bank provided that its capital stock should not exceed $\$ 300,000$, to be divided into shares of one hundred dollars each, onethird thereof to remain open to be subscribed by the Legislature. As soon as $\$ 50,000$ was subscribed and $\$ 10,000$ actually paid in, the bank was to be permitted to commence business and issue notes.

The same Legislature which passed the law incorporating the first bank in the State enacted a supplement to the statute concerning executions, which was the first of a series of legislative attempts to make legal tender of the early bank notes. The legislators made excuse for this supplemental bill by stating that it appeared to "this Legislature that gold and silver coin is so scarce in this Territory that it is utterly impossible for the citizens thereof at present to pay their debts in those metals ; and that attempts to enforce such payments by legal execution, besides the immense sacrifices of property that would result therefrom, would produce many other distressing consequences."

The law provided that all executions should be subject to replevy for one year, unless the plaintiff in the action out of which it grew should give to the sheriff "written authority to receive in discharge of the execution bank notes of any of the chartered banks of Cincinnati and Chillicothe, in the State of Ohio, and of any of the banks of the States of Tennessee and Kentucky, and of the banks of Vincennes, of Missouri, of St. Louis and of Illinois." 
Following the incorporation of the Shawneetown bank, the Legisla ture, at a special session held the following year, incorporated three additional banks. The first of these was "The President, Directors and Company of the Bank of Edwardsville," whose charter was granted upon petition of Benjamin Stephenson, John McKee and others. The act incorporating the bank was similar to the act incorporating the Shawneetown institution and it was to be permitted to commence business when $\$ 50,000$ had been subscribed and $\$ 10,000$ had been paid in. Benjamin Stephenson, James Mason, John McKee, Joseph Conway and Abraham Prickett were appointed to receive subscriptions for the institution. Benjamin J. Seward was the first Cashier of the bank and he was succeeded by $R$. T. McKenney.

"The President, Directors and Company of the Bank of Kaskaskia" was incorporated under a similar statute, but a provision was made that its subscriptions must 'be paid in either gold or silver. A number of the most prominent men in the Territory were named as commissioners to receive subscriptions for this bank and the men connected with it would have made it a strong corporation had it succeeded in getting into business.

The specie subscription requirement, however, made it impossible to secure the requisite investments and the bank never did any business.

Following is a list of the commissioners appointed for the Kaskaskia Bank : Pierie Menard, William Morrison, Sr., Shradrach Bond, William C. Greenup and Hugh H. Maxwell, at Kaskaskia; Benjamin Stephenson, James Mason, Abraham Prickett, John McKee and Joseph Conway, Edwardsville; R. K. McLaughlin, William Mears, William Kinney, John Messenger and Dr. Heath, at Belleville; Daniel Hay, James Graham, James Ratliffe, James Gray and John Kraw, at Carmi; Thomas Sloo, Joseph M. Street, M. S. Davenport, James Wilson and John Caldwell, at Shawneetown : Dr. Woolverton, G. W. Smith, Samuel Marshall, Jesse B. Brown and Seth Gard, at Palmyra ; James Finny, Erwin Morris, Owen Evans, George Evans and Jacob Littleton, at Elvira.

\section{A Phantom Bank Chartered.}

The incorporation of the "The President, Directors and Company of the Bank of Cairo," was the licensing of a chimerical scheme for the building of a great western metropolis at the junction of the Mississippi and Ohio rivers. The bank was to be established on the revenues derived from the sale of town lots and, of course, nothing came of it. The owners of the land, to whom the charter for the City and Bank of Cairo was given were John G. Comyges, Thomas H. Harris, Thomas F. Herbert, Charles Slade, Shradrach Bond, Michael Jones, Warren Brown, Edward Humphreys and Charles W. Hunter. In 1836 a company which had come into possession of the wreck of the old corpora- 
tion, started a bank at Kaskaskia under the charter of the Cairo bank, but the bank was not long in existence.

The banks at Shawneetown and Edwardsville continued to do business for several years, but finally failed. The last-named bank closed its doors in 1819, and the Government, which had used it as a depository for land-office funds, lost some $\$ 54,000$. The Shawneetown bank struggled along and continued to redeem its paper until 1821. In 1823 it was compelled to close up its business, but it managed to make a settlement with its creditors and saved its charter. When the State Bank of Illinois, was established, the charter of the Shawneetown institution was revived and extended for twenty years from January 1, 1837, the date of the expiration of the old charter.

\section{Subsequent History of the Bank at Shawneetown.}

At the time of the renewal of the bank's business it had been in suspension for twelve years. Its name, under the act extending the charter, was changed to "the State Bank of Illinois, at Shawneetown." John Marshall was its first President and John Sidell its first Cashier. On behalf of the State the following directors were appointed: Porter Clay, David J. Baker, H. H. West, J. K. Dubois, William Linn, Wm. Sim, James Dunlap, E. B. Webb and Peter Butler. The stockholders of the institution named the following directors: E. H. Gatewood, Alexander Kirkpatrick, W. A. Docker, W. A. G. Posey, Timothy Guard, Daniel Wood, M. M. Rawlings, P. Redman, Henry Eddy, James C. Sloo and C. C. Valandingham.

The subsequent history of the bank is connected with that of the State Bank. When its business was finally closed up the old bank building came into possession of Governor Joel A. Matteson, who started a bank there in 1853. This bank was organized under the Free Banking Act, and was known as the State Bank of Illinois. Governor Matteson's son-in-law, R. E. Goodell, was made President of this bank and, for four years, A. B. Safford was its Treasurer. The latter moving to Cairo, he was succeeded by L. B. Leach, who conducted the bank's affairs until the opening of the Civil War, when Governor Matteson closed the institution because of the danger of raids from Southern guerillas. Thomas S. Ridgway, afterwards State Treasurer of Illinois, purchased the old building and, in 1865, established in it the First National Bank, of Shawneetown, a prosperous successor to the first banking institution of the Illinois country.

The establishment of the Territorial banks had the desired effect so far as making money plentiful was concerned, but they encouraged speculation, and when the Territory was admitted into the sisterhood of States, there was already some feeling against the banking institutions. It was deemed advisable that the State take charge of the banking business and, accordingly, the following section was inserted in the first constitution: 
"There shall be no other banks or moneyed institutions in this State than those already provided by law, except a State bank and its branches, which may be established and regulated by the General Assembly of the State as they may think proper."

\section{State Bank of Illinois Incorporated.}

In 1819 the State Bank of Illinois was incorporated under the provisions of the first constitution. It was to be a modest affair, which was to commence business when $\$ 15,000$ of its stock had been paid in. The State was to subscribe one-half the stock of the institution, and was to have practical control of it. The bank was authorized to establish ten branches in various parts of the State for the convenience of the citizens of the State. A period of depression came before the bank could be organized and, despite the fact that little money was needed to start it in business, the capital was not subscribed.

A statement of the condition of the banks in 1819 shows that they had a capital of $\$ 140,910$, circulation of $\$ 52,021$, public deposits, $\$ 119,036$, and private deposits, $\$ 32,568$.

Two years later the charter of the first State Bank was repealed and a new State Bank of Illinois, based upon the credit of the State, was incorporated. This bank came into existence after the most memorable legislative fight in the early history of the State. The bill incorporating it was a faulty one in many respects, and it undertook to make the notes of the bank legal tender. At that time all measures of the General Assembly went to a council of revision, and when the bank bill was sent to it, three members of the commission, Governor Bond and Judges Phillips and Reynolds, disapproved it. Judges Wilson and Brown approved the bill and the Legislature sustained the minority, passing the bill over the veto of the Governor and the other judges.

An incident of the fight over the passage of the bank bill was the resignation of John McLean as Speaker of the House of Representatives. Under the rules, the Speaker could address the House only when it was in committee of the whole. McLean, who was bitterly opposed to the bank bill, was prepared to make a speech against the measure, but the leaders of the majority in the House, fearing the effect of his brilliant oratory on the bill, engineered matters so that the House voted against going into committee of the whole on the bank bill. When McLean found that he was to be cut off from participating in the debate, he decided to sacrifice his position. Promptly resigning the Speakership he took his place on the floor, and in a speech that is described as one of the most brilliant in the history of the State, he described all of the evil effects that were sure to come of the ill-advised legislation. His speech did not, however, have the effect that had been feared by the advocates of the bank bill. The measure went through despite the warnings of the gifted and talented Speaker, and the State brought upon itself all the evils that had been predicted by McLean.

Under the act the State Bank was to have a capital of half a million 
dollars and was to issue in the beginning $\$ 300,000$ in notes in denominations of $\$ 1, \$ 2, \$ 3, \$ 5, \$ 10$ and $\$ 20$, bearing two per cent. annual interest and payable in ten years. It was to be managed by directors under control of the General Assembly. The main bank was to be established at Vandalia, the State capital, and branches were to be located at Edwardsville, Brownsville, Shawneetown and Palmyra. The bank was authorized to loan money in less sums than $\$ 100$ on personal security, and larger sums were to be secured by real estate. These loans were renewable on payment of ten per cent. of the principal. Before long all the bank's capital was thus loaned.

\section{Political Bank Launched Without Capital.}

Without any other capital than an appropriation to pay for printing its notes, the new bank started upon its career in the summer of 1821 . The Legislature elected its officers, who were, of course, politicians anxious to curry public favor. The loaning of funds upon doubtful security was a convenient method of securing votes, and since the officers had no personal interest in the bank's securities, they paid little heed to the character of the paper they took in exchange for the bank's currency. Indeed the time came when they were more interested in wrecking the bank's credit than they were in preserving it, for they became heavy borrowers themselves, and the depreciation of the bank's notes made the discharge of these debts easier.

Owing to the rapid decrease in the value of the bank's paper, the State treasury was soon depleted, for while the notes were accepted at par for taxes, the State could not pay its debts upon the same terms with the same money. Even the State officers refused to accept the paper at its face value for their salaries. The bank soon had $\$ 300,000$ in circulation, and at no time was it at par. It began to depreciate as soon as it was thrown into the business world; and finally it dropped to thirty cents on the dollar. In 1825 the State was issuing Auditor's warrants payable in the bank's currency at the rate of three dollars for one. On these warrants the State lost $\$ 75,000$, and Moses, in his history of Illinois, estimates that the total loss to the State as the result of the opera. tions of the bank was no less than $\$ 300,000$. This estimate does not include the private losses and damage to the new country, nor the incalculable injury to the credit of the commonwealth. A loan of the State was negotiated in these notes at par, and the notes were subsequently paid out at fifty cents on the dollar. When the State finally redeemed the notes at par, this was of course an additional source of loss.

In 1824, upon the request of Governor Coles, an investigation of the affairs of the bank was made. This investigation disclosed the fact that the main bank's expenses had exceeded its discounts by $\$ 2,403$. The affairs of the Shawneetown branch were also in bad shape. According to the accounts, the Cashier appeared to be in default $\$ 4,800$, and the 
bank had loaned $\$ 3,750$ without security. The Edwardsville and Palmyra branches had been well conducted and showed some profit, but the Brownsville branch had made bad loans and had lost money.

The Legislature now passed laws designed to reduce the powers of the bank to the collection of its debts, with a view to re-establishing its credit and getting it upon its feet once more. These enactments were ineffectual, however, and the Governor, before retiring from office, advised that the business of the institution be brought to a close.

The Illinois banks had now come into prominence at Washington. Senator Ninian Edwards had been appointed a Minister to Mexico and was preparing to start to his mission when his attention was drawn to a statement by William H. Crawford, Secretary of the Treasury, discrediting testimony he had given before a Congressional committee. Abandoning his trip, Edwards sent a communication to the House, making charges against Crawford's administration and accusing him of being responsible for the loss of United States funds which had been deposited in the Edwardsville bank. Edwards claimed that he had notified the department of the insolvent condition of the bank before the money was deposited there, a statement that was vigorously denied by the Secretary.

A Congressional committee was appointed to investigate the matter and Edwards was invited to return to Washington and make good his charges. He failed to return in time and the committee held its investigation without him. It found that many of the matters of fact stated by Edwards were correct, but it did not find that the accusations of dishonesty or corruption were warranted. Its report said that " nothing had been proved to impeach the integrity of the Secretary or to bring into doubt the general correctness and ability of his administration of the public finances."

\section{Bank Becomes an Issue in State Politics.}

Edwards now resigned his position as Minister to Mexicn with the expectation of returning to the seat he had resigned at Washington. The Legislature, however, declined to re-elect him to fill out his unexpired term, and he thereupon became a candidate for Governor. The Washington controversy had arrayed the banks against the Senator and their influence in the Legislature had been used against him. Accordingly, he made the banks the issue in his campaign, viciously attacking their management, and accusing the officers of the State Bank of corrupt and dangerous business methods. Thomas C. Sloo, Jr., was the opponent of Senator Edwards. He was not able to meet the vigorous campaign of the Senator and Edwards was elected by a plurality of some five hundred votes. The Legislature, however, remained hostile to Edwards.

Following the policy he had mapped out when he entered the fight, Governor Edwards' first official act was the transmission to the Legisla- 
ture of an inaugural address, bitterly attacking the banking system. The friends of the State Bank answered the accusations made by the Governor with the general proposition that the executive was writing for political effect. A heated discussion arose, during which the Governor made some charges which he afterwards retracted, although he never changed his attitude towards the bank and still insisted that it was a corrupt institution. Finally, the hostile Legislature appointed a committee to investigate the charges made by the executive against the management of the Edwardsville Bank. The testimony showed that the bank had been carelessly conducted, but the committee reported that " nothing was proved against the officers of the bank, which would justify the belief that they had acted corruptly or in bad faith in the management as officers of said bank."

The sessions of the Legislature were now devoted largely to banking legislation. Several laws to facilitate the collection of the State bank's debts were enacted, but the politicians studiously avoided the problem of winding up the affairs of the institution and redeeming its paper. To do the latter would involve the making of a loan to cover the amount of the bank's currency and the legislators were afraid to meet the question. Every proposition thus to save the reputation and credit of the State was met with disapproval because of the prospective increase in taxation. It was with difficulty that the Legislature was at last prevailed upon to borrow $\$ 100,000$ for the redemption of State paper. The loan was negotiated with Samuel Wiggins, of Cincinnati, and it aroused just such opposition as had been predicted. Every public man who had anything to do with the matter was excoriated and for a time those who had "assisted in selling the State to Wiggins," could hope for nothing in the way of political preferment. Governor Ford says of this transaction: "The credit of the State was saved, and the Legislature was damned for all time to come."

\section{Another State Bank of Illinois Chartered.}

The public feeling brought about by the disastrous experience with the State Bank caused the Legislature to go to the extreme of refusing banking powers to any business corporation, and it was not until President Jackson began to make National depositories of State banks that there was a change in sentiment. In December, 1834, Acting Governor William L. D. Ewing recommended, "the establishment of a State bank, founded not upon the baseless, impalpable fabric of a vision-but upon a gold and silver reality." Governor Duncan, in his inaugural address, also recommended that a bank be established and cautioned the Legislature to exercise care in framing its charter.

Abraham Lincoln was a member of the General Assembly which passed the new bank bill, in accordance with the recommendation of the Governor. This was his first legislative experience and he took considerable interest in the proposed measure. The bill provided for 
the incorporation of the State Bank of Illinois and it was approved February 12, 1835. Profiting by past experience, a provision was made in the charter by which the State obligated itself not to enact legislation that would obstruct the collection of the bank's debts. The capital stock of the new institution was fixed at $\$ 1,500,000$, which might be increased by individual subscriptions by $\$ 1,000,000$ more.

The business of the new bank was to be entered upon as soon as $\$ 250,000$ in specie was subscribed. The State was to subscribe $\$ 100,000$. The charter contained provisions which were designed to prevent heavy stock-holding and to limit the holders of stock to residents of the State. Both of these provisions failed, however, because of the activity of the agents of those who desired to obtain stock in the bank. These agents soon found means of avoiding the law and the provisions became inoperative against them. At the same time the State Bank was incorporated, the law extending the charter of the Shawneetown bank, already referred to, was passed.

At the time the new bank entered the business world there was a fierce commercial war on between St. Louis and Alton. Both towns were important river points, and both were struggling for control of the Mississippi River trade. The lead mines at Galena were doing a profitable business at this time, and the merchants of Alton and St. Louis contended for the Galena trade with ardor. In order to get business they made heavy investments in Galena property, and held out all sorts of inducements to Galena people. With patriotic fervor the State Bank entered into the commercial fight as a champion of the Illinois city and advanced money with a lavish hand to the Alton merchants. As a result the bank was almost bankrupted within two years of the time it opened its doors. Governor Ford estimated that the bank lost nearly $\$ 1,000,000$ by its Alton operations. Nor was Alton benefited by the aid it reccived from the State Bank. The investments its merchants made in Galena did not save the upper Mississippi trade to them, and the losses that followed their unwise speculations were heavy. The natural advantages possessed by St. Louis were not to be overcome, and that city continued to grow in wealth and power.

\section{An Era of Extensive Internal Improvements.}

In 1836 the Legislature authorized the bank to sell at public auction the additional $\$ 1,000,000$ stock allowed by its charter, and establish three additional branches, conditioned upon its contracting with the Governor to redeem the Wiggins loan. The bank accepted the conditions in June of the same year, at the time when the State was embarking in a gigantic scheme of internal improvements. This scheme was born of a new speculative craze which was sweeping over the western country and contemplated the building of railroads and canals through the unimproved portions of the State. Engineering feats that would cause even the fearless promoters of the present day to hesitate, were 
to be accomplished; gigantic cities were to be built and thrown into communication with each other by a most complete system of transportation facilities, and the whole was to be paid for with bonds that were valuable only to the extent of the faith in the ultimate success of the enterprises. It did not occur to the Illinois projectors of the internal improvements plans that their future might not appear as rosy to the men who were expected to furnish money for the enterprise as it did to them; the speculative mania had possession of them and they could see nothing but the rainbow of their dreams.

\section{General Banking Inflation.}

The Legislature became infatuated with the glowing picture, and at its next session authorized a loan of $\$ 8,000,000$ to carry on the proposed work. The banks were made a part of the scheme. In February the State Bank of Illinois was authorized to borrow $\$ 250,000$ and loan it upon real estate security, and a few days later the Governor was authorized to subscribe for the $\$ 100,000$ of stock the State was permitted to hold in the State Bank, and this enactment was followed by another, increasing the bank's stock $\$ 2,000,000$. This amount was to be subscribed wholly by the State. Then the capital stock of the Shawneetown bank was increased $\$ 1,400,000$, and the State was authorized to subscribe for $\$ 1,000,000$ of this amount.

In anticipation of the growing business that was to come with the rapid growth of the State under the internal improvements scheme, the Shawneetown bank was authorized to establish branch banks at Alton, Jacksonville and Lawrenceville. Provision was made for the issuing of certificates of Illinois Bank and improvement stock to secure a loan of not exceeding $\$ 3,000,000$, which the fund commissioners provided for by the law were to negotiate. The commissioners were permitted to deposit in the State banks all the funds received for internal improvements and the banks were made the agents of the State in respect to these funds.

The magnificent and plausible plan for enriching the State failed, and there followed what has been designated as the period of "hard times in Illinois." Attempts to negotiate the improvement scheme paper in the East came to naught, and the banks undertook to aid the plan, taking $\$ 2,665,000$ of the bonds at par. The Shawneetown bank disposed of its share of $\$ 900,000$, and the remainder was used by the State Bank as capital, until the depression of 1837 compelled the banks to suspend. In order that the suspension of the banks might be legalized, the Legislature was called together and an enabling act was passed which was designed to save their charters. The legalization of the suspension of the banks was in the face of the Democratic leaders who had made an issue of the banks and had taken strong grounds in favor of depriving them of their charters.

Governor Carlin attacked the banks in his first message to the Leg- 
islature, and in 1839 , when they again suspended specie payments, he advised the Assembly not to legalize the suspension. Upon his recommendation, an investigation of the affairs of the State Bank was made, and it resulted in the discovery of some irregularities. The banks, however, had influential friends in the Assembly, and despite the recommendation of the Governor, their suspension was again legalized under restrictions similar to those made in 1837. The Chicago branch of the bank was ordered to be removed and it was afterwards transferred to Rockford. The same Legislature repealed the disastrous internal improvements act.

In 1841 the Legislature was confronted by a bankrupt treasury, and a proposition to increase the banking capital of the State was made. The Governor protested against this and the Legislature being Democratic, it failed, and increased taxes were voted to carry on the State government. The fight to require the State banks to resume specie payments or forfeit their charters was now reopened, and it came near being successful. Indeed, the banks did forfeit their charters because of the failure of the Assembly to extend the time for resumption, but before the Assembly closed its session, there was a reaction of sentiment and the forfeiture was set aside.

\section{Failure of the State Bank.}

The fight against the State Bank had been carried to Washington, and the stories told concerning its stability had resulted in the national authorities refusing to make it a Government depository. Its officers became anxious to redeem its reputation, and they proceeded to tax its resources in order to be able to meet promptly the outstanding Auditor's warrants. Certain of the bank's directors now secured loans to build the Northern Cross Railroad, a relic of the internal improvements scheme, and for the construction of which they were to be paid in canal bonds, which then had no market value. Other loans of the same sort were made, and as the result of this character of financiering, the bank went under in 1842 .

The failure of the State Bank was followed closely by the collapse of the Shawneetown institution, and the State was left practically without money. The depreciated notes of the banks had already driven all the good money out of the State, and when the banks went to pieces the people were without a circulating medium of any sort, good or bad. At this time Illinois bonds sold on the market for only fourteen cents on the dollar. Many men with property and excellent credit could not pay their taxes because of the scarcity of money.

Governor Carlin continued his hostility toward the banks until he retired from office, and one of his last official acts was to send a message to the Assembly recommending that their charters be repealed. Governor Ford, who succeeded him in office, took a different view of the situation. He was anxious to save something of the $\$ 3,100,000$ the 
State had tied up in the banking institutions, and he recommended that a compromise be made. Accordingly, January 24, 1843, an act was passed by the Assembly, placing the State Bank in liquidation, and giving it four years in which to wind up its affairs. During the following month a bill was passed to put the Bank of Illinois, at Shawneetown, into liquidation. These bills provided for the cancelling of $\$ 2,050,000$ of the State's bonds upon the surrender of this amount of bank stock held by the State, a manifest injustice to the other holders of stock. The same Legislature repealed the charter of the Bank of Cairo, which had been revived and used as the basis of a banking institution, at Kaskaskia, that had suspended in 1839.

William Ridgely, of Springfield, is the surviving trustee of the old State Bank, and whatever business growing out of the affairs of that institution remains to be transacted is in his hands. It seems incredible that there should be any such business at this late day, when the old bank is almost forgotten, but occasionally an abstract maker finds a break in a chain of title caused by some transaction in which the bank was concerned. Then the surviving trustee is called upon to straighten matters out. Only a few years ago he made a conveyance of a claim to land in Logan county, and the title to the land on which the great Chicago Auditorium stands was not clear until he had made it so by a conveyance of the same character. Mr. Ridgely is the son of Nicholas Ridgely, one of the pioneer bankers of the State, and the Cashier of the State Bank at the time it went to pieces.

\section{Names Distinguished in the Banking and Political History OF THE STATE.}

A number of noted men were connected in one way and another with the old State Bank. Judge Stephen T. Logan was its Springfield attorney, and his law partner, Abraham Lincoln, did much of the bank's work. In those days the future President of the United States felt honored by so distinguished a client as a State institution, unsteady and uncertain of life though it was. The fees paid by a banking institution to its attorneys at that time would appear ridiculously small in this day, but they were princely in the mind of the early Illinois lawyer.

Judge David Davis, of Bloomington, afterwards United States Senator from Illinois, was the bank's attorney and had much to do with its affairs. Its Chicago representatives were Jonathan Young Scammon and William H. Brown, prominent bankers of that city. Contemporary with them were E. I. Tinkam, Isaac H. Burch, R. K. Smith, Brother \& Johnson, and Seth Payne, who was known as "The Christian Banker," because of his activity in church work. George Smith was one of the most active and aggressive of the early Chicago bankers. He was a native of Scotland and after he had accumulated a fortune in Chicago he returned to London, where he died in the latter part of 1899.

Daniel Wann was the first President of the Galena branch of the old 
State Bank and William C. Bostwick was its tirst Cashier. Mr. Wann was succeeded by Frederick Stohl in 1840, and Mr. Bostwick was succeeded by $\mathbf{E}$. W. Turner. The Galena branch continued to do business until 1842, when Henry and Nathan Corwith and Charles H. Rogers began to absorb the banking business of the place.

\section{State Prohibited from Engaging in Banking.}

When Augustus C. French became Governor of the State (1846) he declared against "incorporate banking." So great had become the popular prejudice against banking concerns that an attempt was made to prohibit them in the constitution which was drafted in 1847. The proposition was defeated by only one vote and in its stead was inserted a clause which prohibited the State from engaging in the banking pusiness; which made shareholders in banking corporations individually liable for the amount of their stock and which provided that all banking acts must be submitted to a vote of the people of the State. These provisions have been preserved in the present State constitution.

The first banking law under the new constitution was modelled after that of New York. Governor French vetoed the measure, but it was passed over his veto and was submitted to the people in November, 1851, the Legislature having legislated all of the county treasurers out of office in order to have a general election at which the banking law could be submitted. Illinois was now entering upon a new period of prosperity; times were good and the outlook for the future was most promising. The people approved the new banking law and within less than a year seventeen banks had been organized.

Under the new banking law provision was made for the deposit of United States or State bonds with the Auditor to secure the circulation of the banks. Three Bank Commissioners were appointed and these were given power to examine into the management of the banks and to call for additional securities whenever they were deemed necessary. Quarterly statements concerning the condition of the banks, made under oath, were required by the statute in order that the commissioners might be able to follow the affairs of the institutions.

Moses, in his history, says that " as a system of legitimate banking the new law was without proper checks and requirements relating to location, capital and redemption, but as a system for furnishing a safe circulating medium, it was well guarded, and proved a success up to the time of the rebellion in 1861. Although frequently called upon to put up margins to make good their depreciated stocks deposited as security for their circulation, they so uniformly responded that out of the 110 banks in operation at the close of 1860 , but fourteen had gone out of existence either by voluntary withdrawal or forfeiture under the law. And of these the securities had been found ample to redeem their notes, dollar for dollar in specie, with one exception, where there was a loss of only three per cent."

During the period of prosperity which came to the State about the 
time the new banking law went into effect, many men who afterwards became prominent in the business world "got their start." Among the prominent private bankers of the early fifties was Jasper Peddecord, the head of the firm of Peddecord, Burrows \& Co., of Decatur. The firm of M. P. Ayers \& Co., of Jacksonville, was organized at about the same time the Decatur firm went into business. Lorenzo and C. $\mathrm{H}$. Bull were the pioneers of the banking business in Quincy. Tincher \& English were the first bankers of Danville, and their business survives in the First National Bank of that city. S. Pulsifer was the first of the Peoria bankers.

Governor Matteson was one of the most extensive of the early bankers. He established the Central Bank, of Peoria, and owned the Merchants and Drovers' Bank, of Joliet, of which R. E. Goodall was Cashier. He also established the Bank of Bloomington, which is now the First National Bank of that city. The Bank of Quincy was another of Governor Matteson's enterprises. It was in charge of his son-in-law, John McGinnis, Jr.

Eames \& Allen established the first bank at Ottawa, a sound institution, which is still doing business as the National City Bank. Henry Eames, the senior member of the firm, became a Chicago banker after he had made a success of the Ottawa institution, being connected with the Commercial National Bank of that city.

General Ashael Gridley was one of the most striking men connected with the early banks of Illinois. He was a man of great force of character, aggressive, determined and untiring. He had much influence with the statesmen of his day, and his suggestions had great weight with them.

General W. F. Thornton was the founder of the Shelbyville Bank, which for years was considered one of the soundest banking institutions in the western country. So long as the general lived the bank did an excellent business. When he died his son, Thomas Thornton, succeeded to the business. He was not successful and the bank went to pieces a few years ago. Another private bank, which has since dropped out of existence, was the firm of Chestnut, Chestnut \& DuBois, at Carlinville.

Although the proposed Bank of Cairo, which was one of the first of the banking institutions authorized by law in Illinois, came to naught, Cairo had its bank in good season. It was established by William P. Halliday and it proved successful. The Belleville Savings Bank, with Henry Abend at its head, was another of the early banks of Southern Illinois.

\section{Small Notes of Banks of Other States Prohibited.}

In January, 1853, Governor French called the attention of the Legislature to the confusion growing out of the circulation of the notes of foreign banks in Illinois, and a law was passed prohibiting the circulation of foreign notes of a less denomination than $\$ 5$. No attention was 
paid to the enactment, however, the foreign notes continued to circulate and the law became a dead letter. In 1854 the Auditor reported that thirty-three banks were in operation. Two had gone into liquidation while still solvent, and one had been placed in the hands of a Receiver for failure to redeem its notes. The next report of the Auditor, two years later, showed that fifty banks were operating under the law, eleven having gone out of business.

The crisis of 1857 had its effect upon the banks of Illinois; a decline in securities following upon the failure of the Ohio Life and Trust Company was met by the filing of additional securities by all but two of the banks. The securities continued to fall and a second call was made. This time three of the banks failed to respond, but the others were able to offer the necessary security. This condition of affairs discouraged the formation of new banks, and the Auditor's report in 1858 showed only fifty-six banks. Of these nine had determined to go out of business. The Legislature made an attempt about this time to correct the evils growing out of the circulation of "wildcat" money, with which the country was flooded. A law was passed which prohibited the location of banks in inaccessible places, and requiring that notes be dated at the location of the bank, but the law could not be enforced, and the abuses continued. In 1860 the banks organized under the general law numbered 110 , and their circulation amounted to $\$ 1,320$,694. Their securities were valued at $\$ 11,336,423$.

\section{Financial Crisis of 1861.}

Sixty per cent. of the securities of the Illinois banks consisted of Southern paper when the crisis of 1861 came. With the threatened secession of the Southern States this paper began to depreciate and the foundation on which the banks of Illinois stood commenced to crumble. The Legislature took early cognizance of the danger and one of the first acts of 1861 was the passage of a law requiring that all future securities of Illinois banks should consist of United States or Illinois stocks. An immense amount of worthless notes was now in circulation and no one knew, from day to day, the value of the paper he carried. Bank-note reporters, which were designed to keep the people informed as to the worth of currency, could not keep pace with the rapidly shifting values.

Because of the depreciation of their Southern securities and their inability to meet the calls of the Bank Commissioners for better securities, many of the banks went out of business and when the Auditor's report for 1862 was made it showed that the nuinber of banks had been reduced to sixty-two. Two years later only twenty-three banks were in operation and ninety-eight were in suspension. Then came the inauguration of the National banking system and the tax on the issue of State banks soon extinguished the circulation of these institutions. In 1867 laws were passed prohibiting the incorporation of banks of issue and to punish the issuing of private notes. 
The banking institutions of the State played a prominent part in the war. Without exception they were loyal to the national Government and their support of President Lincoln was a source of much encouragement to him in the darkest days of the rebellion. When the call to arms was made Jacob Bunn, N. H. Ridgely \& Co., and the Marine and Fire Insurance Bank, of Springfield, immediately offered Governor Richard Yates $\$ 100,000$, to be used in getting the Illinois soldiers into the field. The Chicago banks followed with an offer of $\$ 500,000$ and these offers were followed by others from business men all over the State. The banks of Chicago which joined in the offer to the Governor were : The Marine Bank, Merchants' Loan and Trust Co., Western Marine and Fire Insurance Co., E. I. Tinkham \& Co., H. A. Tucker \& Co., B. F. Carver \& Co., Hoffman \& Gelpecke and J. Young Scammon.

\section{Early Banking in Chicago.}

Gardner G. Hubbard was the first man who did anything resembling a banking business in Chicago, and he had sufficient Eastern credit to draw bills of exchange which were sure to be honored on presentation.

When the second State Bank of Illinois was chartered by the Legislature, a branch of the same was established in Chicago and commenced business there about the middle of December, 1835, and at the time was the only bank in that city. The currency in eirculation consisted of bills of banks, located in the neighboring States, together with those of the State Bank. In 1843, the State Bank failed, and the Chieago bank closed its doors. Much difficulty was felt at this time in obtaining money of any description, and shinplasters and credit tickets, issued by tradesmen, supplied the place of change.

In 1836-37 the Chicago Marine and Fire Insurance Company had been chartered by the Legislature. It was forbidden by its charter from doing a banking business, but was authorized to receive moneys on deposit. This led to the issuing of certificates of deposit in denominations similar to bank bills, which, owing to the credit of the company, were willingly taken and passed from hand to hand as money.

\section{George Smith's Successful Bank.}

Encouraged by the success of the Chicago Marine and Fire Insurance Company, George Smith, who had come from Scotland to Chicago in 1834, took a transcript of the charter of the insurance company, and obtained from the Territorial Legislature of Wisconsin a similar one, incorporating the Wisconsin Marine and Fire Insurance Company. He joined with him in the management of this new concern, Alexander Mitchell, also from Scotland, and although the charter prohibited banking, they commenced the business of issuing certificates of deposit in the form of bank bills. The banking operations of the company were conducted upon the soundest principles. The certificates were paid 
when presented, and had a higher credit than the notes of most of the regular banks. Agencies for their redemption were established at Galena, St. Louis, Cincinnati, and Detroit. At Chicago they were redeemed at the banking house of Strachan \& Scott until 1840, when that firm removed to New York eity, and afterwards by George Smith \& Company. The circulation increased until 1851, when it reached $\$ 1,470$,000 . Every dollar was paid on presentation, and nearly $\$ 24,000$ representing loss by fire, shipwreck and wear, was never presented. In 1853 it was reorganized under the banking law of Wisconsin and is still in existence as the Wisconsin Marine and Fire Insurance Company Bank.

A large part of the business of this institution was done in Chicago, and its bills formed a large part of the circulating medium of that city. Attempts were made by business rivals to injure the credit of the certificates, but always without success, as the reserved resources were such as enabled every demand to be promptly met.

After the failure of the State Bank there were no ircorporated banks in Chicago until the passage of the General Banking Law of Illinois. This left a field for foreign institutions to circulate their bills. Banks located in Washington, D. C., and in Georgetown, in order to secure the circulation of their notes in Chicago, established offices of redemption there. In 1852, nine new banks were established in Chicago under tho General Banking Law of the State, but the new eurrency could not make headway in the face of the free circulation of the bills of George Smith's insurance company. The latter, it seemed, redeemed his Wisconsin certificates in Chicago at a charge of one per cent. for gold; and as the new Chicago banks had to redeem at par, on presentation, their bills were constantly coming in for gold. They therefore suspended specie payments with the proviso that they would redeem at par in gold when Mr. Smith adopted that course. As the latter was master of the situation no arrangement or compromise could be entered into with him, and the banks to get even also issued certificates of deposit.

All of the banks and bankers, including Mr. George Smith, doing business in contravention of the State law, were on December 23, 1852, indicted by the grand jury. Nothing was accomplished except to drive a few of the weaker ones out of business.

This means of putting a stop to irregular banking having failed, the regular bankers working under the State law, appealed to the Legislature and secured the passage of an act prohibiting the circulation of any form of paper money other than that issued by specie-paying banks, organized under State, Territorial, or United States law, under severe penalties. This disposed of insurance company certificates of deposit. Mr. Smith, however, procured a bank charter from the State of Wisconsin, and the Wisconsin Marine and Fire Insurance Company became the Wisconsin Marine and Fire Insurance Company Bank. He also organized the Bank of America under the Illinois State law, and went on with his business as before. As under the Illinois law securities equal to the 
circulation had to be deposited, there was some restriction at times upon the amount of circulation he could issue; and to remedy this Mr. Smith bought the Atlanta Bank of Georgia and the International Bank, of Griffin, Ga., legally chartered by that State. Although this circulation of foreign money in the State interfered with the profits the Illinois bankers derived from their circulation, there seems to have been no remedy, inasmuch as any attempt to force the redemption of the outside money only resulted in a counter effort against the circulation of the Illinois banks. But it was found that as long as Georgia money was paid in Chicago at a discount of three-quarters per cent. in New York exchange, and of one per cent. in gold, people were always glad to take it in spite of opposition by some of the bankers and merchants.

\section{BANKING UNDER Existing LAws.}

When the constitution of 1870 was framed, provision-was made for a banking system which prohibited the creation of a State bank and expressly stated that the State should not own or become liable for any bank stock. Under the general banking act, approved June 16, 1887, as amended by the act of June 3,1889, banks may be formed "for the purpose of discount and deposit, buying and selling exchange, and doing a general banking business, excepting the issuing of bills to circulate as money; and such banks shall have the power to loan money on personal and real estate security, and to accept and execute trusts." Capital must not be less than $\$ 25,000$, and the minimum ranges up to $\$ 200,000$ where the population is over 50,000 , and the entire amount must be paid in in cash before the bank can commence business. The banks are under supervision of the Auditor of Public Accounts, and must make and publish reports not less than four times a year, and are subject to examination at least once in each year. Though no fixed reserve is required by law, in practice a reserve is required equal to fifteen per cent. of deposits subject to notice and twenty per cent. of other deposits. There is no special law governing Savings banks, and institutions organized under the general law may do a combined commercial and savings business, or may be conducted as Savings banks exclusively. Stockholders in banks are liable to double the amount of their shares.

The private banks of Illinois are not under State supervision and their standing depends entirely upon the character and resources of the men behind them. That they do a good percentage of the business in the towns where they are located and that they continue to enjoy the confidence of the people of the State, is evidence of the worth of the private bankers of the State. It is estimated that three-fifths of the banks of Illinois are private banks.

In the latter part of 1899 there were 150 banks reporting to the Auditor of Public Accounts, their total resources being \$195,829,927. Their capital was $\$ 17,798,000$ and surplus and profits $\$ 11,621,335$. Total de- 
posits, exclusive of the amounts due banks, were $\$ 153,300,142$. This includes Savings deposits, which in Chicago, especially, are very large. Twelve trust companies were also reported as having qualified under the provisions of the trust act. Of the total resources of the State banks, amounting to $\$ 195,829,927$, Chicago has $\$ 153,029,946$. Detailed mention of particular institutions in that eity is impossible within the scope of this work. It may be said, however, that two banks-the First National Bank and the Illinois Trust and Savings Bank-stand well in the front ranks of the banks of this country, while there are many others also having a very large volume of business.

State Banks.

\begin{tabular}{|c|c|c|c|c|c|c|}
\hline YEARS. & $\begin{array}{l}\text { No. of } \\
\text { banks. }\end{array}$ & $\begin{array}{l}\text { Loans and } \\
\text { discounts. }\end{array}$ & specie. & $\begin{array}{l}\text { Capital } \\
\text { stock. }\end{array}$ & Circulation. & Deposits. \\
\hline $1835 \ldots \ldots$ & 2 & $\$ 313,902$ & $\$ 243,223$ & $\$ 278,739$ & $\$ 178,810$ & $\$ 123,695$ \\
\hline $1840 .$. & 9 & $5,930,258$ & 756,964 & $5,423,185$ & $3,724,092$ & 805,244 \\
\hline $1845 .$. & 15 & $2,286,902$ & 78,697 & $2,713,640$ & $1,183,256$ & 41,145 \\
\hline $1856 .$. & 36 & 337,675 & 759,474 & $3,840,946$ & $3,420,985$ & $1,267,234$ \\
\hline 1861. & 94 & 546,876 & 302,905 & $6,750,743$ & $11,010,837$ & 807,763 \\
\hline $1867 \ldots . . .$. & 6 & .............. & .............. & 515,000 & ................ & ................. \\
\hline $1872 \ldots \ldots$ & 23 & ............ & ............. & $3,455,000$ & .............. & ................ \\
\hline $1875 \ldots \ldots$. & 9 & $6,989,536$ & ........... & $1,925,000$ & ............... & $9,602,165$ \\
\hline $1887 \ldots \ldots$ & 48 & $5,698,571$ & ............ & $1,655,500$ & $\ldots \ldots$ & $5,178,069$ \\
\hline $1892 \ldots \ldots \ldots$ & 78 & $22,963,975$ & ........... & $6,565,500$ & .............. & $21,155,695$ \\
\hline $1897 \ldots . . .$. & 104 & $22,065,285$ & ............ & $7,265,600$ & ............. & $20,638,396$ \\
\hline
\end{tabular}

National Banks.

Figures are in thousands of dollars.

\begin{tabular}{|c|c|c|c|c|c|c|c|c|c|}
\hline YEARS. & $\mid \begin{array}{ll}0 & 0 \\
0 & 0 \\
0 & 0 \\
\vdots & 0\end{array}$ & $\begin{array}{l}\text { Loans and } \\
\text { discounts. }\end{array}$ & $\begin{array}{c}U . S . \\
\text { bonds. }\end{array}$ & $\begin{array}{c}\text { Cash and } \\
\text { cash items. }\end{array}$ & Capital. & Surplus. & $\begin{array}{c}\text { Undi. } \\
\text { vided } \\
\text { profits. }\end{array}$ & $\begin{array}{c}\text { Out. } \\
\text { standing } \\
\text { circula- } \\
\text { tion. }\end{array}$ & $\begin{array}{c}\text { Indi. } \\
\text { vidual } \\
\text { deposits. }\end{array}$ \\
\hline $1863 \ldots$ & 3 & $\$ 186$ & $\$ 169$ & $\$ 161$ & $\$ 275$ & ...... & $\$ 5$ & ...... & $\$ 313$ \\
\hline $1868 \ldots$ & 83 & 23,313 & 12,961 & 10,683 & 12,070 & $\$ 2,804$ & 1,071 & $\$ 9,597$ & 22,884 \\
\hline $1873 \ldots$ & 134 & 44,768 & 18,427 & 11,412 & 20,267 & 5,507 & 1,886 & 15,262 & 32,564 \\
\hline $1878 \ldots$ & 139 & 34,808 & 13,515 & 12,484 & 15,730 & 5,870 & 1,438 & 8,063 & 31,545 \\
\hline $1883 \ldots$ & 162 & 75,257 & 13,109 & 23,498 & 23,004 & 6,604 & 2,986 & 8,592 & 67,821 \\
\hline $1838 \ldots$ & 182 & 104,530 & 9,124 & 34,338 & 30,074 & 9,937 & 3,977 & 4,730 & 90,170 \\
\hline $1893 \ldots$ & 212 & 116,522 & 8,552 & 45,087 & 38,195 & 17,926 & 5,444 & 5,844 & 104,833 \\
\hline $1898 .$. & 218 & 156,709 & 12,029 & 46,069 & 36,946 & 16,004 & 5,097 & 6,782 & 140,942 \\
\hline
\end{tabular}




\section{MICHIGAN.}

On January 14, 1805, Congress set off Michigan as a separate Territory, and President Jefferson appointed Wm. Hull, Governor. Early in 1806 Russel Sturges and other Boston capitalists made arrangements to organize a bank at Detroit with a capital of $\$ 400,000$, ostensibly to engage in the fur trade. The petition to the Governor and Territorial judges was made early in the spring. Without waiting for action upon the petition they appointed a Cashier and built a banking house. Judge Woodward, one of the judges, appears to have been friendly to the bank, and when a charter was granted in September, 1806, he was elected President and the bank commenced business and issued bills. Almost all of the stock was subseribed in Boston. Governor Hull subscribed to ten shares for the Territory. The bills were signed in large quantities and sent East for circulation. The first lot of capitalists soon sold out to a Mr. Dexter, of Boston, who came on and with a new President prepared another batch of bills, which were also sent East. It is estimated that bills were issued in this way amounting in all to $\$ 1,500$,000. The Territorial charter was to continue one hundred and one years. In 1807 the Congress of the United States disapproved the charter, and after some difficulty between Judge Woodward and the other judges, an act was passed by the Territorial authorities making it criminal to carry on unauthorized banking within the Territory, and this put an end to the Bank of Detroit in the following year.

The Bank of Michigan was chartered in 1817, as it was thought a bank was needed. It was established at Detroit, upon a capital of $\$ 10,000$, which was increased in 1824 to $\$ 60,000$. Its charter originally extended to 1831, but it was then renewed for twenty-five years more. It did a prosperous business until the financial pressure of 1837-38, when it incurred large losses. At this time it was subjected to an examination by a committee of the Legislature who, having no experience in banking matters, refused to regard its bills discounted as reliable assets, and reported that it did not have funds on hand to meet its liabilities. It was placed in the hands of trustees for liquidation in 1842.

Six other banks were chartered by the Territorial Council, and the Michigan Insurance Company, which did business as a bank until 1869, when it sold out to or became merged in the First National Bank, of Detroit.

Michigan was admitted as a State from November, 1835, the date of the adoption of the State constitution, and nine new bank charters were immediately granted. The aggregate eapital of all the banks in the State after these accessions was $\$ 7,000,000$, although but a small proportion was actually paid in.

The Michigan State Bank was incorporated March 26, 1835, apparently by the Territorial Council, in anticipation of the admission of 
Michigan as a State, which was then under discussion. This bank went into operation with an ostensible capital of $\$ 200,000$, only part of which was actually paid in. It was expected to take control of the banking business in the State.

On March 21, 1837, the Legislature authorized the Governor to negotiate a loan on behalf of the State, in order to make internal improvements, railroads, canals, etc., believed to be of advantage to the development of its resources, to the amount of $\$ 5,000,000$, for which bonds bearing interest at $5 \frac{1}{2}$ per cent. payable after twenty-five years, were to be issued. The bonds were to be payable in the United States, but subsequently the interest was authorized to be increased to six per cent., and the bonds were made payable in Europe in pounds sterling and guilders.

The Cashier of the Michigan State Bank was made fiscal agent of the State, with no great discretionary powers, merely keeping the funds of the State in his bank. At this time the banks dealt largely in New York exchange, which was in much demand. They purchased it at six per cent. premium and sold it at ten per cent. and upwards. The bills of Eastern banks had a fictitious reputation and, without much inquiry into the character of the banks issuing them, were considered better than the bills of the home banks. Michigan money was at different rates-Detroit city banks were at par, country banks generally at a considerable discount. The State bonds, if the negotiations had been properly managed, might, perhaps, have been sold to advantage in Europe.

Governor Mason and the State fiscal agent appear to have been innocent of financial knowledge, and after one attempt had been made in vain to sell a portion of the bonds the Governor accepted the services of the Morris Canal and Banking Company, of New Jersey, to aid in negotiating the loan, and made a contract with them. Under this the company was to remit a portion of the proceeds of the bonds in eash, but when the company asked for signification of the terms he yielded step by step, until it was finally agreed that the payments should be made in ninety-day acceptances of the Morris Canal and Banking Company. The whole amount of bonds, $\$ 5,200,000$, were turned over to the company upon their corporate obligation for one-fourth the amount, and the guarantee of the United States Bank of Pennsylvania for the other three-fourths. The principal manager of the Morris Canal and Banking Company was a relative of Biddle, the President of the Bank of the United States. The Morris Canal Company defaulted in 1840. still owing the State a large amount, and the Bank of the United States was in difficulties and did not make full payments. This disappointment compelled the State to issue Treasury scrip which circulated at a discount. Although but little had been received on the bonds the State adhered to her engagements in regard to their payment. Some that had not been sold, but hypothecated for loans by the banks which were 
endeavoring to negotiate them, were recovered by the State upon the payment of the loans.

These transactions extended through the period from 1837 to 1841, one of great financial pressure throughout the United States.

In the meantime, in 1836, the Legislature had taken measures to compel all the banks chartered up to that time, as well as all those that should thereafter receive charters, to provide a safety fund for the payment of the debts of any of their number which should fail. This was a copy of the New York safety-fund system adopted in 1829, and like that required the banks to contribute to the fund annually one-half of one per cent. of their capital until they had contributed three per cent. of such capital. There was a motive for forming new banks consisting in the hope that they might obtain the deposit of Government money, or of some of the surplus revenue received by the State from the United States Treasury. There does not seem to have been any provision for enforcing the payments to the safety fund, as some of the chartered banks complied with the law and some did not. The fund, however, gave the bills of the chartered banks some reputation of superiority over the bills of the banks under the free banking system authorized in 1837. The latter banks were commonly known as wildcats, probably from their being very often located in the wildest sections of the State, but they were very often as reliable as any of the specially chartered institutions.

\section{Provisions of the Free Banking Law.}

The free banks were organized under a general banking law passed March 15, 1837. Under it any persons could associate to form a bank. They were to elect nine directors, residents of the State, and the majority of them residents of the county where the bank was located. One-third of the stock was to be held in the county. The most remarkable and important feature of the act was the one requiring the stockholders to place securities in the hands of the Auditor-General of the State for the full payment in case of default of all the debts of the bank, including its circulating notes. In thus requiring security for the redemption of circulation, this banking law of Michigan is similar in principle to the celebrated free banking law of the State of New York, and what is more surprising was passed about one year before the New York free banking law, which was not passed by the Legislature of that State until April, 1838. It thus seems that the legislators of Michigan deserve the credit of having first put into practice the theory which afterwards became the corner stone of the free banking systems of many of the States, and at length of the general Government, viz., the security of circulation by the deposit of collaterals with the central authority to be used in the redemption of circulation when the bank failed to do so.

While theoretically the legislators of Michigan were thus in advance 
of the age in their ideas of banking, it cannot be said that they showed equal wisdom in carrying the principle into execution. The securities required to be deposited were either the personal bonds of the stockholders, or bonds and mortgages executed by them upon real estate in the State, of equal value, exclusive of buildings. The value of the real estate was to be estimated by the Treasurer, judge, sheriff and clerk of the county. After the President and directors were elected. and other preliminaries arranged, the stockholders and their officers filed a certificate with the Secretary of State, which gave notice of the existence of the bank, its location, etc. A certain proportion of capital - thirty per cent. - was required to be paid in, in specie. Bank Commissioners were to examine each bank as often as once in three months. No bills could be issued until the Bank Commissioners had seen the specie and had countersigned each note.

\section{IMPERFECT Administration OF the LAw.}

These precautions seem to have been rigid enough, if it had been possible to carry them out. There were, however, no severe penalties. imposed by the law and what there were do not appear to have been en-. forced, and all the provisions were either evaded or neglected to the great damage of the public and the regulation of the system.

Forty banks were fully organized within a year from the passage of the law and others were under way, and this notwithstanding the fact, or perhaps on account of it, that an opinion was held by many sound lawyers that the law was unconstitutional, because the constitution prohibited any corporations not authorized by a vote of two-thirds of the. Legislature.

The county clerks and other county officers whose province it was to pass upon the value of lands, and the solvency of freeholders, had as liberal ideas on those points as could be desired. While in some of the older towns these institutions were carried on as prudently and honestly as any others, the general tendency of most of the smaller and some of the larger banks was towards reckless discounting and wild speculation. Competent officers and Cashiers were rare. Men assumed to be bankers who had no business knowledge and who could hardly cast accounts, and many went into the business as an easy way of swindling.

The examinations of the Bank Commissioners were of course the only difficulty that those who started banks for swindling purposes had to encounter. They had to see that the specie required by law was in. the bank before they would permit it to commence or continue business. All sorts of tricks and combinations were resorted to to deceive them. The specie found by them in one bank was sent by hurried journey ahead of them to be counted at the next.

In their reports the commissioners frequently speak of the devices to deceive and the means taken to defeat such efforts. They say, "gold 
and silver flew about the country with the celerity of magic; its sound was heard in the depths of the forest, yet like the wind, one knew not whence it came or whither it was going." Base metals were packed in coin bags and covered over with thin spreadings of coin. The commissioners soon became familiar with these schemes, and even with the appearance of the specie itself, which was shown to them so repeatedly, and exposed the schemers by returning within a day or two, unexpectedly to the banks previously examined.

Specie certificates were also often used instead of specie. These were borrowed by those who wished to start banks, for a consideration, and when the ordeal of examination by the commissioners had been safely passed, were promptly returned. There were banks and individuals in Detroit who made a business of loaning certificates and starting banks.

\section{How Banks Were Put in Operation.}

The bank starter, provided with a specie certificate and engraved bills, would proceed to a distant and often inaccessible county and there select such prominent citizens as suited his purpose, who, ignorant of banking, be would beguile by fascinating representations of the profits to accrue to themselves and the community at large. They were to become stockholders and furnish the necessary personal bonds or mortgages upon their lands, which with the accommodating assistance of the county officers were perfected and sent with the necessary certificate to the Auditor of State. The bank starter was sometimes, though not always, elected President-the Cashier was chosen in the neighborhood. The specie certificate was made ready, awaiting the approach of the examiners. When they came and set the seal of their approval on the bank the bills were immediately signed and prepared for circulation. As very often there was small need of the money in the vicinity of the bank, owing to the lack of inhabitants, the bills and the specie circular went with the bank starter, who returned with them to his native place. Ostensibly he was to put the bills in circulation by exchanging them for bills of other banks, but as often as not he neglected to render any account. If the bank examiners discovered the fraud in time the incipient institution was suppressed. Sometimes the bills were put in circulation in advance of the examiners' approach, and they could in such case only prevent further mischief by closing the bank. Perjury and direct robbery of associates seem to have been frequent in the history of these associations, and no legal penalties appear to have been inflicted.

The stockholders and directors in many cases appear to have been innocent victims of the designing speculator who directed their attention to free banking as a lucrative in vestment. Where loans were made it appears to have been mostly to stockholders, whose only security, their land, was already mortgaged to start the bank. Many of the notes 
did not circulate at all, being refused at any rate of discount. Brokers and merchants were constantly seoking the banks to obtain redemption of the notes-sometimes in vain. If found, the best that could bedone was to obtain bills of other bank $s$ in exchange-some of which might pass at better rates of discount. The price of property went up. Some of the banks started did a legitimate business and redeemed all their obligations, but they were not numerous. Some of those who had innocently become officers and directors of fraudulent concerns, as soon as they discovered the character of those who were seeking to use them, denounced their associates and withdrew from the fraud. The total population of the State was only about 109,000, and the circulation of the chartered and free banks together amounted to enough if it had been equally distributed to give each head of a family $\$ 125$.

At the beginning of 1839 the Bank Commissioners estimated that there were a million dollars of bills of insolvent banks in the hands of individuals and unavailable.

\section{Disasters Due to Imperfect Enforcement of the Law.}

The financial distress of the period soon swept most of the banks of Michigan out of existence, and by the end of 1839 forty-two were in the hands of Receivers, and only two chartered banks and four free banks were still open for business. A very large share of the currency was an absolute loss to the holders. This wholesale disaster does not appear to have been altogether the fault of the principles upon which the free banking law was founded, or the manner in which it was drawn. The difficulty was that if the requirements of the law had been rigidly complied with, if real estate securities and personal bonds had been scrupulously valued and the specie honestly paid in, there would have been no banks, because the securities and specie could not have been obtained, as they were not, at that early day, in the State. In order to have banks the law was laxly executed and men deceived themselves by visionary ideas as to the value of real estate, and by evasions as to specie. The law could not be executed or enforced under the existing conditions, and the result was disaster to the innocent bill holders. The error was in the minds of the legislators, who did not see how utterly impossible it was to have banks without banking capital.

\section{Free Banking Act Declared Unconstitutional.}

In 1844 the question of constitutionality of the free banking law came into court, based upon attempts made to collect the mortgages and bonds given as securities. This had always been a matter of doubt among sound lawyers. The court held that the law was unconstitutional and therefore "void from its inception. The banks were consequently illegal institutions; the securities given for the payment of their debts were void; the obligations they had taken for individuals were nullities. Even the Receiverships which had been created for winding 
up their concerns were of no legal importance further; for the banks, having never had existence, could have no creditors to account to, and such Receivers as were in possession of assets they could make available, pocketed them."

Everything was thus put back as it was before, and except for the worthless bills in the hands of the people, a very few prosperous Receivers, and the discredited securities in the hands of the State Auditor, there was nothing to show that the free banks of $1837 \mathrm{had}$ ever existed.

In 1839 the Legislature, tempted by the great success of the State Bank of Indiana and the recommendation of the Governor, chartered a State Bank of Michigan with a capital of $\$ 2,000,000$, but as the capital could not be procured the bank never commenced business. Only two more banks were chartered by the State after the collapse of the free banking system, and banking business was carried on principally by brokers and private bankers, and an act regulating their business was passed in 1859 and amended in $\mathbf{1 8 7 5}$. It provides that the firm must keep on file with the county clerk a certificate setting forth the names and residences of the firm and the conditions of the partnership, whether limited or not. This certificate is open to public inspection and there are penalties for not filing it, or not making a new certificate if any change is made in the firm. They are also forbidden to use the word bank, exchange office or banking office, except in connection with the individual or firm name, or in any way give the impression that they are an organized bank. In 1850 the constitution of the State was amended so as to forbid the granting of charters except to municipalities; it fixed a personal liability to amount of their shares upon officers and stockholders of banks issuing circulating notes, and provided that no general banking law could be valid unless ratified by the people at the polls.

\section{Present Condition of Banking.}

In 1857 , a general banking law was adopted by the Legislature and ratified by the people in November, 1858. It was similar in its details to the free banking laws of New York, Ohio, Indiana, Illinois, ete. A number of banks organized under this law by 1863, some of which closed and some became National banks.

The State banks in Michigan under the supervision of the Banking Department at the close of 1898 numbered 183, and there were also three trust companies reporting. At this time the excess of the State banks over those operating under Federal charters was about 100. From 1889 to the close of 1898 deposits in the State banks increased nearly $\$ 58$,000,000 . Greater latitude is allowed the State banks than is permitted to the National institutions, and the minimum capital is also smaller. State commercial banks may loan fifty per cent. of their capital upon mortgage security, and twenty per cent. to one person or firm. The 
State law also grants the privilege of doing the dual business of commercial and Savings banks upon one capital, and most banks that wish to do a Savings business take advantage of this provision instead of operating as Savings banks exclusively. Investments of these institutions are under careful legal restrictions, and loans on real estate may not exceed fifty per cent. of the valuation of the property.

A clearer idea of the growth of State banks in Michigan may be gained from the following table:

$\begin{array}{cccc} & 1889 . & 1898 . & 1898 . \\ \text { Ninety banks } & 159 \text { banks and } & 182 \text { banks and } \\ \text { REGOURCES. } & \text { and two } & \text { three } & \text { three } \\ & \text { trust companies. } & \text { trust companies. } & \text { trust companies. }\end{array}$

\begin{tabular}{|c|c|c|c|}
\hline Loans and discounts.............. & $\$ 22,624,667$ & $\$ 32,402,874$ & $\$ 41,384,075$ \\
\hline Stocks, bonds and mortgages.... & $15,645,031$ & $24,804,367$ & $37,453,689$ \\
\hline overdrafts.............................. & 165,315 & 206,537 & 298,762 \\
\hline \multirow{2}{*}{ 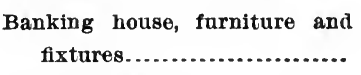 } & & • & \\
\hline & 523,466 & $1,517,146$ & $1,906,096$ \\
\hline 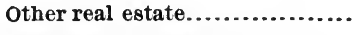 & 253,782 & 647,824 & $2,054,891$ \\
\hline Expenses and taxes paid.......... & 276,624 & 395,207 & (.............. \\
\hline 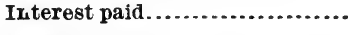 & 210,872 & 352,701 & (n............ \\
\hline Premiums paid..................... & $\ldots \ldots \ldots \ldots$ & ............. & 47,333 \\
\hline \multicolumn{4}{|l|}{ Due from other banks and } \\
\hline 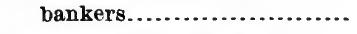 & 298,942 & 450,100 & 893,192 \\
\hline Exchanges for clearing-house.... & 200,024 & 246,416 & 418,372 \\
\hline Checks and cash items........ & 150,252 & 302,096 & 341,835 \\
\hline Nickels and cents.............. & 11,720 & 24,102 & 24,283 \\
\hline Gold coin..................... & 396,827 & $1,698,747$ & $2,448,122$ \\
\hline Silver coin ..................... & 171,666 & 259,119 & 387,684 \\
\hline U. S. and National bank notes.... & $1,242,843$ & $2,312,851$ & $2,754,711$ \\
\hline 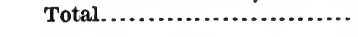 & $\$ 47,354,277$ & $\$ 73,156,116$ & $\$ 106,069,058$ \\
\hline \multicolumn{4}{|l|}{ LIABILITIES. } \\
\hline Capital stock paid in.... & $\$ 7,254,559$ & $\$ 12,311,041$ & $\$ 12,003,600$ \\
\hline Surplus fund................ & $1.132,329$ & $2,443,906$ & $2,981,382$ \\
\hline Gross undivided earnings....... & $1,679,925$ & $2,639,574$ & *1,958,531 \\
\hline Dividends unpaid................. & 2,571 & 18,081 & 8,204 \\
\hline Individual deposits................ & $7,879,586$ & $14,529,942$ & $20,599,904$ \\
\hline Certificates of deposit............. & $4,452,081$ & $6,686,895$ & $9,782,646$ \\
\hline 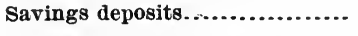 & $23,669,030$ & $32,216,067$ & $54,105,981$ \\
\hline Certified checks.................... & 29,987 & 42,076 & 111,903 \\
\hline Cashier's checks outstanding.... & 21,097 & 29,031 & 19,723 \\
\hline Due to banks and bankers........ & 809,678 & $1,437,360$ & $4,420,425$ \\
\hline Notes and bills rediscounted..... & 386,429 & 654,100 & 51,754 \\
\hline Bills payable...................... & 37,000 & 148,037 & 25,000 \\
\hline Total........................... & & $, 156,116$ & 9,058 \\
\hline
\end{tabular}

* Undivided earnings, less current expenses, interest and taxes paid. 
State Banks.

\begin{tabular}{|c|c|c|c|c|c|c|}
\hline YEARS. & $\begin{array}{l}\text { No. of } \\
\text { banks. }\end{array}$ & $\begin{array}{l}\text { Joans and } \\
\text { discounts. }\end{array}$ & Specie. & $\begin{array}{l}\text { Capital } \\
\text { stock. }\end{array}$ & Circulation. & Deposits. \\
\hline $1835 \ldots \ldots$. & 8 & $\$ 1,336,225$ & - $\$ 112,419$ & $\$ 658,980$ & $\$ 636,676$ & $\$ 686,450$ \\
\hline $1840 \ldots$ & 10 & $2,152,954$ & 42,784 & $1,229,200$ & 261,296 & 342,760 \\
\hline $1847 \ldots . .$. & 2 & 231,703 & 68,487 & 176,167 & 141,854 & 144,129 \\
\hline $1852 \ldots$ & 5 & $1,273,709$ & 161,483 & 861,228 & 920,951 & 698,470 \\
\hline $1857 \ldots$ & 4 & $1,903,603$ & 92,762 & 841,489 & 670,549 & $1,347,956$ \\
\hline $1862 \ldots$ & 4 & 788,028 & 37,996 & 413,030 & 120,124 & 749,828 \\
\hline $1868 \ldots$ & 1 & .............. & ............... & 100,000 & .............. & ............. \\
\hline $1877 \ldots$ & 30 & $7,208,058$ & $\ldots \ldots$ & $2,396,000$ & ............. & $7,409,673$ \\
\hline $1882 \ldots .$. & 28 & $12,216,916$ & ................ & $2,022,400$ & .............. & $15,342,629$ \\
\hline $1887 \ldots$ & 62 & $24,014,650$ & & $4,566,150$ & ........ & $26,069,050$ \\
\hline $1893 . .$. & 159 & $33,633,573$ & .............. & $12,102,955$ & .............. & $54,737,226$ \\
\hline $1897 \ldots$ & 179 & $37,029,743$ & ................ & $12,096,609$ & ............ & $69,447,804$ \\
\hline
\end{tabular}

National Banks.

Figures are in thousands of dollars.

\begin{tabular}{|c|c|c|c|c|c|c|c|c|c|}
\hline YEARS. & 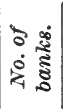 & $\begin{array}{c}\text { Loans } \\
\text { and dis- } \\
\text { counts. }\end{array}$ & $\begin{array}{c}U . S . \\
\text { bonds. }\end{array}$ & $\begin{array}{c}\text { Cash } \\
\text { and cash } \\
\text { items. }\end{array}$ & Capital. & Surplus. & $\begin{array}{c}\text { Undi- } \\
\text { vided } \\
\text { profits. }\end{array}$ & $\begin{array}{c}\text { Out. } \\
\text { standing } \\
\text { circula- } \\
\text { tion. }\end{array}$ & $\begin{array}{c}\text { Indi- } \\
\text { vidual } \\
\text { deposits. }\end{array}$ \\
\hline $1863 .$. & 1 & $\$ 32$ & $\$ 43$ & $\$ 30$ & $\$ 7 \check{5}$ & ...... & $\$ 1$ & ....... & $\$ 52$ \\
\hline $1868 .$. & 42 & 8,221 & 4,979 & 2,425 & 5,210 & $\$ 1,066$ & 424 & $\$ 3,809$ & 7,653 \\
\hline $1873 \ldots$ & 77 & 18,890 & 8,227 & 2,946 & 9,762 & 2,327 & 980 & 6,940 & 11,876 \\
\hline $1878 \ldots$ & 79 & 15,996 & 7,137 & 3,380 & 9,628 & 2,710 & 1,086 & 5,380 & 11,660 \\
\hline $1883 \ldots$ & 88 & 32,978 & 6,287 & 4,808 & 11,665 & $2,15.6$ & 1,678 & 4,973 & 26,804 \\
\hline $1888 \ldots$ & 109 & 42,625 & 3,962 & 5,635 & 14,975 & 2,927 & 1,953 & 2,829 & 33,623 \\
\hline $1893 \ldots$ & 100 & 41,968 & 5,551 & 4,808 & 14,634 & 3,879 & 1,868 & 4,600 & 31,491 \\
\hline $1898 .$. & 82 & 43,368 & 6,152 & 5,007 & 11,895 & 3,247 & 1,275 & 3,897 & 43,090 \\
\hline
\end{tabular}

\section{WISCONSIN.}

Wisconsin was detached from Michigan as a Territory in 1836, the act of Congress taking effect July 4 of that year. The Bank of Wisconsin, at Green Bay, was incorporated by the Legislative Council of Michigan January 23, 1835, and organized November 12, following. In January, 1837, the Secretary of the Treasury said: "The Bank of Wisconsin had not commenced operations in the latter part of November, 1836, although the whole amount of its stock was subscribed in 1835." It did but little business, and was wound up by the AttorneyGeneral in 1839. 
According to a report of a legislative investigating committee, on January 9, 1839, it appears that the paid-in capital of the bank was $\$ 39,125$, the specie held, $\$ 29,242$, and the circulation, $\$ 196,279$. The liabilities exceeded the limit prescribed by the charter (three times the capital paid in, over and above the specie held), the capital was insuffcient, and the panic of 1837 was destructive.

On November 30, 1836, the Miners' Bank, of Dubuque, was chartered, also the Bank of Milwaukee. A history of the former institution will be found in that part of this work relating to the State of Iowa. The Bank of Milwaukee never got into operation at all. On December 2, 1836 , the Bank of Mineral Point was chartered, with a capital of $\$ 200$,000 , the first installment to be paid in specie. No notes were to be issued until $\$ 40,000$ of the capital had been paid in, and denominations were not to be less than $\$$. By act of March 3, 1837, Congress approved the incorporation of these banks, but specified that no circulating notes should be issued until one-half the capital was paid in, that the capital should not be increased to more than $\$ 200,000$ without the consent of Congress, and that the aggregate indebtedness owing by any bank over and above its actual deposits should not exceed twice the paid-up capital.

In November, 1837, a legislative committe reported that the Bank of Mineral Point had failed to comply with the provisions of its charter in effecting an organization, and that only $\$ 2,000$ of the first installment of the capital had been paid in specie, the balance being in notes of the Bank of Detroit and specie certificates of deposit.

In January 1839, another legislative investigation showed that the capital $(\$ 100,000)$ had been paid up, that the circulation was $\$ 53,075$, and deposits $\$ 21,716$. To meet these liabilities the bank had $\$ 36,444$ in specie and $\$ 17,558$ in the notes of New York, Illinois, and Mississippi banks. This committee therefore pronouneed the bank to be in a safe and solvent condition.

In the summer of 1838 a notice appeared in a New York newspaper stating that the notes of the bank would be redeemed at par, and it seems that such of the notes as were payable on demand were in fact redeemed in specie on demand.

In a few months after the above report, the circulation was doubled, and the bank's management fell under suspicion. An examination was made by a legislative committee on September 18, 1840, and many un favorable facts were brought to light, $\$ 20,000$ of worthless assets being reported. But the committee did not find the bank insolvent, and it was permitted to continue business. Another examination was made in March, 1841, the committee this time finding about $\$ 87,000$ of assets not immediately available, and $\$ 17,723$ of no value. During the summer of this year, the bank was enjoined from doing business and Receivers were appointed. A bill to repeal the charter of the bank was approved February 18, 1842. In January, 1847, a legislative committee made a report on the liquidation of the bank, from which it appeared 
that some of the officers had absconded taking with them all the currency and other portable assets. The absconders were captured, but only a small part of the assets was recovered. A compromise was effected by which the Receivers were enabled to reduce the circulation from $\$ 136,000$ to $\$ 43,000$ by receipt of the bank's bills upon debts. They also redeemed $\$ 3,746$ more at fifty cents on the dollar, and $\$ 1,065$ at twenty-five cents, and made a dividend of ten cents on the dollar on $\$ 4,320$. It seems that the stockholders did not lose anything, as they were apparently permitted to withdraw the money paid for their stock before the bank failed.

The same year in which this charter was granted the region between Lake Michigan and the Mississippi began to attract the attention not only of capitalists from the East but of the Old World as well, and during 1835 George Smith, a young Scotchman, of Aberdeen, possessing an inheritance of about three thousand pounds, then considered quite a fortune, visited Northern Illinois and Southern Wisconsin, and was convinced that there was an opportunity to make money in the purchase of lands at small cost; he returned to his native country, got his friends to subscribe stock to the Scottish Illinois Land and Investment Company and coming back to the West made a great financial suceess of his investment company.

In the meantime the great financial disaster of 1837 swept over the country, and started westward a tide of immigration from the Eastern States, so that the population of what is now Wisconsin increased in four years, 1836 to 1840 , some 150 per cent. Young Smith soon saw that money was to be made in other things beside lands, and especially that there was need of some circulating medium-currency to transact the business of this rapidly growing country; but owing to the failure of banks in their Eastern homes, the settlers of the new Territory were opposed to chartering banks, and so fixed was this opposition that the Territorial constitution passed what was called " an act to restrain unauthorized banking, and for other purposes."

\section{History of George SMith's Bank.}

So great was this prejudice that notwithstanding the prohibition by the constitutional law, the Legislature in granting charters invariably put in every bill the clause "providing that nothing in this bill shall be construed as authorizing the business of banking." Even the charter of Plymouth Congregational Church, in Milwaukee, contained this clause.

But George Smith was not to be thwarted in his purpose by any such inhibition; he prevailed upon the Territorial Legislature to charter the Wisconsin Marine and Fire Insurance Company, by local Act 36, Session of 1838-39, to " be of twenty-nine years' duration, or till the first Monday in January, 1868," authorizing it to " insure for all kinds of insurance-fire, life, and other; to receive deposits and loan money at legal 
rates of interest, and to carry on any business usually performed by insurance companies; but nothing contained in this section shall give the company banking privileges." Another section provided that no part of the funds or capital was to be used in traffic of any kind whatever. It authorized the issue of not to exceed 20,000 shares of $\$ 25$ each. The commissioners named to have charge of subscription for stock were Allen W. Hatch, Maurice Pixley, Hans Crocker, Samuel Brown, Chauncey $\mathrm{H}$. Peak and William Brown.

Among the provisions of the charter were the following: The directors to choose a President who, after being sworn by one of the directors, is to swear the others, and the Secretary to give bonds for faithful discharge of his duty; the office to be kept in Milwaukee. Insurance policies to be obligatory on the corporation where signed by the President and Secretary, even if without a corporate seal. All moneys received on deposit, if in bills, notes, or other evidences of debt, issued by any bank, banker, or other corporation, and loaned by the company hereby chartered, shall be endorsed by the President of said company with the corporate name thereof, and shall be redeemed at their usual place of business in gold or silver on demand, if such bank, banker or corporation fail.

With this charter, Mr. Smith wanted a good secretary, and wrote to a young man in Scotland, Alexander Mitchell, whose family he knew, and the brother Scotchman landed in Milwaukee in May, 1839, during which month the company commenced business, with George Smith, President, and Alexander Mitchell, Secretary. Though an insurance company, prohibited from doing a banking business, it did very little insurance, but proceeded to issue certificates of deposit in denominations from one dollar upward, in the similitude of bank bills, in the following form:

$\$ 10$

Capital $\$ 500,000$.

No.
Incorporated 1839. 36,420 .

WISCONSIN MARINE AND FIRE INSURANCE CO.

This is to certify that I. E. BAtes has deposited with this institution TEN DOLLARS, which will be paid on demand to the bearer.

[Man standing with scythe.]
Milwaukee, June 3, 1850.

Alex. Mitchell, Sec'y. Geo. Smith, Prest.

As the whole Northwest had been swept clear of currency by the financial hurricane of 1837, these certificates of deposit had their mission to perform, and the so-called "George Smith's money" passed current all over the Northwest, from Detroit to St. Louis, and even as far 
as Cleveland and Cincinnati, circulating freely on the credit and faith the people had in the integrity of Smith and Mitchell.

In 1843 these circulating certificates had reached $\$ 100,000$; in 1845 it was $\$ 250,000$; in $1847, \$ 300,000$; in $1848, \$ 600,000$, and in 1849 had reached the round sum of $\$ 1,000,000$, although soon thereafter it had fallen off inore than one half that sum. The largest circulation was in 1851 (the year before the general banking law of the State was enacted); its aggregate then was $\$ 1,470,235$.

To all intents and purposes it was wildeat currency, yet it did the State good service, and every dollar of it was promptly redeemed on presentation except some $\$ 32,000$, which was probably lost by fire, flood, etc., and was never presented.

The insurance company had to encounter adverse legislation, organized runs by bankers and brokers of other States with bitter hostility, yet always met its obligations, when George Smith and Alexander Mitchell were not known as now, nor their integrity had been tested; for the two young men might have packed their carpet-bags and left for their homes in Aberdeen, so far as the security was concerned.

As an incident, the Territorial Legislature repealed the insurance company's charter, but this had no effect on the company's businesslegitimate banking in all ways except circulation-Mr. Mitchell maintaining that the charter could not be repealed, and continued as before in the banking business. During its early life the company had several severe runs, the most noted being that of Thanksgiving Day in 1849. On that day Mr. Smith, in observance of the anniversary, closed his bank doors in Chicago, when word went through the country that "George Smith's bank had closed." Brokers hurried their notes to Milwaukee for redemption in coin, and got it without the company's getting outside help, other than that of business, and certificate depositors turning their money into the bank without asking.

After some fourteen years of a prosperous and eventful career of this pioneer bank, the old Wisconsin Marine and Fire Insurance Company, with Mr. Mitchell sole owner, organized, among the first, under the general banking law of Wisconsin in 1853. Of these two trustworthy Scotsmen, George Smith made his home at the Reform Club in London for many years, dying there October 7, 1899, in his ninety-second year. He was never married, was leading a quiet life, and though possessed of a fortune of perhaps more than $\$ 50,000,000$, his appearance was more like that of a hale Scottish farmer than a veteran financier.

Alexander Mitchell, more intimately known in Wisconsin, returning from his Florida home, died in New York, April 17, 1887, aged seventy. In passing from this consecutive history of Wisconsin's famous bank, the name of its faithful Cashier, David Ferguson, should not be forgotten. He retired some years ago, and still resides in Milwaukee, an honored octogenarian. 


\section{Pioneer Private Bankers of the State.}

The history of banking in Territorial Wisconsin would be incomplete without mention of the private bankers doing business in their respective localities prior to Statehood in 1848, and before the enactment of the general banking law in 1852. These include the Bank of Mineral Point, established in 1836 (failed in 1841); the Bank of Fox River Hydraulic Company, established at Depere in 1838; Washburn \& Woodman, at Mineral Point, 1846-55, with C. C. Washburn (afterwards Wisconsin's Governor), President and Cyrus Woodman, Cashier or Secretary; J. Hodges' Bank, of Platteville, 1846; E. D. Richardson, banker, Geneva, 1848; Samuel Marshall, 1847, joined with Charles F. Ilsley, 1849, as Marshall \& Ilsley, now an incorporated bank; Mason C. Darling and Keyes A. Darling, of Fond du Lac, 1849, changed to

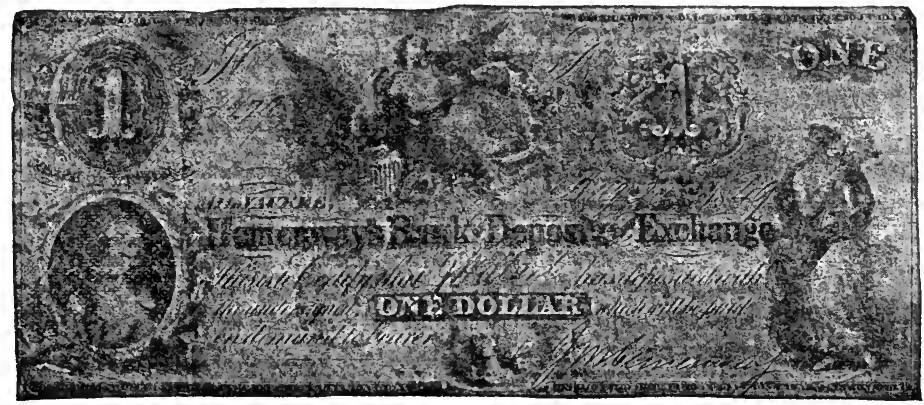

A Specimen of Deposit Currency.

Darling, Wright \& Co., in 1851. J. M. Hemenway's Bank of Deposit and Exchange, Milwaukee, 1849, which issued certificates of deposit for circulation (a specimen of which is given above); Rock River Bank, Beloit; James Kneelan' and D. P. Hull, Milwaukee; Kellogg's Bank, of Oshkosh; Levi Blossom, of Milwaukee; Ullman \& Bell, of Racine, and T. C. Shove, of Manitowoc.

In 1852 the general banking law took effect, having received a majority of the votes of the electors as provided by the constitution.

Article XI of the State constitution of 1849 provided that " the Legislature shall not have power to create, authorize or incorporate, by any general or special law, any bank or banking law or privilege, or any institution or corporation having any banking power or privilege whatever except as herein provided."

This exception was that the question of "bank," or "no bank" might be submitted to a vote of the electors at any general election, and if a majority of such votes were for banks, then the Legislature shall have power to grant bank charters, or to pass a general banking law with such restrictions and under such regulations as they may 
deem expedient and proper for the security of the bill holders; and, provided, that no such grant or law shall have any force or effect until the same shall have been submitted to a vote of the electors of the State at some general election, and approved by a majority of the votes cast on the subject at such election.

Thus guarded against legislative enactments by the constitution, it requires for any change, that first, the Legislature may pass a bill for submission to the popular vote, and such vote must, by a majority, ratify the act before it can become a law. This feature of Wisconsin's banking law is still maintained, and in recent years a general law passed by the Legislature was defeated by the popular vote.

\section{Circulating Notes from Georgia.}

Since banking in Wisconsin comprises the circulation of bank notes designed expressly for use in the State, a sketch of the Bank of Atlanta, Georgia, properly comes within the State's history, the notes of the Bank of Atlanta, being intended to take the place of the Marine and Fire Insurance Company's issues- "George Smith's money."

Georgia granted this charter January 27,1852 , with an authorized capital of $\$ 300,000$, comprised of 3,000 shares, $\$ 100$ each, of which George Smith owned 2,991 in his own name, and the remaining nine were owned by Patrick Strachan, W. D. Scott, George Menzie and Alexander Mitchell. Soon distrust of its methods became general, and a resolution of the Legislature of Georgia requested the Solicitor-General to inquire into its manner of business; but that officer found no violation of charter.

While at this time all other Georgia bank notes were quoted in New York city at five per cent. discount, Mr. Smith arranged to have his Atlanta notes redeemed there at only $1 \frac{1}{2}$ per cent. discount. This made them generally current in Wisconsin and Illinois; but warfare commenced against the Bank of Atlanta and several runs were ineffectually made. While the bank never failed to redeem its paper on demand, the owner became tired of the annoyance and wound up its affairs in 1855 , the banks of Wiseonsin by this time furnishing its required currency. Banking on assets without security, the Atlanta notes circulated throughout northern Illinois and Wisconsin for three years without loss to the holders.

\section{The General Banking Law.}

Chapter 479 of the General Laws of Wisconsin, 1852, provided for a Comptroller, first to be appointed by the Governor, then to be elected for a term of two years. Banks could organize with a capital of $\$ 25,000$ and not to exceed $\$ 500,000$, and do a general banking business, and issue notes to be secured by a deposit with the State Treasurer of United States or State bonds, or Wisconsin railroad bonds at their value, not exceeding par, such value based on the New York market quota- 
tions. Individual bonds were required to cover any depreciation of value in the State bond securities, and the Bank Comptroller was authorized to call for additional public bonds at any time he deemed the security insufficient. Annual reports were to be made; securities could be withdrawn by depositing an equal amount in specie, or of the circulating notes, and upon returning ninety per cent. of its circulation, or specie being deposited instead, it could close business. Interest on loans was limited to ten per cent. Stockholders were individually liable to the amount of their shares for all the indebtedness of the bank. These provisions, with others, of 'minor importance, embraced in the act of 1852 , were submitted to the electors and approved at the general election in November of that year.

Chapter sixty-nine of the General Laws of 1853 , prohibited the issuance or passing of any bills, notes or certificates of deposit not authorized by the express law of some State (designed to cut out the Wisconsin Marine and Insurance paper), the United States or Canada, and redeemable in current gold or silver coin at the place of issuance, and no one to pay sums in bills of less denomination than five dollars, in bills issued outside of the State. Chapter thirty-four of the laws of the following year (1854) repealed the five dollar limit as previously enacted.

Chapter Forty-seven, Laws of 1855, gave the Comptroller power to more effectually secure the people from loss on bank circulation; then for two years, while the wildcat banks were organizing, the laws remained unchanged, but in 1858 , Chapter ninety-eight of that year, amended the general law, striking out railroad bonds for security, and required that bondsmen for the stockholders must be citizens of Wisconsin, and that banks could only be located in towns of not less than 200 voters, and must have an office of redemption in such town; the legal rate of interest was fixed at ten per cent., the manifest purpose of Chapter 47 , of 1855 , being to suppress the wildeats.

Chapter 242 of the Laws of 1861 allowed circulation for the par of bonds (admitted as security) which had been above par for the last six months in New York, and on those below par, but ninety per cent. of the average market price for that time was allowed, and the Governor, Secretary of State and Bank Comptroller, after December 1, 1861 (the war then affecting Southern bonds), were given the right to reject any securities, and accept only Wisconsin State bonds-limited to $\$ 100$,000 by the constitution - and United States bonds-the banks outside of Madison and Milwaukee to appoint redeeming agents, etc., etc. These amendments were submitted to the electors in November, 1861, and then approved. Chapter 203, Laws of 1862, reduced the legal rate of interest to seven per cent., except where contracted it might be at a rate not exceeding ten per cent.

Chapter 102, Laws of 1866 , provided for taxing bank shares, in conformity with the National bank system. In 1868 the office of Bank 
Comptroller was abolished and the duties devolved upon the State Treasurer. Chapter 331, Laws of 1876, provided for the organization of Savings banks, and Savings societies.

In 1885 the law provided that no person should use the name of "bank" or "banking house" without giving the name or names of persons engaged in such business.

\section{Provision for State Examination.}

Without reference to the vote of the electors, the Legislature (by Chapter 291, Laws of 1895), provided for a Bank Examiner to be appointed by the State Treasurer, with the Governor's approval, to hold the office five years; one who shall examine all State, private and Savings banks, including every banking, Savings or trust institution in the State receiving money on deposit. Three reports are to be made to the examiner when called for each year. The only power given this officer is that of imposing a penalty of $\$ 100$ a day for not reporting, but without authority to control the bank's affairs, or do anything more than to publish a poor statement and thus warn the public.

The cost of the examination of banks, with access to books and papers, ranges from $\$ 15$ to $\$ 50$, according to the capital and surplus of the institution. While this act gives an officer authority to learn a bank's condition, it confers on him no practical or effectual means of remedying any wrong, as the examiner can neither close nor take possession of an insolvent bank.

At this period Wisconsin's general banking law, framed as it was. originally for the security of the bill holders--and nothing else, had, with the exception of the numerous acts of the Legislature, hereinbefore enumerated (none of which afforded much improvement for the security of stockholders or depositors) called for a new general law more in keeping with the advanced conditions of all business, and through the efforts of the State Bankers' Association was secured the passage of Chapter 303, Laws of 1897 , for submission to the electors, the provisions of which conformed in many respects to the National Banking. Law; and though more liberal in allowing loans to a limited amount upon real estate, was better guarded against the improper use of bank. funds by officers, directors and employees of the institution-requiring a vote of the directors, to appear of record, approving of any loans to such persons; but, the electors, not comprehending the safeguards to both stockolders and depositors, with some bankers who disliked the restrictions, defeated the law by a vote of 86,872 for and 92,607 against. the revised banking law, leaving it still "for the security of the bill holders," though the bills have long since been taxed out of existence.

Following legislation thus for sixty years, it will be seen that, notwithstanding the many acts passed affecting the banking business, such as could be, without submission to the electors, the general banking law in itself, for the organization and conduct of banks, has. 
not been materially changed, though days of grace and laws in relation to commercial paper have been bettered, and "wildeatting" suppressed.

\section{Wildeat Banks Described.}

New York having had its experience with free banking, allowing real estate security as a basis for bank-note circulation, and Michigan its trials with "red dog" bank notes, Wisconsin, after the enactment of its. general banking laws, came to the front.

With many legitimate institutions, both private and organized banks, the field was open to the speculator for organizing under the law banks solely for the purpose of issuing circulating notes, which at the time (as stated in the order of legislative action), required security to be deposited with the State Treasurer in the form of United States bonds, Wisconsin State bonds and of other State bonds which had not defaulted in the payment of interest, the latter class to be taken at the New York market quotations; and as the bonds of the Southern States were always the lowest priced, these were chosen and deposited for the notes to be had.

To become a bank, and a bank President, required but little capital, the method generally being to arrange with some responsible bank or person to advance, say, five per cent. of the capital stock named, who for this, would purchase the bonds as selected by the new banker, and deposit them in the name of the bank, get the notes printed, and the Comptroller to countersign them; this done, the officers would sign "Prest." and "Cashier," and with the full-fledged paper pay for the bonds, the price ranging from eighty to ninety cents of their par. Personal bonds were required to cover any loss on the value of the bonds put up, and where the market fell off the Comptroller would call to have the necessary additional security deposited.

Thus a bank with $\$ 100,000$ capital could be created with not to exceed an outlay of $\$ 5,000$, often less, according to the commission charged for advancing the money for bonds, plate and printing. With Missouri bonds at eighty cents, the investment yielded from fifteen to twenty per cent.

These banks were usually located in inaccessible places, many in the northern wilderness, where white men seldom trod, and only an Indian guide could find. In some instances they were located within an Indian reservation, and had but a shanty for a bank. This condition could not long continue unmolested. The discount on the notes depended upon the "get-at-a-ble" location of the bank. The notes being redeemable in gold, were picked up, assorted, and the co-called "carpet-bagger" sent. out by the brokers to demand the coin, provided he could find the bank. Sometimes, when coming too near, a woodsman on the watch would meet him, and by intimidation or threat the hunter for coin would retrace his steps without venturing to make his demand.

Gradually, as the laws show, the "wildcat" was, both by legislation 
and the rapid settlement of the country, together with the increasing issues of legitimate banks, and their determination, driven from the field.

In August, 1858, the bankers of Chicago refused to receive the issues of twenty-seven Wisconsin banks, many of which had no local habitation, but had simply the name of some winter lumber-camping place high upon the tributaries of the Wisconsin and Chippewa rivers, owned by non-residents and officered by straw men. The business men of Milwaukee returned the compliment by refusing the notes of banks of similar character in Illinois.

\section{Bankers' Meeting to Secure Reform of the Banking Laws.}

In 1858 a committee of bankers, consisting of N. B. Van Slyke, Samuel Marshall and M. S. Scott, appointed at a former meeting to recommend desirable changes in the banking law, recommended that the value of stocks or bonds deposited for circulation must be five per cent. in excess of the market price; that railroad securities could not be taken; that stockholders' bonds should be given by citizens of the State; that bank capital might be reduced to not less than $\$ 25,000$; that banks could relinquish business when eighty per cent. of their circulation was returned, and that three years after notice of this fact had expired all securities except the personal bonds could be withdrawn, all of which amendinents became laws. In 1859 came another grievance, that of getting bank notes, particularly the "wildcat" notes, redeemed.

\section{First General Convention of Bankers.}

What is believed to be the first general convention of bankers met in Milwaukee August 10, 1859, "for the purpose of considering and planning in detail a system and practical method of protecting the credit of the currency of Wisconsin banks;" in other words, to have a Bank of Mutual Redemptions. After considerable discussion and the adoption of several sound resolutions, when it came to the test, and the constitution with by-laws setting forth its principles was presented at a subsequent meeting, the "wildeat" element prevailed and the project failed.

Less than two years after, with the firing of the first gun at Fort Sumter, all Southern securities rapidly declined, and the banks of mere circulation being unable to keep up their margin for security, were finally driven to the wall, and with the Civil War ended the "wildeat" banks of Wisconsin.

The securities depreciating from twenty to forty per cent. were sold to apply towards redeeming the outstanding notes, and the deficiency, so far as possible, collected from the bondsmen for the several banks, many of whom proved by that time irresponsible, with consequent loss to the bill holders. Bank failures elsewhere, as in Wisconsin, created general distrust, and the demoralization of the currency of the West and Northwest was so great throughout the entire region that deposi- 
tors, not daring to hold bills over night, would bring in their currency deposits several times during a day, lest it die on their hands, or at best, find a heavier discount from day to day. It was not so much the lack of ultimate security as a proper provision for immediate redemption which tended to discredit the notes.

Altlough banks received this currency at such rate as they thought safe, and assorted their tills with the closest care, they usually found the next day more or less to throw out as impassable, if not worthless, not only issues of their own State, but from Maine to the Gulf States. Brokers gained by the people's losses. How little do the people of today appreciate the value of a uniformly secured and readily redeemable currency, such as they now have. Then exchange on Eastern money centers ranged from two to five per cent., and what cost $\$ 50$, is now to be had for a single dollar, and a silver dollar at that! It was a common practice with those going East to take two or three kinds of bank notes, such as would go current in the States through which they passed. No good New York or New England bill would be spent west of Ohio. East of there it was equivalent to gold. Gold only would purchase the public lands, and the loss to settlers in their buying homes was sorely felt. Currency would buy bread and butter, but not Government land.

\section{Changes Wrought by the Civil War.}

Money matters had become somewhat settled for two or three years, when the Civil War came, causing enormous Government expenditure, which advanced prices, induced speculation, and affected Wisconsin in common with all other Northern States. Meanwhile banks flourished, and until the passage of the National Bank Act, there was a clear field for banking generally; bankers then soon availed themselves of the advantages of the new system and there was a decline of the State banks.

The National banks were not subject to local taxation, as the shareholders were not then taxed. With seven-thirty United States bonds as a basis for circulating notes, and other currency taxed out of existence, loans commanded ten per cent. interest, with fair rates for exchange and less competition, and banking was profitable. Subsequently, for a time the law taxed deposits, then the shareholders-practically taxation of the bank by the State-and with the retirement of the higher priced United States bonds, together with the increasing burdens and restrictions placed upon National banks, and not upon State banks, a preference was created for the State system whose privileges are not offset by restraints, such as the limitation on loans and the restriction in regard to taking mortgaged security on real estate-a form of security especially desirable in an agricultural community; hence, outside of commercial centers, State banks in Wisconsin have become a more popular, profitable and independent investment for banking capital. 


\section{Panics and Their Effect on the Banks.}

The first panic to affect Wisconsin was that of 1857 , which owing to the depreciated character of the local currency was more seriously felt than in the East; the number of bank failures was consequently greater than in the older States; "the protection of the bill holders" so strenuously looked after, failed to "protect" the holders of wildcat bills in circulation.

Next came the panic of 1863 , occasioned by the Civil War when the question of ways and means to enable the Government to carry on its struggle for existence was most imminent; this period of financial disaster was more alarming in the East than in the West. Wisconsin felt but a ripple from the New York wave, because prices of all farm products doubled, wheat more than kept pace with the price of gold, and for the time being the agricultural communities prospered.

The panic of 1873 , said to be the most disastrous of the century, commenced September 18, by the failure of Jay Cooke \& Co., followed by many of the most prominent bankers and brokers in New York, was less felt in Wisconsin than the preceding ones of '53 and '63. Not only did the banks suffer less, but the distress was not so great in commercial lines; there being in the State only eighty-one commercial failures for $\$ 1,574,000$-a small proportion as against 5,183 failures for $\$ 229,000$,000 , in the entire country. It was a decided collapse of the stock and bond market. Such was the pressure that in September, Milwaukee and St. Paul common stock fell from fifty-one to thirty. Union

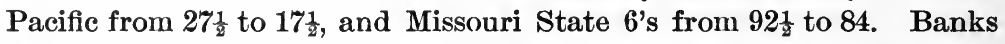
failed all over the country, affecting Wisconsin as little as any locality, there being no question of the currency, nor doubt regarding the Nation's financial strength. Unlike the recent fright of 1893, which was not attributable to bank circulating notes, nor in any great degree to stock speculations, but the fear of Congressional action, or inaction on the vital issue of a gold or silver basis, the wavering of this balance between the metals, the fear of our Government settling to a silver basis, shook confidence from the minds of most experienced financiers, and many banks that were sound under ordinary circumstances were forced to suspend ; bank runs prevailed, gold was sought and hoarded, money demanded without need-in short, the Nation's financial policy was in doubt. Its credit was at stake, and as a consequence the people distrusted everything. The combined Wisconsin banks at that time had $\$ 16,840,000$ cash, against $\$ 70,578,000$ deposits, while with but $\$ 10,612,000$ ready money against $\$ 92,151,000$ deposits, at the present time (1899) say with six millions more money and twenty-two millions less deposits in 1893 , than in 1899 , confidence reigns serene.

The combined capital stock of the State banks in $1863, \$ 3,497,000$, fell off in 1873 to $\$ 715,000$, while the deposits of 1873 were a million greater than in 1863. 
None of the earliest bankers of the Territory are now in the business, and but few of those of $\mathbf{1 8 5 3}$ are to-day thus engaged. Of George Smith and Alexander Mitchell, mention has been made; of the once familiar names are Daniel Wells, Edward D. Holton, Charles D. Nash, A. G. Ruggles, Henry Strong, C. C. Washburn, H. S. Durand, J. G. Ingbusch, J. D. Rexford, L. C. Hyde and others, now gone; while Samuel Marshall, Charles F. Ilsley, B. B. Northrop, Daniel Jones, Hoel H. Camp, N. B. Van Slyke, and perhaps a few others, still remain in harness, realizing as they must how conditions have changed, facilities increased, business magnified in importance and amount, with greater risks assumed than when the debtors' responsibility was better known; rails and wires having shortened the distance and time, and men wondering if in another half-century there can be the same progress and prosperity as in the fifty years just past.

Chartered State Banks in Wisconsin as Reported in Decades.

\begin{tabular}{|c|c|c|c|c|c|c|}
\hline YeARS. & 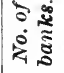 & Capital. & Cash. & $\begin{array}{l}\text { Due from } \\
\text { banks. }\end{array}$ & Loans. & Deposits. \\
\hline $1853 \ldots$ & 8 & $\$ 530,000$ & $\$ 340,000$ & $\$ 198,000$ & $\$ 636,000$ & $\$ 397,000$ \\
\hline $1863 .$. & 69 & $3,497,000$ & 616,000 & $1,472,000$ & $5,062,000$ & $5,274,000$ \\
\hline $1873 \ldots$ & 16 & 715,000 & 870,000 & $1,434,000$ & $5,468,000$ & $6,200,000$ \\
\hline $1883 \ldots$ & 35 & $1,649,000$ & $1,755,000$ & $2,830,000$ & $13,661,000$ & $14,647,000$ \\
\hline $1893 \ldots$. & 119 & $6,806,000$ & $10,064,000$ & $5,714,000$ & $32,637,000$ & $37,826,000$ \\
\hline $1899 \ldots \ldots \ldots$ & 133 & $6,863,000$ & $4,095,000$ & $9,141,000$ & $24,859,000$ & $37,491,000$ \\
\hline
\end{tabular}

Private Banks From Date of First Required Reports Furnished.

\begin{tabular}{|c|c|c|c|c|c|c|}
\hline YRARS. & $\begin{array}{l}\text { No. of } \\
\text { banks. }\end{array}$ & Capital. & Cash. & $\begin{array}{l}\text { Due from } \\
\text { banks. }\end{array}$ & Loans. & Deposits. \\
\hline $1883 \ldots \ldots \ldots \ldots$ & 77 & $\$ 960,000$ & $\$ 1,322,000$ & $\$ 1,604,000$ & $\$ 5,011,000$ & $\$ 6,381,000$ \\
\hline $1893 \ldots \ldots . . . . . .$. & 122 & $1,177,000$ & 827,000 & 855,000 & $4,950,000$ & $5,629,000$ \\
\hline $1899 \ldots . . . . . . . . . . .$. & 114 & $1,022,000$ & 925,000 & $2,150,000$ & $5,343,000$ & $7,880,000$ \\
\hline
\end{tabular}

The Only Savings Bank From Date of First Required Report Furnished.

\begin{tabular}{|c|c|c|c|c|c|c|}
\hline Years. & $\begin{array}{l}\text { No. of } \\
\text { banks. }\end{array}$ & Capital. & Cash. & $\begin{array}{l}\text { Due from } \\
\text { banks. }\end{array}$ & Loans. & Deposits. \\
\hline $1893 \ldots \ldots \ldots \ldots$ & 1 & ….. & $\$ 1,249$ & $\$ 11,621$ & $\$ 166,000$ & $\$ 190,691$ \\
\hline $1899 \ldots .$. & 1 & ....... & 3,419 & 34,525 & 212,969 & 380,240 \\
\hline
\end{tabular}


Combined National, State, Private and Savings Banks, January 1, 1899.

\begin{tabular}{|c|c|c|c|c|c|c|}
\hline *BANKS. & Capital. & Cash. & $\begin{array}{l}\text { Due from } \\
\text { banks. }\end{array}$ & Loans. & Deposits. & $\begin{array}{c}\text { Cir. } \\
\text { culation. }\end{array}$ \\
\hline National..... & $\$ 9,660,000$ & $\$ \overline{5}, 589,000$ & $\$ 3,997,000$ & $\$ 38,574,000$ & $\$ 46,400,000$ & $\$ 2,810,000$ \\
\hline State......... & $6,863,000$ & $4,095,000$ & $9,141,000$ & $24,859,000$ & $37,491,000$ & \\
\hline Private...... & $1,022,000$ & 925,000 & $2,150,000$ & $5,343,000$ & $7,880,000$ & \\
\hline Savings....... & n......... & 3,000 & 34,000 & 212,000 & 380,000 & $\ldots \ldots$ \\
\hline Total....... & $\$ 17,545,000$ & $\$ 10,612,000$ & $\$ 15,322,000$ & $\$ 68,988,000$ & $\$ 92,151,000$ & $\$ 2,810,000$ \\
\hline
\end{tabular}

* At the date of this report there were seventy-seven National banks, 133 State banks, 114 private banks and one Savings bank, a total of 325 institutions.

State Banks, 1838-1846.

\begin{tabular}{|c|c|c|c|c|c|c|}
\hline YEARS. & 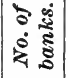 & $\begin{array}{l}\text { Loans and } \\
\text { discounts. }\end{array}$ & Specie. & Capital stock. & Circulation. & Deposits. \\
\hline $1838 \ldots$ & 2 & $\$ 152,676$ & $\$ 83,494$ & $\$ 119,625$ & $\$ 141,363$ & $\$ 43,228$ \\
\hline $1839 \ldots$. & 2 & 231,624 & 65,680 & 139,125 & 235,573 & 109,967 \\
\hline $1840 \ldots$. & 1 & 133,670 & 41,397 & 100,000 & 109,185 & 9,591 \\
\hline $1841 \ldots \ldots \ldots \ldots$ & 1 & 224,365 & ........... & 100,000 & 90,305 & 17,414 \\
\hline $1846 \ldots \ldots . .$. & 1 & 58,789 & 95,967 & 221,475 & 213,479 & 129,636 \\
\hline
\end{tabular}

National Banks.

Figures are in thousands of dollars.

\begin{tabular}{|c|c|c|c|c|c|c|c|c|c|}
\hline YEARB. & $\begin{array}{l}\text { No. of } \\
\text { banks. }\end{array}$ & $\begin{array}{c}\text { Loans } \\
\text { and dis- } \\
\text { counts. }\end{array}$ & $\begin{array}{c}U . S . \\
\text { bonds. }\end{array}$ & $\begin{array}{c}\text { Cash } \\
\text { and cash } \\
\text { items. }\end{array}$ & Capital. & Surplus. & $\begin{array}{l}\text { Undi. } \\
\text { vided } \\
\text { profits. }\end{array}$ & $\begin{array}{c}\text { Out. } \\
\text { standing } \\
\text { circula- } \\
\text { tion. }\end{array}$ & $\begin{array}{c}\text { Indi. } \\
\text { vidual } \\
\text { deposits. }\end{array}$ \\
\hline $1863 \ldots . .$. & 1 & $\$ 162$ & $\$ 67$ & $\$ 146$ & $\$ 200$ & ...... & $\$ 1$ & ........ & $\$ 262$ \\
\hline $1868 . .$. & 36 & 4,537 & 3,559 & 1,975 & 2,860 & $\$ 550$ & 271 & $\$ 2,442$ & 4,778 \\
\hline $1873 \ldots . .$. & 45 & 8,232 & 3,879 & 1,931 & 3,565 & 944 & 321 & 3,007 & 7,265 \\
\hline $1878 . .$. & 38 & 7,386 & 2,987 & 1,660 & 3,265 & 955 & 360 & 1,959 & 6,207 \\
\hline $1883 . . . .$. & 45 & 13,842 & 3,167 & 2,641 & 4,035 & 1,021 & 637 & 2,183 & 14,499 \\
\hline $1888 \ldots$ & 59 & 19,165 & 2,424 & 3,097 & 5,530 & 1,689 & 790 & 1,512 & 17,874 \\
\hline $1893 . . . .$. & 81 & 26,924 & 2,819 & 5,538 & 9,319 & 2,284 & 1,426 & 2,088 & 26,464 \\
\hline $1899 . . . .$. & 78 & 47,156 & 4,121 & 6,304 & 9,660 & 2,304 & 875 & 2,570 & 58,274 \\
\hline
\end{tabular}




\section{MINNESOTA.}

Minnesota formerly constituted a part of Wisconsin Territory. The Legislature of Wisconsin in the General Laws of 1852 entitled "An act to authorize the business of banking," placed the business under the control of the Bank Comptroller, who was an elective officer. This act provided for the issue of bank notes upon the deposit with the State Treasurer of United States and State stocks, which had not for a period of six months previous been sold below par on the New York Stock Exchange; also stocks of railroads within the State of Wisconsin, bearing interest at not less than seven per cent. payable semi-annually. The law also provided for the carrying on of the banking business.

The Wisconsin laws were made applicable to banks and similar corporations, under the provisions of the organic act, and these laws were closely followed by the first Legislature of the new State of Minnesota.

The constitution of Minnesota was adopted April 15, 1858, and Article nine authorized the Legislature to pass by a two-thirds vote a general banking law with several restrictions, and also provided for the taxation of the property of banks and bankers.

\section{The First Banking Law of the State.}

At the first session of the Legislature of the State of Minnesota was enacted Chapter thirty-two of the laws of 1858 , being " An act to authorize and regulate the business of banking," which, as amended at the same session, became the foundation of the banking legislation of the State. This act provided for an issue of bank notes on the basis of a deposit of public stocks of the United States or Minnesota, or of any other State, which stocks should not have been sold at less than par on the New York Stock Exchange within six months preceding the date of deposit. The amount of issues authorized was ninety per cent. of the actual value of such stocks. The minimum eapital stock with which a bank might be incorporated was $\$ 25,000$, and no incorporation was to be allowed for a bank in a town of less than 200 inhabitants.

The supervision of banking was placed under the State Auditor and elaborate provisions were made for the incorporation of banks to issue notes, and also regarding the rights and powers of stockholders and depositors. Quarterly reports were required and it was also provided that interest should not exceed fifteen per cent. per annum.

In defiance of the law the banks organized were, in many cases, located at inaccessible points, and the profits of the business were sought to be derived from interest upon the bonds which were pledged as security for the circulation, and which were bought in small parcels, and paid for by the circulation as fast asit was issued. This privilege was granted under the provisions of Chapter twenty-five of the general laws of 1860 , which also increased the amount of issue to ninety-five per 
cent. of the current value of said stock on the Stock Exchange of New York. A small deposit in New York provided for the redemption of such bank notes as might find their way there, the notes being immediately placed in circulation after being redeemed. Chapter forty-seven of the general laws of 1861 authorized the acceptance by the State Auditor of securities of the United States bearing interest at not less than five per cent ; heretofore the rate required was six per cent.

A law was passed in 1864 providing that securities were not to be withdrawn without the consent of the Auditor and Governor, and further that when they became insufficient for the redemption of the circulating notes, the Auditor might receive the dividends and interest on such securities, this having heretofore been collected by the parties who had issued the circulating notes. The act further provided that no part of the securities or interest thereon should be applied to the payment of fees for protesting the circulating notes, secured by such securities.

An act passed in $\mathbf{1 8 6 5}$ provided for the conversion of State banks into National banks. The State Auditor was authorized to surrender to the National bank the securities deposited by the State bank upon deposit with him by the National bank of an amount of lawful money equal to the amount of outstanding notes of said State bank, to be held and applied by him to the payment of such outstanding notes.

For the ten years ending December 31, 1868, twenty-four banks had been organized, all of which had discontinued, and at the close of 1868 there were no State banks doing business in the State of Minnesota.

\section{Bank of the State of Minnesota.}

* The Bank of the State of Minnesota, the first bank formed under the Minnesota banking laws, was organized at St. Paul on October 1, 1858. Its officers had been engaged in the banking business for many years, and its location at the capital of the State, where it could be easily reached for the redemption of its notes, indicated that the profits of a legitimate business, rather than those arising from the interest on bonds, were sought by its organizers. The capital stock of $\$ 25,000$ was all paid in, and was owned principally by Sewell, Ferris \& Co., of New York, who were the New York correspondents of the bank, and who were ranked as men of abundant capital. The bonds deposited to seeure the circulation were the Minnesota eight per cents, the issue of which was limited by the constitution of the State to $\$ 250,000$. These bonds never fell below par at the New York Stock Exchange.

The State University, in 1858 , issued $\$ 40,000$ of university bonds, bearing ten per cent. interest and secured by mortgage upon the lands donated by Congress for a State university, which lands were then owned by the State. Being so secured the contention was urged by those who desired to use them for banking purposes that they were

*'The information in regard to the Bank of the State of Minnesota was furnished by Mr. N. P. Langford, who was an officer of tha bank. 
State bonds. On October 29, 1858, Hon. C. H. Berry, Attorney-General of the State, in an opinion addressed to Governor Sibley, said: "The State of Minnesota is bound for the redemption of these bonds, and they are to be regarded as State stocks receivable by the Auditor on deposit as a basis for banking." This opinion having settled affirmatively the question whether the State Auditor might properly receive these bonds as a basis for bank circulation, the whole issue was purchased by Sewell, Ferris \& Co., and bonds to the amount of $\$ 10,000$ were deposited with the State Auditor, but no circulation was issued upon them at that time; and soon afterwards $\$ 10,000$ of the Minnesota eight per cent. bonds, heretofore deposited, were withdrawn, leaving $\$ 15,000$ of the Minnesota eight per cents and $\$ 10,000$ of the university ten per cents as security for the circulation of the bank. This was in effect a substitution of $\$ 10,000$ of the university bonds for $\$ 10,000$ of the Minnesota eight per cents. The faith of the State of Minnesota had not, however, been distinctly pledged for the payment of the university bonds. When, therefore, they wers afterwards sold for the redemption of the notes issued, their market value dropped from nearly par, the price which the University of Minnesota sold them for, to twenty-two cents on the dollar. These bonds were afterwards all redeemed or purchased by the State University. Sewell, Ferris \& Co. became involved in disastrous stock speculation in New York, which resulted in their failure in October, 1859, and they decided to wind up the two banks which they had organized in Minnesota-the Bank of the State of Minnesota and the Nicollet County Bank, of St. Peter.

\section{Legitmate Banks of Issue UNPRofitable.}

The local business of the Bank of the State of Minnesota was profitable, but the losses sustained by it in the redemption of its circulating notes were such as to preclude the possibility of any bank maintaining itself in St. Paul, or any city easily accessible, while doing a legitimate business, provided its circulation was at all proportionate to its capital. With the circulation of but $\$ 25,000$ the redemption of its notes in gold coin or New York exchange amounted to about $\$ 300$ per day, at a time when gold coin and New York drafts were selling at from two to three per cent. premium for current money. This condition of affairs was potent in determining the location of nearly all the banks organized in Minnesota in the years 1858 and 1859, none of which, except the two banks in St. Paul, did a legitimate banking business, nor in reality had any substantial capital, in excess of the small sum required to redeem any of the circulating notes that might be presented for redemption. The bonds were bought on credit, to be paid for in the currency which the Auditor issued upon their being deposited, and after paying for the bonds there was rarely anything left for the business of the bank. The corporators expected to receive their profits from the interest on the bonds, and the banks were therefore located in remote or inaccessible 
towns and villages, with which there was no communication by means of stages (there being no railroads in Minnesota then) or public conveyances. It was rightly judged that the difficulties in the way of reaching these towns and villages would operate as a bar to the presentation of notes for redemption. Each of these out-of-the-way banks had an agency in New York or Chicago, where its notes were redeemed in gold at from three to five per cent. discount, and the expense involved in a journey to one of these frontier towns or villages, in order to present notes for redemption at the counter of the bank, was greater than the discount on the notes at the place of redemption, in New York or Chicago.

The following table shows the amount of securities deposited and circulation issued thereon of the various banks, and also the rates of discount at which the notes were received for gold and New York exchange:

\begin{tabular}{|c|c|c|c|}
\hline NAME OF BANK. & $\begin{array}{c}\text { Notes } \\
\text { issued. }\end{array}$ & & Discount. \\
\hline State Bank of Minnesota. & $\$ 25,000$ & $\$ 25,000$ & 5 per cent. \\
\hline Bank of St. Paul........................ & 25,000 & 25,000 & 3 per cent. \\
\hline Farmers' Bank..... & 25,000 & 25,000 & 5 per cent. \\
\hline La Crosse Bank............. & 25,000 & 30,000 & 3 per cent. \\
\hline People's Bank.......................... & 25,000 & 39,000 & 4 per cent. \\
\hline Winona County Bank................. & 25,000 & 29,000 & 3 per cent. \\
\hline Exchange Bank of Glencoe.......... & 79,000 & 84,000 & no quotation. \\
\hline Nicollet County Bank....... & 36,000 & 36,000 & no quotation. \\
\hline Bank of Owatonna...... & 35,000 & 41,000 & no quotation, \\
\hline Chisago County Bank... & 30,000 & 35,000 & no quotation. \\
\hline ank of Rochester..... & 46,020 & 49,000 & no quotation. \\
\hline Imore County Bank. & 25,000 & 33,000 & no quotation. \\
\hline Central Bank, New Ulm & 23,000 & 27,000 & \\
\hline
\end{tabular}

As the seven per cent. bonds never had any market value except as a basis for the circulation issued for the purpose of their purchase in the first instance, it is a marvel that a bank could be found which would redeem the bills at any rate of discount.

\section{Facts Regarding the Early Banks.}

The Farmers' Bank, of Garden City, was organized by the corporators of the Bank of Fox Lake, Wisconsin. Its circulation of $\$ 25,000$ was secured by a deposit of a like amount of the Minnesota 8 per cent. bonds of the $\$ 250,000$ issue.

The Nicollet County Bank, of St. Peter, was organized by Sewell, Ferris \& Co., of New York, with a capital of $\$ 30,000$, its circulating notes being secured by a deposit of $\$ 30,000$ ten per cent. university bonds, called at the time Minnesota State bonds. This bank was closed on the failure of its owners in New York, in October, 1859. Its Cashier, Wm. J. Sewell, is now (1900) United States Senator from New Jersey.

The circulating notes of the Bank of St. Paul, were secured by Ohio State 6 per cent. bonds, always worth par or more. The Chisago County Bank deposited $\$ 25,000$ of Minnesota 7 per cent. bonds (known as the railroad bonds) and $\$ 6.250$ of personal bonds to secure its circulation.

The Bank of Rochester deposited $\$ 30,000$ of Minnesota seven per cent. bonds and $\$ 18,000$ personal bonds as security for its circulation. This bank gave notice that its circulating notes would be redeemed in 
specie at the Bank of Galena, Illinois. The circulation of the Bank of Chatfield was secured by Minnesota seven per cent. bonds, and for the purpose of establishing the confidence of the public in the notes, public notice was given that the bank was owned by Selah Chamberlain, a wealthy capitalist and railroad builder of Wisconsin.

In 1869 the law was amended making bill holders preferred creditors. Securities were to be deposited only by banks issuing circulation.

\section{Banks Placed Under Control of the Public Examiner.}

In 1878 a law was passed removing banking institutions from under supervision of the State Auditor and placing them under control of the Public Examiner, who was made ex-officio Superintendent of Banks, and authorized to make examination into the accounts, securities, books, papers, etc., of any bank as often as may be deemed necessary.

During the ten years ending December 31, 1878, 21 State banks had been organized and 4 had been discontinued, leaving since the commencement 45 organized, 28 discontinued and 17 in operation.

The act of 1881 restated the law of 1858 as to minimum capital of $\$ 25,000$, and that no bank could organize in a town of less than 200 inhabitants. The following provisions were also adopted:

Capital stock must be paid in cash before commencing business; the name must be different from that of any other bank in the State; certificates of organization must be recorded, the certificate to give location, capital stock, names and residence of shareholders, number of shares owned by each, time of commencement and termination of the association, the certificate of organization to be published; increase of capital to be valid only when paid in full; approval of any increase or reduction to be made by the Public Examiner; liability to any association of any person or company, corporation or firm, for money borrowed shall not exceed fifteen per cent. of aggregate amount of capital stock actually paid in and the surplus fund, an exception being made in the case of bills of exchange and discount of commercial paper; banks must have on hand in a vailable funds twenty per cent. of immediate liabilities.

An act was passed in 1883 requiring the quarterly reports to the Public Examiner to be published. In 1887 an act was passed limiting the ininimum capital, as follows: For a town of not more than 1,000 inhabitants, $\$ 10,000$; for a town of not more than 1,500 inhabitants, $\$ 15,000$; for a town of not more than 2,000 inhabitants, $\$ 20,000$; for a town of more than 2,000 inhabitants and upward, $\$ 25,000$.

During the ten years ending December 31, 1888, 68 State banks had been organized and 22 discontinued, leaving since the commencement 109 organized, 50 discontinued and 59 in operation.

Further laws for regulating the banking business were passed in 1889 . This act requires a two-thirds vote of shareholders before a bank may go into voluntary liquidation, and futher provides for publishing notice of liquidation, and requires a report of the progress of liquidation twice a year to the Superintendent of Banks. This officer is empowered to 
take action through the Attorney-General to compel a dissolution of an insolvent corporation and the appointment of a Receiver.

An act was passed in 1895 , entitled an act to revise the laws relating to banks of discount and deposit, some of its provisions being as follows:

Articles of incorporation to be filed with the Superintendent of Banks, who shall issue within thirty days a certificate authorizing the association to begin business; directors to appoint examining committee, who shall examine bank at least once in six months; every bank shall report to the Superintendent of Banks at least four times a year, the reports to be published, and as many special reports made as are deemed necessary; one-tenth of net profits to be set aside for surplus fund until the fund shall equal twenty per cent. of the capital stock; every bank shall at all times have on hand as a reserve fund an amount equal to twenty per cent. of its liabilities, and when the reserve fund shall fall below twenty per cent. of the immediate liabilities, the bank shall make no new loans until the proper amount be restored; on becoming satisfied that any bank has become insolvent, or that its books are kept in a false or fraudulent manner, or that it has refused to pay its deposits in accordance with the terms upon which the deposits were received, the Superintendent may forthwith take possession of books, records and assets, and after detailed examination, finding that assets are sufficient to satisfy all liabilities, except that of stockholders, he may return same to proper officials, or apply to a court of competent jurisdiction for the appointment of a Receiver; National banks having dissolved in accordance with law upon authority of two-thirds of the stockholders, it is lawful for the majority of the directors to organize a State bank under these laws and by approval of the Superintendent of Banks; any bank may go into liquidation and be closed by a vote of its stockholders owning more than one-half of its capital; the name of any banking corporation shall be approved by the Public Examiner.

A law was passed in 1897 providing for the reorganization of insolvent banking corporations.

During the ten-year period ending December 31, 1898, 158 banks were organized and 60 discontinued, leaving since the commencement 267 organized, 106 discontinued and 161 in operation.

\begin{tabular}{|c|c|c|c|c|}
\hline \multicolumn{5}{|c|}{ State Banks of Deposit and Discount. } \\
\hline oans and discoun & $\begin{array}{c}1858 . \\
\$ 5,185\end{array}$ & $\begin{array}{c}1878 . \\
\$ 2,256,712\end{array}$ & $\begin{array}{c}1888 . \\
\$ 16,668,397\end{array}$ & $\begin{array}{c}1899 . \\
\$ 26,727,705\end{array}$ \\
\hline apital............ & 500,000 & $1,060,400$ & $5,733,000$ & $6,667,900$ \\
\hline glus.......... & . . . . . & 61 & 724,775 & 889,704 \\
\hline profit & & 69 & 862,800 & $1,108,358$ \\
\hline itor & & 1,647 & $14,702,9$ & $17,7 \cdot 24$, \\
\hline Total liabilities.... & 113,363 & $2,993,949$ & $23,459,426$ & $38,992,851$ \\
\hline Number of banks... & & 13 & 61 & \\
\hline
\end{tabular}

The law relating to the declaration of dividends was amended in 1899, and some further regulations were fixed regarding the appointment and duties of examining committees. The powers and authority of the Superintendent of Banks were considerably enlarged. The amount of net profits to be set aside for surplus fund was increased from one-tenth to one-fifth of such profits.

During the year ending December 31, 1899, 22 State banks were or- 
ganized and three discontinued, leaving since the commencement 289 organized, 109 discontinued and 180 in operation.

\section{SAvings Banks.}

The General Laws of 1879, being Chapter 109, entitled "An act to conform all Savings banks or institutions of savings to uniformity of powers, rights and liabilities; and to provide for the organization of Savings banks; for their surplus, and for the more efficient protection of depositors in such institutions," provided that every corporation should have not less than seven trustees, with perpetual succession and coinplete control. These trustees were to be bonded for $\$ 5,000$. Previous to organization notice was published, and the Public Examiner, Attorney-General and State Auditor, after examination, authorized the organization and location of the bank. No trustee, officer, clerk or employee was permitted to borrow the funds of the bank, and upon their doing so their office became vacant.

No interest should be paid to depositors, except the same had been actually earned during the period for which the dividend was made.

Investments to the amount of seventy per cent. of the whole deposits of the bank were authorized to be made in mortgages; loans not exceeding twenty-five per cent. of deposits were also authorized on personal security. Banks were required to commence business one year from issue of authorization. They were authorized to accumulate a surplus of fifteen per cent. of their deposits, and required to divide any surplus in excess of that amount among their depositors. Minors and females were furnished with special security for deposits in their own names.

By this act Savings banks were forbidden to deal and trade in real estate, except as necessary for security of their loans. The banks were placed under the jurisdiction of the Public Examiner, and required to make reports to him, and such official was given authority, through the Attorney-General, to institute proceedings to enforce compliance with the law and for the protection of depositors. All Savings banks incorporated prior to the enactment of this law are exempt from these provisions. Under this law there have been organized nine Savings banks, of which five are now in operation, four having been closed.

The Savings banks in the State of Minnesota, except four institutions, are all closely associated with banks of discount and deposit, either National or State. It is thought by many wlo are conversant with the workings of these banks that they have reached a stage in their growth when they might stand independent and be enabled to pay their active officers a sufficient compensation to secure a proper and careful investinent of the funds; and that such independent action would result in a large increase in the volume of the savings deposits of the State and would not lessen the security of such deposits.

There are several Savings banks now operating under the general law of 1867 as annexes of National or State banks. Whils the law un- 
der which they operate is regarded as indefinite and obsolete, attempts to get the Legislature to act in the matter have been unsuccessful.

But one Savings bank in the State now has a capitalization, and it does both a savings and commercial business.

There have been ten associations incorporated under the law of 1867. Of these three have failed (one transferring its charter to another bank), one has discontinued, one accepted the provisions of the law of 1879 , leaving six in operation under the law of 1867 .

The whole number of Savings banks organized is seventeen; four have been discontinued, leaving thirteen in operation at the close of 1899 .

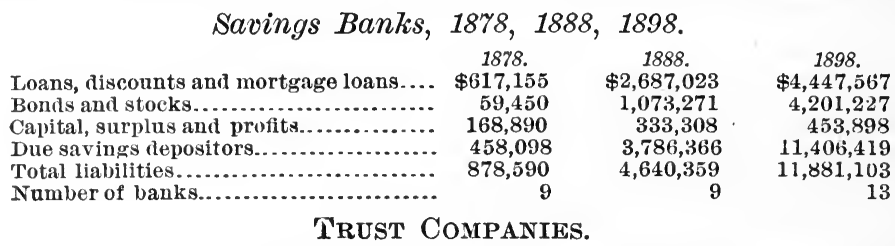

By an act approved March 5, 1883, the organization of annuity, safe deposit and trust companies was provided for, and they were authorized to exercise the powers usually granted to such corporations. The minimum capital was fixed at $\$ 500,000$. They were authorized to receive deposits in trust, but were prohibited from doing a banking business. Trust companies are under supervision of the Public Examiner. The first company was organized in 1883 , and up to the close of 1899 ten companies had been organized with a capital of $\$ 6,650,000$, and in the same time two companies, with a capital of $\$ 1,100,000$ have discontinued. On July 31,1888 , four companies reported, having $\$ 1,295,500$ capital, $\$ 75,000$ surplus, $\$ 99,407$ undivided profits, $\$ 73,547$ trust accounts, and $\$ 2,221,664$ total resources. Ten years later the capital was $\$ 3,640,026$, surplus $\$ 30,000$, undivided profits $\$ 85,891$, personal accounts $\$ 976,654$, trust accounts $\$ 21,302$, and total resources $\$ 5,723,999$.

\section{National Banks.}

Figures are in thousands of dollars.

\begin{tabular}{|c|c|c|c|c|c|c|c|c|c|}
\hline YEARS. & 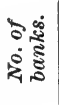 & $\begin{array}{c}\text { Loans } \\
\text { and dis- } \\
\text { counts. }\end{array}$ & $\begin{array}{c}U . s . \\
\text { bonds. }\end{array}$ & $\begin{array}{c}\text { Cash } \\
\text { and cash } \\
\text { items. }\end{array}$ & Capital. & Surplus. & $\begin{array}{c}\text { Undi- } \\
\text { vided } \\
\text { profits. }\end{array}$ & $\begin{array}{c}\text { Out. } \\
\text { standing } \\
\text { circula. } \\
\text { tion. }\end{array}$ & $\begin{array}{c}\text { Indi- } \\
\text { vidual } \\
\text { deposits. }\end{array}$ \\
\hline $1864 \ldots$ & 1 & $\$ 390$ & $\$ 781$ & $\$ 414$ & $\$ .500$ & ...... & $\$ 23$ & $\$ 197$ & $\$ 808$ \\
\hline $1869 \ldots . . . .$. & 17 & 2,981 & 2,041 & 691 & 1,780 & $\$ 286$ & 202 & 1,495 & 2,157 \\
\hline $1874 \ldots$ & 32 & 8,349 & 4,343 & 1,323 & 4,350 & 746 & 341 & 3,359 & 6,297 \\
\hline $1879 \ldots$ & 30 & 10,005 & 3,337 & 1,439 & 4,660 & 786 & 387 & 2,494 & 7,104 \\
\hline $1884 \ldots$ & 50 & 25,320 & 2,737 & 2,977 & 11,358 & 1,718 & 1,046 & 1,996 & 15,971 \\
\hline $1889 \ldots . . . . .$. & 57 & 37,155 & 2,637 & 2,900 & 14,366 & 2,642 & 1,854 & 1,487 & 25,769 \\
\hline $1894 \ldots . . . . .$. & 79 & 37,563 & 2,566 & 5,332 & 15,530 & 2,552 & 2,095 & 1,777 & 29,868 \\
\hline $1899 . . . . . .$. & 69 & 40,510 & 3,160 & 6,162 & 12,290 & 2,078 & 1,294 & 1,911 & 45,655 \\
\hline
\end{tabular}


In order to get a clear knowledge of early banking and the surrounding conditions in the Northwestern Territory and the Territory and State of Iowa, it is well to canvass in brief the geographical development of that Territory from the time it came into the possession of the United States to the present.

Iowa was a part of the Louisiana Territory acquired from France in 1803. In June, 1834, the Territory west of the Mississippi River and north of Missouri, embracing Iowa, was made a part of the Territory of Michigan, and so continued until July 4, 1836, when Wisconsin Territory was organized. This included within its limits the present States of Iowa, Wisconsin and Minnesota. An act of Congress, approved June 12,1838 , created the Territory of Iowa, containing not only the area of the present State, but covering much of Minnesota, and extending north to the British possessions. In December, 1846, Iowa, with her present limits, was admitted into the Union.

The changes thus indicated, with perhaps the exception of the original purchase, have taken place within the memory of men now living. The development of the State from its organization as a Territory, inhabited by Indians and a few trappers and traders, to the great State of to-day, with more banks than any other State in the Union, has been rapid, but it has been due to the possession of resources which have afforded a substantial basis for this development and progress.

\section{The Miners' Bank of Dubuque.}

On November 30,1836 , an act was approved by the Territorial authorities of Wisconsin Territory incorporating the Miners' Bank, of Dubuque. The charter of this bank, the first and only authorized bank up to 1858 in what is now the State of Iowa, provided for a capital of $\$ 200,000$ in $\$ 100$ shares; one-tenth of the capital stock to be paid at the time of subscription, the balance in payments of not more than $\$ 10$ per share as called for by the directors; the bank was permitted to charge seven per cent. interest; every stockholder should have one vote for each share, not in excess of ten, and one vote for every ten shares above that; no notes were to be issued until $\$ 40,000$ of its capital stock was paid up, and no notes under $\$ 5$ were permitted. The Legislature also specifically reserved the right to prohibit notes below $\$ 10$ in four years, and notes below $\$ 20$ in ten years. The stock was to be subscribed in May and June, 1837, and the charter was to run twenty years. No provision was made as to the kind of money that was to constitute the capital stock.*

* As will be seen later, this proved fatal to the prosperity of the bank, as was the case with many others similarly organized. It was one of the notably strong points of the State Bank of Indiana that its capital was fully paid up in specie. 
The Congress of the United States by act of March 3, 1837, approved the act incorporating this bank, subject to the following limitations:

(1) The bank should not issue bills or notes for circulation until onehalf its capital should have been paidin.

(2) The directors should not be restricted to calls of ten per cent. of the capital but might call for forty per cent. if they thought best.

(3) The bank should have no authority to increase its capital to more than $\$ 200,000$ without consent of Congress.

(4) The aggregate indebtedness owing by the bank "over and above its actual deposits" should not exceed twice the paid-up capital.

(5) The charter should be forfeited if not finally complied with by January 1, 1838, and the bank then in operation.

The bank was organized at the beginning of the panic of 1837 , and like many other banks it was plunged into financial disaster from which it never fully recovered.

The Miners' Bank commenced discounting in October, 1837, but from the first there were many disquieting rumors regarding its stability.

An examination made in November, 1837, by a legislative committee showed that its capital $(\$ 100,000)$ had been actually paid in and that it consisted of $\$ 41,147$ in specie and the balance in the notes of various banks in New York, Pennsylvania, Illinois, Wisconsin and Michigan; that the total amount of specie then on hand was $\$ 42,118$; that the amount of bills in circulation was $\$ 11,435$. The committee unanimously pronounced the bank to be "in a sound and solvent condition."

In January, 1838, an examination committee, to which the continued rumors of the bank's instability had been referred, reported that very conflicting testimony had been given them, making "the astounding revelation that the greater part of the first installment was taken with money loaned from the branch bank at Galena, which was paid to the bank immediately, as soon as the stock was all taken. That of the $\$ 80,000$ required to be paid in the second installment only $\$ 4,300$ was actually paid in and that an individual deposit in the bank remained unpaid after having been more than once demanded, and that the amount of specie on hand is only $\$ 1,830$."

In February, 1838, another legislative committee examined the bank and reported that the capital had been paid as follows: $\$ 40,000$ of certificates of specie deposits in Detroit, $\$ 50,000$ in notes of the Jackson County Bank and Bank of Manchester, Mich., and $\$ 10,000$ in specie and other bank notes, the specie on hand being only $\$ 1,318$. This committee made another examination in June of the same year, when they found that none of the specie claimed to be in deposit in Detroit had been secured, and that the specie on hand had decreased to $\$ 45 \% .30$. The circulation in February had been $\$ 12,680$ in post notes, payable twelve months after date, and $\$ 1,350$ in demand notes. By June 14 this amount had been reduced to $\$ 10,5 \%$, and $\$ 460$ respectively.

In December, 1838, after Iowa had been organized as a separate Ter- 
ritory, a legislative committee reported that they had examined the bank and found its entire liabilities to the public to be $\$ 19,711$, of which $\$ 10,990$ was for circulation, $\$ 5,035$ in post notes and $\$ 3,686$ deposits. Its specie amounted to $\$ 3,033$, and notes of other banks, $\$ 18,874$. On this showing the committee declared the bank in a safe and solvent condition.

The bills of the bank do not appear to have been put into circulation to any great extent. In October, 1840, the amount reported was less than $\$ 40,000$, while the specie held was said to be $\$ 45,000$. In March, 1841, the bank suspended specie payment, but resumed July 1, 1842 , but after redeeming about $\$ 25,000$ of its notes in a few days, it was obliged to again suspend. In April, 1844, it again resumed business, but a year later was forced to close up its affairs, the Legislature having repealed its charter.

From the legislative reports on the condition of the bank, which led to the repeal of its charter, it was evident that the institution had been fraudulently capitalized. The charter required that $\$ 100,000$ capital should be actually paid up before any business could be done. It was thought that this had been done, but it was shown that the stock of the bank had been largely paid for by the stockholders' notes.

The bank did not do a large .business because of the general hard times then existing by reason of the panic of 183\%. It struggled along for several years and finally discontinued with but a small loss to its bill holders.

\section{Early Banking in Iowa and Surrounding Conditions.}

With the exception of the bank above described, there was little banking in the Territory of Iowa until its admission as a State in $\mathbf{1 8 4 6 .}$ And even then and well into the fifties, what was known as banking was of the simplest character. With the beginning of Statehood and the opening up of the fertile prairies for settlement, immigration began to pour in and business to grow to such an extent that it became possible to conduct the business of a frontier bank with profit.

The banking business then was very different from that of to-day. There were no railroads, no telegraph or any of the complicated machinery of modern business. The settlers raised enough of stock and grain for their own use and sold or traded the balance to the constantly growing stream of immigrants coming into the country. In later years, when this home market had decreased, they hauled the surplus products of their farms to the Mississippi River to be shipped away by steamboats. Of money there was little, and that little wonderfully diversified. Of gold there were the American coins, English sovereigns, French twenty-franc pieces, and a few Spanish doubloons; in silver, Spanish dollars and quarters, Mexican dollars, five-frane pieces and twelve and one-half and six and one-fourth cent pieces. The paper money consisted of bank bills, part good, part bad and part constantly fluctuating.

The principal business of the Iowa banker in those days was the 
"entering of land on time." That is, buying at the regulation price of $\$ 1.25$ per acre, from the Government any tract of land previously selected by a settler or speculator and selling it to him on one year's credit at $\$ 1.75$ per acre-forty per cent. interest. From $2 \frac{1}{\$}$ to three per cent. were the current rates of interest on ordinary bank loans. Regular bank discounts were seldom applied for. Another source of revenue was the buying of Government land for non-resident settlers and speculators, and the purchase in Eastern cities of Government land warrants. The United States land offices would receive only American coin in payment for land, and because of this, American gold and silver quickly went to a premium and the bankers were able to command a good profit by furnishing it to the new settlers at a good premium in return for Eastern drafts, which they took at a heavy discount. These branches of business with short lines of legitimate discount and the occasional selling of exchange (when the bank was in a position to sell it) with more or less buying and selling of real estate, constituted the banking business of that time.

Among the first bankers scattered along the Mississippi River were Charles Parsons, of Keokuk; Coolbaugh \& Brooks, of Burlington; Green \& Stone, of Muscatine; Cook \& Sargeant, of Davenport; W. J. Barney \& Co. and Langworthy Bros., of Dubuque.

For many years the banking business was confined to the towns along the Mississippi River, but with the development of the interior counties, land agents, general store-keepers and a few other business men began to add some of the functions of banking to their other responsibilities. For some time the amount of strictly banking business transacted by them hardly justified calling them bankers, but year by year the evolution of the banks and bankers grew more complete, and many of the most substantial of Iowa's banking institutions date their beginning in this period.

\section{Equipments of the Pioneer Banks.}

The bank equipments during this period were of the simplest kind. The bank was generally situated in a cheap one-story frame building. A modest pine or walnut counter fenced the bank proper from the outside public. A cheap stand, desk, table and chairs and a big stove completed the furniture. The safe was usually a gorgeously decorated sheet-iron affair, in which the treasures of the bank were nightly stored. All the modern appliances of time locks, vaults and drill-proof steel plates were lacking, the safe being locked by a big key, and the bigger the key the better the lock. In many cases the proprietor of the bank was not only its President and Cashier, but also teller, bookkeeper and janitor.

\section{Banking Made a Penal Offence.}

The young State of Iowa looked with suspicion upon the business of banking, and therefore took no steps to provide a banking system or 
facilities for her citizens. On the contrary, the State discouraged the establishment of banks and absolutely forbade corporations with banking privileges. The first constitution provided "That the General Assembly shall provide for the organization of all other corporations, except with banking privileges, the creation of which is prohibited"; and also, "The General Assembly shall prohibit by law any person or persons, association, company or corporation from exercising the privilege of banking, or ereating paper to circulate as money." A penalty of one year in the county jail and a fine of $\$ 1,000$ was provided for each offender.

On account of the rapid development of the country there was a great demand for money as a inedium of exchange. Several surrounding States, viz., Indiana, Illinois, and Wisconsin, had established practically free banking. The notes of these banks were in some cases based upon bonds of Southern States, the value of which was questionable to start with, and later proved to be absolutely worthless. Because of the fact that Iowa had made no provision for the banking needs of her people, and because of the demand for money, the State was marle the dumping-ground for much of this fluctuating currency from the States above named. The value of these bank notes was constantly changing, and they were the source of great trouble and loss to the people at large and to the banker, who could not tell their value from day to day.

Because banking was prohibited in Iowa and the people were thus compelled to suffer from the lax banking laws in other States without. recourse, and because of the demand for money, some of Iowa's business men determined to start banks of issue in the Territory of Nebraska. In 1855 Nebraska, with a population of less than 5,000, had been made a Territory, and there were no restrictions on its Legislature chartering all the banks called for. Men from Iowa, Illinois, Indiana, and Wisconsin obtained all the bank charters they asked for, and in less than two years eight banks were organized. The first of these was. "The Western Fire and Marine Insurance Company," organized in March, 1855, by Thomas H. Benton, Jr. Until January, 1856, when five more of these will-o'-the-wisp banks were organized, there were more of the issues of this bank in circulation in Iowa than any other; but after that time they with the notes of the Bank of Florence (controlled by Cook \& Sargeant, of Davenport, and Cook, Sargeant \& Downey, of Iowa City), the issues of the Bank of Nebraska (by B. F. Allen, of Des Moines), and those of the Bank of Fontenelle (by Green \& Weare, of Cedar Rapids), were a large part of the circulating medium.

When the panic of ' 57 was precipitated, the Western Fire and Marine Insurance Company was one of the first banks in the West to go. In closing up the concern only $\$ 191.30$ in specie and $\$ 121$ in bills of solvent. banks were found in the bank, and its notes became worthless. The Bank of Florence was kept up as long as the credit of its backers held 
out, its issues being quoted at a discount. They were all finally redeemed. The Bank of Fontenelle followed with the others. Cedar Rapids, Marion, Vinton, Osage, Des Moines, Council Bluffs, Fort Dodge, and Sioux City each had a banking house from which the notes of this bank were floated. The Bank of Nebraska, with a smaller circulation, was the last of these Iowa-Nebraska banks to succumb, for the credit of the founder and owner was still good, and the bills were so promptly redeemed that it was the last to go. The principle was wrong, however, and it finally met the same fate as the others.

\section{A More Lenient View of the Business of Banking.}

The panic and hard times served a useful purpose in opening the eyes of the Legislature and other public men to the importance of providing some stable system of banking to facilitate the rapidly developing business interests of the State. Therefore, when the new constitution was framed in $\mathbf{1 8 5 7}$, it provided that the Leyislature might create corporations with banking powers, which, before becoming valid, should be approved by a majority of the electors at the general or special election; and that they might provide for the establishment of a State bank, with branches, founded on an actual specie basis; that the branches should be mutually responsible for each others' liabilities on all notes intended to circulate as money; that each stockholder should be individually liable to its creditors for all of its liabilities to an amount equal to the shares held by him; that in case of insolvency the bill holder should have preference over other creditors, and that the suspension of specie payments should never be permitted or sanctioned.

Under these constitutional provisions the State Bank of Iowa was incorporated and duly sanctioned by the people. The history of this bank is given in detail because of its many excellent provisions, many of which were afterwards followed in the laws governing National banks, and because this bank was practically the foundation of Iowa's present banking system.

\section{History of the State Bank of Iowa.}

As provided in the constitution, the Legislature passed a law March 20,1858 , which took effect July 29, 1858, after submission to a vote of the people, incorporating the State Bank of Iowa. The law limited the number of branches to thirty and forbade any branches in towns of less than five hundred population, and but one branch in any city or town. A board of ten commissioners from among the leading citizens of the State was named to supervise the first organization of the bank and branches. This board met in Iowa City September 15, 1858, to receive and act upon applications for branches. These applications were referred to committees for personal examination and report. After nearly a month's time devoted to investigation, the commissioners certified to the Governor that the following-named branches were legally 
organized, the stockholders and officers found to be men of responsibility and integrity, and that such branches had fifty per cent. of their capital stock paid up and were lawfully entitled to commence the business of banking under provisions of the law : Muscatine, Iowa City, Des Moines, Dubuque, Oskaloosa, Mt. Pleasant, Keokuk and Davenport. Subsequently, between February, 1859, and February, 1864, seven other branches were admitted as follows: Lyons, Burlington, Washington, Ft. Madison, McGregor, Council Bluffs and Maquoketa, making in all fifteen branches.

The duties of the board of commissioners having been completed, the State Bank was placed under the control of the board of directors, consisting of one member from each branch and three members named by the State Legislature. This board met at Iowa City October 27, 1858, and consisted of the following directors: W. T. Smith, Oskaloosa branch; Sam'l F. Miller, Keokuk branch; Chester Weed, Muscatine branch; P. M. Casady, Des Moines branch ; S. J. Kirkwood, Iowa City branch; R. Bronson, Dubưque branch; T. Whiting, Mt. Pleasant branch; Hiram Price, Davenport branch, and Benj. Lake and Hoyt Sherman, State directors.

\section{Organization and Management of the Bank.}

The first officers of the board were Chester Weed, President; W. T. Smith, Vice-President; Elihu Baker, Secretary. The latter officer and S. J. Kirkwood, Hiram Price and the Vice-President formed the executive committee. By-laws were adopted, defining powers and duties of officers: among other things that the President should personally examine all branches as often as he deemed necessary or on the request of any three directors, and that he should retain custody of bonds of all Cashiers of the branches; that the executive committee hold monthly meetings to examine the monthly statements made by the branches; to make personal examinations when thought wise; to provide for the circulating notes proportioned among the branches and the security given therefor, and have general supervision of the affairs of the bank as well as all the branches. The directors also had the right to fully examine all branches and their officers under oath. Provision was also made for the publication of a consolidated bank statement each month, showing their condition. The branches were required to make semi-annual and also monthly statements verified by oath of the Cashier or President and two directors, and to at once publish the same in a county newspaper and send copies to each branch.

The parent bank was not a bank of issue or deposit. It transacted no business except with and for the branches. It was required by law to keep an office in Iowa City, then the capital of the State, where all records were to be kept open to the inspection of the General Assembly, the Governor, or any committee appointed by the General Assembly. 
At the first meeting it was decided that circulation should be furnished to the different branches in the proportion of one and onehalf dollars of circulating notes to each dollar of paid-up stock. Fifty per cent. of the capital stock of each branch was required to be paid in gold or silver eoin, which should be in the actual possession and the bona fide property of the bank. The balance of the capital to be paid in coin not less than ten per cent. at a payment, and as frequently as every four months if so directed. However, the directors could postpone the deferred payments if satisfied that the public interest did not require them.

\section{Circulation Secured by a Safety Fund.}

All notes for circulation were furnished by the State Bank. Each branch was required to deposit with the State Bank either coin, United States stocks, or interest-bearing State stocks at their current value in the city of New York, but in no case to be taken above their par value in an amount equal to $121 / 2$ per cent. of the circulating notes, delivered to such branch bank. This deposit was to be known as the safety fund and was to be invested by the State Bank in stocks of States or of the United States, as the property of said branch, entrusted for the benefit of the safety fund as a fund for the redemption of the circulating notes of any one or more of said branches that might fail to redeem its notes.

The law further provided that any branch refusing to redeem its notes in coin or the lawful currency of the United States should be declared insolvent and be taken charge of by the State Bank of Iowa; that affairs of each branch should be administered by not less than five nor more than nine directors; that no person could be President or director of more than one branch at the same time; that each branch must have on hand at all times in coin twenty-five per cent. of its outstanding notes, and also in addition twenty-five per cent. of its deposits, and was prohibited from paying interest on current deposits.

Interest and discount were limited to ten per cent. until 1863. The State was prohibited from imposing a greater tax upon property employed in banking under this act than was imposed upon property of individuals.

By an act approved in February, 1862, county treasurers and the State Treasurer were authorized to accept the notes of these branches in payment of taxes, and by an act approved March 10, 1864, payment of taxes, and the interest and principal on school funds might be paid in United States Treasury notes, National bank notes or notes of the State Bank of Iowa, thus showing the unquestionable value of the State Bank circulating notes.

In August, 1859, the branches were authorized to receive the full amount of circulation to which they were entitled by law, that is, two dollars for every dollar of paid-up capital stock.

On February 15, 1860, the board of directors elected Hiram Price, 


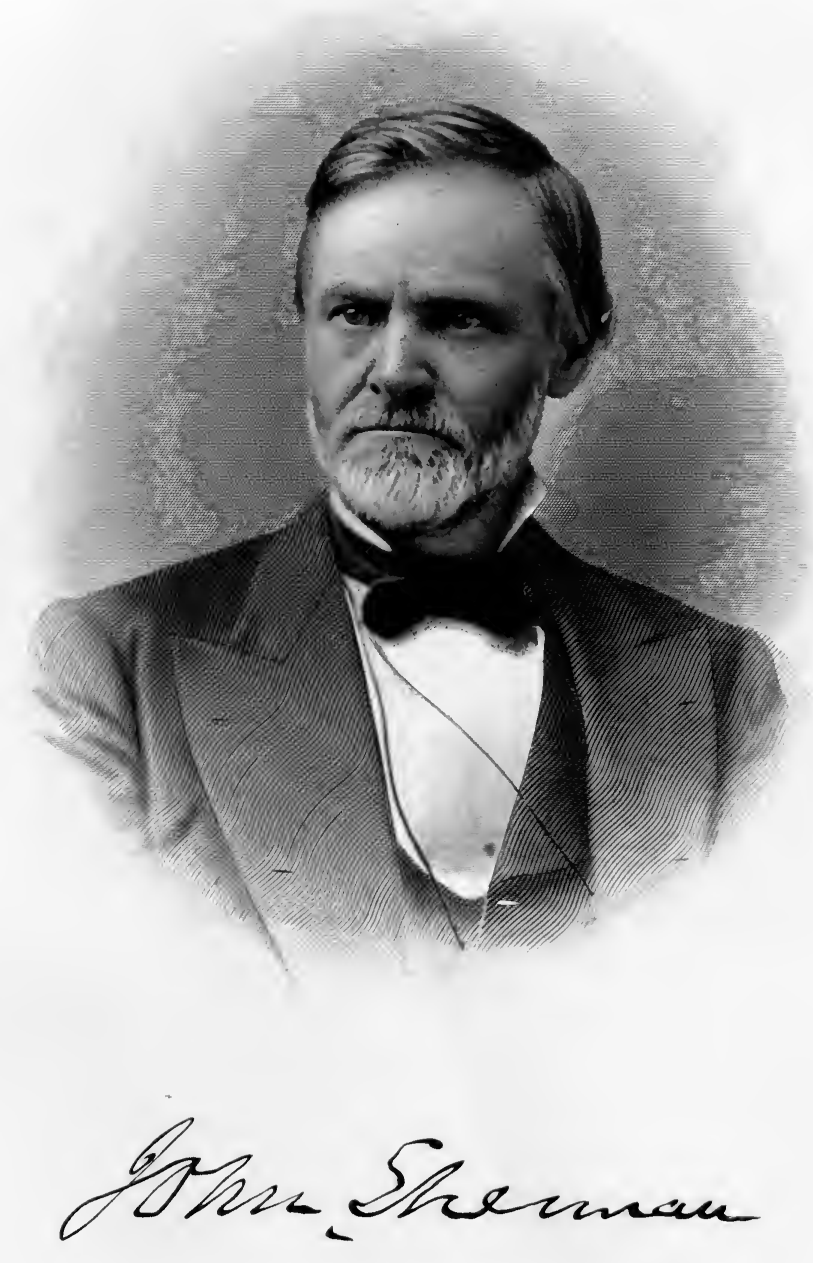



President, and Elihu Baker, Secretary, and these gentlemen were retained in their respective offices during the entire remaining life of the bank.

In 1860 it was learned that one of the branches had made unsafe investments. The executive committee promptly took charge of its affairs and authorized a reorganization, calling upon other branches for such aid as was required, which was given, so that the branch, with no delay and without the loss of a cent to its customers or note holders, or suspension of its legal business, was again put on a firm and solvent basis.

\section{Suspension of Specie Payments During the Civil War.}

Early in the Civil War there was a general suspension of specie payments throughout the country, which action was followed by a heavy premium on gold coin. As the notes of the State Bank, then over a million dollars, were all payable in coin, and the constitution prohibited the suspension of specie payments, it became a serious problem to prevent immediate return for redemption of this large sum, a contingency which would swamp some of the banks and greatly inconvenience public business. In this emergency the board of directors published the consolidated statement of the banks showing their remarkable strength, and passed resolutions that in view of the suspension of specie payments by the general Government and the issuance of the United States greenbacks, which were to be made legal tender for all debts, public or private, that all branches be required to receive such demand notes in payment of any or all debts due them, and in view of the fact that a continuance of the indiscriminate redemption in coin of the circulating notes of the branches would inevitably result in relieving their vaults of the specie on hand to the benefit mainly of non-residents and of brokers engaged in collecting the outstanding circulation for speculative purposes; it was therefore the opinion of the board that the highest consideration of duty to themselves and the people of the State required that all bills be redeemed in United States legal-tender notes, or in coin, as the branches might choose, and that such redemption of their bills in United States legal tenders should not be interpreted as an infraction of the provision of the charter. Although the several branches were urged to redeem their notes in coin when said notes were in hands of people of their own State, yet this action was virtually a discontinuance of specie payment. The branches were ordered to retain within their vaults the full twenty-five per cent. of their circulation. This order was emphasized because of the strong temptation to sell the gold coin and realize the heavy premium at which it was then quoted.

During the war the affairs of the bank and its branches movedalong with but little friction, though several of the branches were found to have adopted some dangerous practices tending to injure their credit, but prompt action on the part of the officers of the State board brought 
them into line again without injury or loss to stockholders or customers, and without knowledge at any time by the public.

To the branch banks of the State of Iowa was largely due the prompt response of the State to the call of President Lincoln for troops to put down the Rebellion of 1861. At that time there was not a dollar in the State treasury to pay for arming and equipping troops, and the only way to obtain the necessary funds was by applying to the banks. As soon as the needs of the State were made known the banks responded promptly and generously, and all united, regardless of politics, to aid the State in fitting out and sending her soldiers to the front.

\section{Closing of the State Bank of Iowa.}

When the National banking system was established and a heavy tax imposed on the circulating notes of banks doing business under the State law, the local bank circulation was rapidly suppressed.

At a meeting of the directors of the State Bank of Iowa in February, 1865, steps were taken to close up the affairs of the bank. It was ordered that all the bank circulation on hand, as well as the mutilated notes returned by the branches, be burned, and that no branch be relieved from any legal obligations to the State Bank until all the circulation of all the branches be redeemed or its redemption provided for beyond a doubt. The branches were forbidden after March 15 of that year to pay out circulating notes of their own or any other branches, and were instructed to send the parent bank at least once every thirty days thereafter all the State Bank notes in their possession. Stringent provision was also made for the redemption of their notes, and they were rapidly withdrawn from circulation, the entire circulation being redeemed without the loss of a cent.

At the meeting of the board in August, 1865, formal action was taken providing for the complete closing of the bank, and notice given that on November 1 , following, the safes and other furniture would be sold and the office at Iowa City formally closed. The last meeting of the board was held in Davenport November 25, 1865.

Most of the branches were at once merged into National banks, and so quietly and easily was this done that the change was little felt.

The first consolidated statement of the eight original branches at the beginning of business February 7, 1859, and also the last statement, January 2, 1865, of the fifteen branches before going out of business, will be found below. 
State Bank of Iowa, Statement February 7, 1859.

ASSETS.

\begin{tabular}{|c|c|c|c|c|c|c|}
\hline NAME OF BRANCHES. & $\begin{array}{l}\text { Safety } \\
\text { fund. }\end{array}$ & Specie. & $\begin{array}{c}\text { Notes of } \\
\text { other } \\
\text { specie pay- } \\
\text { ing banks. }\end{array}$ & $\begin{array}{l}\text { Due from } \\
\text { specie pay. } \\
\text { ing banks. }\end{array}$ & $\begin{array}{c}\text { Loans } \\
\text { and } \\
\text { discounts. }\end{array}$ & $\begin{array}{c}\text { other } \\
\text { items. }\end{array}$ \\
\hline Muscatine Branch............ & $\$ 4,843$ & $\$ 17,560$ & $\$ 25,926$ & $\$ 11,304$ & $\$ 18,380$ & $\$ 6,776$ \\
\hline Dubuque Branch............... & 3,750 & 15,659 & 16,721 & 20,336 & 17,727 & 6,456 \\
\hline Keokuk Branch................ & 3,480 & 17,620 & 3,289 & 19,798 & 26,835 & 2,576 \\
\hline Mount Pleasant Branch...... & 2,940 & 14,467 & 6,885 & 10,462 & 18,718 & 3,186 \\
\hline Merchants' Br., Davenport... & 6,000 & 34,024 & 13,608 & 8,482 & 20,888 & 3,784 \\
\hline Oskaloosa Branch.............. & 3,125 & 15,595 & 4,817 & 13,159 & 13,531 & 1,818 \\
\hline Branch at Iowa City...... & 3,875 & 32,523 & 6,811 & 8,597 & 12,899 & 1,250 \\
\hline Branch at Des Moines..... & 3,666 & 23,798 & 4,201 & 5,224 & 24,433 & 1,850 \\
\hline Total........................... & $\$ 31,680$ & $\$ 171,248$ & $\$ 82,258$ & $\$ 95,365$ & $\$ 153,414$ & $\$ 27,698$ \\
\hline
\end{tabular}

\section{LIABILITIES.}

\begin{tabular}{|c|c|c|c|c|c|}
\hline NAME OF BRANCHES. & Capital. & $\begin{array}{c}\text { Circula. } \\
\text { tion. }\end{array}$ & $\begin{array}{c}\text { Due } \\
\text { other } \\
\text { banks. }\end{array}$ & $\begin{array}{l}\text { Due } \\
\text { to deposi. } \\
\text { tors. }\end{array}$ & $\begin{array}{l}\text { Other } \\
\text { items. }\end{array}$ \\
\hline Muscatine Branch........... & $\$ 34,000$ & $\$ 15,995$ & $\$ 165$ & $\$ 33,945$ & $\$ 686$ \\
\hline 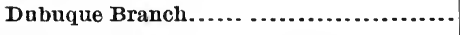 & 30,000 & 11,577 & (....... & 38,374 & 699 \\
\hline Keokuk Branch................... & 26,250 & 17,121 & ....... & 28,674 & 1,110 \\
\hline Mount Pleasant Branch.................. & 25,000 & 10,686 & 443 & 20,060 & 913 \\
\hline Merchants' Branch, Davenport... & 25,300 & 10,189 & 387 & 50,310 & 601 \\
\hline Oskaloosa Branch......... & 25,000 & 12,380 & ...... & 14,340 & 325 \\
\hline Branch at Iowa City..................... & 25,000 & 17,096 & 145 & 23,095 & 617 \\
\hline Branch at Des Moines................... & 25,000 & 11,750 & $\ldots \ldots$ & 25,440 & 983 \\
\hline Total.......... & $\$ 215,550$ & $\$ 106,794$ & $\$ 1,142$ & $\$ 234,241$ & $\$ 5,938$ \\
\hline
\end{tabular}


State Bank of Iowa, Statement January 2, 1865. ASSE'TS.

\begin{tabular}{|c|c|c|c|c|c|c|c|}
\hline $\begin{array}{l}\text { LOCATION } \\
\text { OF } \\
\text { BRANCHES. }\end{array}$ & $\begin{array}{l}\text { Safety } \\
\text { fund. }\end{array}$ & Specie. & $\begin{array}{l}\text { Notes } \\
\text { of other } \\
\text { banks. }\end{array}$ & $\begin{array}{c}\text { Due from } \\
\text { other } \\
\text { banks. }\end{array}$ & $\begin{array}{l}\text { Loans and } \\
\text { discounts. }\end{array}$ & $\begin{array}{c}U . S . \\
\text { and State } \\
\text { bonds. }\end{array}$ & $\begin{array}{l}\text { Other } \\
\text { items. }\end{array}$ \\
\hline Burlington .... & $\$ 35,500$ & $\$ 77,526$ & $\$ 243,654$ & $\$ 139,525$ & $\$ 470,432$ & $\$ 19,100$ & $\$ 3,454$ \\
\hline Council Bluffs. & 68,000 & 6,333 & 25,520 & 64,148 & 59,664 & 1,824 & 11,192 \\
\hline Davenport..... & 25,000 & 3,284 & 217,401 & 58,147 & 166,490 & 54,600 & 11,376 \\
\hline Des Moines.... & 19,500 & 36,731 & 66,646 & 4,735 & 173,894 & 10,000 & 1,986 \\
\hline Dubuque....... & 36,305 & 71,806 & 102,817 & 84,345 & 427,826 & 115,956 & 20,408 \\
\hline Fort Madison.. & 19,000 & 16,674 & 38,433 & 7,577 & 60,272 & 3,588 & 20,021 \\
\hline Iowa City...... & 13,000 & 8,775 & 112,415 & 37,153 & 128,823 & 27,881 & 2,818 \\
\hline Keokuk..... & 20,000 & 38,288 & 71,835 & 41,353 & 169,090 & 40,278 & 2,871 \\
\hline Lyons City..... & 12,500 & 33,678 & 47,487 & 68,223 & 86,037 & 8,200 & 5,227 \\
\hline Maquoketa.... & 7,700 & 15,543 & 46,747 & 27,200 & 30,603 & 1,687 & 4,221 \\
\hline McGregor..... & 7,000 & 4,934 & 8,007 & ............ & 58,981 & 1,050 & 84 \\
\hline Mt. Pleasant.. & 12,000 & 23,526 & 123,446 & 13,383 & 175,677 & 31,287 & 10,993 \\
\hline Muscatine..... & 11,000 & 19,754 & 73,372 & 55,000 & 158,955 & 7,022 & 16,094 \\
\hline Oskaloosa....... & 12,000 & 22,270 & 31,006 & 21,029 & 108,734 & ............ & 6,833 \\
\hline Washington... & 10,400 & 10,674 & 91,688 & 46,686 & 192,877 & 38,700 & 5,260 \\
\hline Total........ & $\$ 308,905$ & $\$ 389,802$ & $\$ 1,300,481$ & $\$ 668,511$ & $\$ 2,468,362$ & $\$ 361,182$ & $\$ 122,844$ \\
\hline
\end{tabular}

LIABILITIES.

\begin{tabular}{|c|c|c|c|c|c|c|}
\hline $\begin{array}{l}\text { Location of } \\
\text { BRANCHES. }\end{array}$ & Capital. & Circulation. & $\begin{array}{c}\text { Due other } \\
\text { banks. }\end{array}$ & $\begin{array}{c}\text { Due to } \\
\text { depositors. }\end{array}$ & $\begin{array}{l}\text { Other } \\
\text { items. }\end{array}$ & $\begin{array}{c}\text { Total } \\
\text { liabilities. }\end{array}$ \\
\hline Burlington .......... & $\$ 150,000$ & $\$ 266,940$ & $\$ 1,265$ & $\$ 552,177$ & $\$ 18,810$ & $\$ 989,193$ \\
\hline Council Bluffs...... & 50,000 & 97,904 & 113 & 57,135 & 31,530 & 236,683 \\
\hline Davenport.......... & 60,000 & 1,785 & 5,454 & 452,751 & 16,308 & 536,299 \\
\hline Des Moines......... & 78,000 & 140,035 & 1,404 & 83,369 & 10,684 & 313,493 \\
\hline Dubuque............ & 150,000 & 283,837 & 9,148 & 361,474 & 55,005 & 859,465 \\
\hline Fort Madison... & 77,000 & 68,886 & 187 & 19,493 & (............ & 165,566 \\
\hline Iowa City........... & 70,000 & 32,276 & 479 & 214,772 & 13,348 & 330,875 \\
\hline Keokuk....... & 80,000 & 132,477 & 1,233 & 156,232 & 13,773 & 383,717 \\
\hline Lyons City........... & 50,000 & 86,586 & 1,501 & 111,758 & 11,509 & 261,355 \\
\hline Maquoketa .......... & 25,000 & 30,640 & 46 & 73,339 & 4,679 & 133,705 \\
\hline McGregor ......... & 50,000 & 19,484 & 296 & 4,009 & 6,268 & 80,058 \\
\hline Mount Pleasant.... & 50,000 & 90,390 & 1,616 & 212,738 & 35,569 & 390,314 \\
\hline Muscatine ......... & 58,200 & 64,390 & 12,069 & 199,816 & 6,722 & 341,199 \\
\hline Oskaloosa............ & 50,000 & 81,131 & .......... & 64,355 & 6,388 & 201,875 \\
\hline Washington........ & 50,000 & 43,003 & 110 & 288,037 & 15,136 & 396,286 \\
\hline Total............ & $\$ 1,048,200$ & $\$ 1,439,764$ & $\$ 34,929$ & $\$ 2,851,462$ & $\$ 245,735$ & $\$ 5,620,091$ \\
\hline
\end{tabular}




\section{The Present State Banking System of Iowa.}

From the merging of the branches of the State Bank of Iowa into National banks in 1864 up to 1873 , a number of banks were organized under the general incorporation laws of the State as banks of discount and deposit. The Code of 1873 provides for the regulation of these banks by the State.

They are required to make quarterly statements to the State Auditor, specifying the amount of capital stock actually paid in, the amount of debts of every kind other than to regular depositors, the total amount due depositors, the amount of deposits with other solvent banks or bankers, specifying places and amount deposited in each, the amount of gold, silver and bullion on hand, and the amount of bills on hand of solvent specie-paying banks, the amount of discounts and other evidences of debt owned by the bank and specified as good, doubtful and in judgment, the value of all real or personal property held by the bank, the amount of undivided profits, if any, and the total amount of all liabilities to the bank on the part of the directors thereof.

The Auditor of the State was empowered to call for a report at any time, as often as four times a year, and he was further empowered to make a personal examination of such banks, if at any time the public interest seemed to warrant it, and in case the state of affairs demanded such action, to direct the Attorney-General to commence proceedings for the closing of the bank and for the liquidation of its business, giving preference in the payment of creditors to depositors. A failure to make the required report to the State Auditor was made punishable by a fine of not less than $\$ 100$ nor more than $\$ 1,000$, or by imprisonment not less than three months nor more than three years in the penitentiary. The provisions of this law were not to be enforced against any existing incorporated banking institution or officers thereof, provided that on or before September 1, 1873, any such institution should file a satisfactory sworn statement of its condition with the Auditor of State.

The law required a capital of $\$ 50,000$ except in towns having a population not exceeding three thousand, where such association might be organized with a paid-up eapital of not less than $\$ 25,000$.

These laws are practically the laws governing the State banks at the present time with the additions that the stockholders are now made additionally liable for all liabilities to the amount of their stock; that in case the capital of the bank becomes impaired an assessment can be made on the stockholders for any sum necessary to make the capital stock good; all State banks located in cities or towns having a population of less than three thousand shall, at all times, maintain a reserve of not less than ten per cent. of their total deposits, and banks located in cities or towns having a population of three thousand or more, shall maintain a reserve of not less than fifteen per cent. of their total de- 
posits; three-fourths of such reserve may be kept on deposit with other banks organized under State or national laws.

A more recent law provided for bank examiners under the direction and supervision of the State Auditor.

The State banks have had a rapid growth, as will be seen by the statement given below giving the consolidated report from the date of the first report to the Auditor to the present time.

Statement Showing the Condition of State Banks for a Series of Years.

\begin{tabular}{|c|c|c|c|c|c|c|c|}
\hline DATES. & 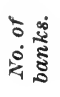 & $\begin{array}{c}\text { Bills } \\
\text { receivable. }\end{array}$ & $\begin{array}{c}\text { All other } \\
\text { assets. }\end{array}$ & $\begin{array}{c}\text { Amount } \\
\text { due } \\
\text { individual } \\
\text { depositors. }\end{array}$ & $\begin{array}{l}\text { Capital } \\
\text { stock. }\end{array}$ & $\begin{array}{c}\text { Other } \\
\text { liabilities. }\end{array}$ & $\begin{array}{r}\text { Total } \\
\text { assets. }\end{array}$ \\
\hline Sept. $26,1873$. & 23 & $\$ 2,968,162$ & $\$ 910,870$ & $\$ 2,555,412$ & $\$ 1,015,956$ & $\$ 307,664$ & $\$ 3,879,033$ \\
\hline Oct. $23,1875 .$. & 23 & $2,511,387$ & 773,962 & $1,621,105$ & $1,307,902$ & 356,342 & $3,285,350$ \\
\hline Sept. 1, 1877.. & 31 & $2,786,246$ & 945,012 & $1,689,227$ & $1,623,652$ & 418,379 & $3,731,259$ \\
\hline Sept. 27, 1879. & 33 & $2,747,793$ & $1,186,803$ & $2,032,344$ & $1,526,305$ & 375,946 & $3,934,596$ \\
\hline Sept. $30,1881$. & 31 & $4,030,381$ & $1,997,287$ & $4,153,493$ & $1,512,755$ & 361,419 & $6,027,638$ \\
\hline Aug. $4,1883$. & 48 & $5,324,200$ & $2,102,426$ & $4,439,653$ & $2,366,793$ & 620,181 & $7,426,627$ \\
\hline June 30,1885 & 50 & $\mathbf{5 , 4 1 7 , 3 8 5}$ & $2,444,153$ & $4,238,226$ & $2,896,043$ & 727,269 & $7,861,539$ \\
\hline June 30,1887 & 66 & $7,444,217$ & $2,832,089$ & $5,747,286$ & $3,579,843$ & 949,176 & $10,276,306$ \\
\hline June 30, 1889 & 80 & $9,945,086$ & $3,225,017$ & $7,271,515$ & $4,416,743$ & $1,481,844$ & $13,170,103$ \\
\hline June 30, 1891. & 122 & $16,510,903$ & $5,258,888$ & $12,960,211$ & $6,460,898$ & $2,338,630$ & $21,769,741$ \\
\hline June :30, 1893. & 177 & $20,534,831$ & $5,586,034$ & $15,725,402$ & $8,074,420$ & $2,321,043$ & $26,120,866$ \\
\hline June 30, 1895 . & 194 & $20,419,528$ & $6,239,898$ & $15,668,647$ & $8,737,900$ & $2,252,879$ & $26,659,427$ \\
\hline June 30, 1897 & 206 & $19,988,145$ & $8,214,601$ & $16,857,239$ & $9,135,700$ & $2,209,806$ & $28,202,746$ \\
\hline June 30, 1899. & 207 & $27,683,416$ & $13,116,684$ & $29,257,807$ & $9,073,170$ & $2,691,123$ & $40,800,100$ \\
\hline
\end{tabular}

\section{Savings Banks of Iowa.}

Provision for the Savings bank system of Iowa was made by the Fifteenth General Assembly in 1874. There had been, it is true, a number of so-called Savings banks prior to this time, but they were such in name only. They included the name Savings in their bank title, but they were left entirely to their own discretion in the transaction of their business.

Under the law of 1874 a Savings bank might be organized by not less than five persons and with a capital of $\$ 10,000$ in towns of ten thousand inhabitants or less, or $\$ 50,000$ capital in towns or cities with more than ten thousand inhabitants. The usual corporate powers were granted. The amount of deposits was limited to ten times the paid-up capital, and in case this amount should be exceeded, the capital must be increased so as to come within the provision of the law. The usual provisions for repayments of deposits were made, and in addition the 
Savings banks were given the privilege of requiring sixty days' notice for the withdrawal of deposits.

The Savings banks were allowed to invest their funds in the securities named below :

(1) Stocks, bonds or interest-bearing notes of the United States.

(2) Stocks, bonds, or evidences of debt bearing interest, of the State of Iowa.

(3) Stocks, bonds and warrants of any city, town village, or school district in the State regularly issued, but not to exceed twenty-five per cent. of the assets of any Savings bank should consist of such bonds or warrants.

(4) Mortgages or debts on unincumbered real estate within the State worth at least twice the amount loaned.

(5) It was made lawful for such banks to discount, purchase, sell and make loans upon commercial paper, notes, bills of exchange, drafts or any other personal or public security, except that such banks should not purchase, hold or make loans upon the shares of their own eapital stock.

The law allowed the banks to own a bank building with lot and also such property as they might acquire by foreclosure of mortgage, providing that such property be not held more than ten years.

The rate of interest to be paid was left to the discretion of the trustees, and the profits, after the payment of such interest and expenses, went to the capital stock.

Stockholders were liable to the creditors besides their stock to an amount equal to the stock held by them, and such liabilities continued for six months after transfer of any stock.

Directors were to receive no compensation.

Officers and directors of the bank were required to give similar security for loans as required of others, and such loans could only be made by the board in the absence of the party applying therefor. The Savings banks were also prohibited from loaning to any individual or firm more than twenty per cent. of the capital stock.

Other banking institutions were prohibited from using the term Savings bank in their title.

All Savings banks were required to make a quarterly statement to the Auditor of the State, giving in detail the statement of condition upon a given day. This statement was made under oath of the officers, and was required to be published in the county where the bank was located.

False statements of condition or false entries on the bank books by any officer, agent or clerk, were declared a felony and punishable with a fine not exceeding $\$ 10,000$ and imprisonment in the penitentiary not less than two, or more than five years.

The State Auditor was given the power to examine any Savings bank at any time, and should the conditions warrant such proceedings, he 
was required to report the facts to the Attorney-General, who instituted proceedings under the law relating to insolvent corporations.

Provision was made for increasing the capital stock by a two-thirds vote of the existing shares. The corporate existence of the banks was placed at fifty years. At all elections each share had one vote.

The statements were required to specify : the capital stock; the debts of every kind; the deposits, sight and time; amount of deposit with other banks; amount of gold and silver on hand; amount of discounts, specified as good, doubtful, or in judgment; amount of personal property; undivided profits and total liabilities on part of directors.

The bank, and not the stockholders, was required to pay the tax, and it was provided that the bank property be subject to no greater tax than other property. It took a three-fourths vote of all the capital stock to dissolve the corporation.

Although at the time this Savings bank bill was passed there was some considerable apprehension in regard to allowing such banks to deal in commercial paper and loan on personal security, yet this has not proved a source of weakness, and was a necessary provision at that time, as a strictly Savings bank, without authority to do any commercial business, would have had insufficient encouragement. That feature of the bill providing for real estate mortgages on unincumbered real estate within the State has been of great value, as such loans, when properly made in the State of Iowa, have always been safe and remunerative.

From 1870 to 1874 there had been a number of Savings banks organized under the regular corporation laws of the State. When the bill above referred to became a law, these institutions adapted themselves to the provisions of the law, and were duly authorized to conduct a Savings bank business under the laws and regulations specified.

The growth of Savings banks in Iowa has been rapid, both in numbers and the amount of business done. There has been little chang in laws governing them. Provision is now made for examination of each bank by a State bank examiner at least once a year. Those Savings banks which do a commercial business in towns of less than three thousand population are now required to keep a cash reserve fund equal to fifteen per cent. of their commercial deposits and eight per cent. of their Savings deposits, and banks in cities or towns having a population of three thousand and over, must keep a cash reserve fund equal to twenty per cent. of their commercial deposits and eight per cent. of their Savings deposits. Savings banks doing an exclusive Savings bank business shall at all times keep a cash fund equal to eight per cent. of their deposits. Three-fourths of such reserve fund may be kept on deposit subject to eall with other banks organized under State or National laws. The table given below shows the growth of the Iowa Savings banks from the organization of the system down to the present time. 
Statement of the Condition of Savings Banks for a Series of Years.

\begin{tabular}{|c|c|c|c|c|c|c|c|}
\hline DATES. & $\begin{array}{l}\overrightarrow{0} \\
0 \\
\dot{0} \\
\dot{4}\end{array}$ & $\begin{array}{c}\text { Bills } \\
\text { receivable. }\end{array}$ & $\begin{array}{c}\text { All other } \\
\text { assets. }\end{array}$ & $\begin{array}{c}\text { Amount } \\
\text { due } \\
\text { individual } \\
\text { depositors. }\end{array}$ & $\begin{array}{l}\text { Capital } \\
\text { stock. }\end{array}$ & $\begin{array}{c}\text { other } \\
\text { liabilities. }\end{array}$ & $\begin{array}{c}\text { Total } \\
\text { assets. }\end{array}$ \\
\hline Oct. $23,1875 .$. & 19 & $\$ 2,620,754$ & $\$ 580,831$ & $\$ 2,338,685$ & $\$ 755,500$ & $\$ 107,399$ & $\$ 3,201,585$ \\
\hline Sept. 1, 1877.. & 19 & $2,737,126$ & 524,049 & $2,295,803$ & 792,500 & 172,872 & $3,261,176$ \\
\hline Sept. 27,1879 . & 20 & $3,018,753$ & 876,560 & $2,868,375$ & 795,300 & 231,638 & $3,895,314$ \\
\hline Sept. $30,1881$. & 22 & $5,306,314$ & $1,401,704$ & $5,513,722$ & 914,000 & 250,296 & $6,708,018$ \\
\hline Aug. 4, 1883... & 28 & $7,193,920$ & $1,225,819$ & $6,761,144$ & $1,335,000$ & 323,594 & $8,419,739$ \\
\hline June 30,1885 . & 34 & $7,644,653$ & $1,974,213$ & $7,401,633$ & $1,645,000$ & 572,233 & $9,618,866$ \\
\hline June $29,1887$. & 37 & $10,326,774$ & $2,339,573$ & $9,969,019$ & $2,128,693$ & 568,635 & $12,666,347$ \\
\hline June 30, 1889 & 50 & $14,343,105$ & $2,842,234$ & $13,125,058$ & $3,256,400$ & 803,881 & $17,185,340$ \\
\hline June 30, 1891. & 83 & $21,225,963$ & $5,258,583$ & $20,821,495$ & $4,565,500$ & $1,097,551$ & $26,484,546$ \\
\hline June $30,1893$. & 148 & $29, \$ 69,994$ & $5,363,982$ & $26,426,031$ & $6,409,700$ & $1,898,244$ & $34.733,976$ \\
\hline June 30, 1895. & 170 & $30,567,691$ & $6,817,938$ & $28,158,489$ & $7,423,400$ & $1,803,741$ & $37,385,630$ \\
\hline June 30, 1897 . & 166 & $28,903,442$ & $8,693,252$ & $28,585,654$ & $7,151,500$ & $1,854,539$ & $37,596,694$ \\
\hline June 30, 1899 & 195 & $43,236,779$ & $14,667,668$ & $48,147,860$ & $7,800,000$ & $1,955,587$ & $57,904,448$ \\
\hline
\end{tabular}

\section{National Banks.}

The banks of Iowa came quickly to the support of the general Government, when Congress provided for the organization of National banks and through them for a market for the Government bonds. As noted elsewhere, the various branches of the Iowa State Bank at once discontinued, and most of them became National banks; one bank, the First National Bank, of Davenport, having the honor to be the first National bank organized in the United States. From that time the growth of this banking system in the State has been steady until now (1899) there are 168 , with total resources of $\$ 73,720,272$.

\section{Private Banks.}

Because of the legislative opposition to banks in the early history of the State, private banking became a necessity to meet the demands of trade. From the admission of Iowa as a State, in 1846, until the organization of the State Bank of Iowa, in 1858, all of the banking business of the State was transacted by private bankers.

With the development of the interior counties, men of other business, such as land agents, general store-keepers, etc., transacted more or less of a banking business in connection with their regular business. As the country grew in population, and as the demand for banking facilities increased, these gradually dropped their other lines of business and became full-fledged private bankers.

A large majority of the private bankers are self-made men in the 
best sense of the term. They have developed with the development of the country about them; their knowledge of banking has been gained by hard experience, and as a class they are careful, shrewd, and substantial business men.

This class of banks number about five hundred and fifty, or as many as all the other banks put together. It is estimated that their total deposits will amount to forty millions of dollars. They enjoy the confidence of the people in their several localities.

From time to time an effort has been made in the State Legislature to bring these banks under State control, but without success.

\section{Iowa Bankers' Association.}

The Iowa Bankers' Association was organized July 26, 1887, with a membership of twenty-nine. From this small beginning it has grown to be one of the largest and most practical of the State bankers' associations of the country. The association has met each year, and has shown a substantial and uninterrupted growth, until at the present. time (1899) the total membership is about four hundred and twenty-five.

The Iowa bankers have taken an advanced position on all matters of practical value to the members. In 1897 the group system was adopted. The same year funds were set aside from the treasury for the apprehension and prosecution of criminals operating against members. of the State association. A prominent lawyer was selected in each county to look after the State association's business for that county, and in every case of fraud against a member the matter has been taken up at once and pushed vigorously, regardless of time and expense. As a result, the association has been able to send a number of criminals to the penitentiary, and it has prosecuted bank swindlers so thoroughly and successfully that the members of the association are remarkably free from such losses.

\section{Business and Banking Characteristics of the State.}

Iowa is one of the principal agricultural and stock-raising States of the Union. It has never had a failure of crops. The history of the State shows a steady and substantial growth every year. For these reasons Iowa is a good banking State. It has no great overshadowing cities, but instead an exceptionally large number of small towns, each of which is a banking and trade center for the surrounding country.

While the aggregate bank capital employed will not compare with several Eastern States, yet in point of money earned on capital employed, Iowa banks will compare most favorably with those of any other State.

Assuming a population of 2,200,000 for the State, the average per capita deposits of the State, as taken from the last statements, would be $\$ 74.50$, thus showing that Iowa is well at the front among the States in bank deposits. 
As has been noted Iowa took a decided stand against wildeat banking, although this system of supplying money was in vogue in most of the surrounding States. From that time down to the present, the banking business has been conducted in the most conservative way. At the present time this State has taken the most advanced position on the gold standard question of any State in the West. This action is doubtless due to the high average intelligence and conservatism of the population.

\section{National Banks.}

Figures are in thousands of dollars.

\begin{tabular}{|c|c|c|c|c|c|c|c|c|c|}
\hline YEARS. & 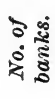 & $\begin{array}{l}\text { Loans and } \\
\text { discounts. }\end{array}$ & $\begin{array}{c}U . S . \\
\text { bonds. }\end{array}$ & $\begin{array}{c}\text { Cash and } \\
\text { cash items. }\end{array}$ & Capital. & Surplus. & $\begin{array}{c}\text { Undi- } \\
\text { vided } \\
\text { profits. }\end{array}$ & $\begin{array}{c}\text { out } \text {. } \\
\text { standing } \\
\text { circula- } \\
\text { tion. }\end{array}$ & $\begin{array}{c}\text { Indi- } \\
\text { vidual } \\
\text { deposits. }\end{array}$ \\
\hline $1863 \ldots$ & 3 & $\$ 92$ & $\$ 131$ & $\$ 100$ & $\$ 97$ & ....... & $\$ 4$ & ....... & $\$ 245$ \\
\hline $1868 \ldots$ & 44 & 6,107 & 4,359 & 2,040 & 3,692 & $\$ 554$ & 419 & $\$ 3,153$ & 6,444 \\
\hline $1873 \ldots$ & 75 & 10,787 & 6,180 & 1,972 & 5,812 & 1,252 & 613 & 4,986 & 9,380 \\
\hline $1878 \ldots$. & 76 & 9,635 & 4,898 & 2,110 & 5,957 & 1,414 & 574 & 3,966 & 7,129 \\
\hline $1883 \ldots$ & 110 & 20,124 & 5,600 & 3,318 & 9,055 & 1,950 & 1,009 & 4,596 & 16,648 \\
\hline $1888 \ldots$ & 129 & 26,322 & 3,283 & 3,885 & 10,148 & 2,708 & 1,258 & 2,753 & 21,278 \\
\hline $1893 \ldots$ & 169 & 33,806 & 3,860 & 4,015 & 14,700 & 3,365 & 1,627 & 3,303 & 24,624 \\
\hline $1899 . .$. & 172 & 43,924 & 6,480 & 4,364 & 13,300 & 3,035 & 1,298 & 4,749 & 42,238 \\
\hline
\end{tabular}

\section{MISSOURI.}

The first currency in Missouri, as in nearly all the other early Western States and Territories, consisted of the skins of animals, known by the term, furs and peltries ; it requiried no mining, smelting, assaying or coining - and it possessed almost as great a range of values as the present United States coinage, beginning with a raccoon skin at twelve and a half cents, and rising through deer skins at forty cents, and marten, wolf, buffalo, bear, beaver, lynx, to five dollars for otter. St. Louis was more fortunate than other early settlements in the West in its more liberal supply of this primitive money. There was never any scarcity of it, and it was more varied than that possessed by any other Western settlement-for St. Louis was founded in $\mathbf{1 7 6 4}$ by Laclede and the Chouteau brothers as a fur-trading post, and it drew its furs and peltries, not only from the adjacent forests, prairies and streams, but from that richest fur region on the continent, the head waters of the Missouri-while the vast herds of buffalo on the plains supplied packs of robes without limit. The fur traders at St. Louis, at an early day, before the Louisiana Territory became part of the domain of the United States, had established forts at several places on the Upper Missouri for the gather- 
ing of skins, and the annual fur pack brought down in Mackinaw boats, barges and bull boats was valued at $\$ 200,000$ a year from 1789 to 1804 , which was much the same as an annual influx of currency of that amount. The packs were shipped to New Orleans, Montreal, Philadelphia and sometimes to London. The different kinds of peltries were redeemable in one another, at established rates, and notes, bills and receipts were drawn for so much money, or so many pounds of shaved deerskins, or so many beaver or otter. As late as December 14, 1807, three years after the cession of Louisiana Territory, including Missouri, to the United States, Judge J. B. C. Lucas, a leading citizen of St. Louis, and founder of one of its most eminent families, bought his first permanent residence lot from Pierre Duchoquette for $\$ 600$, payable in peltries. An advertisement in the local paper of January 4, 1809, announces to the St. Louis public that $\mathrm{H}$. Austin \& Co., have received an assortment of dry goods, consisting of coatings, flannels, blankets, velvets, cassimeres, ginghams, etc., which were purchased in New York for cash and "will be sold as low as any in the Territory for cash, or lead, at $\$ 6$ per hundred." St. Louis was the center of the lead trade in the West, and as lead was indispensable for moulding bullets, and a necessary of life, it was quite as good barter money as skins, though less convenient.

There was a good deal of trading by flat boats and keel boats between New Madrid, Ste. Genevieve and St. Louis, in Missouri, and Louisville, Cincinnati and other places on the Ohio River, and the following extract from a bill of lading of 1809 shows that keel-boat owners, in addition to being public carriers, were sometimes accustomed to act as bankers and collectors on their three months' voyage :

"Shipped by Peter Provenchere of the town of St. Louis, merchant, on board the boat of J. Madison, whereof Charles Quirey is master, ready to depart for Louisville, Ky., six packs of deer skins, marked and numbered as per margin (F. T. 96, 99, $109,111,112,113)$, and a barrel of bear's oil, which I promise to deliver unto Mr. Francis Tarascon, merchant, Louisville, Ky.

I acknowledge also to have of said Peter Provenchere a note of Peter Menard on Louis Lorimer, inhabitant of Cape Girardeau, for one thousand pounds of receiptable deer skins, the said note transferred to my order, and I bind and engage myself to ask of said Louis Lorimer the payment of said note, and if I reclaim it, to deliver to said Francis Tarascon or assigns the thousand pounds of deer skins, together with the said six packs and the barrel of bear's oil now received; and in case of no payment, to return the note to Mr. Tarascon, he or they paying the freight."

Cape Girardeau, where this note was to be collected, was a river town in Missouri, on the way between St. Louis and Louisville. The term "receiptable" had about the same meaning as merchantable. There were three grades of deer skins, the prices being forty, thirty, and twenty cents. 


\section{Introduction of Coin into Circulation.}

The first coin in Missouri was silver, sent from Spain for the payment of the garrison at St. Louis, before the cession of the Territory to the United States in 1804. At times these payments amounted to $\$ 12,000$ a year. Deer-skin notes were current in all settlements and towns on the Mississippi and Ohio rivers, and at the lead mining camps in Missouri and Illinois, but they were convertible into coin only at New Orleans. Twenty years after the cession of Louisiana Territory to the United States, a trade grew. up between St. Louis and Santa Fe and Taos, extending at times as far as Chihuahua, consisting chiefly of tinware and drygoods sold to the Mexicans, for which they paid in silver, and this assisted to keep Spanish and Mexican silver coin in pretty good supply in St. Louis, St. Charles, and Ste. Genevieve. The Spanish and Mexican dollars would be cut in four pieces and these passed for quarters.

\section{Establishment of The First Bank.}

The first bank in Missouri was the Bank of St. Louis, chartered by the Territorial Legislature in 1813, but not organized and opened for business till September 2,1816 . The capital was $\$ 100,000$, and it took three years to secure it, with subscription books opened not only in the seven considerable towns in Missouri Territory-St. Louis, St. Charles, Ste. Genevieve, Mine a Breton, Cape Girardeau, New Madrid, and Herculaneum-but in Kaskaskia and Cahokia, across the Mississippi River in the territory of Illinois, also. The population of Missouri Territory was 58,260, and of St. Louis 2,200. Samuel Hammond was President; and John B. N. Smith Cashier, of this bank.

The people of new countries always grow tired of their own primitive currency, and eagerly, sometimes too eagerly, welcome the more convenient, though not always more reliable, paper notes supplied by banks. And so the Bank of St. Louis started off with everything in its favor-a good business, a large measure of popular favor, a free circulation for its notes, and a field all to itself. But these very advantages proved unfortunate. The control of the bauk was worth striving for, and some ill-advised speculations in which it ventured created dissensions which led to a rupture in the board of directors and violent seizure of the property, and its usefulness was at an end. Its business ran down until, in July, 1819, it went into liquidation and passed out of existence.

\section{Sketch of The BaNk OF Missouri.}

Next came the Bank of Missouri, which was opened for business in St. Louis, February 1, 1817, with a capital of $\$ 250,000$, with Auguste Chouteau, one of the founders of St. Louis, and the wealthiest citizen in Missouri, for its first President, and Lilburn W. Boggs, afterwards Governor of the State, for its first Cashier. It had some important ad- 
vantages in its favor-a good round paid-up capital, and the name and support of a leading and prosperous fur trader; and in addition it was made the depository for Government moneys. But it started at an unfavorable time. "It was," says a western chronicle, "a period of gloom and agony-no money, either gold or silver-no paper convertible into specie-no measure or standard of value left remaining-no price for property or produce-no sales but those of the sheriff, or marshal."

Under the conviction that the supreme need of the country was something that would go for money, the banks of other States were issuing their notes with an extravagance that ought to have excited apprehension, but instead was accepted as a token of returning prosperity. Paper money was abundant, and as there was no increase of industry, but on the contrary increasing idleness, the money went into Government lands at $\$ 2$ per acre, $\$ 80$ down, for a quarter section, and the balance in five years-and everybody was to grow rich by selling out to actual settlers, at ten times the cost before the five-years' limit expired. Towns were laid out and the lots sold for notes-for everybody's credit was good, and everybody was thought to be prosperous, though comparatively few were at work in productive employment. Of course this condition of things could not last long; but it lasted long enough for nearly everybody to get hopelessly in debt-and then, when the demand for settlement came, the end came with it, abruptly and with a shock that brought many of the banks to the ground, the Bank of Missouri among them. It did not fail, but it was forced to go into liquidation and close up in 1822.

The disappearance of the two pioneer banks left the chief town in Missouri, now with a population of 4,500 and a growing trade, without any banking facilities, except such as were supplied by two or three private bankers having credit at Baltimore and Philadelphia, and this condition of things lasted till 1829, when the United States Bank opened a branch at St. Louis with John O'Fallon, a popular citizen and officer in the War of 1812, who afterwards became wealthy, as President, and Henry S. Coxe, who had been an officer in the parent bank at Philadelphia, as Cashier. It continued for four years when, on the refusal of Congress to renew the parent bank's charter, it was discontinued. This left a vacancy which was occupied by the Cincinnati Commercial Agency, possessing banking privileges. It established a branch at St. Louis, which served a very good purpose, the United States Government making it a depository and agent through which its considerable army, Indian and land office business was transacted.

\section{The Bank of the State of Missouri.}

The Bank of the State of Missouri was chartered in 1837, with authority to issue notes at the rate of three to one for the specie in its vaults, and with a branch at each of five considerable towns in different sections of the State-Lexington, Fayette, Palmyra, Cape Girardeau 
and Springfield. Its capital was $\$ 3,450,000$, one-half belonging to the State, which made the bank its depository and fiscal agent. The population of Missouri was 310,000, and of St. Louis 11,500. The first President of the bank was John Brady Smith. Its first notes were issued July 31,1837 , and were gladly received. The smallest was $\$ 10$. With its large eapital and the State behind it, this bank became at once a power in the West, and continued to be so for thirty years.

The management was conservative-too conservative to suit the business men of St. Louis. It dealt only in specie and its own notes, and as the supply of its own notes, which were carried to remote regions in the West and even to the Pacific Coast, was insufficient for the wants of the State, the cheap issues of small banks in Illinois, Michigan and other Western States found an easy entrance into Missouri through the channels of trade that connected St. Louis with these States; and when the "Old Bank," as it was called, refused to receive this money, a public meeting was held which protested against the policy, and which was followed by the withdrawal of a considerable business from the bank. Nevertheless, the rule was resolutely adhered to, for it was clearly a measure of wisdom and safety. Had it been relaxed, the business of St. Louis, which had been conducted by a gold standard, would have been shifted to the unstable basis of a paper currency, the discount on which could be learned only from a monthly or weekly bank-note reporter. In 1866 the State sold its stock in the bank to parties who, by this means, secured control of it and converted it into a National bank. The change of management proved most unfortunate.

It became involved in the building of the great steel bridge at St. Louis and the purchase of the North Missouri railroad ; its means were loaned extravagantly to its directors ; and in a little while this culpable policy inflicted losses which brought a formal reduction of its capital to $\$ 2,500,000$. The management went from bad to worse. The public confidence, which it had enjoyed almost without limit for thirty years, was withdrawn, and finally, on June 30,1877 , it failed, after a career of forty years, nearly three-fourths of the period marked by the highest standard of honor and a large measure of usefulness.

The Presidents of the Bank of the State of Missouri, named in the order of succession, were : John Brady Smith, Ferdinand Kennett, Bernard Pratte, Joseph Charless, Edward Walsh, Robert Campbell, James M. Hughes, Robert A. Barnes and Jas. H. Britton.

\section{Conservative Policy Regarding Circulation.}

Although the Bank of the State of Missouri was established to provide the people of the State with a sound currency, it did not suffciently perform the duty. It was too conservative and cautious. It moved too far within the limits of the field assigned to it, and forebore to use the powers entrusted to it as freely as it ought to have 
done, for the public good. The currency it supplied was good enoughalmost too good, for it was esteemed better than gold, but there was not enough of it. The issues never reached the permissible limit of three to one. In 1856, when the population of Missouri was 840,000, and of St. Louis 125,000, and the indications of substantial prosperity to be seen in every department of business, the bank's circulation was only $\$ 2,200,000$, although its stock of $\$ 1,400,000$ specie warranted notes to the amount of $\$ 4,200,000$ and a considerable part of its circulation was doing duty in California, Oregon and Mexico, whither it had been carried by emigrants and traders. It is no wonder that, under these circumstances, Missouri offered an inviting field for the wildcat money issued so profusely by banks in other Western States, and that its people became victims of an inconvertible and unreliable currency, which the bank-note reporter quoted at a discount all the way from five to twenty-five per cent.

So valuable were the notes of the Bank of the State of Missouri in California, in the fifties, that a gang of counterfeiters took advantage of their popularity and struck off imitations of them in large quantities. They were well executed and were freely taken, not only by the miners, but by merchants and private bankers. A package of them, $\$ 15,000$ in anount, was kept for several years in the St. Louis banking house of Page \& Bacon, which had been taken in at a premium in gold by their San Francisco branch house; and a prominent and wealthy citizen of St. Louis suffered an equal loss through the counterfeits received from California.

\section{State Banks of Issue Chartered.}

It was as a remedy for this evil, which had become unendurable, and in response to the persistent demand of the important commercial interests of the chief city of the State, that the Legislature, in 1857, chartered seven banks of issue, with branches conveniently located for the accommodation of business. Six of the parent banks were in St. Louis -the Mechanics', the Southern, the Exchange, the Merchants', the St. Louis, and the Union; and one in Lexington, the Farmers' Bank of Missouri.

These banks were promptly organized in the spring of 1857 , immediately after the act authorizing them was passed, for the State was prosperous and offered a fair field for legitimate investments. The monetary crisis which was impending, but not discerned, fell upon the country shortly after they had opened for business; but they stood the strain well; two of them, the Mechanics' and the Exchange, of St. Louis, refused to suspend specie payment, and continued to redeem in coin through the panic; and when the Civil War broke upon the country, four years later, these two banks again refused to join in the general suspension, and maintained coin payment under all conditions that followed. 


\section{Issue of a Safe Convertible Bank Currency.}

The system of banks organized under the act of 1857 rendered the important service of partially displacing the uncertain and variable currency issued by banks of other States and Territories, which had found so easy a field in Missouri. The Legislature had also authorized the old Bank of the State to establish additional branches, and to issue notes of $\$ 5$; and in a short time every considerable town in the State had a bank, and the notes of Missouri banks, issued at the rate of three dollars to every dollar of specie on hand, afforded a local currency better than that brought in from the outside, which had for years almost monopolized the field. The wildcat money, nevertheless, made a stubborn contest, and the last of it did not disappear till the National Banking Act went into operation. Although the new notes passed at par, there was a time when dealing with the branch banks was attended by difficulties. Bills were made payable at the branches, and this required them to be presented there; and as the notes'of Missouri banks were not available in the East, the St. Louis banks were in the habit of sending parcels of notes by messenger to the branches to exchange them for gold. This practice met with positive disfavor, and even with threats of open hostility from the local communities in which the branches werelocated, and sometimes with ill-concealed unfriendliness from the officers of the branch bank. On two occasions the messengers were waited on by deputations of citizens and informed that they would not be allowed to raid the bank and take gold out of the town. The necessities of the business called for a pretty high order of talent in the messenger-courage, address, and a capacity for diplomatic dealing. Sometimes, after drawing gold for his parcel of notes, he would be forced to appeal to the local Cashier's sense of justice and professional spirit, to take back the package of coin and keep it in his safe until arrangements could be made for transporting it to the nearest express office, railroad station, or river town. There was but a limited railroad mileage in the State in those days, and some of the branch banks were located where the only regular conveyance was by stage coach-and this sometimes made it necessary, after allaying the local opposition by redepositing the coin in the bank, to withdraw it secretly and carry it off by special conveyance at night. This difficulty, which was only temporary, and the result of crude and clumsy ideas rather than of dishonesty, did not have the effect of depreciating the notes, and no losses ever came to the holders of them. In the wild, reckless period, when almost anything in the shape and appearance of an engraved bill with the name of a bank on it was good enough to buy public land with, and good enough, therefore for all other purposes-and in the later period, when other Western States authorized banks to issue notes based on various kinds of bonds with the place of redemption out of the way and difficult of accesssometimes in a forest or swamp-the Legislature of Missouri refused to 
charter institutions to multiply such currency within the limits of the State. Although the first two pioneer banks came to an end, the first in three years, and the second in five years, through mismanagement, their notes were maintained at par to the end. The notes of the Bank of the State of Missouri, which followed them, were preferred to specie, in New Mexico, Utah and on the Pacific Coast, and the same high character marked the issues of the system of banks authorized by the general law of $185 \%$.

\section{Pioneer Banks of St. Louis.}

Ten years after the establishment of the Bank of the State of Missouri, the Boatmen's Savings Institution, of St. Louis, was opened on October 18, 1847, the population of the city at that time being 55,000 , and of the State 592,000. The first suggestion of the institution came from Geo. K. Budd, who for twenty-six years served on the board of directors, and was at one time Comptroller of St. Louis. In 1873 the institution was reorganized under the name of Boatmen's Savings Bank, and in 1889 the name was changed to Boatmen's Bank, the first part of the name, retained through the successive changes, being a reminder of the stirring steamboat period when the river interest was the sontrolling one in St. Louis, and river men a class whose patronage was worth soliciting.

On October 18, 1897, the Boatmen's celebrated its semi-centennial anniversary, its record showing for that period only three Presidents, Adam L. Mills, Sullivan Blood and Rufus J. Lackland-and four Cashiers, Robert Simpson, Alton R. Easton, Charles Hodgman, and Wm. H. Thomson.

Next in order of time came the German Savings Institution, established in 1853, and one of the still existing prosperous banks of the State.

The State Savings Institution was organized in 1855 with R. M. Henning, a prominent and successful merchant, for President. Four years after its organization, its name was changed to State Savings Association. Later still, it was changed to State Bank of St. Louis; and early in 1899 it absorbed the Commercial Bank, and became the State National Bank of St. Louis, with a capital of $\$ 2,000,000$ and surplus of $\$ 400,000$. It has had but four Presidents from 1855 to $1898-R$. M. Henning, John How, John I. Roe and Charles Parsons, all of them exemplars of the probity and prosperity of their city-and four Cashiers, Isaac Rosenfeld, Jr., Charles Parsons, J. H. McCluney and Logan Tompkins. Mr. Parsons has had a connection with the bank as Cashier and President from 1864 to 1899 - a period of thirty-five years.

In 1857 , the same year the first banking law of the State was passed, an institution called the Building and Savings Association was organized in St. Louis. Its beginning was humble and undemonstrative, but it had the good fortune to be under prudent management from the start, its Presidents in succession, down to 1898, having been Marshall 
Brotherton, Felix Coste, H. S. Reed and W. H. Thompson. In 1870 it became the National Bank of Commerce, of St. Louis, and in 1898 was reorganized as one of the strongest and most prosperous banks in the West.

The Mechanics' Bank, the only surviving State bank organized under the law of 1857 that has preserved its original name and character, has also been fortunate in the personal and official character of its management. The first President was Joseph Charless, followed by J. W. Wills, Oliver Garrison, D. K. Ferguson and R. R. Hutchinson, the latter being President in 1898.

'The Merchants' Bank, one of the original State banks of 1857 , became a National bank in 1865, and afterwards absorbed the Laclede National, and still survives as the Merchants'-Laclede National Bank, of St. Louis, one of the leading institutions of the city.

\section{Banks Organized Under the National System.}

The National banking system was begun in the State by the organization of the First National Bank, of St. Louis, in October, 1863, followed the same year by the Second National and Third National, and next year by the Fourth National Bank. The system extended slowly at first through the State, because Missouri was the theatre of almost constant strife during the Civil War, and of stubborn political disputes and turbulence for several years afterwards; but as these quieted down and the communities in certain quarters overcame their repugnance to the term National, the banks increased more rapidly, and in 1898 there were sixty-two National banks in Missouri-six in St. Louis, six in Kansas City, two in St. Joseph, three in Sedalia, two in Chillicothe, two in. Columbia, three in Carthage, two in Joplin, two in Maryville, and one in each of thirty-four other towns. They were about one-tenth in number of all banking establishments in the State, but they possessed over two-fifths of the capital and nearly one-half the aggregate resources.

\section{Establishment of Savings Banks.}

There were over sixty banks in Missouri in 1898, bearing the word Savings in their titles, but not one of them was such an institution as the title indicated. In the year 1839 a meeting of merchants, traders and manufacturers was held in St. Louis to bring about the establishment of a Savings bank, and a committee was appointed to report a plan at a subsequent meeting; but nothing came of it. Many institutions-twenty-one in all-with Savings in their names, have been organized and started in St. Louis, but not one of them possessed the attributes of a regular Savings bank; and three banks which in age, strength and management, present examples of the law of survival of the fittest, the Boatmen's Bank, the State National Bank, and the National Bank of Commerce, have all in turn dropped the word from their titles. This lack of Savings banks in St. Louis and Missouri is not due so 
much to the absence of that thrift which in some of the industrial States and cities of the country exhibits itself in such surprising aggregates of Savings deposits, as it is to the habit of all the commercial banks of paying interest on time deposits, and thus destroying the inducement for Savings institutions. Nevertheless, it has long been the conviction of thoughtful business men that a State which by the U.S. census of 1890 had 143,139 employees earning $\$ 76,417,364$ annually in its industrial establishments, ought to have special institutions for the custody and investment of their savings.

\section{Noted Private Bankers.}

Before the establishment of the State banks of issue in St. Louis, under the law of 1857 , the banking business in the city was largely in the hands of private firms, and some of these rose to eminence and usefulness, though few of them achieved lasting success. The house of Page \& Bacon, established in St. Louis in 1848, with its branch in San Francisco, known as Page, Bacon \& Co., enjoyed so large a share of the public confidence that it issued notes which circulated freely in Missouri and Illinois. Its deposits in St. Louis amounted to millions, and the deposits and business in San Francisco were also large for that day. But unfortunately the house undertook to finance the Ohio and Mississippi Railroad, then in process of construction between Cincinnati and St. Louis, and the difficulties in the way of selling its bonds brought the house into straits for money, and even the great real estate wealth of Mr. Page, the senior partner, estimated at $\$ 3,000,000$, did not avail to protect it in 1855 from a run which forced it to close its doors. In a heroic effort to save the house, Henry D. Bacon, the junior partner, went immediately to New York and secured a supply of money, not as much as he desired, but what he hoped might prove sufficient, and returned with it to St. Louis, walking twenty miles through a snow blockade in Illinois with the money in his possession. When he reached St. Louis the bank was immediately reopened and was beginning to regain the public confidence, when news came by mail that the San Francisco house had been forced to suspend. This stroke forced the St. Louis house to close its doors again, and they were never reopened. The house had rendered immense service to business in St. Louis, and when it failed there was universal regret that it had not been spared for a better fate.

The house of Lucas \& Simonds, afterwards Lucas, Turner \& Co., and still later, Jas. H. Lucas \& Co., had for its head the largest property holder, and representative of one of the oldest families in the city, and was almost an even competitor with Page \& Bacon, in the liberality of its accommodations and its influence in business circles. It too had a branch house in San Francisco, in which Capt. W. T. Sherman, who afterwards became the distinguished General, was a partner, and for a time, manager. L. A. Benoist \& Co., the senior member of which was 
the first private banker in St. Louis and Missouri, was a staunch and popular house; among others that were prominent in the period from 1840 to 1870 were John J. Anderson \& Co., the head of which became the chief organizer and first President of the Bank of St. Louis; Darby and Barksdale, Tesson \& Danjen, Bogy \& Miltenberger, Allen, Copp \& Nesbit, Bartholow, Lewis \& Co., Clark Brothers \& Co., Loker, Renick $\&$ Co., and B. M. Runyon \& Co. Other private bankers in the State who were for a time prominent, and whose names are still found in the list of bank officers in Missouri, were Milton Tootle and Jas. N. Burnes, of St. Joseph ; Jos. L. Stephens, of Boonville; Harvey Salmon, of Clinton; Phil. T. Chappell, of Jefferson City, and Theo. Bruere, of St. Charles.

St. Louis Clearing-House Organized.

In 1868 the St. Louis Clearing-House Association was organized with thirty-five members, thirty-one banks and four private banking houses, Wm. E. Burr, President of the St. Louis National Bank, being the first President, Charles Hodgman, Cashier of the Boatmen's Savings Institution, the first Vice-President, and James T. Howenstein, first Manager. In 1898 there were nineteen banks members of the association, with Wm. H. Thomson, Cashier of the Boatmen's Bank, President, and T. A. Stoddart, Manager. In the thirty years of its existence the association has had four Presidents-Wm. E. Burr, 1868 to 1873; Charles Parsons, 1873 to 1897 ; R. R. Hutchinson, 1897 to 1898 ; Wm. H. Thomson, 1898.

\section{The Introduction of 'Trust Companies.}

In 1889 the first trust company was organized in Missouri, the St. Louis Trust Company, followed a year later by the Union Trust Company and the Mississippi Valley Trust Company, and in 1894, by the Lincoln Trust Company. These in 1898 had an aggregate capital and surplus amounting to $\$ 9,255,855$, and deposits of $\$ 19,038,562$. The opening of these institutions was at first viewed with some disfavor by the banks, but this did not prevent them from securing a share of the public favor and along with it a considerable share of deposits.

\section{Effects of the Panic of 1873.}

The sudden and unlooked-for collapse of 1873 forced many of the banks in the State into suspension, which was temporary and not attended by serious loss to depositors ; but the wounds inflicted were deeper than at first was thought. A number of small banks, all with the attractive title of Savings, had sprung up in St. Louis, and by paying a high rate of interest on deposits were presenting an appearance of surprising prosperity. But the test they were subjected to was more than they could bear, and in the six years that followed the panic twenty-five banks in St. Louis came to their end by failure and liquidation, the National Bank of the State of Missouri among them, tumbling like a colossus in a circle of pigmies. 
The effects of these failures upon general business were far more severe than those that directly followed the panic several years before. The loans of the St. Louis banks were reduced from $\$ 42,000,000$ to less than $\$ 29,000,000$ in sixteen months, and the number of banks from forty-six to thirty-two-deposits decreasing in the time from $\$ 38,500,000$ to $\$ 27,000,000$, while the cash reserve of $\$ 10,000,000$ at the beginning of the period showed only an insignificant reduction.l The protracted and painful depression that produced these effects in St. Louis was attended by similar results in the next largest city in the State, Kansas City. There the general collapse of values and credit throughout the country was aggravated by a local collapse of real estate values, which brought down the First National Bank, of Kansas City, and the Mastin Bank in a wreck, inflicting great losses and hardship.

It is a curious fact that the three stages in Missouri banking began each in a panic, or on the eve of one. The first bank in the Territory was opened a few months before the monetary collapse of 1817. The experiment of a State bank with the State as half owner and directing its great power at times to political ends, had its beginning in the midst of the disastrous convulsion of 1837 , and twenty years later when the system of seven banks, with twenty branches in the State was devised, the banks had only been fairly organized and opened for business when the crisis of 1857 came to multiply the difficulties and dangers of the enterprise.

\section{General Improvement of Banking Conditions.}

The law of $185 \%$, just and liberal in its spirit, and prudent in its requirements, marks the beginning of a better era in the State, the two special experiments that preceded it having proved unsatisfactory and disappointing. It provided for a Commissioner to visit and examine the banks and exercise a supervision over them, and it contained other safeguards against dangerous practices.

Nevertheless, after the office of Commissioner was abolished, there gradually grew up in St. Louis a number of banks doing business mainly on deposits secured by the payment of a high rate of interest. These were swept away in the panic of 1873 , and the field now remains clear of them.

When the collapse of 1893 came upon the country it found the banks in St. Louis and throughout the State better prepared to meet the strain than they ever had been before-and when it was seen it had passed without the usual wrecks in its wake, a strong impression grew up that the banks of Missouri have at last learned the secret of withstanding these periodical convulsions, and if they have not reached a point where they are safe from the havoc which once attended them, they may at least confidently hope that nothing but a general convulsion extending over the entire country will seriously interfere with their business and impair their capacity for good to the community. 
The progress of banking in Missouri has been slow and cautious in comparison with other Western States, and the facilities afforded were for a long time inadequate to the demands of its commerce and the needs of its people.

In 1850 the population of the State was 682,000 , and of St. Louis 75,000 , yet there was but one bank of issue, with six branches, and one small depository institution aside from private bankers-the total bank deposits being $\$ 1,500,000$, less than $\$ 3$ per eapita. In 1856 , with a population in the State of 800,000 , and in St. Louis of 125,200 , the deposits were only $\$ 1,500,000$, showing no increase in the preceding six years.

In 1860 the population of the State had increased to $1,182,000$, a growth of nearly three-quarters, in the preceding decade, and that of St. Louis to 200,000 , while the taxable wealth of the State had more than doubled; yet the deposits in banks, not including private bankers, were only $\$ 4,557,000$ - less than $\$ 4$ per capita.

The Civil War period of 1861 to 1865 was a time of distress and confusion, and not only did the number of banks decrease, but there was much bewilderment and irregularity in conducting the business.

One of the newer branches of the State Bank of Missouri had been established at Arrow Rock, and as it was not doing well, the parent bank decided to retire it, and the local directors were notified to bring the $\$ 100,000$ in gold which was its capital to St. Louis. Instead of doing this at once, the directors held a hasty consultation, and resolved to resist the order, and accordingly took the money at night into the country and buried it in the earth. It was not long before reflection convinced them that the deed was not in strict conformity to the best banking precedents, and at another meeting a reconsideration was had, the gold dug up and delivered to the parent bank-in no measure impaired in value or quantity by the temporary interment.

In 1881, with a population in the State of $2,200,000$, and in St. Louis of 355,000 , and a taxable valuation in the State of $\$ 532,795,000$, there were 237 banks-twenty-two National, 123 State, and ninety-two private-with an aggregate capital of $\$ 14,334,128$, and deposits of $\$ 57,650$,333 , the deposits showing a per capita of over $\$ 26$. In 1892 the population of the State was $2,700,000$, the aggregate bank capital, with surplus, $\$ 58,000,000$, over $\$ 21$ per capita, and the aggregate deposits $\$ 147,000.000$, over $\$ 54$ per capita, the number of banks being 632 , of which 460 were State banks, eighty National, and ninety-two private.

In 1898 , with a population of $3,000,000$, and a taxable valuation of $\$ 971,935,839$, the number of banks was $651-494$ State, ninety-five private, and sixty-two National, the aggregate capital, with surplus, being $\$ 59,111,000$, and the aggregate deposits $\$ 176,530,000$-nearly $\$ 20$ per capita of capital and surplus, and over $\$ 58$ per capita of deposits.

The St. Louis banks show in a period of twenty-seven years some singular changes. In 1872 there were fifty-eight banks, having an aggregate capital, with surplus, of $\$ 20,196,098$, and aggregate deposits of 
$\$ 36,869,956$. Five years later, in 1877 , the number of banks was reduced to forty-two, and the aggregate capital, with surplus, to $\$ 14,318$,813 , and the aggregate deposits to $\$ 33,794,797$. Five years later still, in 1882 , the number of banks was further reduced to twenty-four, and the capital, with surplus, to $\$ 13,492,964$, while the deposits had increased to $\$ 41,729,011$. The next five years' period, bringing the review down to 1887 , shows the number of banks reduced to twenty-one, aggregate capital, with surplus, slightly increased to $\$ 14,824,115$, and the deposits increased to $\$ 45,878,586$. Still another five years' period, bringing the review down to 1892 , shows the number of banks increased to twenty-six, the capital, with surplus, increased to $\$ 24,745,502$, and the deposits largely increased to $\$ 68,285,730$, and the next six years' period, ending with 1898 , shows the number of banks reduced to twenty-one, the capital, with surplus, reduced to $\$ 23,287,060$, and the deposits largely increased to $\$ 95,411,575$. In the twenty-seven years, from 1872 to 1898 , inclusive, the number of banks was reduced from fifty-eight to twentyone, the aggregate capital, with surplus, was increased only about fifteen per cent., while the aggregate deposits were more than doubled, from $\$ 36,839,956$ to $\$ 95,411,575$.

State Banks.

\begin{tabular}{|c|c|c|c|c|c|c|}
\hline YEARS. & $\begin{array}{l}\text { No. of } \\
\text { banks. }\end{array}$ & $\begin{array}{l}\text { Loans and } \\
\text { discounts. }\end{array}$ & specie. & Capital stock. & Circulation. & Deposits. \\
\hline $1835 \ldots . .$. & 1 & $\$ 85,707$ & $\$ 155,341$ & ............ & ............ & $\$ 526,398$ \\
\hline $1839 \ldots .$. & 2 & $1,570,431$ & 691,070 & $\$ 1,027,870$ & $\$ 671,950$ & $1,101,638$ \\
\hline $1844 \ldots .$. & 4 & 951,949 & $1,260,294$ & $1,200,588$ & 731,080 & $1,116,672$ \\
\hline $1849 \ldots$ & 6 & $3,152,028$ & $2,427,685$ & $1,208,167$ & $2,569,950$ & $1,735,409$ \\
\hline $1854 \ldots$. & 6 & $3,958,055$ & 937,835 & $1,215,405$ & $2,487,580$ & $1,313,744$ \\
\hline $1859 \ldots$ & 29 & $9,830,426$ & $3,921,789$ & $5,796,781$ & $6,069,120$ & $3,123,622$ \\
\hline $1863 \ldots$ & 42 & $12,080,501$ & $3,666,017$ & $11,247,681$ & $4,037,277$ & $3,434,262$ \\
\hline $1868 \ldots .$. & 8 & ............ & ........... & $1,960,300$ & ........... & ............... \\
\hline $1874 \ldots .$. & $\ldots \ldots$. & $22,120,031$ & ........... & $8,156,650$ & 2,425 & $20,912,319$ \\
\hline $1879 \ldots \ldots$ & 107 & $19,584,516$ & ........... & $9,251,016$ & ........... & $23,895,780$ \\
\hline $1884 \ldots . .$. & 178 & $42,183,045$ & ........... & $12,605,043$ & ........... & $44,598,887$ \\
\hline $1887 \ldots .$. & 212 & $44,363,311$ & ............ & $11,626,403$ & ........... & $49,173,704$ \\
\hline $1892 . . .$. & 422 & $67,430,918$ & ............ & $18,265,545$ & ........... & $67,234,147$ \\
\hline $1897 \ldots . .$. & 500 & $60,792,418$ & ........... & $20,057,450$ & ........... & $66,830,544$ \\
\hline
\end{tabular}

The foregoing statistics are from the reports of the Comptroller of the Currency and the Bureau of Statistics of the United States Treasury Department. According to the report of the Secretary of State of Missouri in 1899, there were 488 incorporated State banks, ninety private banks and six trust companies doing business in the State, their condition for the years named being as folle $\mathrm{NS}$ : 
Private and Incorporated Banks, 1895, 1897, 1898.

REsources.
Loans and discounts on personal or collateral security................

Loans and discounts on real estate security........................

overdrafts by solvent customers.....

United States bonds on hand.

Other bonds and stocks at their present cash market price........

Real estate (banking house) atmarket value............................

Other real estate at market value....

Furniture and fixtures...............

Due from other banks, good on sight drafts .............................

Checks and other cash items.........

Currency..............................

Gold coin ............................

Silver coin, including pennies........

All other resources................... Total.

$\begin{array}{r}\$ 64,490,048 \\ 7,343,451 \\ 1,644,205 \\ 162,531 \\ \\ 5,625,195 \\ * 3,436,318 \\ \ldots \ldots \ldots \ldots \\ 757,590 \\ 15,334,191 \\ 1,463,569 \\ 6,035,875 \\ 2,961,631 \\ 539,308 \\ \ldots \ldots \ldots . \ldots . \\ \hline\end{array}$

LIABILITIES.

Capital stock paid in.

Surplus fund on hand.................

Undivided profits less current ex. penses and taxes paid.............

Deposits subject to draft at sight by banks and bankers...............

Deposits subject to draft at sight by individuals and others............

Deposits subject to draft at given dates..............................

Bills payable and rediscounts........

Dividends unpaid.....................

Other liabilities.

Total.
1895.

$\overline{\$ 109,793,918}$

1897.

1898.

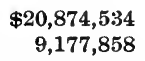

$4,486,453$

$58,494,471$

$15,469,496$

$1,291,105$

.............

$\frac{\cdots \ldots \ldots \ldots}{\$ 109,793,918}$
$\$ 64,953,249$

$7,119,092$

$1,046,295$

174,968

$5,674,868$

$1,258,998$

$1,258,998$

622,226

$18,799,700$

$2,148,264$

$5,631,339$

$3,197,926$

588,593

90,290

$\overline{\$ 113,570,623}$

$\$ 70,290,313$

$7,112,710$

963,254

411,960

$6,240,578$

$2,276,474$

$1,188,897$

581,532

$18,919,910$

$2,783,898$

$7,466,788$

$3,018,833$

643,741

113,655

$\overline{\$ 122,012,553}$

$\begin{array}{rr}\$ 20,633,450 & \$ 20,462,070 \\ 7,386,667 & 7,403,242\end{array}$

$1,373,693$

$1,765,339$

$5,423,114$

$5,760,742$

$61,461,101 \quad 66,258,460$

$16,475,905$

688,791

20,359

107,540

$19,113,605$ 937,902

147,147

$\overline{\$ 113,570,623}$

$\longdiv { \$ 1 2 2 , 0 1 2 , 5 5 3 }$

* Including banking house.

\section{National Banks.}

Figures are in thousands of dollars.

\begin{tabular}{|c|c|c|c|c|c|c|c|c|c|}
\hline YEARS. & 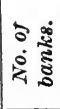 & $\begin{array}{c}\text { Loans } \\
\text { and dis. } \\
\text { counts. }\end{array}$ & $\begin{array}{c}U . S . \\
\text { bonds. }\end{array}$ & $\begin{array}{c}\text { Cash } \\
\text { and cash } \\
\text { items. }\end{array}$ & Capital. & Surplus. & $\begin{array}{l}\text { Undi. } \\
\text { vided } \\
\text { profits. }\end{array}$ & $\begin{array}{c}\text { Out- } \\
\text { standing } \\
\text { circula- } \\
\text { tion. }\end{array}$ & $\begin{array}{c}\text { Indi- } \\
\text { vidual } \\
\text { deposits. }\end{array}$ \\
\hline 1863. & 1 & $\$ 47$ & $\$ 105$ & $\$ 87$ & $\$ 100$ & ........ & $\$ 1$ & ....... & $\$ 75$ \\
\hline $1868 \ldots$ & 18 & 11,722 & 5,557 & 3,410 & 7,810 & $\$ 735$ & 646 & $\$ 4,082$ & 8,259 \\
\hline 1873. & 37 & 16,151 & 7,254 & 2,685 & 9,545 & 1,434 & 925 & 6,131 & 8,158 \\
\hline 1878. & 22 & 8,032 & 2,332 & 2,282 & 4,125 & 902 & 541 & 1,482 & 5,728 \\
\hline $1883 .$. & 34 & 16,808 & 3,000 & 3,964 & 5,850 & 1,216 & 590 & 2,118 & 11,623 \\
\hline $1888 . .$. & 50 & 29,970 & 3,581 & 8,537 & 12,531 & 1,952 & 1,070 & 1,520 & 21,927 \\
\hline 1893. & 78 & 47,465 & 2,696 & 9,576 & 22,865 & 3,610 & 1,594 & 2,064 & 29,138 \\
\hline $1899 \ldots$ & 63 & 87,088 & 6,974 & 16,708 & 17,615 & 4,023 & 3,546 & 4,210 & 68,870 \\
\hline
\end{tabular}


*WESTERN STATES.

While some of the States comprised in this section of the country have their resources but partially developed, others have reached a high degree of productiveness. Nebraska, Kansas, North and South Dakota and Oklahoma are rich in agricultural wealth, and some or them in mineral products also. Colorado leads all the other States in the production of gold, besides possessing numerous other sources of wealth. The other States and Territories are noted for mining and stock raising. Most of the States in this section were admitted into the Union after the suppression of State bank circulation. Their banking history is therefore somewhat limited, and relates chiefly to banks of discount and deposit. The growth of the banks indicates how rapidly this part of the country has advanced in material wealth.

\section{NORTH DAKOTA.}

The organization of the Territory of Dakota in 1861 found but few white men within its northern portion, and they were engaged entirely in trapping, hunting and trading with the Indians. With the advent ot the Northern Pacific Railroad came the pioneers, but not until late in the seventies did the actual settler arrive with his family and make for himself a nome on the broad prairies. From the commencement of settlement the country has continued to grow and prosper.

\section{Beginning of the Banking Business.}

The first person to engage in the banking business was, in all probability, J. W. Raymond, who commenced business July 3, 1873, in Bismarck, aithough Messrs. Shaw and Cathcart, in Bismarck, and E. S. Tyler \& Co., in Fargo, cashed drafts, etc., but did not receive deposits nor make loans. Later Mr. Raymond associated himself with George H. Faurchild, and under the title of the Bank of Bismarck carried on what was the only bank in what is now North Dakota, for a considerable period. They dissolved partnership, and Mr. Fairchild opened the Merchants' Bank, while Mr. Raymond continued as the Bank of

* The division of the country into geographical sections has been made to conform to that adopted in the reports of the Comptroller of the Currency in recent years. 
Bismarck. Mr. Fairchild, with Walter Mann, of St. Paul, organized the First National Bank, of Bismarck, in 1879, being the second in the Territory to organize under the National Act, and the Merchants' Bank transferred its business to the new National institution. Mr. Raymond continued the Bank of Bismarck until 1S82, when the Bismarck National Bank was organized with Mr. Raymond as President, and the business of the Bank of Bismarck was turned over to the new organization. The Bismarck National Bank went into voluntary liquidation, and was succeeded by the Bismarck Bank, with T. C. Power, President and I. P. Baker, Cashier. Mr. Raymond, after serving a term as Treasurer of the Territory of Dakota, moved to Minneapolis, where he became President of the National Bank of Commerce; he resigned to accept the Vice-Presidency of the Northwestern National, and later was elected President of that institution.

It was not until 1878 that a bank was organized in Fargo, now the largest city in the State. Early in January of that year Messrs. A. J. Harwood and J. F. Hummel opened the Bank of Fargo. They were succeeded by Messrs. Sweat \& Miller, under the same title. This bank was merged into the Citizens' National in 1887. with H. F. Miller, President and C. C. Schuyler, Cashier.

\section{The First Incorporated Bank.}

Messrs. E. B. and E. C. Eddy, of Plainview, Minn., and George Q. Erskine, and Harry Stevens, of Racine, Wis., opened for business on January 11, 1878, under the title of the Bank of Dakota, and immediately took steps to organize a National bank, and as a result the First National Bank, of Fargo, was formed. It is without doubt the first incorporated bank in what is now the State of North Dakota, its charter being dated February 13,1878 , with capital paid in $\$ 75,000$; its first officers were: E. B. Eddy, President; N. K. Hubbard, Vice-President, and E. C. Eddy, Cashier. In February, 1887, its capital was increased to $\$ 150,000$; its charter was renewed for twenty years in 1898 . The present officers are W. H. Crosby, President, C. H. Miner, Vice-President and S. S. Lyon, Cashier. E. B. Eddy held the office of President until his death, which occurred February 11, 1885, and was succeeded by his son, E. C. Eddy, who held the position until January, 1887, when he was succeeded by George Q. Erskine. Mr. Eddy, after retiring from the First National, opened a private bank under the title of E. C. Eddy \& Co., but when the State law was passed requiring all banks to organize under either the National or State law, Mr. Eddy discontinued business as a banker.

A few banks were chartered under the general incorporation laws of the 'Territory. The Bank of Grafton, organized in 1881, by F. R. Fulton, S. S. Titus and J. W. Smith, was the first, and was succeeded, in 1884, by the Grafton National Bank. This was followed, in 1882, by the Grand Forks Banking Company and the Bank of Grand Forks, but it 
was not until the State Legislature of 1890 passed a stringent banking law and required that all banks should be organized either under the State or National law (thus prohibiting private banks) that incorporated banks became general. This law also provided for a rigid examination, and made the State Examiner Superintendent of Banks.

\section{Organization Under the New Banking Law.}

The first bank to organize under this law was the Dawson State Bank, under the date of April 26, 1890, but it did not commence business until November 1 of that year. The State Bank, of Lisbon, was the next to organize and commenced business June 28, 1890, with a capital of $\$ 75,000$, closely followed by the Steele County Bank, at Hope, and the Bank of Minnewaukon, June 30. The Northern Pacific Bank, at Mandan, organized Angust 18, but after running a short time sold out to the First National Bank and its corporate existence was dissolved.

The Merchants' State Bank, of Fargo, commenced business August 16,1890 , with a capital of $\$ 50,000$, which has since been increased to $\$ 100,000$. Owing to the fact that an action had been commenced to test the constitutionality of the section of the banking law making it unlawful for private banks to do business, many bankers delayed organizing until the Supreme Court in October, 1890, sustained the law.

Following the decision of the Supreme Court many banks organized, although a number held off hoping to be able to repeal, to some, the obnoxious section, which effort, however, was not successful. The first call on the banks for a statement of condition was made at the close of business October 31, 1890. Eight banks reported under this call.

At the close of business October 31, 1891, sixty-one banks responded to a call by the State Examiner, with total resources of $\$ 3,331,026$, and paid-in capital of $\$ 708,135$.

It was during the year 1892 that the banking interests of the State were discredited throughout the East on account of the questionable character of the numerous institutions organized under the Territorial laws by E. Ashley Mears, formerly of Vermont. Mr. Mears had organized small banks under the State law at points where he had institutions organized some time before under the laws of the Territory; these banks were kept in good condition while the older organizations were grossly mismanaged. The State Examiner did not have authority, under the law, at this time, to take charge of these old institutions, and Eastern people who were looking for high rates of interest took it for granted that the law would protect them, while assisting in its violation. They found, too late, that they had but poor promises for good money invested. All of the Mears institutions have been placed in the hands of Receivers and the assets mostly disposed of, leaving large deficits.

For the year ending October 31, 1893, thirteen new banks were organized; eight of the Mears banks were closed (on account of their manner 
of doing business); three going into voluntary liquidation, and two failed (both, however, paying in full); leaving the number reporting the same as for the preceding year.

For the call for reports at close of business September 29, 1894, seventy banks reported; one new bank organized, one failed and was placed in the hands of a Receiver; two going into voluntary liquidation, and the last two of the Mears institutions were wound up.

The Legislature having changed the date for the fiscal year, the reports of the Examiner for the years subsequent to 1894 are made for the year ending June 30.

For the fiscal year ending June 30, 1896, but three new banks organized; two going into voluntary liquidation, leaving a gain of one for the year.

The Legislature amended the banking law so that five reports are now called for, and at the same date that the calls on National banks. are made by the Comptroller of the Currency.

State Banks.

\begin{tabular}{|c|c|c|c|c|c|}
\hline & 1890. & 1892. & 1893. & 1896. & 1898. \\
\hline \multicolumn{6}{|l|}{ RESOURCES. } \\
\hline 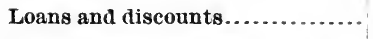 & $\$ 237,087$ & $\$ 2,713,468$ & $\$ 2,341,602$ & $\$ 2,775,817$ & $\$ 3,779,548$. \\
\hline Overdrafts secured and unsecured & 9,566 & 60,352 & 35,201 & 37,553 & 52,202 \\
\hline $\begin{array}{l}\text { Bonds, stocks, securities, claims, } \\
\text { etc................................... }\end{array}$ & 9,101 & 53,905 & 51,422 & 75,098 & 128,845 \\
\hline \multicolumn{6}{|l|}{ Banking house, furniture and fix- } \\
\hline tures............................... & 17,690 & 179,042 & 185,216 & 177,621 & 243,598 \\
\hline 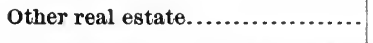 & 1,136 & 50,014 & 59,212 & 160,097 & 186,259 \\
\hline Current expenses and taxes paid. & 5,461 & 90,099 & $\mathbf{5 7 9 , 8 7 9}$ & 63,462 & 176,679 \\
\hline Due from other banks.............. & 86,783 & 734,903 & 101,383 & 486,324 & $1,323,347$ \\
\hline Checks and other cash items...... & 60,143 & 530,582 & 377,392 & 301,846 & 899,099 \\
\hline Total...... & $\$ 426,971$ & $\$ 4,412,370$ & $\$ 3,731,316$ & $\$ 4,077,821$ & $\$ 6,789,582$ \\
\hline \multicolumn{6}{|l|}{ Miabilitiks. } \\
\hline Capital stock paid in........... & $\$ 162,210$ & $\$ 970,500$ & $\$ 1,109,748$ & $\$ 1,151,500$ & $\$ 1,182,435$ \\
\hline 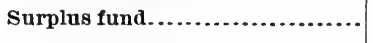 & (............. & $\star 293,700$ & 94,891 & 120,804 & 141,333 \\
\hline Undivided profits.................... & 17,463 & .............. & 236,935 & (............. & 454,614 \\
\hline Individual deposits..................... & 212,355 & $3,003,309$ & $2,078,181$ & $2,483,141$ & $4,880,710$ \\
\hline Due to other banks...................... & 4,862 & 38,239 & 31,405 & 13,019 & 26,887 \\
\hline Notes and bills rediscounted...... & 4,480 & 38,333 & -............ & 46,836 & 25,155 \\
\hline Bulls payable......... & 25,600 & 68,287 & 180,152 & 136,213 & 78,443 \\
\hline Total.......................... & $\$ 426,971$ & $\$ 4,412,370$ & $\$ 3,731,316$ & $\$ 4,077,821$ & $\$ 6,789,582$ \\
\hline Number of banks............... & 8 & 74 & 74 & 71 & 94 \\
\hline
\end{tabular}

* Including profits. 
The call for May 14, 1897, was responded to by seventy-three banks, a gain of two during the year.

During the fiscal year ending June 30,1898 , twelve new banks were organized, one going into voluntary liquidation, making a net gain of eleven. On December 31, 1898, there were twenty-three National banks with a capital of $\$ 1,450,000$, and one hundred and one State banks with a capital of $\$ 1,227,435$-all, with but few exceptions, being in splendid condition. Through the North Dakota Bankers' Association, under the active supervision of the Hon. E. P. Wells, President of the James River National Bank, of Jamestown, many important measures for the betterment of the banking fraternity have been adopted, and the business throughout the State is being conducted on a conservative basis.

\section{National Banks-Dakota}

Figures are in thousands of dollars.

\begin{tabular}{|c|c|c|c|c|c|c|c|c|c|}
\hline YEARS. & 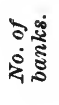 & $\begin{array}{c}\text { Loans } \\
\text { and dis- } \\
\text { counts. }\end{array}$ & $\begin{array}{c}U . S . \\
\text { bonds. }\end{array}$ & $\begin{array}{c}\text { Cash } \\
\text { and cash } \\
\text { items. }\end{array}$ & Capital. & Surplus. & $\begin{array}{c}\text { Undi- } \\
\text { vided } \\
\text { profits. }\end{array}$ & $\left|\begin{array}{c}\text { out. } \\
\text { standing } \\
\text { circula- } \\
\text { tion. }\end{array}\right|$ & $\begin{array}{c}\text { Indi. } \\
\text { vidual } \\
\text { deposits. }\end{array}$ \\
\hline $1873 \ldots . . . .$. & 1 & $\$ 37$ & $\$ 80$ & $\$ 29$ & $\$ 50$ & $\$ 1$ & $\$ 2$ & $\$ 45$ & $\$ 41$ \\
\hline $1879 \ldots . . . .$. & 4 & 354 & 210 & 146 & 205 & 21 & 40 & 117 & 732 \\
\hline $1884 \ldots . . . . .$. & 36 & 3,536 & 878 & 665 & 2,258 & 442 & 297 & 628 & 3,038 \\
\hline $1889^{*} \ldots . .$. & 61 & 7,794 & 1,361 & 749 & 3,930 & 917 & 367 & 892 & 6,469 \\
\hline
\end{tabular}

* After 1889 the Territory of Dakota was divided and the States of North and South Dakota established.

National Banks-North Dakota.

Figures are in thousands of dollars.

\begin{tabular}{|c|c|c|c|c|c|c|c|c|c|}
\hline YEARS. & 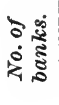 & $\begin{array}{c}\text { Loans } \\
\text { and dis. } \\
\text { counts. }\end{array}$ & $\begin{array}{c}\text { U. S. } \\
\text { bonds. }\end{array}$ & $\begin{array}{c}\text { Cash } \\
\text { and cash } \\
\text { items. }\end{array}$ & Capital. & Surplus. & $\begin{array}{l}\text { Undi- } \\
\text { vided } \\
\text { profits. }\end{array}$ & $\mid \begin{array}{c}\text { Out } . \\
\text { standing } \\
\text { circula- } \\
\text { tion. }\end{array}$ & $\begin{array}{c}\text { Indi. } \\
\text { vidual } \\
\text { deposits. }\end{array}$ \\
\hline $1890 \ldots . .$. & 29 & $\$ 4,145$ & $\$ 509$ & $\$ 411$ & $\$ 1,998$ & $\$ 413$ & $\$ 175$ & $\$ 458$ & $\$ 3,810$ \\
\hline $1893 . .$. & 32 & 5,864 & 619 & 487 & 2,215 & 488 & 257 & 512 & 4,636 \\
\hline $1896 . . .$. & 29 & 5,032 & 490 & 479 & 1,810 & 375 & 230 & 440 & 5,048 \\
\hline $1899 . \ldots \ldots$. & 23 & 4,911 & 418 & 406 & 1,450 & 197 & 281 & 367 & 5,057 \\
\hline
\end{tabular}

SOUTH DAKOTA.

The Territory of Dakota, embracing an area out of which has since been formed the States of Montana, Idaho, Wyoming and North and South Dakota, was authorized by act of Congress March 2, 1861, and organized by the appointment of Territorial officers April 2, 1861. 
The pioneer bank was a private institution located at Yankton and operated by Mark M. Parmer, who came from behind the counter of his father's dry goods store and launched his enterprise without previous experience. This was in the spring of 1869. The population of the Territory at that time, not counting a settlement in the far northeastern corner, at Pembina, numbered about seven or eight thousand, the Territories of Montana, Idaho and Wyoming having in the meantime been organized and their respective areas segregated from the country originally comprising Dakota. These settlers were located along the immediate valley or bottoms of the Missouri River from Sioux City northwestward one hundred and twenty miles, with Yankton near the center. Yankton was the capital of the Territory and at the time contained about four hundred inhabitants.

The banking house of M. M. Parmer was successful from the beginning. The mercantile business of the section was not large, but there was a good demand for money, chiefly on the part of settlers who were desirous of making proof of their claims to public land and paying the Government therefor under the pre-emption law. Loans of this character were uniformly two hundred to two hundred and fifty dollars each, with an assignment of the Receiver's certificate, or the land, for security. The rate of interest demanded and readily paid was two per cent. per month, or twenty-four per cent. a year. In many cases three per cent. per month was paid for the use of money by the borrowers of those early days, but the first statute upon the subject limited the contract rate to twentyfour per cent. per annum, and subsequent loans were so rated.

V. E. Prentis and Henry Newton, under the firm name of Prentis \& Newton, established the second bank in the Territory, at Vermillion, about midway between Yankton and Sioux City, in October, 1871. This was also a private bank, and was discontinued after a few years.

In November, 1872, Mark M. Parmer, L. D. Parmer, Moses K. Armstrong and others organized the pioneer National bank of the Territory, called the First National Bank, of Yankton. Moses K. Armstrong was the President, L. D. Parmer, Vice-President, and Mark M. Parmer, Cashier. The private bank of M. M. Parmer was thereupon discontinued and its business transferred to the new institution. In January, 1874, Mr. Armstrong, who was then delegate in Congress from the Territory, retired, and L. D. Parmer was made President, Mark M. Parmer, VicePresident and C. E. Sanborn, Cashier. In November following Capt. J. C. MeVay, of Pittsburg, with Sanford B. Coulson, who at the time owned a line of steamboats operating on the upper Missouri, bought a large block of stock of the First National and succeeded to its management, Mr. McVay being made President and Mr. Coulson Vice-President, the Messrs. Parmer retiring. In October, 1876, William $\mathrm{H}$. McVay, also of Pittsburg, became interested and was made Cashier, and so officered -except changes in the office of Vice-President-the First National of Yankton has continued, under its renewed charter, to fill its flace in 
that community to the present time. Upon retiring from the First National, in 1874, Mark M. Parmer again engaged in the business of private banking in Yankton, but failed in 1880.

With the rapid growth of population in the Territory, inaugurated during the '70's, banks fast multiplied until division came in 1889, and the two States of North and South Dakota were erected, when sixty National banks and more than double that number of private banks, including banks organized under the general incorporation law and treated as private, were in operation. The division of the Territory and the erection of the two States left in the new State of South Dakota, in November, 1889, thirty-three National and over one hundred other banks, reports having been secured from sixty-one of the latter as a first. effort at the close of that year. From 1872 to the present time there have been established within the boundaries of the present State of South Dakota in all fifty-three National banks. Of this number nine failed, nineteen went into voluntary liquidation or were converted into State banks, and twenty-five are in active operation. The number of other banks established in the meantime is not known, no reports having been required from private banks or any record made concerning the same until some time after the institution of the State. The first showing approaching completeness was made in 1893, when the number of banks in the State not National was given at one hundred and fiftyfive. A great many private banks had in the meantime been established, their advent being especially numerous during the "boom period," but when these active days were past and the demands of business settled to the normal, many were discontinued or lapsed into real estate and loan agencies, actual failures not being especially numerous.

\section{Rapid Increase of Population.}

The "boom period" may be said to have extended from 1879 to 1885, during which time a great influx of settlers came into the Territory, settling all of the prairie country east of the Missouri River where wheat raising engaged the chief attention, and also the Black Hills section, where the mining industry was rapidly developed. The financial depression of 1873 seemed to operate as a serious check upon immigration, doubtless for the reason that those desiring to move westward found themselves unwilling to dispose of their property under the shrinking prices then prevailing, hoping for an early turn and restoration of former values. The turn did not come and the hope for it gave way to a realization that the shrinkage was permanent, which brought with it willingness to accept prices before believed to involve a great. sacrifice, and in 1878-79 the westward movement was resumed, growing into a veritable rush for the free prairie lands and the promising mineral deposits of Dakota during the years from 1880-1882. The census. returns for $18 \% 0$ gave to the whole of Dakota Territory a population of 14,181 , and for 1880, 135,177, while South Dakota alone was found to. 
have 328,808 in 1890 . It is not difficult to imagine the effect had by these people leaving their "dead" property, by sale, in their former localities and bringing the live eash for expenditure in the new community. The new arrivals were generally filled with great enthusiasm and expectancy, and intense purpose to accomplish unusual things prevailed on every hand. The railroad companies at the same time were feverishly pushing their lines over the level prairies, following the tracklayers closely with loaded trains. With the advent of the railroad station towns sprung into existence with surprising rapidity, and the spirit of money making and speculation was everywhere rife. Merchants occupied uncompleted buildings with large stocks of goods and settlers who took up the rich lands bought lavishly.

Along with the lumber yard, the livery stable, the land office, and the general store, came the bank. Its establishment was not difficult -a wire counter-screen, an iron safe and some money, and the equipment was complete. There were no banking statutes to bother and impede, and no State supervision to meddle with the personal affairs or financial standing of those who chose to hold themselves out to the public as proper depositories for the safe keeping of other people's money. Every hamlet had its bank, but no statistics were gathered concerning them at the time, and the number in existence at a particular date can not be given.

Mortgage companies also promptly appeared in the wake of settlement with active agents in all the towns. These largely handled English capital, which appeared to be pushing for investment in farm mortgages in this country at that time, the interest rate secured-ten per cent. flat-being very enticing. The borrower paid from twelve to eighteen per cent., the difference going to the agent as his commission, and it became the practice in many cases to take a second mortgage in lieu of cash for such commission.

The settler, after spending the money brought with him to the country in the establishment of his new home, found an agreeable response to his request for a short-time accommodation at the bank. When this fell due he was given bland attention by the agents of the mortgage companies, and urged to secure from them a mortgage loan for a term of years, being persuaded in many cases to ask for a larger sum than his needs required, the agent having in view his increased commission, and feeling secure in his knowledge of the avidity with which such securities were sought at the time by English and Eastern investors.

Many building and loan associations were instituted and flourished with the times, some of the most enterprising selling their promising shares in large amounts in other States. In short, the facilities for getting into debt could hardly be made easier, and with a future that seemed rosy with promise the new settler offered no resistance. 


\section{Reaction from the Period of Inflation.}

But pay day came, as it always must. Securities which might afford further borrowing were not to be had, and the interest drain had become an exhausting burden. Then came a couple of dry seasons, with a partial failure of crops, and a local financial panic followed. Defaults were the rule, and thousands of settlers abandoned their farms to the mortgage companies, although many other thousands struggled through, and in some way, not easily explained, managed to pay their debts and survive the adverse times. The mortgage companies insisted that the turn in affairs was but temporary, but with the most perverse inconsistency suddenly discontinued loaning, and thereby greatly intensified their own unfortunate situation, while at the same time endeavoring to maintain the full value of their investments in the confident belief of the hoped-for turn until nearly all were finally forced to the wall, the lands which they had acquired failing to sell for the amounts invested in them. Values went out of all kinds of property, and remained out with the inost stubborn persistency. A quarter section of land in one of the northern counties which formerly sustained a mortgage debt of $\$ 800$, which had some years before been fully paid off and discharged, was offered for $\$ 225$, with all taxes paid. It was at the time, and still is, the popular thing to charge the failure of crops with entire responsibility for the adversities of the period referred to, the acute years being 1889, 1890 and 1891. While no doubt the crop failures generally contributed thereto, and in certain localities very much aggravated the situation, the real trouble was the inevitable result of an unreasonable and unwarranted expansion of business, credits and values. The banks, of course, suffered, and the succeeding depression compelled many of them to retire from business. While it was a time when many bank failures might have been expected, but few, in fact, occurred.

\section{Legislation Affecting Banks.}

Legislation having especial reference to the organization of banks or to the business of banking was not attempted until after the admission of the State, except that in 1887 the office of Public Examiner was created, and the incumbent directed to make examination of the affairs of all banks, not National, and of other moneyed institutions incorporated under the laws of the Territory, with a view of determining their financial condition and the legitimacy of their business transactions. Other duties imposed, and which were deemed the more important, occupied the Examiner's time to such an extent that complete banking statistics could not be secured for some years after. Hon. Charles N. Harris, then and now a resident of Aberdeen, was the first incumbent of the office of Public Examiner. The Territorial Legislature passed numerous laws generally affecting the business of banking, such as that 
limiting the contract interest rate-which has by stages been reduced from twenty-four to twelve per cent. per annum-authorizing days of grace, fixing the liability of corporate stockholders, etc.

\section{Banking Law Goes into EfFect.}

South Dakota's first banking act became a law March 10, 1891. It provides that associations for carrying on the business of banking may be formed by three or more persons, at least one-third of the number being residents of the State. A fixed capital is required, thus: In towns containing 500 inhabitants or less, $\$ 5,000$; over 500 and not over 1,000 inhabitants, $\$ 10,000$; over 2,000 inhabitants, $\$ 25,000$. Not less than fifty per cent. of the capital must be paid in before being authorized to commence business, and at least ten per cent. within each period of six months thereafter. Delinquent stock may be sold by the association after giving three weeks' published notice, and if no sufficient bid is offered the amount previously paid on the same is forfeited to the association, but shares of stock so acquired by the association can not be retained for a longer period than six months. The capital stock is divided into shares of $\$ 100$ each, and every director is required to own at least ten shares. Holders of shares are individually responsible, equally and ratably and not one for the other, for all contracts, debts and engagements of the association to the extent of their stock therein at par value, in addition to the amount invested in and due on such shares. Dividends can only be declared on net profits, after deducting losses and bad debts.

Loans cannot be made by an association upon the security of its own stock, nor upon real estate security beyond an aggregate of sixty per cent. of its paid-up capital, nor to any individual or firm in excess of fifteen per cent. of such capital. The act provides that each bank shall at all times have on hand in available funds an amount equal to twenty per cent. of its deposits, one-half of which must be in actual eash and one-half may be balances due from solvent banks. All banks are required to make sworn reports of their condition on a date past, upon the call of the Public Examiner, who is required by law to make such calls at least four times a year. State banks must publish an abstract of such reports in a local newspaper. Severe penalties are provided for any falsification in statements or in entries in bank books, or for refusal or neglect to comply with any lawful requirement made upon the association by the Public Examiner. This official is given wide latitude in enforcing performance in his examinations so as to determine all the facts.

\section{Growth of State and Private Banks.}

The following statistics are given that the situation with reference to the banking business since the organization of the State may be seen more in detail : 


\section{State and Private Banks.}

\begin{tabular}{|c|c|c|c|}
\hline Asset8. & 1889. & 1893. & 1898. \\
\hline Loans and discounts.......................... & $\$ 2,158,539$ & $\$ 4,310,649$ & $\$ 4,688,498$ \\
\hline Overdrafts........................ & 66,157 & 134,794 & 136,710 \\
\hline Stocks, bonds, warrants and tax certificates & 157,263 & 209,592 & 295,382 \\
\hline \multicolumn{4}{|l|}{ Banking house, furniture and fixtures and } \\
\hline other real estate....... & 416,212 & 572,267 & 543,371 \\
\hline Expenses and taxes paid.. & 100,066 & 124,922 & 533,018 \\
\hline Due from other banks...... & 482,109 & 591,552 & 155,842 \\
\hline Cash and cash items............... & 277,126 & 571,608 & 761,567 \\
\hline 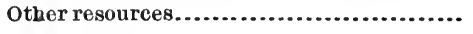 & 26,413 & 68,037 & $1,326,253$ \\
\hline Total. . & $\$ 3,679,885$ & $\$ 6,583,421$ & $\$ x, 440,641$ \\
\hline \multicolumn{4}{|l|}{ LIABILITIES. } \\
\hline Capital stock paid in... & $\$ 1,661,450$ & $\$ 1,987,053$ & $\$ 2,077,980$ \\
\hline Surplus fund.......... & 94,345 & 212,296 & 234,319 \\
\hline Undivided profits and dividends unpaid.... & 220,270 & 325,181 & 378,828 \\
\hline Individual and bank deposits................ & $1,541,774$ & $3,556,148$ & $5,467,859$ \\
\hline Reciiscounts and bills payable.............. & 162,046 & 502,743 & 281,655 \\
\hline Total...... & $\$ 3,679,885$ & $\$ 6,583,421$ & $\$ 8,440,641$ \\
\hline State banks............. & $\cdots \cdots$ & 82 & 95 \\
\hline Private and incorporated, general law....... & *61 & 73 & 69 \\
\hline
\end{tabular}

* About one-half, only, reporting.

Comparative Table Showing Condition of all Banks in South Dakota in 1893 and 1898.

\begin{tabular}{|c|c|c|}
\hline ASSETS. & 1895. & 1898. \\
\hline 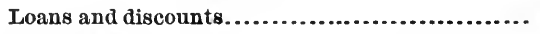 & $\$ 8,564,760$ & $\$ 8,032,837$ \\
\hline Overdrafts......................... & 199,115 & 215,984 \\
\hline United States bonds and premiums................. & 903,941 & 804,645 \\
\hline 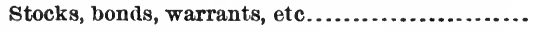 & 910,341 & 912,733 \\
\hline 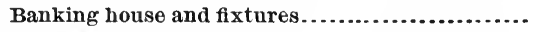 & 962,783 & 828,364 \\
\hline 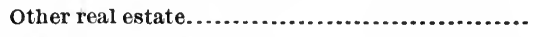 & 282,619 & 824,167 \\
\hline 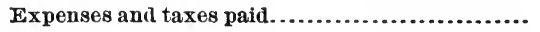 & 124,922 & 155,842 \\
\hline 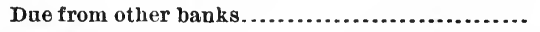 & $1,436,342$ & $2,871,865$ \\
\hline Cash and cash items................................... & $1,291,240$ & $1,547,741$ \\
\hline 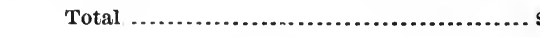 & $\$ 14,676,063$ & $\$ 16,194,178$ \\
\hline \multicolumn{3}{|l|}{ LiABILITIES. } \\
\hline Capital stock paid in & $\$ 4,497,053$ & $\$ 3,662,380$ \\
\hline 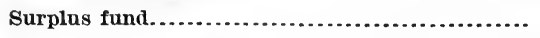 & 812,671 & 525,577 \\
\hline Undivided profits and dividends unpaid.............. & 525,139 & 588,273 \\
\hline 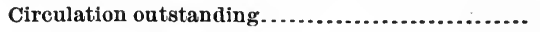 & 616,815 & 455,422 \\
\hline Individual and bank deposits....................... & $7,432,999$ & $10,462,688$ \\
\hline 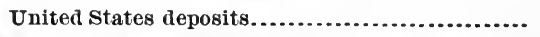 & 142,976 & 199,083 \\
\hline Rediscounts and bills payable...................... & 648,410 & 300,155 \\
\hline Total. & & 4,178 \\
\hline
\end{tabular}


It is certain that lands and other real property in South Dakota are steadily gaining in value, and the above comparative figures show that the banking business is also experiencing a gratifying and healthy improvement.

\section{National Banks-Dakota.}

Figures are in thousands of dollars.

\begin{tabular}{|c|c|c|c|c|c|c|c|c|c|}
\hline YEARS. & 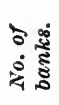 & $\begin{array}{l}\text { Loans } \\
\text { and dis- } \\
\text { counts. }\end{array}$ & $\begin{array}{c}U . S . \\
\text { bonds. }\end{array}$ & $\begin{array}{c}\text { Cash } \\
\text { and cash } \\
\text { items. }\end{array}$ & Capital. & Surplus. & $\begin{array}{l}\text { Undi. } \\
\text { vided } \\
\text { profits. }\end{array}$ & $\begin{array}{c}\text { out. } \\
\text { standing } \\
\text { circula. } \\
\text { tion. }\end{array}$ & $\begin{array}{c}\text { Indi- } \\
\text { vidual } \\
\text { deposits. }\end{array}$ \\
\hline $1873 \ldots . . .$. & 1 & $\$ 37$ & $\$ 80$ & $\$ 29$ & $\$ 50$ & $\$ 1$ & $\$ 2$ & $\$ 45$ & $\$ 41$ \\
\hline $1879 \ldots . . .$. & 4 & 354 & 210 & 146 & 205 & 21 & 40 & 117 & 732 \\
\hline $1884 \ldots . . .$. & 36 & 3,536 & 878 & 665 & 2,258 & 442 & 297 & 628 & 3,038 \\
\hline $1889^{*} \ldots \ldots$ & 61 & 7,794 & 1,361 & 749 & 3,930 & 917 & 367 & 892 & 6,469 \\
\hline
\end{tabular}

*After 1889 the Territory of Dakota was divided and the States of North and South Dakota established.

\section{National Banks-South Dakota.}

Figures are in thousands of dollars.

\begin{tabular}{|c|c|c|c|c|c|c|c|c|c|}
\hline YEARS. & 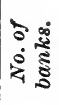 & $\begin{array}{c}\text { Loans } \\
\text { and dis- } \\
\text { counts. }\end{array}$ & $\begin{array}{c}\text { U.S. } \\
\text { bonds. }\end{array}$ & $\begin{array}{c}\text { Cash } \\
\text { and cash } \\
\text { items. }\end{array}$ & Capital. & Surplus. & $\begin{array}{l}\text { Undi- } \\
\text { vided } \\
\text { profits. }\end{array}$ & $\begin{array}{c}\text { Out. } \\
\text { standing } \\
\text { circula. } \\
\text { tion. }\end{array}$ & $\begin{array}{c}\text { Indi- } \\
\text { vidual } \\
\text { deposits. }\end{array}$ \\
\hline $1890 \ldots \ldots$ & 39 & $\$ 4,909$ & $\$ 981$ & $\$ 521$ & $\$ 2,545$ & $\$ 597$ & $\$ 225$ & $\$ 580$ & $\$ 4,075$ \\
\hline $1893 . . . . .$. & 39 & 4,511 & 842 & 569 & 2,510 & 600 & 204 & 615 & 3,561 \\
\hline $1896 \ldots \ldots$ & 30 & 3,222 & 686 & 718 & 1,885 & 371 & 114 & 477 & 3,910 \\
\hline $1899 . \ldots \ldots$ & 25 & 3,761 & 766 & 587 & 1,460 & 270 & 208 & 495 & 5,281 \\
\hline
\end{tabular}

\section{NEBRASKA.}

The history of banking in Nebraska begins with the birth of the Commonwealth.

The history of banking in the United States may be said to be embraced in two distinct epochs. The first, commencing with the issue of paper money by or under the authority of the separate Colonies and continued in the same manner by the several States after the Revolution, and for a time by the general Government, through the Banks of the United States, may be termed the era of "currency banking," which came to a disastrous termination in the panic of $185 \%$. The second era began when the Government issued Treasury notes during the Civil War to circulate as money, and authorized the circulation of bank notes, secured by a pledge of Government securities, and practically prohibited all other forms of paper money. This may be 
called the era of deposit banking, which exists at the present time. The period immediately preceding the panic of 1857 was the high-water mark of currency banking, and may properly be called currency banking run wild.

Nebraska was born when the spirit of wild currency banking pervaded the land, the Kansas-Nebraska Act becoming a law in May, 1854.

\section{Characteristics of the State Bank Notes.}

One fact should always be mentioned when this currency is discussed, because it is not generally understood. The notes were not legal tender; and, unlike the Government currency issued during the Civil War, they were not payable merely in other paper money no better than themselves, but were by their terms redeemable on demand in gold and silver coin. There was in them no trace of the "fiatism" which is now the controlling element with one of the political forces seeking national supremacy upon the money issue. But, notwithstanding this fact, there were just grounds for the antagonism of Jackson, Benton and the rest of the old-time Democratic leaders towards even this apparently harmless species of paper money. Its tendency was to drive gold and silver from circulation, and when the United States Bank currency was issued, this result came very near to being realized. The fall of the United States Bank did not entirely destroy the system. It retarded the inflation business and gave currency banking a check which continued for a number of years, and it was never again undertaken under the direct auspices of the general Government.

The organization and settlement of new States and Territories supplied an exceptional opportunity for the increase of bank-note currency. Not only was capital in demand in these new sections to an extent which invited the issue of credit money, but another favorable feature was added. The more inacessible the place from which the notes were issued the more desirable became that place for the establishment of a bank, and in this manner the names of places, which in fact had scarcely any existence, became familiar throughout the country by reason of their bank notes.

\section{The Currency Era.}

Nebraska opened up a magnificent field for this kind of business. There were no railroads within hundreds of miles, and travel by way of the Missouri River was too uncertain and consumed too much time to give the note issuers much concern or anxiety. To the currency attraction was also added that of speculation in town lots, and the two often went hand in hand.

The main business of the first and second second sessions of the Tervitorial Legislature, aside from the occasional all-absorbing topie of eapital location, was the forming of business corporations under special charters, with banking privileges expressed or understood, and the adop- 
tion of special acts organizing cities and towns which had existence only on paper. Of the numerous municipalities thus established only a few can now be traced on the map of Nebraska, but their non-existence did not prevent speculation in these paper towns to a preposterous extent.

\section{Banking Declared a Chime.}

There were no bank charters directly granted at the first session held in January, 1855. In fact the initial legislative proceedings indicated a decided antipathy to banks, for in the Criminal Code adopted at this session is the following. (Laws of 1855, Chap. 2, Sec. 168):

"If any person shall subscribe to or become a member of, or be in any way interested in any association or company formed for the purpose of issuing or putting into circulation any bill, check, ticket, certificate, promissory note, or other paper of any bank to circulate as money in this Territory, he shall be punished hy imprisonment in the county jail not exceeding one year, or by a fine of not more than one thousand dollars."

Other sections of the same act prohibited incorporated companies, their officers, agents or directors, from issuing notes under penalties, and declared void all notes and obligations given to such companies contrary to the preceding sections.

Notwithstanding this stringent prohibition, several charters were passed at the same session, which, while ostensibly for the business of insurance, were really intended for banking.

Among them was that granted to the Western Exchange Fire and Marine Insurance Company, of Omaha, which subsequently occupied a prominent position among the currency banks and became the official depository of the Territorial government. The only words in its charter which could be construed to authorize a banking business were these: "to receive deposits and issue certificates therefor." Its bank notes for this reason were all in the form of certificates of deposit payable to bearer, with the name of the depositor written in.

Other incorporations were effected of a similar character at this session, but it does not appear that any of the companies engaged in the banking business. One of them carried the following limitation after the words used in the charter of the Western Exchange, which authorized the company to receive deposits, "provided nothing in this act shall be construed as to give the corporation the power of banking," from which it must be concluded that in those days the power to receive deposits did not of itself constitute a banking business, and that banking necessarily had connected with it the power to issue notes.

The second session held in January, 1856, was prolific of bank charters. At this session, general statutes were adopted, and in Chapter 3, under the head of "Corporations," was the following: "Section 1. Any person or persons may be associated and incorporated for the 
transaction of any lawful business." However, as banking was made unlawful in the Criminal Code, special charters were required.

The following clause occurs in all the bank acts passed at this and the succeeding session of the Legislature :

"Section 1. * * * and the said company, under the above name and style, are hereby declared capable in law of issuing bills, notes and other certificates of indebtedness.

Section 2. It shall be the duty of the President or Vice-President (either of whom shall be competent) and Cashier to attach their respective names to all bills or notes issued by said bank to circulate as currency, and the stockholders shall be each and individually liable for the full and final redemption of such issue, payable at their banking house in gold and silver."

Section 3 provides for an annual report to the Auditor of the condi. tion of the bank.

The following banks were given charters at the session of 1856: Bank of Florence; Bank of Nebraska, at Omaha; Nemaha Valley Bank, at Brownville; Platte Valley Bank, at Nebraska City; Fontenelle Bank, at Bellevue.

To this list were added by the session of 1857, the Bank of Tekamah and the Bank of De Sota.*

This coinpletes the list of specially-chartered banks. The last two charters were passed over the Governor's veto. Six others were also passed, but these were killed by the veto.

During the third legislative session, for some special reason the Criminal Code was repealed in its entirety. By reason of this repeal, the banking business was made lawful, and organizations could be effected under Sec. 1 Chap. 3 of the General Statutes already quoted. That the repeal so far as it referred to banks was an oversight is shown in the subsequent passage of an amendment excepting banking from the general privilege, but before this amendment became a law, a number of banks were organized in this manner. At least this is the only plausible explanation for the existence of those banks which did not obtain special charters. It is possible that some were organized in defiance of law, for the Governor at one time ordered the prosecution of one or more for unlawful banking. Nothing, however, came of this effort, and the probabilities are in favor of all these banks having some kind of legal organization.

The following are the banks which were thus organized and issued circulation in varying amounts:

The Waubeck Bank, of De Soto; the Corn Exchange Bank, of De Soto; The Bank of Dakota, Dakota City; The Brownville Bank and Land Company, of Omaha City; the Omaha City Bank and Land Company; the Omaha and Chicago Bank, of Omaha City.

Sainples of the notes of these and other Nebraska banks, together with other State and United States bank currency, are in the Byron

\footnotetext{
* Probably an error in spelling. the name of the town being De Soto.
} 
Reed collection upon exhibition in the Onaha Public Library. The Nebraska bank notes are elegantly engraved, and the signatures appended would indicate that good handwriting was perhaps a more necessary accomplishment for a bank officer then than is the case at present.

\section{History of THE EARLY BanKs.}

The Western Exchange Fire and Marine Insurance Company had for its officers: Thos. H. Benton, Jr., President (a nephew of Senator Benton, of Missouri); Leroy Tuttle, Cashier; A. U. Wynan, Assistant Cashier. The two last named subsequently became Assistant Treasurers of the United States at Washington, under F. E. Spinner, the War Treasurer, and Mr. Wyman afterwards succeeded to the office of Treasurer. $\mathrm{He}$ now (1899) resides in Omaha, being President of the Omaha Loan and Trust Company.

In Sorenson's History of Omaha, it is stated that after the failure of the Western Exchange Fire and Marine Insurance Company in the fall of 1857 the published schedule of its assets showed an aggregate of $\$ 288,083$, the most of which was in "notes and bills receivable," the cash reported being " $\$ 191.03$ in specie and $\$ 121$ in bills of insolvent banks." Nothing was ever realized for creditors from these assets.

\section{The Bank of Nebraska.}

The Bank of Nebraska had for its officers: B. F. Allen, President; Samuel Moffat, Cashier; and D. H. Moffat, Teller.

Mr. Allen was a prominent banker of Des Moines, Iowa, until he removed to Chicago. The disastrous failure in 1875 of the Cook County National Bank of that city, and his connection with it as President, brought him at that time into national prominence.

David $H$. Moffat is now the millionaire banker and mine owner of Denver. He is President of the First National Bank, of Denver, whose stock he mostly owns and to whom he personally supplies a large portion of its aggregate deposits of over $\$ 18,000,000$.

Sorenson says the Bank of Nebraska collapsed in 1856 (1859 intended) "with a balance on its cash books to the credit of the bank of $\$ 8.29$," the meaning of which is not very clear. Another authority says it was the next bank to fail after the Western Exchange. It is possible that this bank finally failed, but it did not fail during the panic. On the contrary, it paid its liabilities in full, and all of its notes bearing the name of $\mathrm{B}$. F. Allen were redeemed by his Omaha agents during many years following. Other parties, to whom Allen and his associates transferred their interest after the panic, undertook to continue the business, but the attempt failed.

It has always been claimed that the Platte Valley Bank, of Nebraska City, met all demands during the panic, and was the only one of the Nebraska banks which succeeded in doing this. It expired, however, in the effort. 


\section{A Bank Whose Notes Were Always Redeemed.}

Several of the remaining banks which were not incorporated until 1857, and had no considerable amount of currency in circulation when the panic came, continued to do business after that event. Nearly all of them, however, were fraudulently managed, and closed their doors after getting into circulation all the notes in their power. There was, however, one honorable exception in the Bank of Dakota City, owned by the Kountze Bros. No banking business was actually transweted at Dakota City. The notes were mainly issued and redeemed in Omaha (to which eity Kountze Bros. removed in the fall of 1857), but to the writer's certain knowledge they were always redeemed on presentation. Mention of this fact is made for the purpose of contradicting an undeserved slur cast upon Kountze Bros. in a paper purporting to be a history of the early Nebraska bank currency, which is published with the proceedings of the Nebraska State Historical Society for 1887. In this paper it is asserted, upon the authority of "three disinterested men who were acquainted with the circumstances," that Kountze Bros. " redeemed the issues of the Bank of De Sota in a sort of desultory manner, buying it up for what it was selling at in the market, and so getting most of it out of the way." This writer is guilty of the inexcusable blunder for a history writer of confusing the name of the "Bank of Dakota" with that of the "Bank of De Sota." Kountze Bros. had nothing whatever to do with the last-named bank, and Sorenson's History, from which the writer inaccurately quotes for the purpose of contradicting, made no error of this kind, but states properly the name of Kountze Bros.' bank.

This ends the chapter of currency banking in Nebraska. Not a trace of the business remained a few years after the panic, and the manner in which the business of the banks was conducted, the volume of business transacted, and everything else connected with them, have become more tradition than history, for no record remains which supplies any basis for statistics. There could not have been many annual reports to the Auditor, if indeed they were made at all, and no reports can now be found. The Hon. A. B. Hepburn, when Comptroller of the Currency, included in his annual report for 1892 some interesting tables of the old State and United States banks from 1774 to 1892. The following figures are given for State banks in Nebraska:

State Banks, 1856-1861.

\begin{tabular}{|c|c|c|c|c|}
\hline & No. of banks. & Capital. & Circulation. & Deposits. \\
\hline 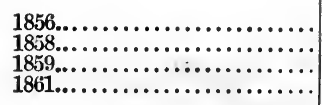 & $\begin{array}{l}4 \\
6 \\
2 \\
1\end{array}$ & $\begin{array}{r}\$ 205,000 \\
15,000 \\
56,010 \\
60,400\end{array}$ & $\begin{array}{r}\$ 355,796 \\
41,641 \\
23,346 \\
16,007\end{array}$ & $\begin{array}{r}\$ 125,291 \\
33,673 \\
23,348 \\
10,717\end{array}$ \\
\hline
\end{tabular}


The name of Nebraska then disappears from these statistics until 1886-7. From whom these figures were obtained and what banks were referred to, is a matter for conjecture, and the accuracy of the figures must be questioned, as they seem to disprove themselves. The number of banks could not have increased in 1858, and if they had done so, there should have been some increase in capital and deposits, instead of the heavy decline shown.

\section{Era of Deposit Banking.}

With 1857 commences the history of deposit banking in Nebraska.

The following are the banks (all private) which commenced business prior to 1860, and they are believed to be given in their proper order:

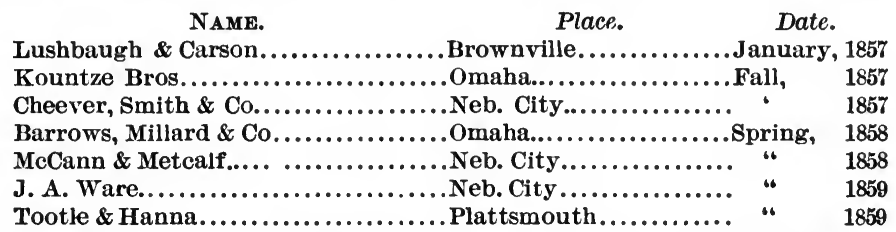

The above seven institutions are the pioneers of banking in $\mathrm{Ne}$ braska. It is a remarkable fact that the banking houses thus established more than forty years ago all survive, although greatly altered in form and name and under different managements.

No greater tribute can be given to the character of their founders than this statement itself carries with it. Panics have come and gone, financial disasters almost unparalleled have afflicted the Commonwealth; in some cases, notably that of the Nebraska City bankers, the individuals themselves have failed and passed from public view, but the work of these men remains and will continue long after the last one of them passes away enduring monuments to their honesty, fidelity and sound business judgment.

\section{Pioneer Banks and Their Descendants.}

The bank of Lushbaugh \& Carson, Brownville, Neb., the name of which was soon changed to John L. Carson \& Co., became the First National, of Brownville. Subsequently, when business was diverted from Brownville to Auburn (by reason of the construction of a railroad in its rear), this bank went into liquidation. Mr. Carson organized the Carson National Bank, of Auburn, and was it President until his death a few years ago.

The name of Cheever, Sweet \& Co., Nebraska City, was early changed to Jas. Sweet \& Co. This business was merged into the James Sweet National Bank, the name of which was afterwards changed to the present Merchants' National Bank, of Nebraska City.

Kountze Bros., of Omaha, organized the First National Bank, of Omaha, in August, 1863, one of the earliest National banks organized 
under the then recently adopted National Currency Act. They continued their private banking firm until July, 1865, when that business was merged into that of the National bank. They also established branches in 1862 in Denver and Central City, Colo., which subsequently became respectively the Colorado National Bank, of Denver, and Rocky Mountain National Bank, of Central City. They disposed of their interest in the Central City Bank, but still own the control of the Denver bank. During the construction of the Union Pacific, they also opened a bank in Cheyenne, Wyo., under the name of Kountze Bros. \& Co., but this bank was in business only a short time. In 1868, one of the brothers, Mr. Luther Kountze, who was the pioneer of the Colorado business, opened a banking office under his own name at 52 Wall Street, New York. He was afterwards joined in the business by his brothers, and the present banking business of Kountze Bros. was organized. The senior brother, Mr. Augustus Kountze, removed from Omaha to New York, where he died a few years ago. Mr. Herman Kountze, the present senior member of the firm, resides in Omaha, and is President of the First National Bank.

Henry W. Yates, while in the employ of Kountze Bros., in 1863, completed the organization papers of the First National Bank, and was connected with that bank as an officer and director until 1882, when he resigned to organize the Nebraska National Bank, of Omaha.

The name of Barrows, Millard \& Co., of Omaha, was early changed to Millard, Caldwell, \& Co. The two brothers, Ezra and Joseph Millard, withdrew from the firm in 1865 in order to establish the Omaha National Bank. The private banking house became Caldwell, Ham. ilton \& Co., and so continued until 1883 , when it was merged into the present United States National Bank. Both Caldwell and Hamilton are dead, but their sons are still represented in the present business as Vice President and Cashier respectively, and Mr. Barlow, the surviving partner of the banking firm, is its President.

Mr. Ezra Millard withdrew from the Omaha National Bank in 1884 and organized the Commercial National Bank, of which he remained President until his death in 1886. His son, Alfred Millard, is the present Cashier of the bank.

Joseph H. Millard, who was formerly Cashier of the Omaha National Bank, succeeded his brother Ezra as its President, and continues so at the present time.

McCann \& Metcalf, Nebraska City, became D. J. McCann \& Co., when Mr. Metcalf retired in $\mathbf{1 8 6 5}$ in order to organize the present Otoe County National Bank, and in 1871 the business of D. J. McCann \& Co. as merged into the existing Nebraska City National Bank.

J. A. Ware, of Nebraska City, organized, in 1866, a branch in Omaha der the name of J. A. Ware \& Co. Ware's bank in Nebraska City failed about 1872, but prior to that time, in 1870 , the Omaha business was bought by ex-Governor Saunders, Frank Murphy, B. B. Wood, 
and others, and organized into the State Bank of Nebraska, which afterwards, in 1882, was converted into the present Merchants' National Bank of Omaha.

The firm name of Tootle \& Hanna (Plattsmouth), was changed to Tootle, Hanna \& Clark by the admission into the firm of John R. Clark, who subsequently removed to Lincoln and became prominently connected with the First National Bank of that city, and was its President at his death some years ago. The business at Plattsmouth was merged into the existing First National Bank of that city.

\section{Nebraska Banking in the Sixties.}

The Pike's Peak gold discoveries of 1859, and later discoveries in Idaho and Montana, caused a heavy travel westward, and Nebraska received its share of the business attending it. The Civil War also worked to its advantage by closing the Kansas-Missouri route and diverting the: entire travel through Nebraska and Iowa. Trade took on new life, and at the main outfitting points of Nebraska City and Omaha bankers: again perceived a chance for profitable business. The emigration of itself distributed some money, for every wagon train (and at times they extended for miles) was obliged to obtain supplies at these outfitting points for the long and dangerous journey across the plains. The main business, however, of the banks, was the purchasing of gold dust from returning miners. The extent to which this business was transacted could not now be easily realized, and no statistics exist to indicate its volume, but it was very heavy. In the mining districts currency was unknown, business was transacted almost entirely by means of what was called "trade dust." Every establishment had its scales, and purchases large and small were settled with dust, every man carrying with him his buckskin wallet from which the dust was poured out as needed. The returning emigrants, coming by wagon train, coach, or down the river for thousands of miles in rudely constructed boats called "mackinaws," were obliged to sell some or all of their dust when they reached the settlements on the Missouri River, and the disposition to sell was increased during and after the war, from the changeable and heavy premium for gold, the risks of which changes the owners of the dust were not often willing to take, when the opportunity to realize was presented. Bankers became experts in the business, not only as handlers of trade dust, which was a mixture of sand and dust, but also of the comparatively pure article. They could determine within a few cents the assay value of any dust offered, although it came from numerous gulches, carrying very different values. The amount of money demanded for the business was far in excess of what there was in circulation. Many amusing stories are told in Omaha of embarrassing situations. In most instances the customer could be persuaded to take part of his pay in New York drafts, but sometimes nothing but money would answer, and the last dollar in the Cashier's till would be paid out, so that when a check was 
presented for payment, the holder would have to be induced to hold on to it until some currency could be obtained, or else leave it on deposit. The situation was well understood and such occurrences caused no comment or talk. But there were times when the till was not sufficient to meet the gold dust demand, and then the practice was for one of the offlicers or employees to keep the customer in conversation and good humor while another would go out and ransack the town for all the money that could be obtained from merchants and others.

During the war the Government also made large expenditures in resisting Indian forays and protecting the overland travel. Dealing in Government vouchers became a very lucrative business, the discount at times amounting to thirty or forty per cent. in cases where irregularities were apparent or expected, and time would be required to correct them. Necessarily the banker also became an expert in untangling and straightening papers to make them conform to the red tape regulations of the department in Washington.

Upon these transitory things the banking business was chiefly maintained and prosecuted until the railroad era of the early seventies demonstrated the fact that there was something nore substantial in sight. As one of our ablest newspaper editors-Dr. George L. Miller-said in the "Omaha Herald" many years ago: "Omaha (and Nebraska would have answered equally as well) was practically extinguished under the financial avalanche of $\mathbf{1 8 5 7}$, and did not emerge from its effects until the advent of railroads."

\section{BANKS IN ExISTENCE IN 1873.}

The seven banks whose histories have been traced to the present time were the only banks in business down to as late a date as $\mathbf{1 8 6 5}$. Bringing the record to the beginning of 1873 , the date of the next great panic, and we find the following were the twenty-four banks doing business in the State at that period:

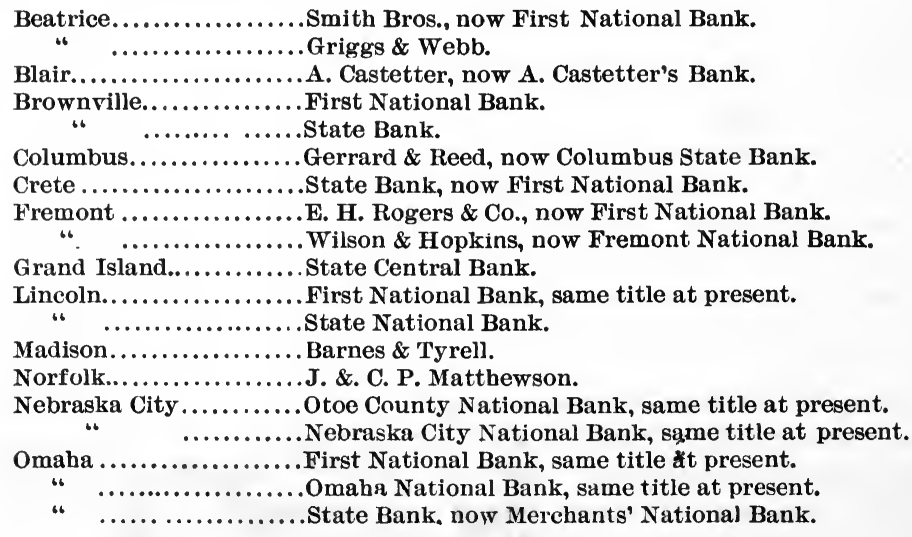


Omaha...................Caldwell, Hamilton \& Co., now United States National Bank.

Pawnee City.............. State Bank, now First National Bank.

Plattsmouth.............. First National Bank, same title at present.

Tecumseh................Russell Holmes, now Tecumseh National Bank.

West Point................ Neligh, Brunner \& Kipp.

\section{The Railroad Era.}

After the panic of 1873 there was no considerable increase in the number of banks until the era of railroad building actually commenced, which was about 1880 . The number of banks then increased so rapidly that they cannot be further given in detail. It is also difficult after this period to obtain definite statistics except for the National banks, and this continued until the passage in 1889 of the act regulating banks and establishing a State Banking Board. This act was a great improvement over any previous legislation, in fact it was the first bank legislation since the currency era. It does not change the manner of incorporating banks, which remains just as it was left by the first Territorial Legislature in the general law referring to corporations; but it effectually regulates them and provides for stated reports and examinations. Doubtless it may be further improved, but as a whole it is satisfactory and probably gives the State as good a banking law as can be found in any Western State and is far superior to the majority of them. The complete annual reports of the Banking Board, which commenced with 1890 , supply all the information desired in the way of statistics from this time on. Prior to that date the only figures to be obtained are for the brief period during which the banks were required to make semiannual reports to the Treasurer of the United States for taxation upon their average capital and deposits.

State Banks, 1876-1898.

\begin{tabular}{|c|c|c|c|}
\hline DATE. & Po. of banks. & Capital. & Deposits. \\
\hline November $30,1876 \ldots . . . \ldots \ldots \ldots . .$. & 35 & $\$ 107,354$ & $\$ 1,250,342$ \\
\hline May $31,1877 \ldots \ldots \ldots \ldots \ldots \ldots \ldots . . . . . . . .$. & 39 & 465,464 & $1,184,932$ \\
\hline May $31,1878 \ldots \ldots \ldots \ldots \ldots \ldots . . . . . . . .$. & 48 & 503,595 & $1,189,250$ \\
\hline May $31,1879 \ldots \ldots \ldots \ldots \ldots \ldots$ & 46 & 444,349 & $1,250,737$ \\
\hline May $31,1880 \ldots \ldots \ldots \ldots \ldots . . . . . . . . . .$. & 83 & 653,890 & $2,019,814$ \\
\hline May $31,1881 \ldots \ldots \ldots \ldots \ldots \ldots . . . . . . . . . .$. & 98 & 944,372 & $2,661,291$ \\
\hline November $30,1882 \ldots \ldots \ldots \ldots \ldots . .$. & 186 & $1,745,302$ & $4,890,753$ \\
\hline October, $1890 \ldots . . . . . . . . . . . . . .$. & 513 & $11,155,412$ & $17,513,696$ \\
\hline October, $1892 \ldots \ldots . . . . . . . . . . . .$. & 513 & $11,257,099$ & $24,891,113$ \\
\hline December, $1893 . . . . . . . . . . . . . . . . .$. & 504 & $10,840,744$ & $17,208,476$ \\
\hline December, $1894 \ldots \ldots \ldots \ldots \ldots \ldots \ldots . . . . . . .$. & 482 & $11,407,838$ & $18,074,832$ \\
\hline December, $1895 \ldots \ldots \ldots \ldots \ldots \ldots . . . . . . .$. & 447 & $9,216,525$ & $14,200,775$ \\
\hline December, $1896 \ldots . . . \ldots . . . . . . . . . .$. & 414 & $8,233,665$ & $10,227,537$ \\
\hline December, $1897 \ldots \ldots \ldots \ldots \ldots$ & 398 & $7,855,278$ & $13,902,940$ \\
\hline December, $1898 \ldots \ldots \ldots \ldots . . . . . . . . . . .$. & 393 & $7,532,023$ & $18,225,180$ \\
\hline
\end{tabular}

Growth of National and State Banks.

The growth of National and State Banks between the years 1882 and 1892 was as follows: 


\begin{tabular}{|c|c|c|c|}
\hline YEAR. & $\begin{array}{c}\text { No. of } \\
\text { banks. }\end{array}$ & $\begin{array}{c}\text { Total } \\
\text { capital. }\end{array}$ & $\begin{array}{l}\text { Total individ } \\
\text { ual deposits. }\end{array}$ \\
\hline & 167 & $\$ 2,697,097$ & $\$ 9,611,365$ \\
\hline & 650 & $24,775,199$ & $53,674,015$ \\
\hline
\end{tabular}

The figures given below also show clearly the changes produced by panic, crop failures, and politics in these classes of banks, as follows:

\begin{tabular}{|c|c|c|c|}
\hline & $\begin{array}{l}\text { Loss in } \\
\text { capital. }\end{array}$ & $\underset{\text { dcpossits. }}{\text { Loss in }}$ & $\begin{array}{l}\text { Cause of } \\
\text { change. }\end{array}$ \\
\hline $\begin{array}{l}\text { October, } 1892, \text { to December, } 1893 . \ldots \ldots \ldots \ldots . \\
\text { December, } 1894 \text {, to December, } 1895 \ldots \ldots \ldots \ldots \ldots \\
\text { December, 1895, to December, } 1896 \ldots \ldots \ldots \ldots . \\
\text { December, 1896, to December, } 1898 \ldots \ldots \ldots \ldots\end{array}$ & $\begin{array}{r}\$ 1,096,355 \\
2,191,313 \\
1,397,860 \\
701,642\end{array}$ & $\begin{array}{r}\$ 16,562,903 \\
5,680,547 \\
4,806,595 \\
* 16,216,170\end{array}$ & $\begin{array}{l}\text { Panic. } \\
\text { Crops. } \\
\text { Election. } \\
\text { Recovery. }\end{array}$ \\
\hline
\end{tabular}

* Gain.

The total loss of State and National banks from all causes from 1892 to 1896 aggregated the large sums of: Capital, $\$ 5,466,534$; deposits, $\$ 26,555,249$; the loss being about fifty per cent. of the deposits and twenty per cent. of the capital.

The total gain from 1896 to 1898 in deposits aggregated $\$ 16,216,170$, an increase of fully sixty per cent. over the aggregate deposits of 1896 ; but the capital continued to go down, which only goes to show that while recovery in deposits is always possible, capital once lost is irretrievably gone. The average capital for National banks is $\$ 100,000$, while that of State banks is $\$ 20,000$, which is a fair indication of the banking requirements in agricultural communities generally.

\section{Savings Banks.}

The State laws of Nebraska have not been favorable for the organization and management of Savings banks. There is no special recognition of them, except in some minor regulations in the Banking Act, and they can only be organized under the general law, which applies to all corporations. Their statisties are included with other State banks in the figures already given. Quite a number, however, of so-called Savings banks were organized during the flush times after 1885, and especially in Omaha, but the record is a sad one.

The oldest, and by far the largest Savings bank in the State, was the Omaha Savings Bank, organized in 1882 . It was honestly and ably managed and deserved to live, but after sustaining a terrific run in 1893, it was finally compelled to close its doors in 1897 . The management of its affairs was subsequently returned to its stockholders by the State officials and it is still in process of liquidation. Eventually its depositors will be paid in full. It ought never to have been closed. At one time its deposits aggregated over $\$ 1,500,000$, all strictly Savings deposits.

Altogether there were eight so-called Savings banks in Omaha in 1893, but at the present time only one continues to do business, the Omaha. Loan and Trust Co's. Savings Baulk. 
No dividends of any considerable amount have been paid by the failed concerns, except the Omaha Savings Bank, already referred to.

The disastrous experience of banks operating under the title of "Savings" has brought blight upon the name, which it may require years to remove.

There were also four similar institutions in Lincoln, but only one continues. Fremont and South Omaha each still list two Savings banks, and there is one each still reported in Beatrice, Fairbury and Schuyler.

A proper law regulating the practice and management of Savings banks would have prevented the disastrous results noted and continued the system for the beneficent service performed by them.

The supposition that the times through which Nebraska has passed account for the result is not well founded. Such times always disastrously affect commercial banks, but Savings banks are of a character which should be able to weather such storms. The difficulty with them was that they were left to their managers' own free wills, who, as a rule, desired to make a large showing of profits, only possible in speculative ventures, which inevitably wrecked the sacred interests committed to their care and keeping.

It has been evidenced in the case of loan companies in the State, honestly and conservatively conducted, that investments in real estate, even under the unfavorable circumstances affecting Nebraska business in the past, have not developed losses, although the liabilities of these companies greatly exceeded the aggregate of the deposits of the Savings banks.

\section{Nebraska Bankers' Association.}

The initiative for a State bankers' association was taken by the $\mathrm{Ne}$ braska delegates to the convention of the American Bankers' Association in Kansas City in 1889. The first convention was held January 22, 1890 , and was a success in every respect. A total membership was reported of 231, and 251 seats were occupied at the banquet given by the Omaha Clearing-House Association. Subsequent conventions were held in 1892 and 1894. The association is still alive, although on account of the political hostility developed towards banks, it has been deemed wise to call no further conventions. The present officers are now considering the advisability of arranging for a group system, patterned after that of some other States, and it is believed that this organization will soon be in operation. The bankers of northwest Nebraska have already organized upon their own inception, and have held successful meetings for several years past.

\section{Currency Reform Agitation.}

In closing this review of banking in Nebraska, one feature in its experience is particularly instructive in these days of currency reform agitation. 
It will have been seen that the issuance of notes to circulate as money secured only by the commercial assets of the issuing banks was not a healthy experience, neither was it in the end beneficial to either the banks who issued the notes or their victims, the general public, by whom they were accepted as money and circulated. Loss and disaster came to both, but to the banks complete annihilation. On the other hand, the bankers who indulged in no such practices, but depended for the growth of their business upon the credit accorded them in the form of deposits, not only were favored with success and prosperity, but the business thus founded has continued to exist to the present date, notwithstanding the great vicissitudes of fortune to which trade and commerce have been exposed during the past forty years.

That a species of prosperity-a condition of affairs which resembles prosperity-will follow the growth of a credit currency is an undeniable fact. This is evidenced in Nebraska history. The second Governor of the Territory, at the beginning of 1857 , when this system had reached its zenith and prevailed in all its glory, had this to say in his message to the Legislature:

"We can boast a population of more than 15,000 intelligent, orderly and energetic citizens, who may challenge comparison with those of any State in the Union; of flourishing towns and prosperous cities, with their handsome church edifices, well regulated schools and busy streets. *** The appreciation of property has far exceeded the expectation of the most sanguine. Business lots upon streets where the wild grass still flourishes are readily commanding from $\$ 500$ to $\$ 3,000$ each ; lands adjacent to our most prosperous towns sell readily at from $\$ 50$ to $\$ 400$ per acre. Credit is almost unknown in our business circles; no citizen oppressed for debt nor crippled in his energies by the hand of penury and want; but all, encouraged by the success of the past, look forward to the future with eager hopes and bright anticipations."

What a picture of happiness and prosperity! Yet only two years were to pass when another Governor in his message to the Legislature then assembled had these melancholy words to utter-unfortunately too well founded-of the conditions prevailing in the same communities:

"It is a matter of bitter experience that the people of this Territory have been made to pass through the delusive days of high times and paper prices, and the consequent gloomy night of low times and no prices."

In a marvelcusly brief period all the prosperity pictured in the first message vanished as by magic. Everyone, with few exceptions, was not only crippled with debts, but succumbed to them in despair and made no effort to pay. The lots commanding from $\$ 500$ to $\$ 3,000$ each upon streets "where the wild grass flourished," would not sell in real money for much more than the value of the wild grass growing upon them, and many years were to come and go before lands near the metropolis of the Territory reached a price as high as $\$ 10$ per acre. The conclusion must be reached that the old adage is verified in currency banking as in other ways of getting rich quickly - " what comes easy will go easy." Such notes are accepted as money in exchange for val- 
uable property, not from a confidence in its goodness based upon the general reputation of or personal acquaintance with their sponsors-a confidence which distinguishes deposit banking-but upon the credulous faith which accepts the similitude of a good thing for the thing itself, and the deception is not removed until something occurs to expose the flimsy sham.

"Notes secured by commercial assets" sounds well, but experience has shown, not only in Nebraska, but in other States, that such security for bank notes is often a very intangible form of collateral.

\section{National Banks.}

Figures are in thousands of dollars.

\begin{tabular}{|c|c|c|c|c|c|c|c|c|c|}
\hline YEARS. & 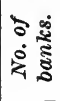 & $\begin{array}{l}\text { Loans and } \\
\text { discounts. }\end{array}$ & $\begin{array}{c}U . S . \\
\text { bonds. }\end{array}$ & $\begin{array}{r}\text { Cash and } \\
\text { cash items. }\end{array}$ & Capital. & Surplus. & $\begin{array}{c}\text { Undi- } \\
\text { vided } \\
\text { profits. }\end{array}$ & $\begin{array}{c}\text { ont. } \\
\text { standing } \\
\text { circula. } \\
\text { tion. }\end{array}$ & $\begin{array}{c}\text { Indi. } \\
\text { vidual } \\
\text { deposits. }\end{array}$ \\
\hline $1864 \ldots$. & 1 & $\$ 11$ & $\$ 30$ & $\$ 9$ & $\$ 35$ & ...... & $\$ 1$ & $\$ 12$ & $\$ 17$ \\
\hline $1869 \ldots$ & 4 & 1,012 & 904 & 292 & 500 & $\$ 54$ & 95 & 168 & 1,342 \\
\hline $1874 \ldots$ & 10 & 2,196 & 1,400 & 512 & 1,025 & 129 & 96 & 895 & 2,518 \\
\hline $1879 \ldots$ & 10 & 2,897 & 1,320 & 670 & 925 & 210 & 132 & 727 & 2,968 \\
\hline $1884 \ldots$ & 63 & 12,598 & 2,406 & 2,096 & 4,735 & 637 & 677 & 1,705 & 9,996 \\
\hline $1889 \ldots$ & 119 & 27,811 & 3,163 & 3,397 & 10,985 & 1,733 & 944 & 2,014 & 20,711 \\
\hline $1894 \ldots$. & 127 & 27,555 & 3,468 & 3,950 & 12,573 & 1,957 & 709 & 2,529 & 21,549 \\
\hline $1899 \ldots$ & 100 & 28,445 & 3,907 & 3,754 & 9,690 & 1,477 & 731 & 2,494 & 29,378 \\
\hline
\end{tabular}

\section{KANSAS.}

This State was the theatre of a bloody conflict between the slavery and anti-slavery factions preceding its admission to the Union, which occurred in 1861, 'the same year in which the Civil War began. By the organic law of the State, the organization of banks was prohibited except under a general law. Some of the regulations affecting banks were that no notes of a less denomination than $\$ 5$ were to be issued, public stocks must be deposited as security, and the offices for the issue and redemption of the notes must be at convenient places in the State, the place to be designated on the notes. The State was prohibited from owning stock in any bank. As in many other States, the people must vote on any banking law before it became effective.

Soon after the admission of Kansas into the Union, the circulating notes of State banks were taxed out of existence by the Federal Government, and the history of banking, therefore, relates only to banks of deposit and discount. Since the recent revision of the banking law there has been a great improvement in the banks of the State. It should be remembered, however, in considering the bank failures prior 
to this time, that many of them were due to speculation rather than to an inherent weakness in the banking system itself. In the years immediately preceding 1890 , a wave of speculation swept over the western half of the State, and prices of real estate were inflated to an enormous extent. Money was loaned on farm and city property in amounts far in excess of the actual value, and when the collapse came those who had procured the loans were denounced for their duplicity. But in most cases the agents of the loan companies, anxious to secure large commissions, were themselves the chief offenders in placing fictitious valuations on the property mortgaged to Eastern money-lenders. The attempt to convert the western third of the State from a grazing into an agricultural country was responsible for much of this loss. From the Missouri River to the Colorado boundary the country rises to an elevation of 3,500 feet, and the climate is much diversified. While the eastern half of the State is perhaps unequalled in agricultural productiveness, the conditions in the western part are less favorable, and in a great portion of this region farming is impossible except in the valleys where it is feasible to irrigate the land. Notwithstanding this many thousands of adventurous people had pushed out on to the frontiers of the State, the population grew astonishingly, towns multiplied and all kinds of business seemed to be thriving. Gradually, the speculation, which was founded upon an unsubstantial basis, subsided, business declined, mortgages began to be foreclosed and towns and farms were deserted. Naturally the banks did not escape the general disaster, and when the 1893 panic came the mortality among them was great, though some of the older-settled States fared equally as bad. On September 1, 1892, there were 447 State and private banks, and on July 14,1898 , there were 364 . This reduction in the number of banks was not, however, due altogether to failures but to a more stringent law and a vigorous enforcement of it.

\section{The Banking Law of 1891.}

Prior to the passage of the law of 1891 there had been no atempt on the part of the State to regulate the business of banking, and as a consequence many institutions that were organized as real estate loan companies and many individuals and firms were engaged in receiving deposits whose principal business was entirely foreign to legitimate banking. Many of these banks and bankers had their entire capital and a large part of their deposits invested in unproductive and unsalable real estate and securities. It was, therefore, found difficult to enforce the law without exercising considerable discrinnination.

\section{Fraudulent loan Companies.}

In his report of September 1, 1894, the State Bank Commissioner stated that during the fifteen years preceding hundreds of companies had been organized in the State for the purpose of loaning money or 
negotiating loans on real estate security. This business proved very profitable so long as conducted on sound principles, but unfortunately these profits attracted the attention of financial adventurers, and many companies were organized apparently "for the sole purpose of robbing their customers at both ends of the line." Companies with an alleged capital of $\$ 25,000, \$ 50,000$, or $\$ 100,000$, with probably not more than ten per cent. paid up, did not hesitate to guarantee the payment, both principal and interest, of loans, amounting to millions of dollars, which were often disposed of through gross misrepresentations as to the value of the securities and the standing of the companies. Thousands of dollars were collected from borrowers and never remitted to the eastern holders of the loans. One company alone collected and failed to remit over $\$ 375,000$. It is probable that much of the discredit which attached to Kansas real estate loans at this time was due to the culpability of the agents of the mortgage companies in making loans on property which they knew was unproductive and greatly overvalued.

\section{New Banking Law Adopted.}

In his third biennial report the Bank Commissioner called attention to the changes in the banking law, which he had previously recommended, but which had failed of adoption. He considered the defects in the law so numerous that he prepared the draft of an entirely new law. This was substantially enacted as the banking law of the State (Gen. Stat. 1897, Vol. 1, p. 187).

\section{Provisions of the Exisiring Banking Law.}

Reference has been made to the provisions of the constitution relating to banking. No bank could be established except under a general banking law; the State was prohibited from holding stock in a bank, and no banking law was to take effect until submitted to a vote of the electors of the State and approved by a majority of all the votes cast at such election. The Supreme Court has decided (Pape vs. Capitol Bank, 120 Kan. 440) that these provisions refer exclusively to banks of circulation, and that a law relating to banks other than banks of circulation need not be submitted to a vote of the people.

Section one of the new law provided for the appointment of a Bank Commissioner, to hold office for four years.

Any five or more persons may organize themselves into a banking corporation to carry on the business usually transacted by banks, including the making of loans on real estate. The amount invested in banking house, furniture and fixtures is not to exceed one-third the capital of the bank. The name of such banking corporation shall include the word "State," and the capital stock must not be less than $\$ 5,000$, all of which must be subscribed before the charter is filed. No business, except that incidental to its organization, is to be transacted until authority is received from the Bank Commissioner. Any individ- 
ual, firm or corporation receiving money on deposit shall be amenable to the provisions of the act. Section seven makes bank officers liable for overdrafts. Banks are prohibited from giving preference to any depositor or creditor by pledging the assets of the bank as collateral, but any bank may borrow money for temporary purposes, not to exceed in amount fifty per cent. of its paid-up capital, and may pledge assets of the bank not exceeding twenty per cent. in excess of the amount borrowed as collateral security therefor. Banks may, however, indorse and rediscount their negotiable notes. It is declared to be unlawful for any bank to issue its certificates of deposit for the purpose of borrowing money, but some banks do not observe the law.

The total investments of any bank, other than Savings banks, shall not exceed four times its paid-in capital and surplus, but United States bonds are not to be counted as a part of such investments. Any individual or firm doing business as a private bank must designate a name for such bank, and in its published statements and stationery must use the words "private bank." All property owned by such bank shall be held in the name of the bank, and is to be exempt from attachment or execution until the debts of the bank are paid.

Capital stock is to be paid in cash, and shareholders are additionally liable for a sum equal to the par value of their shares. Boards of directors are required to hold not less than four meetings in each year, and at such meetings they must make a thorough examination of the bank, putting the results of their examination upon record and transmitting a copy thereof to the Bank Commissioner.

Banks located in cities or towns having less than 5,000 population must have on hand in available funds an amount equal to twenty per cent. of their entire deposits; and banks in cities of over 5,000 population, twenty-five per cent., one-half of which may consist of balances due from good and solvent banks located at commercial centers and at such other points as the Bank Commissioner may approve. Banks that are made the depositories for the reserve of other banks must have on hand, in the manner above described, twenty-five per cent. of their deposits. Cash items are not to be counted as part of the reserves.

Loans to any one person or firm (except discount of bills of exchange, or of commercial paper actually owned) are limited to fifteen per cent. of paid-in capital and surplus. Before the declaration of any dividend, one-tenth of the net profits must be carried to the surplus, until the latter equals fifty per cent. of the capital; when any losses are made up from the surplus fund, one-half of the net earnings must thereafter be devoted to making up the impairment of the surplus.

All banks are required, under penalty, to make and publish quarterly statements of condition, and an examination of each bank must be made annually or oftener. If found insolvent the Bank Commissioner is authorized to take charge and take proceedings for the appointment of a Receiver. 
Savings banks may be authorized with a capital of not less than $\$ 50,000$ nor more than $\$ 500,000$.

By Section seventy-six of the law the provisions of the act are also made applicable to private bankers.

State Banks.

\begin{tabular}{|c|c|c|c|c|}
\hline & 1892. & 1894. & 1896. & 1898. \\
\hline \multicolumn{5}{|l|}{ RESOURCES. } \\
\hline Loans and discounts....... & $\$ 14,061, \dot{3} 02$ & $\$ 12,477,047$ & $\$ 12,169,111$ & $\$ 16,477,473$ \\
\hline Loans on real estate.................. & $1,108,054$ & $1,086,212$ & 997,968 & $1,071,033$ \\
\hline 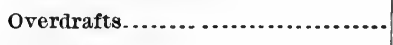 & 414,279 & 265,501 & 226,945 & 216,237 \\
\hline Real estate....................... & $1,684,178$ & $1,503,096$ & $1,549,541$ & $1,243,727$ \\
\hline Furniture and fixtures... ... & 344,643 & 331,108 & 263,891 & 220,410 \\
\hline Expense account............. & 250,999 & 194,099 & 177,336 & 196,832 \\
\hline United States bonds on hand......... & (............ & .............. & 45,147 & 369,717 \\
\hline Other bonds and stocks. ................ & 666,270 & 529,547 & 300,043 & $2 \pm 3,634$ \\
\hline Checks and other cash items.......... & 152,962 & 107,363 & 80,326 & 58,656 \\
\hline Clearing-house items................. & 32,749 & 33,216 & 45,155 & 106,512 \\
\hline Currency ................... & $1,240,089$ & $1,125,867$ & 818,326 & $1,370,221$ \\
\hline Gold coin............ & 512,419 & 676,339 & 645,103 & 994,509 \\
\hline Silver coin................ & 165,674 & 186,468 & $\star 162,955$ & $\star 327,566$ \\
\hline 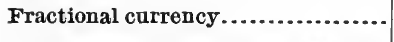 & 8,725 & 12,028 & $\cdots \ldots \ldots \ldots$ & (n............ \\
\hline Due from other banks, sight exch'ge. & $3,788,732$ & $2,262,664$ & $2,694,177$ & $8,037,106$ \\
\hline Other resources................. & $\cdots \cdots \cdots$ & ............. & 104,213 & 76,738 \\
\hline Total............................. & $\$ 24,431,081$ & $\$ 20,790,662$ & $\$ 20,280,245$ & $\$ 31,010,377$ \\
\hline \multicolumn{5}{|l|}{ LIABILITIES. } \\
\hline Capital stock paid in................... & $\$ 8,150,588$ & $\$ 7,449,456$ & $\$ 6,550,870$ & $\$ 6,512,976$ \\
\hline Surplus fund on hand................. & 723,896 & 767,792 & 669,410 & 882,050 \\
\hline 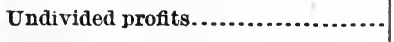 & 361,649 & 384,249 & 308,151 & 723,470 \\
\hline Interest. . . . . . . . . . & 264,823 & 223,223 & 240,620 & (............. \\
\hline 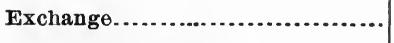 & 36,786 & 19,680 & 22,572 & ............. \\
\hline Dividends declared..................... & 2,958 & 19,419 & 8,146 & 29,182 \\
\hline Individual deposits. .................... & $9,860,354$ & $7,771,681$ & $8,729,317$ & $17,837,958$ \\
\hline Banks and bankers' deposits.......... & 148,261 & 156,739 & 129,088 & 415,688 \\
\hline 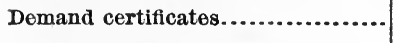 & $1,613,995$ & $1,077,181$ & 955,714 & $1,299,433$ \\
\hline Time certificates........................ & $2,535,013$ & $1,983,902$ & $1,886,124$ & $2,841,875$ \\
\hline 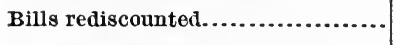 & 183,822 & 135,781 & 767,897 & 128,671 \\
\hline 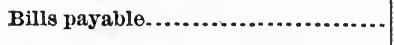 & 548,931 & 801,554 & 12,330 & 146,744 \\
\hline \multirow[t]{2}{*}{ Other liabilities....................... } & (............ & (n............ & ............. & 192,325 \\
\hline & $\$ 24,431,081$ & $\$ 20,790,662$ & $\$ 20,280,245$ & $\$ 31,010,377$ \\
\hline
\end{tabular}

* Including fractional currency. 


\section{National Banks.}

Figures are in thousands of dollars.

\begin{tabular}{|c|c|c|c|c|c|c|c|c|c|}
\hline YEARS. & 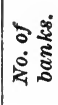 & $\begin{array}{l}\text { Loans } \\
\text { and dis- } \\
\text { counts. }\end{array}$ & $\begin{array}{c}U . S . \\
\text { bonds. }\end{array}$ & $\begin{array}{c}\text { Cash } \\
\text { and cash } \\
\text { items. }\end{array}$ & Capital. & Surplus. & $\begin{array}{l}\text { Undi. } \\
\text { vided } \\
\text { profte. }\end{array}$ & $\begin{array}{c}\text { Out. } \\
\text { standing } \\
\text { circula. } \\
\text { tion. }\end{array}$ & $\begin{array}{c}\text { Indi. } \\
\text { vidual } \\
\text { deposits. }\end{array}$ \\
\hline $1864 \ldots$. & 1 & $\$ 113$ & $\$ 85$ & $\$ 63$ & $\$ 100$ & ...... & $\$ 11$ & $\$ 30$ & $\$ 96$ \\
\hline $1869 \ldots$ & 5 & 476 & 812 & 270 & 400 & $\$ 63$ & 46 & 338 & 667 \\
\hline $1874 \ldots$ & 24 & 2,338 & 1,967 & 582 & 1,730 & 285 & 112 & 1,351 & 2,215 \\
\hline $1879 \ldots$ & 12 & 1,562 & 1,244 & 557 & 838 & 185 & 80 & 675 & 2,138 \\
\hline $1884 \ldots$ & 59 & 8,598 & 1,842 & 2,233 & 3,845 & 431 & 462 & 1,297 & 8,362 \\
\hline $1889 \ldots$ & 161 & 24,185 & 3,870 & 2,233 & 13,182 & 1,879 & 957 & 2,826 & 18,838 \\
\hline $1894 \ldots$ & 126 & 18,514 & 3,025 & 2,279 & 10,427 & 1,499 & 656 & 2,415 & 17,540 \\
\hline $1899 \ldots$ & 98 & 22,212 & 2,768 & 2.487 & 8,092 & 1,402 & 923 & 2,077 & $\mathbf{2 4 , 3 0 6}$ \\
\hline
\end{tabular}

\section{Comparative Progress of National and Other Banks.}

In his Fourth Biennial Report the Còmnissioner published a list of fifteen private banks and twenty-one State banks having an unimpaired surplus equal to or greater than fifty per cent. of their capital. It appears that under the stringent State law now in operation the State and private banks are holding their ground in competition with the National institutions. The number of National banks has fluctuated greatly within short periods, rising from thirty-six in 1883 to 161 in 1889, and falling to ninety-eight in 1899 . The number of State and private banks in operation in September, 1892, was 447; in October, 1893, 420; July, 1894, 410; July, 1898, 364. Thus from 1892 to 1898 there was a loss of eighty-three State and private banks, or about $181 / 2$ per cent. of the number in operation in 1892. The number of National banks fell from 142 in 1892 to ninety-eight in 1899, a loss of forty-four banks, or nearly thirty-one per cent. of those doing business in 1892. The number of private banks appears to have declined from 162 in 1892 to 136 in 1894, while for the same time the State banks declined from 285 to 274 . These figures would seem to indicate a still more favorable showing for the State institutions so far as regards numbers, though the National banks hold about the same amount of deposits as the State and private banks.

The Bank Commissioner, in his Fourth Biennial Report, recommended the creation of a guaranty fund to insure deposits in banks. This he proposed to do, not by a tax, but by requiring the banks to keep one-fourth of their legal reserve (five per cent. of their deposits) on deposit with the State Treasurer, who was in turn to deposit the fund in the banks, secured by the bond of a surety company. Though this plan seemed less objectionable than most schemes proposed for the insurance of depositors in banks, it failed to obtain legislative approval. 
A history of the banks operating under the State laws of Montana is necessarily brief, the State having been admitted into the Union in 1889. There are stringent laws regulating the banking business, provision being made for the organization of trust companies, State banks and Savings banks. Trust companies are authorized to perform the functions usual to such corporations; but few have been organized up to the present time. The minimum capital is $\$ 100,000$. State banks may be organized with a capital of not less than $\$ 20,000$, which must be paid up in cash. No business can be transacted until authorized by the State Auditor. All banks are subject to official State inspection at least once a year, and State banks must make and publish statements of condition semi-annually; other classes of banks report four times a year to the State Auditor. The double liability of shareholders prevails, and this liability continues for six months after the sale or transfer of any stock.

Total liability to any bank is restricted to fifteen per cent. of paid-in capital and permanent surplus. State banks must keep a reserve of not less than twenty per cent. of immediate liabilities, one-half of which may be on deposit with other solvent banks. Taxation is imposed on State banks and trust companies in the same manner as National banks are taxed.

Savings banks may be incorporated by any number of persons not less than three, the paid-in capital being not less than $\$ 100,000$. Onehalf the capital and one-half the deposits must be invested in bonds or other securities of the United States, or any of the States or Territories, or county or city, town or school district of the State of Montana, on which interest is regularly paid, or loaned on unincumbered real estate worth at least double the amount to be secured. There are also limitations of the loans made on personal security. The banks must annually set aside five per cent. of net profits until the surplus amounts to twenty per cent. of the capital. Stockholders elect the directors, who in turn elect the managing officers. Every director must own at least ten shares of stock. Profits go to the shareholders after paying interest on deposits as provided in the by-laws. Officers and directors are prohibited from borrowing from the bank or using any of its funds.

The arerage capital of the banks is higher than that which generally prevails; only seven of the National banks report the minimum capital of such institutions - $\$ 50,000$ - the capital of the others ranging from $\$ 75,000$ to $\$ 250,000$. Most of the State banks also have a much larger capital than the lowest amount fixed by the law. There are several private banking firms of established reputation and great wealth.

It appears that the law has been carefully enforced, and the banks operating under it have established a record for solvency that will com- 
pare most favorably with the history of similar institutions in any of the other States.

The following statistics in regard to State banks in Montana are from the reports of the Bureau of Statistics of the United States Treasury Department:

State Banks.

\begin{tabular}{|c|c|c|c|c|c|c|}
\hline YEARE. & 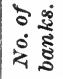 & $\begin{array}{l}\text { Loans and } \\
\text { discounts. }\end{array}$ & Specie. & $\begin{array}{l}\text { Capital } \\
\text { stock. }\end{array}$ & Circulation. & Deposits. \\
\hline $1884 \ldots .$. & 3 & $\$ 191,602$ & ............. & $\$ 75,000$ & ............... & $\$ 179,344$ \\
\hline $1888 \ldots$ & 2 & 286,735 & ........... & 150,000 & .............. & 330,675 \\
\hline $1890 \ldots$ & 2 & 358,411 & ........... & 140,000 & $\ldots$. & 300,244 \\
\hline $1892 \ldots .$. & 8 & $1,586,037$ & ............. & 607,000 & $\ldots$ & $1,433,890$ \\
\hline $1895 \ldots$ & 4 & 738,705 & ............. & 330,000 & ...... & 589,794 \\
\hline $1897 \ldots \ldots$ & 7 & 914,949 & ............ & 405,000 & .............. & 979,018 \\
\hline
\end{tabular}

The Comptroller of the Currency, in his report for 1899, publishes a tabulation of statements from fourteen Montana State banks on June 30,1899 . Their loans and discounts were $\$ 3,205,701$; capital, $\$ 771,000$; deposits, $\$ 3,460,173$.

National Banks.

Figures are in thousands of dollars.

\begin{tabular}{|c|c|c|c|c|c|c|c|c|c|}
\hline YEARS. & 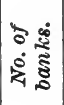 & $\begin{array}{c}\text { Loans } \\
\text { and dis- } \\
\text { counts. }\end{array}$ & $\begin{array}{c}\text { U. S. } \\
\text { bonds. }\end{array}$ & $\begin{array}{c}\text { Cash } \\
\text { and cash } \\
\text { items. }\end{array}$ & Capital. & Surplus. & $\begin{array}{c}\text { Undi. } \\
\text { vided } \\
\text { profits. }\end{array}$ & $\begin{array}{c}\text { Out. } \\
\text { standing } \\
\text { circula. } \\
\text { tion. }\end{array}$ & $\begin{array}{c}\text { Indi- } \\
\text { vidual } \\
\text { deposits. }\end{array}$ \\
\hline $1867 . .$. & 1 & $\$ 75$ & $\$ 60$ & $\$ 36$ & $\$ 100$ & $\ldots$ & $\$ 20$ & $\$ 36$ & $\$ 49$ \\
\hline $1873 \ldots$ & 5 & 612 & 315 & 335 & 350 & $\$ 47$ & 101 & 217 & 630 \\
\hline $1878 \ldots$ & 3 & 868 & 230 & 181 & 200 & 75 & 108 & 110 & 747 \\
\hline $1883 \ldots$ & 10 & 4,730 & 713 & 639 & 1,210 & 170 & 429 & 399 & 4,550 \\
\hline $1888 \ldots$ & 17 & 8,777 & 691 & 1,629 & 1,950 & 506 & 1,271 & 421 & 9,068 \\
\hline $1893 \ldots$. & 22 & 8,487 & 676 & 1,411 & 2,775 & 375 & 1,641 & 517 & 6,958 \\
\hline $1899 . .$. & 21 & 7,924 & 933 & 1,573 & 2,305 & 381 & 742 & 530 & 12,520 \\
\hline
\end{tabular}

WYOMING.

This State was adınitted into the Union in 1890, and while the details of its banking history are meager, it will be seen from the accompanying statistics that the State banks have increased their capital and deposits at a rate indicating a rapid growth in the business interests of the State. Although the resources of the private banks are greater than those of the State institutions, the latter are making a gain that, apparently, will soon place them at the front. 


\section{Requirements of the Banking LAw.}

The Wyoming banking law provides for the organization of State banks, State Savings banks, and loan and trust companies. There must be not less than five incorporators, and as a preliminary to commencing business a certificate must be filed with the State Examiner stating that. all the stock has been subscribed and that at least fifty per cent. has been paid in. The remainder of the capital must be paid in within six months. Real estate holdings, including furniture and fixtures, are limited at the commencement of business to twenty-five per cent. of the capital stock, and the commercial paper to thirty-five percent. Shareholders are additionally liable to the amount of their shares. Reports must be made to the State Examiner when called for by him, and published when made, and all banks must be examined by him as often as once a year. The amount which a bank may loan to one person or firm is limited to one-tenth of the capital. Although there is no fixed reserve required by law, the State Examiner requires that there shall be a reserve of at least twenty-five per cent. in cash and a vailable exchange.

The State is not interested as a shareholder in any of the banks; branches are not allowed, nor is circulation permitted. When a bank becomes insolvent the State Examiner takes possession pending the appointment of a Receiver.

Savings banks must pay depositors not less than four per cent. per. annum before any expense, or salary or profit may be paid or accrue to the bank. They may invest in United States bonds, or in bonds issued within the State, or may loan upon notes or bonds secured by unincumbered real estate or chattels worth at least double the amount of the loan. A reserve fund of at least ten per cent. is required. Officers are prohibited from borrowing, and in the event of insolvency, depositors, are made preferred creditors.

State Banks.

\begin{tabular}{|c|c|c|c|}
\hline 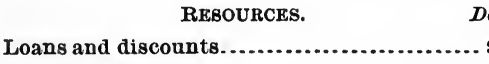 & $\begin{array}{l}\text { Dec. } 15,1897 \text {. } \\
\$ 180,417\end{array}$ & $\begin{array}{l}\text { Dec. } 1,1898 . \\
\$ 226,917\end{array}$ & $\begin{array}{c}\text { Dec. } 2,1899 . \\
\$ 545,581\end{array}$ \\
\hline 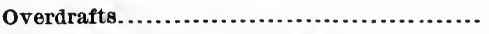 & . $\quad 7,523$ & 7,611 & 18,295 \\
\hline Stocks, securities, judgments, etc............. & 14,942 & 17,018 & 18,959 \\
\hline 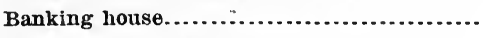 & 6,813 & 3,000 & 11,700 \\
\hline 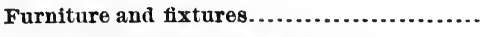 & 5,369 & 3,299 & 4.847 \\
\hline Other real estate, mortgages, etc.............. & 1,773 & 4,998 & 1,216 \\
\hline Expenses and taxes paid............................. & 4,025 & 3,530 & 7,178 \\
\hline Due from banks and bankers................... & 128,550 & 105,344 & 279,376 . \\
\hline Checks and cash items......................... & 952 & 3,908 & 2,700 \\
\hline 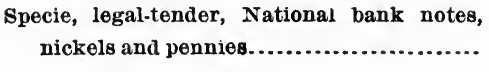 & 19,908 & 24,433 & 45,849 \\
\hline$\ldots$ & & $\$ 400,062$ & $\$ 935,704$ \\
\hline
\end{tabular}


State Banks-Continued. LiABILITIKS.

\begin{tabular}{|c|c|c|c|}
\hline 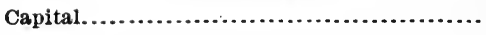 & $\$ 72,000$ & $\$ 82,000$ & $\$ 162,000$ \\
\hline 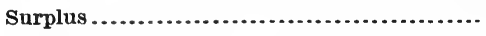 & 28,000 & 16,742 & 19,865 \\
\hline Undivided profits................................ & 20,663 & 14,393 & 38,524 \\
\hline 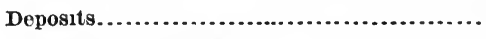 & 249,611 & 286,926 & 706,026 \\
\hline Due banks and bankers........................ & .......... & $\ldots \ldots \ldots$ & 9,288 \\
\hline Aggregates. . & 70,274 & $\$ 400,062$ & $\$ 935,704$ \\
\hline
\end{tabular}

Private Banks.

RESOURCES.

Loans and discounts

Overdrafts

Stocks, securities, warrants, etc.

Banking house

Furniture and fixtures.

Other property, mortgages, etc

Expenses and taxes paid.

Due from banks and bankers.

Checks and cash items.

Specie, legal-tender, National bank notes,

nickels and pennies.

Aggregates

\section{LIABILITIES.}

Capital.

Surplus

Undivided profits.

Individual deposits

Due banks and bankers.

Rediscounts.

Aggregates
Dec. 15, 1897. Dec. 1, 1898. $\$ 584,947$

38,244

28,630

18,768

8,624

12,203

9,310

210,029

1,836

56,852

$\$ 969,448$

$\$ 178,516$

1,000

13,741

769,216

4,754

2,219

$\$ 969,448$
$\$ 736,073$

45,726

24,516

20,413

10,087

1,150

10,987

264,790

6,719

69,020

$\$ 1,189,486$

$\$ 173,516$

3,950

16,808

984,691

518

10,000

$\$ 1,189,486$

Dec. 2, 1899. $\$ 893,804$

55, 116

34,998

18,893

6,744

4,279

16,362

313,925

$\mathbf{3 , 9 3 3}$

70,842

$\$ 1,418,901$

$\$ 186,016$

12,000

41,103

$1,160,471$

9,310

10,000

$\$ 1,418,901$

\section{National Banks.}

Figures are in thousands of dollars.

\begin{tabular}{|c|c|c|c|c|c|c|c|c|c|}
\hline YEARS. & 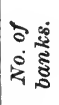 & $\begin{array}{l}\text { Loans } \\
\text { and dis- } \\
\text { counts. }\end{array}$ & $\begin{array}{c}U . S . \\
\text { bonds. }\end{array}$ & $\begin{array}{c}\text { Cash } \\
\text { and cash } \\
\text { items. }\end{array}$ & Capital. & Surplus. & $\begin{array}{l}\text { Undi. } \\
\text { vided } \\
\text { profits. }\end{array}$ & $\begin{array}{c}\text { Out. } \\
\text { standing } \\
\text { circula. } \\
\text { tion. }\end{array}$ & $\begin{array}{c}\text { Indi. } \\
\text { vidual } \\
\text { deposits. }\end{array}$ \\
\hline $1871 \ldots$ & 1 & $\$ 77$ & $\$ 30$ & $\$ 15$ & $\$ 75$ & .... & $\$ \ddot{3}$ & $\$ 27$ & $\$ 55$ \\
\hline $1876 \ldots$ & 2 & 198 & 60 & 96 & 125 & $\$ 21$ & 29 & 50 & 265 \\
\hline $1881 \ldots$. & 3 & 730 & 94 & 201 & 225 & 50 & 48 & 83 & 856 \\
\hline $1886 \ldots$ & 6 & 2,335 & 180 & 401 & 900 & 167 & 193 & 160 & 1,768 \\
\hline $1891 \ldots$. & 12 & 3,257 & 312 & 276 & 1,385 & 239 & 92 & 268 & 2,709 \\
\hline $1896 \ldots$ & 11 & 1,764 & 240 & 270 & 860 & 117 & 65 & 214 & 1,865 \\
\hline $1899 \ldots$ & 11 & 2,262 & 215 & 265 & 860 & 118 & 61 & 192 & 3,092 \\
\hline
\end{tabular}




\section{COLORADO.}

Iegitimate banking in Colorado began after the adoption by Congress of the Legal Tender Act of February 25, 1862. In the meantime, the principal circulating medium was gold dust, carried in small buckskin sacks, and as the smallest price of anything was twenty-five cents, a good deal of waste occurred in making change. The first National Treasury notes began to make their appearance among the miners and merchants in 1863 . Some of the more opulent immigrants brought a few dollars in gold and silver from the States, which soon found their way back again. The greater part of the gold dust was impure; much of that taken from the stamp or crushing mills being debased by the crudeness of the "retorting" process employed, the product carrying more or less quicksilver and copper, with iron in the form of black sand.

No merchantable silver was produced until 1865 , and but little until after the establishment of the Boston and Colorado Smelting Works by ex-United States Senator N. P. Hill in 1867-8. As a primitive substitute for legitimate banking, there were many brokers in gold dust, generally agents of bankers in towns along the Missouri River, as St. Joseph, Atchison, Omaha and Leavenworth, who bought from the miners at various prices, ranging between twelve and sixteen dollars an ounce, according to fineness. The express charge on gold from the mines to the Missouri River in early times was five per cent. of its value; therefore, to avoid this heavy exaction, many shipped by east-bound coach passengers, trusted friends of the brokers, upon such agreements as could be made with them in the way of compensation and insurance.

\section{Private Banking Houses Established.}

The first broker's office established in Denver was that of Samuel and George W. Brown in 1859, which continued until after the founding of the National banks. The next was opened the same year by Turner \& Hobbs in West Denver. The second floor of their building was for some time used by the Territorial Governor (John Evans) as executive offices. George W. Kassler took charge as Cashier, continuing until 1861, when the concern closed.

Clark, Gruber \& Co. organized the first, most extensive and useful of all the institutions classed as banks in the period between 1859 and 1865. Their establishment sprang from a house instituted in-Leavenworth, Kansas, in 1858, by Milton E. and Austin M. Clark and E. H. Gruber. In 1859 they purchased considerable quantities of gold from the Rocky Mountains. They were paying five per cent. expressage on the dust brought in, and equal cost on the coin and currency returned, in addition to the expense of armed messengers or guards each way. To avoid this burdensome expense, they finally conceived the idea of planting coining machinery in Denver and making their own coin. 
After investigating the laws on the subject and finding no absolute prohibition, M. E. Clark proceeded to Boston, purchased the requisite machinery and shipped it to Denver, where it arrived in March, 1860. A two-story brick building was erected in a central part of the town, the machinery placed, and the minting of crude dust into bright, attractive coins began July 20, 1860. The first struck were ten and twenty dollar pieces, bearing on the face a rude representation of Pike's Peak, and on the reverse the firm name of Clark, Gruber \& Co. No alloy was used. They passed into general circulation at par, but soon began to show abrasion from constant use; therefore, in 1861, the firm ordered a complete set of new dies for denominations of $\$ 2.50, \$ 5, \$ 10$ and $\$ 20$, that were close facsimilies of United States coins of like denominations, the only difference being that upon the Cap of Liberty on the face they inserted the words "Pike's Peak," and on the reverse, instead of "The United States of America," they substituted the name of their firm. These coins bore the same percentage of alloy and were of the same color as those issued by the Government mints, but contained one per cent. more gold for the express purpose of protecting the holders against loss, the additional weight covering the cost of transportation to Philadelphia and recoining. These issues passed current throughout the mining region, and all bankers of the East to whom they were known paid a premium for them. The mint thus established continued in active operation about two and a half years, in which time about $\$ 3,000,000$ worth of coins had been struck.

To accommodate large producers they coined their dust for them at a maximum charge of five per cent., but this was soon discontinued. Having abundant funds at command, they carried on an extensive business, buying gold one day and coining it the next, when the money went into immediate circulation. In 1860 an agency was established in Central City, one of the larger centers of mining, where the dust was purchased as it came from the sluices and mills, payment being made in coin, checks, currency or drafts, as the seller might elect. For the further convenience of the public, they issued from well engraved steel plates, five dollar notes redeemable in Clark \& Gruber's coin at their banking house in Denver. In $1862 \mathrm{Mr}$. Austin M. Clark went to Washington and laid the whole matter before Hon. Salmon P. Chase, Secretary of the Treasury, giving him a full and candid statement of what his firm had been doing in Denver, and presented him specimens of all the coins issued. Mr. Chase referred the matter to the Attorney-General, who rendered an opinion in substance that no existing law had been violated. Without going into details, the Government finally purchased the building and grounds from Clark, Gruber \& Co. in Denver, and Secretary Chase drafted a bill for the establishment of a United States coinage mint there but, owing to the influence of the Pacific Coast representatives in Congress, the bill passed locating the branch mint at Carson City, Nevada, instead of in Denver, the building 
designed for that purpose being converted into an assay office and depository of gold purchased on behalf of the United States. In recent years, however, the Government established a mint at Denver.

In September, 1859, Chas. A. Cook and Jasper P. Sears established a wholesale provision house in Denver. As gold dust from the mines became more and more abundant, and a feature of speculative interest to all who possessed capital, they began buying that valuable commodity and later opened a banking house in connection with their mercantile trade. A few months later they issued from steel plates a fractional paper currency in denominations of ten, twenty-five and fifty cents, with one dollar notes, all redeemable at their counters in lawful currency. This paper entered into general use and in the absence of anything better, served the purpose of its creation. During 1863 the issues ceased and the outstanding notes were duly redeemed. In $1860 \mathrm{Dr}$. O. D. Cass, a practicing physician, opened a brokerage business. He was joined shortly afterward by his brother, Joseph B. Cass, from Leavenworth, Kans. As their gains multiplied from profitable traffic in dust, they erected a building of their own and established a regular banking house, purchasing gold and shipping it to Carney \& Stevens, bankers, at Leavenworth; issued drafts and loaned money at five to twenty per cent. per month. Subsequently, they opened a branch in the gold mines at Central City. They closed out their business in 1865 and sold their building to Ben Holliday, who operated a system of stage lines from Denver to the Missouri River and to the mining eamps in the mountains.

In 1861 Warren Hussey opened a broker's office in one corner of a grocery store, Denver, and later a regular banking house, which was merged into the City National Bank in 1872.

\section{Bank Chartered By the Territorial Legislature.}

In 1861 the first Territorial Legislature by special act granted a charter to P. P. Wilcox, E. W. Cobb and E. C. Jacobs, to establish "the Bank of Colorado," in the City of Denver, with a capital stock of $\$ 150$,000. Instead of taking advantage of the charter, in connection with a man named Rogers, Wilcox, under the firm name of P. P. Wilcox \& Co., proceeded to issue and circulate fractional currency in denominations of ten, twenty-five and fifty cents, to the amount of about $\$ 3,000$. The scrip was not engraved, but rudely printed on cheap newspaper. In course of time much of this flimsy paper, issued in violation of law, was destroyed, but the remainder was redeemed when presented. As soon as the volume of United States Treasury notes became sufficiently large to justify their general use, most of the operators of gold mines paid their employees in that currency.

The First National Bank, of Denver, which was authorized April 17, 1865 , and opened for business May 9 following, succeeded the private banking house established some time previous by George T. Clark, who 
became Cashier of the new institution. With its founding disappeared most of the gold dust brokers and sunaller private banks.

\section{A Historic Firm of Bankers.}

The Colorado National Bank, of Denver, was organized in August, 1866 , by the Kountze Brothers. It was based upon the second of five private banks founded by four brothers, Augustus, Herman, Luther and Charles Kountze. Luther came to Denver from Omaha in 1862, and in a corner of a drug store opened a branch of the now famous Kountze Bros. in the Rocky Mountain region. Here he bought gold dust, received deposits, sold drafts on Omaha, discounted commercial paper, loaned money, etc. In 1864, when only 19, Charles B. joined Luther. A twostory brick building had meanwhile been erected, and in 1866, Charles B. Kountze became Cashier of the Colorado National Bank. This is, and has been from the first, the second largest financial institution in the State, and with its connections with the First National of Omaha, conducted by Augustus Kountze, the eldest brother, and the banking house of Kountze Bros., in New York, founded in 1868, and still in successful operation, forms a strong link in the chain of large enterprises created by this remarkable brotherhood, and all under the control of the Kountze family.

\section{Private and State Banks Reorganized Under the National SYSTEM.}

The Union Bank, incorporated under the Territorial laws, in May, 1874, was organized with the title of the Denver Safe Deposit and Savings Bank; authorized capital, $\$ 60,000$, fifty per cent. paid in. It opened for business in July, 1874. In 1882 the capital was increased to $\$ 100,000$ and organized as the Union Bank. It was chartered as a National bank June 17, 1890, with an authorized capital of $\$ 1,000,000$. It failed in 1893 , but subsequently reopened and closed the second time in July, 1895.

The People's Deposit and Savings Bank, of Denver, was organized under State laws and opened July 9, 1888, with a capital of $\$ 150,000$. It went into the National system August 1, 1889, under the title of the People's National Bank. This bank failed in 1893, and has since been in process of liquidation.

In 1872 a private bank was established at Colorado Springs by W. H. Young, who was later succeeded by the El Paso Bank, Mr. Young becoming the founder of the First National Bank. In 1889 Jerome B. Wheeler, of New York, established private banks at Colorado City and Manitou. The Pueblo Savings Bank was incorporated in 1889 and opened January 1, 1890; ex-Gov. Alva Adams is President.

Comparison of State and National Banks.

Since the admission of Colorado as a State in 1876 there have been incorporated under State laws one hundred and five banking institu- 
tions, of which thirty-eight are still in existence. About eight have taken out National charters and a number have reorganized or have been merged into other institutions. It is not possible at present to state the figures exactly.

Since the passage of the National Bank Act there have been incorporated under that law in the State sixty-five banking institutions, of which thirty-seven are still in existence, twenty-one are in liquidation and seven are insolvent.

Thus, at present (1898), there are in operation in Colorado thirtyeight State banks with a capital of $\$ 1,641,961$ and deposits of $\$ 5,285,333$, and thirty-seven National banks with a capital of $\$ 4,707,000$ and deposits of $\$ 39,958,000$.

The first banking association incorporated under the National banking law in the State of Colorado was organized in 1865 with a capital of $\$ 200,000$.

The largest number of National banks in operation in the State at any one time was in 1892 , when there were fifty-three with a capital of $\$ 9,065,000$, and individual deposits of $\$ 28,848,000$. In 1892 the State banks in operation had a capital of $\$ 1,785,000$, making a total banking capital invested in the State in that year of $\$ 10,850,775$. This is exclusive of private or unincorporated banks and bankers, and probably represents the largest amount of banking capital in the history of the State actively employed at any one time.

The banking capital invested in both State and National banks, according to the report of the Comptroller of the Currency for 1898, was $\$ 6,348,000$, or about forty per cent. less than the maximum amount of 1892. Individual deposits of the National banks were in $1892 \$ 28,848$,000 ; in $1898 \$ 33,010,000$.

These figures probably reflect the conditions past and present of the banking business of the State. In the absence of a State banking department the records of the operations of State and private banks are not at all satisfactory. The State Treasurer, who, under the law is the official State bank statistician, reports for the year 1898 but twentyfour State banks in operation, while the Comptroller of the Currency reports thirty-eight "semi-official," and in this number are said to be included sundry private banks. Other authorities report thirty-six banks. This latter number seems to harmonize with the records of the incorporations in the Secretary of State's office.

Attempts to enact suitable laws for the supervision of banks have not been successful, but there is believed to be a growing sentiment in favor of such legislation.

The absence of thorough State supervision has probably caused some hoarding of bankable funds, and has hindered the highest success of institutions operating under State laws. The final outcome of many institutions which suspended in and since 1893 being far from satisfac tory, and returns from those still in process of liquidation being slow, 
the business methods in vogue with those institutions have gradually come to the knowledge of the public, and have caused some distrust of State banking institutions which are doing business at present ; but it is believed that this distrust is not well founded, and that the State banks of Colorado are gradually adopting business methods which the lessons of experience have taught older communities to adopt. The State banks have not held their ground in competition with the National banks as well as in some other States.

The withholding of bankable funds from deposit and employment is particularly noticeable in the case of the Savings banks of the State. Savings banks in Colorado are stock banks, conducted for protit and largely employing their funds in a class of loans which are not permissible to the best class of incorporated Savings banks. They are not sufficiently restricted in the employment of their funds, and in consequence the experience with these institutions has been far from satisfactory.

The function of the Savings bank is to a certain extent fulfilled by the National banks of deposit and discount, but there is under the law of Colorado no adequate provision for institutions for the custody and safe employment of small savings, and consequently thrift is not encouraged among a class of people whose welfare and prosperity are of the greatest importance to the Commonwealth.

\section{High Rates of Interest in the State.}

The prevailing rates of bank discount in Colorado are txcessive when compared with those prevalent in the States of the East. In Denver they are probably lower than any where else in the State. The ruling rate in Denver is ten per cent. for ordinary commercial risks. This is to some extent prohibitive for manufacturers and jobbers who require banking accommodation. It is accounted for in several ways, chief of which is the expense of carrying large reserves. While the rates for money have been largely reduced in the past few years at other financial centers, they have remained practically unchanged in Colorado.

Another cause of this phenomenon is the large amount of what might be termed latent bank resources in the State. Reduction in rates is due to the abundance of funds seeking employment. The census of 1890 gives the average per capita of assessed valuation of property in New York as $\$ 629$, in Colorado, $\$ 458$, while the average per capita bank deposits of the State of New York is about $\$ 300$. At this proportion the average per capita bank deposits of Colorado should be over $\$ 200$ and the aggregate for the State should be $\$ 120,000,000$, instead of $\$ 50,000,000$, as at present. This seems rather an overstatement, but it is certain that there are large sums of bankable funds in the safe-deposit boxes and primitive hiding places of various kinds. Colorado has passed through the pioneer stage of its history and is 
now enjoying an era of great prosperity, having taken rank as the leading gold-producing State of the Union. As the people are progressive, it may be expected that they will gradually adopt such changes in their State banking system as may seem to be desirable. Unfortunately, where the banking laws are not stringent, the opportunities are taken advantage of by reckless bankers who though few in number are yet numerous enough to work great mischief and bring undeserved discredit on the majority of bankers who manage their institutions with skill and prudence.

\section{Laws Relating to Banks.}

State banks may be organized with a capital of not less than $\$ 30,000$, one-half of which must be paid up before commencing business, and the balance within one year. Savings banks must have a paid-up capital of $\$ 25,000$. Whenever a dividend is declared by a State bank, a full statement must be made to the State Treasurer, and this statement must be published. Savings banks must make similar statements quarterly. There is no provision for examination of banks by State officials. Stockholders of State banks may not be indebted to the bank as principals or sureties to an amount greater than two-fifths the paid-in eapital. Savings bank officers are prohibited from borrowing from their institutions. Savings banks may invest one-half their deposits in loans on personal security, or in the bonds or stock of the State or of the United States, or in the bonds of any county, city, town or school district of the State, or loan the same on bonds secured by mortgage upon unincumbered real estate worth at least double the amount loaned. The remainder of the deposits may be placed in National or State banks. Both State and Savings banks must have a reserve of twenty per cent. of their savings deposits. Penalties are prescribed for receiving deposits knowing the bank to be insolvent.

State Banks.

\begin{tabular}{|c|c|c|c|c|c|c|}
\hline YEARG. & $\begin{array}{l}\text { No. of } \\
\text { banks. }\end{array}$ & $\begin{array}{l}\text { Loans and } \\
\text { discounts. }\end{array}$ & Specie. & $\begin{array}{c}\text { Capital } \\
\text { slock. }\end{array}$ & Circulation. & Deposits. \\
\hline $1883 \ldots . . .$. & 8 & $\$ 1,039,334$ & ............... & $\$ 449,500$ & ............. & $\$ 1,063,562$ \\
\hline $1886 \ldots \ldots$. & 8 & $1,169,895$ & .............. & 449,400 & ........... & $1,481,492$ \\
\hline $1889 \ldots \ldots$. & 18 & $2,604,001$ & .............. & 910,000 & ............. & $2,888,842$ \\
\hline $1892 \ldots \ldots$ & 21 & $2,163,056$ & ............. & $1,185,775$ & ............. & $1,899,225$ \\
\hline $1895 \ldots . . . .$. & 33 & $3,866,754$ & ............... & $1,835,000$ & ............ & $3,995,539$ \\
\hline $1897 \ldots \ldots . .$. & 32 & $3,560,455$ & .............. & $2,000,000$ & ............ & $4,854,955$ \\
\hline $1899 \ldots \ldots$ & 28 & $3,776,482$ & • ............. & $1,315,000$ & ............ & $6,453,987$ \\
\hline
\end{tabular}




\section{National Banks.}

Figures are in thousands of dollars.

\begin{tabular}{|c|c|c|c|c|c|c|c|c|c|}
\hline YRARS. & 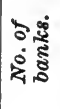 & $\begin{array}{c}\text { Loans } \\
\text { and dis- } \\
\text { counts. }\end{array}$ & $\begin{array}{c}U . S . \\
\text { bonds. }\end{array}$ & $\begin{array}{c}\text { Cash } \\
\text { and cash } \\
\text { items. }\end{array}$ & Capital. & Surplus. & $\begin{array}{c}\text { Undi. } \\
\text { vided } \\
\text { profits. }\end{array}$ & $\begin{array}{c}\text { out. } \\
\text { standing } \\
\text { circula. } \\
\text { tion. }\end{array}$ & $\begin{array}{c}\text { Indi. } \\
\text { vidual } \\
\text { deposits. }\end{array}$ \\
\hline $1865 \ldots . . . .$. & 1 & $\$ 179$ & $\$ 70$ & $\$ 31$ & $\$ 200$ & ...... & $\$ 20$ & $\$ 45$ & $\$ 162$ \\
\hline $1870 \ldots$ & 3 & 552 & 578 & 306 & 350 & $\$ 73$ & 63 & 254 & 1,553 \\
\hline $1875 \ldots .$. & 9 & 2,362 & 783 & 717 & 875 & 284 & 206 & 601 & 2,513 \\
\hline $1880 \ldots .$. & 14 & 5,060 & 1,318 & 1,394 & 1,070 & 299 & 267 & 837 & 8,288 \\
\hline $1885 \ldots$ & 25 & 7,609 & 1,433 & 2,255 & 2,025 & 1,003 & 454 & 927 & 10,282 \\
\hline $1890 \ldots . . . .$. & 46 & 25,093 & 2,401 & 3,491 & 7,365 & 1,613 & 1,172 & 1,164 & 26,326 \\
\hline $1895 \ldots$ & 45 & 19,848 & 1,863 & 5,226 & 6,437 & 1,715 & 1,060 & 1,221 & 24,354 \\
\hline $1899 \ldots$ & 36 & 21,334 & 3,009 & 6,657 & 4,147 & 976 & 905 & 1,664 & 40,295 \\
\hline
\end{tabular}

NEW MEXICO.

"Up to a comparatively recent date," according to the words of the Secretary of New Mexico, "a merchant's desk or a ranchman's bureau drawer was the place of deposit;" but there are now a number of banks organized under National and Territorial laws, as well as several private institutions. The law provides for State banks and Savings and trust associations, with a minimum capital of $\$ 30,000$, one-half of which must be paid up before commencing business and the balance in one year. Both State and Savings banks are required to make reports to the Territorial authorities, and the Secretary of the Territory may make an examination at any time; reports must be published when made. Savings banks may not loan more than ten per cent. of capital to one person or firm, and not more than five per cent. to officers or stockholders, except on mortgage or collateral. They may loan on real estate to the amount of fifty per cent. of its value on improved and thirty per cent. on unimproved. Savings banks must apply to surplus ten per cent. of their annual earnings. The reception of a deposit by a Savings bank after insolvency renders the directors liable for it, and the fact of insolvency is deemed prima facie evidence of knowledge of it.

Savings banks may issue their own evidences of indebtedness and negotiate the same to an amount not exceeding ninety per cent. of the aggregate loans made and held by such association secured by mortgages or deeds of trust on real estate; which shall not be construed to empower the association to issue notes for circulation. Not more than fifty per cent. of the net surplus may be invested in building and real estate necessary for transacting business, and real estate purchased to secure loans may be held for a period not longer than five years. 
State Banks.

\begin{tabular}{|c|c|c|c|c|c|c|}
\hline YEARS. & $\begin{array}{l}\text { No. of } \\
\text { bantes. }\end{array}$ & $\begin{array}{l}\text { Loans and } \\
\text { discounts. }\end{array}$ & Specie. & Capital stock. & Circulation. & Deposits. \\
\hline $1889 \ldots$ & 2 & $\$ 149,717$ & ............... & $\$ 80,000$ & .............. & $\$ 92,380$ \\
\hline $1892 .$. & 4 & 297,304 & ........... & 145,000 & ........... & 372,752 \\
\hline $1895 \ldots$ & 4 & 305,613 & ........... & 201,700 & ........... & 319,181 \\
\hline $1897 \ldots . .$. & 6 & 522,910 & …....... & 241,700 & .............. & 798,276 \\
\hline $1899 \ldots .$. & 7 & 888,404 & ........... & 272,400 & ............... & $1,145,347$ \\
\hline
\end{tabular}

National Banks.

Figures are in thousands of dollars.

\begin{tabular}{|c|c|c|c|c|c|c|c|c|c|}
\hline YEARS. & 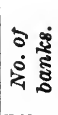 & $\begin{array}{c}\text { Loans } \\
\text { and dis. } \\
\text { counts. }\end{array}$ & $\begin{array}{c}U . S . \\
\text { bonds. }\end{array}$ & $\begin{array}{c}\text { Cash } \\
\text { and cash } \\
\text { items. }\end{array}$ & Capital. & Surplus. & $\begin{array}{c}\text { Undi. } \\
\text { vided } \\
\text { profits. }\end{array}$ & $\begin{array}{c}\text { Out. } \\
\text { standing } \\
\text { circula- } \\
\text { tion. }\end{array}$ & $\begin{array}{l}\text { Indi- } \\
\text { vidual } \\
\text { deposits. }\end{array}$ \\
\hline 1871... & 1 & $\$ 88$ & $\$ 150$ & $\$ 36$ & $\$ 150$ & $\$ 1$ & $\$ 4$ & $\$ 135$ & $\$ 46$ \\
\hline $1876 \ldots . .$. & 2 & 379 & 300 & 56 & 300 & 40 & 25 & 269 & 224 \\
\hline $1881 \ldots . .$. & 4 & 722 & 560 & 197 & 400 & 101 & 50 & 352 & 990 \\
\hline $1886 \ldots$ & 9 & 1,564 & 510 & 346 & 825 & 164 & 53 & 253 & 1,539 \\
\hline $1891 \ldots .$. & 12 & 2,551 & 565 & 250 & 1,115 & 217 & 67 & 326 & 2,203 \\
\hline $1896 \ldots$ & 7 & 1,373 & 502 & 212 & 600 & 143 & 34 & 271 & 1,931 \\
\hline $1899 \ldots . . . .$. & 6 & 1,994 & 615 & 264 & 600 & 133 & 39 & 372 & 3,259 \\
\hline
\end{tabular}

\section{OKLAHOMA.}

Although operating for some years under unsatisfactory laws, the banks of Oklahoma are now governed by stringent legal regulations, the law of March 12, 1897, providing for thorough public supervision of the organization and management of banks. Private banking is prohibited. Reports are called for by the Banking Board on the same dates as reports are made to the Comptroller of the Currency by National banks. On the first Monday in January, April, July and October every bank shall mail to each depositor a statement showing the condition of the bank at the close of the last business day of the previous quarter. Minimum capital is $\$ 5,000$, in cash " or bankable notes or securities actually worth face value." Banks must keep a reserve of fifteen per cent. of their aggregate deposits, two-fifths of the reserve to be in cash held in their own vaults. The aggregate amount of rediscounts and bills payable is limited to two-thirds of paid-up capital. One-tenth of net profits must be carried to the surplus fund until it amounts to twenty per cent. of the capital. Loans to one person or firm are limited to ten per cent. of the capital stock. The Banking 
Board may take possession of an insolvent bank, or one that is being recklessly managed, and apply for the appointment of a Receiver.

Official examination of all banks must be made as frequently as once a year. The Banking Board may make such rules, not inconsistent with the law, as may be deemed proper for the management of the banks.

The growth of Oklahoma from 1890 to 1900 has been remarkable, owing to the rapid settlement of the Territory by an energetic class of people. It seems that the soil is productive and that the country will sustain a large population. There has been a rapid increase in the deposits, both of the National and Territorial banks. A good banking law is now in force, and it appears to have been wisely administered.

In 1896 the Governor of Oklahoma, in his report to the Secretary of the Interior, said that out of a total of fifty-two banks doing business, he had received reports from only eighteen (including three National banks). These had total resources of $\$ 1,282,273$; capital, $\$ 397,614$; surplus, $\$ 41,376$; undivided profits, $\$ 42,259$; deposits, $\$ 733,964$.

He thought a correct summary of the condition of the banks might be had by doubling the figures given.

The report of the Comptroller of the Currency for 1899 places the number of State banks in Oklahoma at sixty-eight, with total resources amounting to $\$ 3,930,720$. Their capital was $\$ 604,600$, undivided profits $\$ 286,952$, and deposits, $\$ 3,022,373$. From 1890 to 1899 the number of National banks increased from three to eight, and the capital from $\$ 200,000$ to $\$ 400,000$, and deposits from $\$ 169,000$ to $\$ 1,438,000$. Total resources grew in the same time from $\$ 408,000$ to $\$ 2,116,000$.

National Banks.

Figures are in thousands of dollars.

\begin{tabular}{|c|c|c|c|c|c|c|c|c|c|}
\hline YEARS. & 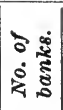 & $\begin{array}{l}\text { Loans } \\
\text { and dis. } \\
\text { counts. }\end{array}$ & $\begin{array}{c}\text { U. S. } \\
\text { bonds. }\end{array}$ & $\begin{array}{c}\text { Cash } \\
\text { and cash } \\
\text { items. }\end{array}$ & Capital. & Surplus. & $\begin{array}{c}\text { Undi. } \\
\text { vided } \\
\text { profts. }\end{array}$ & $\begin{array}{c}\text { out } \\
\text { standing } \\
\text { circula. } \\
\text { tion. }\end{array}$ & $\begin{array}{c}\text { Indi. } \\
\text { vidual } \\
\text { deposits. }\end{array}$ \\
\hline $1890 \ldots$. & 3 & $\$ 133$ & $\$ 50$ & $\$ 40$ & $\$ 200$ & $\ldots$. & $\$ 5$ & $\$ 34$ & $\$ 169$ \\
\hline $1893 . . . .$. & 6 & 339 & 75 & 135 & 300 & $\$ 16$ & 49 & 67 & 592 \\
\hline $1896 \ldots \ldots$. & 5 & 273 & 62 & 79 & 250 & 32 & 11 & 56 & 449 \\
\hline $1899 \ldots \ldots$. & 8 & 1,012 & 125 & 144 & 400 & 33 & 40 & 112 & 1,438 \\
\hline
\end{tabular}

\section{INDIAN TERRITORY.}

In the report of the Comptroller of the Currency for 1896, the following statement appears, made by D. M. Browning, Indian Commissioner:

"There is no provision of law, so far as I am aware, under which corporations, such as you mention [State banks], would have a right to engage in business in the 
Indian country, except under such conditions as other corporations or individuals would be permitted to engage in business. A State banking corporation desiring to operate a bank in the Indian Territory must comply with all the laws of the nation in which such bank is proposed to be located, and obtain a permit in accordance therewith, and must also obtain a license from this office as a trader with said nation. The foregoing applies to the territory occupied by the Cherokee, Creek, Seminole, Choctaw and Chickasaw nations of Indians in the Indian Territory, and commonly known as the Five Civilized Tribes."

In 1898 the number of banks, except National, that had been organized and still doing business, was nineteen, with a capital of $\$ 401,000$.

The first bank was estabiished at Muscogee in 1890. It was the First National Bank, with Robert L. Owen, a prominent Creek Indian, as President. This bank has been successful, having $\$ 100,000$ capital, $\$ 20,000$ surplus and $\$ 10,000$ undivided profits. In the same year two more banks were started, and the number of institutions has constantly increased, eight, with an aggregate capital of $\$ 280,000$, having commenced business in 1898.

The Indians are not only peaceful but many of them are highly civilized and well-to-do. In the towns the whites make up a large part of the population.

\section{National Banks.}

Figures are in thousands of dollars.

\begin{tabular}{|c|c|c|c|c|c|c|c|c|c|}
\hline YEARS. & '0 & $\begin{array}{c}\text { Loans } \\
\text { and dis- } \\
\text { counts. }\end{array}$ & $\begin{array}{c}\text { U.S. } \\
\text { bonds. }\end{array}$ & $\begin{array}{c}\text { Cash } \\
\text { and cash } \\
\text { items. }\end{array}$ & Capital. & Surplus. & $\begin{array}{c}\text { Undi- } \\
\text { vided } \\
\text { profits. }\end{array}$ & $\begin{array}{c}\text { Out- } \\
\text { standing } \\
\text { circula. } \\
\text { tion. }\end{array}$ & $\begin{array}{c}\text { Indi- } \\
\text { vidual } \\
\text { deposits. }\end{array}$ \\
\hline $1890 \ldots \ldots$. & 2 & $\$ 102$ & $\$ 37$ & $\$ 15$ & $\$ 110$ & $\cdots$ & $\$ 3$ & $\$ 18$ & $\$ 61$ \\
\hline $1893 \ldots . . . .$. & 6 & 541 & 90 & 88 & 360 & $\$ 42$ & 20 & 81 & 424 \\
\hline $1896 \ldots . . . .$. & 8 & 816 & 115 & 110 & 460 & 126 & 29 & 104 & 700 \\
\hline $1899 . . . . .$. & 15 & 2,206 & 216 & 191 & 860 & 224 & 74 & 194 & 1,892 \\
\hline
\end{tabular}




\section{VII}

\section{PACIFIC STATES.}

There is one distinctive feature of banking in this part of the country-the large amount of specie held in the reserves. On June 30, 1899 , the National banks held $\$ 14,623,430$ in specie, about $\$ 13,000,000$ of which was gold coin; they held at the same time only $\$ 444,965$ in legal-tender notes. In California contracts for the payment of money are payable in gold, and gold constitutes the principal circulating medium, as in some of the other of the Pacific States. Mining, agriculture, fruit raising and the lumber industry are the chief sources of wealth. The great development in mining on the Pacific Coast following the gold discoveries in 1848 has been far exceeded in more recent years by the growth in production along the other lines mentioned. Banking has not been free from the fluctuations incident to the building up of new States, but as the population became more fixed and business conditions more settled, the banks experienced greater prosperity. Most of these States have stringent bank laws and the banks are under public supervision; and though there is not so much official oversight of the business in some of the other States, the standard of bank management is generally high.

\section{WASHINGTON.}

By Article 12, Section 11 of the State constitution, the issue of cirsulating notes is prohibited, and the general statutes provide as follows : "No corporation organized under this chapter shall, by any implication or construction, be deemed to possess the power of issuing bills, notes, or other evidence of debt for circulation as money." The capital stock of incorporated banks must not be less than $\$ 25,000$, three-fifths of which must be paid in, and affidavit to that effect must be filed with the articles of incorporation. As the statutes of the State do not designate any officer to determine when these conditions have been complied with, enforcement of the law is difficult. Bank officers who receive deposits knowing the bank to be insolvent are guilty of felony, and shall be punished by imprisonment from two to twenty years.

Banking eorporations are required to file with the State Auditor, on the first Monday of June in each year, a statement of their condition. 
There is no penalty for failure to comply with this requirement. In 1897 the State Auditor characterized the law as very defective, and the propriety of enacting a general banking law has been considered in recent years.

It was a matter of considerable pride to the banks of Seattle that although suffering from the effects of a very destructive fire, they were able to withstand the panic of 1893 without any suspensions or failures.

Washington was admitted into the Union in 1889 , and ten years later the capital of the twenty-eight State banks, as reported by the Comptroller of the Currency, was $\$ 1,602,800$. Although the number of National banks is about the same (thirty-one in 1899), their capital is much greater, amounting in the year last named to $\$ 3,360,000$. Individual deposits of the State banks are less than one-third those of the National institutions.

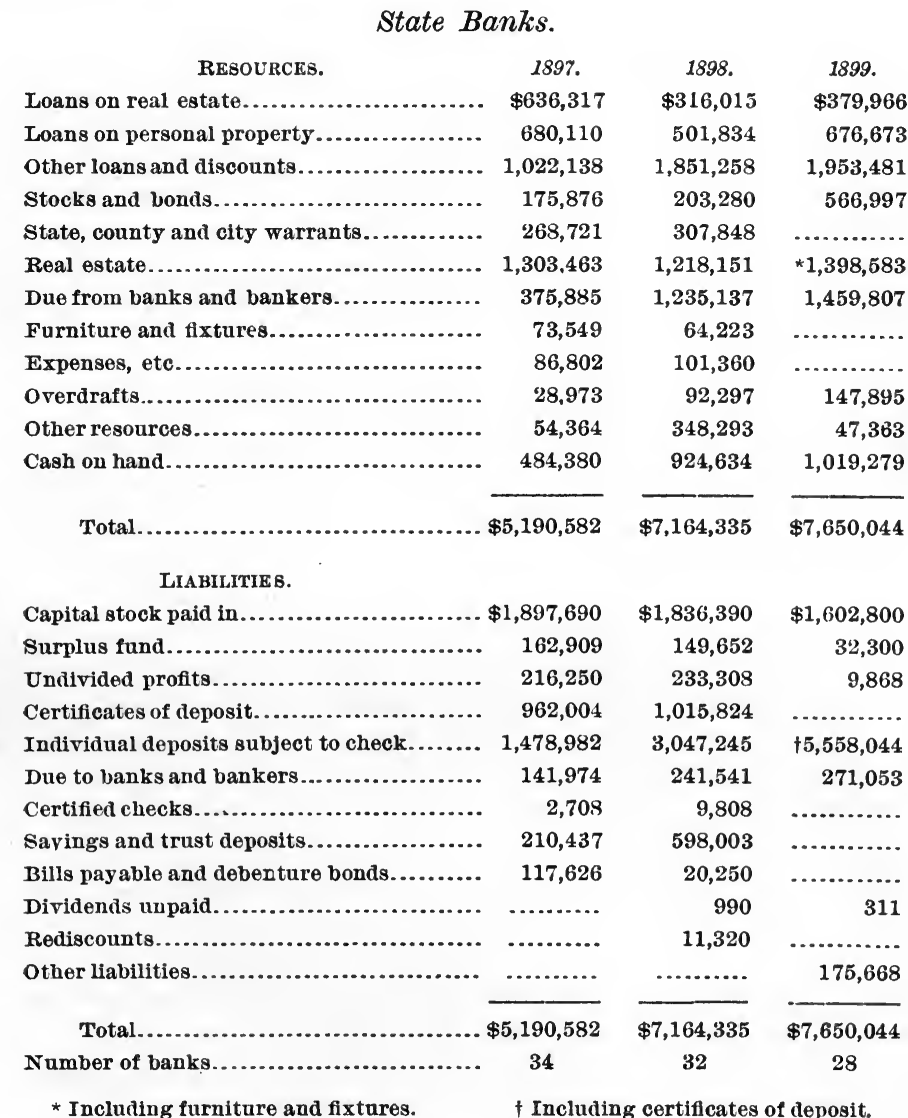


National Banks.

Figures are in thousands of dollars.

\begin{tabular}{|c|c|c|c|c|c|c|c|c|c|}
\hline YEARS. & 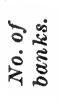 & $\begin{array}{c}\text { Loans } \\
\text { and dis. } \\
\text { counts. }\end{array}$ & $\begin{array}{c}U . S . \\
\text { bonds. }\end{array}$ & $\begin{array}{c}\text { Cash } \\
\text { and cash } \\
\text { items. }\end{array}$ & Capital. & Surplus. & $\begin{array}{c}\text { Undi. } \\
\text { vided } \\
\text { profits. }\end{array}$ & $\begin{array}{c}\text { Out. } \\
\text { standing } \\
\text { circula. } \\
\text { tion. }\end{array}$ & $\begin{array}{c}\text { Indi- } \\
\text { vidual } \\
\text { deposits. }\end{array}$ \\
\hline $1878 \ldots \ldots \ldots$ & 1 & $\$ 126$ & $\$ 100$ & $\$ 88$ & $\$ 150$ & ...... & $\$ 8$ & $\$ 45$ & $\$ 92$ \\
\hline $1883 \ldots . .$. & 12 & 1,851 & 328 & 329 & 760 & $\$ 44$ & 239 & 253 & 1,623 \\
\hline $1888 \ldots \ldots \ldots$ & 24 & 6,232 & 572 & 1,044 & 1,855 & 323 & 756 & 421 & 6,629 \\
\hline $1893 . . . . . .$. & 57 & 12,430 & 1,430 & 1,367 & 6,020 & 1,658 & 807 & 1,242 & 7,010 \\
\hline $1899 . . . \ldots . .$. & 31 & 9,431 & 1,572 & 2,927 & 3,360 & 503 & 474 & 792 & 18,702 \\
\hline
\end{tabular}

\section{OREGON.}

The constitution of the State prohibits banks of issue, and the Legislature may not incorporate any bank. Corporations may be formed under general laws to do a banking business. Stockholders are liable only to the extent of their stock. Incorporated and private banks are in operation under a general law, neither being subject to legislative supervision or restriction. A law exists requiring banks to furnish a list of depositors and amounts of deposits for taxation, but it is apparently inoperative.

\section{First Banks Established in Portland.}

Messrs. Ladd \& Tilton established the first bank in Portland in 1859, the business being conducted over their grocery store. Mr. Ladd died a few years since and Mr. Tilton retired; the business is continued by Mr. Ladd's sons.

The First National Bank, of Portland, was organized in 1865, with $\$ 100,000$ capital, the mercantile deposits amounting at that period to about $\$ 40,000$. Total deposits are now (1899) $\$ 5,202,649$. In 1868 a controlling interest in the bank was purchased by Hon. H. W. Corbett, then a member of the United States Senate. In 1870 the capital was increased to $\$ 250,000$ and to $\$ 500,000$ in 1888 .

The banking house of Ladd \& Bush, at Salem, dates from about 1863 , and is still in successful operation.

Reports from the State banks are, perhaps, incomplete, but the returns indicate that the National banks greatly preponderate over the State institutions in the amount of capital and deposits. The Comptroller of the Currency publishes reports from fifteen State banks on June 30,1899 , their capital being $\$ 858,467$ and deposits $\$ 2,864,564$. There are twenty-eight National banks in the State having a capital of $\$ 2,420,000$ and deposits amounting to $\$ 11,781,000$. 
State Banks.

\begin{tabular}{|c|c|c|c|c|c|c|}
\hline YEARS. & $\begin{array}{l}\text { No. of } \\
\text { banks. }\end{array}$ & $\begin{array}{l}\text { Loans and } \\
\text { discounts. }\end{array}$ & Specie. & $\begin{array}{l}\text { Capital } \\
\text { stock. }\end{array}$ & Circulation. & Deposits. \\
\hline $1887 \ldots \ldots \ldots$ & 4 & $\$ 241,221$ & ............. & $\$ 170,000$ & ....... & $\$ 173,390$ \\
\hline $1889 \ldots \ldots$. & 5 & 381,648 & ............ & 139,593 & & 368,048 \\
\hline $1891 \ldots \ldots \ldots$ & 12 & $1,374,741$ & ............... & 813,825 & ..... & $1,368,306$ \\
\hline $1893 \ldots \ldots$. & 12 & 763,209 & ........... & 553,800 & ............. & 429,726 \\
\hline $1895 \ldots \ldots$ & 10 & 640,310 & ............ & 425,400 & .............. & 582,869 \\
\hline $1897 \ldots \ldots$. & 17 & $1,149,067$ & …........... & 995,650 & ….............. & 916,740 \\
\hline $1899 \ldots \ldots$ & 15 & $1,938,161$ & ............ & 858,467 & ............... & $2,864,564$ \\
\hline
\end{tabular}

National Banks.

Figures are in thousands of dollars.

\begin{tabular}{|c|c|c|c|c|c|c|c|c|c|}
\hline YEARS. & 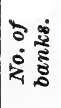 & $\begin{array}{c}\text { Loans } \\
\text { and dis- } \\
\text { counts. }\end{array}$ & $\begin{array}{l}\text { U. S. } \\
\text { bonds. }\end{array}$ & $\begin{array}{c}\text { Cash } \\
\text { and cash } \\
\text { items. }\end{array}$ & Capital. & Susplus. & $\begin{array}{l}\text { Undi- } \\
\text { vided } \\
\text { profits. }\end{array}$ & $\mid \begin{array}{c}\text { Out } \\
\text { standing } \\
\text { circula- } \\
\text { tion. }\end{array}$ & $\begin{array}{c}\text { Indi. } \\
\text { vidual } \\
\text { deposits. }\end{array}$ \\
\hline $1866 . . . . .$. & 1 & $\$ 39$ & $\$ 101$ & $\$ 20$ & $\$ 100$ & $\ldots$ & $\$ 7$ & $\$ 88$ & $\$ 23$ \\
\hline $1869 \ldots \ldots$ & 1 & 137 & 210 & 185 & 100 & $\$ 5$ & 11 & 88 & 115 \\
\hline $1874 \ldots \ldots$ & 1 & 710 & 458 & 164 & 250 & 50 & 220 & 221 & 556 \\
\hline $1879 \ldots \ldots$ & 1 & 767 & 751 & 168 & 250 & 50 & 287 & 213 & 711 \\
\hline $1884 \ldots . . .$. & 8 & 2,181 & 957 & 524 & 695 & 68 & 562 & 359 & 2,074 \\
\hline $1889 . . . . .$. & 31 & 8,771 & 1,170 & 1,096 & 2,590 & 537 & 1,010 & 508 & 8,118 \\
\hline $1894 \ldots . . .$. & 35 & 8,196 & 1,570 & 1,385 & 3,620 & 675 & 849 & 571 & 7,422 \\
\hline $1899 \ldots$ & 28 & 6,268 & 1,517 & 1,891 & 2,420 & 477 & 854 & 832 & 11,781 \\
\hline
\end{tabular}

\section{CALIFORNIA.}

Banking in California dates from the gold discoveries in 1848, the first bankers being merchants who combined the purchase of gold dust with their other business transactions. It was the custom of these merchants to receive gold dust, which was weighed and merchandise given in exchange, the balance, if any, being left on deposit subject to the call of the miner who brought it in.

In 1848 the Miners' Bank was established by Wright \& Co., in San Francisco, and it is said to have paid an annual rental of $\$ 75,000$ for the building in which it did business. It was a bank of deposits and loans, and advertised a capital of $\$ 200,000$. The rate of interest charged on loans varied from eight to fifteen per cent. a month, according to the credit of the borrower.

With the great increase in the production of gold in 1849 , and the 
gain in population, there was an addition to the number of banks, no less than five commencing business during the year. The first of these was opened in January by H. M. Naglee \& Co., composed of H. M. Naglee and Richard Sinton. Banks were also established by Burgoyne \& Co., B. Davidson, Wells \& Co. and James King of William.

The large output of gold in 1850 led to wild speculation; real estate and other forms of property were sold at prices far beyond their actual value. Three new banks were opened in the first half of the year, namely, Tallant \& Wilde, Page, Bacon \& Co., and J. Argenti. Shortly afterwards there was a reaction from the era of inflation, and Messrs. Naglee \& Co. and Wells \& Co. failed. As the other banks weathered the storm, confidence was gradually reștored.

\section{InTRODUCTION OF GOLD COINAGE.}

During 1851 the unique position which gold dust had held as a medium of exchange was supplanted by the introduction of the "slug," issued as a fifty-dollar coin by the newly-established United States Assay Office. Private firms also issued coins of the denomination of $\$ 5$, the Assay Office coining nothing smaller than ten dollar pieces. These private coins, unlike those issued at Denver, which commanded a premium, fell into discredit owing to short weight and other imperfections. Prior to 1850 gold dust was rarely worth more than $\$ 10$ an ounce and was sometimes as low as $\$ 5$.

There was a rapid recovery from the depression of 1850 , and in 1852 there were at least twenty banking firms doing business in San Francisco. The production of gold in that year was estimated at $\$ 50,000,000$; but values had subsided considerably from a speculative basis, the taxes on real estate for 1852 being based upon an assessment of $\$ 14,900,000$, as against $\$ 21,000,000$ for 1851 .

Gradually, in the succeeding years, a number of the older banks withdrew from business and were succeeded by new and stronger institutions.

\section{Financial Crisis of 1855.}

During 1855 disaster overtook several of the San Francisco banks. Page, Bacon \& Co. suspended, followed in a few days by the failure of Adams \& Co. In the following year Palmer, Cook \& Co., a large and apparently sound firm, suspended, and owing to the loss of a steamship with $\$ 2,000,000$ gold on board, Drexel, Sather \& Church suspended for a short period, and Wells, Fargo \& Co. did likewise for three days. This flurry caused the permanent retirement of a number of the smaller banks. Among those which weathered the storm was the banking firm of Lucas, Turner \& Co., of which W. T. Sherman, afterwards the famous General, was then manager.

By 1860 business had revived, and as agriculture became more successful there was a renewed demand for banking capital, and this was 
to some extent influential in attracting foreign banking houses into the State. An attempt was made to organize a trust company to issue paper money secured by real estate; but the people of California preferred gold then, as they do now, and the scheme was never put into operation.

The establishment of the United States Mint in San Francisco in 1854 had an impcrtant effect on the circulating medium. Since its establishment to the present time the coinage has been more than $\$ 1,250$,000,000 , of which the gold coinage has been about $\$ 1,000,000,000$.

\section{Suspension of the Bank of Californta.}

The enormous development of mining in the Comstock Lode in Nevada in $\mathbf{1 8 7 4}$ gave a fresh impetus to speculation. It was then estimated by an expert that the value of the ore in sight was not less than $\$ 1,500$,000,000 . The public demand for money with which to buy shares was felt by the banks, and this pressure was aggravated by the shipment of $\$ 20,000,000$ of gold to the East, against $\$ 300,000$ in the previous year. There were rumors in circulation detrimental to the credit of William. C. Ralston, the Cashier and active Manager of the Bank of California, and a run ensued upon that institution, causing it to close its doors on August 26. Mr. Ralston was requested to resign, and unable to stand the strain of his situation he committed suicide. D. O. Mills, William Sharon and other well-known capitalists came to the rescue of the bank, and it was soon put upon a sound basis, continuing to the present time to be one of the great banks of the Pacific Coast. The bank was founded in 1864 by D. O. Mills, at the suggestion of W. C. Ralston, then a member of the firm of Donohoe, Ralston \& Co., and a man of recognized financial ability.

During this crisis the National Gold and Trust Company, and the Merchants' Exchange Bank suspended and the Savings banks enforced the rule requiring thirty days' notice of withdrawals of deposits.

\section{Organization of National Gold Banks.}

The organic law of California forbids the issue of paper money, and more than almost any other part of the world the State has exclusively adhered to the use of a coin currency. There was also considerable sentiment about this, as was manifested by the opposition to the use of legal-tender notes and National bank notes, not so much during and immediately after the war when they were at a discount as compared with gold and silver, but even since the resumption of specie payments. This feeling had the effect of retarding the organization of National banks in California, and in deference to it, and yet with a wish to extend the benefits of the system to the State, Congress on July 12, 1870, enacted a law for the creation of National gold banks, that is banks the currency of which should be redeemable on demand in gold coin. These banks were to be organized in every respect similar to other National banks, but the bonds deposited by them as a basis for 
circulation bearing interest in gold, were permitted to be a basis for circulation to the extent of eighty per cent. of their par value only, instead of ninety per cent., as in the case of other National banks. This had the effect of rendering the circulation unprofitable. Their reserves on circulation were to be twenty-five per cent. of the aggregate amount outstanding. Gold banks in San Francisco were not required to redeem their notes in New York city as were other National banks in the redemption cities then existing. There was nothing in the law preventing gold banks from being organized elsewhere than in California, and one such, the Kidder National Gold Bank, was organized in Boston, Mass., but never did any business. The First National Gold Bank and the National Gold Bank and Trust Company were organized in San Francisco, and only nine were organized in all in the State. The financial crisis of 1875 gave the gold banks a set-back on account of the suspension of the National Gold Bank and Trust Company, which was aggravated by the refusal of the other banks in California to take the gold notes, although they were amply secured.

On February 14, 1880, another law was passed authorizing the conversion of gold banks into currency banks, and all of these institutions availed themselves of it. Specie payments had been resumed all over the United States, and there was no longer reason for any distinction. Since then the formation of National banks in California has gone on more rapidly, but the State and foreign banks, incorporated and private, still do most of the business in the State, although the system is making headway with the development of the agricultural interests of the State.

\section{BANK OF THE Bonanza Kings.}

The Nevada Bank of San Francisco was established in 1875, and received its name from the State where the fortunes of its foundersJames C. Flood, W. S. O'Brien, John W. Mackay and James G. Fair-had been made. Its original capital was $\$ 5,000,000$, afterwards increased to $\$ 10,000,000$, but owing to unfavorable legislation the capital was reduced in 1879 to $\$ 3,000,000$. While Mackay and Fair directed the actual working of the mines, Flood conducted the financial operations of the firm with marked ability and success. After the death of Mr. Flood the management of the bank went into the hands of Isaias W. Hellman, and in 1898 it reorganized as the Nevada National Bank. Mr. Flood's son and Mr. Mackay are still large shareholders.

\section{San Francisco Clearing-House Established.}

The San Francisco Clearing-House Association was organized in 1876, and its annual clearances rapidly increased till in 1899 they amounted to $\$ 971,000,000$. From 1883 to 1893 gold certificates were largely used in paying balances, but since the latter date their use has been discontinued. 


\section{The Board of Bank Commissioners.}

An act creating a Board of Bank Commissioners and prescribing their duties and powers was approved March 30, 1878, the act going into effect on the 15th of May following. It provided for the appointment of three persons, one of whom shall be an expert accountant, to be styled Bank Commissioners; their office was to be in San Francisco, and they were to receive a salary of $\$ 3,000$, and travelling expenses, not to exceed $\$ 500$ per year, for each commissioner. Banks were required to take out licenses, and were to be examined by one or more of the Bank Commissioners at least once in six months, or oftener as might be deemed necessary. Savings banks were not to be licensed unless at least fifty per cent. of their loans was secured by first mortgage or other prior lien upon real estate within the State; such loans were afterwards to be limited to sixty per cent. of the market value of the security, except when made for the purpose of facilitating the sale of property owned by the corporation. Savings banks were prohibited from investing in mining shares. Semi-annual reports of condition were required, and the commissioners were given full power to cause the banks to obey the law and to close up insolvent institutions.

Banks were to contribute to the payment of the expenses of the Board of Commissioners in proportion to their deposits.

Soon after assuming office the commissioners were confronted with some embarrassments to the banks. From July, 1878, to July, 1880, they estimated that the falling off in the resources and liabilities of the commercial and Savings banks was something over $\$ 25,000,000$. For 1880 the Comstock mines had collected $\$ 6,000,000$ more in assessments than had been paid in dividends, and this alone was a heavy drain on the resources of the people. In the succeeding years there was a gradual revival of business, and a gain in deposits of both classes of banks.

\section{Examination of Private Banks.}

The question having been raised as to the authority of the Bank Commissioners to make examinations of private banks, the matter was brought to the attention of the Legislature. That body refused to compel private banks to submit to examination, but by an act approved March 10, 1887, Section 23 was added to the banking law, requiring unincorporated banks to make reports of their condition twice each year to the Bank Commissioners.

\section{Dividends From ACCRUkD AND UNPaId INTERest.}

In the report of the Board of Bank Commissioners for 1887 reference was made to a custom of many of the banks of "estimating the amount of interest accrued on their loans and carrying the amount into their books as an asset, subject to what might be called a constructive division, as profits earned." This practice was not approved by the Bank 
Commissioners and the matter was referred to the Supreme Court, which decided that "interest accrued, but not payable, and interest accrued, but not paid, though secured by safe mortgages, and drawing interest, are not 'surplus profits,' and therefore can not enter into the dividends which Savings banks are authorized to make out of their 'surplus profits,' since profits must consist of earnings actually received." Prior to this decision most of the commercial banks had discontinued the practice, at the suggestion of the Bank Commissioners.

In March, 1891, a convention of bankers was held at Los Angeles, resulting in the organization of the California State Bankers' Association.

The panic which was felt in this year in some parts of the country owing to the failure of the Barings, in London, in 1890, did not reach California. It escaped this convulsion, as it did that of 1873 , but the latter erisis reacted on the banks of the State a year or so after, as has been previously detailed.

\section{Panic of 1893.}

Although there were bank failures in California, as elsewhere, in 1893 , the banks stood the strain very well. On July 1,1892 , there were 268 banks in operation, and 283 on July 1,1894 . The total resources on the former date were $\$ 301,946,044$, and on July 1 , 1894 , they were $\$ 297,352,916$. These figures include the National banks.

In their report for 1897 the Bank Commissioners condemned the law which permits the placing of an insolvent bank back in the hands of the directors, who wrecked it, for the purpose of winding up its affairs during the process of liquidation. They also recommended that bank directors be required to make a personal examination of their institutions at least twice a year, and certify statements of condition to the Bank Commissioners under oath.

\section{Condition of The Banks in 1899.}

At the close of business on July 31,1899 , there were fifty-three Savings banks, 176 commercial banks, eighteen private banks and thirtyfive National banks doing business in the State. The Bank Commissioners, in their report dated September 4, 1899, said:

"It is with pleasure that we call attention to the fact that the net increase in deposits in the banks of this State for the last twenty-four months has been $\$ 50,382,795-$ more than two million dollars per month. Such increase is distributed in almost equal proportions between commercial, National and Savings banks, both in eity and country, and is a splendid showing, considering the fact that we are recovering from the financial depression of 1893, and have passed through two dry years. It demonstrates that the State has great recuperative powers and producing capacity, and that the financial institutions of California are generally well managed and in a prosperous. condition."

The following statistics, compiled from the annual reports of the Bank Commissioners for a number of years past, illustrate the growth 
of the Savings, commercial and private banks of California from 1879 to 1899 . It will be remembered that the law requiring private banks to make reports was enacted in 1887 .

Savings, Commercial and Private Banks, 1879-1899.

\begin{tabular}{|c|c|c|c|c|c|}
\hline & 1879. & 1884. & 1889. & 1894. & 1899. \\
\hline REsOURCES. & & & & & \\
\hline Bank premises..... & $\$ 3,099,831$ & $\$ 3,001,061$. & $\$ 4,722,016$ & $\$ 6,128,179$ & $\$ 5,794,132$ \\
\hline Other real estate... & $4,851,217$ & $5,217,056$ & $3,569,608$ & $5,779,256$ & $17,534,907$ \\
\hline Stocks, bonds, eto.. & $7,038,943$ & $22,556,565$ & $21,749,059$ & $21,112,517$ & $59,337,348$ \\
\hline Loans on real estate & $58,269,683$ & $46,185,774$ & $80,703,160$ & $124,452,038$ & $107,104,395$ \\
\hline $\begin{array}{c}\text { Loans on stocks, } \\
\text { bonds, etc......... }\end{array}$ & $8,836,169$ & $11,541,199$ & $13,943,126$ & $18,515,687$ & $14,015,177$ \\
\hline $\begin{array}{c}\text { Loans on other } \\
\text { securities.......... }\end{array}$ & $2,413,416$ & $\dagger 7,064,388$ & $5,947,635$ & $4,297,590$ & $6,110,023$ \\
\hline $\begin{array}{c}\text { Loans on personal } \\
\text { security........... }\end{array}$ & $14,470,538$ & $30,019,256$ & $46,756,525$ & $42,122,770$ & $39,890,250$ \\
\hline Money on hand..... & $13,895,642$ & $12,130,851$ & $20,349,799$ & $24,382,836$ & $22,277,639$ \\
\hline Due from banks and & - & & & & \\
\hline bankers............ & $10,407,259$ & $7,848,174$ & $10,631,930$ & $17,080,122$ & $25,611,959$ \\
\hline Other assets........ & $2,872,716$ & $4,310,420$ & $7,037,824$ & $3,791,966$ & $2,257,293$ \\
\hline Total.............. & $\$ 126,155,418$ & $\$ 149,874,750$ & $\$ 215,410,687$ & $\$ 267,662,966$ & $\$ 299,933,126$ \\
\hline LIABILITIES. & & & & & \\
\hline Capital paid up..... & *\$37,134,968 & $* \$ 30,743,276$ & $* \$ 46,804,071$ & $* \$ 52,930,714$ & $* \$ 35,976,318$ \\
\hline Reserve, profit and & & & & & \\
\hline loss.................... & 786,317 & $15,749,455$ & $17,148,946$ & $23,645,384$ & $24,551,906$ \\
\hline Due depositors..... & $76,736,302$ & $96,021,677$ & $142,966,018$ & $181,982,345$ & $225,005,906$ \\
\hline Due banks and & & & & & \\
\hline bankers............. & ................. & (................... & $6,953,224$ & $6,135,973$ & $7,984,405$ \\
\hline $\begin{array}{l}\text { State, county and } \\
\text { city money....... }\end{array}$ & ................ & n.............. & ................. & (n).................. & 134,621 \\
\hline Other liabilities.... & $3,503,830$ & $7,360,339$ & $1,538,425$ & $2,968,549$ & $6,279,967$ \\
\hline Total............. & $\$ 126,155,418$ & $\$ 149,874,750$ & $\$ 215,410,687$ & $\$ 267,662,966$ & $\$ 299,933,126$ \\
\hline Number of banks.. & 83 & 92 & 184 & 248 & 247 \\
\hline
\end{tabular}

* Includes amount due London offices of San Francisco branches of English banks.

† Includes loans on personal securities for Savings banks.

\section{Savings Banks.}

Albert Miller, a native of Germany, established the first Savings bank in California. It was called the Savings and Loan Association, and opened for business in San Francisco in 1854. It was subsequently 
merged into the Savings and Loan Society, the latter being organized July 23, 1857. In 1859 the Hibernia Savings and Loan Society was organized at San Francisco, and from this time on banks of this class continued to be organized in San Francisco and other points in the State.

On January 1, 1880, there were 83,302 depositors in the Savings banks of the State, and from 1857 to the above date the banks had paid dividends to depositors amounting to $\$ 53,119,812$. From 1878 to January 1, 1881, eleven Savings banks went out of business and two new ones were organized.

In their report for 1888 the Bank Commissioners referred to the Savings banks as follows:

"There are no banks in this State now working on the purely mutual principle. All have either a capital stock or a reserve fund, in which only a part of the depositors would be interested in case of liquidation. That is to say, those depositors who have withdrawn, yet whose funds have contributed towards earning the reserve, forfeit all claims to it. * * * As a matter of fact the Savings banks of California are business enterprises of private individuals, with incidental benefit to the public, in nowise differing in this regard from commercial banks."

Perhaps if this test were applied it might be found that there are not any strictly mutual Savings banks in the country, as it is not believed that in any of the States do the withdrawing depositors retain their right to participate in the division of the surplus in the event of failure or liquidation of the bank.

Some banks have been organized on the mutual plan, a notable example being the Hibernia Savings and Loan Society, of San Francisco, the largest and most successful Savings bank on the Pacific Coast.

In many cases the Savings banks of the State are conducted as adjuncts of National and State banks, earrying on business in the same building, and with the same management. While such an arrangement is economical, and has some other advantages, the Bank Commissioners declared in their report for 1891 that it sometimes resulted in making these Savings banks " subject to such risks and hazards as the law particularly intends to protect them against." This view was apprently confirmed by the failure, in November, 1891, of the California Savings Bank, of San Diego, which was conducted as a department of the California National Bank.

This practice of conducting Savings banks in the same buildings with State and National banks, and under the same management, prevails in many States, and though liable to give rise to some abuses, undoubtedly permits the organization of Savings banks in many places where they could not otherwise exist.

The Savings banks in 1896 had total deposits amounting to $\$ 131$,653,634 , and there were 159,856 depositors, making an average of $\$ 823.57$ to each depositor.

Deposits in the Savings banks have increased largely in the last thirty years, as may be seen from the following official statistics: 
Deposits in Savings Banks.

1870 $\$ 36,555,909$

\section{National Banks.}

Figures are in thousands of dollars.

\begin{tabular}{|c|c|c|c|c|c|c|c|c|c|}
\hline YEARE. & 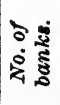 & $\begin{array}{c}\text { Loans } \\
\text { and dis- } \\
\text { counts. }\end{array}$ & $\begin{array}{c}U . S . \\
\text { bonds. }\end{array}$ & $\begin{array}{c}\text { Cash } \\
\text { and cash } \\
\text { items. }\end{array}$ & Capital. & Surples. & $\begin{array}{l}\text { Undi- } \\
\text { vided } \\
\text { profits. }\end{array}$ & $\begin{array}{c}\text { Out- } \\
\text { standing } \\
\text { circula- } \\
\text { tion. }\end{array}$ & $\begin{array}{c}\text { Indi. } \\
\text { vidual } \\
\text { deposits. }\end{array}$ \\
\hline $1871 \ldots$ & 1 & $\$ 852$ & $\$ 500$ & $\$ 118$ & $\$ 1,000$ & ...... & $\$ 41$ & $\$ 277$ & $\$ 199$ \\
\hline $1876 . .$. & 9 & 5,462 & 1,794 & 1,142 & 4,700 & $\$ 347$ & 167 & 1,414 & 2,499 \\
\hline $1881 \ldots$ & 11 & 6,476 & 1,970 & 2,312 & 3,300 & 444 & 314 & 1,334 & 6,165 \\
\hline $1886, \ldots$ & 24 & 12,161 & 1,780 & 3,044 & 5,385 & 908 & 563 & 1,393 & 11,215 \\
\hline $1891 \ldots$ & 36 & 21,631 & 1,831 & 3,757 & 8,425 & 2,307 & 1,210 & 1,221 & 18,608 \\
\hline $1896 \ldots$ & 31 & 17,453 & 2,101 & 5,137 & 7,525 & 2,536 & 922 & 1,479 & 16,181 \\
\hline $1899 \ldots$ & 35 & 28,441 & 2,807 & 8,818 & 10,825 & 3,413 & 1,242 & 1,438 & 33,138 \\
\hline
\end{tabular}

\section{IDAHO.}

This State was admitted into the Union in 1890 , and has not therefore had an opportunity to make much banking history. There is no special law relating to banking, but banks are organized under the general corporation law. The issue of circulating notes is prohibited.

\section{National Banks.}

Figures are in thousands of dollars.

\begin{tabular}{|c|c|c|c|c|c|c|c|c|c|}
\hline YEARB. & $\begin{array}{l}\text { No. of } \\
\text { banks. }\end{array}$ & $\begin{array}{c}\text { Loans } \\
\text { and dis- } \\
\text { counts. }\end{array}$ & $\begin{array}{c}U . S . \\
\text { bonds. }\end{array}$ & $\begin{array}{c}\text { Cash } \\
\text { and cash } \\
\text { items. }\end{array}$ & Capital. & Surplus. & $\begin{array}{r}\text { Undi. } \\
\text { vided } \\
\text { profits. }\end{array}$ & $\begin{array}{l}\text { Out. } \\
\text { standing } \\
\text { circula. } \\
\text { tion. }\end{array}$ & $\begin{array}{c}\text { Indi- } \\
\text { vidual } \\
\text { deposits. }\end{array}$ \\
\hline $1867 \ldots$ & 1 & $\$ 72$ & $\$ 52$ & $\$ 26$ & $\$ 100$ & .... & - $\$ 8$ & $\$ 29$ & $\$ 27$ \\
\hline $1872 \ldots .$. & 1 & 87 & 100 & 33 & 100 & $\$ 12$ & 10 & 89 & 95 \\
\hline $1877 \ldots$ & 1 & 90 & 100 & 41 & 100 & 21 & 3 & 85 & 127 \\
\hline $1882 . . .$. & 1 & 132 & 100 & 81 & 100 & 20 & 9 & 81 & 274 \\
\hline $1887 .$. & 6 & 578 & 143 & 149 & 350 & 29 & 89 & 82 & 577 \\
\hline $1892 \ldots .$. & 11 & 1,804 & 232 & 253 & 700 & 197 & 157 & 152 & 2,005 \\
\hline $1897 .$. & 10 & 1,067 & 237 & 276 & 600 & 246 & 140 & 164 & 2,270 \\
\hline $1899 . .$. & 9 & 1,039 & 253 & 295 & 550 & 196 & 130 & 137 & 3,512 \\
\hline
\end{tabular}


merged into the Savings and Loan Society, the latter being organized July 23, 1857. In 1859 the Hibernia Savings and Loan Society was organized at San Francisco, and from this time on banks of this class continued to be organized in San Francisco and other points in the State.

On January 1, 1880, there were 83,302 depositors in the Savings banks of the State, and from 1857 to the above date the banks had paid dividends to depositors amounting to $\$ 53,119,812$. From 1878 to January 1,1881 , eleven Savings banks went out of business and two new ones were organized.

In their report for 1888 the Bank Commissioners referred to the Savings banks as follows:

"There are no banks in this State now working on the purely mutual principle. All have either a capital stock or a reserve fund, in which only a part of the depositors would be interested in case of liquidation. That is to say, those depositors who have withdrawn, yet whose funds have contributed towards earning the reserve, forfeit all claims to it. * * * As a matter of fact the Savings banks of California are business enterprises of private individuals, with incidental benefit to the public, in nowise differing in this regard from commercial banks."

Perhaps if this test were applied it might be found that there are not any strictly mutual Savings banks in the country, as it is not believed that in any of the States do the withdrawing depositors retain their right to participate in the division of the surplus in the event of failure or liquidation of the bank.

Some banks have been organized on the mutual plan, a notable example being the Hibernia Savings and Loan Society, of San Francisco, the largest and most successful Savings bank on the Pacific Coast.

In many cases the Savings banks of the State are conducted as adjuncts of National and State banks, carrying on business in the same building, and with the same management. While such an arrangement is economical, and has some other advantages, the Bank Commissioners declared in their report for 1891 that it sometimes resulted in making these Savings banks " subject to such risks and hazards as the law particularly intends to protect them against." This view was apprently confirmed by the failure, in November, 1891, of the California Savings Bank, of San Diego, which was conducted as a department of the California National Bank.

This practice of conducting Savings banks in the same buildings with State and National banks, and under the same management, prevails in many States, and though liable to give rise to some abuses, undoubtedly permits the organization of Savings banks in many places where they could not otherwise exist.

The Savings banks in 1896 had total deposits amounting to $\$ 131$,653,634 , and there were 159,856 depositors, making an average of $\$ 823.57$ to each depositor.

Deposits in the Savings banks have increased largely in the last thirty years, as may be seen from the following official statistics: 
Deposits in Savings Banks.

1870 $\$ 36,555,909$

\section{National Banks.}

Figures are in thousands of dollars.

\begin{tabular}{|c|c|c|c|c|c|c|c|c|c|}
\hline YEARE. & 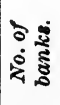 & $\begin{array}{c}\text { Loans } \\
\text { and dis- } \\
\text { counts. }\end{array}$ & $\begin{array}{c}U . S . \\
\text { bonds. }\end{array}$ & $\begin{array}{c}\text { Cash } \\
\text { and cash } \\
\text { items. }\end{array}$ & Capital. & Surplus. & $\begin{array}{l}\text { Undi- } \\
\text { vided } \\
\text { profits. }\end{array}$ & $\begin{array}{c}\text { Out- } \\
\text { standing } \\
\text { circula. } \\
\text { tion. }\end{array}$ & $\begin{array}{c}\text { Indi. } \\
\text { vidual } \\
\text { deposits. }\end{array}$ \\
\hline $1871 \ldots$ & 1 & $\$ 852$ & $\$ 500$ & $\$ 118$ & $\$ 1,000$ & ...... & $\$ 41$ & $\$ 277$ & $\$ 199$ \\
\hline $1876 \ldots$ & 9 & 5,462 & 1,794 & 1,142 & 4,700 & $\$ 347$ & 167 & 1,414 & 2,499 \\
\hline $1881 \ldots$ & 11 & 6,476 & 1,970 & 2,312 & 3,300 & 444 & 314 & 1,334 & 6,165 \\
\hline $1886, \ldots$ & 24 & 12,161 & 1,780 & 3,044 & 5,385 & 908 & 563 & 1,393 & 11,215 \\
\hline $1891 . .$. & 36 & 21,631 & 1,831 & 3,757 & 8,425 & 2,307 & 1,210 & 1,221 & 18,608 \\
\hline $1896 \ldots$ & 31 & 17,453 & 2,101 & 5,137 & 7,525 & 2,536 & 922 & 1,479 & 16,181 \\
\hline $1899 . .$. & 35 & 28,441 & 2,807 & 8,818 & 10,825 & 3,413 & 1,242 & 1,438 & 33,138 \\
\hline
\end{tabular}

\section{IDAHO.}

This State was admitted into the Union in 1890 , and has not therefore had an opportunity to make much banking history. There is no special law relating to banking, but banks are organized under the general corporation law. The issue of circulating notes is prohibited.

\section{National Banks.}

Figures are in thousands of dollars.

\begin{tabular}{|c|c|c|c|c|c|c|c|c|c|}
\hline YRARB. & $\begin{array}{l}\text { No. of } \\
\text { banks. }\end{array}$ & $\begin{array}{c}\text { Loans } \\
\text { and dis- } \\
\text { counts. }\end{array}$ & $\begin{array}{c}U . S . \\
\text { bonds. }\end{array}$ & $\begin{array}{c}\text { Cash } \\
\text { and cash } \\
\text { items. }\end{array}$ & Capital. & Surplus. & $\begin{array}{r}\text { Undi. } \\
\text { vided } \\
\text { profte. }\end{array}$ & $\begin{array}{c}\text { Out- } \\
\text { standing } \\
\text { circula- } \\
\text { tion. }\end{array}$ & $\begin{array}{c}\text { Indi. } \\
\text { vidual } \\
\text { deposits. }\end{array}$ \\
\hline $1867 \ldots . .$. & 1 & $\$ 72$ & $\$ 52$ & $\$ 26$ & $\$ 100$ & $\ldots$ & - $\$ 8$ & $\$ 29$ & $\$ 27$ \\
\hline $1872 \ldots .$. & 1 & 87 & 100 & 33 & 100 & $\$ 12$ & 10 & 89 & 95 \\
\hline $1877 \ldots$ & 1 & 90 & 100 & 41 & 100 & 21 & 3 & 85 & 127 \\
\hline $1882 . .$. & 1 & 132 & 100 & 81 & 100 & 20 & 9 & 81 & 274 \\
\hline $1887 .$. & 6 & 578 & 143 & 149 & 350 & 29 & 89 & 82 & 577 \\
\hline $1892 \ldots . .$. & 11 & 1,804 & 232 & 253 & 700 & 197 & 157 & 152 & 2,005 \\
\hline $1897 \ldots$. & 10 & 1,067 & 237 & 276 & 600 & 246 & 140 & 164 & 2,270 \\
\hline $1899 \ldots .$. & 9 & 1,039 & 253 & 295 & 550 & 196 & 130 & 137 & 3,512 \\
\hline
\end{tabular}


State Banks.

\begin{tabular}{|c|c|c|c|c|c|c|}
\hline YEARS. & 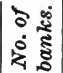 & $\begin{array}{l}\text { Loans and } \\
\text { discounts. }\end{array}$ & Specie. & Capital stock. & Circulation. & Deposits. \\
\hline $1893 \ldots \ldots \ldots . . . . . . .$. & 5 & $\$ 211,917$ & (........... & $\$ 157,500$ & .............. & $\$ 128,196$ \\
\hline $1894 \ldots . .$. & 6 & 181,057 & ............. & 155,000 & ....... & 177,540 \\
\hline $1897 \ldots \ldots \ldots \ldots$ & 5 & 121,782 & ............. & 60,350 & ............... & 272,729 \\
\hline $1899 . . . . . . \ldots \ldots . . .$. & 7 & 320,770 & ............ & 172,165 & ............... & 524,007 \\
\hline
\end{tabular}

UTAH.

Utah, the latest State admitted up to this writing into the sisterhood of the American Union, was settled by the white race in 1847, and is therefore the pioneer settlement of the Anglo-Saxon in the Rocky Mountain region. The State has magnificent resources just beginning to be known to the rest of the world, and has from the first grown slowly but steadily. Her people are largely native born, and the pioneers were mostly New Englanders who have left their stamp and impress upon all who have followed them.

Salt Lake City is laid out with broad straight streets running at right angles to each other north and south, east and west. This city is a type of the Mormon towns of Utah. The pioneers built towns with houses as near together as convenience and good sanitary rules would permit, assigning to each settler, as a rule, an acre and a quarter for occupancy as a "city lot." Then just outside the town were located the "fields," usually divided into lots of five acres each for farming purposes, these being again surrounded still further from the town center by lots of ten acres each. The object of this plan was twofold: first, to afford easy protection against the savages; and, second, to give to the settlers the advantages of easy access to the schools and churches which were an indispensable adjunct of people having the views of life held by most of the early settlers of Utah.

\section{A Private Mint Established.}

Soon after the pioneers entered Salt Lake Valley gold was discovered in California. In fact, the discovery was made by a number of members of what was known as the "Mormon Battalion," at the time working in California after being mustered out of their country's service. Although comparatively few of the early settlers of Utah went to the gold fields, considerable of the product of the latter found its way into Utah, and the people soon felt the inconvenience of handling the gold dust as money. There being no United States mint in the Rocky Mountain region, nor in fact within several weeks' travel by the methods then 
in vogue, a "mint" was inaugurated as a means of accommodating the public. Brigham Young is reputed to have been instrumental in the coinage of the coins made at the mint, and many of the pieces are still in circulation, selling now as a rule at a premium of about one hundred per cent. They consisted of two and one-half, five, ten and twentydollar gold pieces-the last named said to have been the first of this denomination struck in the United States. All were of pure gold, and this absence of alloy of any character made the coins so soft that the loss from abrasion was very great. On all of the early coins made the words "Holiness to the Lord," with a representation of an "All-seeing eye" appeared upon one side; and upon the other, the denomination of the coin, two hands clasped fraternally, the year of mintage (1849 usually) and the initials "G.S. L. C.P. G." A five-dollar gold piece coined in considerable numbers in 1860 bore upon one side a recumbent lion at the base of three mountain peaks, several phonetic characters (taken from the "Deseret alphabet") and the year (1860). Upon the other side were the words "Deseret Assay Office, Pure Gold," encircling a representation of an old-time bee hive surmounted by an American eagle holding in its talons the usual arrows. Below the bee hive appeared "5 D.," indicating the denomination of the coin. So far as known no money was minted in Utah after the year 1860 .

\section{Origin and Development of Banking.}

The province of the banker was occupied in Utah by the merchants until the early seventies. Several large merchants conducted the buying and selling of gold dust as part of their business, just as they bought and sold merchandise. Many of them also acted as depositories for their customers, and took money on deposit, giving a receipt that served a similar purpose to the banker's certificate of deposit. Of the private bankers now doing business in Utah, Messrs. Walker Brothers were the first, having opened their mercantile establishment in 1859, and having acted more or less in the capacity of bankers ever since. Their private bank was later merged into the Union National Bank, which latter again was changed into the present private bank conducted by Walker Brothers. Of the National banks, the Deseret National (one of the best-known banks in the West) is the pioneer in Utah, having been established in 1872, with Brigham Young as its first President. The Deseret National was the outgrowth of a bank organized May 1, 1869, by Wm. H. Hooper, H. S. Eldredge and L. S. Hills, with a capital of $\$ 40,000$. Mr. Hills, who was thus one of the promoters of the original organization under the name of Hooper, Eldredge \& Co., and has been a director of the Deseret National Bank from the beginning, is now its President, and is also Utah's representative in the American Bankers' Association. Of the Savings banks, the largest and oldest is Zion's Savings Bank and Trust Company, organized (also under direction of Brigham Young) August 6, 1873. 
Complete statistics concerning the banks of Utah are not obtainable until the year 1890. Territorial officers were of course appointive, and no statistics are on file in the office of the Secretary of State until the year named. In fact those filed after that date were more the result of the inclination of Gov. Arthur L. Thomas to make his reports to the Secretary of the Interior as complete as possible than to any requirement of the law on the subject. Since Statehood, however, statements of the condition of all banks (except National, which are of course required to report to the general Government) operating under State laws, both incorporated and private, are required to be filed with the Secretary of State at least four times a year, on a date to be named by the Secretary, who is ex-officio State Bank Examiner. For the reasons given the statistics furnished below are not complete, particularly those which apply to amount of capital and deposits in private banks up to and including the year 1895 . They are, however, correct in all other details as gathered from official reports:

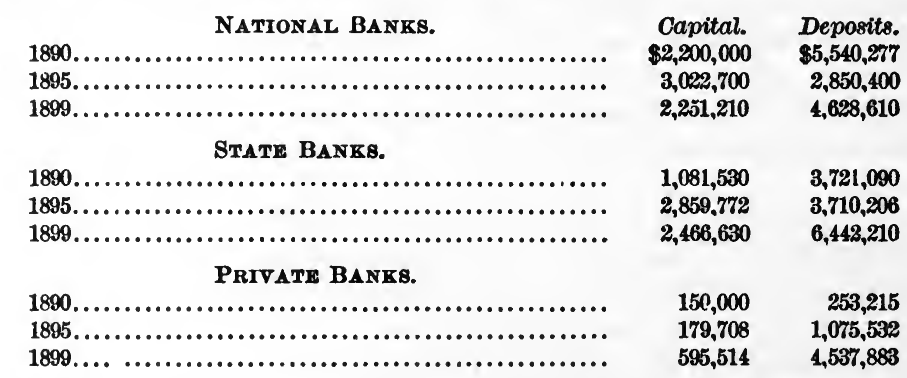

Not included in the above reports is the firm of Wells, Fargo \& Co., which has a branch bank in Salt Lake City, but does not have a separate capital used exclusively in Utah, but draws on the parent institution in San Francisco as its needs require. Among the private bankers one of the earliest firms is that of W. S. McCornick \& Co., established in 1873, and doing probably the largest business in the State.

In 1899 the Comptroller of the Currency, in his annual report, published a tabulation of the statements of eleven Utah State banks, showing loans and discounts amounting to $\$ 3,154,639$, and deposits $\$ 5$,181,428 .

The banks of Utah have, as a rule, been noted for their conservatism. Panics have been almost unknown and failures few and of comparatively small importance. During the panic of 1893 the banks of Salt Lake City stood the test withont a single exception, and the record made was due to the prudence and coolness of the banking fraternity as well as the unshaken confidence of the masses of the people of the State.

Bank robberies, contrary to the supposed experience of frontier States, have been almost unknown in Utah, and those attempting rob- 
bery have in every case been unsuccessful and have been themselves killed or captured in the attempt. The last attempt was one made in 1898 in Springville, Utah county, where the money taken was recovered, one of the robbers killed and the other captured and sent to the State prison.

\section{National Banks.}

Figures are in thousands of dollars.

\begin{tabular}{|c|c|c|c|c|c|c|c|c|c|}
\hline YEARS. & 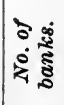 & $\begin{array}{l}\text { Loans } \\
\text { and dis- } \\
\text { counts. }\end{array}$ & $\begin{array}{c}\text { U. S. } \\
\text { bonds. }\end{array}$ & $\begin{array}{c}\text { Cash } \\
\text { and cash } \\
\text { items. }\end{array}$ & Capital. & Surplus. & $\begin{array}{r}\text { Undi. } \\
\text { vided } \\
\text { profits. }\end{array}$ & $\begin{array}{c}\text { Out. } \\
\text { standing } \\
\text { circula. } \\
\text { tion. }\end{array}$ & $\begin{array}{c}\text { Indi- } \\
\text { vidual } \\
\text { deposits. }\end{array}$ \\
\hline $1866 . .$. & 1 & $\$ 142$ & $\$ 50$ & $\$ 16$ & $\$ 150$ & $\ldots$ & $\$ 14$ & $\$ 45$ & $\$ 77$ \\
\hline $1871 \ldots$ & 1 & 256 & 150 & 57 & 100 & $\$ 25$ & .... & 133 & 303 \\
\hline $1876 \ldots$ & 1 & 291 & 75 & 122 & 200 & 35 & 30 & 45 & 253 \\
\hline $1881 . .$. & 1 & 359 & 450 & 209 & 200 & 100 & 54 & 153 & 944 \\
\hline $1886 \ldots$ & 7 & 1,821 & 500 & 460 & 837 & 303 & 137 & 303 & 2,048 \\
\hline $1891 \ldots$ & 13 & 5,000 & 639 & 775 & 2,750 & 914 & 202 & 357 & 3,574 \\
\hline $1896 \ldots$ & 11 & 2,832 & 1,007 & 752 & 1,900 & 689 & 140 & 460 & 2,587 \\
\hline $1899 . .$. & 11 & 2,497 & 1,387 & 1,324 & 1,650 & 393 & 193 & 442 & 4,381 \\
\hline
\end{tabular}

\section{NEVADA.}

Although the State was admitted into the Union in 1864, its population was only 45,761 by the census of 1890 .

By an act of the State Legislature, approved March 23, 1891, banks are organized and divided into seven classes, according to the amount of business done, ranging from $\$ 500,000$ per month to $\$ 25,000$ a month or less. Licenses are imposed ranging from $\$ 200$ to $\$ 12$ a month. The circulation of bank notes or paper money of any kind, except such as may be authorized by Congress, is prohibited.

Publication of statements is sometimes voluntarily made by banks, there being no legal requirement.

State Banks.

\begin{tabular}{|c|c|c|c|c|c|c|}
\hline YEARB. & $\mid \begin{array}{l}0 \\
0 \\
0 \\
0 \\
4\end{array}$ & $\begin{array}{l}\text { Loans and } \\
\text { discounts. }\end{array}$ & Specie. & Capital stock. & Circulation. & Deposits. \\
\hline $1889 \ldots \ldots . .$. & 2 & $\$ 329,891$ & .............. & $\$ 200,000$ & & $\$ 148,895$ \\
\hline $1897 \ldots \ldots$ & 3 & 479,279 & …........ & 323,200 & ...... & 461,671 \\
\hline $1898 \ldots . . . . .$. & 4 & 737,535 & ........... & 370,000 & ............. & $1,074,865$ \\
\hline $1899 \ldots \ldots$. & 3 & 647,219 & ..... & 270,000 & ................. & 997,514 \\
\hline
\end{tabular}




\section{GROWTH OF SAVINGS BANKS.}

Number of Savings Banks in the United States, Number of Depositors, Amount of Savings Deposits, Average Amount due each Depositor for each period of five years from 1820 to 1885 and for each year thereafter up to 1899.

\begin{tabular}{|c|c|c|c|c|}
\hline YEARS. & $\begin{array}{l}\text { Number } \\
\text { of banks. }\end{array}$ & $\begin{array}{l}\text { Number of } \\
\text { depositors. }\end{array}$ & Deposits. & $\begin{array}{c}\text { Average } \\
\text { due each } \\
\text { depositor. }\end{array}$ \\
\hline $1820 \ldots$ & 10 & 8,635 & $\$ 1,138,576$ & $\$ 131.86$ \\
\hline $1825 \ldots$ & 15 & 16,931 & $2,537,082$ & 149.84 \\
\hline $1830 \ldots .$. & 36 & 38,085 & $6,973,304$ & 183.09 \\
\hline $1835 \ldots .$. & 62 & 60,058 & $10,613,726$ & 176.72 \\
\hline $1840 \ldots . .$. & 61 & 78,701 & $14,051,520$ & 178.54 \\
\hline $1845 \ldots . .$. & 70 & 145,206 & $24,506,677$ & 168.77 \\
\hline $1850 \ldots .$. & 108 & 251,354 & $43,431,130$ & 172.78 \\
\hline $1855 \ldots \ldots$ & 215 & 431,602 & $84,290,076$ & 195.29 \\
\hline $1860 \ldots \ldots \ldots$ & 278 & 693,870 & $149,277,504$ & 215.13 \\
\hline $1865 \ldots . . .$. & 317 & 980,844 & $242,619,382$ & 247.35 \\
\hline $1870 \ldots \ldots \ldots \ldots$ & 517 & $1,630,846$ & $549,874,358$ & 337.17 \\
\hline $1875 \ldots .$. & 771 & $2,359,864$ & $924,037,304$ & 391.56 \\
\hline $1880 \ldots \ldots$ & 629 & $2,335,582$ & $819,106,973$ & 350.71 \\
\hline $1885 \ldots .$. & 646 & $3,071,495$ & $1,095,172,147$ & 356.56 \\
\hline $1886 \ldots .$. & 638 & $3,158,950$ & $1,141,530,578$ & 361.36 \\
\hline $1887 \ldots \ldots$ & 684 & $3,418,013$ & $1,235,247,371$ & 361.39 \\
\hline $1888 \ldots .$. & 801 & $3,838,291$ & $1,364,196,550$ & 355.41 \\
\hline $1889 \ldots . .$. & 849 & $4,021,523$ & $1,425,230,349$ & 354.40 \\
\hline $1890 \ldots \ldots \ldots . .$. & 921 & $4,258,893$ & $1,524,844,506$ & 358.03 \\
\hline $1891 \ldots . .$. & 1,011 & $4,533,217$ & $1,623,079,749$ & 358.04 \\
\hline $1892 \ldots . .$. & 1,059 & $4,781,605$ & $1,712,769,026$ & 358.20 \\
\hline $1893 \ldots$ & 1,030 & $4,830,599$ & $1,785,150,957$ & 369.55 \\
\hline $1894 \ldots . .$. & 1,024 & $4,777,687$ & $1,747,961,280$ & 365.86 \\
\hline $1895 \ldots . .$. & 1,017 & $4,875,519$ & $1,810,597,023$ & 371.36 \\
\hline $1896 \ldots . .$. & 988 & $5,065,494$ & $1,907,156,277$ & 376.50 \\
\hline $1897 \ldots \ldots \ldots \ldots$ & 980 & $5,201,132$ & $1,939,376,035$ & 372.88 \\
\hline 1898. .... & 979 & $5,385,746$ & $2,065,631,298$ & 383.54 \\
\hline $1899 \ldots$ & 987 & $5,687,818$ & $2,230,366,954$ & 392.13 \\
\hline
\end{tabular}


Resources and Liabilities of State Banks, Loan and Trust Companies, Savings and Private Banks in the United States, 1899.

\begin{tabular}{|c|c|c|c|c|c|}
\hline \multirow[t]{2}{*}{ Classification. } & State banks. & $\begin{array}{c}\text { Loan and } \\
\text { trust compa. } \\
\text { nies. }\end{array}$ & $\begin{array}{l}\text { Savings } \\
\text { banks. }\end{array}$ & $\begin{array}{l}\text { Private } \\
\text { banks. }\end{array}$ & Total. \\
\hline & 4,191 banks. & $\begin{array}{c}260 \\
\text { companies. }\end{array}$ & 942 banks. & 756 banks. & 6,149 \\
\hline RESOURCES. & & & & & \\
\hline Loans on real estate... & $\$ 51,818,453$ & $\$ 43,640,072$ & $\$ 878,126,859$ & $\$ 7,396,584$ & $\$ 980,981,968$ \\
\hline Loans on other collat'l & $26,871,847$ & $303,173,568$ & $156,359,308$ & $6,886,390$ & $493,291,113$ \\
\hline Other loans and disc'ts & $830,342,896$ & $252,217,393$ & $64,112,422$ & $38,994,838$ & $1,185,667,549$ \\
\hline Overdrafts................ & $8,162,760$ & 105,189 & 328,736 & $1,102,153$ & $9,698,838$ \\
\hline United States bonds... & $6,536,233$ & $29,595,770$ & $136,930,208$ & 911,527 & $173,973,738$ \\
\hline $\begin{array}{r}\text { State, county and mu. } \\
\text { nicipal bonds........ }\end{array}$ & $2,516,644$ & $6,489,823$ & $512,777,336$ & 687,807 & $522,471,610$ \\
\hline R. R. bonds and stocks & $2,183,120$ & $12,450,197$ & $167,998,336$ & 285,910 & $182,917,563$ \\
\hline Bank stocks....... & 211,637 & $1,198,464$ & $36,637,920$ & 320,061 & $38,368,082$ \\
\hline Other stocks, bonds, etc & $160,676,142$ & $216,352,619$ & $230,796,388$ & $2,039,018$ & $609,864,167$ \\
\hline Due from b'ks \& b'krs & $255,523,8 \times 0$ & $130,072,594$ & $112,667,259$ & $17,628,512$ & $515,892,245$ \\
\hline Real estate, fur. \& fixt. & $68,014,008$ & $37,880,338$ & $55,469,869$ & $4,688,168$ & $166,052,383$ \\
\hline Checks and cash items & $70,321,190$ & 451,881 & 52,594 & 642,977 & $71,468,642$ \\
\hline Cash on hand............ & $146,364,560$ & $24,343,833$ & $34,651,724$ & $5,523,930$ & $210,884,047$ \\
\hline Other resources......... & $6,489,292$ & $13,554,253$ & $13,922,513$ & 679,378 & $34,645,436$ \\
\hline Total................. & $1,636,032,662$ & $1,071,525,994$ & $2,400,831,472$ & $87,787,253$ & $5,196,177,381$ \\
\hline LIABILITIES. & & & & & \\
\hline Capital stock............. & $\$ 232,958,027$ & $\$ 104,308,722$ & $\$ 17,492,223$ & $13,987,676$ & $\$ 368,746,648$ \\
\hline Surplus fund........... & $77,459,148$ & $79,707,194$ & $173,807,848$ & $2,720,604$ & $333,694,794$ \\
\hline Other undivi.profits.. & $35,819,210$ & $25,908,973$ & $21,439,191$ & $1,935,919$ & $85,103,293$ \\
\hline Dividends unpaid....... & 971,996 & 184,651 & 17,959 & & $1,174,606$ \\
\hline Individual deposits.... & $1,164,020,972$ & $835,499,064$ & $2,538,125$ & $64,974,392$ & $2,067,032,553$ \\
\hline Savings deposits...... & & & $2,179,468,299$ & $\ldots \ldots \ldots$ & $2,179,468,299$ \\
\hline Due to banks and b'krs & $108,513,138$ & $2,011,661$ & 97,421 & $3,393,839$ & $114,016,059$ \\
\hline All other liabilities.... & $16,290,171$ & $23,905,729$ & $5,970,406$ & 774,823 & $46,941,129$ \\
\hline Total... & $1,636,032,662$ & $1,071,525,994$ & $2,400,831,472$ & $87,787,253$ & $5,196,177,381$ \\
\hline
\end{tabular}




\section{GROWTH OF SAVINGS BANKS.}

Number of Savings Banks in the United States, Number of Depositors, Amount of Savings Deposits, Average Amount due each Depositor for each period of five years from 1820 to 1885 and for each year thereafter up to 1899.

\begin{tabular}{|c|c|c|c|c|}
\hline YEARS. & $\begin{array}{l}\text { Number } \\
\text { of banks. }\end{array}$ & $\begin{array}{l}\text { Number of } \\
\text { depositors. }\end{array}$ & Deposits. & $\begin{array}{l}\text { Average } \\
\text { due each } \\
\text { depositor. }\end{array}$ \\
\hline $1820 \ldots$ & 10 & 8,635 & $\$ 1,138,576$ & $\$ 131.86$ \\
\hline $1825 \ldots$ & 15 & 16,931 & $2,537,082$ & 149.84 \\
\hline $1830 \ldots$. & 36 & 38,085 & $6,973,304$ & 183.09 \\
\hline $1835 \ldots \ldots \ldots \ldots$ & 52 & 60,058 & $10,613,726$ & 176.72 \\
\hline $1840 \ldots .$. & 61 & 78,701 & $14,051,520$ & 178.54 \\
\hline $1845 \ldots .$. & 70 & 145,206 & $24,506,677$ & 168.77 \\
\hline $1850 \ldots .$. & 108 & 251,354 & $43,431,130$ & 172.78 \\
\hline $1855 \ldots$. & 215 & 431,602 & $84,290,076$ & 195.29 \\
\hline $1860 \ldots$. & 278 & 693,870 & $149,277,504$ & 215.13 \\
\hline $1865 \ldots .$. & 317 & 980,844 & $242.619,382$ & 247.35 \\
\hline $1870 \ldots$ & 517 & $1,630,846$ & $549,874,358$ & 337.17 \\
\hline $1875 \ldots .$. & 771 & $2,359,864$ & $924,037,304$ & 391.56 \\
\hline $1880 \ldots . .$. & 629 & $2,335,582$ & $819,106,973$ & 350.71 \\
\hline $1885 \ldots . .$. & 646 & $3,071,495$ & $1,095,172,147$ & 356.56 \\
\hline $1886 \ldots \ldots \ldots \ldots$ & 638 & $3,158,950$ & $1,141,530,578$ & 361.36 \\
\hline $1887 \ldots \ldots \ldots . . . .$. & 684 & $3,418,013$ & $1,235,247,371$ & 361.39 \\
\hline $1888 \ldots \ldots \ldots$ & 801 & $3,838,291$ & $1,364,196,550$ & 355.41 \\
\hline $1889 \ldots$ & 849 & $4,021,523$ & $1,425,230,349$ & 354.40 \\
\hline $1890 \ldots$ & 921 & $4,258,893$ & $1,524,844$, כ06 & 358.03 \\
\hline $1891 \ldots \ldots \ldots . . . .$. & 1,011 & $4,533,217$ & $1,623,079,749$ & 358.04 \\
\hline $1892 \ldots \ldots \ldots \ldots \ldots$ & 1,059 & $4,781,605$ & $1,712,769,026$ & 358.20 \\
\hline $1893 \ldots$ & 1,030 & $4,830,599$ & $1,785,150,957$ & 369.55 \\
\hline $1894 \ldots .$. & 1,024 & $4,777,687$ & $1,747,961,280$ & 365.86 \\
\hline $1895 \ldots .$. & 1,017 & $4,875,519$ & $1,810,597,023$ & 371.36 \\
\hline $1896 \ldots \ldots \ldots . . .$. & 988 & $5,065,494$ & $1,907,156,277$ & 376.50 \\
\hline $1897 \ldots \ldots \ldots \ldots$ & 980 & $5,201,132$ & $1,939,376,035$ & 372.88 \\
\hline $1898 . \ldots . . . \ldots . .$. & 979 & $5,385,746$ & $2,065,631,298$ & 383.54 \\
\hline $1899 \ldots \ldots \ldots$ & 987 & $5,687,818$ & $2,230,366,954$ & 392.13 \\
\hline
\end{tabular}


STATISTICS OF BANKS OTHER THAN NATIONAL. 859

Resources and Liabilities of State Banks, Loan and Trust Companies, Savings and Private Banks in the United States, 1899.

\begin{tabular}{|c|c|c|c|c|c|}
\hline \multirow{2}{*}{ ClaAsSification. } & State banks. & $\begin{array}{c}\text { Loan and } \\
\text { trust compa- } \\
\text { nies. }\end{array}$ & $\begin{array}{l}\text { Savings } \\
\text { banks. }\end{array}$ & $\begin{array}{l}\text { Private } \\
\text { banks. }\end{array}$ & Total. \\
\hline & 4,191 banks. & $\stackrel{260}{\text { companies. }}$ & 942 banks. & 756 banks. & 6,149 \\
\hline RESOURCES. & & & & & \\
\hline Loans on real estate... & $\$ 51,818,453$ & $\$ 43,640,072$ & $\$ 878,126,859$ & $\$ 7,396,584$ & $\$ 980,981,968$ \\
\hline Loans on other collat'l & $26,871,847$ & $303,173,568$ & $156,359,308$ & $6,886,390$ & $493,291,113$ \\
\hline Other loans and disc'ts & $830,342,896$ & $252,217,393$ & $64,112,422$ & $38,994,838$ & $1,185,667,549$ \\
\hline Overdrafts....... & $8,162,760$ & 105,189 & 328,736 & $1,102,153$ & $9,698,838$ \\
\hline United States bonds... & $6,536,233$ & $29,595,770$ & $136,930,208$ & 911,527 & $173,973,738$ \\
\hline $\begin{array}{c}\text { State, county and mu. } \\
\text { nicipal bonds......... }\end{array}$ & $2,516,644$ & $6,489,823$ & $512,777,336$ & 687,807 & $522,471,610$ \\
\hline R. R. bonds and stocks & $2,183,120$ & $12,450,197$ & $167,998,336$ & 285,910 & $182,917,563$ \\
\hline Bank stocks............ & 211,637 & $1,198,464$ & $36,637,920$ & 320,061 & $38,368,082$ \\
\hline Other stocks, bonds, etc & $160,676,142$ & $216,352,619$ & $230,796,388$ & $2,039,018$ & $609,864,167$ \\
\hline Due from b'ks \& b'krs & $255,523,8 \times 0$ & $130,072,594$ & $112,667,259$ & $17,628,512$ & $515,892,245$ \\
\hline Real estate, fur. \& fixt. & $68,014,008$ & $37,880,338$ & $55,469,869$ & $4,688,168$ & $166,052,383$ \\
\hline Checks and cash items & $70,321,190$ & 451,881 & 52,594 & 642,977 & $71,468,642$ \\
\hline Cash on hand........ & $146,364,560$ & $24,343,833$ & $34,651,724$ & $5,523,930$ & $210,884,047$ \\
\hline Other resources........ & $6,489,292$ & $13,554,253$ & $13,922,513$ & 679,378 & $34,645,436$ \\
\hline Total.... & $1,636,032,662$ & $1,071,525,994$ & $2,400,831,472$ & $87,787,253$ & $5,196,177,381$ \\
\hline LIABILITIES. & & & & & \\
\hline Capital stock..... & $\$ 232,958,027$ & $\$ 104,308,722$ & $\$ 17,492,223$ & $13,987,676$ & $\$ 368,746,648$ \\
\hline Surplus fund............ & $77,459,148$ & $79,707,194$ & $173,807,848$ & $2,720,604$ & $333,694,794$ \\
\hline Other undivi. profits.. & $35,819,210$ & $25,908,973$ & $21,439,191$ & $1,935,919$ & $85,103,293$ \\
\hline Dividends unpaid...... & 971,996 & 184,651 & 17,959 & ............ & $1,174,606$ \\
\hline Individual deposits.... & $1,164,020,972$ & $835,499,064$ & $2,538,125$ & $64,974,392$ & $2,067,032,553$ \\
\hline Savings deposits....... & …............. & . & $2,179,468,299$ & (n........... & $2,179,468,299$ \\
\hline Due to banks and b'krs & $108,513,138$ & $2,011,661$ & 97,421 & $3,393,839$ & $114,016,059$ \\
\hline All other liabilities.... & $16,290,171$ & $23,905,729$ & $5,970,406$ & $\mathbf{7 7 4}, 823$ & $46,941,129$ \\
\hline & $1,636,032,662$ & $1,071,525,994$ & $2,400,831,472$ & $87,787,253$ & $5,196,177,381$ \\
\hline
\end{tabular}


Bank of the United States: application for renewal of charter..... as a political issue...................... attack on .............................

Baltimore branch losses................

Baltimore branch speculations........ bonus paid for Pennsylvania charter.. change in management of.............. charter of.

charter of by the Legislature of Penn. sylvania............................ condition of in $1829 . . . . . \ldots \ldots . . . . . .$. condition of the country when it com. menced business.................... debate and passage of bill.............. debates in Congress on bill for renewa of charter. expiration of Federal charter.......... failure of............................... Government profits from............... investigation of by Congress...........

Jackson's attack on....................

Jackson's criticism of.................. liquidation of...................... 47, method of paying capital............... opposition to........................... origin of attack against................ plan for............................... political attack on...................... profits of the Government.............. proposals to recharter proposed removal of public deposits.. provisions of charter....................

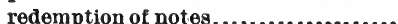
removal of public deposits............. report of condition of. 309,311 report of Ways and Means Committeo on Jackson's message............... resolution by Congress expressing confidence in...................... 70 resolution of House of Representatives against recharter of.

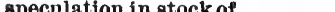

statement of condition, $1809,1811 \ldots . .39$ State taxation of branches........ 70, 494 unpopularity with state banks........ 58 veto of bill to recharter.............. 69 views of Hamilton, Jefferson and others as to constitutionality of charter............................. 37

Bank of Venice, the...................... 2

Bank, origin of the word................ 10

Banks, gold holding 3 of................. 210

increase in business of................ 211

loans of to the Government in $1861 \ldots 136$

methods of organization in the various states.......................... 314

of issue prohibited by Parliament..... 18 proper functions of .................... 9

Baring Bros., failure of................... 196

Benefits of the National banking system 205

Benton, Thos., account of proceedings of Senate during consideration of " $\mathrm{ex}$. punging" resolution
PAGE

condemnation of the Bank of the

United States..................... 76

"expunging" resolution of............ 72 remarks on "expunging" resolution. 73

views of on Bank of the United States 69 Biddle, Nicholas, sketch of.............. 61 Bills of credit, provision for issue of stricken from original draft of U. S. Constitution.

what constitute...................... 24

Black Friday ............................ 104

panic, causes of..................... 271

Bland-Allison act, silver bulition pur. chased and coined under........... 200

Bonds, amount of required to be kept on deposit by National banks.......... 188

as a basis of bank circulation, effect of rise in value........................ 118 contracts for sale of.................. 159

extension of by Secretary Windom.... 170

history of redemption of three per cents................................ 190

method of redemption of.............. 169 plan of Comptroller for reducing inter. est on ........................... 177 purchase of by the Government....... 199 purchase of with surplus revenues.... 192 sale of for resumption purposes....... 157 sale of under refunding and resump. tion acts......................... 159 withdrawal of by banks.............. 168 withdrawai of by banks in liquidation. 273 Boston Clearing-House Association, action of in panic of $1890 \ldots . . . . \ldots \ldots . .197$

Branch banks recommended.............. 212

British debt, statement of.............. 160

Butler, Benjamin F., irredeemable cur. rency proposed by. 279

\section{C.}

Calhoun, John C., amendments offered to bill for establishing a National bank 52 characterization of attack on Bank of the United States.................. 64 remarks on "expunging" resolution.. 73 California:

Bank of California, suspension of..... 845

Board of bank commissioners, creation of .............................. 847

Bonanza kings, bank of the........... 846

California Bankers' Association, or. ganization of..................... 848

Condition of the banks in 1899 ........ 848

Crisis of 1855, the................... 844

Deposits in Savings banks............ 851

Failures in 1855-56................. 844

Gold coinage, introduction of......... 844

Gold coin, use of as currency......... 845 Gold discoveries of $1848 . . . \ldots . . . . . .843$ Gold production, speculation caused

by .............................. 844 Miners' Bank, of San Francisco, the.. 843 National banks, statistics of.......... 851 
Page, Bacon \& Co., failure of.......... 844

Panics of 1890 and $1893 . . . \ldots \ldots \ldots \ldots . . .848$

Paper money, issue of prohibited...... 845

Private banks, examination of........ 847

Ralston, Wm. C., suicide of........... 845

San Francisco Clearing-House, estab-

lishment of......................... 846

Savings banks, history of........... 850

Savings banks, statistics of.......... 851

Statistics of Savings, commercial and private banks..................... 849

Supervision of banks, provisions for.. 847 Cannon, Henry W., appointed Comptrol. ler of the Currency................ 181

Capital of banks, payment of in stock notes............................. 308 minimum fixed at $\$ 50,000 \ldots \ldots \ldots \ldots . .237$

reduction of minimum amount of...... 286

Cause of the panic of $1873 . . . \ldots \ldots \ldots . . .114$

Censure of President Jackson for remov. ing public deposits from Bank of the United States...................

Certificates of deposit for legal-tender notes......................... 186, 273

Certification of checks for speculative purposes

Chase, Salmon P., on State bank issues.. 670 opinion of the legal tenders as a per. manent currency................... 133 plan of for meeting expenses of Civil war.............................. 220 plan of for National bank currency.... 223 proposal of to issue National bank notes.............................. 220 sketch of, with portrait............... 287 views of on state bank notes........... 22 views of on State taxation of National banks.

Checks and credit instruments, nse of... 211

Checks, illegal certification of............ 163 Check8, over-certification of....179, 184, 185 Cheves, Langdon, sketch of......... 60, 565 Chicago fire in 1871, bank losses........ 112 Circulation :

apportionment of among the States.... 270 increase of to par of bonds and capital 286 inequalities in distribution of.......... 271 limit of in proportion to capital........ 270 of National banks, increase of......... 109 privilege, value of in $1879 . . . . . . . . . .162$ proposed for State banks on deposit of United States bonds................226 repeal of bill requiring reserve on..... 277 security of by deposit of bonds......... 95 withdrawal of....................... 110

Civil War, possibility of carrying on with bank notes........................ 135

Civil War, providing funds for........... 220

Clay, Henry, appointed Secretary of State.

Clay, Henry, resolution of, censuring President Jackson

Clearing-house loan certificates, form of. 183 issue of in $1873 \ldots \ldots \ldots \ldots \ldots \ldots \ldots . . . \ldots \ldots$ issue of in $1893 . . . \ldots \ldots \ldots \ldots \ldots \ldots \ldots \ldots . . . . .202$ issue of in the panic of $1884 \ldots \ldots \ldots \ldots . .183$ issue of in the panic of $1890 \ldots . . . \ldots . . .197$ Coe, Geo. S., on resumption act of $1875 . .145$ Coe, Geo. S., proposai of to legalize gold contracts...... .................. 105

Colgate, Mr., on resumption act of $1875 . .143$ Colman, John, author of Massachusetts land bank scheme............... 15 Colonial ioan banks..................... 17 Coionial paper, depreciation of in 1748... 17 Colonial paper money, issue of.......... 15 Colorado:

Bankable funds, hoarding of.......... 834 Bank of Colorado, charter granted to. 831 Clark, Gruber \& Co., mint established by................................ 829

Coinage by private individuais........ 829 Colorado National Bank, of Denver, the 832 First National Bank, of Denver, the..' 831 Gold dnst, bankers as brokers in..... 829 Interest, high rate of................ 834 Laws relating to banks................ 835 National banks, statistics of......... 836 Private and State banks, reorganization of.............................. 832 Private bankers, prominent firms of... 829 Savings banks, limited number of..... 834 State and National banks, comparison of ................................. 832

State banks, statistics of............. 835 Supervision of banks, lack of......... 833 Territorial Legislature, bank char. tered by...........................831 Commercial redemption of National bank notes, lack of...................... 284 Company of the West and Company of the Indies......................... 7 Comparison of past and present financial systems............................ 90

Comptroller of the Currency :

account of crisis of $1884 \ldots \ldots \ldots \ldots \ldots . . .182$

appointment of...................... 97 opposition to Treasury notes and sil. ver certificates....................... 178 plan for reducing interest on bonds... 177 recommendations in $1863 . . . . . . . . . .232$ recommendations of in 1870 ........... 109 recommendations of in 1879 ........... 161 recommendations of in $1895 \ldots . . . . . . .207$ report for $1875 \ldots \ldots \ldots \ldots \ldots \ldots \ldots \ldots . . . \ldots 119$ report for $1879 \ldots \ldots \ldots \ldots \ldots \ldots \ldots \ldots . . \ldots . . . \ldots 6$ report for $1880 \ldots \ldots \ldots \ldots \ldots \ldots \ldots \ldots . \ldots \ldots$ report for $1882 \ldots \ldots \ldots \ldots \ldots \ldots \ldots \ldots \ldots . \ldots \ldots$ report for $1885 \ldots \ldots \ldots \ldots \ldots \ldots \ldots \ldots . \ldots . \ldots . \ldots$

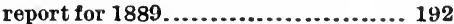
report for $1893 \ldots . . . \ldots \ldots \ldots . . . \ldots . . . . .202$ report for $1895 \ldots \ldots \ldots \ldots \ldots \ldots \ldots \ldots . . . . . .206$ report for $1898 \ldots \ldots \ldots \ldots \ldots \ldots \ldots \ldots \ldots . . . . .215$ views of on proposed retirement of National bank notes............... 142 views of on resumption............... 153 
PAGE

Congress, power of to charter banks.... 21 Conkling, Roscoe, criticism of National banking bill...................... 224

Connecticut:

Bank commissioners, appointment of. 378

Banking law of $1852 . . . \ldots \ldots \ldots . . . . . .383$

Bills issued by the Colony............. 375

Bills of small denomination prohibited 378

Circulation and loans, expansion of... 351

Circulation, limitation of.............. 384

Circulation of small bills prohibited.. 378

Circulation of State banks, retirement

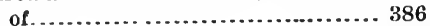

Colonial issue of bills................ 375

Condition of the banks in $1836 \ldots \ldots . .376$

Contraction of circulation, 1839-40... 380

Directors, loans to on pledge of stock. 379

Earnings of National banks........... 386

Examination of banks, legislation pro.

viding for.......................... 376

Expansion of circulation and loans ... 381

Failures, limited number of.......... 381

Failures of State banks in........... 320

First banks chartered in the Colony.. 375

Hartford Bank, incorporation of...... 375

Interest, excessive rate charged on

loans............................ 377

Interest on loans, limitation of........ 384

Interest, prohibition of................ 384

Loans made outside the State.... 377, 384

Loans made to the Government....... 385

Loans to directors on pledges of stock. 379

National banking system, effect of in.

troduction of....................... 385

National banks, earnings of.......... 386

National banks, statistics of.......... 387

Panic of 1857, the .................... 384

Panics of 1884 and 1893 .............. 386

Post notes, issue of................... 380

Reserve on circulation................ 383

Savings banks, historical sketch of... 388

Savings banks, statistics of............ 389

Specie payments, maintenance of in

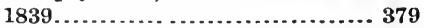

Specie payments, suspension of in 1861385

Specie reserve on circulation......... 383

State as a stockholder in banks....... 383

State bank circulation, retirement of. 386

State banks, statistics of.............. 387

Suffolk system of redemption.... 380, 382

Suspension of specie payments in 1861385

Trust companies, statistics of........ 387

Consolidation of banks................... 205

Constitutionality of State bank notes.... 22

Constitution of the United States and banking..

Constitution of the United States, pro visions of concerning the prerogative of coinage ant issue of bills of credit. Continental Congress, first meeting of... 18 Continental currency, amount and value off.
Continental currency, issue of.......... 19

Contraction of National bank currency

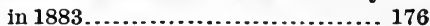

Contraction of the volume of United

States notes....................... 274

Conversion of State banks into National

banks....................... 244, 283

Cooke \& Co., Jay, failure of............... 274

Corning, Erastus, letter of to Mr. Spauld-

ing ............................... 221

Corporate existence of National banks,

extension of ..................... 282

Credit instruments used in retail trade.. 205

Credit instruments, use of................ 211

Credit, use of by banks................... 10

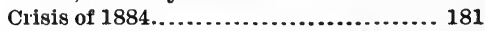

Currency act of June 3, 1864.. 235, 254, 264

Currency act, signed by the President

June 3, 1864..................... 269

Currency, funding and banking act of

March 14, 1900................... 286

Currency, plan for securing uniformity of. 92

D.

Dallas, Alexander J., appointed Secretary of the Treasury ......................

plan of, for a National bank.......... 54

plan of, for securing a uniform cur. rency............................ 92

proposals of, for incorporating a $\mathrm{Na}$ tional bank...................... 52

recommendations of, for a National bank................................ 49

sketch of .............................. 49

Dawes, Charles G., appointed Comptrol. ler................................ 215

Debt, consolidation and funding of....... 106

Debt of Great Britain, the................ 160

Debt, public, Gallatin's view on using as a basis for banking................. 93

Hamilton's proposal for using as a basis of banking..................... 93

refunding of......................... 157

virtual extinguishment of............. 84

Decrease in National bank circulation.189, 194 Delaware:

Bank of North America, charter granted to...................... 466

Charters, banks to be formed under... 468

Circulation, proportion of, issued by the Farmers' Bank................. 467

Failures, limited number of............. 468

Farmers' Bank of Delaware, organization of . .............................. 467

National banks, statistics of.......... 468 New Castle branch of Farmers' Bank, discontinuance of................. 467

- State as owner of bank stock......... 466

State banks, statistics of............... 468 Demand loans as a resource in panics.... 187 Denominations and devices of National bank notes........................ 120 Denunciation of National banks.......... 248 
Deposit of public money in National banks. Deposit of public money in State banks. 80 Deposits, payment of interest on......... 187 Depreciated currency in $1841 . . . \ldots \ldots . . .11$ Depreciation of Continental currency.... 19 Dexter (Me.) bank robbery, the.......... 336 Distribution of shares of National banks 125 Distribution of the surplus revenues among the states

District of Columbia:

Bank of Columbia, the............... 519

Banks, how organized................ 519

Banksoperating under Stateand other authority........................519

Circulation of the banks in 1836, ability of banks to redeem ............. 520

Comptroller of the Currency, banks under supervision of.............. 519

National banks, statistics of.......... 521

Statistics of banks, 1834-1874........ 520

Dividends of National banks, regulations of the law......................... 129

Dividends paid by insolvent State banks. 328

Division of issue and redemption, creation of............................. 286

Duane, Willlam J., appointed Secretary of the Treasury.

removal of as Secretary of the Treas ury.

E.

Eastern States, history of banking in.... 390 Eckels, James H., appointed Comptroller of the Currency................... 201

England, early banking in.............. 4

Ewing, Thos., plan of for a National bank 87

Examination of National banks......... 130

Examiners of National banks, compensa. tion of. 130

Excessive bank loans................. 175

Exchange rates on New York city, 1859 and 1860 .

Exchequer Bank proposed. 115

Execntors and administrators, relief of from liability as owners of National bank stock. 250

“Expunging" resolution, passage of.... 73 Von Holst's comment on.............. 74

Expunging the resolntion censuring President Jackson from the public records.

Extension of corporate existence of $\mathrm{Na}$ tional banks. 171

\section{F.}

Failed banks, liquidation of 188 Failed National banks, per cent of divi. dends paid by.

Failures:

of banks in $1893 . \ldots \ldots \ldots \ldots \ldots \ldots \ldots . . . .204$

of banks in New York in 1844 . of National banks in $1882 \ldots \ldots \ldots \ldots . .175$

of National banks in $1887 . . . . . . . . . . .191$

of National banks in 1888............. 192

of National banks in $1893 . . . \ldots \ldots \ldots . .203$

of State banks, 1864-1896............ 328

of State banks, losses by.............. 315

of the early State banks.......... 319, 325

Financial systems, past and present com. pared.

Financiers of the Civil War period, sketches and portraits of........... 287

First National Bank of Philadelphia..... 97

First National bank organized.......... 97 Florida :

Bank law, the present................ 592

Federal Government, intervention of. 590

Legislation relating to banks, 1839 to

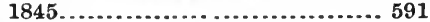

National banks, statistics of.......... 593

Organization, plan of................ 586

Real estate banking................. 586

State banks, statistics of........ 592, 593

Territorial banks, the............... 586

Territorial government, right of to charter a bank.................... 590

Union Bank of Florida, the.......... 587

Forged signatures to National bank notes 102 Form of clearing-house loan certificates. 183 Free banking law in New York..... 408, 413 French copper syndicate, failure of...... 196 Functions of banks..................... 9

Funding act of $1900 \ldots \ldots \ldots \ldots \ldots \ldots \ldots . .286$ Funding of legal-tender notes, repeal of law................................. 136

Funding of Revolutionary debt.......... 20 Funding of the public debt............... 286 Funding provision in legal-tender bill, repeal of ......................... 230

\section{G.}

Gallatin, Albert, on power of Congress to tax State bank notes.............. 317 on the dissolution of the Bank of the United States...................... 316 report of on Bank of the United States 41 sketch of............................ 42 views of on constitutionality of charter of the Bank of the United States... 46

views of on using public lebt as a basis for banking................... 93

Gallatin, James, suggestions concerning resumption...................... 106

Garfield, James A., statement of on use of checks and credit instruments... 212

Genoa, Bank of......................... 3

George Smith's money.................. 741 Georgia :

Banking subsequent to the Civil War. 582 Bank of the United States, branch of ........................... 572, 576

Central Eank, the.................. 575 Central Railroad and Banking Co., the 577 Civil War, destructire results of..... 579 
Georgia (Continued) :

Colonial currency, issue and deprecia-

tion of.

PAGE

Georgia Bankers' Association........ 583

Laws relating to banks, summary of.. 584

Legal-tender paper, issue of....... . 571

National banks, statistics of.......... 585

Notes issued during the Civil War, specimens of..................... 580

Planters' Bank, charter of........... 572

Repudiation of State currency....... 582

Savannah, operations of banks in.... 578

Specie payments, suspension of...... 579

State banks, statistics of ............. 585

Girard, Stephen, assets of Bank of the

United States purchased by....... 47

sketch of ........................... 50

Gold, and silver in the United States in

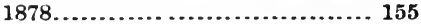

banks, establishment of.............. 108

certificates, amount ontstanding in

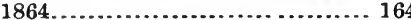

certificates, issue of authorized....... 186

depository established by New York

banks.............................. 164

exports, method of Bank of England

in checking......................... 6

holdings of the banks................ 210

reserve, cost of maintaining........... 213

reserve of Bank of France, how pro.

tected............................. 8

reserve, provisions relating to......... 286

valu $\Theta$ of the legal-tender notes......... 125

Goldsmiths as bankers.................. 4

Goldsmiths' company, the................ 4

Govermment issue of paper money........ 14

Government notes suggested by Presi-

dent Madison as a remedy for depre.

ciated bank notes................. 54

Grant, Ulysses S., veto of inflation bill by. 277

Grant \& Ward, failure of................. 181

Great Britain, debt statement of......... 160

Greenback convention of $1876 \ldots . . . \ldots . .141$

Greenback theory, the................. 279

Greenbacks, opposition to in East and South............................. 280

proposed to replace National bank

notes............................. 141

Growth of Savings banks, 1820 to $1899 . .858$

H.

Hamilton, Alexander, argument of in favor of a Bank of the United States. 37

plan of for funding Revolutionary debt.............................. 20

proposals of for a Government bank... 35

sketch of ........................... 39

suggestions for using public debt as a

basis of banking.

suggestions of, for establishing a bank. 29

Heiser, Henry A., on resumption act of

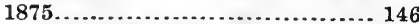

Hepburn, A. B., appointed Comptroller. 201

Holdings of National bank shares........ 127 tavor of $\mathrm{Na}$ tional bank bill..................... 252

Hulburd, Hiland R., appointed Comptroller of the Currency................. 102

I.

Idaho:

Admission of into the Union.......... 851

Banks, how organized................ 851

National banks, statistics of.......... 851

Notes, issue of prohibited............ 851

State banks, statistics of............. 852

Illegal certification of checks............ 163

Illinois :

Bankers, names of prominent ones ... 722

Banking law of 1851, the............. 723

Banking law, the present............. 728

Bank notes as a legal tender.......... 712

Bank of Cairo, the................... 713

Bank of Edwardsville, the........... 713

Bank of Illinois, the................. 712

Chicago, early banking in............ 726

Crises of 1857 and $1861 \ldots \ldots \ldots \ldots \ldots .725$

Inflation for internal improvements.. 720

Internal improvements, era of........ 719

Loans to the Government in 1861.... 726

National banks, statistics of.......... 729

Political banking, an example of..... 716

Small notes, circulation of prohibited. 724

Smith, George, banks established by.. 727

State Bank of Illinois, the.. 714, 715, 718,721

State banks, statistics of............. 729

State prohibited from engaging in

banking........................... 723

Territorial banks, the............... 712

Increase in number and transaction of

banks.............................. 211

Increase of banks, 1834 to $1837 \ldots . . . . .82$

Independent Treasury act, passage of... 86

Independent Treasury act, repeal of..... 87

Independent Treasury, re-establishment

of .................................. 89

Independent Treasury system proposed. 85

Indiana:

Banking law of 1853 , the....... 698, 701

Bank of the State of Indiana, the 698, 701

Bank of Vincennes, the............... 692

Bills, issue of by banks and other cor. porations......................... 701

Circulation, increase in volume of..... 703

Constitution, provisions of regarding

banking ............................. 692

Failures of State banks in............ 323

Farmers and Mechanics' Bank of

Madison, the..................... 692

Fletcher, Calvin, sketch of............ 709

Free banks, statistics of.............. 703

Governor's message in $1853 . . . \ldots \ldots . . .318$

Lanier, J. F. D., sketch of............. 707

McCulloch, Hagh, sketch of.......... 706

Merrill, Samuel, sketch of............. 708

National banks, statistics of......... 710 
Indiana (Continned) :

National system, organization of banks under....................... 704

Panic of 1837, the................... 695

Paper money, large increase in volume of.

Private banks, statistics of.......... 704

Profits to the State from investment in bank stock...................... 692

Red dog currency, issue of............ 701

Savings banks, statistics of.......... 705

Specie payments, suspension of....... 696

State Bank of Indiana, the....... 694, 698

State banks, statistics of............. 711

Territorial government, banking under............................ 692

Trust companies.................... 705

Wildcat banks, how organized and conducted........................ 702

Indian Territory:

Banks, number of doing business in 1898.

Indians, condition of.............. 839

National banks, statistics of.......... 839

Organization of National banks in.... 193

Owen, Robert L., bank established by. 839

Rules regarding the establishment of banks ............................. 838

Inflation bill, veto of by President Grant. 277

Inflation sentiment, decline of........... 278

Interchangeable bond plan, the......... 140

Interest rates to be charged by National banks................. 238, 248, 266

Iowa :

Banking and business characteristics of the State..................... 778

Banking, present system of............ 773

Banking, prohibition of.............. 764

Circulation, safety fund as security for.......................... 768 Constitutional prohibition of banking. 765 Constitution of 1857 , banking author. ized by .......................... 766

Early banking in Iowa, features of... 763

Iowa Bankers' Association, the...... 778

Laws relating to banking............. 773

Miners' Bank of Dubuque, the........ 761

National banks, loans of to the Gov. ernment ........................... 777

National banks, statistics of......... 779

Notes of banks in other States, circulation of ....................... 765

Panic of 1857, the................. 765

Penal offence, banking made a......... 764

Pioneer banks, equipment of.......... 764

Private banks........................ 777

Safety-fund security for circulation... 768 Savings banks, laws relating to....... 774 Savings banks, statistics of............ 777 Specie payments, suspension of....... 769 State Bank of Iowa, the.766, 770, 771, 772 State banks, iaws relating to.......... 773 State banks, statistics of............. 774 Territory, geographical changes in the. 761 Irish banks, note issues of

Issue and retirement of circulation, re. strictions on ....................... 208

J.

Jackson, Andrew, attack on Bank of the United States.................. 70, 75

censure of by Congress for removing public deposits from Bank of the United States... 71 contest of with Clay and Adams for the Presidency...................... issue of specie circular by ............ 81 message of in 1829 criticising the Bank of the United States......... 62 message of in $1831 . \ldots . . . \ldots \ldots \ldots \ldots . .68$ protest against resolution of censure. 71 recommendation of distribution of surplus among the States........... 83 veto of bill to renew charter of the Bank of the United States......... 69

views of on bank bills................ 651 Jefferson, Thos., estimate of concerning Colonial currency issued........... 20 opposition of to charter of Bank of the United States. 20

views of on Continental currency..... 19 Jews, the, as bankers.................. 4

Kansas :

K.

Banking law of 1897, provisions of.... 821

Banking law of 1891, the............ 820

Fraudulent loan companies, opera-

tions of ........................ 821

Insurance of depositors, plan for...... 824

National and other banks, comparative progress of ................... 824

Nationai banks, statistics of.......... 824

Notes of smali denominations prohibited.......................... 819

Popular vote required to make bank. ing law effective.............. 819, 821

Private bankers, application of bank-

ing law to....................... 823

Speculation in real estate.............. 820

State banks, statistics of ............. 823

State prohibited from owning bank stock ............................ 819

Kendall, Amos, sketch of.............. 66

Kentucky :

Bank of Kentucky, the...... 631, 632, 637,642

Bank of the Commonwealth, the....... 633

Barter currency of the pioneers....... 629

Charters, forfeiture of by suspension of specie payments................. 636

Circulation and eapital, comparisons of .641 Circulation, intlation of .............. 639 Civil War, disturbances incident to... 642 Fiat money, experience with......... 631 First incorporated banks, the ......... 630 Fractional currency, issue of........... 636 Hewitt tax law, the.................6 644 
Kentucky (Continued) :

Kentucky Insurance Company, the... 630 Louisville, banking institutions in.... 645 Louisville Clearing.House Assoclation, the.

National banks, statistics of......... 647 Panic of 1837, the................... 635

Panic of 1857, the...................640

Panic of 1873, the...................642

Panic of 1890 , the...................643

Panic of 1893, the................... 646

Spanish milled dollar, circulation of... 630

Specie, limited circulation of.......... 630

Specie payments, suspension of.. 635,640

State banks, statistics of.............. 646

Stay laws, bad effects of...............631

Surplus revenues, deposit of in banks 635

Taxation of banking capital............ 644

Kitchen cabinet, influence of in campaign against the Bank of the United States.......................... 67

Knox, Jolnn Jay, appointed Comptroller of the Currency. 110 recommendation for issue of bank notes on securities other than Gov. ernment bonds.................... 175 views of on funding act of $1881 \ldots \ldots .168$

\section{L.}

Lacey, Edward S., appointed Comptroller. 192 Lack of organization among the banks in 1861 . 134

Land bank in England. 15

Land bank in Massachusetts......... 15, 16

Lawful money, deposit of to retire circulation.

Law, John, originator of the Bank of France.

Legal-tender act, debate on.............. 224 introduction of .................. 96, 222 necessity of as a war measure.......... 223

Legal-tender notes: and National bank notes.............. 132 a temporary expedient................. 134 certificates of deposit for......... 186, 273 comparison of with National bank notes........................... 207 contraction of by Secretary McCulloch. 274 deposit of to retire circulation.......... 126 deposit of to withdraw circulation..... 117 funding provision in original bill...... 229 gold value of.......................... 125 limitation of volume of................. 138 maximum volume ontstanding......... 138 necessity of their issue discussed..... 135 opinions of Chase, Sherman and Spaulding ........................ 133 proposed retirement of................ 214 proposed substitution of for National bank notes.

proposed to replace National bank notes.

redemption of........................... 286

reduction in volume of.................. 150
Legal-tender notes (Continued): PAGE reissue of when retired................. 274 repeal of funding provision............ 136 repeal of law permitting funding into

United States bonds................ 230 retirement of ....................... 138 retirement of prohibited......... 138, 280

Treasury influence in perpetnating... 149 License tax on National banks, repeal of 110 Liquidating banks, withdrawal of circu.

lation............................ 108

Liquidation of failed banks............. 188

Loan and trust companies, statistics of.. 859

Loan banks in the Colonies............. 17

Loans by the banks in 1861 .............. 135

Lombards as bankers in England........ 4

Losses by failures of State banks......... 315

Losses by National bank insolvency..... 175

Losses from bad banking................ 13

Loudon, D. H., proposals of for an Ex. chequer Bank..................... 115 Louisiana :

Bank act of $1842 \ldots \ldots \ldots \ldots \ldots \ldots \ldots .613$

Banking law, the present............. 614

Bank of Louisiana, successful operations of ............................6 611

Circulation of the banks, 1835-1852.. 613 Constitutional prohibition against State owning stock in banks....... 612

Louisiana State bank, State subscription to............................ 611

National banks, statistics of.......... 615

Reports, banks required to make and publish...........................615

Specie reserve required...............6 615

State aid to banking institutions...... 612

State banks, statistics of.............. 614

State prohibited from owning bank stock............................ 612

Union Bank of Louisiana, the........ 611 White, Horace, on bank act of 1842 ... 613 Lubbock, Sir John, report of on use of credit instruments................ 212

\section{M.}

Madison, James, message to Congress, on banking and currency............. 54 veto of bill to establish a National bank........................... 53 Maine :

Admission of State into the Union..... 331 Bills, methods of redeeming........... 330 Circulation, increase of in 1835 ........ 332 Circulation of small bills prohibited... 333 Commissioners' report for 1848 ....... 333 Condition of banks in $1814 \ldots . . . . . . . . .330$

Dexter bank robbery, the.............. 336

Failures of State banks in............. 320

First bank established................. 329

Growth of Savings banks............. 336

Loans to stockholders.................. 331

Maximum number of State banks..... 333

National banking law, effect of on State banks........................ 333 
Maine (Continued) :

National banks, condition of, 18631898

Panic of 1877, confined to Savings banks............................ 336

Portland Bank, organization of........ 329

Resources of National banks, Savings banks, trust companies and building and loan associations. 337

Savings banks, growth of............. 336

Savings banks, laws relating to....... 335

Savings banks, organization of........ 334

Sm:sll bills, circulation of prohibited.. 332

Spccie payments, suspension of....... 333

State banks absorbed into National system......................... 333

State banks, condition of, 1834-1875.. 334

State banks, maximum number of..... 333

Stockholders, loans to................ 331

Suffolk system of redemption, operation of........................... 332

Suffolk system, opposition to......... 332

Suspension of specie payments........ 333

Taxation on bank capital............. 330

Total banking resources............. 337

Trust companies, resources of........ 336

Manhattan Company, the.............. 395

Mann, Abijah, claim of as author of New York free banking law............ 95

Marine National Bank of New York, failure of....................... 181

Maryland :

Agriculture, banks formed to aid..... 472

Baltimore Clearing.House, formation of................................513

Bank of Columbia, the.............. 471

Bank of Maryland, charter of.......... 470

Bank of the State of Maryland, attempts to establish................ 498

Bank of the United States, branch of. 471

Bank of the United States, suspen. sion of .........................504

Capital of banks, increase of, 18431862.

Capital, payment of in stock notes.... 490

Capital, requirement of payment in legal money.......................477

Cash credits......................... 479

Charter for a bank, form of........... 474

Circulation, ratio of specie to.......... 510

Clearing-house, formation of......... 513

Colonial currency, issue of............ 469

Country banks, condition of, 18161820

491

Credit facilities, lack of...............470

Crisis of 1818, the................... 487

Crisis of 1834, the..................... 500

Crisis of 1839, the................... 504

Deposits, allowing interest on......... 480

Early banking, features of........... 476

Elasticity of the currency............ 517

Expansion of banking, 1829-36........ 496

Expansion of State banking...........480

First bank incorporated............... 469

Forgery, abolition of death penalty for 478
Maryland (Continued): $\quad$ PAGE

General banking law, adoption of..... 511

Industrial investments of banks...... 482

Insolvent banks, method of closing... 506

Interest on deposits, payment of..... 480

Loans, limitations in regard to........ 479

Maryland Bankers' Association, organ-

Ization of .......................... 518

McCulloch v8. Maryland............... 494

Monopoly, chartered banks not granted a............................ 478

National bank act, effects of........... 515

National banks, statistics of........... 518

Notes, corporations authorized to

issue............................. 505

discount on .............. 486, 492 issue of small denominations per. mitted........................5 506

limitations on issue of...........477 of small denomination, prohibi-

tion of ........................ 494 purchase of by banks at a dis-

count............................ 492

right of banks to issue.......... 477

Savings banks permitted to issue. 509

Panic of 1825 and $1828 \ldots \ldots \ldots \ldots \ldots . . .495$

Panic of 1837, the.................. 502

Panic of 1857, the................... 512

Paper currency issues, depreciation of. 469

Savings banks permitted to issue

notes........................... 509

Scotch system of cash credits......... 479

Specie payments, resumption of.. 485 , $504,505,512$

Specie payments, suspension of.. 484 , $502,504,512,513$

Specie, penalty for bauk failing to $r e$ -

deem notes in.................488, 514

State banks, statistics of............ 518

Taxation, iucrease of................... 499

Taxation of Bank of the United States. 494

Uniform regulation of banks.......... 498

Union Bank of Maryland, the......... 472

Mason, Jeremialı, opposition to as mana. ger of branch of the Bank of the United States.

Massachusetts

Bank commissioners, creation of board of

Banking law of 1829 , the.............. 362

Banking law of 1851, the............. 364

Bank of Mutual Redemption, organization of ........................ 368

Bank of North America, charter granted to........................ 359

Bills of credit, issue of............... 359

Credit bank, project for establishing.. 359

Credit bills, issue of.................. 359

Dividends paid, 1808 to $1839 . . . . . . .364$

Examination of banks by State author. ity............................... 363

Failures of the early banks............. 319

Free banking law of 1851, the........ 364

Land bank, proposal for................ 359

Massachusetts Bank, organization of. 359 
Massachusetts (Continued):

Massachusetts land bank............. 16

National banks, statisties of........... 369

Notes issued by Massacliusetts Bank. 359

Panic of 1814, strength of banks in... 361

Panic of 1837, the..................... 362

Redemptions under suffolk and Na.

tional systems.................... 368

Reports, law requiring banks to make 360

Savings banks, statistics of........... 370

Specie reserve law, the.............. 363

State banks, statistics of............. 369

Suffolk redemption system, the....... 365

Suffolk system, redemptions under

compared with National system.... 368

Trust companies...................... 370

Whitney, D. R., history of the Suffolk

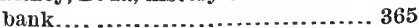

Massachusetts land bank............... 16

Maverick National Bank of Boston, fail.

ure of ........................... 201

McCulloch. Hugh, appointed Comptrol-

ler of the Currency............... 97

as a banker in Indiana................ 706

opinion of on State bank notes........ 12

recommendations of (1) $1863 . . . . . . .2232$

retirement of legal-tender notes...... 138

sketch of. with portrait............... 292

views of on prices and the volume of

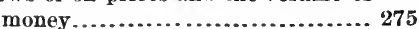

MeCulloch vs. Maryland............ 70, 494

McVickar, John, banking pian of........ 94

Metropolitan National Bank of New York, failure of................... 182

iíichigan:

Bank commissioners, supervision of banks by ......................... 733

Banking law, imperfect administra. tion of .......................... 733

Banking, present condition of......... 736

Banking, unauthorized, prohibited.... 730

Bank of Detroit, the .................. 730

Bank of Michigan, charter of......... 730

Circulation, security of by pledge of

stocks........................... 732

Early banking experience of.......... 324

Free banking law, the.......... 732, 735

Governor's message in $1853 . . . \ldots \ldots . .318$

Michigan Insurance Company, the... 730

Michigan state Bank, incorporation

of............................... 730

National banks, statistics of.......... 738

Provision in banking law requiring deposit of bonds to secure circulation 95

Safety fund, provisions for........... 732

Securities for circulation, pledge of to State............................732

State banks, statistics of........ 737, 738

wildcat banking, features of........... 733

Middle States, history of banking in..... 668 Minnesota:

Banking laws, the..... 753, 754, 757, $\mathbf{7 5 8}, 759,760$

Bank notes, security for............. 753

Bank of the State of Minnesota, the... 754
Minnesota (Continued): $\quad$ PAGE

Capital stock, requirements as to pay.

ment of ............................ 757

Circulation, securities deposited for.. 756

Constitutional provision relating to

banking............................. 753

Discount on bank notes............. 756

Disconnt on State bank notes in....... 324

Early banks, the................... 756

First banking law of the State. ....... 753

Liquidation, vote required to place bank in......................... $\mathbf{7 5 7}$

National banks, statistics of............ 760

Note issues, lack of profit when made legitimately........................ 755

Notes, discount on.................. 756

Publication of reports required........ 757

Public examiner, banks placed under control of........................ 757

Savings banks, laws relating to........ 759

Savings banks, statistics of............ 760

Securities deposited for circulation.... 756

Security for bank notes............. 753

State banks, conversion of to $\mathrm{Na}$ -

tional banks........................ 754

State banks, statistics of............. 758

Supervision of banking, the..... 753, 757

Trust companies................... 760

Mississippi :

Banking system, the present......... 610

Banking, unauthorized prohibited..... 610

Bank of Mississippi chartered......... 602

Bonds issued by the State to aid bank. 603

Bonds issued to aid banks, legality of upheld............................6 608

Bonds issued to banks, payment of opposed...............................6.64 604

Circulating medium prior to $1809 \ldots . .602$

Mississippi Union Bank................ 604

National banks, statistics of..........610

Planters' Bank of Mississippi, the..... 602

Real estate as a basis for banking..... 609

Real estate security for subscriptions

to bank stock...................... 604

Reports, banks required to make...... 610

State banks, statistics of............. 610

State subscription for bank stock, legality of...................... 607

State subscriptions to the capital of banks ............................602 Missouri :

Act of 1857, banks organized under... 785

Banking conditions, improvement of. 790

Banks of Missouri, the ............... 781

Bank of St. Louis, the................ 781

Bank of the State of Missouri, the.... 782

Circulation, conservative policy regarding.......................... 783

Coin, introduction of into circulation. 781

First bank, establishment of.......... 781

National banks, statistics of.......... 793

National system, banks organized under.............................. 787

Notes, safety and convertibility of.... 785

Notes, value of...................... 784 
Panic of 1873, the...................... 789

Private and incorporated banks, sta.

tistics of........................... 793

Private bankers, noted firms of....... 788

Savings banks, establishment of..... 787

Skins, use of as currency............. 779

State banks, statistics of............ 792

State banks of issue chartered....... 784

St. Louis Clearing-House Association,

founding of ......................... 789

St. Lonis, pioneer banks of. .......... 786

Trust companies, introduction of..... 790

Monopoly bank charters and free bank. ing.

Montana :

Admission of State into the Union.... 825

Capital of the banks, high average of. 825

Laws relating to banking........... 825

National banks, statistics of......... 826

Savings banks, provisions for incor. porating........................ 825

State banks, statistics of............ 826

Morris, Robert, plan of for establishing a bank.

sketch of ........................... 27

\section{N.}

National and State banks in New York.. 206 National Bank Act..................... 116 amendment of in 1876 ................ 124 amendments to ................... 235 author of preliminary draft.......... 221 debates on amendments to............. 236 penalties of ........................ 131 requirements and restrictions of...... 129

National banking bill :

anended and passed by House....... 254

discussion of in House. ................. 230 introduction of in House and Senate.

passage of........................... 96 passage of by the House and approval

of by the President............... 231 passage of by the Senate............... 229

National banking capital, maximum of.. 217 National banking law, authorship of..... 96

National banking system, benefits of.... 205 comparison of with State systems.... 13 homogeneity of....................... 189 origin of............................ 91 progress of............................ 208 underlying principles of............. 91

National bauk circulation:

amount outstanding, 1867-1878...... 156

apportionment of among the States... . 270

Comptroller's recommentation for an increase of to amount of paid-incapital............................ 165

contraction of in $1883 \ldots \ldots \ldots \ldots \ldots \ldots 176$

decline in............................. 194

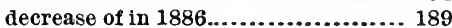

National bank circulation (Continued) :

history of ........................... 155

increase of to par of capital and bonds 286

inequalities in distribution of ......... 271

limitations of....................... 138

limitations of in proportion to capital.

$127,232,270$

opposition to in Congress............ 139

reclemption ot..................... 282

redistribution of ...................... 272

repeal of law requiring reserve on ..... 277

restrictions on ....................... 139

restrictions on issue and retirement of 208 retirement of. ........................ 166 retirement of by deposit of lawful money........................... 277

value of privilege in $1879 \ldots \ldots . . . . .162$

National bank examiners, compensation

of ............................ 130

National bank failures in $1882 \ldots . . . . .175$

National bank legislation of $1881 \ldots . . .166$

National bank notes:

a permanent currency................ 134

and legal-tender notes................ 132

bad condition of in 1874............. 117

based on securities other than Govern.

ment bonds........................ 175

decrease in volume of. ............... 117

denominations and devices of........ 120

lack of commercial redemption....... 284

method of destroying ............... 123

printing of . ......................... 123

proposal of Secretary Chase to issue.. 220

proposed retirement of............... 142

proposed substitution of legal tenders

for . ............................... 161

redemption agency established....... 116

redemption of.................... 129, 239

redemption of by U. S. Treasury...... 148

redemption of in lawful money ........ 147

redemption of when stolen or forged.. 286

repeal of law requiring reserve on .... 116

retirement and redistribution of...... 116

retirement of . .................. 150

withdrawal of.................... 115

National bank, penalty for usury ....... 123

National bank, plan for a.............. 54

National bank shares, distribution of.... 214

ownership of ........................ 127

State taxation of ..................... 122

National bank statistics, 1863-1899...... 295

National banks:

advantages of. ....................... 163

aid furnished in carrying on the Civil

War.......................... 96

appointuent of Recivers of......... 281

bonds to be deposited with Treasurer. 188

branches of illegal . .................. 212

comparison of in 1892 and $1896 . . . . .209$

condition of in $1899 \ldots \ldots \ldots \ldots . . . \ldots 218$

decrease of bonds held, through refund-

ing operations..................... 199

dennnciation of ..................... 248

deposit of public moneys with ........ 191 
National banks (Continued):

PAGE examination of....................... 130 executors, administrators, etc., re-

lieved from liability on shares...... 250 extension of corporate existence of.

171,282

failures of in 1887

191

failures of in $1888 \ldots \ldots \ldots \ldots \ldots \ldots \ldots . . . . . .192$

failures of in $1893 \ldots \ldots \ldots \ldots \ldots \ldots \ldots . . . .203$

failures of in the crisis of $1884 \ldots . . . . . .183$

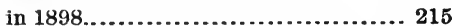

in suburban districts, absorption into reserve cities...................... 193

interest rate to be charged by. 233, 248, 266

law in regard to reports............... 129

location of new organizations in 1889. 192

losses from insolvency............... 175

minimum capital fixed at $\$ 50,000 \ldots . .237$

number of organizations, 1882 to 1887.190 opposition to......................... 139

organization of in Indian Territory.... 193

per cent. of dividends paid by failed

banks ............................. 211

prejudice against..................... 251

reduction of minimum capttal of..... 286

revenue received from................. 214

State taxation of.................... 243

National Currency Act, change in title

of.................................. 116

National gold banks, circulation of...... 119

note issues of ......................... 272

organized............................. 110

National system and New York system compared.........................

Nebraska:

Banking made punishable by fine and inuprisonment.................... 807

Bank of Nebraska, the................ 809

Chartered banks, the................ 808

Commercial assets, notes issued on

security of ....................... 818

Currency era, the................... 806

Currency reform, agitation for....... 817

Deposit banking, era of .............. 811

Early banks, history of............... 809

Growth of State and National banks.. 815

Kansas-Nebraska act, the............. 806

Kountze Bros., notes of always re. deemed.... 810

Loss of State and National banks,

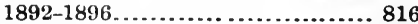

National banks, statistics of.......... 819

Nebraska Bankers' Association, the.. 817

Notes issued on security of commercial assets......................... 818

Note issues, prohibltion of........... 807

Notes of State banks, characteristics of .............................. 806

Pioneer bankers, the................. 811

Railroad era, the.................... 815

Savings banks....................... 816

State bank notes, characteristics of... 806 State banks, statistics of.... 810, 815, 816

Western Excliange. Fire and Marine Insurance Co.
Nevada: PAGK

Licenses imposed upon banks....... 855

National banks, statistics of.......... 856

Population of the State, the........... 855

State banks, statistics of............. 855

New banks, organization of............. 174

Newcomb, Simon, on the interchangeable bond plan....................... 140

New England States, banking in........ 329

New Hampshire:

Artstocratic character of the banking

law............................ 340

Bank commission, ereation of......... 351

Bank commissioners, law providing for................................ 340

Banks required to make reports....... 338

Bills of small denominations prohibited.

Capital and circulation of the banks in 1831

Capital, law requiring to be paid up in cash............................... 340

Charters of the Savings banks, provistons of.......................... 345 Circulation and capital of the banks in

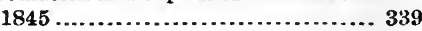

Circulation, limitations of............ 340

Concord Bank, the................ 337, 339

Condition of Savings banks, 1850-98.. 353

Condition of State banks, 1834-1863.. 340

Deposits in Savings banks, compari. sons with other property........... 341

Deposits in Saving banks, taxes re. ceived from....................... 341

Discount on the notes of failed banks. 339 Exeter Savings Bank, failure of....... 344 Failures of banks in the crisis of 1809. 339 Failures of State banks in............. 320 First bank chartered in the State..... 337

First Savings bank chartered.......... 342

Growth of Savings bank deposits...... 341 Guaranty Savings banks, organization of................................. 346

Investments for Savings banks, limitation of....................... 348, 349

Nationai banking law, effect of....... 340

National banks, condition of, 1834-

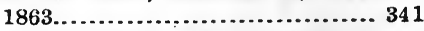

New Hampshire Bank of Portsmouth, the .............................. 337

Notes redeemable at place of i ssue.... 340

Nutes, limitations on issue of.......... 340

Panic of 1893, effect of on Savings banks ............................. 342

Private banking prohibited............ 340

Reports, banks required to make...... 338

Savings bank, charter of the first one. 342 Savings bank charters, provisions of.. 345 Savings bank deposits, growth of...... 344 Savings bank deposits, taxes received from .............................. 341

Savings bank investments, limitation of ........................... 348, 342 Savings banks, condition of, 1850-

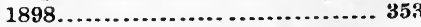


New Hampshire (Continued):

Savings banks, effect of panic of 1893

on................................. 342

Savings banks, history of............. 341

Savings banks, supervision of.... $343 \quad 350$

Savings banks, Western investments

of............................... 349

Small notes prohibited................ 338

Specie, bank bills payable in.......... 340

State banks, condition of, 1834-1863.. 340

State banks in New Hampshire....... 337

Supervision of Savings banks.... 343, 350

Taxes on Savings bank deposits, distribution of...

Trust companies, chartering of........ 347

Trust companies, Savings bank business required to be conducted separately.

Western investments of Savings banks

New Jersey :

Banking law, enactment of...... 432, 434

Banking laws, revision of in 1899 ..... 437

Banks organized for speculative pur. poses.

First banks organized in the State.... 430

General banking law, banks organized under.

436

General banking law, provisions of.... 434

Government, loans made to.......... 432

Incorporated banks, condition of..... 437

Indebtedness, limitation of amount of 433

Limitation of amount of bank's indebt-

edness............................ 433

Loan to a royal customer.............. 431

National banks, statistics of........... 437

Nowark Banking and Insurance Co.,

the................................. 430

Revision of the banking laws in 1899. 437

Royal customer, loan to.............. 431

Savings banks....................... 439

Sarings banks, statistics of........... 441

Specie payments, suspension of in

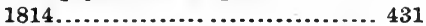

State banks, statistics of........4 436, 437

Trenton Banking Co., the.............. 430

Trust companies, statistics of........ 441

New Mexico:

Laws relating to banks............... 836

National banks, statistics of.......... 837

Real estate, loans on................ 836

Reports, banks required to make...... 836

Savings banks, regulation of.......... 836

State banks, statisties of............ 837

New York :

Bank commissioners, appointment of. 404

Banking laws, revision and consolida. tion of

Bank of America, the.................. 397

Bank of New York, charter of....... .. 393

Bank of North America, charter granted to.......................... 393

Bank of North America, monopoly of banking given to.................... 394

Bills of small denomination, issue of.. 398
New York (Continued):

Bills of small denominations, proposed retirement of.................... 407

Burr, Aaron, procures charter for the Manhattan Company............... 395

Chartered banks, the................. 393

Failures of State banks in............ 321

Fillmore, Millard, opınion of safety. fund system........................ 411

Fillmore, Millard, report of on banks. 405

Flagg, A. C., claims to authorship of safety-fund..................... 402

Forman, Joshua, suggestions of for banking system.................. 400

Free banking law, adoption of by other States............................. 318

Free banking law, the.......... 408, 413

Free banking system, failures under.. 322

Gallatin, Albert, suggests organization of New York Clearing.House....... 423

Hamilton, Alexander, charter procured by for Bank of New York.... 393

Manhattan Company, the.............. 394

National banks, statisties of ......... 423

New York city banks, history of..... 427

New York Clearing-House Associa. tion, the.......................... 423

New York Clearing-House Association, transactions of, 1854-1899... 424

Notes, issue of on basis of State securities................................. 415

Notes, printing of placed under State control...........................4 419

Panic of 1857, the.................... 420

Private banking prohibited........... 396

Redemption, imperfect methods of.... 418

Restraining act of $1818 . . . . . . . . . . . . .399$

Revision and consolidation of the banking laws..................... 421

Safety-fund act, passage of............. 404

Safety-fund and free banking systems, comparison of....................4 410

Safety-fund plan, origin of............. 402

Safety-fund system of chartered banks. 399

Safety.fund system, operations of...... 409

Safety-fund, why only partially successful ............................ 412

Savings banks......................... 425

Specie payments, suspension of....... 408

State and National banks, comparison of ...........................421

State banking history, prominent characteristics of .................... 390

State banks, statistics of.............. 422

State securities, issue of notes on.... 415

Suspension of specie payments....... 408

Supervision of banks by the State.... 404

Trust companies................... 426

Van Buren, Martin, proposals of...... 400

New York banking system and National system compared.................. 95

New York city banks, history of........ 427

New York Clearing-House Association. 423 action of in crisis of $1884 \ldots \ldots \ldots \ldots \ldots . .182$ action of in panic of $1890 \ldots \ldots \ldots \ldots . . . .197$ 
New York Clearing-House Association (Continued) :

action of in regard to resumption of specie payments................... 152

Assistant Treasurer of the United States made a member of........... 153

investigations and recommendations regarding the panic of $1873 \ldots \ldots . .114$

opposition of to Nationai banks...... 100 transactions of, 1854-1899........... 424

North Carolina:

Bank of Cape Fear, the...............544

Bank of Newbern, the ................ 545

Bank of North Carolina, act of incor. poration of ....................551

Bank of North Carolina, history of ... 554 Bank of North Carolina, suspension of $\mathbf{5 5 8}$ Bank of the State of North Carolina, incorporation of ................... 551

Bank of the United States, branch of. 548 Barter currency of the Colonial period 543 Bills of credit, issue of.

Charters, extension and amendments of ............................. 546

Circulation issued by the Bank of North Carolina ................. 555

Civil War, banking during and subsequent to.......................... 5is

Confelerate money, depreciation of... 559

Criticism of the banks................ 549

Dividends received by the State on bank stock.

First chartered banks in the State.... 544

Gold and silver held by the Bank of North Carolina

Increase in number of banks......... 553

Laws in regard to banks and banking. 550

National banks, statistics of........... 560

Note issues, private, prohibited...... 547

Private vanks, statistics of........... 561

Private note issues prohibited........ 547

Savings banks, statistics of........... 561

Specie, repeal of law requiring banks to keep reserves in ................ 559

State as stockholder in banks........ 545

State Bank of North Carolina, the.... 545

State banks, statistics of ... 550,552 , $553,560,561$

Taxation of banks. 559

North Dakota :

Banking, beginning of............... 794

Banking law, amendmeuts to......... 797

Banking law of 1890, the .............. 796

First incorporated bank, the........... 795

First National Bank, of Fargo, incorporation of.

Mears, E. Ashley, organization of banks by ......................... 796

National banks, statistics of.......... 798

Private banking, prohibition of........ 796

Raymond, J. W., bank established by. 794

State banks, statistics of .............. 797

Notes issued by the Government and banks, cost of.
Notes issued on security of general assets 189 Note issues, of Bank of England and Bank of France, comparisons of.... of the Bank of England............... of the Bank of France.................. of the Irish banks....................... of the Scotch banks..................... Note-issuing function, abuse of.......... 11

\section{O.}

Ohio:

Act of 1845, the. 679

Banking law of 1839 and 1842 , the....

672,673

Banking law of 1845, the............ 679

Banking, unauthorized prohibited..... 682

Bank of Marietta, the................. 669

Bank of the United States, branch of prohibited.........................6671

Bank of the United States, opposition to.................................. 674

Bills of smali denominations, prohibi. tion of ............................ 672

Chase, Salmon P., on State bank issues 670

Circulating notes, discount on........ 669 Circulation, unauthorized prohibited. 669

Commercial assets, unsatisfactory experience with notes secured by ..... 677

Crowbar law, the...................... 684

Fidelity National bank, failure of..... 687

Forged notes, discovery of in circulation................................ 683

Free banking law, enactment of...... 682

Growth of the banking business........ 687

Laws regulating banking............. 671

Miami Exporting Company, charter of ................................. 668

National banking system, inauguration of ........................... 684

National banks, statistics of.......... 691

Notes secured by commercial assets, experience with.................. 677

Ohio Life and Trust Company, failure of .............................. 684

Organization and operation of the early banks.......................... 676

Panic of 1873, the .................. 686

Savings banks........................ 688

Specie payments, suspension of.. 669,675

State Bank of Ohio, the............. 675

State banks, statistics of.............. 691

State, partnership of in banks........ 670

Taxation of banks, the.............. 683

Taxes, difficulties in adjusting......... 675

Tax, treatment of banks refusing to pay................................6 684

Oklahoma :

Growth of the Territory............... 838

Laws relating to banking............. 837

National banks, statistics of.......... 838

State banks, statistics of............. 838

Supervision of banks................. 837

Opdyke, Geo., on resumption act of 1875145 
Oregon:

Constitution, note issues prohibited

by ............................ 842

First National Bank, of Portland, establishment of..................... 842

Ladd \& Tilton, bank founded by...... 842

Laws relating to banking............. 842

National banks, statistics of.......... 843

Note issues prohibited by constitution 842

State and National banks, comparison of.

State banks, statistics of............. 843

Organization of banks, methods employed in the various States........ 314

Organization of new banks.............. 174

Origin of banking...................... 2

Origin of the word bank................ 10

Over-certification of checks........ 179, 184

\section{P.}

Pacific States, history of banking in...... 840 Paine, Thos., suggestions of for relief of Revolutionary army .............. 26

Pananıa Canal co , failure of.............. 196

Panic of 1869, causes of................. 271

Pauic of 1873, opinions as to causes of... 274

Panic of 1873, the.................. 113, 273

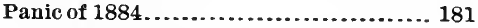

Panic of 1890, action of New York, Boston and Philadelphia banks........ 197

Panic of 1890, the...................... 195

Panic of $1893 . . . . . \ldots \ldots \ldots \ldots \ldots \ldots . . . . . . .201$

Panic of 1893, recovery from........... 204

Panies, demand loans as a resource in... 187

Paper money, authority of State vanks to issue.

issue of by the Colonies............... 15

issue of by the Government........... 14

Parliament proh bits banks of issue...... 18

Payment of incerest on deposits.......... 187

Payment of the public debt............. 84

Penalties of the National bank act....... 131

Penalty for over-certification of checks.. 184

Pennsylvania :

Act of 1814, the.................... 445

Act of April 6, 1850................. 455

Act of 1860 , the.................... 459

Act of 1876, the...................... 462

Agitation against banks.............450

Bank of North America, incorporation of ............................. 442

Bank of the United States becomes a State bank....................... 449

Capital of the banks in 1854-55.. 456, 457

Colonial currency, issue of............. 442

Failure of the United States Bank.... 452

Financial distress, 1816-1820......... 447

First State oanks chartered.......... 443

Forfeiture of bank charters by suspension..................... 452, 453

Free banking system, establishment of. 459 Internal improvement schemes....... 449
Pennsylvania (Continued): PAGB

Morris, Robert, speech of in favor of a bank ............................. 442

National bauks, statistics of.......... 463

National system, organization of banks under............................ 461

Note issues prohibited except by bankiog corporations.............. 447

Notes, liability of stockholders for.... 455

Notes, paying out of other than those issued by specie-paying banks of the state prohibited................ 457

Notes, penalty for bank failing to redeem in specie..................... 459

Notes, provision for maintaining at par............................ 456

Notes, security for under act of 1860.. 459

Panic of 1837, the................... 450

Panic of 1857, the................... 457

Philadelphia Saving Fund Society, the 464

Redemption of notes in specie........ 456

Felief notes, prohibition of........... 456

Resumption of specie payments, 1838. 451

Savings banks, dates of incorporation

of ............................. 456

laws relating to................ 463

statistics of...................... 464

Snyder, Gov., veto of act of $1814 \ldots . . .445$

Specie payments, compulsory resump-

tion of ......................... 451 suspension of in $1860 \ldots \ldots \ldots \ldots . .460$

Specie, penalty for bank failing to redeem notes in..................... 459

specie redemption, of notes enforced.. 447 provisions for maintaining...... 456

State banking department, establish. ment of. 465

State banks, statisties of............. 462

Stockholders, liability of.............. 455

Supervision of banks................. 465

Taxation of State banks.............. 449

Trust companies..................... 464

United States Bank, amounts paid or loaned to State....................453 failure of .................... 452

United States Bank of Pennsylvania, charter of....................... 450

Pennsylvania Bank, the............... 26

"Pet banks," deposit of public moneys in 80 Philadelphia Clearing.House Association, action of in panic of $1890 \ldots \ldots .198$

Potter, O. B., plan of for issuing State bank notes on a deposit of United States bouds...

Prejudice against National banks....... 251

Presidential campaign of $1824 \ldots . . . \ldots \ldots .61$

Presidential campaign of $1896 . . . . . . . .208$

Prices and the volume of money.......... 275

Private banks, statistics of.............. 859

Profits in banking, decline in........... 205

Profits of the Government from the Bank of the United States............... 78

Public debt, funding of.................. 286

Pullan, Richard B., on resumption act of 1875 
PAGE

Purchase of bonds by the Government.. 199 Purchase of bonds with surplus revenues 192

\section{R.}

Real estate taken by National bank to secure pre-existing debt.

Receivers of National banks, appointment of

Receivers of National banks, Comptrol. ler authorized to appoint........... 281

Red dog currency, issue of......... 701, 747 Redemption agency, establishment of....

Redemption agency, operations of........ 120

Redemption bank proposed............. 104

Redemption of National bank notes. 129, 282

by United States Treasury........... 148 in lawful rnoney...................... 147 in legal tenders....................... 102 provisions for....................... 239 recommendations of the Comptroller.. 103 reforms suggested.................... 115 Redemption of notes under Suffolk and National systems.................. 368

Redemption of three per cent. bonds..... 190

Refunding acts, sale of bonds under...... 159

Refunding of the public debt............ 157

Reissue of legai-tender notes............. 274

Reports of condition of National banks, reguiations concerning .............. 129

Reports of National banks, amendment of law requiring returns to be made on fixed dates.

Reserve cities for National banks........ 285

Reserve cities, how established.......... 285

Reserve on circulation, abolishment of.. 116

repeal of law requiring............... 277

Reserve, opposition to law requiring a fixed amount...................... 112

Reserves of National banks, payment of interest by reserve agents.......... 103

Resumption ast of $1875 \ldots \ldots \ldots \ldots . . .125,278$ attacks on ........................... 142 passage of a repeal bill by the House.. 141 sale of bonds under................... 159

Resumption of specie payments, bonds sold for ............................. 157

Comptroller's views on................ 153

in 1879 ............ 159

cpinions of financiers.............. 143

Sherman's statement............. 143

rules of the New York Clearing.House 152

Retirement of legal-tender notes pro. hibited...................... 138, 280

Retirement of National bank notes...... 151 Revolutionary debt, proposed funding of 20 Rhode Island:

Bank commissioners, creation of...... 372

Banking resources of the State........ 371

Bank of Rhode Island, incorporation of ................................... 371

Circulation, limitation of............. 372
Rhode Island (Continued): PAGE Circulation, novel plan of issuing...... 371

Debt, powers conferred on bank officers to collect......................371

Directors, liability of for violating banking law........................ 372

Failures of State banks in ............. 319

Liability of stockholders and directors 372

National banking act, effect of........ 372

National banks, statistics of......... 373

Panic of 1837, the................... 372

Providence Bank, incorporation of.... 371

Reports, banks required to make...... 372

Savings banks, statistics of............ 374

Specie payments, suspension of in 1857.

State banks, statistics of............. 373

Stockholders, liability of .............. 372

Trust companies..................... 374

\section{S.}

Safety-fund banks in New York

Savings banks (see State index for).

Savings banks in the Uniter States, sta tistics of, 1820-1899.............. 858

Savings banks, statistics of ............. 859

Schuckers, J. W., on resumption act..... 143

Scotch banks, note issues of............. 6

Second National Bank of New York, defalcation in...................... 181

Secretary of the Treasury, report of for 1862.

Securities deposited with State and National Governments to secure cir. culation.

Seligman, Joseph, on resumption act of

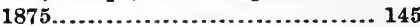

Shares of National banks, distribution of.

125,214

Shares of National banks, ownership of.. 127 Sherman, John, bill for increasing Na.

tional bank circulation.............. 179

explanation of provisions of National

currency act....................... 25s

opinion of funding act of $1881 . . . . . . .168$

remarks on National banks............ 10'

remarks on the legal-tender bill........ 133

gketch of, with portrait............... 291

speech of on National bank bill....... 227 statement of in regard to resumption.

143,146

Silver certificates, opposition of Comptroller to ........................... 178

Silver coinage, inerease in volume of subsidiary coius....................... 286

Silver-purchase acts of 1878 and $1890 \ldots 200$ Siver purchased under act of February $28,1878 \ldots \ldots \ldots \ldots \ldots \ldots \ldots . . . . . . . . . . .200$

Skins, use of as currency............... 779 Smith, George, banks established by.726, 740 South Carolina:

Adger \& Co., James................. 566

Bank of Charieston, charter of......... 566 
South Carolina (Continued):

PAGE

Bank of Sonth Carolina, charter of.... 563

Bank of the State of South Carolina, the 564,565

Bank of the United States, branch of. 563 Cheves, Langdon..................... 565

Civil War, destruction wrought by.... 568

Colonial currency, issue of............ 562

Confederate notes, exchange of for

bank notes......................... 567

First banks established................ 563

Land and Loan Bank of the Carolinas. 562

National banks, growth of............ 569

National banks, statistics of.......... 570

Notable banks and bankers............ 565

Soundness of the State banks..........567

State banks, statistics of............ 570

Williams \& Co., Geo. W.............. 568

South Dakota:

Banks, increase in number of........ 800

First National Bank, of Yankton, founding of...................... 799

Inflation, reaction from period of.... 802

Laws relating to banks................ 802

National banks, statistics of......... 805

Parmer, Mark M., bank established

by ................................ 799

Real estate, speculation in............ 800

Speculative era, the.................. 800

State and private banks, statistics of. 803

Territory, organiźation of.............. 798

Sonthern states, history of banking in... 52'2 Spaulding, Elbridge G., author of Legal-

Tender Act. 96,222

antiruc of preliminary draft of $\mathrm{Na}$ tional Bank Act................... 221

sketch of, with portrait................ 293

letter of to Secretary Chase............ 220

opinion of the repeal of the law permitting refunding of legal-tender notes..

views on the legal-tender act......... 133

work of in drafting National banking law

pecie banks in Boston.

Specie circular, the..................... 81

Specie payments, act providing for resumption of ......................... 278

proposed resumption of.............. 105

resumption of in $1879 . \ldots \ldots \ldots \ldots \ldots \ldots . \ldots 152$

suspension of........................ 84

suspension of in $1814 \ldots \ldots \ldots \ldots \ldots \ldots .48$

suspension of in $1837 \ldots \ldots \ldots \ldots \ldots \ldots .76$

suspension of in $1861 \ldots \ldots \ldots \ldots \ldots \ldots . . .135$

Stamp tax on checks..................... 122

State and National banks in New York.. 206

State bank circulation, tax on........... 99

State bank circulation, withdrawal of.... 247

State bank notes, amendment of the tax

law .............................. 124

constitutionality of ................... 22

expansion of, 1811 to $1819 \ldots \ldots \ldots \ldots . .49$

opinion of Justice Story............... 21

plan for issue of on deposit of United States bonds.
State bank notes (Continued): $\quad$ PAGF power of Federal Government to tax.. 23 proposed taxation of.................. 225 taxation of..................... 232, 317 ten per cent. tax on................... 270 views of Salmon P. Chase............ 22

Webster's opinion................... 21 State banks, as Government depositories, regulations of...................... 82 condition of in $1814 \ldots \ldots \ldots \ldots \ldots \ldots \ldots .48$ conversion of into National banks.....

$98,244,283$

deposit of public moneys in........... 80 development of the sy stem............. 305 dividends paid by those insolvent..... 328 failures of in the crisis of $18 \$ 34 \ldots . . \ldots . .183$ failures of the early............... 319, 325 failures of, 1836-37.................. 13 failures of, 1864-1896................ 328 growth of ............................ 128 increase of, 1834 to $1837 \ldots \ldots . \ldots . . .82$ losses by failures of.................. 315 preference given to holders of charters of in forming National banks...... 270 proposal to permit issues of circula-

tion based on Government bonds... 226 statistics, compilation of.............. 306 statistics of.... 12, 307, 309, 310,311, 312,859

suspension of specie payments by..... 84 States as holders of State bank stocks... 316 State taxation of National bank shares.. 122 State taxation of National banks.... 243, $249,254,258,263,265$

Statistics of National banks, 1863-1899.. 295. Statistics of State banks.. 307, 309, 310,

Statistics of State banks, loan and trust companies, private banks and Sav. ings banks.

Stewart, John A., on resumption act of

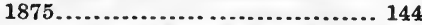

Story, Justice, on State bank notes....... 21 Suburban National banks, absorption of into reserve cities.................... 193

Suffolk banking system, the.............. 365 .

Sumner, Charles, views of on National currency act.................. 261, 264 .

Surplus revenues deposited in State banks ............................. 80

Surplus revenues, distribution of among the States. 83

Suspension of specie payments in $1837 . .76$ Suspension of specie payments in 1861.. 135

T.

Taney, Roger B., appointed Secretary of the Treasury....................... 71

Taxation, of capital and deposits......... 282 of National banks by the States...243, $249,254,258,263,265$. of National bank shares, Statediscrimination............................ 122 
PAGE

Taxation of State bank notes.... 99, 232, 270 amendment of law................... 124 evasion of ........................... 113

Gallatin's views....................... 317 power of Federai Government to im.

pose............................ 23 proposals for........................ 225

Tennessee:

Banking in the principal cities........661

Bank of Tennessee, the.......... 653, 658

Bank of the State of Tennessee, the...

649,650

Bank of the United States, branch of.. 650 Banks, condition of in 1860 .......... 656

Chattanooga, banking in ..........663 663

Civil War, influence of on banks...... 656

Condition of the banks in $1819 \ldots . . . .649$

Confederate funds, seizure of........ 658

Currency, early forms of............. 647

Failures of the early banks........... 650

Free bauking law, the................655

Jackson, Antrew, views of on bank

bills.............................6.61

Johnson, Andrew, message of relating

to banking....................... 655

Knoxville, banking in...............663

Laws relating to establishment of banks..........................6.64

Memphis, banking in............... 661

Nashville, banking in............. 663

Nashville Bank, the............. 648, 649

National banks, failures and liquiı!ations of..........................666 666

National banks, statistics of......... 667

Nichol, Josiah, sketch of............ 648

Political banking, experience with.... 653

Reports, filing of not required........ 647

Skins, use of as a legal tender......... 647

Specie payments, suspension of.. 654, 655

State as a holder of bank stock.......649

State bank issues, losses from........656 656

State bank notes, method of issuing... 654

State bank notes, specimens of........ 660

State banks, statistics of.............. 667

State prohibited from owning bank stock...........................6665

Taxation of banks.................. 665

Union Bank of Tennessee, the........ 652 Texas :

Annexation to the United States...... 618

Bank notes, circulation of on indorsement of individuals................6 620

Banks, incorporation of by the Repub-

lic of Texas.....................6.616

Banks prohibited by State constitution. 620

Characteristics of the State's history.. 615

Circulation of bank notes ou eredit of individuals........................6.620

Commercial and Agricultural Bank,

the ...........................6 619

Constitution prohibits banking. ...... 620

Government bank, proposals for...... 617

Hammered dollar, tr e................ 619

Loan, negotiations for in France..... $\mathbf{6 1 8}$
Texas (Continued): $\quad$ PAGE

Mills, R. \& D. G.................... 620

National banks, statistics of......... 624

Notes issued by individuais, prohibi-

tion of circulation of ...............6 620

Reconstruction ora, banking during

the...............................621

Republic of Texas, finances of........ 616

State banks, reports of.......... 622, 623 statistics of. ...................624

temporarily authorized..........621 why they existed despite consti. tutional prohibition...........6.622

Treasury notes issued by the Repubic of Texas.........................6.616

Tobacco as currency in Virginia......... 523 Treasury influence in perpetuating legaltender notes......................... 149

Treasury notes, authorization of issue of 85,86

Treasury notes of 1890 , cancellation of.. 286 Treasury notes, opposition of Comptrollerto............................ 178

Trenholm, Wm. L., appointed Comptrol-

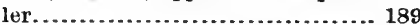

Trust companies (see State index for).

Tyler, John, veto of bill tor a National bank.

U.

United States Bank of Pennsylvania, failure of.......................... 77

United States Bank of Pennsyivania, operations of..................... 77

United States notes, proposed issue of... 220 United States not preferred creditor of failed National banks............... 113

Usury charged by National banks....... 123 Utah :

Admission of State into the Union.... 852

Deseret National Bank, the........... 853

McCoruick \& Co., W.S................ 854

Mint established by private enterprise 852 National banks, statistics of..... 854, 855 Origin and development of banking... 853

Private banks, statistics of........... 854

Reports, banks required to make..... 854

Salt Lake City, plan of................ 852

State banks, statistics of.............. 854

Statistics of National, State and private banks......................... 854

Supervision of banking............... 854

Walker Bros., banking business established by........................... 853

Young, Brigham, mint established by 853 Zion's Savings Bank and Trust Co.... 853

V.

Van Buren, Martin, proposal of independent Treasury...................... 85 Venice, Bank of....................... 2 Vermilye, Mr., on resumption act of 1875144 
Vermont:

Act of 1842, the..................... 356

Bank Commissioner, banks placed under control of.................... 356

Banking uncler safety-fund system.... 355

Bank charters, veto of by Governor... 354

Banks, hostility to................... 354

Bills of credit, State issue of.......... 354

Cashiers, powers given to in collection of debt......................... 355

Charters of the early banks, provisions of.................................. 355

Circulation, limitation of............. 357

Debt, powers given to Cashier to col.

lect............................... 355

Depreciated currency, bad effects of.. 354

Failures of State banks in............. 321

Free banking act of 1851 ............ 357

National banking act, effect of........ 357

National banks, statistics of.......... 358

Panic of 1857 , the................... 357

Prejudice against banks .............. 354

Safety-fund system, banking under... 355

Savings banks, growth of............. 358

State Bank, establishment of.......... 354

State banks, statistics of.............. 357

Statistics of Dational banks........... 358

Statistics of State banks.............. 357

Taxation of banking capital............ 356

Trust companies, statistics of......... 358

Veto of bank charters by the Governor 354

Veto of bill for a National bank.......... 89

Veto of inflation bill by President Grant 277

Veto of National bank bill by President Madison ..................................

Virginia :

Banking laws, simplicity of...... 522, 537

Bank of Alexandria, the......... 522, 527

Bank of Richmond, the.............. 528

Bank of the United States, branch

of ................................ 528

Banks under State control, establishment of.......................... 528

Branch bank system, operations of.... 528

Bills of credit issued by individuals... 523

Circulation, issues of.................. 529

Circulation, regulation of by law...... 531

Civil War, banking subsequent to..... 535

Coinage, bad condition of............. 523

Colonial currency, issue of............ 524

Continental currency, depreciation of. 526

Deposit and discount banks........... 533

Depreciation of paper money......... 525

Free banking system, the............ 532

National banking system, establish.

ment of ...........................535

National banks, statistics of........... 538

Paper money, depreciation of........ 525

Private and State banks, statistics of. 539

Private bank notes, circulation of pro.

hibited........................... 526

Reports, banks required to make...... 537

Safety of the State banks............. 530

Savings banks, statistics of........... 539

Scotch system, banks organized under. 528
Virginia (Continned): PAGE State banks chartered since the Civil

war...........................5 536

State banks, statistics of............. 538

Tobacco currency, depreciation of..... 524

Tobacco, use of as currency........... 523

Trust companies, statistics of......... 539

Unchartered banks declared illegal... 530

Von Holst, comment of on "expunging"

resolution....................... 74

\section{W.}

Walker, Amasa J., on redemption of Na-

tional bank notes.................. 101

Warner, A. J., on resumption act of 1875.145

Washington:

Constitution, note issues prohibited by. 840

National banks, statistics of.......... 842

Notes, issue of prohibited............ 840

Seattle banks and the panic of $1893 . . .841$

State and National banks, comparison

of ................................ 841

State banks, statistics of............. 841

Wealth, creation of by issuing bank notes............................ 313

Webster, Daniel, opinion of regarding State bank notes.................. 21

remarks on "expunging" resolution.. 72

western States, history of banking in... 794

Weston, Geo. M., on resumption act of

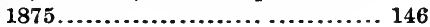

West Virginia :

Banking business, growth of......... 541

Banking centers of the State.......... 542

Banking prior to the Civil War....... 540

First banks established...............5 540

National banks, statistics of......... 543

Savings banks, establishment of...... 542

State banks, statistics of............. 543

Supervision of banks................ 542

Whitney, D. R., History of the Suffolk Bank............................ 365

Wildcat banking............. 702, 734, 747

willing, Thos., sketch of................ 29

Winder, Wm. H., on resumption act of

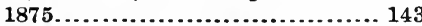

Windom, Wm., plan of for extending bonds................................ 170

Wisconsin :

Bankers, names of the early..........751

Bankers' meeting, a.................. 748

Bank of Miueral Point, the........... 739

Bank of Milwaukee, the.............. 739

Bank of Wisconsin, the................ 738

Circulation, security for............. 745

Circulation, unauthorized prohibited.. 745

Civil War, changes wrought by ....... 749

Convention of bankers, first meeting

of.............................. 748

Deposit currency, specimen of........ 743

Examination, provision for........... 746

General banking law, the............ 744

George Smith's Bank.................. 740 
Wisconsin (Continued):

Miners' Bank of Dubuque, the......... $73 y$

Mitchell, Alex., bank established by.. 740

National banks, statistics of.......... 752

Panics and their effect on banks..... 750

Private banking, pioneers of......... 743

Private banks, statistics of........... 752

Savings banks, statistics of..... 751, 752

Smith, Geo., banks established by.... 740

State banks, statistics of........ 751, 752

Taxation of bank shares............. 745

Territorial banking.................. 738

Wisconsin Marine and Fire Insurance

Co., the..

Wildcat banking, description of

Withdrawal of bonds by banks............ 168 Withdrawal of bonds by banks in liguida. tion.............................. 273

Woodbury, Levi, antagonism of the Bank of the United States.................. 65

Woodbury, Levi, on defects of State banks............................... 315

Wright, Benj. H., on resumption act of

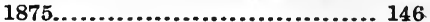

Wyoming :

Admission of State into the Union... 826

Banking law, requirements of........ 827 .

National banks, statistics of......... 828

Private banks, statistics of.......... 823

State banks, statistics of............. 827 .

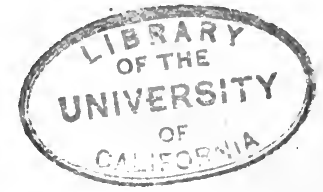







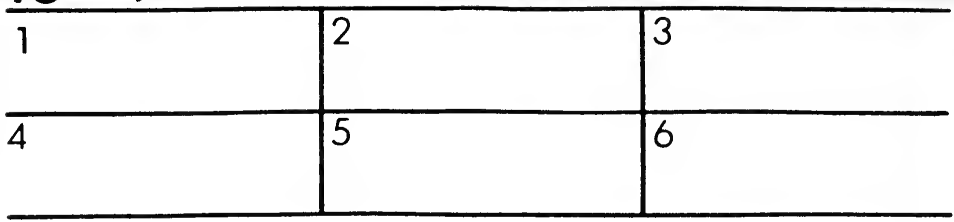

ALL BOOKS MAY BE RECALLED AFTER 7 DAYS

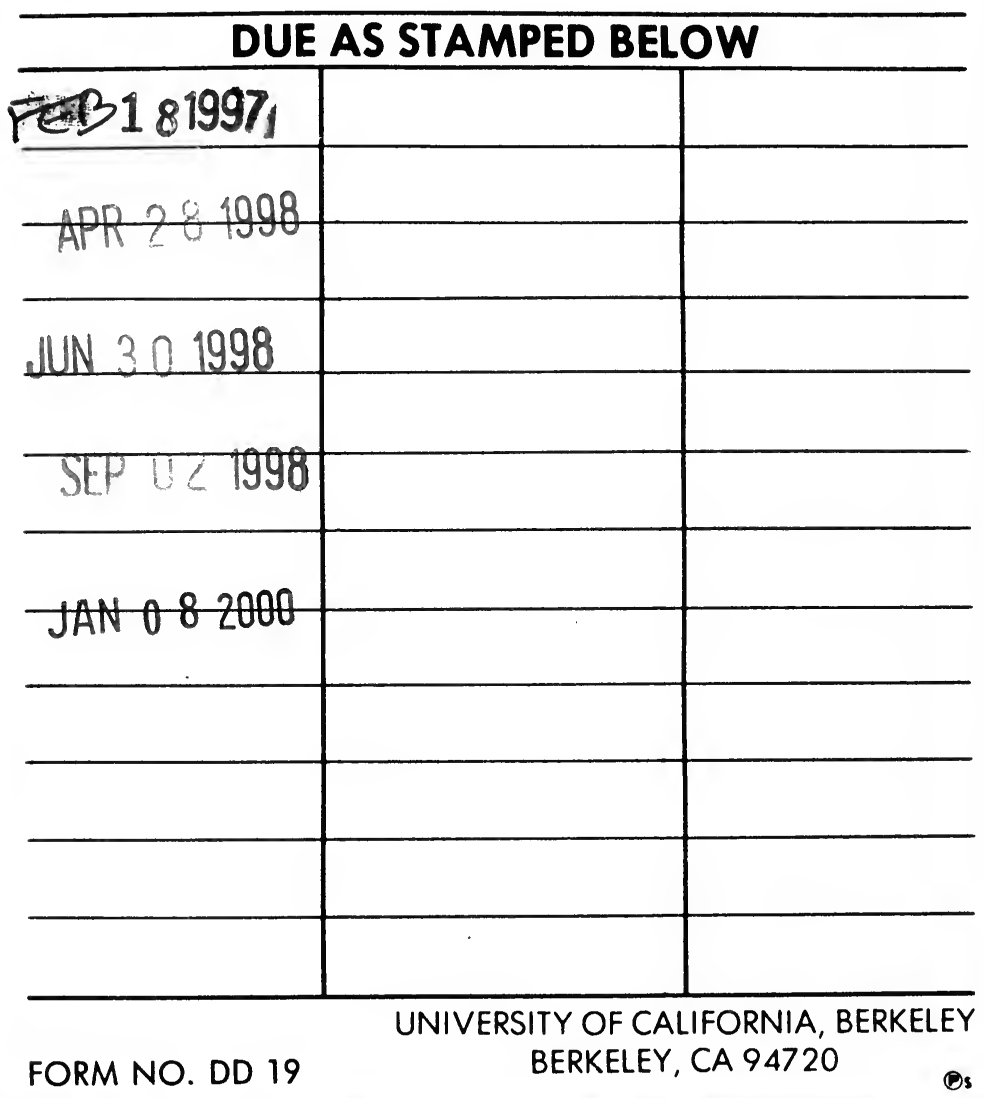

FORM NO. DD 19 


\section{U.C. BERKELEY LIBRARIES}

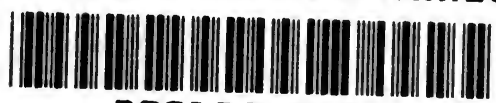
B001024320

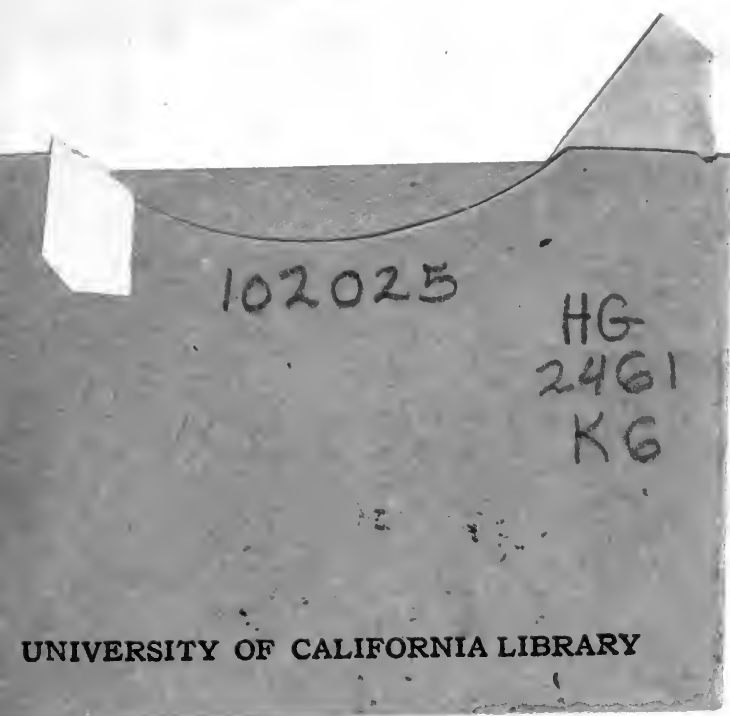

$$
2+3
$$

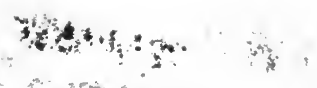


